\title{
Civilizációk Kelettől Nyugatig
}

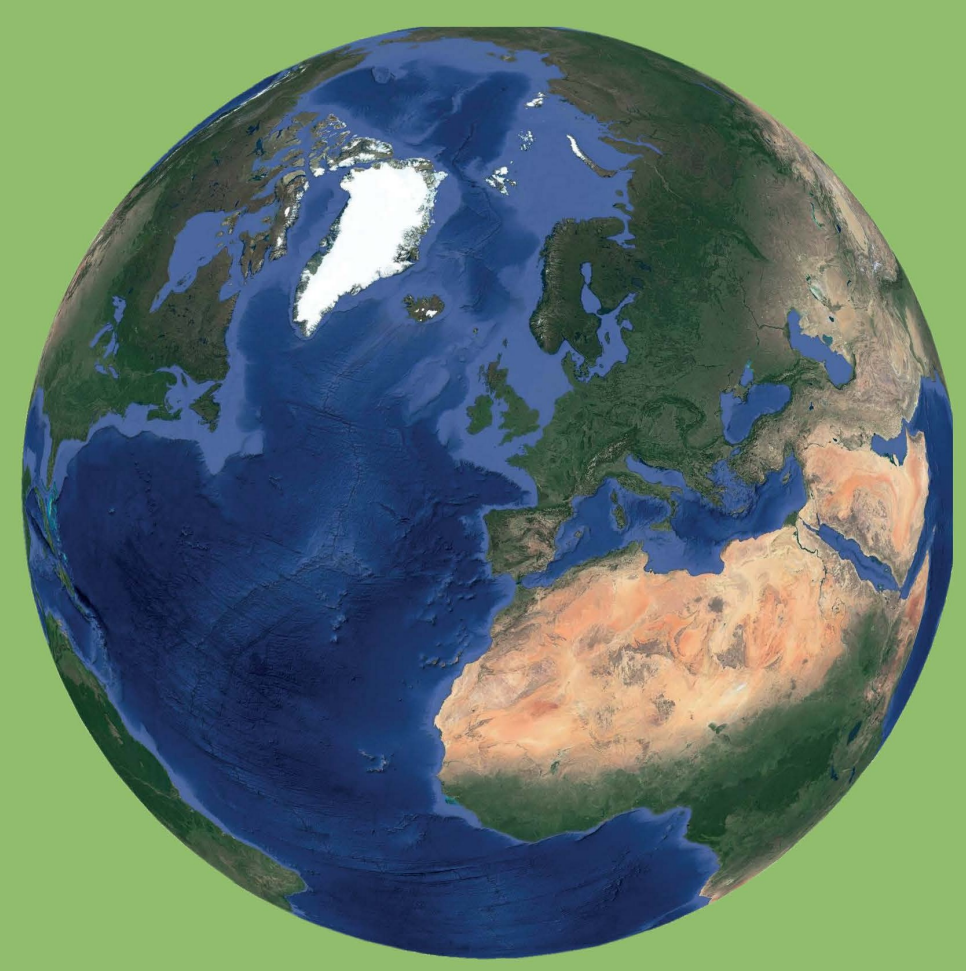

Szerkesztette: DÉVÉNYI KINGA

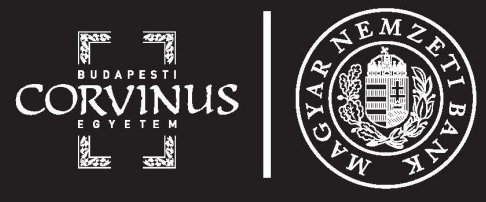


Civilizációk Kelettől Nyugatig 


\section{Dévényi Kinga (szerk.) \\ Civilizációk
Kelettől Nyugatig}

Budapesti Corvinus Egyetem

Nemzetközi Tanulmányok Intézet

Budapest, 2018 
Szerkesztette:

Szerzők:

Térképek:

Tördelés:

Lektor:
Dévényi Kinga

Csicsmann László (Bevezető)

Dévényi Kinga (Iszlám)

Farkas Mária Ildikó (J apán)

Lehoczki Bernadett (Latin-Amerika)

Matura Tamás (Kína)

Renner Zsuzsanna (India)

Sz. Bíró Zoltán (Oroszország)

Szombathy Zoltán (Afrika)

Zsinka László (Nyugat-Európa, Észak-Amerika)

Zsom Dóra (J udaizmus)

\section{Varga Ágnes}

\section{Jeney László}

A kötetben szereplő domborzati térképek a Maps for Free (https://maps-for-free.com/) szabad felhasználású térképek, a többi térkép az ArcGIS for Desktop 10.0 szoftverben elérhető Shaded Relief alaptérkép felhasználásával készültek.

ISBN 978-963-503-690-5 (nyomtatott könyv)

ISBN 978-963-503-691-2 (on-line)

Borítókép: Google Earth, 2018.

A képfelvételeket készítette: Bagi Judit, Csicsmann László, Dévényi Kinga, Farkas Mária Ildikó, Iványi L. Máté, Muhammad Hafiz, Pór Andrea, Renner Zsuzsanna, Sárközy Miklós, Szombathy Zoltán, Tóth Erika. A szabad felhasználású képek forrását lásd az egyes illusztrációknál. Külön köszönet az MTA Könyvtár Keleti Gyüjteményének a kéziratos oldalak felhasználásának engedélyezéséért.

Kiadó: Budapesti Corvinus Egyetem
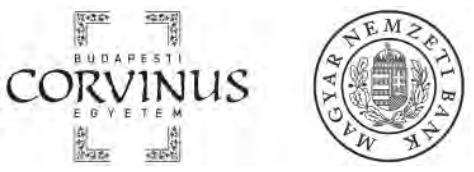

A kötet megjelentetését és az alapjául szolgáló kutatást a Magyar Nemzeti Bank támogatta. 


\section{Tartalomjegyzék}

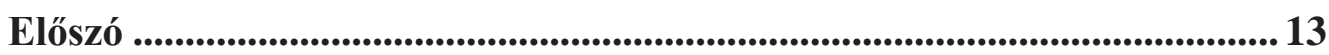

\section{Bevezetés a regionális-civilizációs tanulmányokba: Az új világrend és a} paradigmák összecsapása - CSICSMANN LÁszLó.......................................... 15

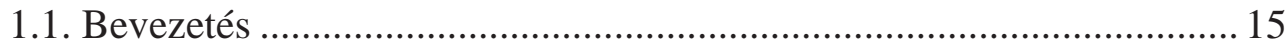

1.2. Az új világrend és a globalizáció jellegzetességei .............................. 16

1.3. Az új világrend vetélkedő paradigmái ........................................................ 23

1.4. Civilizáció és kultúra fogalma(k) és értelmezése(k)................................... 27

1.5. Fejlődés, modernitás és modernizáció .................................................... 31

1.6. Huntington és a civilizációk összecsapásának a tézise............................. 36

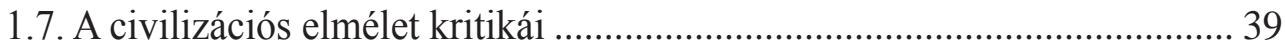

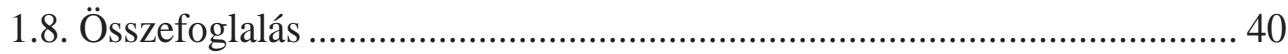

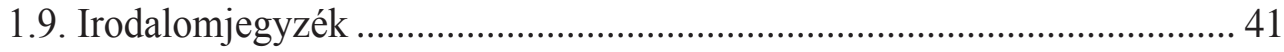

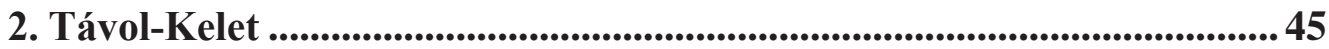

2.1. A kínai civilizáció - Matura TAmás...................................................... 47

2.1.1. A mai Kína számokban........................................................................................ 48

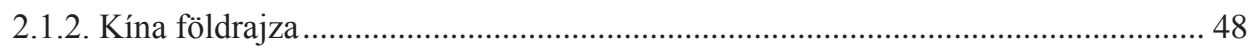

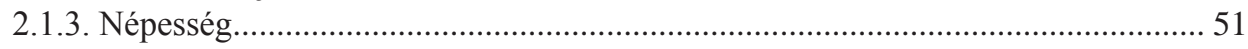

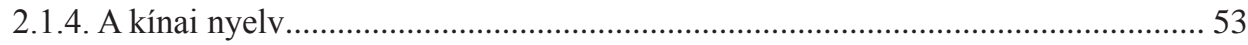

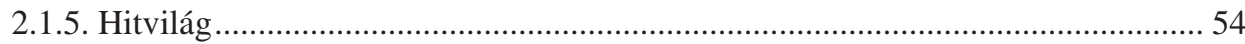

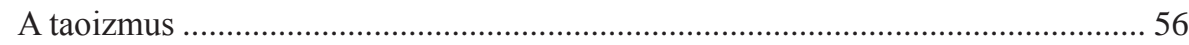

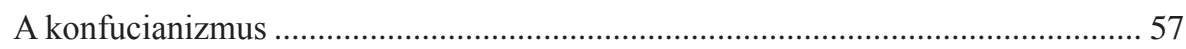

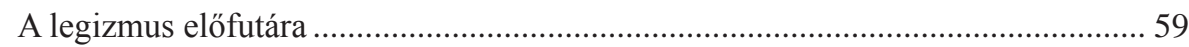

2.1.6. Kína története és annak hatása nemzetközi kapcsolataira...................................... 59

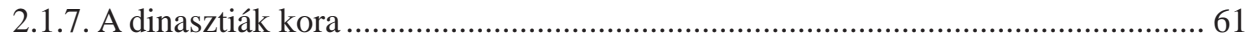

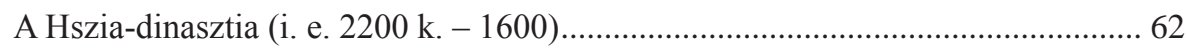

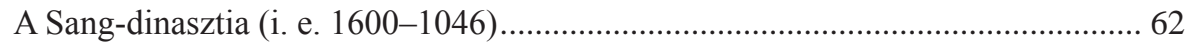

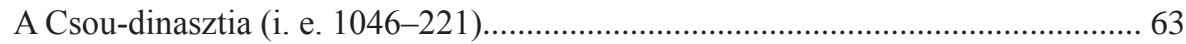

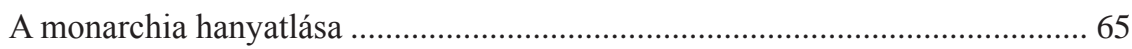

A Hadakozó fejedelemségek kora (i. e. 5. sz. - i. e. 221) …………………….... 66

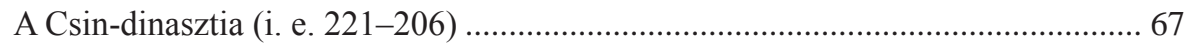

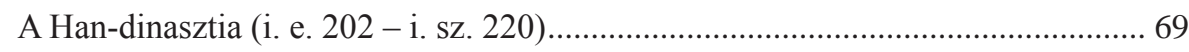

A Három Királyság kora (220-280) ……………………………………………... 70 


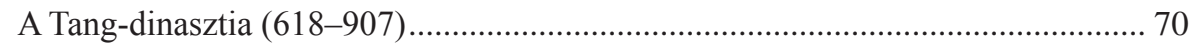

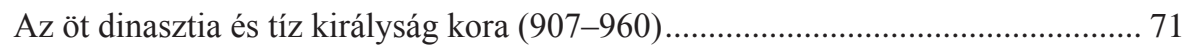

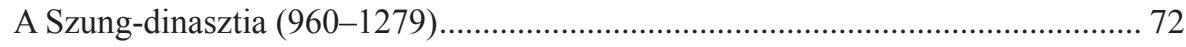

A Jüan-dinasztia (1271-1368) ................................................................................. 72

A Ming-dinasztia és Cseng Ho (Zheng He, 1371-1433) admirális ......................... 74

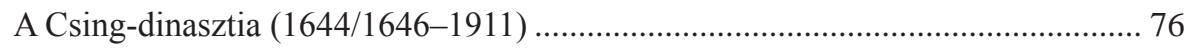

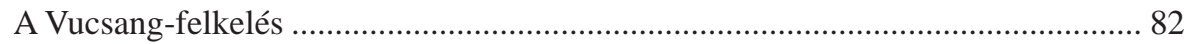

2.1.8. A klasszikus kínai stratégiai kultúra és forrásai ................................................... 83

Filozófiai alapok - a konfucianizmus és a legizmus............................................. 83

Szun-ce és A hadviselés tudománya........................................................................ 84

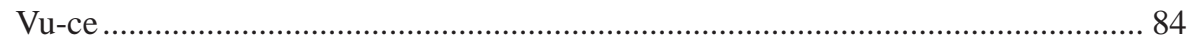

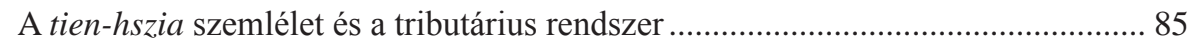

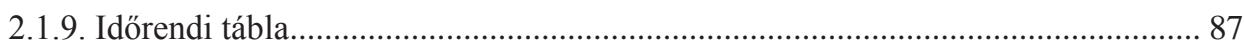

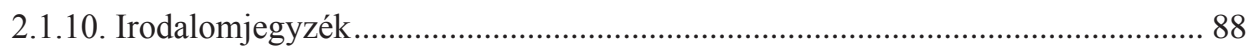

2.2. A japán civilizáció - FARKas Mária Ildikó .................................... 89

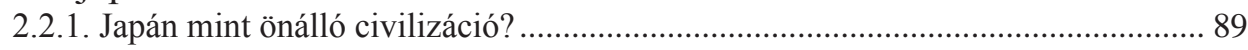

2.2.2. A japán civilizáció forrásai és alapjai .................................................................. 91

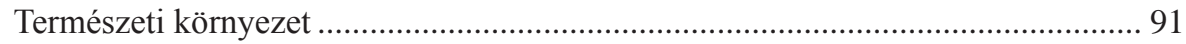

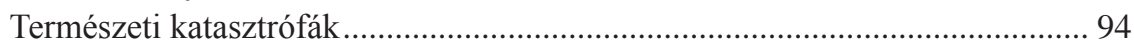

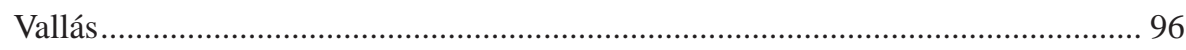

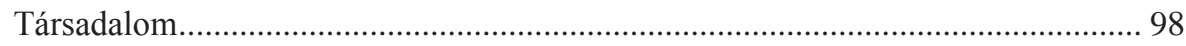

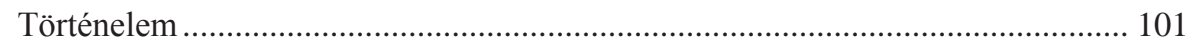

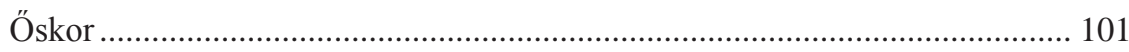

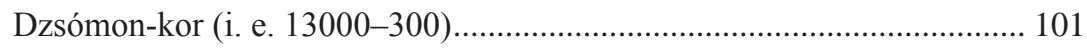

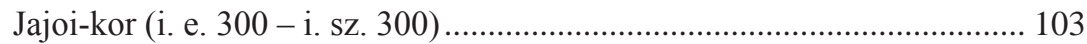

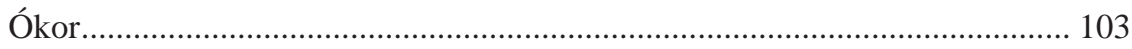

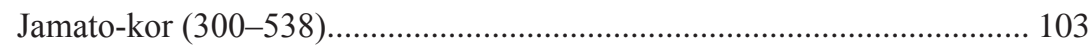

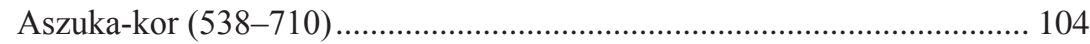

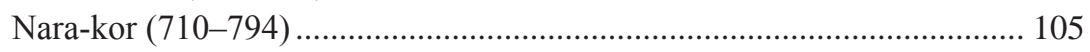

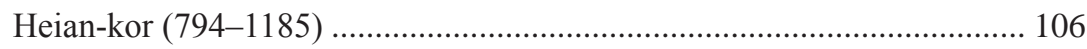

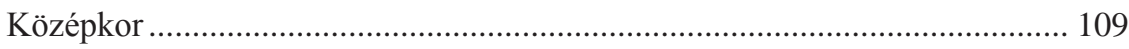

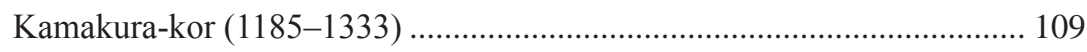

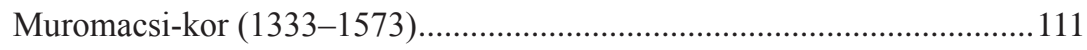

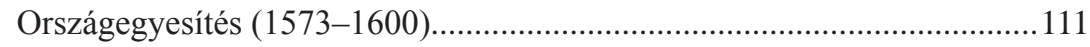

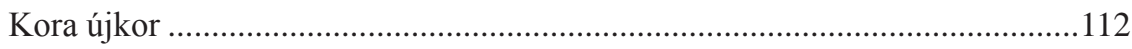

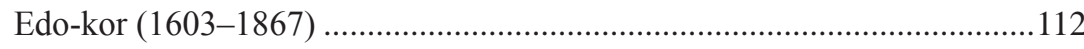

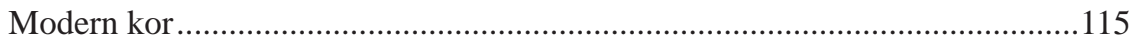

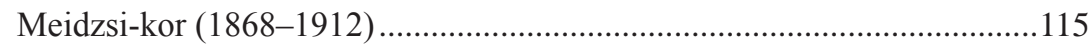

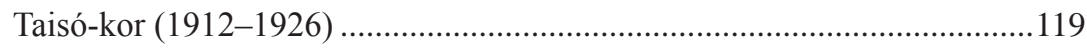

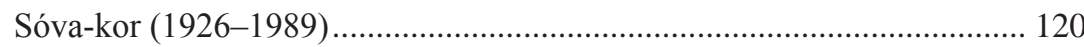

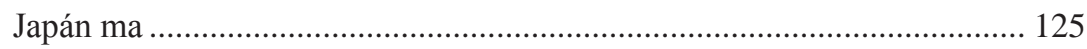

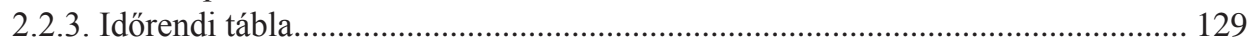

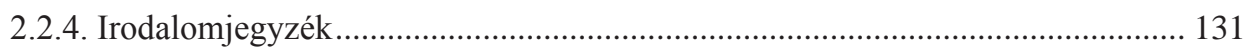




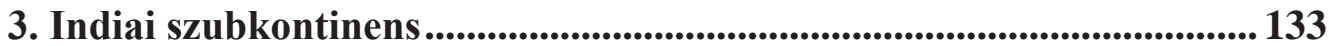

3.1. Az indiai civilizáció - ReNNER ZsUZSANNA ....................................... 135

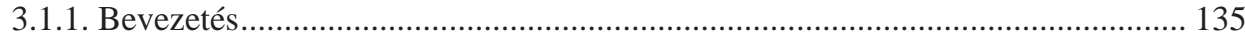

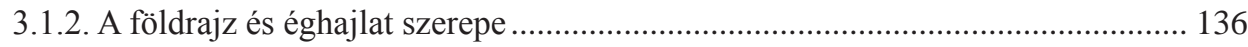

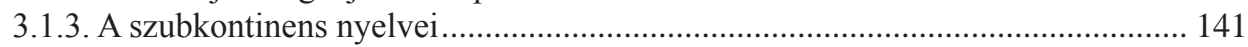

3.1.4. Az indiai civilizáció történetének kronológiája.................................................. 143

Az idő szemlélete, időrend, források .................................................................. 143

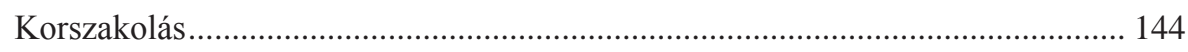

Az egyes történeti korszakok fö jellemzői........................................................ 145

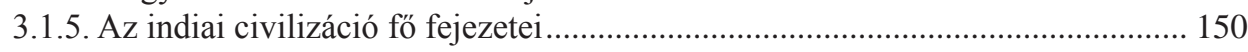

Az Indus-völgyi civilizáció anyagi kultúrája ....................................................... 150

A védikus árják életmódja, vallása és irodalma .................................................. 153

Az indiai civilizáció jellegzetes társadalmi szerkezetének kialakulása .................. 155

Késő védikus kor: a Gangesz-völgy meghódítása .............................................. 156

A második urbanizáció kora: dzsainizmus és buddhizmus.................................. 158

Korai klasszikus kor: a Maurja Birodalom ....................................................... 163

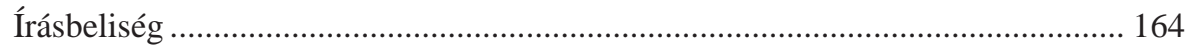

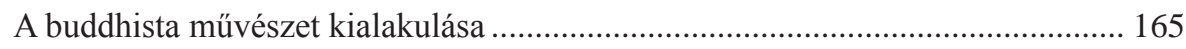

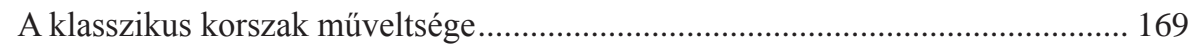

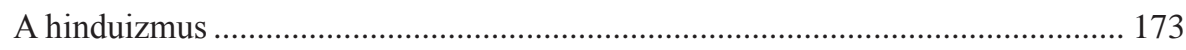

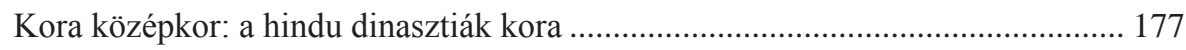

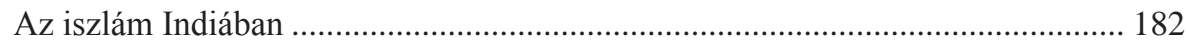

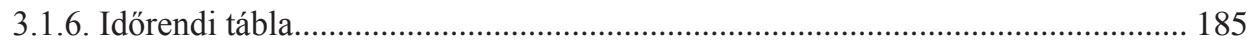

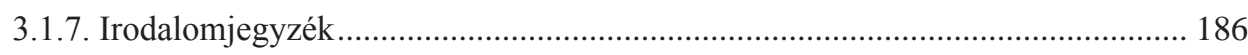

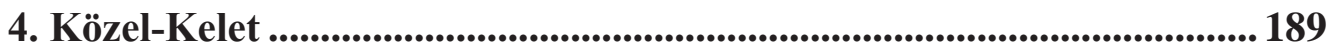

4.1. Judaizmus - Zsom DóRA................................................................. 191

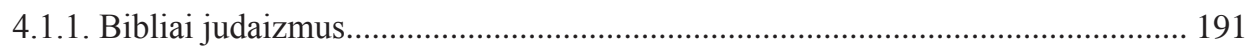

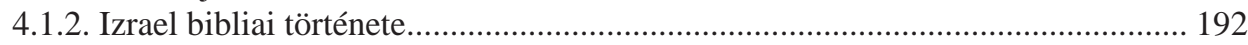

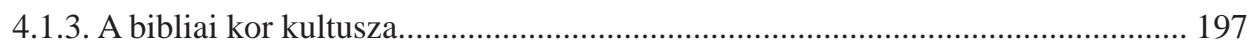

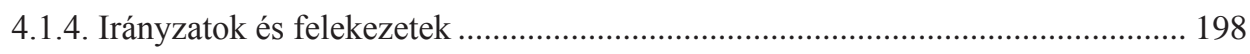

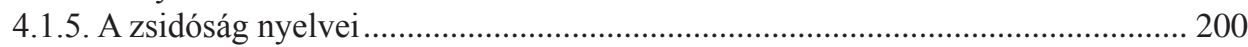

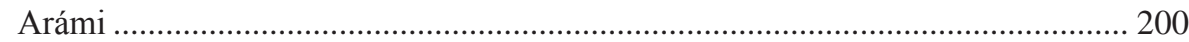

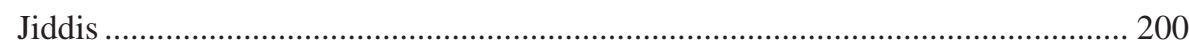

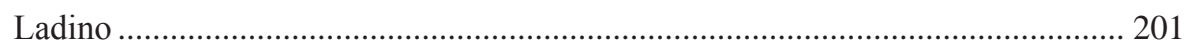

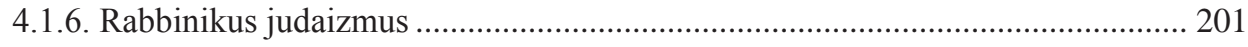

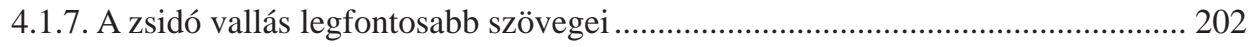

4.1.8. A zsidó életút legfontosabb állomásai, a vallás egyes előírásai .......................... 205

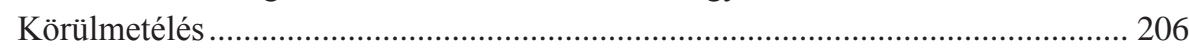

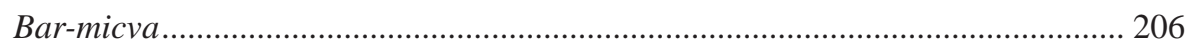

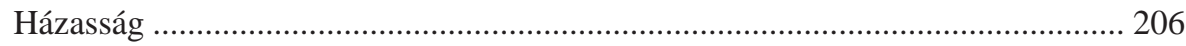

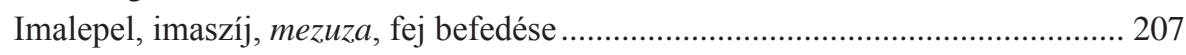




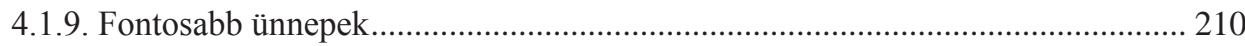

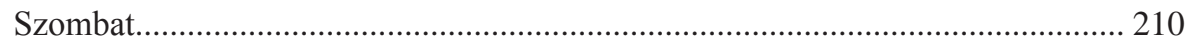

A félelmetes napok: ros ha-sana és jom kippur .................................................. 213

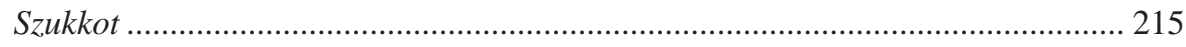

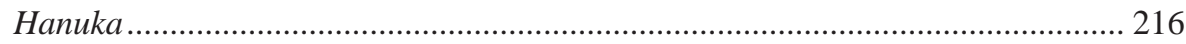

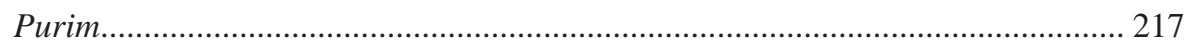

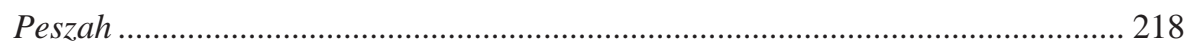

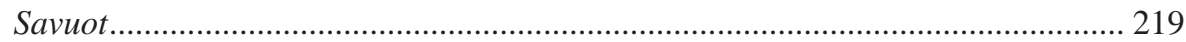

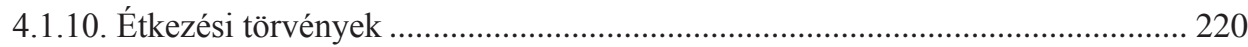

4.1.11. A zsidóság egyes szellemi irányzatai............................................................. 221

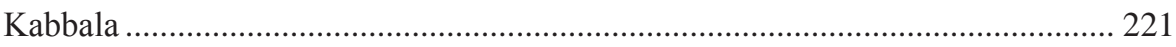

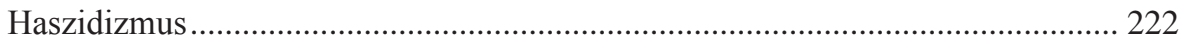

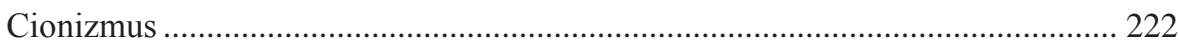

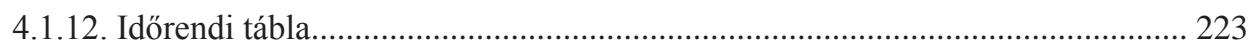

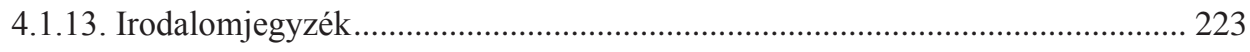

4.2. Az iszlám civilizáció - DÉVÉNYI KINGA ......................................... 225

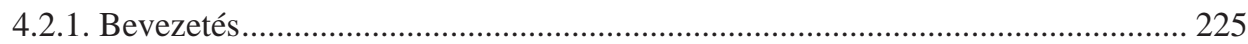

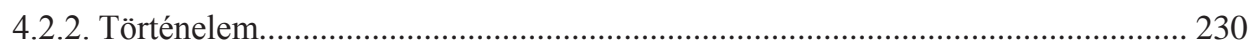

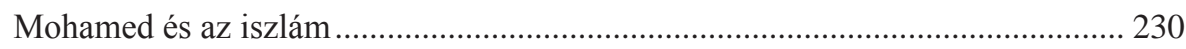

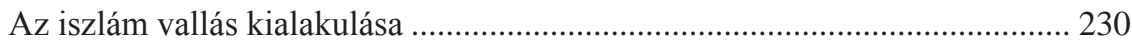

Mohamed éjszakai és égi utazásának a története ............................................ 232

A hidzsra (kivándorlás) ............................................................................. 233

A medinai iszlám ......................................................................................... 233

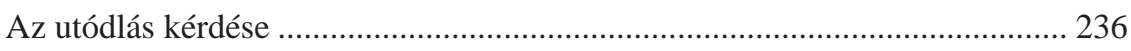

A medinai kalifátus: a négy igaz úton járó kalifa uralkodása ................................ 236

Abu Bakr kalifátusa (632-634) .................................................................. 236

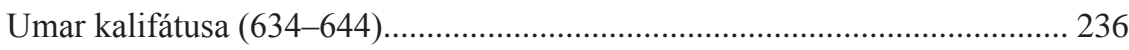

Uszmán kalifátusa (644-656)........................................................................ 237

Ali kalifátusa (656-661) és az első polgárháború (fitna) ................................. 238

A damaszkuszi Umajjád Kalifátus (661-750) ...................................................... 239

A második polgárháború (fitna) (683-692)..................................................... 239

Vallási mozgalmak a 8. század első felében.................................................... 241

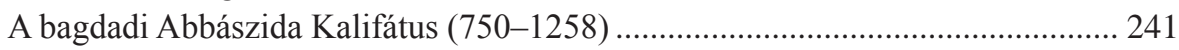

Hárún ar-Rasíd (786-809) kora, a bagdadi kalifátus fénykora ........................ 245

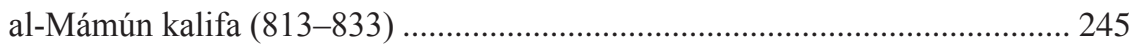

A birodalom széttagolódásának kezdetei ..................................................... 246

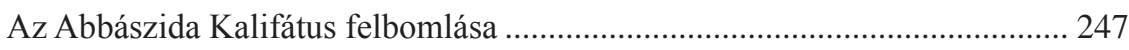

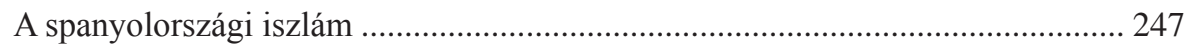

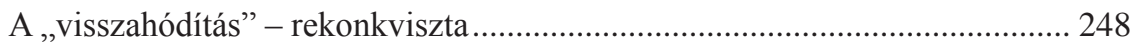

A Közel-Kelet a Bagdadi Kalifátus megszünése után .......................................... 249

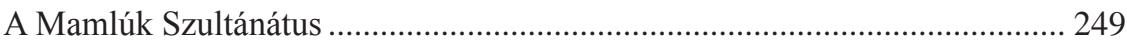

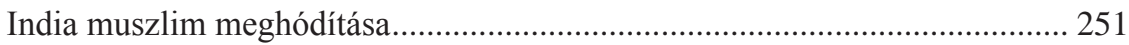

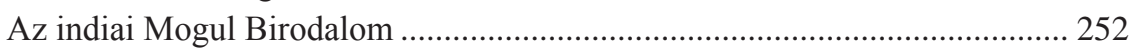

Irán a 16. századot követően ....................................................................... 252

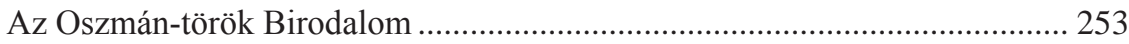




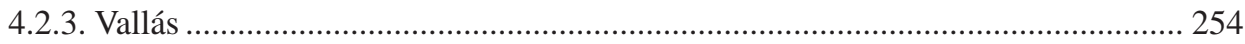

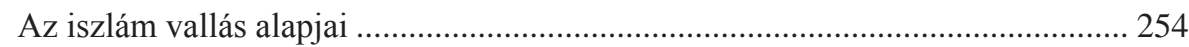

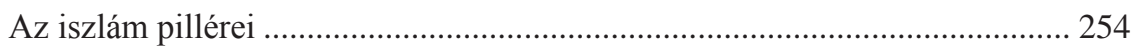

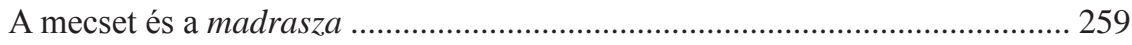

Az iszlám jogrendszerének kialakulása .................................................................... 260

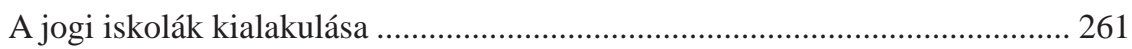

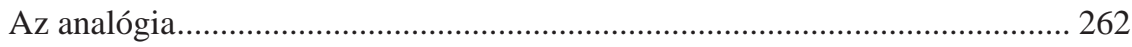

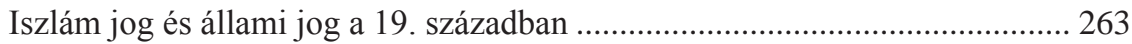

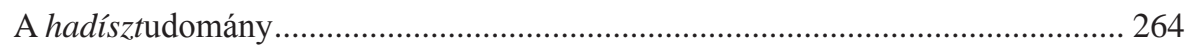

Az iszlám misztikus irányzata, a szúfizmus........................................................ 266

A Korán szerepe a misztikában ...................................................................... 270

A szúfi rendek, az ún. dervisrendek virágkora a 13-19. század között............. 270

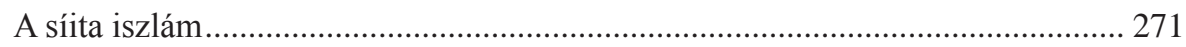

Az imámi vagy tizenkét imámos síiták ............................................................. 272

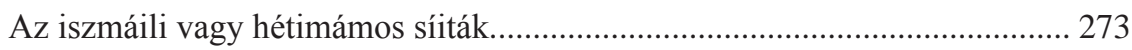

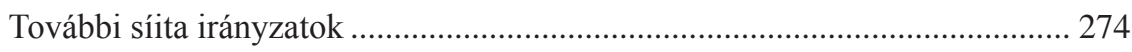

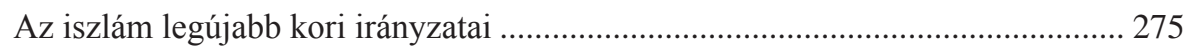

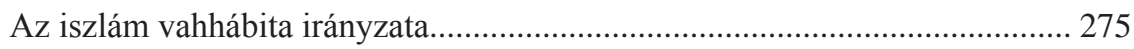

A 19. századi iszlám reform kor (nahda) Egyiptomban................................... 276

Az iszlám 20. századi föbb tendenciái ............................................................... 276

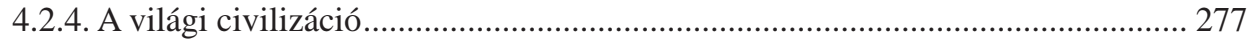

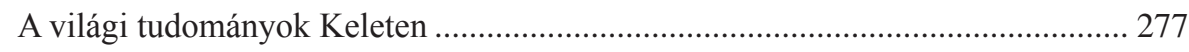

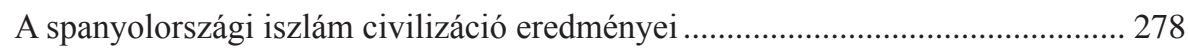

Irodalom az iszlám világ központi területein.......................................................... 279

Arab nyelvủ irodalom a középkorban ........................................................... 279

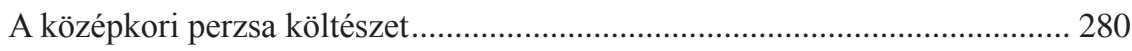

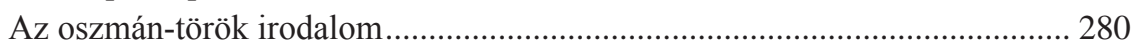

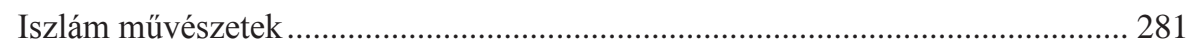

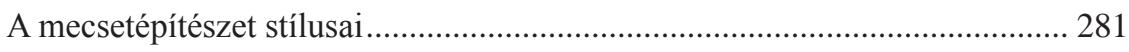

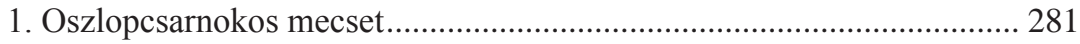

2. A négy ívános mecset ........................................................................... 282

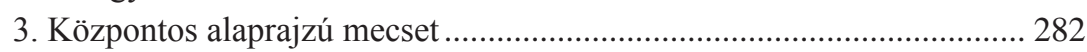

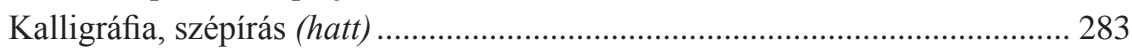

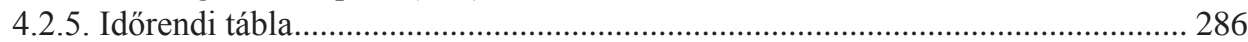

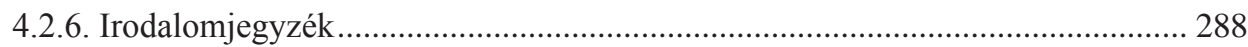

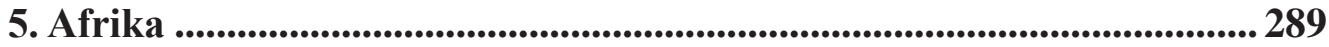

5.1. Afrikai civilizációk - SzOMBATHY ZoLTán ....................................... 291

5.1.1. Terminológiai kérdések és az afrikai civilizációk határai ................................. 291

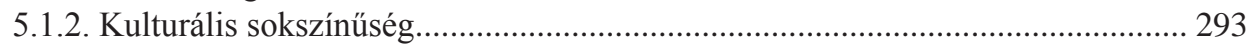

5.1.3. Az afrikai civilizációk képe és torzképe: egzotikum és ideológia ...................... 294

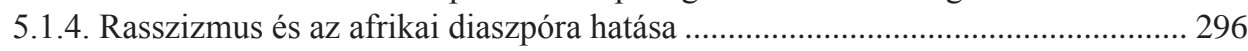




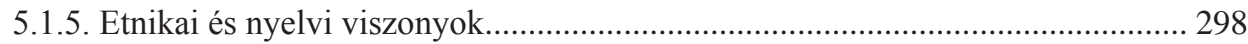

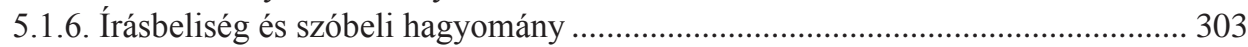

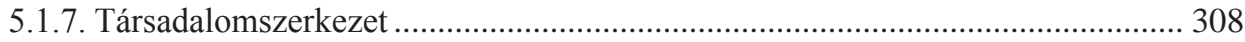

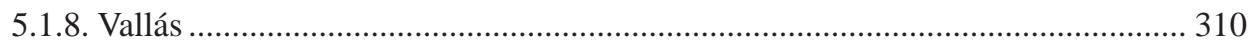

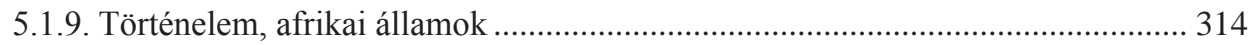

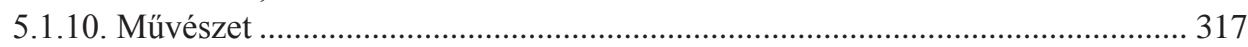

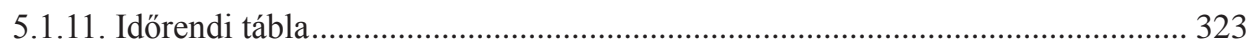

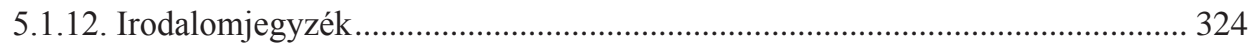

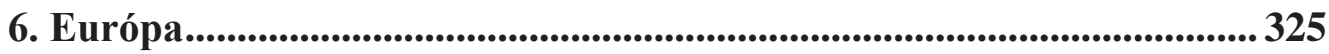

6.1. Az ortodox keresztény Európa: az orosz változat - Sz. BíRó ZoLTÁn 327

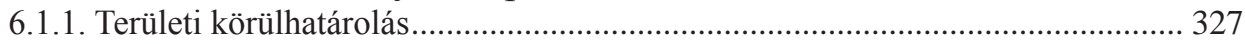

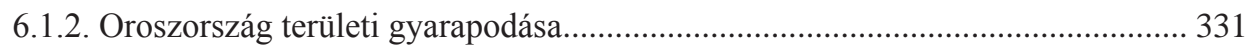

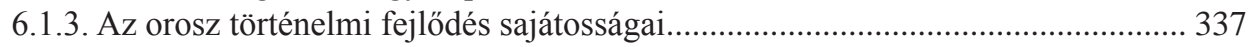

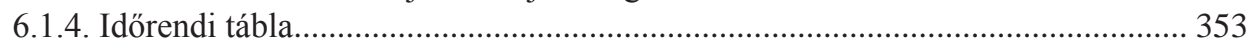

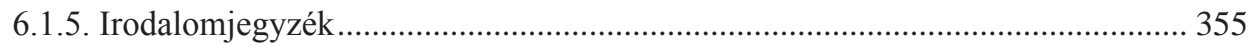

6.2. A nyugati keresztény Európa - Zsinka LászLó................................... 357

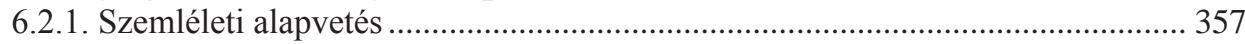

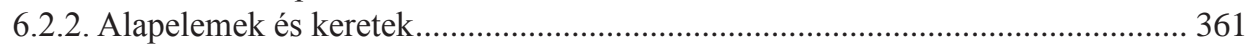

6.2.3. A nyugati keresztény Európa születése (200-1000)............................................ 366

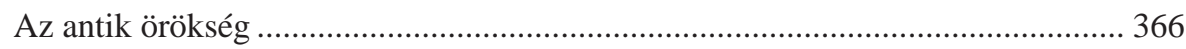

A barbár germán örökség .................................................................................. 368

A latin keresztény kultúrközösség születése ..................................................... 370

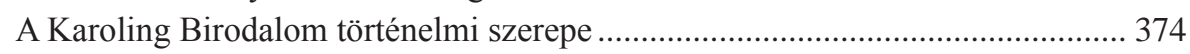

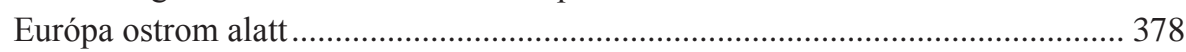

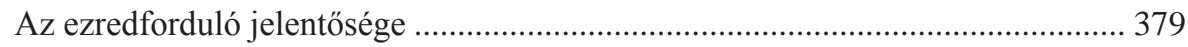

6.2.4. Európa első „nekilendülése” az érett középkorban (1000-1500) ........................ 380

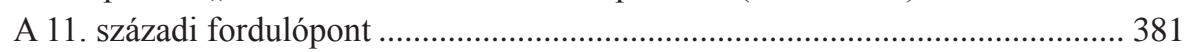

Nyugat-Európa „forradalmai” az érett középkorban ............................................ 383

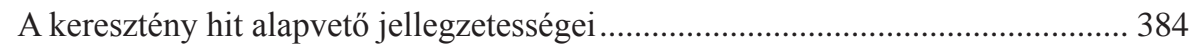

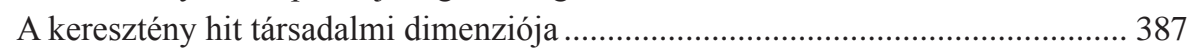

Nyugat-európai „eredeti jellegzetességek” .............................................................. 389

6.2.5. A premodern és a modern határán (1500-1800) ................................................... 391

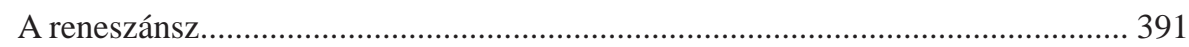

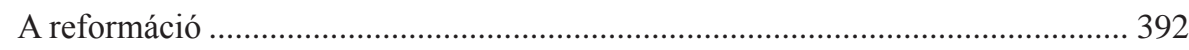

A tudományos forradalom és a felvilágosodás ……........................................... 395

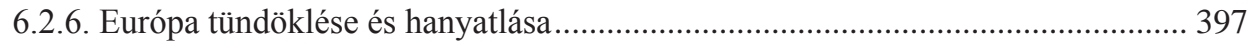

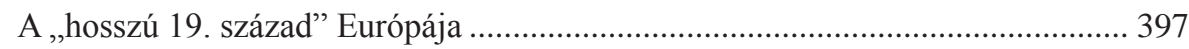

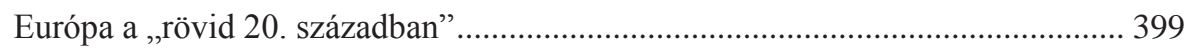

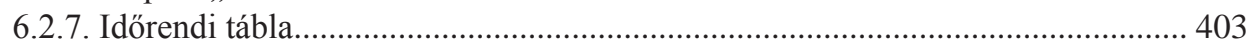

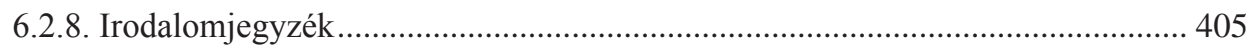




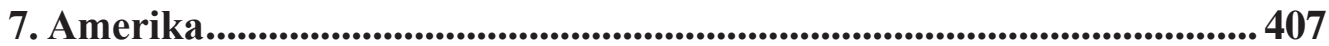

7.1. Az észak-amerikai civilizáció - ZsINKA LÁsZLó ................................. 409

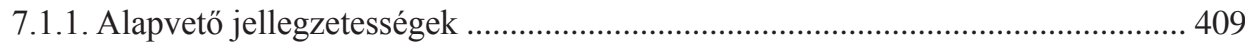

7.1.2. A szabadság „,megalapítása” az Egyesült Államokban ......................................... 414

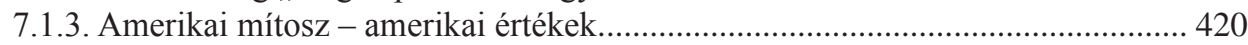

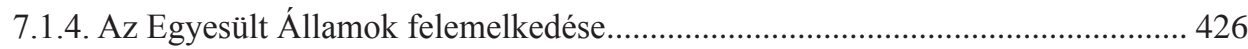

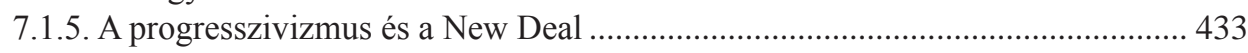

7.1.6. Amerikai civilizációs értékek a 20. század második felében ............................. 438

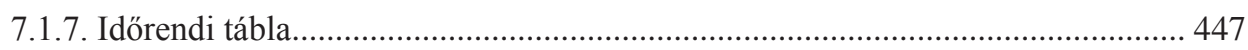

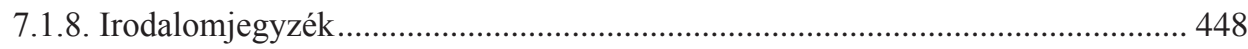

7.2. Latin-Amerika: civilizációk kölcsönhatásos rendszere

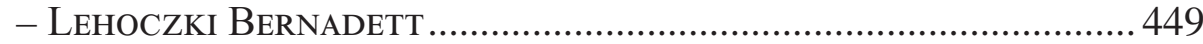

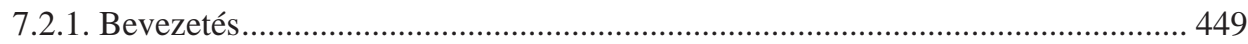

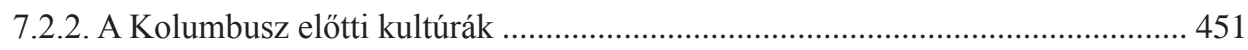

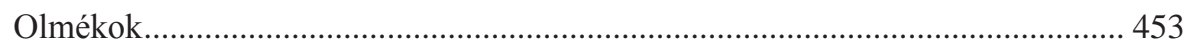

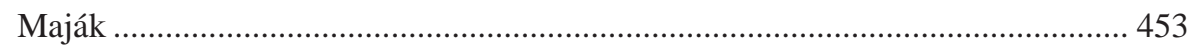

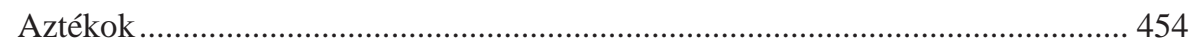

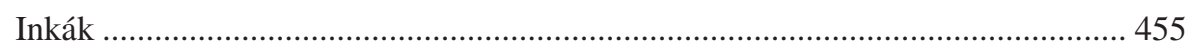

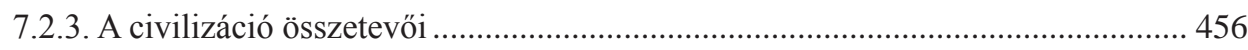

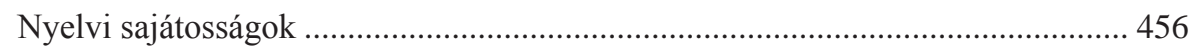

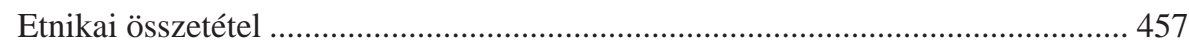

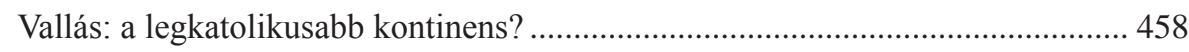

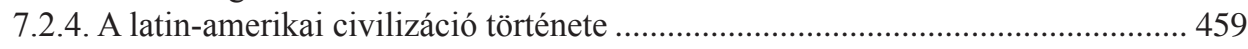

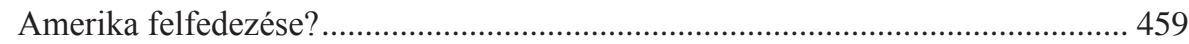

A függetlenség kivívása: közös célok és törekvések?......................................... 464

7.2.5. 20. századi dilemmák: nyugati vagy latin-amerikai út? ..................................... 467

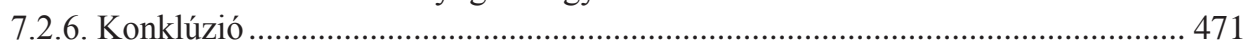

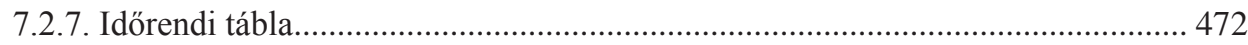

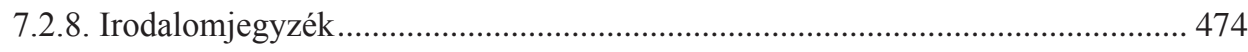

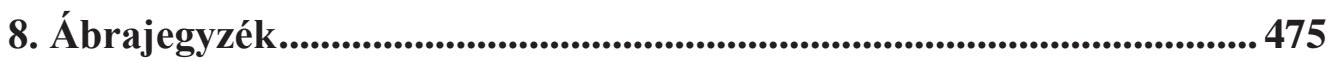

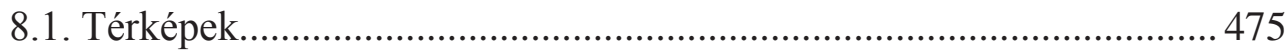

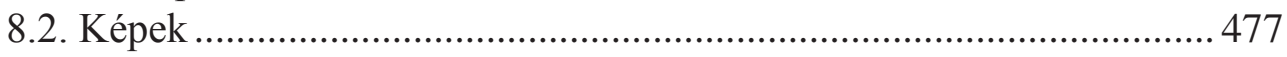

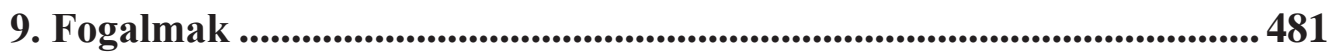





\section{Előszó}

Jelen kötet a világ nagy civilizációit kívánja az olvasó elé tárni, bemutatva történeti korszakaikat kialakulásuktól a 20. század első feléig. A kötet szerzőinek célja az volt, hogy korunk sokszínủ és időnként nehezen megérthető eseményeit, társadalmi, kulturális viszonyait történelmi perspektívába helyezze. A maga nemében egyedülálló vállalkozás magyar nyelven elöször foglalja egyetlen kötetbe a földgolyó összes jelentős ma is fennálló civilizációját.

Ugyanakkor a kötet térségeket kíván összefoglalóan kezelni, nem pedig modern országokat. Ez még akkor is igaz, ha három civilizáció ma egy-egy ország területén található (Kína, Japán és India). Másrészről, a három KözelKeleten kialakult monoteista vallás (a judaizmus, a kereszténység és az iszlám) olyan mértékben meghatározta két térség, a Közel-Kelet és Európa civilizációját, hogy ott vallási alapon lehet csak az adott civilizációt leírni.

Az egyes civilizációk leírása ugyan egységes elvek alapján készült, de az egyedi sajátosságok és az egyes szerzők eltérő megközelítése miatt vannak eltérések. Az egyes térségek - amennyiben az releváns - földrajzi-éghajlati bevezetővel kezdődnek, majd az adott történelmi kereten belül a szerzők bemutatják a térségek társadalmi, vallási és kulturális viszonyainak a kialakulását és fejlődését. Ebben, ha röviden is, de helyet kaphat a föbb irodalmi, müvészeti irányzatok bemutatása éppúgy, mint alkalmanként a vallásjog története is (az iszlám esetében például a jog döntő jelentőségü tényező a társadalmi és politikai élet minden területén). Meghatározó része az egyes fejezeteknek az adott térség és civilizáció geopolitikai jelentőségének a bemutatása is.

Az egyes fejezetek fontos részét képezik az illusztrációk, a kötet számára készített térképek, az időrendi táblák, valamint a kötet végén található fogalomtár. Minden fejezet végén található irodalomjegyzék, amely a Magyarországon könnyen elérhető forrásokat tartalmazza.

A kötet, amelynek szerzői a Budapesti Corvinus Egyetem, ill. más egyetemek és kutatóintézetek munkatársai, elsősorban a nemzetközi tanulmányok szak hallgatói számára készült, de haszonnal forgathatja minden, a téma iránt érdeklődő olvasó is.

Budapest, 2018. május 10.

A szerkesztő 



\title{
1. Bevezetés a regionális-civilizációs tanulmányokba: Az új világrend és a paradigmák összecsapása
}

\author{
CSICSMANN LÁSZLÓ
}

\subsection{Bevezetés}

Az 1989-ben felbomló - az amerikai-szovjet rivalizálásra épülő - ún. bipoláris nemzetközi rendszer kihívás elé állította a nemzetközi kapcsolatokat megérteni próbáló gyakorlati és elméleti szakembereket. Felismerésre került, hogy a vallás, kultúra és civilizáció a korábbiaknál jelentősebb szerepet töltenek be napjaink nemzetközi kapcsolataiban. Felértékelődtek az olyan politikai, gazdasági vagy kulturális jellegü elemzések, amelyek egy-egy Európán vagy a nyugati világon kívüli régiónak a folyamatait elemzik olyan társadalomtudományi módszertannal, amely a térség tendenciáinak megértését segíti.

A nemzetközi kapcsolatok diszciplínája tradicionálisan négy részdiszciplínából tevődik össze:

$\oplus$ a nemzetközi kapcsolatok története / diplomáciatörténet;

$\oplus$ a nemzetközi jog;

$\oplus$ a nemzetközi gazdaságtan / világgazdaságtan és

$\oplus$ a nemzetközi politika elmélete.

A négy terület az 1990-es években kiegészült az ún. regionáliscivilizációs tanulmányokkal, amely kiemelt hangsúlyt fektet az egyes Európán kívüli térségek megértésére. Természetesen 1989 elött is léteztek a Kínatanulmányok vagy a Közel-Kelet-tanulmányok (összefoglalóan Area Studies vagy Régiótanulmányok, Térségtanulmányok, ill. Regionális tanulmányok), amelyeknek különös jelentősége volt az Egyesült Államokban az esetleges szovjet expanzió előrejelzése szempontjából. Ahogy korábban említettük, a szakértők által új világrendnek (New World Order) nevezett 1989 utáni nemzetközi rend keretében felértékelődött a civilizáció, a kultúra és a vallás szerepe. Gondoljunk csak a jelenleg is zajló, Európát is érintő migrációs/ menekültválságra, amely különösen elötérbe állítja a kulturális különbségeket. Ennek a megközelítésnek pedig a külpolitikai döntéseket is megalapozó hatása van (lásd a konstruktivista iskolát).

A civilizációs tanulmányok elsősorban Európa és a nyugati civilizáció fejlődéstörténetéből kiindulva mutatják be a nem nyugati civilizációk történelmi és jelenkori fejlődését. Jelen könyv arra vállalkozik, hogy az elméleti 
bevezetést követően bemutassa azon történelmi mérföldköveket és kulturális jellegzetességeket, amelyek egy-egy civilizációt megkülönböztetnek a másiktól. A viszonyítási pontként minden esetben Európa és az európai civilizáció fejlődéstörténete szolgál, amelynek fejlettségéhez a többi nem európai civilizáció méri magát (lásd a későbbiekben). Mindezt azért is tartjuk fontosnak, mert az általunk használt bizonyos fogalmak nem egy esetben kulturálisan meghatározottak. A demokráciát, mint kormányzati formát referenciaként használják a világ bármely pontján, azonban annak lényegi tartalmát a világ egyes népei felfogásuk, hitéletük és történelmi emlékezetük alapján másként értelmezik. Mielött részletesebben elmerülünk bizonyos alapfogalmakban, érdemes rövid kitérő gyanánt az új világrend bizonyos, számunkra fontos jellegzetességeit kiemelni.

\subsection{Az új világrend és a globalizáció jellegzetességei}

Az új világrend (New World Order) kifejezés a hidegháborús nemzetközi rendszer megszünéséhez kapcsolódik. Ez a nemzetközi rendszernek az amerikaiszovjet rivalizálást követő új korszaka, amelyben az Egyesült Államok vezető szerepet játszik. Nem véletlen, hogy az új világrenddel kapcsolatos retorika leginkább az amerikai politikát jellemzi. George Bush amerikai elnök - többek között - 1991 januárjában az amerikai Kongresszus előtt tartott szokásos évértékelő beszédében utalt az új világrendre, amely a békére, biztonságra, demokráciára és a jog uralmára épülne. Az 1991. januári beszédnek a sajátosságát adja, hogy éppen azokban a napokban robbant ki az ún. öbölháború, amelynek keretében az ENSZ Biztonsági Tanácsának felhatalmazását élvezve az Egyesült Államok egy koalíció keretében elindította Kuvait felszabadítását. Az új világrend kapcsán jelen írás nem tér ki azokra a vitákra, hogy mennyiben tekinthető egypólusúnak (unipolárisnak), és mennyire tekinthető többpólusúnak a világrend.

James N. Rosenau könyvében arra utal, hogy az új világrendet egyidejüleg, egymással ellentétes folyamatok jellemzik. Az általa fragmegrációnak (fragmegration) nevezett fogalom a fragmentáció és az integráció egyidejüségét tekinti az új világrend egyik legfőbb jellegzetességének (RosenaU, JAMES N. 1997). Mások, mint például Zygmunt Bauman szociológus a fragmegráció mintájára a glokalizáció (glocalization) kifejezést alkalmazza napjaink bizonyos jelenségeinek megértésére (BAUMAN, ZYGMunT 2001). A világ tehát egyszerre globalizálódik és integrálódik, ugyanakkor a helyi lokális tényezők szerepe is felértékelödik.

Gondoljunk arra, hogy a nyugati kultúra bizonyos vívmányai különösen amelyek a fogyasztói kultúrával állnak összefüggésben (pl. hollywoodi filmek, McDonalds vagy maga az angol nyelv) - világméretekben elterjedtek. Etiópia 
fővárosában, Addisz Abebában ugyanazt a Big Mac szendvicset lehet vásárolni, mint New Yorkban. A világméretü tendenciák azonban részben védekezésként kitermelik ezek helyi formáját. Az angol nyelvnek például az Indiában beszélt dialektusa teljesen más, mint annak afrikai vagy kínai változata. A McDonald'sban pedig világszerte lehet kapni a helyi termékeket, az arab világban kebabos szendvicset, Indiában füszeresebb kiadásban, Délkelet-Ázsiában pedig a tenger gyümölcseivel. Indiában például a hinduk számára tilos a marhahús fogyasztása, így az ismert ételek nem abból az alapanyagból készülnek.

Ahogy a fentiekben láthattuk, azúj világrend kapcsán a másik kulcsfogalom a globalizáció. A globalizáció fogalmának definiálása jelen tanulmány kereteit meghaladja, azonban érdemes egy-két jellemzőt kiemelnünk. A globalizáció egyik fogalmát Anthony McGrew vezette be: „Azon folyamatok, amelyek révén a világ egyik részén történö tevékenységeknek, döntéseknek és eseményeknek komoly következményei vannak a világ más részén élö népekre." (Anthony McGrew, idézi: RostovánYi Zsolt 1999 pp. 7-8.) A globalizációs folyamat kezdetével kapcsolatosan háromféle vélemény rajzolódik ki.

$\oplus$ Egyes vélemények szerint a globalizáció premodern kategória, vagyis megelőzi a nemzetállamok és a világgazdaság kialakulását. Lényegében egyes felfogások szerint a globalizáció az emberiség születésével egyidős. Az emberiség születésétől kezdve pedig a világ folyamatos egységesülésnek a színtere.

$\oplus$ Mások szerint azonban a földrajzi felfedezések, a gyarmatosítás az egységes világgazdaság kialakulásával inkább modern kategóriaként határozható meg a globalizáció. Akik modern kategóriaként kezelik a globalizációt, a 20. század második felének kommunikációs és technológiai forradalmát a globalizációs folyamat felgyorsulásának, kiteljesedésének tartják.

$\oplus$ A harmadik megközelítés szerint a globalizáció egy posztmodern jelenség, amelynek kezdete az 1970-es évekre, a kommunikáció terén bekövetkezett változásokra vezethető vissza (különösen a negyedik ipari forradalom). (Lásd bővebben McGrew, ANTHONy 2010 p. 23.)

A közfelfogás a második megközelítést fogadja el, és többnyire modern kategóriaként tartjuk számon a globalizációs folyamatot. A globalizáció három szintjét különböztethetjük meg:

1. A gazdasági szint, amely területen a globalizáció a leglátványosabb, a legelörehaladottabb. A globalizáció igazi mozgatórugóját az áruk, személyek, szolgáltatások és a pénz szabad áramlása jelenti. A gazdasági globalizáció kapcsán kialakult annak intézményrendszere, amelynek tagjai - többek között - a Nemzetközi Valutalap (IMF), a Világbank (IBRD) és a Világkereskedelmi Szervezet (WTO). Az egyes nemzetállamok számára a globalizáció gazdasági szempontból elönyöket és hátrányokat 
egyaránt jelent. A globalizáció negatív hatásaival szemben alakultak az ún. globalizáció-ellenes mozgalmak.

2. A politikai szint vonatkozásában a második világháborút követően az Egyesült Nemzetek Szervezete (ENSZ) és annak szakosított intézményei hordozták magukban a globális világkormány létrejöttének a lehetőségét. A második világháborút követően azonban a hatalmi-politikai viszonyok átrendeződését nem követte az ENSZ reformja, így a világszervezet nem képes a nemzeti szuverenitást bizonyos szinten átvenni. Globális világkormány egyelőre nem jött létre.

3. A civilizációs-kulturális szint témánk szempontjából a legfontosabbnak tekinthetö. A globalizáció révén ugyanis nemcsak termékek áramolnak a világ egyik részéből a másikba, hanem a kultúra egyes elemei is. A migrációs folyamat eredményeként ma már világméretekben elterjedt az, amit a szakirodalom ún. davosi kultúraként hív. ${ }^{1}$ A davosi kultúra arra utal, hogy a világnak van egy olyan elitje, amely azonos kulturális elemek birtokában van. Ennek alapja mindenekelött az angol nyelv és a nyugati típusú fogyasztói kultúra elterjedése. A davosi kultúra döntő mértékben a nyugati civilizáció sajátosságait hordozza magán. Vajon a davosi kultúra előmozdítja egy egységes világcivilizáció vagy globális civilizáció kialakulását? A globális civilizáció létrejöttét katalizáló tényezők közül a szakirodalom négyet említ: a globális gazdaságot, a nemzetközi akadémiai elitet, az ún. hamburgerkultúrát vagy McWorld-öt és az evangélikus protestantizmust. A négy tényező vonatkozásában a közös hordozóelem az angol nyelv (V. ö. GombÁr Cs. 2000 p. 28.). Az egységes civilizáció létrejötte előtt azonban komoly korlátok állnak. Mindenekelőtt a globalizáció univerzalizmusa elleni kulturális védekezésként a lokális identitások felerősödése.

Azúj világrend és a felgyorsult globalizáció sajátos-témánk szempontjából - fontos jellemzőit az alábbiakban foglalhatjuk össze.

1. A tér és idő szerepének átértékelödése a nemzetközi kapcsolatokban. A globalizáció eredményeként közhely, hogy a világ egy „globális faluvá" vált. Mára alapvetően elfogadott ténnyé vált, hogy a nyugati időszámítás vált általánosan használttá a Földünkön. A Nyugaton kívüli civilizációk időszemlélete eltérő. Elegendő arra gondolni, hogy az iszlám civilizációban a hidzsra tekinthető az időszámítás kezdetének. Egy esztendő pedig nem fedi le a nyugati időszámítás szerinti évet. A nyugati időszámítás világméretű elterjedése a gyarmatosítással, illetve az egységes világgazdaság kialakulásával hozható összefüggésbe. A számos tekintetben

1 A svájci Davos az évenként megrendezésre kerülő világgazdasági fórum színhelye. 
történelmi mérföldkőnek tartott második évezred a világ Európán kívüli népei számára nem jelent érdemben semmit. A nemzetközi gazdasági és pénzügyi folyamatok, illetve döntések alapja, hogy megfelelő időben információhoz jussanak a döntéshozók. A nemzetközi kapcsolatokban a területiség jelentősége fokozatosan csökken, vagyis a nemzetközi rendszer deterritorializálódik (Lásd Kiss J. LÁszLó 2003 p. 82.). Napjaink háborúira már nem jellemző a területszerző jelleg, mint az elmúlt évszázadokra. Egy államnak a másik állam fölötti befolyásszerzéséhez nem szükséges területet foglalnia, hiszen elegendő gazdasági szempontból érvényesíteni a nemzeti érdekeket. A deterritorializációval egyidejüleg azonban nem csökkent az olyan területek jelentősége, amelyek egy nép vagy közösség identitásában jelentős szerepet töltenek be. Az ún. szakrális terek gyakran fegyveres konfliktusok fő forrásává válnak (BADIE, BERTRAND - SMOUTS, Marie-Claude 1998 pp. 50-52.). Például az Egyesült Államok 2018ban úgy döntött, hogy az amerikai követséget Tel Avivból Jeruzsálembe helyezi át, ezzel kvázi a zsidó állam egy és oszthatatlan fővárosaként ismerve el azt. Jeruzsálem pedig mindhárom monoteista vallás számára kitüntetett helyet foglal el. De említhetjük példaként a tokiói Jaszukuniszentélyt, amely az 1869 óta kül- és belháborúkban elesetteknek, köztük a második világháborús áldozatoknak állít emléket. Kínában, amelyet Japán leigázott, rendszeres tüntetések robbannak ki, amikor az éppen aktuális japán miniszterelnök ellátogat ebbe a szentélybe, amellyel feltépi a történelmi sebeket.

2. Ipari forradalom 4.0. A 21. század elején zajló rendkívül gyors technikai és mindenekelőtt a kommunikációt érintő változásokat a negyedik ipari forradalomként tartja számon a szakirodalom. A kommunikációs fejlődés - az új média - alapvető változásokat hoz a nemzetközi kapcsolatokban. A világhálón gyakorlatilag valós időben értesülünk az eseményekröl, kvázi részesei leszünk. A 2001. szeptember 11-i Egyesült Államokat érő terrortámadás részesei lehettünk, amennyiben a világhálón vagy a televízióban követtük az eseményeket. A mesterséges intelligencia megjelenése alapvetően átformálhatja a kulturális közösségek identitását. Egyáltalán képes-e a mesterséges intelligencia olyan érzések, érzelmek kifejezésére, vagy történelmi narratívák megfogalmazására, amelyek az emberi közösségeket kulturálisan elkülönítik egymástól? Avagy éppen a mesterséges intelligencia segítségével fejlődhet ki egy globális identitás? A negyedik ipari forradalom a maga technológiai megújulásával együtt alapvetően érinteni fogja a kulturálisan meghatározott közösségeket.

3. Fejlödési szakadék kiszélesedése. A globalizációs folyamat kapcsán az egyik legjelentősebb kérdés a fejlett Észak és a fejlődő Dél közötti fejlettségbeli szakadék kérdése. A globalizációs folyamat gazdasági 
értelemben vett nyerteseként említhető az Észak, a nyugati világ, míg a vesztesek elsősorban a szubszaharai Afrika térségéből kerülnek ki. A globalizáció eredményeként a fejlődési szakadék kitágult, vagyis míg az Észak továbbhalmozta a nyereséget, és jóléti rendszereket épített ki, addig a Dél bizonyos területein növekedtek a szegénységi mutatók. Az ENSZ statisztikái szerint a világ lakosságának egy százaléka birtokolja a világ jövedelmeinek 50,1 százalékát (The Guardian 2017). A 2000-es években az ENSZ és a vonatkozó szakosított intézmények felismerik az Észak és a Dél belső tagoltságát is, így különféle jövedelmi kategóriákba sorolják az államokat. Az ENSZ 2000-ben elfogadott nyolc Millenniumi Fejlesztési célja hivatott a fejlődési szakadékot felszámolni. A fejlödés kapcsán világosan látszik, hogy bizonyos országcsoportok (pl. kistigrisek) sikeresebbek mint mások (pl. szubszaharai afrikai államok). A kérdés, hogy a civilizációs-kulturális tényező játszik-e bármilyen szerepet a fejlődésben. Egyes vélemények szerint ugyanis a kistigrisek fejlődésében az ún. konfuciánus etika jelentős szerepet töltött be. Vajon a vallás, illetve a kulturális hagyományok szerepének felértékelődése hogyan érinti a fejlődési szakadék kérdését, különösen a Dél felzárkózását?

4. Aretradicionalizáció jelensége. Azúj világrend egyikjellegzetessége, hogy egyes régiókban a hagyományok - legyenek vallásiak vagy kulturálisak felértékelődnek, és manifesztálódnak a közösségi térben és politikában. A retradicionalizáció egyaránt jellemzi a nyugati és a nem nyugati világot. Minden esetben a háttérben valamilyen identitásválság húzódik meg, amelynek eredményeként a közösséget érintő kihívásokat a hagyományok újraértelmezésével kísérlik meg megoldani. Az identitásválság mellett nem egy esetben a modernizáció, a fejlődés válsága áll a háttérben. A retradicionalizáció valamennyi formájában válaszokat kíván - egy sajátos ideológiával ötvözve - azokra a kihívásokra, amelyek a közösség identitását és kohézióját fenyegetik (lásd bővebben RosTováNYI ZsOLT 2005). Európában például a szélsőjobboldal gyakorta a nacionalizmus egy extrém formájával próbál választ adni olyan kihívásokra, mint az európai muszlim kisebbségek integrálásának nehézségei. Indiában a magát hindu nacionalistának nevező párt, a Bharatíja Dzsanata Párt a választ a brit kolonializmust követően adaptált bizonyos értékek (pl. szekularizmus) felülvizsgálatában látja, és megoldásként a hindu vallás és kultúra alapelveit kívánja bevezetni.

5. A migráció folyamatának élénkülése. Témánk szempontjából kiemelkedő jelentősége van a migráció jelenségének, amely lehetővé teszi a civilizációk és a kultúrák találkozását. Az ENSZ 2017-es nemzetközi migrációs jelentése szerint 258 millió före tehető azon személyek száma, akik a szülőföldjüktől különböző állam területén élnek. Ez 2000-hez 
képest 49 százalékos emelkedést jelent. 2017-ben a Föld lakosságának 3,4 százaléka tekinthető migránsnak. A 258 millió főből 164 millió a fejlett, magas jövedelmü államokban él jelenleg. A migráció elsősorban a fejlett nyugati világ (Európa és Észak-Amerika) felé irányul, ugyanakkor tízmilliós nagyságrendben Latin-Amerikán, Afrikán és Ázsián belül is végbemegy a folyamat. Jelenleg a legtöbb ember, aki szülőhazáján kívül él indiai (17 millió). (UNITED NATIONS 2017) A migráció összetett folyamat, amelyben gazdasági, politikai és kulturális okok egyaránt szerepet játszanak. Az elmúlt évtizedek technikai újításai bizonyos szempontból megkönnyítették a migrációt, ugyanakkor a kulturális hatások elleni védekezésként, politikai okokból nehezebbé vált a fejlett nyugati világ irányába folyó migráció. Természetesen jelen kötet kereteit meghaladja, hogy e folyamat politikai, gazdasági és jogi hátteréről írjunk, ugyanakkor a háborúk, ill. egyéb okok miatt hazájukat elhagyó menekültek kérdését mindenképpen külön kell kezelni. A migrációs folyamat eredményeként akár nagyobb etnikai vagy vallási csoportok is letelepedhetnek egy adott államban. Az Európai Unió területén mintegy 30-40 millió muszlim él, akik gyakran már a második vagy a harmadik generációhoz tartoznak. Európában jelenleg a legnagyobb viták éppen a muszlim közösség integrálódásának nehézségeivel kapcsolatosak.

6. A terrorcselekmények számának növekedése. A terrorizmus egyike azon fogalmaknak, amelyeket nem lehet könnyen definiálni, hiszen több mint száz meghatározása létezik. Ugyanakkor a civil lakosság megfélemlítése végett elkövetett merényletek száma jelentősen emelkedett az elmúlt két-három évtizedben. A 2001. szeptember 11-i terrormerénylet alapjaiban rázta meg az Egyesült Államokat, illetve közvetve a nyugati világot. A globális terrorizmus index alapján 2017-ben öt ország (Irak, Afganisztán, Nigéria, Szíria és Pakisztán) állt a terrorista merényletek számát tekintve az élen (Global Terrorism INDEx 2017). Európában - az elmúlt évek merényleteit figyelembe véve - óriási viták folynak a terrorizmus civilizációs-kulturális meghatározottságáról. Egyes elemzők iszlám terrorizmusról beszélnek, miközben a kereszténység védelme nevében elkövetett merényletekkel kapcsolatban (pl. Utøya 2011) elutasítják a kifejezés használatát (lásd később). A terrorizmus kapcsán tehát különféle politikai narratívák láttak napvilágot. Az egyes államok megbélyegzésekor azonban a terrorizmus kifejezésnek a használata kifejezetten delegitimációs tényező is egyben.

7. A vallás szerepének felértékelödése. A posztbipoláris nemzetközi rendszerben a vallásnak meghatározó szerepe van. A napi világpolitikai döntésekben, illetve a politikai diskurzusokban a vallás mint fontos tényező jelenik meg (Badie, Bertrand - Smouts, Marie-Claude 1998 pp. 50- 
66.). Elegendő például arra utalnunk, hogy a mindenkori amerikai elnök a Bibliára esküszik fel beiktatási szertartásán. Témánk szempontjából pedig kiemelhető, hogy amennyiben két eltérő kultúrkörhöz tartozó állam háborús konfliktusba kerül egymással, akkor a vallás gyakran hivatkozási alapként jelenik meg. Például Geroge W. Bush amerikai elnök a 2001-es afganisztáni beavatkozást egy „hosszú keresztes hadjáratnak” nevezte, utalva a keresztesek történelmi szerepére a Szentföldön. A vallás mint hivatkozási alap - különös tekintettel - megjelenik az ún. vallási fundamentalista csoportok retorikájában. A vallási fundamentalizmus általában egy válsághelyzetre adott válasz. Az adott társadalmi csoport ugyanis gyakran a vallási tradíciókat alkalmazza egy adott probléma felmerülésekor. A vallási fundamentalizmus gyakran radikalizmussal párosul. Az Oszama bin Láden által alapított Zsidók és Keresztesek Elleni Dzsihád Iszlám Világfrontja például az 1998-ban kiadott fatvája alapján valamennyi muszlim kötelességének tekinti a dzsihádot, jelen esetben figyelmen kívül hagyva annak különböző jelentéseit, és szent háborúként fordítva azt.

8. A nemzetállami szuverenitás átalakulása. Az ún. felgyorsult globalizációs folyamat érinti az állami szuverenitást is. Klasszikus értelemben a nemzetközi aktorok közül csak az államok rendelkeznek külső és belső szuverenitással. Egyes vélemények szerint a globalizáció csökkenti az állami szuverenitást, ugyanakkor helyesebb talán arra utalni, hogy a nemzetállamok cselekvőképessége átalakul a nemzetközi rendszer alakváltozásával (Kiss J. LÁszló 2003 pp. 225-248.; SCRUTON, ROGER 2005 pp. 121-148.). Azon államok, amelyek a globalizációs folyamatot elutasítják, jelentős mértékben veszítenek ezen. Pl. Észak-Korea autarchikus fejlődési modellje sem tekinthető sikeres példának.

9. A modern, premodern és posztmodern struktúrák egyidejüsége. Miközben a nemzetközi kapcsolatokban továbbra is az államok (a modern kategória) a meghatározó szereplők, addig egyre nagyobb a súlya az állam alatti és feletti szereplőknek. Az új világrend egyik paradoxona, hogy a nemzetközi rendszerben egyidejüleg vannak jelen modern, premodern és posztmodern struktúrák. A premodern jelenségek közé sorolható például a törzsiség jelentősége Afrikában. Az Afrika első világháborújaként emlegetett kongói háborúba a környező államok - többek között - azért sodródtak bele, mert a határokon átnyúló törzsi csoportok érdekeltek voltak ebben. Posztmodern struktúrának tekinthető például a Greenpeace, amely a maga eszközeivel képviseli a fenntartható fejlödés szempontjait a nemzetközi kapcsolatokban, és mint ilyen, befolyást próbál gyakorolni az államok magatartására. 
1. Bevezetés a regionális-civilizációs tanulmányokba

\subsection{Az új világrend vetélkedő paradigmái}

Az 1990-es években a nemzetközi kapcsolatokkal foglalkozó kutatók egy olyan magyarázó elméletet próbáltak keresni, amely valamilyen elméleti keret alapján leírja a fentiekben ismertetett folyamatokat. Az Egyesült Államokban, az 1990-es években két olyan tudóst említhetünk, akiknek a vitája rányomja a bélyegét az új világrenddel kapcsolatos gondolkodásra.

Az ún. optimista forgatókönyvet testesíti meg Francis Fukuyamának A történelem vége és az utolsó ember címmel magyar nyelven is hozzáférhető kötete (FukuYama, Francis 1992). Fukuyama, aki a nemzetközi kapcsolatok elméletének liberális iskolájából indul $\mathrm{ki}$, olyan folyamatokat lát a világpolitikában, amelyek pozitív irányba haladnak. 1991-ben a Szovjetunió nem egy nagy háború keretében bomlott fel, hanem elsősorban békés úton. Az ideológiák korának lejártával - Fukuyama meglátása szerint - a nyugati értékek (mint a demokrácia, az emberijogok, a szabad piacgazdaság) győzedelmeskednek a Földön. A demokráciák elterjedése pedig egyben a történelem végét is jelenti, a történelmünket végigkísérő háborúk megelőzhetők lesznek, ugyanis a demokráciák - a liberális felfogás szerint - nem háborúznak egymással. Valóban, ha az 1990-es években az éppen a nagy rivális - Huntington - által a demokratizáció harmadik hullámának tekintett folyamatra ránézünk, akkor azt látjuk, hogy nemcsak Európa keleti felén, hanem mindenekelőtt Ázsiában és Afrikában is terjedni kezdett a demokrácia. Fukuyama nézeteit ugyanis az a gondolat is meghatározza, hogy a nyugati értékek szükségszerúen univerzális értékek, azoknak előbb vagy utóbb az egész Földön el kell terjedni. A történelem végének egyetlen korlátja szerinte a szélsőséges nacionalizmus erősödésében keresendő, amelynek egyik megjelenési formája, éppen az 1990-es évek elején kirobbanó délszláv válság.

Az új világrend kapcsán a pesszimista forgatókönyvet képviseli az amerikai politológus Samuel P. Huntington, aki az új világrenddel kapcsolatos állításait először az 1993-ban a Foreign Affairs keretében megjelent cikkében foglalta össze (Huntington, SAmuel P. 1993). Huntington szerint az ideológiák korának végével a nyugati értékek nem győzedelmeskednek, hanem éppen ellenkezőleg, a civilizációs-kulturális különbségek felerösödnek. A később könyvvé formálódott elmélet $A$ civilizációk összecsapása és a világrend átalakulása néven jelent meg, amelynek központi tézisévé vált a címben is szereplő gondolat (Huntington, SAmuel P. 1998). Huntington szerint a fegyveres konfliktusok hátterében minden esetben a civilizációs-kulturális különbségek húzódnak meg. Példaként Jugoszlávia szétesését hozza, amennyiben a délszláv válság keretében három civilizációhoz - a nyugati kereszténységhez (Szlovénia, Horvátország), az ortodox kereszténységhez (Szerbia), illetve az iszlámhoz (BoszniaHercegovina) sorolható - tagköztársaságok között fegyveres konfliktusok 
sorozata bontakozott ki. Huntington elmélete, amelyet a későbbiek folyamán részletekbe menően bemutatunk, nem tekinthető minden téren újdonságnak.

Huntington könyvében öt lehetséges paradigmát említ, amelyek közül az ötödik éppen a civilizációs elmélet, amely alapjaiban meghaladja az első négy elmélet hiányosságait (Huntington, SAmuel P. 1998 pp. 30-39). Az első az ún. egy világ elmélet, amely lényegében a nagy ellenfél, Fukuyama koncepcióját jelenti. Ehelyütt nem ismételnénk meg Fukuyama gondolatait, ugyanakkor arra érdemes utalni, hogy Huntington szerint az elmélet több szempontból sem állja meg a helyét. Egyrészt abból, hogy a demokratizáció harmadik hulláma az 1989-es eseményeket követő években világméretekben kiterjedt, nem lehet azt a következtetést levonni, hogy az államok közötti szembenállás véget ért volna. Huntington éppen Jugoszlávia szétesését, valamint az afrikai kontinensen kirobbant törzsi jellegü háborúkat emlegeti példaként, amelyek szerinte megcáfolják a Fukuyama által a kanti örökbéke koncepcióra épülő víziót.

A második magyarázó elmélet az ún. két világ paradigma, amely vizsgálható Észak és Dél, ill. Kelet és Nyugat szembeállításként. Az új világrendet a fejlett Észak és a fejlődő Dél konfliktusaként meghatározó elmélet abból indul ki, hogy a globalizáció felgyorsulásával az erőforrásokért folytatott harc új szakasza kezdődik. Valamennyi világpolitikai szintü, akár fegyveres erő alkalmazásával együtt járó konfliktusokban jelen van a gazdasági szempont azok szerint, akik Észak-Dél összecsapásként írják le az új világrendet. Edward Lutwak például ún. geoökonómiai háborúkról beszél, amelyben pusztán a gazdasági szükségletek kielégítése játszik szerepet (LuTwAK, EDWARD N. 1990 pp. 17-23.). Ennek egyik kitünő példája az 1990-ben kirobbanó öbölháború, amelynek keretében az ENSZ Biztonsági Tanácsának felhatalmazásával az Egyesült Államok meghirdette Kuvait felszabadítását. Az elmélet szerint az Egyesült Államok testesítette meg a fejlett Északot, míg a Szaddám Huszein vezette Irak a Délt. A harc pedig kifejezetten az olajkészletek feletti ellenőrzésről szólt. Az elmélet meglehetősen leegyszerüsítő, ugyanis számos esetben nem érhető tetten egy háborús konfliktusban ilyen mértékben a gazdasági szempont, illetve az önmagában nem magyarázza a fegyveres összecsapás közvetlen okait. Az olaj mint szempont kétségtelenül szerepet játszott a Sivatagi Vihar nevü hadmüvelet megindításában, ugyanakkor leegyszerüsítés lenne azt állítani, hogy pusztán az olajért indultak az amerikaiak háborúba. A két világ paradigma másik lehetséges értelmezése a Kelet-Nyugat konfliktusként való beállítás. Tulajdonképpen az elmélet abból indul ki, hogy a nem nyugati területek a Nyugat jelenlegi fölényét kísérlik meg elhódítani. Az előbbiekben említett öbölháború több szempontból is jó hasonlat. Szaddám Huszein ugyanis megkísérelte a történelmi kolonializmushoz hasonlítani a második öbölháborút, amelyben az Egyesült Államok egy harmadik világbeli államot kísérel meg leigázni. Az iraki elnök elsősorban a Közel-Kelet és a tágabb harmadik világ közvéleményét 
kísérelte meg meggyőzni. Valójában azonban a „keletiként” aposztrofált államok egy része - pl. Egyiptom, Szíria - éppen az Egyesült Államokat támogatta a fenti konfliktusban. Huntington szerint a Kelet valójában minden, ami nem nyugati: the West and the Rest. Ankerl Géza arra utal a könyvében, hogy míg a nyugati világ egységes szempontok szerint épül fel, és egy szerves fejlödés keretében alakult ki, addig Keletröl ebben az értelemben nem beszélhetünk. A keleti kultúrák teljesen eltérő hagyományokkal és értékekkel rendelkeznek, és nem tekinthetök egységesnek (ANKERL GÉZA 2000).

A harmadik elmélet az ún. 184 állam paradigmája. Az elmélet a nemzetközi kapcsolatok elméletének klasszikus magyarázó elméletére, az ún. realista nézőpontra utal, amely szerint az egyes államok nemzeti érdekei ütköznek az új világrendben kialakult fegyveres konfliktusok során. Valójában a realista paradigma abból indul ki, hogy a megváltozott nemzetközi viszonyok ellenére is a nemzetközi kapcsolatok föszereplői maguk az államok, amelyek önérdekkövetőek, és fegyveres konfliktusokba keverednek. Ez a magyarázó paradigma kézenfekvő, ugyanakkor Huntington szerint meghaladottnak tekinthető annyiban, hogy nem veszi például figyelembe az államok alatti és feletti szereplőket, illetve a premodern és posztmodern struktúrákat.

A negyedik elméletet a nem egy esetben divatossá vált teljes káosz paradigmája testesíti meg. Az új világrenddel kapcsolatban számos - fóként amerikai - gondolkodó pesszimista nézeteket fogalmazott meg. Az új világrendet úgy írják le, amelyben a nemzetközi kooperáció legkisebb formája sem érvényesül, a nemzetközi jog pedig nem akadályozza meg az államok közötti konfliktusokat. John J. Mearsheimer „vissza a jövőbe” elmélete például 1990-ben látott napvilágot, és Európa területén a hidegháborús szembenállásnál jelentősebb konfliktusokat vetít előre (MEARSHEIMER, JoHN J. 1990 pp. 5-56.). Például az egységes Németország szerepét negatívan látja az európai erőegyensúly kapcsán. Huntington azzal fordul szembe az anarchia koncepciójával, hogy az új világrend alatt a nemzetközi jog, illetve a nemzetközi szervezetek továbbra is féken tartják az államokat, illetve a kooperáció jelei napi szinten jelen vannak. Az első négy elméletet elvetve fejti ki a korábbiakban röviden bemutatott civilizációk összecsapásának tézisét, az ötödik paradigmát, amely alapjaiban meghaladja az első négyet.

A 20. század elején két különböző nyelvterületen munkálkodó történész foglalkozott a civilizációs folyamatokkal. A német nyelvterületen a világháború generálta pesszimizmus egyik hangadója Oswald Spengler, akinek A Nyugat alkonya címen megjelent munkája a napjainkban az Európa jövőjéről szóló vitákban hivatkozási alapként merül fel (SPENGLER, Oswald 1994). Spengler szerint a történelemben több kultúra létezett, amelyek közül több mára megszünt létezni (pl. ókori Egyiptom). Véleménye szerint a civilizációk ciklikus fejlődésen mennek keresztül. A Nyugat szerinte a hanyatlás stádiumába 
került. Spengler nyolc magaskultúrát különböztet meg: az antik, az arab, a nyugati, a babiloni, az egyiptomi, a kínai, az indiai és a mexikói kultúrákat. Felfogása teleológikus, vagyis - a biológiai törvényszerüségek következtében elkerülhetetlen a hanyatlás. Spengler szerint valamennyi magaskultúra átmegy ugyanazon fejlődési szakaszokon, amelyek az előidő, a koraidő, a kései kor és a hanyatlás korszaka, amelyet a civilizációval azonosít. Véleménye szerint a nyugati civilizáció története az első évezred környékén kezdődött. Az ipari forradalom, a pénz elterjedése, a városiasodás szerinte a hanyatlás szimbólumai. A Spengler-féle megközelítés megkülönbözteti a magaskultúra fogalmát a civilizációtól. Az utóbbi szükségképpen a hanyatlás folyamatához tartozik. Szerinte az ipari forradalommal és az urbanizációval egyidejüleg a nyugati civilizáció a hanyatlás korszakába lépett, a civilizáció szakaszába, amelyet nem lehet megállítani, ugyanis egy fatalista determinizmus érvényesül.

$\mathrm{Az}$ angolszász nyelvterület egyik meghatározó gondolkodója Arnold Toynbee A Study of History címü 12 kötetes munkájában alapvetően bírálja kortársa, Oswald Spengler munkásságát (ToYnBEE, ARNOLD 1988). Toynbee szerint is a civilizációk megszületnek, majd elérik fénykorukat és hanyatlani kezdenek, végül pedig eltünnek. Toynbee elveti Spenglernek azt a nézetét, amely a fatalista determinizmusra utal, illetve bírálja a magaskultúra zártságának elméletét. Toynbee abban azonban egyetért Spenglerrel, hogy a nyugati civilizáció a hanyatló korszakba lépett, azonban bírálja annak determinista jellegű gondolkodását. Toynbee szerint ugyanis egy kreatív kisebbség újításaival megmentheti a civilizációt a pusztulástól. A civilizációkat mindig is érték külső hatások, amelyek előkészítették a megújulást. Tekintve a nyugati civilizáció történelmét a Toynbee féle megújulásnak lehetnek alapjai.

Ugyancsak Huntingtont több évvel megelőzve fogalmazza meg az orientalisták doyenjeként számon tartott, nemrégiben elhunyt Bernard Lewis a civilizációk szembenállásának a tételét. Lewis elsősorban a Közel-Kelettel, és azon belül is az iszlám világgal foglalkozó tudós, aki a The Roots of Muslim Rage címmel 1990-ben az Atlantic Monthly-ban publikált tanulmányában fejtette ki az iszlám világban megfigyelhető nyugatellenesség, döntő mértékben anti-amerikanizmus alapjait. Lewis szerint elsősorban Washington Közel-Kelet politikája tehető felelőssé azért a frusztrációért, amely végső soron a vallási fundamentalizmust táplálja. Ez utóbbi kifejezetten szemben áll a szekularizmus, illetve a modernitás értékeivel (Lewis, BeRnARD 1990 pp. 47-60.). Bernard Lewis-hoz hasonlóan Tariq Ali a ,fundamentalizmusok összecsapásaként” értelmezi az iszlám és a nyugati civilizáció közötti törésvonalat (ALI, TARIQ 2002).

A civilizációs szembenállás nézete megjelenik Benjamin Barber Jihad vs. McWorld címü munkájában is (BARBER, BENJAMIN 1995). Barber munkásságának a lényege, hogy a demokrácia világméretü elterjedésének lehetőségeit vizsgálja. 
1. Bevezetés a regionális-civilizációs tanulmányokba

A McVilágot a globalizáció erőivel azonosítja, amelyben a pénzügyi szektor, a bankvilág normái érvényesülnek. A dzsihád pedig a globalizációval szemben védekező jellegü, célja a helyi identitás megvédése a külső hatásoktól. Barber annyiban pesszimista, hogy sem a McVilág, sem a dzsihád nem tekinthetök demokratikus erőknek.

Huntington gondolatmenete tehát annyiban újszerü, hogy a fenti nézetek nála kapcsolódnak össze egy koherens egésszé. Huntington talán az első az új világrend gondolkodói közül, akik a nemzetközi politikai viszonyokra tekintettel alkalmazzák a civilizációk összecsapásának tézisét. Mielőtt azonban az elméletben elmerülünk, érdemes bevezető jelleggel néhány alapfogalmat tisztázni.

\subsection{Civilizáció és kultúra fogalma(k) és értelmezése(k)}

Talán kevés olyan kifejezés van, amely annyira szerteágazó értelmezéssel bír, mint a civilizáció és a kultúra. Az adott nyelvterületen élö közösség számára mást és mást jelent a terminus. Ráadásul bonyolulttá teszi a helyzetet, hogy míg egyes nyelvterületeken (angolszász világ) a civilizáció és kultúra fogalma közé gyakran egyenlöségjelet tesznek, addig más közösségek különbséget tesznek a kettő között.

Vitányi Iván tanulmányában megállapítja, hogy a kultúraértelmezésekben közös, hogy a kultúrának van alanya, tárgya, cselekménye és eredménye (az objektiváció) (VITÁNYI IvÁN 2002). A kultúrának az alanya az ember vagy a tágabb közösség, amely végzi a tevékenységet. Az egyes kultúrák például abban is különböznek a többitől, hogy az egyént lehet-e önmagában értelmezni, avagy csak a közösség részeként. Az individualista jellegủ nyugati kultúra alapvetően eltér az inkább közösségi alapon szerveződő nem nyugati kultúráktól. A kultúraértelmezések általában két nagy csoportba sorolhatók, attól függően, hogy mi áll a középpontjukban. Az ún. antropológiai kultúraértelmezések középpontjában a kultúra alanya, az ember vagy emberek csoportjai állnak, míg az ún. objektivációs kultúraértelmezések a tevékenység eredményét, az objektivációt állítják a középpontba. A kultúra a latinból származik, ahol elsősorban földművelést jelent.

A civilizáció fogalmunk a francia forradalommal egyidős, és elsősorban a barbár, primitív társadalommal való szembeállításként jelent meg. A köznyelvben napjainkban is egy negatív jelenséggel szembeállítva használjuk a fogalmat. Például ha egy elmaradott területröl visszatérünk a fejlett városba, gyakran mondjuk, hogy „,visszatérünk a civilizációba”. Jelen munka, illetve Huntington elmélete kifejezetten szembehelyezkedik a civilizáció fogalmának ilyen értelemben vett alkalmazásával. Huntington, aki az angolszász nyelvterület képviselője gyakorlatilag nem lát lényegi különbséget a civilizáció és a kultúra 
fogalma között. A kultúra: „olyan társadalmi jelentéstartalmak összessége, amely megkülönbözteti az egyes népcsoportokat másoktól" (HunTington, SAmuel P. 1998 pp. 48-57.). A civilizáció legfontosabb összetevői: a nyelv, a vallás, a hagyományok, a közös történelem stb. Huntington e tényezők közül a vallást tartja a legfontosabbnak, ugyanis véleménye szerint valamennyi valaha is létező civilizáció egy önálló vallással jellemezhető leginkább. A civilizációt és a kultúrát pusztán térbeli és időbeni kiterjedése különbözeti meg, ugyanis a „civilizáció a legtágabb kulturális entitás” (Huntington, SAmuel P. 1998 p. 53.).

Egyes nyelvterületeken - különösen a német kultúrkörben - élesen szembeállítják a civilizáció és kultúra fogalmát, amely az arisztokrácia és a polgárság közötti ellentétekre vezethető vissza. A kultúra gyakran a szellemiintellektuális teljesítményeket fejezi ki, a müvészetek mellett a tudományokat is ide sorolják. A civilizációt a materiális eredményekkel azonosították, és a kultúra felsőbbrendűségét hangsúlyozták. Ezzel szemben az angolszász nyelvterület lényegében azonos értelemben használja a civilizáció és a kultúra fogalmát. ${ }^{2}$

A civilizáció fogalmát használhatjuk egyes vagy többes számban. A civilizáció egyes számban arra a korábbiakban is említett vitára utal, hogy vajon kifejlődhet-e egy világcivilizáció vagy globális civilizáció, amely megszünteti a kulturális különbségeket. A téma azért is érdekes, hiszen az új világrend jellegzetességei kapcsán utaltunk a migráció jelenségére, amelynek keretében a kulturális értékek hazát cserélnek. Vajon milyen hatással lehetnek egymásra a kultúrák és civilizációk, ha találkoznak egymással? Általában négyféle együttélési modellt lehet említeni (Tariq Modood alapján):

$\oplus$ Az asszimiláció, amikor is az adott kultúra beolvad a fogadó állam kultúrájába, a közösség elveszíti kulturális jellegzetességeit.

$\oplus \mathrm{Az}$ individualista integráció, az együttélés az egyéni és nem közösségi szinten valósul meg. Ebben az esetben a kisebbség integrálódik, és közösségként nem jelenik meg a közösségi szférában.

$\oplus$ A multikulturalizmus normatív értelemben pedig azt jelenti, amikor a fogadó állam kultúrája párhuzamosan egymás mellett létezik az idegen kultúrával, és egyik sem törekszik a másik megszüntetésére. A két vagy több kultúra között egyenrangú viszony áll fenn az adott társadalomban.

$\oplus$ A kozmopolitanizmust többen a multikulturalizmus egyik formájának tartják. A lényegi különbség a kettő között, hogy míg a multikulturalizmus esetén a csoportnak vagy közösségnek politikai és polgári jogai vannak, addig a másik esetben ez nem lényeges sajátosság (MODOOD, TARIQ 2011).

2 Jelen írás kereteit meghaladja, hogy részletesen bemutassa, hogy az európai filozófiai gondolkodásban mikor és hogyan értelmezték a kultúra fogalmát (lásd bővebben WeSSELY ANNA 2003 pp. 7-27.). 
Amennyiben az együttélési modellek nem müködnek, úgy az ellentétet a szegregáció modellje képviseli. A szegregáció esetén a kisebbség kiszorul a társadalom perifériájára, annak jogait sem egyéni, sem közösségi szinten nem ismerik el. Leegyszerüsítve a fenti eseteket az asszimiláció, integráció és szegregáció hármasságát különíthetjük el, mint az adott társadalom és az idegen kultúra közötti kapcsolatok három modelljét (Lásd FeISCHMIDT Margit 1997 pp. 7-29.).

A fenti elméletek kapcsán óriási viták bontakoztak ki arról, hogy melyik tekinthető a kívánatos modellnek. Az európai kultúrkörben a viták összefonódnak a mintegy 30-40 millió lélekszámot kitevő muszlim kisebbség integrálásának kérdésével. Európai politikusok - köztük Angela Merkel vagy David Cameron - nem egy alkalommal hangoztatták, hogy a multikulturalizmus nem oldja meg a problémákat, és valójában párhuzamos társadalmak kialakulásához vezet. Kérdéses azonban, hogy egyáltalán beszélhetünk-e arról Európában, hogy a multikulturalizmus modelljét valóban alkalmazták a kisebbségek integrációja kapcsán.

Az egyes számban használt civilizációfogalom kapcsán számos dilemma merül fel. A korábbiakban láthattuk, hogy a fragmentáció és lokalizáció eredményeként a kultúrák a globalizáció univerzalizáló hatásával szemben védekeznek. Így miközben a Föld jómódú elitje (lásd korábban davosi kultúra) egy és ugyanazon angol nyelvet beszéli, hasonló életvitel szerint él, és hasonló termékeket fogyaszt, a kulturális különbségek mégsem szünnek meg.

Az általunk bemutatott szerzők többsége a civilizációt többes számban használja. Spengler, Toynbee és Huntington is arról értekezik, hogy egy adott időben, egymás mellett párhuzamosan több civilizáció létezik. A civilizációk között pedig az értékeik alapján nem lehet különbséget tenni. Minden egyénnek vagy közösségnek az a magasabb rendü civilizáció, amelyikben született, ugyanis a világról és a transzcendentális kérdésekről vallott felfogás kulturálisan determinált. Például Huntington szerint jelenleg hét vagy nyolc civilizáció létezik egyidejüleg, amelyek jól elkülöníthető civilizációs jellemzőkkel írhatók le. A hét vagy nyolc civilizáció a következő (a felsorolás nem jelent rangsort):

$\oplus$ a nyugati, amelynek két alcivilizációja van: az európai és az északamerikai,

$\oplus$ az ortodox-orosz civilizáció, amelynek központi eleme az ortodox kereszténység,

$\oplus$ a hindu-indiai,

$\oplus$ az iszlám civilizáció,

$\oplus$ a konfuciánus-kínai civilizáció,

$\oplus$ a japán civilizáció,

$\oplus$ a latin-amerikai és

$\oplus$ az afrikai civilizáció. 
Az utolsó két civilizáció kapcsán Huntington tulajdonképpen magával is vitatkozik annyiban, hogy mennyiben tekinthető a latin-amerikai vagy az afrikai civilizáció önálló civilizációnak. Latin-Amerika kapcsán a spanyol nyelv és a nyugati kereszténység (a „legkatolikusabb” kontinens) valójában a nyugati civilizációhoz való tartozást sugallja. Huntington mégis amellett érvel, hogy a Latin-Amerikát érő külső hatások - ősi helyi kultúrák, az afrikai rabszolgák behurcolása, illetve a nyugati hatások - találkozása eredményeként valami új alakult ki. Afrika kapcsán azonban az olvasóra bízza a civilizációs meghatározottság eldöntését. Ennek elsődleges oka, hogy miután a civilizáció központjában a vallás áll, az afrikai kontinens meglehetősen megosztott vallásilag (iszlám, kereszténység, animizmus), illetve közös nyelvvel sem rendelkezik, így kérdéses, hogy a huntingtoni meghatározás értelmében van-e bármilyen értelme egységes civilizációról beszélni (Huntington, Samuel P. 1998 pp. 57-62.). Huntington tehát Fukuyamával és sok más gondolkodóval (pl. Amartya Sen) szemben úgy látja, hogy a nyugati értékek nem univerzálisak, hanem azok elsődlegesen a nyugati civilizációra jellemzőek. Továbbá a hét vagy nyolc civilizáció egymástól eltérő értékrendszerrel rendelkezik, amelyek megkülönbözetik az egyik civilizációt az összes többitől. Huntington azonban - a nyugati civilizáció kivételével - adós marad a civilizációs értékek tételes felsorolását illetően.

Véleménye szerint a nyugati civilizációt az alábbi nyolc jellemző egyidejü meglétével lehet definiálni (Huntington, SAMuel P. 1998 pp. 101-104.):

$\oplus$ klasszikus örökség,

$\oplus$ nyugati kereszténység,

$\oplus$ európai nyelvek,

$\oplus$ a világi és a spirituális tekintély elkülönülése,

$\oplus$ jog uralma,

$\oplus$ társadalmi pluralitás,

$\oplus$ civil társadalom,

$\oplus$ képviseleti testületek és individualizmus.

Huntington azonban nem írja le, hogy például a latin-amerikai civilizációt mely jellemzöi alapján különbözteti meg a nyugati civilizációtól. Ronald Inglehart és kutatócsoportja a World Values Survey (WVS) időben és térben összehasonlítható adatai alapján elkészítették a világ ún. civilizációs térképét (1. kép). Két ismérvet a koordinátarendszer pontjaira vetítve a Huntington által felvázolt hét vagy nyolc civilizáció jól elkülöníthető. A x tengelyen a materiális (túléléshez kapcsolódó) értékek kontra az önkifejezéssel kapcsolatos értékek (pl. polgári és politikai szabadságjogok), míg az y tengelyen a tradicionális kontra szekuláris értékek láthatók. Az origótól legtávolabb a protestáns Európa található, ahol az önkifejezési és szekuláris értékek dominálnak. Az origóhoz a 
1. Bevezetés a regionális-civilizációs tanulmányokba

legközelebb az afrikai és az iszlám civilizáció látható, ahol pedig a tradicionális és a túléléshez kapcsolódó értékek a meghatározóak. A kulturális térkép természetszerüleg nem azonos a Huntington-féle felosztással, ugyanakkor annyiban egyezik a szellemisége, hogy az egyes civilizációk eltérő értékekkel jellemezhetők. Az Inglehart-Welzel-féle kulturális térkép pedig az első empirikus jellegű igazolása a civilizációs értékeknek.

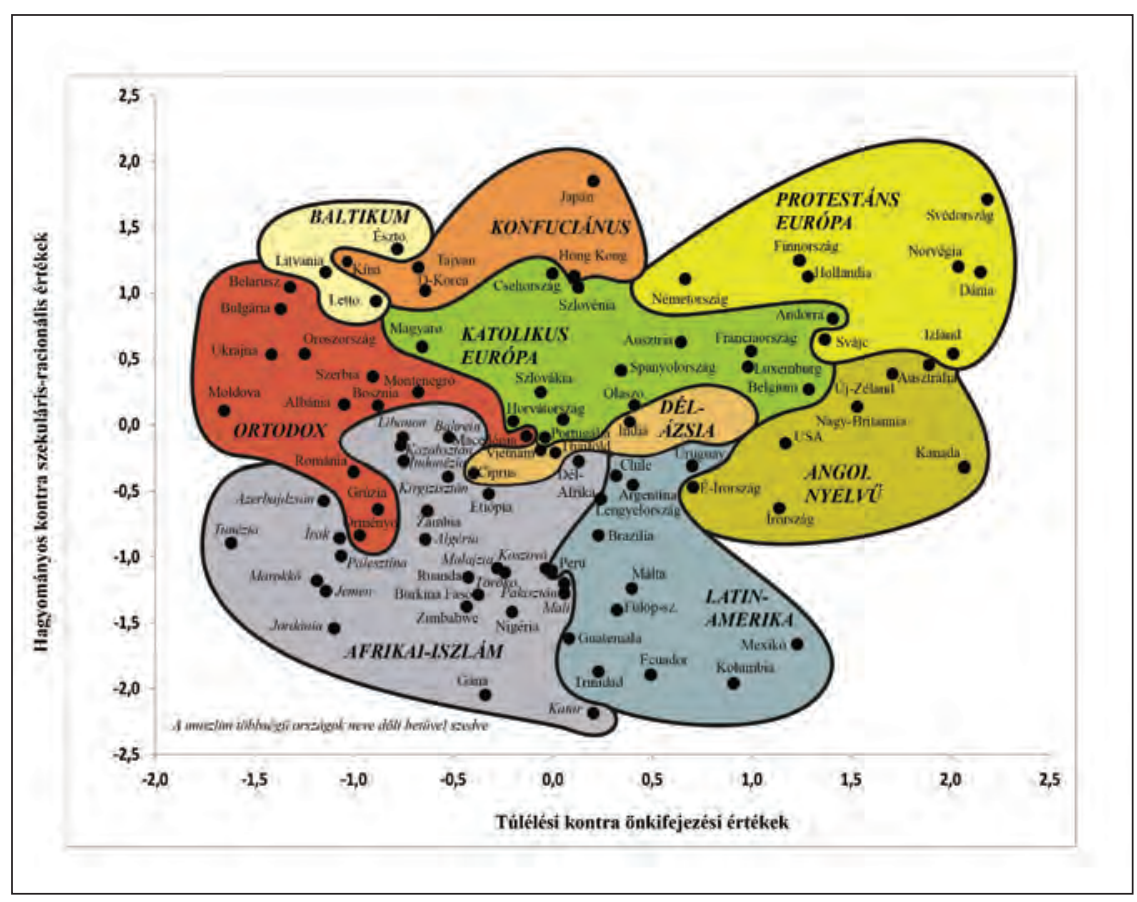

1. kép: Az Inglehart-Welzel-féle kulturális térkép

Forrás: World VALUeS SuRveY honlapja ${ }^{3}$ alapján DÉvÉNYI KINGA szerkesztése

\subsection{Fejlődés, modernitás és modernizáció}

A civilizációs elmélet kapcsán a legnagyobb vitát az a kérdés váltja ki a szakirodalomban, hogy az adott civilizáció milyen módon viszonyul a kihívásokhoz és változásokhoz. A civilizációs elméletekkel foglalkozó gondolkodók többsége egyetért abban, hogy a jelenleg létezö hét vagy nyolc civilizáció közül a nyugati civilizáció áll a hatalmi és gazdasági viszonyok alapján a hierarchia élén. A nyugati civilizáció uralja például a világgazdasági folyamatokat és katonailag is domináns, ugyanakkor elindult a hanyatlás folyamata. A civilizációs elméletekkel foglalkozó kutatók - így Toynbee, Spengler és Huntington - elfogadják a civilizációk fejlődésének gondolatát. A

3 http://www.worldvaluessurvey.org/WVSContents.jsp?CMSID=Findings - 2018. 07. 15. 
civilizációk időben több száz éven, akár évezredeken keresztül léteznek (longe durée). A civilizációnak időbeni és térbeni határai vannak, amelyeket pontosan a legtöbb esetben nem lehet körülhatárolni. A civilizációk története legjobban egy termék életciklusgörbéjével szemléltethető. A civilizációk megszületnek, majd fejlödnek és elérik a fénykorukat, ezt követően pedig a hanyatlás állapotába kerülnek. Ahogy Toynbee és Spengler utalt rá a nyugati civilizáció túl van a fénykorán, és a hanyatló stádiumban van. Huntington szerint ez empirikusan is igazolható. A terület és népesség vonatkozásában a nyugati civilizáció folyamatosan veszít a részesedéséből. 1900-ban a nyugati világ részesedése a világ összlakosságának 30 százaléka volt, 2020-ra mindössze 10 százalékra esik vissza. A folyamat visszavezethető a dekolonizáció folyamatára, ugyanis 1900ban még a nyugati világ ellenőrizte Latin-Amerika kivételével a világ legtöbb területét, amelyek függő viszonyban álltak (Huntington, SAmuel P. 1998 pp. 124-127.). Kérdéses, hogy a terület, lakosság, össztermelés adataiból le lehet-e vonni azt a következtetést, hogy a nyugati civilizáció hanyatlóban van. Talán a hanyatlásnak sokkal inkább más jegyei vannak, amelyek empirikusan kevésbé bizonyíthatóak. Elegendő napjaink európai válságjelenségeire utalni, úgymint a migrációs válság, az európai szuverén adósságválság, amelyek jellegzetességei egy tágabb identitásválságnak. Toynbee ugyanakkor arra emlékeztet, hogy a nyugati civilizációnak páratlan a megújulási képessége.

A nyugati civilizáció sajátossága a felvilágosodással egyidejűleg az ész hatalmába vetett hitnek a megjelenése. A 18-19. század politikai és társadalmi fejlődése eredményeként a nyugati civilizáció a modernitás korszakába lépett, amely egyet jelentett a korábbi tradíciókkal való szembefordulással, illetve az alábbi normák elterjedésével: modern értelemben vett nemzetállam, a szekularizáció, a demokrácia, a szabad piacgazdaság és az individualizmus (emberi jogok). A modernitás jelenleg csak a nyugati civilizáció történetét jellemzi.

A nyugati civilizáció hanyatlásával egyidejüleg a nem nyugati civilizációk felemelkedése zajlik. Huntington különösen Kelet-Ázsiát, a kínai civilizációt emeli ki, amelynek páratlan gazdasági fejlődése és az ezzel egyidejű katonai modernizációja a nyugati civilizáció dominanciáját fenyegeti.

A nem nyugati civilizációk a fentiekben említett gazdasági és politikai folyamatok következtében a nyugati civilizációhoz kísérelnek meg felzárkózni. A felzárkózásnak több útja is ismeretes:

$\oplus$ az ún. unilineáris fejlódési modellek abból indulnak ki, hogy a felzárkózásnak egyetlen útja lehetséges, éspedig a nyugati civilizáció által bejárt út. A fejlődéstanulmányokat a 20 . század nagy részében uraló ún. modernizációs teória arra alapult, hogy a vidéki társadalomból az iparosodásba való átmenet, és az ún. modern társadalmak kialakulása elsőként Nyugaton ment végbe (a modernizációs elmélet bemutatását lásd 
részletesen TIPPS, DEAN C. 1973 pp. 199-226.). A nem nyugati civilizációk számára a modernizációs elmélet a nyugatosítást kínálja megoldásként, vagyis urbanizációt, iparosodást és technológiai fejlődést. Az elméletet elfogadók úgy vélekednek, hogyha a gazdasági fejlettség (az 1 före jutó GDP) elér egy bizonyos szintet, akkor az politikai változásokat generál, amely a demokratikus átalakulás első lépése. A modernizációs elmélet elöfeltevéseire a 20. század második felének neoliberális gazdasági receptjeinek egy jelentős része épült, amelyek azonban nem tudták kezelni a nem nyugati civilizációkban kialakult modernizációs válságot. Ez utóbbi elsősorban azért alakult ki, mert a nyugatosítás logikája figyelmen kívül hagyja a fejlődés kérdésének helyi kulturális dimenzióit.

A kulturális kontextus pedig kiváltképp fontos annak a megértéséhez, hogy a pusztán a nyugatosítást, a nyugati értékek elterjesztését előtérbe helyező elméletek szükségképpen kudarcra ítéltetnek. Elegendő példaként említeni az államiság kérdését. A modern nemzetállam a vesztfáliai nemzetközi rendszer létrejöttének fó vívmánya, amely apránként az egész világon elterjedt. Az államiság azonban mint közösségszervező politikai formáció idegen volt a nem nyugati civilizációk döntö többségében. Míg a nemzetállami fejlődés a nyugati civilizációban szerves fejlődés eredménye, addig a nem nyugati civilizációk vonatkozásában a nemzetállam idegen hatás eredményeként, tulajdonképpen a gyarmatosítást követően terjedt el. A szubszaharai afrikai területeken a törzsiséghez és nem a nemzethez kötődik elsődlegesen a közösség identitása, míg az iszlám civilizációban döntő mértékben a vallás jelöli ki az egyén helyét a társadalomban. Manapság számos politikai mozgalom megkérdőjelezi a fennálló államhatárokat a nem nyugati világban. Ilyen jelenségnek tekinthető az Iszlám Állam Irakban és Szíriában, amely paradox módon maga is az államiság ideáját használja fel az adott terület feletti szuverenitás megvalósításához.

A nem nyugati civilizációk nagyrészt kipróbálták az ún. nyugati fejlődési modelleket (pl. kapitalizmus, demokrácia, jog uralma) és átvették a politikai és jogi intézményrendszer egy jelentős részét is (pl. alkotmány, parlament). A nyugati modellek azonban kevésbé müködnek nem nyugati kulturális és társadalmi kontextusban. A modernizációs válság többnyire összekapcsolódik egy identitásválsággal is, amely alapját képezi a vallási és egyéb kulturális hagyományok előtérbe kerülésének. A modernizációnak teljes egészében nyugatosításként való értelmezése tehát alapvetően téves megközelítés. Azon civilizációk, amelyek vonatkozásában például sikeresen átültetésre került a demokrácia - lásd pl. India vagy Japán -, a helyi hagyományokhoz való adaptáció kulcsfontosságú volt.

$\oplus$ Az ún. multilineáris fejlődés modell szerint a modernizáció nem azonos a nyugatosítással. A fejlődésnek több útja létezik, amelyeket az adott 
civilizációk társadalmi-kulturális kontextusa jelöl ki. A modernizáció akkor lehet sikeres, ha a kezdeti időszakban az adott civilizáció nagyrészt a nyugati technológiai vívmányok átvételére korlátozódik, majd ezt követően a saját társadalmi-kulturális kontextus útján folytatódik tovább. Huntington az alábbi ábrát használja a modernizáció és a nyugatosítás kapcsolatának megértéséhez (2. kép).

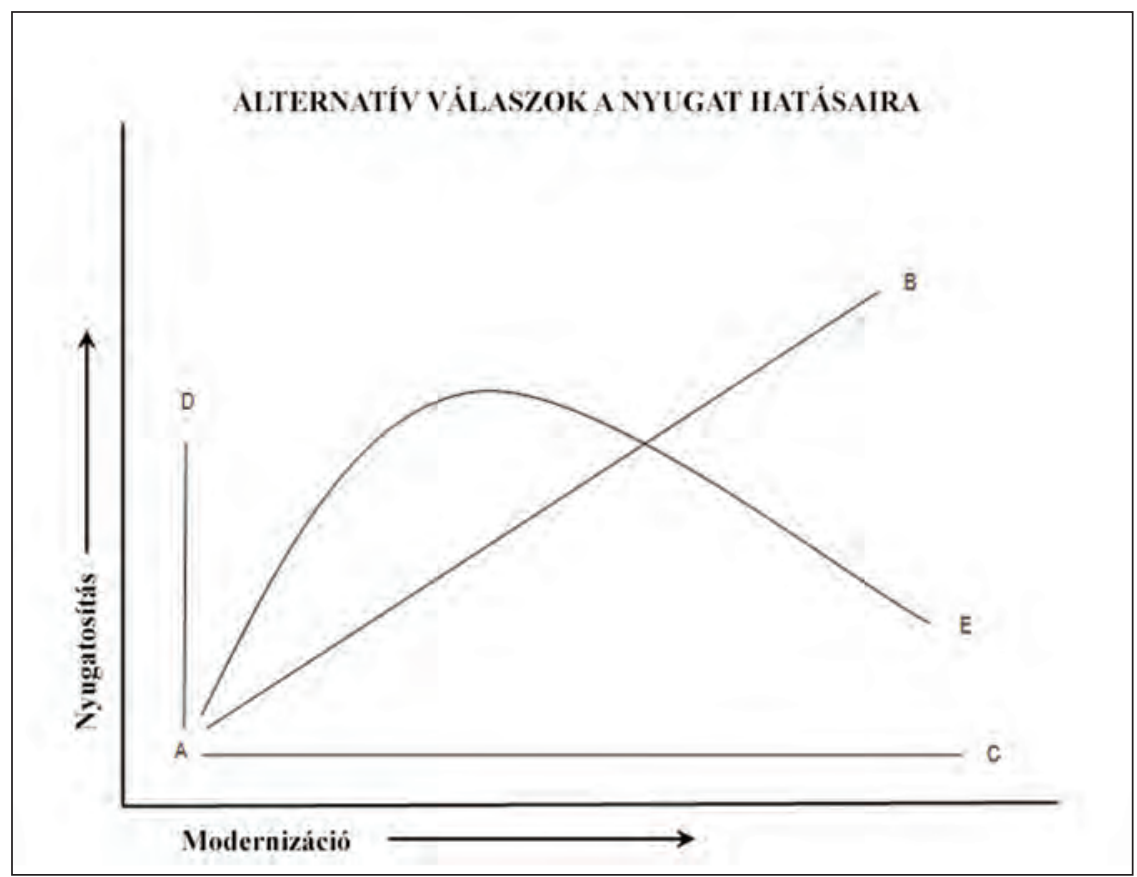

2. kép: A modernizáció és a nyugatosítás viszonya

Forrás: Huntington, SAmuel P. 1998 p. 111. alapján DÉvÉNYI Kinga szerkesztése

Az ábra szerint a modernizáció és a nyugatosítás kapcsolatának négy esete lehetséges (Huntington, SAmuel P. 1998 pp. 105-115.).

$\oplus$ Az y tengely mentén haladó államok a modernizációt a nyugatosítással azonosítják (AD). Huntington az afrikai államokat említi példaként, amely talán nem a legjobb példa abból a szempontból, hogy az említett régióban az őshonosodásnak, az afrikanizációnak jelentős támogatói vannak. A szélsőséges nyugatositás általában a helyi vallási és kulturális hagyományok háttérbe szorításával jár. Azon államok, amelyek szélsőséges nyugatosításba fognak, abból az előfeltevésböl indulnak ki, hogy a gazdasági és társadalmi problémák megoldásának az egyetlen módja a nyugati társadalmi és intézményrendszer átvétele. Megfordítva a gondolatmenetet, a fejlődés gátját látják a vallási és kulturális hagyományokban. Valójában ez a modell visszavezethető az 
unilineáris fejlődési modell tételére. Jelen sorok írójának egyik példája a forradalom előtti Irán, ahol a Pahlavi dinasztia az iszlám hagyományok degradálásával, az ősi perzsa zoroasztriánus vallási elveket kísérelte meg középpontba állítani. A vallási elit (az ulema) összefogva a bazárral egy alulról szervezett forradalmat hajtott végre, amely véget vetett az egyoldalú nyugatosításnak. Talán Huntingtonnak igaza van az afrikai példa említésében, ha arra gondolunk, hogy a lakosságtól elszakadó elit saját hasznát szem előtt tartva szélsőségesen másolja a nyugati civilizációt. Ahogy a korábbiakban említettük, mindez modernizációs válsághoz és öshonosodáshoz, valamint vallási fundamentalizmushoz vezet.

$\oplus$ A második lehetöség a nyugatosítás teljes elutasítása, az x tengely mentén való haladás (AC). A modernizáció ilyen értelmezése a nyugati értékek teljes elvetésével jár, és gyakran ezen államok a globalizációs folyamatot is teljes egészében elutasítják. A nyugatosítás elutasításának egyik legjobb példája a Kim Dzsong-Un által vezetett Észak-Korea, ahol a legfőbb állami ideológiát a koreai hagyományokra építkező ún. csucshe eszmerendszer képezi. A csucshe ideológiája az önvédelemre és az önellátásra, vagyis egy olyan autarchikus fejlődési modellre épül, amely valamennyi külső hatást megpróbálja kiküszöbölni. Ahogy Észak-Korea példája is mutatja egyrészt e fejlődési modellek a leszakadáshoz, az alulfejlett gazdasági struktúrához vezetnek, így nem tekinthetők sikeresnek. Másrészt pedig a globalizáció következtében kialakult interdependenciák, azaz kölcsönös függőségi viszonyok következtében nem lehet kikerülni a nyugati ún. demonstrációs hatást sem, amely jól érzékeltethető a Kim dinasztia luxusfogyasztásán keresztül.

$\oplus$ A harmadik lehetőség az $\mathrm{AB}$ vonal mentén való haladás, amit Huntington a török példa nyomán kemalizmusnak hív. A török példa jelen sorok írója szerint sokkal inkább a szélsőséges nyugatosítás példája, semmint a nyugatosítás és a helyi kulturális vívmányok összeegyeztetésére épülő modernizációs stratégia. A modern Törökország 1920-as években való megteremtése együtt járt az oszmán és az iszlám hagyományok teljes felszámolásával. A modern Törökország új alkotmányra, a francia értelemben vett szekularizmusra, latin betüs írásra és új családnevekre támaszkodva indult el történelmi fejlődésének útján. A modernizáció során Kemál Atatürk nem vette figyelembe a török múlt hagyományait, sőt azokat éppen a haladás előtti gátnak tekintette. Valójában a legnagyobb vitát éppen az váltja ki a szakirodalomban, hogy ha elfogadjuk, hogy az egyes civilizációk önálló értékekkel rendelkeznek (lásd a fentiekben kifejtett vitát), akkor azon értékek mennyiben képezik a fejlődés gátját, avagy hogyan lehet ezen értékeket felhasználni a haladás érdekében. Bernard Lewis szerint az iszlám és a modernitás értékei között feszültségek 
vannak. Véleménye szerint az iszlám civilizációban a francia forradalom jelszavai, mint a szabadság, testvériség és egyenlőség történelmileg is más jelentéstartalommal bírnak, így ezen értékek elterjedésére nem lehet számítani. Lewis munkája kétségtelenül felhívja a figyelmet arra, hogy az általunk megismert fogalmak mint a demokrácia, a szabadság vagy az emberi jogok esetenként mást jelentenek egy nem nyugati civilizációban (Lewis, Bernard 1990 pp. 82-95.). Mások pedig azt állítják, hogy semmilyen ellentmondás nincsen ezen értékek között, sőt egyesek éppen ezen eszmék iszlám gyökereit hangoztatják (V. ö. MAzRUI, Ali 1997 pp. 118-132.). Amartya Sen, a Nobel-díjas közgazdász azon a véleményen van, hogy a fejlödés a szabadság elterjedésével lehetséges csak. A demokráciák és az emberi jogokat tiszteletben tartó államok képesek hosszú távon fejlődni. Számos történelmi példát hoz - így többek között - a demokratikus berendezkedésű Indiát (Sen, AmarTYA 2003 pp. 243248.).

$\oplus$ Huntington a negyedik fejlödési modellt (AE görbe) tekinti normaként, amely ötvözi a nyugatosítást a kulturális adaptációval. A modernizáció első időszakában a nyugati technológiai vívmányok átvételén van a hangsúly, majd a második szakaszban előtérbe kerülnek a kulturális hagyományok. Példaként Délkelet-Ázsia fejlődése hozható, ahol különösen az ún. kistigrisekként nevezettállamok egyrészt élvezték a nyugati tudományos és technológiai eredményeket, másrészt a konfuciánus etika hagyományaira alapozott önálló fejlődési utat jártak be.

\subsection{Huntington és a civilizációk összecsapásának a tézise}

Ahhoz, hogy alaposan megértsük Huntingtonnak a civilizációk összecsapására vonatkozó nézeteit, érdemes néhány, a munkában használt fogalmat áttekintenünk (HunTINGTON, SAMuEL P. 1998 pp. 214-251.):

$\oplus$ tagállam: Minden egyes civilizációnak vannak ún. tagállamai. Magyarország a nyugati civilizáció tagállama, Argentína pedig a latinamerikai civilizáció tagállama. A civilizáció tehát nem egy politikailag definiálható entitás, hanem valójában a nemzetközi rendszer föszereplöiből, az államokból tevődik össze.

$\oplus$ magállam: Valamennyi civilizációban létezik egy politikailag, gazdaságilag és katonailag domináns regionális hatalom, amelynek felelőssége az ún. civilizáción belüli rend fenntartása. Egyes civilizációkban akár egyszerre több állam is betöltheti a magállam szerepet. A nyugati civilizációban például az Egyesült Államok, Franciaország, Németország és NagyBritannia egyaránt hasonló szerepkörben van, amennyiben meghatározzák a civilizáció fejlődésének irányát. Latin-Amerikában például Mexikó és 
Argentína mellett a portugál nyelvű Brazília is aspirál a domináns szerepre. A legnagyobb probléma az iszlám civilizációban fedezhető fel, amennyiben nincsen magállam. Huntington és tulajdonképpen Bernard Lewis szerint az iszlám civilizáció határai részben azért is „véresek”, mert jelenleg nincs olyan magállam, amely fenntartaná a civilizációs rendet. Az arab tavasz kirobbanásával párhuzamosan a Közel-Keleten egy regionális vetélkedés van kialakulóban, amelyet egyes szakértök új közel-keleti hidegháborúként definiálnak. A verseny elsősorban Irán és Szaúd-Arábia között zajlik, és számos helyi konfliktusban megjelenik (pl. szíriai polgárháború).

$\oplus$ A magányos államok azon országok, amelyek nem tartoznak egyetlen civilizációhoz sem. Ilyennek tekinthető például Izrael Állam, amely jelen kötet értelmezésében ugyan részese a nyugati kultúrkörnek, mégis tradícióit tekintve önálló civilizációként definiálható. Huntington magányos államként említi például Mongóliát, amely szerinte nem sorolható be egyetlen létező civilizáció alá sem.

$\oplus$ A „testvérország” szindróma egy elsősorban konfliktushelyzetben megmutatkozó jelenség, amikor is az adott civilizációhoz tartozó államok a civilizációt érő külső fenyegetettség esetén összezárnak. Tipikus példaként említi Huntington az ún. délszláv háborúkat, Jugoszlávia szétesésével kapcsolatban. A külső hatalmak bizonyíthatóan a saját civilizációjukhoz tartozó államokat támogatták a konfliktusban. Így Oroszország Szerbiát, Németország illetve az európai államok a katolikus Szlovéniát és Horvátországot, míg Törökország és Szaúd-Arábia az iszlám vallást követő bosnyákokat részesítette előnyben. Az 1990-ben kirobbant öbölválság során Szaddám Huszein pedig az arab/iszlám világot kísérelte meg megszólítani az Egyesült Államokkal, illetve szövetségeseivel szemben. Huntington elméletének az egyik gyengesége éppen abban rejlik, hogy az utóbbi esetben, míg az arab/iszlám közvéleményt általánosságban sikerült az Egyesült Államok ellen hangolni, ugyanakkor a közel-keleti államok szintjén ez sikertelen volt. Reálpolitikai okokból számos közelkeleti állam az Egyesült Államok oldalán harcolt (pl. Egyiptom vagy Szíria), ami megkérdőjelezi az elmélet általános érvényét.

$\oplus \mathrm{Az}$ ún. civilizációt váltó államok az adott civilizációból egy másikba kívánnak átlépni. A huntingtoni elmélet keveset foglalkozik a civilizációk közötti kölcsönhatásokkal. Mégis fontos szempontként említhetőek azon államok, amelyek hátat fordítanak vagy fordítottak a saját múltjuknak, és egy másik civilizáció értékrendszerét vallják magukénak. Általánosságban ez csak abban az esetben lehet sikeres, ha nemcsak a szükebb értelemben vett elit, hanem a szélesebb társadalmi rétegek is osztják ezt a nézetet mindkét civilizációban. Konkrét példaként említhető Törökország, amely az iszlám civilizációból a nyugatiba, Mexikó, amely a latin-amerikai 
kultúrkörből a nyugatiba, illetve Oroszország, amely az ortodox-orosz civilizációból ugyancsak a nyugatiba kíván( $\mathrm{t}$ ) váltani. Ausztrália pedig egyedi abból a szempontból, hogy a nyugati civilizáció részeként jelenleg egy önálló ausztrál identitás kialakításán munkálkodik. Talán az európai civilizációt leginkább Törökország fejlődése izgatja. Kemál Atatürk - ahogy arra a korábbiakban utaltunk - egy modern, főként a nyugati értékekre épülő szekuláris nemzetállam kiépítésén munkálkodott. 2023ban Törökország fennállásának a 100. évfordulóját fogja ünnepelni. Ma Európában és lassan a török társadalomban is konszenzus alakul ki annak kapcsán, hogy Törökország Európai Uniós csatlakozása nem időszerü. Mintha az elmúlt egy-két évtizedben az az egyetértés, amely Törökországot nyugati államként definiálta, megszünt volna létezni, ami megmutatkozik a török külpolitika által képviselt új irányokban. Ehelyütt nincs lehetőségünk részletes kifejtését adni a civilizációk egymásra hatásának, ugyanakkor bizonyos időszakokban a nemzetközi rendszerben domináns szerepet betöltő civilizáció (ami jelenleg a hanyatlása ellenére is a Nyugat) viszonyítási ponttá válik.

$\oplus$ A hasadó államok azon államok, amelyek egyidejűleg két vagy több civilizációhoz tartoznak. Ezen államok szükségképpen felbomlásra ítéltetnek a közeljövőben, ugyanis a civilizációs törésvonal szétfeszíti az állam egységét. A hasadó állam egyik aktuális példája Ukrajna, ahol a lakosság egyik fele, föként a keleti területeken Oroszország irányában lojális, míg az ország nyugati felén inkább az európai eszmék a meghatározóak. A Krím-félsziget kapcsán Oroszországgal dúló konfliktus jól példázza a hasadó állam jellegzetességeit.

A Huntington-féle civilizációk összecsapásának tézise tehát abból indul ki, hogy az új világrendben kialakuló valamennyi fegyveres és nem fegyveres konfliktus mögött civilizációs ellentétek, civilizációs törésvonalak állnak. A civilizációs törésvonal térben és virtuálisan is létezik. Egyrészt két civilizáció földrajzi határai mentén kialakulnak a törésvonalak. Jugoszlávia szétesése három civilizáció metszéspontjában bontakozott ki: míg Horvátország és Szlovénia a nyugati civilizációt, Bosznia-Hercegovina az iszlám civilizációt, addig Szerbia az orosz ortodox civilizációt testesítette meg a háborúban. Másrészt, törésvonalak nemcsak földrajzi értelemben léteznek, hanem ideológiai síkon is. Jelenleg kétségtelenül a nyugati és az iszlám civilizáció között létezik a legjelentősebb törésvonal mind földrajzi, mind ideológiai értelemben. A nyugat által képviselt modernitásnak és a felgyorsult globalizációnak legélesebben az iszlám civilizáció áll ellen. Huntington a jövő veszélyeként veti fel, hogyha a konfuciánus-kínai civilizáció és az iszlám civilizáció összefog, akkor az a Nyugat jelenleg domináns helyzetére nézve negatív hatással lesz. A két civilizáció közötti 
1. Bevezetés a regionális-civilizációs tanulmányokba

valódi (nyugatellenes) együttmüködéssel kapcsolatban azonban részletekbe nem bocsátkozik. Esetleg Kína és Pakisztán szoros együttmüködése, illetve Kína és Irán kooperációja veszélyes lehet a Nyugatra nézve.

Huntington szerint a civilizációk összecsapásának két szintje létezik (Huntington, Samuel P. 1998 pp 343-346.; 418-434.):

$\oplus$ az ún. törésvonal-háborúk, amelyek elsősorban a földrajzi értelemben definiált törésvonalak mentén robbannak ki. Ilyen pl. a kasmíri konfliktus, ahol a kasmíri muszlimok Pakisztán támogatását élvezik, míg a hinduk érdekeit India képviseli. A törésvonal-háborúk igen gyakoriak, lényegében valamennyi fegyveres konfliktus ezt a formát ölti.

$\oplus$ Az ún. magállamháborúk keretében két civilizáció domináns hatalma kerül fegyveres konfliktusba, amely sokkal súlyosabb mint a törésvonalháborúk. Erre ezidáig nem került sor, ugyanakkor Huntington szerint nagy a veszélye, hogy az új világrend keretében bekövetkezik. Pl. ha Oroszország és az Egyesült Államok közvetlen háborús konfliktusba keveredne, akkor az a huntingtoni értelemben vett magállamháború lenne.

\subsection{A civilizációs elmélet kritikái}

Miközben az elmélet látszólag koherens alapokon áll, mégis számos kritikát fogalmazhatunk meg.

$\oplus$ A fogalomhasználat kapcsán elsődleges probléma, hogy a civilizáció és kultúra fogalmai statikusan jelennek meg az elméletben, és kevésbé foglalkozik a kettős és többes identitások szerepével. Huntington maga is szerepet tulajdonít a civilizációk történelmi összekapcsolódásának és egymásra hatásának, ugyanakkor nem veszi figyelembe, hogy az egyes civilizációk maguk is változnak. Huntington egyik nagy kritikusa a palesztin származású amerikai irodalomtörténész Edward W. Said, aki szerint nem megalapozott a civilizációs paradigma, és a civilizációk ilyetén való szembeállítása, elkülönítése mesterséges, minden alapot nélkülöz. „Huntington tulajdonképpen ideológus, aki a 'civilizációkból' és az 'identitásokból' valami egészen mást akar csinálni, mint amik azok valójában: leegyszerüsített és lecsupaszított entitásoknak képzeli őket, amelyek meg vannak tisztítva az emberi történelmet mozgató folyamatok és ellenfolyamatok miriádjaitól" - vélekedik Said (SAID, EDWARD W. 2002).

$\oplus$ Többhelyen elemzi aziszlám és a nyugati civilizáció közötti konfliktusokat, amelyek kapcsán sommás megállapításokat tesz. Például egy másik írásában utal arra, hogy a törésvonal-háborúk többségében föként a muszlimok érintettek, és ennek elsődleges okát a „muszlimok nehéz kezelhetőségében” keresi (Huntington, SAmuel P. 2001 pp. 140-144.). 
Véleménye szerint „,az iszlám határai véresek”- többek között-azért, mert az iszlám civilizáció erőteljesen militarizált. Miközben nehezen vitatható az empirikus megállapítás, amely szerint a törésvonal-háborúkban muszlimok nagy számban részt vesznek, ugyanakkor Huntington ennek történelmi okait (pl. országhatárok meghúzása a nyugati érdekek mentén) nem veszi számításba. Vitatható általában az iszlám vallással kapcsolatos megállapítása, amely részben Bernard Lewis munkásságán alapul.

$\oplus$ Egyes nem tudományos kritikák szerint félő, hogy az elmélet egy önmagát beteljesítő jóslattá válik. A 2001. szeptember 11-i terrortámadás látszólag Huntington nézeteit igazolta. Huntington maga úgy nyilatkozott, hogy a terrortámadás szélsőséges csoportok által elkövetett merényletsorozat volt, és nem értelmezhető a civilizációk összecsapásaként, ugyanakkor könnyen azzá fajulhat (Huntington, SAMuel P. 2002). Lényegében a szélsőséges csoportoknak (pl. al-Káida vagy Iszlám Állam) kifejezett célja, hogy generálja a civilizációk összecsapását. Bármilyen jellegü fegyveres konfliktus szítása a radikális csoportok érdekében áll.

$\oplus$ Kérdéses, hogy mennyiben tekinthető újszerünek az elmélet, hiszen a történelem a civilizációk összecsapásának a története. Gondoljunk az iszlám és a nyugati civilizáció közötti fegyveres konfliktusokra a 8. század elején. Továbbá a civilizációk nemzetállamokból állnak, így végső soron nem a civilizációk, hanem a nemzeti érdekek állnak egymással szemben (lásd realista megközelítés). Huntington szerint ráadásul a civilizáció nem egy politikai kategória, hanem kulturális meghatározottságú fogalom.

$\oplus$ Az elmélet kevésbé foglalkozik olyan intracivilizációs és intercivilizációs konfliktusokkal, ahol nem feltétlen a civilizációs szempont a meghatározó, hanem mondjuk a gazdasági érdekek. A világ valamennyi konfliktusára nehezen illeszthető rá a civilizációs paradigma.

$\oplus$ Továbbá egyes kritikusok megjegyzik, hogy nincsen alátámasztva a könyvben az iszlám és a kínai-konfuciánus civilizáció nyugatellenes összefogása. Huntington egy-két konkrét példát említ (pl. Kína és Pakisztán együttmüködése), amelyből azonban nem következik, hogy a több mint 50 országot számláló iszlám világ általában összefogna Kínával.

\section{8. Összefoglalás}

Miközben az ún. civilizációs paradigma kapcsán számos kritikát megfogalmazhatunk, az elmélet rámutat a 21. századi nemzetközi kapcsolatok egy olyan szegmensére, amely valós folyamatokat tükröz. Kétségtelen ugyanis, hogy a nemzetközi politikai viszonyokban az identitás, a vallás, a kultúra vagy a civilizáció egyre inkább meghatározó tényezők. Gondoljunk bele, napjaink Európát érintő migrációs- és menekültválságának lényegi vitája 
1. Bevezetés a regionális-civilizációs tanulmányokba

éppen a Huntington-féle megközelítés mentén zajlik. A közösségi média és az egyre inkább az intolerancia irányába tolódó európai politika szükségképpen leegyszerüsítve állítja szembe a muszlim migránsokat az európai többséggel. A civilizációs paradigma segíthet annak megértésében, hogy az Európában jelenleg megfigyelhető többszörös válságjelenség (identitásválság, politikai válság, valamint az adósságválság) szükségképpen elötérbe állítja azon vitákat, hogy pontosan miben áll az európai identitás. A Közel-Keletről érkező nagyszámú menekült pedig mint külső fenyegetettség jelenik meg, amellyel szemben védekezni kell.

Nem pusztán az európai civilizációt érintő tendenciákról beszélhetünk. Érdemes említeni például Indiát, ahol a hindu nacionalista párt, a BJP 2014-ben megnyerte az országos választásokat. Az ország miniszterelnöke, Narendra Módi a viták kereszttüzébe került, ugyanis mint Gudzsarát állam korábbi kormányzója jelentős szerepet játszott a hindu-muszlim ellentét felkorbácsolásában. Indiában ugyanazon viták folynak mint Európában. India vajon szembefordul a Gandhiféle „egység a sokféleségben” koncepcióval, és nyíltan a hindu nacionalizmus logikájának megfelelően kirekesztő hindu államot épít ki? A modernizációs útkeresés valamennyi civilizáció meghatározó sajátossága, amely folyamat hátterére kétségtelenül a civilizációs paradigma mutatott rá. Ugyanakkor tévedés lenne az elméletet abszolutizálni, és különösen a világpolitika középpontjába állítani a civilizációk összecsapásának tételét.

A civilizációs paradigma abban is segít, hogy megértsük az egyes civilizációk eltérő érték- és fogalomrendszerét. Az utóbbi kapcsán érdemes megemlíteni, hogy a nyugati modernitáshoz kapcsolódó fogalmak - demokrácia, emberi jogok, szabad piacgazdaság - mennyiben más jelentéstartalommal bírnak a nem nyugati kultúrkörökben.

\subsection{Irodalomjegyzék}

Ali, TARiQ 2002: The Clash of Fundamentalisms. Crusades, Jihads and Modernity. London and New York: Verso

ANKerL GÉza 2000: Nyugat van, Kelet nincs. Értöl az Óceánig. Budapest: Osiris Badie, Bertrand - Smouts, Marie-Claude 1998: A visszájára forduló világ. A nemzetközi színtér szociológiája. Budapest: Aula Kiadó

Badie, Bertrand 2000: The Imported State. The Westernization of the Political Order. Stanford: Stanford University Press

BARBer, BenJAmin 1995: Jihad vs. McWorld. New York: Time Books

Bauman, Zygmunt 2001: Globalizáció. A társadalmi következmények. Budapest: Szukits Könyvkiadó

FeISCHMIDT MARGit 1997: Multikulturalizmus: kultúra, identitás és politika új diskurzusa. - In: Feischmidt Margit (szerk.): Multikulturalizmus. 
Budapest: Osiris pp. 7-29.

Fukuyama, Francis 1992: A történelem vége és az utolsó ember. Budapest: Európa Könyvkiadó

Global Terrorism Index 2017: - http://globalterrorismindex.org/ - 2018. 07. 15. GombÁr Csaba - Hankiss Elemér - Lengyel LÁszló - SzilÁGyi Ákos 2000: A kérdéses civilizáció. Budapest: Helikon - Korridor

GombÁr Csaba 2000: Létezik-e globális civilizáció? - In: Gombár Csaba - Hankiss Elemér - Lengyel László - Szilágyi Ákos: A kérdéses civilizáció. Budapest: Helikon-Korridor

HANKISS EleméR 1999: Proletár reneszánsz. Tanulmányok az európai civilizációról és a magyar társadalomról. Budapest: Helikon Kiadó

Huntington, Samuel P. 1993: The Clash of Civilizations? - Foreign Affairs, Summer 72. (3): pp. 22-49.

Huntington, Samuel P. 1998: A civilizációk összecsapása és a világrend átalakulása. Budapest: Európa

Huntington, Samuel P. 2001: The Age of Muslim Wars. - Newsweek 138, pp. 140-144.

Huntington, Samuel P. 2002: „Nem, nem a civilizációk összecsapása”. - In: Kovács Zsuzsa - NÉmeti TAMÁs (szerk.): Szeptember 11. Értelmezések, elméletek, viták. Budapest: Balassi Kiadó, pp. 31-33.

Inglehart, Ronald - Norris, Pipa 2003: The True Clash of Civilizations. Foreign Policy, March-April (135): pp. 62-70.

Kiss J. LászLó 2003: Globalizálódás és külpolitika. Budapest: Teleki László Alapítvány

Lewis, Bernard 1990: The Roots of Muslim Rage. Atlantic Monthly, September, pp. 47-60.

LEWIS, BernARD 2002: What Went Wrong? The Clash between Islam and Modernity in the Middle East. New York: The New York Times

LutwaK, Edward N. 1990: From Geopolitics to Geo-Economics: Logic of Conflict, Grammar of Commerce. The National Interest, Summer (20): pp. 17-23.

Mazrui, Ali 1997: Islamic and Western Values. Foreign Affairs, SeptemberOctober 76. (5): pp. 118-132.

McGrew, Anthony 2010: Globalization and Global Politics. - http://www. good-governance-debates.de/wp-content/uploads/2015/03/Globalizationand-global-politics-by-Anthony-McGrew_2010.pdf-2018. 07. 15.

MEARSHEIMER, JoHN J. 1990: Back to the Future: Instability in Europe after the Cold War. International Security, Summer 15. (1): pp. 5-56.

MODOOD, TARIQ2011:Multiculturalism andIntegration: Struggling with Confusions. European University Institute, Robert Schuman Centre for Advanced Studies. Accept Pluralism 7th Framework Programme Project - https://www.coe. 
1. Bevezetés a regionális-civilizációs tanulmányokba

int/t/dg4/cultureheritage/mars/source/resources/references/others/38\%20 -\%20Multiculturalisme \%20and\%20Integration \%20-\%20Modood $\% 20$ 2011.pdf - 2018. 07. 15.

Rosenau, James N. 1997: Along the Domestic-Foreign Frontier: Exploring Governance in a Turbulent World. Cambridge: Cambridge University Press

RostováNYI Zsolt 1999: Globalizáció avagy civilizációk és kultúrák harca? Külpolitika, Tavasz-nyár 5. (1-2): pp. 3-45.

RostováNYI ZsOlt 2005: Globalizáció és civilizáció(k). A „glokalizálódó” nemzetközi rendszer civilizációs-kulturális elemzése, különös tekintettel az „iszlám versus Nyugat” szembenállásra. Budapest: MTA Doktori értekezés (kézirat)

SAID, EDWARD W. 2002: A „tudatlanságok összecsapása”. - In: Kovícs ZsuzsA - NÉmeti TAMÁs (szerk.): Szeptember 11. Értelmezések, elméletek, viták. Budapest: Balassi Kiadó, pp. 33-37.

SCRUTON, Roger 2005: A nemzetek szükségességéröl. Két tanulmány. Budapest: Helikon Kiadó

Sen, Amartya 2003: A fejlődés mint szabadság. Budapest: Európa Könykiadó

SPENGleR, Oswald 1994: A Nyugat alkonya I-II. A világtörténelem morfológiájának körvonalai. Budapest: Európa

Stiglitz, Joseph E. 2003: A globalizáció és visszásságai. Budapest: Napvilág Kiadó

THE GuARDIAN 2017: Richest 1\% own half the world's wealth, study finds. The Guardian, 14 November - https://www.theguardian.com/inequality/2017/ nov/14/worlds-richest-wealth-credit-suisse - 2018. 07. 15.

TiPPS, Dean C. 1973: Modernization Theory and the Comparative Study of Societies: A Critical Perspective. Comparative Studies in Society and History, Mar. 15. (2): pp. 199-226.

ToynbeE, ARnold 1988: Volume I: Abridgement of Volumes I-VI. Oxford: Oxford University Press

United Nations 2017: International Migration Report 2017. New York: United Nations - http://www.un.org/en/development/desa/population/migration/ publications/migrationreport/docs/MigrationReport2017_Highlights.pdf - 2018. 07. 15.

VITÁNYI IváN 2002: A civilizáció és a kultúra paradigmái. Magyar Tudomány (6): pp. 720-729.

Wessely AnNa (szerk.) 2003: A kultúra szociológiája. Budapest: OsirisLáthatatlan Kollégium

World Values Survey - http://www.worldvaluessurvey.org/WVSContents. jsp?CMSID=Findings -2018.07 .15 . 

2. Távol-Kelet 



\title{
2.1. A kínai civilizáció
}

\author{
Matura TAMÁs
}

Kína, azaz a „Középső Birodalom” a világ egyik legősibb, folyamatosan fennálló civilizációja, a kelet-ázsiai régió kulturális központja és meghatározó nagyhatalma az elmúlt legalább négyezer év folyamán. Bár a történelmi Kína területén számos népcsoport, nyelvjárás és szokás keveredett, a han kínaiakhoz kötődő kultúra alapvető szerepet játszott és játszik napjainkig az egész térség életében. Ebből is fakad, hogy a Kínai Birodalom és a ma létező Kínai Népköztársaság lakói elsősorban nem nemzetállamként, hanem civilizációként tekintenek saját országukra, és az azt körülvevő befolyási övezetre, azaz a sinoszférára (3. kép).

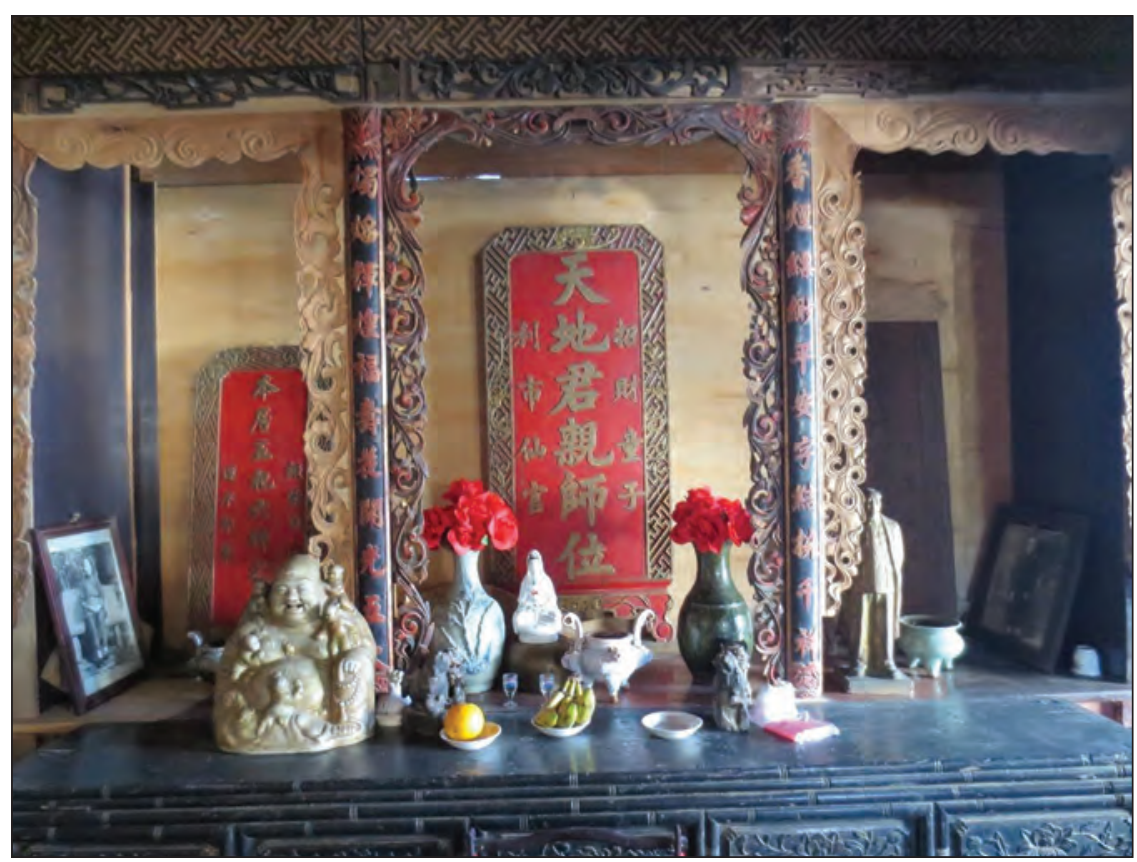

3. kép: Családi oltár, amelyen jól látható a politika és a vallások keveredése, Jünnan (Yunnan) tartomány Forrás: BAGI JuDIT felvétele

E civilizáció regionális egyeduralma könnyen megérthető, ha figyelembe vesszük a térség földrajzi és történelmi adottságait, amelyek Kína a világ más nagy kultúráitól való jórészt izolált fejlődéséhez, és ezáltal egy minden tekintetben egyedi, a nyugati világtól jelentősen eltérő karakterü önálló univerzum kialakulásához vezettek. A kínai civilizáció térben és időben olyan 
hatalmas kiterjedésủ és olyan mélységü, hogy arról a rendelkezésre álló keretek között nem lehetséges teljes képet adni, így a nemzetközi tanulmányok szak szempontjait szem elött tartva szemezgetünk egyes elemeiből. Az alábbi fejezet Kína prehistorikus időszakától kezdve a dinasztikus ciklusokon keresztül a császárság bukásáig tekinti át az ország történetének azon fejezeteit, amelyek a legmeghatározóbbak Kína világszemlélete és külpolitikai magatartása megértése szempontjából. ${ }^{4}$

\subsubsection{A mai kína számokban}

Bár e kötet az egyes civilizációk történeti és kulturális hátterét hivatott bemutatni, érdemes megismerkedni a mai Kína jellemzőivel is. Közismert, hogy Kína a világ legnépesebb országa, lakóinak száma meghaladja az 1,4 milliárd föt, amely hazánknak több, mint száznegyvenszerese. Ugyan a 2020-as évek folyamán India előreláthatólag megelőzi Kínát e téren, az ország hatalmas embertömege továbbra is igen jelentős erőforrást jelent majd.

\subsubsection{Kína földrajza}

Területét tekintve a Kínai Népköztársaság (KNK) 9,6 millió km²-rel Kelet-Ázsia legnagyobb országa, a világ harmadik vagy negyedik legnagyobb kiterjedésű állama, amely több, mint kétszer akkora, mint az Európai Unió, és százszor nagyobb Magyarországnál. A világrangsorban betöltött helyének bizonytalansága egyes vitatott területek beszámításától függ. A nyugati listák nem veszik figyelembe ezen területeket - pl.: Tajvan (Taiwan) szigete vagy Kasmír egyes részei -, így a KNK némileg kisebb az Egyesült Államoknál, míg a Kínában használatos rangsorban természetesen e régiók is számítanak, így Kína némileg nagyobb mint az USA. A politikai állásfoglalástól függetlenül elmondható, hogy a kontinentális, tehát a 1,5 millió $\mathrm{km}^{2}$-es Alaszka nélküli USA területe jelentősen kisebb, mint Kínáé. Az ország hatalmas kiterjedése és változatos topográfiája meghatározza klimatikus viszonyait, ami viszont a mezőgazdasági termelés lehetőségeit befolyásolja, így végső soron alapvető hatással volt és van Kína történelmére és kultúrájára (1. térkép).

A kínai civilizáció történetét és fejlődését, sőt máig érvényes geostratégiai megfontolásait is leginkább meghatározó földrajzi adottsága az országot körülvevő területek által okozott természetes elzártság, izoláció. A könnyebb megértés érdekében érdemes egy képzeletbeli körutat tenni Kína határai mentén. Az Indokínai-félsziget legtöbb országát sürü esőerdőkkel benőtt

4 A szerző ezúton is szeretné megköszönni Kusai Sándor, korábbi pekingi magyar nagykövet úrnak a fejezet végső formába öntése során nyújtott segítségét és tanácsait. Külön köszönet Bagi Judit sinológusnak a kínai nevek átírásának egységesítéséért és az illusztrációkért. 
magashegységek zárták el Északkelet-Ázsia felől, így a mai Thaiföld, Laosz, Kambodzsa és Mianmar területén létezett korábbi államalakulatok és a Kínai Birodalom közötti kulturális kommunikáció minimális volt, kivéve az ősi teautat, amelyen élénk kereskedelmi kapcsolat folyt. Ezen kívül az egyetlen, ámde jelentős kivételt Vietnam jelentette, amely tengerparti, így könnyen megközelíthető országként élénk kulturális és politikai kölcsönhatásban állt Kínával. A fentiekhez kapcsolódó érdekes adalék, hogy az említett elszigeteltség a nyelvekben és különösen az írásrendszerekben is felfedezhetö. Míg a thai, kambodzsai és egyéb délkelet-ázsiai nyelvek írása jelentősen eltér a kínaitól, addig Vietnamban egészen a 19. századi francia hódításig a kínai írásjegyek voltak elterjedtek, és csak az európai nyomásra tértek át a latin betük használatára.

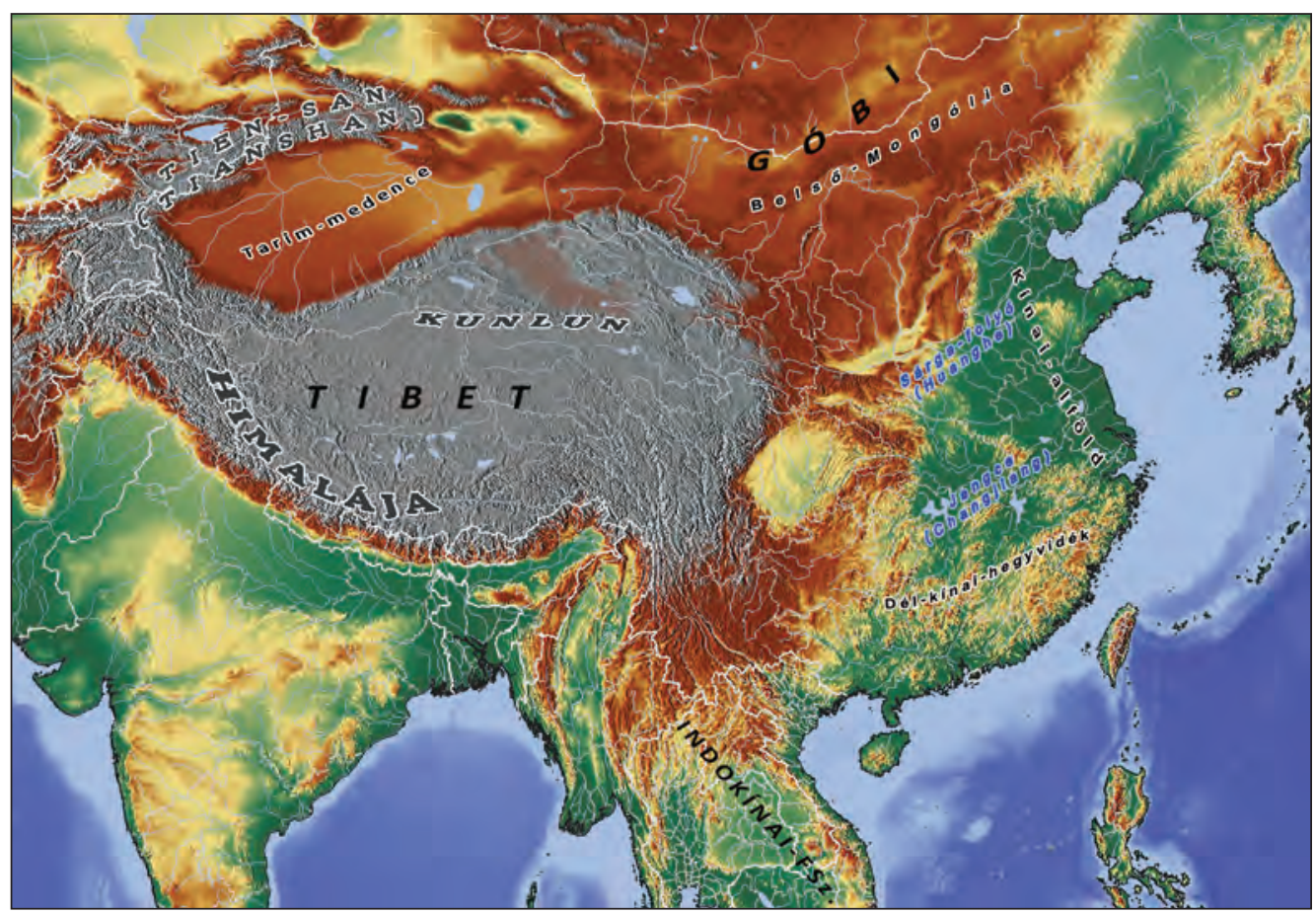

1. térkép: Kína elhelyezkedése és természeti viszonyai Forrás: VARGa ÁGNes szerkesztése

Tovább haladva délnyugati irányba a világ egyik leglátványosabb természetes határa, a Himalája és kapcsolt hegységrendszerei tornyosulnak Kína és a másik ősi, folyamatosan létező civilizáció, India között. A sok ezer kilométeres fal olyannyira hatékony választóvonalnak bizonyult, hogy hiába terjesztette ki a Kínai Császárság hatalmát többször is a tibeti fennsíkra, az interakció mértéke így is viszonylag csekély volt Kína és India között, sőt, a két óriás háborút sem viselt egymás ellen egészen a 20. századig. 
Talán még a Himalájánál is egyértelmübb a Nyugat és Kína közötti hatalmas távolság és a kietlen táj szerepe. A birodalom magterülete, tehát a mai Kelet-Kínából nyugat felé indulva az egykori karavánok számára évszázadokon át a következő jelentős civilizációt Európa, délnyugati irányban Perzsia és a Török Birodalom jelentette, amely régiókat több ezer kilométernyi, néhol sivatagos, nomád törzsekkel pettyezett pusztaság választotta el egymástól. Az egykori Selyemút is számtalan veszéllyel tarkított, hosszú hónapokig vagy akár egy évig is tartó utazást jelentett, így nem meglepő, hogy a Római Birodalom vagy a későbbi európai, nyugat-ázsiai államalakulatok és Kína közötti kulturális kölcsönhatás igencsak gyenge volt.

Észak felé tekintve pedig előbb a mongol területek portyázó nomád törzsei, majd Kelet-Szibéria üres pusztasága határolta a birodalmat, míg keleten a tengerek zárták el a kínai civilizációt más kultúráktól egészen az európaiak 18. század végén megindult inváziójáig, így ezen égtáj felé a birodalom csak a könnyen elérhető területekre, Koreára, Japánra és a délkelet-ázsiai szigetvilág egyes területeire terjesztette ki civilizációs hatását.

Topográfiai szempontból a kínai területek lépcsőzetes képet mutatnak, amelynek legmagasabb foka a 4000 méteres átlagos tengerszint feletti magassággal rendelkező tibeti fennsík. Kelet felé haladva fokozatosan csökken a magasság, a Kunlun (Kunlun), a Tien-san (Tianshan) és a jünnani (yunnani) fennsík jelentik a következő lépcsőt, majd a Nyugat- és Északnyugat-Kínában húzódó Taklamakán és Góbi sivatag, illetve a szecsuani (sichuani) medence területei következnek, míg végül a civilizáció magját jelentő tengerparti alföldek zárják a sort. Az ország óriási kiterjedése és felszíni adottságai meghatározzák a klimatikus viszonyokat is, hiszen Kína térképét Európára vetítve azt tapasztalnánk, hogy a KNK északkeleti régiója az Urál-hegység északi vonulataira, a nyugati Hszincsiang (Xinjiang) autonóm terület Izland, míg a déli Hajnan-szigete (Hainan-szigete) Szicília környékére esik. Ebből is következik, hogy az egykori Mandzsúria északi területein télen szibériai éghajlat tapasztalható, míg a déli Kantonban - Kuangtungban (Guangdongban) - és Hajnanon már szubtrópusi a klíma. Mindeközben a Himalája képződése során felgyürt Tibeti fennsíkot gyakran a Föld harmadik pólusának is szokták nevezni, mivel a több mint egymillió $\mathrm{km}^{2}$-es terület az Északi- és Déli-sark után a világ harmadik legnagyobb édesvíz készletét jelenti hó és jég formájában. Ugyanakkor a csapadék nem is jut tovább Belső-Ázsia felé, így Csinghaj (Qinghai), Hszincsiang, Ninghszia (Ningxia) és Belső-Mongólia összesen közel 3 millió négyzetkilométeres területe csapadékban szegény, kopár, gyakran sivatagi tájat rejt.

A kínai civilizáció szempontjából különösen fontos az országot átszelő három nagy folyó. Északon a közel 5500 kilométer hosszú Sárga-folyó - Huangho (Huanghe) -, az ország középső tájait pedig a világ harmadik leghosszabb 
folyama, a 6380 kilométeres Jangce - Csang-csiang (Chang jiang) - szeli ketté. Szintén kiterjedt vízrendszert alkot a Dél-Kínát behálózó Gyöngy-folyó - Csucsiang (Zhujiang) - vízrendszere.

A fentebb röviden bemutatott földrajzi adottságok egyik különösen jelentős következménye, hogy az ország müvelésre alkalmas termőterületei viszonylag kis területen, az ország keleti felében, különösen az észak-kínai alföldeken koncentrálódnak. Mindeközben a KNK területének nyugati fele lényegében alkalmatlan a földmüvelésre, így mind az elmúlt évszázadokban, mind pedig manapság igen látványos különbségek mutatkoznak a népsürüségi adatokban is. A kelet-nyugati megosztottságot egy észak-déli választóvonal egészíti ki. Bár a közhiedelemben a rizs Kína legfőbb eledele, ez valójában inkább csak a déli országrészre igaz, míg - a klimatikus viszonyokból adódóan - az északi területeken inkább a szárazabb éghajlatot kedvelő gabonafélék (régmúltban a rozs, napjainkban a búza) az elterjedtek. Egyes elméletek szerint e különbségek még a lakosság mentalitására is hatással voltak. Mivel a rizstermesztéshez, a teraszok és öntözőcsatornák kialakításához jelentős közösségi összefogás szükségeltetett, a dél-kínaiak kollektívában gondolkodnak és holisztikusabb a szemléletük. Ezzel szemben az egy-egy család által is megoldható búzatermesztés miatt az északi területeken élők individualistábbak és gondolkodásmódjuk inkább analitikus. Természetesen az elmúlt évtizedek jelentős országon belüli népességmozgásai egyre inkább elmossák ezeket a különbségeket, de azért Európához hasonlatosan - továbbra is felfedezhető néhány eltérés az északi és a déli területek gondolkodásmódja, életstílusa között.

\subsubsection{Népesség}

Kína egész történelme során a világ legnépesebb területeihez tartozott. Becslések szerint körülbelül hetven millióan lakhatták már kétezer évvel ezelőtt is, azaz lélekszáma nagyjából megegyezett a Római Birodalom lakosságával. Az ezt követő évszázadokban hullámzó módon, de lassan növekedett a népesség, amely azonban a 19. század vérzivataros időszakában stagnálni kezdett. A KNK megalapításakor, 1949-ben körülbelül 500 millióan lakták az országot, és az idővel stabilizálódó élelmiszerellátásnak köszönhetően elképesztő ütemben kezdett nőni a lélekszám. Az 1960-as évek közepén már 700 millióan, 1982-re több mint egymilliárdan, 2010-re pedig közel 1,4 milliárdan éltek Kínában. Mára egy-egy kínai tartomány lélekszáma jelentős országokkal veszi fel a versenyt: Szecsuan, Santung (Shandong) és Kanton tartományokban külön-külön is többen élnek mint Németországban. Hasonlóan a mezőgazdasági területekhez, a népesség is rendkívül egyenetlenül oszlik el az országon belül, hiszen az államterület keleti 45 százalékán koncentrálódik a népesség 94 százaléka. Azaz, az ország nagyobb, nyugati fele kínai mércével szinte üres. A több mint másfél 
millió négyzetkilométeres Hszincsiang autonóm terület lakossága alig haladja meg a húszmillió főt, míg az 1,2 millió négyzetkilométeren elterülő Tibeti Autonóm Régió alig 3 millió ember otthona.

Nemzetiségi szempontból az ország szintén rendkívül heterogén képet mutat, hiszen hivatalosan 55 etnikai kisebbséget ismernek el a han többség mellett. Bár több, a kínai állam fenntarthatóságában kételkedő megfigyelő is amellett szokott érvelni, hogy nem lehetséges hosszabb távon egyben tartani egy 56 nemzetiségủ országot, az ilyen állítások figyelmen kívül hagyják a lakosságon belüli számarányokat. A han kínai többség ugyanis a népesség 91,5 százalékát teszi ki, azaz a többi 55 kisebbség összesen 8,5 százalékos részarányt képvisel (4. kép). Míg több mint 1200 millió han kínai alkotja a többségi társadalmat, a legnagyobb kisebbségi csoport, a csuang (zhuang) nép alig tizenhat millió föt számlál, tibetiből pedig hatmilliót tartanak nyilván a hivatalos adatok szerint. A nemzetiségek eloszlása sem egyenletes az országban. A han népcsoport döntő többsége a kínai civilizáció magterületén, az ország keleti tartományaiban, azaz a földmüvelésre leginkább alkalmas vidékeken összpontosul, így a népsürüség is rendkívül magas ebben a régióban. Eközben az ország területének nyugatabbra eső 55 százaléka kínai szinten üresnek mondható, hiszen a fentebb leírtak szerint a tibeti, ujgur, mongol és egyéb népcsoportok lélekszáma rendkívül alacsony az általuk hagyományosan benépesített területek méretéhez képest.

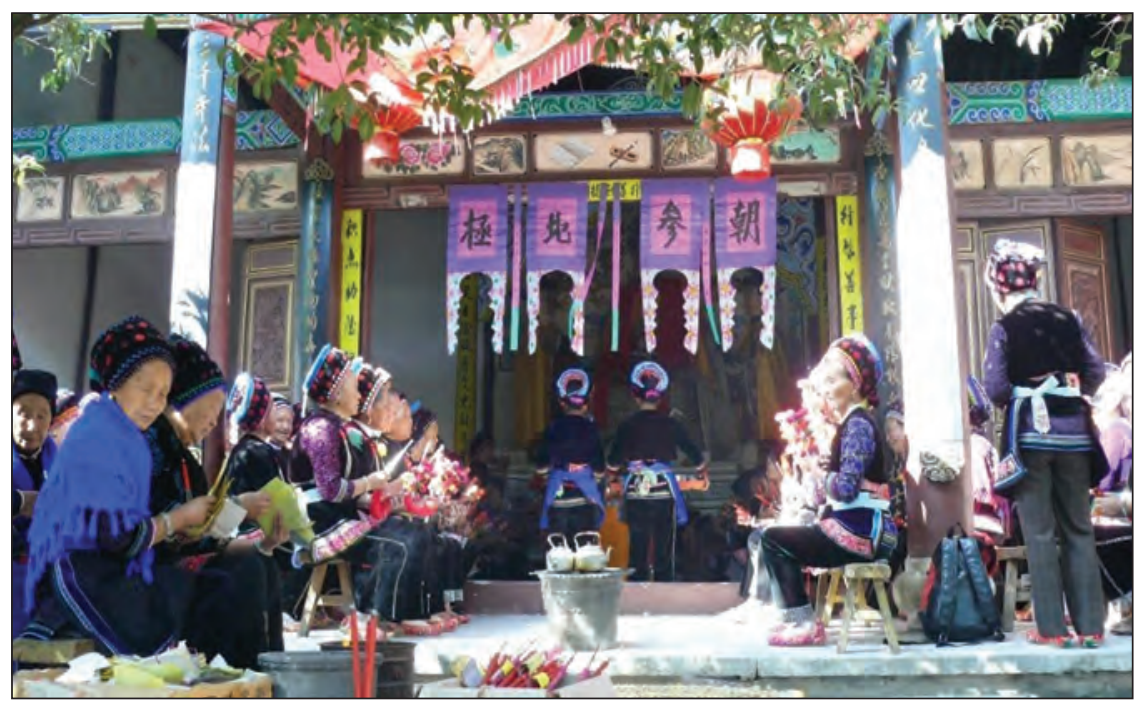

4. kép: Paj (Bai) nemzetiségü buddhista női közösség az idősek ünnepén, Jünnan (Yunnan) tartomány Forrás: BAGI Judit felvétele

A han kínai népesség etnogenezise 4-5 ezer éve kezdődött, és az azóta eltelt időszakban számos kisebb-nagyobb etnikumot olvasztott magába. Ez 
a folyamat ma is tart, hiszen a technológiai fejlödésnek köszönhetően egyre nagyobb teret kap a hivatalos államnyelv a pu-tung-hua (putonghua), így folyamatosan csökkennek a kínai nyelvjárások közötti regionális különbségek, és egyre több kisebbség asszimilálódik a többségi társadalomba (5. kép).

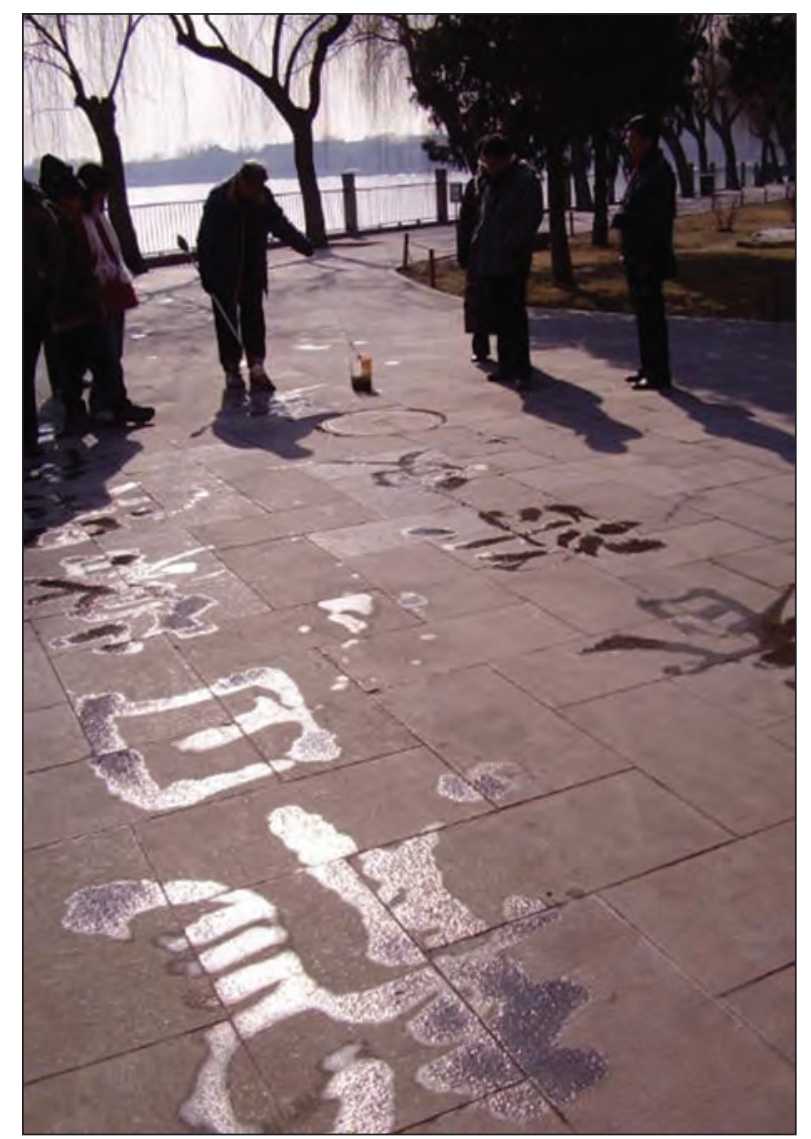

5. kép: Az írás szentsége. Szabadtéri kalligráfia Pekingben Forrás: BAGI Judit felvétele

Mindezzel összefügg a kínai nemzettudat kérdése is, amely elsősorban nem klasszikus etnikai, hanem tágabb, civilizációs-politikai alapú, amely a kisebbségeket is magába foglalja. Érdemes felhívni a figyelmet, hogy az ország elnevezése sem etnikai identitást tükröz - Csungkuo (Csung-hua): Zhongguo (Zhonghua) -, hanem egyfajta világfelfogást tükröz: a „Középső Birodalom”.

\subsubsection{A kínai nyelv}

A kínai nyelv a sino-tibeti nyelvcsalád részét képezik, és az 1,2 milliárd fös han népesség tagjai mind e nyelv valamely variációját beszélik. Valójában 
pontosabb lenne kínai nyelvekről beszélni, hiszen a nyelvtudomány képviselői szerint az ország egyes területein használatos szóbeli kommunikáció között akkora különbségek vannak, hogy azok inkább egy nyelvcsalád külön-külön tagjainak tekinthetők. A kínaiak maguk inkább a közös kínai nyelv dialektusairól szoktak beszélni, pedig az egyes nyelvjárások közötti különbségeket a latin nyelvek közötti eltérésekhez szokás hasonlítani. A legelterjedtebb, a körülbelül 960 millió fő által beszélt mandarin kínai, amelynek Peking (Beijing) környékén használatos változata a hivatalos nyelv (pu-tung-hua) alapja. További jelentős dialektus a vu (wu) (80 millió beszélő), amely Sanghajban (Shanghaiban) és környékén, a Jangce alsó folyása mentén használatos; a délkelet-kínai min (min) (70 millió beszélö) és a dél-kínai, Kantonban és környékén elterjedt jüe (yue) nyelv (60 millió beszélö). Fontos megjegyezni, hogy az egyes nyelvjárások (nyelvek) használói nem értik egymást. Az észak-kínai dialektusok hasonlatosak, de jelentősen eltérnek a Dél-Kínában használatos nyelvektöl, miközben a délkínaiak egymást sem értik. (Például a sanghaji magyar fökonzulátuson mandarin kínaira fordítótolmácsotalkalmaznak, ha a kantoni, vagymás dél-kínainyelvjárást beszélő helybelivel kell szót érteniük). E nyelvek különlegessége, hogy a szavak kiejtésének, a négy főbb hanglejtésnek jelentés megkülönböztető szerepe van, azaz tonális nyelvek. Szerencsére, a Csin-dinasztia (Qin-dinasztia) egységesítési törekvéseinek köszönhetően az íráskép az egész országban egyforma, így ilyen módon mindenki tud kommunikálni a más nyelvjárást beszélőkkel is, illetve ez magyarázza, hogy minden televíziós adást feliratoznak. Külön meg kell még említeni a pin-jin (pinyin) rendszert, amely a kínai írás 1950-es években kifejlesztett hivatalos, nemzetközileg elfogadott átírása latin betükre - egyik atyja, Csou Ju-kuang (Zhou Youguang) 2017. januárjában hunyt el száztizenegy éves korában. Ugyanakkor létezik más átírásmódja is a kínai karaktereknek, magyar változatból több is előfordul. A pin-jin (pinyin) átírási rendszer bevezetéséig Magyarországon a szakirodalomban a magyar tudományos átírást, míg a népszerűsítő kiadványokban, nem sinológiai tudományos müvekben és a hírközlésekben a magyar népszerü átírást használták. Jelen fejezetben az alábbi megoldást követjük. Minden kínai kifejezést és nevet magyar népszerü átírással közlünk, de a szó első előfordulásakor zárójelben megadjuk a nemzetközi szakirodalomban használt ún. pin-jin átírást is, amennyiben az különbözik.

\subsubsection{Hitvilág}

A kínai hitvilág föszereplöi a három tanítás: a konfucianizmus, a taoizmus és a buddhizmus, amelyek közül az első kettő kínai eredetű és egyben a legelterjedtebbek. ${ }^{5}$ Ugyan a hétköznapi nyelvezet gyakran vallásnak titulálja

5 A buddhizmus leírását ld. az indiai civilizációt ismertető fejezetben. 
a kínai hitvilág e három elemét, azonban sokkal inkább tekinthetők filozófiai iskolának, élet- és államvezetési sorvezetőnek, mintsem a nyugati értelemben vett klasszikus vallásnak. Míg a három nagy nyugati, egy tőről fakadó vallás, azaz a keresztény, a zsidó és az iszlám hitvilág jórészt egyezik abban, hogy monoteista, exkluzív és (a judaizmust kivéve) térítő jellegü, addig a kínai megközelítés teljesen eltér ettől. Egyfelől nem beszélhetünk egyistenhitről, sőt az istenek is inkább emlékeztetnek a nyugati szentekre, hiszen többnyire az egykoron élt ősökröl, esetleg mitologikus lényekről van szó. Emellett nem érvényesül a kizárólagosság elve sem, azaz miközben egy keresztény nem lehet egyszerre zsidó és muszlim is (illetve vice versa), addig a kínai (keleti) kultúrában nincs ilyen éles választóvonal az egyes hitek között, sokan párhuzamosan több „vallás” tanítását és szokásait is követik. Talán ebben is a kínai pragmatizmus mutatkozik meg, amely sokkal inkább a lehetőségekre koncentrál, mintsem önként kizárná magát a többi hitvilág által nyújtottakból.

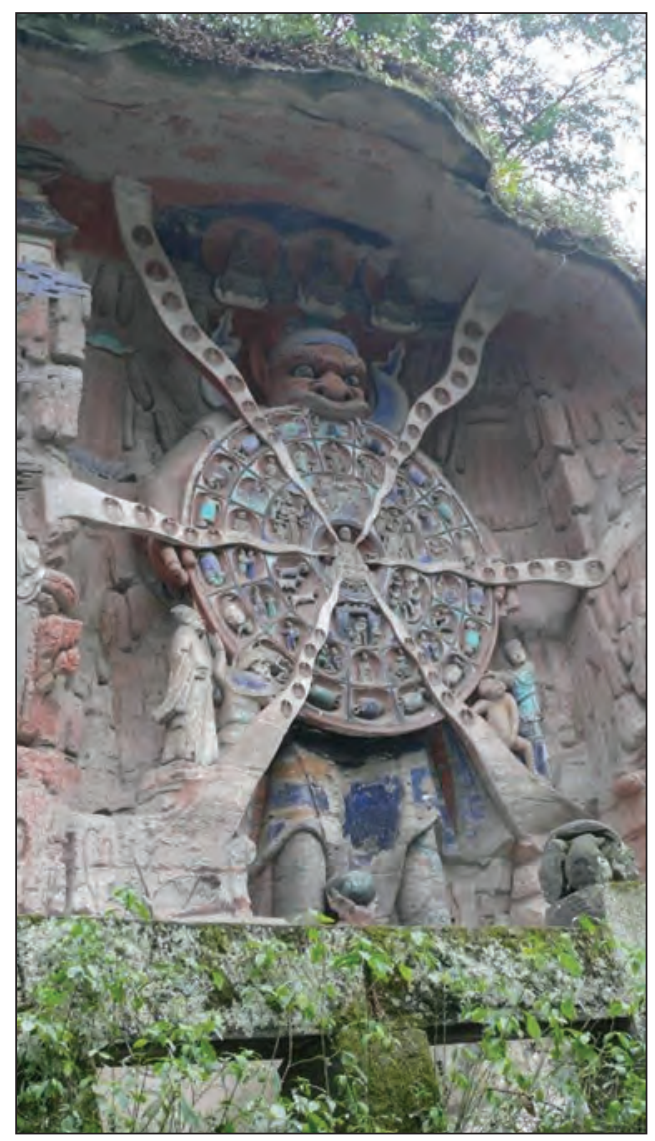

6. kép: Életkerék. Kőfaragás a buddhista, konfuciánus és taoista hitet is tükröző Tacu (Dazu) barlangokból, Szecsuan (Sichuan) tartomány

Forrás: BAGI Judit felvétele 
A nyugati terminológia e jelenséget a szinkretizmus fogalmával írja le, amely szerint - szemben a nyugati egyistenhívő, exkluzivitásra törekvő vallásokkal és jó részt ezen alapuló kategorikus gondolkodásmóddal - a keleti emberek lehetségesnek tartják egyszerre többféle igazság létezését is. Mindez befogadóvá teszi szellemi értelemben a keleti kultúrákat, amennyiben képesek más szellemi irányzatokat a saját képükre formálva adaptálni.

Pont e jelenség miatt viszont a statisztikák készítése sem egyszerü feladat, így csak becslések vannak egyes hitek követőinek száma kapcsán. A helyzetet tovább bonyolítja, hogy a KNK hivatalosan csak öt vallást ismer el, a buddhizmust, a taoizmust, az iszlámot, a protestantizmust és a katolicizmust (de nem a római, hanem a kínai katolikus egyházat), míg a konfucianizmust csak a 21. század hajnalán kezdték el nem hivatalosan újra elfogadni (6. kép). Mindemellett fontos megemlíteni a népi vallásokat is, hiszen a felmérések szerint a lakosság többsége ezek valamelyikét (illetve taoizmussal kevert változatát) követi, míg 10-15 százaléka buddhista, 2-4 százaléka keresztény és 1-2 százaléka muszlim.

\section{A taoizmus}

Lao-ce (Laozi, i. e. 6. század) kiléte bizonytalan, egyes kutatók tagadják, mások elfogadják létét és nevét, mint vallásalapítóét. A hagyomány szerint királyi levéltárosként kezdte pályafutását. Idővel elhagyta a királyi udvart, és különböző területeken élt, amíg legfontosabb, máig meghatározó „Az Út és Erény könyve" - Tao Te King: Tao-tö-csing (Daodejing) - címü, a taoizmus legfontosabb forrásának számító munkája megszületett. Lao-ce múvében a világegyetem müködéséről fejtette ki nézeteit közérthető formában. A tao (dao) az egyetemes erö, amely spontán mozgásával irányítja az univerzum müködését. Nézete szerint a bölcs ember a természetességre, az ürességre törekszik, amihez „nem-cselekvés” - vu-vej (wuwei) - vezeti el. A mű idealizált patriarchális társadalmat állít elénk, amelynek irányítója, szellemi vezetője a „bölcs”. A taot nem teremtette senki, ő a minden és a semmi, érzékszervekkel felfoghatatlan, mégis állandó és kimeríthetetlen. A tao időn és téren kívül létezik, ő a végtelenség és az abszolútum, a tao szül mindent. (Ha valakinek a fenti leírás ismerősen csengene a modern popkultúrából, akkor nem téved nagyot, ugyanis egyes vélekedések szerint a Star Wars sokat merített a taoizmusból az „Erő” leírásakor).

A taoizmus szerint világunkban minden viszonylagos, sőt gyakran egyenesen illuzórikus, így kérdéses, hogy érdemes-e megterhelni magunkat gondokkal, társadalmi kötelezettségekkel. A taoista gondolkodás ugyanakkor egyfajta metafizikai alapot szolgáltatott az olyan, gyakorlatibb beállítottságú filozófiai iskolák számára, mint például a legizmus-fa-csia(fajia). Elnevezéséből 
is adódik, hogy ezen irányzat központi szereplője a jog, azaz a szabályokon és törvényeken alapuló társadalmi rend. A kínai jogelméletet alapjaiban határozza meg a konfuciánus és legista megközelítés, amelyek egyik fontos tényezője a moralitás, azaz a társadalmi normákat a jogi normákkal egybeolvasztó, az ősi Kínában általános szemlélet. A jog és az erkölcs nem volt elválasztható egymástól, miközben a bírói és az adminisztratív hatalom is egységet alkotott, így nem meglepő, hogy - sokszor máig tartó gyakorlatként - az autoriter szokásjog alapján egyén és állam viszonyában rendszerint az utóbbi javára dőltek el a vitás ügyek. Kínában nem alakult ki bizalom a nép részéről a törvények és a jogrend iránt, ugyanis nem akadt olyan jogintézmény, amelyhez bizalommal fordulhattak volna jogaik csorbulása esetén. Megfigyelhetö, hogy a Középső Birodalom történetében nem merült fel a hatalmi ágak szétválasztásának igénye sem, a jogszabályok rendszerét az alárendelő jellegü, büntető célzatú törvények és rendelkezések uralták, miközben hiányoztak a mellérendelő, polgári típusú jogviszonyokat rendező normák. Az i. e. 4. század zavaros időszakában már nem lehetett az addig bevált állami eszközökkel fenntartani a társadalmi rendet, ezért olyan, új elveket kellett alkalmazni, amelyek megfeleltek a helyzetnek, és képesek voltak alkalmazkodni a változó körülményekhez is. Ezek az eszközök a törvények lettek.

A legisták a legkülönbözőbb filozófiai iskolákból kerültek ki, így a taoisták közül is. Az i. e. 3-4. században terjedt el leginkább a legizmus, legisták eleinte szemben álltak a konfucianizmussal, hiszen a konfuciánusok ebben az időben az elméletet szembefordították a gyakorlattal. Míg a konfuciánusok az erkölcs és a szokásjog addig bevált princípiumait tekintették mérvadónak, addig a legisták feltétel nélkül a törvényt tartották a viselkedés meghatározójának. A legista tanok szerint a törvényeknek változniuk kell a korral, sőt, a szabályok nem is maradhatnak hosszú távon változatlanok, hanem mindig meg kell felelniük az adott kor körülményeinek. Amennyiben a törvények már nem felelnek meg a kritériumoknak, és nem is változtatják meg őket, akkor kitör a zürzavar. Ezt már csak azért is el kell kerülni, mert a törvények morális alapját a hatékonyságuk adja, azaz, hogy a megfelelő szabályozást biztosítják, és így megfelelö eredményre vezetnek.

\section{A konfucianizmus}

A másik meghatározó kínai filozófiai iskola Konfuciusz - Kung Csiu (Kong Qiu), i. e. 551-479; Kung-ce (Kongzi); Kung Fu-ce (Kong Fuzi) nevéhez köthető. Filozófiája mára már vallásnak számít, bár természetesen nem a hagyományos nyugati értelemben. Konfuciusz azt vallotta, hogy a közügyek reformjának feltétele a család és az egyes ember megváltozása. A Konfuciusz korára már kiüresedett társadalmi konvenciók és viselkedési 
szabályok újjáélesztése érdekében a mester elengedhetetlennek tartotta, hogy az uralkodó is példamutató módon viselkedjen. Azt vallotta, hogy ha az uralkodó helyes magatartást követ, akkor alattvalói is hajlamosabbak ezen utat követni, így kormányzásuk is sokkal egyszerübbé válik. Ezzel szemben, a helytelenül viselkedő uralkodónak idővel még a parancsait sem teljesítik majd. Ez a politikai alapvetés egyértelmüen máig tartó, egyetemes tanításnak tekinthető, amelyhez a Kínai Népköztársaság vezetői is igyekeznek tartani magukat a külsőségekben, és azokra, akik rossz fényt vetnek viselkedésükkel a kormányzatra (pl.: korrupció), a törvény szigorával sújtanak le.

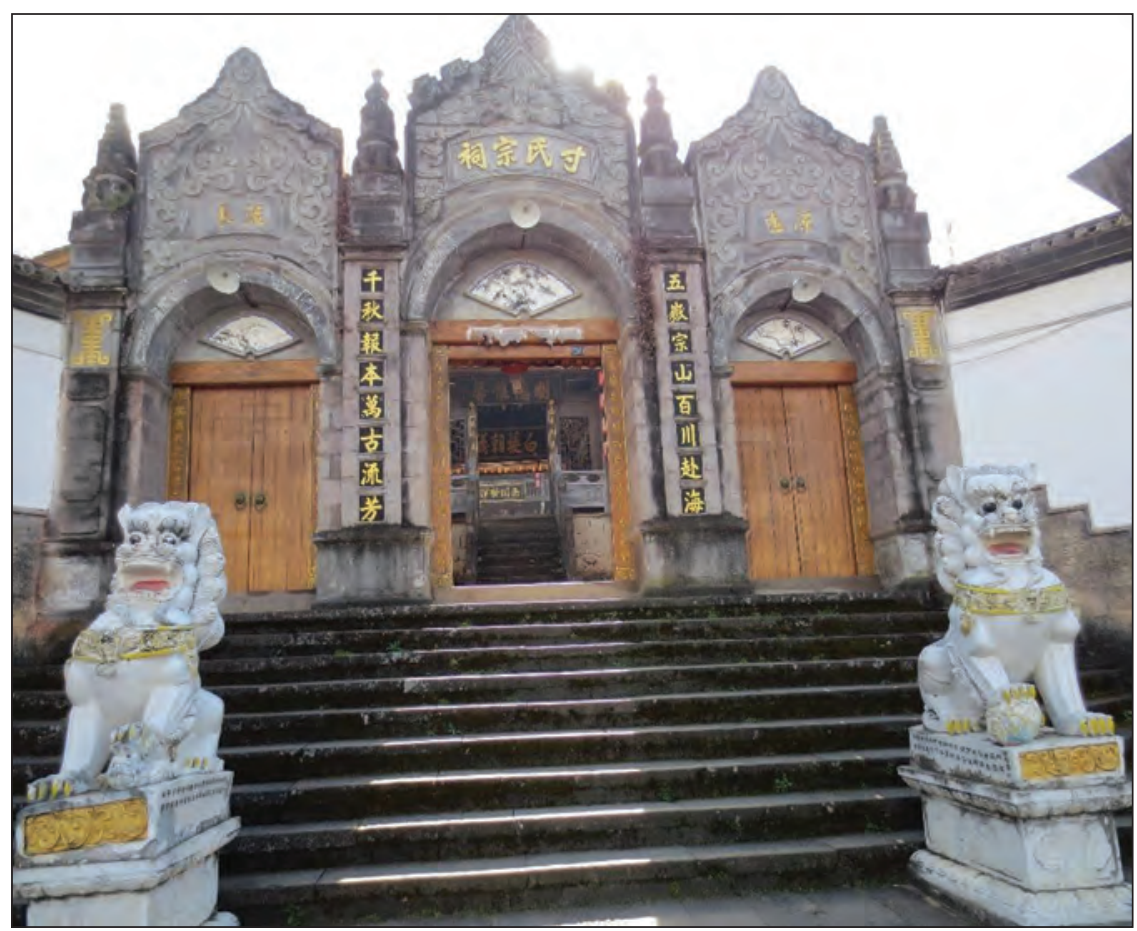

7. kép: Ösök temploma, Tengcsungban (Tengchong), Jünnan (Yunnan) tartomány Forrás: BAGI Judit felvétele

Később, a Han-korban a fennálló kormányzati rendszer bírálata helyébe annak megingathatatlanságának elve lépett. Az eredetileg humanista alapokon nyugvó konfuciuszi világkép ekkor a kínai hivatalnoki rendszer eszmei alapjává változott, amely nagy hatással volt az ország életére. A kínai felfogásban szoros kapcsolat köti össze az embert és a közösséget, az egyén mikrokozmosza és a világmindenség, az egyszerü halandók makrokozmosza és az istenség közötti viszony közvetlen. Ebből is következik az a társadalomkép, amely egyébként egész Kelet-Ázsiára jellemző, hogy az egyén szerepe és érdeke alárendelt viszonyban áll a közösség szerepével és érdekével szemben (7. kép). Ez, a 
nyugati egocentrikus társadalmi berendezkedéstől jól megkülönböztethető jellegzetesség igen nagy hatást gyakorol a kínai politikai életre, mind a bel-, mind pedig a külpolitika terén is, hiszen filozófiai alapot biztosít a Kínában fennálló hatékony rendszernek. Sőt, azt a kínai érvrendszert is alátámasztja, amely szerint a nyugati demokrácia Kínában alkalmazhatatlan, mert nem oldaná meg az ország problémáit, nem töri meg a hivatalnokok és üzletemberek visszaéléseit és nem védi az átlagemberek érdekeit. Mindezek miatt egyenesen kontraproduktív lenne Kína számára, és könnyen az ország destabilizálódásához vezethetne, legalábbis a kínai vezetők szerint.

\section{A legizmus elöfutára}

A konfuciánus és legista tanokon túl létezik még egy harmadik megközelítés is, a Kuan-ce - Kuan Csung (Guan Zhong), i. e. 720-645 - nevéhez köthető úgynevezett fontos és kevésbé fontos dolgok egyensúlya elmélete. E gondolatkör a kormányzást a gazdasági tevékenységen keresztül kívánja megvalósítani, miközben világos sorrendet állít fel a dolgok között fontosságuk (sürgősségük) alapján, ezzel javítva a probléma megoldás hatékonyságát. A legistákhoz hasonlóan Kuan-ce is a közös érdekekre helyezi a hangsúlyt az államközi kapcsolatok terén, ugyanakkor az előbbiektől eltérően a gazdasági erőket a jog elé helyezi az állam irányítása terén. A jog hatékonysága nem önmagából fakad, hanem abból a gazdasági környezetből, amelyben az adott szabályozás megszületett. Az uralkodó csak akkor képes az államot irányítása alatt tartani, ha a gazdaságot is sikerrel felügyeli. Míg a konfucianizmus az erényt tartja a legfontosabbnak, Kuan-ce tanítása szerint az erény „csupán” a gazdasági érdekből fakad. Az államok közötti viszony kapcsán a mester szintén a gazdaságot tartja a legfontosabbnak, felismerve azt a tényt, hogy a harcoló felek közül többnyire a gazdaságilag erősebb kerül ki győztesként. Eszerint a gazdasági hatalom a döntő tényező, és egy állam hatalmát leginkább azon lehet lemérni, hogy mekkora javakat birtokol, és hogy e javakat milyen gyorsan képes mozgósítani a háború során.

\subsubsection{Kína története és annak hatása nemzetközi kapcsolataira}

Az alábbi fejezetben megkíséreljük röviden összefoglalni Kína közel ötezer éves történetének föbb állomásait. A mai Kína számára a jelenlegi világrend alapjaiban különbözik az elmúlt évezredek során „megszokottól”. A birodalom fennállása alatt többnyire egyszemélyi császári hatalom alatt egyesítette az általuk ismert világ nagy részét, a háborúk pedig elsősorban a császári hatalomért folytak, azaz inkább belső konfliktusoknak tekinthetők, mintsem valódi nemzetközi összeütközéseknek. A 18-19. századot megelőzően 
egyértelműen Kína volt Ázsia vezető állama gazdasági és kulturális téren egyaránt. Bár hosszú történelme folyamán számtalan külső támadás érte a Középső Birodalmat, annak méretei és népes lakossága miatt végül maguk a hódítók is beolvadtak a kínai kultúrába. A szuverén, egyenrangú államok rendszere ezért nem természetes a kínai gondolkodás számára, a kívülről jötteket csupán barbároknak tartották az idők folyamán, követeket küldeni külföldre pedig feleslegesnek tűnt számukra. Így volt ez annak ellenére, hogy például a Selyemúton Kína is küldött követeket történetének különböző korszakaiban. Az Európára olyannyira jellemző hatalmi egyensúly rendszere és mechanikája Kína számára ismeretlen volt egészen a nyugati hódítóktól elszenvedett vereségek és megaláztatások beköszöntéig. Az alábbiakban megkíséreljük felvázolni a kínai történelem legjelentősebbnek ítélt momentumait és időszakait, annak érdekében, hogy az elmúlt évezredek kontextusába helyezzük a kínai stratégiai és külpolitikai gondolkodás bemutatását. A kép természetesen nem lehet teljes, a rendelkezésre álló terjedelmi keretek mellett az ország történelmét és civilizációját leginkább meghatározó, a mai külpolitikai magatartására is hatással lévő főbb eseményeket, időszakokat vesszük számba.

A mai Kína területe már a történelem elötti időkben is lakott volt, az 1965-ben bekövetkezett felfedezését követően közkeletủen csupán „pekingi embernek" hívott homo erectus több mint egymillió évvel ezelőtt jelent meg az észak-kínai területeken. Egyes archeológiai leletek szerint 1,2 millió évvel ezelőtt már a tüzhasználatra utaló nyomok is felfedezhetőek.

Az első kultúrák Kína területén, akárcsak számos másik ősi civilizáció esetében, elsősorban a nagy folyók, a Sárga-folyó és a Jangce völgyében, illetve a tengerparti területeken jelentek meg időszámításunk elött 8000 környékén. Az i. e. 8. évezredből, azaz azújkőkorból származnak az első mezőgazdálkodást jelző bizonyítékok, majd idővel a Sárga-folyó völgye vált a kulturális központtá, ahol az első állandó falvakat is megalapították. A kínai civilizáció sajátossága, hogy egyedülállóan régre nyúlik vissza írásbelisége. Bár a Ninghsziaban felfedezett, sziklába vésett írásjegyek az i. e. 6000-5000 közötti időszakból származhatnak, ezek még csak nyomokban hasonlítanak a legkorábbinak elfogadott valódi kínai karakterekhez. Azonban a már valóban kínai írásbeliségnek tekinthető, teknőspáncélra karcolt feliratokat tartalmazó leletek is az i. e. 2000-1500 közötti időszakból származnak, azaz legalább 3500-4000 évesek. Európai szemmel ennél is megdöbbentőbb, hogy ezen írásjegyek némelyikének formája és jelentése nem, vagy csak alig változott az azóta eltelt évezredek folyamán.

Az írásbeliség kezdetéhez köthető Kína úgynevezett mitikus időszaka, a Három fenség (i. e. 2800-2737) és az Öt (mitikus) császár kora (i. e. 27372698), akikre utódaik félistenként tekintettek, és a mai napig Kína legősibb „istenségei” között szerepelnek (istenekről valójában nem beszélhetünk Kína esetében, ld. a vallásokról szóló részt). Az Öt (mitikus) császár korának alapítóját, 
a Sárga Császárt máig a kínai civilizáció létrehozójának és a kínai nép ősének tekintik, bár számos tudományos kutatás megkérdőjelezi, hogy valóban létezett. Valószínüleg inkább egyfajta kultúrhéroszról van szó, aki évszázadokkal később öltött alakot a történetírók müveiben.

\subsubsection{A dinasztiák kora}

A kínai történelem szempontjából a dinasztiák egymást követő sora a legfőbb igazodási pont. Nagyban meghatározza a kínai nép történelemszemléletét a dinasztiákhoz köthető ciklikusság, illetve az ezzel összefüggő rend és káosz váltakozása. Erősen leegyszerüsítve elmondható, hogy míg az európai történelemszemlélet lineárisan viszonyul az időhöz, amelyben szakadatlan fejlődést vél felfedezni, addig a kínai (keleti) látásmód sokkal inkább az ismétlődő, körforgás szerü időszakokat helyezi előtérbe. A ciklusok egyes szakaszaihoz ráadásul különböző társadalmi viszonyokat társít, hiszen egy-egy dinasztia megalakulása, felemelkedése, tündöklése, majd bukása természetesen alapvetően meghatározta az adott kor emberének mindennapjait, életét és gyermekei jövőjét. Az akár szinuszritmusként is ábrázolható kínai történelemben egymást követték a felemelkedő és lehanyatló dinasztiák, azonban az átlagember szempontjából a jó és stabil, prosperáló időszakokat leginkább a hullám felszálló ága és csúcsa jelentette, míg a hanyatló szakasz egyre több nehézséget, éhséget, majd végül háborút, belharcokat hozott magával. Az új dinasztia alapítója többnyire egy rátermett, tehetséges, gyakran alacsony társadalmi rangból önmagát felküzdő hadvezér volt, aki hatalma megszilárdítását követően véget vetett a belső harcokat jellemző káosznak és az ország megosztottságának, és nagy uralkodóként vonult be a történelembe (az más kérdés, hogy kortársai szempontjából gyakran egy keménykezü, az országot vérrel és vassal összekovácsoló autokratikus uralkodóról volt szó). Leszármazottai az évtizedek, évszázadok múltával egyre kevésbé foglalkoztak az ország dolgaival, virágzott az udvari intrika, elharapódzott a Kínára jellemző korrupció, gazdasági problémák támadtak, és a helyzetet időnként természeti katasztrófák, klímaváltozás vagy éppen nomád törzsek betörése is súlyosbította. A dinasztia hanyatlásának végső szakaszában elvesztette belső legitimitását, elvesztette az „ég mandátumát” az ország vezetésére és a belső vagy külső támadások hatására elbukott. Helyét egy új, erős vezető vette át, aki megszerezte az „égi mandátumot”. Fontos emlékeztetni arra, hogy ezt a köztes időszakot valójában egy belháborúkkal, megosztottsággal, az ország szétesésével és tömeges lakosság illetve vagyonvesztéssel járó periódusként írhatjuk le, így érthető, hogy a kínai néplélek számára az uralkodó dinasztia, és így az ország stabilitása fontos, míg alapvetően tartanak az ország vezetésében, rendjében beálló változásoktól. 
Az első, mitikus dinasztia - Hszia (Xia) -, amelynek létezése nem teljesen bizonyított, csupán évszázadokkal később keletkezett forrásokban olvashatunk róla, ahol a magas szintü államvezetés és közigazgatás kiváló példájaként írnak róla. Így, nem zárható ki, hogy csupán példabeszédként jöttek létre a Hsziadinasztiáról szóló történetek. Ugyanakkor néhány Honan (Henan) tartományban fellelt archeológiai lelet is köthető ezen időszakhoz (2. térkép), így egyelöre további kutatásokat folytatnak a kérdésben. Mindeközben Európában a minószi kultúra virágzott Krétán az i. e. 27-15. század között.

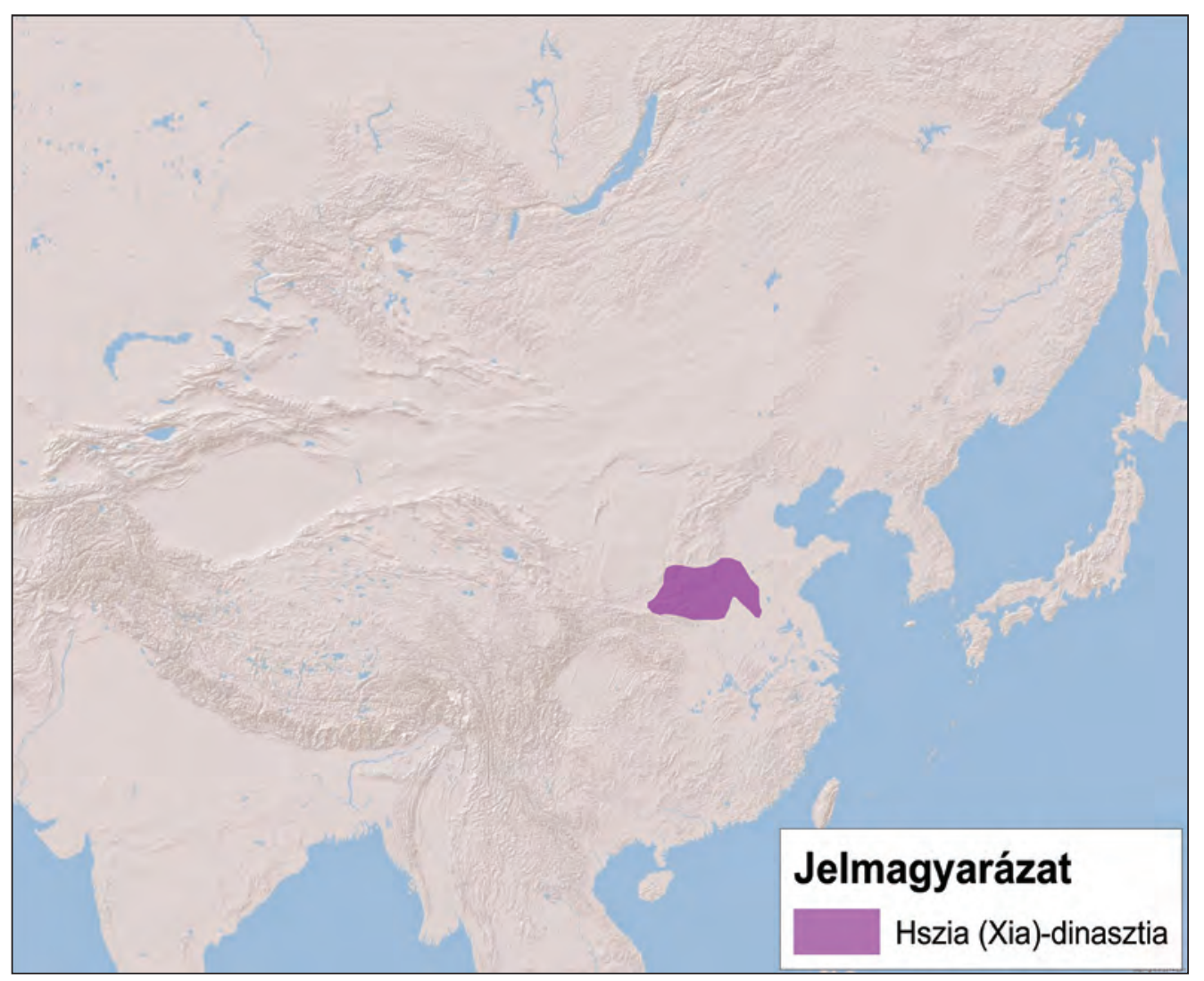

2. térkép: Az első, mitikus dinasztia feltételezett elhelyezkedése Forrás: VARGa ÁGNes szerkesztése

A Sang-dinasztia (i. e. 1600-1046)

A Sang-dinasztia - Sang (Shang) - bronzkori időszakából származnak az első kínai írásos nyelvemlékek, a vésett jóslócsontok, majd a dinasztia kései szakaszában már egy teljesen kifejlett rendszert használtak bronz, kerámia, kő 
és jade kristály felületeken. Utolsó királya öngyilkosságot követett el, amikor haderejét legyőzte a Csou (Zhou) sereg. Eközben Európában Mükéné vette át a kulturális központ szerepét az i. e. 1600-1100 közötti időszakban.

\section{A Csou-dinasztia (i. e. 1046-221)}

A leghosszabb ideig regnáló kínai uralkodóház, félfeudális rendszer jellemezte, és királyai vezették be az „égi mandátum” koncepciót, amellyel hatalmukat legitimizálták. A kínai történetírás a Csou-koron - Csou (Zhou) belül két időszakot különböztet meg. Az elsőben a dinasztia királyai a Vei-folyó - Wei-folyó; Vej-ho (Weihe) - völgyében építették fel fővárosukat (Nyugati Csoukor, i. e. 11. századtól i. e. 771-ig). Az ezt követö szakasz (a Keleti Csou-kor) a főváros áthelyezésével kezdődött Csengcsouba (Chengzhouba), és i. e. 256-ban ért véget, amikor Csin fejedelemség megdöntötte a Csouk uralmát. Az ország i. e. 221-es egyesítését megelőző kort a szakadatlan háborúk miatt a Hadakozó fejedelemségek - Csan-kuo (Zhanguo) - korának nevezzük. Ez utóbbi kezdetét egyesek i. e. 451-re, a Csin (Jin) fejedelemség felosztásának évére, mások i. e. 403-ra teszik, amikor a Csou uralkodó hivatalosan is elismerte ezt a felosztást és az így létrejött új fejedelemségeket - Han, Vej (Wei) és Csao (Zhao). A kínai „feudalizmus" meglehetösen egyedi sajátosságokat mutat, azoknak a szoros kötelékeknek köszönhetően, amelyek azt eredményezték, hogy a politikai intézmények függő helyzetbe kerültek az őskultusz intézményétől, s összevonták a katonai és vallási funkciókat. Ezt a rendszert tehát még mindig erős szálak füzték az archaikus monarchiához, amelyböl kinőtt. Ugyanakkor fel kell hívnunk a figyelmet arra a jellegzetességre, hogy az ősi Kínával kapcsolatban a „feudális” kifejezést már oly sokszor használták tévesen, hogy teljesen elvesztette eredeti jelentését. Ezért helyesebb tehát, ha a korszak jellemzésekor eltekintünk e jelzőtől, s csupán a sajátságos intézményeknek és annak a politikai és társadalmi rendszernek a bemutatására szorítkozunk, amely a kínai világ hosszú történelme során a leginkább hasonlított a nyugati történészek által elöször feudálisnak nevezett európai társadalomra. A kínai „feudalizmus” földbirtokrendszer hierarchiáján és az öskultuszon alapult. A királyi birtok, illetve a Csou uralkodók őseinek kultusza tekinthető e berendezkedés központjának. A király az Ég Fia - Tien-ce (Tianzi) - címet viselte, akinek a Magasságos Úrtól - Sang-ti (Shangdi) - eredeztethető hatalma, így csak neki volt joga bemutatni a legföbb istennek szánt áldozatokat.

A földterületek egyfajta „kirajzási” folyamat eredményeképpen növekedtek. Az adományföldek rendszere tette lehetővé az előkelő családoknak, hogy az általuk birtokolt területen a katonai és vallási hatalmat egyaránt kezükben tartsák. Azaz tulajdonképpen a királyi hatalomnak a családok és a földbirtokok kiterjedt

6 A fejezet erösen támaszkodik Jacques Gernet: A kínai civilizáció története címü alapmüvére (GERNET, J. 2005). 
hierarchiájába helyezett megtestesüléséről volt szó. A rendszer összetartó ereje az őskultusz intézménye volt. Az úgynevezett föágakhoz tartozó nemzetségek fejei egyenes ági leszármazottai voltak a nemzetségalapító ősnek, akinek a tiszteleti kultusza generációról generációra öröklődött. Minden előkelő családban az volt a szokás, legalábbis a Sang-kor végétől kezdve, hogy a föfeleség elsőszülött fiúgyermeke örökölte a kötelezettségeket és a vallási kiváltságokat. Ezért tulajdonítottak különösen nagy fontosságot a föfeleség és a fiúági öröklés intézményének.

A fejedelemségek szervezeti felépítése megegyezett a királyi udvaréval: a fejedelmet főhivatalnokok - taj-fu (daifu) - és miniszterek - csing (qing) segítették. A legelőkelőbb családfők a fejedelem mellett olyan hivatalokat töltöttek be, amelyek idővel lényegében örökletessé váltak. A másodlagos ágakból származó köznemesek - si (shi) - a miniszterek és a föhivatalnokok alatt álltak a hierarchiában. Legfontosabb kötelezettségük az volt, hogy háború esetén, a harci szekereken teljesítsenek szolgálatot, míg a parasztságból állt elő a gyalogság - tu (tu) -, s természetesen ők müvelték a földeket, amelyeknek a termése az előkelöségeket illette.

A hadsereg a közigazgatás és a családon belüli hierarchia mintájára épült fel, mivel az előkelöségeknek és a főhivatalnokoknak, csakúgy, mint a fejedelemségek vezetőinek, akik a királyi udvar befolyásos méltóságai voltak, a rangban náluk magasabban állók parancsára kötelességük volt harci szekerekböl és gyalogosokból álló csapatot kiállítani, s hadba vonulni.

Bár a Sangok idején az elhunyt királyok kultusza és leszármazottjaik tekintélye igen mélyen áthatotta a társadalmi és politikai rendszert, az ezt követően kialakult, sokkal összetettebb és ingatagabb rendszerben a király hatalma már csupán egyfajta döntőbírói szerepre korlátozódott. Annak ellenére, hogy elvileg az adományozott hivatalokat és kiváltságokat vissza is vonhatta volna a király, a fejedelemségek fejlődése és a főhivatalnokok családjainak megerősödése miatt idővel ezek örökletessé váltak.

Ezt a fejlődési folyamatot az i. e. 8. század első felétől még inkább felgyorsították a Senhszi (Shaanxi) tartományban élő népek támadásai és a királyi birtok területének csökkenése. Zheng fejedelemség mellett, amely a főváros átköltöztetésének idején a Csou királyok fö szövetségesének számított, de hamarosan elvesztette kivételezett helyzetét, további erős fejedelemségek alakultak ki a Kínai-alföldön: Szung (Song), Vej (Wei), Lu (Lu), Cao (Cao), Csen (Chen), Caj (Cai) és mások. Az i. e. 8. században a számos kisebb város mellett tucatnyi ilyen kis államocska létezett. Az erősebb és gyengébb fejedelemségek szövevényes rendszerében ekkor már nem a királyok vallási és katonai önállósága, hanem a rituális szertartások és az ősök ismerete volt a meghatározó tényező. Ezek a viszonyok határozták meg a szövetséges, egyszersmind azonban egymással rivalizáló kis államocskák kapcsolatrendszerét, amelyeket hol egységbe 
tömörítettek, hol pedig megosztottak a háborúk, a bosszúhadjáratok, a házassági szövetségek, a szerződések, az árucsere és az egymásnak tett szolgálatok. A Csoudinasztia idejére esett Róma megalapítása (i. e. 753), a Peloponnészoszi háború (i. e. 431-404) és Nagy Sándor uralkodása (i. e. 356-323).

\section{A monarchia hanyatlása}

A Tavasz és ösz korszak - Csun-csiu (Chunqiu) - során a Kínai-alföld ősi városai, a „középső fejedelemségek” - Csin, Csi (Qi) és Csu (Chu) -, s a külső területeken terjeszkedő, politikailag egyre erősebb fejedelemségek közötti általános ellentétek mindjobban kiéleződtek. Az Észak-Kínában élő népcsoportok betörései az i. e. 8. században is kezdődtek, majd az i. e. 7. század közepére egyre erőteljesebbekké váltak. E külső hatás arra késztette Csi és Csin állam uralkodóit, hogy vezetésükkel olyan szövetségeket hozzanak létre, amelyek fö célja Kína határainak védelme volt a külső támadásokkal szemben. E szövetségi rendszerek ugyanakkor elősegítették a nagy fejedelemségek hegemonikus törekvéseit. A Csi fejedelemség hegemóniáját i. e. 651-ben nyilvánították ki. Ezt követően Csin állam uralkodója lett a hegemón. Az i. e. 6. század elejétől azonban a hegemóniák jellege és céljai módosultak, miután Csuang (Zhuang), Csu királya i. e. 597-ben vereséget mért a Csin seregekre. Ettől kezdve a nagyhatalmú fejedelemségek rákényszerítették akaratukat a gyengébbekre, majd az így kialakult új politikai helyzetet kierőszakolt hüségesküvel szentesítették.

Miután létrejöttek Kínán belül a nagyobb politikai egységek, az egyes fejedelemségek közötti konfliktusok is új jelleget öltöttek. Már nem pusztán az egyes családok vitáiról beszélhetünk - amelyeket fegyverekkel próbáltak eldönteni -, hanem a szövetséges, de ugyanakkor rivalizáló fejedelemségek háborúiról. Ugyanakkor e fejedelemségek a kulturális hátteret és hagyományokat tekintve nem különböztek egymástól lényegesen. A korabeli civilizáció délkelet felé való terjeszkedése során két új államalakulat is létrejött: $V u(W u)$ és Jüe (Yue). E a tengerparti és folyami állam a megerősödésével az i. e. 6. század elején a nyugati szomszéd, Csu fejedelemség hatalma hanyatlani kezdett. Válaszul a fejedelemségekben a katonai elemek kerültek túlsúlyba, ami természetesen magát a társadalomszerkezetet is módosította, majd válságba sodorta. Az előkelőségek társadalmának válságára utaló jelek i. e. 600tól kezdve mind gyakoribbakká váltak. Az i. e. 6. század folyamán olyan intézményeket alakítottak ki a fejedelmek, amelyek elsősorban saját hatalmuk és függetlenségük megerösítését szolgálták: megjelentek a mezőgazdaságra kivetett első adófajták; bevezették azt a gyakorlatot, hogy az előkelőségek emberek helyett fegyverekkel és gabonával járultak hozzá a háborúskodáshoz.

$\mathrm{Az}$ i. e. 5. század elejétől egyre hevesebbekké váltak a fejedelemségek közötti harcok. Lu államban, Santung tartomány nyugati részén, három befolyásos, elökelö csoport, a Meng-szun (Mengsun), a Su-szun (Shusun) és a Csi-szun (Jisun) 
család vezetői ragadták magukhoz az uralmat. Csin államban a fejedelem három hadseregét irányító hat fóhivatalnok-család vetélkedett egymással a hatalomért. A háborúskodás i. e. 453-ban Csin megsemmisülésével és felosztásával ért véget. Területén három független politikai alakulat jött létre a Han, a Vej és a Csao család uralma alatt. Csi fejedelemségben, i. e. 386-ra a Tien (Tian) család végleg megfosztotta az uralkodócsaládot összes előjogától. A fent leirt viszályok és hatalmi harcok alapozták meg a Hadakozó fejedelemségek korának háborúit, amelyek elkerülhetetlenül vezettek a központosított állam, a birodalom megalapításához.

\section{A Hadakozó fejedelemségek kora (i. e. 5. sz. - i. e. 221)}

A kínai történelem egyik legmeghatározóbb időszaka volt a hadakozó fejedelemségek kora, amikor hét államalakulat jött létre a meggyengülő Csoudinasztia területén (3. térkép), amelynek uralkodója csupán szimbolikus szerepet töltött be már csupán. Az ország egésze feletti hatalomért zajló elnyúló harc az utolsó olyan hosszú időszak volt Kína életében, amely az európai viszonyokhoz, azaz több, hasonló erejü állam egymással való háborúskodásához hasonlítható.

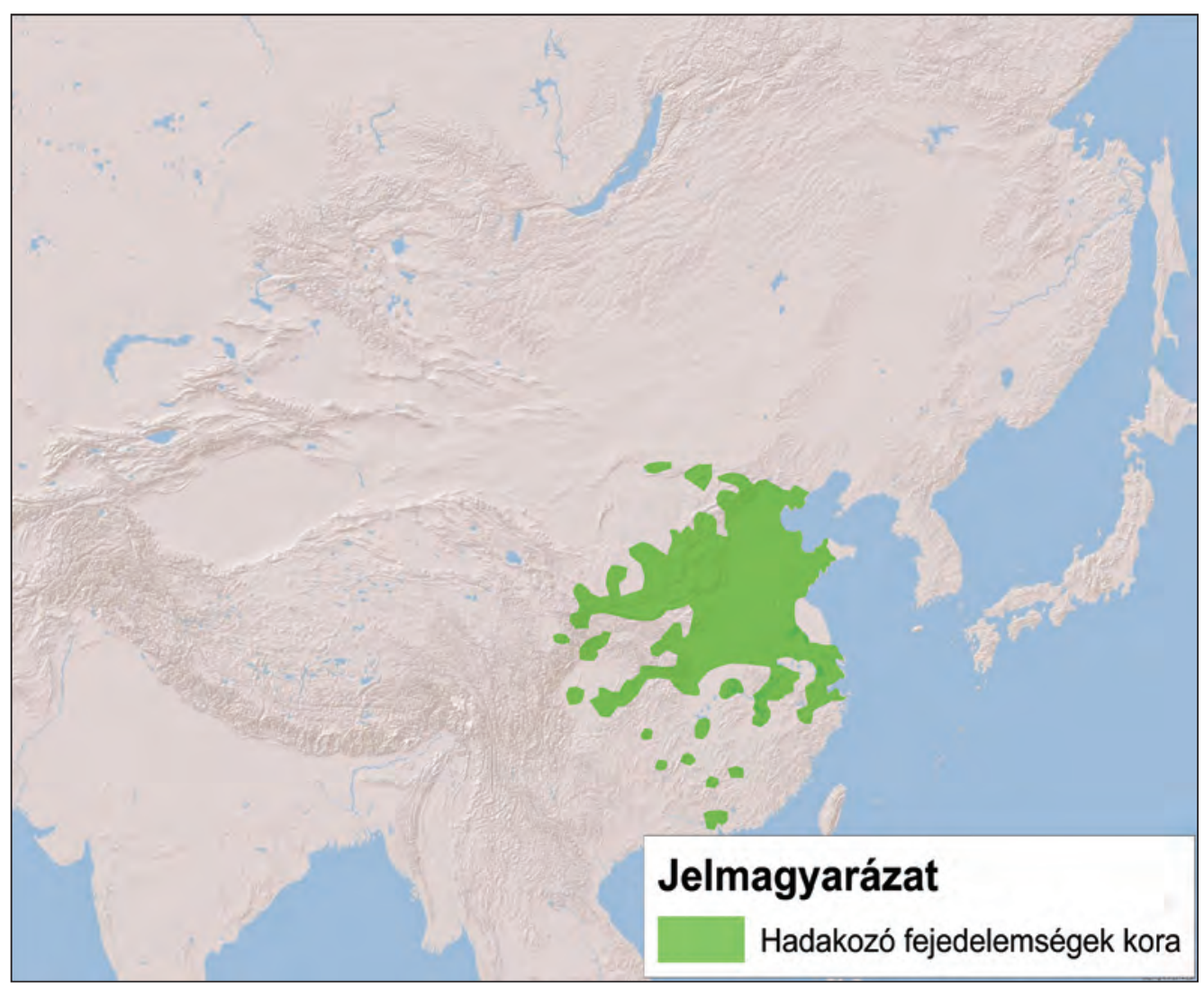

3. térkép: Kínai területek i. e. 5. századtól i. e. 221-ig Forrás: VARGa ÁGNES szerkesztése 
A több évszázadig tartó harcot végül a Csin (Qin) fejedelemség megerősödése, majd területi expanziója zárta le. A reformok segítségével újjászervezett Csin fejedelemség első nagy katonai sikere az északi nomádok felett aratott győzelem volt i. e. 314-ben, majd meghódította i. e. 311-ben Szecsuan tartományban, a csengtui (chengdui) medencében fekvő Su (Shu) államot, és további területeket szerzett az Észak-Szecsuan hegyei közt meghúzódó, nem kínai törzsek lakta $\mathrm{Pa}(\mathrm{Ba})$ állam területén. A Han-folyó felső völgyének meghódítása lehetővé tette, hogy Csin, i. e. 278-277-ben Csu kárára terjeszkedhessen Hupej (Hubei) tartományban. Ezután több hadjárat is indult Csin keleti szomszédai, Han, Vej és Csao fejedelemségek ellen. A Csinhadak egészen Hantanig (Handanig), a Hopej (Hebei) tartomány legdélkeletibb sarkában fekvő Csao fővárosig nyomultak elöre, de i. e. 257-ben kénytelenek voltak felhagyni a város ostromával. Amikor i. e. 249-ben Csin megszállta a Honan tartománybeli Keleti Csou-fejedelemséget, a nagy múltú Csou-ház hatalma is elenyészett.

\section{A Csin-dinasztia (i.e. 221-206)}

Bár csak rövid ideig tartott a Csin-dinasztia (Qin) uralma, mégis alapvető jelentőségű az ország története és kultúrája szempontjából. A Kínát fegyverrel egyesítő s az ország történelmének első birodalmát létrehozó államférfi, a Csin állambeli Cseng (Zheng) király (i. e. 259-210) i. e. 247-ben került hatalomra. Tízévnyi háborúskodás során megsemmisítette Hant (i. e. 230), Csaot (i. e. 228), Vejt (i. e. 225), Csut (i. e. 223), Jent (Yant) (i. e. 222) és Csit (i. e. 221). Miután i. e. 221-re befejezte Kína egyesítését, felvette a Felséges Úr - Huang-ti (Huangdi) - címet, amely a későbbiekben a császárok hagyományos elnevezésévé vált. Öt magát azonban a történelem az „Első Császár” - Si Huang-ti (Shi Huangdi) néven ismeri. Az egyesítés nem csupán a han kínaiak által lakott régiókra terjedt ki, hanem délen egészen a Dél-kínai-tengerig elért (4. térkép). Ennél is fontosabbnak tekinthető azonban, hogy a császár egységesítette a kínai írásbeliséget (így az eltérő nyelvjárások dacára az írott nyelvet mindenhol megértik a KNK területén) a mértékegységeket, a pénz- és a jogrendszert, birodalmi úthálózatot hozott létre, megépíttette az egységes Nagy Falat, és abszolutizálta uralkodói hatalmát. Mindemellett felszámolta a korábbi korokra jellemző feudalizmust, és új, korszerü közigazgatási rendszert vezetett be. Emlékének fennmaradását nagyban segítette elképesztő méretủ síremlékének felfedezése 1974-ben, amelyben közel hatezer, ember nagyságú terrakotta katona örzi örök álmát (8. kép). 
Civilizációk Kelettől Nyugatig

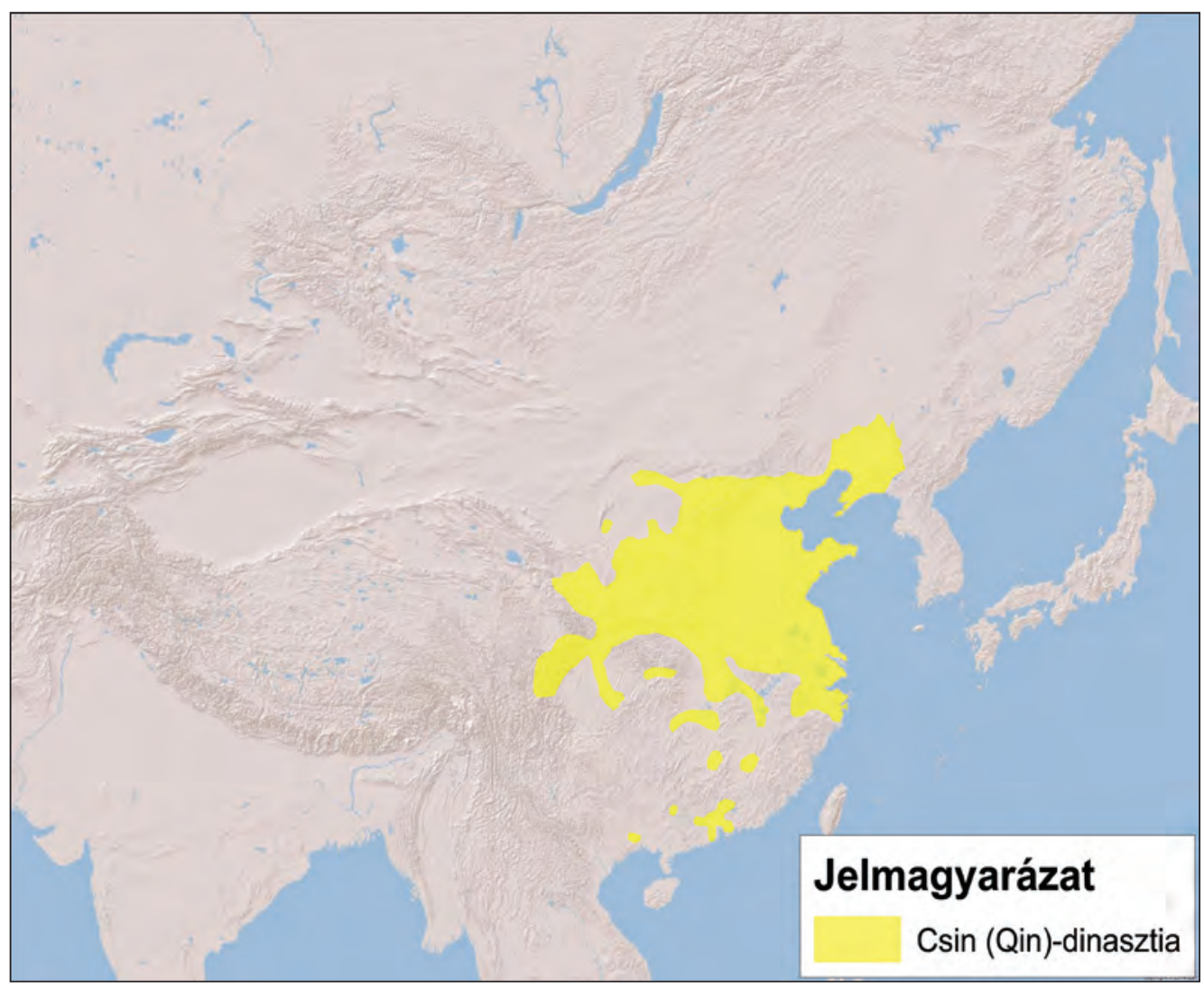

4. térkép: Kína az i. e. 3. század végén

Forrás: VARGA ÁGNES szerkesztése

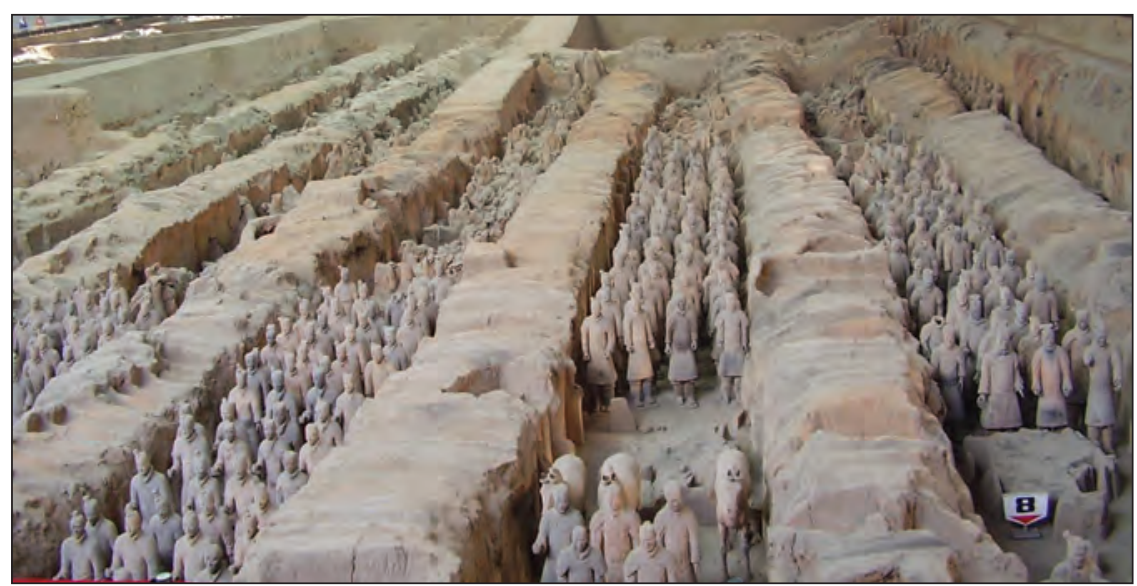

8. kép: Az agyaghadsereg Hszian (Xi’an) város közelében

Forrás: BAGI Judit felvétele 
Uralkodása idejére esik a második pun háború, amelynek során a karthágói hadvezér, Hannibal fél Európát megkerülve átkelt seregeivel az Alpokon és Itáliában támadta meg a Római Köztársaságot i. e. 218-ban.

A Han-dinasztia (i.e. $202-i$. sz. 220)

A Csin-dinasztia rövid, ám meghatározó időszakát a Han korszak követte, amelynek uralkodói felszámolták a helyi hadurak hatalmát, állami szintre emelték a konfucianizmust, tartományokra osztották a birodalmat, és biztosították annak határait a hsziungnu törzsek (xiongnu, azaz ázsiai hun, a kínaiak szerint a magyarok ősei) betörései ellen (9. kép). Az államigazgatás terén bevezették a hivatalnok vizsgák rendszerét. A dinasztia jelentőségéről sokat elárul, hogy a kínai többségi társadalom a mai napig han etnikumúnak nevezi magát. Mindeközben Európában elbukott a köztársaság Rómában, létrejött és hatalmasra nőtt a Római Birodalom. Megszületett a kereszténység és Han-dinasztia végére esett Caracalla császár uralkodása.

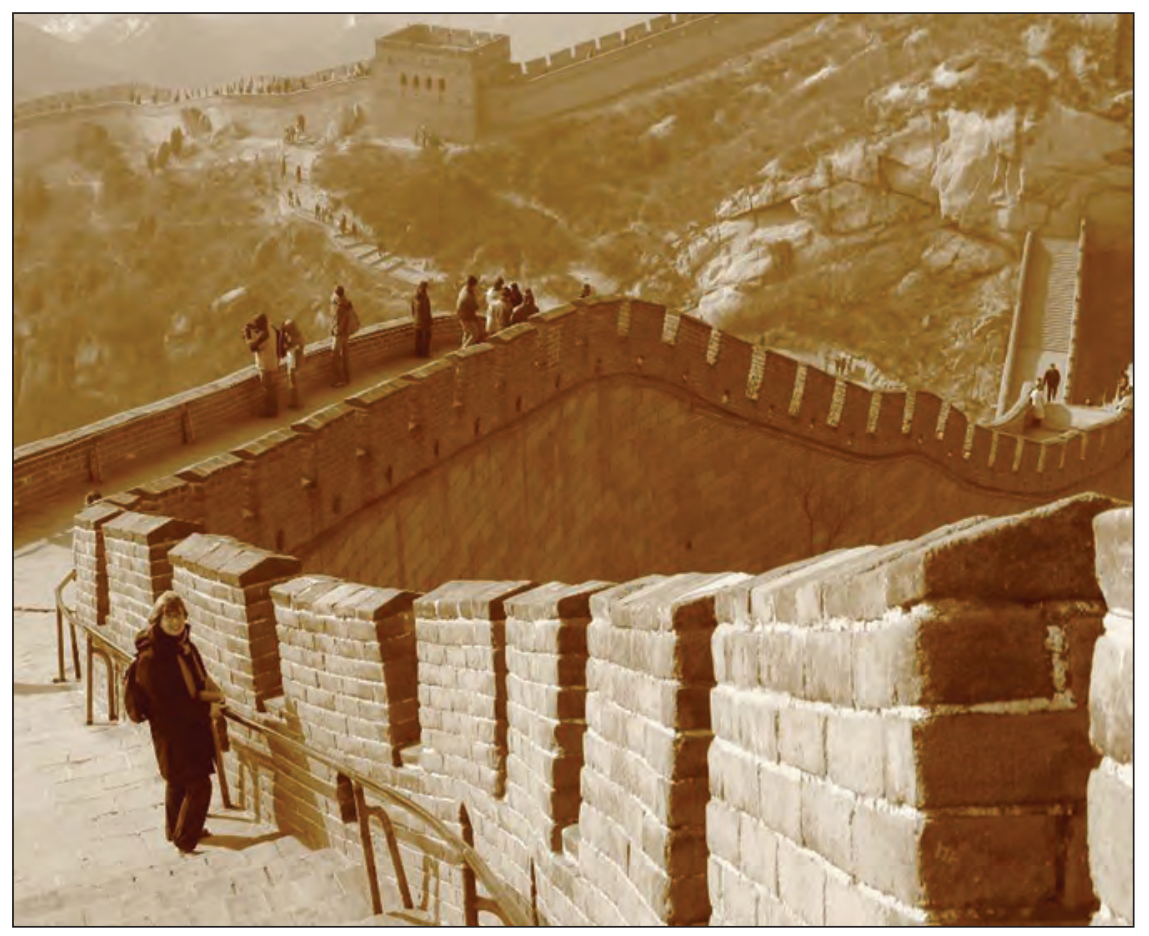

9. kép: A kínai nagy fal építése a Han-dinasztia idején kezdődött Forrás: TóTH ERIKA felvétele 
A hanok bukását a birodalom időszakos szétesése követte, amikor három királyság osztozott az ország területén. Északon a Vej, délen a Vu, míg nyugaton a Su állam terült el, amelyek folyamatos háborúskodásban álltak egymással. A viszonylag rövid, ám kaotikus időszak mély nyomot hagyott a kínai történelemszemléletben, hiszen az ország szétesését azóta is a zürzavarral és pusztítással köti össze a néplélek. A kínai kultúra máig örzi e kor lenyomatát. Itt gondolhatunk akár a Csen Sou (Chen Shou, 233-297) által a 3. században lejegyzett a Három királyság története címü kötetre, akár a Lo Kuan-csung (Luo Guanzhong, 1330-1400) tollából egy évezreddel később született, A Három Királyság románca címü regényre, vagy az időszak leghíresebb csatájának és Cao Cao (Cao Cao, 155-220) hadúr bukásának történetét 2008-ben feldolgozó John Woo rendező Vörös szikla című filmjére.

\section{A Tang-dinasztia (618-907)}

A Tang-kor folyamán a császárság expanzív külpolitikát folytatott a magterületek védelme érdekében, így nyugati irányban uralma alá hajtotta a Selyemút egyes szakaszait, meghódította a Koreai-félsziget és Vietnam északi részeit. A 8. század folyamán azonban sorozatos vereségeket szenvedtek el az előrenyomuló iszlámmal szemben, így a kínai befolyás visszaszorult KözépÁzsiában.

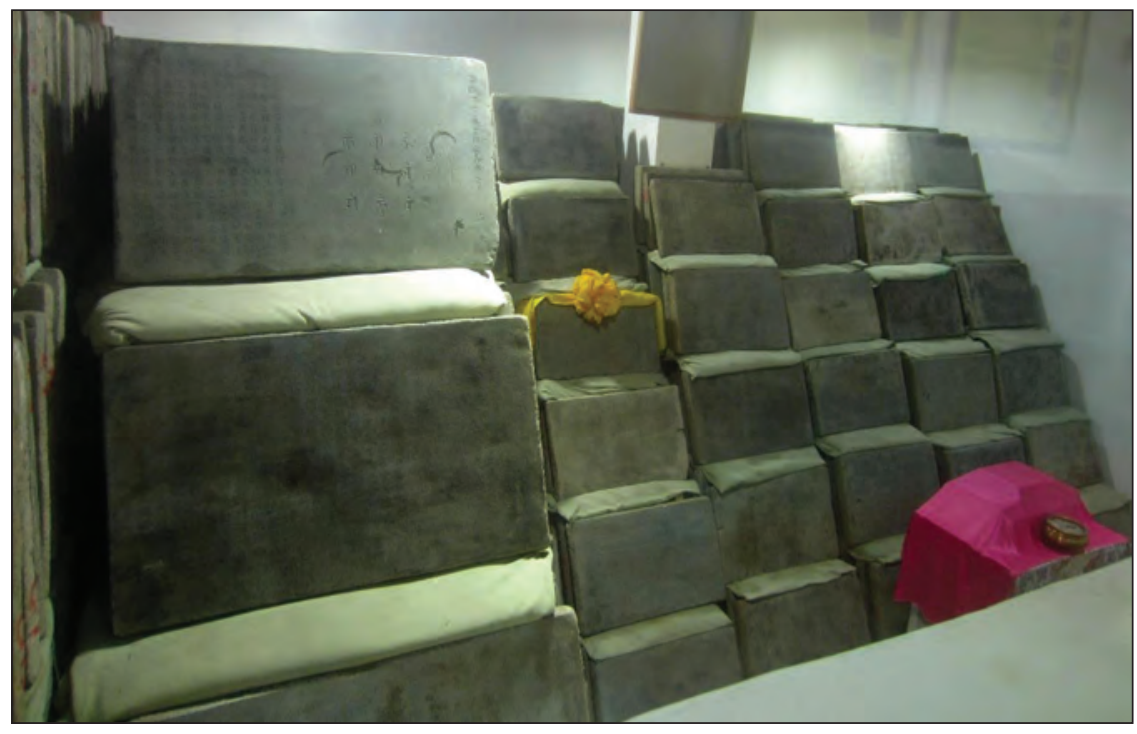

10. kép: Feliratos kőtáblák a Jün-csü (Yunju) templomban, Peking közelében Forrás: BAGI Judit felvétele 
A dinasztia idejére tehető számos jelentős technológiai fejlesztés is, így a puskapor, a porcelán vagy éppen a könyvnyomtatás egy korai típusának a feltalálása (10. kép). Eközben Európa belesüllyed a korai középkor zürzavarába, átesett a pestis pusztításán, amely a 6 . századra elpusztította lakossága felét, a muszlim sereg megkezdte az Ibériai-félsziget meghódítását, majd Nagy Károly uralkodása (i. sz. 742-814) hozott némi megújulást a korba.

\section{Az öt dinasztia és tíz királyság kora (907-960)}

A Három Királyság időszakához hasonlóan egy újabb rövid életű, de annál zürzavarosabb periódus következett Kínában a Tang-dinasztia bukását követően. Az ország északi része ugyan a császárok fennhatósága alatt maradt, ám öt dinasztia is uralkodott e pár évtized alatt (5. térkép), miközben a birodalom déli részéböl tucatnyi kisebb állam szakadt ki (ezek közül tíz fontosabb volt). Mindez anarchiát, korrupciót, éhínséget és folyamatos katonai konfliktusokat hozott magával, amely ismét megerősítette a népességben az ország egysége iránti vágyat.

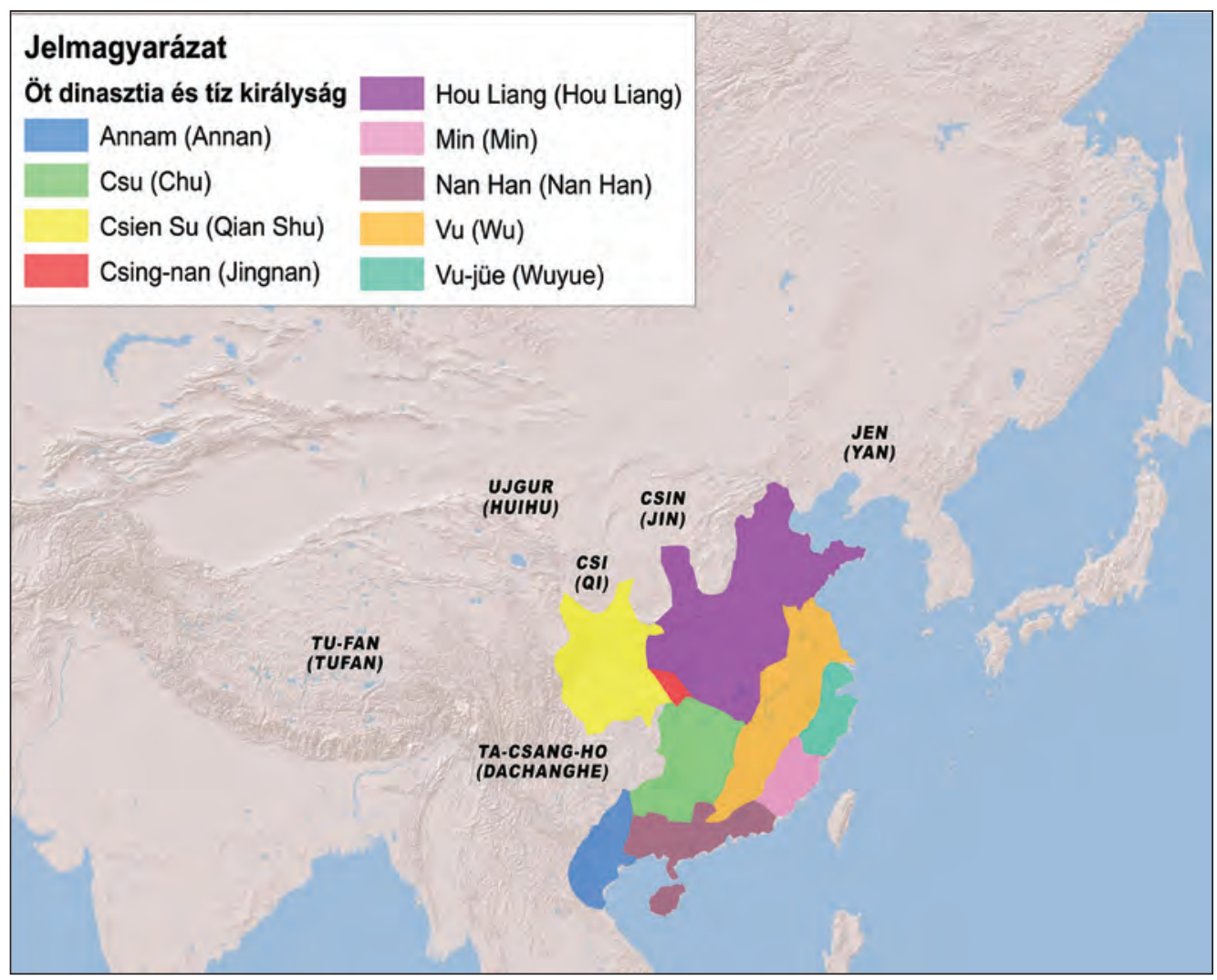

5. térkép: Kínai államok a 10. század első felében

Forrás: VARGA ÁGNEs szerkesztése 


\section{A Szung-dinasztia (960-1279)}

Az öt dinasztia káoszának egy új dinasztia színrelépése vetett véget, amikor a katonai vezető Csao Kuang-jin (Zhao Kuangyin, 927-976) a hadsereg támogatásával császárrá kiáltotta ki magát, és az ország nevét Szungra változtatta, célja pedig az ország teljes egyesítése volt. Ez csupán részben és korlátozott ideig sikerült, hiszen 1127-re az északról betörő dzsürcsik véget vetettek az egységes Szung államnak, és Csin (Jin) néven kiterjesztették birodalmukat Észak-Kínára. Ezt követően a Déli Szung Birodalom élt tovább az ország déli részén egészen az 1279-es mongol hódításig. Bár a Szung-dinasztia nem tartozott a nagy hatalmú és stabil uralkodóházak közé, mégis erre az időszakra esett a középkori kínai kultúra egyik legfényesebb időszaka (11. kép).

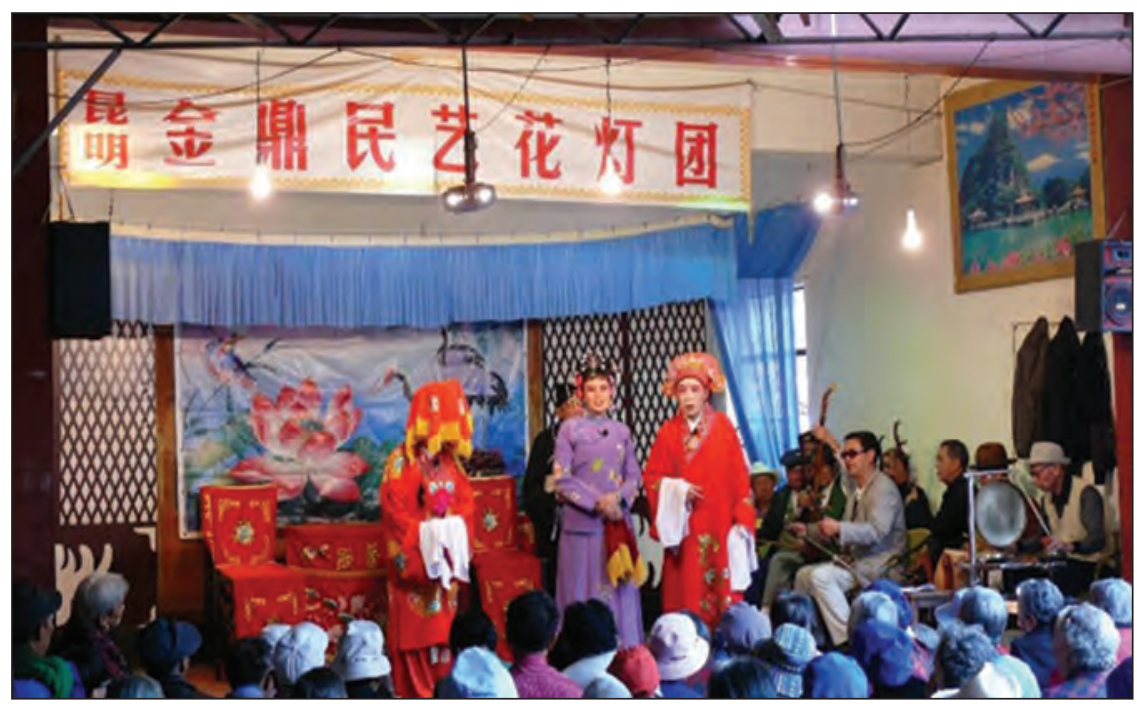

11. kép: Népi színjáték Kunmingban, Jünnan (Yunnan) tartomány Forrás: BAGI Judit felvétele

Létrejött az első kínai hadiflotta, feltalálták az iránytüt és katonai célokra kezdték alkalmazni a puskaport. Emellett élénk társadalmi élet alakult ki, jelentős müvészeti alkotások születtek, fejlődött az irodalom és a társasági élet, amit a könyvnyomtatás elterjedése is elősegített.

\section{A Jüan-dinasztia (1271-1368)}

A nemzetközi kapcsolatok kínai típusú felfogása a Jüan-dinasztia (Yuan) történetén át is megvilágítható. Bár sok kínai igencsak büszke erre az időszakra, hiszen az ország hatalmas területen terült el (6. térkép), feltalálták a papírpénzt 
és egyéb technológiai vívmányokat, valójában a mongol hódítás eredményeként jött létre a Jüan dinasztia. A Kubiláj kán vezetésével északról betörő mongol hadaknak évtizedekbe telt az egész ország elfoglalása, és érzékelve az óriási, közel nyolcvanmilliós ám inkább békés, letelepedett kínai népesség, illetve a jóval kisebb számú, pár százezer mongol harcos közötti számbeli különbséget, az uralkodó számos reformot hajtott végre a lakosság megnyerése érdekében, és megalapította Tatut (Dadut), azaz a „nagy fővárost”, a mai Pekinget. A mongol uralom kezdetén tiltották ugyan az uralkodó népcsoport keveredését a kínaiakkal, azonban ez nem tarthatott sokáig, így végül győzedelmeskedett a kínaiak létszámbeli fölénye, azaz a hatalmas embertömeg és fejlett kultúra abszorpciós, asszimiláló képességének köszönhetően végül magába olvasztotta a külföldi hódítókat, és a Jüan császárok idővel minden szempontból kínaivá váltak. Az ország későbbi történetében többször is megismétlödött e jelenség, ha olyan külső ellenséggel került szembe, amelyet nem tudott a harcmezőn legyőzni, akkor a „lassú víz, partot mos” elvét követve idővel végül magába olvasztotta azt. A 18. század végén megjelenő európai hódítókkal szemben azonban már nem vált be az ősi módszer.

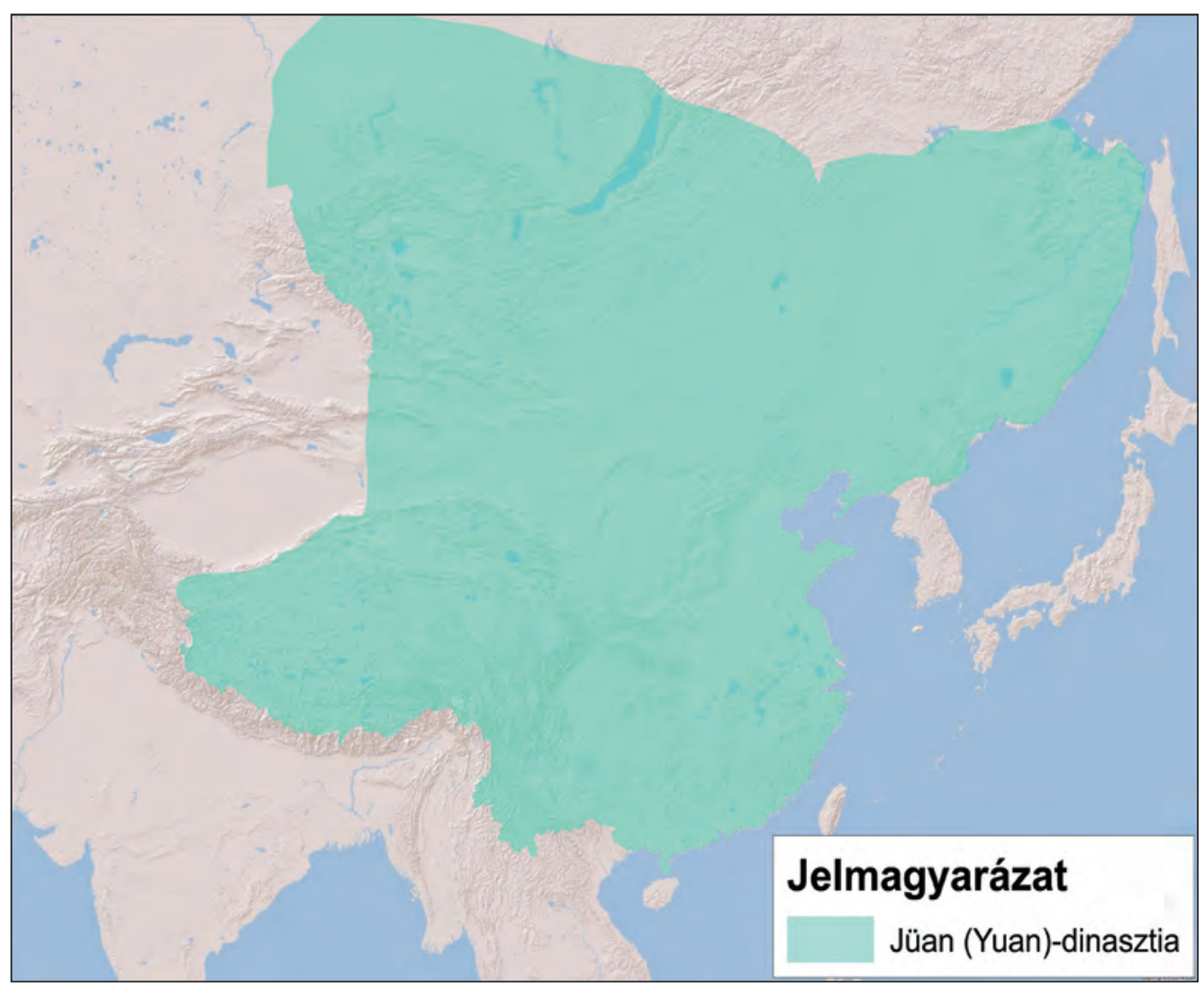

6. térkép: Kína a 13-14. században

Forrás: VARGA ÁGNes szerkesztése 
A Mongol Birodalom felemelkedése elért egészen Európáig, így a 13. században Batu kán vezetésével csapataik egészen Magyarországig és Lengyelországig nyomultak elöre. A Jüan-dinasztia uralkodásának végére esett a fekete halál pusztítása Európában, amely végzett minden második emberrel.

\section{A Ming-dinasztia és Cseng Ho (Zheng He, 1371-1433) admirális}

A Ming-dinasztia (1368-1644) Kína történelmének legkiemelkedőbb korszakai közé tartozik, amikor a Középső Birodalom technológiai, gazdasági, társadalmi és kulturális fejlettsége messze megelőzte a korabeli Európáét. A Jüan-dinasztia gazdasági és belpolitikai nehézségei közepette számos felkelés tört ki az országban, a déli területek felett a szegény paraszti sorból hadvezérré emelkedett Csu Jüan-csang (Zhu Yuanzhang, 1328-1398) vette át az irányítást, aki végül észak felé nyomulva kiszorította a megmaradt császári erőket, és véget vetett a mongol eredetü Jüan uralomnak. Csu császárrá nyilvánította magát és megalapította a Ming-dinasztiát 1368-ban, fővárosát Nankingban - Nancsingban (Nanjingban) - rendezte be. Idővel megszilárdította hatalmát a han területek perifériáin is, több nemzetiségi felkelést leverve Dél- és Délnyugat-Kínában, majd az északi, mandzsúriai területeken fennmaradt mongol erőkkel is leszámolt. Utóda áthelyezte a birodalom fövárosát a mai Pekingbe és 1407-1420 között felépítették az új települést, középpontjában a császári palotával, a Tiltott Várossal. A Kínával foglalkozó írások visszatérő eleme, hogy a birodalom az elmúlt kétezer év folyamán szinte végig a világ legfejlettebb, leggazdagabb régiója volt, sőt, a Római Birodalom bukását követően évszázadokon keresztül jóval civilizáltabb és technológiailag elörehaladottabb volt, mint Európa. Felmerül viszont a kérdés, hogy ez esetben viszont miért nem Kína hódította meg a világot? A tizenötödik században meginduló kolonizációnak köszönhetően a huszadik századra alig maradt olyan területe a világnak, amelyet Európa ne hajtott volna uralma alá részben vagy egészben. Több magyarázat is létezik a kérdés kapcsán, amelyek mindegyike részben hozzájárulhatott a világtörténelem alakulásához. A földrajzi determinizmuson alapuló elméletek ugyan néha túlzottan leegyszerüsítik a képet, Kína és Európa összehasonlítása során mégis érdekes megállapításokat tehetünk. Az egyik legfeltűnőbb különbség, hogy míg a kínai magterület (a mezőgazdasági müvelésre alkalmas keleti és északkeleti síkságok és az ország déli része, ahol a népesség döntő többsége koncentrálódik) egyetlen nagy, összefüggö, leginkább kontinentális régió, addig Európa rendkívül tagolt földrajzi szempontból. Elég csak arra gondolni, hogy ugyan Afrika területi kiterjedése háromszorosa az öreg kontinensének, partvonala mégis rövidebb. Európa területét tengerek szabdalják félszigetekre és szigetekre, míg az olyan hegységek, mint a Pireneusok, Alpok, Kárpátok 
vagy a skandináv hegységrendszer tovább növelik a jól körülhatárolható területek számát. Ez is hozzájárulhatott ahhoz, hogy Európát sosem sikerült tartósan egységes államba szervezni, bár számos hadvezér, uralkodó és diktátor próbálkozott vele az elmúlt évszázadokban, az utolsó hosszan tartó siker e téren valójában a Római Birodalom volt. A földrajzi, topográfiai határok kedveztek az önálló nemzetállamok kialakulásának, és akadályozták a nagyléptékủ hódításokat. A mai Európa térképen jól látható, hogy a legtöbb földrajzi egység egyben önálló állam is, az efféle felépítés pedig folyamatos államközi konfliktusokhoz, háborúkhoz vezetett abban a korban, amikor még a föld, az államterület számított a hatalom és vagyon elsőszámú forrásának. Az európai királyságok csak egymás kárára, zéróösszegü játszmákban szerezhettek nagyobb hatalmat, így egyes becslések szerint az 1500 és 1945 közötti négy és fél évszázad során egyetlen év sem telt békésen az öreg kontinensen. A háború azonban végső eszközökkel vívott versenyként is felfogható, amelynek egyfajta „mellékhatása” a technológiai fejlődés, katonai és persze minden más téren is. A nemzetközi rend szempontjából pedig elvezetett a vesztfáliai rendszer és az állami szuverenitás koncepció kialakulásához, ami tehát európai találmány, és csupán a gyarmatosítással megindult globalizáció terjesztette el, vagy éppen erőltette rá a világ más tájaira.

Mindeközben Kína teljesen másképp tekintett a világ rendjére, hiszen az i. e. 221-ben bekövetkezett egyesítése óta nem találkozott olyan nemzetközi rendszerrel, ahol megközelítőleg egyenlő erejü entitások állnának szemben egymással. Emlékezzünk rá, hogy az ország földrajzi szempontból szinte minden irányból elszigetelt, miközben magterülete jórészt nagy, így könnyen egyesíthető síkvidékekből áll. Így egyfelől Kínának nem kellett szembenéznie államiságát veszélyeztető külső államokkal (vagy magába olvasztotta azokat), másfelől nem volt szüksége új területek elfoglalására népessége eltartása érdekében. A magyarázat elméleti oldala mindezzel szoros összefüggésben azt írja, le, hogy az egyenrangú vetélytárs hiányában a kínai „nemzetközi politikaelmélet" a világot koncentrikus körökként írja le, amelynek közepén a császári trón áll, körülötte a palota, akörül a föváros, majd a birodalom területei következnek. E mentalitást jól példázza az ország neve is, amely (hasonlóan a magyar esethez) saját nyelvén teljesen más, mint a világ egyéb tájain használatos elnevezés: Csungkuo, azaz a Középső Birodalom, vagy a „közép birodalma”. Így - legalábbis elvi szempontból - a tényleges határokon túli vidékek is a Birodalom és a császár fennhatósága alá tartoznak. Ez, az úgynevezett tien-hszia (tianxia) elv, amely szerint minden, ami az ég alatt van, a birodalom része, csak éppen a határokon túli népek nem elég fejlettek ahhoz, hogy részesülhessenek a Kínai Császárság gazdagságából, kultúrájából, életszínvonalából. Ezen elv meghatározó jelentőséggel bír a kínai világképre, amely szemben az európai, vesztfáliai világrenddel, nem szuverén (nemzet)államok egyenrangú, ma már 
liberális közösségében gondolkodik, hanem koncentrikus körökként fogja fel a világot. E világ középpontjában pedig Kína áll, amelyet periferikus országok hierarchikus gyürüi vesznek körbe.

Valószínúleg a fenti okok is közrejátszottak abban, hogy amikor Kolumbusz elött közel 90 évvel, 1405-ben Cseng Ho admirális a császár parancsára épített, 317 hatalmas, a korabeli európai árbócosoknál akár ötször nagyobb hajókból álló, huszonnyolcezer tengerészt számláló flottájával DélKínából elhajózott Délkelet-Ázsiába, Indiába és talán Kelet-Afrikába is, anélkül tért haza, hogy meghódította volna e területeket. Összesen hét, az 1430as évekig tartó expedíciói során nem tett annál többet, mintsem informálta a helyi lakosságot uralkodójuk üzenetéről, hogy időről-időre beszedik majd a szimbolikus sarcot. Az újonnan trónra került császárok azonban erősen hittek Kína felsőbbrendüségében, így értelmetlennek találták a flotta fenntartását, hiszen a „barbárok” semmit sem adhatnak a fenséges és fejlett Birodalomnak, ráadásul újabb mongol támadás fenyegetett északról. Angus Deaton Nobeldíjas közgazdász szerint emellett az udvari elit is féltékenyen tekintett az expedícióknak köszönhetően erösödő tengeri kereskedelemre és a kereskedők növekvő vagyonára, így, a protekcionizmus és járadékvadász politika egyik ékes példájaként végül, udvari intrikákat követően a felfedezőutakat leállították, sőt, még emlékét is megpróbálták kitörölni a kínai iratokból. Részben a Kínai Birodalom mindenhatóságába vetett hit vezetett e döntéshez, amely a következő bő ötszáz évre meghatározta az ország sorsát. Miközben Peking az önkéntes izolációt választotta, az európai technológiai fejlődés lehetővé, míg a kontinens viszonyai szükségszerűvé tették a kolonizációs időszak megkezdését, amelynek köszönhetően a következö évszázadokban Európa gazdasági és katonai fölényre tett szert Kínával szemben. A keserü ébredés a 19. században következett el Kína számára, amely száz év megaláztatást, pusztulást, tízmilliók halálát és az ország részleges gyarmatosítását hozta magával.

A Ming-dinasztia idejére esett az európai gyarmatosítás kezdete és az ipari forradalom korai szakasza. A reformáció és a reneszánsz jelentősen hozzájárult Európa felemelkedéséhez, a globális kereskedelem és világrend kialakulásához. Ekkor alkotott Machiavelli és indult meg az Oszmán Birodalom növekedése.

\section{A Csing-dinasztia (1644/1646-1911)}

A Ming-dinasztia legyőzésével került hatalomra az utolsó kínai uralkodóház, az északkeletről érkező mandzsu hódítás következtében. A Csing (Qing) uralkodó elit idővel ugyanúgy beolvadt és asszimilálódott a kínai társadalomba, mint elődei, hatalmát kiterjesztette a mai Hszincsiangra, 
Tibetre, Mongóliára és egyes dél-szibériai területekre (7. térkép). A 19. századra belső folyamatok következtében a dinasztia hatalma meggyengült, ami szerencsétlenségére egybeesett az európaiak (majd később amerikaiak és japánok) érkezésével. Gazdasági szempontból e gyengülési folyamatot leginkább az ún. magas szintủ egyensúly csapda (high-level equilibrium trap) számlájára szokták írni. Az elmélet kidolgozója, Mark Elvin történész szerint dacára annak, hogy Kína évszázadokon keresztül jóval fejlettebb volt gazdasági és társadalmi szempontból, mint a Nyugat, mégsem ment végbe belső eredetü ipari és technológiai forradalom, mert a késő császárkorra a birodalomban kiegyensúlyozottá vált a kereslet és a kínálat a hatékony kereskedelmi és termelési rendszereknek köszönhetően.

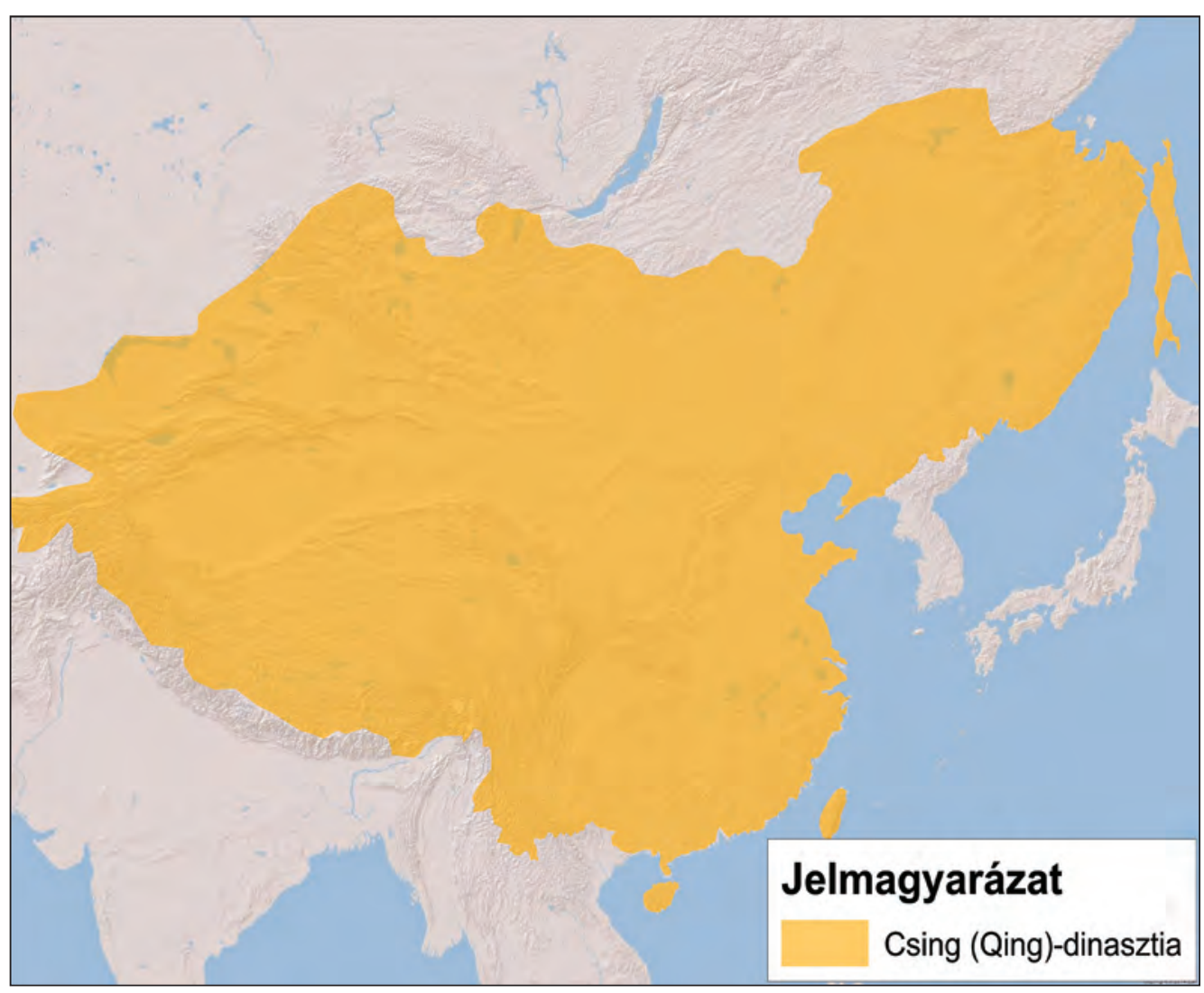

7. térkép: Kína területe az utolsó uralkodóház idején Forrás: VARGA ÁGNES szerkesztése

A kínai gazdaság hatalmas mérete és a fejlett közúti és vízi csatorna szállítási hálózatnak köszönhetően a helyi áruhiányokat ki lehetett egyenlíteni más területek többletével. Mindeközben rendkívül olcsó volt a munkaerö, mivel a 17. századra minden megmüvelhető területet termelés alá vettek, és 
Kína hatalmas méretének köszönhetöen ez elég volt a folyamatosan növekvö lakosság ellátásához, a mezőgazdaság nem szívott fel újabb munkásokat, így a munkaerő kínálat növekedése lenyomta a béreket. E két tényező együttes hatása azt eredményezte, hogy a technológiai fejlesztésekbe és ezáltal további hatékonyságnövelésbe való tőkebefektetés nem volt kifizetődő. Elvin szerint ehhez hozzájárulhatott még a korban bekövetkezett filozófiai váltás, amelynek során a természettudományok és a világ megismerése iránt érdeklődő taoizmus felől a társadalomfilozófiai és morális kérdésekre koncentráló konfucianizmus irányába mozdultel abirodalom gondolkodásmódja. Emegváltozott intellektuális környezet sem kedvezett a technológiai fejlesztéseknek. További fontos elem lehetett, hogy felhalmozott vagyonuknak köszönhetően a kereskedők markukban tartották az állami tisztviselőket, és a törvényeket saját érdeküknek megfelelően alakíttatták, elkerülendő, hogy a profit a tényleges munkát végző termelőknél csapódjon le, így ezeknek nem maradt tőkéje a hatékonyságnövelő technológiai fejlesztésekre. Elvin elmélete mellett érdemes még visszautalni arra a már korábban leírt jelenségre, hogy földrajzi adottságainak köszönhetően Kínának évezredekig nem kellett szembenéznie egy hasonló méretủ entitás jelentette kihívással, versennyel. Köznapi nyelven úgy is összefoglalható a magas szintü egyensúly csapdája, mint egyfajta „langyos víz” helyzet, ahol a viszonylagos jólét és a verseny hiánya, illetve a gazdasági elit önző protekcionizmusa ellehetetlenítette az ország fejlődését. Ráadásul egy hasonló megrekedés Cseng Ho expedícióinak leállítását követően már másodszor sújtotta Kínát néhány évszázadon belül.

A fenti folyamatok a lehető legrosszabbkor játszódtak a le a Középső Birodalomban, hiszen bármilyen messze is feküdt Európa Kínától, a 18. század végére a nyugati hatalmak mégiscsak megjelentek az ország partjainál, és megkezdték a Mennyei Birodalom részleges gyarmatosítását.

1793-ban III. György brit uralkodó követe, Lord Macartney érkezett a pekingi császári udvarba, azzal a céllal, hogy új kikötőket nyisson meg és lazítson a korlátozásokon a kereskedelmi kapcsolatok fejlesztése érdekében, állandó nagykövetséget nyisson és megszerezzen brit használatra egy kisebb szigetet a kínai partok mentén. A 17-18. században fokozatosan kialakult kantoni rendszerben zajló kereskedelmi kapcsolatokat tizenhárom, a császári udvar által kijelölt cégen keresztül tartották fenn 1757-ig, amikor az ország társadalmi viszonyainak külföldi hatásra történő megváltozásától félő Csienlung (Qianlong, 1711-1799) császár korlátozta a kereskedelmet. Megtiltotta, hogy kínai nyelvre tanítsák a külföldieket, vagy, hogy azok asszonyaikat a birodalom területére vigyék. A század végére a brit kereskedőket már erősen nyomasztotta a rendszer, ráadásul jelentősen megnőtt a külkereskedelmi deficit a tea, porcelán és selyem import miatt, amiért a briteknek ezüsttel kellett fizetni. Végül a kereskedők elérték a királynál, hogy követséget küldjön 
Pekingbe George Macartney vezetésével. A közel egy éves hajóutat követően azonban már a ceremoniális ügyekben is megmutatkozott a Kína és a Nyugat közötti jelentős szemléletbeli különbség. Míg a császári udvar a Birodalomnak alávetett (tributárius) országokból érkező hűbéres látogatásnak tekintette Macartney érkezését, addig a britek két szuverén és ezáltal egyenrangú uralkodó közötti kommunikációként gondoltak a küldöttségre. Így a császár azon elvárása, hogy Macartney a koutou ősi rítusával hódoljon elötte (térdre ereszkedés és a homlok padlóhoz érintése kilencszer) erős megütközést keltett a brit követség tagjai körében. Hosszas huzavonát követöen a császár nagylelküen beleegyezett volna, hogy Macartney kilenc helyett csupán egy alkalommal boruljon földre, míg a britek azt javasolták, hogy akkor egy hasonló rangú kínai tisztviselö tegye ugyanezt György király portréja előtt. Ez utóbbi ötlet azonban elképzelhetetlen volt, hiszen az Ég Fiával senki sem lehetett egyenrangú. Noha a császár már a találkozó lemondását fontolgatta, végül belement, hogy Macartney úgy köszöntse öt, mint saját uralkodóját, fél térdre ereszkedve. Végül sikerült ugyan átadni György király levelét és elöterjeszteni kéréseit, Csien-lung császár azonban, elődeihez hasonlóan, nem látta értelmét a távoli barbárokkal folytatott cserekapcsolatok fejlesztésének, az ajándékba hozott angol ipari termékeket lenézte, és a kínai birodalmi szemlélet értelmében a nagykövetség nyitásnak még az elvét is elvetette. Az angol kérések megfontolása helyett üzenetet küldött a brit uralkodónak, amely szerint elvárta, hogy az Pekingben térdre boruljon császára, az Ég Fia előtt. A megalázott angol delegáció dolgavégezetlenül tért vissza hazájába, amelyet a következő években elsősorban a napóleoni háborúk foglaltak le, így nem volt idejük Kínával foglalkozni.

Az európai koncertrendszer és stabilitás kialakulása azonban lehetővé tette, hogy a nyugati hatalmak ismét Kelet felé forduljanak. Bár Kína jóval messzebb volt, mint India, kincsei, így elsősorban a porcelán, a tea, selyem és füszerek vonzó kereskedelmi célponttá tették. A kínaiak idővel lehetővé tették a kereskedelmet néhány kikötővároson keresztül, amely azonban igen egyoldalúnak bizonyult. Az európaiak nagy mennyiségben vásárolták a luxuscikkeket, míg - kissé a mai helyzetre emlékeztetve - ellenkező irányba alig irányult áruforgalom. Mindez jelentős európai külkereskedelmi deficithez vezetett, ami az elterjedt fizetőeszköznek számító ezüst fokozódó kiáramlásához és európai pénzügyi gondokhoz vezetett. Látva a helyzetet, a britek indiai gyarmataira és az ott található munkaerőre támaszkodva egy új termék kínai piacra történő bevezetése mellett döntöttek. A Dél-Ázsiában megtermelt ópiumot a Brit Kelet-India Társaság hajói kezdték Kínába szállítani, ahol hamar népszerü lett, és az ópiumbarlangok elterjedésével előbb egyensúlyba került a kétoldalú kereskedelem, majd az ezüst elkezdett visszaáramlani az európai gazdaságokba. 
Természetesen a pekingi udvarban is feltủnt a lakosság körében egyre gyorsabban terjedő addiktív szer jelentette veszély, így császári ediktumban tiltották meg az ópiumimportot. Az intézkedés a britek tiltakozása ellenére is érvényben maradt, ami háborús indokként szolgált, így 1839-ben kitört az első ópiumháború. A Középső Birodalom nagyságába vetett kínai hitre sokként hatott, hogy csupán néhány brit sorhajó szinte veszteségek nélkül tönkreverte a császári flottát, majd a partvidéken végig hajózva tüz alá vették a kínai városokat. Az erőviszonyokat jól mutatja, hogy míg az egyik oldalon hatvankilenc brit, addig a másik oldalon közel húszezer kínai esett el a konfliktus során. Belátva tehetetlenségét, a birodalom 1842-ben megkötötte az egyenlötlen Nankingi Békét a britekkel. Ennek értelmében Hongkong Hsziangkang (Xianggang) - brit uralom alá került. Amikor 1856-ban a kínaiak feltartóztattak egy brit csempészhajót, kirobbant a második ópiumháború, amelynek során a brit katonák megostromolták Kuangcsou - Guangzhou (Kanton) - városát. A következö évben angol és francia hadihajók lerombolták Taku (Dagu) városának erődítményeit, amelyek a Haj (Pej)-folyó - Hai (Bei)folyó - torkolatát védelmezték Tiencsin (Tianjin) közelében, a Pekingbe vezető úton. 1858-ban a Csing-kormányzat kénytelen volt aláírni a háború első szakaszát lezáró tiencsini szerződést, amelynek értelmében a kínaiak újabb tíz várost nyitottak meg a külföldiek elött, akik koncessziós területeket kaptak ezekben a városokban, és Kínának hadi jóvátételt kellett fizetnie. A második ópium háborút végleg lezáró 1860 -as pekingi egyezményben a nyugatiak további engedményeket csikartak ki a kínaiaktól, amelyek részeként Tiencsin városát is megnyitották, és újabb kártérítést kaptak. Gazdasági szempontból óriási jelentősége volt annak, hogy az egyezmény értelmében a kínai piacra szánt brit textiltermékek vámmentességet élvezhettek, és a külföldi hadihajók ezentúl szabadon közlekedhettek a kínai folyókon. Mivel ekkora a legfejlettebb európai országokban már kialakult a modern gyáripar a kínaiak által pontosan betartott új egyezmények hamarosan éreztetni kezdték a hatásukat a kínai gazdaságban. Kína nemcsak a saját vámjai feletti kontrollt vesztette el, hanem vámhivatalainak felügyeletét is át kellett engednie a briteknek, akik kisajátították a kínai vámbevételeket.

A külföldi hatalmak behatolása az országba, a számtalan elszenvedett megalázó vereség és békeszerződés sokkoló hatással volt a kínai társadalomra, amely eddig önnön felsőbbrendüségének tudatában élt. A nyugati hódítók jóval fejlettebb eszközökkel rendelkeztek, mint a kínaiak, ráadásul a fegyverek mellett a keresztény hittérítést is bevetették az ország meghódítása érdekében. Az idegen hatalmak által kicsikart előjogok hatása a kínai gazdaság számára is katasztrofális volt. Bár a nyitott városok vonzották a tőkét és a kínai munkaerőt, ugyanakkor ez erős egyenlőtlenségeket alakított ki a belső területekkel szemben. Másfelől a fejlett ipari országokból beérkező, a kedvezmények által is dotált 
áruk sok tekintetben elsorvasztották a kínai ipart, így az ország egyre inkább függő helyzetbe került az importtól és ezzel áttételesen a nyugat által dominált világgazdaságtól és világkereskedelemtől.

Legalább ennyire negatív hatással járt a külföldiek térnyerése a kínai társadalomra. Egyre gyakoribbá váltak a konfliktusok a Kínába érkező, vagy ott letelepedett külföldiek és a helyi lakosság között. Ennek másodlagos következménye volt, hogy a nyugatiakkal szemben érzett ellenszenv idővel az általuk képviselt értékekre is kiterjedt, így kialakult egy, az újításokat és reformokat elutasító kínai attitüd is. Emellett a külföldiek gyakran arrogáns viselkedése és gazdagsága csak tovább erösítette a kínai emberekben azt a kisebbségi érzést, amelyet a nyugatiaktól elszenvedett katonai vereségek alapoztak meg. E hatások együttesen igen megnehezítették az elkerülhetetlen és szükségszerü változások társadalmi elfogadását. Annak ellenére, hogy Kínára ösztönzően is hatott a külföld részéről tapasztalható katonai, gazdasági és kulturális nyomás, a 19. század végén ezek hatására az ország évezredes társadalmi struktúrája és kohéziója töredezni kezdett, majd felbomlott, amely az ország méreteiből adódóan sokkal komolyabb következményekkel járt, mint más, hasonló sorsra jutott gyarmatosított országok esetében.

A 19. század közepére széleskörü elégedetlenség alakult ki a kínai elit és a tömegek körében is, amely az ország megújítását, a lemaradás leküzdését tủzte ki célul. A belső forrongások felkelések sorozatához vezettek, amelyek külön-külön is szörnyü veszteségeket okoztak az országnak. Ezek közül is kiemelkedik a keresztény Taj-ping (Taiping) Mennyei Béke Birodalmának tizenöt éven át tartó felkelése (1851-1864), amely Kína területének egyharmadán pusztított, és akár harmincmillió halálos áldozattal is járhatott. Sorban követték a további lázadások - pl.: Nien (Nian) felkelés, muszlim felkelés. A polgárháborús helyzet és a külső hatalmakkal vívott elvesztett harcok is a Csing adminisztráció tehetetlenségét mutatták. Az 1899-ben kitört boxer lázadás (Eredeti nevén az Igazságos és Harmonikus Ököl lázadása, amelynek sok tagja jártas volt a harcmüvészetekben, innen ered a boxer lázadás kifejezés) már a külföldi behatolók ellen irányult, amelynek keretében felgyújtották a pekingi nagykövetségeket és több nyugati diplomatát is meglincseltek, összességében pedig kétszáz hittéritőt és több mint harmincezer kínai keresztényt öltek meg. Erre válaszul a Nyolchatalmi Szövetség (a brit, német, francia, osztrák-magyar birodalmak, Olaszország, az Egyesült Államok és a Japán Császárság) büntetőhadjáratot indított Peking ellen. A tiencsini partraszállást követően ötvenezer szövetséges katona a föváros ellen vonult, legyőzte a Peking védelmére rendelt császári hadsereget, és végül felszabadította az ostrom alatt álló követségi negyedet, majd kifosztotta Peking és a Tiltott Város nagy részét. 
Talán még a nyugatiak betörése az országba sem váltott ki akkora sokkot azonban, mint a Japán elleni kínai vereség. Az évszázadokon át lenézett, a Kínai Császárság adófizetői közé tartozó feudális Japán alapvető változásokon ment keresztül a 19. század második felében, amikor az 1868-ban meghirdetett Meidzsi reformoknak köszönhetöen rendkívül gyors, nyugati mintát követő iparosodás és modernizáció söpört végig az országon. Ennek egyik eredményeként megnőtt a természeti kincsek iránti japán igény, és ezt a kornak megfelelően leginkább területi expanzióval kívánta kielégíteni. Ennek iránya pedig nem is lehetett más, mint a kínai érdekszféra, így az 1894 és 1895 között alig fél év alatt lezajlott első japán-kínai háború látványos japán győzelmet, és a simonoszeki béke értelmében a Korea feletti kontrollt, illetve a Liaotungfélsziget (Liaodong-félsziget), Tajvan és a Penghu-szigetek megszerzését hozta a szigetország számára. Emellett a Csing Birodalom elképesztő mértékü hadisarcot (hivatalosan jóvátételt), 260-340 millió tael, azaz 10-15 ezer tonna ezüstöt fizetett a Japán Császárságnak.

A sorozatos vereségek okozta sokk hatására természetesen a császári udvar is bevezetett több modernizációs kísérletet. Az első ópiumháborút követően katonai fejlesztésekbe kezdtek, nyugati fegyvereket és hadihajókat vásároltak, mindez azonban elégtelennek bizonyult. A második ópiumháborút követően már a kormányzat modernizációja került napirendre, amely a Kuang-hszü (Guangxu, 1871-1908) császár által 1898-ban meghirdetett száz napos reformmal teljesedett ki: eltörölték a hagyományos közigazgatási vizsgarendszert, megalapították a Pekingi Egyetemet, mezőgazdasági iskolákat hoztak létre vidéken, az abszolút monarchia felől az alkotmányos uralkodás irányába tettek lépéseket, kapitalista modellt vezettek be a gazdaságban és általában erősítették az iparosítás folyamatát. Mindez azonban a konzervatív udvari érdekcsoportok áskálódásának következtében kevés eredményt tudott végül felmutatni. Ez ahhoz vezetett, hogy a szélesebb társadalmi rétegek számára is egyre nyilvánvalóbbá vált a császárság és a dinasztia megújulására való képtelensége, és egy újfajta modernizáció iránti igény, amelyet Szun Jatszen - Szun Ven (Sun Wen), 1866-1925 - mozgalma képviselt.

\section{A Vucsang-felkelés}

A Csing-dinasztia vesztét végül egy újabb felkeléssorozat hozta el 1911ben. A Csing udvar államosítani kívánta a tartományi, jórészt kisrészvényesek tulajdonában álló vasúttársaságokat, hogy azokat újabb bevétel és kölcsönök fejében a külföldi bankoknak adja el. A kezdeményezés akkora felháborodást váltott ki, hogy több helyen is zavargások törtek ki. A Szecsuan tartományban fegyvert fogó elégedetlenkedők ellen küldött haderő őrizetlenül hagyta a szomszédos Hopej tartományban található Vucsang (Wuchang) városát, ahol 
az alkalmon kapva szintén lázadás ütötte fel a fejét, és a helyiek sikeresen el is kergették Peking helyi képviselöjét. A császári udvar egyik modernizált hadseregét küldte a felkelés leverésére, annak vezetője, Jüan Si-kaj (Yuan Shikai, 1859-1916) tábornok azonban ekkor már más gondolatokat forgatott a fejében, és titkos tárgyalásokat kezdett a lázadókkal. Eközben a terjedő ellenállás hírére hazatért a kínai köztársasági mozgalom emblematikussá vált figurája, Szun Jat-szen az Egyesült Államokból, ahol módos kínai támogatókat igyekezett szerezni a császárság elleni harcnak. A gyorsan eszkalálódó események hatására tizennyolc dél- és közép-kínai tartomány mondta ki elszakadását a Csing Birodalomtól 1911 decemberében, és még ebben a hónapban ideiglenes köztársasági elnököt választottak Szun Jat-szen személyében. A kiváló tartományok 1912. január 1-én kikiáltották a Kínai Köztársaságot, amelyet Jüan Si-kaj hadserege is támogatott, így végül 1912. február 12-én az akkor hatéves császárt lemondásra kényszerítették, és ezzel véget ért a kétezer éves Kínai Császárság korszaka.

\subsubsection{A klasszikus kínai stratégiai kultúra és forrásai}

A klasszikus kínai stratégiai kultúrát és nemzetközi politikai gondolkodást egyaránt mélyen áthatja a tradicionális kínai filozófia és a hosszú történelemböl fakadó számtalan tapasztalat. Mindezek lecsapódása megfigyelhető az ősi hadtudományi forrásokon, amelyek közül a legfontosabbak „A hadművészeti kánon hét könyve" - Vu csing csi su (Wu jing qi shu) - közé beválasztott művek. Ezen müveket az i. sz. 11. században gyüjtötték egybe, mint a kínai katonai és stratégiai ismeretek legfontosabb forrásait. A hét klasszikus forrás magában foglalja Csiang Ce-ja (Jiang Ziya) Tajkung (Taigong) Hat titkos tanítását, Sze-ma Zsang-csü (Sima Rangju) A háború müvészetét, Szun-ce (Sunzi) A hadviselés tudományát, Vu Csi (Wu Qi) Vu-ce (Wuzi) címü müvét, a Vej Liaocet (Wei Liaozit), illetve Huang Si-kung (Huang Shigong) Három stratégiáját és Tang Taj-cung (Tang Taizong) és Li Vej-kung (Li Weigong) beszélgetéseit. Ezek közül alább Szun-ce és Wu Csi munkásságát emeljük ki.

\section{Filozófiai alapok - a konfucianizmus és a legizmus}

A mai kínai stratégiai és nemzetközi gondolkodás megértéséhez elengedhetetlen a filozófiai hagyományok és a kínai gondolkodásmód megismerése. E filozófiai háttér - amely idővel bizonyos értelemben vallásokká is átalakult - olyan mélyen beivódott a kínai mindennapokba és az emberek gondolkodásmódjába, hogy sokszor észrevétlenül is befolyásolja a (külpolitikai) döntéshozatalt. Azaz, lényegében, a kínai kultúra egyik legalapvetőbb, legmélyebb aspektusáról van szó. A két legelterjedtebb és 
legnagyobb hatással bíró filozófiai iskola a Lao-ce (Laozi, i. e. 6. sz.) nevéhez füződő gondolatvilág, illetve a Konfuciusz által megalapított konfucianizmus (lásd feljebb).

Szun-ce és A hadviselés tudománya

Szun-ce (i. e. 544-496), a zseniális, máig ható kínai katonai stratéga Vej király csapatait vezette sikeresen a háborúk során. Tudását és tanításait A hadviselés tudománya (más fordításban: A háború müvészete) címü müvében gyüjtötte össze, amely mára már az egész világon alapmünek számít, ráadásul nem csupán a szüken vett katonai szférában, hanem a döntéshozatal minden területén, legyen az üzleti vagy politikai. Szun-ce szerint a háború müvészetének ismerői harc nélkül győzik le az ellenséges hadsereget, támadás nélkül foglalják el a városokat, és hosszas hadmüveletek nélkül döntik meg az államhatalmat.

Szun-ce könyvének jelentőségét nehéz lenne túlbecsülni, amit jól példáz az, hogy napjainkban már nem csupán a katonai akadémiákon, egyetemeken, hanem minden jelentős nyugati gazdasági vezető, menedzserképző egyetemen, intézetben alapvető kézikönyv. Ennek elsődleges oka, hogy Szun-ce elvei olyan alapvető jelentőségüek, hogy a stratégia minden formájában sikerrel alkalmazhatók, sőt, nélkülözhetetlenek. Az i. e. 6. századból származó mü tanításai a modern kínai vezetés elveiben is visszaköszönnek, gondoljunk csak Teng Hsziao-ping (Deng Xiaoping, 1904-1997) híres mondására: „figyelj éberen; biztosítsd a pozíciódat; nyugodtan állj az ügyek megoldásához; titkold a képességeidet és várj türelmesen; próbálj szerény maradni; soha ne követelj hatalmat magadnak." (idézi: KISSINGER, H. 2014, p. 458.)

\section{Vu-ce}

A Vu-ce a kínai hadtudomány egyik legrégibb és legfontosabb alkotása, szerzője Vu Csi (i. e. 440-381) a Hadakozó fejedelemségek korának egyik legjelentősebb politikusa és katonai vezetője volt. A Hadakozó fejedelemségek korában a szembenálló felek az állandó háborúskodás közepette többször kísérleteztek egyfajta horizontális, illetve vertikális szövetség kialakításával, amelyben a fejedelemségek erejének kiegyenlítését és a térség ideiglenes pacifikálásának lehetőségét látták. Ahogy a történelmi áttekintés során már láthattuk a megoldást végül az egységesített birodalom megalapítása jelentette a Csin fejedelemség vezetésével i. e. 221-ben. Bár Vu Csi eleinte konfuciánus tudósoktól tanult, mégis az első jelentős legista gondolkodók közé soroljuk. Mủvében forradalmi elveket fogalmaz meg a hadviselés terén, amelyek szöges ellentétben álltak a patriarchális konfucianizmus hadvezetési technikájával. 
Vu Csi könyvében nyomon követhető az a folyamat, ahogyan a konfuciánus terminológia legfőbb fogalmai új értelmezést nyernek, illetve a hadtudomány nyelvezetére átültetve jelentésük bővül, módosul.

Ezek a változások alapozták meg idővel a politikai filozófiában használt terminológiai rendszert is. A Vu Csi életéről fennmaradt történetek tele vannak olyan utalásokkal, amelyek egy nagyon erös, törvénykező személyiséget jellemeznek. A Cao Caohoz (155-220) hasonlóan kissé Machiavellire emlékeztető Vu Csi nem riadt vissza semmilyen eszköztől, hogy akaratát keresztül vigye. Egyes kutatók feltételezik, hogy a Vu-ce egy sokkal bővebb első változata, amelyet csakugyan maga Vu Csi írhatott, elveszett, s a ma ismert hatfejezetes változata csupán egy Han-korban született összefoglalás. A kutatók egy másik része ugyanakkor úgy gondolja, hogy a szöveg bizonyos részei annyira pontosan ábrázolják a Hadakozó fejedelemségek korát, hogy annak mindenképpen az adott korszakban kellett megszületnie. Az igazság valószínüleg valahol félúton lehet, azaz az eredeti mủ a Han-korban már csak töredékesen volt fellelhető, amit a korabeli tudósok saját idejük haditechnikai és hadtudományi fejlettségének megfelelően kibővítettek. A kínai történelem hosszú évszázadain keresztül a Vu-ce szövegét valamennyi hadvezérnek és államférfinak kötelező jelleggel ismerni kellett, sőt a Szung-dinasztia idején, i. sz. 1080-ban összeállított hadi kánonba az addig született több száz mü közül beválasztották a hét legfontosabb forrás közé is.

\section{A tien-hszia szemlélet és a tributárius rendszer}

Kína történelme folyamán leginkább olyan országként és civilizációként tekintett önmagára, amely a világ közepén helyezkedik el, és minden más, külső entitás csupán barbárnak tekinthető, amely szükségszerűen csakis alárendelt helyet foglalhat el a Középső Birodalommal szemben. Ez a szemléletmód még a kínai építészetben és városrendezésben is megjelenik, gondoljunk csak arra, hogy a Tiltott Város mint középpont körül hogyan épült fel Peking. A koncentrikusan gondolkodó kínaiak szerint e középpontból radiálisan sugárzik ki a Középső Birodalom hatalma és befolyása.

A tien-hszia, azaz az „ég alatti” holisztikus világszemlélet a konfucianizmus egyik fontos eleme, amely filozófiai alapot és magyarázatot ad a tributárius rendszernek. A tradicionális kínai gondolkodásban az ég alatti nem csupán a fizikai világot jelenti, hanem valójában egy kulturális koncepcióról van szó, amely a moralitást és általában a világ müködését, rendjét is beleérti a tien-hszia fogalmába. A tributárius rendszer lényege az egyenlőtlenség, amelyet ugyanakkor áthat a tien-hszia és a „nagy harmóniára” - ta-tung (datong) - való törekvés szelleme. A nyugati terminológiával kissé nehezen megfogalmazható rendszer lényege, hogy a világon létező dolgok 
(esetünkben: emberek, népek, országok) nem egyenlőek, a középpontban Kína áll, amit koncentrikusan vesznek körbe az egyéb területek. Ugyanakkor minden az ég alatt egyetlen nagy, hierarchikus rendszer része, amelyben per definitionem nem léteznek ellentétek, minden ország a Kína által vezetett világhoz tartozik. Ebből fakadóan nincs semmi sem távol, nincs semmi, amit el kéne foglalni katonailag, hiszen minden egy egészet alkot, aminek a középpontjában a Középső Birodalom fekszik. A ta-tung szerint az ember és természet egységére kell törekedni, ami ugyancsak a kínai világkép fontos része. A társadalom fennmaradásához ugyanakkor elengedhetetlenül szükséges a hierarchikus rend, amely a tributárius rendszer alapja is. Ez a hierarchia azonban nem a nyugati értelemben vett erős-gyenge pároson alapul, hanem inkább az apa-fiú viszonyhoz hasonlítható. A kínai társadalmat átszövő viszonyrendszerekre (apa-fiú, császár-miniszter, báty-öcs, férjfeleség, barát-barát) épülő kormányzást és hatalmat „Li-csenek”(„Lizhinek”) nevezték, ami lényegében az erkölcsön és etikán nyugvó kormányzásnak feleltethető meg.

Miután a fentebb látható módon a tradicionális kínai gondolkodás nem különböztetett meg önálló, szuverén állami entitásokat, hanem minden az ég alatt egyetlen egységbe tartozott felfogásuk szerint, ezért nem is alakult ki a klasszikus értelemben vett nemzetközi kapcsolatokról való gondolkodás. A tributárius rendszerbe tartozó országok (időben változó módon a Koreaifélsziget államai, Japán, Vietnam, Közép-Ázsia ${ }^{7}$ egyes részei), királyságok tulajdonképpen laza adófizetői, vazallusi kapcsolatban álltak Kínával, szatellitként keringtek a nagyságrendekkel nagyobb és erősebb kínai állam körül. Az egyes nemzetek és népek közötti kapcsolatokat ugyanazon törvényszerüségeknek és szabályoknak megfelelően fogták fel, mint a társadalmon belüli, illetve ember és ember közötti viszonyt. Ezt, a nyugatitól merőben eltérö, némiképp univerzalisztikusnak tekinthető szemléletet nagyban segítette Kína földrajzi elhelyezkedése is. Az ország ugyanis bizonyos szempontból egyfajta hatalmas, ám izolált szigetnek is tekinthetö. Ahogy azt a fentebbi fejezetekben bemutattuk, domborzata miatt a legtöbb irányból nehezen megközelíthető, délről sürü esőerdők és a Himalája hegyei, keletről a tenger, északról Szibéria és Mongólia végtelen pusztái, míg nyugatról a Taklamakán és Közép-Ázsia hegyei határolják. A hatalmas távolságok miatt Kína interkulturális kapcsolatai viszonylag alacsony szinten maradtak történelme folyamán, így nem tapasztalhatta meg az egyenrangú hatalmak között kialakuló nemzetközi rendszert sem egészen a 19. századi európai hódítás kezdetéig.

7 A hagyományos magyar orientalisztikában: Belső-Ázsia 


\subsubsection{Időrendi tábla ${ }^{8}$}

\begin{tabular}{|c|c|}
\hline dátum & esemény \\
\hline i. e. 8000 & Az első kínai kultúrák megjelenése \\
\hline i. e. $2207-1766$ & A Hszia-dinasztia \\
\hline i. e. $2000-1500$ & Az írásbeliség megjelenése \\
\hline i. e. $1765-1122$ & A Sang-dinasztia \\
\hline i. e. $1122-256$ & A Csou-dinasztia \\
\hline i. e. 604 & Lao-ce \\
\hline i. e. 453 sz. - i. e. 221 & A hadakozó fejedelemségek kora \\
\hline i. e. $551-479$ & Konfuciusz \\
\hline i. e. $544-496$ & Szun-ce \\
\hline i. e. $440-381$ & Vu-ce \\
\hline i. e. $221-206$ & A Csin-dinasztia \\
\hline i. e. 221 & Csin Si Huang-ti egyesíti Kínát \\
\hline i. e. $206-$ i. sz. 220 & A Han-dinasztia (Keleti majd Nyugati Han) \\
\hline $220-265$ & A Három Királyság kora \\
\hline $618-907$ & A Tang-dinasztia \\
\hline $907-960$ & Az öt dinasztia és tíz királyság kora \\
\hline $960-1127$ & Az Északi Szung-dinasztia \\
\hline $1127-1279$ & A Déli Szung-dinasztia \\
\hline 1279-1367 & A Jüan-dinasztia \\
\hline 1367-1644 & A Ming-dinasztia \\
\hline $1407-1420$ & A Tiltott Város felépítése \\
\hline 1405-1433 & Cseng Ho admirális felfedezőútjai \\
\hline $1644-1911$ & A Csing-dinasztia \\
\hline 1793 & Lord Macartney követsége \\
\hline 1839-1842 & Az első ópium háború \\
\hline $1856-1860$ & A második ópium háború \\
\hline 1851-1864 & A Taj-ping felkelés \\
\hline 1894-1895 & Az első japán-kínai háború, a simonoszeki béke \\
\hline 1899-1901 & A boxer lázadás \\
\hline 1911 & A Vucsang felkelés és a császárság bukása \\
\hline 1912. január 1. & A Kínai Köztársaság kikiáltása \\
\hline
\end{tabular}

8 A kínai történelem régmúltba nyúló eseményei kapcsán gyakran több, némileg eltérő évszám is fellelhető, így jelen rövid kronológiában a Jacques Gernet által közölt dátumokat alkalmaztuk. 
Civilizációk Kelettől Nyugatig

\subsubsection{Irodalomjegyék}

Ajánlott irodalom

DAWSON, RAYMOND 2002: A kínai civilizáció világa. Budapest: Osiris GERNET, JACQUES 2005: A kínai civilizáció története. Budapest: Osiris JiANG, Rong 2008: Farkastotem. Budapest: Magvető

JORDÁN GYULA 2008: „Az ég magas a császár messze van”-Igazságszolgáltatás, jog és politika Kínában. Budapest: ELTE Eötvös Kiadó

Kissinger, Henry 2014: Kínáról. Budapest: Antall József Tudásközpont

KulcSÁr KÁlmán 2007: Kína a világpolitikában. Budapest: Akadémiai Kiadó LAO-CE 2001: Tao-Te King. Budapest: Tericum Kiadó

PATAKI IvÁN 2007: „Egy alapvető hadtudományi munka az ókorból00 - Szun-ce:

A hadviselés tudománya”. Új Honvédségi Szemle (7)

Szun Ce 1996: A hadviselés tudománya. Budapest: Göncöl Kiadó

TÁlas Barna 2006: Kína - a 21. század leendő hiperhatalma. Külügyi Szemle (1-2): pp. 16-68.

VASZILJev, L. Sz. 1977: Kultuszok, vallások és hagyományok Kínában. Budapest: Gondolat Kiadó

Vu CE 1999: A háború útja. - Fordítás és előtanulmány: Tokaji Zsolt. Budapest:

Terebess Kiadó

További irodalom

Feng, Huiyen 2007: Chinese Strategic Culture and Foreign Policy DecisionMaking - Confucianism, leadership and war. London - New York: Routledge

Friedman, George 2006: The Geopolitics of China. Stratfor, April 26.

GEERAERTS, GUSTAAF - MEN JING 2001: International Relations Theory in China. Global Society 15 (3)

Hui, Victoria Tin-BOr 2005: War and State Formation in Ancient China and Early Modern Europe. Cambridge: Cambridge University Press

Kang, David C. 2007: China Rising - Peace, Power, and Order in East Asia. New York: Columbia University Press

Kissinger, Henry 1998: Diplomácia. Budapest: Panem-Grafo Kiadó

QIN, YAQING 2010: Why is there no Chinese international relations theory? In: ACHARYA, AmitaV - BuZAN, BARry (eds.): Non-Western International Relations Theory. New York: Routledge

Song, XINNING 2001: Building International Relations Theory with Chinese Characteristics. Journal of Contemporary China 10 (26): pp. 61-74. 


\title{
2.2. A japán civilizáció
}

\author{
FARKAS MÁRIA ILDIKÓ
}

\subsubsection{Japán mint önálló civilizáció?}

A világ ma létező civilizációi mind időben és térben változó méretü nagyobb területeket és több népet, etnikumot, nyelvet, kultúrát felölelő egységek, amelyek között az egyetlen országot, népet és kultúrát jelentő japán civilizáció elég különösnek tünik. Milyen tényezők indokolják, hogy Japánt az összehasonlító civilizációtörténeti szakmunkák önálló civilizációnak tekintik?

Hová is tartozik Japán? Kétségkívül a világ legfejlettebb ipari országai közé, magasan fejlett ipari - sőt inkább már posztindusztriális - gazdaságával, társadalmával és demokratikus politikai és intézményi rendszerével a nyugati civilizáció része, a legfejlettebb országok csoportjának (G7) tagja. Ugyanakkor elhelyezkedése, kulturális meghatározottsága, vallásai, írásrendszere és számos egyéb kulturális hagyománya tekintetében erősen különbözik a nyugattól és Ázsiához kötődik, ahonnan civilizációjának egyes elemei származnak.

Ez utóbbi felvetheti, hogy Japán tulajdonképpen a kínai civilizáció perifériája, amely a történelem során nagy és jelentős hatást gyakorolt Japánra. Japán földrajzi-politikai értelemben a kínai civilizáció határvidékén helyezkedett el egy évezredig, időnként igazodott a Kína-központú kelet-ázsiai rendhez és átvette annak eredményeit, de időnként bezárkózott, kívül maradt a kínai civilizáció hatókörén, és fejlődése eltérő irányt vett. Az átvételeket pedig addig alakította saját képére, míg azok „eljapánosodtak”, és jobban megfeleltek a japán sajátosságoknak, a belső, a kínaitól erősen különböző fejlődés által megteremtett viszonyoknak. Merész állítás, de megkockáztatjuk: Japán sosem lett integráns része a Kína-központú kelet-ázsiai világrendnek.

Ebben valószínűleg fontos szerepet játszik szigetország-mivolta, az (Ázsiától való) elzárkózás lehetőségével. Az ázsiai kontinens mentén elhelyezkedve történelme során több elemet is átvett a kínai kultúrából (amelyeket aztán saját hagyományai szerint alakított át, így jött létre a japán buddhizmus, a japán konfucianizmus, számos müvészeti müfaj), ugyanakkor Japán jelentős különbségeket mutat a kínai civilizációhoz képest vallási és kulturális életében, és főként történelmének alakulásában. A sintó mint önálló japán vallás, a sajátos japán családrendszer, a középkori feudalizmus, a sikeres 19. századi modernizáció, a modern államiság Ázsiában 1945 előtt és a demokratikus államiság 1945 után mind olyan elemek, amelyek jelentősen különböznek a kínai civilizáció jellemzőitől, és sokkal inkább Európával hozhatók párhuzamba. 
Különösen érvényes ez az összehasonlítás a 19. század közepétől, amikor is Japán a nyugati civilizáció perifériája lett. Japán az 1850-es évekig elzárkózva élt, a nyugati hatalmak behatolása után (1868-tól) a gyarmati sorsot elkerülve sikeresen modernizálódott. Japán így egyedi pozíciót vívott ki magának mint a Nyugathoz csatlakozott ország: bizonyos szempontból „nyugati”-nak minősül, de fontos dimenziókban jól láthatóan nem az, így Japánnal kapcsolatban felvetődött a „kettős civilizáció”, illetve a „két civilizáció (nyugati és a kínai) keveréke" meghatározás is.

A japán modernizáció sikeressége a 19. század folyamán és ebben páratlan volta Ázsiában felvetette annak lehetőségét, hogy Japán nem az ázsiai (kínai) civilizáció része, de nem is a nyugatié, hanem egyediségénél fogva önálló civilizációt alkot (Eisenstadt, Sh. N. 1996; Huntington, S P. 1998). A japán hagyományok és jellegzetességek ugyanis mindig utat törtek minden külföldi befolyás és átvétel rendszerén, legyen az kínai vagy európai hatás. A Japán-szigetek földrajza és az általa meghatározott életforma (kultúrökológia), a sintó, a japán feudalizmus, a busidó, a különleges etnikai és kulturális homogenitás hagyománya biztosította az átvételekkel együtt a japán történelem sajátos jellegét: az állandóság és a változás különleges egységét. Japán Ázsiától való különbözősége nem a modernitás (azaz a nyugati civilizáció hatásának) eredménye, hanem annál sokkal mélyebb gyökerei vannak. A sajátos japán fejlödés a kínai, majd a nyugati átvételek mellett is a kontinensétől, illetve a Nyugattól mindig eltérő irányt vett, amit elösegített a japán történelem ciklikusan ismétlődő jelensége: az elzárkózások időszakai. Mindez együttesen joggal veti fel egy önálló japán civilizáció lehetőségét, amely megmagyarázza a japán fejlödés sajátosságait.

Kijelenthetjük tehát, hogy Japán önálló civilizációt képez, ami egészen egyedi jelenség, hiszen ez esetben egy ország, egy állam, egy nép (98 százalék japán), egy nemzet, egy kultúra, egy nyelv alkotja a világ ma létező civilizációinak egyikét. Kapcsolódik ugyan a kínai civilizációhoz (olyan kulturális elemek átvételével, mint a tao, buddhizmus, konfucianizmus, írásrendszer), de történeti fejlődésében attól független utat járt be (középkori feudalizmus, sikeres modernizáció a 19. században), így nem tartható a kínai civilizáció részének. Ugyanakkor bár a nyugati civilizációhoz is kapcsolódik, annak sem integráns része, föként kulturális örökségének és identitásának köszönhetően. Ennek az a magyarázata, hogy a modern Japán megteremtése az akkori, a 19. század második felére jellemző európai fejlődési mintát követte, de amire épített, az a japán kulturális hagyományból eredt, amely még a nyugati típusú modernizáció előtt formálódott meg. Ezzel a kulturális identitással Japán a modernizáció „,nem nyugati” útját valósította meg, elsőként és hosszú ideig (a 20. század közepéig) egyedüliként. 


\subsubsection{A japán civilizáció forrásai és alapjai}

Hogyan, mikor, milyen körülmények között jött létre a japán civilizáció? Milyen összetevőkből, milyen alapokról, milyen tényezők hatására, hogyan alakult ki? Hogyan formálta az itt élő népesség életformáját, ebből következően kultúráját természeti környezete? Milyen hitvilág és világszemlélet következett ebből? Milyen külső hatások érvényesültek a kultúra változásaiban? Hogyan hatott a kialakult kultúra sajátos jellege a történelmi változásokra?

\section{Természeti környezet}

Az önálló japán civilizáció kialakulására nyilvánvalóan nagy hatással volt a terület sziget-mivolta, ami akadályt jelentett a kívülről érkező akár pozitív, akár negatív hatások érvényesülése számára, és bizonyos mértékben és időszakokban elszigetelt helyzetben tartotta a Japán-szigetek népességét.

Japán területe tulajdonképpen egy $2400 \mathrm{~km}$ hosszan elterülő vulkanikus szigetcsoport Kelet-Ázsia keleti pereme mentén. A mai Japánt 4 fő sziget (Hokkaidó, Honsú, Sikoku, Kjúsú) és több mint 3000 kisebb-nagyobb lakott és lakatlan sziget alkotja $377923 \mathrm{~km}^{2}$-nyi területen, amely Európában egy körülbelül Norvégia nagyságához hasonló, Németországnál nagyobb területet jelent. (Magyarországnál körülbelül négyszer nagyobb.) Az egyes forrásokban látható eltérő adatok (néhány $\mathrm{km}^{2}$ esetében) magyarázata, hogy az apró szigetek száma állandóan változik, a tektonikus mozgások következtében folyamatosan süllyednek a tengerbe, illetve emelkednek a vízszint fölé. Lényegesen nagyobb eltérés látható az úgynevezett „Északi területek” (a Kuril-szigetek egy része, $\mathrm{kb} .5000 \mathrm{~km}^{2}$ ) miatt, amely területet jelenleg is Oroszország birtokolja (még a második világháborúban foglalta el a Szovjetunió a Japán birtokában lévő szigeteket), de amelyet Japán magáénak tart és hivatalos területébe is beleszámol.

A természeti környezetre jellemzö, hogy Japán területének 72 százaléka hegyvidék, a szigeteket gyakorlatilag egy tengerből kiemelkedő lánchegység alkotja az ország teljes hosszán végigvonuló hegyláncolattal (legmagasabb tengerszint feletti magassága a Fudzsi hegycsúcsa 3776 méterrel). A magas hegységek, meredek hegyoldalak, szük völgyek miatt az ország területének közel háromnegyede emberi megtelepedésre és mezőgazdasági művelésre alkalmatlan. A nagyon kevés müvelhetö terület mellett a hegyoldalakat is próbálták hasznosítani teraszos müveléssel, amelynek kialakítása és fenntartása rengeteg többletmunkát jelentett és jelent ma is a mezőgazdasági müvelés számára. Az ország lakható területe csekély, így az emberek élettere szükös, zsúfolt, a mindössze egynegyednyi ország területen (azaz egy kb. magyarországnyi területen) 127 millió ember él. Japán népsürüsége még a teljes területével számolva is a világ élmezőnyébe tartozik (18.) a 337 fö/ $/ \mathrm{km}^{2}$ értékkel 
(Európában az egyik legnagyobb népsürüséggel rendelkező Belgium mutat ilyen értéket, 339), viszont ez a népesség nagyon egyenetlen eloszlásban él a szigeteken: az ország népességének több mint fele ( 57 százalék) területének alig 2,2 százalékán lakik, 90 százalék városokban (8. térkép). A tokiói metropolisz régió népsürüsége $5000 \mathrm{fő} / \mathrm{km}^{2}$ értéknél is nagyobb, ezzel a legsürübben lakott városok (Monaco, Makaó, Szingapúr és Hongkong) után következik a világranglistán, népessége (34,5 millió) alapján pedig a legnépesebb városi agglomeráció a világon.

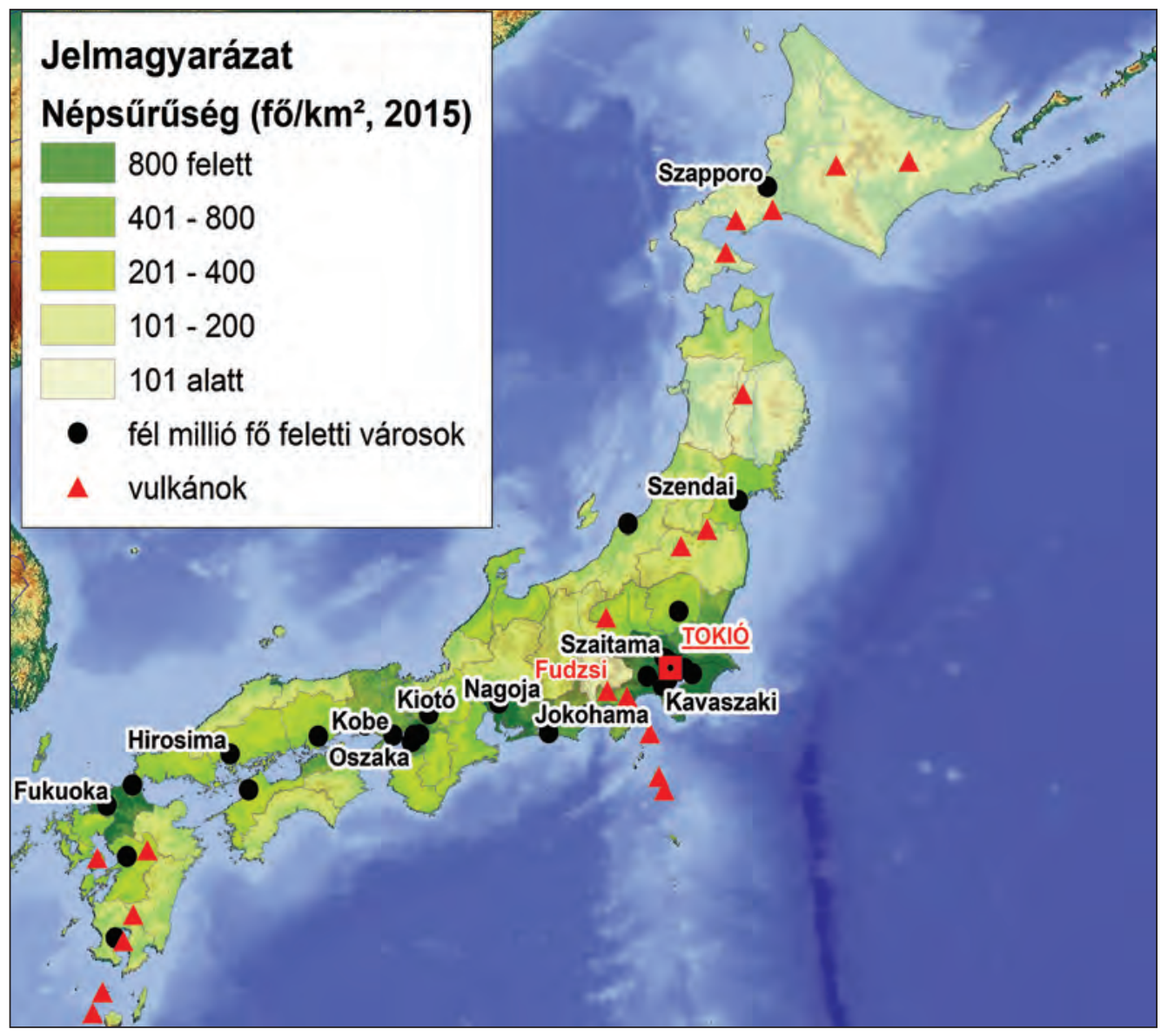

8. térkép: Japán domborzata, fóbb vulkánjai és nagyvárosai Forrás: VARGa ÁGNES szerkesztése

A természeti kincsek tekintetében Japán kifejezetten szegény országnak számít, amihez képest meglehetősen ellentmondásosnak tủnik, hogy jelenleg is a világ harmadik legnagyobb gazdaságát mondhatja magáénak (az USA és Kína mögött, ha az Európai Uniót nem számoljuk egységes gazdaságnak, mert akkor „csak” a negyedik). Ez azt jelenti, hogy Japán esetében gazdasági sikereinek 
hátterében nem a kedvező természeti feltételek állnak (mint pl. az olajjal, vagy gazdag szén- és vasérclelőhelyekkel rendelkező térségek esetében), hanem valamilyen más tényezők játszhattak fontos szerepet. Japánnak nyersanyaga, ásványkincse, energiaforrása gyakorlatilag nincs, ha van is valami kevés szén, vasérc, réz, cink, arany, ezüst, ólom, gáz, kén, azokat a természeti környezet miatt vagy teljességgel lehetetlen feltárni és bányászni, vagy csak nagyon gazdaságtalanul lehetne. Így az ország minden fontos alapanyagból behozatalra szorul a modern iparosodott korszak kezdete óta, és az állandóan fenyegető külkereskedelmi hiány erős késztetést jelentett (és jelent ma is) az exportorientált gazdaság kialakítására és fenntartására.

Milyen hatással volt ez a természeti környezet az itt kialakuló emberi kultúra sajátosságaira? Az egész történelem során a kedvezőtlen és nehéz természeti körülmények az emberi élet fenntartása szempontjából azt jelentették, hogy folyamatos, nehéz és kitartó munka volt szükséges az életben maradáshoz. A kevés művelhető terület sok és nehéz emberi munkát igényelt a föld hasznosításához: gátak, csatornák és öntözőrendszerek építése, a hegyoldalak teraszos kialakítása, folyamatos fenntartása, a rendszer állandó karbantartása.

Japán éghajlata mérsékelt égövi, de óriási változatosságot mutat a hideg mérsékelttől a szubtrópusi klímáig terjedően. A változatosság okai egyrészt a szigetek észak-déli nagy kiterjedése (Észak-Amerika térképére vetítve ez a Montreal-Miami távolságot jelenti, vagy Európából indulva a Kijevtől Kairóig terjedő távot), másrészt az ország közepén végighúzódó hegylánc éghajlat- és vízválasztó hatása. Ez utóbbi miatt a klíma különbözik a csendes-óceáni és a japán-tengeri oldalon: a Japán-tenger mentén a kontinens hatása érvényesül (nyáron nincs monszun, viszont télen hideg és hatalmas havazások érkeznek), a Csendes-óceán partvidékén pedig azóceáni hatás miatt télen kevés hós és enyhébb idő van, de nyáron esőzések és forró, párás idő érezhető. Hokkaidó kivételével a szigetek a monszunövezetbe tartoznak, a nyári esős évszak (6 hét) nagy csapadék mennyiséget, forróságot, magas páratartalmat jelent. Ugyanakkor még az óceáni áramlatok hatása is érvényesül: északról hideg, délről meleg áramlat hüti, illetve füti a szigeteket, tovább növelve a hőmérsékleti különbségeket az északi és déli területek között. Például Szapporo ugyan Milánóval fekszik azonos szélességi körön, de a hideg áramlat hatása miatt éghajlata annál sokkal hidegebb, ugyanakkor Tokió környékén Athén klímájához hasonlóan meleg, csak az óceáni áramlat és a monszun hatása miatt sokkal párásabb éghajlat érvényesül.

Az éghajlati különbségek és a nem ritkán szélsőséges időjárás (hatalmas esőzések, áradások, havazások, tájfunok) a folyamatos alkalmazkodás szükségességét és képességét alakították ki az itt élő emberi közösségekben. Ennek egyik konkrét példája a hagyományos japán építészet, amely éppen a nem szilárd alapanyagokat (fa) részesítette előnyben a szilárddal (kö) szemben, 
hiszen egy fából épült épület (és egy egész falu) ugyan könnyebben elpusztult a továbbiakban ismertetett természeti katasztrófák, vagy csak a szélsőséges időjárás következtében, ugyanakkor néhány nap alatt újjá is lehetett építeni, és folytatni lehetett a mindennapi életet.

\section{Természeti katasztrófák}

A természeti környezet katasztrófákkal is sújtja a szigetek népességét.

1. Vulkánok: Japán területe tulajdonképpen egy vulkáni szigetív, amely a földkérget hordozó lemezek mozgásának következtében - a Japán-tengert is hordozó Eurázsiai-lemez, valamint északon a Pacifikus-lemez, délen pedig a Fülöp-szigeteki-lemez ütközésével képződő vulkáni tevékenységgel jött létre (12. kép). A szigeteket nagyjából középen végighúzódó törésvonal szeli ketté, e mentén helyezkednek el a vulkánok. Japánban 150-200 kialudt vulkán mellett 36 aktívan müködő vulkánt tartanak számon. A világ összes működő vulkánjainak 10 százaléka Japánban található.

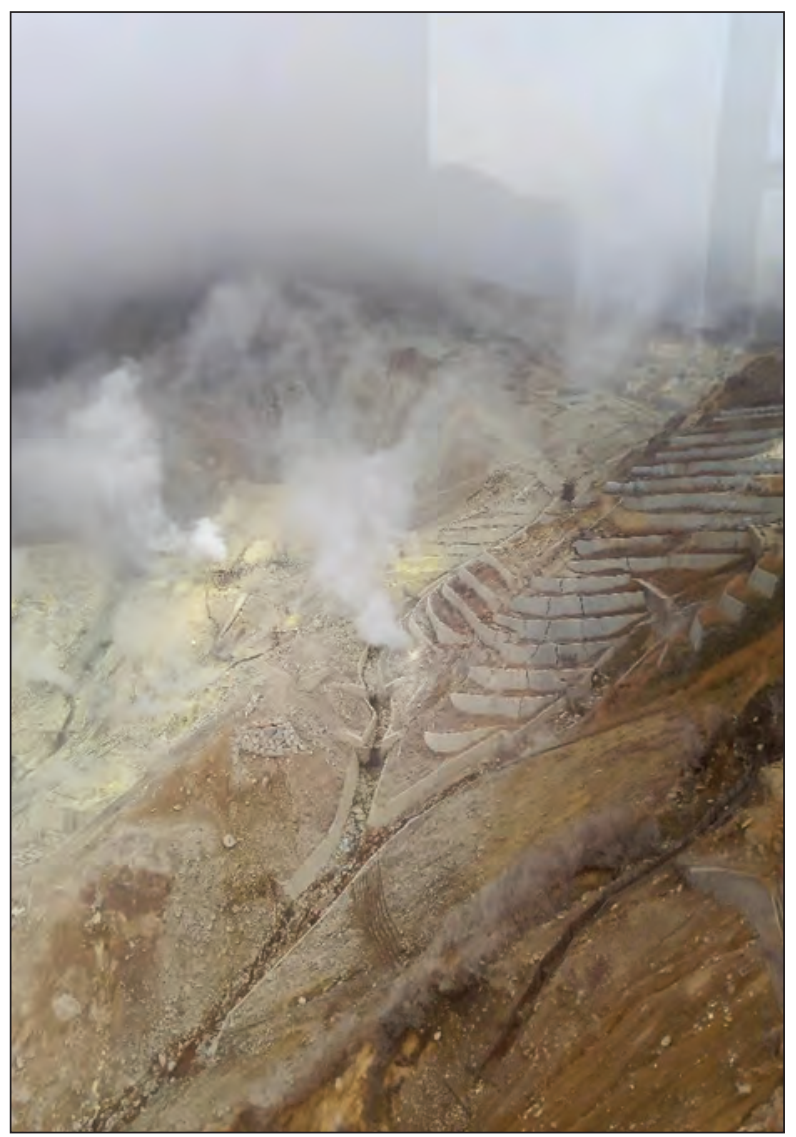

12. kép: A vulkanikus Hakone-hegység ma is aktív kénes nyílásai Forrás: PóR ANDREa felvétele 
2. Földrengések: Japán területe és környéke tektonikai szempontból a világ egyik legaktívabb, legváltozékonyabb területe. A földkéreg lemezeinek mozgása, ütközése miatt ez a térség a Föld földrengések által leginkább veszélyeztetett területe. Évente 1500 földrengést, általában 4-es és 7-es fokozat közötti földmozgást regisztrálnak, ami azt jelenti, hogy Japánban mindennaposak a kisebb rengések, és majdnem mindig valahol mozog a föld. Sajnos pusztító földrengések is rendszeresen sújtják a szigetek népességét, valamint a tengeren bekövetkezett földrengés katasztrofális következménye lehet az árhullám jelensége (cunami). A 20. században az 1923-as nagy kantói földrengés több mint százezer halálos áldozatot követelt, és szinte teljesen elpusztult Tokió (a mai város az azutáni újjáépítés eredménye). Japán a világon a legfelkészültebb ország a földrengésekre, és a speciális építkezésnek, a megfigyelő, biztonsági és riasztó rendszereknek köszönhetően az emberi és az anyagi veszteségeket jelentősen csökkenteni tudják, de a pusztító természeti katasztrófákat nem lehet teljesen kivédeni. 2011ben Japán északkeleti partvidéke mentén az emberi történelemben valaha feljegyzett egyik legnagyobb földrengés ( 9 feletti magnitúdóval) zajlott, hatalmas árhullámot elindítva, amely 40 méteres magassággal zúdult a japán partok felé. A földrengés következtében Honsú szigete 2 és fél méterrel keletre tolódott, és a Föld tengelye is $10-25 \mathrm{~cm}-\mathrm{rel}$ kilengett. A katasztrófa mintegy 15 ezer halálos áldozatot követelt (hozzá kell tennünk, 2006-ban a hasonló szökőárt elindító nagy indonéziai földrengés több mint 300 ezer áldozattal járt). A katasztrófa legsúlyosabb következménye a fukusimai atomerőmű sérülése volt. Bár Japánban az atomerőmüvek építésénél komoly biztonsági rendszereket alkalmaznak, amelyek a földrengés észlelésénél le is állították az erőmü müködését, a cunami több mint 30 méteres hullámait a több méteres parti beton védmüvek sem tudták megállítani, és az árhullám még mintegy $10 \mathrm{~km}$-en át zúdult a japán szárazföldre, az útjában elpusztítva mindent és megrongálva az atomerőművet is.

A nagy katasztrófákon kívül még egyéb, kevésbé pusztító, de olykor igen jelentős kárt okozó természeti jelenségek is veszélyeztetik a japán népesség életét és javait. Augusztustól októberig a Csendes-óceán délebbi térségéből érkező tájfunok elérhetik az ország délkeleti részét, télen a Szibéria felől érkező hatalmas havazások az északnyugati részt, és ez a hó mennyiség olvadásakor súlyos áradásokat és földcsuszamlásokat okozhat. A szigetek Hokkaidó kivételével a monszunövezetbe tartoznak, az ezzel járó hatalmas esőzések a nyár elején szintén áradásokat okozhatnak, de az sem jó, ha az eső mennyisége kevés, mert ez esetben aszály fenyegetheti a termést. 
A mostoha természeti környezet következményekkel járt az emberek létfenntartásában és világhoz való viszonyában: az állandó bizonytalanság és veszélyhelyzet létszükségletté tette a körülményekhez való alkalmazkodás képességét, a rugalmasságot, a folyamatos, nehéz és kitartó munkát a mindennapokban, és az ismétlődő újrakezdés természetességét. Az emberek megtanultak együtt élni a kiszámíthatatlan és gyakran veszélyes környezettel, a természetnek való kiszolgáltatottsággal. A közösségekben már a korai időktől hangsúlyozták a szervezettség, együttmüködés, vészhelyzetre felkészültség fontosságát, és maximálisan kihasználták az erőforrásokat és az emberi munkát.

\section{Vallás}

Egy civilizáció jellegének formálódásában meghatározó szerepe van a hitvilágnak és a világszemléletnek, a vallásnak. Japán ebben is egyedi, mert több különböző vallási tradíció egymás mellett élése, sőt szinkretizmusa (bizonyos szintü összeolvadása, egymásba fonódása) határozta - és határozza - meg a japán vallásosságot, amely ráadásul - ismét egyediségként - nem is vallási (teológiai) tanításokban nyilvánul meg, hanem inkább követendö életszemléletet, hagyományt, életmódot jelenít meg a japánok számára. A belső, saját hagyomány (sintó) és a kívülről érkezett vallási és filozófiai irányzatok (tao, buddhizmus, konfucianizmus) együtt, egymás mellett és bizonyos mértékben egymást kiegészítve és befolyásolva léteztek, és a japánok számára gyakorlatilag egy egységes rendszert alkottak, amely felölelte a hitvilágot, a világszemléletet és a moralitást, etikát. A közösségi vallási gyakorlat meghatározta az egyén életét is.

A természet körülményeknek való kiszolgáltatottság eredményezhette a japánok sajátos viszonyát környezetükhöz, és saját természetimádó vallásuk, a sintó kialakulását is. Mivel annyira kiszolgáltatottak voltak a földrajzi és időjárási elemeknek, a japánok a természetben, annak isteneiben (kami) látták életük irányítóit, akik szinte megszámlálhatatlanul sokan vannak, $\mathrm{s}$ a természeti jelenségekben lakoznak. Az ember élete tőlük függ, a kamik segíthetnek, megharagudhatnak, de kiengesztelhetők szertartásokkal, áldozatokkal, imákkal. A sintó tehát archaikus természetimádó hiedelemvilág; szertartások, varázslások, helyi kultuszok halmaza, eredetileg erkölcsi tanítások és metafizikai mondandó nélkül (13. kép). Az ösök tisztelete, a természeti jelenségek imádata, a szellem halhatatlanságába vetett hit jellemezte, milliónyi kamival.

A 6. században került Japánba a buddhizmus, de nem szorította ki a sintót, hanem inkább kiegészítette és kiszélesítette a vallási életet, a halottakról való gondoskodással, a túlvilág fogalmával és képével, a buddhista filozófiával, teológiával és moralitással. Mindmáig jellemző a japánokra, hogy úgy tartják, a sintó az evilági élettel foglalkozik (születéssel, gyermekünnepekkel, 
esküvőkkel, a mezőgazdasággal kapcsolatos rítusok, szertartások és ünnepek zajlanak a szentélyekben), a buddhizmus pedig a lélekkel és a túlvilággal (azaz a mi fogalmaink szerint inkább a vallási dolgokkal). A japánok mindkettő rítusait végzik, az egyén életének különböző szakaszaiban és az év különbözö ünnepségeihez kapcsolódóan látogat el sintó szentélybe vagy buddhista templomba. A rítusok, ünnepek nagyon fontosak a mai világban is, még ha már nem is kapcsolódnak szorosan vallásos hithez, de egyrészt az egyén életének fontos fordulópontjait jelzik, másrészt az ünnepek jelentős közösségi események, és a közösség összetartozásának megnyilvánulásai, ünnepei.

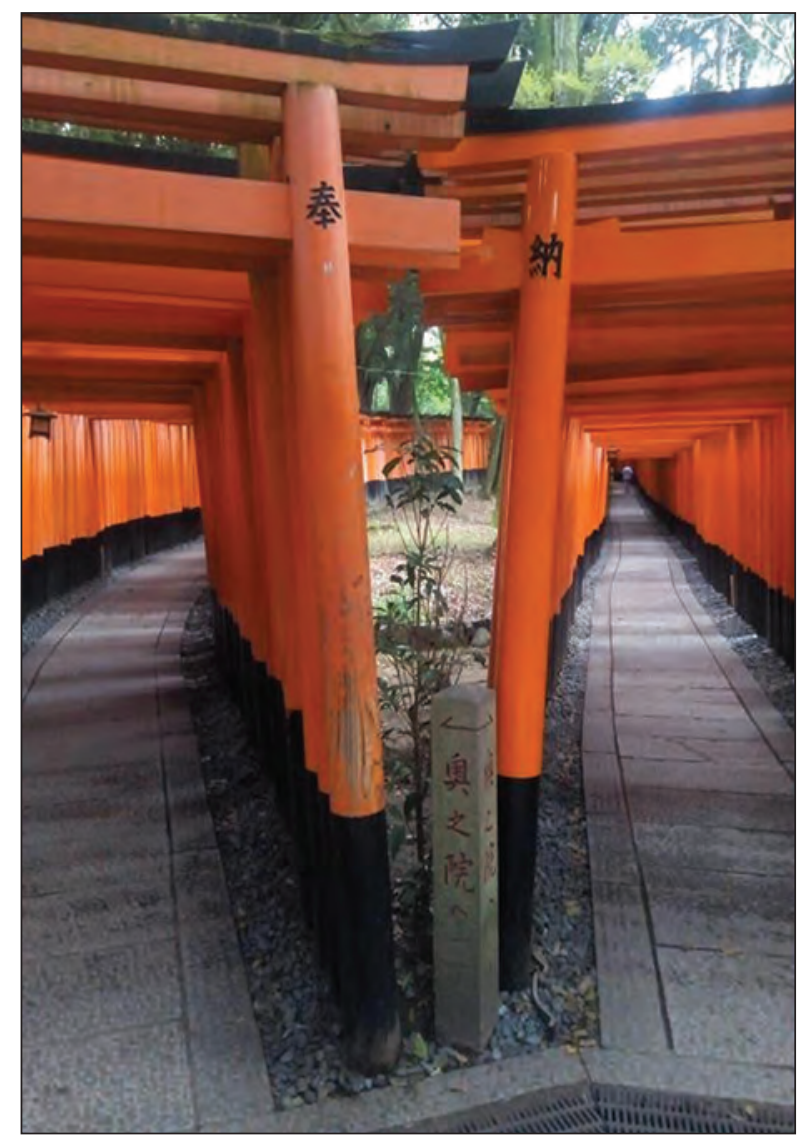

13. kép: Az egyik legnagyobb sintó szentély, a Fusimi Inari-szentély kapusora Forrás: PóR ANDREA felvétele

Szintén az 5-6. században a tao és a konfucianizmus is bekerült Japánba, és része lett a japán vallási hagyománynak. A tao hagyományából elterjedt a jin és jang tana, az asztrológia, a jóslás és varázslatok szokása, a tér elrendezésének (mai utóda a feng sui) és az öt elemnek a tana, a (csillagállások szerinti) szerencsés és szerencsétlen hely, idő, cselekedet, előjel stb. hite, azaz a tao 
elemei mélyen beleivódtak a népi vallásosság rendszerébe. A konfucianizmus inkább etikájával, morális mondanivalójával hatott, amellyel mintegy útmutatót nyújtott az élethez, meghatározta az emberek közötti viszonyokat (hierarchia), a társadalom müködését (harmónia), az egyén kötelességeit (tekintélytisztelet, erkölcsös és fegyelmezett élet, önmüvelés fontossága). A buddhizmus Japánban sajátos fejlődésen ment át, kialakult és ma is működik a sajátos japán buddhizmus, saját mondanivalóval (14. kép). Az Amida (Buddha) hiten alapuló Dzsódósinsú irányzat a japán buddhizmus máig legeröteljesebb és legtöbb követővel rendelkező ága; a japán Zen buddhizmus a „legjapánabbnak” tartott művészeti ágak, esztétika és filozófia meghatározó szellemisége; és szintén máig él a 13. században alapított, hangsúlyozottan ,japán” (nemzeti) buddhizmust hirdető Nicsiren (Hokkesú) irányzat (hozzá kötődő kulturális egyesület, több iskola és politikai párt is van).

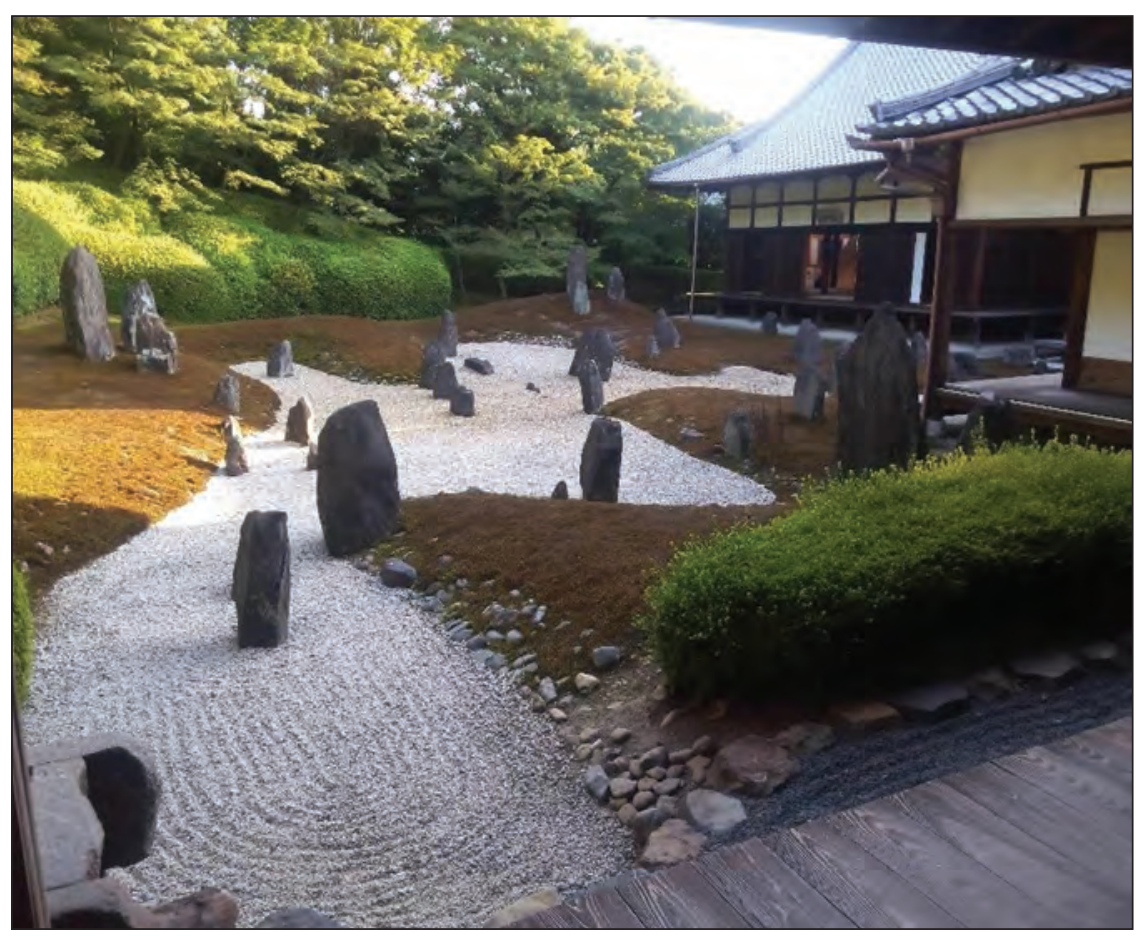

14. kép: A japán Zen buddhizmus elvei alapján tervezett kert (Kómjóin, Kiotó) Forrás: PóR ANDREA felvétele

\section{Társadalom}

A japán társadalmat alapvetően kollektivista társadalomnak tartják (ahogyan általában a kelet-ázsiai társadalmakat), szemben az individualistának tartott „nyugati” társadalmakkal. A kollektivista kultúrában a társadalmi 
létezés alapja a „mi-tudat”, az egyén csak közösségben tudja meghatározni magát. A csoport érdekét előbbre valónak tartják az egyén érdekénél, ugyanis mivel az egyén a csoporttól függ, a csoport jóléte biztosítja az egyén jólétét is, így minden tag számára a közösség jóléte az elsődleges fontosságú. Az egyén és a közösség viszonya kétirányú: az egyén lojalitást mutat a csoport iránt, a csoport pedig gondoskodik tagjairól (paternalizmus), és ez jelenti a kollektivista kultúra hasznát az egyén számára: életre szóló védettséget. Ezzel szemben az individualista társadalmakban (Európa, Észak-Amerika) az egyén boldogulásának alapját az egyéni képességekben és teljesítményben látják, a függetlenség és az önállóság a hangsúlyos. A társadalom az individuumot, az egyéni megmérettetést, a versenyt, a teljesítményt díjazza, míg a kollektivista kultúrában az egyén önmagában szinte nem létezik, csak mint egy csoport tagja, és értékelésében kevésbé egyéni kiválósága számít, hanem inkább az, hogy a közösség szempontjából mennyire értékes tagja a csoportnak. Fontosak a csoporton belüli emberi kapcsolatok és viszonyrendszer, amely általában hierarchikus, és minden egyénnek kijelöli a maga helyét, feladatát, amelynek tejesítése az egyén megítélésének alapja (ezt nevezik „feladatorientált" társadalomnak is, szemben a nyugati „célorientált” megközelítéssel). A közösség fennmaradásának és megfelelő, sikeres működésének egyik alapja a csoporton belüli összhang, együttmüködés, konfliktusmentesség, amit összefoglalóan a „harmónia” megnevezéssel illetnek, és fenntartását az egyének fontos feladatának tekintik, akár az egyén saját érzelmeinek visszafogásával, saját érdekeinek háttérbe szorításával is. A kelet-ázsiai konfucianizmus éppen ezeket az értékeket hangsúlyozza: kollektivizmus, harmónia, hierarchia tisztelete, lojalitás, gondoskodás, egyéni érdek visszaszorítása, együttmúködés. Vajon visszavezethetö-e valamilyen közös eredetre ezen társadalmak hasonló szerveződése, amit a közös értékrendszer, a konfucianizmus is megfogalmaz, mind a mai napig erősen meghatározva ezen országok világszemléletét? Létezik olyan elmélet, amely szerint a föként ,keleti” (ázsiai) kollektivizmus és az inkább „nyugati” individualizmus eltérése a mezőgazdasági termelés különbözőségében gyökerezik, elsősorban a rizstermesztés körülményeiben („rizskultúra” és „gabonakultúra” különbsége). A Kelet-Ázsiában alapvető élelmezési gabonát, a rizst öntözéses, árasztásos gazdálkodással termelik, ami szervezett, irányított, fegyelmezett csoportmunkát (gátak és csatornák építése, karbantartása, együtt és egyszerre végzett munkafolyamatok a palántázásnál, árasztásnál stb.) igényel, és magas fokú együttműködést a csoport tagjaitól. Az együttes munkához pedig olyan vezető is kell, akinek mindenki engedelmességgel tartozik, és aki az egész közösségért felelős. Az egyének tapasztalata, hogy csak együttes munkával érhetik el céljukat, a jó termést, és ez a közös cél mindannyiuk alapvető érdeke. Ezzel szemben a búza (és a rozs, árpa, zab, azaz az Európában legelterjedtebb gabonafélék) termesztése nem igényel sem árasztást, sem öntözést, és a különbözö 
termelöknek nem kell összehangolni munkafolyamataikat, azaz a termeléshez nem szükséges csoportmunka. A földmüvesek egyénileg is meg tudták müvelni földjeiket. A rizstermesztés kb. időszámításunk előtt a 3-2. század folyamán terjedt el a japán szigeteken, meghatározó mezőgazdasági tevékenység lett, és döntően befolyásolta a japán nép közösségi szerveződését. A japán közösségi szerveződés így kialakult rendszere az egész társadalom működésének mintája lett (nemcsak a mezőgazdasági termelésé), s tulajdonképpen mind a mai napig meghatározza a japánok társadalmi szerveződését, kollektivizmusát.

Ugyanakkor a kelet-ázsiai mértékkel mérve a japán társadalom „,individualistább” a környezö kultúrákénál, amelynek oka föként a történelemben keresendő: a szamuráj hagyományban. Az önálló kistulajdonosi réteg, a föld örökletes magánbirtoklása, a feudális viszonyok személyes jellege (hübérúr és vazallus), az egyéni harci képességek mind az egyén jelentőségét erősítették az egyébként valóban kollektivista társadalomban. A hagyományos japán nagycsalád sem kiterjedt nagycsalád volt, hanem csak az apai ágú leszármazást számon tartó hierarchikus család, apáról fiúra öröklődő családnévvel és vagyonnal. Más ázsiai társadalmakban a csoport iránti hüség inkább „születési adottság" volt (a család, vagy a helyi közösség által meghatározottan), míg Japánban ez gyakran választás kérdése lehetett (választott hübérúr, örökbefogadás a családokban), ami a mai japán társadalomban a munkavállalók által a (választott) munkahely iránt tanúsított (vagy tőlük elvárt) lojalitás jelentőségét is megmagyarázza. Japán társadalmát „maszkulinnak” is tartják, nemcsak azért, mert a férfi és a női szerepeket még mindig élesen elkülönítik, hanem mert a hagyományosan férfiasnak tartott értékeket tekintik elsősorban fontosnak: versenyszellem, teljesítmény, munkamánia, siker a fó motiváló tényező, és az erre való „kondicionálás” már kisgyermekkorban elkezdődik, és egész életen át tart. Ugyanakkor ez a japán kollektivizmussal párosulva nem egyéni versengést jelent, hanem csoportok közötti versenyt, ami az egyénekre nézve tulajdonképpen nagyobb terhet ró, hiszen ha egy csoport az egyik tagjának a gyengébb teljesítménye miatt marad le, akkor annak a tagnak nem a saját sikertelenségével kell szembenéznie (mint a nyugati társadalmakban), hanem egész csoportjának sikertelenségével. Az pedig, hogy miatta vallottak kudarcot, óriási szégyen, amit az egyén a régi értékrend szerint öngyilkossággal tud lemosni magáról, és ezzel a csoportjáról is. Japánt így ,a szégyen társadalmának” is nevezik (szemben a nyugati kultúra „bünorientált" felfogásával), ami azt jelenti, hogy a társadalom nem általános erkölcsi normák alapján ítéli meg az egyén tetteit, hanem annak alapján, hogy a csoportja iránti kötelezettségét megfelelően teljesítette-e, és ha nem, akkor az szégyent hoz az egyén egész csoportjára. Az egyén tehát mindent megtesz, nehogy rajta múljon valaminek a sikertelensége, gyakran jóval többet is, mint amennyit saját érdekeiért megtenne (ebben rejlik a hírhedett japán munkamánia és egészségtelen méreteket öltő túlórázás 
alapja). A kollektív dicséret és büntetés alkalmazása nagyon hatásos motiváció már kisgyermekkortól kezdve. Ehhez kapcsolódik a japán mindennapokban is tapasztalható kiválóság és tökéletesség igénye is (tisztaság, csomagolás, viselkedés). A hierarchikus társadalomban mindenki a pozíciójának megfelelö feladatot látja el, annak megfelelö kötelezettségei vannak a viselkedés, etikett, sőt még a nyelvhasználat terén is.

Japán sajátos civilizációja erős egységérzetet épített a népességben, a „homogén társadalom” érzetét (egyes vélemények szerint illúzióját), amely szerint Japán etnikailag, nyelvileg, kulturálisan, világnézetileg egységes ország, ahol a társadalmi, vagyoni, iskolázottsági és életmódbeli egyenlőtlenségek kisebbek a hasonló fejlettségü országokhoz képest, és ahol a társadalom fegyelmezettsége nagyon magas, éppen a közös értékeknek és homogenitásnak köszönhetően. Különösen jelentős, hogy Japán a világ kiemelkedően biztonságos országai közé tartozik nagyon alacsony bünözési aránnyal. Ennek okai között nemcsak a homogén, fegyelmezett kollektivista társadalom értékszemlélete (a bűnelkövető társadalmi kirekesztettsége), a szigorú büntetések és a nagyon szigorú fegyvertilalom állhat (azaz a bűnmegelőzés és a megtorlástól való félelem), hanem a munkanélküliség, a szegénység és a kábítószer-használat (azaz a bünözést elősegítő társadalmi tényezők) alacsony aránya is.

\section{Történelem}

A sajátos japán fejlődés a külső átvételek ellenére a kontinensétől mindig eltérő irányt vett, amit elősegített a japán történelem ciklikusan ismétlődő jelensége: az elzárkózások időszakai. Japán történelme az állandóság és változás sajátos elegyét mutatja a nyitáshoz kapcsolódó átvételek ciklikus váltakozásaival és az elzárkózás korszakainak belső fejlődésével. A történelem korszakolása nem teljesen felel meg az európai történetírásban használt korszakoknak.

\section{Öskor}

$\oplus$ Dzsómon-kor (i. e. 13000-300):

A Japán-szigeteket gyakorlatilag egy törésvonal mentén felgyürődött hegylánc alkotja, amely a jégkorszakokban összefüggött az ázsiai kontinenssel. Az emberi jelenlétre utaló legkorábbi leletek kora kb. 130 ezer év. 32 ezer évvel ezelőttől található őskőkori, paleolitikus kultúrák létezését bizonyító leletanyag. 13 ezer éve az utolsó jégkorszakot követő felmelegedés miatt a tengerszint emelkedése kialakította a mai Japán-szigetvilágot. Ekkor, a holocénben egy nagyobb, eszközhasználatban sokkal fejlettebb, gyüjtögető társadalom tünt fel. A Dzsómon-kultúra az agyagedények jellegzetes zsinórmintás díszítéséről kapta nevét. A Dzsómon-korszak az (i. e. 14. évezredtől az i. e. 3. század elejéig) emberei készítették a világ első agyagedényeit és agyagfigurákat (15. kép). A 
feltárt települések a félig letelepedett mezolitikus - vagy egyes vélemények szerint neolitikus - életforma jellegzetességeit viselik. Az ugyancsak erre a korszakra datálható kőszerszámok a világ legelső csiszolt kőeszközei. Mindezek alapján létezik egy olyan vélemény, amely szerint a japán civilizáció - a letelepedett életforma, a fejlett szerszámok és a legelső agyagedények készítésével és használatával - mintegy kétezer évvel megelőzte a közel-keleti civilizáció létrejöttét.

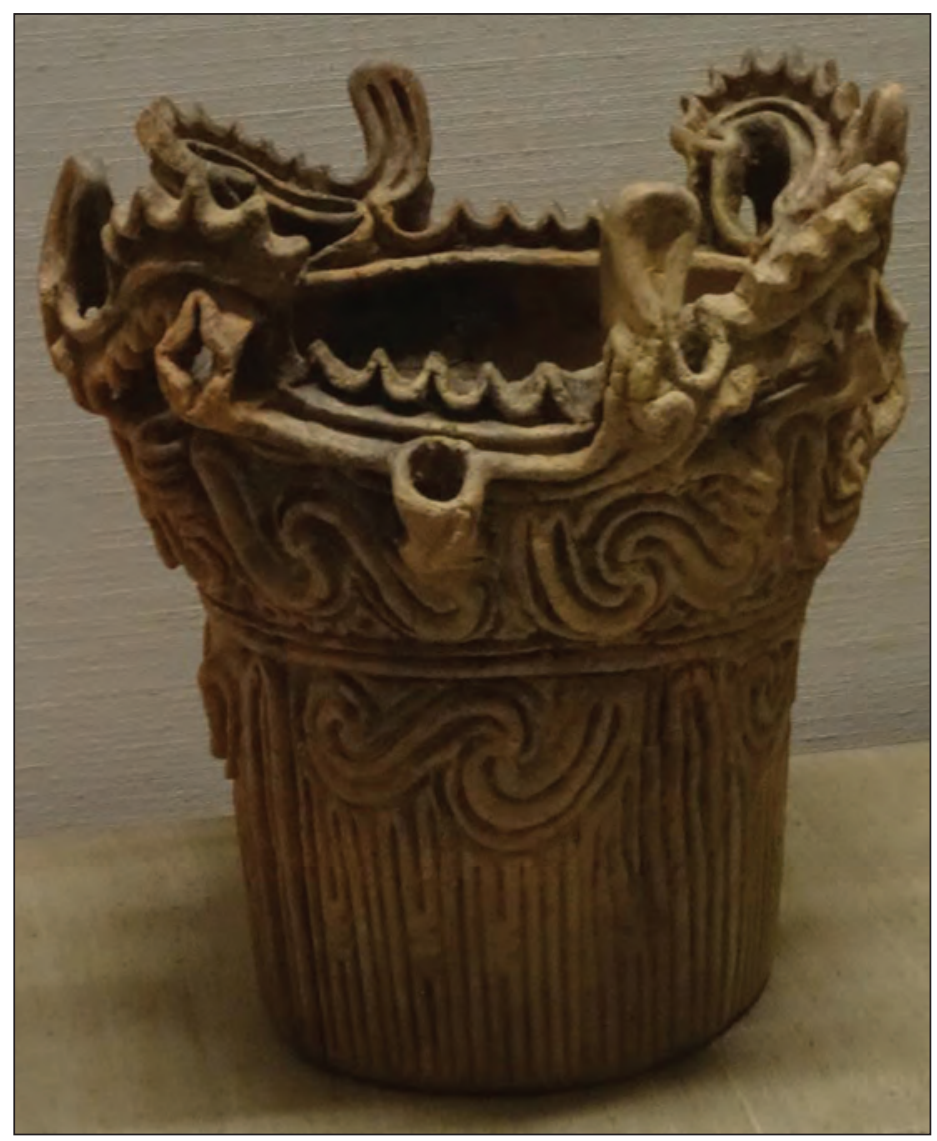

15. kép: Dzsómon-kori kerámia

Forrás: FARKas MáRIA ILDIKó felvétele

Az, hogy ez a népesség - vagy népességek - a mai japánok ősei-e, illetve van-e közük a mai japánoknál régebben a szigeteken lakó ajnukhoz (akik 2008 óta a japán állam által is elismerten „őslakosok”, mára alig 20 ezres népességükkel Hokkaidón), máig vitatott kérdések. A japán nép eredetére vonatkozóan a tudósok véleménye eltérö, és ezek a kérdések mindmáig a japán őstörténet-kutatás alapvető problémái. Egyes vélemények szerint a japán szigetvilág első lakói, közöttük feltehetően a mai ajnuk ősei is Észak-Ázsiából 
és Kelet-Ázsiából az akkor még létező földhidakon keresztül érkeztek erre a területre kb. 35 ezer évvel ezelőtt. Más kutatások arra utalnak, hogy néhány népcsoport hajóval is jött erre a vidékre Délkelet-Ázsiából, a csendes-óceáni nagy vándorlási időszakban. A leginkább elfogadott vélemény szerint a japán nép több irányból érkezett népcsoportok keveredéséből alakult ki.

$\oplus$ Jajoi-kor (i. e. 300 - i. sz. 300):

Ebben a korszakban a kontinensről újabb embertípus érkezett a szigetekre, és a dzsómon-kori népességgel való keveredéssel kezdett kialakulni a mai japán nép. Az Ázsiából átkerülő rizsművelési és öntözési technikáknak, valamint a fémmegmunkálás ismeretének köszönhetően ekkor már letelepedett földművelö társadalomról beszélhetünk. Ez a földmüves társadalom terjeszkedni kezdett, belső szerkezete egyre összetettebb lett, és a regionális szerveződések eredményeként területi egységek alakultak egy-egy nagy hatalmú földbirtokos család (nemzetség, törzs) vezetésével. A helyi közösségek vezetöit hatalmas halomsírokban (kofun) temették el. A háborúk és a kialakuló szövetségek utat nyitottak a nagyobb és szervezettebb egységek kialakulása felé.

Örökség: rizstermesztés, fémmegmunkálás, erős kontinentális hatás, bevándorlás, új embertípus a Japán-szigeteken, a mai japán nép kialakulása.

Ókor

$\oplus$ Jamato-kor (300-538):

A Japán-szigeteken a 3-4. század folyamán jött létre az első államalakulat, egy törzsi-nemzetségi jellegü, a legerősebb nemzetségek szövetségén alapuló szerveződés a leghatalmasabb törzs, a Jamato nemzetség vezetésével. A törzsek (udzsik) mintegy harcos arisztokráciaként (16. kép) saját területeket birtokoltak, amelyeket a dolgozó és adózó köznép művelt. A nemzetségfők a nagykirály (ókimi) udvarában udvari rangokkal rendelkeztek. A kontinentális hatás miatt erős párhuzamok láthatóak a Koreai-félsziget kultúrájával (sírkamrák, viselet, építészet, lovas harcmodor terjedése, fegyverek).

Örökség: fegyveres arisztokrácia, földek örökletes magántulajdona, uralkodó szakrális jellege, nemzetségi rendszer. 


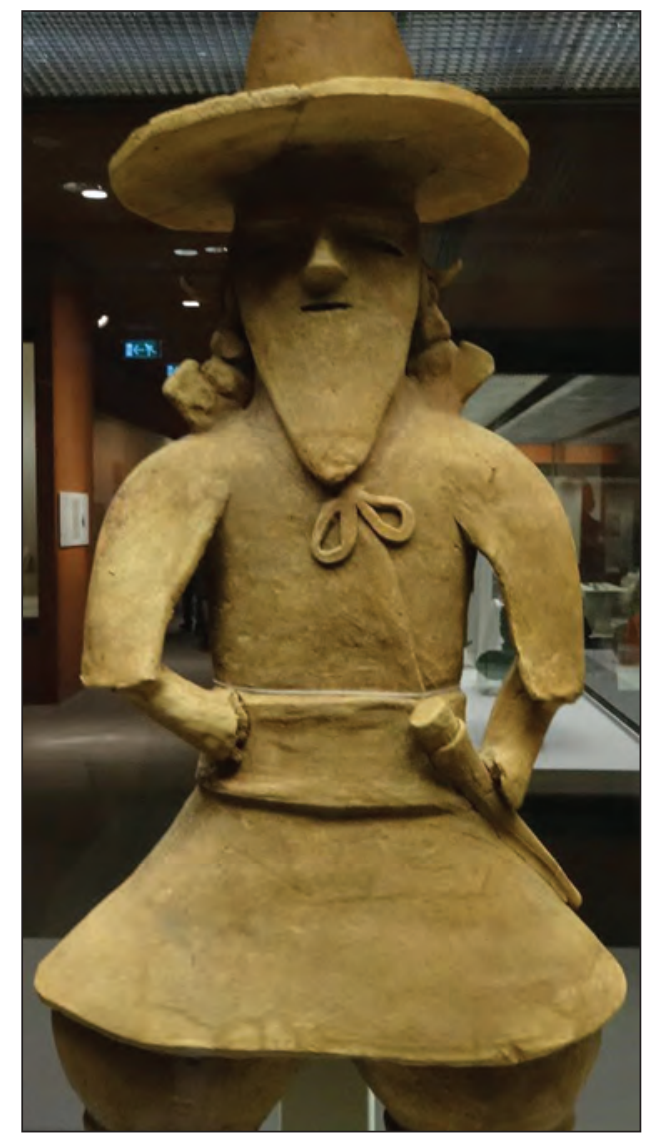

16. kép: A korabeli harcos viseletét jól tükröző terrakotta szobor (haniva)

Forrás: FARKAS MáRIA ILDIKó felvétele

$\oplus$ Aszuka-kor (538-710):

A kialakuló állam kapcsolatba lépett a kontinenssel, és megismerkedett környezetének hatalmi központjával, az akkor már évezredes Kínai Birodalommal, amelynek kultúrája, civilizációja, jól szervezett állama példaként szolgált a Jamato Királyságnak (17. kép).

A 7. század folyamán ezt az aránylag laza államszövetséget, a Jamato Királyságot kínai mintára egy központosított, szigorúan szervezett állammá alakították át. Új állami hivatalokat létesítettek, bevezették a császár mint abszolút uralkodó fogalmát, az állami földek rendszerét a magántulajdon helyett, új adórendszert és udvari rangokat alapítottak. A reform megalkotói és támogatói (a császári ház tagjai és néhány nagyobb hatalmú nemzetségfö) részben a belső hatalmi harcok megszüntetése érdekében, részben a Kína és a Koreai-félsziget államai felöl érkező külső fenyegetés hatására érezték fontosnak egy erős központosított állam létrehozását. A koreai és kínai 
kapcsolatoknak köszönhetően a kontinentális kultúra minden eleme megjelent Japánban: buddhizmus, konfucianizmus, tao, kínai írásrendszer, tudományok (csillagászat, orvoslás, építészet).

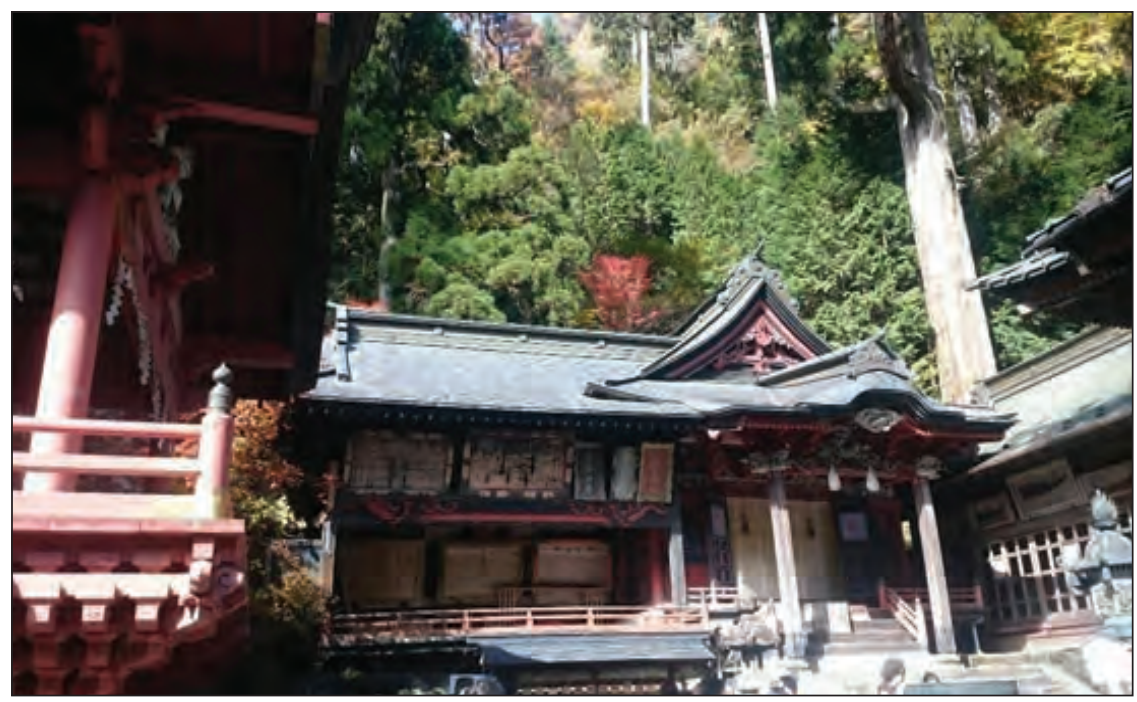

17. kép: Az eredetileg 586-ban alapított Haruna-szentély

Forrás: PóR ANDREA felvétele

Örökség: nagy sírdombok (kofunok), kínai civilizáció elemeinek átvétele, szoros kapcsolat a Koreai-félsziget államaival és Kínával, kontinentális kultúra hatása.

$\oplus$ Nara-kor (710-794):

A 8. századi joggyűjjtemények (Ricurjó) meghatározták az új állam szerkezetét és szabályozták müködését. Ezek értelmében az uralkodó - akit ekkortól neveztek kínai mintára „mennyei császárnak” (tennó) - az ország egész területe és népe felett abszolút hatalommal, istenként uralkodott. Hatalmát a törvényeknek megfelelően az intézmények és a kinevezett hivatalnokok révén gyakorolta, minden föld az ö tulajdona lett állami földként (ezzel elvileg megszüntették a magántulajdont, mint Kínában). A Nara-kor az átvételek és a kínaias kultúra időszaka volt Japánban (18. kép). Ez a rendszer tehát egy külföldi mintaátvétele volt: a Kínai Birodalom, mint a térség legerősebb hatalma, számított példának politikai berendezkedésében, ideológiájában (konfucianizmus, buddhizmus), kultúrájában (a kínai írásrendszer), művészetében, de még divatjában is. A korszakban a buddhizmus a kontinentális mintát követve magasan fejlett teológiai és filozófiai irányzattá fejlődött Japánban is.

Örökség: a narai buddhizmus 


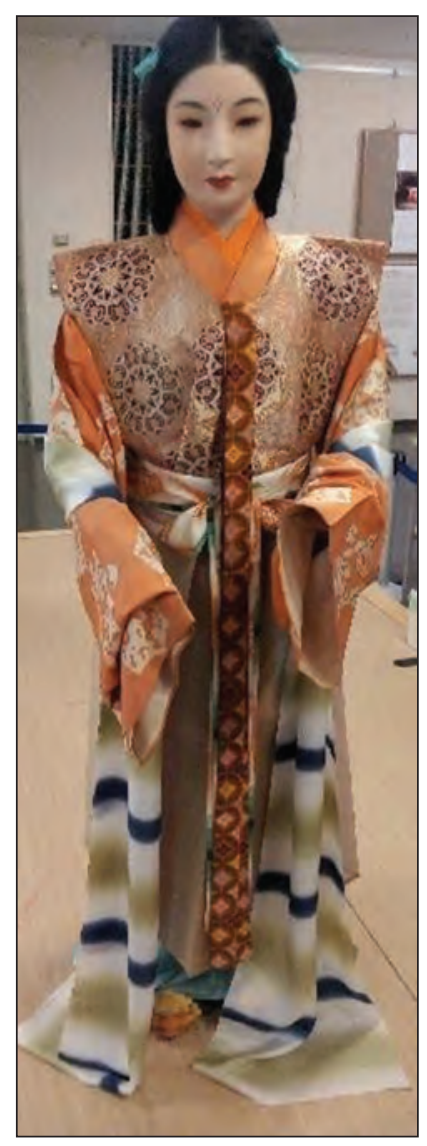

18. kép: Nara-kori női viselet

Forrás: PóR ANDREa felvétele

$\oplus$ Heian-kor (794-1185):

A Ricurjó-állam (a kínai típusú jogrendszerre épülő államszerkezet) nem az addigi japán fejlődésben gyökerezett, s így nem is volt ami a bevezetése idején fennállott külföldi fenyegetés érzetének elmúltával igazában fenntartotta volna, aminek következményeként a központosított monarchia csak eszmény maradt Japánban. Az örökletesség, a magán földtulajdonlás és a nemzetségi elv nem tünt el, s előbb-utóbb ismét ez irányította a társadalom mozgását. Az örökletessé vált hivatali címekkel és udvari rangokkal a földbirtokok is magánbirtokká váltak, így alakult ki az udvari arisztokrácia. Az adóbevételek növelésére az állam adózó magánbirtokok kialakulását engedélyezte. A földbirtokok, így a vagyon és a hatalom, a központi kormányzattól átkerültek a vidéki nagy földbirtokosok kezébe. Az állami földek - és az onnan befolyó adók - csökkenésével a központi hatalom rendfenntartó ereje egyre gyengült, a 10. századra gyakorlatilag meg is szünt a központi hadsereg, így vidéken megkezdték a védelem és rendfenntartás 
megszervezését, azaz fegyverkezni kezdtek. Részben a kistulajdonosok maguk fegyverkeztek, részben a nagyobb földbirtokosok felbéreltek fegyvereseket, így alakult ki a fegyveres harcos réteg, a szamurájság. A 10. század végére a hatalom alapja a magánbirtok lett, s a földet birtoklók különböző rétegeit bonyolult függőségi rendszer kötötte össze, mely leginkább a hübéri hierarchiával jellemezhető, és a feudális viszonyok kialakulását jelentette.

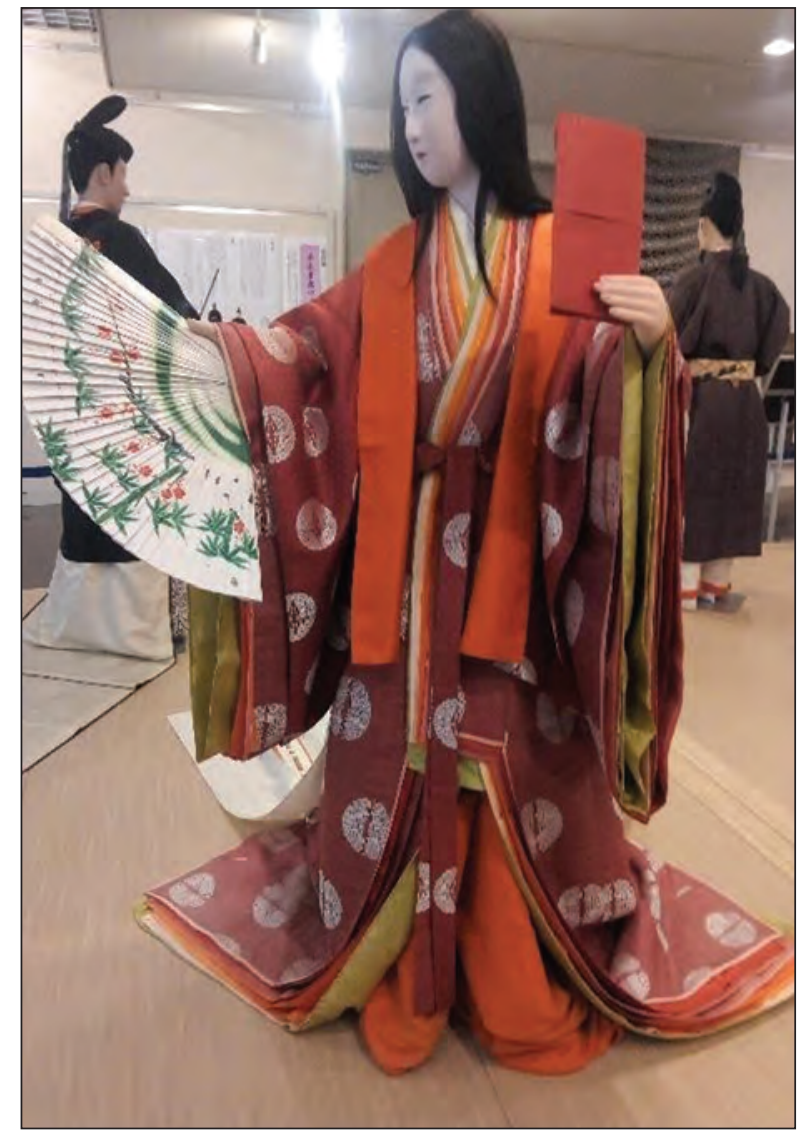

19. kép: Heian-kori női viselet Forrás: PóR ANDREA felvétele

A 9. század folyamán a Kínai Birodalom meggyengülésével csökkent az érdeklődés a kontinens kultúrája iránt, és a kelet-ázsiai változásokra - új államok megjelenése a Koreai-félszigeten, új Kínai Birodalom kialakulása Japán nem reagált, nem vette fel a hivatalos kapcsolatokat, nem érintkezett a kontinenssel egészen a 12. század második feléig. Ez adott lehetőséget a sajátosan japán kultúra megszületésének és fejlődésének. A Heian-korszak folyamán az állami élet minden faktorát uraló kínai modell dominanciája fokozatosan eltünt, kialakult a nemzeti kultúra, megjelentek a japán nyelven 
és japán írással írt, japán ízlésvilágot tükröző sajátos müfajok (19-20. kép). A Heian-kort a japán nemzeti kultúra kialakulása és egyben egyik legmagasabb színvonalú megjelenése korszakának tarthatjuk.

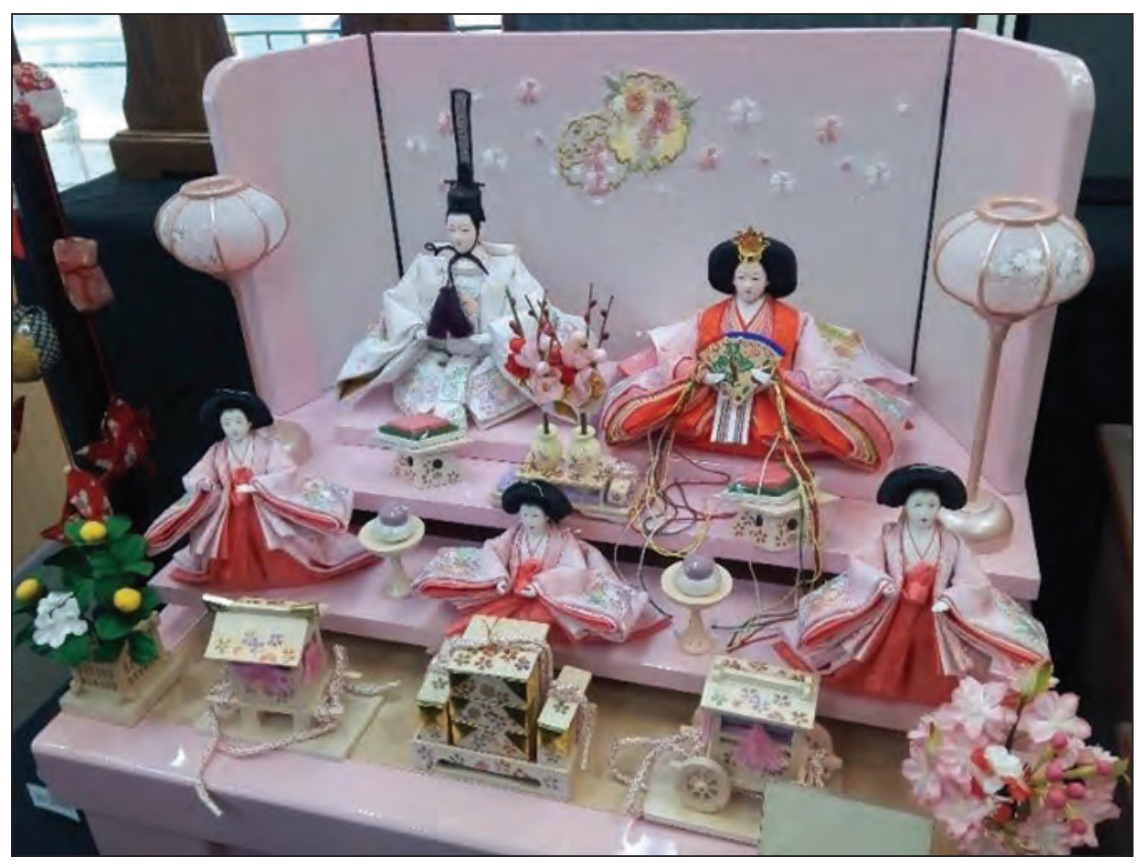

20. kép: A császárt, a császárnét és három udvarhölgyet ábrázoló babák Heian-kori viseletben a Hina macuri (Babaünnep) alkalmából kiállítva

Forrás: PóR ANDREA felvétele

A 9-11. század folyamán, a tartományokban egyre zavarosabbak lettek az állapotok. A központi hatalom egyre kevésbé tudta rendfenntartó szerepét ellátni, a nagybirtokok, templomok, de a tartományi hivatalok is egyre inkább a kialakuló fegyveres réteget vették igénybe önvédelemre és rendfenntartásra. A katonáskodás egyértelmüen a vidéki elit harcos réteg - szamuráj vagy busi - feladatává lett (21. kép). Ez a folyamat vezetett aztán a 12. század végéhez, amikor a szamurájok az egyik magasra emelkedett család (Minamoto) vezetésével megalakították saját „kormányukat”, s a politikai hatalmat kivették az udvari arisztokrácia kezéből.

Örökség: $\quad$ kínai befolyás, majd japanizáció - a nemzeti kultúra születése, nemzeti kultúra nagy korszaka, a feudális viszonyok kialakulása, a szamurájság születése. 


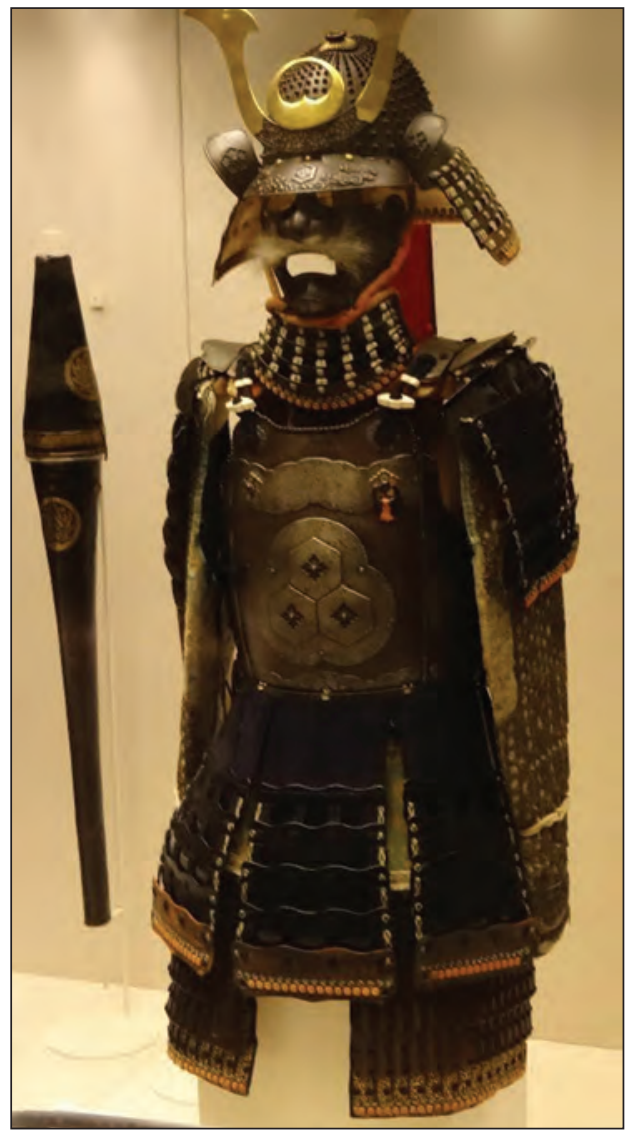

21. kép: Szamuráj viselet

Forrás: FARKAS MÁRIA ILDIKó felvétele

\section{Középkor}

$\oplus$ Kamakura-kor (1185-1333):

A Kamakura-korszakban a sógun, a szamurájok legfőbb hübérura, a császártól nyert (katonailag kikényszerített) felhatalmazással Kamakura központtal az egész országra kiterjedő végrehajtó és ellenőrző rendszert épített ki vazallusaival. Hatalmának alapja a földtulajdon volt, és az erre épülő feudális hierarchia, amelyben személyes függőség kötötte össze a hübérurat és a vazallust. Az intézményekkel - sóguni államtanács, kincstár, a tartományokba kirendelt védnök (tkp. a tartomány sóguni helytartója) és a magánbirtokokra(!) kihelyezett sóguni intéző - az összes tartományt, a magánbirtokok területét, a birtokosokat, a szamurájokat, az udvari nemeseket és a császári udvart is irányítani és ellenőrizni tudta. A császár és az udvari arisztokrácia felsőbbsége névlegessé vált, legfőbb tevékenységük a müvészetek gyakorlása maradt. A busi-hatalom egészen 1868-ig fennállott Japánban. A harcosok rétegének 


\section{Civilizációk Kelettől Nyugatig}

megjelenése nemcsak a politikai struktúra átalakulását vonta maga után, hanem a mủvészi ízlés változását, a filozófia és vallás újabb irányzatainak (zen) érvényesülését (22. kép), a társadalmi szerveződés új formáinak (az ie mint a busi családmodell, valamint a hübéri viszonyrendszer) kialakulását is.

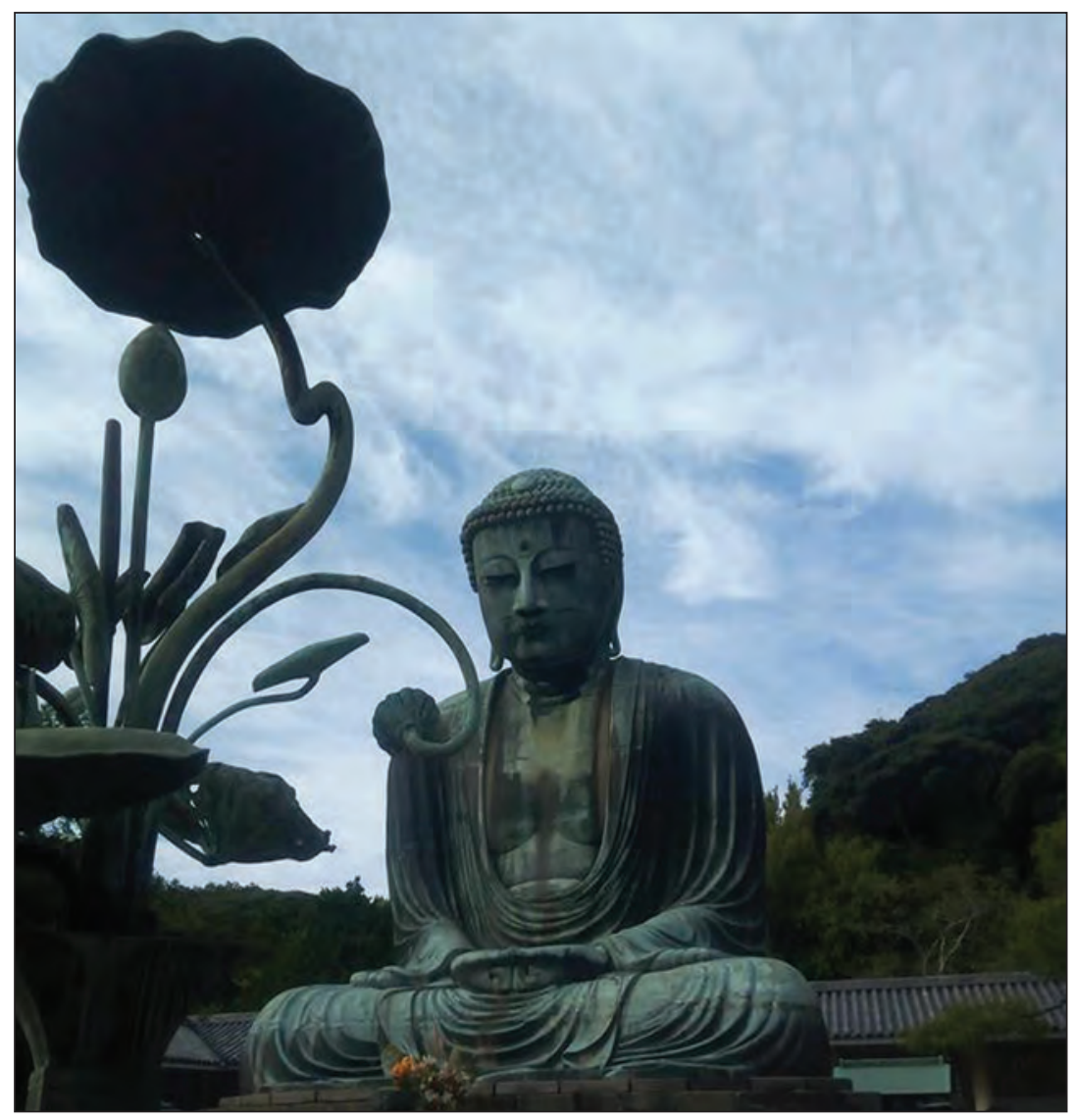

22. kép: A kamakurai Nagy Buddha

Forrás: Pór ANDREA felvétele

A Japánt ért mongol támadásokat $(1274,1281)$ ugyan a japánok visszaverték (az „isteni szél”, a kamikaze segítségével), de a sok évnyi nyereség nélküli háborús készültség anyagi nehézségbe sodorta a szamurájságot, így meggyengült a központi hatalom iránti hüség, és a nagyurak önállósodni kezdtek a sóguntól, ami a kamakurai katonai kormányzat (bakufu) bukásához vezetett 1333-ban.

Örökség: $\quad$ szamuráj, sógun (katonai kormányzat), japán feudalizmus, ie társadalom, Zen buddhizmus. 
$\oplus$ Muromacsi-kor (1333-1573):

A császári udvar kísérlete a valós hatalom visszaszerzésére (1333-1336) kudarcba fulladt, és a szamurájság uralma folytatódott, de a sóguni címet megszerző Asikaga család nem volt képes az egész országot ellenőrzése alá vonni, így a Muromacsiban székelő bakufu hatalma csak a központi tartományokra vonatkozott, de az is meggyengült idővel. A 15. századtól egyre több tartományi zavargás és helyi háborúskodás tört ki, és a központi hatalom lassan elveszítette irányító és ellenőrző erejét. A tartományokban a szinte állandóvá váló háborúskodásban végül egy nagyúr vált a terület egyedüli urává, és a tartományban élő szamurájok az ő vazallusai lettek. A területi nagyurak függetlenedtek a sóguntól, és egész tartományokat uraltak kiskirályként (daimjó). A korszak egyik részét „,hadakozó tartományok korának" is nevezik (1467-1560), arra utalva, hogy az így létrejövő független uradalmak folyamatosan harcban álltak egymással a területekért, illetve gyakran a tartományokon belül is harc folyt a hatalomért. A 16. század első harmadára mintegy 250 önálló tartomány alakult ki, mindegyik saját uralkodóval. A 15-16. század a szamurájok „klasszikus” korszaka. A széttagoltság időszaka azonban nemcsak háborúskodást jelentett az országnak. A kontinensről a kereskedelmi cikkek mellett újabb ismeretek, kulturális áramlatok érkeztek. A mezőgazdasági termelékenység növekedett, a különböző területek egyedi termékei állandósuló piacokon - a kialakuló városokban - cseréltek gazdát, az egyre növekvő számban megjelenő kereskedők révén. Különösen a tartományurak központi vára körül jöttek létre a nagyobb városok, a jelentős önálló rétegként megjelenő városlakó - kézmüves és kereskedő - népességgel. Az önállóságra kényszerített - magára hagyott, de az adókötelezettségeket teljesíteni köteles vidéken megkezdődött a faluközösségek kialakulása, amelyek zárt, hierarchikus és önigazgató egységekként foglalták keretbe a parasztság életét.

Ekkor (1543) érkeztek először európaiak (először portugál kereskedők és jezsuita misszionáriusok, majd spanyolok és hollandok is) Japánba, s bár az általuk hozott puska és dohány hamar meghonosodott, ekkor még hatásuk nem lehetett hosszantartó és jelentős, mert néhány évtizedes jelenlét után az egységesedő országból kiszorították az idegeneket, az általuk terjesztett kereszténységgel együtt.

Örökség: feudalizmus, szamuráj hadviselés, kulturális virágzás, várak, várvárosok, kereskedők, városi kultúra, faluközösségek, európaiak és kereszténység Japánban.

$\oplus$ Országegyesítés (1573-1600):

A széttagoltság idejét szükségszerủen az egységesítés időszaka követte. A 17. század elejére három nagy hadvezérnek kevesebb, mint ötven év alatt sikerült megteremteni az ország egységét, és az utolsó országegyesítő, Tokugava 
Iejaszu és utódai, a Tokugava-sógunok a japán történelem legszilárdabb, két és fél évszázadon keresztül fennálló hatalmi rendszerét építették ki (23. kép).

Örökség: középkori viszonyokból átalakulás kora újkorivá, katonailag, közigazgatásilag, gazdaságilag és politikailag egységes állam megszervezése.

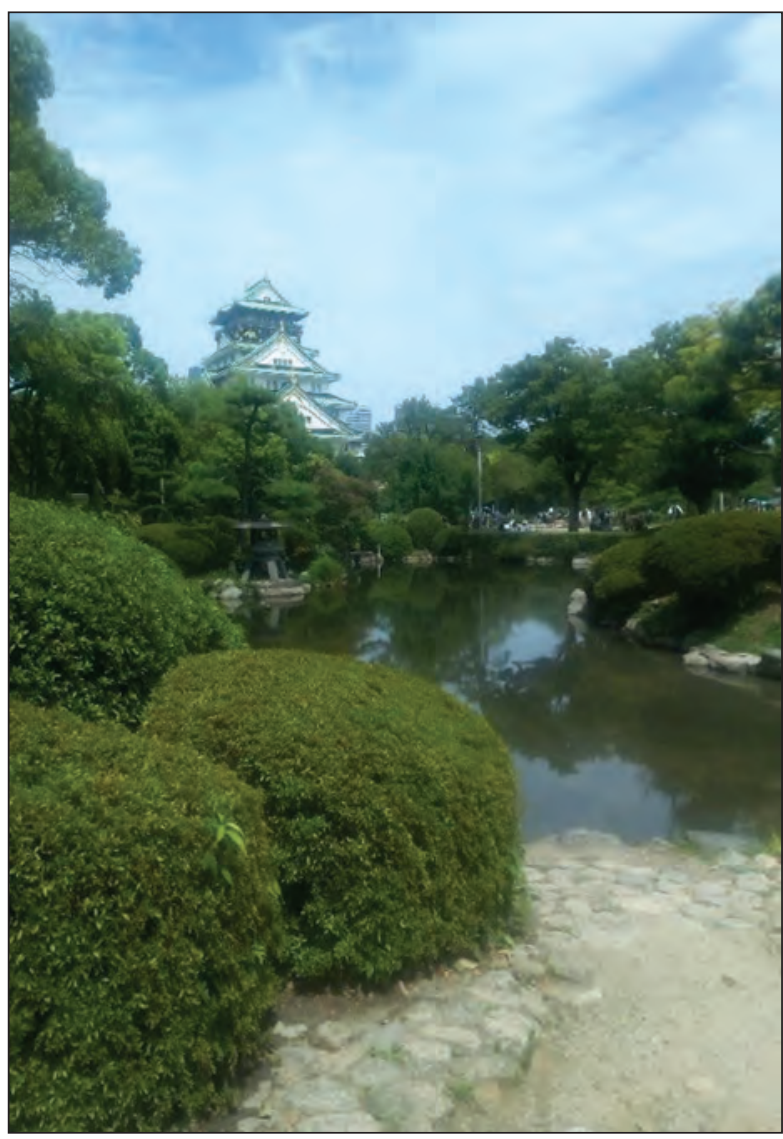

23. kép: Az eredetileg a 16. sz. végén épült oszakai várkastély és kertje Forrás: PóR ANDREA felvétele

\section{Kora újkor}

$\oplus$ Edo-kor (1603-1867):

A Tokugava- (vagy más néven Edo-) kor (1600-1868) a japán történelem legbékésebb korszaka volt, a középkori anarchia után az országegyesítés befejeztével, majd a külvilág (spanyol, portugál hittérítők és kereskedők) fokozatos kizárásával lehetőség nyílt a békés, külső hatásoktól mentes fejlődésre.

A Tokugavák birtokaik központjából (Edo, a mai Tokió) igazgatták az országot, stabil hatalmuk egyrészt hatalmas magánbirtokaikon alapult (katonai erő), illetve a hüség alapján újraosztott földbirtokokkal rendelkező 
vazallusi rendszeren, amelyben a nagyurak személyes függőségben álltak a sóguntól (24. kép). A stabilitást szolgálta továbbá a neokonfuciánus ideológia által is erősen hangsúlyozott hierarchikus, szigorúan szabályozott társadalmi rendszer, a lakóhely szerint is elkülönített rétegekkel, valamint a magas szintü intézményrendszer és adminisztráció. A szamurájok feladata a békeidőben már nem lehetett a harc, de továbbra is kötelességük volt harci jártasságuk gyakorlása, kulturális és müvészi képzésük folytatása, ami a polgárság fejlődésével együtt magas szintű iskolázottságot eredményezett. A hosszú békeidőben a szamurájréteg gyakorlatilag civil állami hivatalnokokká vált, polgárosodott.

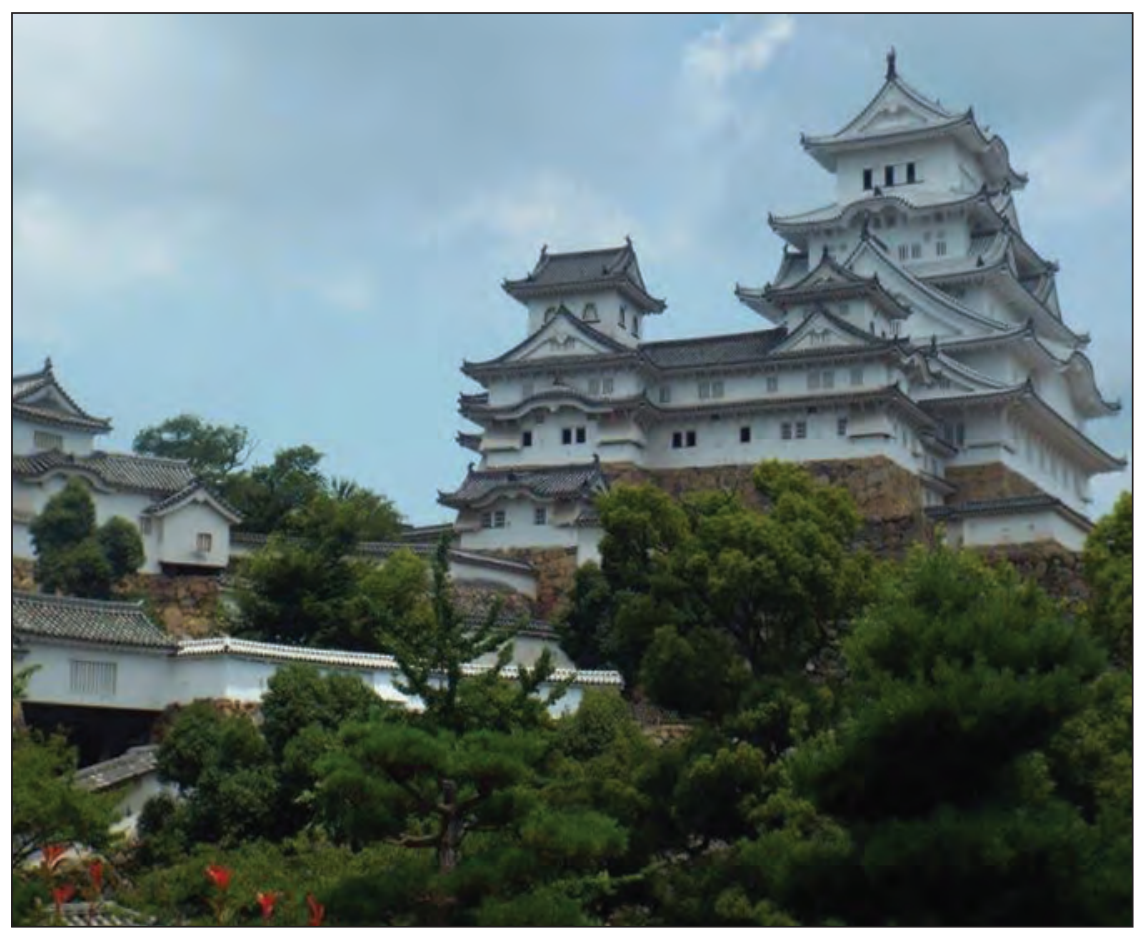

24. kép: Az Edo-kor elején épült kastély Himedzsiben Forrás: PóR ANDREA felvétele

A nagyurak (és háznépük és kíséretük) kötelező edoi tartózkodása erős lendületet adott a városfejlödésnek, amelyhez hozzájárult még a kereskedelem fejlödése és a szamurájság városokba költözése is (25. kép). A harmincmilliós népesség nagy többsége ( $k b .85$ százalék) ugyan egy alapvetően agrártársadalom része volt, de a falvak autonómiája, az árutermelésre berendezkedett tehetős parasztgazdák rétege, a bérleti rendszer egy Ázsiában szinte páratlan állandó életszínvonal-emelkedést biztosított, és nagyszámú munkaerő-felesleget is termelt. A már létező fejlett pénzgazdálkodás (a városi tőkeerős kereskedőházak szinte bankokként tevékenykedtek) szintén túlnőtt már az agrárgazdaság keretein. 
A polgárság megteremtette saját müvészeti müfajait (színház, bábszínház, városi szórakoztató irodalom, a híres japán fametszetek), amelyek szintén a nemzeti kulturális hagyomány részei lettek.

$\mathrm{Az}$ elszigeteltség nemcsak hátrányt (a technikai fejlődésről való lemaradást) jelentett Japánnak, hanem magas szintü zavartalan belső fejlődést eredményezett, amelyben megteremtődtek az átalakulás anyagi, tárgyi feltételei, ugyanakkor kialakult egy erős hagyományokkal rendelkező homogén nemzeti kultúra is. Szigorúan ellenőrzött hierarchikus társadalom, erös központi államszervezet, agrárgazdaság, fejlett pénzgazdálkodás, jelentős urbanizáció, önálló városi kultúra, magas szintü jogfelfogás, törvényi szabályozottság és iskolázottság jellemezte ezt a korszakot. A 19. század elején a japán népesség írni-olvasni tudása az akkori Európa legfejlettebb területeivel volt azonos szinten. Az intellektuális fejlődés, s az új ideológiai és politikai koncepciók megjelenése közepette a japán hagyományok (elsősorban a sintó) előtérbe kerülése elősegítette a japán kulturális identitás meghatározását. Mindez a gazdasági fejlődéssel együtt megteremtette a modern Japán alapjait.

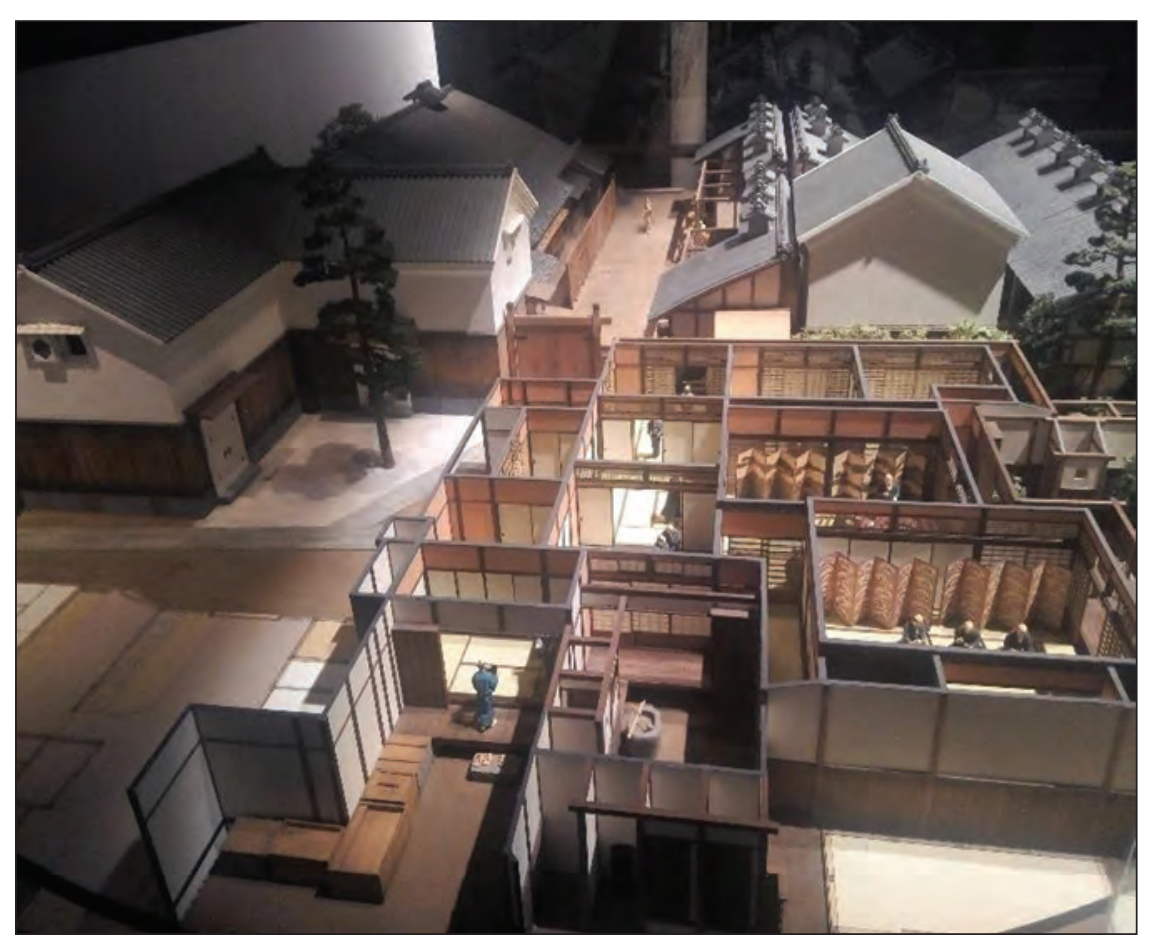

25. kép: Edo-kori házbelső Forrás: PóR ANDREA felvétele

A 19. századra azonban belső problémák és külső fenyegetés veszélyeztette a Tokugava-rendszer stabilitását. A pénzügyi helyzet természeti katasztrófák, 
sorozatos rossz termés és más problémák miatt romlani kezdett, ami általános elégedetlenséget váltott ki. A társadalmi rend is bomlani kezdett, a szamurájság elszegényedése és a kereskedők gazdagodása mellett a hagyományos falvakba is behatolt a pénzgazdálkodás és a vagyoni rétegződés.

A 19. század közepén megmutatkozott az elzárkózás hátránya: Japán lemaradt a technikai fejlődésben. Amikor az 1850-es évektől kezdve megjelentek a japán partoknál az ország megnyitását követelö amerikai, angol, francia és orosz hajók, nyilvánvalóvá vált a Nyugat technikai fölénye, s az is, hogy ezzel Japán nem szállhat szembe. 1853-ban az USA az ország megnyitására kényszerítette Japánt, majd jöttek az európai nagyhatalmak is. A Tokugavákkal szembeni elégedetlenség erősödött a külföldiek megjelenése után, és a sintó hagyomány szerinti császárközpontú állam eszméjével párosulva erős Tokugavaellenes szövetség jött létre, amelynek tagjai felismerték a Nyugat erőfölényét, és belátták a nyitás szükségességét. A mintegy másfél évtizednyi belső hatalmi harcok után a „császárság hatalmának visszaállítása” (azaz az évszázadok óta a császár helyett kormányzó katonai vezetés eltörlése) programjával 1868ban uralomra került szamurájcsoport deklarálta a nyitást és modernizációt meghirdető új korszakot: Meidzsi („,Felvilágosult Kormányzás”).

Örökség: a modern Japán alapjai - a japán kultúra elemeinek homogenizálása, japán identitás kialakulása. 250 év béke, külső hatásoktól mentes, békés belső fejlődés. Proto-indusztrializáció, gazdasági fejlődés.

\section{Modern kor}

$\oplus$ Meidzsi-kor (1868-1912):

Az 1868-ban udvari nemesekből és Tokugava-ellenes szamurájokból álló csoport császári legitimációval a háta mögött meghirdette az ország gazdasági és állami berendezkedésének nyugati mintájú átalakítását. A reformok célja elsődlegesen az volt, hogy Japán elkerülje a gyarmati vagy félgyarmati sorsot, független maradjon, majd hogy megerősödve a Nyugat hatalmaival egyenrangú országgá váljon. Japán „megnyitása” után feszített tempójú, irányított modernizációt kezdett, hogy technikai lemaradását behozza és egy modern államot építsen fel, amely az akkori hatalmakkal minden tekintetben egyenrangú helyet foglal el a világban.

Az új kormányzat az élet minden területén alapvető reformokat léptetett életbe, az első években mindehhez külföldi szakértők és tanácsadók segítségét vették igénybe. Eltörölték a társadalmi korlátozásokat és előjogokat, ezzel megnyílt azút a társadalom átalakulása elött. Megszüntették a feudális tartományi rendszert és modern közigazgatási rendszert vezettek be, a nagybirtokok eltörlésével pedig széles körủ földreformot hajtottak végre. Megszervezték a modern közoktatási rendszert is, az általános tankötelezettség meghirdetésével, 
középiskolák és egyetemek alapításával. Azáltalános katonai sorozás bevezetése volt az alapja az új, modern, reguláris állami hadsereg felállításának. Az első intézkedések között volt az infrastruktúra kiépítése és fejlesztése: postarendszer és távíróhálózat kialakítása, vasút és kikötők építése, az első ipari létesítmények (bányák, textilüzemek) alapítása. 1871-ben egységesítették a nemzeti valutát (jen), és megalapították a japán bankrendszert.

A japán ipari forradalom az 1860-as években a textilipar gépesítésével, termelékenységének növelésével kezdődött. Az 1868-tól 1884-ig tartó időszakban megteremtették az iparosítás alapjait, a következő, 1884-től az első világháború végéig tartó időszak pedig már a gyors gazdasági növekedés időszaka lett. A könnyüipar felfutása után (1887-1896) a nehézipar kialakítása és fejlesztése lett a fô cél (1897-1906). 1890-ben alapították az első vas- és acélműveket, ekkor indult meg a hajógyártás, ehhez kapcsolódóan a gépgyártás is, valamint a bányászat. Az 1872-ben megnyitott első, $30 \mathrm{~km}$-es Tokió és Jokohama közötti vonalat 1905 -re 7800 km vasút megépítése követte.

A fejlesztés főként állami beruházásokkal valósult meg, azaz az iparágak nagy részét állami vállalkozásként indították be (könnyüipar, vasút, bányák, hajógyártás, nehézipar), amelyeket aztán - egy évtized múlva - privatizáltak, $\mathrm{s}$ így az iparosítást már döntően a magánszektor végezte. A kormányzat azonban továbbra is aktív szerepet játszott a gazdaságfejlesztésben, és a kialakult magángazdaságban közvetlenül is támogatták a japán üzleti és ipari cégeket. A gazdaságfejlesztéshez jó alapot biztosított az Edo-korszak, a nagyszámú iskolázott népességgel, az agrárszektor munkaerő-feleslegével, a monetarizált gazdasággal, a tőkeerős kereskedőréteggel és az irányító-szervező munkát ellátó művelt szamurájréteggel.

A Meidzsi-kor elején intenzív nyugatosítás zajlott, Japán igyekezett mindent átvenni a Nyugattól, beleértve az eszméket, a kulturális áramlatokat, művészeti stílusokat. A Nyugat fejlett ismeretanyaga lenyügözte a japánokat, és mindent meg akartak tanulni: küldöttségek indultak Európába, Amerikába, hogy tanulmányozzák a fejlett országok viszonyait, törvényeit, gazdaságát, politikai életét. Külföldi szakértőket hívtak Japánba az átalakítás levezénylésére, és japán diákok rajzottak ki Európa egyetemeire. Az így felhalmozott tudásanyagot pedig rögtön a gyakorlatba ültették. Ugyanakkor az 1880-as évektől egyre inkább előtérbe került a japán identitás problémája, a hagyományos értékek fontossága. A korszak fontos dokumentumai és irányadó deklarációi a konfuciánus etikára építve a hagyományos japán erényeket nevezték meg a legfontosabb alapelveknek: alattvalói hüség, fiúi tisztelet, harmóniára való törekvés, szerény és mértékletes magaviselet, szorgalmas tanulás és munkavégzés, erkölcsös élet, törvények tisztelete, haza iránti önfeláldozó szeretet. Mindehhez kapcsolódott a japán nemzeti mitológia és császárkultusz hivatalos ideológiává emelése, amelyek segítségével Japán sajátos identitását megfogalmazta, és mindezzel 
nemzeti jellegét, szellemiségét, kulturális hagyományait és örökségét meg tudta tartani.

Az 1880-as években felgyorsult a politikai rendszerátalakítása. Anagyrészt porosz mintára készített alkotmány (1889) kimondta, hogy a császár a legfőbb hatalom, ugyanakkor megteremtette a parlamentáris rendszert: a kétkamarás országgyülést, a kabinetet, a miniszterek és a miniszterelnök feladatkörét. Az 1880-as években megalakultak a pártok, és 1890-ben megtartották Japánban az első választást. Korlátozott szavazati jog alapján (az összlakosság 1,6 százaléka szavazhatott), ám mégis, Japánban (sőt, gyakorlatilag egész Ázsiában először) első ízben a népképviselet elve alapján ülhetett össze országgyülés. A pártok többször is átalakultak, nevet változtattak, de bizonyos érdekeket képviseltek, így szavazóikkal befolyásolták a politika alakulását. Igaz, szinte már a kezdetektől szorosan kapcsolódtak egyes gazdasági érdekcsoportokhoz, s ez, a politika és az üzleti élet összefonódása (és a korrupció) jellemző vonása lett a japán közéletnek. Minden hibája ellenére is azonban a japán parlamentáris rendszer alig egy évtized leforgása alatt müködőképes lett, olyan utat téve meg ezzel, ami más országokban évszázadokig tartott.

A századfordulóra lezárult a modern államszerkezet és gazdaság kialakítása, és innen kezdődött és tartott az első világháború végéig a modern kori Japán történelem aranykora: folyamatos gazdasági fejlődéssel, gyarapodással és győzelmekkel.

Nehézségeket okozott viszont az ország nyersanyagszegénysége. Az évszázadokig önellátó Japán a modern ipar megteremtéséhez és fejlesztéséhez erősen a külkereskedelemre szorult, mindezekért a Meidzsi-korszak elején még csak mezőgazdasági termékeket (tea, rizs, dohány, selyem) tudott exportálni korlátozott mennyiségben, így az import értéke mindig meghaladta az exportét. Csak 1890 után kezdődött a késztermékek kivitele, de a nyersanyaghiány továbbra is súlyos probléma maradt, amelynek megoldását egyre inkább a terjeszkedésben, külső hódításban látták. A gazdasági kérdés, a külkereskedelmi mérleg egyensúlya nemzetbiztonsági kérdés lett, amelyet részben békés kereskedelemmel, részben területszerzésekkel, azaz katonai eszközökkel próbáltak megoldani.Alegközelebbi megoldásnak Kína látszott, hatalmas területével, nyersanyagforrásaival, ásványkincseivel, felvevőpiacával. Ez vezetett az 1894-1895-ös japán-kínai háborúhoz, amelyben Japán látszólag simán, tíz hónap alatt győzelmet aratott, és amellett, hogy birtokait (Tajvan, Okinava) és érdekszféráját (Korea) Kínával elismertette, még óriási hadisarcot és kínai területeket is kapott. Japán legyőzte az egykori civilizációs mintát, és a helyére lépve Ázsia nagyhatalmává lett. Japánt a nemzetközi megítélésében már egyértelmüen a hódítók és nem a meghódítandók körébe tartozónak tekintették. A szigetország távoli céljaként Kína helyére kívánt lépni, egy Japán-központú kelet-ázsiai világrend kiépítésére törekedett, amelyet Nagy Kelet-Ázsiai Új Világrendnek nevezett el. 
A kontinensen való terjeszkedése azonban az orosz expanzióba ütközött, és ez az ellentét vezetett az 1904-1905-ös orosz-japán háborúhoz, amelyben Japán ismét győzelmet aratott. Ezzel Japán a nyugati nagyhatalmakkal egyenrangú helyzetbe került, és azokkal sorra egyenrangú szerződéseket köthetett. Japán érdeklődésének fö területe Korea és Mandzsúria lett, Koreában 1905-ben protektorátust létesítettek, majd 1910-ben minden nemzetközi bonyodalom nélkül annektálták az országot. Japán ekkortól úgy tekintette magát, mint a világ nyolcadik hatalma, s ez a korabeli nemzetközi sajtóban is megjelent. Ekkortól kezdtek ,sárga veszedelemről” cikkezni az európai lapok, hangsúlyozva, hogy Japán példáját követheti a többi ázsiai ország is, amelyek modernizálódva, „öntudatra ébredve”, megerősödve komoly veszélyt jelenthetnek a „fehérek” uralmára. Ázsiában ambivalens érzésekkel fogadták Japán győzelmét: egyrészt a japán győzelem valóban bátorító volt az ázsiaiak számára, hogy a nyugatiakat le lehet győzni, ugyanakkor Japán hódításait teljes joggal ugyanolyan imperialista agressziónak ítélték, mint a nyugati nagyhatalmakét. Japán Ázsiában már nyugati hatalomként viselkedett, és a modern Japánnak (1890-1945) ez a magatartása, annak emléke máig súlyosan terheli Japán és kelet-ázsiai szomszédjainak viszonyát. Japán a 20. század elejére egyértelmủen nyugati típusú modern állam lett, a nagyhatalmak közé tartozott, Ázsia számára pedig nyugativá (hódítóvá) vált.

A századfordulóra Japán társadalma is átalakult. A társadalom - bár hierarchikus maradt - megnyílt, és az általános oktatás elvileg mindenkinek biztosította az esélyegyenlőséget. A társadalom - különösen a középosztály életében központi szerepet kapott a tanulás (mint ahogy az ma is), a gyermekek taníttatása, hiszen a karrier, az egész későbbi élet a vizsgákon múlott (mint ahogy múlik ma is). Bár a szamurájok státusa és gyakorlatilag rétege is megszünt, szellemiségük és legendájuk (tekintélyelvűség, hűség, önfeláldozás, hősiesség) a japán nemzettudat szerves részévé vált. A nyugati eszmék ellenére - melyek leginkább csak az értelmiség és a felsőbb rétegek életére voltak hatással - a japán társadalom alapvetően kollektivista maradt. A japán család évszázadok óta fennálló rendszere tovább élt nemcsak vidéken, és nemcsak a parasztok körében - a városi népesség, a volt szamurájok, a gazdasági elit mind a hagyományos mintát követte, sőt gyakran az újonnan alakított vállalatokat is a családmodell mintájára építették ki. Maga a japán társadalom is erre a mintára épült, a legmagasabb szintü közösségként az állam jelent meg.

Örökség: $\quad$ gyors modernizáció, nyugatosítás, modern nemzetállam, iparosítás, urbanizáció. Feudális rendszerből modern ipari állam, elzárkózásból felzárkózás a nyugati nagyhatalmakkal egyenlő helyre. Nyugatosítás ÉS erős japán nemzeti identitás a japán hagyományok alapján. Japán mint nyugati hatalom Ázsiában, nacionalizmus. 
$\oplus$ Taisó-kor (1912-1926):

Meidzsi császár halála 1912-ben egy korszak végét jelölte. A nagy átalakulás lezajlott, az ezt végigvivő nagy generációk kihaltak, már olyan nemzedékek éltek Japánban, akik az új világban születtek. A hatalmat különbözö elitcsoportok (udvari tisztviselök, közhivatalnokok, hadsereg, flotta, parlamenti pártok, gazdasági elit) birtokolták kényes egyensúlyban.

A parlamentáris rendszer Japánban ekkor még alig néhány évtizede működött, és éppen ezért hiányzott belőle az évszázados rendszerekben kifejlődött „meggyökeresedés”: még nem alakult ki a pártok széles társadalmi beágyazottsága, stabil szavazóbázisa és háttere. Bár látszólag a parlamentáris rendszer jól müködött, a pártoknak értelmiségi tábora, ideológiája és következetes politikai programja is volt, de igazából nem volt mögöttük széles társadalmi bázis és támogatás, így a politikai élet gyakorlatilag szük elitcsoportok vetélkedésének színtere lett. A különböző kormányválságok, változások, átalakulások (egy kormány sem bírta fél évnél tovább) követhetetlenek voltak az átlagember számára, és a politikát, amely egyre szorosabban összefonódott a gazdasági érdekekkel, haszontalanságnak ítélte meg, aminek később súlyos következményei lettek. A parlament hatalma még nem volt szilárd, a császár hatalma abszolút volt, amelyet azonban nem ő, hanem a nevében fellépő csoportok bármikor kihasználhattak (ez meg is történt).

Az új nemzedékek számára természetes volt a nyugati forma a politikai életben, az állam felépítésében, a gazdaságban, a külpolitikában, sőt a társadalomban is. Az addig elért sikereket a nyugatosodásnak tulajdonították, így természetes volt a Nyugat-imádat. Az 1912-től 1926-ig tartó Taisokort a „liberális húszas évek” megjelölésével szokták emlegetni, a nyugati típusú parlamentáris, polgári kormányzás korszaka volt. Igaz, a gazdasági fejlődés a világháborús virágzáshoz képest visszaesett, lelassult, bankcsődök és „rizslázadások” is előfordultak, viszont akkor még ezek nem látszottak a stabilitást fenyegető tényezőknek. A korszak a nyugatias életforma, stílus, divat és életérzés megjelenése volt Japánban, és a régi normák kezdtek fellazulni. Mégis, mondhatjuk, mindez inkább felszínes volt, mert az alapvető értékek érintetlenek maradtak: családmodell, hierarchikus társadalom, sintó. Mindezek a későbbiekben, a világválság hatására a „Nyugattól” való elfordulást követően újra hangsúlyosan jelentek meg a társadalom életében.

Az első világháború Japán számára lehetőséget kínált a további keletázsiai területi terjeszkedésre is. Saját céljaira használta fel az Európában kitört háborút, az angol szövetség ürügyén saját hódításokat folytatott. Japán a világháborút lezáró békekonferencián a győztesek oldalán, az öt nagyhatalom egyikeként vehetett részt. Kínai hódításait megtarthatta, és vitathatatlanul a Távol-Kelet vezető hatalma lett. 
Mégis, mindez nem egyértelmủen jelentett sikert az országnak. A háborús konjunktúra vége (1918) nagy csapást jelentett a japán ipar számára. A háború után az európaiak visszatértek az ázsiai piacokra, és ez nehezítette a nagyra nőtt háborús ipar alkalmazkodását a megváltozott körülményekhez. Japán modern kori gazdasági fejlődésében (1880 és 1945 között) az 1920-as években volt leglassúbb a fejlődés, sőt, komoly válsághelyzet alakult ki több alkalommal is, már a gazdasági világválságot megelőzően is. A fejlődő japán ipar egyre nagyobb problémája volt, hogy nagymértékben függött a külföldi piacoktól és nyersanyagoktól. Mindez hovatovább nemzetbiztonsági kérdés lett, azaz a katonai terjeszkedés, területszerzés egyértelmüen nyersanyag- és piacszerző célokat szolgált. A húszas években azonban a békés tárgyalásokra és egyezményekre épülő nemzetközi helyzet nem kedvezett az agresszív külpolitikának, és Japánon belül is a békés megoldások hívei kerekedtek felül (egyelőre), így a nyitott világkereskedelemre (globalizáció) alapozták a japán gazdaságot, amely rendszer aztán 1929-ben összeomlott.

Japánt minden sikere ellenére sem kezelték egyenrangú félként a győztes nagyhatalmak, ami a japán közvéleményben egyre növekvő nyugatellenességet eredményezett. Korábbi szövetségesei, elsősorban az angolok, egyre növekvő gyanakvással és félelemmel követték Japán távol-keleti térhódítását, és már nem szövetségesként, hanem fö riválisként tekintettek rá. Különösen az Egyesült Államok magatartása vált fenyegetővé Japán számára, egyértelművé tette, hogy a Csendes-óceán térségében a japán terjeszkedés ellentétes az amerikai érdekekkel, és több, japánokat korlátozó intézkedést vezettek be (japán flotta korlátozása, japán érdekszféra visszaszorítása Kínában, japán bevándorlás tiltása az USA-ban). A japán közvélemény nemcsak a belső válság nem megfelelö kezelése miatt volt elégedetlen a kormányzattal, hanem amiatt is, hogy úgy érezték, a kormányzat nem képviseli kellőképpen a japán érdekeket a nagyhatalmakkal szemben. A kormánnyal szembeni elégedetlenséghez a Nyugatból való kiábrándulás és a japán értékekhez való visszafordulás társult, ami a nacionalista irányzatok erősödéséhez vezetett.

Örökség: Taisó demokrácia: új demokratikus, liberális trendek politikában és a társadalom életében ÉS: radikális nacionalizmus, expanzionalizmus és antiliberalizmus gyökerei.

$\oplus$ Sóva-kor (1926-1989)

1945 elött:

1926-tól új korszak kezdődött: Sóva császár uralkodása (egészen 1989ig). 1930-ban a válság nagy erővel elérte Japánt, a külföldi piacok elvesztek, a bankok tönkrementek, a termelés visszaesett, a japán exporttól külföldön magas vámokkal védték a belső piacokat. Mindez a gazdasági összeomláson túl tudati 
válságot is előidézett az országban: a nyugatból való kiábrándulást. Előtérbe kerültek a japán értékek, a nemzeti jellegzetességek, a saját fejlődés elemei, és egyre inkább elvetették a nyugati eszméket és gyakorlatot. Szélsőséges politikai ideológiák jelentek meg és hódítottak, amelyek sajátos módon ötvözték a japán hagyományokat a modern radikális, szélsőséges eszmékkel (mint pl. a „Sóva restauráció" elmélete, amelyben államszocializmust akartak megvalósítani katonai diktatúrával, és amely szerint a gazdagoknak fel kell áldozni vagyonukat a köz javára, a politikusoknak meg vissza kell adni a hatalmat a császárnak). A húszas évek kényes egyensúlya felbomlott, és a hatalmi ürt az egyre erösödö hadsereg kezdte betölteni. Az 1930-as évek folyamán a katonai vezetés megszerezte az ellenőrzést a polgári kormányzat felett, és 1940-re katonai diktatúrát épített ki.

1931-ben japán csapatok támadást indítottak Kínában, amivel megkezdődött egy majdnem 15 éves küzdelem Kína és Japán között. 1932-ben az elfoglalt mandzsúriai területeken létrehozták Mandzsukuo japán bábállamot, amelyet a Népszövetség nem ismert el, sőt kizárta Japánt a tagjai közül. 1936ban Japán aláírta az Antikomintern paktumot Németországgal, amivel egy újabb szövetségi rendszerbe tagolódott, bár attól függetlenül saját háborúját vívta. 1937-ben a Japán Birodalom elfoglalta Kína egyes részeit, elindítva a második kínai-japán háborút. A belpolitikában egyre diktatórikusabb elemek kaptak szerepet: a politikai ellenzék üldözése, nacionalista és militarista propaganda, a pártok betiltása (1940). 1939-ben kitört az európai háború, amelybe Japán nem avatkozott be, viszont a német sikerek hatására 1940-ben általános meggyőződéssé vált Japánban, hogy Németország győzni fog, és ez 1940 szeptemberében a Háromhatalmi Egyezmény megkötéséhez vezetett.

A japán stratégiai cél a haditengerészeti fölény megszerzése volt a csendes-óceáni térségben, majd a stratégiai fontosságú nyersanyaglelőhelyek megszerzésével előnyös béke megkötése az Egyesült Államokkal és NagyBritanniával. 1941. december 7-én Japán megtámadta a Pearl Harbor-i amerikai haditengerészeti bázist és hadüzenetet küldött az Egyesült Államoknak. A Csendes-óceán térségében folyamatosan terjeszkedett, és 1942-re elérte birodalmának legnagyobb kiterjedését: ellenőrzése alatt tartotta Kína nagy részét, Koreát, szinte a teljes Délkelet-Ázsiát (Indokína, Malajzia, Burma, Thaiföld, Fülöp-szigetek, Indonézia) és a Csendes-óceáni szigetvilágot, egészen Ausztrália partjaiig. Az amerikaiak ellentámadásba kezdtek, és 1943-1944 folyamán sorra visszafoglalták a japánok területeit. 1945 februárjában az amerikai légierő megkezdte a japán hadiüzemek és városok módszeres bombázását. Miután az USA az atombombát is bevetette Japán ellen és a Szovjetunió is belépett az ország elleni háborúba, Japán augusztus 15 -én feltétel nélkül megadta magát a szövetségeseknek. A háború Japánban több millió emberéletet követelt és elpusztította az ország gazdaságát és infrastruktúráját. 
Örökség: $\quad$ Militarizmus, háborús terjeszkedés, ultranacionalizmus, háborús kegyetlenkedések, kamikaze.

Amerikai megszállás (1945-1951):

Az ország romokban hevert, a háborús pusztítás nagyobb volt, mint Németországban, az ipari körzeteket teljesen lebombázták, az ipari termelés leállt. A háború áldozatainak száma több mint 2 millió volt. Az ország a második világháborúban nemzeti vagyonának 26 százalékát veszítette el, valamennyi nagyvárosát lerombolták, felszerelés és munkaerő hiányában a mezőgazdaság sem müködött. Az országban éhínség fenyegetett és az egészségügyi helyzet is katasztrofális volt. A háborús vereséget bejelentő császári beszéd (1945. augusztus 14.) azonban tartalmazott egy lényeges kapaszkodót, és a romok között már megfogalmazódott a program a japánok számára: „elviselni az elviselhetetlent". Túlélni, újjáépíteni, elviselni a megaláztatást, az amerikai megszállást, és változtatni mindazon, ami rossz irányba vitte az országot.

A világháború után Japánt lényegében az USA foglalta el. Hat és fél éven át tartó katonai megszállás és gyámság következett, amely simán, incidensek nélkül zajlott le. A megszállás fő célja Japán átalakítása volt, azaz egy olyan ország létrehozása, amely nem jelent veszélyt sem az USAra, sem a világ békéjére, és a nyugati demokrácia elvei és gyakorlata szerint müködik. Az amerikaiak kezdetben ellenállásra számítottak a reformálási törekvésekkel szemben, de a japánok fegyelmezetten hajtották végre a megszállók rendelkezéseit. A japán nép kollektív célja - amellyel mindig is mozgósítani lehetett a társadalmat - ekkorra az újjáépítés és a talpra állás lett, és ehhez akkor az amerikaiak segítséget nyújtottak. Ez motiválta a japán együttmüködési készséget.

A megszállás célja Japán demilitarizálása és demokratizálása volt, és ugyanolyan horderejű reformfolyamatot és átalakítást jelentett, mint a Meidzsi-kori modernizáció. Földreform, emberi jogok az alkotmányban, általános választójog, a császár szimbolikus szerepre korlátozása, közigazgatási decentralizációs reform, oktatás átalakítása, demilitarizálás, politikai tisztogatás, titkos szabad választások, parlamenti reform és a háborúról való lemondás. A mai demokratikus Japán megteremtése zajlott le akkor, amerikai vezénylettel. Az 1947-ben életbe léptetett új - az amerikai megszállók által írt - Alkotmány a mai napig Japán hatályos alaptörvénye. Nevezetes 9. cikkelye a világon egyedüliként tartalmazza a háborúról való lemondást, ami akkor tükrözte az amerikaiak céljait Japánnal („békés állammá alakuljon”), és egybeesett a japánok akkori helyzetértékelésével (,soha többé háborút”), viszont már néhány év múlva problémákat okozott („lehet-e akkor Japánnak védelmi hadereje?”), és ez a probléma a mai napig fennáll, mivel Japán eddig még nem módosította Alkotmányát. 
1948 folyamán azonban a világpolitikai helyzet változása felértékelte Japán szerepét az USA számára, és érdekeltté tette abban, hogy Japán gazdaságilag megerősödjön. Az USA részben elengedte a japán háborús jóvátételt, részben pénzügyi stabilizációs politikával és konkrét segélyekkel - az amerikai piac megnyitása a japán áruk előtt, technológia átadása, hitelek nyújtása, géppark biztosítása - segítette a rekonstrukciót. 1951. szeptember 8-án 48 állam békeszerződést kötött Japánnal San Franciscóban, amely elismerte Japán teljes szuverenitását, ugyanakkor Japán lemondott területi igényeiről Ázsiában és elismerte Korea függetlenségét. A békeszerződés 1952-ben lépett életbe, és az amerikai megszállás végét jelentette. Ugyanakkor Japán hadsereg híján védtelen volt, és rászorult az USA védelmére. Így a megszállás befejeztével megkötötték a kétoldalú biztonsági szerződést Japán és az USA között, amelynek értelmében amerikai támaszpontok maradtak Japán területén, ott állomásozó csapatokkal. Japán ma is az USA katonai rendszerének alappillére Kelet-Ázsiában.

Örökség: a mai Japán formálódása, demokratizálás, demilitarizálás, amerikai szövetség.

Az 1950-es évek - a ,japán csoda” kezdete:

Japán visszanyerte teljes szuverenitását, és nekilátott, hogy átalakított gazdaságát és teljes berendezkedését nemzeti sajátosságaihoz igazítsa. Az 19501953 között zajló koreai háború fellendítette a japán gazdaságot, a japán áruk keresettek lettek, újra megindulhatott a háború elött már világszínvonalon termelő nehézipar. Az ipar újjáépítésében fontos szerepe volt az állami ellenőrzésnek, amely az olyan - az iparosítás első szakaszában kulcsfontosságú - ágazatok fejlesztését szorgalmazta, mint az acélipar, a hajógyártás, a szénbányászat és a vegyipar. Az adókedvezményekkel, a jól átgondolt hitelkihelyezésekkel, az export ösztönzésével is ezeket az iparágakat támogatták. A japán gazdaság fejlődése meghaladta az évi 10 százalékot, a GNP növekedése 1951-1955 között 8,6 százalék, 1955-1960 között 9,1 százalék volt. Japán gyorsan növelte exportját, melynek legfőbb ismérve akkoriban még az olcsósága, nem pedig a minősége volt.

Az 1950-es években Japán az USA szövetségi rendszerében helyet foglaló független, egyenrangúállamlett(1956-tólENSZ-tag),parlamentárisdemokráciával, fellendülö gazdasággal, és egyértelmüen pozitív nemzetstratégiával: immáron békés eszközökkel (gazdaság erősítése, külkereskedelem növelése), de Japán újra a legfejlettebb államok közé kívánt kerülni. Ebben a kormányzatnak méltó partnere volt a közös célért jól mozgósítható, fegyelmezett, szorgalmas japán társadalom, amely a gazdasági sikerek elérését mindennél fontosabbnak tartotta, mert ezáltal nemcsak az ország erősödését - és ezzel természetesen saját sorsának is jobb alakulását - remélte, hanem a világháborúban elvesztett presztízs és kedvező országimázs visszaszerzését is. 
Az 1960-1970-es évek:

Az 1964-es tokiói olimpián a világ rácsodálkozott a lendületesen fejlődő országra (26. kép). Ekkor vált nyilvánvalóvá, hogy Japánnal mint gazdasági nagyhatalommal kell számolni. A japán áruk versenyképessége a minőség javulásával egyre erősödött a világpiacon. A hatvanas évek második felében óriási ütemben indult meg az autók gyártása és exportja, és megkezdődött az elektronikai ipar felfutása. Az exportösztönző politikának és a jen még mindig stabil, alacsony árfolyamának köszönhetően a japán termékek elárasztották a világot. A japán gazdaság fejlődése meghaladta az évi 10 százalékot.

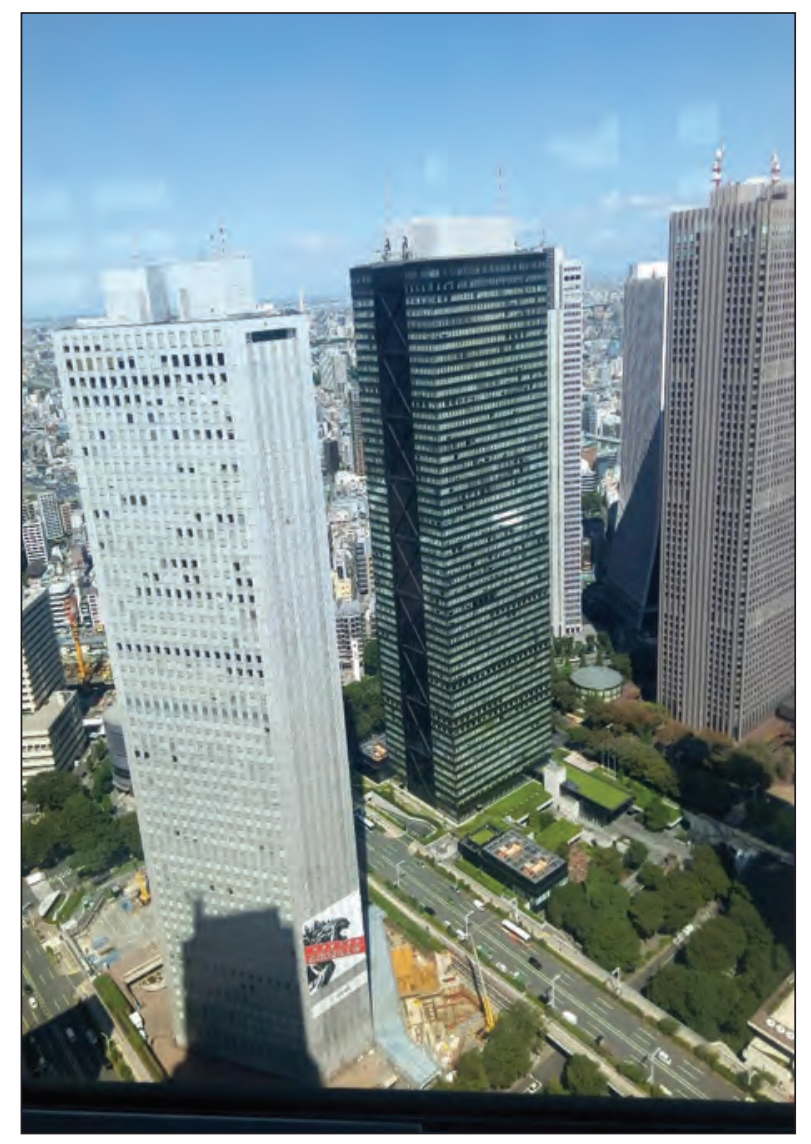

26. kép: Felhőkarcolók Tokióban

Forrás: PóR ANDREA felvétele

Japán 1965-re már a fejlettebb iparosodott országok közé számított, és 1968-ra a világ harmadik legfejlettebb piacgazdasága lett, és mindezt úgy érte el, hogy gyakorlatilag semmilyen ásványkinccsel, energiaforrással nem rendelkezett. A nagyarányú gazdasági növekedést elösegítette az állam gazdaságnövelö, élénkítő, irányító szerepe (kedvező hitelek vagy támogatások nyújtása a kiemelt, 
az iparfejlesztés szempontjából fontos beruházásokra; exporttámogatás a japán export növelésére) és a japán nemzeti bank iparfejlesztő tevékenysége (a lakossági megtakarítások felhasználásával). Fontos szerepet játszott, hogy Japán a „békealkotmányának” köszönhetően alacsonyan tartotta katonai kiadásait (1 százalék alatt, míg más országok a GDP több mint 10 százalékát is katonai kiadásokra költötték), és az így „,megmaradt” anyagi erőt mind az iparfejlesztésre lehetett fordítani. A profitot is nagy részben újra befektették, és innovációra, technológiai fejlesztésekre fordították, amivel a japán ipar folyamatosan fejlődött, és a legkorszerübb technológiákat tudta alkalmazni. Ekkor szilárdult meg a ,japán típusú" menedzsment és munkáltatói rendszer, amely a kollektív (konfuciánus) értékekre - együttműködésre, munkahelyi harmóniára, lojalitásra és paternalizmusra - alapozva konfliktusok nélkül, békés együttmüködésben tudta a munkaadók és munkavállalók érdekeit kezelni, összeegyeztetni, és ezzel a termelés folyamatos magas szintjét biztosítani. A nagyszámú, iskolázott, jól képezhető, szorgalmas és keményen dolgozó népesség is hozzájárult a sikerhez, mert a háború után gyakorlatilag társadalmi konszenzus jött létre abban a kérdésben, hogy a gazdaságfejlesztés kiemelten fontos terület, hiszen ezzel válhat ismét sikeressé Japán, és ezzel nyerheti vissza a háborúban elvesztett jó hírét, pozitív nemzetközi megítélését. Kétségtelen viszont, hogy az állam alacsonyan tartotta a szociális kiadásokat, azaz nem építették ki a jóléti államot, és a japán munkavállalók életszínvonala ugyan nőtt az ország gazdagodásával, de életminőségük (szociális ellátó rendszer, lakhatás minősége, infrastruktúra, szabadidő, egészségbiztosítás, nyugdíj, munkaidő) messze elmaradt a hasonló fejlettségű országok népességétől.

Az 1970-es évek energiaválságára a japán ipar szerkezetátalakítással válaszolt: a kevésbé energiaigényes, viszont magas fokú technikai fejlettséget és szakértelmet igénylő iparágak felfuttatásával: csúcstechnológia, elektronika, számítástechnika, stb. A sikerekben nem kis szerepet játszott a sajátos japán menedzsment rendszere is, valamint a munkáltatói rendszer, amelyek a japán közösségi és családi szerveződés hagyományait vették mintának. Az 1970es évektől a kormányzat programként kezelte az életszínvonal, majd az életminőség javítását is a japán népesség számára. A súlyos környezetszennyezés ellensúlyozására, megállítására és visszafordítására az 1970-es évektől komoly környezetvédelmi törvények születtek.

Örökség: gazdasági növekedés, fejlődés, posztindusztriális gazdaság kialakulása, „hightech” iparágak, amerikanizálódás, egyedi japán kultúra és életvitel.

\section{Japán ma}

Mára Japáné a világ második legnagyobb gazdasága, a világ összes GNPjének 14 százalékát állítja elő. A nemzetközi kereskedelembe kerülő árucikkek 7 százaléka innen kerül a világpiacra. A világ összes külföldi müködőtőke- 
beruházásának több mint 10 százaléka az ország tulajdonát képezi. Japán második világháború utáni fejlődésében egyértelmüen a nyugati demokrácia elemei dominálnak, nemcsak az intézményrendszerben, hanem a mindennapokban is. Változtak az öltözködési és étkezési szokások, a lakásviszonyok, a hétköznapi életet is mind több modern eszköz segíti, és persze a szórakozás formái és eszközei is „nyugatosodtak”. Az ezredfordulóra a társadalom is kezdett átalakulni, a viselkedési szokások, a nyelv is változik; úgy tünik, ma már a japán életforma hagyományos keretei is megváltoznak. A társadalmi változások a hagyományos életviszonyok átalakulását eredményezték, a nagycsaládok a belső migráció, urbanizáció miatt felbomlottak, és helyüket átvették a kiscsaládok; a népesség elöregedése egyre aggasztóbb méreteket ölt. A tömegkultúra (divat, film, szórakoztatóipar, média, pop kultúra) egyértelmüen amerikanizálódott (27. kép). Ma Japánhoz leginkább a következő jelzőket társítják: modern (sőt posztmodern), magasan fejlett, high-tech, demokratikus, pacifista, gazdag ország. Ebben az értelemben Japán a nyugati világ része.

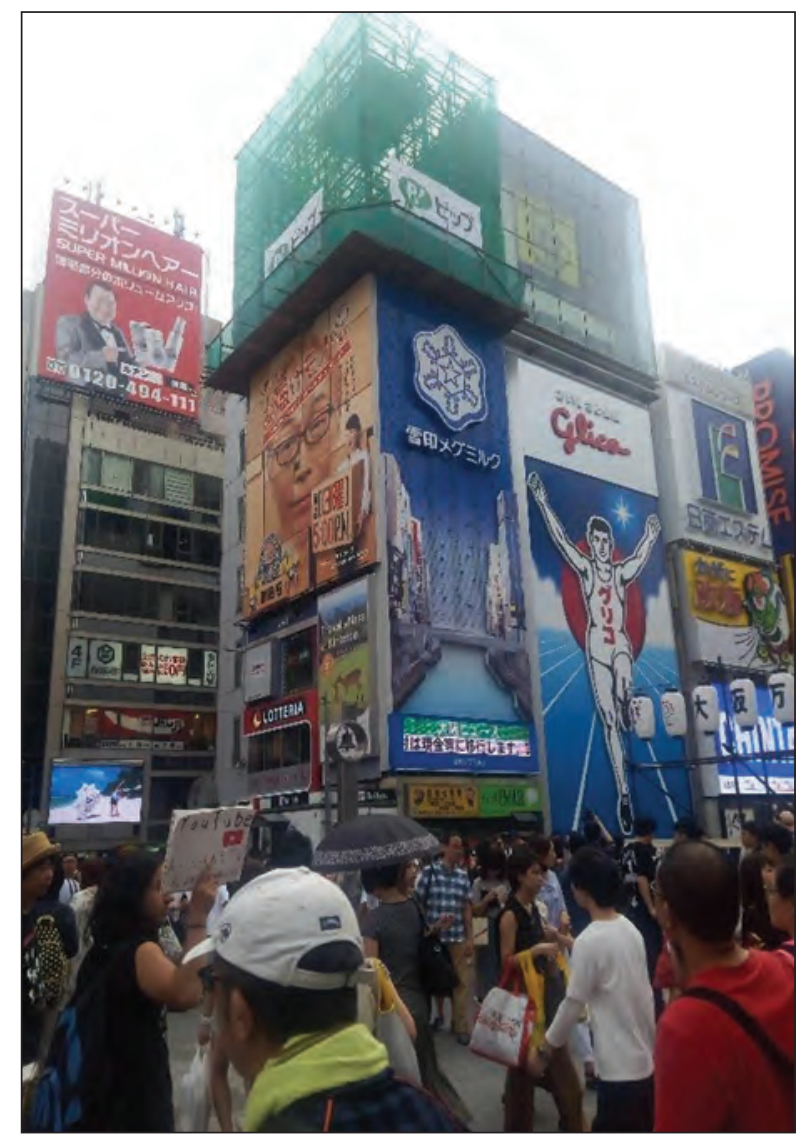

27. kép: Reklámok a Dótonbori negyedben (Oszaka) Forrás: PóR ANDREA felvétele 
Ugyanakkor a mai Japánban is azt láthatjuk, hogy mindmáig fontosak a japán kultúra hagyományos elemei, a konfuciánus értékek (szorgalom, kemény és kitartó munka, lojalitás, tekintélytisztelet, felelősség, paternalizmus) meghatározóak a munkában, az oktatásban, a társadalmi életben (hierarchia által meghatározott viselkedés, etikett, nyelvhasználat). Mindez továbbra is a japán kulturális hagyomány fontosságát és ezzel a japán kultúra egyediségét mutatja, az önálló japán civilizáció létét (28. kép).

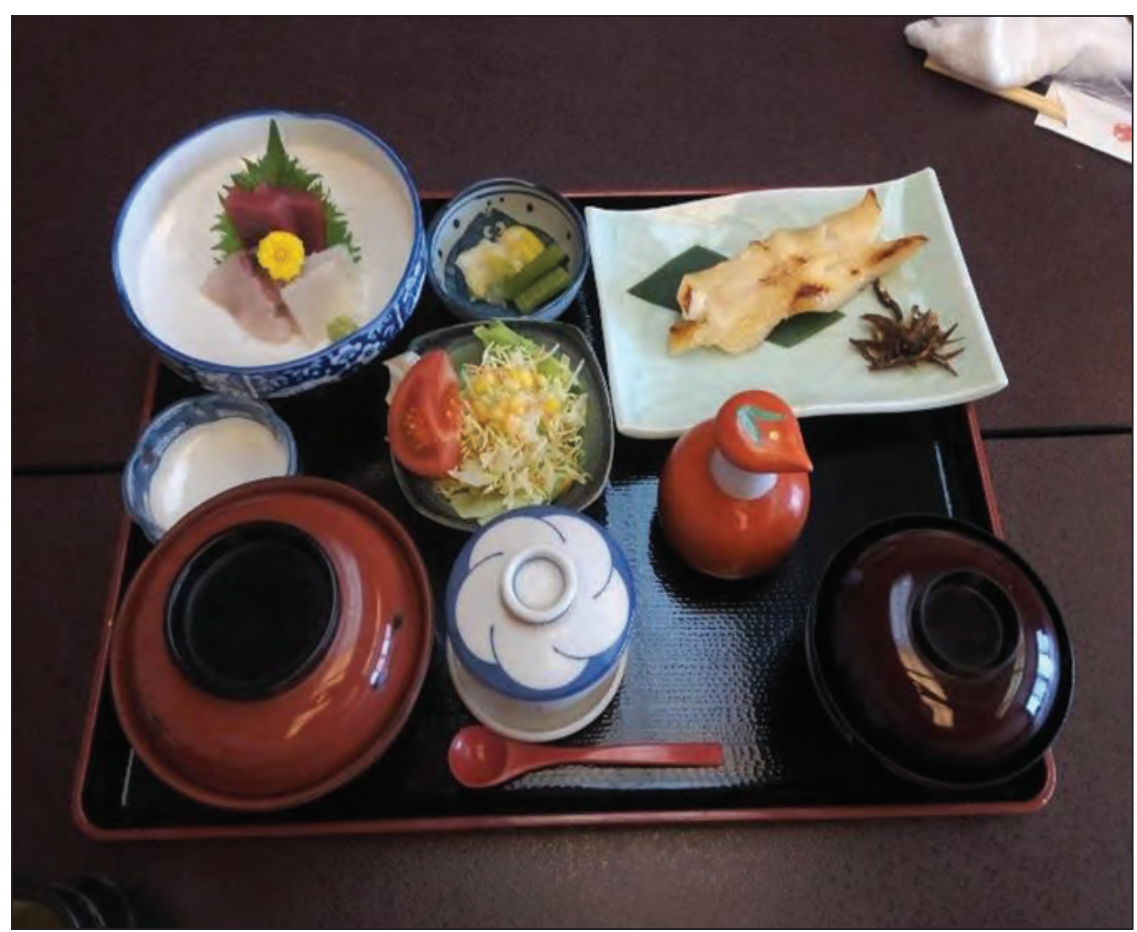

28. kép: Hagyományos, mégis modern japán tálalás Forrás: PóR ANDREA felvétele

Japán saját kulturális hagyományára építve tudta a modernizációt „nemnyugati" módon véghezvinni, és ezzel elsőként mutatta fel a lehetőségét egy „nem-nyugati” modernitásnak, egy, a nyugatitól különböző fejlődési modell létének. A 20. század második felében a „kistigrisek” fejlödése is (több kelet-ázsiai állam indult gazdasági, majd társadalmi és politikai fejlődésnek) szintén részben a nyugati modernizáció útját követve, részben attól jelentősen különböző módon ment végbe, a japán modellhez hasonló módon. Mindez már elég meggyőzően bizonyítja, hogy létezik a modernizáció „,nem nyugati útja”, amit már Japán fejlődése kapcsán is emlegetni kezdtek. Mára már széles körben elfogadott nézet, hogy ezen államok nem egyszerüen lemásolták a „nyugati modellt”, hanem saját viszonyrendszerükkel, társadalmi és kulturális 
hagyományaikkal valósították meg a modern kapitalista fejlődést, amelynek ezzel egy új formáját mutatják. Mára már egyértelmüen beszélhetünk az ázsiai kapitalizmus létéről, amiben Japán példája kimondva vagy kimondatlanul, nagy szerepet játszott a térségben.

Az ,ázsiai kapitalizmus” (Japán mintájára, Dél-Korea, Tajvan, Szingapúr, részben Vietnám is) a kapitalista modernitás nem individualista változatát jelenti, amely olyan konfuciánus értékeken alapul, mint a kollektív szolidaritás és fegyelem, a network kapitalizmus jellegzetességeivel és a családi értékekkel erősítve. Gazdaságilag a pénzügyek állami ellenőrzését, a stratégiai szektorban az állami cégek dominanciáját, a nagy „nemzeti” magáncégek támogatását jelenti, erős függőségben az exportpiactól, a lakossági megtakarítások magas arányával (ez utóbbit a jóléti állam fejletlensége, a szociális rendszer hiányosságai teszik szükségessé).

A gazdasági sikerek hatására az ezredforduló időszakára megnőtt Japán diplomáciai tekintélye is, és mind belföldön, mind külföldön felmerült az igény arra, hogy az ország eddigi passzív, gazdasági súlyával nem arányos nemzetközi tevékenységéhez képest aktívabb külpolitikát folytasson, sőt, esetleg katonai erejét is megnövelje. A japán kultúra pedig addigi föként befogadó kultúrából - ami a 2. világháború után különösen az amerikai tömegkultúra beáramlását és gyakran parttalan terjedését jelentette - az utóbbi évtizedekben kezd „,terjeszkedő”, exportáló kultúrává válni. Ezt a jelenséget a soft power néven illetik, és ez a katonai és gazdasági erőt jelentő hard powerrel szemben az emberek tudatára ható befolyást jelenti (kultúra, sport, tudomány, divat), amely azonban nem kevésbé fontos, gazdaságilag pedig kifejezetten jelentős. Ezt ismerte fel a japán kormány is, mikor meghirdette a Cool Japan programot, Japán kulturális nagyhatalommá válásának programját. A japán hagyományos és modern kultúra elemei - divat, zene, történelem és filozófia, harcmüvészetek, popkultúra, trendek, dizájn, manga és anime, modern elektronikus eszközök és kommunikációs formák - mindinkább megjelennek a nyugati kultúrában, divatot teremtenek, követőkre találnak. Az egykor elszigetelt, egzotikusnak tartott civilizáció a ma nemzedékei számára már mindennapjainak részévé vált.

A fö kérdés a továbbiakban az, hogy a második világháború után egyértelmüen a Nyugat (és elsősorban az Egyesült Államok) mellett elköteleződött Japán a jelenben és a jövőben hogyan fogalmazza meg saját helyét, feladatát, azonosságát Ázsiában és a világban. 


\subsubsection{Időrendi tábla}

\begin{tabular}{|c|c|}
\hline dátum & esemény \\
\hline i. e. $13000-300$ & Dzsómon-kor: őskori kultúrák \\
\hline i. e. 300 - i. sz. 300 & $\begin{array}{l}\text { Jajoi-kor: Rizstermesztés, fémmegmunkálás és -használat, } \\
\text { letelepedett életforma, mezőgazdasági termelés, társadalmi } \\
\text { rétegződés, regionális szerveződés }\end{array}$ \\
\hline $300-538$ & $\begin{array}{l}\text { Jamato-kor: az első államalakulat, törzsszövetség jellegü, szoros } \\
\text { kapcsolat a Koreai-félsziget államaival és Kínával. Kofun-kultúra }\end{array}$ \\
\hline $538-710$ & $\begin{array}{l}\text { Aszuka-kor: kínai civilizáció átvétele - buddhizmus, } \\
\text { konfucianizmus, tao, írás, tudományok, jogrendszer, államszervezet, } \\
\text { abszolút császári hatalom koncepciója }\end{array}$ \\
\hline $\begin{array}{l}538 \text { (más vélemények } \\
\text { szerint 552) }\end{array}$ & Buddhizmus bekerülése Japánba \\
\hline 645 & $\begin{array}{l}\text { Taika reformok: új kormányzati és adminisztratív rendszer } \\
\text { bevezetése kínai mintára. Új állami hivatalok, császár mint abszolút } \\
\text { uralkodó fogalma, állami földek rendszere a magántulajdon helyett, } \\
\text { adórendszer, udvari rangok rendszere }\end{array}$ \\
\hline $710-794$ & $\begin{array}{l}\text { Nara-kor: a kínai mintájú centralizált bürokratikus monarchia } \\
\text { korszaka }\end{array}$ \\
\hline 794-1185 & $\begin{array}{l}\text { Heian-kor: a japán nemzeti kultúra kialakulása és fejlődése, } \\
\text { udvari kultúra virágzása. A földbirtokrendszer átalakulásával a } \\
\text { szamurájréteg kialakulása, erősödése, hatalomra jutása, feudalizmus } \\
\text { kialakulása }\end{array}$ \\
\hline 1185-1333 & Kamakura-kor: a szamuráj hatalom kialakulása, feudalizmus \\
\hline 1232 & Új szamuráj jogrendszer \\
\hline 1274,1281 & Mongol támadások Japán ellen \\
\hline $1333-1573$ & $\begin{array}{l}\text { Muromacsi-kor: feudális széttagoltság, "hadakozó fejedelmek kora", } \\
\text { szamuráj kultúra virágzása. Kereskedelem és városok fejlödése. } \\
\text { Faluközösségek kialakulása }\end{array}$ \\
\hline 1543 & Az európaiak megjelenése Japánban \\
\hline $1573-1600$ & Országegyesítés \\
\hline $1603-1867$ & $\begin{array}{l}\text { Edo-kor: Kora újkor. Belső egység, béke, bezárkózás, gazdasági, } \\
\text { kulturális fejlődés. A modern Japán alapjainak kialakulása }\end{array}$ \\
\hline 1853 & $\begin{array}{l}\text { Az USA az ország megnyitására kényszeríti Japánt - belső viták az } \\
\text { ország megnyitásáról }\end{array}$ \\
\hline $1868-1912$ & $\begin{array}{l}\text { Meidzsi-kor: A nyitás meghirdetése. Gyors modernizáció, } \\
\text { nyugatosítás, modern nemzetállam megteremtése, iparosítás, } \\
\text { urbanizáció. Feudális rendszerből modern ipari állam, elzárkózásból } \\
\text { felzárkózás a nyugati nagyhatalmakkal egyenlő helyre }\end{array}$ \\
\hline 1889 & Nyugati típusú alkotmány \\
\hline 1894-1895 & Japán-kínai háború (japán győzelem, Tajvan japán birtoka) \\
\hline
\end{tabular}




\begin{tabular}{|c|c|}
\hline dátum & esemény \\
\hline 1904-1905 & $\begin{array}{l}\text { Orosz-japán háború (japán gyözelem, további területszerzések } \\
\text { Kelet-Ázsiában és Kínában) }\end{array}$ \\
\hline 1910 & Korea annektálása \\
\hline $1912-1926$ & $\begin{array}{l}\text { Taisó-kor: Taisó demokrácia: új demokratikus, liberális trendek } \\
\text { politikában és a társadalom életében. ÉS: radikális nacionalizmus, } \\
\text { expanzionalizmus és antiliberalizmus gyökerei }\end{array}$ \\
\hline 1926-1989 & Sóva-kor \\
\hline 1945 elött & $\begin{array}{l}\text { „sötét völgy”. Militarizmus, háborús terjeszkedés, nacionalizmus } \\
\text { (,Japán fasizmus”) }\end{array}$ \\
\hline 1929 & $\begin{array}{l}\text { Gazdasági világválság hatására hatalmas válság Japánban, radikális } \\
\text { mozgalmak erősödése, a hadsereg fokozatosan átveszi a hatalmat }\end{array}$ \\
\hline 1932 & Mandzsúria elfoglalása \\
\hline $1937-1945$ & Japán-kínai háború (Japán területeket foglal el Kínában) \\
\hline 1940 & Japán-német-olasz szövetség - a „Tengelyhatalmak” megalakulása \\
\hline 1941. december 7 . & Japán megtámadja az USA-t (Pearl Harbor, Hawaii-szigetek) \\
\hline 1945. augusztus 6,9 . & $\begin{array}{l}\text { Az USA atombombát dob Hirosimára és Nagaszakira, Japán pár nap } \\
\text { múlva feltétel nélkül megadja magát }\end{array}$ \\
\hline $1945-1951$ & $\begin{array}{l}\text { Amerikai megszállás: a mai Japán formálódása, demokratizálás, } \\
\text { demilitarizálás, amerikai szövetség }\end{array}$ \\
\hline 1947 & $\begin{array}{l}\text { Új (mai) Alkotmány: a császár csak szimbólum. Alapvető emberi } \\
\text { jogok, általános titkos választójog, népfelség elve. Demokratikus } \\
\text { politikai rendszer. 9. cikkely: háborúról való lemondás }\end{array}$ \\
\hline 1952 & $\begin{array}{l}\text { San Fransisco-i békeszerződés: Japán visszanyerte szuverenitását, } \\
\text { de rászorul az USA katonai védelmére, az USA-nak stratégiailag } \\
\text { fontos Japán: amerikai-japán biztonsági szerződés. Japán az USA } \\
\text { szövetségi rendszerének fontos tagja }\end{array}$ \\
\hline $1950-1953$ & $\begin{array}{l}\text { Koreai háború: Gazdasági haszon Japánnak: újra beindulhatott a } \\
\text { nehézipara, majd a többi iparág is }\end{array}$ \\
\hline 1950-es évek & $\begin{array}{l}\text { A ,japán csoda" kezdete. Gazdasági növekedés, fejlődés, } \\
\text { amerikanizálódás, egyedi japán kultúra és életvitel. GNP növekedés: } \\
\text { 1951-1955: 8,6\%, 1955-1960: 9,1\% }\end{array}$ \\
\hline 1968 & Japán a 3. legnagyobb gazdaság a világon \\
\hline 1970-re & Japán a világon az 1. gyártó: hajó, rádió, televízió \\
\hline 1973 & $\begin{array}{l}\text { olajválság - Japán: sikeres váltás, szerkezetátalakítás a kevésbé } \\
\text { energiaigényes, high-tech iparágakra. Posztindusztriális gazdaság, } \\
\text { életminőség javítása }\end{array}$ \\
\hline 1980 & autó, high-tech elektronikai termékek \\
\hline
\end{tabular}




\subsubsection{Irodalomjegyzék}

\section{Ajánlott irodalom}

Benedict, Ruth 2006: Krizantém és kard. A japán kultúra újrafelfedezése. Budapest: Nyitott Könyvmühely

Collcutt, Martin - Marius Jansen - Isao Kumakura 1997: A japán világ atlasza. Budapest: Helikon

FARKas Ildikó - SÁGi AtTila (szerk.) 2015: Kortárs Japanológia I. Budapest: L'Harmattan

FARKAS ILDIKó (szerk.) 2009: Ismerjük meg Japánt! Bevezetés a japanisztika alapjaiba. Budapest: ELTE Eötvös Kiadó

FARKAS ILDIKÓ 2018: A japán modernizáció ideológiája. Budapest: L'Harmattan Gy. HoRváTH LÁszló 2018: Japán kulturális szótár. Budapest: Corvina Kiadó

HidASI Judit 1999: Na és, hogy tetszik Japán? Budapest: Terebess

Huntington, Samuel P. 1998: A civilizációk összecsapása és a világrend átalakulása. Budapest: Európa

Ito Nobuo - Maeda TAiJI 1980: Japán müvészet. Budapest: Corvina

Jamadzsi Maszanori 1989: Japán. Történelem és hagyományok. Budapest: Gondolat

KIDDER, Edward 1987: Az ösi Japán. Budapest: Helikon

Reischauer, Edwin O. 1995: Japán története. Budapest: Maecenas

Totman, ConRad 2006: Japán története. Budapest: Osiris

További irodalom

Arnason, Johann P. 2010: Social Theory \& the Japanese Experience. The Dual Civilization. New York: Kegan Paul International

EARHART, Byron H. 1982: Japanese Religion: Unity and Diversity. Belmont, California: Wadsworth.

Eisenstadt, Shmuel N. 1996: Japanese Civilization: a Comparative View. Chicago: University of Chicago Press

Fukutake, Tadashi 1989: The Japanese Social Structure, Its Evolution in the Modern Century. Tokyo: University of Tokyo Press

Jansen, Marius B. 2000: The Making of Modern Japan. Cambridge, Mass. : Belknap Press of Harvard University Press,

Morishima, Michio 1994: Why Has Japan Succeded? Western Technology and the Japanese Ethos. Cambridge: Cambridge University Press

NAKANE, Chie 1972: Japanese Society. Berkeley: University of California Press

Reischauer, Edwin O. 1999: The Japanese Today. Change and Continuity. Tokyo, Tuttle Publishing 

3. Indiai szubkontinens 



\title{
3.1. Az indiai civilizáció
}

\author{
RENNER ZSUZSANNA
}

\subsubsection{Bevezetés}

Az indiai civilizáció a világ egyik legősibb civilizációja, amely más ókori civilizációkkal ellentétben a mai napig fennáll. Az indiai szubkontinensen alakult ki és formálódott az itt lejátszódott sokrétü társadalmi-gazdasági-politikai folyamatok eredményeképpen. Magában foglalja a társadalom és a kultúra sajátosan indiai jelenségeit, az indiai vallásokat (hindu, buddhista, dzsaina és szikh), az indiai nyelveket, filozófiát, irodalmat, építészetet, képzőmüvészetet és tudományokat mindazokat az anyagi és szellemi értékeket, amelyeket az itt élő népek a civilizáció fennállása során létrehoztak. Bár alapvetően az indiai szubkontinens földrajzi régiójának sajátja, az 5. századtól Délkelet-Ázsia jelentős részére is kiterjedt. Kulturális kisugárzása ennél is szélesebb körü: a buddhista vallás és müvészet révén Közép-Ázsiában és a Távol-Keleten is maradandó hatást gyakorolt. Az indiai gondolatiság a modern korban Nyugaton is befogadó közegre talált, s népszerüsége ma reneszánszát éli.

Az i. e. 2. évezred közepéig tartó prehistorikus elözmények után az indiai civilizáció kialakulásának csaknem ezer éven át tartó korai korszaka az árják megjelenését és az indiai szubkontinensen való széttelepülését foglalja magában (kb. i. e. 1500-tól 600-ig). Tipikus sajátosságainak kibontakozása az i. e. $600-$ i. sz. 1200 közötti időszakra tehető. A 13. század eleje mérföldkő a szubkontinens történetében, ekkor ugyanis a mélyen benyomuló iszlám hódítás és a nyomában kialakuló indiai iszlám államiság véget vetett az indiai civilizáció kizárólagosságának a szubkontinensen. A merőben új helyzet hosszú távon állandósította az indiai és az iszlám civilizáció szubkontinensen belüli együttélésének, kölcsönhatásának és konfliktusának máig ható problémáját. Bár az indiai civilizáció nem szünt meg létezni, de az iszlám terjeszkedéssel párhuzamosan regionális királyságai a szubkontinens legdélibb része kivételével tartományokként betagozódtak a szubkontinensen létrejött szultanátusok politikai szervezetébe. A gyarmatosítással újabb civilizáció, a nyugati is megjelent a térségben. 1858 és 1947 között az indiai brit kormányzat elöször egyesítette politikailag a szubkontinens egészét, ahol fennhatóságát részben közvetlenül, részben a brit korona föhatalmának alávetett, félszuverén hindu és muszlim fejedelemségeken keresztül gyakorolta. A gyarmati politika ugyan deklaráltan nem avatkozott vallási kérdésekbe, de gazdasági, társadalmi, közigazgatási és politikai téren annyi változást hozott, hogy az a civilizációs alapokat sem hagyhatta érintetlenül. Az indiai civilizáció fennmaradt, de magán viselve mind az iszlámmal, mind a nyugati civilizációval való együttélés nyomait. 
A független India a szubkontinens jelentős részét és mindhárom civilizáció örökségét magáénak tudhatja. Alkotmánya kimondja az indiai kultúra összetett jellegét. A régi indiai civilizáció az Indiai Köztársaság földrajzi-politikai keretei között él tovább, ahol a többségi, de nem egyedüli kultúrát alkotja. India gyarmati múltjának súlyos örökségéhez tartozott a szubkontinens önfenntartó gazdaságának lerombolása és a britek által is elmélyített hindu-muszlim ellentét. Ugyanakkor a modernizációs törekvésekben, amelyekben India fontos sikereket könyvelhet el, jelentős erőforrásnak bizonyult a Brit-Indiától átvett politikai rendszer, az angol nyelv használata és a szubkontinens alapvető kommunikációs rendszerének (vonat, posta, utak, távközlés) megléte.

India ma a világ legnagyobb müködő demokráciája, dinamikusan fejlődő gazdasági nagyhatalom. Az előrejelzések szerint 2050-re egy före eső nemzeti összterméke csaknem eléri az Egyesült Államokét. Hatalmas tehertételét jelenti ugyanakkor népességének robbanásszerü növekedése, amely 1947 óta megháromszorozta lakosságát. További súlyos problémát jelent a társadalmi egyenlőtlenség, a vidéki lakosság szegénysége, a környezetkárosodás és az írástudatlanság (az UNESCO 2011-es adatai szerint 27,9 százalék), amelynek aránya a nők körében különösen magas. A hindu többség és a muszlim kisebbség együttélése folyamatosan napirenden tartja az indiaiság definíciójának problémáját, és az indiai diszpóra hatalmas arányú növekedése is az indiaiság és a hindu valláshoz tartozás fogalmainak alapvetően új megközelítését teszi szükségessé.

\subsubsection{A földrajz és éghajlat szerepe}

A földrajzi környezet, ahol az indiai civilizáció kialakult és fejlödött, az indiai szubkontinens vagy mai kifejezéssel Dél-Ázsia. Ezen a hatalmas területen, amely hozzávetőleg akkora, mint Európa, ma több ország: India, Pakisztán, Banglades, Nepál, Bhután, Srí Lanka és a Maldív-szigetek osztozik, de olykor ide sorolják Afganisztán északkeleti részét is, amely fontos szerepet játszott a szubkontinens történetében (9. térkép). Az eurázsiai kontinens többi részétől természetes határok választják el: északon a Himalája 2500 km hosszú vonulata, nyugaton a Hindukus, északkeleten nagy kiterjedésü, szinte járhatatlan trópusi őserdők és az Arakánhegység. Félszigeti részét tengerek ölelik körül: nyugaton az Arab-tenger, keleten a Bengáli-öböl, délen az Indiai-óceán. E fizikai adottságok a szubkontinens elkülönülő, de nem elszigetelt fejlődését biztosították. A Himaláját áttörő folyóvölgyek és magashegyi átjárók, amelyeken tibeti népcsoportok közlekedtek, összeköttetést jelentettek a Tibeti-fennsíkkal. Északkeleten Manipur folyóvölgyei és a tengerparti sáv biztosított kapcsolatot Kína, illetve Burma (Mianmar) és Délkelet-Ázsia irányában. Nyugaton a beludzsisztáni sivatagos hegyvidék peremén az Indus-völgyi síkságra nyíló Bolan-hágó bonyolított valamelyes kereskedelmet, 
és népmozgások is zajlottak itt. De a legfontosabb összeköttetés a külvilággal a szubkontinens északnyugati szögletében, a Kabul-folyó völgyében húzódó Haibar- (Khyber-) hágó volt, a szubkontinensre érkező népek, népcsoportok fö közlekedési útvonala, ahol a legtöbb hódító: árják, perzsák, görögök, párthusok, szkíták, kusánok, afgánok, törökök, patánok India földjére léptek.

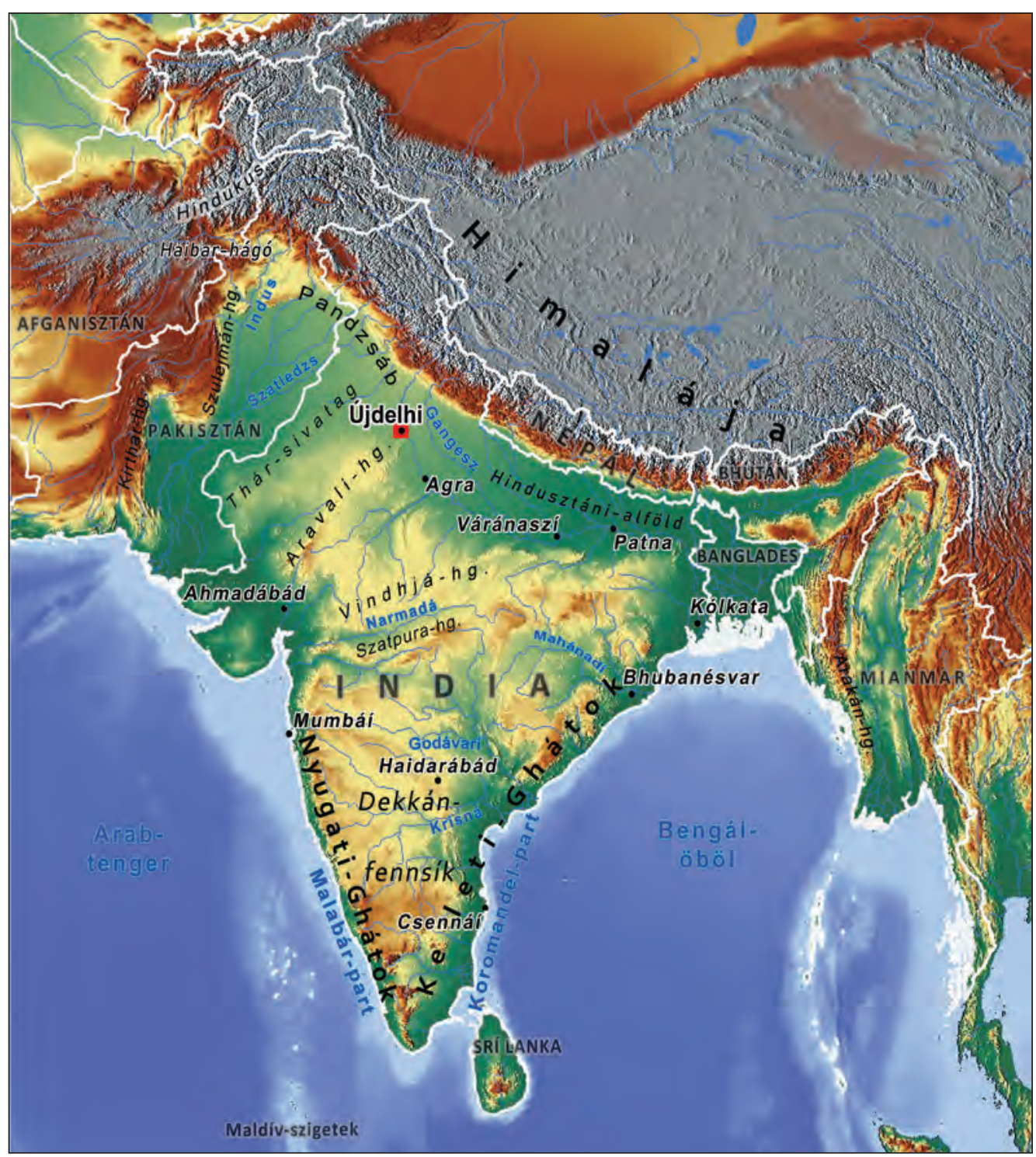

9. térkép: Az indiai szubkontinens Forrás: VARGA ÁGNES szerkesztése

A szubkontinensen túlra irányuló fő szárazföldi kereskedelmi útvonal, a Selyemút indiai leágazása is erre vezetett, amely nemcsak a kereskedelmi áruk 
cseréje, hanem a szellemi javak terjedése szempontjából is döntő fontosságúnak bizonyult. Erre terjedt észak felé a buddhizmus, s vele a buddhista müvészet Indiában kialakult alapformái.

A tengerekkel övezett félszigeti rész a hosszanti irányban járható tengerpartok, valamint a tengeri hajózás és kereskedelem révén a történelem elötti időktől részt vett a külvilággal való kapcsolatok fenntartásában. Már az Indus-völgyi civilizáció tengeri kereskedelmi kapcsolatot létesített Mezopotámiával a part menti hajózás révén. Az Indus-völgyi kereskedők áruikat Ománig, illetve Bahreinig szállították, ahonnan helyi kereskedők vitték tovább Mezopotámia városaiba. A későbbiekben rendszeres forgalom bonyolódott a Római Birodalom keleti tartományai (elsősorban Egyiptom) és az indiai kikötők között is. A korai délkelet-ázsiai királyságok - Szuvannabhúmi Burma, a Mon Királyság Thaiföld déli részén, Funan és Csenla a mai Kambodzsában, Tyampá (Champa) Vietnamban, Srívidzsaja Szumátrán és Jáván - létrejöttét nagyrészt a tengeri kapcsolatok kiépülése segítette. A korai kapcsolatok a nyugati tengerpart kikötőjéből, Bharukaccshából (ma Bharuch, Gudzsarát) kiindulva létesültek, később ezt a szerepet a keleti part kikötői vették át.

A szubkontinens belsejét folyók és hegyvonulatok tagolják, $s$ a régészet tanúsága szerint a fő kulturális régiók a történelem előtti időktől fogva szorosan követik ezeket a természetes földrajzi határokat. Az északon a Himalája hegylánca, délen a Narmadá folyó, illetve a Vindhjá-hegység vonulata által határolt északi régió az Indus és a Gangesz nagy kiterjedésủ síkságait foglalja magában. Az Indus medencéje volt az Indus-völgyi civilizáció bölcsője, majd felső folyása - a Pandzsáb, az „öt folyó” vidéke - a szubkontinensre érkező árják első szállásterülete. A történeti korokban a Gangesz és mellékfolyója, a Jamuná medencéje játszott kulcsszerepet. Ez a termékeny folyamvölgy India legbővebben termő vidéke, amely mind gazdasági erejénél, mind pedig a síkvidék jobb járhatósága következtében kedvező feltételeket teremtett a nagy kiterjedésű államok kialakulásához. A középső régió a Dekkán-fennsík hegyeserdős, vízmosásokkal tagolt, nehezen járható vidéke, amely a Narmadá és Krisná folyó között terül el. Erős regionális királyságok és jelentős dinasztiák felemelkedésének színtere volt ez, ahol az északi és a déli régió politikai és kulturális befolyása változó mértékben érvényesült, s emellett elzárt foltokban az őslakos népesség törzsi kultúrája is a legutóbbi időkig, sőta mainapig fennmaradt. A Krisnától délre eső régió a tipikus dél-indiai kulturális sajátosságok hordozója, amelyek észak és dél hagyományos elkülönülését megalapozták és a mai napig fenntartják. A tengerparti sávokban hosszanti zónák alakultak ki, amelyeket a keskeny tengerparti sávok és a mögöttük fekvő hegységek, a Nyugati-, illetve a Keleti-Ghátok hátországának kulturális sajátosságai határoznak meg.

A szubkontinens fizikai földrajza mellett az indiai hagyományban létezik egy szakrális földrajz is, amelyben szentségnek örvendenek India hegyei, 
elsősorban a Himalája (szanszkrit: „,a hó hazája”) hófödte csúcsai, ahová az indiai mitológia az istenek égi lakhelyét helyezi. Vallásos tiszteletben részesítik a föld termékenységét biztosító folyókat, amelyeket istennők személyesítenek meg. Vizük szoros kapcsolatban áll a rituális tisztasággal is, ezért a folyókban való megmerítkezés és a halottak hamvainak folyóba szórása a legismertebb hindu rítusok közé tartozik. A legszentebb folyó a Himalájában eredő és a Bengáliöbölbe ömlö Gangesz (indiai nevén Gangá), amelynek útját zarándokhelyek láncolata kíséri: Haridvár, ahol a Himalájából kilép a síkságra; Allahábád vagy Prajág, ahol a Jamunával találkozik, s ahol összefolyásuknál 12 évente sor kerül a nagy kumbh mélá zarándoklatra (a becslések szerint legutóbb, 2013ban 120 millió zarándok vett részt rajta); de mindenekelőtt Váránaszí vagy Kásí, a legszentebb hindu város, a hindu müvelődés központja (29. kép). A szubkontinens szent földrajzának a hindu vallás kialakulásával egyidős képzetei mellé a 19. századi függetlenségi mozgalom során egy újabb is társult, amikor India egészét kezdték a hinduizmus szent földjének tekinti, s egy hindu istennő, Bhárat Mátá (India Anya) képében megszemélyesíteni. Ez a jelkép politikai felhangoktól volt terhes, és India földjének a hindu vallással való asszociációja miatt a vallási kisebbségek tiltakozását váltotta ki.

A szubkontinens éghajlata melegebb, mint azt földrajzi helyzete indokolná, a Himalája hegylánca ugyanis az északi szeleket és a délnyugat felöl érkező monszunszeleket egyaránt feltartóztatja. A monszunszelek három hónapon át hajtják a szubkontinens fölé a csapadékkal terhes felhöket. A földeket repedezettre szikkasztó, perzselő forróság hónapjai után örömünnep kíséri a várva várt, megtermékenyítő eső érkezését. A vízzel megtelö tavakat lótuszok borítják, kizöldülnek a földek, virágba borulnak a fák, bódító illatok úsznak a levegőben. A költészet és a festészet megannyi toposza: a rikoltó pávák, az esőben találkára siető vagy szépítkező kedves jelzi, hogy Indiában ez a szerelem évszaka.

A csapadék azonban nem egyenletesen oszlik el a szubkontinensen. A legtöbb eső a Himalája déli oldalán és a Nyugati-Ghátok tenger felöli oldalán esik, s a lezúduló csapadék sokszor pusztító áradásokat okoz, miközben a Dekkán-fennsík belsejében trópusi szavanna, illetve forró félszáraz, északnyugaton a Thár-sivatagban forró sivatagi éghajlat uralkodik. Az éghajlat és az esőzés kiegyenlítetlensége miatt az indiai civilizációban az uralkodó legfőbb feladatai közé tartozott a földek termékenységének biztosítása. $\mathrm{Az}$ uralkodói székvárosokban mesterséges víztárolókkal és a folyók vizét felduzzasztó völgyzáró gátak építésével biztosították két monszunesőzés között a szükséges vízmennyiséget. Ezeknek a tervezése, müködtetése magas szintü müszaki ismereteket követelt meg és az alapvető civilizációs vívmányok közé tartozott. Kiegészítő vízforrásul a kutak szolgáltak. Egyszerü ásott kúttal, ahonnan nők hordták a vizet, lehetőleg minden falunak rendelkeznie kellett. Az 
indiai szubkontinens nyugati, legszárazabb vidékein ugyanakkor nagyméretü, sajátosan az indiai civilizációra jellemző lépcsős kutak is épültek. E többemeletes földalatti paloták egész évben biztosították a talajvíz elérhetőségét, forró évszakban a hüsölést, s mindezért az isteneknek való hálaadást, tehát társadalmivallási jelentőségük sem volt elhanyagolható.

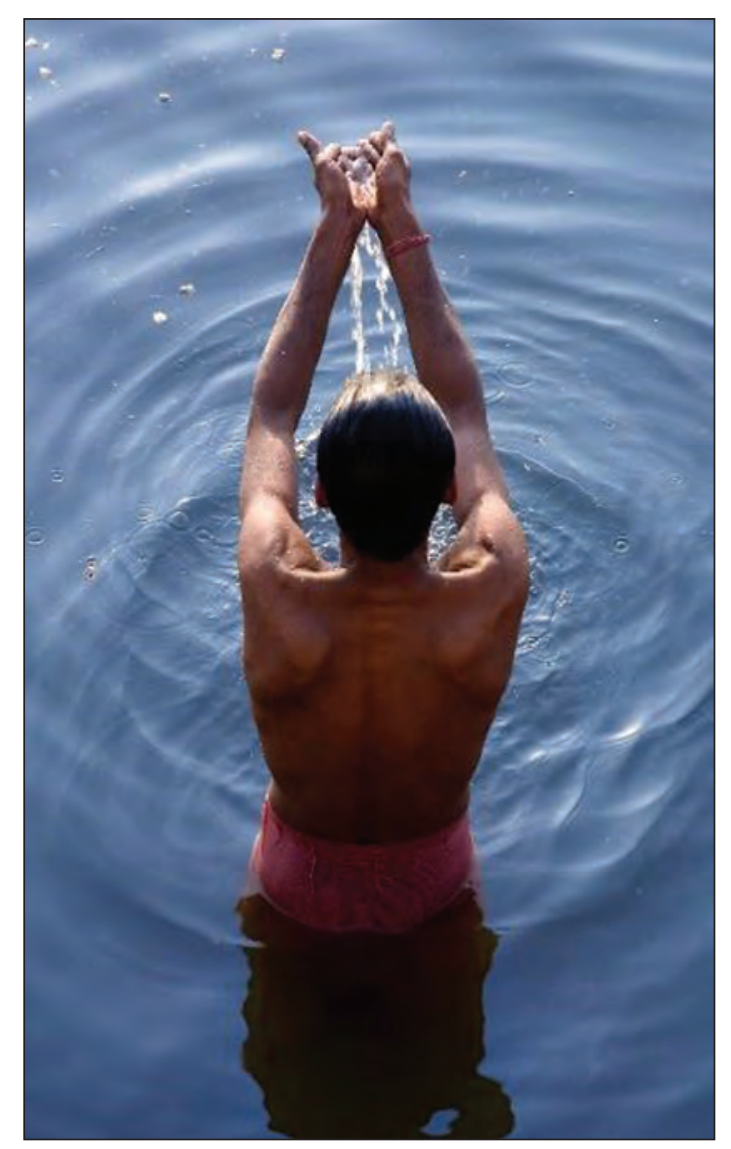

29. kép: Reggeli rítus a Gangeszen Váránaszínál

Forrás: Jorge Royan. Forrás: https://commons.wikimedia.org/wiki/File:India_-_Varanasi_ ba\%C3\%B1o_Ganges_-_0072.jpg

A szubkontinenst behálózó utaknak óriási szerepe volt a térség benépesülésében, az indiai civilizáció kialakulásában, a kereskedelemben és a vallások, különösen a buddhizmus terjedésében. A legfőbb kereskedelmi útvonal, a Gangesz-völgyet az északnyugati Gandhárával összekötő „,északi út" volt, amelynek keleti elágazásai Kína, illetve a Bengáli-öböl régi kikötője, Támralipti (ma Tamluk, Nyugat-Bengál) felé vezettek, északnyugati elágazása pedig a Selyemútba csatlakozott. Nagy jelentőségủ szárazföldi út kötötte össze a Gangesz-völgy keleti medencéjében fekvő királyi székvárost, Pátaliputrát (ma 
Patna, Bihár) a nyugati tengerpart kikötővárosával, Bharukaccshával, ahonnan a kereskedők Arábia és Kelet-Afrika partjait vették célba. A félsziget belsejében eleinte preárja területeken vezetett a „déli út”. A szárazföldi utakat azonban csak a száraz évszakban lehetett használni, a monszun alatt járhatatlanná váltak. A vándorszerzetesek ilyenkor barlangokba húzódva várták az esőzés végét. Ezeken a helyeken alakultak ki az első buddhista barlangszentélyek, amelyek ennek az indiai civilizációra olyannyira jellemző szakrális építészeti formának az első megnyilvánulásai közé tartoztak. A szárazföldi kereskedelem számos veszélyt is rejtegetett, ezért a szubkontinens királyságai területszerzési törekvéseinek mozgató rugói között kiemelt helyen szerepelt a kereskedelmi utak és csomópontok feletti ellenőrzés megszerzése.

A szubkontinens fizikai adottságai tartósan fennálltak, bár ez nem jelenti azt, hogy ne lettek volna változások. Az utolsó két és fél évezredben a szubkontinens síkságait öntöző folyamok, amelyek ma is szabályozatlanok, időről időre változtatták medrüket, s ezzel az áradásos gazdálkodásra épülő korai kultúrák és államalakulatok létét alapvetően befolyásolták. A nagy mennyiségü hordalék lerakása miatt eltolódás következett be a folyódeltákban is. Az Indus folyásirányának jelentős megváltozása és a Szaraszvatí kiszáradása a monszun széljárás irányának megváltozásával párosulva döntő szerepet játszott az Indusvölgyi civilizáció megszűnésében. A monszun keleti eltolódása hozzájárulhatott a Thár-sivatag fokozatos terjeszkedéséhez és az Indus alsó szakaszát övező erdőségek kiszáradásához. A nagy indiai eposzok, a Rámájana és a Mahábhárata tanúsága szerint a szubkontinens nagy részét egykor sürü erdők borították. Az óind irodalmi müvekben az erdő, mint a remeték, erdei állatok és démonok lakhelye, háborúk és csaták színtere fontos gyakorlati szerepe mellett szimbolikus értelemben a városok és falvak civilizációba bevont, megszentelt világának ellentéteként jelenik meg.

\subsubsection{A szubkontinens nyelvei}

Az indiai szubkontinensen jelenlévő nyelvcsaládok közül beszélői számarányát tekintve kiemelkedik az indoeurópai nyelvcsalád, amely legalább az i. e. 2. évezred óta jele van, túlnyomó többségében az indoiráni ághoz tartozó indoárja nyelvek révén. Ide tartozik a szanszkrit (,összetett”, „feldíszített”), amelynek archaikus formáját a szubkontinensre északnyugat felől betelepülö árják beszélték. Az árja (jelentése „,nemes”) az indoeurópai nyelvcsalád indoiráni ágához tartozók önmegnevezése, etnikai vonatkozása nincs. Szanszkrit nyelven születtek meg India legösibb szent szövegei, a Védák, valamint az ókori India hatalmas terjedelmủ vallási, filozófiai, tudományos és szépirodalma. Nyelvtanát és fonetikáját az i. e. 5. században élt Pánini írta le a világ első rendszeres grammatikai művében (Astádhjájí), amely a későbbiekben kötelező érvénnyel 
bírt. A szanszkrit nyelv az árják széttelepülésével egész Észak-Indiában elterjedt, majd további térnyerésük során egyszerüsödött helyi változatai alakultak ki, az ún. prákrit nyelvek. Legismertebb közülük a páli, a déli (théraváda) buddhizmus irodalmának és a Páli Kánonnak a szent nyelve. A prákrit nyelvekből erednek a ma beszélt újind nyelvek: a hindi India középső részén, a gudzsaráti és a rádzsasztháni nyugaton, a pandzsábi és a szindhi északnyugaton, a dárd nyelvek, köztük a kásmíri a legészakibb szögletben, a pahári és a nepáli északon, a bihári, bengáli, orija és ászámi keleten, a maráthi délen és a szingaléz Srí Lankán. Az iráni nyelveket a beludzs és a pastu képviseli nyugaton, illetve északnyugaton, a káfíri/nurisztáni pedig a szubkontinens távoli északnyugati részén. A Mogul (más néven Mughal) Birodalom idejének hivatalos nyelve a perzsa volt. A szubkontinensen használt indoeurópai nyelvek között említést érdemel az angol nyelv széles körü használata hivatalos nyelvként és modern lingua francaként.

A dravida nyelvcsaládhoz tartozó nyelvek, amelyeknek időszámításunk kezdete körültöl vannak feliratos emlékei, a szubkontinens déli részén koncentrálódnak, de maradványaik megtalálhatók Közép-Indiában (gond) és Beludzsisztánban (brahui) is. A dél-indiai dravida nyelvek közé tartozik a tamil, a kannada, a malajálam és a telugu, amelyek mindegyike gazdag irodalmat hozott létre. A dravida nyelvet beszélők korai történetéről nagyon keveset tudunk. Egyes nézetek szerint az Indus-völgyi civilizáció népességét protodravida nyelvet beszélők alkották, akik i. e. 4500 körül vándoroltak be ide az Iráni-fennsík felől, $\mathrm{s}$ akiket a betelepülő árják szorítottak fokozatosan délre. Az Indus-völgyi írás megfejtetlensége miatt azonban erre a kérdésre jelenlegi ismereteink alapján nem lehet biztos választ adni. Annyi bizonyos, hogy az árjákhoz hasonlóan a dravidáknak sincsenek egyértelmü etnikai jellegzetességeik, ami régészeti azonosításukat gyakorlatilag kizárja. Ugyanakkor a szanszkrit nyelvbe átkerült nevek és jövevényszavak a védikus irodalom legkorábbi rétegétől kezdve igazolják a dravidák jelenlétét, ami valószínűsíti, hogy az árjáknál korábban érkeztek a szubkontinensre.

Az ausztroázsiai nyelveknek - a mundának Közép- és Kelet-Indiában, a khászinak Ászámban - csak az utolsó néhány évszázadban van írott emléke. Beszélőik azonban a jövevényszavakból ítélhetően valószínűleg a dravida és az árja nyelvi csoportok elött érkeztek a szubkontinensre. A sino-tibeti nyelvcsalád tibeto-burmai ágához tartozó nyelvi állományt képviselő népcsoportok a Himaláján átkelve a szubkontinens északi és északkeleti peremvidékére szivárogtak be. Jelenlétüket az i. sz. 4. századtól kezdve feliratos emlékek őrzik a Kathmandu-völgyben. A tibeto-burmai ágba tartozó tibetit és nevárit ma a Himalája vidékén beszélik. 


\subsubsection{Az indiai civilizáció történetének kronológiája}

\section{Az idő szemlélete, időrend, források}

Az indiai civilizáció történelmi dátumainak megállapítása a kutatás kezdetétől nagy nehézségekbe ütközött. Az indiai hagyományban ugyanis nem létezett olyan rendszerezett történetírás, mint amilyen Európában, Kínában vagy az iszlám kultúrában. Az események időbeliségének és az egyén történelmi szerepének jóval kisebb vagy semmiféle jelentőséget sem tulajdonítottak. Történelmi hagyomány létezik ugyan, főként királylisták és leszármazási sorok (genealógiák) formájában, amelyek azonban a puránák („régi történetek”, az indiai kozmológiai, mitológiai és történeti hagyomány enciklopédikus jellegü müvei) mitikus történeteibe ágyazottan jelentkeznek, sokszor egymásnak ellentmondóak, és ritkán köthetők konkrét személyekhez, dátumokhoz, eseményekhez vagy helyszínekhez. Ennek mélyen fekvő oka a jelenségek földi világát relativizáló szemléletben keresendő. Az indiai civilizáció múltra vonatkozó elbeszéléseiben kozmikus logika működik, amely a földi időt és a földön élö embert a világegyetem müködésének perspektívájába helyezi, így érthető, ha jelentősége ebből a nézőpontból viszonylagossá válik vagy eltörpül. Az indiai civilizáció világról alkotott elképzelésében az idő nem lineáris, hanem ciklikus természetü, $\mathrm{s}$ benne a világegyetem fennállásának és pusztulásának (visszahúzódásának) öröktől fogva ismétlődő ciklusai váltják egymást. A kozmológiai időt az istenek napjaiban és éveiben mérik. A világegyetem fennállásának egy ciklusa (szkt. kalpa, „eon”) Brahmá isten egy napjának felel meg, amely 4,32 milliárd földi évvel egyenlö, s amelyet Brahmá ugyanilyen hosszúságú éjszakája (a visszahúzódás ciklusa) követ. Egy kalpa 1000 nagy korszakból (mahájuga) épül fel, amelyek egyenként négy korszakból (juga) állnak. Ezek (szatja, tréta, dvápara és kálijuga) nem egyenlő hosszúságúak, hanem egyre rövidülő időtartamúak, s a rend, a törvény, az erkölcs fokozatos romlása jellemzi őket. Leghosszabb az aranykornak is nevezhető szatjajuga, amikor az emberek legközelebb álltak az isteni törvényekhez, s legrövidebb és egyben legromlottabb a kálijuga, amikor a világ megérik a megújulásra. Ez utóbbi isteni beavatkozásra következik be, majd kezdődik elölről a négy juga megállíthatatlan körforgása. Brahmá egyetlen napja alatt a négy juga ezerszer forog körbe. Az ezekben lejátszódó események - beleértve az istenek megtestesüléseit, Buddhák és Dzsinák megjelenését, nagy háborúkat és sorsfordító történelmi pillanatokat - azonosak, azok a történések tehát, amelyeket a földi ember megél, végtelen számban megtörténtek már a múltban és újra be fognak következni az eljövendő világkorszakokban. Brahmá egy éve 360 ilyen napból áll, élettartama pedig, amely bármily hosszúnak tủnik is, véges, földi időben számolva 311 billió 40 milliárd év - az univerzum egésze 
szempontjából csupán egy villanás. Nem is egyedüli ö, az univerzum világaiban Brahmák sokasága keletkezik és tünik el az anyagi világ oksági összefüggéseinek alárendelten.

A hagyományos indiai történelemszemléletet elsődlegesen a puránák és az eposzok formálják. A puránák keletkezése első verzióban az i. sz. 4-10. század közöttre tehető, de a leírt történetek ősi időkbe nyúlnak vissza. Az eposzok és más irodalmi müvek is sok történeti jellegü utalást tartalmaznak, ám legtöbbször maguk is nehezen datálhatók, keletkezési idejük nem ritkán több száz éves intervallumban mozog. A tudományos igényü történeti kutatás, amelynek legfontosabb forrásait a dátumozott feliratok és pénzérmék jelentik, folyamatosan törekszik a puránikus és epikus irodalomból kinyerhető adatok datálható személyekkel és eseményekkel való összevetésére, azonosítására, ami azonban csak az esetek egy részében jár sikerrel. Régészeti kutatások az Indiai Régészeti Felügyelőség létrejötte (1861) óta folyamatosan zajlanak, de az indiai civilizáció óriási kiterjedése és a szent helyek folyamatos lakottsága és kultikus használata mindezidáig nem tette lehetővé még a legjelentősebb lelőhelyek akár csak megközelítőleg teljes feltárását sem. A becslések szerint az indiai civilizáció tárgyi-múvészeti örökségének túlnyomó részét ma is a föld rejti, így egy-egy jelentősebb felfedezés nagymértékben megváltoztathatja még a jövőben a civilizációról alkotott képünket.

\section{Korszakolás}

$\mathrm{Az}$ indiai civilizáció történetének nem létezik általánosan követett korszakolása. Főbb fázisait korábban szokás volt hindu, muszlim és brit korszakként leírni. Ez azonban megtévesztő volt, mert úgy tünhetett, mintha a hindu, az iszlám és a brit civilizáció kora egymást váltó korszakok lettek volna a szubkontinens történetében, holott az indiai civilizáció az idegen hódítók államalakító szerepe ellenére sem szünt meg létezni. Ugyancsak elterjedt korábban és részben ma is használatos az ókor, középkor, újkor felosztás, annak ellenére, hogy a nagy történelmi periódusokhoz köthető indiai gazdasági-társadalmi sajátosságok a nyugatiaktól jelentősen eltérnek. Szintén bevett módszer a dinasztiák szerinti korszakolás, amelynek fó fogyatékossága az, hogy az indiai civilizáció történetének egyetlen korszaka sem köthető egyetlen dinasztiához, hiszen a szubkontinens egészét elöször Brit-India (hivatalos angol nevén Indiai Birodalom) egyesítette. A közelmúlt és a ma történetírásában ezért rendszerint olyan korszakolás érvényesül, amely egyfajta vegyes szempontrendszert alkalmazva figyelembe veszi a társadalmi és gazdasági folyamatok dinasztiákon átívelő tendenciáit is. Általánosan elfogadott rendszer híján azonban a korszakolás történeti iskolánként vagy akár az egyes történészek különböző munkáiban is eltérő lehet. Az indiai 
civilizáció történetének fő korszakai vegyes szempontrendszert alkalmazva a következők:

$\oplus$ Prehistorikum kb. i. e. 1500 -ig

- Indus-völgyi civilizáció kb. i. e. 2600-1900

$\oplus$ Ókor

- Védikus kor kb. i. e. 1500-600

- Második urbanizáció kora kb. i. e. 600-200

- Korai klasszikus kor kb. i. e. 200 - i. sz. 320

- Klasszikus kor kb. i. sz. 320-650

$\oplus$ Középkor

- Kora középkor (hindu dinasztiák kora északon) kb. 650-1200

- Késő középkor (Delhi Szultanátus kora) kb. 1200-1526

$\oplus$ Újkor

- Kora újkor (Mogul Birodalom kora) 1526-1858

- Újkor (indiai brit gyarmatbirodalom és függetlenség kora) 1858-tól máig

\section{Az egyes történeti korszakok fö jellemzöi}

Az emberi megtelepedésnek az öskőkortól kezdve vannak régészeti nyomai az indiai szubkontinensen. Az első jelentős civilizáció az Indusvölgyi civilizáció volt, a mezopotámiai és az egyiptomi mellett az ókori Kelet nagy folyamvölgyi kultúráinak egyike. Közvetlen elözményét a Bolan-hágó keleti oldalán fekvő neolitikus telepek jelentették, amelyek i. e. 7000 körül keletkeztek. Az Indus-völgyi civilizáció előtörténete i. e. 3300 körül kezdődött, érett városi fázisa az i. e. 2600-1900 közötti időszakra tehető. Hatalmas területén, amelyhez pakisztáni (Szind, Pandzsáb, Beludzsisztán), északnyugatindiai (Pandzsáb, Harjáná, Gudzsarát, Rádzsaszthán) és északkelet-afganisztáni területek tartoztak, jelenleg több mint kétezer városa ismert. Összlakosságát 2-5 millió közöttire becsülik. A civilizáció pusztulása valószínűleg klimatikus okokra vezethető vissza, városai i. e. 1700-ra elnéptelenedtek.

Az Indus-völgyi civilizáció hanyatlása egybeesett az indoárja nyelvet beszélő népcsoportok szubkontinensen történt megjelenésével, amelyet északindiai széttelepülésükkel párhuzamosan a védikus kultúra (kb. i. e. 1500-600) kibontakozása követett.

A Gangesz-völgyben lejátszódó ún. második urbanizáció (kb. i. e. 600200) korára tehető a buddhista és a dzsaina vallás kialakulása, ÉszaknyugatIndiában a görög és perzsa hódítások nyomán a hellenisztikus és nyugat-ázsiai hatások érvényesülése, a szubkontinens első nagybirodalmának, a Maurja államnak a létrejötte (10. térkép), valamint Dél-Indiában a tamil kultúra első virágzása. 


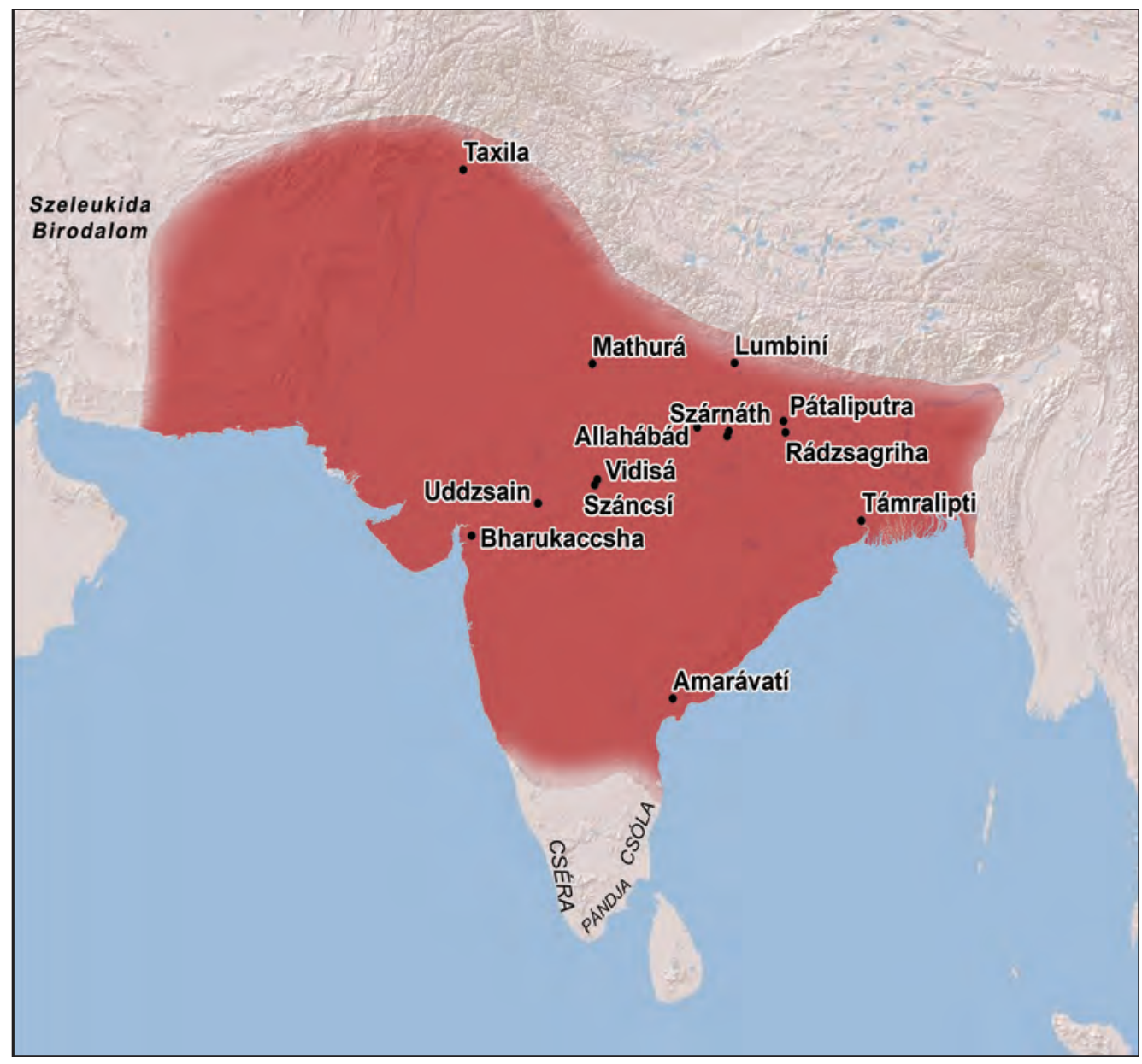

10. térkép: A Maurja Birodalom i. e. 250 körül Forrás: VARGa ÁGNes szerkesztése

A korai klasszikus korszak (kb. i. e. 200 - i. sz. 320) közép-ázsiai és hellenisztikus hatásokat hozott és a buddhizmus második virágkorát a Kusán Birodalom égisze alatt, a klasszikus kor (kb. i. sz. 320-650) pedig a hindu vallás és müvelődés első birodalmi szintü felvirágzását a Gupta állam keretében (11. térkép). A Gupta-Vákátaka dinasztiák nevével fémjelzett korszakot Észak-India aranykorának is nevezik, amely a tudományok, képző- és előadóművészetek, irodalom páratlan felvirágzását hozta egy kifinomult városi kultúra keretében. Dél-Indiában a Pallava-dinasztia a délkelet-ázsiai tengeri kapcsolatok kiépítésével alapozta meg hatalmát. 


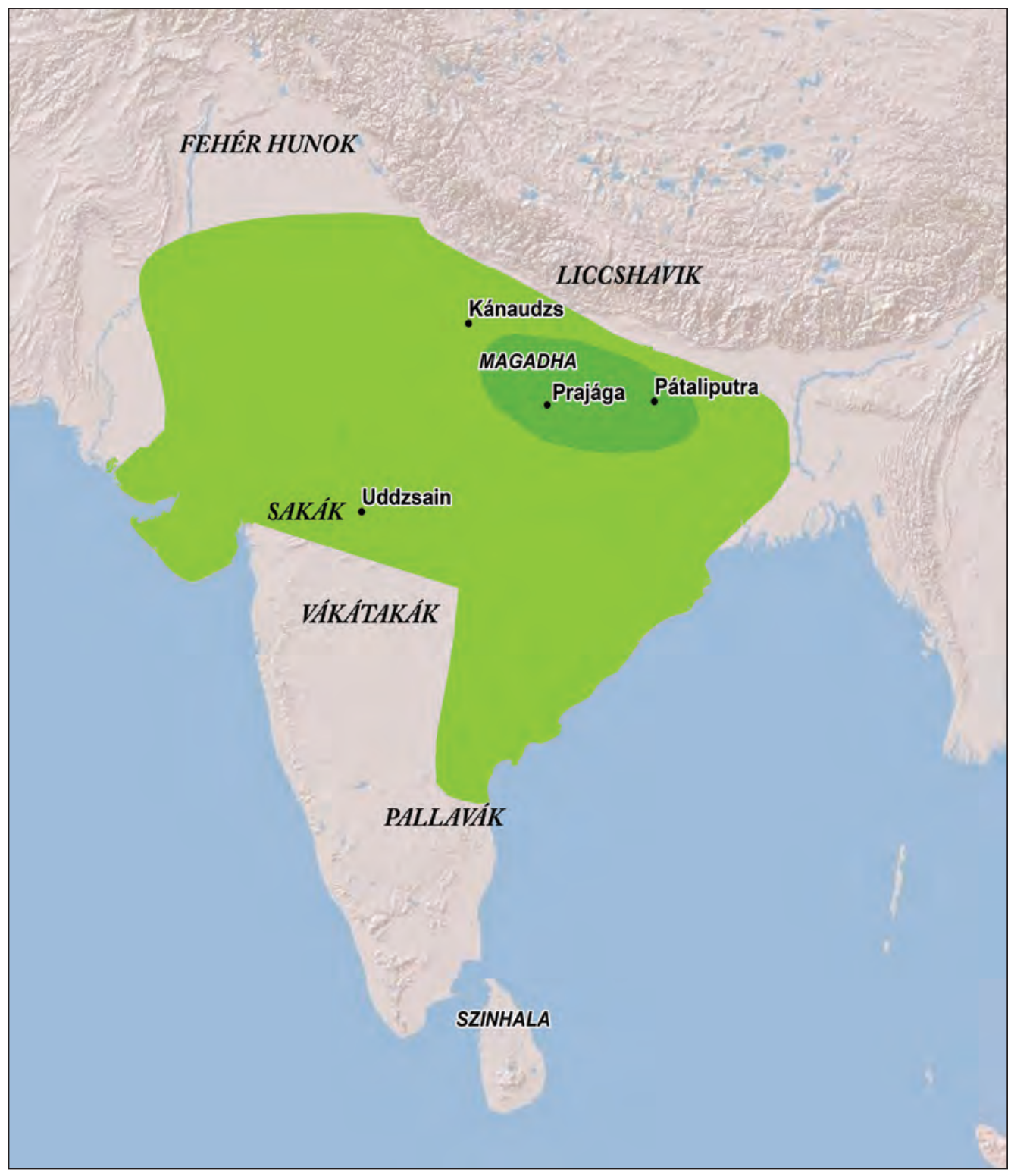

11. térkép: A Gupta állam és szomszédai i. sz. 400 körül Forrás: VARGA ÁGNes szerkesztése

A korai középkort (kb. 650-1200) a politikai széttagolódás és a hindu dinasztiák hatalomra kerülése, északon az iszlám hódítók sürüsödő betörései jellemzik. A késő középkor századai (kb. 1200-1526) északon az indiai iszlám állam (Delhi Szultanátus) és utódállamai kialakulását és terjeszkedését, valamint a muszlim lakosság számarányának növekedését hozzák. A hindu vallásosságot a személyes és odaadó istenszeretetet előtérbe állító bhakti mozgalom elterjedése 
Civilizációk Kelettől Nyugatig

jellemzi; részben ezzel függ össze a szikh vallás kialakulása a Pandzsábban. Dél-Indiában a Csóla Birodalom emelkedik fel nagyhatalomként, majd az észak-indiai iszlám terjeszkedés idején Vidzsajanagar válik a hindu államiság letéteményesévé. Északon a rádzsput fejedelemségek veszik fel a harcot a terjeszkedő iszlám hatalommal szemben.

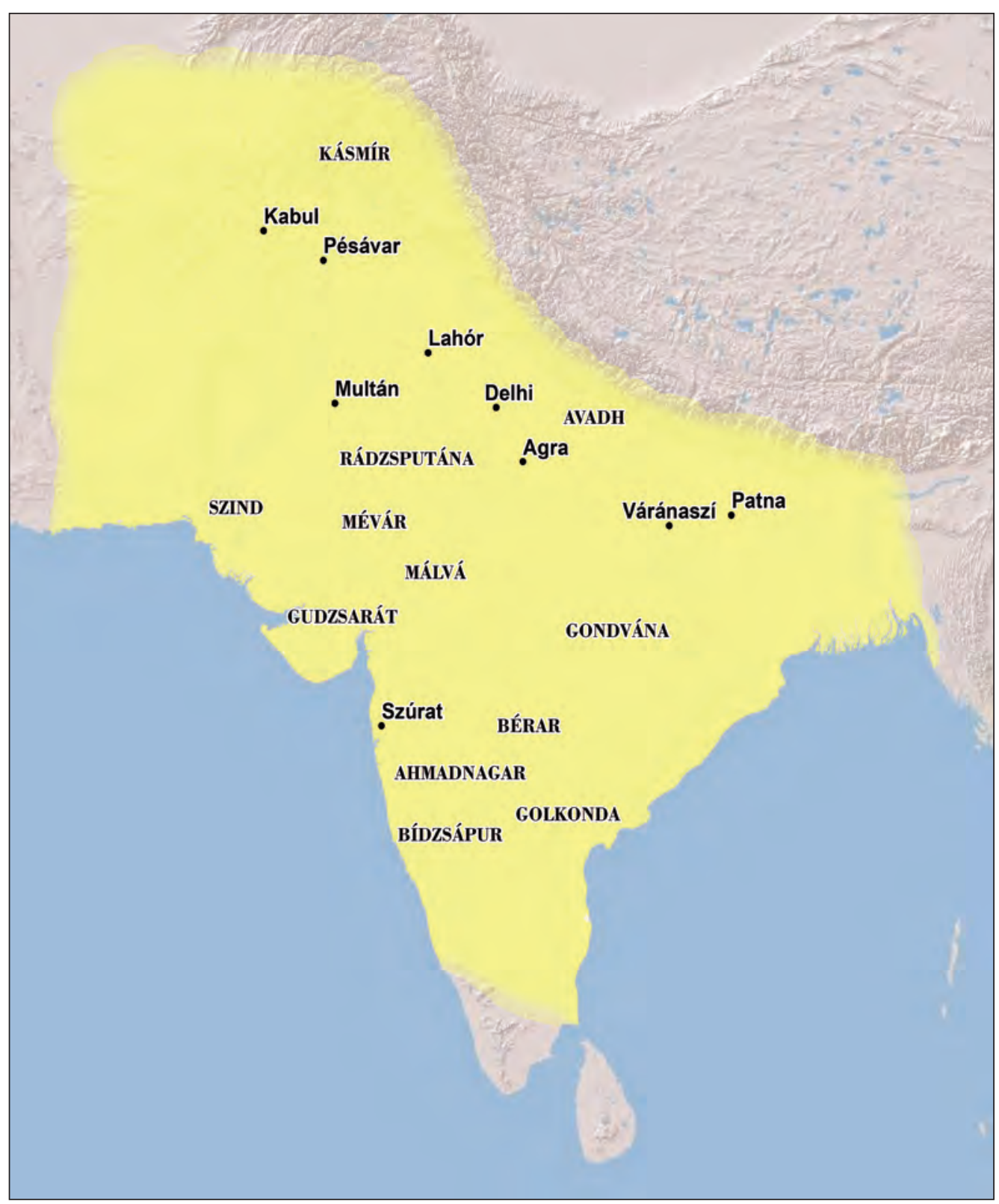

12. térkép: A Mogul Birodalom legnagyobb kiterjedése (17. század vége, 18. század eleje) Forrás: VARGa ÁgNes szerkesztése 
A kora újkorban (1526-1858) újabb iszlám hódítók, a Mogulok hoznak létre az eddigieknél hatalmasabb és csaknem az egész szubkontinensre kiterjedő iszlám birodalmat (12. térkép), amellyel szemben azonban az ellenállás is megszületett a szikh és a marátha állam formájában.

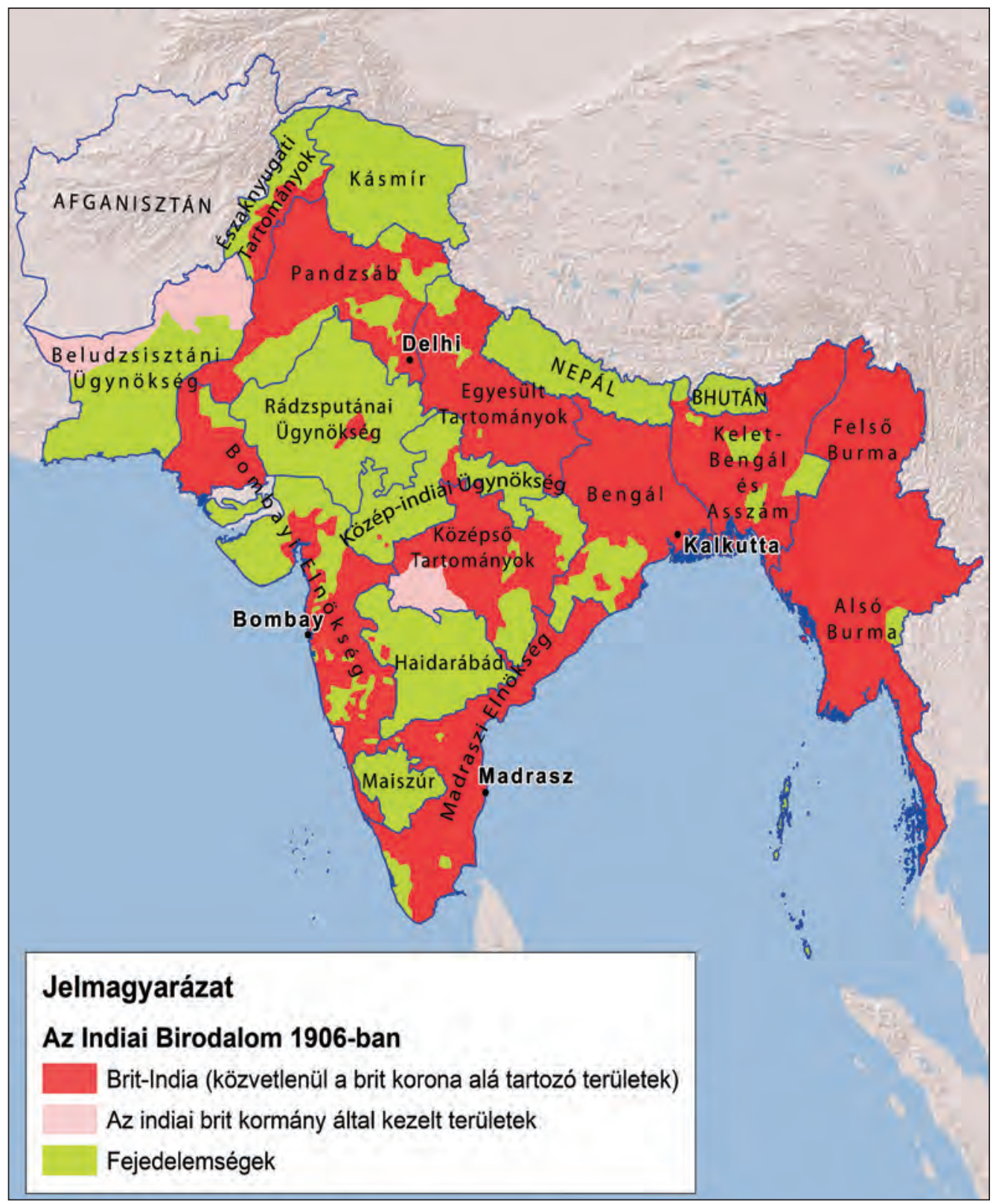

13. térkép: India a brit fennhatóság idején 1906-ban Forrás: VARGA ÁGNES szerkesztése 
Ez a kolonizáció kora is: az európai kereskedők ekkor vetik meg a lábukat a tengerparti területeken. A nyugati hatalmak itteni vetélkedéséből a britek kerülnek ki győztesen, s innen egyenes út vezet az indiai brit gyarmat kialakulásához. Mérföldkő ebben az ún. szipolylázadás leverése, ugyanis ezt követöen 1858-ban a Kelet-Indiai Társaság helyén a brit korona veszi át a gyarmati területek kormányzását (13. térkép). A kibontakozó függetlenségi mozgalom a 2. világháború után, 1947-ben elvezet a független Indiai Köztársaság kikiáltásához, valamint India és Pakisztán szétválásához.

\subsubsection{Az indiai civilizáció fő fejezetei}

\section{Az Indus-völgyi civilizáció anyagi kultúrája}

Az Indus-völgyi civilizáció, amely nagy és jól tervezett városairól ismert, az első urbanizációs periódust képviseli a szubkontinens történetében. Jóllehet sem civilizációs teljesítményeinek, sem pedig azok létrehozóinak összefüggése a szubkontinens későbbi civilizációjával nem ismert, a párhuzamba állítható jelenségek nagy száma mégis megengedi valamiféle, ma még nem tisztázott kontinuitás feltételezését. A nyitott kérdések megválaszolását hátráltatja, hogy rendelkezésre álló ismereteink szinte kizárólag a régészet által feltárt maradványok értelmezésén alapulnak. Az Indus-völgyi írás máig megfejtetlen, sőt jellegének megítélésében is jelentős különbségek mutatkoznak. Az egyik feltételezés szerint kép- és szótagírás, amely egy korai dravida nyelv lejegyzésére szolgált, míg az ellenkező álláspont szerint nem írás jellegủ szimbólumrendszer. Négyszázat meghaladja ugyan az ismert írásjelek száma, de ezek pecsételőkön, kisméretü táblácskákon, kerámiaedényeken maradtak fenn, s a feliratok átlagos hossza mindössze 4-5 karakter. Jelenleg tehát az sem minden kétséget kizáróan eldöntött kérdés, hogy az Indus-völgyi civilizációnak volt-e írásbelisége. Számos kutató úgy véli, hogy egy ilyen méretü és szervezettségü civilizáció nem lehetett meg írásbeliség nélkül, és feltételezi, hogy romlandó anyagot használtak írás céljára, aminek következtében az írásos emlékek mind elpusztultak.

A civilizáció egészében magas fokú tervezettség és szabályozottság valósult meg, ami erős központi hatalom meglétére utal. Ennek a hatalomnak a mibenlétéről azonban semmiféle információ nem áll rendelkezésünkre. A legjelentősebb városok (Mohendzsó-dáró, Harappá, Lóthal, Kálibangan) citadellatömbre és alsóvárosra tagolódtak, mindkettőt fallal vették körül. Feltételezik, hogy a citadella az elit lakhelyéül szolgálhatott, de uralkodói palota vagy nagyméretű sírépítmény nyoma nem bukkant elő. A legismertebb építmény Mohendzsó-dáró citadellatömbjében az ún. Nagy Fürdő, egy téglával burkolt és bitumennel vízmegtartóvá tett medence, amely sokakban a dél-indiai templomi medencék párhuzamát idézte fel. Valószínünek tarthatjuk, hogy Mohendzsó-dáró 
Nagy Fürdőjének építőit rituális célok vezérelték. A medence körül apró cellák sorakoztak, amelyeket talán papok használhattak. Azonban egyik városban sem tártak fel olyan épületet, amelyik egyértelmüen templomként lenne azonosítható.

Az alsóvárosban az észak-déli és kelet-nyugati irányban futó utcák szabályos hálót alkottak és derékszögben metszették egymást. Ez a fajta várostervezés, sőt az utcák hierarchiája a civilizáció későbbi fázisaiban a vásztusásztrák (építészeti kézikönyvek) leírásaiban és az ezek alapján megvalósított városépítkezésekben köszön vissza. Az alsóvárosban állt a lakóépületek nagy része, amelyek az utca felé csaknem zárt, gyakran kétszintes épületek voltak a belső udvar köré épített lakóhelyiségekkel, igen hasonlóan a tehetősészak-indiaivárosi kereskedőktipikusközépkoriéskoraújkorilakóházaihoz (havélí). Feltünő a vízellátottság és a korszakban páratlan csatornarendszer. A városokban elszórtan közkutak álltak, de a nagyobb házaknak saját kútja is volt a kapun belül (középkori párhuzama pl. a gudzsaráti Ahmadábád régi városrészében látható). Sok házban volt fürdőszoba, a szennyvizet a főutcákon húzódó fedett csatornákba vezették. A házak lapos tetejét különféle célokra használták, ahogyan ma is. Az alsóvárost elsősorban kereskedők és kézmüvesek lakták, akik jól elhatárolt városrészekben éltek. A külső részeken voltak a kézmüvesek, boltosok, munkások, parasztok zsúfolt lakónegyedei. A foglalkozási (kaszti) alapú városszerveződés a dél-ázsiai városok morfológiájának tipikus jelensége a történeti korszakokban is, csakúgy, mint a várost övező falak és a föutak végén nyíló városkapuk. Harappában különféle mesterségeket üzők mühelyeit tárták fel: fazekasok égetőkemencéit, textilfestők kádjait, fémművesek olvasztóüzemét, kagylófaragók mühelyeit és gyöngykészítők fúróműhelyeit. A temetkezésekből előkerült ékszerek - többszörös gyöngysorokból készült övek, nyakékek, stb. a megszólalásig hasonlítanak a korai mủvészet (pl. a Madhja Pradés-i Bhárhut egykori sztúpakerítése) nőalakjain ábrázolt ékszerekhez. A figurális ábrázolások között gyakori a púpos (zebu) bika, amely a későbbi kultúrában is nagy fontossággal bír (a zebut az indiai szubkontinensen domesztikálták). A kisszámú bronzfigura a bronzöntés viaszvesztéses technikájának ismeretét bizonyítja.

Az Indus-völgyi civilizáció a hossz, a tömeg és az idő mérésében magas fokra jutott. A civilizáció teljes területén, fennállásának 700 éve alatt egységes súly- és mértékrendszert használtak. Az építészet és az építési technológia fejlettségéröl tanúskodnak a városokat körülvevő masszív falak, hatalmas téglaplatformok, a folyópartra telepített nagyméretü gabonatárolók, raktárak, dokkok. Akikötőépületek tervezése az árapály és az áramlatok pontos ismeretéről tanúskodik.

A magas fokú urbanizáció ellenére a lakosság nagy része falvakban élt. A vidék túlsúlya és a falvak szerepe az indiai civilizáció fö letéteményeseként a későbbiek során is mindvégig fennmaradt. A feltárt emberi csontvázak alapján az antropológiai szempontból vegyes összetételü népességben a leggyakoribb a proto-ausztraloid és a mediterrán típus. A megélhetés elsődleges forrása 
a földművelés volt, fő táplálékul a búza, az árpa és a hüvelyesek szolgáltak. Háziállatként szarvasmarhát, bivalyt, juhot, kecskét, disznót és talán szárnyast is tartottak. A betakarított terményeket ökör vagy bivaly vontatta kétkerekü kocsikon szállították, hasonlóan ahhoz, ahogy ma is látjuk Indiában. A földmüvelésben az Indus és a Szaraszvatí vízrendszerének éves áradását, valamint kutak vizét hasznosították. Az ekét már a városi fázis előtt is ismerték.

A kereskedelemnek kulcsszerepe volt. Ez biztosította a városok összeköttetését a hátországgal és a szükséges nyersanyagok - zsírkő, lápisz lazuli, karneol, réz, ón, arany - beszerzését. A civilizáció városai között az összeköttetést a folyók jelentették, ezt bizonyítják a folyópartra települt magtárak, ahová a vidék városi fogyasztásra szánt terményeit beszállították. Az Indus-völgyi leletek előbukkanásából ítélve szárazföldi kereskedelmi kapcsolat létesült a szubkontinens belsejével, Afganisztánnal, a Perzsa-öböl tengerparti régiójával és Mezopotámiával is.

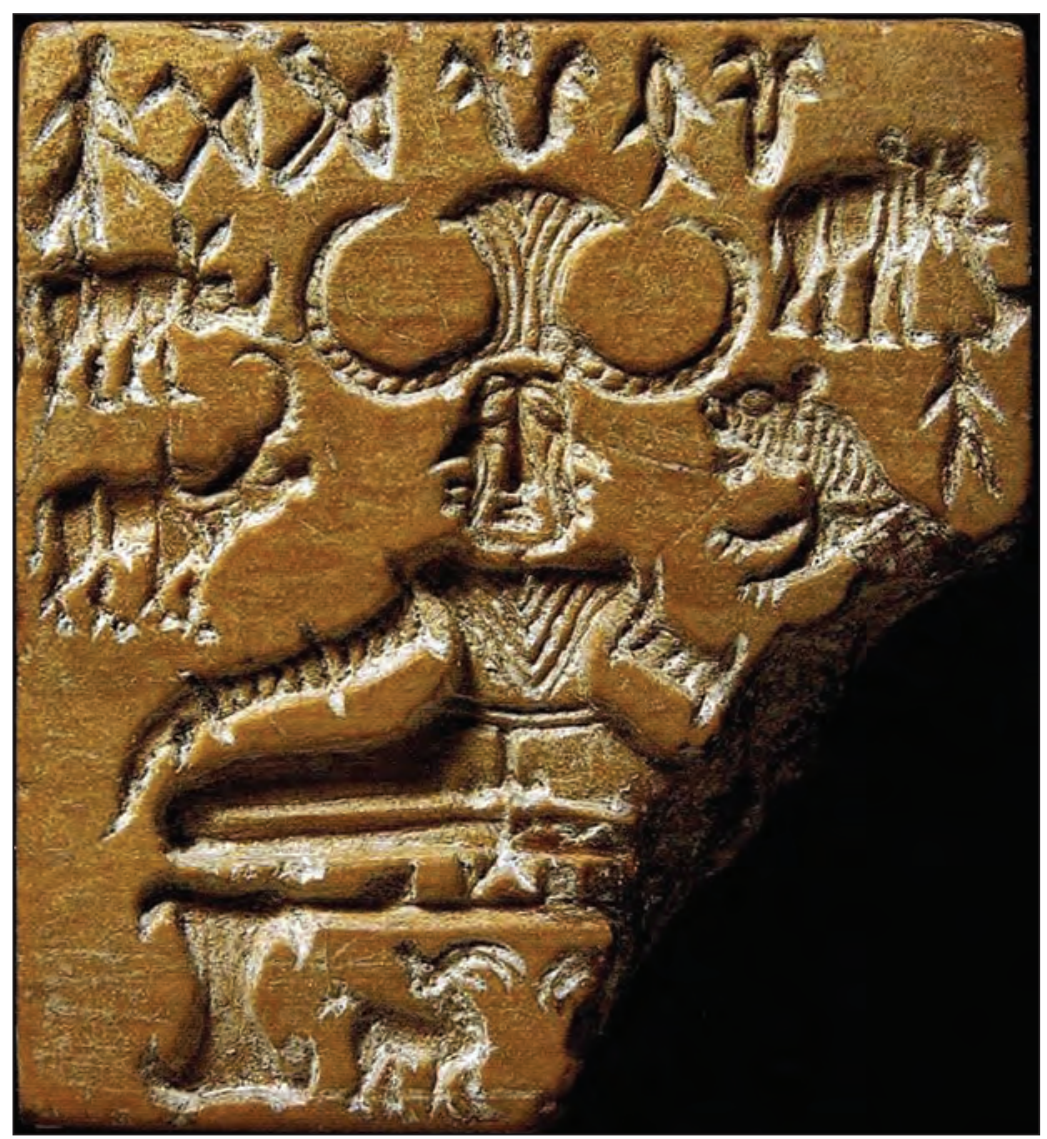

30. kép: Jógapózban ülő férfialak. Indus-völgyi pecsételő, Mohendzsó-dáró (Pakisztán), i. e. $2600-1900$

Forrás: https://commons.wikimedia.org/wiki/File:Shiva_Pashupati.jpg 
Az Indus-völgyi civilizáció vallását nem lehet rekonstruálni, de mindenképpen figyelemre méltó, hogy az Indus-völgyi kultúra számos eleme a szubkontinens későbbi vallásaiban újra felbukkan. A víz feltünő jelenléte a városokban és a „Nagy Fürdő” arra utalhat, hogy a víznek talán már ekkor rituális szerepe lehetett. A terrakotta női figurák a beludzsisztáni földműves közösségek anyaistennő-figuráival rokoníthatók. A pecsételők némelyikének ábrázolásain megjelenő női figurák - a faágak között álló nőalak vagy a hét nőalak csoportja - a későbbi hindu kultuszban is nagy szerepet játszó anyaistennő Indus-völgyi gyökereit, a női termékenység és a természet reprodukciós képességének párhuzamán alapuló ősi jelképiség Indus-völgyi eredetét jelzi. Már az Indus-völgyben felbukkannak a fallikus ábrázolások, a későbbi Siva-kultusz alapvető szimbólumai, és a női termékenységre utaló gyürükövek. A pecsételők jógapózban ülő alakjai a későbbi valamennyi indiai vallásban használt ülésmód, s talán elmélyedési technika ősi gyökereit sugallják (30. kép). A pecsételők ábrázolásai között megtaláljuk a rövid szárú keresztet és a szvasztikát is. A tört szárú vagy horogkereszt, szanszkrit nevén szvasztika (a su + aszti, ,jó-lét” szóból) ősi ázsiai nap- és termékenységi jelkép, az indiai civilizáció vallásaiban, a hinduizmusban, buddhizmusban és dzsainizmusban egyaránt használatos szakrális szimbólum; eredeti jelentésének semmi köze a 20. századi náci Németország rasszista hatalmi jelképéhez. Az Indus-völgyiek halottaikat eleinte eltemették, majd később a hamvasztás és a hamvak urnába helyezése terjedt el.

\section{A védikus árják életmódja, vallása és irodalma}

Az indiai szubkontinensre érkező árják - törzsek, nemzetségek, népcsoportok - radikális változásokat hoztak: lóháton nyargaltak, pásztorkodtak és ló vontatta szekerekkel harcoltak, ami biztosította fölényüket a helyi lakossággal szemben. Vallásukban, amelyet Indián kívülről hoztak magukkal, számos istent és istennőt tiszteltek. Az isteneikhez intézett himnuszokból, imákból, énekekből, továbbá varázsmondásokból és kommentárokból nagy terjedelmű szóbeli költészet és prózairodalom keletkezett, amelyet később gyüjteményekbe rendezve hagyományoztak. A védikus korra - azaz az árják indiai megjelenésének és észak-indiai széttelepülésének korára - vonatkozólag ezek az irodalmi müvek jelentik a fö forrást. Az árják laza törzsszövetsége ugyanis kevert népességet takart, amelynek csak a nyelve volt közös, így antropológiai azonosításuk a régészeti leletek alapján nem lehetséges. Régészeti nyomuk ettől eltekintve is csekély, mivel nomád pásztorok lévén nem építettek városokat. Fő foglalkozásuk a marhatartás volt, a földmüvelést kezdetben a helyi lakosságra hagyták. Kerek vagy négyszögletes kunyhóikat bambuszból, szalmafonatból építették, házaikat és karámjaikat palánkkal és döngölt földböl 
vert fallal vették körül. A Gangesz-völgyi megtelepedés idején keletkezett szövegek már nagyobb, fából épített, többszobás, kerttel körülvett házakról beszélnek. Településeiket sáncokkal erősítették meg. Mindennek azonban semmiféle régészeti nyoma nem maradt.

A védikus kor szöveges forrásai a Védák (innen a kor elnevezése), az árják legrégibb és legszentebb vallási-irodalmi művei. A négy Véda - Rigvéda, Jadzsurvéda, Számavéda és Atharvavéda - magját egy-egy himnuszgyüjtemény alkotja, amelyekhez a későbbiek során terjedelmes kommentárirodalom csatlakozott. Ennek egy része az áldozati rítusok szabályait és magyarázatát tartalmazza (bráhmanák), más része az áldozatok jelképrendszerét fejtegeti (áranjakák), illetve elméleti-filozófiai spekulációkat tartalmaz (upanisadok). A Rigvéda legrégibb himnuszai i. e. 1500 körül keletkeztek a Pandzsábban, míg a három későbbi Véda földrajzi horizontja a Gangesz-völgy betelepülésének folyamatát tükrözi. A Védák a szájhagyományban keletkeztek és örökítődtek, leghitelesebbnek tartott változataik a mai napig szóban hagyományozódnak. Miközben a középkortól írott kéziratok is keletkeztek, a több mint háromezeréves szövegek változatlan formában történő megőrzését a szóbeli hagyományozás folytonossága biztosította. Az átörökítésre komplex recitációs rendszerek jöttek létre, amelyek biztosították a szövegek szó szerinti memorizálását, beleértve a hangok pontos kiejtését, hangmagasságát és a hangsúlyokat is. Ezt a világon egyedülálló rendszert az UNESCO 2003-ban az Emberiség szóbeli és szellemi örökségének részévé nyilvánította. A szóbeliség a későbbiek során is az indiai civilizáció mélyen gyökerező hagyománya maradt.

Az árják vallásgyakorlatának középpontjában az áldozati rítusok álltak, amellyel együtt járt az áldozati adomány megosztása az istenekkel és a közösség tagjaival. A tủzáldozatok során állatokat vagy egyéb áldozati adományt (tejet, tisztított vajat) ajánlottak fel a védikus istenek (dévák) számára. Más típusú áldozatok is léteztek, például az uralkodó felszentelésének rítusa vagy a nagy lóáldozat, amely az uralkodó hatalmát erősítette meg, illetve terjesztette ki, vagy a szómapréselés és -fogyasztás szertartása. Az áldozatokat az istenekhez intézett himnuszok recitálása kísérte. A népes istenvilág természeti erőket és elvont képzeteket megtestesítő tagjai a hierarchikusan felépített világ három szféráját: a földet, a légkört és az eget lakták. A földi szféra istenei közé tartozott Agni, a tüzisten, az áldozati tűz megtestesítője, közvetítő az emberek és az istenek között; Brihaszpati, az istenek tanácsadója és a földi bráhmana papok égi prototípusa; valamint Szóma, a szertartásoknál használt kábító hatású erjesztett ital istene. A levegő istenei a harcos Indra, az istenek királya; Váju, a szélisten; a kiszámíthatatlan és pusztító Rudra és a viharisten Marutok. Az églakók közé tartozik Djausz égisten, a görög Zeusz védikus megfelelöje; a kozmikus rend őrei, Mitra és Varuna; Szúrja napisten és az előtte járó hajnalistennő, Úsasz; és a nap perzselő erejét megszemélyesítő Visnu, aki ekkor még nem emelkedett 
föisteni rangra. Az áldozatok egy része rendkívül bonyolult volt és bemutatása akár több napot vagy hetet is igénybe vett. Az áldozati oltár építésének részletei, a kedvező időpontok megállapítása, a rítusok pontos betartása, a recitálandó szövegek mind olyan tudást igényeltek, amelynek csak a bráhmana papok voltak birtokában, akik nélkülözhetetlenségük révén nagy hatalomra tettek szert. Az áldozatok bemutatói között ksatriják (harcosok, királyok) és tehetős vaisják (közrendủ szabadok) voltak, akik gyermekáldásért, gazdagságért, a föld termékenységéért fohászkodtak. Az áldozatok egy része a mai hinduizmusban is fennmaradt, de az áldozatokban a védikus isteneket a puránikus mitológia későbbi istenei (elsősorban Visnu és megtestesülései, Siva megjelenési formái és az Istennő különféle alakjai) váltották fel. A védikus istenek megváltozott funkcióban (égtájörökként) élnek tovább a hinduizmusban.

\section{Az indiai civilizáció jellegzetes társadalmi szerkezetének kialakulása}

$\mathrm{Az}$ árják hatalmi fölénye nagyon hamar elvezetett a jellegzetes indiai társadalmi szerkezet, a varnarendszer kialakulásához, amely domináns pozíciójukat megerősítette és konzerválta. Négy osztály (szanszkrit szóval varna, „szín”) jött létre: a papok (bráhmanák), a harcosok (ksatriják), a földmüvesek, kereskedők (vaisják) és a szolgarendüek (súdrák) osztálya, amelyek közül az első három az árják közül, a negyedik pedig a többségi szubsztrátum lakosság köréből került ki. A társadalmi hierarchia csúcsán a bráhmana papok álltak, a szent szövegek és az áldozati rítusok kizárólagos ismeröi, később mindenfajta szellemi tevékenység fő letéteményesei.A ksatriják közül kerültek ki a királyok, az ö kezükben volt a hadsereg vezetése, s ezáltal a tényleges hatalom. Míg a ksatriják hozták létre a bráhmanákat is védelmező államhatalmat, s látták el őket adományokkal, addig a bráhmanák voltak egyedül hivatottak a királyi hatalom szentségét és legitimitását biztosítani. Emiatt már a késő védikus korban kölcsönös függés alakult ki a két felső varna között, s rivalizálásuk a társadalmi hierarchiában betöltött vezető szerepért végigvonul az indiai civilizáció történetén. A vaisják osztálya az előző kettőnél jóval népesebb volt, ide tartoztak a szabad közemberek, a kereskedelemmel, földmüveléssel, iparokkal kapcsolatos foglalkozások gyakorlói. A három felső varna tagjai voltak az ún. „kétszer születettek”, akik felnőtt korba lépésükkor beavató szertartásban részesültek, amelynek során rituális státusuk külső jeleként megkapták a szent fonalat. Ezzel másodszor is megszülettek, azaz az árja társadalom teljes jogú tagjává váltak: tanulmányozhatták a szent szövegeket és részt vehettek a szertartásokon és az ünnepeken. A súdrák feladata a másik három osztály kiszolgálása volt. Gazdaságilag alávetett, alacsonyabb rendủ iparokat üző vagy szolgarendü személyek tartoztak ide, akik a „kétszer születettek” rituális kiváltságaiból ki voltak zárva. A későbbiek 
során keletkezett törvények a varnák közötti házasság tilalmával igyekeztek elejét venni a varnák keveredésének, s ezzel konzerválni az árja hódításkor kialakult hierarchiát.

Az i. sz. 1. század körül keletkezett Manuszmriti (Manu törvénykönyve) már egy jóval összetettebb társadalmi rendszert tükröz, amely a varnarendszer differenciálódásával jött létre. Ebben a struktúrában nagyszámú dzsáti (későbbi, portugál eredetủ szóval kaszt) létezett, amelyek endogámiát (csoporton belüli házasodást) gyakorló örökletes foglalkozási csoportok vagy céhek voltak. A kaszt, amelybe az egyén születésénél fogva tartozott, nemcsak a hierarchiában elfoglalt helyét, hanem az életfeladatát és életlehetőségeit is kijelölte. A négy varna mellett népes réteg alakult ki a varnán kívüli érinthetetlenekből, ami összefüggött a rituális tisztaság, illetve tisztátalanság fogalmának kialakulásával, amely a Védákban még nem volt jelen. Az érinthetetlenek (más néven dalitok vagy Mahátmá Gandhi elnevezésével haridzsanok, isten gyermekei) közé rituálisan tisztátalannak tartott foglalkozások űzői, törzsi népcsoportok, nomádok tartoztak, akiknek a társadalom domináns csoportjaival való érintkezésére szigorú megkötések vonatkoztak. A jogaikért folytatott harc vezéralakja a függetlenségi mozgalom idején B. R. Ambedkar jogász, politikus, társadalmi reformer volt, aki maga is érinthetetlen kasztból származott. A kasztrendszert és az érinthetetlenséget a független India alkotmánya eltörölte, ám ennek ellenére mindkettő a mai napig létezik.

\section{Késő védikus kor: a Gangesz-völgy meghódítása}

A Rigvéda elbeszéli, hogyan égették és irtották az árják a Gangeszmedencét borító erdőket, hogy mủvelhető földterületre tegyenek szert. A tüzön kívül lovak, bivalyok, szekerek, kocsik, vízi alkalmatosságok, bronzeszközök, majd az i. e. 12. századtól vasszerszámok is segítették a terjeszkedést. A késő védikus kor (kb. i. e. 1100-600), a Gangesz-völgy meghódításának kora, régészetileg a vaskornak felel meg. Az árják gazdasági életében a marhatartás mellett mind nagyobb jelentőségre tett szert a mezőgazdasági tevékenység. A Jadzsurvéda egy helye szerint több tucat ökörrel szántották földjeiket. A rizs először az Atharvavédában jelenik meg, földrajzilag a középső Gangeszmedencében. Valószínűnek látszik, hogy Kínában vagy Délkelet-Ázsiában domesztikálták, s innen került már kultúrnövényként az indiai szubkontinensre. A Gangesz-medencében kialakuló központok (i. e. 8-6. század) némelyikében királyi dinasztiák emelkedtek fel. Négy állam: Kuru, Pancsála, Kószala és Vidéha létezett ebben az időszakban. A Gangesz-medencével párhuzamosan a Jamuná folyótól délre, a mai Madhja Pradés, Gudzsarát, Mahárástra, Orisza területén is folyt az árják terjeszkedése, ám itt, úgy tünik, szorosabb kölcsönhatás alakult ki a letelepedett földművelő életmódot folytató preárja lakossággal. 
A védikus korszak háborúinak és hódításainak emlékét őrzik India nagy eposzai, a Rámájana és a Mahábhárata. Ma ismert szövegük jóval később, i. e. 400 - i. sz. 400 között keletkezett, de történetük magja a kutatók egy része szerint erre az időszakra megy vissza. A Mahábhárata középpontjában a Kaurava és a Pándava nemzetség nagy csatája áll, amely a hagyomány szerint a Gangesz és a Jamuná közének felső vidékén, i. e. 1000 körül játszódhatott le. A Rámájana Ráma király számüzetésén és Ajódhjá trónjának visszaszerzésén keresztül a félsziget árják általi meghódítását beszéli el, le egészen Srí Lankáig. Formálódásuk hosszú ideje alatt az eposzok a bővítéseket, aktualizálást és módosításokat lehetővé tevő énekmondói hagyomány miatt a feltételezett eredeti változataikhoz képest többszörösükre duzzadtak. E folyamat során a két eposz a hindu hagyomány és mủvelődés valóságos enciklopédiájává, a vallási kötelesség és erkölcs követendő példáinak tárházává bővült. Történeti hitelességüket a hindu hagyomány nem kérdőjelezi meg, bár a kutatásnak mindezidáig nem sikerült ezt régészeti adatokkal hitelt érdemlően alátámasztania.

A védikus kor vége felé a védikus áldozati rítusokhoz füzött legkésőbbi magyarázó szövegekben, az upanisadokban kialakuló filozófiai gondolkodás az ember mikrokozmosza és a világ makrokozmosza közötti kapcsolatot kezdte keresni. Upanisadok a védikus kor vége után is több száz éven keresztül keletkeztek, de az upanisadi filozófia alapvetése szempontjából legfontosabbak a müfaj legrégibb művei, a Brihadáranjaka- és a Csándógja-upanisad (i. e. 800-600 között). Az új gondolatok az egyéni megismerés lehetőségét hangsúlyozzák, $\mathrm{s}$ minden jelenség végső egységét, amelyek csak látszólag különböznek. Az upanisadok legfőbb tanítása az abszolút létező (brahman) és az egyéni lélek (átman) azonossága, amely megvetette a későbbi indiai vallásfilozófia és miszticizmus alapjait. Az upanisadokban megjelenő bölcsek közül sokan ksatriják voltak, az újjászületés (reinkarnáció) ezoterikus tanát is egy ksatrija tanító fejti ki. Az isteni lényeggel való azonosság megtapasztalása véget vethet az újraszületések láncolatának - ebben a reményben minden indiai vallás legfőbb célja fogalmazódik meg. Az upanisadi filozófia szülőhazája a Gangesz keleti medencéje, Vidéha, a védikus kultúra új központja, amiben minden valószínüség szerint szerepet játszhatott a szubsztrátum lakosság vallásának hatása. Az itt megfogalmazódó gondolatok később Sankara (i. sz. 8. század) nagyhatású filozófiájában nyerték el végső szintézisüket. A késő védikus kor filozófiai útkeresésének sokrétüségére utal, hogy a későbbi hindu filozófiai rendszerek közül, amelyeknek az írásba foglalása csak jóval később, az időszámításunk szerinti első századokban történt meg, a szánkhja és a jóga tanai is már ekkor megfogalmazódtak. A szánkhja a világ keletkezését két teremtő elv, a purusa (tudat) és a prakriti (anyag) kettősségéből vezeti le, a jóga filozófiai és gyakorlati rendszere pedig e kettősség megszüntetését elmélyedés (meditáció) révén véli elérni. A szánkhja, a jóga és a védánta a hat ókori indiai ortodox filozófiai iskola (darsana) közé tartozik. 
Az i. e. 600-200 közötti időszakban a Gangesz középső medencéje - Madhjadésa, a „Középső ország” - vette át az indiai civilizáció központi területének szerepét. A vizekben gazdag, termékeny régió egyre nagyobb részét vonták mezőgazdasági művelés alá, a rizstermesztés kiterjedt, a föld eltartó képessége nőtt, a népesség számban és javakban gyarapodott. Az Indus-völgyi civilizáció megszűnése után egy évezreddel újabb urbanizációs folyamat indult el. Ezzel párhuzamosan a korábbi négy állam helyén 16 ún. mahádzsanapada, „nagy ország” alakult ki, amelyek azonban ekkor már nem csupán a Gangeszvölgy középső részét foglalták magukban, hanem a szubkontinens északnyugati részén fekvő Gandhárától a keleti Bengálig terjedtek, s birtokba vették a Gangesz-völgy peremvidékeit, sőt az attól délre eső, a Jamuná és a Narmadá, illetve Táptí folyók között fekvő területeket is. A folyóvölgyek sík vidékei kedveztek a királyságok kialakulásának, míg a hegyvidéki területek jellemző államformája az oligarchikus törzsi köztársaság volt. A városok közötti utak élénk kereskedelmi forgalmat bonyolítottak, aminek biztos jeleként kezdetét vette a pénzverés.

Miközben a késő védikus kortól, de különösen a második urbanizáció korától a társadalom jóval bonyolultabbá, differenciáltabbá vált, a régi védikus vallás belemerevedett a túlzott ritualizmusba és megkérdőjelezhetetlenné tette a bráhmana papok vallási monopóliumát. A városlakókban, különösen azok tehetős rétegében (kereskedők, hivatalnokok) egyre inkább felébredt az igény valamiféle személyesebb vallási tapasztalat iránt. A ksatrija származásúak egy része éppen a bráhmanák túlzott hatalma miatt szintén fogékony volt a közvetítőt nem igénylő vallási tanokra. Az erdőkben megszaporodtak a világtól elvonult remeték, önsanyargató vezeklők, vándoraszkéták, kolduló szerzetesek - összefoglaló néven az ún. sramana-mozgalmak (a sramana, ,vezeklő” szóból) -, amelyeknek vallási eszméi tagadták a bráhmanák által képviselt rituális ortodoxiát. Ezekben születtek meg, illetve öltöttek rendszerezett formát azok az eszmék és elképzelések, amelyek a későbbi indiai vallásosság, közte a formálódó hinduizmus jól ismert sajátosságai közé tartoznak: a világról való lemondás eszméje, az újjászületések szenvedésekkel teli láncolatáról (szamszára) és az ettől való megszabadulásról (móksa) szóló tan. A sramana-mozgalmak közül emelkedett ki s vált önálló vallássá az Indiában ma is létező dzsainizmus és a világvallássá lett buddhizmus.

A két vallás közül valamivel régebbi a dzsainizmus, amelynek alapítója, Vardhamána Mahávíra i. e. 599-527 vagy 540-468 között élt. Ö magát nem tartotta vallásalapítónak, hanem huszonnegyediknek a tírthankarák (szkt. „ösvénycsináló”, „gázlókészítő”) sorában. Akárcsak ifjabb kortársa, Gautama Sziddhártha, ksatrija fejedelmi család sarja volt. A hercegi rangról lemondva 
vándorszerzetesnek állt, s 12 évi önsanyargató aszkézis után a test kötöttségein és az érzékeken felülkerekedve elérte a megvilágosodás állapotát és felszabadult az újjászületések láncolata alól. Ettől kezdve neve Dzsina („Győztes”). Tanai hirdetésének három évtizede alatt tanítványait szigorú szerzetesrendbe szervezte és a világi hívőkre vonatkozó életmód elöírásait is lefektette. Tanításának alapköve a lélek tökéletesítése és teljes megtisztítása azoktól az anyagi jellegü szennyeződésektöl, amelyek a tettek következményeként tapadnak rá, s újjászületések sokaságán át kötik a fizikai testhez. Ebből következően a szennyeződésektől való megszabadulás egyszersmind az újjászületéstől való megmenekülést is jelenti. A lélek (dzsíva) attól kezdve a mindentudás örök ragyogásának állapotában létezik. Addig azonban hosszú időnek kell eltelnie, akár születések sorának. Ezért a földi lét célja nem a közvetlen megvilágosodás keresése, hanem a fegyelmezett, érdemszerzö, erkölcsös életmód és a nemártás legfőbb elvének gyakorlása minden élet, emberi és állati, tiszteletben tartásával. A szerzetességhez mindezek mellé a szerzetesi fogadalmak betartása és aszkétikus életmód társult. Ez utóbbiban Dzsina saját példájával járt elöl: 72 éves korában úgy halt meg, hogy halálra éheztette magát.

A későbbiek során a dzsaina szerzetesrendnek két fő szektája alakult ki: a digambara (szkt. „égruhájú”, azaz ruhátlan) rend, amelynek tagjai a test igényeinek elnyomásában odáig mentek, hogy a ruhaviseletről is lemondtak, és a svétámbarák, azaz a fehér ruhájúak, akiknek szerzetesi elöírásai a digambarákéinál kevésbé szigorúak. Mindkét szekta ma is létezik. A dzsaina vallás mindenféle erőszakot, ártást tilt. A szerzetesek söprögetik az utat a lábuk előtt, nehogy valamilyen apró élölényre rálépve kioltsák annak életét, $\mathrm{s}$ szájuk elött maszkot viselve akadályozzák meg, hogy akaratlanul beszippantva történjék hasonló. Ugyanezért a világi hívek számára kerülendőek a földmüvelö foglalkozások, hiszen pl. szántás közben a földben lakó állatok sérülhetnek. Mind a szerzetesek, mind a világi hívők szigorú vegetáriánus étrendet követnek. A mezőgazdasági foglalkozások tilalma miatt elsősorban városlakók, közöttük is sok kereskedő vált a dzsaina vallás követőjévé. A törekvő, tevékeny élet pozitív vallási megerősítése is hozzájárulhatott ahhoz, hogy a dzsaina kereskedőközösség az egyik legsikeresebb India számos jól müködő kereskedőközössége között. Adományaik a szerzetesi közösségek fenntartásához és a dzsaina templomépítészet és művészet virágzásához is hozzájárultak. A dzsainizmus számos fontos monasztikus központtal és zarándokhellyel rendelkezik, amelyek Nyugat- és Dél-Indiában koncentrálódnak. A faragványokkal gazdagon díszített, gyakran fehér márványból épített dzsaina templomok föszentélyében Dzsina ábrázolását helyezik el. A dzsaina vallás nagy terjedelmű irodalmi hagyatékot is magáénak mondhat, amelynek müvei magadhai prákrit, szanszkrit és újind nyelveken íródtak. Kanonikus szövegei az ágamák. A dzsaina vallás nem folytatott térítő tevékenységet, hanem megmaradt Indián belül, illetve csak 
a diaszpóra kialakulásával került India határain kívülre. Indiában viszonylag csekély számaránya (az összlakosság nem egészen 0,4 százaléka, mintegy 4,5 millió fö) ellenére szilárdan tartja magát. 2014-ben nemzeti kisebbségi státuszt kapott.

A buddhizmus alapítója, Gautama Sziddhártha, a későbbi Buddha („Megvilágosodott”) (31. kép) feltételezhetően i. e. 563 és 483 között élt. (Életének pontos dátumait illetően különbözö buddhista hagyományok és kutatói elképzelések léteznek.) Életéről kevés biztosnak mondható adatáll rendelkezésre. Legendás és csodás elemekkel egybeszőtt életrajzát (Buddhacsarita) Asvaghósa írta meg szanszkrit nyelven az i. sz. 1. században. Történeti személy volt, a mai India és Nepál határvidékén, Lumbiníban látta meg a napvilágot a sákja törzs királyának fiaként. Erre utalnak későbbi nevei: Sákjamuni („Sákják bölcse”) és Sákjaszimha („Sákják oroszlánja”) is. Fogantatását és születését csodás jelek kísérték, s testi jelei alapján a látnokok azt jövendölték, hogy világuralkodó vagy világot megváltó próféta válik belőle. Trónörököshöz illő neveltetésben részesült, tanulmányokat folytatott, megházasodott, fia született, ám mindez nem elégítette ki. A hagyomány szerint az öregséggel, betegséggel, halállal szembesülve ébredt rá az evilági lét szenvedésekkel teli természetére, s szerzetesnek állt, hogy a kivezető utat megtalálja. Különféle szerzetesi iskolákhoz csatlakozott, sanyargatta magát, mígnem rájött, hogy a túlzott aszkézis nem vezet sehová. Elvetette hát a vezeklés szélsőségeit, de a világi kényelmet is, s helyette a „középút” követését tüzte célul. Miután a szenvedés problémájára hosszú ideig hiába kereste a választ, elhatározta, hogy egy fa alá leülve addig meditál, míg a szenvedésből kivezető utat meg nem találja. Hétszer hét napi böjt és elmélyült meditáció után felismerte a szenvedés okát és megtalálta a szabadulás módját - azaz megvilágosodott.

Első prédikációját a Benáresz melletti Szárnáthban tartotta, ahol a hagyomány szavaival „megforgatta a Tan kerekét”. Élete hátralevő 44 évében vándortanítóként a felismert igazságot hirdette, amelynek alaptézisei a „négy nemes igazság” és a „nemes nyolcrétü ösvény”. A „négy nemes igazság” így hangzik: az élet szenvedés; a szenvedés oka a vágy és a ragaszkodás; a szenvedés megszüntethető a vágyak kioltásával; a szenvedés megszüntetésének módja a nemes nyolcrétü ösvény követése. Ez pedig a következő: helyes szemlélet, helyes szándék, helyes beszéd, helyes cselekvés, helyes életmód, helyes erőfeszítés, helyes gondolkodás, helyes elmélyedés. A Buddha a mindennapi életben az erkölcsös magatartást tartotta feltétlenül követendőnek. A világi hívő számára öt elöírást fogalmazott meg: ne ölj, ne lopj, ne paráználkodj, ne hazudj, ne részegeskedj. A szerzetesekre ezen kívül nőtlenségi és szegénységi fogadalom vonatkozott. A szerzetesek közössége (szangha) és világi követőinek száma gyorsan növekedett, és tehetős támogatói is akadtak. A Buddha elvetette a Védák feltétlen tekintélyét és a bráhmanák születési elöjogait. Bár tanítványai 
nagyrészt a bráhmanák és a ksatriják közül kerültek ki, ez nem zárta ki, hogy alacsonyabb származásúak is csatlakozzanak a közösséghez. Az apácarend létrehozásával nők felvételét is engedélyezte a rendbe. Tanítványainak egy része már ekkor útra kelt és India-szerte hirdette a tant. A Buddha megvilágosodásával elvágta újjászületései láncolatát és Kusinagarában bekövetkezett halálával a nirvánába (szkt. „kialvás”, a létkötöttségektől való megszabadulás) távozott. Testét elhamvasztották, szétosztott maradványai felett földhalmokat (sztúpákat) emeltek.

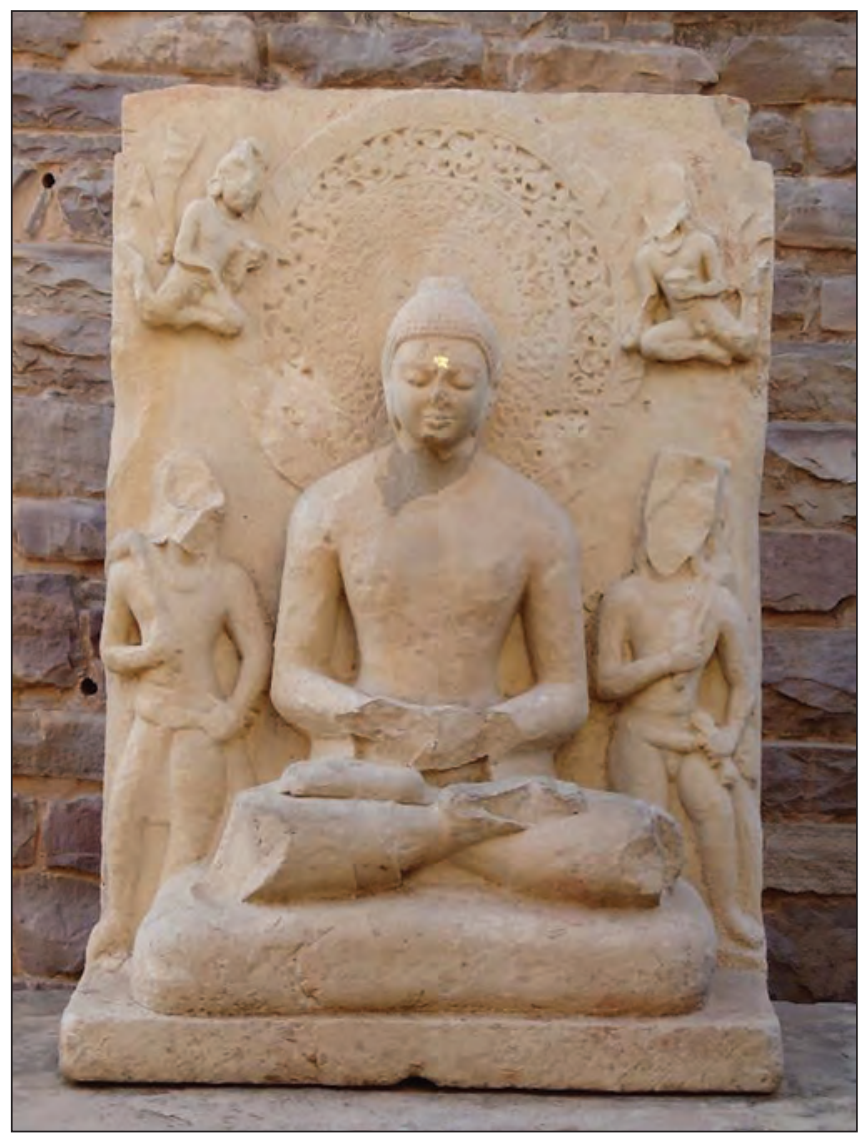

31. kép: Meditáló Buddha. Dombormű a Nagy Sztúpa keleti oldalán. Száncsí (Madhja Pradés), Gupta korszak, 5. század közepe körül

Forrás: RenNer Zsuzsanna felvétele

A Buddha tanait nem foglalta írásba és nem jelölt meg utódot. Tanítványainak és követöinek elkülönülését a szangha biztosította: a sáfrányszínű köntös, a rendszeres találkozók, az egybegyültek egyhangú döntésével hozott határozatok. A hagyomány szerint a Buddha halála után Rádzsagrihában összeültek a rend tagjai és megállapították a tan (páli dhamma) 
és a szerzetesi fegyelem (vinaja) főbb pontjait, ahogyan az a tanítványok emlékezetében élt. A tan hosszú ideig szájhagyományban őrződött meg. Az időről időre összeülő tanácskozások arra törekedtek, hogy a Buddha hitelesnek tekintett tanait megerösítsék, ám a nézetkülönbségek fokozódtak, és a buddhizmus felekezetekre szakadt. A tanok i. sz. 1. században történt lejegyzése - páli nyelven Srí Lankán, szanszkritul Kásmírban - megpecsételte a ma ismert két fó ág, a théraváda és a mahájána buddhizmus kettéválását. A théraváda - a thérák (páli „vének”), azaz a Buddha közvetlen tanítványainak tana - Indiától délre, Srí Lankán és Délkelet-Ázsia országaiban: Burmában, Thaiföldön, Laoszban és Kambodzsában terjedt el, ezért déli buddhizmusnak is nevezik, míg a mahájána (szkt. „,nagy kocsi”, „széles ösvény”) Indiától északra: Ladakhban, Nepálban, Tibetben, Mongóliában, Kínában, Koreában és Japánban hódított, ezért északi buddhizmusként is ismert. Belöle nött ki viszonylag késői fejleményeként a vadzsrajána (szkt. „,gyémánt kocsi”, „gyémánt ösvény”) vagy tantrikus buddhizmus, amelynek ezoterikus rendszerében a szellemi emanációk, a nagyszámú bódhiszattva, köztük félelmetes istenségek és mindezek női megfelelői komplex rendszert alkotnak. Emellett fontos szerephez jutnak a mantrák (varázsformulák), a mandalák (mágikus diagramok) és az egyéb rítusok. A théraváda ideálja az arhat, a nirvánát elért szerzetes, aki egyéni öntökéletesítés útján már a földön megszabadult a vágyak kötöttségétől és a halálban teljesen megsemmisül. Ez az út azonban csak kiválasztott kevesek számára áll nyitva, emiatt ezt az irányzatot a mahájána hívei némi gúnnyal hínajánának (szkt. „kis kocsi”, „keskeny ösvény”) nevezték. A mahájána hívei, éppen ellenkezőleg, abban hittek, hogy maguk is elérhetik a megvilágosodást. A mahájána ideálja a könyörületes és önzetlen bódhiszattva (szkt. „megvilágosodás lényegü”), azaz olyan személy, aki eljutott a megvilágosodás fokára, de lemond a nirvánáról, hogy a földi létszférában maradva segítse a híveket a megvilágosodás felé vezetö úton.

A déli buddhizmus kánonja a Tipitaka (páli „Hármas kosár”), azaz hármas gyüjtemény, amelynek részei: 1. Vinaja-pitaka („,Fegyelem kosara”), a szerzetesi közösség rendi szabályainak gyüjteménye; 2. Szuttapitaka („Tanítóbeszédek kosara"), amely Buddha beszédeit és mondásait tartalmazza, s mint ilyen, a Tan fó forrása; 3. Abhidhammapitaka („Magasabb Tan kosara”), a Tan skolasztikus kifejtése. A théraváda iskola által összeállított kánon évszázadokig szájhagyományban őrződött meg, majd a Srí Lanka-i hagyomány szerint a harmadik zsinat után Mahinda, Asóka király fia vagy öccse vitte Srí Lanka szigetére, ahol az i. e. 1. században írásba foglalták. A mahájána tanait szútrák tartalmazzák. A legfontosabbak közé tartozik a Mahávasztu, a Lalitavisztara, a Divjávadána és a Szaddharma Pundariká. Az eredeti szanszkrit szövegek egy jelentős része kínai és tibeti fordításban maradt fenn. Mindkét hagyomány úgy tekinti magát, mint amelyik Buddha eredeti tanításait örzi. 
A tizenhat mahádzsanapada közül a legkeletibb, a Gangesztől délre fekvő Magadha (a mai Bihár állam területén) Pátaliputra fővárossal a szubkontinens birodalmi törekvéseinek kiinduló pontjává válva a többi mahádzsanapada rovására rohamosan terjeszkedett. Ez idő alatt a szubkontinens északnyugati részének Induson túli területei két évszázadra a perzsa Akhaimenida Birodalom fennhatósága alá kerültek. Gandhára fővárosában, Taksasílában (Taxila) a védikus és az iráni müveltség egyaránt jelen volt. A perzsa uralomnak Nagy Sándor hadjárata vetett véget, aki i. e. 326-ban betört Indiába. Átkelve a Hüdaszpész (ma: Dzshélam) folyón gyözelmet aratott az ellene vonuló indiai hadak felett, de katonái lázadása miatt letett a további indiai hódítás tervéről. Seregével végigvonult az Indus mentén, majd helytartókat hagyva hátra csapatai egy részével szárazföldi úton hagyta el Indiát, csapatai másik része hajóra szállva tért vissza Perzsiába. Bármilyen átmeneti is volt azonban Nagy Sándor indiai tartózkodása, messzemenő következményekkel járt, mert megnyitotta a hellenisztikus világ és India között azt a kommunikációs csatornát, amelyen attól kezdve több évszázadon át görög és perzsa kulturális hatások érkeztek az indiai szubkontinensre.

A szubkontinens első nagybirodalmának létrehozása a Maurja-dinasztia nevéhez füződik. A magadhai származású Csandragupta, a dinasztia alapítója, aki i. e. 321 és 298 között uralkodott, Nagy Sándor utódait kiüzve egyesítette Észak-Indiát. Csandraguptát a hagyomány szerint Kautilja (más néven Csánakja), az Arthasásztra („,A haszon tankönyve”) címü politikai és államtudományi mü szerzője segítette a birodalomalapításban. A klasszikussá vált müvet sokan későbbi keletkezésünek tartják, de egyes részei minden bizonnyal a Maurjakorra mennek vissza. Kautilja, Csandragupta föminisztere és tanácsadója a kormányzás minden részletére kitér művében a hadviselés módjától a birodalom megszervezésén át az adózásig. Alaptétele, hogy az állam gazdasági erejénél fogva válik képessé a szomszédain való felülkerekedésre, mert ez teszi lehetővé az erős hadsereg fenntartását. Kautilja felismeri az információszerzés fontosságát, mủvében ennek megfelelő hangsúlyt kap a futárok, kémek, hírvivők rendszere. Csandragupta unokája, Asóka (i. e. 268-232) a legdélibb részek kivételével az egész szubkontinensre kiterjesztette a fennhatóságát, birodalma Bengáltól Afganisztánig terjedt. A kelet-indiai Kalinga megszerzéséért vívott háború során azonban megcsömörlött a vérontástól, $\mathrm{s}$ buddhista hitre tért. Birodalomszerte oszlopokat állíttatott és sziklaediktumokat helyeztetett el, amelyekre buddhista vallási tanokat, valamint kormányzási elveit vésette.

Asóka uralkodói támogatása fordulópontot jelentett a buddhizmus történetében. A kezdeményezésére összehívott harmadik zsinattól datálódik a buddhizmus Indián kívüli térítő tevékenysége. Asóka szerzeteseket küldött India 
határain túlra a szélrózsa minden irányába: északon Gandhárába, Kásmírba és más, a Himalája lábainál fekvő országokba, délen Srí Lankára és Hátsó-Indiába. Bár e missziók közül ez idáig csak a Srí Lanka-i térítés történetiségét sikerült igazolni, a burmai buddhista hagyomány is szilárdan őrzi az Indiából érkezett szerzetesek emlékét. A Srí Lankán létrejött első és sokáig egyetlen buddhista királyság lett később a délkelet-ázsiai buddhizmus elterjedésének és számos megújulásának forrása. A harmadik zsinat azonban nem terjedt ki az egész buddhista közösségre, így feltehető, hogy már ekkor megtörtént az északi és a déli ág elkülönülése.

\section{Írásbeliség}

Az indiai civilizáció írásbeliségének vitatott Indus-völgyi előzményei után a történeti korból fennmaradt legkorábbi összefüggő írások Asóka oszlop- és sziklafeliratai (i. e. 3. század), amelyek mindenütt a helyi prákrit nyelveken íródtak. Lejegyzésükhöz az ún. bráhmí írást használták, amelyböl India és Délkelet-Ázsia valamennyi írása származik, többek között a szanszkrit és a hindi lejegyzésére használt dévanágarí is. Rövidebb bráhmí feliratok az i. e. 4. századból származó edénytöredékeken is fennmaradtak. A bráhmí és származék írásai szótagírások, amelyekben a szótagképző magánhangzókat a mássalhangzókhoz kapcsolódó mellékjelek (ún. diakritikus jelek) jelölik. Asóka északnyugati feliratai ugyanakkor egy másik, az ún. karósthí írással készültek, amelyet Gandhárában, Pakisztánban, Afganisztánban, majd Baktriában és a Kusán Birodalomban használtak.

A feliratok - kőbe, majd rézlemezre vésett változatban - a hindu dinasztiák fennállásának végéig az indiai civilizáció legfontosabb írott emlékei közé tartoznak. Korai időktől fennmaradtak feliratok pénzérméken is. A szerves anyagból készült hordozók (pálmalevél, nyírfaháncs, papír) élettartama a trópusi éghajlat alatt az esetek többségében nem túlságosan hosszú. A szárított és füstöléssel kezelt, átlyukasztott és zsineggel könyvvé összefüzött pálmalevél kéziratok legkorábbi fennmaradt példánya egy 9. századi saiva szöveg, amelyet ma a cambridge-i egyetemi könyvtár öriz. A papírra írott kéziratok átlagos élettartama Indiában általában mindössze 200-300 év, ezért az ilyen kéziratokat tartalmazó könyvtárakat (pl. bráhmana közösségek leszármazási iratait) folyamatosan másolták. A legkorábbi papír alapú kéziratok a középkorból maradtak fenn. A Rigvéda legrégibb kézirata, ugyancsak papír alapon, 1362ből származik és a Bengáli Ázsiai Társaság könyvtárának gyüjteményében található. 


\section{A buddhista müvészet kialakulása}

Az Indus-völgyi civilizáció prehistorikus előzményeit követő mintegy másfél évezredes hiátus után a Maurja-korban jelenik meg újra a művészet. A főváros, Pátaliputra palotájának fennmaradt töredékei perzsa és görög hatást tükröznek; nem véletlenül, hiszen a szubkontinensnek az Akhaimenidák, majd Nagy Sándor által meghódított északnyugati részei - Baktria és az Indus felső szakaszának vidéke - Csandragupta hódítása révén a Maurja Birodalom fennhatósága alá kerültek. Az észak-indiai területegyesítés élénkítőleg hatott a kereskedelemre és a diplomáciai kapcsolatokra. Megaszthenész, a görög történész és diplomata, I. Szeleukosz Nikatór követeként négy évet töltött Csandragupta pátaliputrai udvarában. A kapcsolatok legnyilvánvalóbb hozadéka a hatalmi jelképeket is hordozó művészeti hatások megjelenése a Maurják birodalmi mủvészetében. Ezek közül a legismertebb, az oroszlános oszlopfő nem sokkal később, Asóka uralkodása alatt új szimbolikus tartalommal gazdagodva egyszerre hirdeti a császár (szkt. csakravartin) és a Buddha dicsőségét.

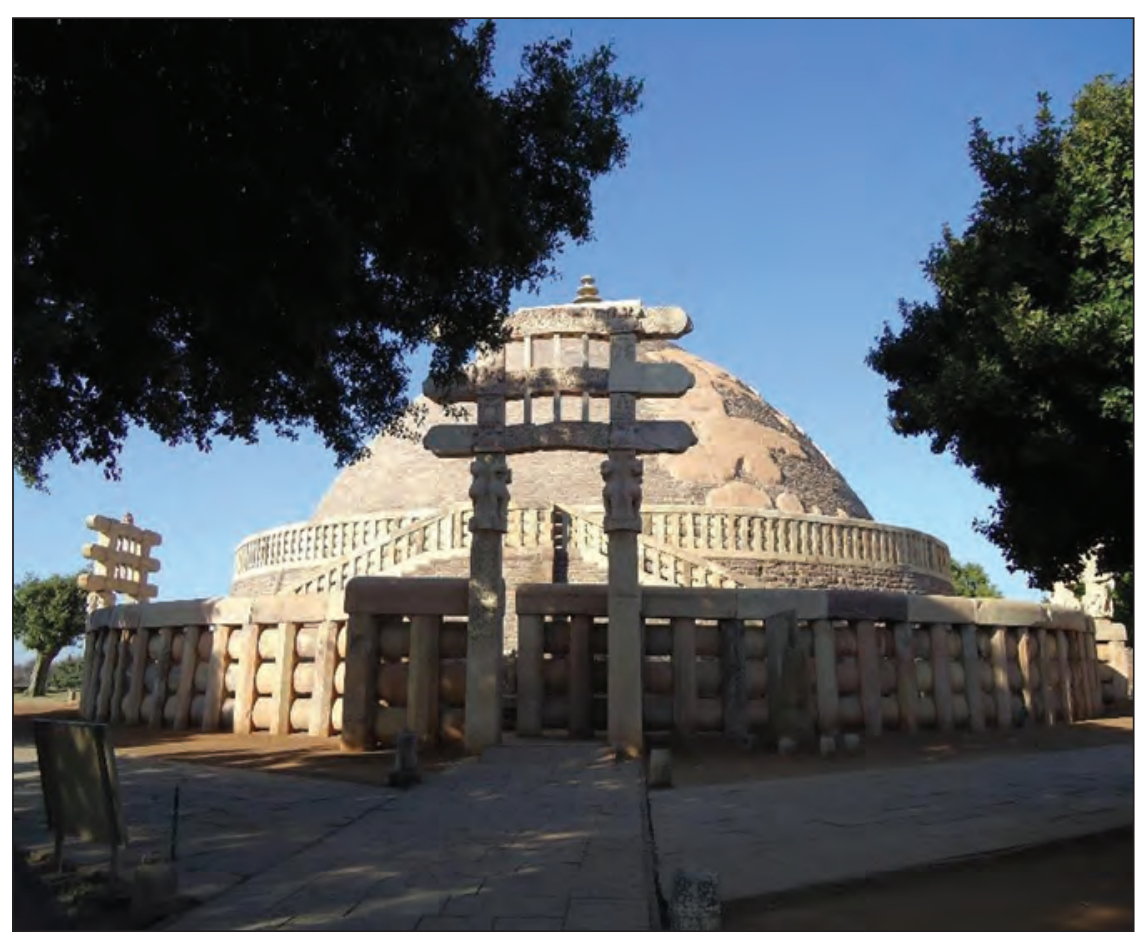

32. kép: A Nagy Sztúpa. Száncsí (Madhja Pradés), i. e. 3. század - i. sz. 1. század Forrás: RenNer Zsuzsanna felvétele

A kialakuló buddhista müvészet számos idegen elemet vett át, de helyi forrásból is táplálkozott: a népi kultusz természeti szellemeinek és félisteneinek 
(jaksák és női párjaik, a jaksik) embernagyságot meghaladó, súlyos és korpulens ábrázolásai fontos szerepet játszottak az indiai típusú Buddha- és bódhiszattvaábrázolások kialakulásában.

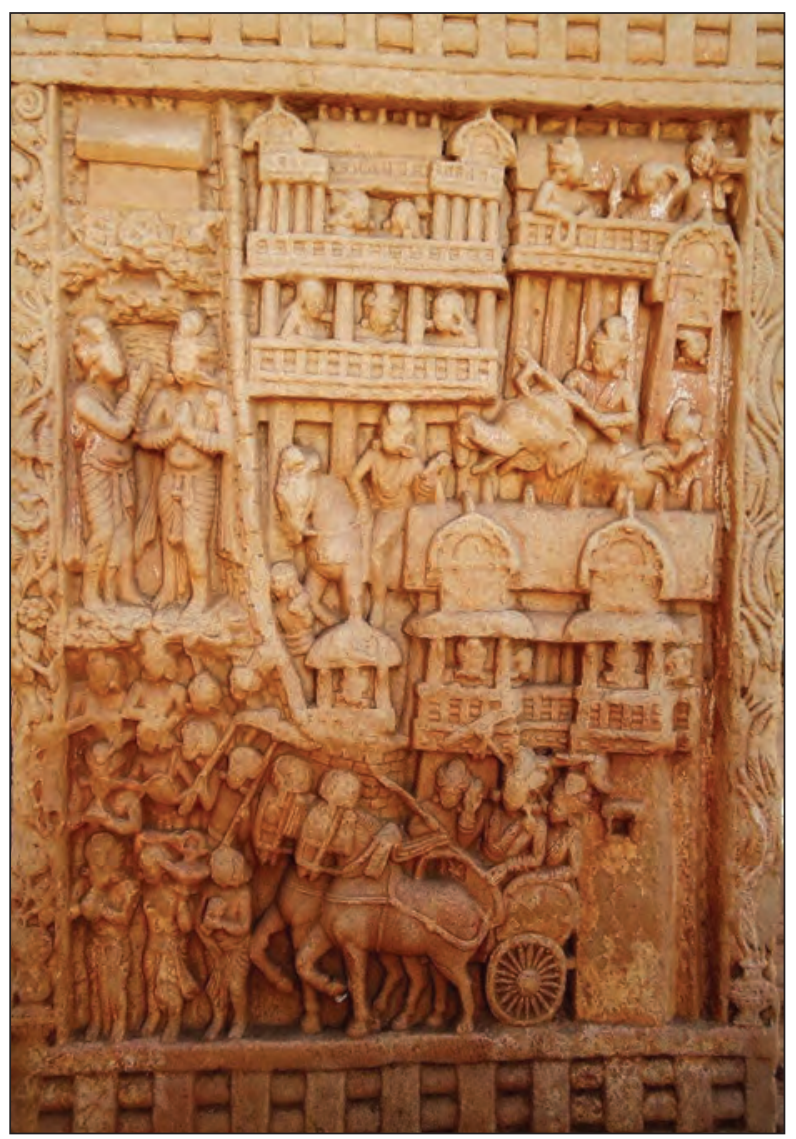

33. kép: Rádzsagriha uralkodója, Bimbiszára kíséretével elhagyja a palotát, hogy meglátogassa a Buddhát. Dombormú a Nagy Sztúpa keleti kapuján. Száncsí (Madhja Pradés), i. sz. 1. század 2-3. évtizede

Forrás: RenNer Zsuzsanna felvétele

A buddhista kultusz legjellemzőbb építménye a sztúpa. Az első sztúpák Buddha testi ereklyéinek elhelyezésére szolgáltak. Kezdetben egyszerü földhalmok voltak, majd téglával, kővel burkolták és kerítéssel vették körül őket. A sztúpa félgömb alakú teste az eget formázta, a középpontjában álló oszlop a világtengelyt (axis mundi) jelképezte. A rituális körüljárásra (szkt. pradaksina, „jobb kéz felé”, azaz a vallási tisztelet tárgyának körüljáráskor mindig a hívőtől jobbra kellett lennie) szolgáló ösvény a nap látszólagos pályájára utalt. A szakrális teret a világi környezettől elválasztó kerítés díszes kapui a négy égtáj irányába nyíltak, s a sztúpa alaprajza szvasztikát, tört karú keresztet, a nap ősi 
jelképét rajzolta ki. A korai sztúpák közül ma is régi fényében látható a száncsí sztúpa (Madhja Pradés) (32. kép). Kerítéskapuit az i. sz. 1. században készült dombormüvek borítják, amelyeken a Buddha életének és előző születéseinek történetei elevenednek meg a korabeli városi és vidéki élet nyüzsgő jeleneteibe ágyazva (33. kép).

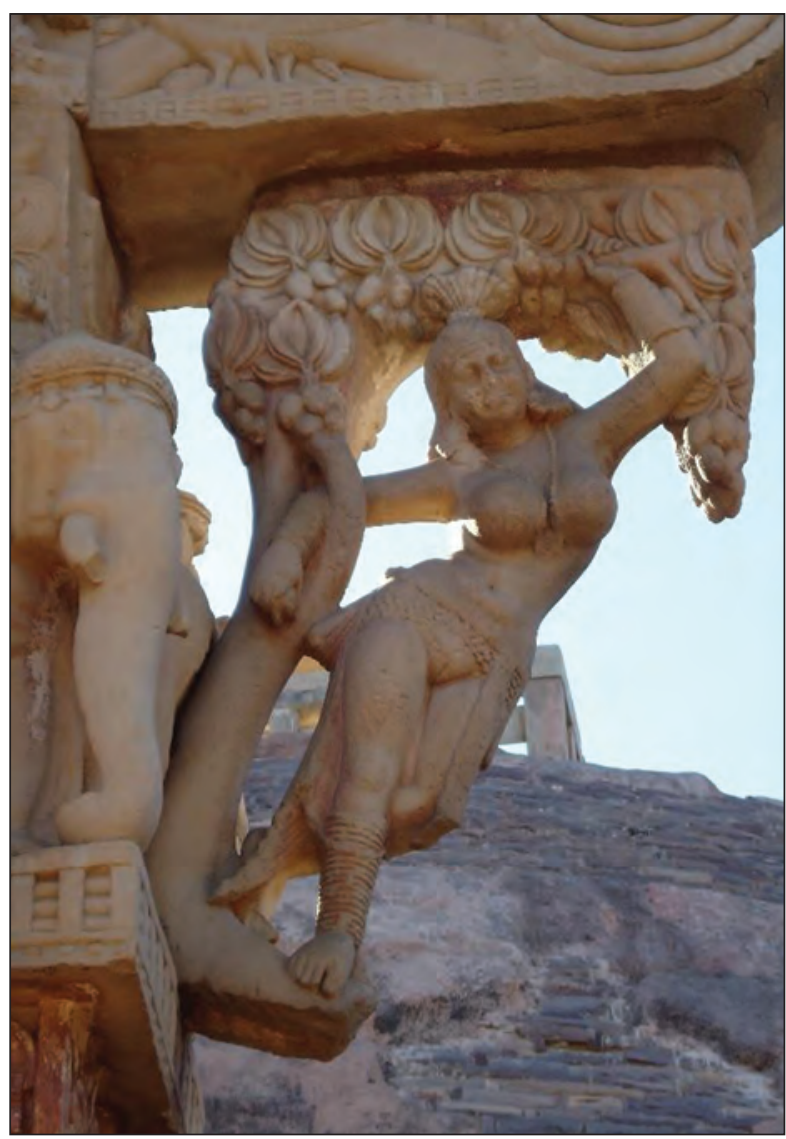

34. kép: Faistennő a Nagy Sztúpa keleti kapuján. Száncsí (Madhja Pradés), i. sz. 1. század 2-3. évtizede

Forrás: ReNnER ZsuzsanNa felvétele

A domborművek adományozási feliratai arról tanúskodnak, hogy a száncsí monasztikus központot és buddhista közösséget számos gazdag kereskedö, céhelöljáró, gazda, városlakó férfi és nő támogatta, ezzel is hozzájárulva a számukra előnyös vallási keretek fenntartásához. A sztúpák környezetében megjelenő csábos nőalakok - jaksík, faistennők -, akiknek dús idomait alig kendőzik a fátyolszerüen áttetsző ruhadarabok, az indiai kultúrának arra az alapvonására világítanak rá, hogy a szakrális mủvészet körébe nem kizárólag szorosan vett vallási ábrázolások és szimbólumok tartoznak, hanem például 
termékenységi jelképek, erotikus ábrázolások is. Ezek az indiai szemlélet szerint kedvező előjelűek és szerencsehozó, megszentelő jelleggel bírnak, így nem idegenek attól a vallási környezettől - legyen az buddhista sztúpa vagy később hindu templom -, amelyben elhelyezésre kerülnek (34. kép). A korai buddhizmus szentélyeit és gyülekező helyeit gyakran barlangcsarnokokban alakították ki. A trópusi nap heve és a monszunesőzés ellen védelmet nyújtó barlang nyilvánvaló éghajlati szerepén túl természetes módon hordozza az indiai templomépítészet alapvető jelképiségét, amely a hegy és a hegymélyi barlang - az istenek égi lakhelyét, illetve földi megtestesülésének helyszínét jelképező szentélytorony és szentély - kapcsolatára épül.

A korai buddhista művészetből hiányzik magának a Buddhának az ábrázolása, jelenlétét csupán szimbólumok - üres trónus, ernyő, lábnyomok, a megvilágosodás fája stb. - jelzik. Mi ennek az oka? A Buddha maga tiltotta, hogy ábrázolják, és ez így is maradt mindaddig, míg emberi mivolta élő hagyomány volt. Amikor a theisztikus vallási tendenciák felerősödésével istenként kezdték tisztelni, ábrázolásai is megjelentek, hozzávetőleg egy időben az északnyugati Gandhárában és a Jamuná folyó partján fekvő Mathurában. A görög müveltségü Baktriát és Észak-Indiát Mathuráig hatalmuk alatt egyesítő belső-ázsiai kusánok a buddhizmus támogatásával hatalmas lendületet adtak a buddhista vallás megszilárdulásának és elterjedésének Kína és Belső-Ázsia felé. Ekkorra tehető a buddhista ikonográfia megszilárdulása, amely nemcsak az indiai szubkontinensen, hanem az egész buddhista világban a szimbolikus Buddha- és bódhiszattva-ábrázolások egységes közös alapjává vált. A Buddhát mindig szerzetesként, borotvált fővel, szerzetesi átvetőben ábrázolják, míg a bódhiszattvák fejedelmi öltözetben, gazdagon ékszerezve jelennek meg. A testés kéztartások kötöttek, és többnyire a Buddha életének fontos eseményeire emlékeztetnek, például a meditációs kéztartás a megvilágosodás előtti elmélyedés heteire, a tanító kéztartás az első prédikációra, a fekvő ábrázolás a nirvánába való távozásra. A természetfeletti mivoltára utaló testi jelek közül a megnyúlt füleket, a hármas nyakredőt, a fej tetején lévő dudort, a szemöldökök közötti szőrcsomót szinte mindig megjelenítik, olykor a tenyéren és a talpakon lévő csakrákat, a térdig érö karokat vagy a hatalmas testméretet is. A Kusán-korban kétféle ábrázolási hagyomány alakult ki párhuzamosan: a hellenisztikus stílus hatása alatt álló gandhárai iskola, amelyből görögös, szinte Apollószerü Buddhák kerültek ki, és a helyi, hús-vér jaksaábrázolások hagyományából kinövő mathurái iskola. A gandhárai iskola alkotta a szubkontinens északnyugati peremvidékén az afganisztáni Bámiján óriás Buddháit a 4-5. században, amelyeket 2001ben az iszlám radikális ágához tartozó tálibok leromboltak. Gandhára stílusa a Selyemút mentén észak felé terjedve mély nyomot hagyott az északi buddhizmus országainak művészetén is. Délkelet-Ázsiában a Buddha-ábrázolások néhány új ikonográfiai típusa is kialakult, és előszeretettel ábrázolják az óriás Buddhákat, 
valamint az előző világkorszakok buddháit. Az északi buddhizmus országaiban a mahájána, illetve vadzsrajána pantheon számtalan bódhiszattvája szolgál az ábrázolások kimeríthetetlen forrásául. Különösen népszerü Avalokitésvarának, a könyörületesség bódhiszattvájának ábrázolása.

\section{A klasszikus korszak müveltsége}

Az indiai civilizáció klasszikus korszaka a Maurja-kor lezárulásával veszi kezdetét és a Gupta-korszak végéig tart. A szubkontinens történetének legfontosabb eseményei ekkor négy fó régióban zajlanak. A Gangesz keleti medencéje továbbra is a szubkontinensen belüli egyesítés és birodalmi ambíciók kiindulópontja. A Maurjákat követő Sungáknak, majd a Gupta-dinasztiának is ez a magterülete. Mindkét dinasztia hindu vallású. Az északkeleti régió továbbra is a szubkontinensre irányuló hódítások bázisa, a kultúrák érintkezésének és keveredésének színtere. Az indogörög, indoszkíta, indopárthus és indoszászánida királyságok (i. e. 2. - i. sz. 1. század), majd a kusánok (i. sz. 1-3. század) tettek itt szert jelentőségre, $\mathrm{s}$ hatalmuk időnként mélyebben is benyúlt a szubkontinens belsejébe. A Dekkánon önálló királyság alakul a Szátaváhana-dinasztia vezetésével, amelynek hatalma az Arab-tengertől a Bengáli-öbölig ívelte át a félszigetet. Dél-Indiában felvirágzik a tamil nyelvü irodalom (szangam-korszak, kb. i. e. 300 - i. sz. 300), amely a dél merev kaszti korlátoktól mentes társadalmi szerkezetét és egy, az északitól egyelőre nagymértékben független klasszikus kultúra kibontakozását tükrözi. A szangam-korszak végére alakul ki Dél-India három meghatározó királysága: a Csóla, a Cséra és a Pándja.

A Gupta-dinasztia, amelynek uralkodását (kb. i. sz. 320-550) az indiai civilizáció aranykorának szokás nevezni, Észak-Indiát és a szövetséges Vákátakák birtokaival együtt a Dekkánt vonta fennhatósága alá. A Gupta uralkodók katonai sikereinek köszönhetően évszázadok óta elöször sikerült az idegeneket kiüzni a szubkontinensről és a birodalmat centralizálni. A megelőző korszakok hosszú fejlődése és a belpolitikai stabilitás kimagasló civilizációs eredményeket és korábban nem tapasztalt, kifinomult városi kultúrát hozott magával, amelynek anyagi alapjához a széles körü távolsági kereskedelem nagyban hozzájárult. Ebböl a korból maradtak fenn a hindu istenek tiszteletére emelt első templomok, és az uralkodói támogatásnak köszönhetően ismét megerősödtek a bráhmanák. Virágzottak a tudományok (orvostudomány, matematika, asztronómia), a filozófia, a szanszkrit irodalom és a müvészetek. Az 5. században élt Kálidásza, a legnagyobb óind drámaíró és költő, aki a szanszkrit nyelvü udvari költészetet és prózát (kávja) soha nem látott magasságokba emelte. Mủvei közül magyar fordításban is olvasható a Kumáraszambhava („Hadisten születése”) címü eposz, a Málavikágnimitra („A király és a bajadér”) c. dráma és a Méghadúta („,Felhökövet”) c. lírai költemény. A müvészetek az ideális formákat keresték. A 
kávja nyelvezete díszes, telve költői képekkel, szójátékokkal, kétértelműségekkel. Nemcsak az előadómüvészetekre (zene, tánc, színház), hanem az irodalomra is nagy hatást gyakorolt a drámai müvészetek Bharatának tulajdonított kézikönyve, a Nátjasásztra, amelynek keletkezési idejét az i. e. 1. század - i. sz. 3. század közé teszik. A Nátjasásztra a rasza („,íz”) elmélet megfogalmazásával lefektette az indiai esztétika alapjait. Eszerint bármely műnek - legyen az zene, dráma vagy képi ábrázolás - az esztétikai értelemben vett íze vagy esszenciája a kívánt érzéseket kiváltva hozzásegíti a nézőt egyfajta katarzis átéléséhez, amelynek célja a transzcendens valóság megtapasztalása. A raszaesztétika mủvelt, értő befogadói közegben érvényesülhetett, $\mathrm{s}$ ez közvetetten utal a Gupta-kor városi társadalmának magas kulturális színvonalára.

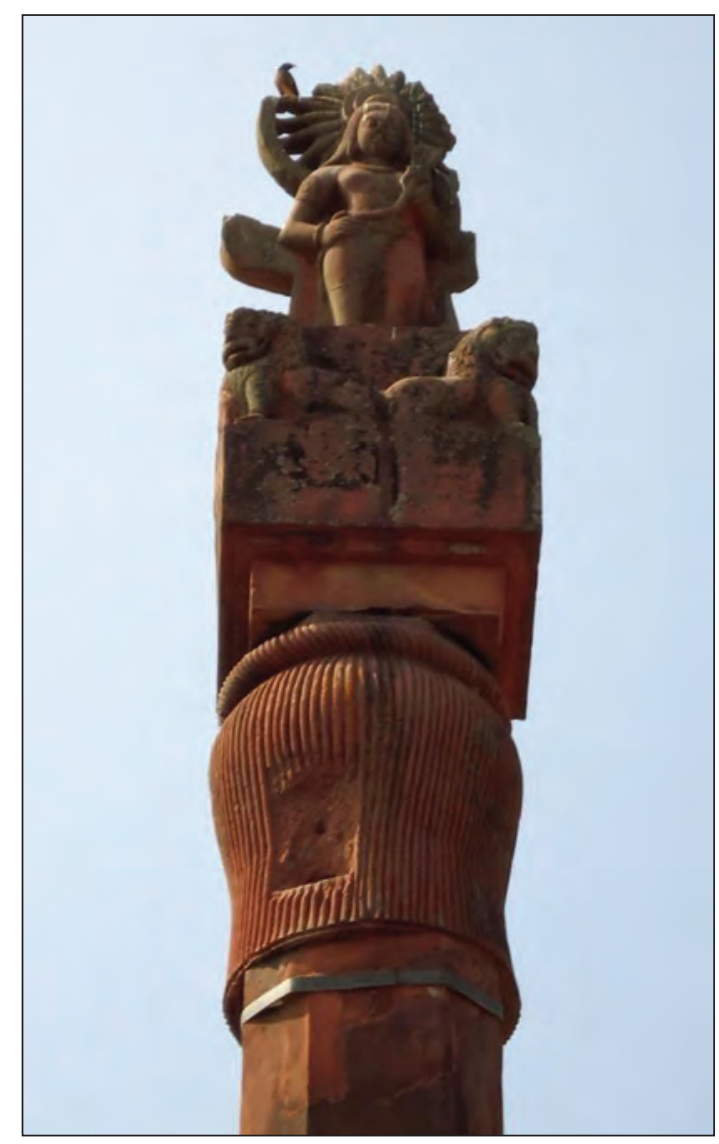

35. kép: Budhagupta uralkodása idejéből származó oszlop felső része a mitikus napmadár, Garuda ábrázolásával. Éran (Madhja Pradés), Gupta korszak, i. sz. 484. Forrás: RenNER Zsuzsanna felvétele

A városi élet egy különleges aspektusát tárja fel az 5. században keletkezett Kámaszútra („,Szerelem tankönyve”), amely erotikus indíttatásán túl meglepő 
kifinomultságról, az emberi kapcsolatok és a női műveltség iránti érdeklődésről tesz tanúbizonyságot. A szanszkrit irodalom népszerü történetekben, mesékben is bővelkedett. A Pancsatantra c. mesegyüjtemény, amely már a 11. században eljutott Európába, eredetileg a politikai etikát taglaló mủvek (nítisásztra) sorába tartozott, és mint ilyet, királyok viselkedéskódexének szánták. Aforizmáiban a ravaszság és éleseszűség jelenik meg fő erényként. Délen a Pallava Királyság (4-9. század) támogatta a szanszkrit kultúra átvételét, amely együtt járt a bráhmanáknak juttatott adományokkal és az előző korszak törzsi széttagoltságát felváltó egyesítő törekvéssel. Egyidejüleg ekkor volt zenitjén a tamil nyelvü világi és vallási irodalom is. A hinduizmus történetében nagy hatást gyakorolt a Siva és Visnu iránti odaadást hirdető költészet kialakulása, amely a devocionális bhakti kultuszt és költészetet India-szerte elterjesztette.

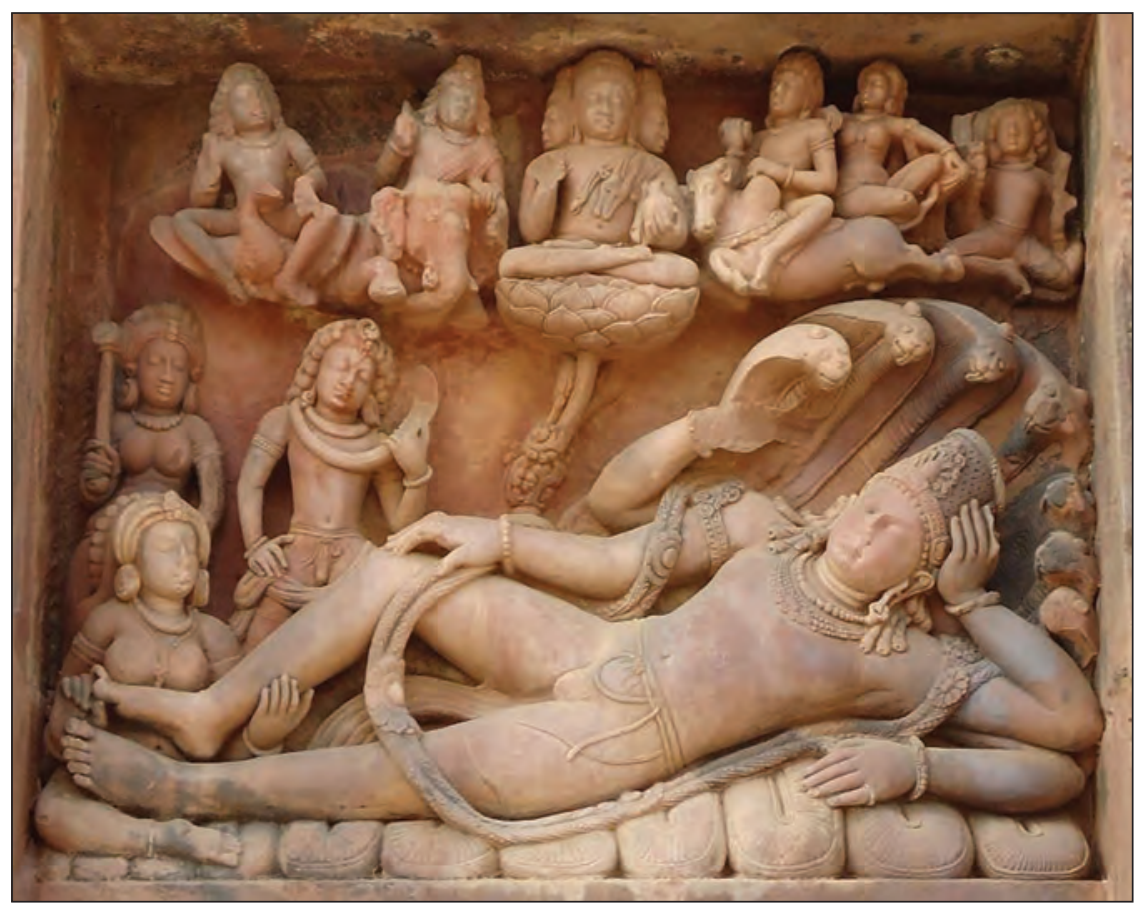

36. kép: A Végtelenség kígyóján fekvő Visnu (részlet). Dasávatára templom, Deogarh (Uttar Pradés), 6. század eleje

Forrás: RenNer ZsuzsanNa felvétele

A képzőművészetekben letisztultság és harmónia uralkodik. A szobrászat ekkor teremti meg az emberi test ábrázolásában az elmélyült befelé fordulást, az emelkedettséget és a spirituálisan átszellemült, földi hibáktól mentes emberi test érzéki szépségét mesterien ötvöző klasszikus indiai hagyományt. A buddhista ábrázolások mellett a hindu ikonográfia is készen áll ekkor: Visnut és avatáráit (megtestesüléseit), Siva különféle megnyilvánulási formáit a ma ismert test- 
és kéztartásokkal, attribútumokkal (jellegzetes tárgyakkal), hordozó állatokkal ábrázolják. A mindent látás, a mindenütt jelenvalóság szimbólumaként gyakoriak a sokkarú, sokfejü ábrázolásmódok. Visnut magas koronával, nyakában erdei virágokból font füzérrel, uralkodói ékszerekkel ábrázolják, kezeiben korongot, csigakürtöt és buzogányt tart. Hordozó állata a mitikus Garuda madár (35. kép). Egyik jellegzetes ábrázolásán a Végtelenség kígyójának összetekeredett gyürüin fekszik, köldökéből lótusz nő ki, melynek kelyhében a világot teremtő Brahmá isten ül (36. kép).

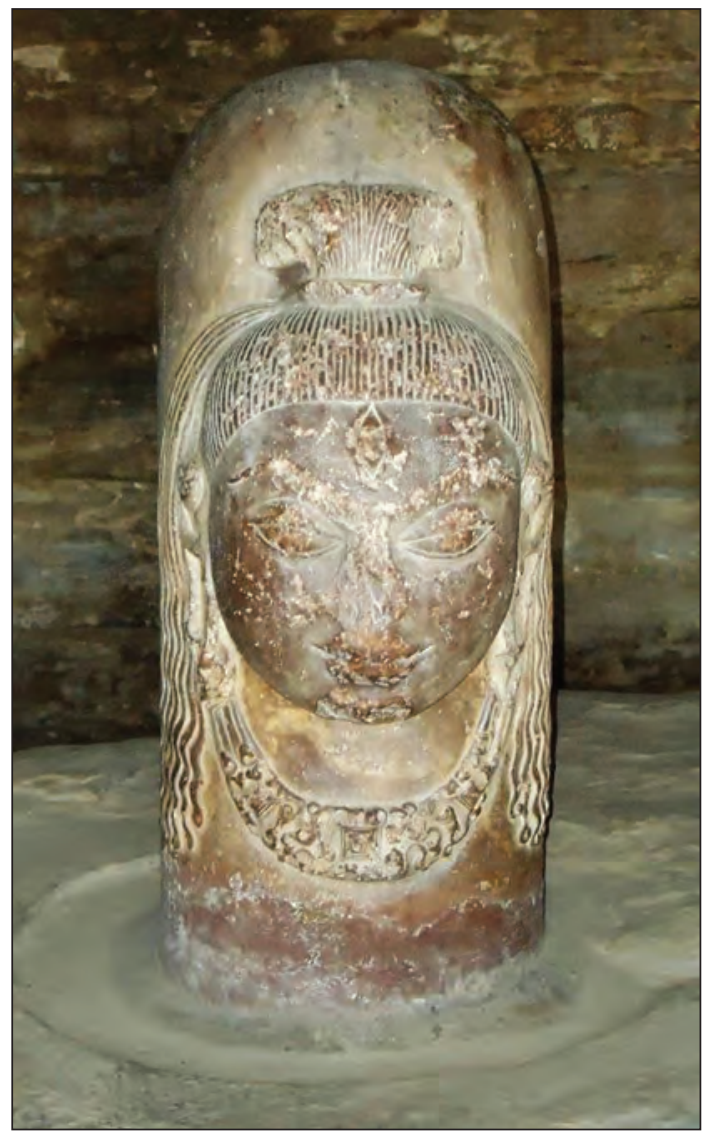

37. kép: Lingam Siva arcának ábrázolásával. Udajagiri (Madhja Pradés), 4. sz. barlang. Gupta korszak, 5. század első negyede

Forrás: RenNer Zsuzsanna felvétele

Visnu népszerüségéhez jelentősen hozzájárult női párja, Srí Laksmí, a jószerencse, bőség, boldogság istennője, akivel gyakran ábrázolják együtt. Tíz avatárája - Hal, Teknős, Vadkan, Emberoroszlán, Törpe, Csatabárdos Ráma, Ráma, Krisna, Buddha (vagy Balaráma) és Kalki - önállóan, tízes csoportban vagy Visnu környezetében is előfordul az ábrázolásokon. Siva, aki a jóga 
uraként ismert, gyakran jelenik meg aszkétaként. Koronát nem hord, feje tetején feltornyozott fürtjeibe tüzve holdsarlót visel. Homloka közepén a harmadik szem a transzcendens látás érzékszerve. Mellén vadbör van átvetve, nyakában kobra tekergőzik. A tánc uraként (Natarádzsa) vad táncát járva elpusztítja a világmindenséget. Gyakori attribútumai a háromágú szigony és a homokóra alakú dob, hátas állata Nandi, a fehér bika. Női párja Párvatí, a Himalája leánya, gyermekei az elefántfejü Ganésa, az akadályok elhárítója és Szkanda (Kárttikéja) hadisten. Leggyakrabban fallikus szimbóluma, a lingam formájában jelenítik meg (37. kép). A teremtő Brahmát négy fejjel, lótusztrónuson vagy fehér lúdon, kezeiben könyvvel (a Védával), áldozati kanállal és a halhatatlanság italával teli korsóval ábrázolják. A legkorábbi fennmaradt hindu templomok a Gupta-korból származnak.

\section{A hinduizmus}

A hindu vallásnak nincs alapítója, így kezdő időpontja sem. Eredete kevert és összetett; mintegy kétezer éves elötörténete során rakódtak egymásra azok a rétegek és hatások, amelyek a kialakulásához vezettek. Az árja civilizációnak a szubkontinensen való terjeszkedése során számtalan helyi hagyományt, kultuszt, rítust magába olvasztva formálódott. Ezek két fő vonulata a védikus árják szanszkrit irodalma és gyakran természeti jelenségeket megszemélyesítő isteneik népes tábora, illetve a preárja népek hitvilága, középpontjában az anyaistennő és a termékenység kultuszával. A hinduizmus maival összevethető formája időszámításunk első századaiban alakult ki és a Gupta-korra öltött kifejlett formát. Visnu és Siva ekkor emelkednek ki mint föistenségek, s mellettük megjelenik a különféle neveket viselő Istennő (Déví) hagyománya is.

A hinduizmus jellemzőit nehéz általánosságban megfogalmazni. Nemcsak alapítót, de minden hívőre kötelező szent könyvet, mindenki által elfogadott tanítást sem lehet megnevezni; nincs közös egyháza, nincsenek kidolgozott hitelvei. Jól megfér benne a rajongó istenszeretet és az ateizmus, a magasrendủ filozófiai irányzatok követése és a népi kultuszok körébe tartozó fa- és kígyótisztelet, a nem-ártás (ahimszá) és az állatáldozat. Kialakulásának körülményeit és történetét ismerve nem meglepö, hogy a hinduizmus valójában nem egy vallás, hanem számtalan vallás és kultusz elegye, amelyek soha nem kovácsolódtak össze homogén rendszerré. Maga a hinduizmus elnevezés is új keletü, s nem is indiai, hanem a 19. századi brit tudományosság szülötte, amelyet a jellegzetesen indiai vallási eszmék és gyakorlat megnevezésére alkottak. A hindu elnevezés ennél jóval régebbi, az Indus folyón túl élő népeket nevezték így a perzsák és a görögök. A középkorban a szubkontinens lakói magukra is kezdték alkalmazni, megkülönböztetésül az észak-indiai muszlim hódítóktól, $\mathrm{s}$ innen már csak egy lépés volt, hogy a szó vallási jelentést kapjon. Mióta a 
hinduizmus fogalma Indiában elfogadást nyert, követői vallásuk megnevezésére az indiai nyelvekben meghonosodott változatát, a hindú dharmát használják. Elterjedt a szanátana dharma („örök vallás”) kifejezés használata is, amely a hinduizmus vallásgyakorlatában meglévő különbségek feletti örök érvényü spirituális jelleget hangsúlyozza.

A hinduizmus legszembeszökőbb sajátossága az istenek sokasága, ezért látszatra sokistenhitnek tünik. Mivel azonban a hindu hívő a sok isten közül azt az egyet tiszteli legföbb istenként, amelyiknek a kultusza családjában hagyományozódik, inkább vallási pluralizmusról beszélhetünk, semmint politeizmusról. Ezzel együtt a hindu hívők a többi isten létét sem tagadják. Azt vallják, hogy az isteni lényeg végtelenül sokféle formában nyilvánulhat meg, így a hozzá vezető út is sokféle. A vallásgyakorlat is különböző lehet. A templomba járás nem kötelező, sőt az istenhit sem, ateistaként is lehet valaki hindu, pusztán azáltal, hogy beleszületett egy hindu kasztba.

A spiritualitás hangsúlyos szerepe ellenére a hinduizmus társadalmi aspektusai rendkívül erősek. A rituális tisztaság és tisztátalanság szabályrendszerével átszőtt és megerősített társadalmi hierarchia (varna- és kasztrendszer) elválaszthatatlanul összefonódott a hindu vallás elöírásaival és gyakorlatával. A hindu vallás történetét döntően befolyásolta az uralkodó dinasztiák támogatása, akiktől nemcsak a királyság isteni eredetét jelképező templomok építése függött, hanem a papi osztály fenntartását szolgáló uralkodói adományok is. Vallás és társadalom összefüggésrendszeréhez tartozik az emberi élet négyes céljáról alkotott elképzelés, a társadalmi osztályok (varnák) és életszakaszok (ásramák) kötelességeinek tana (varnásramadharma), valamint azátmeneti rítusokhoz (szanszkárák: születés, névadás, első hajlevágás, házasság stb.) kapcsolódó szokások betartása is. A négy életcél a következő: dharma, azaz az egyén saját élethelyzetére és társadalmi csoportjára vonatkozó vallási-rituális előírások összessége; artha, azaz pénz, gazdagság vagy egyszerüen megélhetés; káma, azaz érzéki, házastársi örömök; móksa, azaz a transzcendenssel való egyesülés. A négyes életcél tana létjogosultságot adott az élet különböző aspektusai megélésének, a varnák és életszakaszok tana pedig hozzájárult ezek egyensúlyához azáltal, hogy kijelölte az emberi élet fő periódusainak hangsúlyait. Az ifjúkor feladata a tanulás volt, a felnőtt férfié a családalapítás, a család eltartása és a gyermeknemzés, az idősödő férfié a visszavonulás, az utolsó életszakaszé pedig az otthontalan vándorlás, felkészülés az evilági létből való kilépésre. A leghangsúlyosabb fogalom ezek közül a dharma, amely magát a vallást jelenti, tágabban pedig mindazt a szabályrendszert, amely magában foglalja az egyén saját életfeladatait (szvadharma) és a különböző társadalmi csoportokhoz való tartozásából eredő kötelességeit. Ez utóbbiakhoz tartoznak elsőrendűen a kaszti kötelezettségek (dzsátidharma), de pl. a nők (sztrídharma) vagy a királyok kötelességei (rádzsadharma) is. A hindu dharma 
legföbb jogforrása az i. sz. 1. század körül keletkezett Manu törvénykönyve (Manuszmriti, másnéven Mánava-dharmasásztra), a legnagyobb tekintélyü óind törvénykódex volt. A Manuszmriti által tárgyalt témák közé tartoznak az egyes életszakaszokra elöírt szertartások, az átmeneti rítusok, a kasztok és az uralkodó kötelességei, közöttük az igazságszolgáltatás is. Tehát az uralkodó által gyakorolt büntetőjog mellett a dharma mint vallási törvény, vallásgyakorlat, kötelesség, erény, viselkedési norma kap központi szerepet a müben. Manu törvénykönyve ilyenformán elsősorban az életmód- és viselkedéselöírásgyüjteménye. A későbbi törvénykönyvekben (dharma-sásztrák) a tisztán jogi jelleg került előtérbe.

Ahindu vallás másik alapfogalma a karma, amely az előző élet cselekedetei által meghatározott sorsot jelenti. A vallása elöírásait követő hindu hívő arra törekszik, hogy életvitelével következő életében jobb sorsot érdemeljen ki, $\mathrm{s}$ újjászületések során át, amelyet szamszárának neveznek, egyre közelebb kerüljön a megváltáshoz ( $m o ́ k s a$ ). Az indiai vallások (hinduizmus, buddhizmus, dzsainizmus) alaptézisként fogadják el a lélekvándorlás tanát, $\mathrm{s}$ a megváltást mindegyikük számára a létkörforgásból való kikerülés, az újjászületések láncolatának megszakadása jelenti. A hindu vallás keretei között csakis az számít erényes életnek, hogyha valaki a saját dharmáját követi, azaz a rá és társadalmi státusára vonatkozó előírásokat szigorúan betartja. Ha király, akkor kiváló a királyi kötelességek teljesítésében, ha cserzővarga, akkor a bör kikészítésében jeleskedik. A kasztrendszer éppen azért merevedik meg, mert ki-ki csak a születésétől meghatározott helyen teljesítheti életfeladatait, s csak sorsának engedelmeskedve remélheti, hogy következö életében jobb újjászületés lesz az osztályrésze.

A hinduk többsége számára a Bhagavadgítá (A Magasztos Szózata) az egyik legszentebb szöveg. Feltehetöleg az i. e. 4. - i. sz. 2. század között keletkezett, és a Mahábhárata részeként maradt fenn. Az egymással szemben álló Kauravák és Pándavák döntő csatája készülődik, a Pándavák seregét vezető Ardzsuna azonban kétségbe esik, hiszen unokatestvérei, hozzátartozói vérének kiontására készül. Ekkor kocsihajtója, Krisna kozmikus isteni valóját feltárva beszédet intéz Ardzsunához. Az embernek be kell töltenie a társadalom által rárótt feladatot. A harcos dolga (dharmája), hogy csatázzon, de ne gyülöletből, hanem kötelességtudatból tegye, annak tudatában, hogy megölni csak a testet lehet, a lélek (átman) halhatatlan; újjászületések sokaságán át vándorol a létkörforgásban a megszabadulást (móksa) keresve. Teofániájában Krisna önmagát a legföbb lényeggel (brahman) azonosnak mutatja, akiből minden élölény és a világ minden jelensége kiárad a teremtés kezdetén, $\mathrm{s}$ a végén oda hullik vissza. A jelenségek világa nem más, mint káprázat, illúzió (májá), amelyből Krisna a megszabadulás egyik útjaként az iránta érzett áhítatos szeretetet (bhakti) kínálja. 
A hinduizmus tanai és kultuszai a mítoszokat, legendákat, szájhagyományt egybegyüjtő puránákban bontakoztak ki, illetve nyertek megerősítést, csakúgy, mint a világ ciklikus újjáteremtéséről kialakított felfogás, és ezzel kapcsolatban a világot teremtö, fenntartó és elpusztító mindenható istenség alakja. A fö kultuszok Visnu, Siva és az Istennő, Déví körül alakultak ki (vaisnavizmus, saivizmus, illetve saktizmus), de idővel önálló vallássá növekedett Krisna kultusza is. Visnu és Siva szétágazó hagyományát a hindu istenhármasság (trimúrti) konstrukciójában törekedtek összeegyeztetni a teológusok, amelyben Visnu fenntartó és Siva pusztító szerepét Brahmá mint teremtő egészítette $\mathrm{ki}, \mathrm{s}$ amelyben mindhárom istenséget a legföbb transzcendens lényeg, a brahman megnyilvánulásának tekintették. Ez azonban jórészt megmaradt a spekuláció szintjén, többek között azért, mert Brahmá kultuszának jelentősége elhanyagolható volt Visnuéhoz és Siváéhoz képest. Az Istennő számtalan különféle nevében és alakjában, önálló és a föistenekhez kapcsolódó kultuszában az anyaistennő (Magna Mater, „Nagy Anya”) ősi női princípiuma nyilvánult meg. Az anyaistennőket (mátrikák, ,,anyák”) csoportosan is tisztelték és ábrázolták. A puránák tág teret szentelnek a templomok és ábrázolások leírásának, továbbá a szent helyek látogatásából nyerhető előnyök ecsetelésének, ezzel megszilárdítva a templomi kultusz, a képi ábrázolások és a zarándoklatok hindu hagyományát.

A hinduizmus tendenciái történeti koronként változtak. A Gupta-dinasztia tagjai Visnu hívei voltak, így uralkodásuk alatt Visnu kultusza uralkodói támogatást élvezve megerősödött. A Guptákat felváltó hindu dinasztiák korában általános jelenségként a Siva-hitü vallásosság előtérbe kerülése figyelhető meg, ami azonban korántsem jelenti a vaisnavizmus teljes háttérbe szorulását. Gyakran egyazon dinasztián belül is hol saiva, hol vaisnava uralkodó került hatalomra. Az indiai iszlám uralmát, melynek valódi hatalma kb. 1200 és 1750 közöttre tehetö, a bhakti mozgalom erősödése és közösségi összetartó erejének elötérbe kerülése jellemzi. A gyarmatosítás kora döntő hatást gyakorolt a modern hinduizmus kialakulására. Egyrészt a hindu gondolkodók és reformerek a hinduizmus európai leírói és bírálói szemüvegén keresztül kezdtek saját hagyományaikra tekinteni, s ez megújulási mozgalmakat indított el. Elsőként Ram Mohan Roy mozgalma (Brahmó Szamádzs, „Brahma Társaság”, 1828), majd az Árja Szamádzs („Árja Társaság”, 1875) tủzte ki célul a hinduizmus reformját. Másrészt a függetlenségi mozgalommal való összefonódása miatt a hinduizmus ekkor kapott politikai színezetet. A hinduizmus fogalmának átvétele kapóra jött a kezdettől fogva hindu jelleget öltő nemzeti egység összekovácsolásában. A vallási különbözőségek ellensúlyozására hasznos eszköznek bizonyult a Védák szentségének szintén Nyugatról kiinduló hangsúlyozása és a „misztikus India" eszméjének erösítése. Az Indiát a hinduizmus szent földjévé avató hindu újjászületési mozgalom patriotizmusa összefonódott a bhakti kultusszal, $\mathrm{s}$ a bengáli Rámakrisna miszticizmusa újfajta nemzetépítő erőként hatott. 
Rámakrisna legfőbb tanítványa, az eszméit nyugaton terjesztő Vivékánanda és a dél-indiai alapítású, de székhelyét 1875-ben New Yorkba áttevő Teozófiai Társaság fontos szerepet játszott az indiai vallási és filozófiai gondolatok nyugati elterjesztésében.

Ahindu vallás gyakorlásához, illetve a hindu életformáhozhagyományosan hozzátartoznak a gyakran több napig tartó ünnepek, a nem-ártás (ahimszá) elvén alapuló vegetarianizmus, a tehenek tisztelete, a kasztrendszer élö hagyománya, a kaszti megfelelőségen és a horoszkópok egyezésén alapuló elrendezett házasság is. Mindezek gyakorlásában azonban igen jelentős társadalmi és regionális különbségek figyelhetők meg, amelyeket a városi vagy vidéki környezet és a kulturális háttér is befolyásol.

\section{Kora középkor: a hindu dinasztiák kora}

A Gupta Birodalom szétesésével a politikai széttagolódás évszázadai köszöntöttek a szubkontinensre, s legközelebb csak a muszlim Mogul-dinasztia alapított a szubkontinens csaknem egészére kiterjedő centralizált államot a 16. század közepén. Regionális hindu királyságok alakultak ki és háborúskodtak folyamatosan a számtalan helyi vazallus állam feletti fennhatóságért. Északkeleten a Pálák (8-12. század), északnyugaton a Gurdzsara-Pratihárák (7-10. század), délnyugaton a Rástrakúták (8-10. század), a Dekkánon a Csálukják (7-8. század), délen a Pallavák (7-9. század), majd a Csólák (9-13. század) uralkodtak jelentős területek felett. A szubkontinens államait a nyugati típusú államtól eltérően nem a területük, hanem a központjuk határozta meg, az istenített uralkodó székvárosa és a világ rendjére vonatkozó kozmikus elképzelések középpontja. Az uralkodó hatalma a maga teljességében csak a központ közvetlen környékén érvényesült, attól távolodva egyre csökkent, és a perifériális területek függése laza vagy névleges volt. A királyságot akár többszörös gyürüben vazallus területek másod- és harmadlagos központjai vehették körül. Ezt a fajta államszerkezetet, amelyben a hatalomgyakorlás módját már Kautilja Arthasásztrája leírta, a kutatás mandala-államnak nevezte el (a mandala a világegyetemet ábrázoló diagram, középpontjában a többszörös védőgyürüvel körülvett istenséggel). Az uralkodó a királyság szakrális középpontjában építette fel templomát, amelynek szentélyében felállította az általa tisztelt istenség szobrát, ezzel kinyilvánítva hatalma isteni eredetét. A dévarádzsa (szkt. „istenkirály”) Indiában gyökerezö koncepciója és annak kultikus-építészeti vetülete a délkelet-ázsiai királyságokban öltött kiforrott formát, de a karizmatikus hatalomgyakorlás igénye Indiában is szakrális központok sokaságának kialakulását eredményezte. Ez hatalmas lökést adott a hindu építészet és szobrászat fejlődésének. A buddhizmus a 8. századra Északkelet-Indiára szorult vissza, ahol a Pála-dinasztia alatt utolsó indiai virágkorát élte. A 13. század elején a hódító iszlám lerombolta 
virágzó monasztikus központjait és híres egyetemeit (Nálandá, Vikramasílá). Szerzetesei ekkor külföldre menekültek, s ezzel a buddhizmus gyakorlatilag megszünt Indiában. Dél-Indiát elsőként a Csóla uralkodók egyesítették. A tamil eredetű dinasztia a 11. században emelkedett fel délkelet-ázsiai hódításai révén szárazföldi és tengeri nagyhatalomként. Nagy flottával és hadsereggel rendelkezett, birodalmi ambíciói mögött jelentős gazdasági erő állt. Kulturális téren mind Dél-Indiában, mind Délkelet-Ázsiában maradandó nyomokat hagyott. A Csólák a saiva hindu vallásosság feltétlen híveiként Délkelet-Ázsiában is a hinduizmusnak ezt a formáját terjesztették. Dél-Indiában hatalmas templomokat emeltek Siva tiszteletére. Monumentalitásra törekvésük nyomán alakultak ki az első templomvárosok (Tandzsavúr, Csidambaram). Bőséges adományaikkal megalapozták a templomok önálló gazdasági szereplőkként való részvételét a királyság életében.

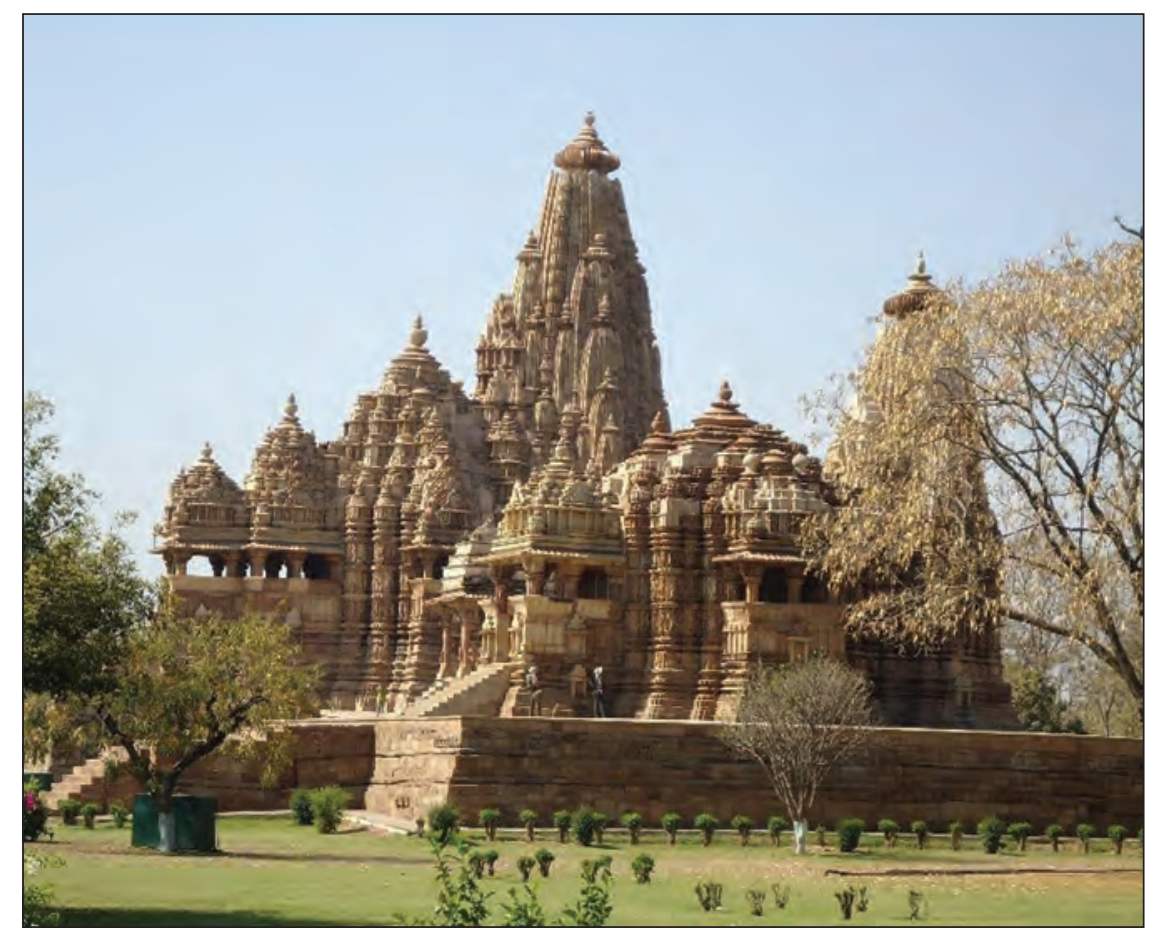

38. kép: Khadzsuráhó templomai. Csandélla-dinasztia, 11. század Forrás: RenNer Zsuzsanna felvétele

A hindu templom valójában maga is háromdimenziós mandala: a világmindenség szimbóluma, középpontjában az istenséggel. Alapvető szimbolikáját a hegy és a mélyében megbúvó barlang - a torony és a szentély - hordozza. Az istenség szobrát (Siva templomok esetében mindig a lingam) a zárt, sötét, cellaszerü szentélyben (szkt. garbhagriha, ,anyaméh-ház”) helyezik 
el. A rituális körüljárás után a hívő az előtéren és az oszlopcsarnokon (mandapa) keresztül érkezik ide, hogy az istenség látásában (darsana) részesüljön és elhelyezze áldozati ajándékát (púdzsá). A hindu templom kozmikus jelképrendszerét istenségeknek, égi lényeknek a templom falait elborító serege erősíti. A hindu templomépítészetet - szemben a világi építészettel - kezdettől fogva a tartós anyagok (tégla, kő) használata és konzervatív építési technológiák jellemezték. A hindu építészet rituális elöírásai tiltják a boltív és a kupola használatát, így ezeket gerendás áthidalások, álboltívek, vízszintes rétegekböl felrakott méhkas alakú tornyok és álkupolák helyettesítik. Mivel ez az építési technológia nagy terek lefedésére nem alkalmas, a hindu templomok belső terei néha kifejezetten szükek, sok hívő befogadását nem teszik lehetővé. Az északindiai (nágara) építészet legtisztább formában a Madhja Pradés-i Khadzsuráhó 10-11. században épült templomain tanulmányozható (38. kép).

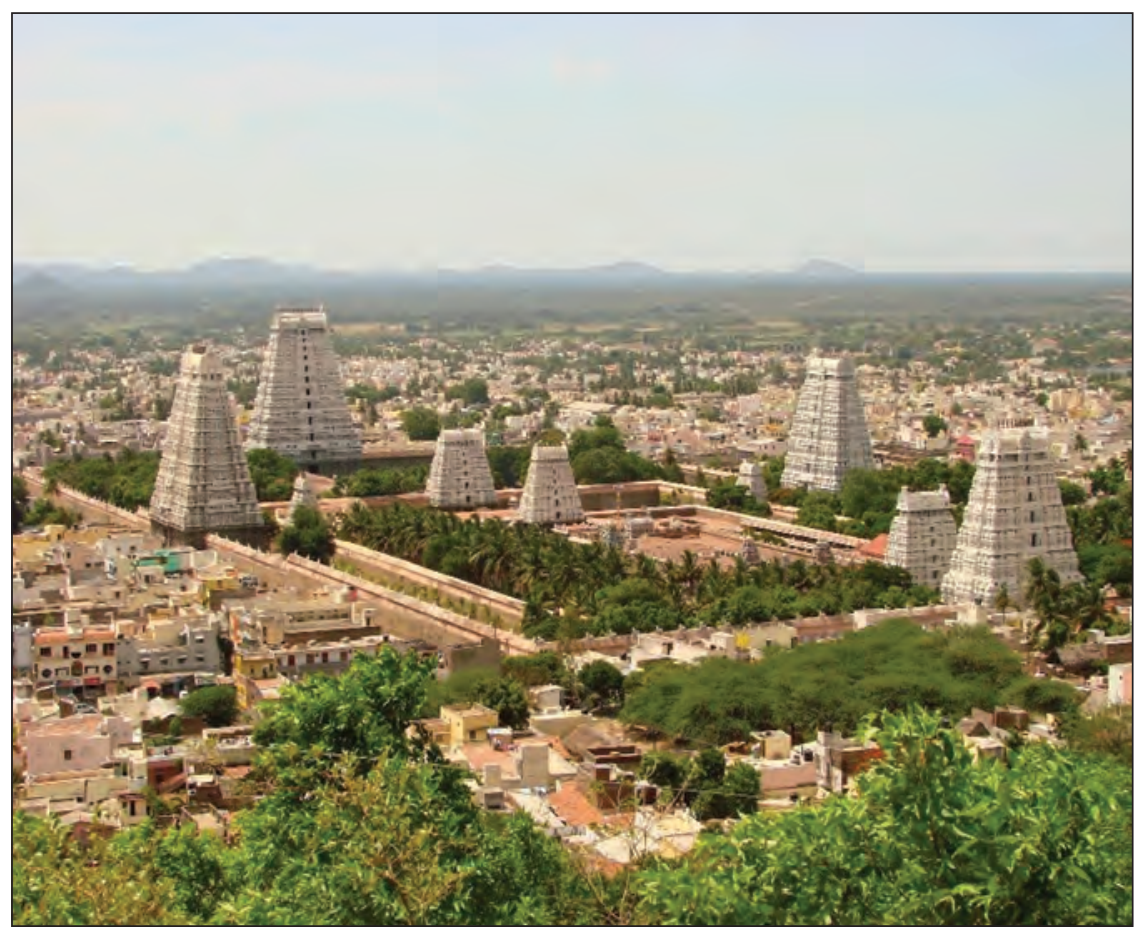

39. kép: Arunácsalésvara templom, Tiruvannámalai (Tamilnádu)

Forrás: Adam Jones adamjones.freeservers.com. Forrás: https://commons.wikimedia.org/wiki/ File:View_over_Arunchaleshvara_Temple_from_the_Red_Mountain__Tiruvannamalai_-_India_01.JPG

A déli (dravida) templomépítészetben az istenség égi jármüvét jelképező szentély és felépítménye eltörpül a templomi körzetet övező falak 
bejáratai felett emelkedő hatalmas kaputornyok mellett. A legfontosabb déli zarándokközpontok a 16. századtól nagy kiterjedésű templomvárosokká alakultak, amelyeknek a fenntartását és müködését bőkezü uralkodói adományok, kiterjedt földbirtokok és népes személyzet biztosította. A templom elmaradhatatlan tartozéka a rituális fürdő céljára szolgáló nagyméretü medence. A koncentrikus kerítőfalak közötti udvarokban oszlopcsarnokok, kisebb szentélyek, zarándokszállások, konyhák, raktárak és egyéb kiszolgáló épületek kaptak helyet. A nagy dél-indiai templomvárosok: Tandzsavúr (korábban Tanjore), Madurai, Rámésvaram, Tiruvannámalai mai formájukat a dél-indiai templomépítészet utolsó nagy korszakában, a 16-18. században nyerték el (39. kép).

A középkori müvészetről szólva feltétlenül említést kell tennünk a bronzszobrászatról, amely a Csóla művészet ikonikus alkotásai révén ekkor jutott csúcspontjára. A dél-indiai templomi kultuszhoz rengeteg bronzszoborra volt szükség, amelyeket a hatalmas templomcsarnokokban helyeztek el és ünnepeken körbehordoztak a városban. A nagyméretü, tömör Csóla bronzok készítése nemcsak a müvészeti alkotókészség magas színvonaláról, a spirituális szépség tökéletes formai megvalósításáról tanúskodik, hanem a felhasznált fémek hatalmas mennyisége miatt jelentős gazdasági erőt követelt, az alkalmazott öntési technológia (az ún. viaszvesztéses eljárás) pedig magas szintü fémöntési és fémmegmunkálási ismereteket feltételezett. A dél-indiai templomi mủvészet - építészet és bronzszobrászat - jó példa arra, hogy az indiai civilizációban a legnagyobb erőforrásokat megmozgató alkotó tevékenység technikai, gazdasági és esztétikai értelemben egyaránt a szakrális müvészet volt, melyben a legnemesebb anyagokat, a legmagasabb ismert technológiát és az emberi alkotókészség legjavát használták fel. A szobroknak meg kellett felelniük az ábrázolási előírásoknak és technikai értelemben is tökéletesnek kellett lenniük, mert csak így válhattak alkalmassá a kultikus használatra. A tökéletességre aspiráló mủalkotások készítői azonban az esetek többségében ismeretlenek, az indiai mủvészetben csak ritka kivételként maradtak ránk alkotók nevei. Megörökítésüket a művészet jellege, amelynek egyetlen igazi célja a transzcendens valóság megközelítése volt, és az építők, kőfaragók, szobrászok, bronzöntők alacsony társadalmi rangja egyaránt kizárta.

Délkelet-Ázsiában az 5-13. század között indiai típusú királyságok, majd hatalmas birodalmak alakultak ki, amelyekben az indiai hatások érvényesülését a közvetlen kapcsolatok (pl. indiai bráhmana papok jelenléte a királyi udvarokban), a szent szövegek és az irodalmi müvek, közöttük elsősorban a Mahábhárata és a Rámájana biztosították. A korszak elején még fennállt a kereskedelmi kapcsolat a Mediterráneummal, helyét azonban csakhamar a dél-kínai kapcsolatok vették át. A megélénkülő tengeri forgalom lökést adott a Kína felé vezető tengeri út mentén fekvő délkelet-ázsiai területek indiai 
kereskedelmi és kulturális érdekkörbe vonásának. A Thaiföld és Burma déli részén a 8 . századig fennállt Mon Királyságot új hatalmi központok váltották fel. Ezek hatalmi szerkezete az indiai mandalatípusú királyságok mintájára alakult. A mai Kambodzsában Csenla helyén a 9. században Angkor központtal létrejött a Khmer Birodalom, Délkelet-Ázsia leghatalmasabb királysága, amelynek hatalmi ellensúlyát a térség északi részén fekvő, Pagan központú Burmai Királyság jelentette. A kettő közötti ütközőzónában a thaiföldi királyságok: Haripuncsai, Szukhothai és Ajutthaja folytattak változó kimenetelü küzdelmet szomszédaik ellen. A szárazföld keleti felét az észak felöl érkező kínai nyomásnak sokáig ellenálló Tyampá (Champa) uralta. A Maláj-félsziget, Szumátra, valamin Nyugat- és Közép-Jáva a Srívidzsaja Királyság birtokában volt. A 11. században a Csóla Birodalom fennhatósága alá vonta Srí Lankát és a Khmer Királyság oldalán sikerrel avatkozott be Srívidzsaja és Angkor hatalmi vetélkedésébe, amelynek során megszállta Srívidzsaja egyes részeit. A hindu kultúra ebben a korszakban a khmer és a tyam területeken, valamint Kelet-Jáván volt meghatározó (a közeli Bali szigetén máig él a hinduizmus egy speciális helyi változata), míg a többi királyságban a fö vallási irányt jelentő buddhizmus mellett létezett. A hindu vallásosságon belül a saiva, vaisnava irányzat, a bhakti és a teremtő energiát középpontba állító tantrikus kultuszok változó súllyal, de egyaránt jelen voltak. A nagy indiai eposzok valamennyi királyságban megtermékenyítően hatottak a helyi irodalomra és művészetekre, különösen a narratív ábrázolásokra, a táncra és a bábjátékra. A délkeletázsiai hatalmi központokban létrejött épületegyüttesek (Angkor, Pagan, My Son [ejtsd: Mi Szan], Prambanan, Borobudur stb.) Ázsia és a világ szakrális müvészetének legfontosabb helyszínei közé tartoznak. Mủvészetükben a meghatározó indiai jelleg mellett helyi stílushatások és kreatív elgondolások érvényesültek. A hindu templomépítészet csúcspontjának bizonyos értelemben az angkori templomok tekinthetők, amelyek a templomhegy koncepciója révén a legmaradéktalanabbul valósítják meg a világ felépítéséről - a középpontban magasodó világhegyről (Méru) és az azt övező szárazföldekről és óceánokról alkotott indiai elképzeléseket. A víztározók és -rendszerek építése magas szintü mérnöki ismereteket feltételezett, amelyek előképei Indiában is megtalálhatók. A világ legnagyobb buddhista sztúpája a jávai Borobudurban épült fel. A nagy királyságok lehanyatlásával a hindu kultúra hatása megszünt Délkelet-Ázsiában, azonban az indiai kultúra öröksége a théraváda buddhizmus formájában a régió szárazföldi részének arculatát a mai napig alapvetően meghatározza. Kivételt képez Vietnam, ahol a buddhizmus mahájána ágához tartozó „Tiszta Föld” iskola tett szert népszerüségre. 
Az iszlám hódítás a szubkontinens középkori történetének vízválasztója. Az iszlám már a hidzsra után nem egészen száz évvel az arab hódítók, illetve később az iszlámra tért perzsák, afgánok és közép-ázsiai törökök révén megvetette a lábát az indiai szubkontinens északnyugati részén, az Industól nyugatra eső területeken, s innen vezették egyre gyakoribb hadjárataikat az észak-indiai területekre. 1203-ban a rádzsput fejedelemségek ellenállását megtörve bevették Delhit és megalapították az első észak-indiai iszlám államot. A szubkontinens történetében rendszeresnek mondható korábbi nomád inváziókkal szemben a döntő különbséget az jelentette, hogy míg korábban a betelepülőket a szubkontinens társadalmi-politikai-kulturális rendszere gyorsan asszimilálta, addig az iszlám saját jogi és adminisztratív rendszerét, vallását és etikai elveit vezette be a szubkontinensen. A Delhi Szultanátus gyorsan terjeszkedett, és egymást követő dinasztiái kiterjesztették hatalmukat Észak-Indiára és a Dekkán nagy részére. A hódítás sok áldozatot szedett és jelentős pusztítással járt. A hódítás útjába eső hindu templomokat lerombolták, helyükön mecseteket emeltek, a hindu lakosságra fejadót vetettek ki. Bár erőszakos térités is történt, az áttérés kínálta előnyök miatt a szubkontinens muszlim lakossága az önkéntes áttérések révén - különösen a hindu társadalom alsó rétegeiböl - is gyorsan növekedett. Az indiai muszlimok túlnyomó többsége az áttért helyi lakosság köréből került ki. A hindu civilizációval szemben az iszlám kultúra a városokra koncentrálódott, ahol nagyszabású építkezések zajlottak, s ez hamar átalakította a városok arculatát. Megjelentek az iszlám jellegzetes épülettípusai: a hatalom katonai jellegét jelző erődök, a vallásgyakorláshoz nélkülözhetetlen mecsetek és minaretek, valamint a síremlékek, kertek, medreszék. Noha a magyar történelemböl is jól ismert muszlim földbirtok- és közigazgatási rendszer a hindu társadalom vidéki alapjait érintetlenül hagyta, a hindu államiság megszünése miatt az egykori királyi központok azokon a területeken is pusztulásnak indultak, amelyeket a katonai hódítás közvetlenül nem érintett. $\mathrm{Az}$ indiai iszlám államiság létrejötte azonban az ellenállást is megszülte: az iszlám indiai betörését sokáig megakadályozó, katonai erényeikről híres rádzsput dinasztiák nyugat-indiai erődjei jelentették az ellenszegülés és a változó sikerrel folyó katonai müveletek legfőbb bázisát (40. kép). A Delhi Szultanátus hatalmi ellenpontja a félsziget déli részén a hindu Vidzsajanagar Királyság volt, amelyben a hindu kultúra a 16. század közepéig zavartalanul virágzott. 


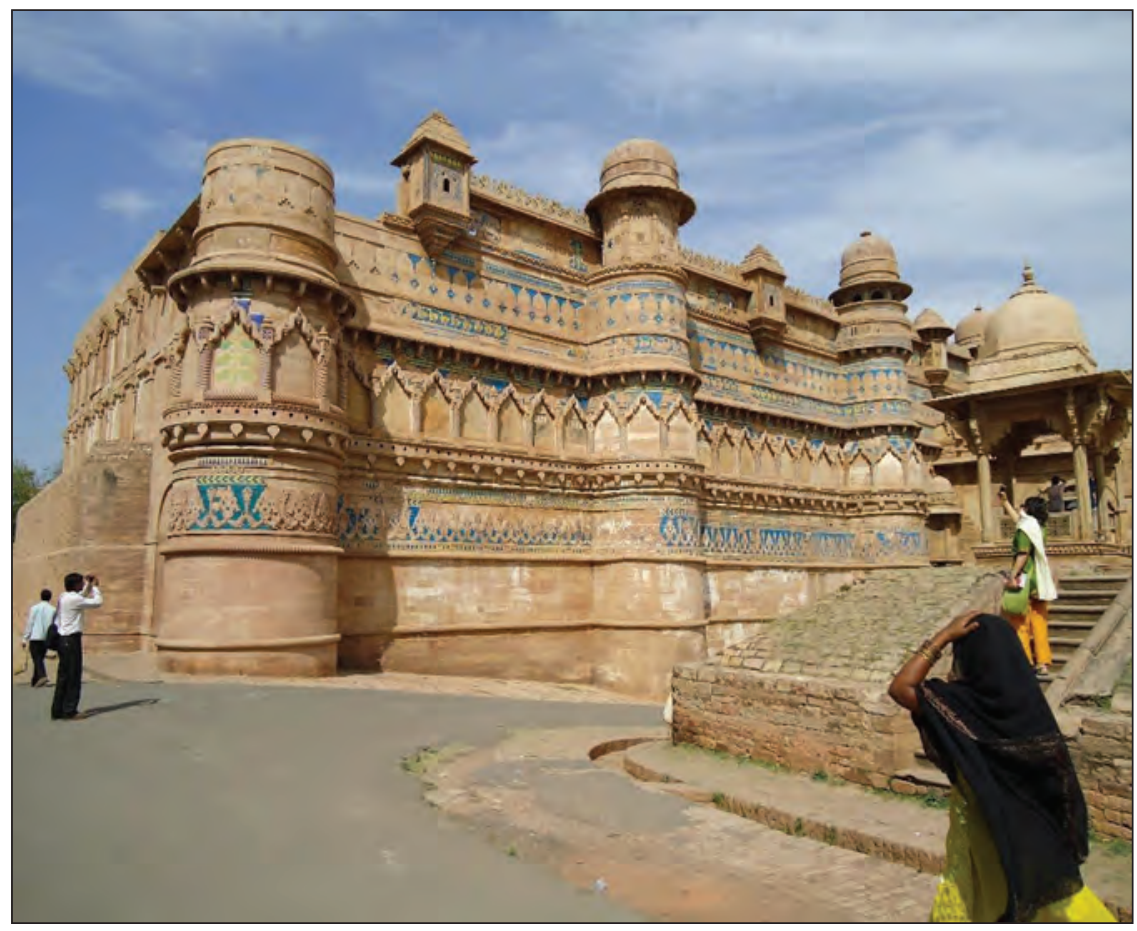

40. kép: A gválijari (Gwalior) erőd, Madhja Pradés. Mai formájában a 15-16. században épült ki

Forrás: ReNner Zsuzsanna felvétele

A Delhi Szultanátus valójában csak az előjátékát jelentette a Mogul Birodalom (1526-1858) létrejöttének, amely hatalma zenitjén a félsziget déli csúcsa kivételével a teljes indiai szubkontinenst a fennhatósága alatt egyesítette. A hatalmas birodalom kutatói vélemények szerint a maga korában Kínát is megelőzve a világ legnagyobb gazdasági hatalma volt, amelynek erejét a mezőgazdasági termelés növekedése, a kereskedelmi tőke felhalmozódása és az urbanizáció viszonylag magas szintje biztosította. A három fövárosból irányított közigazgatás hivatalos nyelve a perzsa volt. A Mogul-dinasztia legjelentősebb uralkodója, Akbar (1556-1605) rádzsput hercegnőt vett feleségül, s más módon is közelíteni igyekezett az iszlám és a hindu kultúrát. Tanulmányozta az indiai vallásokat és egy fúziós vallásban (Dín-i-iláhí, „isteni vallás”) ötvözte az iszlám és a hinduizmus akkor ismert irányzatainak elemeit. Utódai nem követték Akbart a vallási türelem útján, de az iszlám és hindu kultúra egyfajta szintézise mégis megvalósult, különösen az építészetben. A Mogul uralkodók mindegyike alatt hatalmas építkezések zajlottak, de közülük is kiemelkedett Sáh Dzsahán (16281658), a delhi és az agrai erőd, valamint a világhírü síremlék, a Tádzs Mahal építtetője. A kor muszlim épületein megjelennek a hindu építészet elemei, 
létrehozva a megkülönböztető jelleggel bíró indiai iszlám stílust. De az igazi szintézis még sokkal nyilvánvalóbb a rádzsput építészetben, amely nemcsak stíluselemeket (pl. karéjos ívek) vett át, hanem épülettípusokat (erőd, palota), technológiákat (boltozat, boltív, kupola) és szerkezeti megoldásokat (többemeletes, egybefüggö belső terek) is. Vallási téren az iszlám miszticizmus és a szúfi szentek jelenléte gyakorolt hatást a hindu vallásosságra, nyelvi szempontból az urdu nyelv kialakulása köszönhető a perzsa és az ind nyelvek kölcsönhatásának, zenében a hindusztáni (északindiai) klasszikus hangszeres és vokális zene viseli magán a perzsa és arab hatások bélyegét. A művészetben a kifinomult Mogul miniatúrafestészet - amely nem tiltotta az emberábrázolást - gyakorolt maradandó hatást a helyi indiai festészetre. Az iszlám az iparművészet és kézművesség számos, Indiában addig ismeretlen ágát honosította meg: a mázas kerámia készítését, a fémművesség megannyi válfaját, köztük a díszes fegyverek előállítását, a drágakőfaragást, a textilművességek közül a fémszálas és egyéb hímzéseket, a brokátszövést, a szőnyegszövést, és még hosszan folytathatnánk a sort. Ezeket a kézmủves ágakat, amelyek legnagyszerübb alkotásai a Mogul uralkodói mühelyekben (karkhána) készültek, Indiában ma is gyakorolják.

Az iszlám civilizációs ellenpontot jelentett India számára. Kozmopolita kultúrája, vallásának monoteizmusa és gyülekezeti jellege, épületeinek egyszerü és tiszta struktúrái, hatalmas terei, az emberábrázolás tilalma és a szobrászat teljes hiánya, az írás kalligráfiában is megnyilvánuló fontossága, az idö lineáris szemlélete és a történetírás szerepe mind szöges ellentétben állt az indiai civilizáció több ezer éves kulturális mintáival. Sokrétű kulturális hozadéka ugyanakkor az együttélés évszázadai során kitéphetetlenül beleivódott a szubkontinens civilizációs szövetébe. Az indiai civilizáció a gyarmatosítás és a modernizáció korában a hindu reneszánsz és a hindu vallási töltöttségü függetlenségi mozgalom összefüggésében további változásokon ment keresztül. Ma, amikor a vallási ellentétek sajnálatos módon nem csökkennek, hanem fokozódnak és a politikai csatározásokban a szenvedélyek felszítására alkalmas tényezővé válnak, csak remélhetjük, hogy India ma is élő civilizációja a tolerancia és a különféle gyökerủ kulturális jelenségek összeegyeztetésének régi hagyománya alapján képes lesz sokszínű múltját a szó legjobb értelmében befogadni és erőforrásnak tekintve azt a maga javára fordítani. 


\subsubsection{Időrendi tábla}

\begin{tabular}{|c|c|}
\hline dátum & esemény \\
\hline kb. i. e. $2600-1900$ & Indus-völgyi civilizáció \\
\hline kb. i. e. 1900-tól & Árják Indiába érkezése \\
\hline kb. i. e. $1500-600$ & Védikus kor \\
\hline i. e. 1500 körül & A Rigvéda keletkezése \\
\hline i. e. 6. század & Magadha felemelkedése, fővárosa Rádzsgriha, majd Pátaliputra \\
\hline $\begin{array}{l}\text { kb. i. e. } 599 / 570- \\
527 / 489 \text { vagy } 468\end{array}$ & Vardhamána Mahávíra, a Dzsina \\
\hline kb. i. e. $563-483$ & Gautama Sziddhártha, a Buddha \\
\hline i. e. $327-325$ & Nagy Sándor indiai hadjárata \\
\hline kb. i. e. $323-185$ & Maurja-kor \\
\hline kb. i. e. $268-231$ & Asóka Maurja \\
\hline i. e. $180-130$ & Indogörög királyságok északnyugaton \\
\hline $\begin{array}{l}\text { i. e. 1. század - i. sz. } \\
\text { 1. század }\end{array}$ & Saka és párthus királyságok északnyugaton \\
\hline $\begin{array}{l}\text { kb. i. e. 2. század - } \\
\text { i. sz. 2. század }\end{array}$ & Szátaváhana-dinasztia a Dekkánon és Közép-Indiában \\
\hline 1-3. század & Kusán-kor Északnyugat- és Közép-Indiában \\
\hline kb. $320-550$ & Gupta Birodalom kora \\
\hline kb. 3-6. század & Vákátaka-dinasztia az Észak-Dekkánon \\
\hline $\begin{array}{l}\text { kb. 600-1200, Dél- } \\
\text { Indiában 1761-ig }\end{array}$ & Hindu dinasztiák kora \\
\hline $\begin{array}{l}\text { kb. 6. század közepe } \\
\text { - 8. század közepe }\end{array}$ & Korai Nyugati Csálukja-dinasztia a Dekkánon \\
\hline 7-9. század & Pallava-dinasztia Ándhrában, Tamilnáduban \\
\hline 8-10. század & Rástrakúta-dinasztia a Dekkánon \\
\hline 8-12. század & Pála-dinasztia Kelet-Indiában \\
\hline $\begin{array}{l}\text { 9. század közepe - } \\
\text { 13. század }\end{array}$ & Csóla-dinasztia Tamilnáduban \\
\hline $1206-1526$ & Delhi Szultanátus \\
\hline $1526-1858$ & Mogul Birodalom \\
\hline 1556-1605 & Akbar \\
\hline $1627-1658$ & Sáh Dzsahán \\
\hline 14-19. század & $\begin{array}{l}\text { Rádzsput fejedelemségek Rádzsaszthánban, Közép-Indiában, a } \\
\text { Himalája lábánál fekvő területeken }\end{array}$ \\
\hline 1336-1565 & Vidzsajanagar \\
\hline $1858-1947$ & Indiai brit gyarmatbirodalom \\
\hline 1947 & $\begin{array}{l}\text { A függetlenség kikiáltása, az Indiai Köztársaság és Pakisztán } \\
\text { szétválása }\end{array}$ \\
\hline
\end{tabular}




\subsubsection{Irodalomjegyzék}

\section{Ajánlott irodalom}

Albanese, Marilia 2001: Az idötlen India. Budapest: Officina '96

Albanese, Marilia 2002: Angkor. A titokzatos ösi khmer birodalom. Budapest: Officina '96

BAKTAY ERvin 1932: India. 1-2. Budapest: Singer and Wolfner

Bhagavad-gítá. A Magasztos Szózata, 1997. - Szanszkrit eredetiböl fordította, az utószót és a jegyzeteket írta: Vekerdi József. Budapest: Terebess

Brockington, John L. 2007: A szent fonál. A hinduizmus folytonossága és változatossága. Budapest: General Press

Dezső Csaba (szerk., bev.) 2006: Óind irodalom. - In: SzePessy Tibor (föszerk.): Ókori és keleti irodalmak (szöveggyüjtemény). Antiqua et orientalia. Tananyagok az ókori és keleti nyelvek és kultúrák oktatásához. Budapest: Eötvös Loránd Tudományegyetem - http://gepeskonyv.btk. elte.hu/adatok/Okor-kelet/Okori.es.keleti.irodalmak/index.asp_id=716. html - 2018. 01. 07.

Dezső Csaba 2006: Hinduizmus. - In: DÉRI BALÁzs (főszerk.): Ókori és keleti vallások. Antiqua et orientalia. Tananyagok az ókori és keleti nyelvek és kultúrák oktatásához. Budapest: Eötvös Loránd Tudományegyetem http://gepeskonyv.btk.elte.hu/adatok/Okor-kelet/Okori.es.keleti.vallasok/ index.asp_id=17.htmlSzöveggyüjtemény - 2018.01.07.

FAJCSÁK GörgYI - RenNer Zsuzsanna 1997: Délkelet-ázsiai buddhista müvészet. Budapest: Iparmüvészeti Múzeum

GÁTHY Vera (szerk.) 1985: Falvak és kasztok a változó Indiában. Budapest: ELTE Állam- és Jogtudományi Kar-MTA Szociológiai Intézet

GÁTHY Vera 2017: India. A múltból a jövő felé. Budapest: Typotex / Pázmány Péter Katolikus Egyetem

Indiai regék és mondák, 1963. - Feldolg. Baktay Ervin. Budapest: Móra

IONS, Veronica 1991: Indiai mitológia. Budapest: Corvina

JeLen JÁNOS - Hegyi GáBor 1991: Angkor és a khmerek. Budapest: Officina Nova

Johnson, Gordon 1998: Az indiai világ atlasza. Budapest: Helikon KiadóMagyar Könyvklub

KelÉNyi Béla - RenNer Zsuzsanna 1991: Vajang. Jávai báb-és árnyjáték. Budapest: Hopp Ferenc Kelet-Ázsiai Művészeti Múzeum

KelÉnYi Béla - Renner Zsuzsanna 1993: Indonézia müvészete. Solaeman Pringgodigdo gyüjteménye. Budapest: Hopp Ferenc Kelet-Ázsiai Müvészeti Múzeum

Mahábhárata, 1965. - Ford.: Szerdahelyi István. Budapest: Európa 
MAJOR István 1978: A tamil irodalom kistükre. Budapest: Európa

NÉGYESI MÁRIA (szerk., bev.) 2006: Közép- és újind irodalom. - In: SzEPESSY TiвOR (föszerk.): Ókori és keleti irodalmak (szöveggyüjtemény). Antiqua et orientalia. Tananyagok az ókori és keleti nyelvek és kultúrák oktatásához. Budapest: Eötvös Loránd Tudományegyetem - http://gepeskonyv.btk. elte.hu/adatok/Okor-kelet/Okori.es.keleti.irodalmak/index.asp_id=718. html - 2018. 01.07.

Puskás ILDIKó 2000: Lélek a körforgásban. A hinduizmus születése. Budapest: Balassi

Rawson, Philip 1977: Az indiai civilizáció. Budapest: Helikon

RENNER ZsuzsanNa 2007: Indiai és délkelet-ázsiai müvészeti címszavak. - In: FAJCSÁK GyÖRGYI (szerk.): Keleti müvészeti lexikon. Budapest: Corvina

Renner Zsuzsanna: Indiai múvészet. - In: Dezső Tamás (föszerk.) - SzÁNTó Iván (szerk.): Ókori és keleti müvészet. Oktatási segédanyag. Antiqua et orientalia. Tananyagok az ókori és keleti nyelvek és kultúrák oktatásához. Budapest: Eötvös Loránd Tudományegyetem - http://gepeskonyv.btk. elte.hu/adatok/Okor-kelet/Okori.es.keleti.muveszet/index.asp_id=182. html - 2018. 01. 07.

Sanyal, Sanjeev 2013: Land of Seven Rivers. A Brief History of India's Geography. Penguin

Schmidt JózSEF 1923: Az ind filozófia. Budapest: Genius. - Elektronikus kiadás: Terebess Ázsia E-tár - https://terebess.hu/keletkultinfo/schmidt1. html - 2018. 01.07.

Schmidt József 1924: Ázsia világossága. Buddha élete, tana és egyháza. Budapest: Athenaeum

Schwartzberg, Joseph E. 2006: A Historical Atlas of South Asia. Second impression. Copyright (C) 1978 by the Regents of the University of Minnesota, assigned 1988 to Joseph E. Schwartzberg, additional material copyright (C) 1992 by Joseph E. Schwartzberg. Digital South Asia Library. - http://dsal.uchicago.edu/reference/schwartzberg/

SZENTKIRÁLYI ZoLTÁN 1980: Az építészet világtörténete. I-II. (India építészete c. fejezet, I. Budapest: Képzőművészeti Alap, pp. 229-272.

TÉCHY OLIVÉR 1986: Buddha. Budapest: Gondolat

VEKERDI JózSEF (szerk.) 1982: Mesefolyamok óceánja. Válogatás a szanszkrit elbeszélésirodalomból. I-II. Budapest: Európa

Wojtilla Gyula 1988: A mesés India. Budapest: Gondolat

WoOD, Michael 2007: The Story of India. BBC Books

Wood, Michael 2007: The Story of India. BBC documentary series, Episodes $1-6$. 



\section{Közel-Kelet}





\subsection{Judaizmus}

\section{ZsOM DÓRA}

A zsidó vallás a kereszténység és az iszlám mellett a három monoteista (egyistenhívö) vallás egyike, azok közül a legősibb. Kialakulása nem köthető egy adott történelmi eseményhez, mint ahogy a kereszténység Jézus Krisztus megjelenéséhez, vagy az iszlám Mohamed tevékenységéhez. A kereszténységtől és az iszlámtól eltérően továbbá a zsidó vallás nem térítő vallás, nem lép fel azzal az igénnyel, hogy az egész világ elismerje és kövesse. A zsidók önmagukat tulajdonképpen egy igen kiterjedt család tagjainak tekintik, akik egymással rokonságban állnak, a zsidó vallás pedig ennek a családnak, törzsnek vagy népnek a sajátos vallása. A családhoz (néphez) tartozás anyai ágon öröklődik. Emellett mindig is lehetséges volt csatlakozni a zsidósághoz egyfajta „örökbefogadás” révén, de ennek mértéke viszonylag korlátozott, és a zsidóság aktívan soha nem térített a nem-zsidó népek között.

A zsidó vallás eredete az ókori Mezopotámia és Egyiptom között vándorló nomád törzsekre vezethető vissza, amelyek saját törzsi istenüket tisztelték, annak áldozatokat mutattak be. A törzsek egy közös őstől, Izraeltől származtatták magukat, önmagukat „Izrael fiai”-nak nevezték. Ezen törzsek szövetsége az i. e. 13-12. század között telepedett meg Kánaánban, vagyis a mai Izrael, Palesztina, Libanon és Jordánia területén. Jeruzsálem központtal királyságot alapítottak, amely azonban már az i. e. 10. században kettészakadt egy északi (Izrael) és egy déli (Júda) királyságra. A környező birodalmak hódító hadjáratainak következtében mindkét királyság elvesztette függetlenségét: Izraelt, mint független királyságot az Asszír Birodalom az i. e. 8. században végleg felszámolta, Júda pedig előbb az Asszír, majd a Babiloni, a Perzsa, és végül a Római Birodalom fennhatósága alá került. A rómaiak lerombolták az ókori izraeliták központi kultuszhelyét, a jeruzsálemi templomot (i. sz. 70-ben), aminek következtében a vallás jellege teljesen átalakult. Ennek megfelelöen különbséget kell tennünk a bibliai kor vallása (bibliai judaizmus) és a későbbi korok zsidósága (rabbinikus judaizmus) között.

\subsubsection{Bibliai judaizmus}

Sem a zsidó Biblia, sem más zsidó szent szövegek nem használják a „judaizmus” fogalmát. A szó görög eredetijét a hellenisztikus korban kezdték használni a zsidó vallás követői sajátos vallásgyakorlatuk jelölésére. (Lásd 2 Makk. 2:21, 8:1, 14:38. Azsidó Biblia nem ugyanazokat a könyveket tartalmazza, mint a katolikus, a Makkabeusok könyve nem része a zsidó Bibliának.) A szó 
Ábrahám ősatya egyik dédunokájának, Júdának a nevéből ered, akitől Júda törzse származtatja magát. Többszörös átvételeken keresztül, Júda nevéből ered a magyar nyelv „zsidó” szava is. A „héber” szó a Bibliában előforduló „,ivri” alak magyar megfelelője, mely az ,átkelni, átmenni, vándorolni” jelentésü héber szóból származik. A Biblia a zsidóság ősatyját, a nomád Ábrahámot nevezi „,ivri”-nek. Ábrahám fia Izsák, az ő fia pedig Jákob, akit új nevén Izraelnek neveztek. Ök hárman a zsidó nép ősatyjai (pátriárkái). Izrael (Jákob) tizenkét fiától származik Izrael tizenkét törzse, köztük a már említett Júda is. A mai magyar nyelvben a „zsidó” szót a nép és a vallás, az „izraelita” szót a vallás, a „héber” szót pedig elsősorban a nyelv megnevezésére használjuk.

A bibliai kor vallására vonatkozó legfőbb forrás maga a Biblia. A zsidó Biblia nagyjából a protestáns Biblia Ószövetségének felel meg, vagyis ugyanazokat a könyveket tartalmazza, de más csoportosításban. A zsidó Biblia három részre oszlik (Tóra, Próféták, Írások). A Tóra (jelentése: Törvény, Mózes öt könyvét foglalja magában) elsősorban jogi szöveg, de a Tórában található a világ és az első emberpár teremtésének leírása, a vízözön és Noé bárkája, a Bábel tornya és a nyelvek összekeverésének története, az ösatyák vándorlásai, Izrael kivonulása Egyiptomból, Mózes csodatételei, a Tízparancsolat, a pusztai vándorlás leírása is. Az ókori Izrael történetének folytatása, vagyis a honfoglalás és a két királyság története az ún. korai és kései próféták könyveiben (Józsué, Bírák, Sámuel, Királyok, Ézsaiás, Jeremiás, Ezékiel) olvasható, amelyek a 12 kispróféta könyvével együtt alkotják a zsidó Biblia második nagy egységét, a „Próféták”-at. A harmadik csoport, az „Írások”, költői és történeti könyveket egyaránt tartalmaz: Zsoltárok, Példabeszédek, Jób, Énekek éneke, Rút, Jeremiás siralmai, Prédikátor, Eszter, Dániel, Ezsdrás-Nehemiás könyve, Krónikák. A három csoport nem tükrözi a szövegek létrejöttének kronológiáját, ami különben igen összetett probléma: a bibliai történeteket kezdetben szóban hagyományozták, majd írásba foglalták, a ma ismert szöveg pedig különbözö források összedolgozása eredményeképp, több szerkesztési fázis során jött létre. Az összedolgozott, egy egységes történetté gyúrt források eltérő korúak és eredetűek, és különböző műfajúak. Műfajilag és tartalmilag is a környező népek irodalmi hagyományába illeszkednek, sok közismert bibliai történet és motívum (a világ teremtése, vízözön, stb.) az ókori Közel-Kelet több népénél is ismert.

\subsubsection{Izrael bibliai története}

A bibliai történet szerint Isten megparancsolta Ábrahámnak, hogy hagyja el atyái földjét, és vándoroljon abba az országba, amelyet majd mutat neki (1Móz 12:1-3). Ábrahám és családja a dél-mezopotámiai Urból Kánaánon keresztül Egyiptomba vándorolt, és útja során Isten ígéretet tett neki, hogy Kánaán földjét családjának és utódainak adja birtokul (14. térkép). 
4.1. Judaizmus

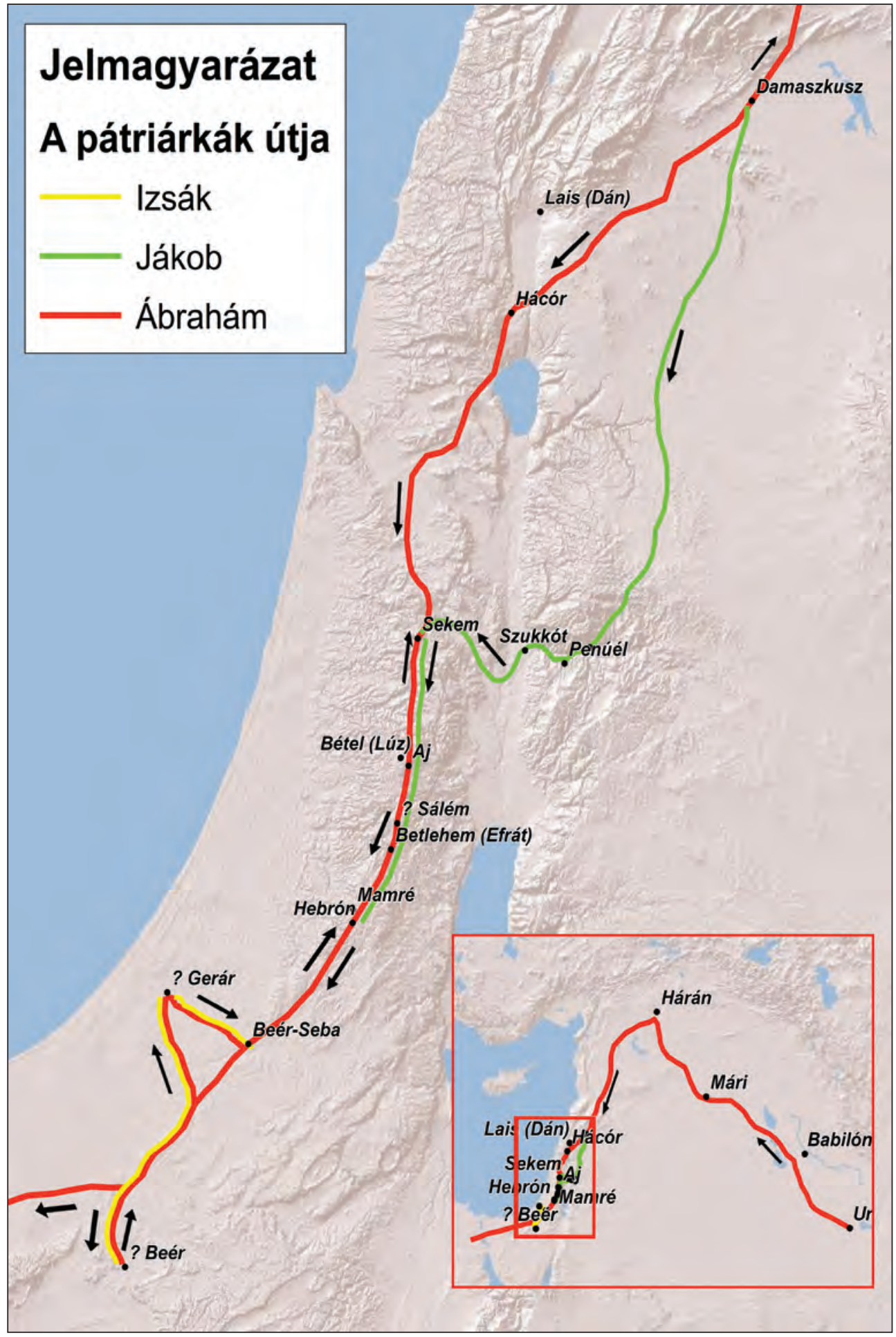

14. térkép: Az ősatyák vándorlása a Biblia alapján Forrás: VARGA ÁGNES szerkesztése 
Ennek megerősítésére Isten szövetséget kötött Ábrahámmal, amelynek jele a körülmetélés (1Móz 17:1-14). A pátriárkák, vagyis Ábrahám, fia Izsák, és annak fia, Jákob idejében Isten többször megismételte a családnak tett ígéretét, azonban a család (törzs) ekkor még nem telepedett le Kánaán területén, hanem legeltető nomád életmódot folytatva, Egyiptom és Mezopotámia között vándorolva többször áthaladt a későbbi Izrael földjén. Az Izrael elnevezést a Biblia egy csodás történettel magyarázza: Jákob ősatya egy éjjel egészen hajnalig küzdött egy rátörő angyallal, aki küzdelmük végén az Izrael nevet adta neki, mert „küzdöttél Istennel és emberekkel, és győztél” (1Móz 32:29). A népetimológia szerint a héber yisrael szó ugyanis beszélő név, melynek jelentése „aki küzd Istennel, kitart Istennel szemben”. Jákob tizenkét fia a Kánaánt sújtó éhínség elöl Egyiptomba menekült, ahol letelepedtek és megsokasodtak. Izrael (Jákob) tizenkét fiától származik Izrael népének tizenkét törzse, akik egy néppé az Egyiptomból történő kivonulás során kovácsolódtak.

Mózes második könyve számol be arról, hogy Izrael sora megromlott Egyiptomban, mivelazegyiptomiak szolgasorba taszították anépet. Szószólójukká Mózes vált, aki Isten parancsára azt követelte a fáraótól, engedje útjukra őket, hagy menjenek vissza Kánaánba. Mikor a fáraó a kérés teljesítését megtagadta, Isten tíz csapással sújtotta Egyiptomot, amelyek közül a legsúlyosabb az elsőszülöttek halála volt. A történet szerint Isten megparancsolta Izraelnek, hogy vágjanak le áldozati bárányokat, a húst kovásztalan kenyérrel egyék meg, a bárány vérét pedig kenjék az ajtófélfára, éjszakára pedig zárkózzanak be házaikba, mert: „Amikor átvonul az Úr, hogy megverje Egyiptomot, és meglátja a vért a szemöldökfán és a két ajtófélfán, akkor kihagyja az Úr azt az ajtót, és nem engedi, hogy bemenjen a pusztító a ti házatokba. (...) Történt azután éjfélkor, hogy megölt az Úr minden elsőszülöttet Egyiptom földjén, a trónján ülő fáraó elsőszülöttjét csakúgy, mint a tömlöcben levő foglyok elsőszülöttjét, és az állatok minden elsőszülöttjét." (2Móz 12:23, 29) Ezután a fáraó beleegyezett abba, hogy Izrael kivonuljon országukból, de hamarosan meggondolta magát, seregével üldözőbe vette, és utolérte őket a Vörös-tengernél. Mózes ekkor botjával kettéválasztotta a Vöröstengert, Izrael száraz lábbal kelt át a kétoldalt falként álló víztömeg között, az üldözőik azonban a visszazúduló tengervízbe fulladtak. Ezek után Izrael népe negyven évig vándorolt és bolyongott a pusztában, mely során Isten megtanította őket arra, hogyan kell őt szolgálni. A pusztai vándorlás elején került sor a Sínaihegyi kinyilatkoztatásra, amikor Isten átadta a kőtáblákra vésett tízparancsolatot, és közölte Mózessel többi parancsolatát és törvényét is, és szövetséget kötött a néppel (2Móz 20:1-17, 24:3-8, 12). Az isteni kinyilatkoztatás túlságosan félelmetes volt a nép számára, ezért azt kérték, Mózes képviselje őket Isten előtt. Mivel azonban Mózes túl sokáig maradt távolt, úgy vélték, talán felemésztette az isteni jelenlét elviselhetetlen ereje. Ezért bálványistent, aranyborjút készítettek maguknak. 


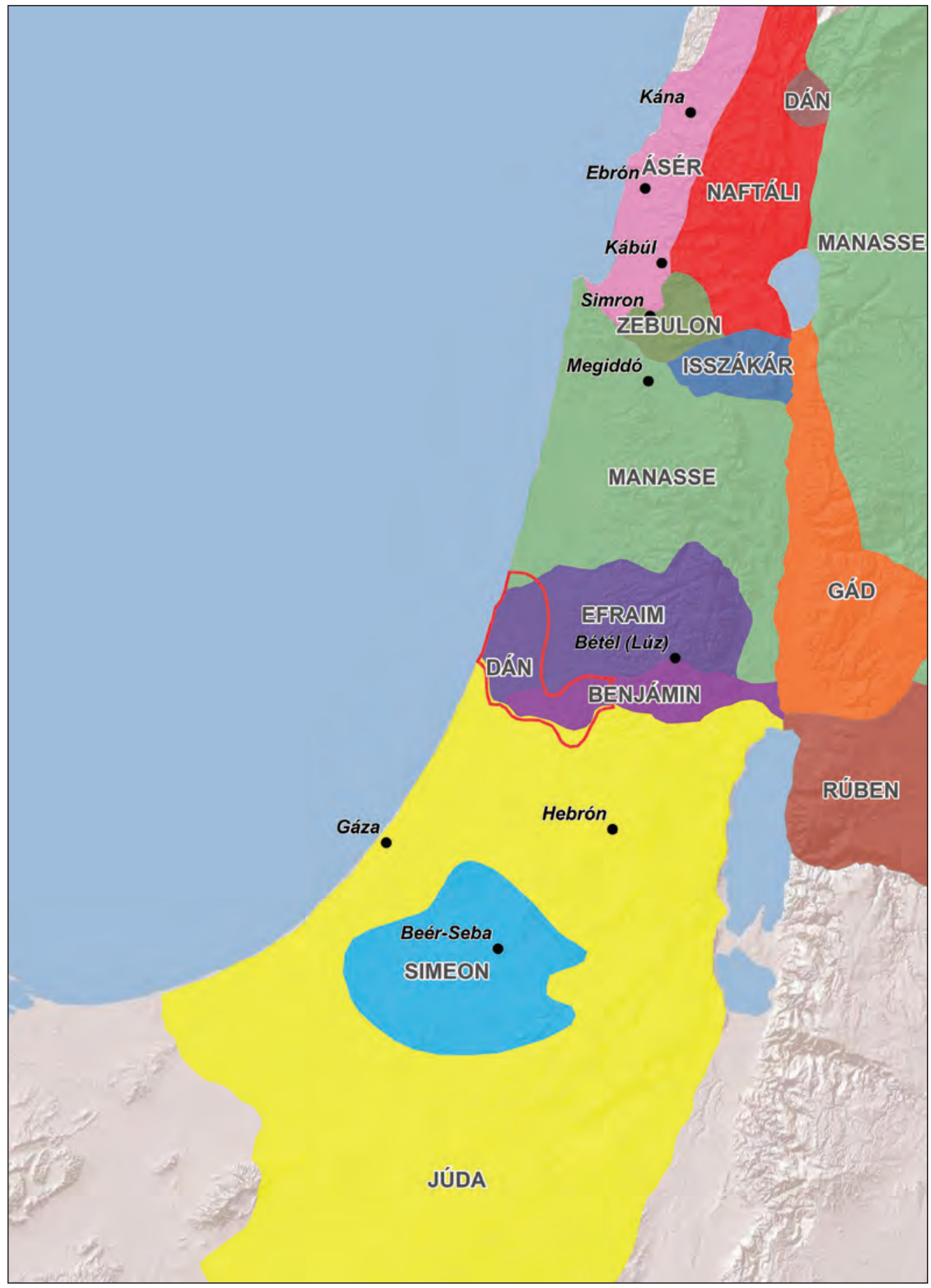

15. térkép: Törzsi tagolódás a Biblia alapján Forrás: VARGA ÁGnes szerkesztése 
Mózes a Sínai-hegyről negyven nap után visszatérve a népet bálványimádó kultusz gyakorlása közben találta, ezért dühében összetörte a kőtáblákat, amelyekre Isten saját maga írta fel törvényeit. A nép azonban bünbánatot tartott, így Isten parancsára Mózes újból elkészítette a kőtáblákat, ezúttal ő írta rá fel a parancsolatokat. A vándorlás során maga Isten vezette a népet, és kultuszhelye a hordozható pusztai szentély volt. A szövetség ládája (frigyláda) a rajta lévő szárnyas kerubokkal a láthatatlan Isten kézzelfogható trónja volt, az isteni jelenlét megnyilvánulásának helye.

Kánaán elfoglalására csak a hosszas pusztai vándorlás után került sor, amikor a népet már Józsué vezette. A tizenkét törzs felosztotta egymás között az elfoglalt területeket, és igyekeztek megtartani azokat a szomszédos népek betöréseivel szemben (15. térkép). A törzsszövetség hamarosan királysággá alakult, amelynek élén először Saul, majd Dávid (i. e. 10. sz. első fele), aztán fia, Salamon állt (i. e. 10. sz. második fele). Jeruzsálemet Dávid foglalta el, és tette királysága fővárosává. A központi kultuszhelyet, a jeruzsálemi templomot Salamon építette. A kultusz lényege az áldozatbemutatás volt, amiről a papi rendek (kohenek, leviták) gondoskodtak. Salamon halála után a királyság két részre szakadt, tíz északi törzs Izrael néven önálló királyságot hozott létre, még a két déli törzs (a nagyobb Júda és a kisebb Benjamin) Júda néven alkotott közös királyságot. A következő két évszázadban (i. e. 9-8 sz.) a két királyság egymással, a környező népekkel és a térség két meghatározó birodalmával (Egyiptom és Asszíria) is hadakozott, míg végül Izraelt az Asszír Birodalom beolvasztotta (i. e. 721) (16. térkép). Az Asszír Birodalom politikájának megfelelően a lakosság jelentős részét a birodalom más területeire deportálták, Izraelbe pedig a birodalom más részeiröl származó népcsoportokat telepítettek be. Hamarosan Júda is Asszíria fennhatósága alá került, majd az Asszír Birodalom bukása után az Újbabiloni Birodalom részévé vált. Nebukadneccar (Nabú-kudurri-uszur) babilóniai uralkodó i. e. 597-ben elfoglalta Jeruzsálemet és a lakosság egy részét deportálta („bábeli fogság”). Mintegy tíz évvel később Júda fellázadt a babilóniai uralom ellen, mire a babilóniai hadsereg megostromolta és elfoglalta Jeruzsálemet. A várost és a templomot lerombolták (i. e. 587). Kürosz perzsa király i. e. 540-ben legyőzte Babilóniát, és engedélyt adott a deportált zsidóknak arra, hogy visszatérjenek Jeruzsálembe, de a templom újjáépítése csak i. e. 516-ban fejeződött be („,második templom”). A következő évszázadok eseményeiről a zsidó Biblia már nem tudósít: Júda újabb birodalmak érdekszférájába került: miután Nagy Sándor elfoglalta, görög katonai és kulturális befolyás alatt maradt, ami ellen i. e. 167-ben a zsidók fellázadtak (Makkabeusfelkelés). Pompeius i. e. 63-ban sikeres hadjáratot vezetett Júda ellen, ami után a királyság a Római Birodalom érdekszférájába került, hol júdeai királyok, hol római kormányzók (prokurátorok) irányították. A római uralom elleni zsidó felkelésre adott válaszul i. sz. 70-ben a római hadsereg lerombolta Jeruzsálemet és a második templomot, ami ezután soha nem épült újjá. 


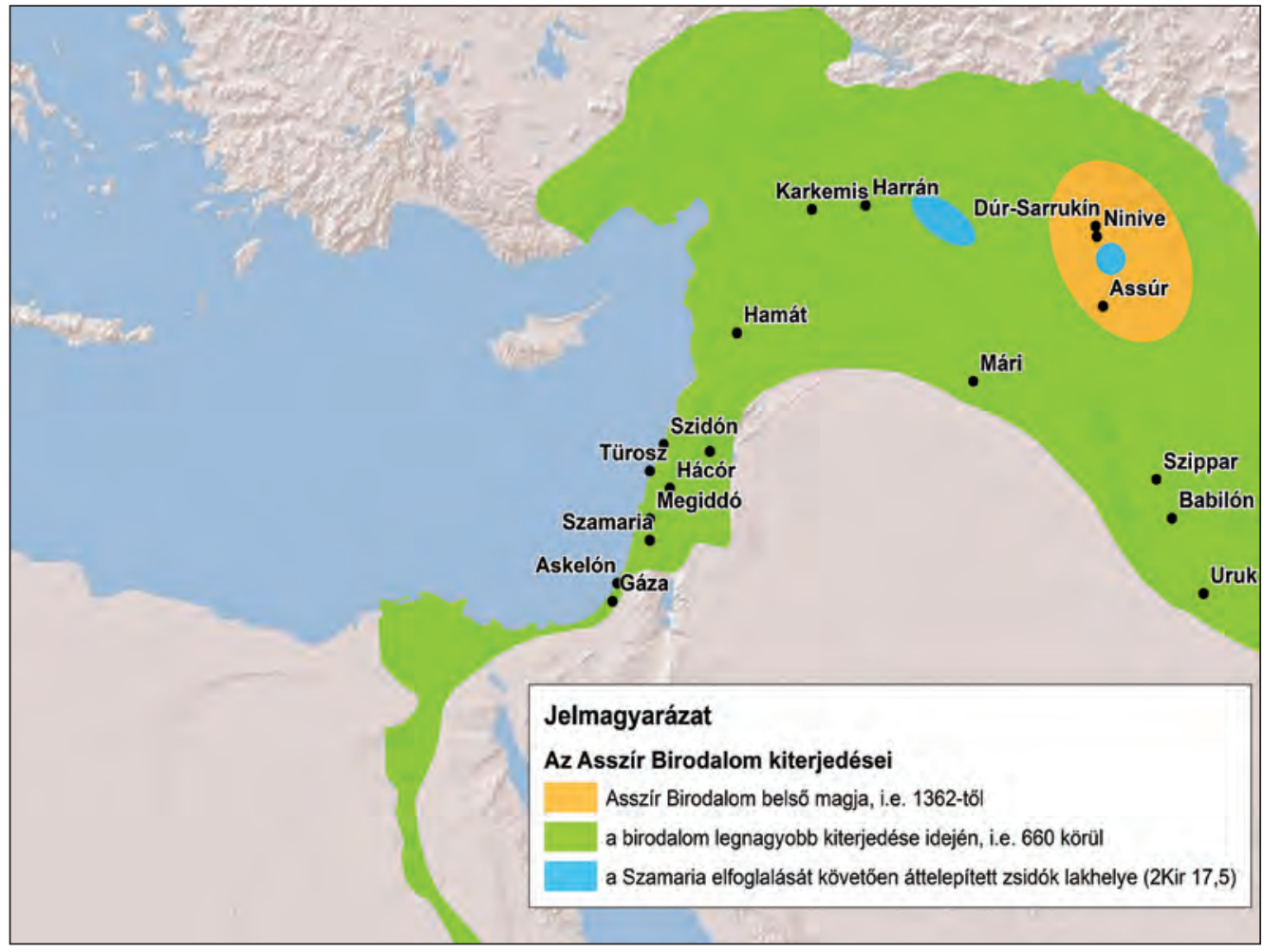

16. térkép: Az Asszír Birodalom Izrael beolvasztása után Forrás: VARGA ÁGNES szerkesztése

A templom körzetéhez tartozó egyetlen ma is álló fal a Siratófal (más néven nyugati fal), amely azonban nem a templom épületének fala, hanem a templom körzetét körülkerítő fal egy szakasza, amelyet Nagy Heródes (uralk. i. e. 37. - i. e. 4.) építtetett. Jelentőségét az adja, hogy a gyakorlatban ma egy vallásos zsidó a Siratófalnál közelebb nem juthat az egykori templom területéhez, amely az iszlám hódítás után muszlim szent hely (is) lett. Az egykori templom helyén ma a Szikladóm áll.

\subsubsection{A bibliai kor kultusza}

A kezdeti idő törzsi kultusza lassan alakult át központosított vallásgyakorlattá, amelynek alapvető fogalma a szövetség, kezdetben Isten és egy konkrét személy (Ábrahám) között, majd Isten és egy törzs (Ábrahám leszármazottai) között, végül Isten és egy nép (Izrael) között. A szövetség két fél szerződése, amelynek pontosan meghatározott feltételei vannak, s amelyben a szerződő felek bizonyos kötelezettségeket vállalnak magukra. A bibliai történet szerint Isten arra tett ígéretet, hogy Izraelt saját választott népének tekinti, önmaga 
vezeti be Kánaánba, amelyet örökül ad nekik. Izrael kötelessége pedig az, hogy betartsa Isten törvényeit: „Mózes felment Istenhez, az Úr pedig így kiáltott hozzá a hegyről: Így szólj Jákob házához, és ezt hirdesd Izrael fiainak: Ti láttátok, mit cselekedtem Egyiptommal, hogyan hordoztalak benneteket sasszárnyakon, és hogyan hoztalak ide benneteket. Most azért, ha engedelmesen hallgattok szavamra, és megtartjátok szövetségemet, akkor ti lesztek az én tulajdonom valamennyi nép közül, bár enyém az egész föld. [...] Az egész nép egy akarattal felelte: Megtesszük mindazt, amit az Úr mondott.” (2Móz 19:3-5, 8)

A kultusz elsősorban áldozatok bemutatásából és bizonyos vallási ünnepek megtartásából állt, amelyek közül három ünnepen az egész nép köteles volt Jeruzsálembe zarándokolni és ott áldozatot bemutatni a jeruzsálemi templomban. A templom egyes részeinek szentsége szerint különböző területekre oszlott: a külső udvarba mindenki, még a nem-zsidók is bemehettek; a belsőbe a nem-zsidók már nem léphettek be, de a zsidók nők igen; még beljebb már csak a zsidó férfiak mehettek; a belső termekbe pedig csak a papok léphettek be. A legszentebb terület az úgynevezett „Szentek Szentje” volt, ahová csak a föpap léphetett be évente egyszer, az engesztelés napján (jom ha-kippurim, jom kippur), ahol a szövetség ládája fölött láthatatlanul maga Isten volt jelen. Ez volt az egyetlen nap, amikor Isten tulajdonképpeni nevét a föpap kimondta. A zsidó hagyomány szerint Isten négy betüből álló tulajdonnevét (tetragrammaton) tilos kimondani, csak helyettesítő neveket szabad használni, mint például „Úr”, vagy „Örökkévaló”. A négybetüs istennévnek olyan erőt és hatalmat tulajdonítottak, ami a föpapra nézve is életveszélyes volt, amikor ezen az egy napon, az isteni elö́rásnak engedelmeskedve kimondta a tabu nevet.

A templom lerombolása után az addigi vallásgyakorlat gyökeresen átalakult, hiszen központi eleme, az áldozatbemutatás lehetetlenné vált. Annak szerepét a szent szövegek tanulása, recitálása, magyarázata és kommentálása vette át.

\subsubsection{Irányzatok és felekezetek}

A második templom lerombolása (i. sz. 70) után a zsidóság többsége diaszpórába kényszerült, vagyis szétszóródott a világban. A zsidó nép története ezért rendkívül szerteágazó, hiszen az egyes országok történelmének képezi szerves részét. Az egyes közösségek saját hagyományaikat követték, a többségi társadalmon belül mindig kisebbségben, a többséghez kisebb vagy nagyobb mértékben asszimilálódva (például nyelvükben, szokásaikban, öltözetükben és jogrendjükben) éltek. A közösségek nem alkottak egyetlen hierarchikus szervezetet, hanem igen nagyfokú függetlenséget élveztek. Közös eredetük, szokásaik és rítusaik alapján három nagy csoportot különböztethetünk meg: az askenázi, a szefárd és a mizrahi zsidókat. 
Askenázi zsidóknak nevezik azokat, akik Németország, ill. ÉszakFranciaország területéről származnak, és az ott kialakult rítust és szokásokat követik, bárhol is élnek napjainkban: az Egyesült Államokban, Izrael államban vagy éppen Budapesten. A középkorban Németország és Franciaország a zsidóság egyik szellemi központja volt, ezért Európában az askenázi zsidóság vált mérvadóvá. Az askenázi zsidók beszélt nyelve a germán nyelvcsaládba tartozó jiddis volt, kisebb mértékben még ma is az. Askenaz Németország neve a középkori héber szövegekben.

Szefárd zsidóknak nevezik az Ibériai-félszigetről elszármazott zsidókat. A középkor végéig a mai Spanyolország és Portugália területén virágzott a zsidó kultúra. Amikor 1492-ben a „katolikus királyok”-ként (Reyes Católicos) ismert Kasztíliai Izabella és Aragóniai Ferdinánd királyságaik területéről kiűzték az utolsó muszlim hódítókat is, úgy döntöttek, hogy egy vallású, egységesített nemzetet hoznak létre. Ezért az uralmuk alatt élő zsidókat választás elé állították: vagy áttérnek a kereszténységre, vagy elhagyják az országot. A kivándorlás mellett döntő közösségeknek három hónapos türelmi időt hagytak arra, hogy addigi életüket felszámolják, ingatlanjaikat eladják, és útra keljenek. Az ingatlanárak természetesen azonnal a mélybe zuhantak, hiszen köztudomású volt, hogy a távozó zsidók bármilyen alacsony áron is, de mindenképpen kénytelenek lesznek pénzzé tenni vagyonukat, hiszen a türelmi idő lejárta után zsidó - halálbüntetés terhe mellett - nem tartózkodhatott a katolikus királyok országaiban. A vagyon kivitelét különben nagyban megnehezítette, hogy megtiltották a nemesfémek kivitelét az országból. A kivándorló zsidók egy része Észak-Afrikában és az Oszmán Birodalomban telepedett le, más részük azonban a közeli Portugáliába költözött át, ahol azonban hamarosan újabb megpróbáltatás várta őket. Portugáliában 1497ben adtak ki a spanyolhoz hasonló kiüzési rendeletet, azzal a különbséggel, hogy a türelmi idő csak egy hónap volt. Azonban a portugál kiüzésre végül nem került sor: amikor a tengerre szállásra kijelölt kikötőkben az indulásra megadott napon a zsidók összegyültek (miután felszámolták üzleteiket és eladták házaikat), a papság és a katonaság egyszerüen körbefogta őket, és a távozni készülőket erőszakkal megkeresztelték, majd, mint friss keresztény alattvalóknak, megtiltották nekik, hogy elhagyják az országot. Ennek oka az volt, hogy a portugál uralkodó időközben rájött, gazdasági hátrányt jelentene a számára, ha azt a kisiparos, kereskedő és bankár réteget, amit a zsidóság jelentett, száműzné az országból. Annak ellenére, hogy a kikeresztelkedett zsidók utazását Spanyolországban is korlátozták, és a vallási életre mindkét országban az Inkvizíció felügyelt, a következő évszázadok során folyamatos volt a zsidó származású keresztények elvándorlása az Ibériaifélszigetről. Az Ibériai-félszigetről származó zsidók a szefárd zsidók (Szefarad a középkori héber irodalomban Spanyolország neve), akik a ladino nyelvet beszélték egészen a legutóbbi időkig, vagyis tulajdonképpen megtartották a spanyol nyelvet az országtól elszakadva is még mintegy ötszáz éven át. 
A mizrahi, vagyis héberül „keleti”, zsidók azok a muszlim területeken élő zsidók, akik nem az Ibériai-félszigetről kivándorolva telepedtek meg muszlim országokban, hanem már korábban. Mizrahi zsidók élnek a Közel-Keleten, Irakban, Iránban, a Kaukázus térségében, Indiában és Pakisztánban is. Mivel azonban a szefárd zsidók túlnyomó többsége is muszlim országokban élt, gyakran a „keleti” zsidókat is szefárdoknak nevezték.

\subsubsection{A zsidóság nyelvei}

A zsidóságra jellemző, hogy saját, héber nyelve mellett vagy helyett annak a területnek a domináns nyelvét is beszéli, ahol él. Amikor Szíria-Palesztina térségében az arámi vált közvetítő nyelvvé, az arámit a zsidóság is átvette, olyannyira, hogy a héber egyre inkább a kultusz és a müvelt írásbeliség területére szorult vissza, az általánosan beszélt nyelv azonban az arámi lett. Amikor a zsidóság szétszóródott a világban, az egyes zsidó közösségek anyanyelve annak az országnak a nyelve lett, ahol letelepedtek. Az is előfordult azonban, hogy egy ekképpen átvett idegen nyelvhez annyira ragaszkodtak, hogy akkor is tovább használták, amikor más nyelvterületre vándoroltak tovább. A középkorban az Ibériai-félszigeten letelepedő zsidók például spanyolul beszéltek (a spanyol korabeli nyelvállapotának megfelelően), és ezt a nyelvet az után is megőrizték, hogy 1492-ben kiüzték őket Spanyolországból, és szétszóródtak Észak-Afrikában, a Földközi-tenger keleti partvidékén és Kis-Ázsiában. Az alábbiakban csak három fontosabb nyelvről teszünk említést.

\section{Arámi}

Az arámi nyelv az Újasszír Birodalom idején vált egyfajta lingua francavá Mezopotámiában és a Közel-Keleten, így Szíria-Palesztina térségében is. A Biblia egyes részei arámiul íródtak (Dániel, Ezsdrás könyve), és időszámításunk kezdete körül a zsidók (így Jézus is) arámiul beszéltek. Arámiul van a posztbiblikus zsidó irodalom jelentős része: a Talmud jelentős része, különböző exegetikai gyüjtemények (midrások), és természetesen a Biblia arámi fordításai (Targumok) is.

\section{Jiddis}

A középkorban kialakult dialektus, amelyet az Európában élő zsidók használtak. Tulajdonképpen a német nyelv egy dialektusa, de igen sok héber és más eredetü jövevényszót is tartalmaz, és héber betükkel írják. Főleg akkor terjedt el, amikor a héber nyelvet már nem beszélő tömegek számára jiddisre fordították a Bibliát és annak magyarázatait. Ma a modern héber fokozatosan 
háttérbe szorítja a jiddist, de még mindig sok, többségükben már rég nem Európában élő ortodox közösség beszélt nyelve.

\section{Ladino}

Az Ibériai-félszigetről 1492-ben kiűzött zsidók leszármazottainak nyelve, mely egészen egy-két generációval ezelőttig széles körben beszélt nyelv volt elsősorban a törökországi zsidók körében. (A spanyolországi kiüzést követően a zsidók nagy számban vándoroltak az Oszmán Birodalom területére). Izrael állam létrejötte óta a muszlim területeken élő zsidóság szinte teljes egészében Izraelbe vándorolt, és ott a több száz éven át használt ladino nyelvet pár generáció alatt elvesztette. A ladino sok tekintetben a spanyol nyelv 15 . századi állapotát konzerválta, miközben persze rengeteg héber és más eredetü jövevényszóval is gazdagodott. Héber betűkkel írják.

\subsubsection{Rabbinikus judaizmus}

A zsidó vallásban központi szerepet betöltő rabbi (tanítómester) szó egyáltalán nem szerepel a zsidó Bibliában. Előfordul azonban az Újszövetségben, és az időszámításunk kezdeteire datálható zsidó iratokban, így például a Misnában. A rabbi a vallásjogot nemcsak tanította, hanem annak megfelelően döntéseket is hozott a vitás ügyekben, mind a vallásjog, mind a polgári vagy büntetőjog területén. Amikor a zsidóság szétszóródott a világban (diaszpóra), a rabbi szerepe módosult, mivel az egyes országokban a zsidó vallásjog mellett az adott ország törvényeit is tekintetbe kellett venni, ami sok esetben nem, vagy csak korlátozott mértékben engedte például az országétól eltérő, külön büntetőjog alkalmazását. Kezdetben a rabbiknak saját mesterségük is volt, amelyböl családjukat eltartották, mivel a rabbiságért nem fogadhattak el fizetést. Az egyes zsidó közösségek élén rabbik álltak, és állnak a mai napig, akik annak a közösségnek az ügyeit a közösség más tisztségviselőivel együtt igazgatják. Az egyes közösségek autonómok, vagyis más közösség nem szólhat bele az ügyeikbe, nem bírálhatják felül döntéseiket: a zsidóságon belül nincs olyan hierarchia, mint pl. a katolikus egyházban, ahol az egész szervezet élén a pápa, mint legfőbb hatalom áll. Ez természetesen nem jelenti azt, hogy minden közösség egyenlő súlyú lenne; politikai, gazdasági, vagy kulturális (intellektuális) okokból is túlsúlyba kerülhet egy adott közösség másokkal szemben. Ha ez megtörténik, a többi közösség a vezetö közösséghez kezd igazodni, annak gyakorlatát követi, addig legalábbis, amíg a vezető közösség dominanciája fennáll. A zsidó diaszpóra sajátosságaiból kifolyólag rendszerint egyszerre több vezető közösség létezik, amelyek azonban egymással nincsenek hierarchikus viszonyban. 


\subsubsection{A zsidó vallás legfontosabb szövegei}

A Biblia mellet a zsidóság legfontosabb szövegei a Misna és a Talmud, valamint ezek magyarázatai. A Biblián belül különleges jelentőséggel bír a Tóra (jelentése: tanítás, tan, törvény), vagyis Mózes öt könyve (41. kép). A zsidó hagyomány szerint a Tórát Mózes kapta Istentől a Sínai-hegyen, és vele együtt kapta meg a Tóra szóbeli magyarázatait is. Eszerint hagyományosan különbséget tesznek ,írott tan” (írott Tóra) és „szóbeli tan” (szóbeli Tóra) között. Ez utóbbit elsősorban a későbbi vallásjogi gyüjtemények, a Misna és a Talmud tartalmazzák.

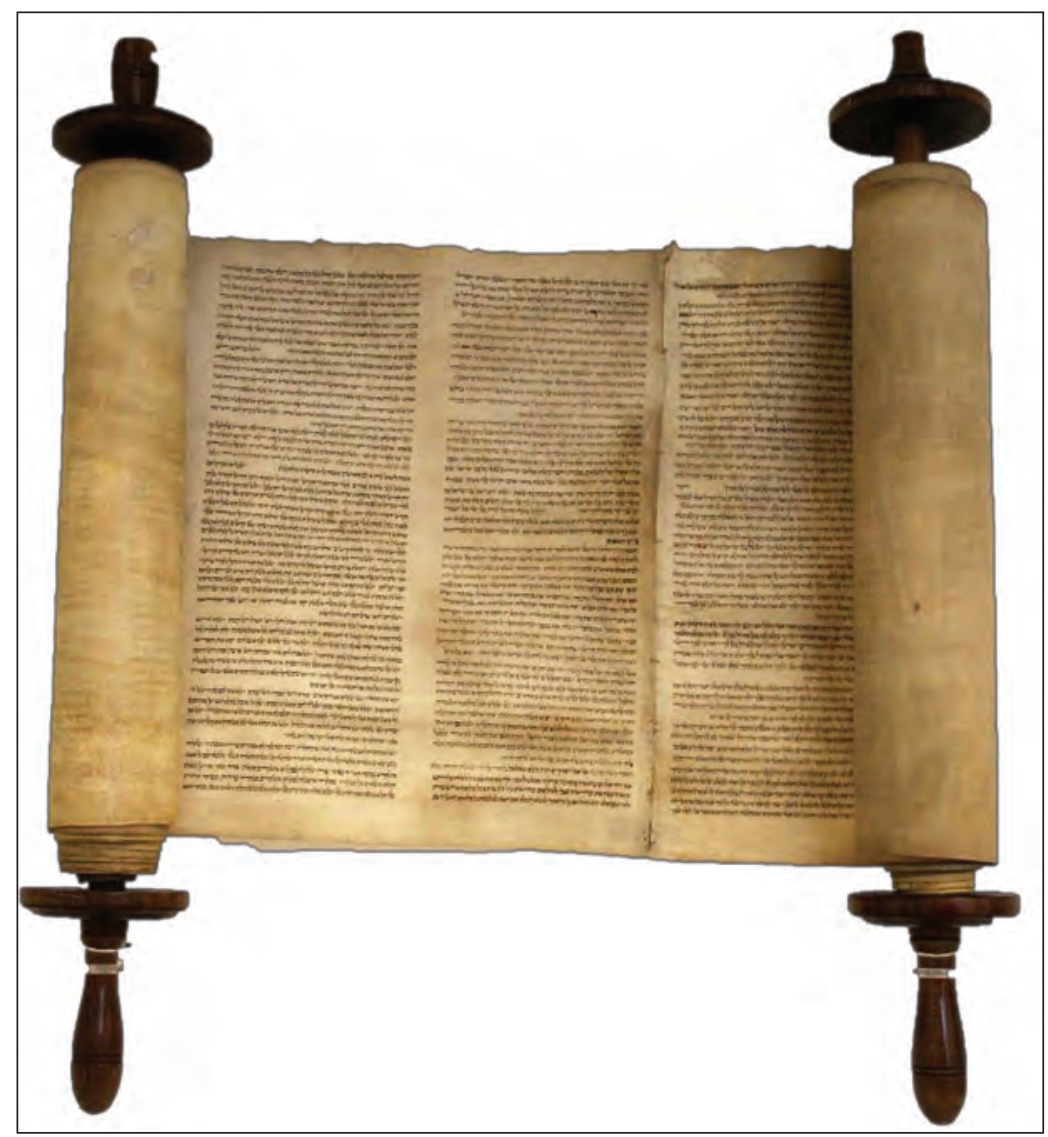

41. kép: Tóratekercs a Munk-Munkácsi gyüjteményböl, MILEV Forrás: http://collections.milev.hu/items/show/31795-2018. 01. 03.

A Tórából minden héten felolvasnak egy nagyobb részt, az úgynevezett hetiszakaszt a zsinagógában (hétfön, csütörtökön és szombaton). A Tóra 54 hetiszakaszra van osztva; ebben a heti bontásban lvassák fel nyilvánosan minden évben az egész szöveget. (A zsidó naptár és az ünnepek sajátosságai miatt több hetiszakasz van, mint ahány hét egy évben, ezért egyes hetekre két 
hetiszakasz is esik.) A szöveget jellegzetes intonációval, kántálva olvassák, a szöveget közben kis, a végén kéz alakú ezüstpálcával, tóramutatóval követik (42. kép). Nem kötelező ezüst tóramutatót használni, a lényeg az, hogy puszta kézzel ne érintsék meg a szent szöveget.

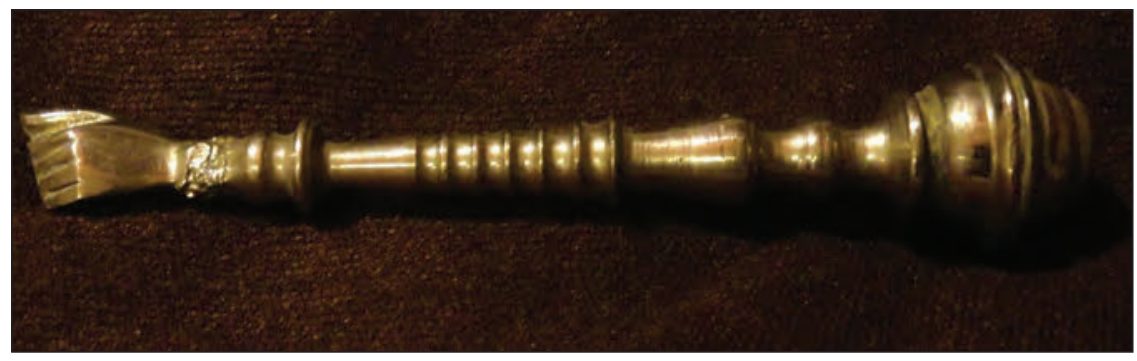

42. kép: Tóramutató, Marrakes, Zsidó Múzeum Forrás: DÉvÉNYI KINGA felvétele

A Tórát egyetlen pergamentekercsre, kézzel írják, a tekercs két végére tartóbotokat erősítenek, ezekkel lehet a pergament tekerni. A pergamen rituálisan tisztának számító állat bőréből készül, ennek megfelelően igen drága.

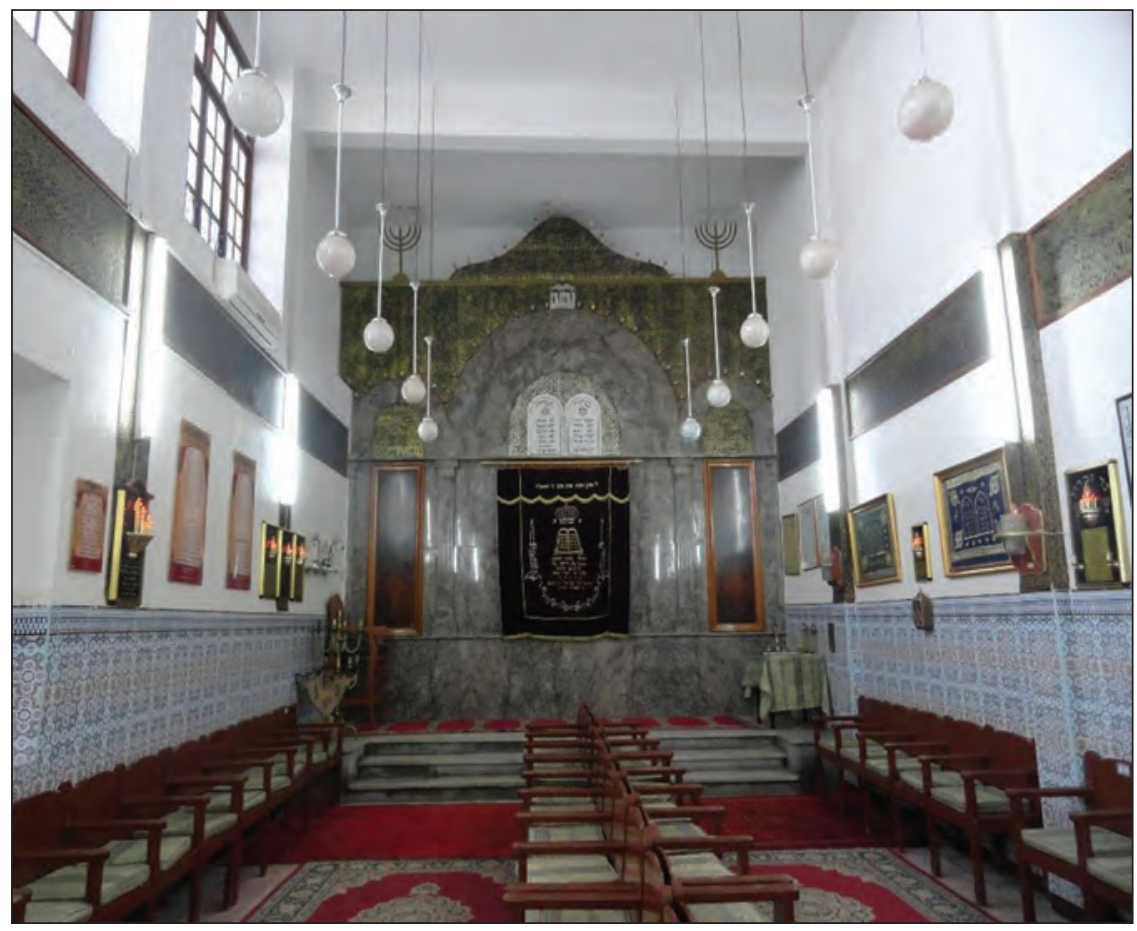

43. kép: A marrakesi Lazama zsinagóga

Forrás: DÉvÉNYI KINGA felvétele 
A szöveget oszlopokba rendezik, az egyes oszlopok mérete pontosan meghatározott (általában 42 sor oszloponként, egyes közösségekben kisebb eltérések lehetnek). A másoló képzett írnok, aki szigorú szabályoknak megfelelően dolgozik, és a másolás maga rendszerint több mint egy évig tart. A tóratekercs elkészülte nagy örömünnep, a tekercset táncolva, kézben viszik a zsinagógába (43. kép). A tekercset tokban tartják, amelynek anyaga és formája az adott közösség szokásaitól függ. A tóratekercseket a zsinagógában a díszes tóraszekrényben tárolják, mely rendszerint a Jeruzsálem felé néző fal közepén helyezkedik el (vagyis a közösség a tóraszekrény felé fordulva imádkozik, mivel az imairány Jeruzsálem). A tóraolvasás végén a nyitott tekercset felemelik és körbemutatják a közösség számára.

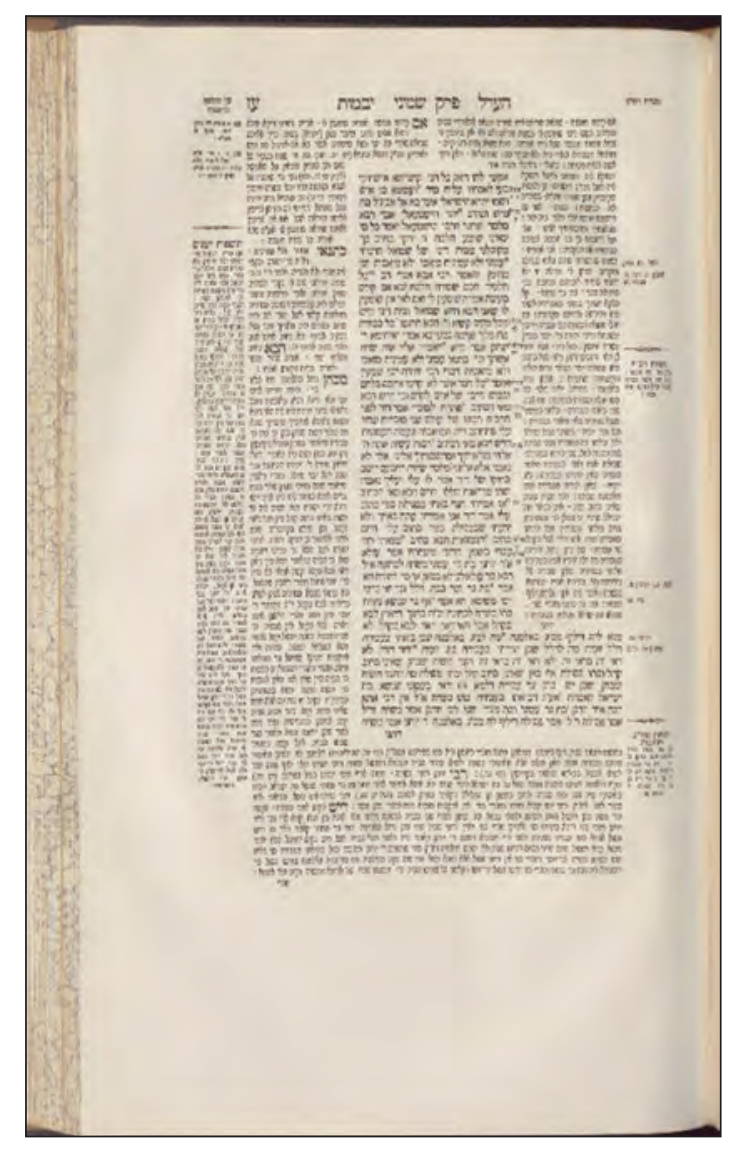

44. kép: Babiloni Talmud. Prága: Landau, 1832.

Forrás: MTA Könyvtár, Keleti Gyüjtemény

AMisna az úgynevezett ,szóbeli tan” törvénygyüjteménye, melyet egészen az i. sz. 2. század végéig héberül, szóban hagyományoztak, azután pedig írásba foglaltak. A Misna a zsidó vallásjog legalapvetőbb forrása, de jogi szövegeken 
kívül a kommentár- és a bölcsességirodalom müfajába tartozó szövegeket, rövid elbeszéléseket, történeteket is tartalmaz. A misna héber szó körülbelül azt jelenti, „ismétlés”, „tanulás”. A Misna nemcsak az egész gyüjtemény neve, hanem az egyes alfejezeteké, szakaszoké is (vagyis egy adott misna a Misna nevü gyüjtemény egy törvénye vagy története).

A Talmud (jelentése „tanulás”) szintén a szóbeli tan gyüjteménye, de későbbi a Misnánál, és azt tartalmazza is (44. kép). A Talmud alapvetően a Misna kifejtése és magyarázata, amit felépítése is tükröz: az egyes misnaszakaszokat azok hosszas magyarázata követi, jobbára arámi nyelven (a Talmud tehát kétnyelvü). A törvénymagyarázatok műfaja alapvetően a vita, amit a Talmud szinte dialógusként rögzít, azonban sokszor a résztvevők megjelölése nélkül. Mivel pedig mind a héber, mind az arámi írás csak a mássalhangzókat rögzíti, a szöveget pedig írásjelek nem tagolják, a talmudi viták nehezen követhetőek, hiszen az olvasó még abban sem lehet mindig biztos, hogy egy adott mondat hol kezdődik, és hol végződik. Mivel kezdetben a Talmudot is szóban hagyományozták, tömör fogalmazásra törekedtek. A Talmud tanulása ezért általában nem egyénileg, hanem párban vagy csoportban zajlik, ahol a tanulók rekonstruálják, és esetleg folytatják is a talmudi bölcsek vitáját. A Talmud tanulásával a dialektika, a vita művészete sajátítható el. Tanulása minden felnőtt férfi vallási kötelessége a mai napig. A Talmud müfaja (vagyis a vita) és évszázadokon át tartó folyamatos tanulmányozása valószínűleg befolyásolta a zsidóság arculatát, karakterét. A Talmud gyakran vált az antiszemita indulatok célpontjává, a történelem során többször esett nyilvános könyvégetés áldozatává.

\subsubsection{A zsidó életút legfontosabb állomásai, a vallás egyes előírásai}

A zsidó vallás alapja a Tórában található 613 parancsolat (micva) betartása. A parancsolatok a Bibliában nincsenek tételesen felsorolva, a rabbinikus szerzők vették őket lajstromba. A parancsolatokat különböző szempontokból szokás felosztani: Az ember testrészeinek megfelelően 248 tevőleges (pozitív) elöírásra, és az év napjainak megfelelően 365 tiltásra. (Az ember testrészeinek számát a zsidó hagyomány határozza meg 248-ban.) Más szempontból megkülönböztetnek az Istennel szemben kötelezö, ill. az emberekkel szemben kötelező előírásokat. Különbséget tesznek továbbá a megszabott időhöz kötött, és az attól független parancsok között. Megszabott időhöz kötött parancs például a szombati Tóra-olvasás, amit szombaton reggel a zsinagógában végeznek el. Az időhöz kötött parancsok a nőkre nem vonatkoznak, mert - a hagyományos felfogás és magyarázat szerint - nekik elsősorban a családdal és a gyerekekkel kell foglalkozniuk, a gyerekek gondozása pedig sokszor összeegyeztethetetlen a pontos időkorlátokkal. 


\section{Körülmetélés}

A születés utáni nyolcadik napon kötelező körülmetélni a fiúgyerekeket. A körülmetélés a Biblia szerint Isten és Izrael szövetségének jele: „Így tartsátok meg szövetségemet, amelyet veletek és utódaitokkal kötök: metéljenek körül nálatok minden férfit! [...] Ez lesz a veletek kötött szövetségem jele. [...] Ott lesz az én szövetségem a testeteken örök szövetségként." (1Móz 17:10-11, 13) A körülmetélést erre kiképzett szakember végzi (mohel), vallási szertatás keretein belül. Ilyenkor adnak nevet is a gyermeknek. (A lánygyermekeknek a közösségben végzett tóraolvasás során adnak nevet: az apát felhívják a Tórához, ekkor hirdeti ki a közösség számára lánya nevét.) A szertartást ünnepi étkezés zárja.

\section{Bar-micva}

A fiúgyerekek tizenhárom éves koruktól kötelesek betartani a zsidó vallási törvényeket (a lányok tizenkét éves koruktól, de rájuk kevesebb elöírás kötelező, mint a fiúkra). A bar-micva (szó szerint „,a parancsolat fia”) egyrészt a tizenharmadik életévét betöltött fiút jelöli, másrészt azt az ünnepi alkalmat is, amelyen elöször teljesít a közösség elött egy olyan parancsot, amit korábban soha sem. Ez rendszerint a zsinagógában végzett Tóra-olvasást jelenti, ahol a fiú a szertartáson felolvas egy szakaszt, de képzettségétől függően további megtisztelő feladatokat is bízhatnak rá.

\section{Házasság}

A házasulandók házassági szerződést kötnek, amelyben a férfi vállalja, hogy eltartja a feleségét. Maga a szertatás nagyjából a következőképpen zajlik: A vőlegényt a menyasszonyhoz vezetik, megfogja a menyasszony fején lévő fátylat, és betakarja vele a menyasszony arcát, majd az esküvői baldachin (hupa/hüpe) alá megy. Odavezetik hozzá a menyasszonyt, aki hétszer megkerüli a vőlegényt, miközben a jelenlévők égő gyertyákat tartanak a kezükben. Az askenázi szokást követők a szabad ég alatt állítják fel a baldachint, mert az ég arra az ígéretre emlékeztet, amelyet Isten Ábrahámnak tett: „Tekints fel az égre, és számold meg a csillagokat, ha ugyan meg tudod számolni! Ennyi utódod lesz." (1Móz 15:5) A vőlegény felemeli a menyasszony fátylát, majd mindketten isznak egy korty bort. Ezután a férfi gyürüt húz a menyasszony ujjára, a következő kijelentés kíséretében: „Ez által a gyürü által légy nekem szentelt Mózes és Izrael törvénye szerint." Meghallgatják a házasságukra mondott hét áldást, újból isznak egy kortyot, majd a férfi a talpa alá teszi és összetöri a poharat, 
amelyből ittak. Erre nagy üdvrivalgás tör ki, és táncos-zenés mulatság kezdődik. A pohár összetörésének hagyományos magyarázata az, hogy egyetlen zsidó öröme sem lehet teljes, amíg a jeruzsálemi templom újjá nem épül: „Ha megfeledkezem rólad, Jeruzsálem, felejtsen el a jobb kezem! Nyelvem tapadjon az ínyemhez, ha nem téged emleget, ha nem Jeruzsálemet tartom legföbb örömömnek!” (Zsoltárok 137:5-6) A pohár összetörése az örömbe vegyülö keserüséget jelképezi. Ezután az ifjú férj és feleség rövid időre különvonul: a hagyományos társadalmakban és régebbi korokban ez volt az első alkalom, amikor először felügyelet nélkül, kettesben maradhattak. A házasságon belüli nemi életet is vallási elöírások szabályozzák.

Érdemes megjegyezni, hogy a zsidó vallásjog szerint lehetőség van válásra: a válópert három rabbiból álló testület (rabbinikus bíróság) előtt kell lefolytatni, a polgári válás zsidó jogi szempontból nem érvényes.

Imalepel, imaszíj, mezuza, fej befedése

A Tóra pozitív parancsainak egyike, hogy minden olyan ruhára, amelynek négy széle van, rojtokat kell varrni: „Szólj Izrael fiaihoz, és mondd meg nekik, hogy csináljanak bojtokat a ruhájuk szegélyére nemzedékrőlnemzedékre, és tegyenek a szegélyen levő bojtokba kék bíborzsinórt. Arra való ez a bojt, hogy valahányszor ránéztek, emlékezzetek az Úrnak minden parancsolatára, teljesítsétek azokat, és ne csábítson el titeket sem a szívetek, sem a szemetek!" (4Móz 15:38-39) Ennek megfelelően a zsidó férfiak alsóruhájuk felett ún. talit katant hordanak, ami négyszögletes alakú, és a sarkaira az elöírás szerint négy bojt van erősítve. Ezt egész nap viselik. A reggeli ima idején pedig egy hasonló, csak nagyobb és díszes talitba, imalepelbe (45. kép) burkolóznak, amelyen szintén megtalálható a négy bojt.

A hétköznap reggeli ima idején a zsidó férfiak imaszíjakat (tefillin) viselnek. A tefillin két, fekete bőrből készült kis doboz, amelyekben idézetek találhatóak a Tórából, pergamenre írva. A dobozkákhoz bőrszíjak vannak erősítve, ezekkel kötik fel a tefillint, az egyiket a fejre, a másikat a bal karra. 


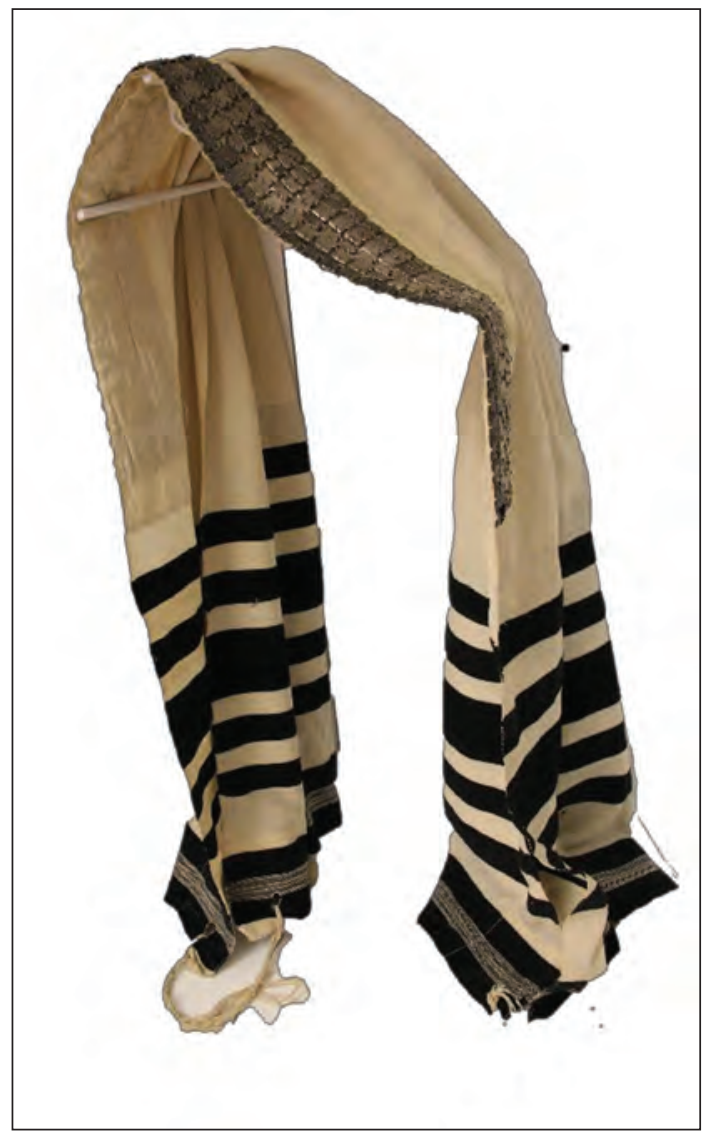

45. kép: Imasál (talit) ezüstveretekkel, MILEV

Forrás: http://collections.milev.hu/items/show/32623 - 2018. 01. 3.

A tóraidézetek a zsidó hit alapelveit tartalmazzák, a testre kötözés pedig a teljes elfogadást, alárendeltséget szimbolizálja. Az Isten szavainak mintegy a testen viselésére a tefillin tóraszakaszai is utalnak: „Halljad Izrael! Az Úr a mi Istenünk, az Úr egyetlenegy! Szeresd az Urat, a te Istenedet teljes szíveddel, teljes lelkeddel és minden erőddel! Maradjanak szívedben azok a szavak, melyeket ma parancsolok neked. Ismételgesd azokat fiaid előtt, és beszélj azokról, akár házadban vagy, akár úton jársz, akár lefekszel, akár felkelsz! Kösd azokat jelként a kezedre, és legyenek homlokdíszként a szemeid között! Írd azokat házad ajtófélfáira és kapuira!" (5Móz 6:4-9) Ez a szakasz egyben a zsidó egyistenhit legtömörebb megfogalmazása, a zsidóság egyik legfontosabb imája, ami a mindennapi imarendben ötször szerepel. A fenti tóraszakasz utolsó mondatának teljesítése gyanánt a zsidó otthonokban az ajtófélfára (jobb oldalra) mezuzat helyeznek (46. kép). Ez egy kis tokból, és a benne lévő pergamentekercsből áll, amelyre meghatározott tóraidézeteket írtak. A tok rendszerint díszes, fémből, 
fából vagy műanyagból van, külsejére pedig Isten egyik nevét írják: Saddaj (Mindenható). Szokás megérinteni (megcsókolni) a mezuzat, amikor az ember elhalad mellette.

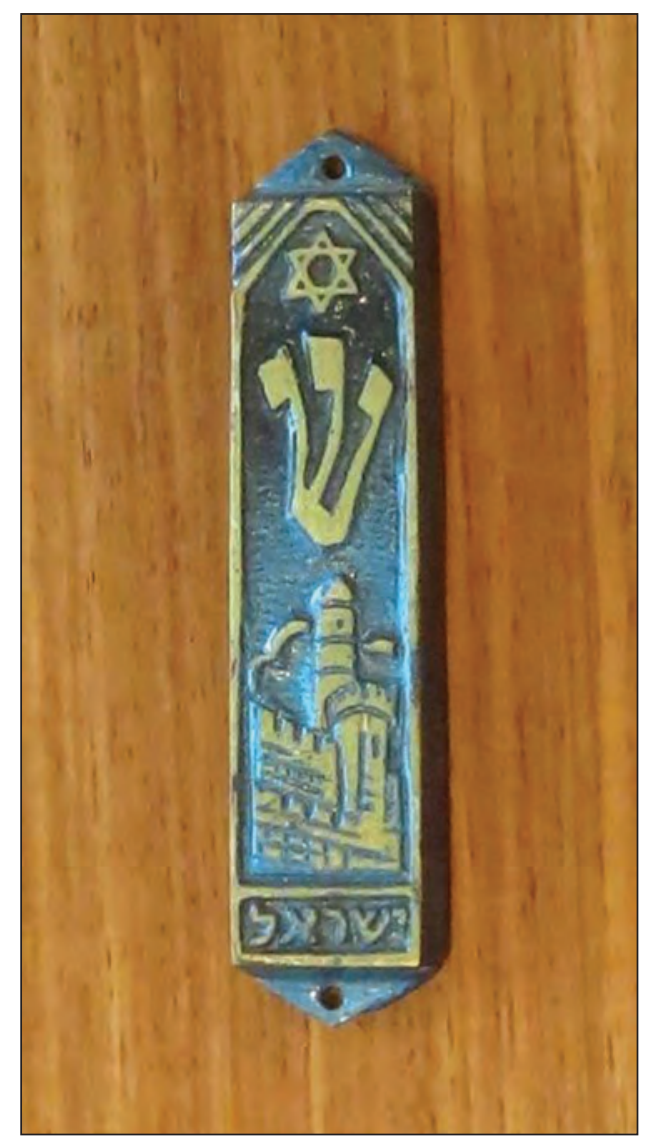

46. kép: Szefárd mezuza Macedóniából

Forrás: PretoriaTravel, https://commons.wikimedia.org/w/index.php?curid=23829644

A fej befedése a vallásos zsidók megjelenéséhez annyira hozzátartozik, hogy a külső szemlélők számára talán ez a zsidóság legismertebb jele. A kalap, sapka vagy más fejfedő viselése azonban nem tórai parancs, hanem szokás, az Isten iránti tisztelet kimutatásának egy módja. A hagyományos magyarázat szerint a Római Birodalomban a befedett fej a szolgaság jelképe volt, a szabad emberek fedetlen fejjel jártak. A zsidók azért fedik be fejüket, hogy emlékezzenek rá, ők Isten szolgái. A kalap és egyéb fejfedők mellett elterjedt az ún. kippa viselése, ami egy kis kerek sapka, sokszor fekete selyemből, bársonyból varrt vagy színes fonálból horgolt fejfedö. Nagysága, anyaga és színe vallási közösségenként változik, vagyis a férfiak (öltözetük egyéb darabja mellett) a kippával mutatják ki, melyik közösséghez vagy irányzathoz tartoznak. 


\subsubsection{Fontosabb ünnepek}

Tekintettel arra, hogy a zsidóság története során, és részben ma is diaszpórában él, valamint arra, hogy a közösségek nem szervezödnek hierarchikus rendbe, az ünnepeket övező szokások sokszínúek, és az ünnepekre vonatkozó elöírások értelmezése közösségenként változik. Az alábbi áttekintés ezért csak a legalapvetőbb vonásokra szorítkozik, amelyektöl egy adott közösség akár jelentősen el is térhet.

Az ünnepek időpontját a zsidó időszámítás szerint állapítják meg, amely luniszoláris időszámítás, vagyis egyszerre veszi tekintetbe a Nap, ill. a Hold Föld körüli mozgását. A zsidó hónapok holdhónapok (újholdtól újholdig tartanak), az év azonban megfelel a napév időtartamának. Mivel a holdév 11 nappal rövidebb, mint a napév, az eltérés kiegyenlítésére meghatározott időnként (minden második, harmadik évben) egy plusz holdhónapot iktatnak be az évbe. Az egyes napok naplementétől naplementéig tartanak, vagyis este kezdődnek.

\section{Szombat}

A szombat megszentelésének parancsa szerepel a Tízparancsolatban: „Hat napon át dolgozz, és végezd mindenféle munkádat! De a hetedik nap a te Istenednek, az Úrnak a nyugalomnapja. Semmiféle munkát ne végezz azon, se te, se fiad, se leányod, se szolgád, se szolgálód, se állatod, se a kapuidon belül tartózkodó jövevény. Mert hat nap alatt alkotta meg az Úr az eget, a földet, a tengert és mindent, ami azokban van, a hetedik napon pedig megpihent. Azért megáldotta és megszentelte az Úr a nyugalom napját." (2Móz 20:9-11) Ez a szakasz azonban a megszentelés mikéntjét nem fejti ki pontosan. A szombati munkatilalmak közül csak egy, a tüzgyújtás tilalma van egy más helyen nevesítve a Tórában (2Móz 35:3).

Mivel a zsidó időszámítás szerint az egyes napok a naplementével kezdődnek, így a szombat is pénteken este kezdődik. Mivel a szombat bejövetele után már nem szabad munkát végezni, még péntek délután kell elvégezni minden ünnepi előkészületet: kitakarítani a lakást, megfőzni az ünnepi ételt, megteríteni az ünnepi asztalt, megmosakodni, ünnepi ruhába öltözni, stb. A család számára a szombat a két szombati gyertya meggyújtásával kezdődik, amit a háziasszony végez el napnyugta elött körülbelül húsz perccel, majd a meggyújtott gyertyákra áldást mond, miközben eltakarja a szemét. A szombati asztalra két felvágatlan kalácsot (vagy kenyeret) helyeznek, amelyeket asztalkendővel takarnak le, mellé pedig borospoharat, úgynevezett kiddus-poharat tesznek, mert a szombatot a borra mondott áldással szentelik meg (ez a szertartás a kiddus).

A szombat bejövetelét a férfiak és lehetőség szerint legalább a nagyobb gyerekek a zsinagógában ünneplik. A nőknek nem kötelező részt venniük 
a zsinagógai szertartáson, és sokan a szombati elökészületek után szívesen pihennek kicsit a szombati vacsora elött, vagy foglalkoznak a kisebb gyerekekkel, mielött a család és a szombati vendégek megérkeznének. Sok nő azonban részt vesz a zsinagógai szertartáson is: ez egyéni körülményeitől és igényeitől függ.

A zsinagógai szertartás után a család az ünnepi asztal körül gyülik össze, gyakran vendégeikkel együtt. Közösen vallásos dalokat énekelnek, és szokás az is, hogy vacsora elött az apa megáldja gyerekeit, majd a borospohárral a kezében elmondja a kiddust, és mindenki iszik a borból (a gyerekek szőlőlevet isznak, amely rituális szempontból bornak számít). Ezután szertartásosan, a megfelelö áldások kíséretében kezet mosnak, majd az apa megáldja a kenyeret (kalácsot), darabokra vágja és szétosztja a jelenlévők között. Ezután kerül sor az ünnepi étkezésre, melynek szüneteiben szokás vallásos témákról (is) beszélgetni. Az étkezést közösen elmondott, vagy lehetőleg elénekelt hosszú áldások zárják.

A szombat reggeli zsinagógai szertartás a hétköznapinál sokkal hosszabb, szinte az egész délelőttöt kitölti. A nőknek ezen sem kötelező részt venniük. Délben kerül sor a második ünnepi étkezésre, melynek lefolyása az elsőhöz hasonló. A délutánt többnyire pihenéssel, sétával, beszélgetéssel, játékkal, esetleg tanulással töltik. A tanulás ebben a kontextusban Tóra-tanulást jelent, annak tágabb értelmében: vagyis a Biblia és magyarázatai, vagy a zsidó jogi irodalom (Misna, Talmud) egyéni vagy közös olvasását, megvitatását. A Tóratanulás szombaton kötelező (a férfiaknak), de ennek a kötelességnek mindenki eleve eleget tesz, ha részt vesz a zsinagógai szertartáson, ahol a szertartás részeként felolvasnak a Tórából. Az elmélyültebb, további szombati tanulás nagyon elterjedt szokás, de nem kötelező. A szombat a harmadik étkezés és a napnyugta után, a teljes sötétség beálltakor az ,elválasztás” (havdala) szertartásával végződik. Ennek során újból áldást mondanak a borra, majd egy díszes dobozban tartott illatos füszerkeverékre, végül meggyújtanak egy több szálból összefont gyertyát, és áldást mondanak a tűzre. Ezután elmondják a tulajdonképpeni havdala-áldást: „Áldott vagy te, Örökkévaló Istenünk, a Világ Királya, aki elválasztod a szentet a világitól, a fényt a sötéttől, Izraelt a többi néptől, a hetedik napot a hat munkanaptól! Áldott vagy Te, Örökkévaló, aki elválasztod a szentet a világitól!"

A szombat legfőbb jellemzője a nyugalom, amelyet a munkatilalmak szövevényes rendszere biztosít. A munka vallásjogi fogalma nem azonos a szó hétköznapi jelentésével: a munka nem egyenlő sem a foglalkozással (állás, hivatás), sem a fizikai erőfeszítéssel. A Tóra nem értelmezi a szombati munkatilalom mibenlétét, és nem sorolja fel tételesen a szombaton tiltott tevékenységeket. Ezeknek kifejtését a későbbi, rabbinikus irodalomban találjuk. A munkatilalmak megállapítása egy sajátos zsidó exegetikai, vagyis írásmagyarázó elv alkalmazásával történt, amely az egyes tórai szakaszok egymásutániságát többletjelentésként értelmezi. Eszerint két, egymástóllátszólag független tartalmú 
tórai szakasz között pusztán az a tény, hogy egymás után állnak, kapcsolatot létesít, a kettőt egy kontextusba helyezi. Márpedig a Tórában a pusztai szentély elkészítésének előírásait azonnal követi egy, a szombat megtartására vonatkozó felhívás (2Móz 31:1-13). Ezt már az ókorban úgy értelmezték, mint célzást arra, melyek is tulajdonképpen a szombaton tilos tevékenységek: mindazok, amelyek a pusztai szentély elkészítéséhez (amit szombaton szüneteltetni kell) szükségesek, akár áttételesen is. A Misna (Sabbat 7:2) harminckilenc ilyen tevékenységet sorol fel. Azonban ezekből a tevékenységekből (ún. „,őmunkákból”) további származtatott munkák százai vezethetőek le, ami a szombati munkatilalmak rendszerét nagyon bonyolulttá teszi. Például, a pusztai szentélyben áldozati kenyerek voltak, ebből következően tilos szombaton minden olyan tevékenység, amely a kenyér elóállításához szükséges, úgymint a szántás, vetés, aratás, kévekötés, cséplés, őrlés, dagasztás, sütés. Voltak a szentélyben továbbá vásznak, kelmék, papi ruhák is: ebből következően tilos a birkanyírás, kártolás, mosás, festés, varrás is. Ezeket a kategóriákat azonban nem hétköznapi értelmükben, hanem absztrakt módon kell érteni: a gyapjúnyírás absztrakt lényege például az, hogy egy élő testből nőtt dolgot elválasztunk a testtől: ebböl következik egyebek között a fésülködés tilalma szombaton, hiszen a fésülködés során általában néhány hajszál kihullik, vagyis a fésűvel az élő testből nőtt dolgot (hajszálakat) választunk el a testtől, még ha szándékolatlanul is.

A villanygyújtás tilalma a tüzgyújtás tilalmából következik. Ez természetesen nem jelenti azt, hogy az ünnepnapot sötétben kuksolva töltenék a zsidók: egyszerüen csak odafigyelnek arra, hogy már péntek délután felkapcsolják a lámpát, és egy időzítővel előre beprogramozzák, meddig égjen. Az elektromos áram feltalálása előtt ugyanez a megfelelő mennyiségű lámpaolaj stb. elöre biztosításával volt lehetséges. A szombati munkatilalom tehát nem függ attól, hogy egy adott tevékenység a szó hétköznapi értelmében valamennyire is munkának tekinthető-e, hanem kizárólag attól, hogy szerepel-e a Misnában felsorolt fömunkák és származékaik között. Külső szemlélő számára talán úgy tủnhet, mintha a szombat megtartása sok nehézségbe ütközne, ez azonban nincsen így: minden korban és környezetben megvan a jól bevált és közismert módja annak, hogyan lehet és szokás a szombatot megülni, és a szombattartó közösségek ezeket a módszereket követik.

Meg kell jegyezni, hogy a zsidó vallásjog szerint az élet fenntartása és védelme minden vallási elöírásnál fontosabb, ezért szükség esetén (három kivételével) minden parancs megszeghető. Tehát ha egy ember élete csak a szombati munkatilalom megszegése árán menthetö meg, akkor minden zsidónak kötelessége megszegni a szombatot. Ugyanezért múködhetnek szombaton is a különböző életmentő intézmények is: a kórházak, mentők, tüzoltók, és ezért kapnak részleges felmentést a szombati törvények alól eleve a különböző fegyveres testületek tagjai is. (A három elöírás, amelyek életveszély esetén sem 
szeghetőek meg: a bálványimádás, a gyilkosság és a tiltott szexuális kapcsolatok tilalma.)

A félelmetes napok: ros ha-sana és jom kippur

A zsidó év első tíz napját „félelmetes napoknak” nevezik. A periódus a zsidó újévvel (ros ha-sana) kezdődik, és az engesztelőnappal (jom kippur) ér véget.

A ros ha-sana a világ teremtésének évfordulója, tíznapos bünbánati időszak kezdete. Ekkor fújják meg a zsinagógákban a sófárt, vagyis a kosszarvból készült kürtöt, amelyet a bibliai korban a nép összehívására, háborúba szólítására, és az ellenség megfélemlítésére használtak (47. kép). Három modulációja van: hosszan elnyújtott, három szaggatott, ill. hét rövid, szaggatott hang. A sófár hangja nem kellemes, hanem riasztó, megrázó.

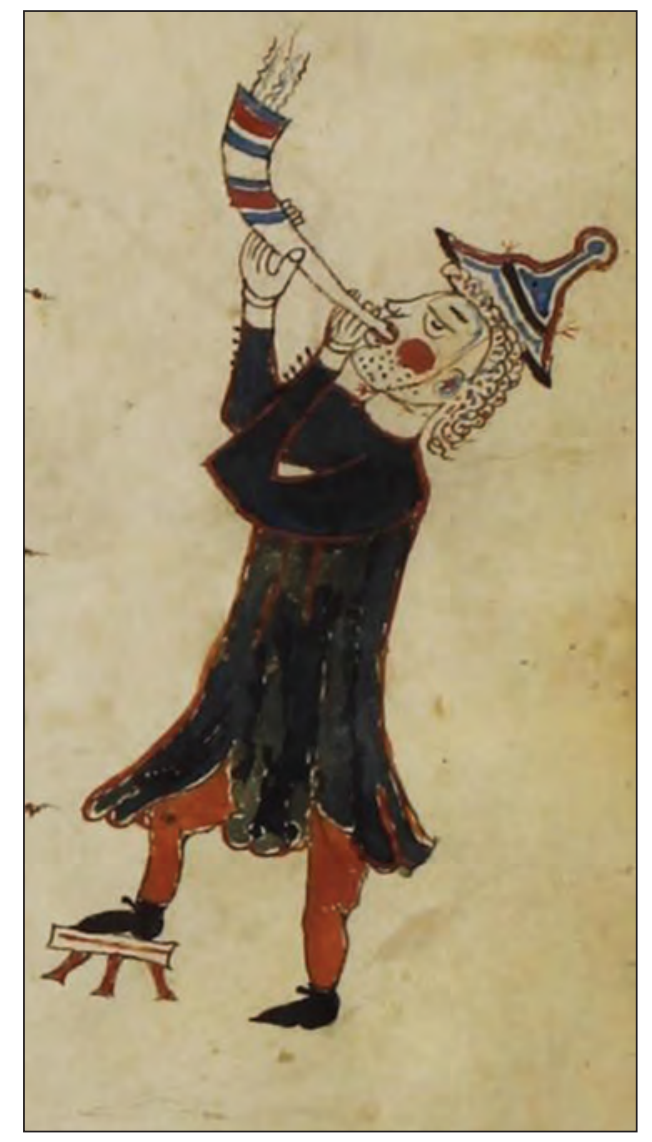

47. kép: Kosszarvból készült kürtöt (sófár) fúvó férfi. Ünnepi imakönyv (mahzór), DélNémetország, 13. sz. vége

Forrás: MTA Könyvtár Keleti Gyüjtemény, Kaufmann A 388, II. fol. 12v 
Az ünnep estéjén szimbolikus ételeket fogyasztanak, amelyek az elkövetkező évre utalnak: mézbe mártott kalácsot vagy almát (hogy édes legyen az újév), hal- vagy bárányfejből készült ételt (hogy fogyasztója a „fej” vagyis a vezető szerepét töltse be, ne pedig az alávetettét), gránátalmát (hogy az embernek annyi érdeme legyen, mint ahány magja a gránátalmának), stb.

A jom kippur a bünök miatti engesztelés napja, amelyen a közösség tagjai szigorú böjtöt folytatnak: mintegy 26 órán keresztül nem esznek, nem isznak, semmi olyan tevékenységet nem végeznek, ami a test számára kellemes (például a minimálisnál nagyobb mosdás, bőrcipő viselése). A böjt délután, napnyugta előtt kezdődik, és másnap este, a teljes sötétség beállta után ér véget. A jom kippuri szertartás feloldozást ad a másik ember ellen elkövetett bünök alól, de csak akkor, ha az illető is megbocsátott, vagyis a szertartás előtt bocsánatot kell kérni mindenkitől, akit az ember esetleg megbántott. Az engesztelés napja tehát az emberi kapcsolatok helyreállításának napja is. Ami az Isten ellen elkövetett bünöket illeti, azokat a hagyomány szerint megbocsátja Isten, ha az ember őszinte bünbánatot tanúsít. Az istentisztelet a Kol nidré („minden fogadalom”) nevü megrázó dallamú imával kezdődik, ami tulajdonképpen egy jogi formula, amely a következő évre előre érvénytelennek nyilvánít minden olyan, az Istennek tett fogadalmat, amit a hívő bármilyen okból nem volna képes betartani. A középkori zsidóüldözésektől kezdve ez a szertartás sajátos jelentőségre tett szert, és nagyon súlyos érzelmi töltettel terhelődött. A középkori zsidóüldözések és a kereszténységre való erőszakos áttérítés következtében zsidók tömegei voltak kénytelenek elhagyni vallásukat (az erőszakos térítés mértéke olyan nagy volt, hogy egyes országokban a zsidók többségét, vagy akár a teljes zsidó lakosságot is erőszakkal megkeresztelték). Az áttérített zsidók keresztény vallásgyakorlatát azután az katolikus egyház sajátos intézménye, az Inkvizíció ellenőrizte, amely a zsidó vallás egyes előírásait titokban megtartani szándékozó kikeresztelt zsidók tízezreit ítélte halálra. Az engesztelőnapi böjt és bünbánat azonban olyan erős vallási kötelesség, hogy még a zsidó szempontból törvényszegőnek minősülő kikereszteltek is szerették volna a lehetséges mértékben megtartani, és sokan ilyenkor csatlakoztak az ünneplő zsidókhoz. Egyes értelmezések szerint ez az oka annak, hogy a Kol nidré éneklése elött a kántor fennhangon kinyilvánítja: „Az Isten beleegyezésével és a közösség beleegyezésével, a fenti itélőszék engedélyével és a lenti ítélőszék engedélyével szabad a törvényszegőkkel együtt imádkoznunk."

Az engesztelönap egésze bünbocsánatért mondott imákkal telik, egyre felfokozottabb hangulatban. A széles körben elterjedt hagyomány szerint az engesztelőnap az évnek egyetlen olyan napja, amikor a Sátán nem vádolhatja az embert az Isten előtt. Erre utal, hogy a Szatan, vagyis Sátán jelentésü héber szó betủinek számértéke 364, vagyis eggyel kevesebb, mint az év napjainak száma. Az engesztelönap tehát kivételes alkalom a megbocsátás kérésére. Napnyugta 
elött egy utolsó közös imával könyörög a közösség: a Neila (kapuzárás) ima eredetileg a jeruzsálemi templom kapuinak bezárásakor hangzott el, ma azonban az ég kapuinak bezárását értik alatta. Amíg az ég kapui nyitva állnak, Isten meghallgatja a bünbánó imádságot, a kapuzárás közeledtével pedig a közösség utolsó erőfeszítéseket tesz a kegyelem kikönyörgésére. A népi hagyomány szerint ekkor csukja be Isten az „Élet és halál könyvét”, amelybe ezen a napon írja be, kik élik meg a következő engesztelőnapot, és kik távoznak addigra az élők sorából.

\section{Szukkot}

Szukkot jelentése „sátrak”, amelyekben az Egyiptomból kivonuló zsidók éltek negyven éven át, pusztai vándorlásuk idején (48. kép). A sátoros ünnep alatt erre az eseményre emlékeznek, sőt jelképesen újraélik, amennyiben egy héten át sátrakban „laknak”, vagyis a lehető legtöbb időt töltik ott.

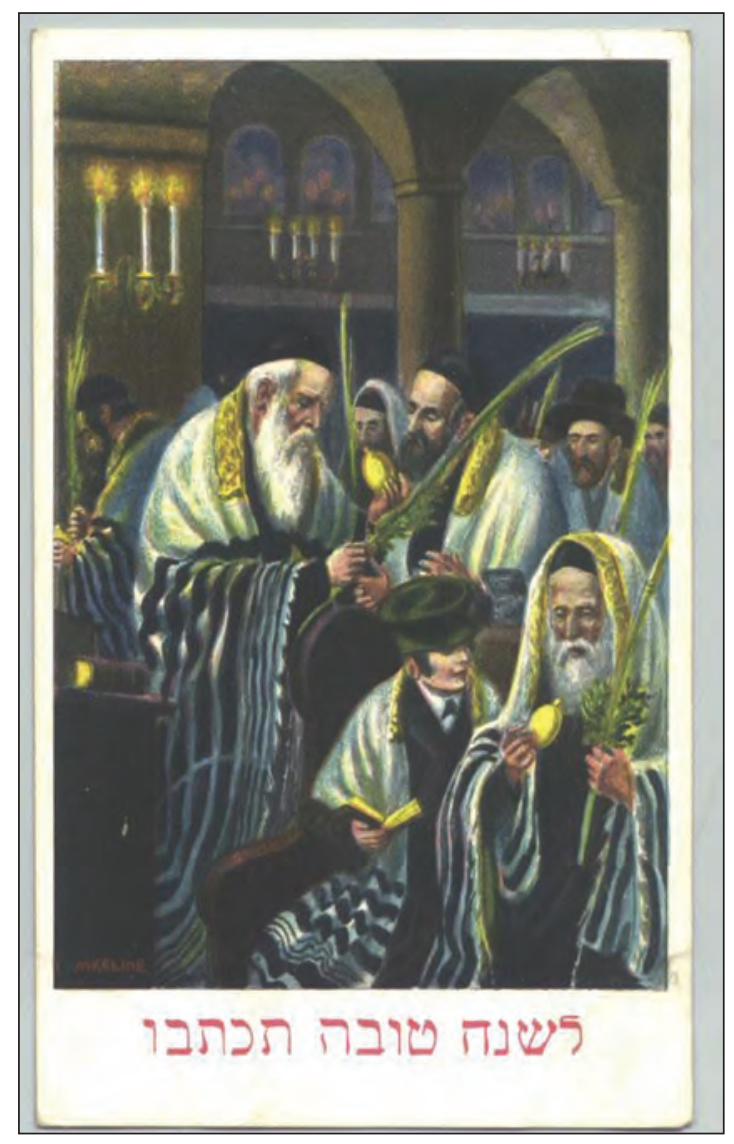

48. kép: F. Kaskeline, Szukkot ünneplése a templomban, MILEV

Forrás: http://collections.milev.hu/items/show/31846 
A sátrakat, vagy bódékat a kertben, az erkélyen állítják fel, és legalább az étkezés idejére mindenképpen ide vonulnak vissza. A sátor nem készülhet bármiből és ideiglenes jellegünek kell lennie: a tető csak földből növő növényből lehet (faág, gabonaszár, nád), de az ágakat-szárakat nem szabad összekötözni. A szukkot ünnep ősz elejére esik, amikor Izrael államban kellemes az idő és a sátorban lakás nem jelent nagyobb kihívást. Az európai országokban azonban sokszor ilyenkor már kifejezetten hideg, esős idő van, ezért csak az ünnepi időszak első két estéjén kötelező a sátorban étkezni minden körülmények között. Az ünnep alatt egy különleges csokrot lengetve imádkoznak, amely egy citrusfajtából (etrog), mirtuszból, füzfagallyból és pálmaágból áll.

\section{Hanuka}

A Hanuka (jelentése: „felavatás”) téli ünnep, annak állít emléket, hogy a Makkabeusok i. e. 165-ben győzelmet arattak az Izrael felett uralkodó szíriai görögök fölött, és visszafoglalták a jeruzsálemi templomot. Mivel a görögök megszentségtelenítették a templomot, azt meg kellett tisztítani, és újból fel kellett avatni (innen származik az ünnep neve).

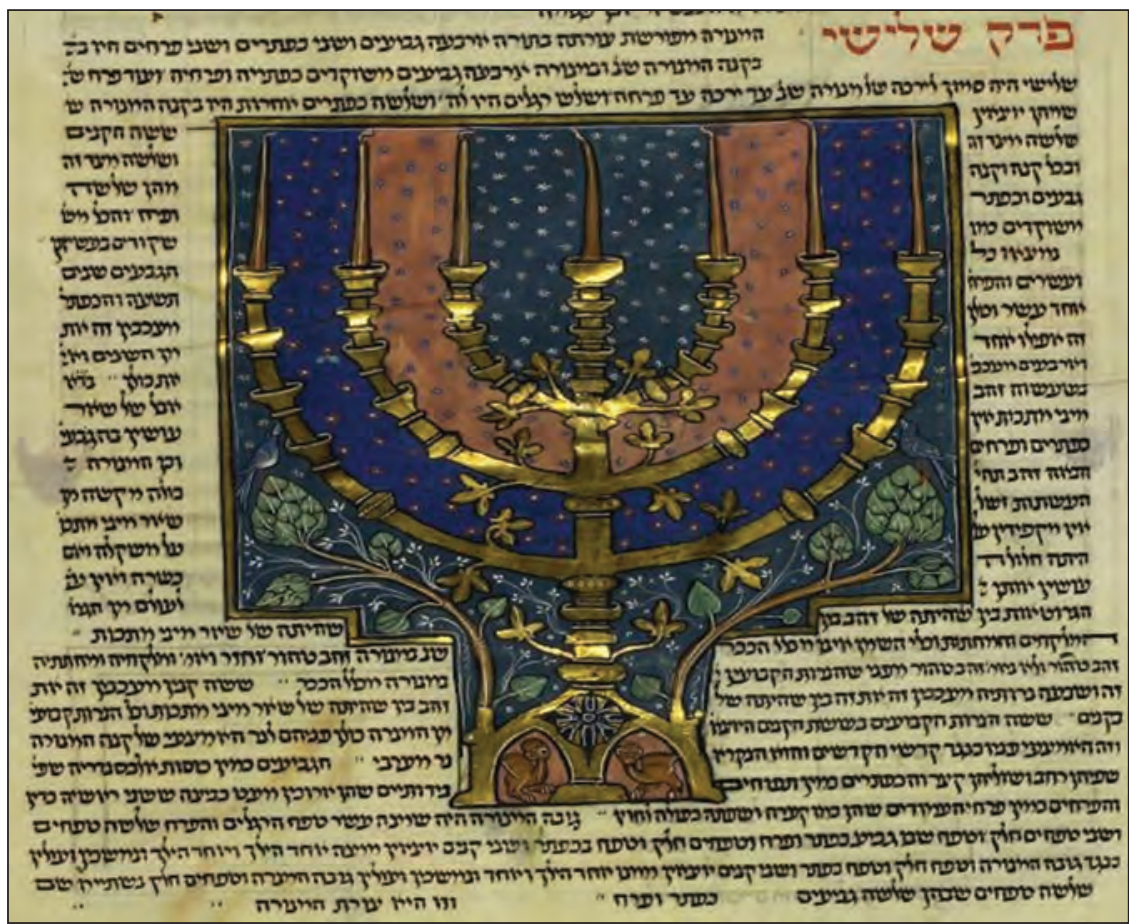

49. kép: Menóra ábrázolása Maimonidész, Misné Tóra című művének kéziratában, Északkelet-Franciaország, 1296.

Forrás: MTA Könyvtár Keleti Gyüjtemény, Kaufmann A 77, III. fol. 3v 
A régi istentiszteleti rend szerint a templomban olajjal kellett meggyújtani a menóra, a hétágú gyertyatartó (valójában mécses tartó) lángjait, azonban a megszentségtelenített templomban csak egy napra való tiszta olajat találtak (49. kép). Az új olaj préselése nyolc napig tartott, és ez idő alatt csodálatos módon kitartott az egy napi adag. Ennek emlékére gyújtják meg a nyolc plusz egy ágú hanukai gyertyatartóban a gyertyákat, vagyis nyolc napon keresztül minden nap eggyel több gyertyát. Az ünnep napjai alatt nincsen semmilyen munkatilalom. $\mathrm{Az}$ ünnephez különbözö népszokások társulnak, mint az olajban sült fánk evése, a gyerekek megajándékozása, az ünnephez kötődő gyerekjátékokkal, pl. pörgettyüvel (trendeli) játszás (50. kép).

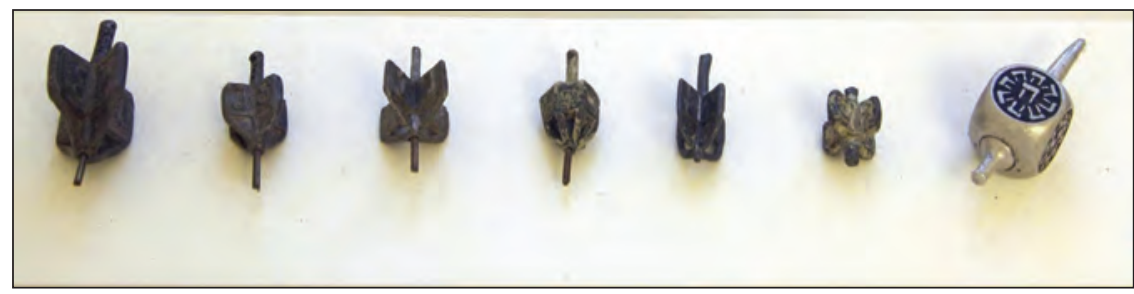

50. kép: Pörgettyü, hanukai játék, MILEV

Forrás: http://collections.milev.hu/items/show/29761

Purim

A purim (jelentése: „sorsvetés”) ünnepe a bibliai Eszter könyvében elbeszélt történetnek állít emléket. A Perzsa Birodalomban Ahasvéros király uralma idején az uralkodó politikai elit egyik főembere, Hámán a birodalomban élő zsidóság kiirtásának elrendelésére vette rá az uralkodót azzal az indokkal, hogy a zsidók nem tartják be a birodalom központi vallását. Hámán sorsot vetett, hogy mely napon kerüljön sor a zsidók kiirtására, innen származik az ünnep neve. Habár a zsidó származású Eszter királyné rávette a királyt szándéka megváltoztatására, a kiadott rendeletet már nem lehetett visszavonni, azonban a király megengedte, hogy a kiirtásukra kijelölt napon a zsidók védekezzenek, így végül győzelmet arattak ellenségeik felett. A purim a hanukához hasonlóan kifejezetten vidám ünnep, mely során kötelező ételböl-italból álló ajándékcsomagot küldeni legalább két embernek, adományokat juttatni a szegényeknek, ünnepi étkezést tartani, és felolvasni az Eszter-tekercset (a Bibliának ezt a könyvét is hagyományosan pergamentekercsre írják). Az ünnep alatt nincs munkatilalom, ellenben egyfajta karneváli hangulat uralkodik (az ünnep a téli időszak végére esik), jelmezbe öltöznek, a „gonosz Hámán”-t jelképező bábukat nyilvánosan elégetik, az Eszter-tekercs felolvasása során pedig ahányszor Hámán neve elhangzik (54-szer), a közösség kereplökkel és más módon csap zajt, hogy Hámán nevét (vagyis emlékezetét) eltörölje. 
Mindezek különösen a gyerekekből váltanak ki nagy lelkesedést. A jelmezbe öltözés egyes magyarázatok szerint arra utal, hogy Isten is rejtetten uralja a történelmet.

\section{Peszah}

A tavaszi peszah ünnep, a „zsidó húsvét”, az egyiptomi kivonulás és a kovásztalan kenyér ünnepe. Arról emlékezik meg, hogy évszázados egyiptomi szolgaság után a fáraó tilalma és ellenállása ellenére Izrael törzsei Mózes vezetésével, csodálatos események közepette kivonultak Egyiptomból. Jelentőségét az adja, hogy a hagyomány szerint a kivonulás formálta egyetlen autonóm néppé az addig másoknak alárendelt törzseket, így a peszah valójában a szabadság ünnepe.

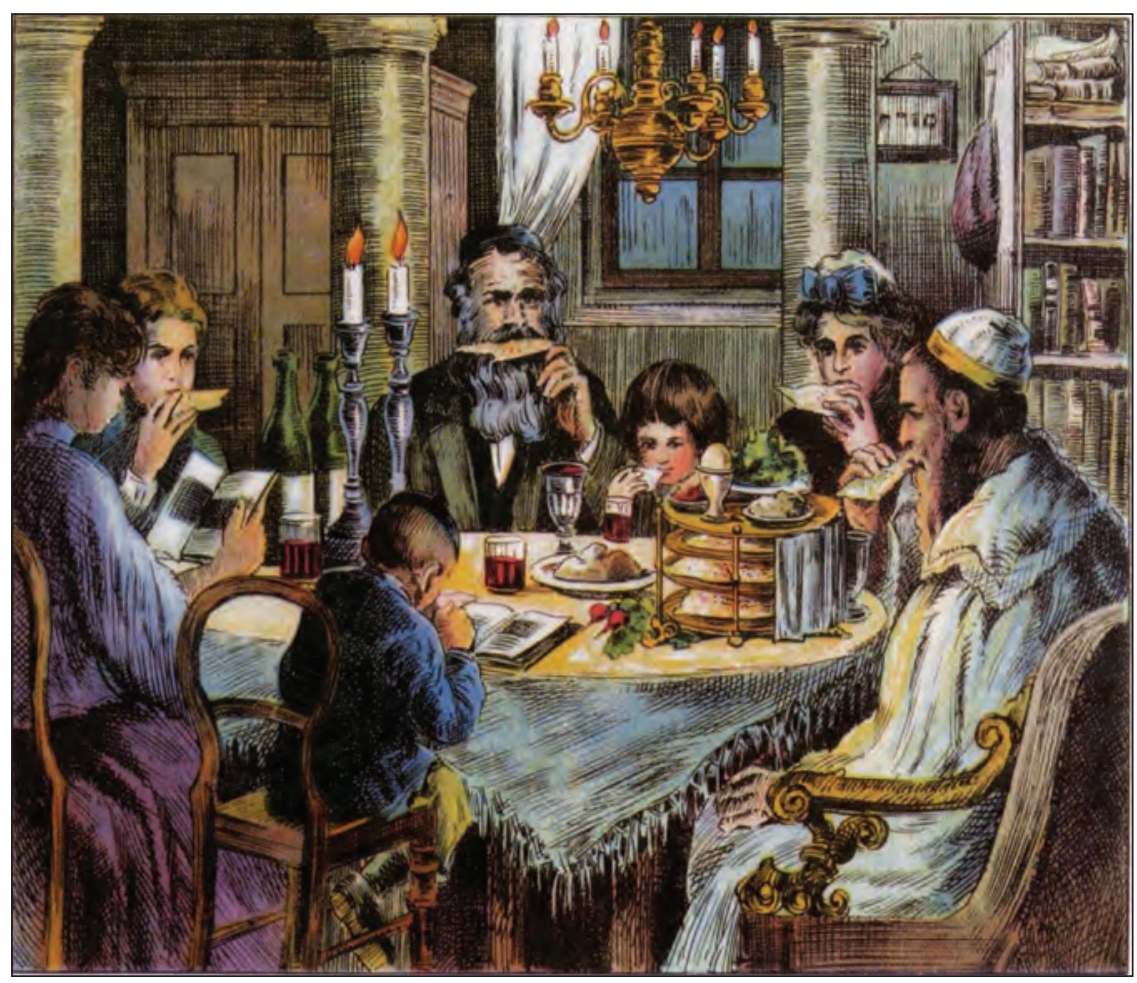

51. kép: Széderre terített asztal

Forrás: Singer Leó: Haggadah sel Peszach. Budapest, Schlesinger 1917

Az első, még Egyiptomban megtartott peszah csütörtökre esett, Isten parancsának megfelelően azon az estén minden zsidó családnak le kellett vágnia egy áldozati bárányt, és azt közösen el kellett fogyasztaniuk, a bárány vérével pedig be kellett kenniük a házuk bejárati ajtaját. A bárány vére védte meg a 
zsidókat az Egyiptomon áthaladó halál angyalától, aki azon ez éjjelen minden elsőszülöttel végzett. A vérrel megjelölt ajtókat azonban ,átugrotta”, kihagyta (paszah), innen ered az ünnep neve, peszah. Ezután a zsidóknak olyan sietve kellett távozniuk az országból, hogy kenyerüknek se volt ideje megkelni. Ennek emlékére az ünnep időtartama alatt (Izraelben hét, a diaszpórában nyolc napon keresztül) tilos kovászos dolgot enni, vagy azt birtokolni. A kivonulás története a Bibliában 2Móz 1-15 fejezetben olvasható.

Az ünnep legföbb eseménye a Széder-este, vagyis a peszah első estéjén sajátos szertartásrend szerint levezetett vacsora, mely a kivonulás eseményeit eleveníti fel jelképes cselekedetekkel és ételekkel (51. kép). A vacsora levezetésének rendje a rendszerint gazdagon illusztrált haggadában (jelentése: „elbeszélés”) található, melyet a tulajdonképpeni vacsora elött családi körben, közösen hangosan felolvasnak (sok részét éneklik). A haggada szövegéhez nem ragaszkodnak mereven, hiszen az csak az elbeszélés vázát és legfőbb pontjait nyújtja, hanem a haggada szövegének szellemében a résztvevők maguk is magyarázatokat füznek a bibliai történethez és azok későbbi, rabbinikus értelmezéseihez. Ezek egy része kérdés-felelet formájában zajlik, hiszen a kivonulás elbeszélése tulajdonképpen tanulás, vagyis párbeszédet, esetleg vitát (eltérö nézetek ütköztetését) is feltételez. A haggada felolvasása a kötetlen szóbeli kiegészítésekkel együtt több órán keresztül tart. Eközben fogyasztják el a jelképes ételeket: a keserủ füvet (például tormát) a keserü kényszermunka emlékére; fött tojást (a templom lerombolása miatti gyászra való utalásként); petrezselymet vagy zellert (a megújulás, a tavasz, a termékenység jelképeként); sós vizet (a szenvedés, könnyek szimbólumaként); reszelt almát dióval, fahéjjal és borral keverve, mely a habarcsot jelképezi (újabb utalás a kényszermunkára). A széder-tálra ezenkívül egy darab csontos húst is helyeznek (bárányt vagy csirkecombot), amit azonban nem esznek meg: ezjelképezi az eredeti bárányáldozatot, amit azonban a templom lerombolása után nincsen mód az elöírásoknak megfelelően bemutatni. A kovásztalan kenyér jelentését a haggada ekként magyarázza (arámi nyelven): „Ez a szegényég kenyere, ezt ették atyáink Egyiptom földjén. Mindenki, aki éhes, jöjjön és egyék, mindenki, aki rászorult, jöjjön peszahot tartani. Most itt, de jövöre Izrael földjén. Most szolgaként, de jövőre szabad emberként.” A haggada szövege alapvetően héberül van, de egyes részei arámiak, mivel keletkezésükkor, vagyis időszámításunk első századaiban az arámi volt a zsidóság beszélt nyelve. A zsidó hagyomány szerint minden embernek úgy kell tekintenie magára, mintha személyesen őt magát vezette volna ki Isten Egyiptomból, vagyis tette volna szolgából szabad emberré.

\section{Savuot}

Hét héttel az egyiptomi kivonulás után történt a Sínai-hegyi kinyilatkoztatás, amikor Isten átadta Mózesnek és a népnek a tízparancsolat kőtábláit, a Tórát és 
annak minden magyarázatát. Ekkor kötött szövetséget Isten Izraellel: „Most a maga népévé emel téged, ő pedig Istened lesz, ahogyan megígérte neked, és ahogyan megesküdött atyáidnak, Ábrahámnak, Izsáknak és Jákobnak.” (5Móz 29:11-12) A zsidó hagyomány szerint a szövetségkötésnél a zsidóság egésze, vagyis a később születendők, sőt a zsidóságba betértek is jelen voltak, vagyis minden egyes zsidó az idők végezetéig, hiszen a tórai szakasz így folytatódik: „Nemcsak veletek kötöm ezt a [...] szövetséget, azokkal, akik ma itt vannak velünk, hanem azokkal is, akik ma nincsenek itt velünk." (5Móz 29:13). Savuot éjjelén szokás egész éjjel közösen tanulni.

\subsubsection{0. Étkezési törvények}

Az étkezési előírások alapfogalma a „kóserság” (mai izraeli kiejtéssel „,kasrut”), melynek jelentése: a vallási elöírásoknak megfelelő. Vallásos zsidók csak kóser ételt fogyaszthatnak. A Biblia különbséget tesz tiszta és tisztátalan állatok között: a marha, a kecske, a csirke például tiszta, de a nyúl, a disznó tisztátalan. (3Móz 11, 5Móz 14:2-21) A tisztátalan állatokat eleve tilos megenni. Tiszta állatot is csak akkor szabad fogyasztani, ha a rituális vágás előírásainak megfelelően vágták le, és megvizsgálták, nem volt-e az állatnak olyan betegsége, ami fogyasztásra alkalmatlanná teszi, mert ebben az esetben a tiszta állat sem számít kósernak. A húst teljesen ki kell véreztetni, mert a vér evése tilos. Ugyanígy a fogyasztásra szánt növényeket is alaposan meg kell vizsgálni, nem kukacosak, férgesek-e, mert ebben az esetben a fogyasztásuk tilos.

Az ételeken belül három kategóriát különböztetnek meg: húsos, tejes, neutrális (se nem húsos, se nem tejes). A húsos és tejes fogalmak nem csak kifejezetten a húsra, ill. a tejre vonatkoznak, hanem bármire, ami ezekből készül, és a zsiradékokra is, ami ezekből származik. A húsos és a tejes ételek egymással nem keveredhetnek. Ez az egyszerünek hangzó tilalom számos következményt von maga után: a húsos és a tejes ételek nemcsak a fözés vagy a fogyasztás során nem keveredhetnek, hanem egyáltalán semmilyen módon, még a gyomorban, az emésztés ideje alatt sem. Ezért a húsos és tejes ételek fogyasztása között meghatározott időnek kell eltelnie (ha tejes után esznek húsosat, akkor kevesebbnek, mert a tej könnyebben emészthető; húsos étel után azonban csak több óra elteltével szabad tejes ételt enni). A kétféle ételhez különböző edényeket és evőeszközöket is kell használni: a vajazó késsel nem szabad például húst vágni, vagy egy olyan edényben, amiben tejes ételeket föznek, nem szabad húsos ételt készíteni. A neutrális ételeket (például zöldségeket) húsos és tejes ételekkel is szabad fogyasztani, csak arra kell figyelni, hogy az evőeszközök, edények ne adjanak át húsos vagy tejes jelleget a neutrális (héberül: parve) ételnek. A mustár például parve: se nem húsos, se nem tejes, és mindkét 
kategóriával együtt fogyasztható. Ha azonban az ember azzal a késsel nyúl a mustáros üvegbe, amivel éppen fött virslit eszik, akkor az evőeszköz átadja a húsos jelleget a mustárnak, és az is húsossá válik, ami után már nem szabad tejes ételhez (például sajthoz) fogyasztani. Ezért egy zsidó konyhában parve evőeszközök és edények is vannak, a harmadik kategória számára. A különbözö kategóriájú evőeszközöket általában színekkel jelölik (például a piros nyelü kések húsosok, a kékek pedig tejesek), vagy más módon különböztetik meg őket. Az étkezési törvények rendkívül bonyolultak, alaposabb bemutatásukra nincsen mód.

\subsubsection{A zsidóság egyes szellemei irányai}

\section{Kabbala}

A zsidó misztika legfőbb (de nem egyetlen) irányzata a kabbala, amely Isten megismerhetetlen lényegét igyekszik megragadni. A kabbala rendkívül sokrétü és szerteágazó misztikus tan, sokféle irányzatra bomlik szét, ezért átfogó ismertetése csak a legáltalánosabb elvekre szorítkozhat. A kabbalista tanítás szerint Istenről tulajdonképpen semmilyen állító kijelentést nem lehet tenni, mivel valódi mibenléte megismerhetetlen. Ezzel együtt a kabbalista Isten intim ismeretére, közelségére törekszik. Az Istennel való kommunikáció a szefirot (szférák, számok) rendszerén keresztül lehetséges, amelyek Isten belső lényegének emanációi. A kabbalista nyelvhasználat nagymértékben megszemélyesítő, szexuális vonatkozásoktól sem mentes. Isten női princípiuma fontos szerepet tölt be a kabbalista hagyományban, ebben a tekintetben a Kabbala egyedülálló a zsidó szellemi irányzatok között. A legfontosabb kabbalista mü a Zohar (Ragyogás könyve), amelyet arámi nyelven írtak a 13. században, Spanyolországban.

A legnagyobb befolyású kabbalista mester Jichak Luria (1531-1572), akinek tanítása szerint a teremtés Isten összehúzódása révén vált lehetségessé, vagyis Istennek bizonyos mértékben háttérbe kellett szorulnia ahhoz, hogy a világ létrejöhessen. Isten teremtő fényét a világ anyagi formáiba árasztotta, de azok túl gyengék voltak fénye elviselésére, és szétrobbantak, széttörtek, az isteni fény szikrái pedig a széttörő formák burkaiba záródtak. A zsidó vallás parancsolatainak betartása révén kiszabadíthatóak a teremtő fény szikrái, ami által a hithü zsidó valójában a teremtés müvét fejezi be. Isten passzív marad ebben a folyamatban, a teremtés, a világ alakulásának sorsa az ember tevékenységétől függ. 


\section{Haszidizmus}

A tizennyolcadik században Lengyelország és Ukrajna területén alakult ki a haszidizmus mozgalma. A haszidok a kabbalista tanokból föleg az Isten intim közelségére vonatkozó elemeket vették át és fejlesztették tovább. Isten közelsége az életöröm fontosságát implikálta számukra: nem intellektuális, hanem intuitív módon igyekeztek Isten közelébe jutni. Tanításaikat elsősorban történetekkel, tanmesékkel, példázatokkal hirdették, és hamarosan valódi tömegmozgalommá váltak. Az egyszerü emberek számára a „szent” rabbi, a rebbe avagy caddik (,,igaz ember”), közvetítette Isten akaratát, egyfajta közvetítővé vált Isten és ember között, aki a teremtés rendjén felül állva akár csodákat is tehet. A haszid mozgalom a mai napig él, elsősorban Izraelben és az Egyesült Államokban.

\section{Cionizmus}

A zsidóság emancipációja a francia forradalom idején kezdődött. Az állampolgárság fogalma lassan elvált a kereszténységtől, vagyis a társadalomnak azon rétegei is egyenjogú állampolgárokká válhattak, akik nem voltak tagjai valamelyik hivatalos keresztény egyháznak. Az emancipáció asszimilációt vont maga után: amilyen mértékben lehettek egyenrangú tagjai a többségi társadalomnak a zsidók, olyan mértékben kezdtek a többséghez önként hasonulni. Az ortodox zsidó vallást modernizálni igyekeztek, illetve sokan teljesen elfordultak a vallástól és szekuláris életet éltek. A szekularizáció a cionizmusban csúcsosodott ki, amely azt tủzte ki célul, hogy a zsidó nép épp olyan nemzet legyen, mint a többi, saját országgal és önrendelkezési joggal. Legfőbb ideológusuk a Magyarországon született Herzl Tivadar (1860-1904) volt, aki egyben a nemzetközi cionista mozgalom alapítója volt. A cionisták Palesztina területén nagyszabású földvásárlási akciókba kezdetek, a mozgalom követői pedig az így megvásárolt területeken telepedtek le azzal a céllal, hogy a rabbinikus zsidóságtól független új zsidó kultúrát, végső soron pedig saját államot hozzanak létre. Az ortodox zsidóság kezdetben inkább ellenezte a cionista törekvéseket, hiszen azokban az Istentől való elfordulást látott. A holokauszt azonban nagyban megváltoztatta a zsidóság hozzáállását a szekuláris zsidó állam gondolatához. A holokauszt traumája miatt zsidók tömegei vélték úgy, hogy kizárólag a saját államuk szavatolhatja biztonságukat, így a második világháború végét követően egyre nagyobb számban vándoroltak Palesztina területére, és az ENSZ erről szóló határozatát követően 1948 május 14-én megalapították Izrael államot. 


\subsubsection{Időrendi tábla}

\begin{tabular}{c|l} 
dátum & \multicolumn{1}{c}{ esemény } \\
\hline i. e. 13-12. sz & Izrael letelepedik Kánaán területén \\
\hline i. e. 721 & Izrael az Asszír Birodalom részévé válik, az északi királyság vége \\
\hline i. e. 587 & $\begin{array}{l}\text { Babilónia elfoglalja Jeruzsálemet, lerombolja a várost és az első } \\
\text { templomot }\end{array}$ \\
\hline i. e. 167 & Makkabeus-felkelés kezdete \\
\hline i. e. 63 & Pompeius júdai hadjárata \\
\hline 70 & A római hadsereg lerombolja Jeruzsálemet és a második templomot \\
\hline 1492 & A zsidók kiűzése Spanyolországból \\
\hline 1948 & Izrael állam létrejötte
\end{tabular}

\subsubsection{Irodalomjegyzék}

\section{Ajánlott irodalom}

A bibliaidézetek a Magyarországi Egyházak Ökumenikus Tanácsának Ószövetségi és Újszövetségi Bibliafordító Szakbizottsága fordítását veszik alapul. (1977, Budapest: Református Zsinati Iroda Sajtóosztálya). A Makkabeusok könyveihez lásd pl. Ó- és Újszövetségi Szentírás a Neovulgáta alapján. 2007. Budapest: Szent Jeromos Katolikus Bibliatársulat

Allerhand, JACOB 1988: A zsidóság története. Budapest: Magyar Izraeliták Országos Képviselete

Borowitz, Eugene B. 1987: „Judaism”. - In: Mircea Eliade (szerk): The Encyclopedia of Religion 8. New York: Macmillan Publishing Company, pp. 127-205.

BRIGHT, JosePH 1993: Izráel története. Budapest: Kálvin János Kiadó

Deutsch RÓBert - LANDESzMan GyÖRgy - LŐWy TAMás - RAJ TAMÁs SCHŐNER AlfrÉD - Singer ÖDÖN 1988: Halljad Izrael. A zsidó vallás alapjai. Budapest: Magyar Izraeliták Országos Képviselete

Donin, Hayim Halevy 1998: Zsidónak lenni. Budapest: Göncöl

HaHn István 2005: Zsidó ünnepek és népszokások. Budapest: Neumann Kht.

Jólesz KÁROLY 1985: Zsidó hitéleti kislexikon. Budapest: Magyar Izraeliták Országos Képviselete

Lau, Israel MeIr 2000: A zsidó élet törvényei. Tel-Aviv: Massoret Yeshivat Chaje Moshe

Rogerson, JoHn 1994: A bibliai világ atlasza. Budapest: Helikon

SzÁrAz MikLós György 2011: Írd fel házad kapujára ... Budapest: M-érték 



\title{
4.2. Az iszlám civilizáció
}

\author{
DÉVÉNYI KINGA
}

\subsubsection{Bevezetés}

Az iszlám vallás a három nagy közel-keleti egyistenhitủ vallás közül a legkésőbb jött létre, a 7. században. Az iszlám azonban mind a mai napig több mint vallás, az élet minden területét szabályozza és befolyásolja. Egészen a 20. század első évtizedéig a szellemi és tárgyi kultúrát is szinte kizárólagosan meghatározta. Ezért nevezzük az iszlám világban a 7-20. század közti időszakot az iszlám civilizáció korának. Az utóbbi 100-150 évben már egyre erősödött a nyugati kultúra és a civilizáció részben pozitív, részben negatív, taszító hatása, ezért az iszlám civilizáció történetének tárgyalását erre az 1300 évre korlátozzuk.

A világon jelenleg mintegy 1,7 milliárd muszlim, vagyis az iszlám vallás hívője él. Nagy részük olyan országban lakik, ahol az iszlám vagy kizárólagos vallás, vagy a lakosság döntő többségének a vallása. Ezen országok összességét nevezzük iszlám világnak, azonban az iszlám világon kívül is sok muszlim él kisebbségben (17. térkép). Az iszlám világ országai Délkelet Ázsiától ÉszakAfrikáig, illetve Nyugat-Afrikáig helyezkednek el. Ezek:

$\oplus$ Délkelet- és Dél-Ázsiában:

- Indonézia, Brunei, Malajzia, Banglades, Maldív-szigetek

$\oplus$ Közép-Ázsiában:

- Tádzsikisztán, Kirgizisztán, Kazahsztán, Üzbegisztán, Türkmenisztán, Azerbajdzsán

$\oplus$ a Közel-Keleten:

- nem arab országok: Afganisztán, Pakisztán, Irán, Törökország

- arab országok: Szaúd-Arábia, Jemen, Omán, Egyesült Arab Emirátusok, Katar, Bahrein, Kuvait, Irak, Szíria, Libanon, Jordánia

$\oplus$ Észak-Afrikában:

- Szudáni Köztársaság (Észak-Szudán), Egyiptom, Líbia, Tunézia, Algéria, Marokkó, Mauritánia

A többi afrikai ország közül muszlim többség van, Maliban, Nigerben, Dzsibutiban, Szomáliában, Szenegálban, Gambiában, Guineában, Sierra Leoneban, Burkina Faso-ban, és a Comore-szigeteken, a lakosságnak mintegy a fele muszlim Csádban és Nigériában. Európában Albánia, Bosznia, és Koszovó számít muszlim többségű országnak. 


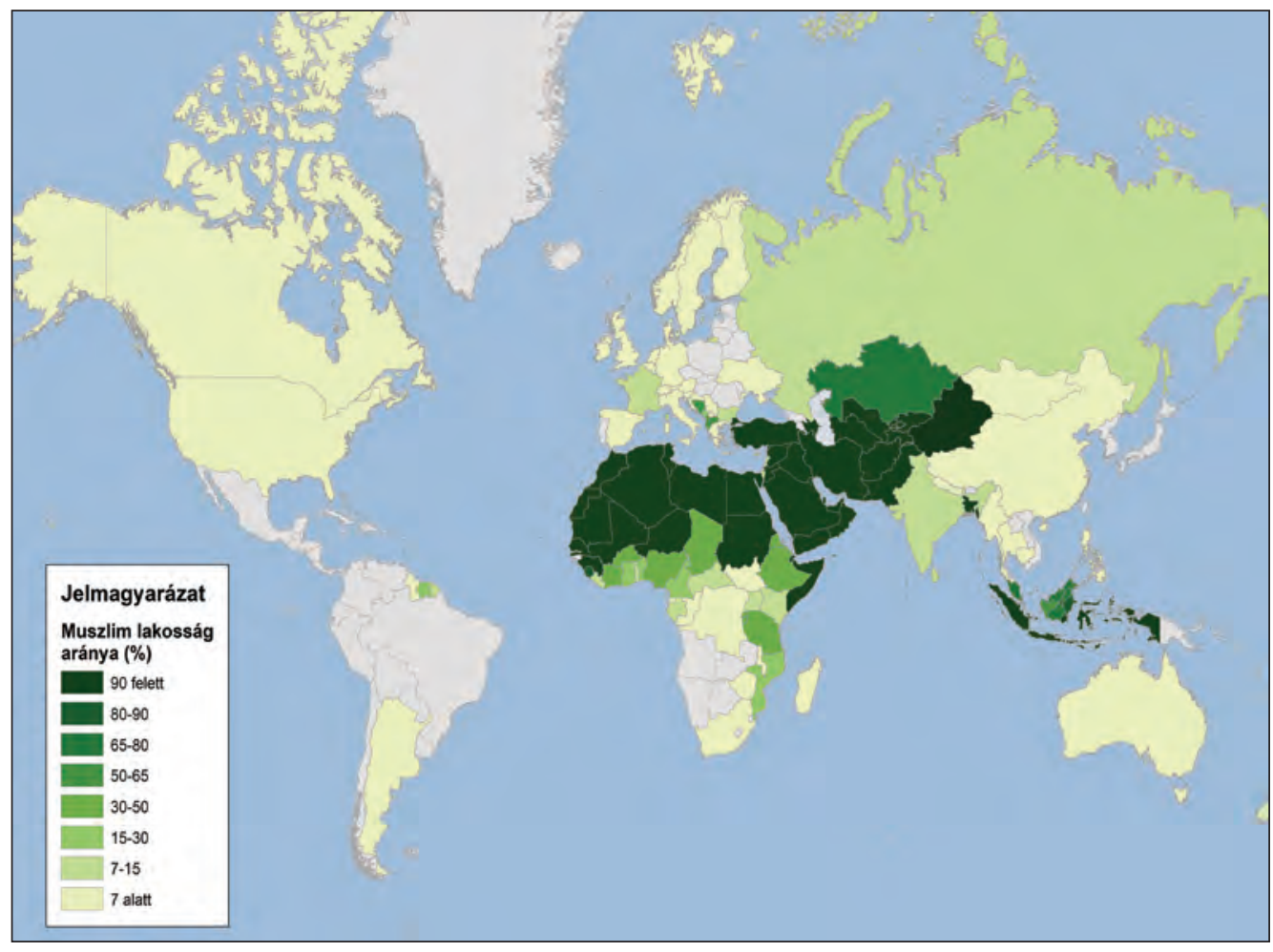

17. térkép: A világ muszlim népessége 2018-ban

Forrás: VARGa ÁGNES szerkesztése

A muszlimok számos további országban élnek kisebbségben. Közöttük vannak olyanok, akik mindig azon a területen éltek, csak idővel áttértek az iszlámra, a lakosság többségével ellentétben. Ilyenek többek között Ázsiában a Fülöp-szigeteken és Indiában élő muszlimok, Kínában az ujgurok, Oroszország egyes területein élők, mint például a csecsenek és a tatárok. Afrikában sok országban teszik ki a muszlimok a lakosság kisebb-nagyobb százalékát (részletesen lásd az afrikai civilizációról szóló fejezetet). Egy másik népes csoportja a kisebbségben élö muszlimoknak azok, akik az elmúlt évszázad során vándoroltak be különböző módon és okokból Európába, valamint Északés Dél-Amerikába. Ök magukat régebben „emigrációban” élőknek nevezték, ma muszlim kisebbségnek. Számukat Nyugat-Európában 25 millióra, Északés Dél-Amerikában összesen mintegy 3-4 millióra becsülik. Tőlük meg kell különböztetni azokat az afro-amerikai muszlimokat, akik 1950 után vették fel az iszlám vallást. A muszlimok máshogy használják az „,iszlám világ” kifejezést, minden területet, országot beleértenek, ahol muszlimok élnek.

A fentiek alapján nyilvánvaló, hogy az ún. iszlám világ, a szükebb és tágabb értelemben véve is az etnikumok (népfajok) és nyelvek tarka 
sokaságát foglalja magába, jóllehet eredetileg az arab volt és maradt az iszlám „anyanyelve” (18. térkép). A muszlimok legnagyobb tömegükben ma is arabok, több mint 400 millióan. A következő népcsoport az indiai, akik Pakisztánban és Indiában élnek, majd az indonéz, maláj, a különböző török népek és a perzsák következnek. Ehhez járul a különböző afrikai népcsoportok sokasága, ill. az afro-amerikaiak. Nyelvileg is az arab a legfontosabb és legnagyobb nyelv az iszlám világban, ezt követi az urdu (Pakisztán és India), az indonéz és maláj, a török nyelvek és a perzsa. Az iszlám civilizáció történetében az arab és a perzsa volt a két legfontosabb nyelv, amelyek azután nagy hatással voltak a többi nyelvre, elsősorban az oszmán-törökre és az urdura.

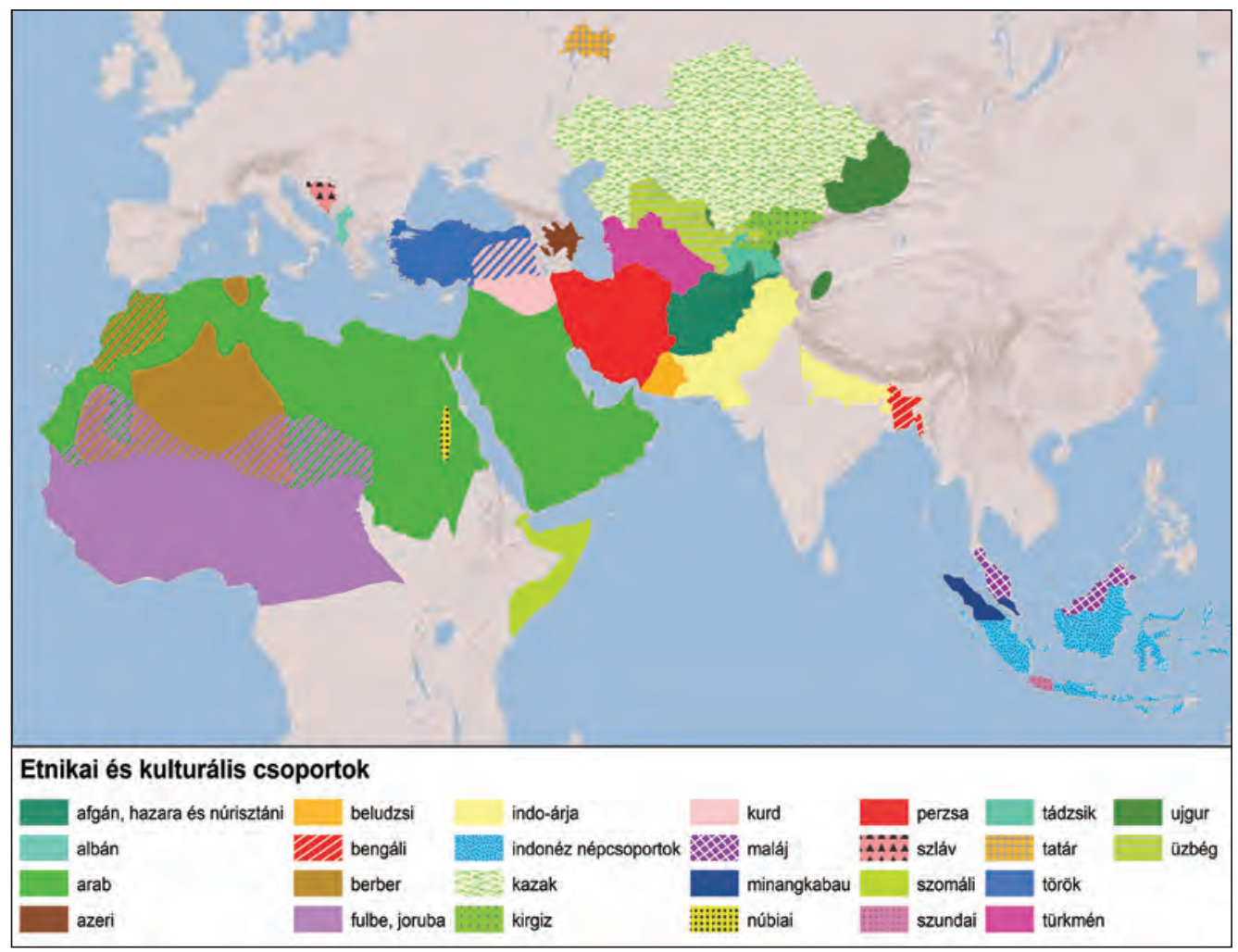

18. térkép: Az iszlám világ főbb etnikai és kulturális csoportjai 2018-ban Forrás: VARGA ÁGNes szerkesztése

Az arab nyelv hatása nemcsak a szókincsre volt nagy az iszlám nyelvei tekintetében, pl. a kelet-afrikai szuahéli nyelv szókincsének mintegy 35-40 százaléka arab eredetủ, míg a modern perzsa irodalmi nyelvben is közel 3035 százalék az arab szavak aránya, hanem az arab írásrendszer átadásában is megmutatkozott a történelem során. Közülük a perzsa, az urdu, az azeri, a pastu, az iraki és iráni kurd ma is arab írást használ, a szuahéli 1870, a török 
1926 óta latin betűt, míg a belső-ázsiai török népek a szovjet uralom éveiben 1921 után a cirill betüs írást vették át. A maláj és az indonéz, két rokon nyelv, sokáig abban különbözött, hogy az előbbi egyik változata, a dzsávi, a 20. század végéig megőrizte az arab írást, míg az utóbbi a holland gyarmati uralom alatt, a 19. században áttért a latin betüs írásrendre. Az arab írás az egyik legnagyobb írásrendszer a latin és a kínai mellett.

Az iszlám világ létrejöttének és elterjedése első félévezredének a földrajzi jellegzetessége az, hogy jól meghatározható zónába esik, az északi félgömbön a Ráktérítőtől északra elterülő sávba (19. térkép). Ennek a területnek egyik fö sajátossága a kevés csapadék (Pakisztán és Észak-India kivételével) és ennek következtében a hatalmas sivatagok, amelyet sok térségben (pl. Arábiában) csak kopár hegyek és magasföldek szakítanak meg. Emellett azonban itt vonul keresztül az Eurázsiai-hegységrendszer is, ami Afganisztán, Kelet-Irán, Törökország (Anatólia) és az észak-afrikai Atlasz-hegység különböző vonulatait jelenti.

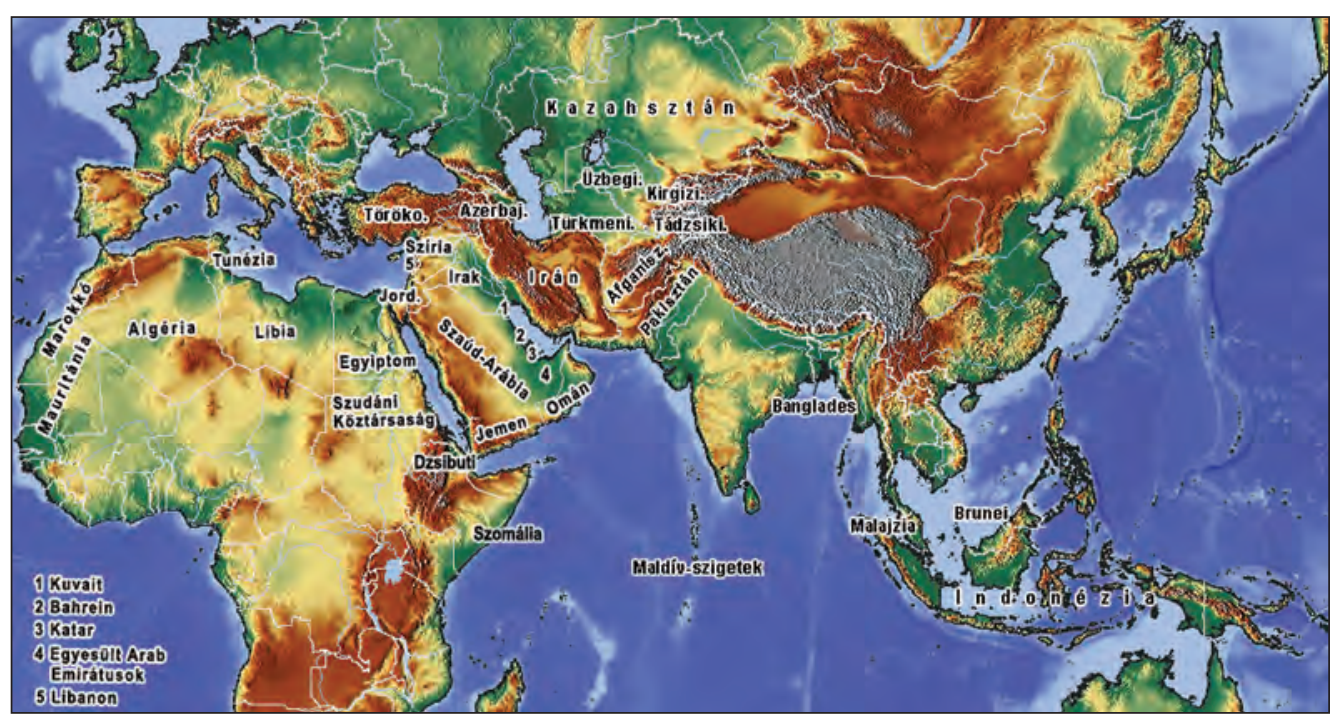

19. térkép: Az iszlám világ földrajzi jellegzetességei

Forrás: VARGa ÁGNES szerkesztése

A sivatag jellegzetes életformája egészen a 20. század utolsó harmadáig a nomadizálás volt évezredeken keresztül, ami a szórványos vízforrásokon alapult, s amelyet az oázisrendszerek tettek teljessé, ahol állandó kutak mellett kert jellegü mezőgazdaság és kisállattenyésztés (birka, kecske) is kialakulhatott (52. kép). A sivatagi nomádok ún. tevés nomádok voltak, mivel a teve jól türi a vízhiányt és nagy távolságokat képes megtenni víz nélkül. 


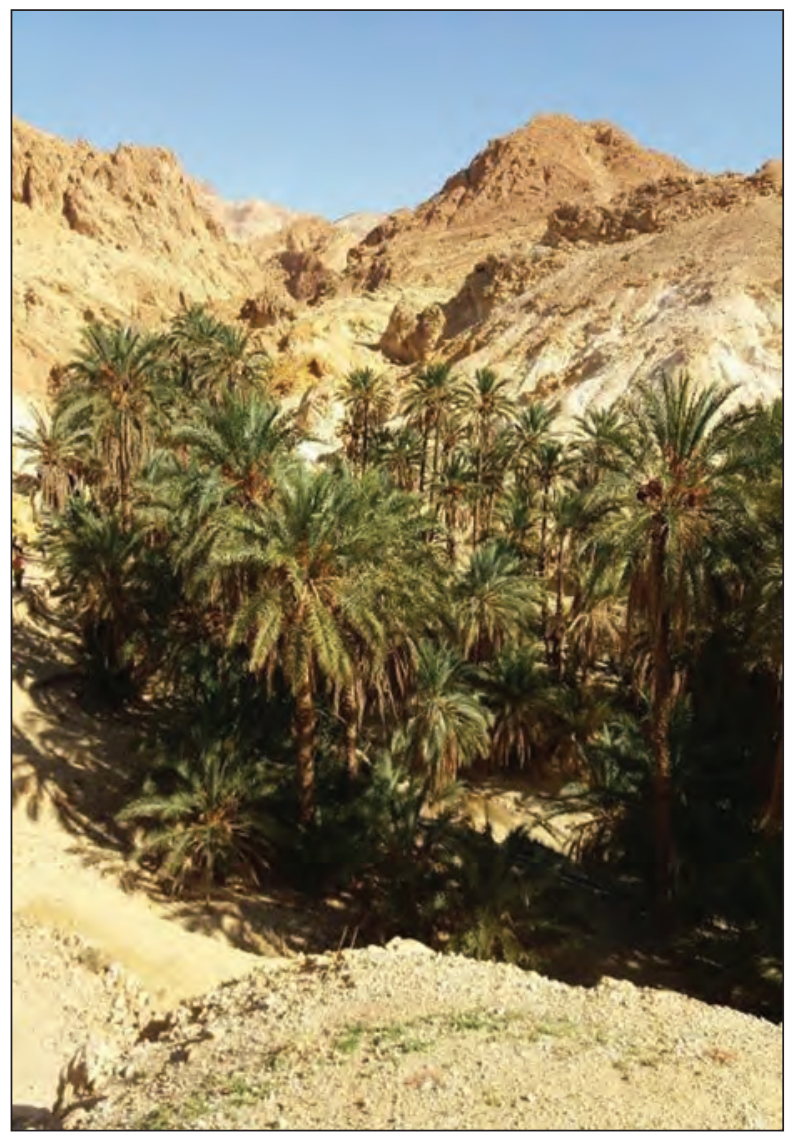

52. kép: A kopár vidékeken a mai napig a datolyapálma oázis a megélhetés egyik legfőbb forrása Forrás: DÉvÉNYI KINGA felvétele

Geopolitikai szempontból az iszlám világ nagy részét, földrajzi fekvéstől függetlenül (Pakisztán, Indonézia, Malajzia és a nyugat-afrikai muszlim országok kivételével) magyarul Közel-Kelet néven szokták emlegetni az elmúlt évtizedekben, míg a nemzetközi elnevezés a legtöbb nyelven a Közép-Keletnek felel meg (pl. Middle East). A közel-keleti térség jelentősége nagymértékben megnövekedett 1930 után, amikor a térség több országában (Irak, Irán, SzaúdArábia, Egyesült Arab Emirátusok, Katar, Omán, ill. Észak-Afrikában Líbia és Algéria) hatalmas kőolajkészleteket találtak és tártak fel egyre növelve a kitermelést és ezek közül föleg a kisebb lakosságú országok gazdagodását. A közelmúltban a térség ismét a nemzetközi figyelem középpontjába került az ott zajló politikai változások (,arab tavasz”, „Iszlám Állam”), ill. az onnan kiinduló migráció következtében, amely a közelség miatt speciális feladatok elé állítja az Európai Unió határvédelmét (20. térkép). 


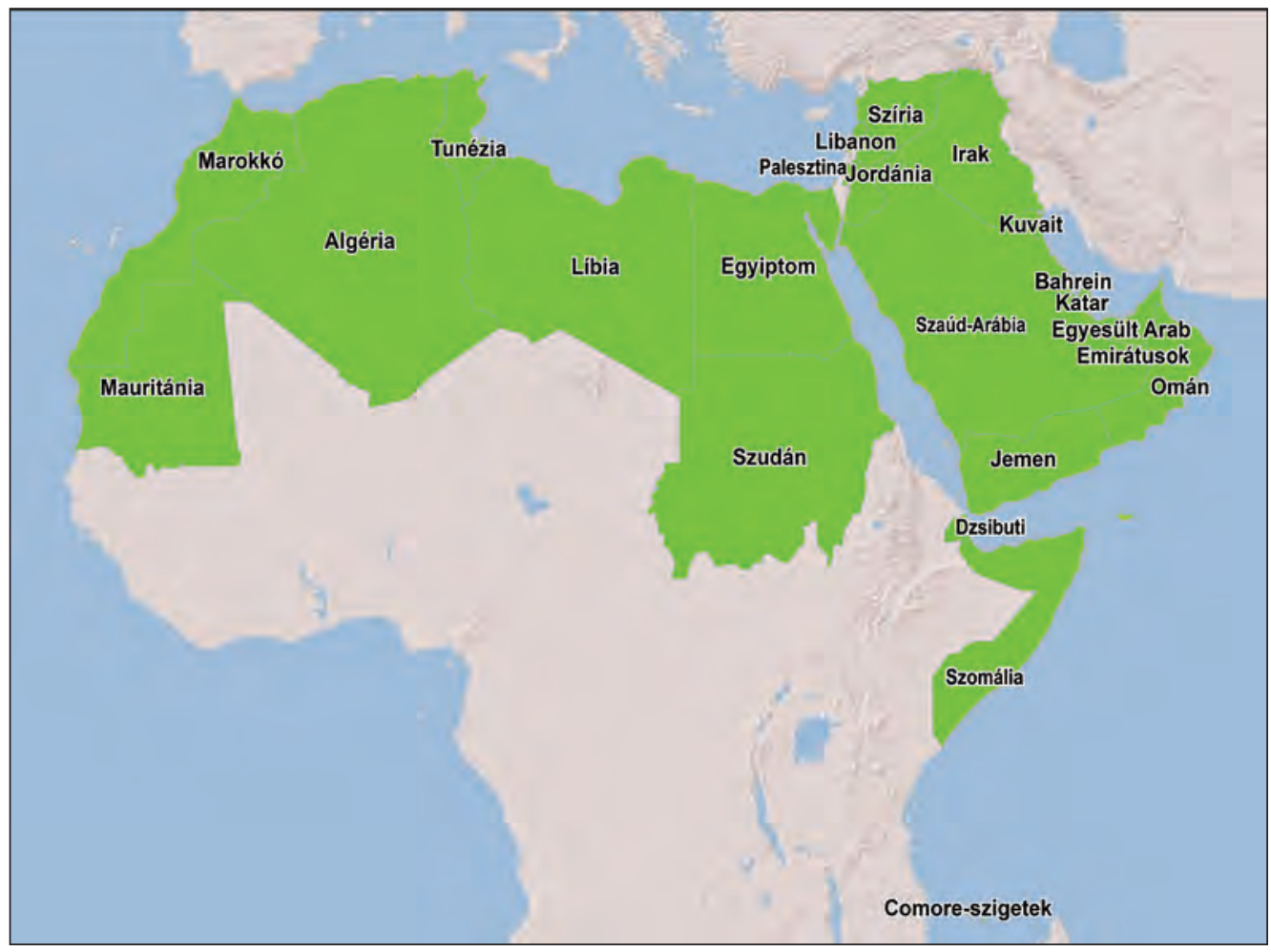

20. térkép: Az iszlám világ keletkezésének központi terülein fekvő arab államokat fogja össze az 1945-ben Kairóban alapított Arab Liga, amelynek jelenleg 22 tagja van Forrás: VARGa ÁGNes szerkesztése

\subsubsection{Történelem}

\section{Mohamed és az iszlám}

\section{Az iszlám vallás kialakulása}

Az iszlám vallás a 7. század első harmadában jött létre, megalapítója Mohamed próféta (megh. 632) volt. Abdalláh fia Mohamed 570 körül született az arábiai Mekkában. Korán árvaságra jutott, ami növelte társadalmi érzékenységét, s ez az iszlám szent könyvében, a Koránban is kifejezésre jut. A hagyományos törzsi társadalom ugyanis igyekezett gondoskodni az árvákról és özvegyekről, ez azonban a kereskedelmi tevékenységre és ennél fogva nagyobb fokú individualizmusra épült mekkai társadalomban háttérbe szorult. Mohamed azonban sorstársainál szerencsésebb helyzetbe került. Miután első gyámja, nagyapja, Abd al-Muttalib is meghalt, a törzsi szokások szerint legidősebb nagybátyja, Abu Tálib lett a gyámja, aki haláláig megvédte a később egyre erősödő támadásoktól a Prófétát, habár maga nem tért át az új 
vallásra. A másik szerencsés körülmény az volt, hogy feleségül vehette a gazdag kereskedőasszonyt, Hadídzsát, aki mellett biztos munkát és megélhetést talált, $\mathrm{s}$ aki maga is igyekezett védeni őt, sokkal idősebb lévén. Ebben a többnejüségen alapuló társadalomban Mohamed nem is vett magához másik feleséget amíg Hadídzsa élt. Mohamed kereskedelmi utazásai során megismerkedhetett a zsidó és keresztény vallás tanaival és a bibliai történetekkel.

Mohamed fiatalkori utazásaival kapcsolatban a legismertebb történet az ún. Bahíra legenda. Az arab történészek szerint a 12 éves Mohamedet nagybátyja elvitte egy szíriai kereskedelmi útra, ahol találkoztak egy szír keresztény szerzetessel, Bahírával. Az behívta a cellájába hüsölni a kereskedőket, akik kint hagyták a fiút a tüző napon, hogy vigyázzon a tevékre, egy abban az órában szokatlan felhő azonban árnyékot borított Mohamedre. Ezt az eseményt a szerzetes csodának minősítette és megjósolta, hogy Mohamedből próféta lesz.

Arábiában egyébként feltehetőleg sok helyen, így Mekkában is rendszeresen jártak prédikáló keresztény szerzetesek. Az Arábiát körülvevő ún. Termékeny Félholdon keresztény arabok éltek, akárcsak a félsziget déli részén. Zsidók pedig a félsziget több oázisvárosában éltek, mint például Jaszrib és Hajbar. A Korán szövegéből, egyes nyelvi fordulataiból világosan kitünik, hogy a mekkaiak ismerték a bibliai történeteket, prófétákat és magát az egyistenhitet is.

Mohamed feltehetőleg 30 éves kora körül elkezdett töprengeni az élet kérdésein, az igazságosságon, az élet értelmén és a lelki tisztaságon. Továbbra is tiszteletben tartotta a mekkai szokásokat és szertartásokat, de évröl évre eljárt a közeliHira-hegység egy barlangjába, ahovákorábban mármások isvisszavonultak elmélkedni. Ezek során, valószínúleg 40 éves kora körül, 610-611-ben, drámai események történtek vele. Egy ilyen visszavonulása során egy hangot hallott és látomása volt, amely felhívta Isten imádására, aki megteremtette a világot, az Egy-Istenére, akinek a neve Allah, akit az arabok tiszteltek, de akinek nem volt sajátos kultusza körükben. Felesége, Hadídzsa bátorítására felismerte, hogy a hang tényleg magától Istentől jött és Gábriel arkangyal hozta el hozzá, Isten kiválasztott prófétájához. Ettől kezdve folyamatosan kapott újabb üzeneteket látomásai során, amelyek összefoglaló neve a Korán, ami eredetileg „recitációt” jelent. Egy ideig csak a feleségének és néhány közeli barátjának beszélt az isteni üzenetekről, három évvel később azonban úgy érezte, hogy prófétai küldetése van népéhez és elkezdte az új kultusz nyilvános hirdetését Mekkában. A Kurajs, Mekka törzse bizalmatlanul és többnyire elutasítóan fogadta az új tanításokat, amelyekben részben Mohamed egyéni hatalmi törekvését, részben pedig, az ismert keresztény tanításokhoz való hasonlóságai miatt, a Bizánci Birodalom cselszövését látták, amellyel, mint korábban máskor is, a mekkai kereskedelmet igyekeztek ellenőrzésük alá vonni. Ugyanakkor féltették a pogány kultuszokat és bálványokat, amelyek az éves mekkai zarándoklattal és vásárokkal, valamint 
a harcmentes szent hónapok kijelölésének jogával együtt Mekka fensőbbségét biztosították Arábia törzsei felett. Emiatt nyilvános igehirdetései során számos inzultus és gúnyolódás érte, ami azonban nem tudta eltántorítani. Híveinek száma lassan nőtt pár tucatra, elsősorban a hátrányos helyzetben lévő árvák és rabszolgák körében, és hamar kialakult az az írástudókból álló csoport, amelyik követte és feljegyezte tanításait. Ezek a pálmalevelekre, csontokra, papiruszés bördarabokra, ill. puha homokkövekre írt feljegyzések alkották az alapját a későbbi Korán összegyüjtésének.

Az életrajzában rögzített számos esemény mutatja, hogy sem a kinyilatkoztatások előfordulása, sem azok tartalma nem állt Mohamed tudatos ellenőrzése alatt. A legkorábbi kinyilatkoztatások után hosszú ideig nem kapott semmilyen isteni útmutatást, ami súlyos depresszióba ejtette, amelyen csak felesége, Hadídzsa folyamatos bátorítása és hite segítette át. Később már szükség szerint érkeztek a várva várt kinyilatkoztatások, de így is előfordult, hogy nem kapta meg a várt isteni döntést egy fontos kérdésben, és ezt úgy értelmezte, hogy hibái miatt Isten így akarja megalázni. Ilyen észrevételek magában a Koránban is előfordulnak, amely sokszor tartalmazza Isten Mohamedhez intézett szavait.

Az arabok számára nem volt ismeretlen az, ha valaki azt hangoztatta, hogy egy rajta kívülálló lény kerítette hatalmába, az adja a szájába a szavakat, és a korai Korán részletek rímes prózája is ismerős lehetett, mert ez volt a jósok (káhin) elragadtatott kijelentéseinek a nyelvezete is. Ugyanakkor a költők (sáir) is azt állították, hogy szellemek (dzsinnek) sugallják törzsüket harcra buzdító és dicsőitő szavaikat. Éppen ezért Mohamed és a későbbi muszlimok is nagy erőfeszítéseket tettek, hogy megkülönböztessék a Korán kinyilatkoztatásait a jósok és költők szavaitól.

A mekkaiak egyre növekvő ellenszenvvel figyelték Mohamed hittérítő tevékenységét, és miután nem tudták rávenni nemzetségét a Banu Hásimot arra, hogy tagadja meg Mohamedtől a törzsi erkölcsök szerint kötelező védelmet, az egész nemzetség ellen léptek fel 616-ban, három évre bojkottálva őket. Nem lehetett a Banu Hásim nemzetséggel kapcsolatot fenntartani, velük kereskedni. 619-ben azonban két olyan esemény történt, amely negatívan érintette Mohamedet: meghalt a felesége, Hadídzsa, és védelmező nagybátyja, Abu Tálib.

\section{Mohamed éjszakai és égi utazásának a története}

A sorsát nagymértékben befolyásoló tragikus események, felesége és nagybátyja halála, feltehetőleg kétségbeesett állapotba kergették Mohamedet, aki elbizonytalanodott küldetése sikerét illetően. Ekkor, 619 körül látomást kapott, amelyre a Koránnak csak egy félmondata utal, de amely a hagyományok tucatjaiban van részletesen leírva. A Korán idézet így szól (17:1): „Dicsőség Istennek, aki egy éjszakai utazás során szolgáját a Szent Mecsetből elvitte a legtávolabbi mecsetbe”. Az itt szereplő szó alapján a történet első részét ,éjszakai 
utazásnak" (iszrá) nevezik, és minden muszlim vallástudós elfogadja hitelességét. A részleteket a hadíszok fejtik ki, Mohamed elbeszélésére hivatkozva. Éjjel, mekkai háza tetejéről vezette el Gábriel arkangyal a legtávolabbi mecsetbe, amelyet a névazonosság alapján a vallástudósok a jóval később épített jeruzsálemi Akszá mecsettel azonosítanak. Az elbeszélések szerint Mohamed ébren volt és a Burák nevü öszvéren követte az angyalt. A mecsetben együtt imádkozott a korábbi nagy prófétákkal, Mózessel és Jézussal, akik Mohamedet kérték meg, hogy imámként vezesse az imát. A látomás ily módon erősíthette Mohamed küldetéstudatát. A történet második része nem támaszkodhat koráni bizonyításra, ezért nem is minden vallástudós fogadta el, bár az egész iszlám világban megünneplik feltételezett időpontját. Ez az „égi utazás” (mirádzs). Eszerint Gábriel a „legtávolabbi mecsetből” a hét mennyországba vezette a Prófétát, ahol mindegyikben a Bibliából ismert próféták várták és üdvözölték, végül eljutott Isten trónusához.

\section{A hidzsra (kivándorlás)}

Abu Tálib utóda egy másik nagybátyja lett, akit a Korán csak Abu Lahab (,,a láng apja”) néven említ, ami átvitt értelemben azt jelenti, hogy pokolra való. Ő nem kívánta megvédeni Mohamedet, akinek így Mekkán kívüli támogatást kellett keresnie. Ezt meg is találta a Mekkától 320 km-re északra fekvő Jaszrib, a későbbi Medina lakosaiban. A jaszribiak mezőgazdasággal, azon belül elsősorban datolyatermesztéssel foglalkoztak. Az ott élt három zsidó törzs mellé idővel beköltözött két pogány arab törzs, az Ausz és a Hazradzs is, akik állandó harcban álltak egymással. Ösi arábiai szokás szerint szívesen láttak a városban egy semleges döntőbírót, aki megfelelő erkölcsi tekintéllyel és bölcs belátással bír, s ezt találták meg Mohamed személyében. A tárgyalások 621-622 során folytak, megkötötték a két ún. akabai szerződést, amelyben elfogadták az új vallást és vezetőnek Mohamedet, ugyanakkor neki, a mekkai muszlimoknak és családjaiknak azt a védelmet ígérték meg, amelyet saját törzseik tagjainak, asszonyaiknak és gyerekeiknek is biztosítottak. Ezek után 622 szeptemberében a muszlimok mintegy 70 fös csoportja elhagyta Mekkát, majd Mohamed is követte öket. Ennek a kivándorlásnak a neve arabul hidzsra, és ez lett később a muszlim időszámítás kezdete. A kivándorlásnak gyorsnak és titkosnak kellett lenni, mert Mekka és Jaszrib (Medina) között a muszlimok sem a régi, sem az új védelmet nem élvezhették, bárki szabadon megölhette volna őket, következmények nélkül.

\section{A medinai iszlám}

$\mathrm{Az}$ új városban elsősorban gazdasági, anyagi nehézségekkel kellett szembenézni a muszlimoknak, akik nem értettek a mezőgazdasághoz. Az első időkben ezt úgy oldották meg, hogy az új, medinai muszlimok - anszár 
(„,ámogatók”) - testvérükké fogadták a kivándorlókat (muhádzsirún). 624 elején Mohamed egy olyan módszerhez folyamodott, amely egyszerre segített megoldani az anyagi gondokat és a mekkai pogányok gyengítésével a vallás ügyét is elöre vitte. Megtámadták az egyik szent hónapban (amikor tilos a harc) a Szíria felé árukkal megrakodva igyekvő mekkai karavánt. Bár sokan még a muszlimok közül is rosszallásuknak adtak hangot a szent hónap megsértése miatt, egy koráni kinyilatkoztatás (2:217) ezt megengedettnek mondta a nagyobb rossz, a pogányság elleni harcban. A legnagyobb sikert azonban a badri csatában (624. március) aratta Mohamed, ahol már jól őrzött, nagy karavánt sikerült kirabolni a kisebb létszámú muszlim erőknek. A siker nemcsak anyagilag volt jelentős, hanem megerősítette Mohamed tekintélyét is, amit az is jelzett, hogy az ellene áskálódó egyik zsidó törzset, a Banu Kajnukát sikerült elüznie Medinából. Ezeknek a csatáknak még volt egy ideológiai jelentősége is, ugyanis nemzetségtagok harcoltak nemzetségtagokkal, sőt muszlim családtagok pogány családtagok ellen. Mohamed kinyilvánította, hogy vége van a régi törzsi rendszernek, a muszlimok egy szupertörzset alkotnak, amelynek a neve umma. Ennek a tagjai nem állhatnak kapcsolatban régi törzsi társaikkal, nem örökölhetnek tőlük és azok sem örökölhetnek őtölük. A következö évben a túl vérmes fiatalok belevitték Mohamedet egy súlyos vereségbe Uhudnál, azonban a mekkaiak nem tudták kihasználni győzelmüket és eltiporni Medinát. Ugyanakkor Mohamednek sikerült a mekkaiakat támogató másik zsidó törzset, a Banu Nadírt is elüznie. Ök már nem vihették magukkal vagyontárgyaikat, amelyek így a muszlimok birtokába jutottak. A mekkaiakkal is tovább folytatódott az ellenségeskedés, akik kereskedelmük védelmében 627ben döntő lépésre szánták el magukat. Sok ezres beduin sereget gyüjtöttek össze szövetségeseik köréböl, maguk a mekkaiak is sokan csatlakoztak hozzájuk és Medina alá vonultak, hogy megostromolják és elfoglalják. Mohamed azonban időben értesült a tervükről és mély árkokat ásatott a város védelmében, míg a kiásott föld védőfalként szolgált. Az ,árok (handak) csatája” egy hónapig elhúzódott és a mekkaiak eredmény nélkül voltak kénytelenek visszavonulni. Ez Mohamed medinai pozíciójának megerősödéséhez vezetett. A csata után az utolsó, a mekkaiakkal összejátszó medinai zsidó törzset, a Banu Kurajzát egy muszlimokkal való összetűzés ürügyén lemészárolták. Ezzel mind a külső, mind a belső ellenállás megszünt és Mohamed figyelme a muszlim közösség vallási alapon történő megszervezése felé fordulhatott, amelybe most már Medina minden lakosa beletartozott, elismerve Mohamed irányítását.

A medinai korszak első éveiben Mohamed nem törekedett azúj közösséget irányító általános érvényű rendelkezések megalkotására. Úgy tünik, hogy a világvége váró hangulatban csak rövid életünek tartotta a muszlimok evilági életét. Ahogy azonban nőtt a tekintélye és hatalma, egyre több szükség volt törvényalkotásra, s ez a Korán medinai fejezeteiben is egyre jobban kiviláglott 
az idő előrehaladtával. A törvények egy csoportja az istentisztelet különböző formáinak elvégzésére vonatkozott: hitvallás, imádkozás, alamizsnaadás, böjtölés és zarándoklat nem mindig teljes elöírásai. Később ezeket kiegészítették a Mohamed által végzett tényleges vallásgyakorlás hagyományaival. A törvények másik csoportja az emberek egymás közti kapcsolataival foglalkozott: házasság, válás, öröklés, kereskedelmi szerződések. Ezek is csak annyiban voltak leírva, amennyiben eltérést tartalmaztak a létező szokásoktól és normáktól. Egy harmadik csoport az erkölcsi követelményekkel foglalkozik, mint például az új, iszlám által elfogadott házassági kapcsolaton kívüli nemi kapcsolatok bünösnek nyilvánítása. A medinai kinyilatkoztatások rögzítették bizonyos főbünök (hudúd) - gyilkosság, lopás, paráználkodás, rágalmazás büntetési módját. Ugyanakkor meghatározták a legfontosabb tilalmakat, az étkezés és házasság terén.

A Próféta tekintélyének növekedése nem mindenkinek tetszett Medinában, ellenségei kihasználták például egyik feleségével, Áisával kapcsolatos híreszteléseket. Ezért a Korán számos olyan utasítást is tartalmaz, amelyek csak Mohamedre és háza népére vonatkoztak. Végül fontos volt a régi mekkai törzs és nemzetség pogányságban maradt tagjai elleni harc törvényesítése, az iszlám gyakorlását megtiltók elleni harc, a dzsihád meghirdetése. A Korán azonban arról is szól, hogy ennek a harcnak - szó szerint erőfeszítésnek - a muszlimok lelkében kell elkezdődnie, hitük megerősítése érdekében. Az iszlám Korán által kijelölt világában azonban az egyének csak mint a muszlim közösség, az umma tagjai érhetik el az evilági és túlvilági boldogulást, ezért arra buzdít, hogy a muszlimok egymást segítve és helyes útra térítve igyekezzenek az Isten által kijelölt „egyenes úton” haladni.

628-ban Mohamed merész lépésre szánta el magát: hívei - a környező beduinokkal is gyarapodott táborával - fegyvertelenül Mekka alá vonult, hogy elvégezzék a zarándoklatot. A mekkaiak békét ajánlottak, ennek fejében a következő évben, 629-ben a muszlimok elvégezhették a zarándoklatot. 630ban azonban egy incidens alapul szolgált Mohamednek a béke felmondására és elfoglalta Mekkát. A hódítás vértelen volt, a mekkaiak behódoltak az iszlámnak és hat héttel később már együtt harcoltak és győztek a hunajni ütközetben az ellenséges beduin törzsek ellen. 631 hozta meg a végső áttörést, amikor is Arábia valamennyi törzséből küldöttségek érkeztek, jelezve csatlakozásukat az iszlámhoz, s ugyanakkor elkezdődtek a kisebb portyák, hadjáratok a környezö Szászánida Perzsa Birodalom és Bizánc határterületeire. 632-ben Mohamed, aki úgy döntött, hogy továbbra is Medinában marad, újra elvégezte a mekkai zarándoklatot - ún. búcsú zarándoklat -, majd hamarosan, közeli társai számára is váratlanul, meghalt. 
Az utódlás kérdése

Mohamed nem jelölt ki utódot (kalifa), ezért ennek kiválasztását nagy viták előzték meg. Amedinai muszlimok úgy érezték, hogy ők tették lehetővé az iszlám sikereit és ezért közülük kellene az utódnak kikerülnie, a mekkaiak azonban érvényre juttatták azt az elvet, hogy annak Mohamed törzséből, a Kurajsból kell kikerülnie. A törzsi hagyományok kétfajta utódlást tettek lehetővé. Vagy választás útján egy tapasztalt, bölcs vezetöt jelöltek ki, vagy az elhunyt törzsfö közvetlen családjának - háza népének (ahl al-bajt) - legérdemesebb tagja lett az új törzsfö. A muszlimok végül Umar javaslatára, aki már Mohamed életében is jelentős szerepet játszott a közösség életének irányításában, a legidősebb és egyik első muszlimot, Abu Bakrot választották meg első kalifának. Ez azonban nem nyerte el a muszlimok egy részének a tetszését, akik a Próféta unokatestvérét és egyben lányának, Fátimának a férjét, Alit szerették volna kalifának. Ezek „Ali pártjának" (síat Ali) nevezték magukat és belölük alakult az iszlám egyik, ma is létező vallási irányzata, a síita iszlám.

A medinai kalifátus: a négy igaz úton járó kalifa uralkodása

Abu Bakr kalifátusa (632-634)

Abu Bakr legfontosabb feladata az volt, hogy leverje a beduin törzsek iszlámról való leválási törekvéseit (ridda). A törzsek ugyanis a hagyományos szövetségi szerződésnek tartották az iszlámhoz való csatlakozást, amely Mohamed személyéhez kötődött és annak halálával azt érvénytelennek tekintették. Abu Bakr seregei azonban Arábia több pontján is győzedelmeskedtek, így ő újra egységesíteni tudta a félszigetet. A hatalom és egység fenntartásában azonban nagymértékben segítségére volt az a körülmény, hogy folytatva a már Mohamed által is elkezdett külső hódításokat, csapatokat küldött a Bizánci Birodalom és a Szászánida Perzsa Birodalom ellen. A győztes ütközetekben szerzett hadizsákmányok szétosztása fokozta a beduin törzsek lojalitását és harci kedvét. Abu Bakr idős korban került hatalomra és két év után meghalt, de előtte még kinevezte utódát Umar ibn al-Hattáb személyében, hogy elkerüljék azokat a vitákat, amelyek az ő kinevezését megelőzték.

\section{Umar kalifátusa (634-644)}

Umar, a második kalifa három területen ért el az iszlám története szempontjából tekintve fontos eredményeket. Először is megerősítette az új, egyre növekvő birodalom szervezettségét és belső rendjét. Már Mohamed életében is ö volt a rend öre, sokkal nagyobb szigorral lépett fel az általa erkölcstelennek és iszlámellenesnek tartott jelenségekkel szemben, mint maga Mohamed. Például a hagyományok úgy tartják, hogy a borivás teljes tilalmát is ö szorgalmazta a medinai korszak vége felé, mert a részegeskedés 
rendzavarásokhoz vezetett. Uralkodása alatt pedig sietett betiltani az ún. élvezeti házasságot, amely időszakos kapcsolat volt, s amelyet a Korán is engedélyezett. Ezt azzal a magyarázattal tette, hogy az csak Hajbar oázis elhúzódó ostroma miatt lett ideiglenesen megengedve, amikor a harcoló muszlimok sokáig nem tudtak kapcsolatot tartani feleségeikkel. A másik terület, ahol Umar kalifa a legnagyobb sikereit aratta, a gyors és hatalmas katonai győzelmek voltak. 635-ben az iszlám seregei elfoglalták Damaszkuszt, 636-ra pedig a Bizánci Birodalom egész szíriai és palesztinai tartománya is az iszlám kalifátus része lett. Végül 638 és 641 között Egyiptomot is elfoglalták Bizánctól. Kelet felé is folytatódtak a gyors katonai sikerek. 637-ben az iraki Kádiszijja mellett döntő győzelmet arattak a Perzsa Birodalom fölött, amelynek a fővárosa és központi területei a birodalom nyugati határvidékét képező Irakban voltak. A győzelem után folytatódott az arab hódítás és pár év alatt az egész hatalmas Szászánida Birodalom a muszlimok kezére került. Umar minden sereg és újonnan elfoglalt tartomány élére a hozzá hủ embereket nevezte ki és így tudta kézben tartani a váratlan gyorsasággal megnövekedett kalifátust. A harmadik terület, ahol Umar tevékenysége máig ható jelentőséggel bírt, a Korán egyes részeinek összegyüjtése és elrendezése volt. Ezzel a munkával a Próféta írnokát, Zajd ibn Szábitot bízta meg, akinek a tevékenysége nyomán kialakult a Korán ma is ismert szerkezete, verseinek (ája) és fejezeteinek (szúra) a sorrendje. Umart 644-ben egy vélt személyes sérelem miatt, imádkozás közben gyilkolták meg.

\section{Uszmán kalifátusa (644-656)}

Umar utóda Uszmán ibn Affán lett, a legtekintélyesebb mekkai nemzetség, a Banu Umajja tagja, Mohamed egyik lányának a férje. Uszmán is átlátta a Korán jelentőségét és azt a megbízást adta egy Zajd által vezetett bizottságnak, hogy gyüjtsék össze az összes létező Korán példányt és egységesítsék az írást, a nyelvi változatok eliminálásával. Ezután Uszmán a változatokat elégettette és az egységesített Koránt annyi példányban másoltatta le, hogy minden tartományba jusson belőle.

Uszmán uralkodása alatt is folytatódtak a hódítások mind a Perzsa Birodalom keleti tartományai felé, mind pedig Észak-Afrikában, Líbia irányába. Ugyanakkor azonban nőtt az elégedetlenség annak következtében, hogy a kalifa minden fontos tisztségre családja és nemzetsége tagjait nevezte ki. Így lett a fontos szíriai tartomány parancsnoka Muávija, a pogány kori Mekka Mohamed-ellenes vezetőjének a fia, a későbbi kalifa. Ugyanakkor egyre nőtt Ali tábora (a síiták) is. Végül 656-ban a lázadók saját házában megölték Uszmán kalifát. Az utódlás kérdésében a muszlimok nem tudtak egységre jutni. 
Ali kalifátusa (656-661) és az első polgárháború (fitna)

Medinában Alit választották kalifának, de ezt a szíriaiak nem fogadták el. Ök Muáviját választották meg. Ali és Muávija csapatai 657-ben találkoztak az Eufrátesz partjánál (Sziffín, a mai Rakka), ahol ösi arab szokás szerint döntőbíráskodást határoztak el, amelynek alapján a nyugati területek Muávija, a keletiek pedig Ali uralma alatt maradtak. Ali híveinek egy része ezt nem fogadta el, kivonult a táborából azzal a felkiáltással, hogy Ali Isten rendeletéből lett kalifa, és ezt emberek nem változtathatják meg. Arábia középső részein önálló államot alapítottak. Az utókor háridzsitáknak („kivonulók”) nevezte el öket. Közben Ali és hívei Dél-Irakba vonultak, az egyik új katonai városba, Kúfába, ahol 661 elején egy háridzsita meggyilkolta a mecsetből kijövő Alit. Ezzel Muávija lett az egyedüli uralkodó.

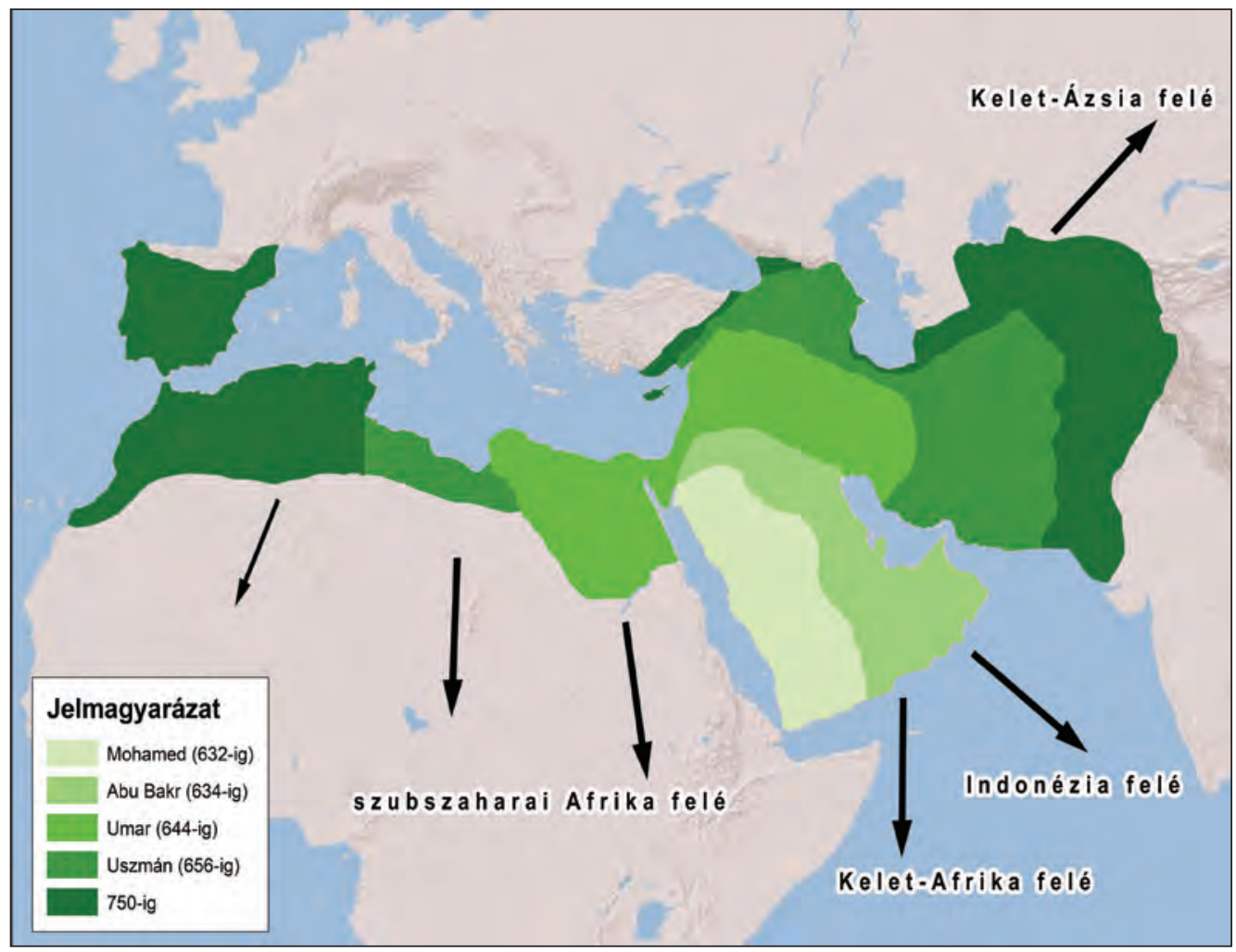

21. térkép: Az iszlám térhódítása

Forrás: VARGA ÁGNES szerkesztése

A háridzsiták az iszlám első szektáját alkották. Szigorú nézeteik szerint, aki föbünt követ el, azt halállal kell büntetni, kalifának pedig a legalkalmasabb muszlimot kell megválasztani, függetlenül származásától. Aki pedig nem az ő tanításaikat követi, az nem muszlim és szabadon meg lehet ölni. Ezek az 
eszmék a 20-21. században éledtek újra a szélsőséges politikai iszlámban. A 8. századot követően a háridzsiták kiszorultak Arábia központi területeiröl és az iszlám világ határterületein, eldugottabb részein alapítottak államokat (21. térkép). Ezek közül a legjelentősebb a 9. században a mai Algéria területén fennállt Rusztamida Imámátus volt. A háridzsiták egyik mérsékelt ága az ibádi, akik Ománban hoztak létre a mai napig fennálló, önálló államot. Kisebb ibádi közösségek léteznek a mai Algéria területén, a Mzáb-völgy vidékén, illetve Líbiában, Tunéziában és Zanzibárban.

\section{A damaszkuszi Umaijád Kalifátus (661-750)}

Muávijával az umajjád dinasztia került hatalomra, akik Damaszkuszból irányították a hatalmas birodalmat. Az első korszakot (661-683) szufjánida umajjád dinasztiának nevezzük, mert az umajjád nemzetség Szufjántól származó tagjai közül kerültek ki a kalifák. Közülük az első Muávija volt (661-680), aki a szíriai arab törzsekre támaszkodva uralkodott. Miután Ali halálával véget ért az Iszlám Birodalom első ún. polgárháborúja (fitna), a muszlimok többsége egységre törekedve támogatta az Umajjádokat. A maradék belső ellenállást, Ali híveit és a háridzsitákat sikeresen leverték katonai erővel, s ugyanakkor folytatódtak a külső hódítások, elsősorban egy Bizánc ellen felépített erős és sikeres flotta segítségével, amely el is foglalta Ciprus szigetét. Ekkor már nyilvánvalóvá vált az új tartományok befolyása az iszlám kalifátusra, hiszen a sivatagi beduin törzsek nem értettek a hajózáshoz, ebben a szíriai, palesztin és egyiptomi muszlimokat vették igénybe. Az Umajjád Kalifátus az állami élet minden területén erőteljesen támaszkodott a meghódított Szíria bizánci hagyományait tovább vivő keresztényekre, akik az állami adminisztrációt görög nyelven végezték. A pénznemet azonban a Szászánida Perzsa Birodalomból vették át, az ezüst drachmát, az arabosított dirhemet. Muávija halála után ugyancsak bizánci hatásra az örökletes uralom vált szokássá és öt fia, I. Jazíd követte. Az utódlás körüli vitákat szándékoztak kihasználni a Dél-Irakban többségben lévő Ali hívek, a síiták, akik Ali fiának, Mohamed unokájának, Huszajnnak a vezetésével elindultak az umajjád helytartó ellen. A túlerőben lévő ellenfél azonban a Kúfához közeli Kerbela mellett legyőzte őket és Huszajnt is meggyilkolták. Halála mind a mai napig a síiták gyászünnepe, az ásúra, a holdév első hónapjának (muharram) 10. napján.

\section{A második polgárháború (fitna) (683-692)}

Jazíd halála után az umajjád nemzetség másik ágába tartozó I. Marván került hatalomra (683-685). Miután az utódlás módja elvileg sosem lett szabályozva, és a hüségesküt a törzsfőnökök mindig a kalifa személyére tették le, nem a dinasztiára, Jazíd halálakor megint több trónkövetelő is jelentkezett. 
Zubajr a tekintélyét vesztett Medinában szerezte meg a hatalmat és onnan próbált uralkodni, Muhtár Kúfában a síiták jelöltje lett. A harcok végül csak Marván fia, Abd al-Malik (685-705) katonai sikerei után értek véget, aki csak 692 után lett az egész birodalom tényleges és elismert ura. Uralmának három jelentős mozzanata volt, amelyek hatással voltak az iszlám későbbi fejlődésére.

$\oplus$ Egyrészt a térség nagy birodalmainak a mintájára és hatására a kalifa, a törzsi és katonai vezetőktől való függését felszámolva, abszolút hatalommal rendelkező uralkodó lett.

$\oplus$ Másrészt erős katonai kormányzókra támaszkodva megszilárdította a hatalmát az új tartományokban, elsősorban Irak és Irán területén. Itt évtizedekig Haddzsádzs volt a kormányzó, aki nemcsak tovább folytatta kelet felé a birodalom terjeszkedését, de hatékony adórendszert is sikerült meghonosítania. Az iszlám sosem kényszerítette a meghódított területek lakosságát az áttérésre, Haddzsádzs azonban adózási szempontok miatt kifejezetten akadályozni kívánta az iszlamizációt. A muszlimok ugyanis csak földadót (harádzs) fizettek, míg az elismert vallások követői, az ún. dzimmik (zsidók, keresztények, ill. Iránban a zoroasztriánusok) ezen kívül fejadó (dzsizja) fizetésére is kötelezve voltak. Ezért az utókor iszlámellenesnek is nevezte, mert igyekezett megtiltani az áttérést, illetve megakadályozni, hogy a földmüvesek elhagyják falvaikat és az új városokba költözzenek. Ennek volt még egy oka: az új katonai helyőrségi városok, mint a dél-iraki Kúfa és Baszra elégedetlenkedő lakossága az örök ellenzéki síiták táborát erősítette.

$\oplus$ A harmadik mozzanat Abd al-Malik uralkodásában az állam arabizációja volt. A hivatalos nyelv az eddigi görög helyett az arab lett, új pénzeket veretett a görög pénzek helyett, arany dínárt, amelyeken már nem az uralkodó képe szerepelt, hanem egy Koránból vett idézet, és a keresztények kezéből folyamatosan a tanult arab muszlimok kezébe került az államigazgatás.

Abd al-Malik utódai alatt nyugat felé haladt a birodalom terjeszkedése, amely 711-ben döntő szakaszába érkezett. Tárik ibn Zijád vezetésével átkeltek a meghódított és iszlámra áttért észak-afrikai berber törzsekkel megerösödött muszlim seregek Európába, a ma Gibraltári-szorosnak nevezett helynél. Gibraltár (Dzsabal Tárik, „Tárik hegye”) neve a mai napig e hadvezér nevét őrzi. Ettől kezdve gyorsan haladtak előre és az északi hegyvidék kivételével az egész Hispániai-félszigetet (a mai Spanyolországot és Portugáliát) uralmuk alá vetették. Ezt a területet al-Andalusznak (Andalúzia) nevezték, amely nagyobb volt, mint Spanyolország mai andalúz tartománya. Az Umajjádok uralma alapvetően az arab törzsi rendszer támogatásán alapult, ami bizonyos stabilitást jelentett a kalifátusnak, ugyanakkor ki volt téve a törzsek közti torzsalkodás 
negatív hatásainak elsősorban az északi és déli arab törzsek, a viszonylag késői bevándorló Kajsz és a már korábban Szíriába érkezett Kalb törzs között. Ez a vetélkedés a seregekkel átkerült Andalúziába is, ahol évszázadokig feljegyezték harcaikat. Az arab törzsi rendszerre épülő jellege miatt nevezték a későbbi arab történészek a damaszkuszi kalifátust „Arab Királyságnak”. Ez ugyanakkor kiváltotta a nem-arab muszlimok elégedetlenségét. Nekik, ha el akarták ismertetni magukat a városi életben, valamelyik arab törzs, nemzetség vagy családfő védelme alá kellett magukat helyezni „védencekként” (maulá, „kliens”). Ez az elégedetlenség vezetett ahhoz az egyre erősödő mozgalomhoz, majd nyílt lázadáshoz, amelyet abbászida forradalomnak szokás nevezni és amely 750-ben a szíriai Umajjád Kalifátus bukásához és az iraki Abbászida Kalifátus létrejöttéhez vezetett.

\section{Vallási mozgalmak a 8. század első felében}

Az umajjád korszak második felében megerősödő elégedetlenség a különböző vallási mozgalmakban is éreztette hatását. A dinasztiát egyértelműen elutasító síitákon és háridzsitákon kívül számos vallási irányzat és nézet hívei ugyan elfogadták a fennálló hatalmat, de kritikus nézeteket is megfogalmaztak. A murdzsiiták („elhalasztók”) ugyan elégedetlenek voltak a rendszer vallásosságával, de elhalasztották ítéletüket és Istenre bízták, hogy megítélje az uralkodókat az Utolsó Ítélet napján. A kadariták azt vallották, hogy Isten igazságos és az emberek szabad akaratukból követik a jót vagy rosszat. Tanulmányozták a Koránban az isteni elrendelés (kadar) fogalmát és arra a nézetre jutottak, hogy Isten nem mindent rendezett el előre. Követöik föleg az Umajjádokból kiábrándult déli arab Kalb törzs tagjai voltak. Ezzel ellentétben a dzsabriták (dzsabr, „kényszer”) az isteni eleve elrendelést vallották, és azt tanították, hogy az emberi szándéknak nincs szerepe tetteink meghatározásában. Kialakult a 9. században döntő fontosságúvá vált mutazilita tanítás is. A mutaziliták politikai kérdésekben nem foglaltak állást, elfogadták a szabad akaratot és az isteni igazságosság gondolatát. Ők azonban nem Szíriában tevékenykedtek, hanem a dél-iraki Baszrában.

Muávija kalifa fia, a lovas balesetben fiatalon elhunyt I. Jazíd (uralk. 680683), az észak-iraki kurdok egy része körében sajátos tiszteletnek örvendett. Követőik, a jazídik leváltak a szunnita iszlámról. A jazídik zárt, endogám közössége mind a mai napig Észak-Irakban él.

\section{A bagdadi Abbászida Kalifátus (750-1258)}

Bár a dinasztia tagjai 750 és 1258 között viselték a kalifa címet, tényleges hatalmuk jóval rövidebb ideig, 945-ig tartott. Attól kezdve a hatalom különböző katonai dinasztiák kezébe került, míg a kalifák e dinasztiák uralkodásának a 
törvényességét és jogszerüségét jelképezték az alattvalók szemében, mivel a mindenkori katonai kormányzók (emír) felesküdtek a kalifára. Az abbászida dinasztia tagjai Abbásztól, Mohamed próféta egyik nagybátyjától származtak. Magukat Isten kiválasztott földi helytartóinak („Isten árnyéka a Földön”) tartották és ennek megfelelően hatalomra kerülésük után Isten akaratára utaló trónneveket vettek fel. Az első, aki hatalomra juttatta a családot Szaffáhnak (,vérontó”) hívatta magát, arra utalva, hogy Isten őt jelölte ki arra, hogy a hitetlennek tartott Umajjádokat és híveiket kiirtsa, amit nevéhez méltóan meg is tett. Egyetlen umajjád férfi tudott csak elmenekülni, aki Andalúziába ment és ott a baráti arab törzsekre támaszkodva, az Abbászidáktól elszakadva, I. Abd ar-Rahmán néven önálló Umajjád Emirátust hozott létre. Szaffáh rövid uralma alatt (750-754) azért tudott hatékonyan leszámolni ellenfeleivel - majd később veszélyessé vált támogatóinak egy részével is -, mert nem a törzsi arabokra támaszkodott, akik körében még a kalifának is meg kellett gondolnia, ha le akart számolni egy veszélyessé vált riválisával, mert a hagyományos törzsi szellemben tartania kellett a kötelező vérbosszútól. Az Abbászidák azonban mozgalmukban a keleti-iráni, elsősorban a horaszáni hegylakókra és az iráni-iraki paraszti tömegekre támaszkodtak. Így érthető, hogy a későbbiekben fővárosukat is ebben a térségben, az egykori Szászánida Birodalom fővárosához közel választották.

Szaffáh utóda Manszúr (,akit Isten támogat”) kalifa lett (754-775), aki először az Eufrátesz folyó partjához közeli dél-iraki kastélyába, al-Hásimijjába költözött, hamarosan azonban új föváros alapítását vette tervbe északabbra, a Tigris folyó partjánál, egy kis perzsa falu, Bagdad mellett. Ez a hely rendkívül alkalmas volt mind katonailag, mind közigazgatásilag, mind pedig kereskedelmi szempontból. Itt a két nagy folyó, az Eufrátesz és a Tigris közel folyik egymáshoz, hatalmas csatornarendszer kapcsolta össze öket, amely körülvette Bagdadot is, és itt metszette egymást ősidők óta a kelet-nyugati (Selyemút) és az északdéli kereskedelmi út. Közel volt hozzá a régi szászánida főváros Ktésziphón és tőle délre kezdődött a Perzsa Birodalmat is ellátó nagy mezőgazdasági terület, a Szavád (,fekete föld”). Az eredeti elképzelés az volt, hogy a kettős várfalrendszerrel körülvett és formája miatt kerek városnak elnevezett birodalmi székhelynek csak a kalifa és udvara, a közigazgatást irányító hivatalnokok, a kincstár és mindenekelőtt a kalifa nagy létszámú testőrsége lesz a lakója. A városba 762-ben költözött be Manszúr kalifa és hivatalosan Madínat aszSzalámnak, a Béke Városának nevezték el, de a köznapi életben kezdettől fogva Bagdad lett a neve. Bár a kalifa úgy képzelte el, hogy a szükséges árucikkeket csak odaszállítják a kereskedők és kézmüvesek a kerek városba, de a letelepedés meg lesz tiltva nekik, félve a lakosság és a katonaság összetűzésétől, illetve az esetleges lázadások negatív hatásától. Hamarosan azonban különböző kisebb városok alakultak ki a Tigris jobb partján fekvő főváros körül, amelyek később egybefonódva a középkor leghatalmasabb városát alkották. 
Ezzel a kalifátus súlypontja végérvényesen keletre helyeződött, és ez is hozzájárult ahhoz, hogy a nyugati tartományokat, Egyiptom kivételével, nem tudták megőrizni. Az ibériai Umajjád Emirátuson kívül önálló emirátusok jöttek létre a mai Tunézia, Algéria és Marokkó területén is (53. kép).

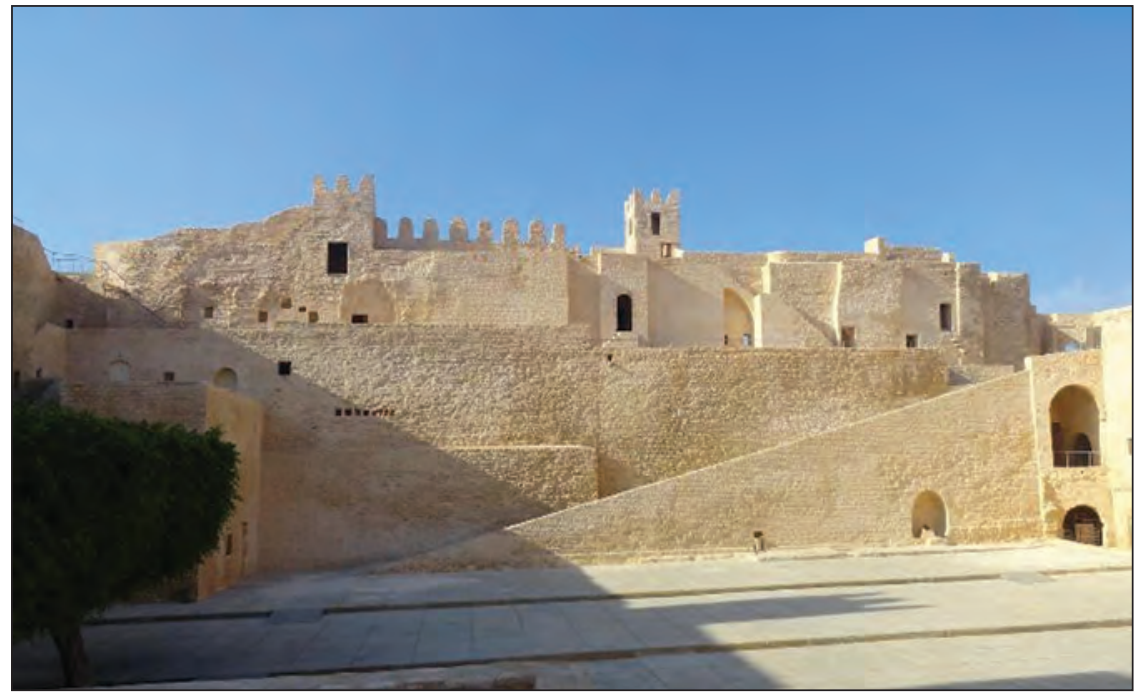

53. kép: Az eredetileg a 8. sz. végén az abbászida kormányzó által építtetett monasztiri erőd (Tunézia), amelyet a későbbi helyi dinasztiák idején is használtak és kibővítettek Forrás: DÉvÉNYI KINGA felvétele

Az Abbbászida, más néven Bagdadi Kalifátus legfontosabb eltérése damaszkuszi elődjétől az volt, hogy Szíriát háttérbe szorítva, Irak vált központtá minden téren. Itt fejlesztették a mezőgazdaságot, itt jöttek először létre új kézműves foglalkozások, mint pl. a papírgyártás, $\mathrm{s}$ az iraki és iráni származású hivatalnokok leszármazottjai adták a hivatalnok réteget a szíriaiak helyett. A bagdadi kalifák átvették a korábbi hivatalok (divván) rendszerét, de kiegészítették azt egy új hivatallal, a főminiszter (vezír) hivatalával, akinek a feladata ugyan a kalifa utasításainak a végrehajtása volt, de sok kérdésben egyénileg dönthetett és saját hivatalnok gárdája volt. A kalifa többé már nem a legmagasabb rangú arab sejk volt, hanem a muszlimok Isten által megbízott védelmezője.

Az Abbászidák hatalomra kerülésével a hadsereg összetétele is elkerülhetetlenül megváltozott. Az Umajjádok feletti katonai győzelem föként a Horaszán tartományból verbuvált zsoldos katonaságnak volt köszönhető és fél évszázadig ők lettek a kalifátus legfőbb támaszai. Amikor 820 után egy Táhir nevü katonai parancsnok és dinasztiája alatt a tartomány félig függetlenné vált és nem adott több katonát, akkor a kalifák különböző török törzsekből származó zsoldos hadseregre támaszkodtak és nem az arab törzsi seregekre, mint az Umajjádok. Kivételt csak a határvidékek képeztek, ahol önkéntes csapatokat 
alakítottak helyi lakosokból, akik a gázi (,hitetlenek elleni harcos”) címet viselték és az esetleges hadjáratok zsákmányaiból részesültek.

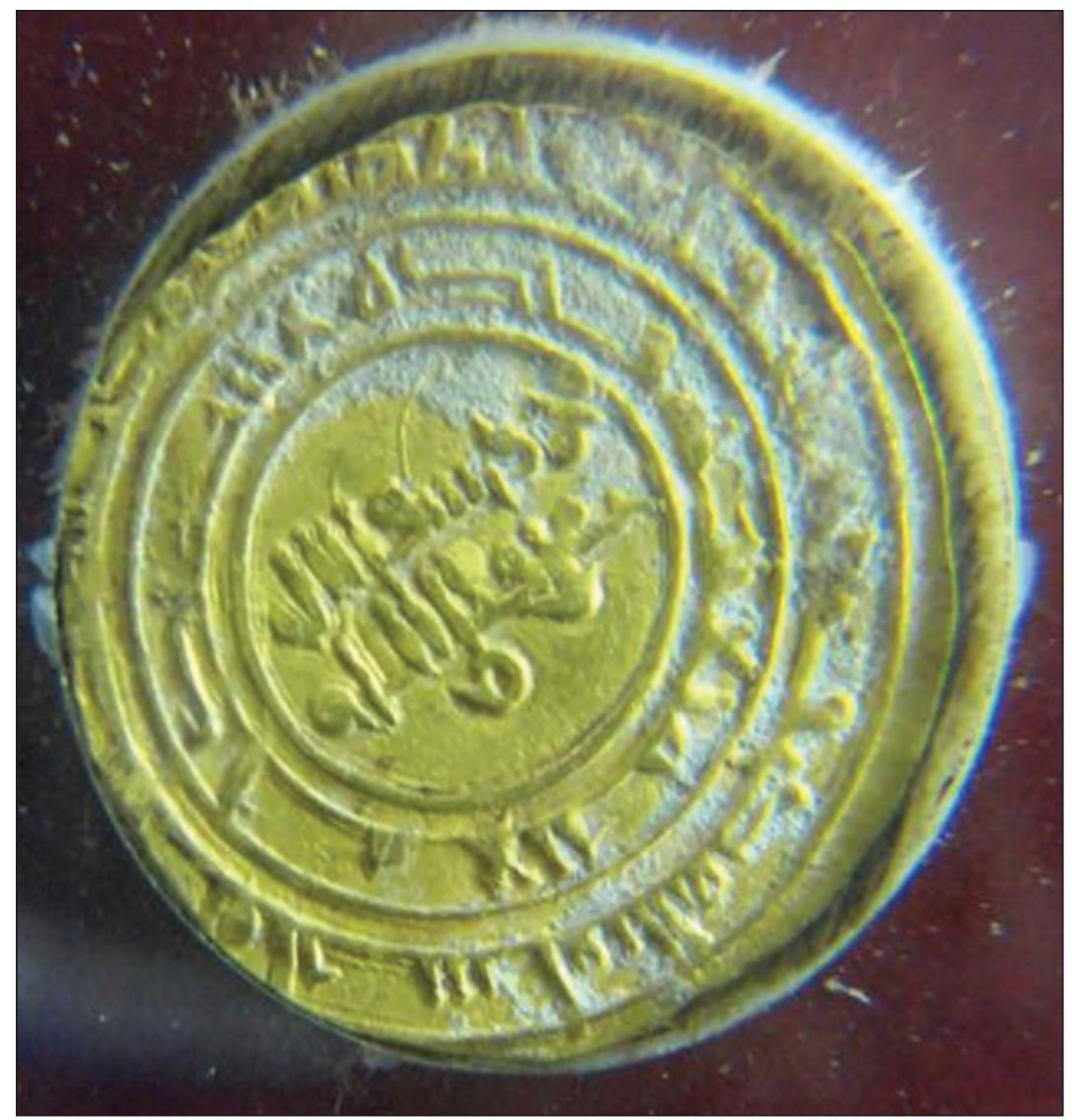

54. kép: Arany dínár arab felirattal, Mahdiai Múzeum (Tunézia)

Forrás: DÉvÉNYI KINGa felvétele

Az első abbászida korszakban, 750 és 830 között nagy gazdasági fellendülést lehet megfigyelni. Az egységes és kiterjedt birodalom hatalmas piacot biztosított a mezőgazdasági és kézmüves termékeknek, és a mekkai hagyományok szellemében uralkodó kalifák igyekeztek elősegíteni a kereskedelmet, amely az árucikkeket nyugaton az Atlanti-óceánig, keleten pedig Indiáig terítette. Mindez szükségessé tette a fejlett pénzügyi rendszer és a kereskedelmi hitellevelek forgalmazásának a kialakítását. A pénzváltóknak naprakészen kellett tudni a birodalom iráni részén használatos ezüst dirhem és a bizánci hagyományoknak megfelelő arany dínár átváltási árfolyamát (54. kép). Annak érdekében, hogy a kereskedőknek ne kelljen zsákban cipelni az ezüstöt és aranyat, kialakult a csekkeken alapuló hitelrendszer, amelyet a bagdadi kereskedőktől Marokkóban éppúgy elfogadtak, mind Szind tartományban, az Indus partján. Maga a csekk szó is arab eredetű (szakk). Miután 
az iszlám tiltja azt, hogy a pénz pénzt fialjon, mert ezt uzsorának tartja, ezért a pénzintézetek többségét zsidók és keresztények müködtették.

\section{Hárún ar-Rasíd (786-809) kora, a bagdadi kalifátus fénykora}

A belső lázadások leverése után a kalifa figyelme a birodalom megszervezésére irányult. A kalifa, aki egyben mindig is „az igazhívők parancsnoka" volt, személyesen vezetett egy csapatot minden évben. Egyszer a mekkai karavánt kísérte, a következő évben a szokásos Bizánc elleni hadjáratot. A központi hatalom legföbb feladatának a közbiztonság biztosítását tekintette, a magánélet szférájába igyekezett nem beleszólni, a jogi és vallási kérdéseket is többnyire a jog- és vallástudósokra hagyta. A kalifa és udvara azonban mindig is hathatósan támogatta a kultúrát és tudományt. Hárún ar-Rasíd neve hosszú időre fogalommá vált a bagdadi lakosság körében, és az Ezeregyéjszaka korai keletkezésű történeteinek egyik főszereplője lett, mint az igazságos uralkodó, aki álruhában a nép közé megy, hogy meghallgassa és orvosolja panaszaikat. Ennek egyik valóságos megnyilvánulása a jogtalanságok orvoslására hetente a kalifa vezetésével tartott bíráskodás (mazálim bíróság) volt, ahol mindenki a kalifa elé járulhatott a panaszaival. Ez az eredetileg perzsa királyi udvarból származott szokás még évszázadokig fennmaradt, de a 10. századtól kezdve már nem az uralkodó, hanem a föminiszter vezetése alatt. Előnye az volt, hogy nem volt megkötve az uralkodó vagy föminiszter keze az iszlám jog nehézkes elöírásai által, azonnal hozhatott ítéletet a saját kényére-kedvére. A 17. századot követően a Török Birodalomban létrehoztak egy külön hivatalt díván al-mazálim néven, amelyben bírók vizsgálták ki a panaszokat, amelyeket hivatali döntések ellen adtak be.

A bagdadi kalifa udvara híres volt pompájáról és fényüzéséről. Az épületek és kertek szépségéről csak azért nem tudunk képet kapni, mert a 13. században a mongolok mindent elpusztítottak, s csak az iraki mintára épített andalúziai létesítmények adhatnak erről képet, mert azokat nem pusztították el a visszahódítás (rekonkviszta) idején (12-15. sz.) a keresztény hadseregek.

\section{al-Mámún kalifa (813-833)}

al-Mámún, aki testvérháború során foglalta el Bagdadot, korlátozni igyekezett a hagyományokra támaszkodó vallástudósok jogkörét, akik az örökké létező Koránra támaszkodva igyekeztek megszabni a vallási, jogi és társadalmi élet szabályait. Ezért a mutazilita irányzatot tette hivatalos dogmává, amely képviselői a teremtett, tehát nem örökké létezö Koránt és a szabad akaratot tanították. A Korán teremtett jellege azt jelenti, hogy Isten máshogy is megteremthette volna, mint amit ma ismerünk, és ezáltal esélyt ad arra, hogy az uralkodói, kormányzati akarat is érvényesülhessen az isteni törvények értelmezésében, mert megszünik a Korán abszolút jellege. Ez a dogma Mámún és utódai alatt kötelezővé vált az 
állami tisztségviselők és a mecsetek vallási emberei számára, s aki nem vallotta a teremtett Korán tanítását, azt bebörtönözték. Ezt inkvizíciónak (mihna) nevezték.

\section{A birodalom széttagolódásának kezdetei}

A 9. század második felében az Abbászidák hatalma meggyengült, a hatalmasra nőtt birodalmat nem tudták közvetlenül kinevezett kormányzókkal igazgatni. A tartományi kormányzók hatalmának megerősödését leginkább az jelzi, hogy helyi dinasztiák alakultak ki, amelyek ugyan elismerték a bagdadi kalifákat, de önállóan kormányoztak és legtöbbször a beszedett adók is őket gazdagították. Elsőnek a keleti területek függetlenedtek Bagdadtól. A Szaffáridák Iránt és Szind (mai Pakisztán, Afganisztán) tartományt igazgatták, majd az őket is legyőző Számánidák Közép-Ázsiába tették át központjukat, Buhara fővárossal. Ök az iszlám előtti perzsa uralkodóház leszármazottjainak tartották magukat és az új perzsa irodalmi nyelv és perzsa kultúra terjesztését tartották fö feladatuknak, az arabizált kultúrával szemben. Öket a saját török zsoldosaik fosztották meg a hatalmuktól, akik Gazna központtal hozták létre 1000 után a Gaznavida Birodalmat. Ök is a perzsa kultúra támogatói voltak. Első uralkodójuk, Mahmúd (997-1030) érdeme a perzsa kultúra egyik legnagyobb alkotása létrejöttének támogatása: Firdauszi „Királyok könyve” (Sáhnáme) c. történeti eposzát neki ajánlotta a szerző.

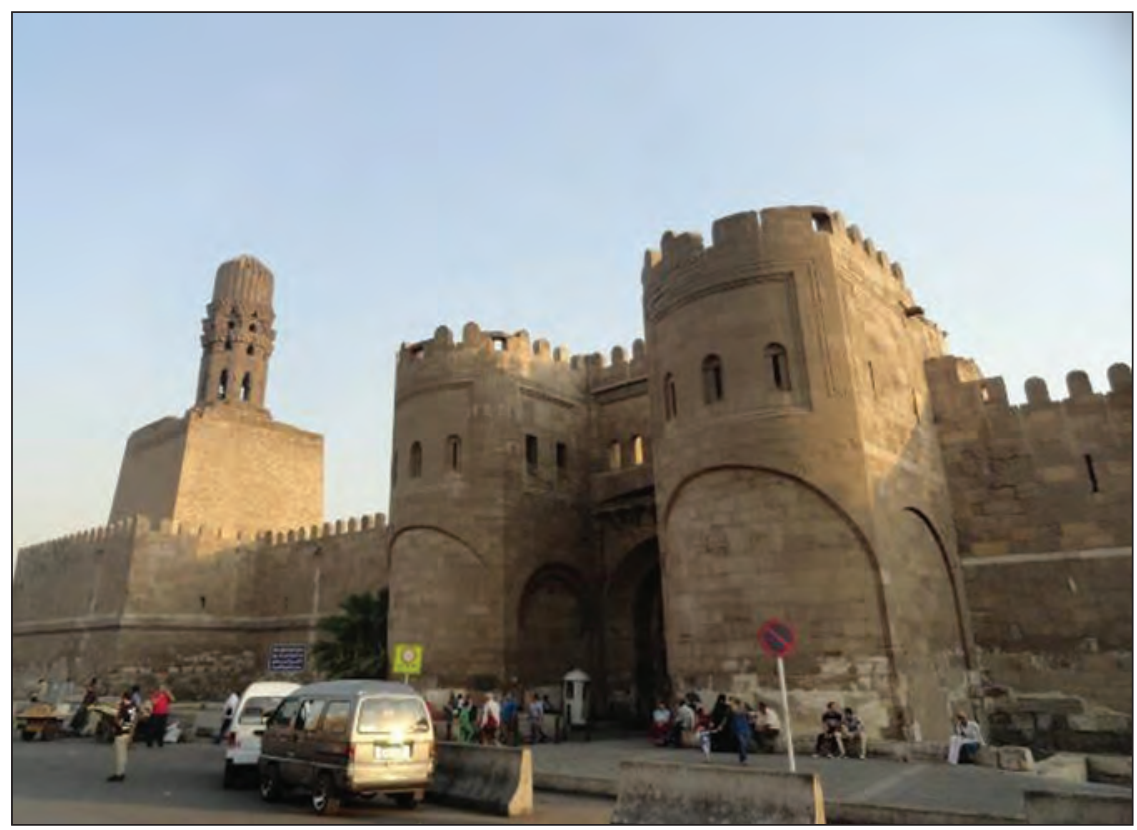

55. kép: A Fátimidák által a 11. században épített Báb al-futúh (Hódítások kapuja) Kairóban. A háttérben a 6. fátimida kalifáról elnevezett Hákim mecset egyik minaretje

Forrás: DÉvÉNYI KINGA felvétele 
A Bagdadi Kalifátus központi területein, Irakban és Nyugat-Iránban az iráni síita Bújidák (más néven Buvajhidák) vették kezükbe a tényleges hatalmat 945-ben mintegy fél évszázadra, akik a bagdadi kalifát hatalmuk hitelesítésére használták fel.

Egyiptomban, a mai Tunézia, Algéria és Marokkó területén is katonai kormányzók dinasztiái uralkodtak a 9. században. Ezek a dinasztiák azonban mind elismerték a bagdadi kalifát az Iszlám Birodalom fejének és vallási vezetöjének, és nem indítottak ellene harcot, mivel nem voltak vallási-ideológiai nézeteltéréseik. A spanyolországi Umajjád Emirátus is elismerte a bagdadi kalifát vallási vezetőnek minden politikai nézeteltérésük ellenére. A 10. század elején azonban új hatalom jelent meg Észak-Afrikában, a síita Fátimidák (55. kép).

\section{Az Abbászida Kalifátus felbomlása}

1095-ben II. Orbán pápa meghirdette az első keresztes háborút a Szentföld, vagyis Jeruzsálem felszabadítására, és a keresztes hadak - akiket az arabok frankoknak neveztek, bárhonnan jöttek is - hamarosan több kisebb-nagyobb fejedelemséget hoztak létre a Földközi-tenger közelében, Szíria és Palesztina térségében, amelyek közül a legjelentősebb a Jeruzsálemi Királyság volt.

A keresztesek elsősorban a Szíriát, majd később Egyiptomot is birtokló Szeldzsuk Emirátussal vívtak nagy csatákat, amelyek közül kiemelkedett a Hattinnál vívott ütközet 1187-ben, amelyben Szaladin emír legyőzte a keresztes hadakat és egy időre visszafoglalta Jeruzsálemet is. A kisebb keresztes államok azonban még száz évig tartották magukat, egészen 1291-ig, amikor elesett az utolsó palesztin város, Akkó is. A keresztes háborúk a végső sikertelenség ellenére is nagy hatással voltak a Közel-Kelet történelmére. Megnyitották a Földközi-tenger keleti térségét az európai, elsősorban velencei kereskedők elött, az iszlám civilizáció pedig jelentős tárgyi és eszmei hatást gyakorolt a középkori Európára.

\section{A spanyolországi iszlám}

Az iszlám hadai, akiknek soraiban akkor már az észak-afrikai területek őslakói, a berberek is harcoltak, 711-ben hatoltak be a Hispániai-félszigetre, és ott különböző iszlám államokat alkottak egészen 1492-ig, Granada elestéig. A Damaszkuszból elmenekült umajjád emír és leszármazottjai 756-tól 1031-ig uralkodtak Córdoba központtal a félsziget nagy részén. 929-ben III. Abd arRahmán kalifának kiáltotta ki magát, így vallásilag is elszakadt Bagdadtól, de sem ideológiai, sem katonai ellenséges akciókat nem indított a keleti kalifátus ellen. A Córdobai Kalifátus nemcsak csodálatos tárgyi emlékeket - épületeket, kerteket és különféle kisebb tárgyakat - hagyott hátra, amelyek ma is tanúskodnak 
a korszak fejlett civilizációjáról, hanem az első csatornát képezte, amelyen a keleti kultúra és civilizáció termékei és eredményei eljutottak Európába. Ezt többek között az a sok száz kulturális szakkifejezés is tanúsítja, amelyek arab nyelvből spanyol közvetítéssel bekerültek az európai nyelvekbe, s némelyikük a magyarba is, sokszor olasz közvetítéssel. Csak néhány ezek közül: adobe, algebra, alkímia, esztrád, magazin, tarifa, zsiráf. A muszlim uralom alatt nagyon sok keresztény és zsidó élt szabad vallásgyakorlatban, ugyanakkor nyelvileg és kulturálisan is keveredve az arab-berber muszlim lakossággal.

A Córdobai Kalifátus 1031-ig állt fenn, amikor is az utolsó umajjád uralkodó halála után széthullott kis regionális városállamokra, ezt nevezik a „részkirályságok” korának, spanyol-arab kifejezéssel „,reyes taifas”. Ez a kor a kiskirályságok egymás elleni harcával telt el, amelyben az északi keresztény fejedelemségek hol az egyik, hol a másik muszlim uralkodót támogatták katonailag is. A kereskedelmi és kulturális kapcsolatok ugyanakkor folyamatosan fennálltak mind a muszlim fejedelemségek között, mind a keresztény uralom alatt lévő területek között.

A ,visszahóditás” - rekonkviszta

A 11. század végén fordulat állt be a félsziget politikai viszonyaiban. A keresztény királyságok kihasználva a nyugati iszlám világ széttöredezését, támadásba lendültek, és a rekonkvisztának nevezett és 1492-ig tartó harcok kezdeteként 1085-ben Toledo, az északi muszlim területek központja, keresztény uralom alá került. A kasztíliai hódítás után Toledo továbbra is megmaradt fontos kulturális központnak. Arab nyelvü könyvtárát nem bántották, az ott megalapított iskolában muszlim és zsidó tudósok fordították az arab és héber nyelvű filozófiai, logikai és matematikai müveket kasztíliai nyelvre, amelyeket aztán spanyol tudósok tovább fordítottak latinra, a kor európai tudományának a nyelvére. Ezáltal az Európa számára hosszú időn keresztül elveszett ókori görög tudományok el tudtak terjedni a keresztény Európában.

Toledo elestének másik következménye az volt, hogy a muszlim kiskirályságok behívták a Marokkó területén uralkodó berber dinasztia, az Almoravidák seregeit a keresztény hódítás megakadályozására. Ez azonban kétélű fegyvernek bizonyult, mert az Almoravidák amellett, hogy megállították a keresztény hódítást, ott is maradtak a félsziget iszlám fennhatóság alatt álló területein, amelyeket saját birodalmukhoz csatoltak. Az Almoravidák eredetileg az Északnyugat-Afrikában élő nomád berberek vallási szövetségét alkották. Maga a név is azt jelenti, hogy ,akik egy rendház jellegü erődben (ribát) élnek és harcosan terjesztik az iszlámot". A férfiak elfátyolozták az arcukat, mint kései utódaik, az észak-afrikai tuaregek. Szenegálból kiindulva elfoglalták Marokkót, ahol 1062-ben megalapították Marrakes városát, amely végig fóvárosuk maradt. 1086 és 1147 között fokozatosan elfoglalták a muszlim Spanyolországot. 
Vezetőik magukat „az igazhívők parancsnokának” (emír) nevezték és vallási kérdésekben elfogadták a bagdadi kalifák fennhatóságát. Különösen az építészet terén hagytak hátra jelentős emlékeket. Ibériai fővárosuk nem Córdoba, hanem Sevilla volt.

A 12. század elején Északnyugat-Afrikából egy új berber vallási mozgalom indult útnak, amely aztán 1147-re meghódította az Almoravida Emirátust. Ök voltak az Almohádok, amely név az arab ,al-muvahhidún”, az isteni egység szigorú értelmezőinek spanyolos változata. 1146-ra elfoglalták az Almoravidák spanyol területeit és 1147-ben a fövárosukat, Marrakest is. Vallási tanaikat első vezetőjük, az aszkéta életet élő Ibn Túmart fogalmazta meg, aki ellenezte a zenét, táncot és az iszlám általi tiltás ellenére elterjedt borivást. Magát Isten küldöttének, mahdinak tartotta. Utódai felvették a kalifa címet és vallási téren is elkülönültek a keleti iszlámtól, bár magukat szunnitának vallották. Hatalmukat kiterjesztették egész Észak-Afrikára, az egyiptomi határig. Ők egész birodalmuk fővárosának Sevillát tették meg, nem csak a spanyolországi területeknek. Bár az Almohádok elsődleges célkitüzése a spanyolországi szent háború és a keresztény hadak elöretörésének megakadályozása volt, a 12. század végétől kezdve fokozatos katonai kudarcokat szenvedtek és végül 1212-ben a Las Navas de Tolosa-i csatában egész hatalmas seregük odaveszett a keresztény királyságok egyesült hadaival szemben és ezzel megszünt az egységes Iszlám Birodalom az Ibériai-félszigeten. Egyetlen muszlim állam tudott csak fennmaradni, a Granadai Emirátus, még további 250 évig.

\section{A Közel-Kelet a Bagdadi Kalifátus megszünése után}

\section{A Mamlúk Szultánátus}

A Magyarországot is súlyos csapásként ért mongol hódítás egy déli vonulata a Bagdadi Kalifátus területeit is fokozatosan meghódította és feldúlta, majd 1258-ban Hulágu mongol vezér hadai lerombolták Bagdadot, lakosai nagy részét megölték, velük együtt az utolsó kalifát is. Ezután a Közel-Keleten különböző mongol utódállamok jöttek létre, amelyek közül a legjelentősebb Timur Lenk (európaiasan Tamerlán) iráni birodalma a 14. században. Ezzel egy időben 1250 után az Ajjúbida Emirátus helyén létrejött a Mamlúk Szultánátus, amely 1517-ig fennmaradt Egyiptomban, Szíriában, Palesztinában és a hidzsázi szent helyeken, Mekka és Medina területén (22. térkép).

A mamlúk ${ }^{9}$ szó rabszolga katonát jelent, akiket egészen fiatal korban vásároltak, elsősorban Közép-Ázsiában és a kairói fellegvár barakkjaiban képezték ki őket katonának. Mivel semmilyen társadalmi kötődéssel nem rendelkeztek, bízni lehetett az uralkodó iránti hüségükben. A különböző emírek,

9 A mamlúk szó a magyarban mameluk alakban honosodott meg a 19. századi politikai életben és a kormányhű képviselőket jelentette. 
parancsnokok és maga a szultán is közülük került ki. A fiaikból nem lehettek mamlúkok, katonák mindig csak a fiatalon behozott rabszolgák lehettek. A mamlúk vezető réteg nemcsak a katonaságot uralta, hanem a gazdasági életet is, mivel a termőföldek többsége az ő kezükben volt.

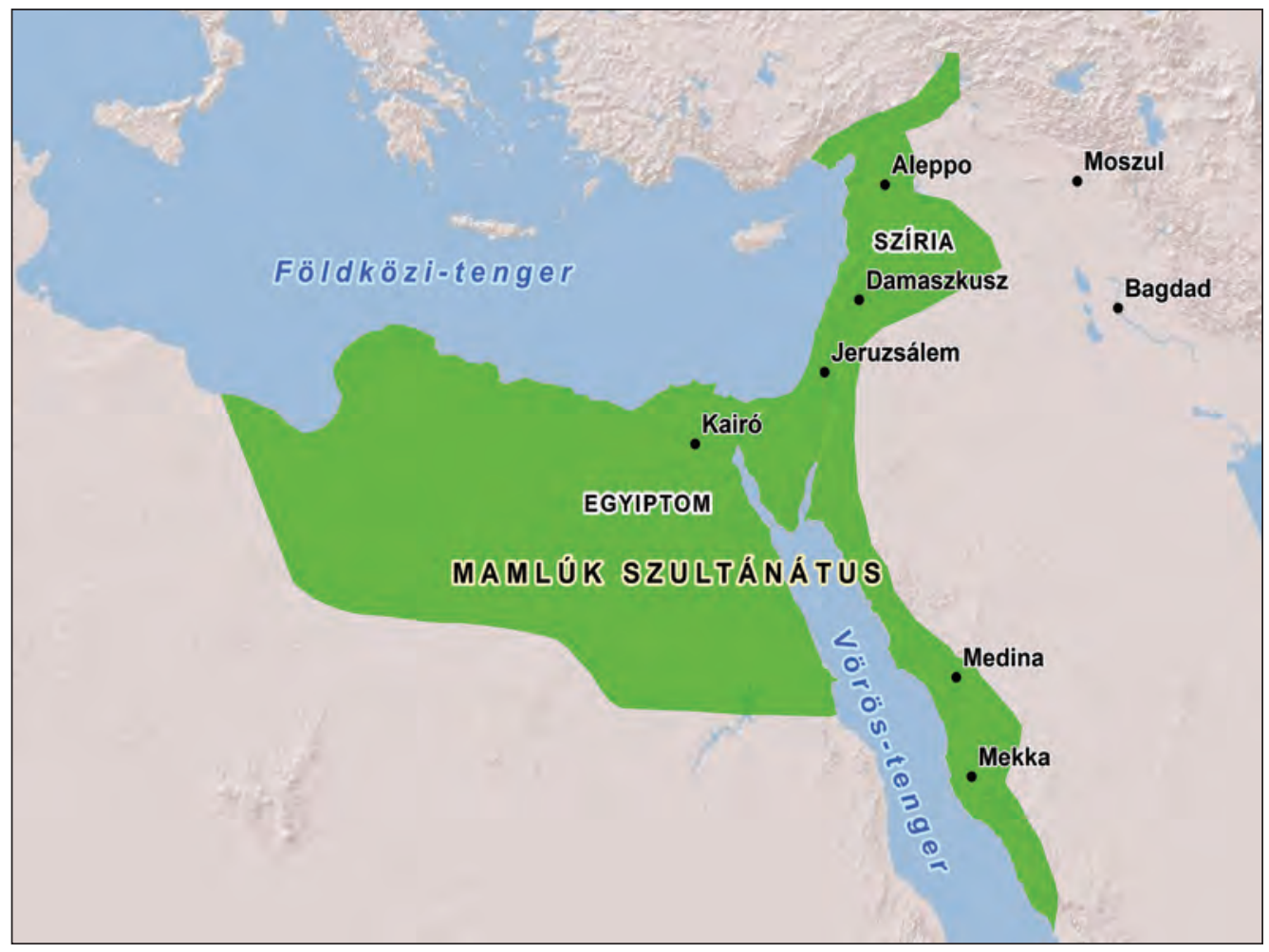

22. térkép: A Mamlúk Szultánátus legnagyobb kiterjedése Forrás: VARGa ÁGNes szerkesztése

Az első korszakban, 1250-1382 között, a mamlúk szultánok a Nílus Róda szigetérôl irányították a birodalmat, ezért szokás őket bahri (folyami) mamlúkoknak nevezni (56. kép). Ök föleg török nemzetiségűek voltak. Később, 1382 és 1517 között, az Ajjúbidák által épített fellegvárba költöztek át a szultánok, ezért őket a burdzsi (várbeli) mamlúkoknak szokás hívni. Ők főként cserkesz származásúak voltak. A mamlúkok elsősorban lovasságukra voltak büszkék. Kedvenc időtöltésük a lovaspóló volt. Vereségüket és a birodalom megszünését is ennek köszönhették 1517-ben, amikor az ágyúkkal rendelkező oszmán-török hadsereggel szemben csak a lándzsákkal és nyilakkal felszerelt lovasságot tudták felállítani. 


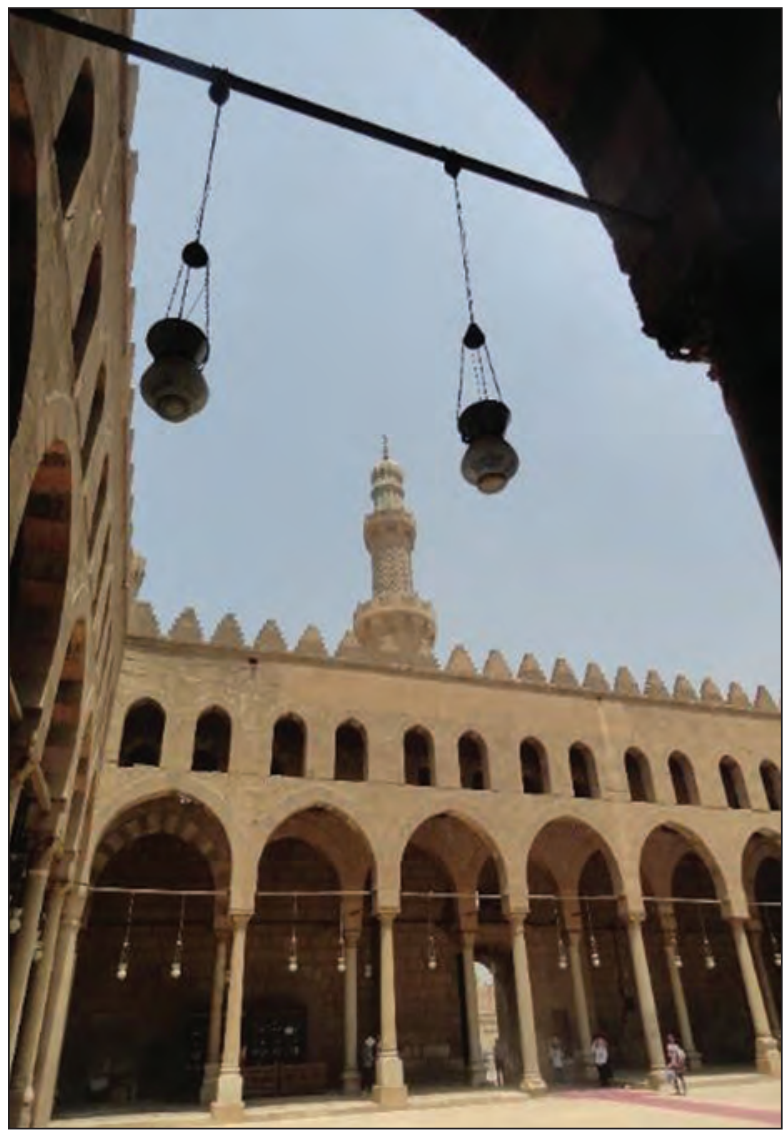

56. kép: A bahri mamlúk an-Nászir Muhammad ibn Kaláún szultán által a 14. század elején a kairói citadella területén építtetett mecset

Forrás: IváNYI L. MÁTÉ felvétele

A mamlúk kor, föleg Egyiptomban, az építészet terén hagyott hátra maradandó emlékeket. A tudományok terén elsősorban az orvostudomány, azon belül is a szemészet, valamint az állatorvostan fejlödött sokat.

\section{India muszlim meghódítása}

Az első négy kalifa alatt, 660-ig bezárólag, a muszlim hadak keleten a mai Afganisztán területéig jutottak el, majd a 7. sz. második felében tovább nyomultak elöre Szind tartományban, a modern Pakisztán területére, egészen az Indus folyóig. A béke azonban nem állt helyre a kezdeti hódítások után sem, mert a különböző helyi uralkodók még évtizedekig folytatták a harcot a keleti tartományok (Szísztán, Horaszán és Szind) muszlim kormányzói ellen a nehéz és magas hegyi terepen. Ezért a határvidékeken az arabok stratégiája inkább az adószedés, mint a hatalom megszilárdítása volt. Szind tartomány teljes meghódítása végül csak a damaszkuszi kalifátus idején, 720-ban fejeződött 
be. Hind tartományban, a mai India területén, csak ideiglenes sikereket tudtak ebben a korban elérni. Közép-Ázsia felöl csak a 13. század elején sikerült a török-afgán mamlúk seregnek betörnie India területére és megalapítani a Delhi Szultánátust. Itt járt a 14. század első felében a híres marokkói utazó, Ibn Battúta, aki - magyarul is olvasható - részletes leírást adott az indiai muszlimokról. A Szultánátus talán legnagyobb érdeme az volt, hogy megakadályozta a mongol hordák betörését India területére, amelyek a mai Afganisztán, Irán és Irak területén is hatalmas pusztítást végeztek.

\section{Az indiai Mogul Birodalom}

A Timur Lenk által alapított közép-ázsiai birodalom egyes részei egészen 1507-ig álltak fenn utódai alatt. Timur 1398-ban meghódította és feldúlta a Delhi Szultánátust azzal az ürüggyel, hogy a muszlim szultán túl elnézően bánt hindu vallású alattvalóival. Utódai alatt a birodalom részekre esett szét, mígnem a 16. század elején a magát Dzsingisz kán és Timur utódjának valló Bábur („Tigris”), miután elveszítette elődei üzbegisztáni birtokait és fővárosukat, Szamarkandot, dél felé fordult és elfoglalta Észak-Indiát, megalapítva ott a Mogul Birodalmat, amely több mint 300 évig állt fenn, 1526 és 1857 között, bár az utolsó 100 év alatt már csak névleg létezett. Fővárosuk a Delhitől keletre fekvő Agra városa volt. A birodalom a 16. században csak Észak-Indiára terjedt ki, később azonban a mai Afganisztán, Pakisztán (Szind) és Közép-India is uralmuk alá került, egészen 1739-ig, amikor a perzsa Nádir sah elfoglalta Delhit, a Mogul Birodalom nagy részével együtt.

A mogul kultúra maradandó nyomokat hagyott, elsősorban Észak-India területén. Építészeti emlékei közül kiemelkedik a Tádzs Mahal, amelyet a világ egyik legszebb épületének tartanak. A mogul korszak a képzőmüvészet és az irodalom terén is az indiai kultúra egyik kimagasló állomása volt.

\section{Irán a 16. századot követöen}

Az Iránt is magába foglaló Timurida Birodalom szétesése után 1502-ben az Azerbajdzsán területén különböző nemzetiségekből szervezett hadsereggel rendelkező Szafavidák alapítottak a térségben birodalmat, amely magába foglalta a mai Iránon kívüli Azerbajdzsán, Grúzia, Észak-Kaukázus, Afganisztán területeit, ill. egy évszázadon keresztül Irakokot, Bahreint, valamint Szíria és Anatólia egy részét is. A Szafavidák eredetileg egy szúfi rend tagjai voltak, akik úgy érezték, hogy vallási küldetésüket csak a politikai hatalom megragadásával tudják teljesíteni. Első uralkodójuk, I. Iszmáíl sah áttért az iszlám tizenkét imámos síita irányzatára, amelyet államvallássá tett. Ennek a hatása a mai napig tart, hiszen Irán, Irak és Azerbajdzsán lakóinak a túlnyomó többsége síita. A Szafavidák megpróbáltak nyugat felé terjeszkedni Anatóliában, ahol összeütközésbe kerültek az Oszmán-török Birodalommal. 
Az Oszmán-török Birodalom

A 13. század utolsó éveiben Északnyugat-Anatóliában az oguz-török törzs feje, Oszmán a szeldzsuk-törökök leverésével birodalmat alapított, amely 1354 után kiterjedt a Balkánra is, körül ölelve a Bizánci Császárságot (23. térkép). Végül 1453-ban Hódító Mehmed szultán (uralk. 1451-1481) bevette Konstantinápolyt és véget vetett az ezer éves Keletrómai Birodalomnak. Amikor a Perzsa Birodalom a katonaságot az anatóliai türkmének közül kezdte toborozni, a veszélyes szomszéd ellen hadba vonultak a törökök és ágyúik segítségével nagy győzelmet arattak 1512-ben a Szafavidák fölött, ezzel megállítva előnyomulásukat és kiszorítva őket Kis-Ázsiából.

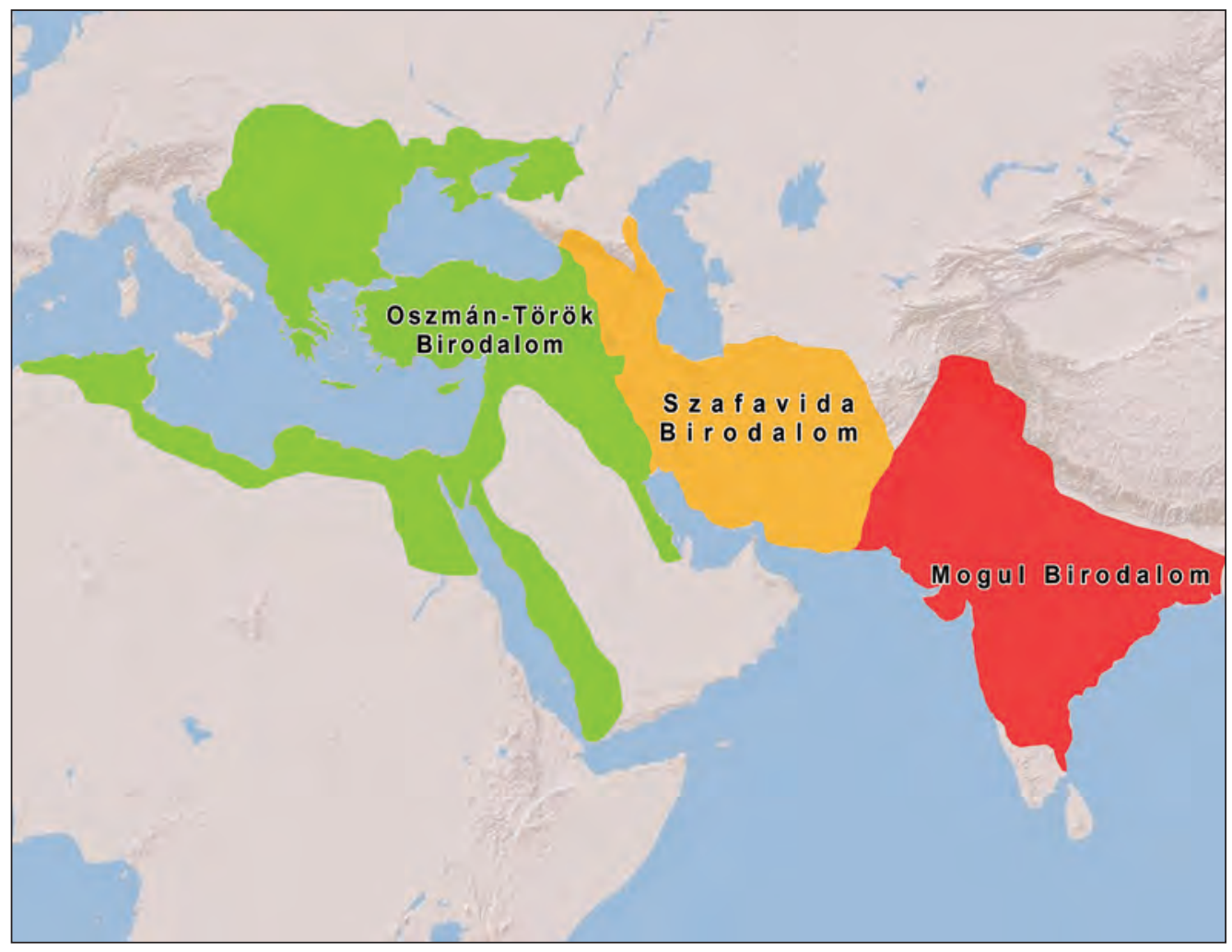

23. térkép: Az ún. puskapor birodalmak

Forrás: VARGA ÁGnes szerkesztése

Hasonlóanágyúikra támaszkodva győzték le 1517-ben az egyiptomi-szíriai mamlúk sereget, ezzel véget vetve a negyed évezredes Mamlúk Szultánátusnak. Ezután nemcsak Egyiptomot, Szíriát, Palesztinát és a Hidzsázt, vagyis a mamlúk birodalmat, hanem az észak-afrikai arab területeket is elfoglalták, azaz a mai Líbiát, Tunéziát és Algériát, kivéve a mai Marokkót. Az 1526-os mohácsi győzelem után Magyarország jelentős részét is elfoglalták a törökök, de tovább 
nem jutottak nyugat felé. Legnagyobb uralkodójuk, Nagy Szulejmán szultán Magyarországon halt meg 1566-ban, Szigetvár ostroma közben.

Az Irán ellen folytatott több mint százéves háború a 16-17. században Irak elfoglalásával ért véget. A törökök ezt a háborút nem pusztán területszerzési céllal folytatták, hanem mint az iszlám világ vallási vezetői. Miután a szultánok felvették a kalifa címet is a szunnita iszlám védelmezőinek tekintették magukat az ,eretnek” síitákkal szemben.

A Török Birodalom az 1699-es karlócai béke után kiszorult Magyarországról, de balkáni területeit és Görögországot még a 19. század első harmadáig megtartotta. Az arab országok közül Algéria 1830-ban, Tunézia pedig 1891-ben került francia gyarmati uralom alá. Egyiptom, Szíria, Palesztina és a Hidzsáz az I. világháború végén szakadt el Törökországtól. A Török Szultánátus végül 1922-ben szünt meg, amikor kikiáltották a köztársaságot.

A török civilizáció alapvetően perzsa-arab hatás alatt állt, az oszmán-török nyelvet is arab írással írták. Az irodalomra a perzsa, a vallási életre és vallási irodalomra az arab nyelv volt nagy hatással. Az öltözködésben, szokásokban és általában a mindennapi és társasági élet különböző területein a felsőbb rétegek alapvetően erős perzsa hatás alatt álltak.

\subsubsection{Vallás}

Az iszlám vallás alapjai

Az iszlám pillérei

Az iszlám hitrendszere, alapvető tanításai és a magánéletet, valamint a társadalmi életet szabályozó jogrendje csak több évszázad alatt kristályosodott ki. Az egész közösséget érintő szertartások azonban elég hamar megszilárdultak. Ezeket nevezzük mind a mai napig az iszlám öt pillérének (arkán). Ezek a következök:

1. A hitvallás (saháda), vagyis annak az elismétlése, hogy „Nincsenek istenek, csak az Egy Isten és Mohamed az Isten küldötte” (57. kép). Az iszlám tanítása szerint azok a próféták számítanak küldöttnek (raszúl), akikkel Isten könyvben rögzített kinyilatkoztatást is elküldött. Ezek Mózes a Tórával, Jézus az Evangéliummal, és Mohamed, a próféták pecsétje, a Koránnal. A hitvallás első része az iszlámot elkülöníti a bálványimádó pogányoktól, a második része pedig a többi monoteista vallástól, a zsidóktól és a keresztényektől.

2. Az imádkozás (szalát), amelyet napjában ötször kell elvégezni: napfelkelte elött (reggeli ima), közvetlenül dél után (déli ima), a délután közepén (délutáni ima), napnyugta elött (naplementi ima) és az este közepén (esti ima). 


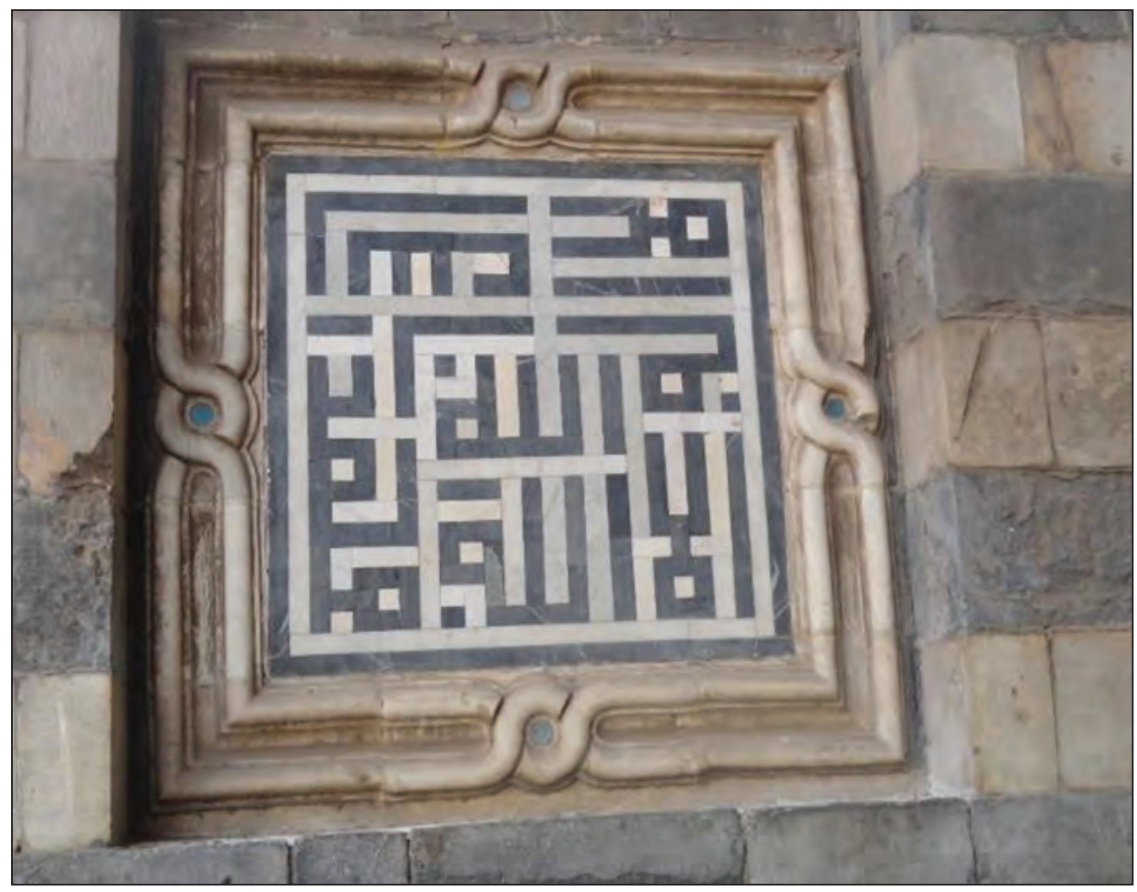

57. kép: A hitvallás arab szövegének kalligráfiája egy kairói mecset falán Forrás: DÉvÉNYI KINGA felvétele

A pontos időpontok természetesen évszakonként és földrajzi helyenként változnak. Három ima, mint láthattuk, a Nap járásával van szoros összefüggésben, de nem szabad pont a napfelkeltekor, deleléskor és naplementekor imádkozni, hogy elkerüljék a pogány napimádás kultuszával való hasonlóságot. Az imát megelőzően az imára hívás (adzán) figyelmezteti a muszlimokat vallási kötelességükre. Ezt hagyományosan a muaddzin (törökből ismert alakjában: müezzin) kántálta el, aki minden alkalommal felment a mecset részét képezö magas torony, a minaret tetejére, hogy jobban hallják a szavát a környék lakói. Ma már ezt többnyire hangszórók közvetítik felvételröl. Az imát bárhol el lehet végezni, nem csak a mecsetben, de mindenképpen csak rituális mosdás (vudú) elvégzése után, ami az arc, kezek és lábak pontos elöírás szerinti lemosását jelenti. A mecsetben ez a mecsetudvaron (szahn) lévő kútnál (mídá) végezhető el. Az ima másik fontos elöírása az, hogy az imádkozó arca ima közben az imairány (kibla) felé nézzen, amely a Mekkában lévő szentély, a Kába irányát jelenti. Az ima szövege speciálisan kiválasztott Korán idézetekböl áll, amelyet minden esetben arabul kell elmondani a nem arab anyanyelvüeknek is. Az ima szövege mindig tartalmazza a hitvallás szövegét, amely az iszlám alapját képezi és az úgynevezett takbír formulát, vagyis annak kifejezését, 
hogy Isten a legnagyobb (Alláhu akbar). Minden imát két vagy több rakaa alkot, ami a meghajlás és leborulás sorozata. Az imát ajánlott mecsetben elvégezni, ahol a hívők sorba rendeződnek és egy imám (előimádkozó) vezetésével, aki kicsivel előbb mondja el ugyanazt az imaszöveget, mint a többiek, együtt imádkoznak. A mecset belső terében az imairányt egy falba épített, félkör alakú fülke, a mihráb jelzi (58. kép). Különleges jelentőséggel rendelkezik a péntek déli ima, amelyet a közösség (város) lehetőleg valamennyi felnőtt férfi lakosa a dzsámiban (pénteki gyülekezeti mecset) végez el, ahol az ima után elhangzik a szentbeszéd (hutba). Ez a középkor folyamán mindenütt arab nyelvü volt és politikai jelentőségét jól mutatta, hogy meghatározott formát öltött, amelyben elhangzott az elismert muszlim uralkodó, általában a kalifa neve.

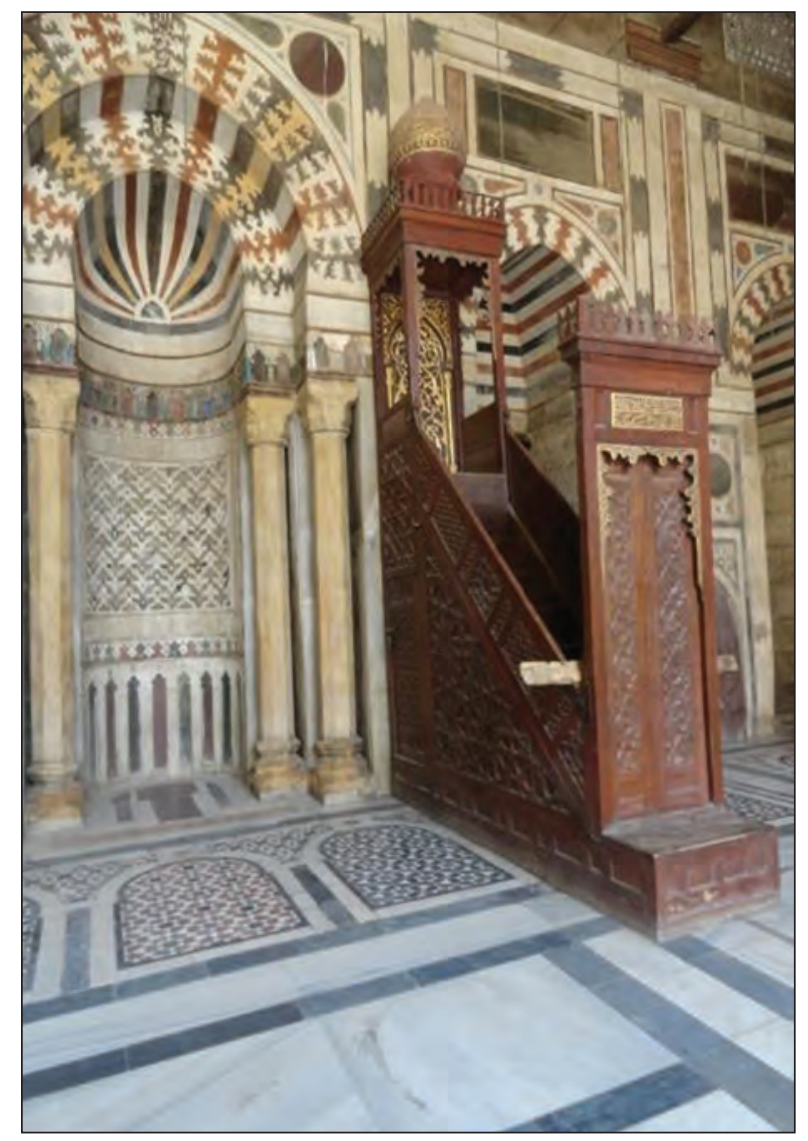

58. kép: Mihráb és minbar egy kairói mecsetben Forrás: DévÉNYI KINGA felvétele

A politikai változásokat az alattvalók igen gyakran csak úgy tudták meg, hogy megváltozott a szentbeszédben említett uralkodó neve. Politikai 
jelentősége napjainkban is megmaradt, például az iráni iszlám forradalom előkészítésében is nagy szerepet játszottak a pénteki szentbeszédek 1979 elött. A szentbeszédet a hitszónok (hatíb) egy erre a célra a mihráb mellé felállított szószékről (minbar) mondja el, amelyhez lépcső vezet fel.

3. Aböjt (szaum), minden évben az iszlám naptárának 9. hónapjában, ramadán havában, részben annak az emlékére, hogy ebben a hónapban kezdődött a Korán kinyilatkoztatása. A böjt hónap kezdetét minden országban a legmagasabb vallási méltóság jelenti be, miután éjszaka egy magaslati ponton megpillantja a ramadán holdhónap újholdját. A böjt minden nap napfelkeltétől napnyugtáit tart, ami azt jelenti, hogy a nyári hónapokban a leghosszabb a böjt, amikor egyébként is a legnehezebb ital nélkül meglenni ezekben a meleg égövi országokban. A böjt ideje alatt ugyanis sem ételt, sem italt nem szabad fogyasztani, tilos dohányozni, tilos a nemi érintkezés, és a szigorúbb értelmezés szerint még a saját nyálat sem szabad lenyelni. Böjtölni csak az egészséges, 12 évnél idősebb férfiaknak és nőknek kell. A böjt megszakítható különböző okok miatt (pl. utazás, menstruáció stb.). Ebben az esetben utólag kell a kihagyott napokat pótolni. A böjt kezdetét és végét hagyományosan még pár évtizeddel ezelött is sok helyen ágyúlövés tudatta a hívekkel. A böjt végeztével este következik a közös étkezés (iftár), amelynek erős közösségformáló ereje van. A prófétai hagyományok szerint a böjt után elöször fogyasztott étel datolya legyen, ha nincs datolya, akkor vízzel kell megtörni. Utána általában éjszakába nyúló szórakozás, utcai ünneplés következik, amely alkalomból az utcákat lampionokkal szokás feldíszíteni. Sokan töltik a mecsetekben az éjszaka egy részét, speciális ramadán éjszakai imádságokat (tarávíh) recitálva. Hajnalban aztán a legtöbben felkelnek egy böjt előtti étkezésre. A böjthónap végén van a három napos böjtutó ünnep (íd al-fitr), vagy más néven a kisebbik ünnep, amelyet egy speciális csoportos reggeli imával szokás megnyitni.

4. Az alamizsna vagy vallási adó (zakát), amely napjainkban csak azok erkölcsi kötelessége, akik megtehetik, hogy adományozzanak a szegények számára. Eredetileg és a középkorban végig kötelező adó volt, amelyet évente kellett megfizetni kinek-kinek vagyoni helyzete alapján. Ez hagyományosan egy muszlim teljes vagyonának és megtakarításának az 1/40-ed része (2,5 százakék) volt, a megélhetéshez szükséges minimum felett. Az összegyüjtött adót (ami nem jelentett szükségszerüen pénzt) a szegény muszlimok, majd a vallási emberek, mecsetek között osztották szét. Napjainkban a vallási adót a legtöbb országban önkéntes alapon gyüjtik, általában a mecsetek. Néhány muszlim országban azonban az állam szedi be kötelezően, mint pl. Szaúd-Arábiában, Pakisztánban, Malajziában. A síitáknál, szemben a szunnita iszlámmal, a zakát fizetése mindig önkéntes alapon történt és mindig a mecsetek végezték a begyüjtését. 
5. A mekkai zarándoklat (haddzs) a holdév 12. hónapjában (dzu l-hiddzsa), a 7. és 9. nap között, amelynek során mindenki, aki egészségi állapota vagy vagyoni helyzete alapján megteheti, életében egyszer elzarándokol Isten Házához, a Kába szentélyéhez (59. kép). Ma, amikor a zarándokok száma az évi 3 millióhoz közelít, az országonként megszabott kvótarendszer is akadályozza, hogy mindenki részt vegyen a zarándoklatban legalább egyszer életében.

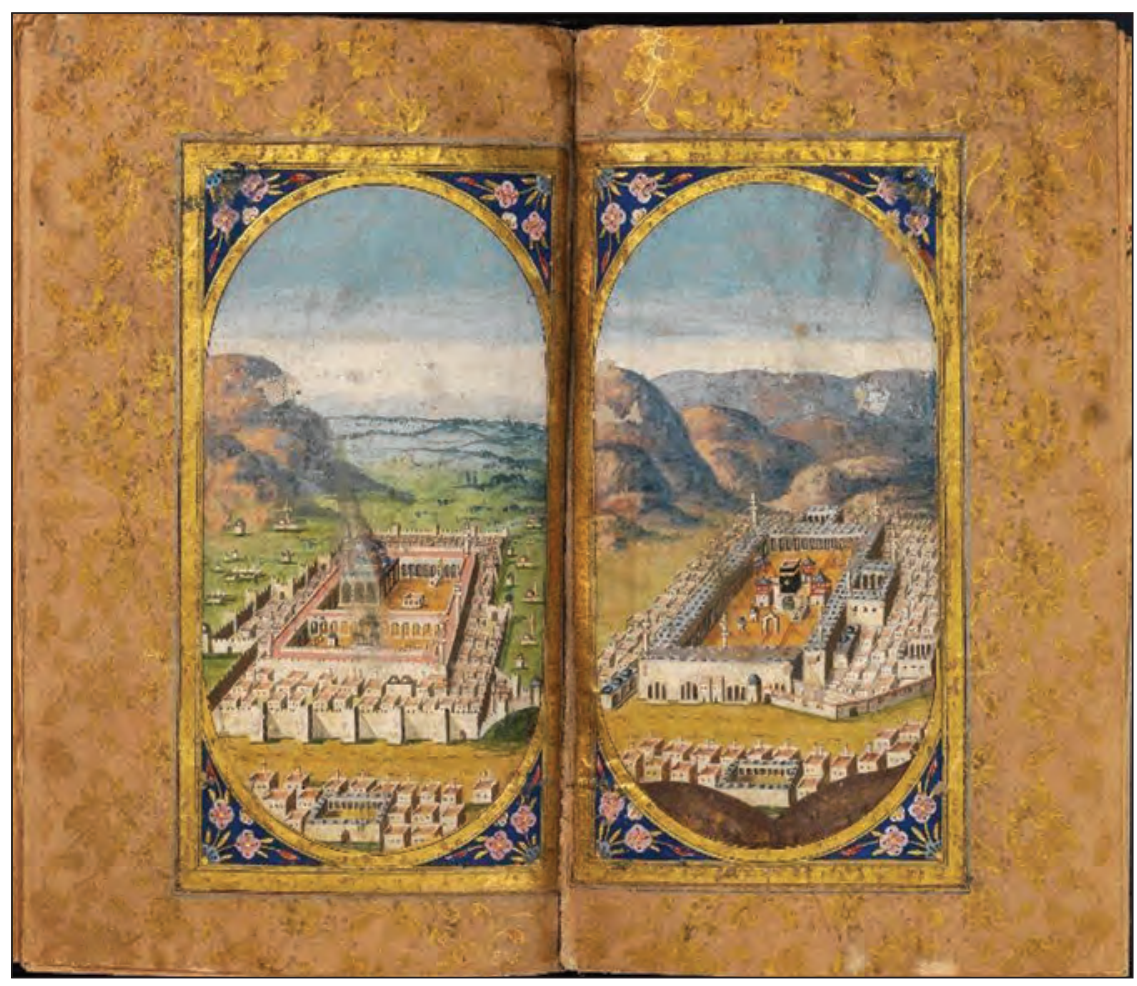

59. kép: Mekka és Medina egy 18. században másolt muszlim imakönyvben Forrás: MTA Könyvtár Keleti Gyüjtemény, Arab O. 54, fol. 11v-12r

A zarándokokat egész életükben nagy megtiszteltetés övezi és megilleti a háddzs (ha férfi), ill. a háddzsa (ha nö) elnevezés. A zarándokok csak speciális öltözékben (ihrám) léphetnek be Mekka szent körzetébe, amely a férfiak számára két beszegetlen fehér leplet jelent, míg a nők nem viselhetnek kesztyüt és arcukat fedő fátylat. A zarándoklat jellegzetessége, hogy míg a mecsetekben mindenütt elkülönítik a nőket a férfiaktól, addig itt együtt végzik a szertartásokat. A zarándoklat elején és a végén van a körözés (taváf), a Kába építményének gyors megkerülése hétszer. Utána a zarándokok futva (vagy gyors léptekkel) hétszer megteszik (szaaj) a Kábához közeli két domb közti távolságot - jelenleg a nagymecset egy 
hosszú külső folyosója -, annak az emlékére, hogy itt keresett a sivatagban vizet Ábrahám próféta felesége Hágár, saját maga és fia, Iszmáíl számára. A Korán ugyanis a Kába szentélyének a megépítését Ábrahám nevéhez füzi, Iszmáílt pedig az arabok ősapjának tartják. A következő napon a zarándokok együttesen a Mekka melletti Muzdalifa síkságra vonulnak, ott imádkoznak, és ott töltik az éjszakát sátrakban. Innen mennek a hónap 9. napján Arafát dombjához, ahol kis kövekkel, kavicsokkal megdobálják a Sátánt jelképező oszlopokat. A következő nap kezdődik az áldozati ünnep (id al-adhá) vagy „,nagy ünnep”, amely szintén speciális csoportos reggeli imával kezdődik, majd szertartásos állatáldozattal folytatódik, amelynek során a zarándokok Mekkában, a többi muszlim pedig a saját lakhelyén birkát vág.

Sokan tartják az iszlám hatodik pillérének a dzsihádot, amelynek kettős jelentése van a Korán értelmezése alapján. A nagy dzsihád a hívők lelkében az igaz hitért vívott küzdelmet jelenti, míg a kis dzsihád a muszlimok és az iszlám vallás gyakorlása védelmében vívott harcot jelenti.

\section{A mecset és a madrasza}

A mecset elsődleges funkciója ugyan a napi öt ima elvégzésének a színtere volt, ugyanakkor azonban az imádkozások közti időkben a társadalmi élettér szerepét is betöltötte. Itt lehetett találkozni, beszélgetni, szerződéseket kötni, békítő akciókat folytatni, házasságokat elrendezni. Mindezekben nem csak a hely szent jellege, hanem a jelenlévő vallási emberek, elsősorban a mecset imámja is szerepet játszottak. Az imádkozás előtt és után a Korán olvasó részleteket recitált a szent könyvböl. Itt lehetett jogi tanácsokat kérni az ebben jártas vallástudósoktól is. De a délutáni sziesztára is alkalmas volt a hüs, szellős, szőnyegekkel borított imaterem. Minden nagyobb városban volt egy nagyobb, központi mecset, ahol a helyi uralkodó vagy vezető jelenlétében tartották a péntek déli imát és utána a szentbeszédet. Ennek a mecsetnek dzsámi („összegyüjtő mecset”) a neve, utalva a péntek arab nevére (,a gyülekezés napja").

A mecset kezdettől fogva a tanítás színhelye is volt. A tanítás kis körökben (halka) folyt, a tanárok (sejkek) egy-egy oszlopnak vetették a hátukat, a diákok pedig körbevették őket. A tanítási módszer egységes volt egészen a 20. századig: a diákok memorizálták az időnként versbe szedett tömör alapszöveget, amelyet a tanár magyarázatokkal látott el. A kisgyerekek alapfokú oktatása - írás, olvasás, Korán recitáció és memorizálás - is a mecsetben folyt, vagy a mecsethez csatlakozó iskolában, amelynek a nevek maktab vagy kuttáb.

A legnagyobb igény a jogtudósok tanítására volt, ezért a 11. századtól egy sajátos intézmény terjedt el az iszlám világban, a madrasza (,iskola”, tkp. 
főiskola, más kiejtéssel medresze), ahol elsősorban az iszlám jogot tanították, mellette a szövegek értelmezéséhez alapvető eszközként szolgáló nyelvtudomány volt a legfontosabb tárgy (60. kép). Az első ilyen típusú föiskolát a Szeldzsuk Birodalom főminisztere, Nizám al-Mulk (megh. 1092) alapította Bagdadban (Nizámijja madrasza), majd a birodalom többi nagyvárosában.

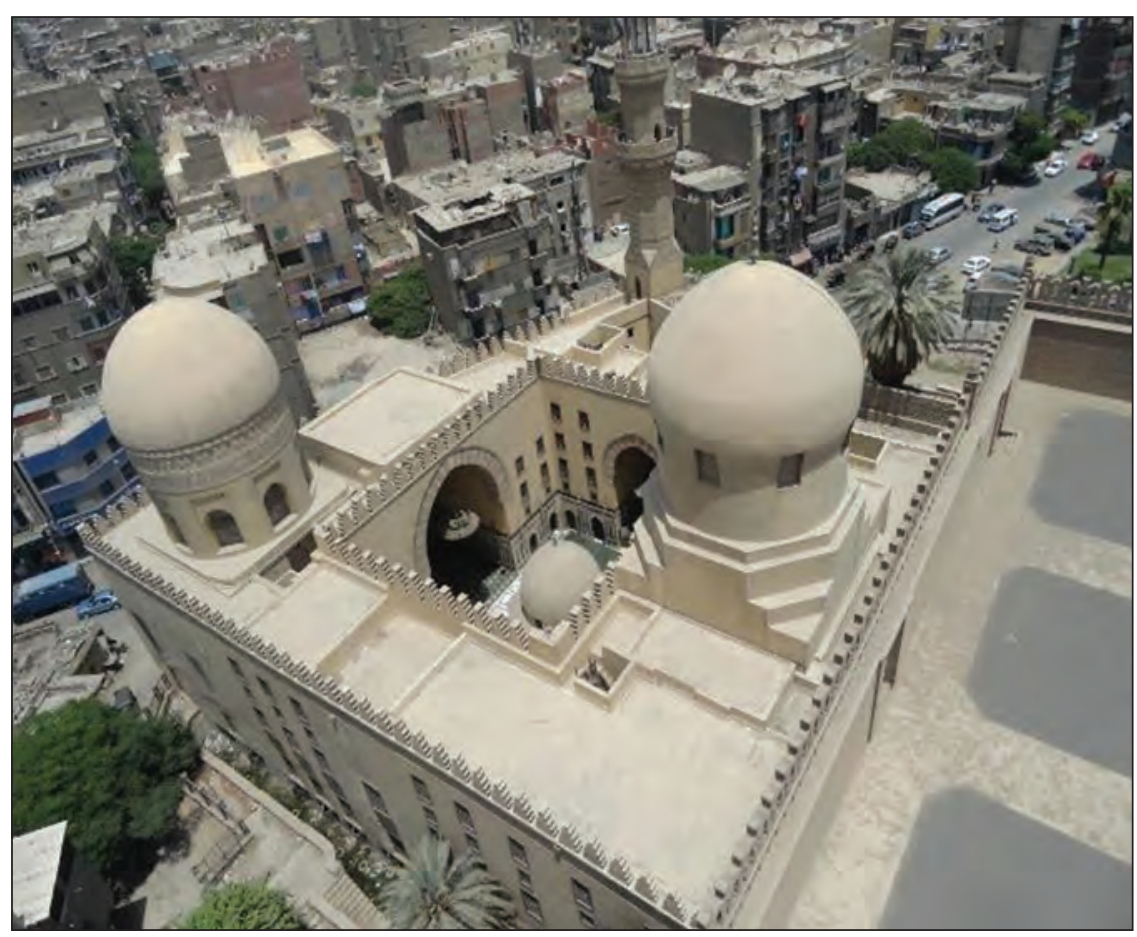

60. kép: Az 1356-ban épült kairói Szargatmis madrasza, amelyben mecset és mauzóleum is található

Forrás: DÉvÉNYI KINGA felvétele

\section{Az iszlám jogrendszerének kialakulása}

Az új birodalomban az élet minden területét szabályozó erkölcsi és jogi rendszer csak több mint két évszázad alatt, a 9-10. századra kezdett megszilárdulni. A vallási élet szertartásait az iszlám forrásai, a Korán és a prófétai hagyományok, a hadísz alapján már viszonylag korán szabályozták, a mindennapi életet, az emberek egymás közti kapcsolatait és a családjogot irányító elöírások azonban sokkal lassabban kristályosodtak ki és gyakran viselték magukon a terület korábbi szokásainak a nyomait. A Korán egyes helyeinek az értelmezése csak a 9. századra kezdett kialakulni, a hadíszok összegyüjtése is csak a 8. század közepén kezdődött meg, a százezres nagyságrendủ hagyományállomány rendszerezése, kritikai elemzése pedig még egy további évszázadot vett igénybe. 
Ezeknek a hagyományoknak kellett megmutatni, hogy Mohamed próféta isteni sugallatra hogyan élt, viselkedett, cselekedett és ítélt az élet ezernyi kérdésében. A Mohamed által követett szokások összessége a szunna (szó szerint „szokás”), ami aztán mintaként szolgálhatott a későbbi nemzedékeknek.

Mi a saría? Amit mi iszlám jognak nevezünk, az tulajdonképpen a muszlimok egész életét, minden cselekedetét irányító elöírások összessége. Ez a saría (szó szerint „út”), amelyet Isten kijelölt, és amelyet követni kell, tulajdonképpen az isteni törvény. Az isteni akarat azonban nem világos mindenki számára, azt meg kell érteni. Az értelmezést azoknak kell elvégezniük, akik elmélyülten, igaz hittel és erkölcsös magatartással egész életüket az isteni források tanulmányozására fordítják, egyéni erőfeszítést (idzstihád) tesznek. Ahogyan ők megértik, leírják, és az embereknek tanítják a saríat, az a fikh (szó szerint „megértés”), és ez az, ami a szorosabban vett iszlám jog. Aki ezzel foglalkozik, az a fakíh, jogtudós. Míg tehát a saría az egy és oszthatatlan isteni törvény, addig a fikh annak a sokszínü és egymástól néha teljes mértékben különböző emberi tevékenységnek az eredménye, amit a fakíhok végeznek.

\section{A jogi iskolák kialakulása}

Az egyes területek jogtudósai az első időkben egymástól sokszor teljesen függetlenül dolgoztak, értelmezéseket és jogszabályokat szolgáltatva a térség bíróinak, ill. az ott élő muszlimoknak. Idővel ezeknek az irányzatoknak a száma négyre szükült le. Ezeket madzhaboknak nevezik és szokásos fordításuk rituális vagy jogi iskola. Legkorábban a 8 . század második felében, két fontos területen, Medinában és Irakban alakult ki ilyen iskola. Később az iraki iskola, első mesteréröl, Abu Hanífáról a hanafi madzhab nevet kapta, míg a medinait Málikról, a nagy medinai tanítómesterről máliki madzhabnak nevezik. A harmadik a 9. század elején a sáfii madzhab lett. Névadója as-Sáfii, aki hosszas tanulmányutak megtétele után Egyiptomban telepedett le. A negyedik a hanbali madzhab, amely a 9. sz. első felében élt Ibn Hanbalról kapta a nevét. A hanafi irányzat létrejöttekor még csak csekély mértékben tudott támaszkodni a hadíszokra, ezért az iraki szokásjogon kívül a jogtudós egyéni vélekedését (raj) is jogalkotási eszköznek tekintették a hanafi fakíhok. Málik elsősorban a medinai hagyományokra támaszkodott, de már jelentős mértékben figyelembe vette a rendelkezésére állt hadíszokat is. Kézikönyve, az al-Muvatta („A kitaposott út") bár hagyományokat tartalmaz, nem hadíszgyüjtemény, hanem jogi kérdések magyarázatára szolgáló hadíszokat tartalmazó tanítások gyüjteménye, amelyeket aztán tanítványai jegyeztek le. Megjegyzendő, hogy Abu Hanífa sem írta le jogi értelmezéseit, hanem azt ő is a tanítványokra bízta. Ennek részben az is lehetett az oka, hogy a papírgyártás az Iszlám Birodalomban csak 770 után terjedt el, Abu Hanífa halála után és Málik életének utolsó szakaszában, és a nagyméretü könyvek írása csak ezután vált lehetségessé. As-Sáfii igyekezete 
arra irányult, hogy a korábban létrejött két jogtudományi irányzat, a Korán szövegét egyedül a hadísz szövegeivel kiegészítő iskola, illetve a Korán utalások hiányát egyéni vélemény alapján pótló iskola helyett kidolgozza azt az elméletet, amely szerint a jogi döntések csak a Koránon alapulhatnak. Ennek az elméletnek az alapján a prófétai hagyományok felhasználására is a Korán buzdít, amikor azt mondja, hogy „kövessétek a Prófétát, engedelmeskedjetek neki”. Ugyanakkor a szabályozatlan egyéni vélemény (raj) helyett kidolgozta az analógia (kijász) használatának a szabályait, amelynek segítségével egy írott szövegben lefektetett eset alapján megfelelő megoldást lehetett találni egy olyan esetre is, amelyről nem szólnak az iszlám szövegei (nassz), s amelynek a jogosultsága szerinte azon alapul, hogy a Korán szintén alkalmaz analógiákat.

\section{Az analógia}

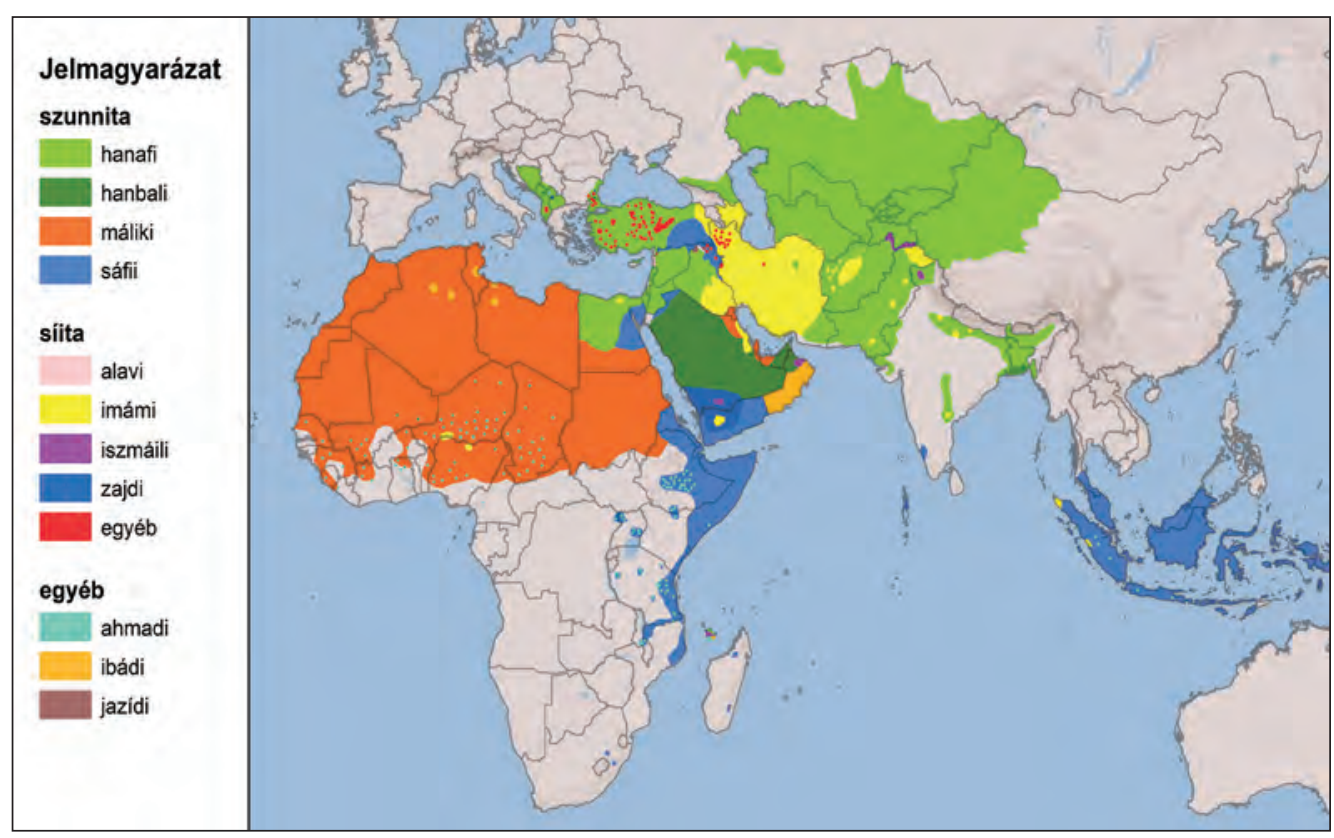

24. térkép: Az iszlám főbb irányzatai és jogi iskolái Forrás: VARGa ÁGNes szerkesztése

A vallási szövegek értelmezésének legfontosabb eszköze tehát az analógia (kijász), amely megoldja azt a problémát, amelyet egy középkori vallástudós így jellemzett: A szövegek száma véges, az életben előforduló esetek száma azonban végtelen - ezt csak az analógia szabályaival lehet áthidalni (24. térkép). Az eredmény attól függ, hogy a vallásjogi irányzat mit tekint az analógia alapjának. Ezt úgy határozzák meg, hogy megpróbálják megállapítani, hogy mi volt a Törvényhozó (Isten, ill. az ő ihletére Mohamed 
próféta) szándéka az eredeti szöveg megalkotásakor, vagyis a jog szellemét kívánták követni. Példaként álljon itt egy hadísz analógián alapuló kiterjesztése. A Próféta az arábiai Hajbar oázis meghódításakor meghagyta a földeken az eredeti tulajdonosokat felesbérlőként a datolyapálmák gondozása fejében. Ezen alapultak az ún. „közös öntözéses gazdálkodás” szerződései az iszlám jogban, azonban az egyes jogi iskolák különbözőképpen értelmezték ezt a hagyományt. Abu Hanífa elvetette ennek a felhasználását azzal a kifogással, hogy bizonytalan, milyen lesz a termés és mennyi lesz a haszna a két félnek. Málik ezzel szemben minden kertészeti termékre kiterjesztette a szerződés hatályát - gyümölcsfák gondozására, szőlő- és zöldségtermelésre. As-Sáfii csak a szőlőtermelésre és a datolyapálmák gondozására engedélyezte a felesbérleti szerződést. Azok azonban, akik a szövegeket csak szó szerint voltak hajlandók értelmezni, nem használtak analógiát és azt mondták, hogy a hadísz alapján ilyen szerződést csak datolyapálmákra lehet kötni.

\section{Iszlám jog és állami jog a 19. században}

Az iszlám jog (saría) soha nem volt kizárólagos jogi forrás az iszlám világ története során, mindig szükség volt uralkodói rendeletekre, utasításokra olyan kérdésekben, amelyekkel az iszlám jog nem foglalkozott, vagy amelyek tárgyalása nehézkes lett volna a saría bíróságokon - ahol például két vagy négy tanúval kellett alátámasztani az ügyeket. Az Oszmán-török Birodalomban ezeket az uralkodói jogszabályokat kánúnnak nevezték, ezek foglalkoztak például az adózás, közigazgatás, pénzügyek, vagy a büntetőjog kérdéseivel. Ezek sokszor csak kiegészítették, máskor helyettesítették az iszlám jogi rendelkezéseket. A kánúnrendszer ugyanakkor segített azoknak a problémáknak a leküzdésében, amelyeket az okozott, hogy a muszlim vallásjog nagy mértékben a vallástudósok szövegértelmezéseire támaszkodott, ami lehetetlenné tette az egységesen szabályozott bíráskodást.

A 19. század második felében az Oszmán Birodalom jogrendszere jelentős reformon ment keresztül, amelyet újjászervezésnek (tanzímát) neveztek. Ez a napóleoni törvények hatása alatt állt, és az európai hatalmak nyomása érződött azokban a törvényekben, amelyek a különböző vallásúak egyenjogúsítását és az európaiaknak adott kereskedelmi jogokat célozták. Jelentős változás volt továbbá az is, hogy ezeket az állami törvényeket az iszlám vallási tanácstól független, újonnan alapított állami bíróságok alkalmazták.

$\mathrm{Az}$ arab világban először a félig-meddig török uralom alatt álló, de az angolok által ellenörzött Egyiptomban modernizálták a 19. század utolsó évtizedeiben török mintára a bírósági szervezetet és a családjog kivételével állami bíróságok vették át a kádi bíróságok szerepkörét, a jogszabályokat pedig állami törvényekben rögzítették. Egyiptomban is létrehozták az állami bíróságok piramis rendszerét, alapfokú, felsőfokú és fellebbezési bíróságokat. 
Az iszlám jog ugyanis nem ismeri a magasabb szintü bíróság fogalmát, ahova fellebbezni lehet egy ítélet ellen, s nincs sem a vádnak, sem a védelemnek külön képviselője, a bíró egy személyben dönt.

Ezzel egy időben felállították az államilag kinevezett országos mufti hivatalát és hatáskörébe adták a halálos ítéletek jóváhagyását. Az egyiptomi főmufti mind a mai napig él is ezzel a jogkörével. Ezt egy 1987-es példával szeretném illusztrálni. Egy férfi a rendőrségen bevallotta, hogy elrabolt, fogva tartott és megerőszakolt egy nőt. Miután tanú nem volt, ennek a vallomásnak az alapján ítélte halálra a bíróság a férfit, jóllehet a bíróságon visszavonta a vallomását. Az egyiptomi törvények alapján azonban a rendőrségi vallomás is perdöntö. Az ítélet a fömufti elé került, aki elutasította, azzal, hogy a Próféta hadíszai között talált egy olyan esetet, amelyet analógiával fel lehet használni erre az ügyre is. Ugyanis a Próféta elé vittek egy férfit, aki bevallotta, hogy elrabolta és megerőszakolta valakinek a feleségét. Tanú nem volt. A Próféta azt mondta, vigyétek el és kövezzétek halálra. Egy fél nap is eltelt, amire visszatértek a kövezéssel megbízottak, és amikor a Próféta megkérdezte, hogy mi tartott ilyen sokáig, azt válaszolták, hogy az elítélt elfutott és hosszú ideig tartott, amíg elfogták és halálra tudták kövezni. A Próféta erre azt mondta, hogy helytelenül cselekedtek, mert a férfi futásával visszavonta a vallomását, ezért nem lett volna szabad megkövezni.

\section{A hadísztudomány}

Az abbászida dinasztia 750-ben azzal az ideológiai háttérrel jutott hatalomra, hogy ök helyreállítják az igaz iszlámot és annak törvényei szerint uralkodnak. Ennek egyikjele az volt, hogy támogatták a Próféta hagyományainak, a hadísznak a gyüjtését. A hadísz szó jelentése „közlés, beszéd”, és a Próféta szavát, valamint azoknak a társainak a szavait tartalmazza, akik jelen voltak, amikor a Próféta cselekedeteivel irányította a muszlimokat. A hadísz jelentősége azon az elven nyugszik, hogy minden, amit a Próféta mondott, isteni ihletésü. A vallástudósok szerint a Próféta egész élete, tettei és szavai, összerakva hadíszok formájában egyben a Korán magyarázatát is adják. A hadísz tehát egy mondás, amelyet azok a társai, akik hallották, később elmeséltek másoknak is, azok pedig Mohamed halála után továbbadták a következő generációnak. Később valóságos divat lett ezeket megtanulni és keresni azokat a társakat, akik tudtak ilyen szóbeli közlést. Miután a hódítások során a társak szétszóródtak a birodalom különbözö tartományaiban, sok ilyen hadíszgyüjtő hosszas utazásokat tett, hogy addig még nem ismert hagyományokhoz jusson. Egy idő után nemcsak magát a mondást jegyezték meg, ill. jegyezték fel később írásban is, hanem azt is, hogy kitől hallották, az kitől hallotta, egész addig a személyig, aki ott állt a Próféta mellett, amikor az beszélt. Ezeknek a közlőknek vagy továbbadóknak a láncolata adja a 
hadísz első felét, amit „támasznak” (isznád) neveznek, míg maga a mondás teszi ki a második felét, ezt nevezik „törzsnek” (matn). Miután azonban a Próféta utánzása követelmény lett az élet minden területén, a hadíszok gyüjtésének a jelentősége megnőtt. Ez azzal a következménnyel járt, hogy sokan gyártották a hadíszokat, részben azért, hogy minél több hagyományt tudjanak elmondani, ami jól jövedelmező foglalkozás lett, részben pedig azért, hogy alátámasszák nézeteiket, politikai álláspontjukat.

Irakban két katonai helyőrséget hoztak létre a Próféta halála után, Kúfát és Baszrát. Ezek a későbbi évszázadokban fontos politikai, vallási, tudományos és kulturális központokká váltak és rivalizálni kezdtek egymással. Saját jelentőségüket és kitünőségüket alátámasztandó, mindkét város lakói olyan hadíszokat hamisítottak, amelyekben a Próféta az ő városukat dicséri, jóllehet azok még nem is léteztek az ő életében. Ezenkívül sok jó szándékú hamisítást is elkövettek a hagyományok továbbadói és gyüjtői. Így nagyon sok közismert bölcs mondást és közmondást is a Próféta szájába adtak. Nagyon sok egymásnak ellentmondó tartalmú hadísz is van, ami nem utal okvetlenül hamisításra, hanem csak arra, hogy a Próféta az alkalomnak és szükségszerüségnek megfelelően máshogy reagált bizonyos kérdésekre. Például egyszer tiltotta a sírok látogatását és tiszteletét, máskor viszont javasolta azt. Sok esetben a hadíszok hamisítása könnyen kiderült, mert azállítólagos közlők nem éltek egy időben vagy egy helyen és ezért nem adhatták tovább a hagyományt egymásnak, vagy az első közlő nem élt a Próféta korában. A hamisításokat a 9. században kialakult hadísztudomány müvelői is észrevették, ezért első lépésként összegyüjtötték a közlők neveit, és megpróbálták kideríteni életrajzukat, vizsgálva, hogy milyen szellemi és erkölcsi tulajdonságokat jegyeztek fel róluk. Ezek alapján tettek kritikai észrevételeket az általuk továbbadott hadíszokra nézve. A hagyományokat azonban alapvetően csak az isznád, a továbbadók láncolata alapján minősítették, nem a tartalmuk alapján. A következő lépésként a 9. század második felében létrejöttek azok a nagy hadíszgyüjtemények, amelyeket mind a mai napig szent könyvekként tisztelnek. Kezdetben a közlők alapján rendszerezték a hadíszokat, ilyen pl. Ibn Hanbal 28 ezer hadíszt tartalmazó könyve, később azonban tartalmi alapon rendezték el őket. Hat ilyen könyv készült, amelyek közül a leghíresebbek al-Buhári és Muszlim Szahíh (,ép”) címü könyvei, amelyek mintegy hétezer helyesnek tartott hadíszt tartalmaznak. Al-Buhári azt írja, hogy mintegy 600 ezer hagyományból válogatta ki az „ép”, vagyis mindenki által elfogadott hagyományokat. A kiválasztás alapja a közlök láncolata volt. Alapkövetelmény volt, hogy tökéletes - kitűnő jellemü, szavahihetö, jó memóriájú - férfiak megszakítatlan láncolatán nyugodjék a hagyomány. A másik szempont az volt, hogy egy elbeszélés több közlési láncra is támaszkodjék. Például, ha tudták, hogy sokan hallgatták a Prófétát, de csak egy közlőn keresztül jutott el az elbeszélés az utókorhoz, akkor elvetették a hadíszt. Bizonyos elveket persze a tartalom 
(matn) elfogadhatóságára is felállítottak: a hadísz nem állhat ellentmondásban a Korán tanításával és az iszlám alapelveivel, nem ellenkezhet a természet törvényeivel és a muszlimok közös tapasztalataival, nem dicső́thet személyt, helyet vagy törzset - amit sok hadísz megtett. Nem utalhat egy hadísz jövőbeni eseményekre, hely idő megjelölésével, és nem mondhat vagy cselekedhet a Próféta egy hadísz szerint olyat és úgy, ami ellenkezik a Próféta szentségével és az iszlámnak a prófétákra vonatkozó tanításaival. A hadíszok tiszteletének növekedésével alakult ki az a máig fontos tanítás, hogy a muszlimok első három nemzedéke alkotja a „kegyes ősök” (szalaf) azon csoportját, akiket követni kell, mert ők a prófétai hagyományok letéteményesei.

A következő hadísz Buhári gyüjteményében található, amely könyvekre és fejezetekre oszlik, az 1. számot viseli „A kinyilatkoztatás kezdete” címü könyv első fejezetében: „al-Humajdi Abdalláh ibn Zubajr hagyományozta nekem, mondván: Szufján hagyományozta nekem, Jahja ibn Szaíd al-Anszárira hivatkozva, aki azt mondta: Mohamed ibn Ibráhim at-Tajmi közölte velem, hogy hallotta Alkama ibn Vakkász al-Lajszit amint azt mondja: Halottam Umar ibn al-Hattábot, aki a szószéken állva azt mondta: Hallottam a Prófétát, hogy azt mondta (eddig tartott az isznád, a közlők láncolata, amely visszamegy egészen a Prófétáig): „A cselekedetek csak a szándékok szerint (lesznek megítélve). Minden ember csak azt kapja, amit szándékozott. Akinek a kivándorlása a világi életért történt, az eléri azt, vagy egy asszony kedvéért, az elveszi feleségül - a kivándorlása révén azt éri el, amiért kivándorolt." (Ez a rész a matn, a hagyomány szövege).

A hadíszoknak általában több változatuk van. Egy másik változatban még van egy további mondat: „Aki Istenhez vándorol ki és az ő Prófétájához, az elér Istenhez és az ő Prófétájához." Ugyanakkor ezt a hagyományt más lánccal is továbbadták, ez biztosítja a helyességét. Azt a hadíszt, amelyet csak egy láncon adtak tovább, gyanakvással szokták szemlélni.

\section{Az iszlám misztikus irányzata, a szúfizmus}

Az umajjád kor végén és az abbászida kor első évszázadában egyre erősödtek az Iszlám Birodalom egyes tartományaiban, elsősorban Iránban és Irakban, a világtól való elfordulást hirdető aszkétikus irányzatok és a világ misztikus felfogását valló szúfi mozgalmak. Az aszkéták nem csoportosultak, hanem egyénileg vonultak vissza a világi élettől, mint remeték vagy vándorok, a halál utáni túlvilági életre vágyakoztak, miután megcsömörlöttek a világ romlottságától és hiábavalóságától. A misztikusok szintén a világi törekvések, kapcsolatok, célok hiábavalóságát vallották, de az aszkétáktól eltérően már életükben el akarták érni a boldogságot azáltal, hogy Isten felé közelednek szívükben. Isten megismerésére és az iránta érzett szerelemre törekedtek, úgy 
gondolva, hogy ez vezetheti öket az Isten közelségébe vivő úton. Minden misztikus felfogásnak, nem csak az iszlám misztikának, alapvető jellegzetessége az, hogy Isten világának (,a tölünk távol levő világnak”) a megismerése nem lehetséges a szövegek racionális értelmezése, olvasata révén. Eszerint a Korán minden mondata, szava, és a világ tényei valami mást, rejtett dolgot is jelentenek, amit csak misztikus elmélyülés, töprengés, révület állapotában lehet megismerni.

A 8. század második felében még a világtól való elfordulást tekintették a legfontosabb lépésnek azok, akiket később, mint korai misztikusokat tiszteltek. Egyikük előkelő herceg volt, aki egy éjszakai látomás hatására koldusruhát öltött, a másik útonállók vezére volt, aki a Korán recitálásának hangjára hagyott fel mesterségével és indult vándorútra. Mások temető magányába visszavonulva hallottak hangokat. Ez az első állomása a misztikus útnak, amelyet megtérésnek vagy bünbánatnak neveznek és lényege a világi kötődések elvágása. A misztikusokat a 9. század közepén nevezték először szúfiknak a hosszú, durva szövésủ gyapjú (szúf) köpenyükről. A szúfi a megtérés után egy ideig visszavonult a világi élettől, akár otthonában bezárkózva, akár egy távoli kietlen helyen, és elmélkedett. Utána azonban rögtön társakat és tanítómestert keresett, hogy az Istenhez vezető helyes útra találhasson. Ez különbözteti meg a szúfit a remetétől. A mester részben a misztikus utazásra indulni kész tanítványok (,akarók”, muríd) körében mutatta be azokat a szertartásokat, amelyek segítségével a szúfi a megfelelő elragadtatott állapotba (hál) juthat, részben a tanítvánnyal folytatott személyes beszélgetésben jelölte ki az adott tanítványnak megfelelö lelkigyakorlatokat. Az „akarók” így juthattak előre az út állomásain, amelyek közé tartozik a világtól való elfordulás - amely itt nem végcél, hanem átmeneti állapot, a tovább haladás eszköze - és a szegénység, amely egyszerre jelenti a világi javakról való lemondást és a „szükséget szenved” értelemben azt, hogy szüksége van Istenre. Ez annyira jellemző tulajdonsága volt a szúfik többségének, hogy az arab fakír (szegény) és a perzsa dervis (koldus) szó általában jelölte a megszállott misztikusokat. A törvénytisztelő szúfik nem vetették el az iszlám jog, a saría elöírásait és megbecsülték a vallástudományokat, de úgy gondolták, hogy ez a külső tudás csak a kiindulás, és a taríka, a misztikus út követésével elöre haladó tanítványok végül eljuthatnak a mesterek szintjére, ez a hakíka, Isten valósága.

Ezzel együtt igen fontos tulajdonsága az igazi szúfinak az alázat, megalázkodás. A 9. század egyik leghíresebb közép-ázsiai misztikusának tartott Bisztámi egy tanítványa, egy gazdag, előkelően öltözött kereskedő panaszkodott a mesternek, hogy már húsz éve részt vesz a misztikus összejöveteleken, szertartásokon, de még soha nem jelent meg álmában sem Mohamed, sem Isten, és soha nem fogta el az az érzés, hogy felfedezte szíve mélyén Istent. Bisztámi végignézett rajta, majd azt tanácsolta neki, hogy öltözzék rongyokba, vegye a nyakába a koldusok szokásos edényét, tegyen bele diókat, hogy csörögjenek 
minden lépésénél, és így álljon ki a piacra, a boltja elé, ahol mindenki ismeri. Akkor majd Isten is a közelségébe segíti. A kereskedő természetesen nem vállalkozott erre a megalázkodásra.

A mester hiánya szenvedést okozott az isteni szerelemre vágyó szent életủ muszlimoknak, ezért, ha saját városukban nem találtak mestert - arab sejk, perzsa pír -, akkor hosszú vándorútra indultak. Néha akkor is elindultak más mesterektöl tanulni, ha már volt mesterük. Erre maga a mester is ösztönözte tanítványait. Az a mondás járta körükben, hogy ,akinek nincs mestere, annak a mestere a Sátán". A szúfi út állomásait az egyes mesterek különbözőképpen jelölték ki, de úgy gondolták, hogy minden út, amely Istenhez vezet, egyformán jó. A szegénység és a földi kapcsolatok elvágása után a szúfi általában eljutott a mámorosság (szakr) állomására, amely megelégedettséget és boldogságot okozott, ezt azonban gyorsan követte a kijózanodás (szahu), egyfajta kiábrándulás és szomorúság, amikor a szúfi rádöbben, hogy Isten elérhetetlen messzeségben van fölötte. Ez elöször félelmet (hauf) okoz, majd ezt követi a remény (radzsá), hogy mégis eljuthat az út végállomására, Isten megismerésére és az isteni szerelem állapotába. Aki megszilárdította ezeket a lelkiállapotokat jelentő állomásokat, az fontos szakaszba jutott misztikus létében, az elengedettség (baszt), majd ezt követően a szorongás (kabd) állomására. Az első a hosszan tartó boldogság és öröm, a második az elhúzódó kétségbeesés szakasza.

Bisztámiról írták, hogy húsz évig volt a szorongás állapotában, s ezalatt a városi életet elkerülve, elhagyott helyeken bolyongott. A révület állapotában elfogadottnak számított, hogy a szúfi olyan dolgokat mondjon, ami az átlagembertől törvénytelennek és tiltottnak számított volna. Bisztámi többek között azt mondta: „Én dicsőségem! Milyen nagy az én dicsőségem!” Ez a jelző azonban csak Istennek jár az iszlámban. Szavainak magyarázói szerint azonban ezt nem önistenítésnek kell értelmezni, hanem úgy, hogy szívében csak Istennek jutott hely, a szíve eggyé lett Isten dicsőségével.

Bisztámi maradt napjainkig a mámoros szúfi mintaképe, míg a 9-10. század fordulóján élt bagdadi Dzsunajd józan szúfi volt. A későbbi misztikus szervezetek, az ún. dervisrendek azonban mindkettőjüket egyaránt „égi” mesterüknek tekintették. A szúfi végső célját azonban csak akkor érte el, ha eljutott Isten közelségébe, intim kapcsolatba (unsz) került vele a lelkében. Ezt nevezik „megvalósulásnak”, ami azonban csak Isten akaratából és segítségével érhető el. Aki eljutott ebbe az állapotba, az „visszatérése” után kötelességének érezte, hogy mester legyen és másokat vezessen. Az ilyen szemléletünek és szúfi bölcsnek tartott mestereket, egy Korán idézet alapján, „Isten barátjai” (aulijá Alláh) névvel illették, egyes számban röviden veli, amit európai nyelvekre általában szentnek szokás fordítani.

Akinek elterjedt a szent ember híre, ahhoz messze földröl tódultak a szúfi tanítványok. Voltak persze kivételek, akik menekülni próbáltak ez elöl a 
népszerűség előlés a magányt keresték. Voltak aztán egész csoportok, elsősorban a kelet-iráni Nisápurban, akik titkolták mély misztikus vallási elkötelezettségüket, sőt vállalták a kívülállók vádjait (maláma), hogy nem igazán vallásosak, ezért őket malámatiknak nevezték. Ök lenézték azokat, akik magukat szúfiknak nevezték és csoportosan vonultak az utcákon, Istent dicsőítve és koldulva a megélhetésükért, mert otthagyták eredeti foglalkozásukat. A malámatik ezzel szemben kézmüvesek és kereskedők voltak, akiket valószínüleg a közös szakma, a céhrendszer hozott össze, hiszen nem kerestek nyíltan követöket és tanítványokat.

A szúfizmus irányzatának további alakulására egy drámai esemény volt nagy hatással a 10. század első harmadában. Halládzs, a nagy hatású bagdadi misztikus, a mérsékelt szúfi Dzsunajd tanítványa, révületben mondott kijelentéseivel felkavarta a bagdadi utcák és piacok lakóinak a lelki nyugalmát, nagyszámú követője miatt ugyanakkor valószínüleg politikailag is gyanús személlyé vált, és hosszas bebörtönzés után 922-ben kegyetlen körülmények között kivégezték, felkoncolták, majd máglyán elégették. Elsősorban két mondása miatt emelték ellene az eretnekség vádját. Az egyik a „beköltözés” (hulúl) tanítása, hogy ti. Isten beköltözött a lelkébe és ezért azt is mondta, hogy „én vagyok a Valóság (Hakk)”, ami Isten legfontosabb neve a szúfik körében. A másik az a mondása, hogy a zarándoklatot el lehet végezni bárhol, akár körülötte is lehet forogni, mint a mekkai Kába körül, és a zarándoklatot a szívben is el lehet végezni. Halládzs mártírhalála évszázadokig kijózanítóan hatott a szúfikra és kézikönyveik általában annak a hosszadalmas bizonyításával kezdődtek, hogy a szúfik mindenben betartják az iszlám elöírásait és a saría törvényeit. Szertartásaik, vallásosságuk nem a saría elöírásai helyett vannak, hanem többletet jelentenek ahhoz képest. Kritikákat váltott ki a szúfiknak az az igénye is, hogy Istennel akarnak egyesülni, Isten tulajdonságait akarják átvenni a földi, emberi tulajdonságok helyett. Ennek reakciójaként alakult ki az, hogy a szúfik tulajdonképpen Mohamedet tartják példaképüknek, az ö életét akarják utánozni, ő a „tökéletes ember” mintája, és ő rajta keresztül kívánnak Istenhez közeledni. Ennek egyik jele volt az, hogy több szúfi is megtette a maga „égi utazását" a hét mennyországba, Isten trónusának lábazatáig, de míg Mohamed ébren és testében vitte ezt végbe a (nem minden vallástudós által elfogadott) éjszaki utazásában (lásd mirádzs) és megláthatta Istent, addig a szúfik, például Bisztámi, csak azt hirdették, hogy ők álmukban és a szívükben jutottak el a hét mennyországon keresztül Istenhez.

Mohamed próféta kiemelkedő szerepére a szúfizmusban az egyik első fennmaradt írásos bizonyíték a 9. századi iráni Hakím Tirmidzi (,a tirmidzi bölcs”) misztikus önéletrajzában található, amely több tucat álom leírása. Az egyik első álom arról szól, hogy Mohamed kézen fogva bevezeti a városi mecsetbe Tirmidzit, ahol már várja a tömeg a pénteki imát, s felvezeti a 
szószékre. A szószék legfelső fokán Mohamed áll, jobb kezével felmutat Istenre, ballal fogja Tirmidzi jobbját, míg Tirmidzi a bal kezével a mecsetben lévőkre mutat. Ez egyrészt azt a láncolatot jelképezi, amely a bölcset Isten közelségébe juttatta, másrészt azt a megbízatást, hogy Tirmidzi vezesse a muszlimokat a szúfi útra.

\section{A Korán szerepe a misztikában}

$\mathrm{Az}$ iszlám misztikus megközelítésének kialakulásában természetesen nagy szerepük volt különféle külső hatásoknak, többek között a 8. századi szír kereszténységnek is, azonban a szúfik minden eszmét és tanítást igyekeztek a Koránból származtatni, a Korán valamely versére visszavezetni. A fentebb említett kabd és baszt fogalmak jó példával szolgálnak erre a persze sajátos értelmezésre. A Koránban a két szó a következő versben szerepel: „Isten adhat szűkmarkúan és bőkezűen” (2:245). Itt az „ad” úgy van kifejtve, hogy „szétnyitja a tenyerét" (baszata) - mint ahogy a koldusnak is nyitott tenyérrel adunk pénzt -, míg a „megtagadja az adást”, a kabada igével, vagyis „összezárja a tenyerét”. A szúfik ezt úgy értelmezik, hogy Isten a szívüket tárja ki az isteni kegyek és sugallatok befogadására, majd azután összezárja, s ezzel a kétségek és szorongás állapota következik be.

A szúfi rendek, az ún. dervisrendek virágkora a 13-19. század között

A 9-12. század között az iszlám világ különböző részein kialakult szúfi misztikus irányzatok arculata és jellege a 13. századot követően gyorsan és némileg váratlanul megváltozott. Egyének és kis csoportok sokszor titkos vallásgyakorlásából egész városnegyedeket, városokat mozgósító, valamilyen módon soraikban tudó testvériségi szervezetek, európai fordításban dervisrendek jöttek létre.

Fontos lépés volt a rendek kialakulása felé a vezető (mester, sejk) és a kereső (tanítvány, muríd) kapcsolat rendszeressé válása, amely során a mester irányításával igyekeztek eljutni a misztikus út különböző állomásaira (makámát). A korai mesterek inkább vezettek, mint tanítottak, a gyakorlat fontosabb volt, mint a bölcselet, a tanok összefoglalása másodlagos volt.

A szúfi rendek magukra a taríka, út szót használták. A taríka gyakorlati módszer a kereső vezetésére egy bizonyos (kipróbált) rendszer szerint haladva, amely biztosítja a misztikus állomások elérése mellett az (elragadtatott) szellemilelki állapotok megtapasztalását is. A korai időkben két 9. századi szúfi iskolát különböztettek meg, mint irányelvet: Dzsunajd józan elmélkedését és Bisztámi mámoros elragadtatásait, $\mathrm{s}$ a különböző rendek általában mindkettőt tisztelték és ösi mesterüknek tekintették. A meghalt mesterek is a „rend” részét képezték a „láncban”, az élő és meghalt tanítók sorában, amely visszavezet Mohamed prófétáig, akinek a közbenjárásában reménykedtek Istennél. 
A rendek kiemelkedő mesterek körül kezdenek kialakulni a 12-13. században. Abd al-Kádir al-Dzsíláni (megh. 1166) a kádirijja rend, Abu 1-Haszan as-Sádzili (megh. 1258) a sádzilijja rend alapító szentje, mindkettő elsősorban Észak-Afrikában és Egyiptomban terjedt el, míg Muín ad-Dín Csisti (megh. 1236) az indiai csistijja rend megalapítójának számít. A korai csoportok egymáshoz lazán kapcsolódó, mozgékony társulások voltak. Tagjaik utaztak, mestereket kerestek vagy helyben maradtak, mesterséget üztek vagy alamizsnából éltek. Lakhelyük általában a számukra adományokból létrehozott hánka vagy ribát volt, amelyben lakófülkék és mecset mellett raktárak, konyha, fürdő és kút is volt, teljes ellátó személyzettel. Amíg a dervisek a szálláshelyen laktak, addig szigorú előírásoknak kellett megfelelniük, például nem végezhettek világi foglalkozást, csak vallási feladatokat láthattak el, mint a Korán és más vallási könyvek másolása. Részt kellett venniük a heti 3-4 megemlékezés szertartáson és a napi ötszöri imádkozáson. Ök alkották az egyre terebélyesedő rendek belső körét, magvát, őket nevezték derviseknek. Egy bizonyos rendhez való tartozás azonban nem zárta ki azt, hogy egy másik városban egy másik rend házában keressen egy dervis menedéket. A külső kör tagjai, akik száma akár százszorosa is lehetett a dervisekének, nem vettek részt a mesterek csoportos vagy egyéni foglalkozásain, de ellátogattak hetente többször is a mecsetekben vagy rendházakban tartott szúfi szertartásokra, megtanulták a rend imakönyvét és azt együtt szavalták, vagy éneklés szerüen kántálták, adományokkal segítették a derviseket és hozzájuk tartozóknak érezték magukat.

Később egyre több dervisrend jött létre az iszlám világ minden pontján, és sok helyen komoly politikai szerephez jutottak. A 14. században létrejött bektási rend a janicsárok hivatalos szúfi intézménye volt az Oszmán-török Birodalomban, a mevlevi rend a török szultán és udvar hivatalos rendje volt, míg a halvati rendhez a közemberek tartoztak. A mevlevi rend tagjai a 13. században Anatóliában élt és müködött perzsa szúfi író és költő, Dzsalál ad-Dín Rúmi tanításait és misztikus gyakorlatát követik azzal, hogy szertartásaikon sajátos táncot mutatnak be, amiért őket kerengő derviseknek szokás nevezni.

\section{A siita iszlám}

A legtöbb vallási és jogi elöírás tekintetében csak jelentéktelen különbség van a szunniták és a síiták között. Lényeges különbség az imám személyében van, aki Ali leszármazottja kell, hogy legyen. Ugyanakkor az imám nem tanulás, hanem örökölt isteni ihlet alapján szerzi meg tévedhetetlen tudását. Miután a 9. században az utolsó imám eltünt, ezért az ún. távollét idején a legfőbb síita vallástudós örökli ezt a tudást. 
Az imámi vagy tizenkét imámos síiták

A síita irányzat Ali pártjából fejlődött ki az évszázadok során (61. kép). Alapvető tanításuk az, hogy Mohamed után Alinak kellett volna következnie a kalifátusban, majd utána az ö leszármazottjainak, vagyis a Próféta legközelebbi rokonainak, „háza népének”. Ezért már Korán kialakult a „bitorló” kalifák, elsősorban Oszmán átkozásának a szokása a síiták körében. Az évszázadok során kialakult az a dogma, hogy Ali titkos tanítást kapott Mohamedtől, ill., hogy Isten sajátos tudást adott Alinak, amelyet az utódai, a síita imámok is örököltek. A szunnita iszlám vallástudósai azt vallották, hogy az iszlám jog, a saría, a hitelesnek elfogadott normák autonóm, minden földi hatalomtól független korpusza, amelyet a közösség egésze tart fenn és őriz meg akár az uralkodóval szemben is. Ezzel szemben a síita tanítások szerint az isteni törvény folyamatosságát, akár csak Mohamed korában, az isteni akarat küldetéssel rendelkező, hiteles szószólójának kell biztosítania, az igaz imámnak. Az Ali és családja iránti hűség ezt a kiválasztott személyt biztosította. Ali a szemükben nem egyszerüen a 4. kalifa volt, hanem az az egész életében Mohamed közelében tartózkodó ember, aki így sajátos tudást szerzett, s így, aki elhagyta Ali táborát, az isteni igazságot hagyta el. Az Ali iránti hüség ugyanakkor biztosított egy olyan ezoterikus tudást, amelyet mások nem tudtak megszerezni. Ez a titkos, rejtett tudás az imámok birtoka, és ezt csak a síiták tudják értékelni és megismerni. Ehhez járult az „elöre kijelölt vezető”, a mahdi várása, aki majd az igaz útra vezeti a társadalmat az utolsó ítélet napja elött. A síiták számára a Korán titkos magyarázata is az imámokról és azok sorsáról szól. Ezek az imámok Ali leszármazottjai voltak két fiától, Haszantól és Huszajntól. Életükben legtöbbször nem töltöttek be sem politikai, sem vallási szerepet, az egy Dzsaafar asz-Szádik (,az igazmondó”) kivételével, akinek a vallási tanításait még a szunniták is tiszteletben tartják. Ő volt a hatodik imám. Utána a síiták többsége fiát, Músza al-Kázimot ismerte el imámnak. Az ő utódai a tizenkét imámos vagy imámi síiták, akik ma is a síita többséget alkotják Iránban és Irakban. A 9. és 10. imám kisgyermekként halt meg, így nekik elfogadták az imámságukat, fel kellett, hogy tételezzék nemcsak azt, hogy az ő szavuk isteni kijelölés révén igazság, és azt, hogy az imám tévedhetetlen, hanem azt is, hogy az imám az isteni ihlet birtokosa és azt továbbítja utódjának anélkül, hogy földi ismereteket kellene szereznie. Amit továbbad utódjának, az a speciális isteni fény, amelyet Isten belehelyezett, és amelynek következtében természeténél fogva ismeri az igazságot. A 11. imámot, Haszan al-Aszkarit kivégezték a kalifa udvarában 873-ban. Neki nem volt ismert fia, de egy bizonyos Mohamed állítólag az ő leszármazottja, aki gyerekként eltünt egy barlangban. Ö a rejtőzködő imám, akinek a visszatérését a mai napig várják a síiták. Öt négy megbízott vagy helyettes képviselte 940-ig, akik biztosították az isteni tudás tovább élését. Ez az ún. „kis távollét”. Miután az utolsó megbízott nem nevezett 
meg ilyen helyettest, elkezdődött a „nagy távollét” (gajba), amikor nincs a síita közösségnek Isten által irányított vezetője. Később, amikor a tizenkét imámos síiták Iránban hatalomra kerültek a 16. században, kialakították azt a dogmát, hogy az imám távollétében a vezető vallástudós, az ajatollah örökli az isteni ihletet és ő lesz a közösség tévedhetetlen vezetöje. Az imámokat, akik kozmikus értékkel lettek felruházva, a síita történeti leírások szerint mindig üldözték, bebörtönözték és kivégezték vagy megmérgezték az umajjád és abbászida uralkodók. A síita ünnepek, évfordulók és zarándoklatok épp ezért az ő siratásukat jelentik, legfőképpen pedig Huszajnét, aki szomjan vergődött a sivatagban, saját hívei is elárulták, majd ellenségei meggyilkolták a kerbelai ütközetben. A jog és a társadalom kérdéseiben azonban csak kismértékben különböznek a síiták a szunnitáktól. Általában jobban ragaszkodnak a Korán szavaihoz és elutasítják azt, hogy egyik Korán hely törölje egy másik érvényét, vagy egy hagyomány a Korán verset. Mohamedre visszamenő hagyományaik föleg annyiban különböznek a szunnita hagyományoktól, hogy előnyben részesítik azokat, amelyek Mohamed családjára mennek vissza és főleg azokat, amelyek Ali öröklési jogát és kiválóságát támasztják alá.

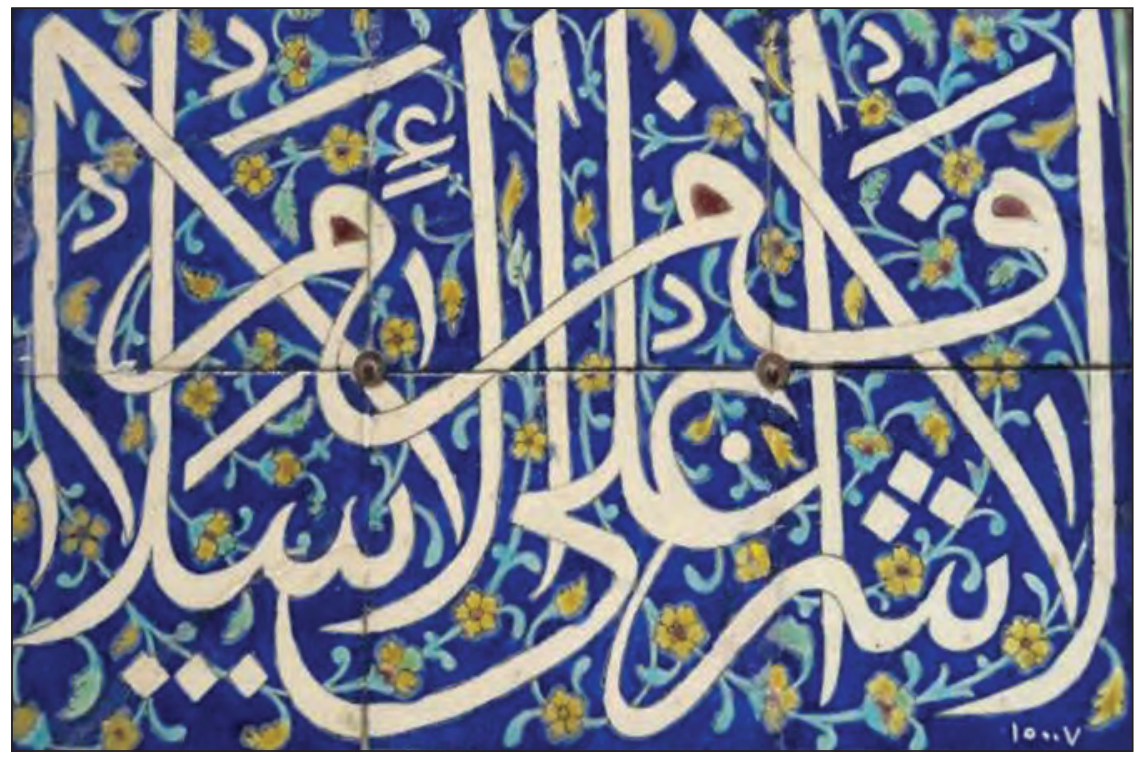

61. kép: Ali bölcs mondása kalligrafikus elrendezésben: „Nincs magasabb tisztesség az iszlámnál". Kairó

Forrás: DévÉNYI KINGA felvétele

Az iszmáili vagy hétimámos síiták

Voltak azonban, akik Dzsaafar egy másik, még apja életében meghalt fia, Iszmáil leszármazottjait tartották az igaz imámnak. Az ő követőik az iszmáili 
vagy hétimámos síiták, akik a 10-12. században a Fátimida Kalifátust hozták létre Észak-Afrikában és a Közel-Keleten. Fő jellegzetességük az volt, hogy dinamikus társadalmi és értelmiségi mozgalmat indítottak el, amely számtalan lázadást támogatott. 909-ben a magukat Mohamed lányától, Fátimától származtató Fátimida dinasztia első tagja, Ubajdalláh Mahdi, elfoglalta a mai Tunéziában az Abbászidákat támogató kormányzó fővárosát és magát kalifának kiáltotta ki. Ez volt az első eset, hogy egyszerre két földi helytartója, kalifája is lett a muszlimoknak. Az iszmáili Fátimidák egyik fegyvere a misszionáriusok kiküldése volt, akik távoli területek lakóit is az ő tanaikra térítették. 969-ben meghódították Egyiptomot, majd Szíria nagy részét és a Hidzsáz szent városait, Mekkát és Medinát. Egyiptomba helyezték át központjukat és új fóvárost építettek, Kairót, és állandó összeütközésben voltak a bagdadi kalifátussal.

Tanításukban egyértelműen a Korán rejtett, csak a beavatottak számára érthető jelentésére támaszkodtak, míg a 12 imámos síiták ezt csak részben tették. Az is különbség közöttük, hogy az iszmáili tanítások szerint a hetedik imámnak, Iszmáílnak mindig vannak örökletes imámjai. Jelenleg (1957től) a 49. imám, IV. Aga Kán vezeti a világban szétszóródva élő iszmáili közösségeket.

A 11. század végén, az utódlási vitában megölték Nizárt, a fátimida kalifátus egyik jelöltjét, és hívei a nizári iszmáili közösség tagjai elmenekültek Egyiptomból a Közel-Keletre. Egyik csoportjukból alakult ki a drúzok szektája, akik ma is Libanonban, Szíriában és Izraelben élnek az ún. Drúz-hegység vidékén. Más részük több magas hegyi várat elfoglalva egy erődrendszert hozott létre Szíriától Kelet-Iránig, ahonnan 150 évig rettegésben tartották a környezö síkságok államait. Őket feltételezett hasis szívó gyakorlatuk miatt aszaszinoknak (arab: hassásín) nevezték. Miután öngyilkos merényleteket követtek el neves államférfiak ellen, több európai nyelvben is a nevük ,gyilkos”-t, ill. ,gyilkolni”-t jelent (angol: assassinate).

A Fátimida Kalifátus belső viszályai miatt nem tudott ellenállni a szunnita hit védelmezője és az Abbászida Kalifátus helyreállítója szerepében érkező új katonai rendszereknek. Elöször a szeldzsuk-törökök foglalták el a Fátimidák szíriai tartományát, majd a kurd ajjúbida hadsereg 1171-ben elfoglalta Kairót és egész Egyiptomot. Az új Ajjúbida Birodalom vezetője Szaladin (Szaláh ad-Dín, uralk. 1171-1193) lett, aki elvette Szíriát is a szeldzsukoktól, de akár csak azok, ő is hüséget esküdött a bagdadi kalifának.

\section{További síita irányzatok}

Az 5. imámtól kezdődően eltér a mérsékelt síita zajdi irányzat, akik 6. imámnak Zajd ibn Alit tartják és nem Muhammad al-Bákirt. Ma a legnagyobb zajdi közösség Jemenben található, ahol az északi országrészt a zajdi imámok vezették egészen a 20. század végéig. 
Meg kell még említeni az alavi irányzatot, amely a tizenkettes síitákból levált szélsőséges szekta. Mivel irataikat titokban tartják, korábbi nevük Ali iláhi árulja csak el központi tanításukat, ami Ali istenítése. Jelenleg Szíriában alkotnak jelentős kisebbséget, de közösségeik megtalálhatók Törökországban és Libanonban is.

\section{Az iszlám legújabb kori irányzatai}

\section{Az iszlám vahhábita irányzata}

A 18. században egy új, puritán és az iszlám tanait szélsőségesen értelmező, hanbali alapon álló mozgalom indult hódító útjára, amelyet alapítójáról vahhábita irányzatnak szokás nevezni. Mohamed Ibn Abd al-Vahháb (1703-1791) az Arábia közepén lévő Nadzsdban élt és tanított. Úgy érezte, hogy a tudatlanság sötétsége uralkodik, ezért azt tanította, hogy az igazi fegyvert a könyvek, a tudás jelentik. Fellépett a különböző népi szokások és babonák ellen, mint a Próféta sírjánál közbenjárás, segítség kérése, a szent fák, kövek és sírok tisztelete. Célja az volt, mint írta, hogy visszaállítsa az iszlámot, ahogy a Próféta és az első kalifák alatt volt, a más vallásokból átvett elemek elhagyásával. Ezáltal a modern fundamentalista, szalafi (az ősök követése) iszlám megalapozójának tekinthetö. Életének első szakaszában sok ellensége volt, mindenkit eretneknek tekintett, aki ellentmondott neki - ez a 20-21. századi szélsőséges vallási irányzatok jellemzője lett. Meggyőződése volt, hogy mind a magánéletet, mind pedig a közéletet a vallás irányítása alá kell helyezni. Ugyanakkor olyan pozitív tanításai is voltak, amelyeket kései utódai már nem követnek: hirdette a társadalmi igazságosságot, a muszlimok egyenlőségét, a nők, a szegények és a tulajdon védelmét, a korrupció elvetését. Azt hirdette, hogy harcot csak indokolt esetben szabad folytatni, a tanítás és a prédikálás a meggyőzés eszközei. Tanítását az Isteni Egység hirdetésének (tauhíd) nevezte, hívei mai napig „egységesítőknek” (muvahhidún) nevezik magukat.

Döntő változást jelentett a vahhábita irányzat történetében, amikor 1744ben szerződést kötött a harcias nadzsdi törzsfönökkel, Muhammad Ibn Szaúddal. Ennek értelmében az lett a világi parancsnok, emír, míg Ibn Abd al-Vahháb az imám, az iszlám vallási feje. Ezáltal a törzsi alapokon álló királyságot, a nadzsdi szaúdi államot vallásilag legalizálta és ez megsokszorozta a törzsi rablóhadjáratokat, a razziákat. A dzsihád, vallási háború az új állam feladata lett ugyan, de a vahhábita tanítás szerint előbb fel kell szólítani a legyőzötteket a 'megtérésre', és az átállásra, s csak azután szabad megölni őket, ha ezt nem teszik meg. Mohamed Ibn Abd al-Vahháb csalódott és visszavonult a közvetlen vezetésben való részvételtől 1770 után, mivel a csapatok ezt nem tartották be: gyilkoltak, fosztogattak és mindent elpusztítottak. Tanításai tovább éltek, már a 19. században is sok térségben hatottak, pl. Egyiptom és India, míg a 20. század első harmadában létrejött Szaúd-Arábia hivatalos vallási irányzata lett. 


\section{A 19. századi iszlám reform kor (nahda) Egyiptomban}

A 19. sz. második felében az európai, angol-francia gyarmatosítás során több arab országban is közvetlen kapcsolatba kerültek a nyugati civilizációval a vallástudósok és értelmiségiek. A nyugati hatás kettős volt: felébresztette a vágyat a Nyugat utolérésére, a régi dicsőség helyreállítására, másrészt elutasítást is kiváltott az iszlámellenes, világias külső hatalom. Ennek a kettős reakciónak a hatására alakult ki az iszlám reformmozgalom (iszláh), elsősorban Egyiptomban, és mellette a világi kultúra megújítására való törekvés, amelyet reneszánsznak (nahda) neveztek. A vallási reformok atyja mindenekelött Mohamed Abdu (18491905) volt, egyiptomi jogtudós, vallástudós és liberális reformer, akit az iszlám modernizálására való törekvések legfontosabb alakjának tekintenek. Szakított a merev dogmatizmussal, meghirdette azt a tanítást, hogy a vallási megújítás és az új értelmezések kapui nem zárultak be a középkorban. Fiatal korában erős indíttatást kapott és sokat tanult az 1870-es években Egyiptomban tartózkodó Dzsamál ad-Dín al-Afgánitól(1838-1897), aki reformer, megújító és agitátor, liberális és szélsőséges volt egyszerre. Elsőnek az ö kettejük müködése során öltött némileg összefüggő alakot az iszlám hatalmának a visszaállításáért és az európai előrenyomulás megakadályozásáért folytatott intellektuális küzdelem. A nyugati racionalizmus befolyása, az iszlám egységére való törekvés, a nyugati imperializmus kritikája, a modern civilizáció átvétele volt ennek a reformmozgalomnak a jellemzője. Al-Afgáni a pániszlám törekvéseket hangsúlyozta, a török szultánátust képzelte el az iszlám világot egybefogó kalifátusként. Abdo tevékenységét Egyiptomra korlátozta, ahol megújítónak és újjáélesztőnek tartották, aki a nyugati civilizáció eredményeinek átvétele mellett a vallásgyakorlatot akarta elmélyíteni. Ebben segítette az, hogy élete végén Egyiptom hivatalos főmuftijává nevezték ki. Ebben a funkciójában kiállt a nők egyenjogúsága mellett és harcot indított az általa a fejlődés gátjának tekintett szúfi rendek tevékenysége ellen.

\section{Az iszlám 20. századi fóbb tendenciái}

A 19. század végén egy nagy hatású szunnita hitszónok Mirza Gulám Ahmad (1835-1908) követői különálló csoportot alkottak az indiai Pandzsábban. A vezetőjüket Mohamed után a második prófétának tartották és magukat ahmadi muszlimoknak nevezték. Az üldöztetések következtében ma a világon szétszórva élnek és erőteljes hittérítő tevékenységet folytatnak.

A 20. században az I. világháború utáni években alakultak ki a politikai iszlám különböző tendenciái az iszlám világ számos helyén. Ezek közül a legfontosabb a közel-keleti térségben létrejött Muszlim Testvérek mozgalma, elsősorban Egyiptomban és Szíriában. A mozgalom elindítója az 1949-ben meggyilkolt egyiptomi Haszan al-Banná volt, célja a hatalom elnyerése volt, jellegzetessége pedig elsősorban az, hogy nem vallási emberekre, hanem laikus értelmiségiekre támaszkodott. 
A politikai iszlám legnagyobb hatású alakja az indiai szubkontinensen, illetve 1947 után Pakisztánban Abu 1-Aalá Maudúdi (1903-1979) volt. Célja az iszlám tanításainak és az iszlám törvénykezésnek a terjesztése volt a muszlim tömegek körében. Elképzelése szerint a hatalmat csak akkor lehet átvenni az iszlám alapon álló szervezeteknek, ha a nép körében elfogadottá váltak ezek a gondolatok.

Haszan al-Banná és Maudúdi gondolatait fejlesztette tovább és publikálta egyszerü, közérthető módon az 1966-ban kivégzett egyiptomi Szajjid Kutb, akinek a későbbiekben népszerüvé vált alapgondolata az volt, hogy a modern kori muszlim országok valójában a pogány korban (dzsáhilijja) élnek. Nem elég, ha valaki muszlimnak vallja magát, hanem mindent meg kell tenni, akár erőszakkal is, hogy a világot Isten akaratának megfelelően az iszlám tanításai irányítsák. Az iszlám síita irányzatában ezt az elvet az 1979-es iráni iszlám forradalom révén Homeini ajatollah (1902-1989) valósította meg. Az így létrejött Iráni Iszlám Köztársaságban a politikai vezetést a vallástudósok kezébe adták (velájat-e fakíh).

Az iszlám világban a nem szélsőséges muszlim vallási mozgalmak körében is elterjedt az a nézet, hogy helyre kell állítani az iszlám isteni törvényén (saría) alapuló jogrendet. A saría mint állami jog a szunnita iszlámban egyértelmủen Szaúd-Arábiában valósult meg, ahol mind a politikai, mind a vallási hatalom a király kezében van. Ez azt jelenti, hogy azokat a kérdéseket, amelyekben a vallástudósoknak a szent szövegek alapján joguk van ítéletet hozni, nem rögzítik állami törvények. Ennek ellenére a jogszabályok kétharmad részére állami törvényeket kell hozni, mert azok kívül esnek a saría hatáskörén. A 20. század második felében a szélsőséges muszlimok magukat szalafiknak nevezték, azt állítva, hogy ők a Próféta korának és az utána következő három nemzedéknek (szalaf „kegyes ösök”) az életmódját, erkölcseit követik. Mindenkit, aki nem osztja a nézeteiket - és ez a muszlim társadalmak többségét jelenti - hitetlennek tartanak (takfir). Ennek az az értelme, hogy a Korán tanítása szerint muszlim nem harcolhat másik muszlim ellen, kivéve, ha az hitetlennek lett nyilvánítva.

A modern kori iszlám másik sokat használt fogalma a dzsihád, amely elsősorban az elmúlt negyven évben vált a szélsőségesen politizáló muszlim aktivisták jelszavává „szent háború” értelemben. Ezt a harcot szerintük az iszlám világon belül és kívül is meg kell vívni.

\subsubsection{A világi civilizáció}

\section{A világi tudományok Keleten}

Hárún ar-Rasíd fia, al-Mámún kalifa híressé vált a görög és szír nyelvből készült fordítások támogatására apja által létrehozott „Bölcsesség Háza” működésének további kiterjesztésével és jelentős mértékủ anyagi támogatásával 
a 9. század első évtizedeiben. Ezzel részben a vallástudományok térhódításának ellensúlyozását is próbálta elérni. Ez az intézmény a fordítók lakhelye mellett hatalmas könyvtárat foglalt magába. Mintegy 80 szerzőtől fordítottak itt le több száz mủvet, elsősorban filozófiai és természettudományos jellegủ írásokat, amelyek nagy hatással voltak az intellektuális és vallási életre egyaránt.

A görög tudomány legjelesebb képviselöinek a munkáit az ún. második fordítási korszak idején, a 9. század második felében azok az Észak-Szíriában élt szír keresztény tudósok ültették át arab nyelvre, akik ezeket görögről már korábban szír nyelvre fordították. Legjelentősebb közülük Hunajn ibn Iszhák volt, aki Arisztotelészt, Platónt és orvosi műveket fordított. Kuszta ibn Lúka Arisztotelészt, Plutarkhosz történeti munkáit és Euklidész alapvető matematikai könyvét, az Elemeket fordította arabra. Mivel mindezeket a mủveket később latinra fordították, a középkori Európa arab közvetítéssel ismerte meg az ókori görög tudományt. Az arab filozófusok és természettudósok nemcsak értelmezték a görög müveket, hanem sok esetben továbbfejlesztették azokat. A legnagyobb tudósok a filozófus-logikus al-Fárábi (megh. 950 k.) és a filozófus-orvos Avicenna (Ibn Szína) (megh. 1037) voltak. Utóbbi A gyógyítás könyve címü sok kötetes munkájában a tudományok teljes rendszerét adta, míg Az orvostudomány enciklopédiája (al-Kánún fi t-tibb) címü müvében az orvoslást foglalta össze. A matematika terén is nagy hatású volt az arab nyelven író tudósok tevékenysége. Az algebra szó arab eredetü: al-dzsabr, ,a hiányos részek kiegészítése”, vagyis a keresett ismeretlen megtalálásának módozatai. Az araboktól származik a nulla beiktatása a számsorba: szifr, francia chiffre, ebből származik a magyarban a „sifrírozni” azaz rejtjelezni. Az első nagy matematikus és csillagász al-Hvárizmi (megh. 850) volt, az ő nevéből ered európai nyelvekben az algoritmus szó.

Az arab történetírás nagyszámú értékes alkotása közül kiemelkedik Tabari (megh. 922) évkönyv jellegü Világtörténete (Táríh). A tudományos történetírás legnagyobb alakja az újkori európai történetírásra is nagy hatást gyakorolt Ibn Haldún, akinek a világtörténete elé írt Bevezetö (Mukaddima) címủ müve elméleti és gyakorlatias alapokat nyújt a történelemírás számára.

\section{A spanyolországi iszlám civilizáció eredményei}

A tárgyi kultúra terén elsősorban az építészet és kertépítés volt hatással a rákövetkező évszázadok európai civilizációjára a Spanyol Királyságon keresztül. Az 1492-ben befejeződött visszahódítás után még több mint száz évig a félszigeten maradhattak az egykori, látszatra kikeresztelkedett muszlimok, akiket a spanyolok mindig azzal gyanúsítottak, hogy valójában régi hitüket gyakorolták. Öket hívták moriszkóknak (sp. morisco, „,mór szerü”). Ök alkották az új Spanyol Királyság kézmüves rétegét, és közvetítették a tudomány és kultúra termékeit a Közel-Keletről Európa felé. A legnagyobb hatású muszlim 
tudós a 12. században az Almohádok alatt élt filozófus, Ibn Rusd (Averroës) volt, akinek a munkáit lefordították latinra és ezeket a keresztény teológusok is felhasználták, mint pl. Aquinói Szent Tamás, a középkori keresztény teológia legnagyobb alakja. Az arab orvostudományi müvek is Spanyolországban lettek latinra fordítva, amelyek közül Ibn Szína fent említett müvét Európában még a 19. század elején is tanították az egyetemeken. Amikor 1609-ben az inkvizíció követelésére III. Fülöp spanyol király elrendelte a mórok és zsidók kiűzését Spanyolországból, azok elsősorban Észak-Afrikába menekültek, ez azonban hatalmas szakember hiányt okozott a királyságban. Spanyol történeti források szerint több mint fél millió mórt üldöztek el ekkor. Az általuk hátrahagyott és eretnek iratokként elégetett arab nyelvü könyvek számát pedig mintegy 600 ezerre becsülik. A mecseteket templomokká alakították át, a „pogány” muszlim kultúra jelképének tekintett sok ezer fürdőt pedig lerombolták. Granada eleste és a 17. század első évtizede között összességében azonban mintegy hárommillió mórt ủztek el vagy végeztek ki az iszlámba való visszaesés büne miatt.

\section{Irodalom az iszlám világ központi területein}

\section{Arab nyelvü irodalom a középkorban}

A középkori arab irodalom legfontosabb müfaja a költészet volt. Részben folytatódtak a pogány kori költészet hagyományait őrzö müfajok: a dicsvers, elégia és gúnyvers, részben pedig új müfajok születtek, mint a borvers, szerelmes vers, vallásos vers. Miután a klasszikus arab versek nagyon erős formai előírásokat és szójátékok tömkelegét tartalmazzák, fordításban nem nagyon lehet öket visszaadni.

Az első arab szépprózai mü a 8. századi Kalíla és Dimna, ami egy állatmeséket tartalmazó, az uralkodó számára készített példázat gyüjtemény. A mesék többsége indiai eredetü. Még ismertebb és nagyobb méretü az Ezeregyéjszaka címü, szerző nélküli mesegyüjtemény, amely fél évezred alatt alakult ki, indiai, perzsa és arab forrásokból. Sajátos arab müfaj a 10. században kialakult makáma, amelyben az állandó beszélő első személyben rímes prózában meséli el kalandjait egy állandó szélhámossal, amelyek az arab világ más és más városában estek meg vele. A legnevesebb makáma szerző a 12. századi al-Haríri, akit még Arany János is megemlít A poloska címủ versében. Az andalúziai arab irodalom kiemelkedő alakja a szintén 12. századi Ibn Tufajl, akinek A természetes ember címü filozófiai kisregénye magyarul is megjelent. Ugyancsak olvasható magyarul a keresztes háborúk korának egyik legérdekesebb forrása, Uszáma ibn Munkidz visszaemlékezései, A példázat könyve (Kitáb al-Itibár). Az útleírás irodalom legjelesebb alkotása a 14. századi Ibn Battúta vándorlásait bemutató, magyarra is lefordított útirajz. A szerző mintegy 20 ezer kilométernyi utat tett meg a világ körül. 
A középkori perzsa költészet

A korai muszlim birodalmak idején az arab nyelv használata az írásbeliségben háttérbe szorította a perzsát. Az arab betükkel írt újperzsa nyelvnek első és máig egyik legnagyobb hatású alkotása Firdauszi (940 k.-1021 k.) Sáhnáme („Királyok könyve”) címü történeti eposza. Az újperzsa nyelvü irodalom legismertebb alkotásai a költészet köréből kerültek ki. Umar Hajjám (1048-1131) négysoros (rubáijját) borversei és szerelmi költészete mellett a 14. századi Háfiz versei emelkednek ki európai ismertségükkel is. A 12. század kiemelkedő költője volt Nizámi, akinek fő müvét, az öt hosszú elbeszélő költeményt tartalmazó „Öt kincs”-et (Pandzs gandzs) hosszú évszázadokon keresztül előszeretettel illusztrálták. Ugyanígy fontos alkotások a 13. századból a nagy misztikus költő Dzsalál ad-Dín Rúmi párversei (mesznevi) és Szádi Rózsáskert címü, magyarul is olvasható mủve, amelyben élményeit, kalandjait, illetve az utazások során szerzett ismereteit, tapasztalatait bölcsességekké rendszerezve állította össze. A 15. században élt, a mai Afganisztán területén született Dzsámi mủvei elsősorban a misztikus naksbandi rend révén a perzsa kultúrájú térség egészében elterjedtek, Közép- és Dél-Ázsiában egyaránt. Legismertebb, hét müvét tartalmazó mủve a Haft aurang („Hét trónus”), amelynek egyik története (Júszuf va Zulejka) József és Putifárné történetét dolgozza fel a Korán 12. fejezete alapján.

\section{Az oszmán-török irodalom}

Szájhagyományon alapuló folklór anyagotés a hozzá soha nemkapcsolódott írott szövegeket egyaránt tartalmaz a törökül írt oszmánkori irodalom. A török irodalmat, amelyet arab betükkel írtak, nagymértékben befolyásolta az arab és perzsa irodalom. Akárcsak az elöző kettőben, az ún. díván költészet volt az uralkodó müfaj, a prózairodalom kevésbé volt jelentős. Mind a népi költészetet, mind az írott költészetet nagymértékben áthatották a misztikus eszmék. Az első jelentős költő Júnusz Emre (1238-1320) volt, a szúfi miszticizmus kiemelkedő alakja, aki nagy hatást gyakorolt a török irodalomra annak minden szakaszában. Korának azon költöi közé tartozott, akik nem az irodalmi nyelvben megszokott, perzsa és arab befolyás alatt álló oszmán-török nyelven írtak, hanem a beszélt nyelvhez sokkal közelebb álló szókincset használtak. Az azeri származású Fuzúli (1483-1556) a kor szokásai szerint törökül és perzsául is jelentős műveket alkotott. Nagy Szulejmán szultán korának reprezentatív költője Báki (15261600) volt, akit nagy stilisztának és nyelvmüvésznek tartanak nyilván. Nedím (1681-1730), a „tulipán korszak” forradalmi újításokat hozó költője átszötte az elit irodalmi nyelvét a népköltészetből vett fordulatokkal. A prózairodalom egyik kiemelkedő műfaja az utazási irodalom (szijáhetnáme) volt, amelynek legkiválóbb müvelője Evlija Cselebi (1611-1684). Müvében Magyarországról is írt, érdekes képet festve a 17. századi magyar közállapotokról. 


\section{Iszlám müvészetek}

Az iszlám térbeli és időbeli változatosságának hü képét adja a térség művészetének sokszínüsége. A fejezet keretei nem teszik lehetővé az összes művészeti ág bemutatását, ezért abból csak a két legjelentősebb, a mecsetépítés és a kalligráfia kerülhet röviden említésre.

\section{A mecsetépítészet stílusai}

1. Oszlopcsarnokos mecset: Ez a legegyszerübb típus, amely a muszlimokat az első mecsetre, Mohamed próféta medinai házára emlékezteti. Ezt az alaprajzot építették meg a leggyakrabban iszlám világszerte (62-63. kép) a négy ívános mecset 12 . századi elterjedése előtt. A legismertebb mecset ebben a stílusban a tunéziai Kajravánban található.

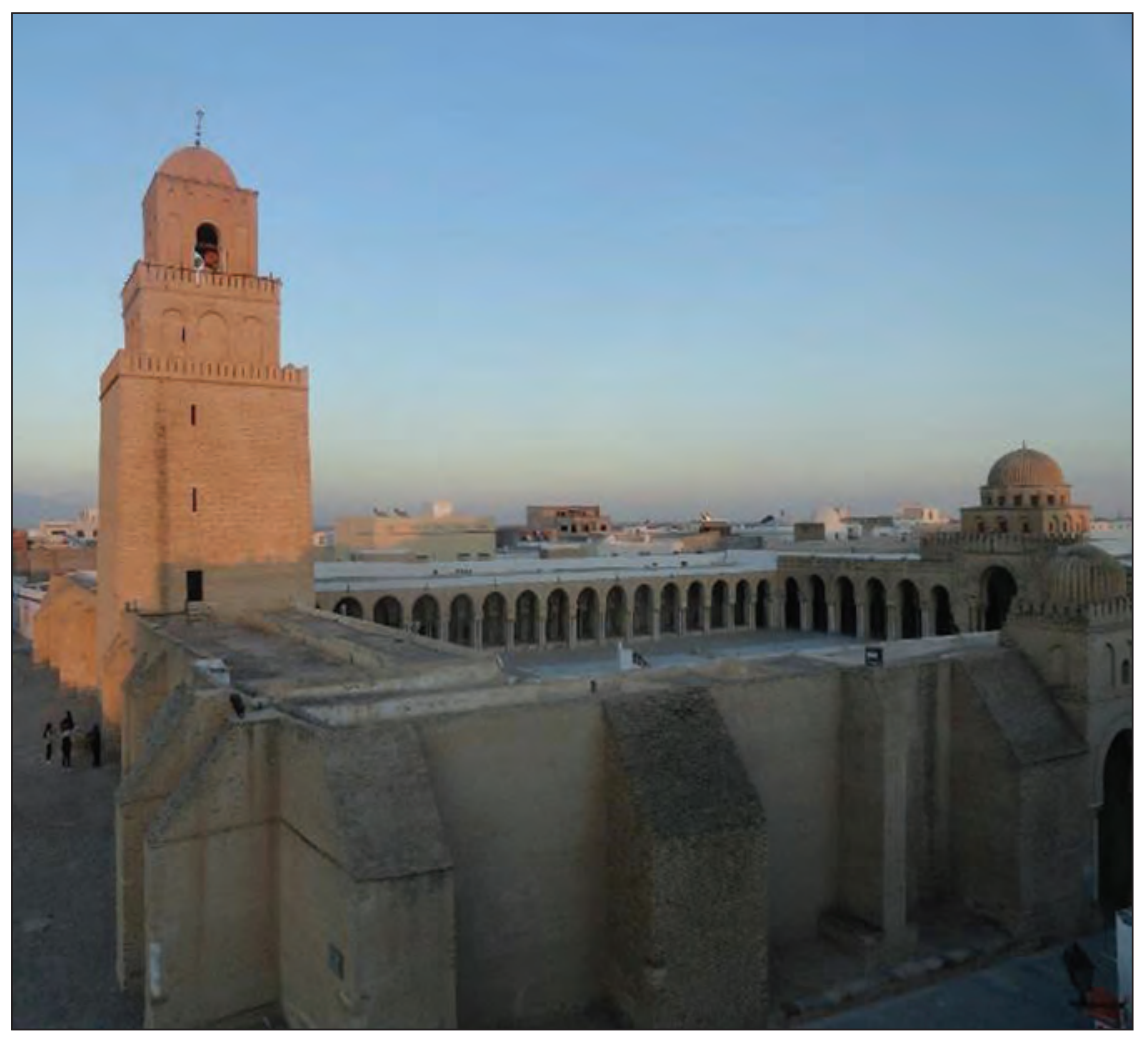

62. kép: Az Okba ibn Náfi által 670-ben alapított kajraváni nagymecset, amely végső formáját az Aglabida dinasztia uralma alatt, a 9. században nyerte el

Forrás: DÉvÉNYI KINGA felvétele 


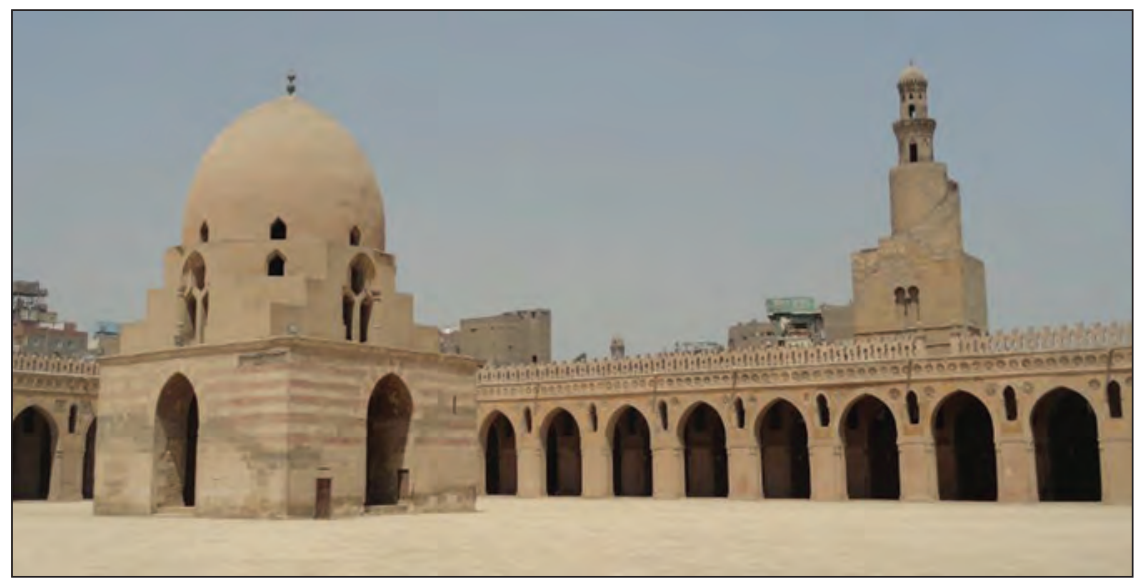

63. kép: A 879-ben épült kairói Ibn Túlún mecset és minaretje Forrás: DÉvÉNYI KINGA felvétele

2. A négy ívános mecset: Az íván az udvar felé nyitott, nagyméretủ boltozott csarnok (64. kép). Akárcsak az oszlopcsarnokos mecset, itt is egy hatalmas udvart zárnak körbe a falak. A legnagyobb íván az, amelyik az imairány (kibla) felé néz. Jóllehet Iránban alakult ki régi perzsa hatásra, később Indiától Kairóig elterjedt a vallási és világi építészetben egyaránt.

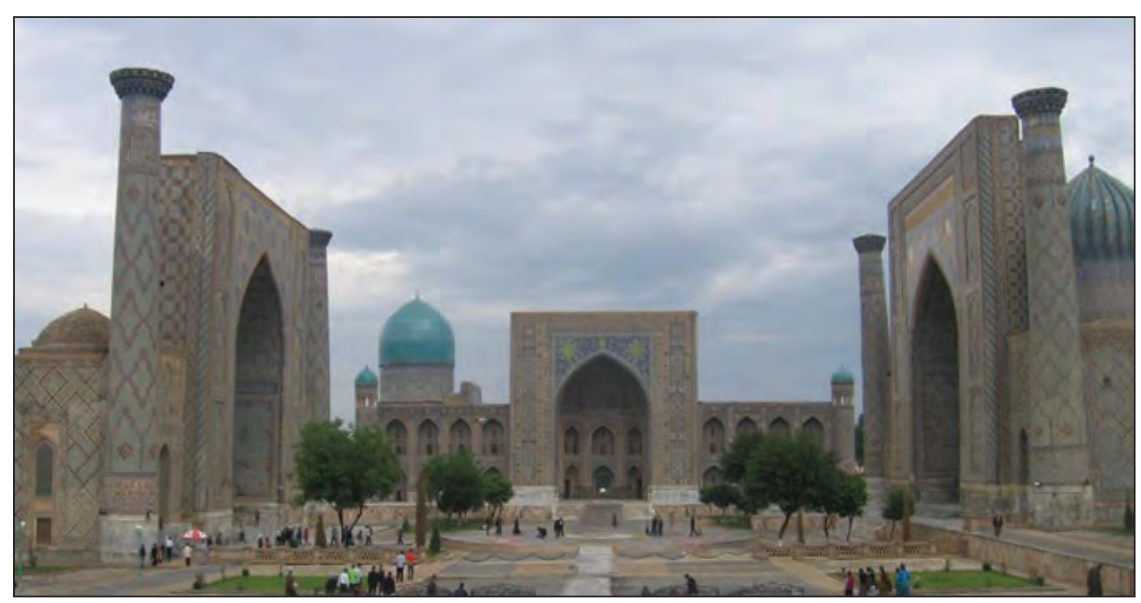

64. kép: Három 15-17. századi madrasza ívánjai Szamarkand egykori föterén (Régisztán, azaz „poros tér”)

Forrás: SÁRKözy MiKLós felvétele

3. Központos alaprajzú mecset: Az oszmán-török építészetet nagymértékben befolyásolta az isztambuli Hagia Szophia (újgörögösen Aja Szofia) templom, amely az összes bizánci templom közül a legnagyobb volt, 
s amelynek a jellegzetességét a hatalmas méretủ templomhajó fölött elhelyezkedő monumentális központi dóm adja. A török mecsetek többnyire ezt a mintát másolták.

Kalligráfia, szépirás (hatt)

Az iszlám világban a modern kor előtt a képzőművészet legfontosabb, sok helyen az egyedüli területe az arab írásos kalligráfia volt. Az írásnak oly mértékben fontos tulajdonsága volt a szépségre való törekvés, talán a könyvmásolás nagy részét leszámítva, hogy az arab írás neve, hatt, egyben kalligráfiát is jelent. A kalligráfia müvelése a magas szintű tudásanyag részét képezte és a föhivatalnokok közül kerültek ki a leghíresebb kalligráfusok (hattát), mint pl. Ibn Mukla (megh. 940), több abbászida kalifa főminisztere.

Az arab írás két, egymástól geometriailag különböző változatban fejlődött ki a 6-7. században. A szögletes kúfi írás a dél-iraki Kúfa városáról kapta a nevét (65-66. kép). Ezt használták épületek feliratai és a Korán példányok másolására a 10. századig, díszítésként azonban később is gyakran alkalmazták.

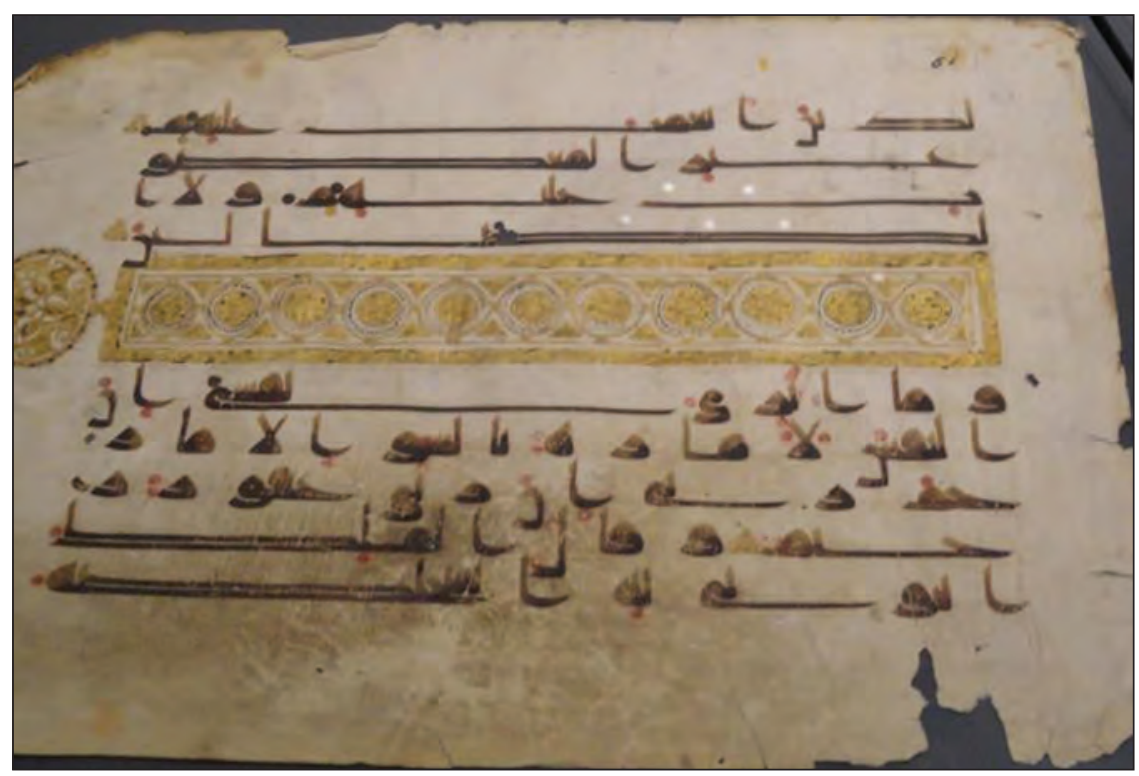

65. kép: Kúfi írásos Korán részletek $(1: 7 ; 12: 53)$ a 8. századból, a fejezeteket elválasztó dísszel. Isztambul, Iszlám Művészeti Múzem

Forrás: IváNYI L. MáTÉ felvétele 


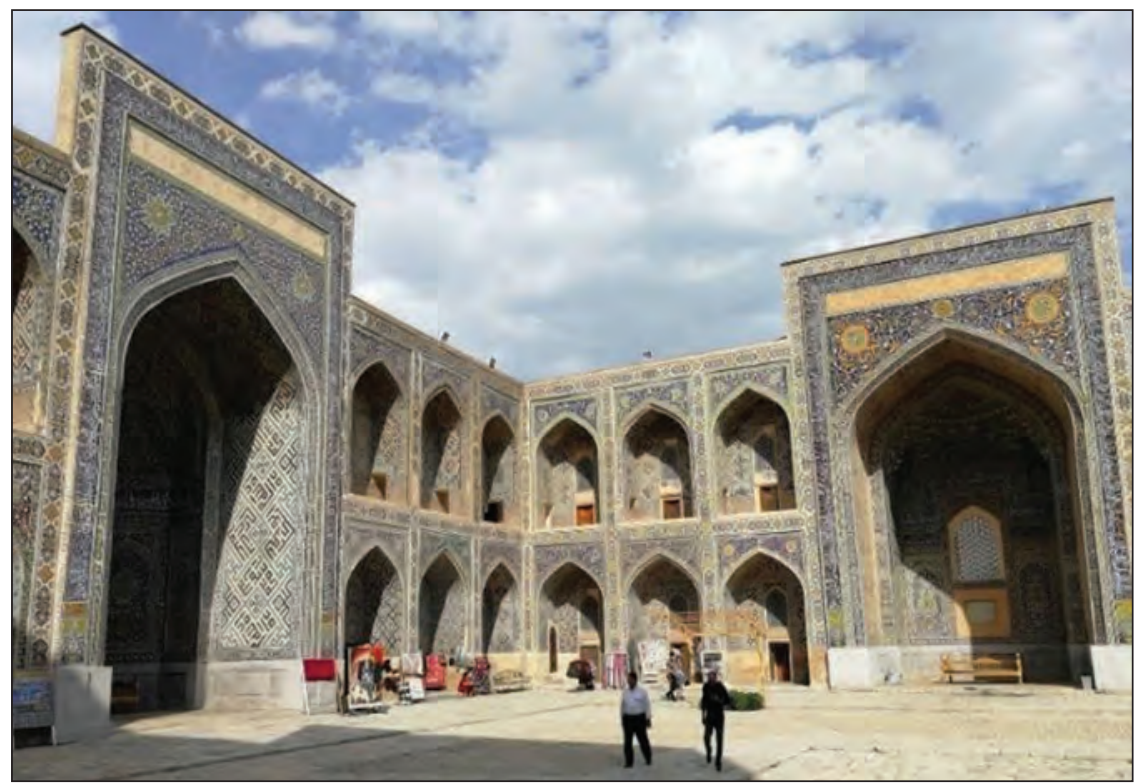

66. kép: Kúfi írásos felirattal díszített íván. Bahádur Dzsalangtús madraszája, Szamarkand, 17. század Forrás: SÁRKÖZY MiKLós felvétele

A kúfi írásból fejlődött ki a magrebi, amelyet a könyvmásolók is használtak a könyvnyomtatás bevezetéséig, és a Koránt még nyomdai formában is ezzel írták. A másik írásfajta a kerekded naszhi írás, a „másolói írás”, amellyel a kéziratokat írták a 19. század közepéig. Ebből az írásból kifejlesztettek számos díszírást is, mint pl. a szulusz, díváni, muhakkak, és ez lett a Korán írásmódja is 1000 után. A naszhi írás volt az alapja a különböző perzsa írásváltozatoknak, mint a taalík és a belőle kifejlődött nasztaalík (67. kép). A hivatalok írásmódja az apró, vékonybetüs sikaszte volt, amelyet a Török Birodalomban is átvettek. 


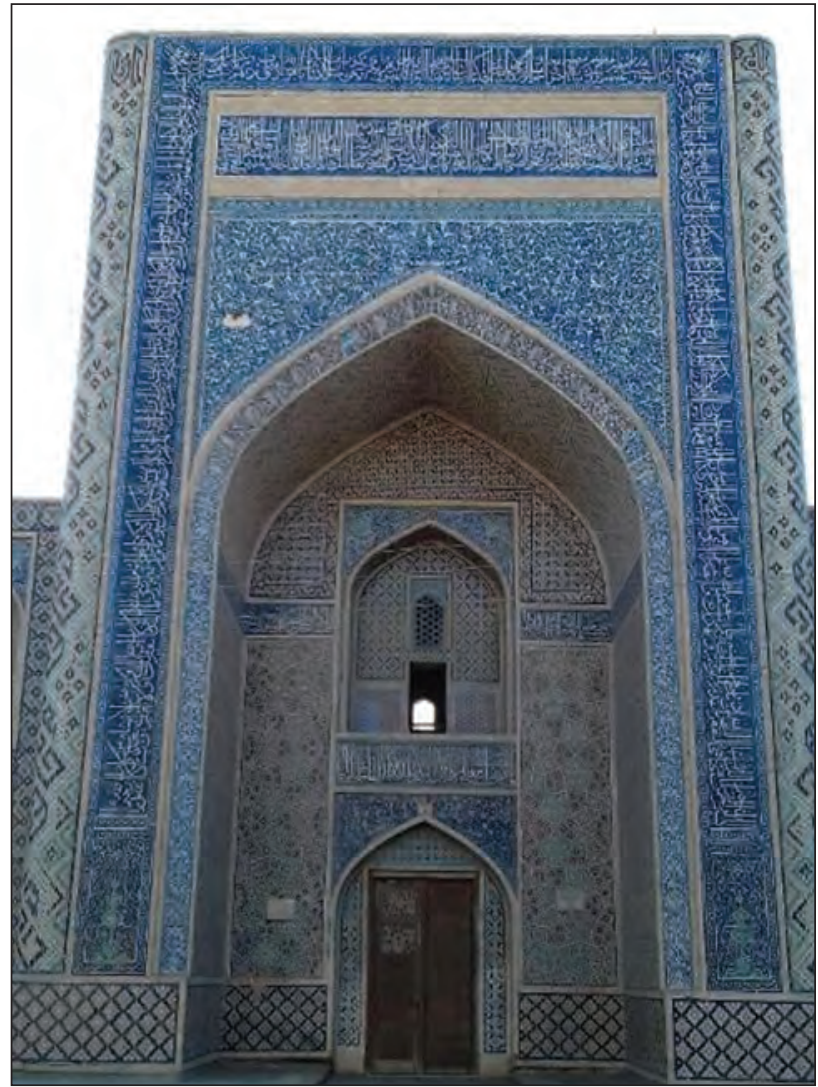

67. kép: Feliratokkal gazdagon díszített csempeburkolat. Buhara, Abdallah Hán madraszája, 16. sz. Forrás: SÁRKözy MikLós felvétele

A kalligráfia a mai napig megőrizte modern képzőmüvészeti funkcióját (68. kép).

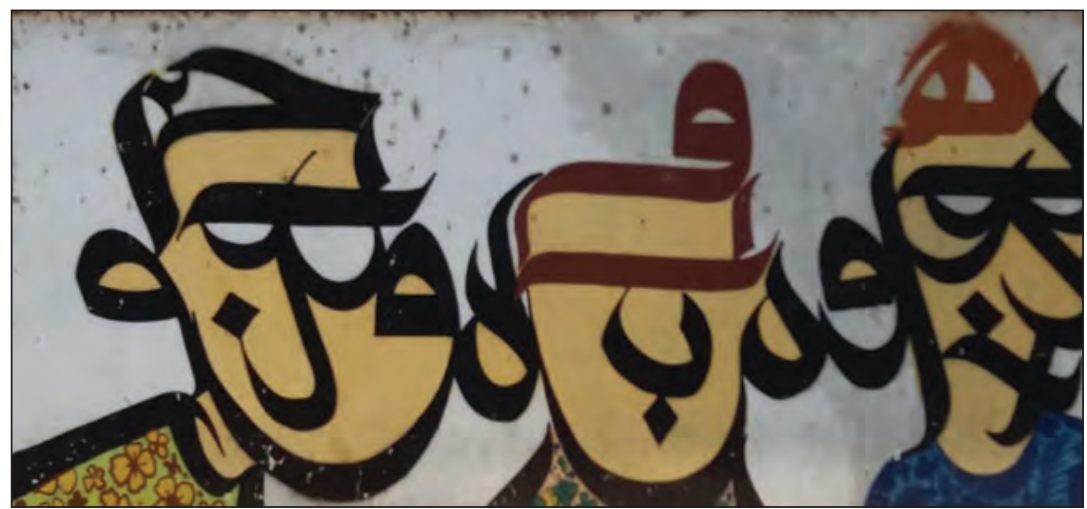

68. kép: Az arab kalligráfiát felhasználó modern kairói utcai művészet Forrás: DÉvÉNYI KINGA felvétele 


\subsubsection{Időrendi tábla}

\begin{tabular}{|c|c|c|}
\hline dátum & korszak & esemény \\
\hline 570 kör. & \multirow{12}{*}{$\begin{array}{l}\text { Mohamed } \\
\text { és az iszlám } \\
\text { kialakulása }\end{array}$} & Mohamed próféta születése \\
\hline 611 kör. & & A Korán hirdetésének kezdete \\
\hline 622 & & $\begin{array}{l}\text { A hidzsra, Mohamed kivándorlása Mekkából Medinába, a } \\
\text { muszlim időszámítás kezdete }\end{array}$ \\
\hline 624 & & $\begin{array}{l}\text { Badri csata, Mohamed első nagy győzelme a mekkai } \\
\text { pogányok fölött }\end{array}$ \\
\hline 630 & & Mekka meghódítása \\
\hline 632 & & Mohamed próféta halála \\
\hline $632-661$ & & A négy első, ,igaz úton járó” kalifa uralkodása Medinában \\
\hline $632-634$ & & Abu Bakr, az első kalifa \\
\hline $634-644$ & & Umar kalifa uralkodása \\
\hline $644-656$ & & Uszmán kalifa uralkodása \\
\hline $656-661$ & & Ali kalifa uralkodása, Kúfa központtal \\
\hline 657 & & $\begin{array}{l}\text { A sziffíni ütközet Ali és Muávija között, döntőbíráskodás, a } \\
\text { háridzsiták kivonulása Ali táborából }\end{array}$ \\
\hline $633-651$ & \multirow{5}{*}{ Hódítások } & Mezopotámia és Perzsia meghódítása \\
\hline $634-641$ & & Szíria meghódítása \\
\hline $639-642$ & & Egyiptom meghódítása \\
\hline $647-722$ & & Észak-Afrika (Magreb) meghódítása \\
\hline $711-722$ & & Hispánia (Andalúzia) déli és középső részének meghódítása \\
\hline $661-750$ & \multirow{2}{*}{$\begin{array}{l}\text { Arab } \\
\text { dinasztiák }\end{array}$} & Umajjád Kalifátus Damaszkuszban \\
\hline $750-1258$ & & Abbászida Kalifátus Bagdadban \\
\hline 756 & \multirow{7}{*}{$\begin{array}{l}\text { További } \\
\text { dinasztiák arab } \\
\text { területeken }\end{array}$} & Umajjád Emirátus Córdobában \\
\hline 929-1031 & & Umajjád Kalifátus Córdobában \\
\hline 909-1171 & & Fátimida Kalifátus Észak-Afrikában és a Közel-Keleten \\
\hline $1174-1260$ & & Ajjúbida Szultánátus Egyiptomban és Szíriában \\
\hline $1040-1147$ & & Almorávidák uralma Észak Afrikában, majd Andalúziában \\
\hline $1147-1269$ & & Almohád Kalifátus Észak-Afrikában és Andalúziában \\
\hline $1251-1517$ & & Mamlúk Szultánátus, Kairó fővárossal \\
\hline
\end{tabular}




\begin{tabular}{|c|c|c|}
\hline dátum & korszak & esemény \\
\hline 819-999 & \multirow{11}{*}{$\begin{array}{l}\text { További } \\
\text { muszlim } \\
\text { uralkodóházak }\end{array}$} & $\begin{array}{l}\text { Perzsa származású Számánidák Emirátusa Kelet-Irán, } \\
\text { Afganisztán, Közép-Ázsia és Nyugat-India területén, } \\
\text { Szamarkand, majd Buhara (Közép-Ázsia) fővárossal }\end{array}$ \\
\hline $945-988$ & & $\begin{array}{l}\text { Iráni síita Bújidák emirátusa Nyugat-Iránban és Irakban a } \\
\text { bagdadi kalifák elismerése mellett }\end{array}$ \\
\hline $977-1186$ & & $\begin{array}{l}\text { Gaznavida Emirátus, Gazna fővárossal (Afganisztán) a } \\
\text { korábbi Számánida Emirátus területén - török származású } \\
\text { rabszolga katonák uralma }\end{array}$ \\
\hline $1050-1153$ & & $\begin{array}{l}\text { Nagy Szeldzsuk Birodalom Iszfahán (Irán) központtal. } \\
\text { Uralmuk az egész Közel-Keletre kiterjedt }\end{array}$ \\
\hline 1299 & & $\begin{array}{l}\text { Oszmán szultán (bég) megalapítja a nevét viselő Oszmán- } \\
\text { török Birodalmat Kis-Ázsiában }\end{array}$ \\
\hline 1453 & & $\begin{array}{l}\text { Mehmed szultán, a hódító, elfoglalja Konstantinápolyt, amely } \\
\text { Isztambul néven a birodalom fóvárosa lesz }\end{array}$ \\
\hline 1502 & & A síita Szafavida Birodalom megalapítása Perzsiában \\
\hline $1520-1566$ & & $\begin{array}{l}\text { Nagy Szulejmán szultán uralma az Oszmán-török } \\
\text { Birodalomban }\end{array}$ \\
\hline 1526 & & $\begin{array}{l}\text { A Mogul Birodalom megalapítása Bábur szultán vezetésével } \\
\text { Indiában }\end{array}$ \\
\hline $1794-1925$ & & A Kádzsár dinasztia uralma Iránban \\
\hline 1925-1979 & & A Pahlavi dinasztia Iránban \\
\hline $1922-23$ & \multicolumn{2}{|c|}{$\begin{array}{l}\text { A Török Szultánátus eltörlése és a Török Köztársaság kikiáltása, Kemál } \\
\text { Atatürk vezetésével }\end{array}$} \\
\hline 1979 & \multicolumn{2}{|c|}{ Iráni iszlám forradalom, Homejni ajatolláh vezetésével } \\
\hline
\end{tabular}




\subsubsection{Irodalomjegyzék}

Ajánlott irodalom

Apor Éva 1991: Irán: birodalmak, hagyományok. Budapest: Kőrösi Csoma Társaság

DÉVÉNYI KINGA - IváNYI TAMÁs 1987: , Kiszáradt a toll”: az arab irás története. Budapest: Körösi Csoma Társaság

FeHÉRvÁRI GÉZA 1987: Az iszlám müvészet története. Budapest: Képzőművészeti Kiadó

FodOR SÁNDOR 2009: Szúfizmus és mágia: amulettek az iszlám világából.

Keszthely: Helikon Kastélymúzem / Budapest: Eötvös Loránd

Tudományegyetem

Germanus Gyula 2004: Allah akbar. Budapest: Palatinus

GoldziHer IGNÁC 1981: Az iszlám kultúrája, I-II. Budapest: Gondolat

GolDZIHER IGNÁc 1995: Az arabok és az iszlám: válogatott tanulmányok. -

Budapest: Magyar Tudományos Akadémia Könyvtára - Körösi Csoma

Társaság - http://real-eod.mtak.hu/27/

GolDZIHER IGNÁC 2008: Elöadások az iszlámról. Budapest: Katalizátor

Hillenbrand, Carole 2016: Az iszlám: új történeti bevezetés. Budapest:

Kossuth

Hodgson, Marshall G. S. 1977: The Venture of Islam: Conscience and History

in a World Civilization. 3 vols. Chicago: University of Chicago Press

Jeremiás Éva M. (szerk.) 2007: Iráni föld - perzsa kultúra. Piliscsaba: Avicenna

Közel-Kelet Kutatások Intézete

Káldy-Nagy Gyula 1974: Szulejmán. Budapest: Gondolat

LEWIS, BERNARD 1981: Isztambul és az oszmán civilizáció. Budapest: Gondolat

Lings, MarTin 2003: Az iszlám prófétája. Budapest: Salam

RostovÁnYi Zsolt 1983: Mit kell tudni az iszlámról? Budapest: Kossuth

RostovánYI Zsolt 1998: Az iszlám a 21. század küszöbén. Budapest: Aula

RostováNYI Zsolt 2011: A Közel-Kelet története, 1918-1991. Budapest:

Kossuth

VÁMBÉRY ÁrMIN 1966: Dervisruhában Közép-Ázsián át. Budapest: Gondolat

VinCze Frigyes 1912: Az oszmán irodalom föirányai. Budapest: Nemzetközi

Közép- és Kelet-ázsiai Társaság Magyar Bizottsága

Watt, William Montgomery 1974: The Majesty that was Islam: The Islamic World, 661-1100. London: Sidgwick and Jackson

Watt, William Montgomery 2000: Az iszlám rövid története. Budapest: Akkord

Weiss, Bernard G. - Arnold H. Green 2008: Az arabok rövid története. Budapest: Körösi Csoma Társaság 


\section{Afrika}





\subsection{Afrikai civilizációk ${ }^{10}$}

\section{SZOMBATHY ZOLTÁN}

A fejezet címében szereplő többes számú alak - „civilizációk”, nem pedig „civilizáció” - nem véletlen elírás, hanem nagyon is indokolt és szándékosan használt forma. A könyvben tárgyalt egyéb civilizációkkal szemben ugyanis Afrika (és azon belül Fekete-Afrika) civilizációit igen kevés jellegzetesség köti össze olyan mértékben, hogy az indokolttá tenné, hogy egyetlen, többé-kevésbé egységesnek számítható civilizációként tekintsünk a földrészre. Afrika kulturális, vallási, társadalmi téren olyan változatosságot mutat, hogy valójában szinte lehetetlen egyetlen civilizációként kezelni, ám jobb megoldás híján itt mégis ezt fogjuk tenni. Éppen ezért elsőként pontosan azt kell kiemelni és hangsúlyozni, hogy mennyiben és milyen értelemben beszélhetünk „afrikai civilizáció”-ról, vagy másképpen fogalmazva milyen mértékben és milyen módon képez - ha képez egyáltalán - civilizációs egységet, önálló kultúrkört az afrikai kontinens, vagy legalább annak a Szaharától délre eső része. A legfontosabb általános elv, amelyet rögtön meg kell állapítanunk, az afrikai civilizáció(k) definíciójára vonatkozik: Afrika kizárólag földrajzi (és embertani) értelemben alkot egy civilizációt, kulturális egységről Afrika esetében bajosan beszélhetnénk. Az afrikai kontinenst már csak azért sem tekinthetjük kulturálisan értelmezett civilizációnak, mert jelentős átfedés figyelhető meg más - e könyvben is tárgyalt - civilizációkkal. Így teljesen abszurd lenne például úgy tárgyalni az iszlám civilizációt, mintha a leírtak nem érintenék a fekete-afrikai muszlim népességet (a világ muszlimjainak közel ötödét, amely arány egyébként egyre nö). Itt nem elhanyagolható részletkérdésekről van szó: Fekete-Afrika népességének jelenleg legalább egyharmada muszlim (ily módon az iszlám civilizációra vonatkozó fejezetben írottak őket is tárgyalják), s közel fele keresztény (így a nyugati, illetve a keleti keresztény civilizációkról szóló fejezetek jelentős részben rájuk is vonatkoznak).

\subsubsection{Terminológiai kérdések és az afrikai civilizációk határai}

Az afrikai civilizációk tárgyalásához hasznos lesz legelöször tisztázni néhány terminológiai szempontot. Az első ezek közül maga a térség elnevezése, amely nem pusztán nyelvi kérdés, hanem egyszersmind a tárgyalandó civilizációk határvonalait is érintő elvi probléma. Az angol, francia spanyol

10 A legtöbb afrikai nyelvnek ma latin betüs írása van, amelyek természetesen eltérnek a magyar helyesírási szabályoktól, az egységes írásmód érdekében azonban minden afrikai nyelvekből vett szót és nevet magyaros helyesírással közlünk. 
és egyéb nyugati nyelveken íródott szakirodalomban gyakran találkozhatunk a „szubszaharai” melléknévvel (angol: Sub-Saharan; francia: subsaharien; spanyol: subsahariano; stb.) képzett összetételekkel (,szubszaharai Afrika”, „szubszaharai térség”), amelynek előnye az, hogy ideológiai megfontolásoktól mentes, semleges, leíró jellegü földrajzi terminus. Sajnos két hátránya is van: egyfelől a kifejezés azt sugallja, hogy a Szahara valamiféle kulturális-civilizációs határ két teljesen eltérö térség között - mint látni fogjuk, ez távolról sem igaz -, másfelől pedig (s talán ez még komolyabb gond) a kifejezés egyszerủen magyartalan, nyelvileg szerencsétlen választás. A magyar nyelvben inkább a „Fekete-Afrika” elnevezés a megszokott, s ezen semmi okunk változtatni, hiszen a magyar nyelvben a „fekete" melléknévhez semmilyen szisztematikus pejoratív értelem nem kapcsolódik. A továbbiakban tehát a „Fekete-Afrika” elnevezést fogjuk használni, illetve a tömörség kedvéért, ha külön nem jelezzük, az „Afrika” szó ebben a fejezetben Fekete-Afrikát fogja jelenteni. Megjegyzendő azonban, hogy a „Fekete-Afrika” kifejezés megfelelői több európai nyelvben használatosak voltak s részben ma is azok (pl. angol Black Africa; francia Afrique noire; stb.); ezek visszaszorulása kifejezetten politikaiideológai okokra vezethető vissza, hiszen alapvetően szintén leíró terminusokról van szó: azt a tényt tükrözik, hogy a Szaharától délre fekvő területeket zömében igen sötét bőrszínủ népesség lakja.

Mint érintőlegesen már említettük, mind a „Szubszaharai Afrika”, mind a „Fekete-Afrika” elnevezés felvet egy komoly - és végső soron megoldhatatlan - elvi problémát, jelesül azt, hogy északi irányban hol húzhatók meg FeketeAfrika embertani és kulturális határai. A probléma azért megoldhatatlan, mert valójában sehol: bár az észak-afrikai arab országok térsége meglehetősen más világ Fekete-Afrikához képest (föleg embertani, sokkal kevésbé kulturális értelemben), éles határvonal sehol sem állapítható meg. Más szóval a Szahara nem határ, hanem inkább átmeneti terület. A sivatag nagy részében a népesség többsége fekete-afrikai jellegü, míg kulturális téren bizonyos térségekben (pl. Csád szaharai területei) a fekete-afrikai kapcsolatok dominálnak, más térségekben (pl. Mauritánia vagy Algéria egyes régiói) inkább az észak-afrikai hatások. A teljes szaharai népesség muszlim, ám ez elmondható a délebbre fekvő fekete-afrikai térségről (az ún. Száhel-övezetről) is. A Szaharát az ókor óta számtalan kereskedelmi útvonal szelte át, amelyek állandó kapcsolatokat biztosítottak a sivatag két peremvidéke között; s ahogy Fekete-Afrikában is élnek (kis részben) arab származású és (nagy részben) arab kultúrájú és nyelvü népességek (Szudán, Csád), Észak-Afrikában is találunk alapvetően feketeafrikai eredetủ népelemeket (ez a marokkói és algériai ún. harátín népesség).

Egy további terminológiai kérdést is szükséges itt röviden érinteni. A magyar nyelvben (és más európai nyelvekben is) gyakran találkozunk azzal a jelenséggel, hogy afrikai népcsoportokkal kapcsolatban a „törzs” szót 
használják olyan esetekben is, amikor ez egyáltalán nem indokolt. Ez elöítéletes gondolkodást tükröz: teljesen indokolatlan olyan társadalmi csoportok esetében, amelyekre Európában vagy Ázsiában a „nép”, „népcsoport” vagy „etnikum” szót használnánk, Afrikában a „törzs” szót használnunk. Egy olyan társadalmi csoport, amely adott esetben több százezer vagy több millió főt számlál, saját közös nyelvét beszéli, esetleg politikai egységet is képez, s magára önálló népként gondol, az Afrikában is „nép” vagy „,népcsoport”, nem „törzs”. Afrikában is vannak törzsek - ahogy Ázsiában és régebben Európában is -, de az a társadalomszerveződés más (alacsonyabb) szintje. Így például a szomálik egy nép, de ezen a népen belül léteznek törzsek (pl. Dáród, Iszák, Dir, Havije, Rahanvejn, stb.).

\subsubsection{Kulturális sokszínüség}

Ahogy a bevezető sorokban már hangsúlyoztuk, Afrika kulturális téren rendkívül változatos képet mutat - ilyen mértékü változatosságot csak az ázsiai kontinens esetében figyelhetünk meg, ám Ázsiát nem is szokás egyetlen civilizációként kezelni (ahogy például ez a könyv sem teszi). A sokszínűség kérdése e fejezetben újra és újra előjön majd a különböző kulturális jellegzetességek (nyelv, vallás, társadalmi berendezkedés, politikai struktúrák, államok, külső kulturális hatások) ismertetése során. A konkrét kérdések tárgyalásakor emiatt bővebben is visszatérünk erre a szempontra; most csak általánosságban jeleznénk, hogy a kultúrának szinte nincs olyan területe vagy jelensége, amellyel kapcsolatban Afrika egységes lenne.

Kezdjük a vallás kérdésével! Az idegen hatásoktól eltekintve is - bár, mint látni fogjuk, ezektől nem lehet eltekinteni - Afrika hagyományos vallásai kevés közös, mindenütt megfigyelhető vonást mutatnak. Ám ennél is fontosabb, hogy Fekete-Afrika számos térsége a középkor óta alapvetően iszlám vallású és kultúrájú terület, míg más afrikai régiók ugyanilyen mély keresztény gyökerekkel bírnak. E két térség kevés közös vonást mutat, s kulturális orientációjuk különbözőbb már nem is lehetne (adott esetben a földrajzi közelség ellenére: a keresztény etiópiai magasföldek, illetve a muszlim Kelet-Etiópia és Szomália földrajzilag közel, vallásilag és kulturálisan fényévekre fekszenek egymástól).

Afrika nyelvi térképe még sokkal nagyobb változatosságot mutat. Egy sor - egymással semmilyen rokonságban nem lévő - nyelvcsalád nyelveit beszélik sokszor egy kisebb régión belül is, ráadásul számtalan fekete-afrikai nyelv legközelebbi rokonait más földrészeken találjuk. A Madagaszkáron beszélt nyelvek többsége például Indonézia és a Csendes-óceán térségének nyelveivel áll rokonságban (legközelebbi rokonaikat az indonéziai Borneó szigetén találjuk); Nigéria középső és északi sávjának nyelvei közelebbi rokonságban vannak például a héberrel vagy az arabbal, mint a délebbre fekvő nigériai régók nyelveivel. Szudán Kordofán tartományának déli részében legalább 
négy különböző nyelvcsaládba tartozó nyelveket beszélnek, sokszor egymás közvetlen szomszédságában fekvő hegyvonulatokon, olyan nyelvi mozaikot képezve, amely leginkább talán a Kaukázus egyes vidékeire emlékeztet.

$\mathrm{Az}$ életmód, a tárgyi és szellemi kultúra megint csak hihetetlen változatosságot mutat, amelyet reménytelen vállalkozás lenne néhány mondatban összefoglalni. Különösen figyelemreméltó, hogy sok esetben a lehető legkezdetlegesebb kultúrákat találjuk egészen fejlett államok és kultúrák közvetlen szomszédságában, amelyek adott esetben állandó és mély kulturális kölcsönhatásban voltak, vannak távoli (afrikai és Afrikán kívüli) térségekkel, ám minimális a kapcsolatuk a szomszédságukban található primitívebb kultúrájú közösségekkel. Példaként említhetjük az etiópiai magasföldek keresztény magaskultúráját, $\mathrm{s}$ tőlük nem messze olyan, végtelenül kezdetleges pásztorkodó kultúrákat, mint a muszlim afaroké vagy az Omo folyó völgyének animista töredéknépeié. A nigériai hausza és fulani nép muszlim magaskultúrái és államai mellett ott találjuk az ún. Középső Sáv (Middle Belt) igen kezdetleges kultúrájú, animista (ma részben keresztény, kisebb részen muszlim) apró népcsoportjait, anélkül, hogy a két közeg komolyabb kapcsolatban lett volna egymással. A Kongó-medence feudális államainak (köztük a 16. század óta katolikus, erős portugál kapcsolatokat ápoló Kongó Királyságnak) közelében egészen napjainkig fönnmaradtak a pigmeusok vadászó-gyüjtögető őserdei közösségei.

\subsubsection{Az afrikai civilizációk képe és torzképe: egzotikum és ideológia}

A nagyon különböző fejlettségủ afrikai társadalmak párhuzamos létezése érdekes és tanulságos torzulásokhoz vezetett mind a népszerü irodalomban, mind a szakirodalom egy részében. Az Afrikával kapcsolatos torz és hamis elképzelések három fö okra vezethetők vissza: elöször is az egzotikum hangsúlyozására az ismerős vonásokkal szemben, másodszor a politikai és ideológiai szempontok érvényesítésére, s harmadszor az ilyen szempontok egy sajátos válfajára, a rasszizmusra. Az elsőként említett tényező, az egzotikus elemek túlhangsúlyozása mélyen emberi hiba s többnyire nem húzódnak meg mögötte politikai szándékok, ám attól még igen káros lehet. Az ún. colonial gaze, a gyarmatosító szeme gyakran csak arra volt nyitott, ami idegen és bizarr, miközben az afrikai civilizáció jelentős része egyáltalán nem érthetetlen a nyugati megfigyelő számára sem.

Afrika leírásaiban sokszor túlsúlyba kerülnek a föntebb említett kezdetleges kultúrákról szóló beszámolók, miközben kevés szó esik például a külső kulturális hatásokról: ami kezdetleges és idegen, az „érdekesebb”, mint ami fejlettebb és ismerős. Tragikomikus példája ennek a tendenciának Leni Riefenstahl (19022003), a neves fényképész és filmes szudáni munkássága, amelynek során a primitív kultúrájú nuba népcsoport életét és kultúráját „mutatta be”, elfelejtve 
megemlíteni (s persze bemutatni) azt, hogy az érintettek időközben jórészt muszlim hitre tértek és maguk sem ragaszkodtak hagyományos, de nagyon kezdetleges életmódjukhoz. A szudáni muszlim kultúra nyilvánvalóan nem tűnt elég egzotikusnak ahhoz, hogy érdemes legyen megörökíteni - vagy legalább említést tenni róla.

Más esetekben a torzkép kifejezetten ideológiai megfontolások eredménye. Különösen igaz ez arra a kérdéskörre, hogy egyes afrikai kultúrák vagy kulturális elemek mennyire tekinthetők „autentikusan” afrikainak. Természetesen ez az egész gondolat tudományosan értelmezhetetlen. A civilizációk mindig is hatottak egymásra, s mivel a tengerek nem áthatolhatatlan akadályok, a kulturális hatások nem állnak meg egy-egy kontinens partjainál. Mint már utaltunk rá (a vallással és nyelvekkel kapcsolatban), az idegen kulturális hatások mindig is ugyanúgy jelen voltak Afrika történelme során, mint a világ más részein, így annak taglalása, hogy mennyire ,autentikus”, „őseredeti” egy-egy afrikai civilizációs jelenség, pontosan ugyanannyira értelmes kérdésfelvetés, mint például Európa esetében lenne. Másképpen, konkrétabban fogalmazva: hogy mennyire „autentikusan afrikai” például a muszlim szuahéli kereskedővárosok vagy az ortodox keresztény Etiópiai Császárság kultúrája, az ugyanannyira terméketlen vitatéma, mint hogy mennyire ,autentikusan európai” a nyugati kereszténység, amelynek gyökerei - mint tudjuk - a Közel-Keletre nyúlnak vissza, vagy mennyire japán a Zen-buddhizmus, amelynek előképe Kínából (de végső soron Indiából) származik. S vajon miért ne lenne az afrikai civilizáció szerves része például egy portugál barokk stílusban épült mecset, amelyet Brazíliából Nigériába visszatelepült joruba rabszolgák építettek saját vallási céljaikra a dél-nigériai Lagosban? Mégis gyakoriak az ilyen abszurd kérdésfelvetések - részben még a szakirodalomban is -, ami annyit jelent, hogy más mércével mérnénk az afrikai civilizációkat, mint a világ más civilizációit. Ez indokolatlan, s biztos jele az ideológiai szempontok jelenlétének.

Az ideológiai célok sokszor az afrikai politikai és tudományos elit körében is megfigyelhetők: például ilyen volt Mobutu Sese Seko zaire-i elnök ún. autenticité ideológiája, amelynek keretében többek között ,,autentikus” afrikai személyneveket vett fel az ország elitje, jóllehet Afrika-szerte századok óta elterjedt az arab vagy európai eredetủ személynevek használata (a későbbi Zaire területén pl. már a 16. századtól használtak keresztény személyneveket). Az autentikusság abszurd kérdése szinte minden fontosabb afrikai magaskultúrával kapcsolatban felmerült, mind kívülállók, mind afrikaiak részéről, különösen olyan esetekben, amikor egy afrikai társadalom élénk kereskedelmi és kulturális kapcsolatokat épített ki és tartott fönn a kontinensen kívül élőkkel is.

A teljesség igénye nélkül említsünk néhány afrikai népcsoportot, társadalmat, amelyeknek ,afrikaiságával” kapcsolatban értelmetlen viták folytak (és sajnos néha ma is folynak): az etiópiai magasföld keresztény népei 
(az amhara és tigrinya nyelvü népesség), az arab nyelvű szudániak és csádiak, a kelet-afrikai tengerpart szuahéli népessége, az angolai és kongói keresztény elit, a madagaszkári népesség, Nyugat-Afrika Amerikából visszatelepült fekete népessége (Brazíliából visszatért jorubák Nigériában, kreolok Libériában és Sierra Leonéban). A sor hosszan folytatható volna, de egy konkrét példa elegendő lesz illusztrációként. Az egyiptomi-szudáni határvidék fekete népessége, a núbiaiak bár afrikai nyelvet beszélnek, ám az ókor óta számos idegen kulturális hatásnak voltak kitéve: kezdve az ókori Egyiptom erôs hatásával, folytatva a középkori monofizita kereszténységgel, majd a késő középkortól kezdve az iszlám mindenütt jelenlévő hatásával. A núbiaiakat érő idegen hatások között még a Balkán-félszigetről és Magyarországról származó maroknyi bevándorlót - vagy ilyenekről szóló legendákat - is találunk (így jöttek létre az ún. kussáf és magyaráb közösségek). Mindemellett a núbiaiak ma is saját nyelvüket beszélik, őrzik jellegzetes saját kultúrájukat, s nevetséges lenne „nem valódi afrikai” népként beszélni róluk, bármit is jelentsen ez.

Nincs hely itt részletesen kifejteni az afrikai civilizációkat érő számtalan idegen hatást, még annak föbb típusait sem; de példaként említhető rengeteg kultúrnövény (az amerikai eredetü kukoricától, kakaótól és dohánytól egy sor délkelet-ázsiai füszernövényig), nagy számú hangszer és zenei jellegzetesség, írásrendszerek (lásd alább), a folklór számos eleme (pl. jellegzetes eredetmondák és népmesetípusok), és természetesen a két fö világvallás (iszlám és kereszténység), azok egész kulturális hagyományával egyetemben. A fö gyarmatosító hatalmak (angolok, franciák, portugálok) mellett különösen erős hatást gyakoroltak Afrika civilizációira az arabok (részben Észak-Afrikából, részben az Arab-félszigetről kiindulva), s újabban (de sokkal kisebb mértékben) az indiaiak. Csupán helyi jelentőségü, ám érdekes tény a zsidó kultúra hatása Etiópia magasföldi területein (az izraelita vallást átvett, s magukat zsidónak tartó falasa népcsoporton keresztül) és a kínai hatás Kelet-Afrika tengerpartján (ahol a 15. század első felében Cseng Ho (Zheng He) tengernagy vezetésével kínai flotta is látogatást tett, $\mathrm{s}$ ahol a szuahéli elit körében divatos volt bizonyos kínai luxuscikkek, például porcelánedények használata). Európa (és Amerika) hatása főleg a gyarmati kortól kezdődően jellemző, ám a világ egyéb részeihez hasonlóan ez a hatás Afrikában is erős: említhető itt az anyagi kultúra, a zene, a filmek, és persze Afrika keresztény területein a vallás.

\subsubsection{Rasszizmus és az afrikai diaszpóra hatása}

Az ideológiai megfontolások sajátos - és Afrika esetében sajnos igen nagy jelentőségü - válfaja a rasszizmus. Különös fontosságot kölcsönöz ennek a kérdésnek az, hogy Afrika kulturális változatossága miatt a rassz kérdése tulajdonképpen az afrikai egység egyetlen valódi alapja. A rasszizmus eredetileg 
az európai gyarmatosítók gondolkodásához kötődött, amely igyekezett Afrika kultúráit értéktelennek, illetve nem helyi eredetünek beállítani. Említhetök itt azok a konok próbálkozások, hogy a zimbabwei állam épületegyütteseit és egyéb kulturális vívmányait - minden alap nélkül - megpróbálták Afrikán kívüli jövevényeknek tulajdonítani, vagy a szuahéli városállamokat ,arab kereskedővárosokként" átértelmezni. Leo Frobenius (1873-1938) német néprajzkutató és afrikanista elképzelései az „eritreai” és „atlantiszi” típusú afrikai civilizációkról jó példái a rassz alapú (bár az ő esetében alapvetően jó szándékú) megközelítésnek.

A rasszizmus azonban korántsem csak az európai és amerikai kutatásra nyomta rá a bélyegét; zavarba ejtő a rasszista elképzelések népszerüsége az afrikai és amerikai fekete kutatók egy részének munkásságában is. Itt említhető a francia nyelvterület ún. négritude mozgalma, vagy az egyes amerikai tanszékek munkájában meghatározó ún. afrocentrism. Mindkét irányzatot az afrikai hagyományok ünneplése, az afrikai kulturális egység mítosza és jó adag rasszizmus jellemzi, amelyhez gyakran képtelen, minden alapot nélkülözö tényállítások társulnak az afrikai kultúrával és történelemmel kapcsolatban. (E körökben kezelik például úgy az ókori Egyiptomot, mintha az Fekete-Afrika része lett volna, s akkor vívmányai nyílván fekete-afrikai vívmányok.) Ezek az elképzelések részben egy helyrehozhatatlan, szomorú történelmi tényböl következnek: hiába az érthető nosztalgia az őshaza, Afrika iránt az amerikai fekete diaszpórában, a rabszolga-kereskedelem jellemzői miatt ma egyetlen amerikai fekete sem tudhatja pontosan, honnan származtak az ösei. Emiatt marad egyfajta összafrikai nosztalgia, és ami ezzel jár: Afrika egységének teljesen hamis elképzelése.

Afrika civilizációinak hatása az amerikai fekete diaszpórára ennek megfelelően teljesen eklektikus. Megférnek benne egymás mellett a ghánai asanti nép kente szövetei és ruhái, a Kongó-medence és más területek fafaragásai és maszkjai, a legkülönbözőbb afrikai nyelvek iránti érdeklődés, a szenegáli muszlim muríd szekta ünnepei Harlemben és másutt, az iszlámra való tömeges áttérés (a Nation of Islam fekete muszlim közössége), a legkülönbözőbb afrikai ügyekért történő politikai lobbizás, és sohasem volt afrikai ünnepek (pl. a teljesen fiktív, a karácsonyt felváltani hivatott kvanzaa) kiagyalása és ünneplése. A diaszpóra kevés eredeti kulturális hagyományt örzött meg, ami a rabszolgakereskedelem következménye: a különböző etnikumokból és területekröl származó rabszolgák egymással összekeveredve elkerülhetetlenül elvesztették nyelvüket és kulturális hagyományaikat. A diaszpórában megőrződött néhány vallási hagyomány (pl. megszállottsági kultuszok: az arab világban a zár és gnáva, Brazíliában a macumba és candomblé, a Karib-tenger térségében a vudu és santería). Bizonyos nyelvjárásokban ugyancsak megörződtek egyes afrikai szavak; erre példa a Dél-Karolina állam szigetein beszélt gullah nyelvjárás, 
bizonyos joruba szavak a brazíliai portugálban és ewe szavak a haiti kreolban, stb. Az afrikai kulturális hatások legfőbb területe azonban egyértelmüen a konyha (pl. karibi fekete konyhamüvészet, amerikai soul food, kreol konyha, stb), illetve a zene, amelyben az afrikai hatás vitathatatlan olyan zenei müfajokban, mint a jazz, a reggae és egy sor latin-amerikai zenei stílus, vagy éppen a marokkói gnáva zene.

Ahogy Afrika hatott az amerikai földrész és az arab világ fekete diaszpórájára, a fekete diaszpóra szintén hatott Afrikára. Itt újra csak a zenét említhetjük, ahol számos - sokszor afrikai gyökerekből táplálkozó - zenei stílus visszajutott Afrikába, s ott nagy népszerüségre tett szert; ilyen például az Afrika-szerte népszerủ reggae vagy a kongói (de más afrikai területeken is művelt) rumba. Egy érdekes, de igen korlátozott mértékü hatás a Jamaicában létrejött rasztafári szekta jelenléte egyes afrikai országokban. A szekta tanításai hangsúlyozzák Afrika (főleg Etiópia) mint őshaza vonzását és a visszatelepülés vágyát, amelyet egyes szektatagok meg is valósítottak. Bár történelmi okokból gyakorlatilag kizárható, hogy bármely jamaicai fekete ősei Etiópiából származnának, a dél-etiópiai Sasemene városban az odatelepült jamaicaiakból létrejött egy kis létszámú rasztafári közösség. Mint említettük, a diaszpóra számára - érzelmi és ideológiai okokból - Afrika tulajdonképpen egyetlen civilizációs egység, még ha a tények ennek ellent is mondanak.

\subsubsection{Etnikai és nyelvi viszonyok}

Ahogy más földrészek népeit, úgy Afrika lakosságát is többféle szempontból lehetséges kategorizálni. Használhatunk származási, biológiai, kulturális és nyelvi kritériumokat, s ezek mindegyike nyilvánvalóan más felosztást fog eredményezni. Például teljesen azonos származású vagy egymással közeli embertani rokonságban álló népességek adott esetben nagyon különböző nyelveket beszélhetnek; hasonló kultúrájú népek sokszor teljesen más nyelveket használnak és egészen eltérő a származásuk, és így tovább. A következőkben a leginkább objektívnek tünő szempontot, a nyelvi hovatartozást választjuk alapvető kritériumnak s ez alapján mutatjuk be Afrika népeinek fóbb csoportjait, újra csak hangsúlyozva, hogy ez nem az egyetlen lehetséges módja a kategorizálásnak. Ugyancsak érdemes hangsúlyozni, hogy a nyelvi kötődés egyáltalán nem feleltethető meg a leszármazásnak: így például a fekete-afrikai arab nyelvü népesség (elsősorban Szudánban és Csádban) elhanyagolható kivételekkel egyáltalán nem arab származású, hanem olyan fekete-afrikai, fekete bőrủ népesség, amely az utóbbi pár évszázad során átvette az arab nyelv használatát (és kis mértékben keveredett is arab bevándorlókkal). A kelet-afrikai országok (Kenya, Tanzánia) „arab” lakossága szintén túlnyomórészt afrikai származású, sőt itt még az arab nyelv használata sem jellemzö, csupán fiktív arab ösökre történik hivatkozás. Az 
etiópiai keresztény amhara nép egy sémi nyelvet beszél, de származására nézve nem tisztán sémi nép, hanem (nagyobb részt) a helyi afrikai népesség és (kisebb részt) Arábiából érkező bevándorlók keveredéséből alakult ki.

A keveredés kérdése rendkívül fontos Afrika történelme és néprajza szempontjából, így a nyelvi felosztás tárgyalása előtt legalább röviden erröl is szólni kell. Akárcsak Európában, Afrikában is igaz az, hogy a legnagyobb létszámú népcsoportok zöme kisebb népek tömeges asszimilációja során jött létre. Sok esetben az asszimiláció úgy zajlott, hogy egy kiterjedt, nagy hatalmú feudális állam államalkotó népcsoportja asszimilálta magához az alávetett helyzetủ népek tömegeit, de a folyamat sokszor központosított állam - sőt bármiféle államhatalom - nélkül is lezajlott. A Nyugat-Afrika-szerte elterjedt fulani (más néven fulbe) nép például több nagy iszlám teokratikus államot hozott létre (többek között a mai Nigéria és Mali területén), s ezekben az államokban tömegesen vették át más népek tagjai a fulani nyelvet és kultúrát, $\mathrm{s}$ váltak ilyen módon fulanivá. (A folyamat nyilvánvaló párhuzamokat mutat sok európai nép kialakulásával, elegendő itt a francia állam szerepére utalni a francia nép kialakulásában és más nyelvű népességek asszimilációjában.) A kelet-afrikai partvidék szuahéli népessége vagy Észak-Nigéria hausza népessége kisebb helyi államok keretei között asszimilált magához hasonló módon más népeket. Dél-Etiópia oromo (más néven galla) népcsoportja pedig úgy olvasztott magába hatalmas számban idegen etnikai elemeket, hogy egyáltalán nem hozott létre államot, így az asszimilációs folyamat nem kötődött a szervezett politikai vezetéshez. Érdemes megjegyezni, hogy az ilyen módon létrejött népek közül nem egy Afrika legnagyobb lélekszámú népei közé tartozik (a hausza ma Fekete-Afrika legnagyobb, az oromo pedig a második legnagyobb lélekszámú népcsoportja, $\mathrm{s}$ a fulani is egyike a legnagyobb afrikai etnikumoknak). A nyelvi-etnikai asszimiláció jelentőségét nehéz lenne eltúlozni, ráadásul az ilyen folyamatok ma is alakítják Afrika etnikai térképét.

Mindezek elörebocsátásával tekintsük át röviden Fekete-Afrika népességének nyelvi csoportosítását (25. térkép)! A csoportosítás során praktikus szempontok szerint haladunk: a gyorsabban áttekinthető - mert kisebb jelentőségü - nyelvi csoportokkal kezdjük, s az összetettebb, sok nyelvet magukba foglaló és Afrika nagyobb részén jelen levő csoportokat a végére hagyjuk.

Inkább kuriózumnak tekinthető Afrika egésze, az afrikai civilizáció szempontjából az úgynevezett koiszan nyelvcsalád. Az ebbe a nyelvcsaládba tartozó nyelveket néhány, a kontinens déli részén élő vadászó-gyüjtögető töredéknép beszéli (elsősorban a dél-afrikai és namíbiai Kalahári-sivatag területén), s a történelmi korokban e népek jelentősége minimális volt. A nyelvcsalád két fó ága a koin, illetve a szan nyelvek csoportja. A koin nyelvü népeket régebben a tisztázatlan eredetü hottentotta névvel illették, míg a szan népekre a busman (a. m. „bozótlakó”) szót használták; e nevek használata a szakirodalomban ma nem szokásos. A koiszan nyelvek legfeltünőbb sajátossága 
Civilizációk Kelettől Nyugatig

a különféle csettintő hangok használata; e nyelvek beszélőinek száma csökken a nyelvi asszimiláció miatt.

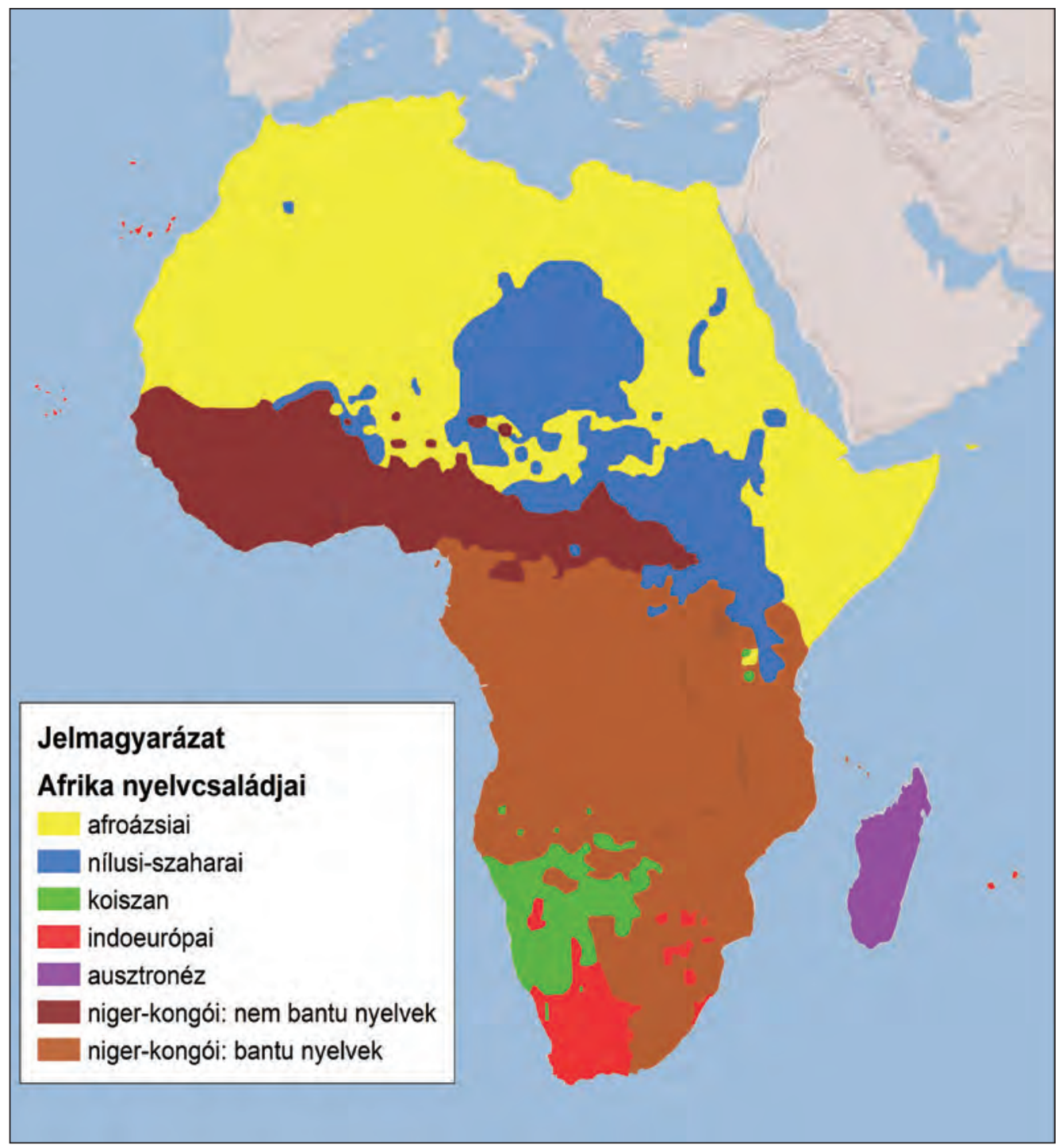

25. térkép: Afrika nyelvcsaládjai

Forrás: VARGA ÁGNES szerkesztése

Az afrikai kontinensen nem, ellenben a kontinens keleti partjai mentén húzódó Madagaszkár szigetén nagy számban vannak jelen az ausztronéz (régebbi nevén maláj-polinéz) nyelvcsalád nyelvei. E nyelvcsalád nyelveit nagyrészt Délkelet-Ázsia és a Csendes-óceán térségében beszélik, s Madagaszkárra is e térségből érkező bevándorlók hozták az ilyen nyelveket. A bevándorlók később az afrikai kontinensről érkező egyéb népelemekkel keveredtek, így az ausztronéz 
nyelveket itt fekete-afrikai eredetű népességek is használják. Madagaszkár hivatalos nyelve, a malgas (franciás írásmóddal malgache) jellegzetes ausztronéz nyelv. A nyelvcsalád jelentősége Afrika egyéb területei szempontjából elhanyagolható.

Szólni kell az indoeurópai nyelvcsaládról is, bár ezeket a nyelveket (elsősorban az angolt, franciát és portugált) nagyobb mértékben csak a huszadik századtól használják Afrikában. Ezeknek a nyelveknek a jelentőségét az adja, hogy bár nagyon kevés afrikai használja öket anyanyelveként, a volt gyarmattartó hatalom hivatalos nyelvét a legtöbb afrikai ország megőrizte hivatalos, állami nyelvként. Ennek okaként többnyire az afrikai országok nyelvi sokszínűségét szokták említeni - hiszen ez szükségessé teszi egy összekötő nyelv használatát - , de ez az indok két okból sem állja meg a helyét. Egyrészt a soknemzetiségü, soknyelvü afrikai országok nagy részében létezik egy afrikai összekötő nyelv is, amelyet a többség megért (pl. Szenegálban a volof, Kongóban a lingala, Elefántcsontparton a gyula, a kelet-afrikai országokban a szuahéli, stb.). Másrészt jellemzően azokban az afrikai országokban is megőrizték a volt gyarmattartó nyelvét hivatalos célra, amelyek gyakorlatilag egynyelvűek: jó példa erre a francia mint hivatalos nyelv Ruandában, ahol mindenki jól beszéli a helyi kinyarvanda nyelvet. A soknyelvüség tehát inkább ürügynek tünik, s a valódi ok az lehet, hogy a gyarmati korban létrejött afrikai politikai elit igyekszik hatalmi és kulturális monopóliumát megörizni, s a társadalmi mobilitást nyelvi eszközökkel is korlátozni. Anyanyelvként az európai nyelveket igen kevesen beszélik Afrikában, bár itt-ott kialakultak sajátos helyi változatok (pl. a dél-nigériai pidgin English vagy a Sierra Leone-i krio), és persze ott van még a Dél-Afrika fehér népessége által beszélt angol és a holland egy változatának nevezhető afrikaans.

Az afroázsiai (régebbi elnevezéssel sémi-hámi) nyelvcsalád neve magáért beszél: e nyelveket részben Afrika, részben Ázsia területén beszélik; megjegyzendő, hogy az afroázsiai nyelvek beszélőinek nagy többsége afrikai. E nyelvcsalád nyelvei több ágba sorolhatók; amelyek közül említésre méltó a sémi, a berber, az óegyiptomi, a kusita, a csádi és az ún. omói (vagy omotikus) nyelvek ága. A ma már kihalt (és egyébként sem Fekete-Afrikában használt) óegyiptomi nyelvvel és az Etiópia délnyugati részén aprócska néptöredékek által beszélt omói nyelvekkel itt nem foglalkozunk, de a másik négy csoportot külön is tárgyaljuk:

A sémi nyelvek egy részét (például a hébert, az arámit, részben az arabot) Délnyugat-Ázsia, a Közel-Kelet területén beszéliknem afrikai eredetűnépességek. A sémi nyelvủ népesség nagyobb része azonban afrikai. Messze a legfontosabb sémi nyelv az arab, amely az afrikai kontinens északi sávjának hivatalos nyelve, ám Fekete-Afrikán belül, a Szaharától délre is rengeteg ember anyanyelve. Több millió arab anyanyelvü beszélő él Szudánban és Csádban, amely népesség zöme az arab nyelv használatát átvett afrikaiaktól származik. A sémi nyelvek másik nagy tömbje Fekete-Afrika területén, az etiópiai magasföldön található, ahol a többségében keresztény vallású amhara és tigrinya nyelvü népesség politikailag 
is vezető szerepet játszik, így Etiópia hivatalos nyelve az amhara. Ezek a modern sémi nyelvek a középkori ge'ez nyelv leszármazottai, amely írott nyelvként egészen napjainkig fönnmaradt az etióp keresztény egyházban.

Noha a berber nyelvjárásokat nagyrészt Észak-Afrikában és a Szahara nyugati felében beszélik, a déli berber anyanyelvü csoportok (föleg a tuaregek, akiknek nyelve tamasek néven ismeretes) Nyugat-Afrika bizonyos területein (pl. Maliban, Nigerben) is jelen vannak. A rabszolgaság és a gyakori vegyes házasságok következtében a berber nyelvű afrikaiak jelentős része fekete bőrü. Megjegyzendö, hogy a tuaregek önálló írásrendszert (az ún. tifinagh írást) is kialakítottak, bár a nomád életmód körülményei között ennek használata mindig is korlátozott volt. Ennek az írásnak a modern változatát Marokkóban ma már általános iskolákban tanítják a standardizált berber nyelv lejegyzésére.

A kusita nyelvek Afrika egyik legfontosabb, legtöbbek által beszélt nyelvcsoportját alkotják. A kusita nyelvek beszélőinek túlnyomó többsége muszlim, s jobbára az etiópiai magasföldek körül találjuk őket déli, keleti és északkeleti irányban. A legnagyobb kusita nyelv az oromo, de nem sokkal kevesebben beszélik a szomálit sem; jóval kevesebb beszélöje van az afar (vagy danakil) és a szudáni bedzsa nyelvnek.

A csádi nyelveket - az elnevezésnek megfelelően - a Csád-tó környezetében beszélik, föleg Nigéria, Csád és Kamerun területén. Bár rengeteg csádi nyelv létezik, ezek közül igazi jelentősége egynek van, amely a szuahéli után a második Afrika nyelvei között a beszélők számát tekintve: ez a hausza. Anyanyelvként a hauszát leginkább Nigéria és Niger területén beszélik, de második vagy összekötő nyelvként Nyugat-Afrika más területein is használják; a hausza nyelvü népesség szinte teljesen muszlim.

A nílusi-szaharai nyelvcsalád neve is földrajzi meghatározáson alapul, $\mathrm{s}$ arra mutat rá, hogy ezeket a nyelveket részben a Szaharában (konkrétabban a Szahara déli és délkeleti szegélyén), részben a Nílus mentén beszélik. S valóban, a nílusi (vagy nilotikus, nilóta) nyelvek beszélőit Egyiptomtól délre, elsősorban a Felső-Nílus vidékén találjuk, ahonnan egyes nílusi nyelvű (nomád állattenyésztéssel foglalkozó) etnikumok az elmúlt néhány évszázadban délebbre vándoroltak Kelet-Afrikába, a mai Kenya és Tanzánia területére. Ilyen csoport a kenyai luo, a kenyai és tanzániai maszai, míg a Felső-Nílus mentén maradt nílusi nyelvü népességek közül említésre méltók a dél-szudáni dinkák és nuerek. A nyelvcsalád szaharai ágának legfontosabb nyelve a Maliban és Nigerben, a Niger folyó középső folyása mentén használatos szongai, de említhető még a Csád és Szudán északi részén beszélt tubu és zagáva is.

Aniger-kongói nyelvcsaládAfrika-földrajzi szempontból-legelterjedtebb nyelvcsaládja, s valószínúleg ez az az afrikai nyelvcsalád, amely a legtöbb nyelvet foglalja magába. A Niger Nyugat-Afrika, a Kongó pedig Afrika déli felének legnagyobb folyója, s ez nagyjából ki is rajzolja a nyelvcsalád földrajzi 
kiterjedését: Nyugat-Afrika nagy részében és Afrika egész déli felében ilyen nyelveket beszélnek. Egy ennyire hatalmas területen elterjedt nyelvcsalád természetesen igen változatos, így leírásához belső felosztásra is szükség lesz. Két fö ágat, s azokon belül további alcsoportokat kell megkülönböztetni; a két fö ág: Nyugat-Afrika nyelvei egyfelöl, s az Afrika déli felében beszélt úgynevezett bantu nyelvek másfelöl.

Nyugat-Afrika nyelvei egy sor különálló ágba sorolhatók. Ezek közül mindenképpen említésre méltók a következők: a nyugat-atlanti nyelvek a Szenegáltól nagyjából Libériáig terjedő óceán menti területeken, melyek közül kiemelkedő fontosságú a volof (Szenegál kvázi hivatalos nyelve) és a fulfulde (a Nyugat-Afrikában mindenütt elterjedt fulani nép nyelve); a mande nyelvek Mali, Elefántcsontpart, Gambia és Guinea területén (pl. a banmana, a gyula és a mandinka); a voltai nyelvek (főleg Mali, Burkina Faso és Ghána területén); és az úgynevezett kwa nyelvek ága a Guinea-öböl partvidékén (pl. az asanti Ghánában és a joruba és igbo Nigériában).

Afrika egész déli fele a bantu nyelvek területe, mely nyelvcsoportnak önmagában is egy sor alcsoportja létezik. A bantu szó jelentése „emberek”, s azt jelzi, hogy ezekben a nyelvekben többnyire ennek a szónak valamilyen alakja fejezi ki ezt a fogalmat (pl. szuahéliül „emberek”: vatu). A bantu nyelvek közül messze a legfontosabb a szuahéli, amelyet eredetileg Afrika keleti tengerpartjának lakossága használt anyanyelveként. Erre utal maga az elnevezés is, hiszen a „szuahéli” (eredetiben: kiszvahili) szó az arab szaváhil (,partvidékek”) szóból származik. Az erős arab kulturális hatás nemcsak a szuahélik iszlám vallásában jelentkezik, hanem abban is, hogy a szuahéli szókincs egy nem elhanyagolható része arab eredetủ kölcsönszavakból áll, bár a szókincs nagyobb része és a teljes nyelvtan tisztán bantu. Az anyanyelvi beszélők mellett a szuahéli összekötő nyelvként is széleskörüen használatos Kelet-Afrika valamennyi országában, így ma a legtöbb ember által beszélt afrikai nyelvnek tekinthető. További fontos (regionális szinten összekötő nyelvként is használt) bantu nyelvek: a lingala és a kikongo a Kongó-medencében, a zulu és a kosza Dél-Afrikában, a kikuju Kenyában, és a luganda Uganda területén.

\subsection{6. Írásbeliség és szóbeli hagyomány}

Gyakran olvasható megállapítás, hogy az afrikai civilizációban az írásbeliség nem létezett, illetve elhanyagolható szerepet játszott. Ez ugyan ilyen formában egyáltalán nem igaz, de az kétségtelen tény, hogy a hagyományos afrikai kultúrákban sok helyen ismeretlen volt az írás, ahol pedig létezett, ott sokkal kisebb szerepet játszott, mint például Európában vagy a Közel- és Távol-Keleten. $\mathrm{Az}$ is fontos tény, hogy az írás ismerete és használata - ahol egyáltalán volt írott hagyomány - jellemzően szük, specializált csoportok privilégiuma volt, s az írást 
sohasem használták banális, hétköznapi célokra. Afrika társadalmainak egy része tehát valóban nem használt írást, más társadalmak pedig használták ugyan, de csak bizonyos korlátok között. Az utóbbi helyzetre a szakirodalom a „korlátozott írásbeliség" (restricted literacy) kifejezést alkalmazza; Afrika civilizációinak jelentős részében a gyarmati kor előtt ez a helyzet volt megfigyelhető.

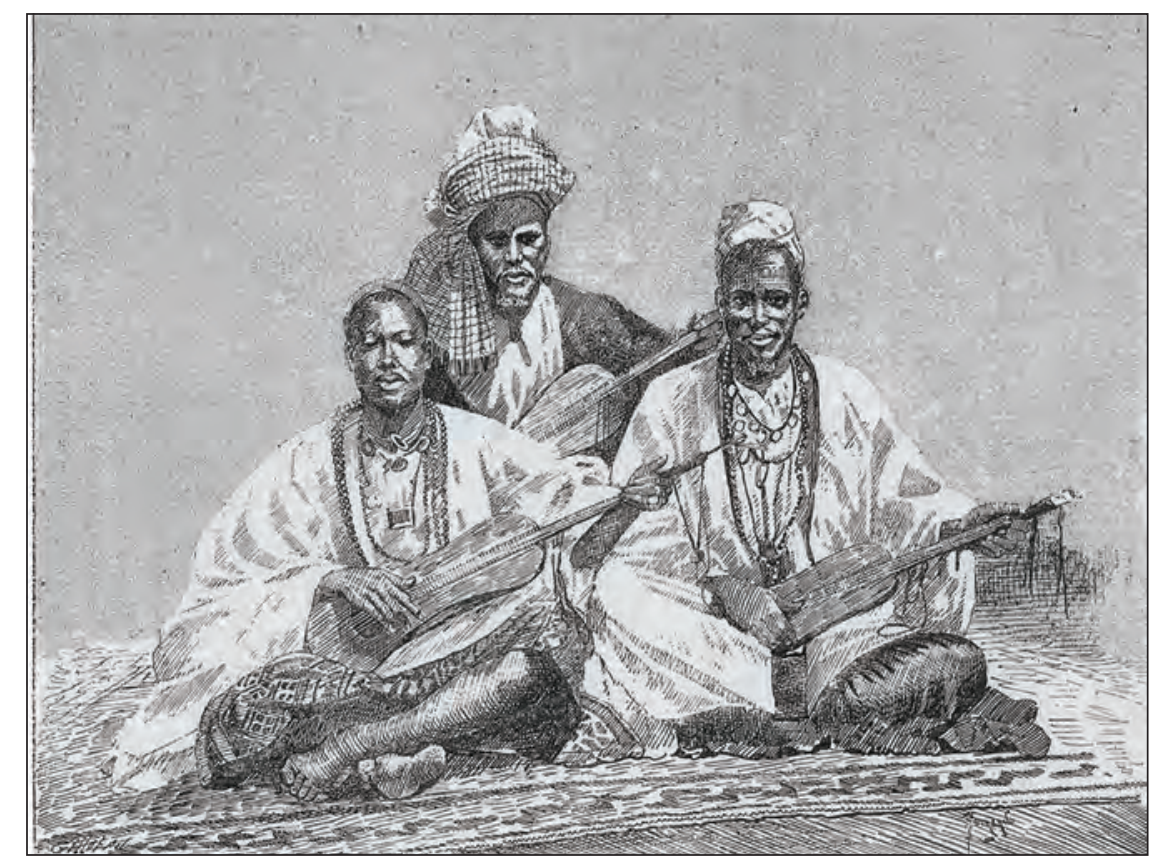

69. kép: Énekmondók (griot) Szambala király udvarából (Medina, Mali) Forrás: Henri-Nicolas Frey, Côte occidentale d'Afrique: vues, scènes, croquis, C. Marpon \& E. Flammarion, Paris, 1890, p. 128.

A szóbeli hagyományok ennek megfelelően igen hangsúlyos szerepet játszottak a történelmi emlékezet fönntartásában Afrika nagy részén. Olyannyira, hogy egy sor afrikai társadalomban külön specializált réteg - sok esetben gyakorlatilag egy endogám (csoporton belül házasodó), zárt kaszt - feladata volt a szóbeli hagyományok memorizálása, továbbadása, és az erre szolgáló alkalmakkor az előadása. Erre jó példa a Nyugat-Afrika szavannaövezetének államaiban létező úgynevezett griot (ejtsd: grió) kaszt, amelynek tagjai az uralkodók vagy nemesemberek szolgálatában pontosan ezzel foglalkoztak, méghozzá teljes munkaidőben: a történelmi hagyományok, eredetmondák, uralkodói és más előkelő családi genealógiák megjegyzésével, ápolásával és továbbhagyományozásával. Az ilyen hagyományokat sokszor zenekísérettel adták elö, így amolyan muzsikusként vagy énekmondóként is meg kellett állniuk a helyüket. A történeti hagyományok némelyike igen hosszú és részletes volt, 
annyira, hogy egyfajta eposznak is felfoghatók (69. kép). Talán a legismertebb és legnagyobb hatású ilyen eposz a Mali Birodalom alapító figurájáról, az uralkodó dinasztia első tagjáról, Szungyata Keitáról - egy valóban létezett történelmi személyről - szóló mü, amelyet mindmáig számos változatban öriznek és rendszeresen elő is adnak, többek között a térség rádióiban és televízióiban is.

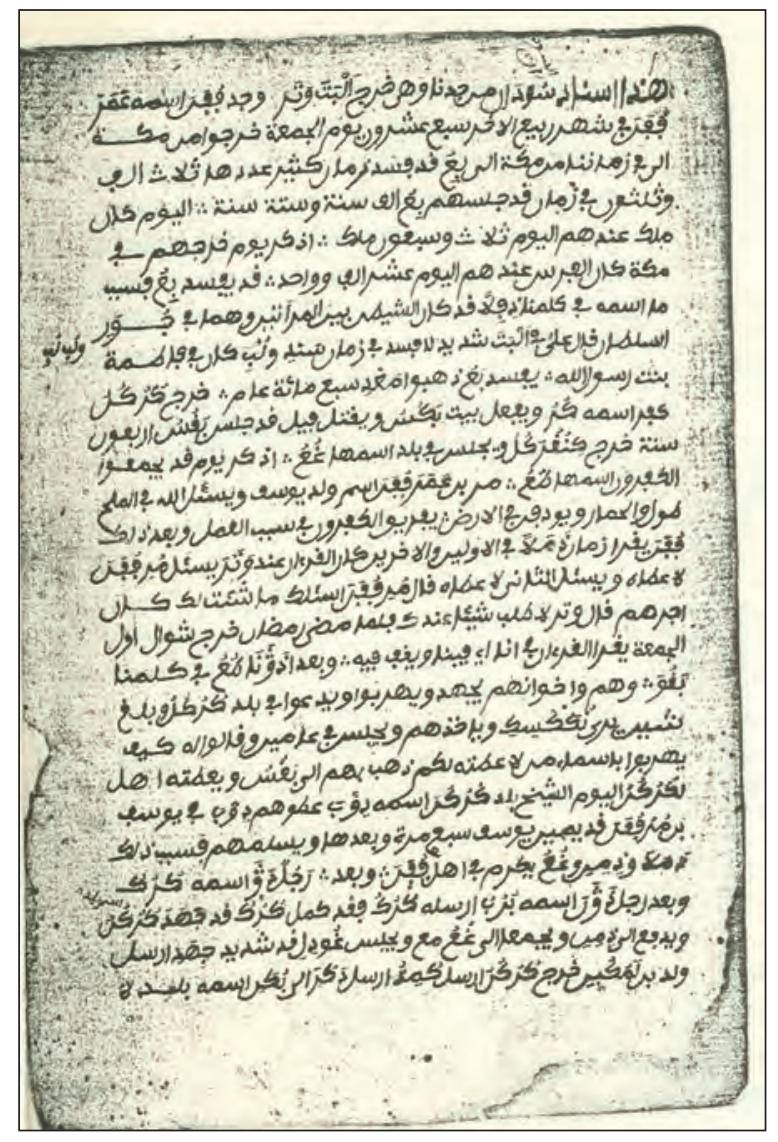

70. kép: Egy 19. századi észak-ghánai családi krónika első lapja Forrás: Muhammad Hafiz felvétele

Az afrikai írásbeliség ránk maradt alkotásai elsősorban történeti munkák (államok, dinasztiák, népcsoportok vagy családok krónikái), adminisztratív dokumentumok (adóösszeírások, birtokhatárokat rögzítő iratok, stb.) és vallásos témájú mủvek (Biblia-fordítások, Korán-másolatok és Korán-kommentárok, keresztény vagy muszlim szentek életrajzai, iszlám vallásjogi munkák). Kisebb számban irodalmi alkotások is fönnmaradtak írásos formában (például a 18. századi szuahéli költő, Mujaka bin Mvinyi Hadzsi versei). Az írott krónikák igen értékes forrásai az afrikai történelemnek, $\mathrm{s}$ ahol ilyenek léteztek és ránk maradtak, azokon a területeken természetesen sokkal többet tudunk a történelmi 
múltról, mint ahol nem állnak rendelkezésre (70. kép). Különösen kiváló történeti forrás például a középkori nyugat-afrikai birodalmak (lásd alább) két nagy arab nyelvű helyi krónikája, Mahmudu Kaati Táríh al-fattás című (késő 16. sz.) és Abd ar-Rahmán asz-Szaadí Táríh asz-szúdán címü (17. sz.) munkája. Etiópia történetével kapcsolatban is viszonylag sok írott forrás maradt fönn, $\mathrm{s}$ a kelet-afrikai tengerparton is számos verses vagy prózában írt történeti munka (utenzi és habari) létezik, többek között a középkori Kilva (Tanzánia) és Pate (Kenya) szultánságok krónikái.

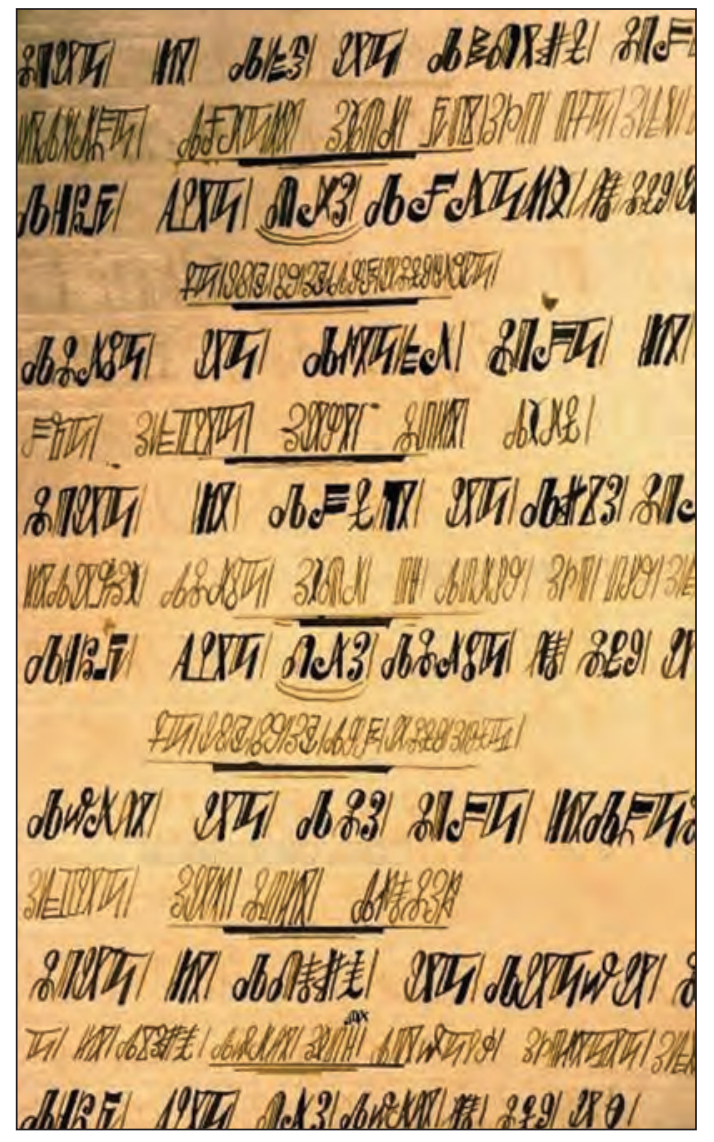

71. kép: A kameruni bamum nép írásával készült könyv, 1910 körül Forrás: Patrick Landmann/Science Photo Library

Az afrikai írásbeliség három különböző kategóriába sorolható. Ezek a következők: 1. idegen írásrendszerek használata idegen nyelvek lejegyzésére, ám afrikaiak által; 2. idegen írásjegyek használata afrikai nyelvek lejegyzésére; 3. helyben kifejlesztett írásjegyek használata afrikai nyelvek lejegyzésére. A sorrend egyben a gyakoriságot is jelzi, azaz a legelterjedtebb az volt, hogy afrikaiak saját céljaikra, egymás között idegen nyelven (konkrétan arabul vagy 
egyes európai nyelveken) írtak, az adott nyelv szokásos írásrendszerét használva, a legritkább pedig az, amikor saját írásrendszert fejlesztettek ki saját nyelvük lejegyzésére. A középső eset, amikor idegen (arab vagy latin) betükkel jegyeztek le különböző afrikai nyelvü szövegeket, bizonyos területeken nem volt ritka, de általánosnak azért messze nem mondható. Muszlim környezetben az ilyen típusú (arab betükkel, de afrikai nyelveken) született írásbeliséget gyakran adzsami (arab eredetü szó; a. m. „nem-arab”) írásnak nevezték, s a késő középkortól kezdve számos muszlim afrikai nép nyelvén találunk ilyen munkákat: például hauszául, fulfuldéül, voloful, jorubául, szuahéliül, oromóul, stb. A latin betük használata afrikai nyelvek lejegyzésére sokkal később vált jellemzővé, s eleinte a misszionáriusokhoz és a Biblia-fordításokhoz kötődött, ám idővel a latin betüs írásbeliség elvesztette vallási kötődését, s ma már - praktikus megfontolásokból - a muszlim afrikai népek is jobbára latin betúkkel írják a nyelvüket (így például az imént felsorolt népcsoportok is). Az afrikai nyelvekre helyben kifejlesztett írásrendszerek többségét mindig is kevesen és ritkán használták, de több ilyen is létezett, illetve létezik: ilyen volt a mai Mali és Mauritánia területén a középkorban kifejlesztett jászíní írás, a Maliban élő banmanák n’ko nevü írásrendszere, vagy a kameruni bamum (71. kép) és a libériai vai nép írása.

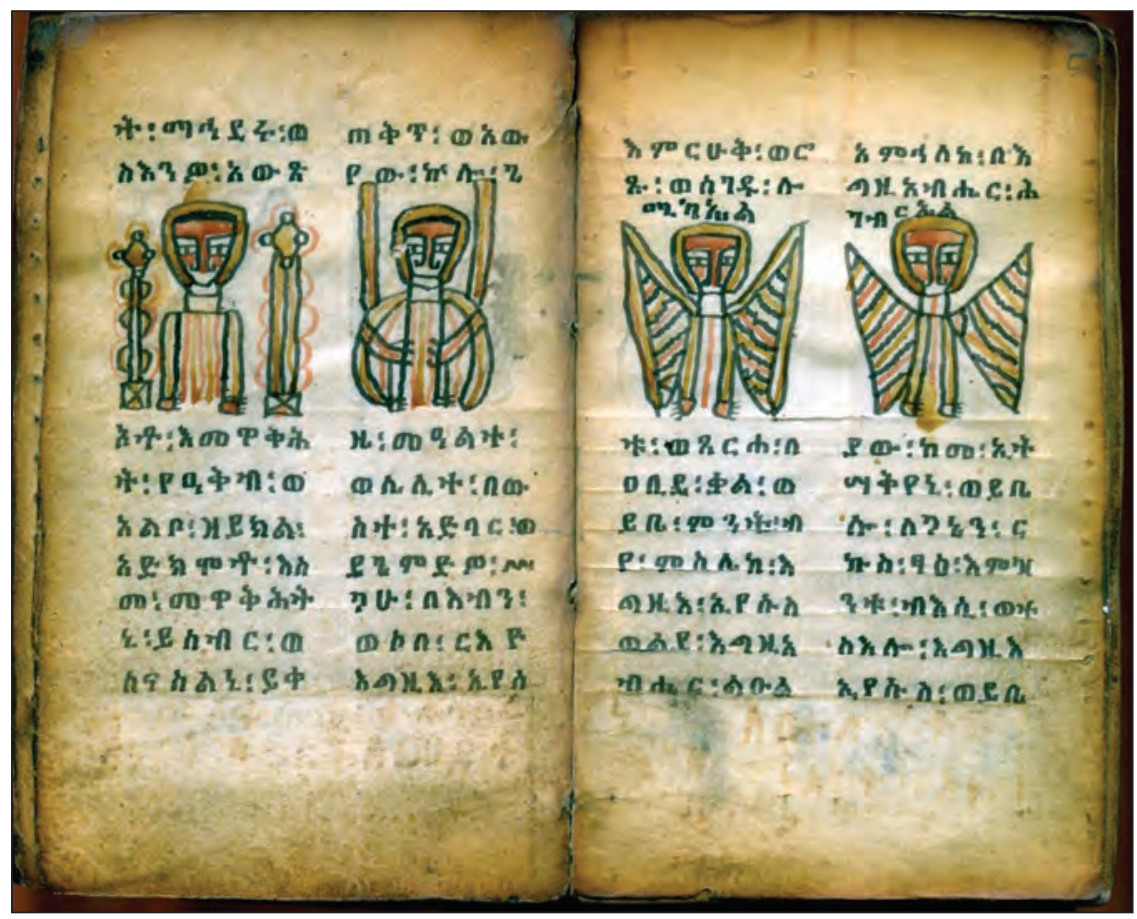

72. kép: Etióp kézirat evangélium kivonatokkal és imákkal ge’ez nyelven. A képen jobbra Mihály és Gábriel arkangyalok Forrás: MTA Könyvtár Keleti Gyüjtemény, Etióp 4 
Egyetlen olyan afrikai írásrendszer van, amelyet ösidők óta, mindmáig használnak és amelyen jelentős mennyiségü írott anyag született (beleértve ma már az újságokat, könyveket, internetes oldalakat, stb.): ez az etiópiai keresztény hagyomány lejegyzésére használt ge'ez nyelv (majd az amhara és tigrinya nyelvek) írása, amely lenyügöző vallási és irodalmi hagyomány megörökítésére szolgált és szolgál (72. kép). Bizonyos afrikai nyelvek akár többféle írásjegyeket is használtak az idők folyamán. Így például a kameruni bamumok (akik nagyrészt muszlimok), nyelvüket írták arab betükkel (adzsami), latin betükkel, majd a 20. század elején Ndzsoja nevü szultánjuk kidolgozott egy saját írásrendszert is.

\subsubsection{Társadalomszerkezet}

Afrika társadalmi berendezkedéseiről nehéz címszavakban beszélni vagy általános megállapításokat tenni. Ez egyike azoknak a témáknak, ahol a kontinens változatossága igen korlátozott mértékben engedi meg az általánosítást. Fontos azonban egy alapvető különbségtétel: míg az afrikai népesség zöme lényegében feudális berendezkedésü királyságok keretei között élt, más népcsoportok társadalmi szerveződése nem haladta meg a törzsi szintet (utóbbiakra példák Kelet- és Északkelet-Afrika állattartó nomád népei: a kusita nyelvü szomálik és afarok és a nílusi nyelveket beszélő maszaik, dinkák, nuerek). Bizonyos afrikai társadalmak meglehetősen egalitárius jellegüek voltak, kismértékü vagyoni és rangbéli különbségekkel, más társadalmakat (például Nyugat-Afrika birodalmait) kifejezetten éles osztálykülönbségek, sőt szinte kasztszerủen zárt társadalmi rétegek jellemeztek. Az utóbbi típusú társadalomban szinte mindenütt megtalálunk négy alapvetö réteget: az uralkodó környezetét adó nemességet és katonai arisztokráciát, a jobbára földműveléssel foglalkozó közembereket, a kézműves és egyéb specializált kasztokat (köztük - ahol volt ilyen - az írástudó elit csoportját és a griot-kat), s végezetül a rabszolgákat. A kontinens nagy részén jellemző volt az, hogy egy-egy állam, régió vagy település első lakói, a korai telepesek vagy alapítók, speciális jogokat élveztek, s a később odatelepült népességeket szimbolikusan az ő ,vendégeiknek”, őket pedig a későbbi jövevények ,vendéglátóinak” tekintették. Kifejezetten hasznosnak bizonyult ez a felfogás a távolsági kereskedelem számára, hiszen egy területen megjelenő idegen kereskedőcsoport jelképes státuszt nyert, mint az eredeti helyi lakosság „vendége”, s ily módon könnyebben tudott békés kapcsolatokat kiépíteni helyben, ami a sikeres kereskedelmi tevékenységet nagyban elősegítette.

A legtöbb fekete-afrikai társadalom megkülönböztetett jelentőséget tulajdonított az életkornak. Nem ritkán ez odáig ment, hogy a közösség feletti uralom kifejezetten életkori alapon szerveződött, s a legfőbb hatalom birtokosai a közösség legöregebb tagjai voltak. Az ilyen társadalmi berendezkedést 
gerontokráciának (a. m. „az öregek uralma”) nevezzük, s a szó teljes mértékben illik sok hagyományos afrikai társadalomra. Egyes népcsoportok még tovább mentek, s korcsoportokba (angol: age set) vagy generációkba sorolták a társadalom valamennyi tagját, $\mathrm{s}$ az egyes emberekkel szembeni társadalmi elvárások ahhoz igazodtak, hogy az illető melyik életkori csoport tagja. Különösen jellemző volt ez a berendezkedés például Kelet- és ÉszakkeletAfrika kusita és nílusi nyelvü pásztornépeire. Az oromo nép például 8-9 évente alakította meg egy-egy újabb korcsoportját, s akik egyazon csoport tagjai voltak, különös szolidaritást tanúsítottak egymás iránt, s közösen töltötték be az életkoruk szerint nekik kijáró társadalmi szerepet, együtt jutva el végül (mármint aki megérte) a vének nagy hatalmú kategóriájáig. Az életkor jelentősége abban is megnyilvánult, hogy a legtöbb afrikai nép ismerte és gyakorolta valamilyen formában a felnötté avatás vagy beavatás közösségi szertartását, amelynek során az érintettek rituálisan - és gyakran hosszas tanítás és felkészítés után - kiléptek a gyermek szerepéből és megkapták új társadalmi státuszukat mint újdonsült felnőttek. A beavatási szertartások mindkét nem esetében szokásosak voltak, de nemek szerint egymástól külön folytak.

Afrika fejlettebb civilizációiban - s kiváltképp a nagyobb birodalmakban - a népesség zöme ugyan földmüveléssel foglalkozott, ám a lakosság jelentős része valamilyen specializált tevékenységet ellátó csoport tagja volt. Mint föntebb említettük, külön szakemberek kasztszerü csoportja látta el a történelmi hagyományok megőrzésének és továbbadásának feladatát. Ugyanígy külön társadalmi csoport, sőt adott esetben külön etnikai csoport birtokolta az írástudást igénylő pozíciókat (ilyen volt például a nyugat-afrikai szavannaövezet muszlim írástudó elitje, az úgynevezett gyakanke etnikum). Különösen nagy jelentőséggel bírtak a távolsági kereskedelmet müvelő - sok esetben kifejezetten monopolizáló - rétegek vagy etnikai csoportok. Az ilyen specializált kereskedő közösségek gyakran hatalmas területet behálózó kereskedelmi hálózatokat müködtettek; jó példa erre a nyugat-afrikai vangara vagy gyula etnikum kereskedelmi hálózata a Guineai-öböl partvidékétől egészen a Szahara déli szegélyéig. Ez a hálózat déli irányban szaharai sót és észak-afrikai luxuscikkeket szállított dél felé, ellenkező irányban pedig kóladiót, szöveteket, elefántcsontot és föleg aranyat.

$\mathrm{Az}$ arany a gyarmatosítás kora elött Afrika egyik legföbb exportcikke volt, s Fekete-Afrikán belül is keresett árunak számított. Aranybányák sokfelé müködtek, mindenekelőtt a mai Guinea és Ghána, illetve Zimbabwe és Mozambik területén. A középkori és kora újkori nyugat-afrikai birodalmak (például a Mali és Szongai Birodalom és később az Asanti Királyság) gazdagságukat mindenekelött az arany exportjának köszönhették, s ugyanez elmondható KeletAfrika olyan államairól is, mint például a mai Zimbabwe területén létezett Monomotapa. Európába olyan mennyiségben érkezett az afrikai eredetü arany, hogy az etimológiai magyarázatok szerint az angol guinea („,font, aranytallér”) 
szó a Guinea földrajzi névre vezethető vissza. Amikor Mansza Músza Keita (1312-1337) mali császár mekkai zarándoklata során kíséretével áthaladt Kairón, hosszú évekre leverte ott az arany árfolyamát, olyan mennyiségben hozott magával a nemesfémből.

$\mathrm{Az}$ arany mellett volt egy másik exportcikke is Afrikának, amelynek kereskedői igen nagy haszonra tehettek szert: a rabszolga. A rabszolgakereskedelem és a rabszolgaság mindig is jelen volt Afrika társadalmaiban - legalábbis a rétegzett társadalmakban -, ám többnyire korlátozott mértékü maradt és nem határozta meg alapvetően a társadalom jellegét és müködését. Ez a helyzet két tényező miatt változott meg a kora újkorban: egyfelől a Közel-Kelet arab országai immár nem tudtak Európa és Közép-Ázsia felől nagy mennyiségben rabszolgákat importálni, így figyelmük Fekete-Afrika felé fordult, s ennél is nagyobb jelentőségü és tragikusabb volt az Újvilág ültetvényes gazdálkodásának munkaerőigénye, amely az afrikai rabszolgák millióira teremtett keresletet. Afrika számára igazán az utóbbi, az atlanti rabszolga-kereskedelem járt tragikus következményekkel: szétzilálta a hagyományos társadalmi kereteket, létbizonytalanságot teremtett és folyamatos háborúkat szított. A rabszolgák összefogdosásából és eladásából a közvetítő kereskedők csoportjai komoly gazdagságot harácsoltak össze, de egyfajta parazita gazdasági berendezkedést hoztak létre, s szomszédjaikra mérhetetlen szenvedést zúdítottak. Ilyen parazita kereskedö-közösségek a nyugat-afrikai és a kelet-afrikai partvidéken is létrejöttek; az előbbiek jórészt keresztény, az utóbbiak muszlim afrikaiak. (A gazdag rabszolga-kereskedő réteg tipikus példája a késő 19. századi, kongói származású kereskedő, Hamed bin Muhammed al-Murdzsebi, közismertebb ragadványnevén Tippu Tip, akinek önéletrajza mellesleg a szuahéli irodalom egyik klasszikus szövege.) A pontos számot felbecsülni is nehéz, de Afrika népességéből sok-sok milliót hurcoltak el az Atlanti-óceán túlpartjára, s további milliók vesztették életüket az út során vagy a háborúskodásokban. Afrika történetében nem találunk még egy olyan tragikus epizódot, mint a rabszolgakereskedelem kora.

\subsubsection{Vallás}

A hagyományos afrikai vallási élet annyira változatos, hogy igen kevés az általánosan jellemző vonás. Az afrikai helyi vallások többsége kifejezetten csak egy-egy etnikum sajátja volt, vagyis etnikai vallásokról beszélhetünk; például a pásztorkodó maszaik föistene, Ngai az ószövetségi istenséghez hasonlóan csak egyetlen etnikum sorsát tartotta szem elött (többek közt a világrend elleni bünnek tartotta, ha a maszaikon kívül más népek is szarvasmarhákat birtokoltak). Már abban sem egységes a kép, hogy az afrikai vallások monoteizmusnak vagy politeizmusnak mondhatók inkább. A legtöbb afrikai vallás számon tartott 
egyetlen teremtő istenséget, aki az egész világot - s így a többi istenséget vagy szellemet is - megteremtette. Emiatt akár egyistenhitnek is nevezhetjük ezeket az elképzeléseket, amennyiben hangsúlyozzuk, hogy a többi istenség alacsonyabb státuszú lény, mint a teremtő isten. Egyes afrikai vallások - például a kusita nyelvü népek ég-istenének, Váknak a kultusza - pontosan ezt a felfogást mutatják, s így joggal tekinthetők egyfajta monoteizmusnak. Más afrikai népek vallási életében azonban inkább az volt a hangsúlyos elem, hogy a teremtéssel véget ért a föisten tevékenysége, $\mathrm{s}$ a továbbiakban már nem avatkozik a világ dolgainak folyásába (az ilyen szerepet betöltő istenséget nevezi a szakirodalom latin kifejezéssel deus otiosusnak); így a tulajdonképpeni vallási kultusz központjában a többi, teremtett istenség áll, amelyek a világ dolgait igazgatják, s amelyeknek emiatt szükséges a kedvére tenni. Ilyen értelemben az afrikai vallások gyakran inkább a politeizmus vonásait mutatják. Megjegyzendő azonban, hogy ez attól is függ, hogy ezeket a lényeket ,istenség”-ként vagy inkább „,szellem”-ként definiálják a kultusz követői, hiszen utóbbi értelmezés összefér a monoteista tanokkal (így az iszlámmal és a kereszténységgel is). Ez teszi lehetővé, hogy például a joruba muszlimok és keresztények is megörizhessék az úgynevezett orisák kultuszát, de immár nem isteneknek, hanem szellemeknek tekintve ezeket.

A különböző testetlen, láthatatlan, ám az emberekkel kölcsönhatásban álló lényekben való hit általánosan jellemző volt - ma is az - Afrikában. Ezt a hitet, amely szerint az állatok, növények, sőt élettelen tárgyak is lélekkel, s ennek folytán akarattal is bírnak, animizmusnak hívjuk. Az afrikai vallásos elképzelésekben a szellemek (vagy istenségek) sokféle típusa jelenik meg, s mindegyik típus sajátos szertartások tárgya. Így egyes szellemek helyekhez kötődnek (helyi szellemek), mások védelmeznek egyes személyeket vagy közösségeket (védőszellemek), ismét mások beköltözhetnek az emberek testébe (megszálló szellemek), s talán mindezeknél fontosabb és elterjedtebb az ősök szellemeiben való hit és ezek kultusza.

Az ősök kultusza sokféle formát ölthet - gyakori szertartás például a speciálisan erre szolgáló oltároknál bemutatott étel-, ital- vagy állatáldozat az ősöknek -, s ezek közül igen fontos típus a maszkos szertartások jelensége. A maszkok használata vallási szertartások során Afrika jelentős részén elterjedt, de számos afrikai népnél mégis ismeretlen (például a kusita és nílusi nyelvü népek sohasem használtak maszkokat). A maszkok mủvészeti alkotásokként is csodálatosak, s mint ilyenek számos európai és amerikai múzeum kincsei ám fontos hangsúlyozni, hogy egyrészt afrikai felfogásban ezek nem öncélú müalkotások, hanem kultikus szerepet betöltő tárgyak, másrészt pedig fö funkciójuk egy szellem (vagy istenség) megszemélyesítése s a maszkot viselö ember elrejtése, így egy afrikai maszknak mindig szerves része a hozzá csatlakozó, egész testet eltakaró (szövetböl vagy növényi anyagokból készített) kosztüm. Híres és máig gyakori példája a maszkos szertartásoknak a joruba 
nép egungun szellemeinek kultusza Nigériában és Beninben. Az egungun maszkok az ősök szellemeit testesítik meg, amelyek időről időre megjelennek, hogy leszármazottaikat a helyes viselkedésre, a hagyományok betartására figyelmeztessék, a szertartás során furcsa, magas hangú, békavartyogáshoz hasonló hangon szólva az emberekhez. A maszkos szertartások keresztény és muszlim környezetben is tovább élnek (a jorubák nagy többsége protestáns keresztény vagy muszlim), sőt például az Elefántcsontparton és Maliban élö, századok óta muszlim gyula nép do maszkjai föleg a nagy muszlim ünnepek alkalmával jelennek meg. Az afrikai vallási élet azonban az utóbbi 100-200 évben hatalmas változáson ment keresztül: az afrikaiak túlnyomó többsége (ma több mint 90 százaléka) a két nagy világvallás, a kereszténység és az iszlám követöjévé vált. Ez nem jelenti a hagyományos vallások teljes eltűnését: a régebbi kultuszok sok eleme - például a szellemek kultuszai, a maszkos szertartások, stb. - beépül a muszlim és keresztény hívők vallásos életébe, egyfajta vallási szinkretizmust (különböző eredetủ vallási elemek keveredését) eredményezve. Az afrikai iszlámot és kereszténységet egyaránt általánosan jellemzi a szinkretizmus, bár mindkét vallási hagyományban ma sokan bírálják a jelenséget.

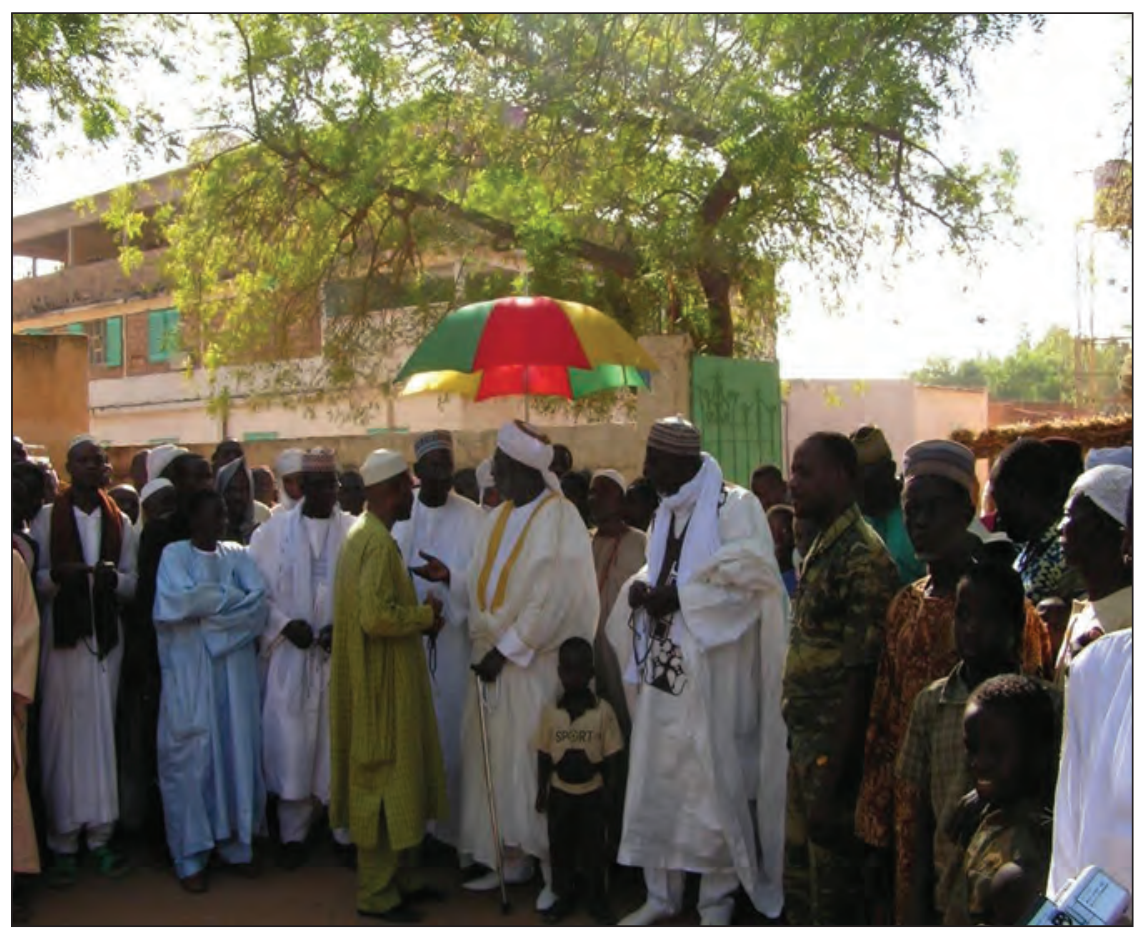

73. kép: A Tídzsánijja szúfi rend helyi vezetői Niger délnyugati részén, Kiota városkában Forrás: Szombathy ZoLtán felvétele 
Az afrikai muszlimok körében rendkívül elterjedt az iszlám misztikus ága, a szúfizmus, s egyes szúfi irányzatok erősen szinkretikus vonásokat mutatnak (ilyen például a szenegáli muríd szúfi rend, s még inkább annak mbaj-fall nevü alcsoportja) (73. kép). A kereszténységen belül is számtalan kisegyházat találunk Afrikában, amely az afrikai vallásosság elemeit keveri a keresztény tanokkal; híres példái ennek a dél-nigériai aladura („fohászkodó”) szekták vagy a kongói Simon Kimbangu követői.

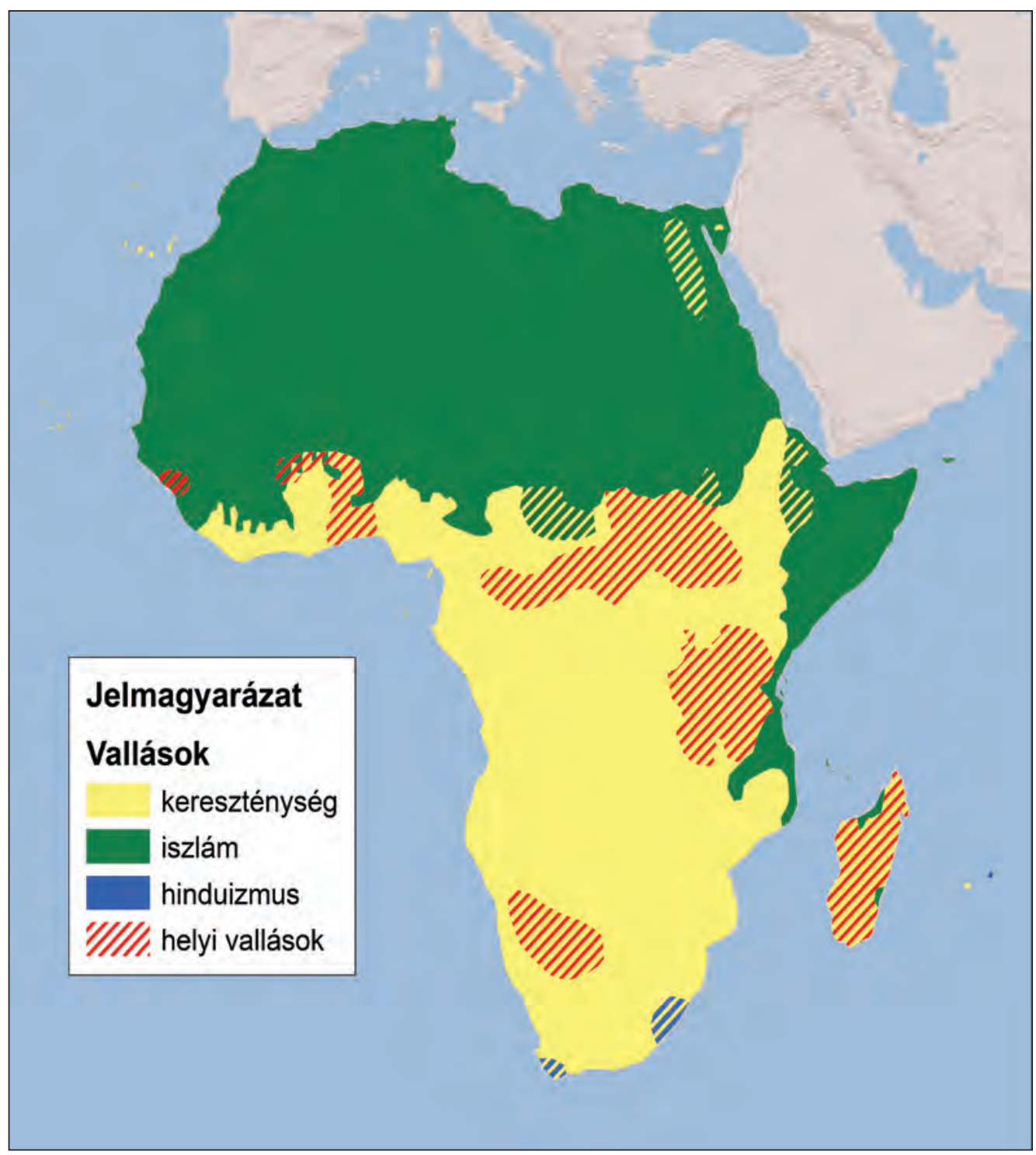

26. térkép: Afrika vallásai

Forrás: VARGA ÁGNES szerkesztése 
Mind a kereszténység, mind az iszlám igen korán megjelent FeketeAfrikában: a kereszténység már a kora középkorban (a 4. századtól) meghatározó volt az etiópiai magasföldeken (és átmenetileg Núbiában), s mint azt az afrikai muszlimok büszkén hangsúlyozzák, az arábiai Mekkán kívüli első muszlim közösség Etiópiában, egy Negas nevü településen jött létre (ez az ún. „első kivándorlás”, arabul al-hidzsra al-úlá). A középkorban az iszlám elterjedt Nyugat-Afrika nagy részén, Északkelet-Afrikában és a kelet-afrikai tengerparton, de utóbbit leszámítva a gyarmati korig kisebbségi vallás maradt. Az áttérés folyamatában a gyarmati kor, s föleg a huszadik század eleje volt a fordulópont: ekkor vált Fekete-Afrika jelentős része szinte teljesen iszlám vallásúvá, más részei pedig kereszténnyé. Ma a fekete-afrikaiak fele (főleg a kontinens déli felében) keresztény, s több mint harmada muszlim (26. térkép).

A legutóbbi évtizedek nyugtalanító fejleménye Afrika-szerte a modern vallási fundamentalizmus ( $\mathrm{s}$ az ezt kísérő vallási türelmetlenség) mind a kereszténységen, mind az iszlámon belül. Afrika keresztény régióiban ennek fő hordozói az amerikai ihletésü pünkösdista és evangéliumi (evangelical) kisegyházak, míg muszlim környezetben a főleg szaúd-arábiai hatást mutató szalafita és vahhábita irányzatok és ezek dzsihádot (szent háború) hirdető elfajulásai.

\subsubsection{Történelem, afrikai államok}

Az afrikai kontinensen ugyan - mint föntebb már említettük - léteztek állam nélküli népek, ám az afrikaiak többsége legalább a középkor óta különféle királyságok keretei között élte életét. E királyságok nagyon változatos képet mutatnak, ám az uralkodó abszolút hatalma és az ezt támogató feudális elit általánosan jellemző vonás. Az abszolút hatalmat általában szimbolikus eszközökkel is kifejezték - ilyenek voltak a pompázatos királyi jelvények (trónszékek, napernyők, hordszékek, kürtök, díszruhák), vagy éppen az, hogy a király „tolmácson” keresztül szólt csak alattvalóihoz-, és egyes társadalmakban ez egészen az istenkirályság intézményéig fejlődött. A feudális államok gazdasági alapját egyfelől a többséget alkotó paraszti réteg, másfelől az igen nagy hasznot hozó távolsági kereskedelem adóztatása adta. A katonai alapot a szavannaövezet államaiban a lovas hadseregek biztosították, az őserdővidékek királyságaiban ahol az álomkór miatt lovat nem tarthattak - többnyire a gyalogos íjászok. Az európaiak megjelenése, a 16. század után gyorsan elterjedtek Afrika-szerte a lőfegyverek, s a következő századokban a feudális királyságok jelentős része (pl. a ghánai Asanti Birodalom a 18. századtól) ezekre alapozta a hadseregét.

A gyarmatosítás kora elötti Afrikában három területen koncentrálódott a legfejlettebb királyságok nagy része (27. térkép). Ezek: 1. Északkelet-Afrika (Etiópia magasföldjei és a szomszédos Szudán Nílus-menti vidékei); 2. Nyugat- 
Afrika; 3. a bantu nyelvü területek (ezen belül több fő régió: a Kongó-medence; a mai Zimbabwe térsége; Kelet-Afrika tengerpartja).

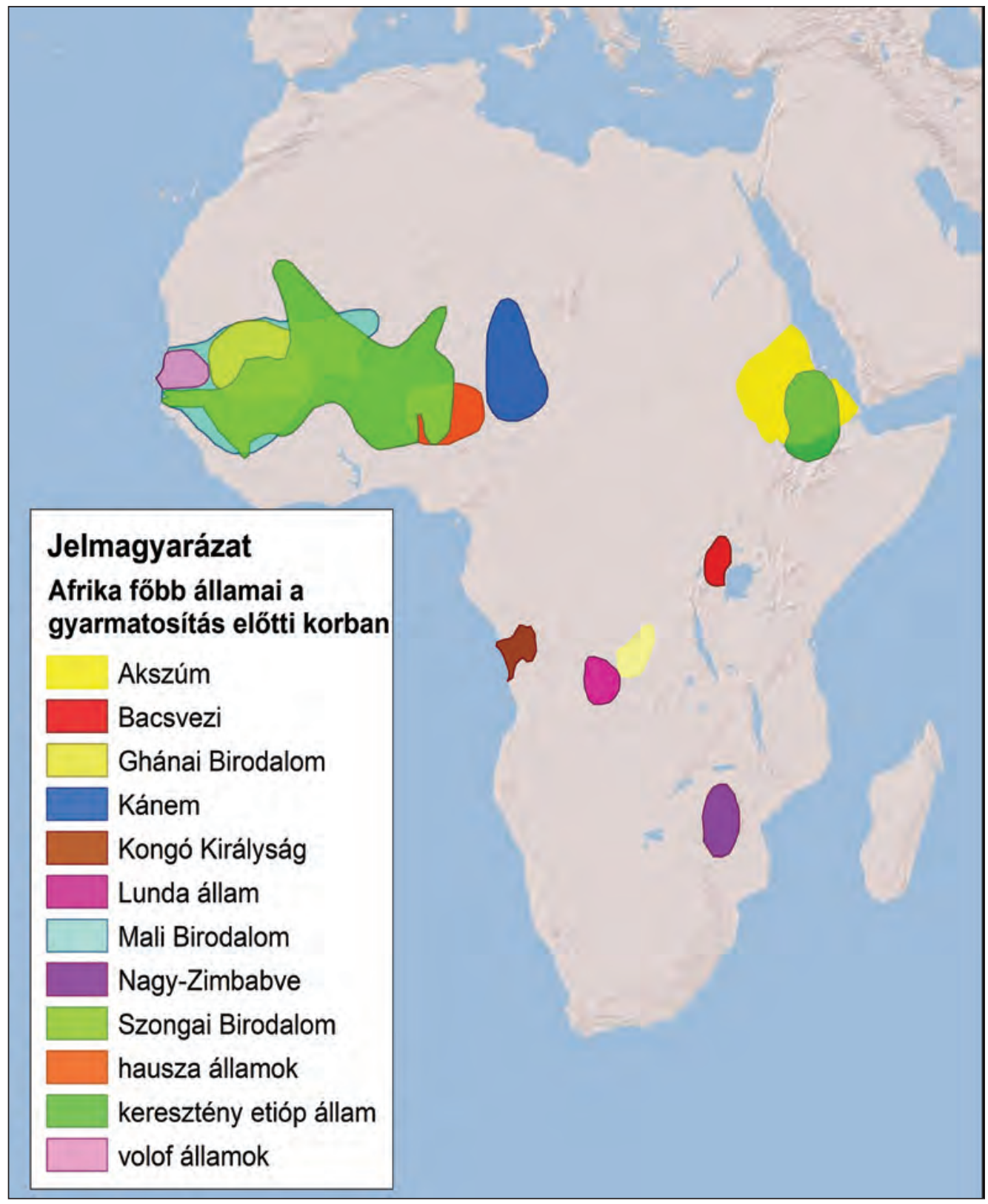

27. térkép: A gyarmatosítás előtti főbb államok Afrikában Forrás: VARGa ÁGNes szerkesztése

A legkorábbi fekete-afrikai államok az elsőként említett térségben alakultak ki már az ókorban. Messze a legősibb fekete-afrikai államiság az 
erős óegyiptomi hatás alatt álló Núbia területén jött létre. A XXV. dinasztia fekete bőrü fáraói például Núbából kiindulva hódították meg Egyiptomot az i. e. 8. század közepén, s Meroe és Napata núbiai államai ezt a hagyományt tükrözik. Núbia később is komoly egyiptomi hatás alatt állt, ami a kora középkorban monofizita keresztény, a késő középkortól pedig muszlim államokban öltött testet. Az etiópiai magasföldek területén szintén az ókortól kezdve fejlett államok jöttek létre, amelyekre részben a keresztény Egyiptom volt erős hatással - például az etiópiai monofizita egyház feje sokáig az alexandriai pátriárka volt - másfelől az Arab-félsziget déli részéről, Jemen felől érkező keresztény (és kisebb részben izraelita) vallású bevándorlók. az ókorban. Az etióp állam az ókortól máig keresztény, s hatalmát az utóbbi évszázadokban tudta csak kiterjeszteni a peremterületek muszlim és animista népességére is. Nyugat-Afrikában jóval később kezdtek kialakulni az első államok, majd birodalmak, mint az imént tárgyalt térségben, ám a középkorban egyik óriási birodalom követte a másikat a szavannaövezetben. A három nagy nyugat-afrikai birodalom közül az első, Ghána (nem elődje a hasonló nevü mai államnak, s nem is ugyanabban a térségben terült el!), eleinte nem volt muszlim vallású, csak lehanyatlása előtt, a 11. században tért át erre a vallásra, ám a szavannaövezet további birodalmai mind muszlimok voltak.

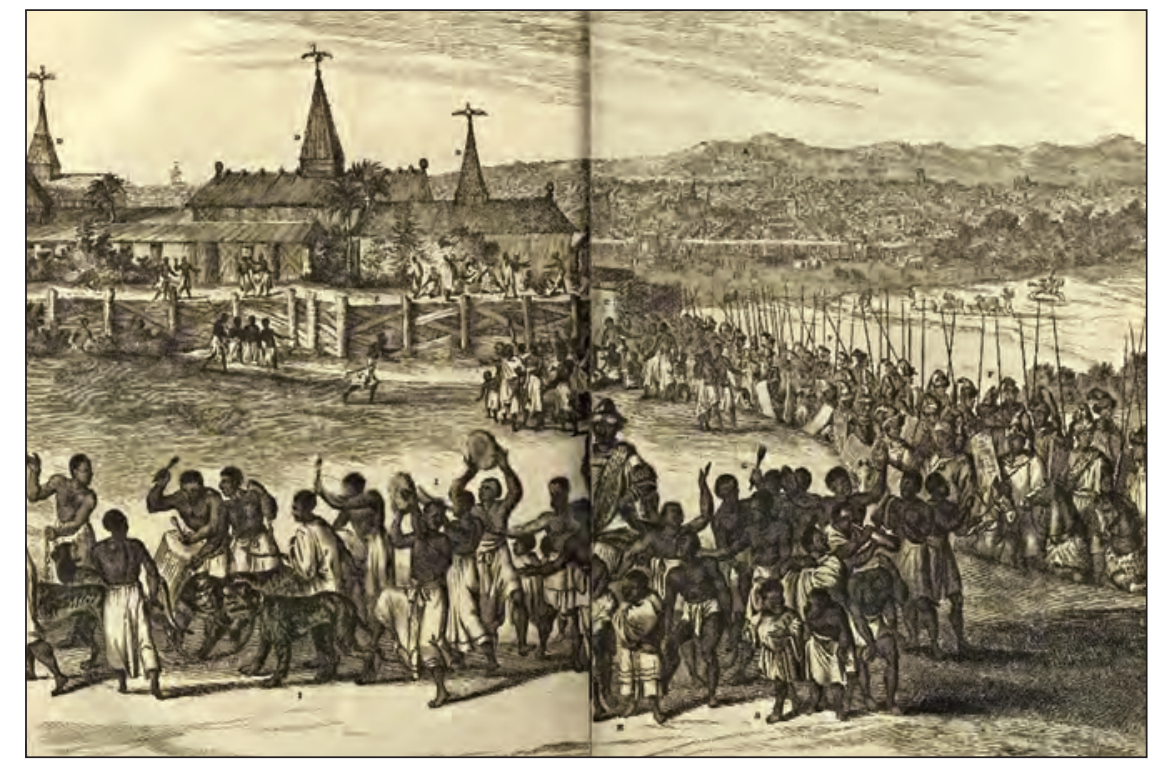

74. kép: Holland ábrázolás Benin városáról (ma Nigériában), 1668.

Forrás: Olfert Dapper, Naukeurige Beschrijving der Afrikaensche gewesten. Jacob van Meurs, Amsterdam, 1678 (eredeti kiadás 1668), pp. 678-679. 
Ghána után a Mali Birodalom következett, amely a 14. században ért el hatalma tetőpontjára; majd ezt követte a 15-16. században a Szongai Birodalom a mai Mali és Niger területén. Ezektől keletre virágzottak további (kisebb) muszlim államok, például Bornu a Csád-tó környékén és a hausza nép államai a mai Észak-Nigéria területén. A nyugat-afrikai államok történetét a kora 18. századtól a gyarmatosítók megjelenéséig az iszlámot „megtisztítani” kívánó muszlim dzsihád-mozgalmak és az ezek nyomán létrejött, a fulani nép uralma alatt álló teokratikus államok határozták meg. Nyugat-Afrika legdélibb sávjában, a Guineai-öböl partvidékén is egy sor feudális állam jött létre, de ezekben az iszlám vallás szerepe kisebb, sőt sok esetben elhanyagolható volt. Ilyenek voltak a joruba nép királyságai (mindenekelőtt a nigériai Benin, amely nem azonos a mai hasonló nevü állammal) és a ghánai Asanti Birodalom (74. kép). Afrika déli felében, a bantu nyelvü területeken számos fontos királyság jött létre a Kongó-medencében (például a kuba nép királysága és a 16. századtól erős portugál hatás alatt álló Kongó Királyság), a mai Zimbabwe és a környező országok területén (itt jött létre például az arany exportjából meggazdagodott késő középkori Monomotapa Birodalom a Zambézi folyó mentén), és a muszlim szuahéli városállamok a kelet-afrikai tengerpart egész hosszában.

\subsubsection{Müvészet}

Sok afrikai társadalomállított elö nagy mennyiségben gyönyörü szöveteket. A müfaj típusai túl változatosak ahhoz, hogy itt röviden áttekinthessük, helyette inkább néhány ismertebb példa: a ghánai asantik adinkra és kente nevü mintás szövetei, a Kongó-medencében a rafiapálma rostjaiból szőtt csodálatos, hímzett szövetanyagok - amelyeket sokszor kongói bársony néven is emlegetnek -, és az észak-nigériai Kano városban elöállított, indigóval festett gyapotszövetek.

A szobrászat talán a legismertebb és legjellegzetesebb afrikai müvészeti ág. Az afrikai szobrászat legjavát az absztrakt ábrázolásmódra való hajlam jellemzi; ez olyan vonás, amelyben a kontinens meglepő egységességet mutat. Ez nem amiatt van, mintha az afrikai müvészek a realisztikus ábrázolásra képtelenek lettek volna: a benini bronzszobrok, a kongói faszobrok egy része például döbbenetesen életszerü, portré jellegü alkotás. A geometrikus formákra történő lebontás, az absztrahálásra való hajlam, bizonyos hangsúlyos formai jellegzetességek szinte karikatúraszerü kiemelése inkább tudatos müvészi módszer, amely annyira megfogott sok európai képzőmüvészt a huszadik század elején, hogy a kubizmus irányzatát kifejezetten az afrikai müvészet látásmódja ihlette.

Az afrikai képzőmüvészet talán legfontosabb müfaja az igen magas színvonalú fafaragás. A sokszor kultikus célokat szolgáló szobrok mellett sok afrikai népcsoport állított elő maszkokat, melyek vallásos szerepéről az 
előzőekben már szóltunk. A Kongó-medence egyes népei s a kelet-afrikai makonde nép különösen híres famegmunkálásáról. A kongói kuba nép királyságában például minden egyes uralkodóról készült egy fából faragott „hivatalos” portrészobor (ndop). Noha a ndop szobrok erősen stilizált portrék, mindig szerepel rajtuk egy szimbolikus tárgy (iboi), amely utal a király kilétére azáltal, hogy az adott uralkodóhoz kötődik: például Sjam a-Mbul a-Ngvong, a 93. kuba király (16. század vége) rajongott egy jellegzetes afrikai táblás társasjátékért, ezért hivatalos portrészobrán (ma a British Museum tulajdona) is egy ilyen tábla szerepel.

Egyes afrikai népek a fa mellett fémet is gyakran használtak szobrászatuk alapanyagaként. A legfontosabb joruba államok, mindenekelött Ife és Benin századokon át tömegesen állították elő a döbbenetesen magas mesterségbeli tudásról árulkodó, úgynevezett viaszvesztéses eljárással készült gyönyörü bronzszobrokat (75. kép).

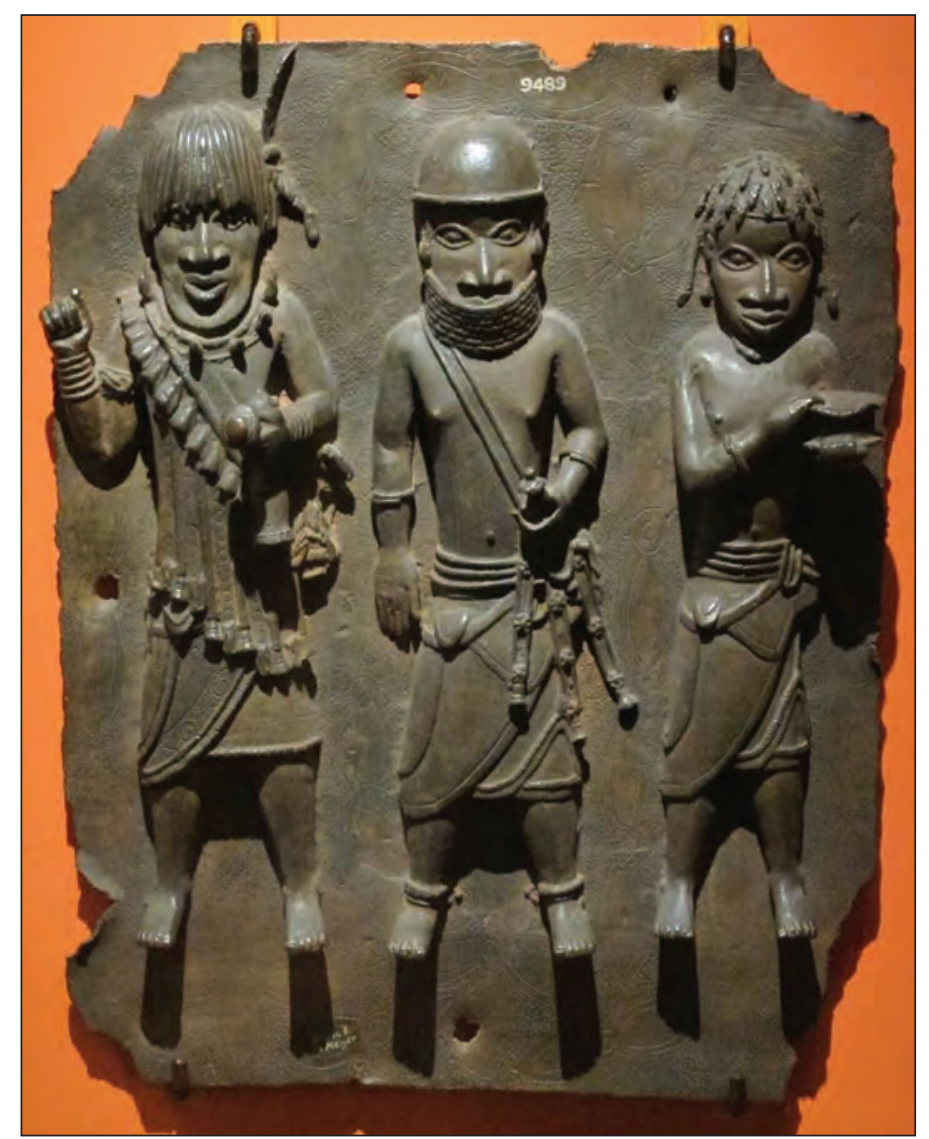

75. kép: Három benini harcost ábrázoló benini joruba bronzlap, 16-17. század Forrás: Saiko. Forrás: https://en.wikipedia.org/wiki/Benin_Bronzes\#/media/File:Benin, placca_con_tre_guerrieri,_XVI-XVII_sec.JPG 
A szobrok témája igen változatos, de jobbára igen életszerü portrék (egy híres darab például 16. századi portugál muskétás katonát ábrázol) és állatfigurák (76. kép). A művészeti ág alkotásainak java részét a brit gyarmatosítók kivitték a térségből, s Nigéria máig hiába próbálja visszaszerezni azokat. Ezt a müvészeti ágat más szomszédos joruba államok is átvették, s Benin városában máig müvelik.

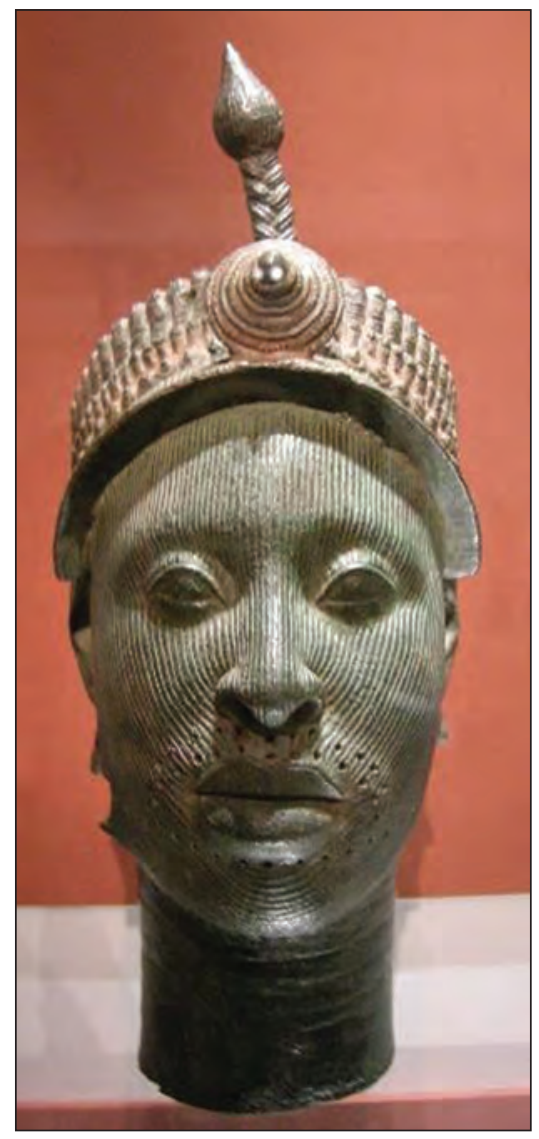

76. kép: Joruba bronzportré Ife városából, ma a British Museumban

Forrás: Saiko. Forrás: https://en.wikipedia.org/wiki/Bronze_Head_from_Ife\#/media/ File:Arte_yoruba,_nigeria,_testa_da_ife,_12-15mo_secolo.JPG

Ugyancsak az afrikai fémszobrászat csúcsához sorolható a ghánai asanti nép fantasztikus réz- és bronzmüvességének tipikus müfaja: az aranypor mérésére szolgáló, gondosan kidolgozott szobrocskák (mrammu) (77. kép).

Az afrikai népek jelentős része ugyan nem építkezett tartós anyagokból - sok helyen ilyenek egyszerüen nem álltak rendelkezésre -, ám bizonyos társadalmak mégis magas szintre fejlesztették az építészetet. A legkorábbi példák a maradandó építészeti alkotásokra a Szudán núbiai térségében található 
piramisok (főleg Meroe város környékén), amelyek minden különbségük ellenére egyiptomi mintákat tükröznek.

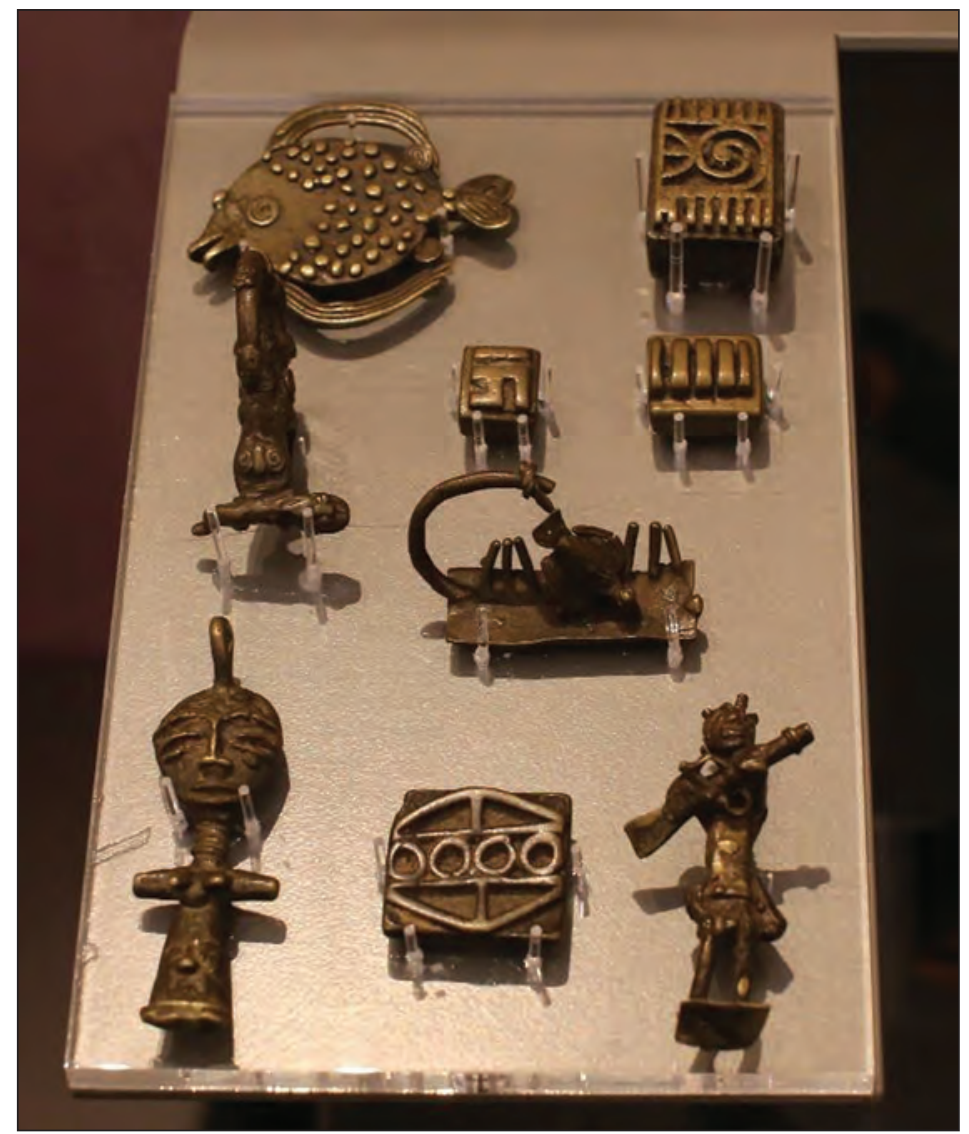

77. kép: Arany mérésére szolgáló asanti rézszobrocskák Ghánából, az angliai Beaney House of Art and Knowledge (Canterbury) gyüjteményében

Forrás: Geni. Forrás: https://en.wikipedia.org/wiki/Akan_goldweights\#/media/File:Ashanti_ goldweights.JPG

Ma Szudánban több piramist találunk, mint magában Egyiptomban. Ugyancsak lenyügözőek a keresztény etiópiai területek kőből emelt építészeti emlékei, melyek közül kiemelendők az Akszúm városban látható hatalmas ókori sztélék, Lalibela város középkori, kőből kivájt sziklatemplomai, Tigraj tartomány kolostorai és a késő középkori etióp főváros, Gondar épületei (többek között erődje) (78. kép).

Etiópia muszlim területei ugyan nem bővelkednek hasonló építészeti csodákban, de van egy fontos kivétel: Harar hatalmas középkori óvárosa és sok kilométeres városfalai. Afrika bantu nyelvü délebbi vidékein nagy számban maradtak meg kőből épült emlékek például a kelet-afrikai partvidéken, amelynek szuahéli városállamaiban a fó építőanyag a korallmészkő volt. A teljesség 
igénye nélkül megemlíthető itt Zanzibár (Tanzánia), Lamu és Mombasza (Kenya) és Mogadisu (Szomália) óvárosa, Gedi romjai a kenyai tengerparton és mindenekelött a középkori Kilva szultánjainak székhelye Tanzánia déli részén, amelynek legfontosabb maradványa a szultánok óriási erődje (Huszuni Kubva).

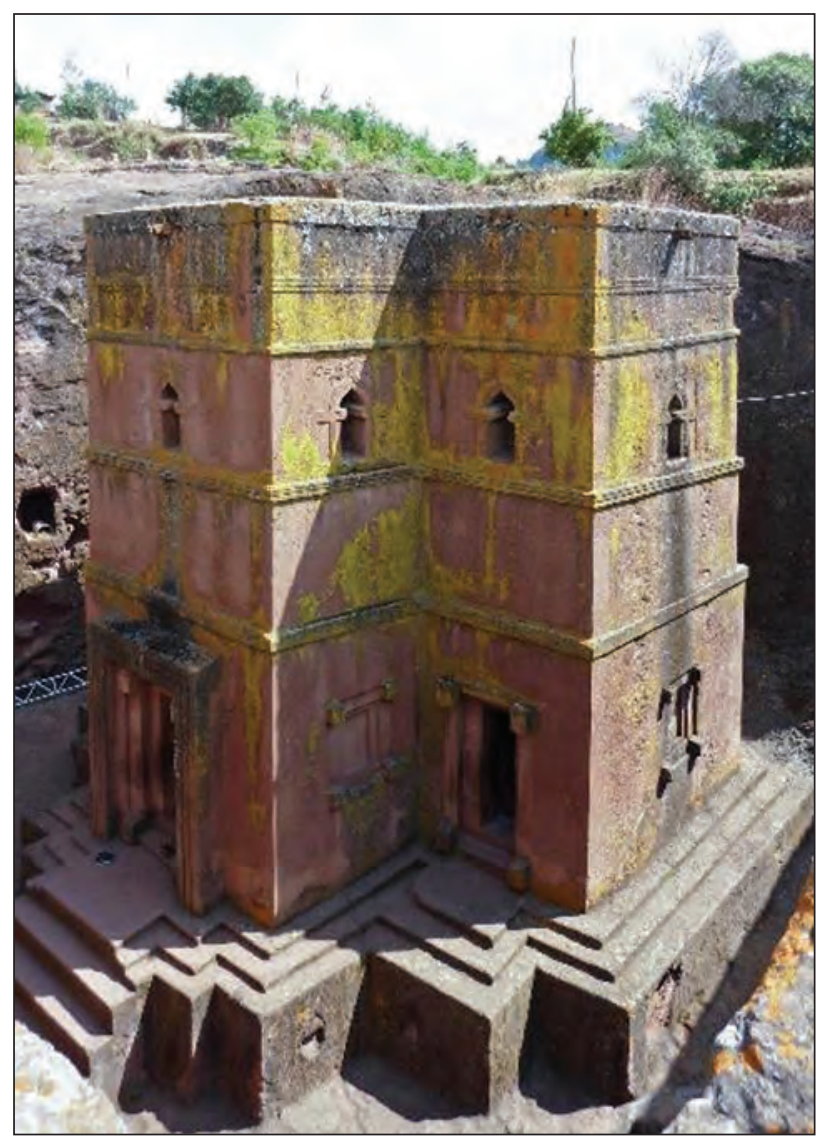

78. kép: A lalibelai (Etiópia) Bete Gijorgisz (Szt. György-templom)

Forrás: Bernard Gagnon. Forrás: https://en.wikipedia.org/wiki/Church_of_Saint_George, Lalibela\#/media/File:Bete_Giyorgis_03.jpg

A partvidéktől távolabb maradandó építészeti emlékeket elsősorban a zimbabwei térségben találunk, ahol számos kőből épült, fallal kerített hatalmas épületegyüttes romjai csodálhatók meg. A legjelentősebb ilyenek között említhető az úgynevezett Nagy-Zimbabwe - erről kapta nevét a mai Zimbabwe állam - és Mapungubwe. Ezeknek a hatalmas kerek épületegyütteseknek az ihletői a kutatók szerint egyszerü, tüskés ágakkal kerített marhakarámok voltak, amelyeket eleinte kisebb méretekben, de immár kőfalakkal építettek (e közbülső állapotot illusztrálják például a kenyai Thimlich Ohinga romjai), majd később hatalmasra növelt változatok is épültek (79. kép). 


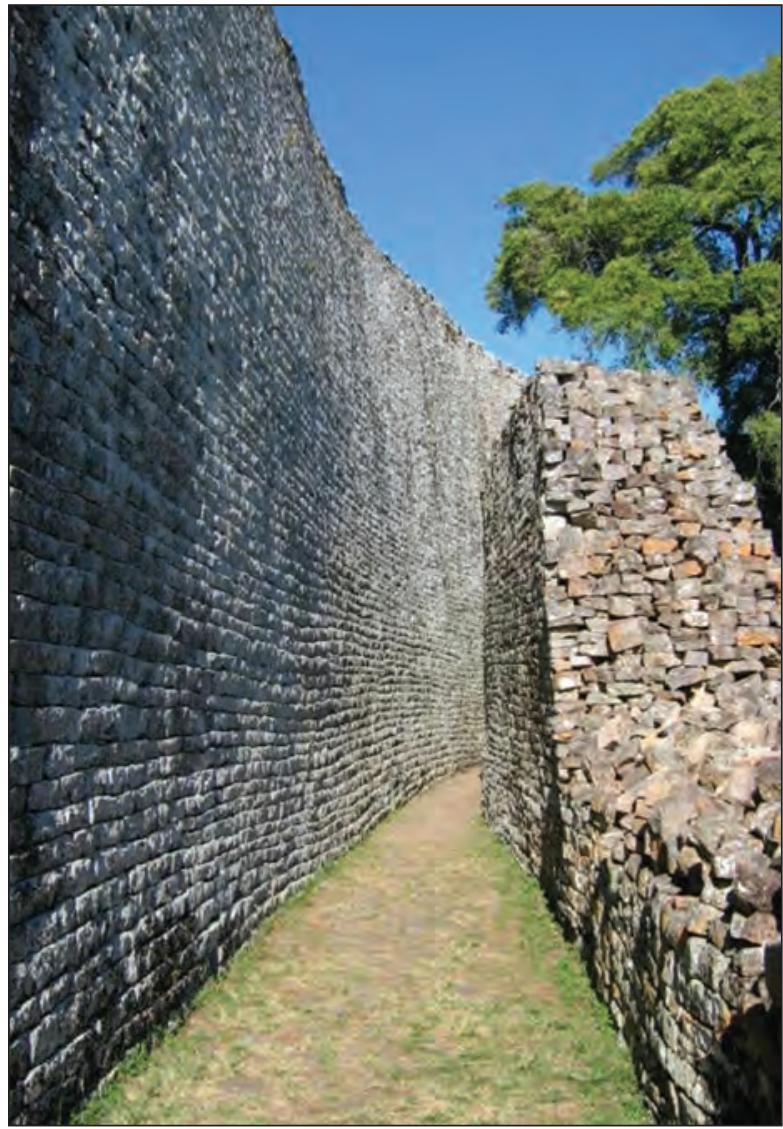

79. kép: A Nagy-Zimbabwe épületegyüttesének részlete

Forrás: Vinz és Korrigan. Forrás: https://en.wikipedia.org/wiki/Great_Zimbabwe\#/media/ File:Great_zimbabwe_2.jpg

Nyugat-Afrika nagy részén a kő nem állt rendelkezésre elegendő mennyiségben ahhoz, hogy abból építkezzenek, de a szavannaövezet államaiban az agyag felhasználásával alakítottak ki lélegzetelállító építészeti stílust, az ún. „,szudáni gótikát”. (A melléknév itt nem a mai Szudánra utal, hanem a Szaharától délre fekvő egész szavannavidékre.) Az agyagépítészetet már az itteni állam nélküli népek is magas szintre fejlesztették, erre példák a csádi muszgum nép hatalmas agyagházai vagy az észak-togói és északbenini tamberma nép agyagerődjei (tata). A nagy nyugat-afrikai muszlim birodalmakban aztán ezt a technológiát továbbfejlesztve óriási, csodálatos szépségü középületeket emeltek agyagból, amelyeket az esős évszak befejeztével a falakba beleépített faállványzatnak köszönhetően lehetett évente újravakolni. Híres példák e stílusra a mali Dzsenné nagymecsete (és számtalan hasonló mecset Maliban és a környező országokban), Timbuktu óvárosa, a Szongai Birodalom uralkodói mauzóleuma Gao városban és 
Agadez város minaretje Nigerben (a világ legmagasabb agyagépítménye) (80. kép).

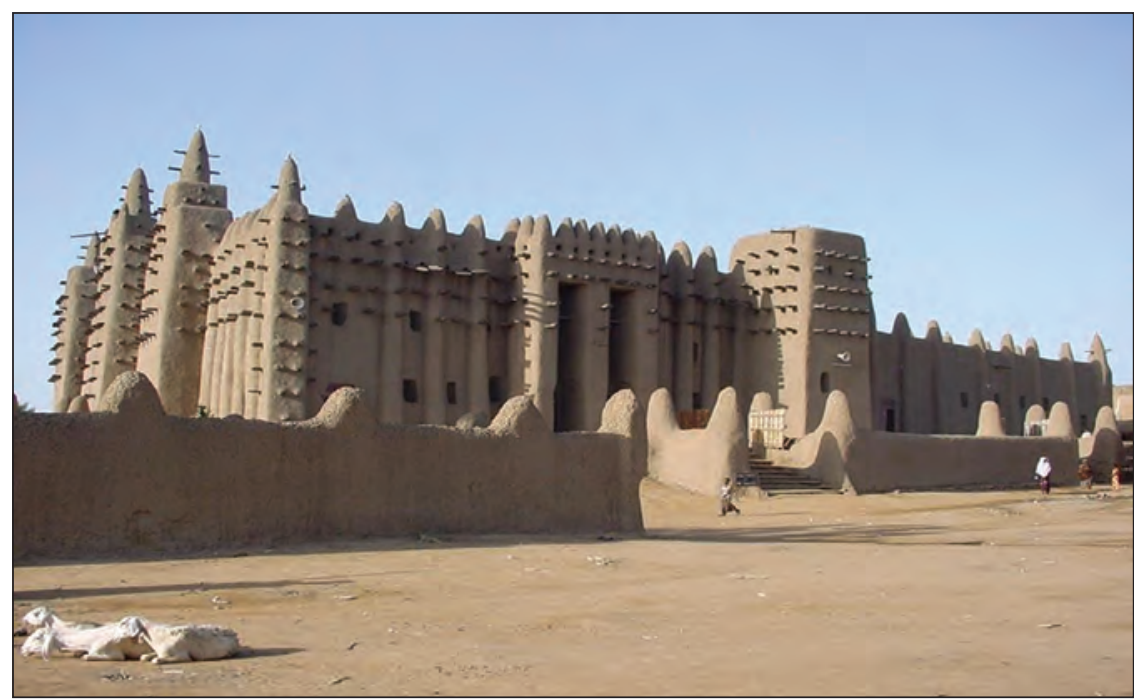

80. kép: A dzsennéi Nagymecset, a szudáni gótika egyik legkiemelkedőbb alkotása Forrás: Andy Gilham. Forrás: https://en.wikipedia.org/wiki/Great_Mosque_of_ Djenn\%C3\%A9\#/media/File:Great_Mosque_of_Djenn\%C3\%A9_1.jpg

\subsubsection{Időrendi tábla}

\begin{tabular}{c|l}
\multicolumn{1}{c|}{ dátum } & \multicolumn{1}{c}{ esemény } \\
\hline i.e. 2000 -től & Óegyiptomi hatás alatt kifejlődő núbiai államok \\
\hline i.e. $500-$ i.sz. $500 \mathrm{k}$. & Meroe \\
\hline 300-800 k. & Akszúm \\
\hline $600-1100 \mathrm{k}$. & Ghána \\
\hline $1200-1500 \mathrm{k}$. & Mali Birodalom \\
\hline $1200 \mathrm{k} .-1591$ & Szongai Birodalom \\
\hline $125-1500 \mathrm{k}$. & Nagy-Zimbabwe \\
\hline $1450-1700 \mathrm{k}$. & Monomotapa \\
\hline $1500 \mathrm{k}$. & A portugálok megérkeznek a Guineai-öbölbe, majd Kelet-Afrikába \\
\hline $18-19$. század & $\begin{array}{l}\text { A Szaharától délre eső szavannaövezetben muszlim teokratikus } \\
\text { államok jönnek létre }\end{array}$ \\
\hline $17-19$. sz. & A transzatlanti rabszolga-kereskedelem kora \\
\hline $1700-1900 \mathrm{k}$. & Asanti Birodalom \\
\hline $1884-91$ & Afrika felosztása a gyarmatosító hatalmak között \\
\hline $1956-80$ & Afrika országai sorra elnyerik függetlenségüket \\
\hline 1963 & Az Afrikai Egységszervezet (OAU) létrejötte
\end{tabular}




\subsubsection{Irodalomjegyzék}

Ajánlott irodalom

Ade Ajayi, J. F.; Crowder, Michael 1985: Historical Atlas of Africa. London: Longman

Bodrogi TiBoR (szerk.) 1981: Törzsi müvészet. 1. kötet. udapest: Corvina, pp. 159-248.

BRAUER-BENKE JÓZSEF 2007: Afrikai hangszerek. Budapest: L'Harmattan

Cattaneo, Marco; Trifoni, Jasmina (szerk.) 2004: Ösi civilizációk. Budapest: Alexandra, pp. 122-191.

Csodatévő Takla Hájmánót, 1986. - Ford. és utószó: Ormos István. Budapest: Helikon

Davidson, Basil 1965: Az újra felfedezett ösi Afrika. Budapest: Gondolat FaGe, J. D.; Tordoff, William 2004: Afrika története. Budapest: Osiris Finnegan, Ruth 1970: Oral Literature in Africa. Oxford: Clarendon Press Frobenius, Leo 1981: Afrikai kultúrák. Budapest: Gondolat FüssI-NAGY GÉZA 1982: Bevezetés az afrikanisztikába. Budapest: Tankönyvkiadó FÜssI-NAGY GÉZA 1987: Szájhagyományok és irodalom a mai Afrikában. Budapest: Akadémiai Kiadó

Garlake, Peter 1988: Afrikai királyságok. Budapest: Helikon

General History of Africa, 1990 - Abridged Edition. 8 kötet. Berkeley-ParisLondon: University of California Press / James Currey: UNESCO

KIRÁLY IstváN (szerk.) 1970-1984 [és további kiadások]: Világirodalmi lexikon.

8 kötet. Számos afrikai témájú szócikk. Budapest: Akadémiai Kiadó

MagYar AfriKa TÁRSASÁG: Magyar Afrika Tudástár. - http://afrikatudastar.hu Murdock, George Peter 1959: Africa: Its Peoples and Their Culture History.

New York - Toronto - London: McGraw-Hill

Murray, Jocelyn 2003: Az afrikai világ atlasza. Budapest: Helikon

Sanneh, Lamin 1996: Piety and Power. Muslims and Christians in West Africa. Maryknoll (N.Y.): Orbis Books

SEbestyén Éva - Szombathy Zoltán - TARRósy István (szerk.) 2006: Harambee. Pécs: Publikon

SzOMBATHY ZoLtán 2007: „Az iszlám a mai Fekete-Afrikában”. - In: TÜSKE

LÁszló (szerk.): Elöadások a mai iszlám világáról. Piliscsaba: Avicenna Közel-Kelet Kutatások Intézete, pp. 219-236.

Szungyata, az oroszlán fia. Mandinka hösének, 1983. - Ford.: Szegő György, utószó: Alpha A. Diallo. Budapest: Európa

Zaslavsky, Claudia 1984: Afrika számol. Budapest: Gondolat 
6. Európa 



\title{
6.1. Az ortodox keresztény Európa: az orosz változat
}

\author{
Sz. BÍRÓ ZOLTÁN
}

\subsubsection{Területi körülhatárolás}

A nyugati és keleti kereszténységet elválasztó európai határvonal többkevesebb pontossággal ott húzható meg, ahol Oroszország határos Finnországgal, Észtországgal és Lettországgal, ahol Belarusz határos Lettországgal, Litvániával és Lengyelországgal, ahol a határ Ukrajnát elválasztja Lengyelországtól, Szlovákiától és Magyarországtól, ahol Románia nyugati határa húzódik, ahol Szerbia határos Magyarországgal és Horvátországgal, és ahol Montenegro határai találkoznak Horvátország és Bosznia-Hercegovina határaival. Ezek a határok azonban felettébb viszonylagosak, mert Belarusz, Ukrajna és Románia nyugati területein jelentős számban élnek olyanok, akik nem a helyi ortodox egyház hívei, hanem a nyugati kereszténység valamelyik felekezetéhez tartoznak, vagy az ország laikus közösségének tagjai. Ennek ellenére a fent meghúzott határvonal világosan elkülöníti azokat a területeket, amelyek fejlődésében az ortodox és nem a latin kereszténység vagy az iszlám játszotta a meghatározó szerepet. A ma létező európai országok közül Oroszország, Ukrajna, Belarusz, Grúzia, Románia, Moldova, Szerbia, Montenegro, Macedónia, Bulgária, Albánia, Görögország és Ciprus tartozik ebbe a körbe. A felsorolt országok többségében, de nem mindegyikében, autokefál, vagyis önálló - némi leegyszerüsítéssel: nemzeti - ortodox egyház müködik (28. térkép). Ilyen kivételnek számít Moldova, Belarusz, Montenegro és Macedónia, ahol ilyen autokefál egyház nincs, mert a Moldova területén élő pravoszláv hívők vagy a Román Ortodox Egyházhoz, vagy - ahogy a Belaruszban élök is - a Moszkvai Pátriárkatushoz tartoznak, míg a montenegrói és a macedóniai keleti keresztények a szerb egyházhoz. Ukrajna annyiban tekinthető egyedi esetnek, hogy a Szovjetunió felbomlását követöen nemcsak a helyi klérus jelentős része, de a világi hatalom is komoly erőfeszítést tesz annak érdekében, hogy az országnak a többi autokefál egyház által is elismert egységes és önálló keleti keresztény egyháza legyen. Ugyanakkor - a már említetteken túl - máig kölcsönösen elismert autokefál ortodox egyházként tartják számon a konstantinápolyit, az alexandriait, az antiochiait, a jeruzsálemit, a lengyelt, valamint a közösen müködő cseh és szlovákot. A felsoroltakon kívül létezik még egy ortodox keresztény egyház, az amerikai, ám annak önállóságát máig nem ismerte el valamennyi keleti egyház, ezért szoktak általában 14, vagy 14+1 autokefál ortodox egyházról beszélni. Mindebből az is kiderül, hogy a nyugati és keleti kereszténységet elválasztó 
határvonalon túl is müködnek kanonikus, vagyis kölcsönösen elismert ortodox egyházak, mint amilyen a lengyel, illetve a közös cseh és szlovák, ahogy olyan apostoli alapítású egyházak is, amelyek hívei már jó ideje jelentős kisebbségben vannak az ott élő más felekezetek követöihez képest. Ilyen autokefál keleti egyház a konstantinápolyi, az alexandriai, az antiochiai és a jeruzsálemi.

A keleti, avagy ortodox egyházak elnevezésében az „ortodox” annyit tesz, hogy helyesen gondolkodó, igazhitü. Az „ortodoxia” pedig magát az igaz hitet - nem pedig a konzervativizmust vagy a maradiságot - jelenti, szemben a heterodoxiával (a más vagy idegen hittel) és a kakadoxiával (a tévhittel). A pravoszláv pedig nem más, mint a görög eredetű ortodox melléknév orosz fordítása, vagyis annak jelentése sem más, minthogy igazhitü.

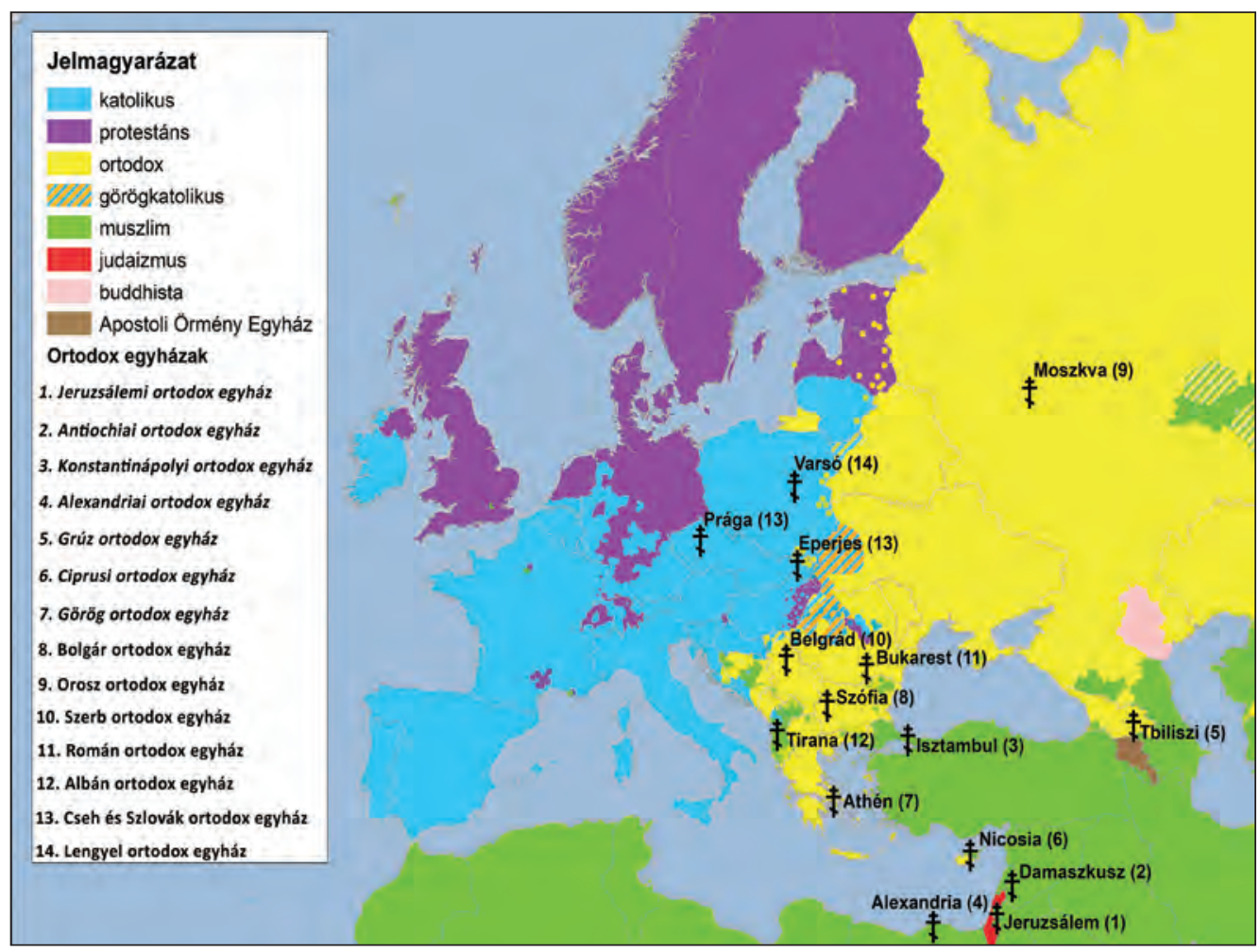

28. térkép: Ortodox egyházak Európában és a Közel-Keleten ${ }^{11}$ Forrás: VARGa ÁGNes szerkesztése

Az 1054-es nagy egyházszakadást követően fokozatosan alakult ki az a hagyomány, hogy a nyugati, avagy latin kereszténység egyházát katolikusnak, míg a keletiét ortodoxnak kezdték nevezni. Hosszú története van annak, ahogy a

11 Az első hét - dőlt betüvel jelzett - ortodox egyház apostoli alapítású, azaz az 1. században jött létre. 
kezdetben egységes keresztény közösség kétfelé vált és eltávolodott egymástól. Ebben a folyamatban történelmi és politikai tényezők mellett nyelvi, dogmatikai és liturgiai okokon túl szerepet játszottak egyházpolitikai és egyházszervezeti ellentétek is. A számos dogmatikai vita közül a legismertebb a Szent Lélek eredetének kérdése körül kialakult „Filioque”-vita volt. A keleti egyházak ugyanis - kitartva a 4. században elfogadott egyetemes zsinati tanítás mellett úgy tartották, hogy a Szent Lélek egyedül az Atyától ered, míg a nyugati egyház - a Fiú isteni tekintélyét védve - úgy gondolta, hogy nemcsak az Atyától, de a Fiától is ered (ex Patre Filioque procedit). Ám a dogmatikai ellentéteknél is fontosabb szerepet játszott a két egyház egymástól való eltávolodásában a szervezeti rendjük közt kialakuló különbség. Ennek hátterében az állt, hogy míg a Római Birodalom keleti részén az apostolok hithirdetése nyomán helyi egyházak alakultak, amelyeket a közös hit kapcsolt össze, miközben belső igazgatásuk egymástól független maradt, addig a nyugati részeken ez a folyamat egészen más irányt vett, mert a Nyugatrómai Birodalom összeomlásával új politikai helyzet jött létre, amelyben az egyház túlélése szempontjából előnyösebbnek tünt a spirituális hatalom egy központba történő koncentrálása. Keleten annak következtében, hogy a világi hatalom meg tudta őrizni erejét, a császár fenn tudta tartani a rendet és a törvényességet, az egyház nem kényszerült arra, hogy a spirituális hatalomtól idegen szerepeket is magára vállaljon. Nyugaton viszont más volt a helyzet. Az új germán királyságok egymással vetélkedtek. Ebben a közegben egyedül a pápa képviselt bizonyos fokú egységet és folytonosságot. Ezzel olyan szerephez jutott, amilyenhez a keleti pátriárkák soha nem jutottak. A folyamat végül odavezetett, hogy egyre nyilvánvalóbbá vált a különbség a nyugati egyház centralizált irányítása és a keleti pátriárkatusok szinodális afféle kollegiális - vezetési módja között. A bizánciak mindaddig nem ítélték el a nyugati egyházszervezet centralizálását, amíg a pápa nem próbált beavatkozni a keleti egyházak életébe. Ez azonban egy idő után megváltozott és a 9. századtól elkezdett felerősödni az a nyugati meggyőződés, hogy a pápák kánoni joghatósága kiterjed a keleti területekre is. Az ott élő keresztények azonban miközben készek voltak Róma tiszteletbeli elsőségét elismerni és a pápára, mint a pentarchia, az öt ősi pátriárkatus, vagyis Róma, Konstantinápoly, Alexandria, Antiochia és Jeruzsálem alkotta ötös hatalom első püspökére tekinteni - nem fogadták el, hogy a pápáé lenne minden fontos kérdésben a végső szó. Szerintük a hit ügyeiben nem dönthet egyetlen személy, csak az egyház valamennyi püspökéből álló zsinat.

Bizánc a 9. század közepétől kilépett addigi „,felségterületéről” és intenzív térítő munkába kezdett Közép- és Kelet-Európában. Ebben a missziós tevékenységben különösen fontos szerepet töltött be két szerzetes, Kirill (826869) és Metód (815-885). Első térítő útjuk a Kaukázusba vezetett, majd a morvai fejedelemségbe. A helyi uralkodó ugyanis olyan térítőket kért Bizánctól, akik 
szláv nyelven tudják hirdetni a keresztény hitet és képesek elkészíteni a Biblia szláv fordítását. Ehhez viszont meg kellett teremteni a megfelelő szláv írást is. Kirill és Metód rövid időn belül teljesítette mindkét kérést, megteremtve ezzel a szláv keresztény egyházi kultúra alapjait. Az ortodoxiához csatlakozó szlávok a Biblia és az istentiszteleti könyvek fordításával olyan nyelvi és kulturális előnyökhöz jutottak, amelyekkel a nyugati kereszténység hosszú időn át nem szolgált: a Szentírást és az istentiszteleteket kezdettől fogva saját nyelvükön hallhatták.

Morvaország után sorra jöttek az újabb megtérített közösségek a bolgároktól a szerbeken át a románokig. A keleti szlávok krisztianizálása a 10. század végén vette kezdetét. A kereszténység felvétele utóbb meghatározó szerepet játszott abban, hogy a tatár megszállás évszázadai alatt (1237-1480) a keleti szlávok meg tudták örizni identitásukat. Azok után pedig, hogy Konstantinápoly és a többi keleti pátriárkatus - az alexandriai, az antiochiai és a jeruzsálemi -, valamint a balkáni egyházak török uralom alá kerültek, miközben az akkoriban Moszkóviaként számon tartott Oroszország megszabadult a tatár felügyelet alól, megteremtődtek a feltételei annak, hogy az orosz egyház vezető szerephez jusson az ortodox világban. Ez a folyamat két lépésben ment végbe. Elöször az egyház tényleges önállóságát teremtették meg azzal, hogy 1448ban az orosz püspökök Konstantinápolyt megkerülve választották meg egyházi vezetőjüket, az új moszkvai metropolitát. Ezzel kezdetét vette az orosz egyház - mások által még el nem ismert - tényleges autokefálitása. Ezt a de facto önállóságot a Konstantinápolyi Pátriárkatus csak másfél évszázaddal később, 1589-ben ismerte el és emelte ezzel párhuzamosan pátriárkai rangra a moszkvai metropolitát.

Moszkva és Bizánc kapcsolatában fontos új elemet jelentett az is, hogy III. Iván (1462-1505) moszkvai nagyfejedelem 1472-ben feleségül vette az utolsó bizánci császár unokahúgát. Moszkva ura ettől kezdve használja az autokrátori címet, míg államcímerként a bizánci kétfejű sast. És ekkortájt jelent meg a „,Moszkva-harmadik Róma” ideológiai konstrukciója is. Eszerint az első Róma a barbárok uralma alá került és eretnekségbe esett; a második Róma, azaz Konstantinápoly a firenzei uniótól fertőződött meg és török uralom alá került, ekképpen mindkét korábbi Róma elbukott, de „a harmadik áll, és negyedik nem lesz". Ez a gondolat egyfajta orosz messianizmust is sugallt, azt az érzetet keltette, mintha az oroszok joggal gondolhatnák magukat Isten kiválasztott népének.

Az orosz ortodox egyház ugyan nem ismerte a reformációt és az annak nyomán kialakuló vallásháborúkat, ám ez nem jelentette azt, hogy életét időről időre ne rázták volna meg komoly hitviták. Ezek közül a legjelentősebb Nyikon pátriárka újításai körül bontakozott ki. A 17. század közepén tevékenykedö egyházfö revízió alá vette az orosz liturgikus könyveket az eredeti görög szövegek alapján. Eközben ahhoz is ragaszkodott, hogy az oroszok is görög 
módon, három újjal - és ne kettővel, ahogy az körükben megszokott - vessenek keresztet. Nyikon azonban nem érte be ennyivel. Arra is kísérletet tett, hogy az egyházat az államhatalom fölé emelje. Ez azonban szakítást jelentett volna az Oroszországban bizánci mintára meghonosodott diarchikus - két hatás uralmán nyugvó - rendszerrel, vagyis azzal a modellel, amelyben a világi és egyházi hatalomnak egyaránt fontos szerep jut, merthogy kettejük szimfóniája - szoros és harmonikus együttmüködése - teremti meg a közösség hatékony irányításának alapját. Nyikon ebben a konfliktusban végül alulmaradt, de újításaival két dolgot mégiscsak „elért”. Egyfelől szakadást idézett elő az orosz egyházban, kialakítva ezzel a reformokat el nem fogadók népes körét. Ök lettek az óhitü szakadárok. Másfelől a szakadás következményeként oly mértékben sikerült meggyengítenie az egyházat, hogy néhány évtizeddel később I. Péter (16821725) különösebb ellenállás nélkül tudta azt nemcsak hogy a világi hatalomnak alávetni, de annak részévé is tenni.

\subsubsection{Oroszország területi gyarapodása}

A keleti szlávok első állama a Kijevi Rusz volt. A jelentős kiterjedésü államalakulat azonban nem bizonyult tartósnak. Ebben közrejátszott az első szülötti jog uralkodó család körében való ismeretlensége, ami rövid időn belül egymással is vetélkedő részfejedelemségekre bontotta szét a korábban egységes államot. Ez súlyosan meggyengítette az Európa felé tartó mongol-tatár erőkkel való szembenállás erejét, aminek következtében a keleti szlávok által lakott területek jelentős része már a 13. század közepén tatár függésbe került. Míg az ország déli és középső részeit az Aranyhorda, addig a nyugati területeit a felemelkedő Litván Nagyfejedelemség szerezte meg. Egy idő után a szlávok által lakott terület északkeleti részén lévő Moszkvai Nagyfejedelemség válik az orosz földek ismételt egybegyüjtőjévé. A Kijevtől távoli fejedelemség, amely a 14 . század elején még csak 20 ezer négyzetkilométeres, III. Iván trónra lépésekor, 1462-ben már 430 ezer négyzetkilométer felett rendelkezett, vagyis másfél évszázad alatt több mint hússzorosára nőtt (29. térkép). Ez a lendületes területszerzés később sem tört meg: III. Vaszilij (1505-1533) halálakor a moszkvai állam már több mint hatszorosa volt a hetven évvel korábbinak.

A Moszkva központú orosz állam felemelkedésében, majd területének gyors növekedésében fontos szerepet játszott az Aranyhorda és Bizánc bukása, vagyis annak a két birodalomnak az összeroppanása, amely a 15 . század derekáig valamilyen módon - politikai vagy vallási tekintetben - hatalmat gyakorolt felette. Megszabadulva befolyásuktól Moszkóvia egyre gyorsabb expanzióba kezdett. Ez a folyamat gyorssá kiváltképp azok után vált, hogy IV. Iván (15331584) a 16. század közepén legyőzte az Aranyhorda két utódkánságát, a kazanyit (1552) és az asztrahanyit (1556). 


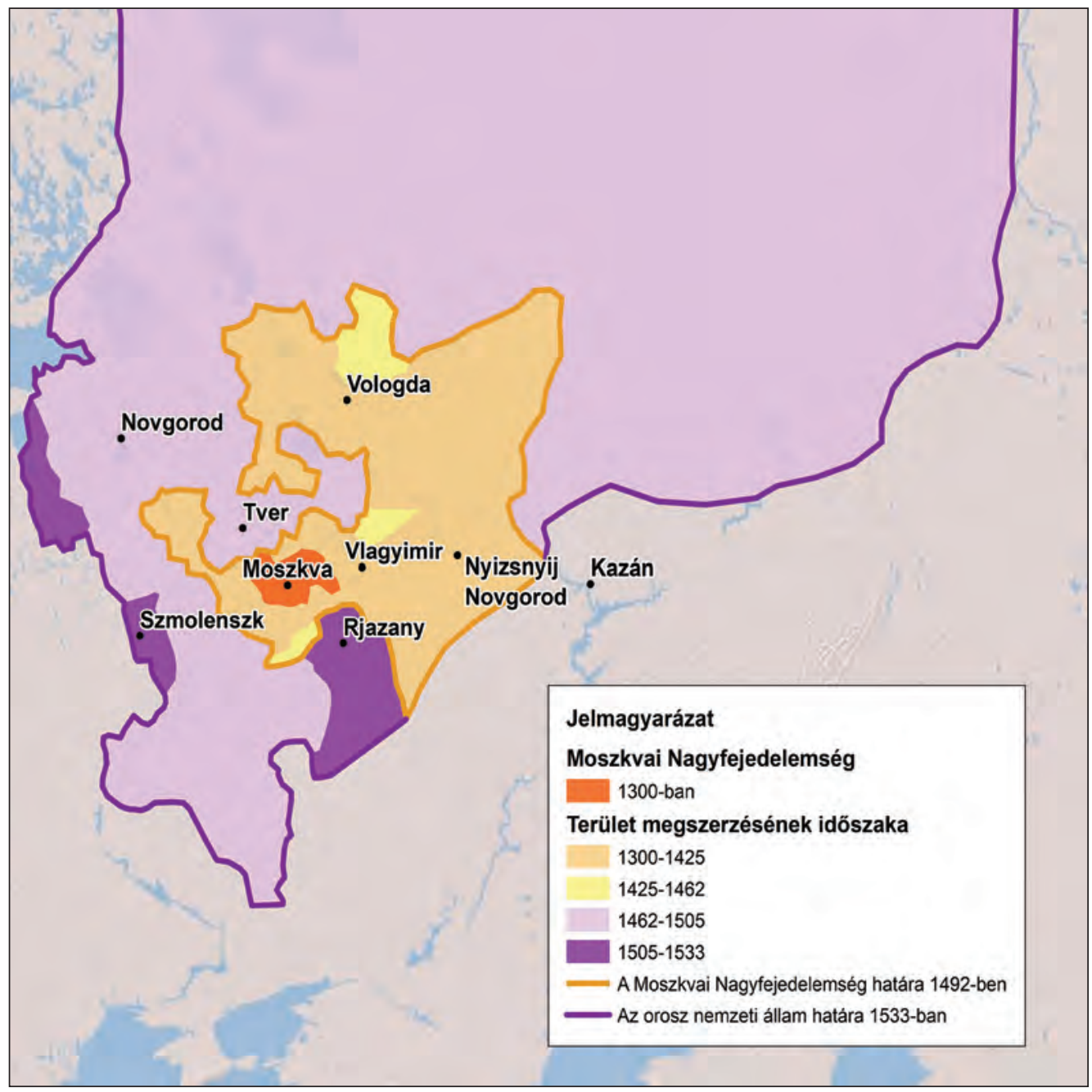

29. térkép: Moszkva befolyási övezetének területi gyarapodása a 16. századig Forrás: VARGA ÁGNES szerkesztése

Az ország területe uralkodása idején csaknem megduplázódott, 2,8 millió négyzetkilométerről 5,4 millióra nőtt. Ez már a moszkvai állam nagy és tartós triumfalizmusának korszaka volt, ami IV. Iván halálával sem tört meg. Olyannyira nem, hogy az azt követő 150 évben a Moszkvai Nagyfejedelemség területe évről évre átlagosan 35 ezer négyzetkilométerrel - vagyis egy-egy mai Hollandiának megfelelő területtel - gyarapodott. Ennek következtében 1600ban az orosz állam már akkora volt, mint Európa többi része. Az a szibériai terület pedig, amit a 17. század első felében sikerült meghódítani, akkora volt, mint két, Oroszország nélküli Európa (30. térkép). Ugyanakkor ez a gyors terjeszkedés jórészt olyan területeket érintett, amelyeknek alig volt lakossága. Még a legsürübben lakott Novgorod és Pszkov környékén sem élt jelentős számú 
népesség, nem beszélve az Urálon túli területekről. A népsürüség a 16. század közepén még az orosz állam európai részein sem volt négyzetkilométerenként két-három fönél nagyobb, miközben Nyugat-Európában már ennek tízszerese volt a jellemző. Az alacsony népsürüség kedvezett ugyan a gyors, kevés ellenállásba ütköző hódításnak, ám annál nehezebbé tette a megszerzett területek kínálta lehetőségek kiaknázását és a hatalmasra nőtt ország irányítását.

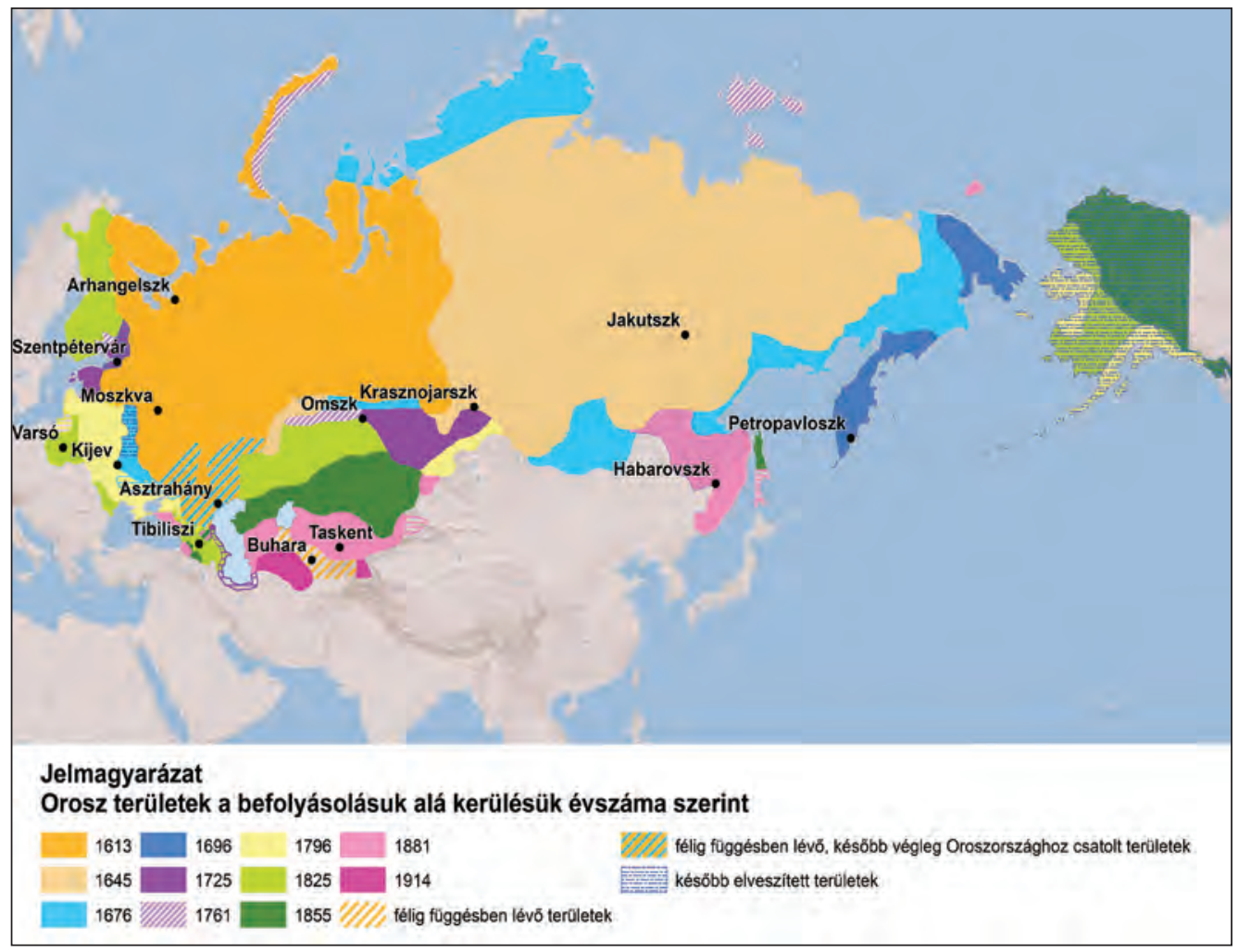

30. térkép: Oroszország területi gyarapodása a 17. századtól az I. világháborúig Forrás: VARGa ÁGNes szerkesztése

Minderre azonban még az előtt került sor, hogy I. Péter 1721-ben birodalommá nyilvánította volna államát. Ez az új helyzet nemcsak gyakorlati következményekkel járt, de érintette az orosz államiság eszmei alapjait is. Péter nem vetette el az orosz állam küldetésének szakrális megalapozását, de azt nem tartotta elégségesnek és ezért megpróbálta annak elemeit valamiképpen kombinálni a nyugati racionális tradíciókkal. Mindez azzal függött össze, hogy nem csupán egy bizánci mintájú egyetemes pravoszláv birodalmat szeretett volna létrehozni, hanem egy olyan világbirodalmat, amely egyesítette volna magában a bizánci és a nyugat-római impérium hagyományait. Ennek jegyében alapította meg az ország új fővárosát és nevezte el azt Szentpétervárnak. Már maga a 
névadás sem volt véletlen. Az ugyanis arra volt hivatott, hogy emlékeztessen a régi Rómára, Péter apostol városára. Még a város címerének kulcsai is Vatikán címerének apostoli kulcsaira emlékeztetettek. Azúj fỏváros alapításával az Orosz Birodalomnak két szakrális központja lett: Moszkva Harmadik Rómaként, míg Szentpétervár az ókori Róma, Péter apostol városának analógjaként.

A fentieken túl van még egy bizonyítéka annak, hogy I. Péter számára - a szakrális hagyományokon túl - mennyire fontos volt hatalmának evilági megalapozása. Ez pedig az a mód, ahogy az uralkodó felvette az imperátori címet. Eljárása ugyanis alapvetően különbözött attól, ahogyan azt IV. Iván 1547ben a cári titulussal tette. Az utóbbi a cári cím felvételekor megkoronáztatta magát, míg I. Péter az új titulus felvételekor ezt nem tartotta szükségesnek. Mindebből joggal lehet arra következtetni, hogy míg a cári cím felvétele mindenekelőtt vallási, addigi az imperátorié kulturális aktus volt. Az utóbbit nem kísérte semmiféle vallási ceremónia, sőt azt sem lehet állítani, hogy annak célja az uralkodói hatalom kiszélesítése lett volna. I. Péter döntésének hátterében az ország kulturális orientációjának megváltoztatása állt. Az uralkodói cím átnevezése a péteri reformok Európa felé nyitó általános irányvonalát volt hivatott még hangsúlyosabbá tenni.

A birodalom területi növekedése a 18. században - vagyis I. Péter és $I I$. Katalin (1762-1796) uralkodása idején - sem állt le. Már csak azért sem, mert az országnak együtt kellett élnie sajátos földrajzi adottságaival. Azzal a már korábban megszerzett hatalmas területtel, amelynek - az északi Jeges-tengert és a Csendes-óceánt leszámítva - nem voltak és ma sincsenek természetes határai. Ezért az orosz állam - ahogy korábban, úgy a 18. században is - sebezhetőnek és kiszolgáltatottnak érezte magát. Azért, hogy félelmét leküzdje, maga kezdett másokat fenyegetni és próbálta meg - ameddig csak tudta - határait kiterjeszteni. Ennek következtében a század elején a Baltikum egy része, míg a század második felében Litvánia, illetve újabb és újabb lengyel területek kerültek orosz felügyelet alá. Ugyancsak II. Katalin uralkodására esett Alaszka fokozatos meghódítása, mint ahogy a Fekete-tenger északi partvidékéé is. Az orosz erők ekkorra érték el a Kaukázus északi oldalát és 1784-ben megalapították a híres erődvárost, Vlagyikavkazt, ami magyarul annyit jelent, hogy „urald a Kaukázust”. Ennek ellenére ekkor még nem sikerült a hegyvidék északi részét teljes egészében pacifikálni. Az itt élő kis hegyi népek még évtizedekig ellenálltak az orosz gyarmatosításnak. Ezzel szemben a Kaukázus déli oldalán élő grúzok, örmények és azerik, akiket akkor még hegyi tatároknak hívtak, már a 19. század első harmadában bekerültek a birodalomba. Furcsa helyzet teremtett ez, amit a cári hatalom szeretett volna minél gyorsabban felszámolni, ám az észak-kaukázusi kis népek ellenállását csak a hatvanas évek derekára sikerült megtörni és a Kaukázus feletti teljes ellenörzést megszerezni. Ezzel pedig el is jutottunk ahhoz a történelmi pillanathoz, amikor az Orosz Birodalom elérte területe legnagyobb 
kiterjedését. Ez az időszak 1864-1866-ra esett, amikor már a birodalom része volt a napóleoni háborúk idején megszerzett Finn Nagyhercegség és Besszarábia, továbbá az egykori Lengyel Királyság területe. Immár Oroszországé volt a teljes Kaukázus, de a szentpétervári udvar még nem adta el Alaszkát az Egyesült Államoknak. A birodalom összterülete ezekben az években már csaknem 24 millió négyzetkilométer volt. Ettől kezdve azonban elkezdett csökkeni az ország területe. Részben Alaszka 1867-es eladásával, részben az 1904-1905-ös japánorosz háború kudarca nyomán elvesztett északkelet-kínai területekkel, valamint a Szahalin-sziget felének japánoknak történő kényszerü átadásával.

Az óriásira nőtt birodalom igazgatása még azokban az években is nehéz feladatnak bizonyult, amikor a „végeken” épp nem akadt komoly probléma, mert senki nem lázadt fel és senki nem akart kiválni. Elég csak arra gondolni, hogy a főváros és a kamcsatkai erődváros, Petropavlovszk között $9500 \mathrm{~km}$ volt a távolság. A még ennél is távolabb eső alaszkai orosz erődökbe pedig nemcsak azért, mert azok egy másik kontinensen voltak - még a 19. század első felében is sokkal gyorsabban és olcsóbban lehetett óceánokon átkelve eljutni, mint Szibérián keresztül. A szárazföldi szállítás költségei ugyanis többszörösei voltak a tengerinek. Ráadásul az utóbbi jóval biztonságosabb is volt. Ezért a központi hatalom inkább választotta a Szentpétervárról vagy Odesszából kiinduló, a Földet csaknem megkerülö hajózást, mintsem hogy szárazföldön át juttassa el az utánpótlást - benne a gabonát - az alaszkai helyőrségeihez.

Ez a történet azonban ,visszafelé” is igaz volt. Ahhoz például, hogy az Alaszkában elejtett vadak prémjét az orosz kereskedők Szibérián át eljuttathassák Kínába még a 19. század közepén is csaknem két év kellett. Ezt a feladatot az amerikai hajók öt hónap alatt megoldották. Mindez azt jelentette, hogy Oroszország perifériáit - hiába volt szárazföldi birodalom - nehezebben érte el, mint más birodalmak tengerentúli gyarmataikat, vagyis „India mind technikai, mind lélektani értelemben közelebb volt Londonhoz, mint az Orosz Birodalom számos kormányzósága Szentpétervárhoz."

Az óceánok ugyanis - paradox módon - nem elválasztották, hanem inkább közelebb hozták egymáshoz a távol eső területeket. „A tengereken ugyan felbukkanhattak ellenségek és kalózok, de olyan alattvalók, akik idegenek, szegények, elégedetlenek vagy engedetlenek lettek volna és ezért meg kellett volna őket békíteni, hosszasan tanulmányozni, esetleg áttelepíteni, felvilágosítani, rájuk adókat kivetni, körükből regrutákat szedni, és akikért a világ elött felelősséget kellett volna vállalni, ilyenek a tengereken nem akadtak." (ETKIND, A. 2011, p. 15.) - foglalta össze a tengeri kapcsolattartás elönyeit az orosz belső gyarmatosításról írt könyvében Alexander Etkind. Vagyis a hatalmas távolságok és a hiányzó köz- és vasutak miatt még normális „üzemmódban” sem volt egyszerü feladat egyben tartani és hatékonyan igazgatni a hatalmasra nőtt szárazföldi birodalmat. 
Nyilván ez a körülmény is közrejátszott abban, hogy a központi hatalom sokáig halogatta a reformokat, és amikor a 19. század derekán végre elszánta magát, akkor ragaszkodott ahhoz, hogy a birodalom politikai rendszere érintetlen maradjon. II. Sándor (1855-1881) - aki egyébként se szerette volna uralmát korlátok közé szorítani -, meg volt ugyanis győződve arról, hogy a főhatalom alkotmányos korlátozása - valamilyen képviseleti intézménnyel történő megosztása -, veszélyeztetné a birodalom irányíthatóságát. Szerinte kizárólag az egyeduralom volt alkalmas a hatalmas ország hatékony igazgatására. A 20. század elején unokája, II. Miklós (1894-1917) mégis kénytelen volt elfogadni egyeduralmi rendszerének korlátozását. Ám utóbb ez sem volt elég ahhoz, hogy a birodalom egyben maradjon.

Az I. világháború keltette kormányzati, majd általános politikai válság átmenetileg fölbomlasztotta minden idők harmadik legnagyobb impériumát. A hatalmas ország perifériái sorra váltak le. Egy részük ideiglenesen, más részük tartósan. De akadtak olyan területek is, mint például Finnország és Lengyelország, amelyek végérvényesen búcsút mondtak a birodalomnak. A bolsevikoknak azonban - köszönhetően annak, hogy a csatlakozó államok bíztak formális függetlenségük megőrzésében - sikerült az impériumot csaknem teljes egészében helyreállítaniuk. Négy szovjet szocialista köztársaság - az orosz, az ukrán, a belorusz és a kaukázusontúli -, szövetségkötésével 1922. december végén létrehozták a Szovjetuniót. Az új szövetségi állam területe azonban megalakulásakor még kisebb volt, mint az Orosz Birodalom 1914-ben. Ez a helyzet azok után sem változott, hogy a horezmi és a buharai népköztársaságok 1923-1924-ben csatlakoztak a szövetségi államhoz. A Szovjetunió területe még ezek után is csak 20,9 millió négyzetkilométert tett ki, vagyis továbbra is kisebb volt, mint az Orosz birodalom az I. világháború előtt. Az új szövetségi állam nagyobbá csak azok után vált, hogy a II. világháború korai szakaszában - a németekkel való titkos alku alapján - Moszkva magához csatolta KeletLengyelországot, a három addig független balti államot és a két világháború között Romániához tartozó Besszarábiát. Ezzel a Szovjetunió területe már több mint 22 millió négyzetkilométerre nőtt, tehát már nagyobb volt, mint az Orosz Birodalom felbomlásakor, de kisebb, mint az 1864-1866-os csúcs idején.

A Szovjetunió egyben tartása mindaddig nem okozott problémát, amíg az azt alkotó köztársaságok élén ugyanannak a pártnak, a Szovjetunió Kommunista Pártjának tagjai álltak. Ez önmagában garantálta a szovjet államkeret érinthetetlenségét. Ám azzal, hogy a késői gorbacsovi évekre megszűnt a kommunista párt monopol helyzete, a Szovjetunió jövője is kérdésessé vált. A szecesszió első jelei a Baltikumban és Grúziában mutatkoztak meg, vagyis ott, ahol az önálló állami létnek voltak hagyományai, még ha nem is feltétlenül közeliek. Az a Gorbacsov ellen szervezett puccskísérlet pedig, amelynek célja a szovjet államkeret megőrzése volt, épp az ellenkezőjét érte el: 1991 
augusztusában felgyorsította a bomlási folyamatot. Ennek első állomásaként röviddel az elvetélt puccs után teljesen legitim és békés körülmények között „elbocsátották” a Szovjetunióból a három balti köztársaságot. Ekkor még senki nem tudta, hogy mi lesz a hatalmas országgal, noha annak eresztékei akkor már hangosan recsegtek-ropogtak. A végszót 1991. december 7-én mondták ki, amikor a belorussziai Belovezsszkaja Puscsában a három szláv tagköztársaság - az orosz, az ukrán és a belorusz - vezetője aláírta a Szovjetunió feloszlatását kimondó dokumentumot, benne annak 5. cikkelyével, amely kimondta, hogy „,a Magas Szerződő Felek elismerik és tiszteletben tartják egymás területi épségét és a Közösség keretein belül a létező határok sérthetetlenségét." Ehhez az elvhez leszámítva a még a késői szovjet korszakban egymással fegyveres konfliktusba keveredő Örményországot és Azerbajdzsánt - a szerződő felek, illetve a szerződéshez néhány héttel később csatlakozó önállóvá vált egykori szovjet köztársaságok tartották is magukat. Ezt a hagyományt törte meg Moszkva azzal, hogy 2014 márciusában annektálta az Ukrajnához tartozó Krím-félszigetet.

\subsubsection{Az orosz történelmi fejlödés sajátosságai}

Oroszország a 17. század végén még Európa perifériájának számított. I. Péter uralkodása elött nem akadt egyetlen olyan európai állam sem, amely komolyan mérlegelte volna annak lehetőségét, hogy a Moszkvai Nagyfejedelemséggel szövetséget kössön. A cárok országa ugyan itt volt Európában, ám a szomszédjain kívül alig vettek róla tudomást. Vagy, ha mégis, akkor Oroszországban leginkább csak az elrettentő példát látták. Még Jean Bodin is, aki a 16. század végén kiadott, államról értekező könyvében a moszkvai fejedelmet - a török szultán mellett - Európa egyetlen olyan uralkodójának tartotta, aki országában nemcsak az ott élő embereknek, hanem javaiknak is kizárólagos ura, és ,akinek az alattvalóit holopnak, azaz rabszolgának hívják”. Vagyis a moszkvai fejedelem hatalma még Bodin szerint is más természetü volt, mint az Európa többi részén „,a királyi vagy törvényes monarchiában” megszokott. Az utóbbiban ugyanis ,az alattvalók engedelmeskednek az egyeduralkodó törvényeinek, az pedig a természeti törvényeknek, meghagyva az alattvalóknak természetes szabadságukat és tulajdonjogukat" (BoDin, J. 1987, pp. 135-136).

A Moszkvai Nagyfejedelemségben valóban nem ez volt a helyzet. Itt hosszú időn át nem vált el egymástól a tulajdon (dominium) és a hatalom (imperium) fogalma. Az uralkodó nemcsak úgy tekintett alattvalóira, mint akik felett hatalmat gyakorol, de egyben úgy is, mint akik a tulajdonában vannak. Európa keleti peremén ugyanis a nyugati feudalizmus két szubsztantív eleme a feltételes földbirtoklás és a vazallitás intézménye - vagy hiányzott, vagy egyes elemei akkor és olyan körülmények között jöttek létre, amikor a kontinens nyugati 
részén már egészen más folyamatok zajlottak. Oroszországban az allodiális örökbirtokot (votcsina) akkor váltotta fel a szolgálati birtok (pomesztye), amikor Európában pont a fordítottja történt: a benefíciumok mind gyakrabban váltak a hübéri szolgáltatástól mentes szabad birtokká. Ennek pedig mindenekelött az volt az oka, hogy Keleten ,sohasem jött létre a nyugati feudális szintézis pontos másolata”. A moszkvai államban „a feudalizmus alkotóelemeit meglehetősen zavaros módon, ferde és aszinkrón kombinációkba keverték össze, melyeknek egyike sem rendelkezett soha teljesen az eredeti szintézis befejezettségével vagy egységével" (ANDERson, P. 1989, p. 294.). Ezért történhetett meg, hogy Oroszországban nem egy alapvető politikai készség elsajátítása és fontos intézmény létrejötte maradt el. Ott azonban, ahol a hübéri viszony kiépült, annak belső szerkezete, reciprocitása jelentős mértékben segítette egy olyan politikai gyakorlat kialakulását, amely végső soron elvezetett a megegyezés-keresés kultúrájához. A senior és a vazallus magánszerződése ugyanis a felek tényleges helyzetétől és lehetőségeitől, helyzetük aszimmetriájától elvonatkoztatva rögzítette kölcsönös kötelezettségvállalásukat. Vagyis - bármennyire különböztek is egymástól lehetőségeik - egyikőjük sem volt kiszolgáltatva a másiknak, már csak azért sem, mert az egymásnak tett hüségesküt nemcsak a hübérúr, de a hübéres is felmondhatta. Ez volt a diffidatio intézménye, ami annak feltételezésén és megengedésén alapult, hogy a hübéri szerződést törvénytelenül a feudális felsőbbség is megszegheti. Ha pedig a feudális hierarchiában elfoglalt előnyösebb helyzetből nem következik a mindenkori jogszerü magatartás privilégiuma, akkor szükség van egy olyan intézményre is, amely a felek konfliktusa - bármelyik fél hitszegése (felonia) - esetén elfogulatlanul tud igazságot tenni. Lényegében ez a szükséglet, továbbá a világi hatalomtól elkülönült, azzal rivalizáló egyház jelenléte hozta létre már viszonylag korán Nyugat-Európában a mindenkori hatalomtól független bíróságokat. Sőt, túlzás nélkül állítható, hogy a hüség felmondásának joga volt az az eleme az irányítók és irányítottak, a felül- és alullévők közti megállapodásnak, amely - miután megalapozta az ellenállás jogát - valóságos fordulatot idézett elő Európa politikai, társadalmi és jogi fejlődésében.

Oroszországban azonban nem alakult ki hübéri hierarchia, és nem jött létre az ahhoz kapcsolódó magánszerződések rendszere sem. A fejedelem és bojárjai között nem köttetett kölcsönös kötelezettségekkel járó megállapodás. Tényleges helyzetük különbözőségét - egymásnak való alá- és fölérendeltségét - semmiféle szerződés nem korrigálta. A felek közti egyenlőtlenség kapcsolatukat egyirányúvá tette, amelyben nem volt helye a diffidatiónak. Ennek következtében Oroszországban az igazságszolgáltatás intézményei is másfajta késztetésre és más módon jöttek létre, mint Európa nyugati és középső részein. A hübéri megállapodás azonban nemcsak a felek jogilag meghatározott viszonyát rögzítette, hanem egyben a kölcsönös jóindulat kinyilvánítását is 
szolgálta. Ez nem azt jelenti, hogy a középkori Nyugat-Európa a prolongált társadalmi béke világa lett volna. Ahogy a keleti, úgy a nyugati fejlődésből sem hiányzott az erőszak. Csakhogy az utóbbiban - épp a kölcsönös jóindulat egyre szélesebb körben terjedö gyakorlatának köszönhetően - már viszonylag korán megjelentek a konfliktusmegoldás másfajta, nem feltétlenül erőszakhoz folyamodó vagy azzal fenyegető eljárásai. Mindennek óriási jelentősége volt. A kölcsönös jóindulat kinyilvánítása ugyanis annak a később kiteljesedö belátásnak volt az előképe, amely a politikai ellenfélben is a közjó képviselőjét látta. Az emberek közti érintkezésnek ez a világa egy olyan politikai kultúra kialakulását előlegezte meg, amelynek - a jogkövető magatartáson túl - fontos elemévé vált a kölcsönös tolerancia, és az a fajta szemlélet, amely a politikai riválist nem megsemmisítendő ellenségnek, hanem csak ellenfélnek tartotta. Oroszországban azonban a hübéri hierarchia hiánya egyirányú kapcsolatokat alakított ki még a privilegizált helyzetben lévő rétegen belül is. Ez utóbbi az úgynevezett „szolgáló emberek” csoportja - azokból állt, akik a fejedelem környezetében bojárként, vagy a fejedelmi kíséret tagjaként katonai, udvari vagy adminisztratív szolgálatot teljesítettek. Helyzetük bár privilegizált volt, de még ők sem számíthattak arra - nem beszélve a társadalmi hierarchiában „alattuk lévő”, úgynevezett „teherviselő emberekröl” -, hogy konfliktus esetén a jog és az elfogulatlan bíróságok megvédik őket.

Ezzel szemben Nyugaton már viszonylag korán megjelentek a feudális szerződéseket általánosító alkotmányok és a hűbéri jogvitát eldönteni hivatott független bíróságok, ahogyan annak igénye is, hogy ne csak a „lélek”, de a „test” se legyen kiszolgáltatott a mindenkori hatalom önkényének. A Habeas Corpus, vagyis a „test szabadságának” intézménye kezdetben Nyugaton is csak kevesekre vonatkozott. De ahogy a hübéri megállapodás, mint a szerződéses politikai magatartás ősképe egy idő után túllépett eredeti rendeltetésének és érvényességének határain, $\mathrm{s}$ kezdett általánosan követett mintaként szolgálni, úgy vonta fokozatosan oltalma alá a Habeas Corpus is az alattvalók egyre szélesebb körét. Nyugat-Európa középkori társadalmaiban a „test szabadságát” a horizontális szolidaritás eszközeivel kényszerítették ki. Ez azonban aligha lett volna lehetséges, ha Nyugaton a római joghagyomány nyomán nem különböztették volna meg egymástól a politikai uralom és a tulajdon fogalmait. Merthogy épp ebböl a különbségtételből következett, hogy az alattvalói engedelmesség nem jelentette egyben a természetes szabadság és a tulajdonjog feladását is. Az uralkodó csak a Bodin által „despotikus monarchiaként” emlegetett rendszerekben rendelkezhetett alattvalói javaival és személyével. A középkori és kora újkori orosz államban ugyanis a magántulajdon intézményét semmi nem védte: se szokások, se törvények, se a római jog élő és elfogadott hagyománya. Ugyanez volt a helyzet a „test szabadságát” illetően is. Olyannyira, hogy egészen a 18. század végéig még a nemes embereket is meg lehetett 
testileg fenyíteni. Mindez nem meglepő ott, ahol a hübéri rendszer hiánya miatt még a hüségeskü is csak az alárendelt helyzetben lévő eskütevőre rótt kötelezettségeket, megmutatva ezzel az egyoldalú függésnek azt a szerkezetét, amelyben ,az alárendeltségen belül is megőrzött emberi méltóság” (SzŰCS J. 1983, p. 30.) ismeretlen maradt.

I. Péter előtt az ortodox egyház a világi hatalommal szoros szimbiózist alkotott, vagyis annak sem alávetettje, sem riválisa nem volt. Az orosz történelmi fejlődés ugyanis nem ismerte a hatalommegosztás középkori nyugat-európai formáját, a temporális és spirituális hatalom elkülönülését. Nyugaton - a latin kereszténység közegében - az állam mindenhatóságának határt szabott az egyház, míg Keleten - az ortodoxia világában - e szerep betöltetlen maradt. Európa nyugati felén a középkori ember két világban élt, a „test” és a „lélek” világában. Míg az előbbiben a laikus hatalom volt illetékes, addig az utóbbiban nem ismerték el annak főségét. Kettős hatalom, kettős alárendeltség jött így létre. Ez fejeződött ki a jog megkettőződésében is. Míg az egyházi igazságszolgáltatás az egyetemes kánonjogot követte, addig a világi a sajátos „nemzeti jogra” hivatkozott.

Mindez - többek között - azért volt lehetséges, mert az európai kultúra legitim hagyománya volt a magasabb és független elvként elismert transzcendencia, vagyis annak megengedése és elfogadása, hogy az esendő világi létező mögé „odahelyezhető” a tökéletes létező. Nyugat-Európában mindenekelőtt e hagyomány következtében fejlödhetett az egyház a világi struktúrákkal szembeállítható, azok hatalmi ambícióit korlátozó alternatív képződménnyé. Mindazonáltal a transzcendencia legitim tételezésének mégoly fontos, másutt ismeretlen szellemi hagyománya sem lett volna elégséges ehhez. Mert igaz ugyan, hogy a keresztény világ határain kívül sehol sem képződött az érdekeknek olyan sajátos és szent szférája, amely hozzáférhetetlen, sőt tiltott lett volna az állam számára - merthogy mindenütt másutt maga az állam volt szent, így a vallás követelményei egybeestek az államéval -, ám ez önmagában aligha tette volna az egyházat a laikus hatalom erős e világi korlátozójává. Ehhez szükség volt még valamire, mégpedig arra, hogy összeomoljon a Nyugatrómai Birodalom és helyén átmeneti politikai vákuum jöjjön létre. Miután azonban létrejött, ez a helyzet egyben magyarázatot ad arra is, hogy a keresztény ökumenéhez tartozó Oroszország esete miért más, mint Európa nyugati és középső részéé.

Másképpen fogalmazva: ez a körülmény arra a kérdésre is választ ad, hogy Oroszországban miért nem tudott a közös keresztény kulturális hagyomány legitim kritikai készsége valódi politikai ellenerővé válni. Nos, többek között azért nem, mert Európa keleti peremén a kereszténység a világi hatalom védelme mellett és többnyire annak tevékeny közremüködése folytán jelent meg. Erre másképp nem is kerülhetett volna sor, mert például a Kijevi Ruszban, annak krisztianizálása elött nem éltek keresztény közösségek. Már csak emiatt is az egyház kezdetben 
kifejezetten rászorult az állam patrónusi támogatására. Ráadásul az ország bizánci típusú megkeresztelése egy olyan politikai minta átvételét is jelentette, amelynek alapját a temporális és spirituális hatalom összefonódása, úgynevezett szimfóniájának állami doktrínája alkotta. Míg Nyugat-Európa társadalmaiban a mindennapi élet természetes része volt az egyház és a laikus közösség, a világi jog és a vallási normák konfliktusa, addig a kijevi, majd a moszkvai államban az értékeknek csak egyetlen hierarchiája alakult ki. A keleti ortodoxia a kultúrának éppúgy alapzatául szolgált, mint a „politikai közösségnek”. A középkori orosz állam és annak ,polgárai” épp ezért elképzelhetetlenek az egyházi kereteken és előírásokon kívül. A profán és szakrális szféra szimbiózisa az I. Péter előtti Oroszországban olyannyira erőteljes volt, hogy még egy olyan nyilvánvalóan „e világi” politikai fogalom is, mint amilyen az önkényuralom, ,az orosz nép tudatában nem jogi elöírásként, hanem maga Isten által megjelenített tényként" (FloRENSZKIJ, P. 1916, p. 26.) mutatkozott meg.

Nagy Péterrel azonban megváltozott az egyház és a világi hatalom kapcsolatának korábbi jellege. A szoros egymásrautaltság felbomlott, miután az egyház a péteri politika következtében nem egyszerủen a világi hatalom szoros felügyelete alá került, hanem annak alárendelt részévé vált. Az uralkodó 1721-ben - miután akkor már 21 éven át betöltetlen volt a moszkvai pátriárka posztja - felszámolta a pátriárkatus intézményét. Helyét a Péter idején Egyházi Kollégiumnak, majd halálát követően Szent Szinódusnak nevezett kollektív irányító testület foglalta el, élén a világi hatalom akaratát képviselő, kiterjedt hatáskörrel felruházott föügyésszel. I. Péter nemcsak az egyház müködésének jogi kereteit alakította át radikálisan, hanem megkezdte relatív autonómiájuk alapját adó allodiális birtokaik felszámolását is. Ez a folyamat hosszú évtizedeken át tartott és csak a század második felében, II. Katalin uralkodása idején teljesedett ki. Ö azonban - a még megmaradt egyházi örökbirtokok kisajátításának ellentételezéseként - a klérus mind nagyobb részének kezdett rendszeresen illetményt folyósítani és ezzel a papságot a nemességhez hasonló szolgáló renddé alakítani. A papság kincstári finanszírozása azonban még a 19. század második felére sem vált teljes körüvé. Fizetést még ekkor is csak azok kaptak, akik az egyház adminisztratív irányítását ellátó intézményekben, illetve az egyházi iskolákban dolgoztak, továbbá azok, akik a periféria kis parókiáin teljesítettek szolgálatot. Ez a kincstári „apanázs” azonban ritkán volt elégséges, így az egyházfik egyéb módokon, főként földműveléssel, a hívek adományaival és más helyi források bevonásával egészítették ki jövedelmüket.

I. Péter azonban nemcsak az egyház helyzetén változtatott: tervei ennél jóval ambiciózusabbak voltak. Nem kevesebbre szánta el magát, minthogy kivezesse Oroszországot abból a zárt és archaikus világból, ami az uralkodása elötti időszakra volt jellemző. A megkésett fejlődés hátrányait felismerve olyan racionálisan szervezett reguláló állam megteremtését tủzte ki célul, amely 
nemcsak arra képes, hogy hatékonyan irányítsa az országot, de arra is, hogy betartassa a törvényeket és megvédje a lakosságot a bürokrácia önkényétől.

A péteri reformok rendkívül sokrétüek voltak és alapjaiban próbálták átalakítani az országot. A cár mindenekelött a kormányzást szerette volna racionalizálni. Ehhez azonban át kellett alakítania az államhatalom intézményeit. Az uralkodó ezért felszámolta a korábbi rendszer két tartópillérét: a „bojár tanácsot" és a központi hatalom legfőbb igazgatási szerveit, az ország területi gyarapodásával párhuzamosan létrejövő, egy-egy újabb megszerzett terület komplex irányítását ellátó úgynevezett „intézőségeket”. Az előbbi helyére felállította a Szenátust, míg az utóbbiakat - az ágazati elv alapján szerveződő és az ország egész területén illetékes - kollégiumokkal váltotta fel. Ezek lettek a 19. század elején felálló minisztériumok elődei.

A politikai rendszer átalakításakor a cár elsősorban az államapparátus és a központi igazgatási intézmények megújítására koncentrált, továbbá arra, hogy megszervezze az ország első reguláris hadseregét, és ehhez biztosítsa a megfelelő anyagi fedezetet. A reformok nemcsak az igazgatás hatékonyabbá tételére irányultak, hanem arra is, hogy az új körülmények között az uralkodó megbízható és erős felügyeletet gyakorolhasson mind az államapparátus, mind a hadsereg felett. Ezt a célt szolgálta I. Péter híres 1722-es rendelkezése, az úgynevezett Rangtábla-törvény, amelyben az uralkodó a földbirtoklás feltételéül szabta az államnak való civil vagy katonai szolgálatot. A rendelkezés további jelentőségét az adta, hogy racionalizálta - egységes és rendszerezett szabályok alá vonta - az állam szolgálatának gyakorlatát, és egyben átalakította a szolgálati előmenetel feltételeit. Az utóbbi azt jelentette, hogy a kinevezések és előléptetések során egyre fontosabbá vált a jelöltek rátermettsége és szakmai hozzáértése, ami bizonyos fokig „demokratizálta” is a rendszert, hiszen a szolgálati előmenetel alakulása immár nem kizárólag az előkelő származástól függött, hanem egyre inkább a szolgálati teljesítménytől is.

A kormányzás racionalizálása nemcsak intézményi átalakításokkal járt, hanem az ügyvitel egységesítésével és modernizálásával is. Ekkor váltotta fel az utasítások papírtekercseken történő rögzítését a dokumentálás modernebb formája, a füzet- és könyvhasználat. Még ennél is alapvetőbb változást hozott, hogy a számok addigi cirill betükkel történő jelöléséről végre Oroszországban is áttértek az arab számok alkalmazására. 1700-tól már az évek sem a régi orosz szemléletet tükrözve szeptemberben, hanem - Európa többi részéhez hasonlóan - januárban vették kezdetüket. Vagyis a reformok mind több területen próbálták Oroszországot egyre közelebb vinni Európához. I. Péter rendkívül tudatosan és kitartóan törekedett a nyugati értékek, életforma, törvénykezés, technológiai tudás és terminológia átvételére. A folyamat felgyorsítása érdekében még attól sem riadt vissza, hogy jelentős számban hívjon meg nyugati szakembereket a hadsereg, az államapparátus és az ipar fontos irányító posztjainak betöltésére. 
Mindazonáltal az ország türelmetlen és erőszakos péteri europaizálása paradox módon - olyan társadalmi struktúrákat konzervált, amelyek az orosz fejlődés ázsiai vonásait, nemcsak hogy nem eliminálták, hanem még inkább fölerősítették. „Nagy Péter - ahogy erre Tallár Ferenc rámutat - nem is tett kísérletet arra, hogy a középkori orosz társadalom »pórusai« közt zárványokként fejlődő városok potenciáljára támaszkodva, a faluközösségek óriási agrártársadalmát egy kapitalista típusú, piaci, pénz- és áruviszonyokon alapuló fejlődés irányába mozdítsa el. Sőt: rendkívül szigorú, az adófizető népességet határtalanul kiszipolyozó, nemegyszer véres kegyetlenséggel keresztülvitt adópolitikájával és a kapitalista termelés bázisát képező, szabad munkaerőalap kialakulását gátló, még jelentkező kezdeményeit is visszaszorító rendeleteivel, melyek skrupulózus alapossággal a birodalom egész lakosságát meghatározott jogú és kötelességü rendekké tagolták, s minden egyes alattvalót egy-egy közösséghez írtak, Péter lényegében meg is gátolja az ilyen irányú, egyébként egyelőre igen szerény fejlődés további kibontakozását." (TALLÁR F. 1984, p. 22.) A Herzen által „embertelen péteri dresszúraként” emlegetett reformok mindezek ellenére megtették hatásukat. Oroszország katonailag megerősödött, így képessé vált hatékony választ adni a kor kívülről jövő kihívásaira. Ám ennek nagy ára lett: a birodalom egyre mélyebb evolúciós csapdába került. Ez azonban akkor még nem látszott. Az viszont igen, hogy I. Péter halálakor, 1725-ben Oroszország már egyike volt a kontinens öt nagyhatalmának. A hátrahagyott birodalom, ha nem is volt porosz mintára afféle ,állammal rendelkező hadsereg”, ahol a haderő szükségletei minden más igényt és intézményt maguk alá gyürtek, de mégiscsak olyan hatalmi képződmény volt, amely legfőbb feladatának az ország katonai képességeinek folyamatos fejlesztését és fenntartását tartotta. Minderre azért volt szükség, mert - mint ahogy Perry Anderson fogalmaz - ,a feudalizmus egyenlőtlen fejlődése Európában (...) nem a kontinens megfelelő régiói közötti kereskedelmi mérlegben, hanem a fegyverek mérlegében találta meg a legjellemzőbb és legközvetlenebb kifejezési formáját.” (ANDERSON, P. 1989, p. 256.) Péternek nem volt ideje más módon eljárni. Neki, ha állni akarta a kor versenyét, akkor a nyugati abszolutizmusokkal egyenértékü központosított államgépezetet kellett létrehoznia, mégpedig rövid időn belül.

I. Péter, miközben katonailag megerösítette birodalmát és ehhez megfelelö hadiipari háttért is teremtett, aközben arról is gondoskodott, hogy a kialakulóban lévő és új alapokon egységesülő privilegizált rend tagjai kötelesek legyenek az államot katonaként vagy hivatalnokként szolgálni, e nélkül nem lehetett földbirtokuk. Ez a szigorú rendszer egészen 1762-ig állt fenn, amikor is a nemesség mentesült az állam addigi kötelező szolgálata alól. Ettől kezdve belátásukra lett bízva, hogy hajlandóak-e továbbra is az állam javára civil vagy katonai feladatokat ellátni. III. Péter (1762. január 5. - július 9.) szabadságlevele ugyanis garantálta, hogy a nemesség az állam szolgálata nélkül is megtarthatja 
földjeit és egyéb kiváltságait. Sokan e szabadság elnyerését követően, felhagyva addigi szolgálatukkal, visszatértek birtokaikra. Ott azonban egy részük, miután szembesült jobbágyai életkörülményeivel, új hivatásra lelt. Ezentúl - az állam és a társadalom elvont szolgálata helyett - a „nép” iránti odaadásban és önfeláldozásban találta meg azt a szerepet, amellyel a gyakorlatban adózhatott az európai felvilágosodás eszményének. A nemesség felvilágosult része ebben az új helyzetben kezdte magát mindinkább a „nép” erkölcsi vezetőjének és kulturális mentorának tekinteni. Erre azért volt képes, mert a 18. század során - miközben renddé szerveződött és öntudatra ébredt - fokozatosan átvette és átformálta a Nyugat világi kultúrájának számos elemét. Ez a folyamat nem volt ellenére a korszak - I. Péter melletti - legjelentősebb orosz uralkodójának, II. Katalinnak sem. Ö ugyanis éppúgy, ahogy az orosz felvilágosodás meghatározó alakjai - Novikov, Fonvizin, Krilov, Ragyiscsev és Karamzin-, azt szerette volna, ha mind nagyobb számban tünnek fel - ahogy Marc Raeff fogalmaz - olyan „tevékeny személyiségek, lojális alattvalók és hazafiak, akik tudatában vannak nemcsak az állammal és a birodalommal, de a társadalom valamennyi tagjával, így a parasztokkal szembeni erkölcsi kötelességüknek is" (RAEFF, M. 1990, p. 134.). II. Katalin azonban eközben szigorúan ügyelt arra, hogy a születőben lévő rendek ne hozhassanak létre olyan alapítványokat és jótékonysági intézményeket, amelyek az államtól függetlenül próbálnának segíteni az éhezőkön és a betegeken, vagy tennének kísérletet a népoktatás kiszélesítésére. A kormányzat ugyan jóindulattal viseltetett az erkölcsi kötelességüket felismerö, a társadalom jóléte iránt elkötelezett, az ország anyagi és szellemi fejlődésében aktívan közremüködő felvilágosult emberek iránt, ugyanakkor semmiképpen sem szerette volna, ha az általuk képviselt erkölcsi, kulturális és szociális célok elérése valamiféle független és intézményesült tevékenységhez, a társadalmi szolidaritás dinamikus hálózatának kialakulásához vezettek volna. Ez ugyanis azt a kockázatot rejtette magában, hogy az adminisztráció elveszíti az ellenőrzést felettük. A felvilágosodás öszinte híve, a korszak francia filozófusainak levelezőpartnere efféle óvatlanságot semmiképp sem szeretett volna elkövetni.

II. Katalin igyekezett az orosz társadalmat a nyugat- és középeurópai feudalizmusból ismert rendekbe szervezni. Ezek a rendek azonban Oroszországban nem a társadalmi fejlődés, hanem az uralkodói akarat eredményeképpen jöttek létre, ezért az egyes rendek tagjai soha nem bízhattak jogosítványaik tartósságában. Többek között ezért is vita tárgya máig, hogy Oroszországban léteztek-e „valódi” rendek, és ha igen, mikortól. Európa keleti peremén ugyanis - ellentétben Nyugat- és Közép-Európával - a rendek jogait az uralkodó akaratával szemben nem védte törvény. Ezek a jogok az uralkodói kegy megnyilatkozásai voltak, vagyis nem garantálta őket sem a monarcha által kikezdhetetlen törvény, sem a nemesi, illetve más rendi korporációk társadalmi súlya és politikai ereje. Mindeközben Nyugaton a rendek nemcsak a társadalmi 
szerkezet részét képezték, hanem egyben a politikai rendszerét is. Az utóbbi meghatározó eleme volt a rendi képviselet alapján létrejött és müködö parlament, szejm vagy landtag. Ilyen rendi alapon szerveződő képviseleti intézményt azonban az I. Péter utáni orosz fejlödés nem ismert. Ha Oroszországban valaki valamilyen szabadságot vagy előjogot élvezett, „az csak azért volt az övé, mert az állam a szolgálatában ellátott feladatok jutalmaként megengedte neki” (BLum, J. 1971, p. 150.). A nemesség annak köszönhette polgári jogait, hogy az uralkodó igyekezett a maga szolgáló rétegét „kellő erkölcsi tekintéllyel és anyagi biztonsággal felruházni, hogy feladatait elláthassa” (BECKER, S. 1985, p. 28.).

Ugyanakkor ezek az állam szükségleteiből következő és a hatalom nemesség és uralkodó közti megoszlásának aszimmetrikus szerkezetébe illeszkedő jogok felettébb ingatagok voltak, az uralkodó jóakaratán kívül nem garantálta őket semmi. Jól mutatja ezt II. Katalin nemesi kiváltságokról rendelkező adománylevelének sorsa. Az ugyanis kibocsátását követően alig több mint tíz éven át volt csak érvényben, amikor is a kiváltságlevelet az uralkodónő fia, I. Pál (1796-1801) - semmiféle ellenállásba nem ütközve visszavonta, helyreállítva ezzel a nemesség kötelezö állami szolgálatát és a korábban velük szemben betiltott testi fenyítés alkalmazhatóságát. Ugyan néhány év elteltével az új uralkodó, I. Sándor (1801-1825) trónra lépésekor visszavonta elődje rendelkezését, vagyis a kiváltságlevélben foglaltak ismét hatályossá váltak, ám ettől még a nemesi kiszolgáltatottság továbbra sem szünt meg. Ez a döntés ugyanis nem változtatott azon a tényen, hogy a mindenkori uralkodó továbbra is az állam pillanatnyi szükséglete és saját belátása szerint szabályozhatta - bővíthette vagy korlátozhatta - a nemesi elöjogokat, csakúgy, mint a többi rend jogosítványait. I. Miklós (1825-1855) például jelentősen megszigorította a nemesek külföldi utazásának és tartózkodásának feltételeit, és újból elrendelte a birodalom nyugati kormányzóságaiban élő kevésbé tehetős lengyel nemesek kötelező állami szolgálatvállalását. Hiába tiltakozott volna e döntések ellen bárki is, életbelépésüket nem tudta volna megakadályozni. Főképp azért nem, mert az oroszországi nemesi rendből hiányzott a korporatív fegyelem és szolidaritás. Leginkább a kölcsönös vertikális lojalitásból volt komoly hiány. Ez mindenekelőtt a vazallusi rendszer intézményformáit nem ismerő orosz fejlődésből következett, vagyis abból, hogy Oroszországban a rendi privilégiumoknak soha nem volt szilárd jogi alapja.

A legfelsőbb hatalommal szemben az orosz nemesség - ellentétben a nyugatival - soha nem tudta jogait peres úton megvédeni, mert alapjuk „mindig politikai volt" (RomANOvics-SZlaVATYINSZKiJ, A. 1870, p. 214.). A mindenkori politikai célszerüség határozta meg, hogy egy-egy rend jogosítványai miképpen alakulnak - elvesznek-e belőlük éppen valamit vagy kibővítik őket. A jogok politikai jellege tette lehetővé, hogy ,a főhatalom az állam igényeitől függően egyeseket jogokkal ruházzon fel, míg másokat megfosszon tőlük." (RoMANOviCs- 
SZLAVATYINSZKIJ, A. 1870, p. 214.) Ebben - az államigazgatás szükségletein és a racionális belátáson kívül - lényegében semmi nem korlátozhatta a főhatalmat. Mindebből világosan kitünik, hogy Oroszországban, ha megkésve is, de a 18. század második felére éppúgy kialakultak - merthogy az állam létrehozta öket az egymástól jogállásukban különböző társadalmi csoportok, a rendek, ahogyan korábban Nyugat- és Közép-Európában is, csak épp Oroszországban a rendi jogoknak semmiféle intézményes biztosítéka nem létezett. Egyedül az uralkodó volt hivatva eldönteni, bővíti-e vagy szükíti-e őket, kizárólag az ő belátásán múlott, mikor von meg addig érvényes előjogokat és mikor egészíti ki őket újakkal.

Az oroszországi körülmények között kialakult rendszerben a birodalom alattvalóinak társadalmi helyzetét és státuszát alapvetően az határozta meg, hogy milyen rendhez (szoszlovije) tartoztak. A rendekre vonatkozó törvény, amely egészen 1917-ig volt érvényben, kimondta, hogy „,a városi és falusi lakosságon belül jogállásuk különbsége alapján az emberek négy alapvető fajtája (rod) különböztetendő meg: a nemesség, a papság, a városi és a falusi lakosság. Az „emberek fajtája” és „,egy adott rendhez tartozás” azonban csak az első két rend esetében esett egybe.

Ezzel szemben a városi és falusi lakosság már nem egy-egy jól elhatárolt rendet alkotott, hanem több - jogállásában egymástól eltérő - rend között oszlott meg. A városokban élők rendi hovatartozásuk tekintetében lehettek tiszteletbeli polgárok - e rendnek létezett örökletes és személyes válfaja is -, továbbá kereskedők, kézmüvesek és kispolgárok. A falusi lakosság legnépesebb rendjét a különböző jogállású parasztok alkották, de falusi alattvalóknak számítottak külön rendként a kozákok is. Az utóbbiak azonban - ellentétben a parasztsággal - számos elöjog birtokosai voltak. Az orosz fejlődés még egy rendet ismert, az úgynevezett idegenekét. Ök voltak azok, akikre valamilyen ok miatt - ami lehetett etnikai, felekezeti, vagy életformabeli - nem tudták kiterjeszteni a birodalmi törvények hatályát, ezért azok után is saját szabályaik szerint éltek, hogy orosz felügyelet alá kerültek.

A felsoroltak közül kiváltságos, vagyis nem adózó rendnek számított a nemesség, a papság, valamint a tiszteletbeli polgárok alkotta csoport. Nekik nem kellett fejadót fizetniük. De nem ez volt az egyedüli privilégiumuk. Fontos további előjoguknak számított, hogy sem állami szolgálatra kötelezni, sem regrutaként katonának adni, sem pedig testi fenyítésnek alávetni nem lehetett őket. Ehhez képest a kereskedői rend már csak félig privilegizált csoportnak számított. A rend legtehetősebb részét alkotó kereskedők az általános hadkötelezettség 1874-es bevezetéséig a katonai szolgálat alól is mentesültek. Ezekkel a jogokkal azonban a legszegényebb kereskedői réteg soha nem rendelkezett. Alávetettségüket jól mutatja, hogy őket testileg éppúgy meg lehetett fenyíteni, mint a kispolgárokat, a kézmüveseket és a parasztokat. 
Végső soron a fejadó-kötelezettség volt az a vízválasztó, amely a társadalmat két, egymástól alapvetően különböző csoportra osztotta: egyfelöl a kiváltságosokra, másfelől az előjog nélküli teherviselőkre, az adózókra. $\mathrm{Az}$ állam társadalommal kapcsolatos politikája elsősorban nem a rendek kialakítására, hanem mindenekelőtt annak meghatározására irányult, hogy a társadalom mely csoportjai kerülnek az adózásra kötelezettek közé és melyek nem. Az adókötelesek közé kerülés jelentősége sem abban állt elsősorban, hogy az odatartozóknak adót kellett fizetniük, hanem abban, hogy ezzel a státusszal számos további jogkövetkezmény járt. Aki ugyanis adókötelessé vált, azt státuszából következően alá lehetett vetni testi fenyítésnek, korlátozni lehetett szabad mozgásában és katonai szolgálatra lehetett kényszeríteni. Aki viszont nem volt adóköteles az mentesült a fenti joghátrányoktól. A két állapot közti különbség oly jelentős volt, hogy azt senki nem tekintette csupán státuszbelinek. Az adózó rendekhez való tartozás ugyanis annál jóval többet jelentett. Aki ugyanis az utóbbiba tartozott, joggal érezhette magát megbélyegzettnek. A privilegizáltak is ennek tudatában tekintettek rájuk. Nem véletlen, hogy a köztük lévő különbséget pusztán csak a jobbágyfelszabadítás jogi aktusával nem lehetett felszámolni. Olyannyira nem, hogy még évtizedekkel az emancipációs törvények után sem tünt el az a lélektani gát, ami e két csoportot elválasztotta egymástól.

Ez a mesterségesen kialakított rendi szerkezet is veszélybe került a francia forradalom nyomán. Az ancien régime összeomlása Európa szerte új helyzetet teremtett. A forradalom Kelet- és Közép-Európa uralkodói körében egyaránt aggodalmat keltett. Olyannyira, hogy az utóbbiakat - miután úrrá lettek első félelemmel teli meglepetésükön - a forradalom, de még inkább Napóleon hadserege arról győzték meg, hogy addigi politikájukon mindenképpen változtatniuk kell. Két lehetőség állt előttük: vagy önként teszik ezt, vagy rá lesznek kényszerítve. E felismerés jegyében előbb Poroszország kezdett átfogó reformokba, amelyek eredményeképpen még a 19. század elején felszámolták a jobbágyi függést, kialakították a helyi önkormányzatiság első intézményeit és bevezették az általános hadkötelezettséget. Ausztria viszont csak évtizedekkel később lépett; ott a jobbágyságot csak 1848-ban számolták fel. Ugyanebben az évben az osztrák császár parlamentet adományozott népének, hogy a következö évben már fel is oszlassa azt. Poroszországban azonban hagyták működni a népképviselet intézményét, az 1849-ben felállított Landtagot.

Ezzel szemben Oroszországban semmi hasonlóra nem került sor. A francia forradalom hatása - túl az első aggodalmat keltő hullámokon - csak megkésve érte el az Orosz Birodalmat. Ráadásul ez a megkésett hatás rögtön két, egymással ellentétes reakciót váltott ki. Egyfelől radikalizálta a nemesi elit egy részének szemléletét, másfelől elvette a hatalom kedvét a nyugati minta további követésétől. A radikalizálódás következményeként került sor 1825- 
ben a dekabristák alkotmányt követelő összeesküvésére. Kudarcuk nyomán azonban hosszú időre az is eldőlt, hogy az ekkor trónra lépő uralkodó, I. Miklós szakít elődei - I. Péter, II. Katalin és I. Sándor - Európát mintának tekintő politikájával, és megpróbálja birodalmát az onnan érkező hatásoktól minél inkább elzárni. Mindez egybeesett az egyeduralom új kultuszának kialakításával, illetve az orosz ,sajátos út” konzervatív koncepciójának megszületésével. Ez utóbbi azonban többféle változatban is létezett. Egyik variánsát a szlavofilek képviselték. Elképzelésük azonban jóval szabadabb és nyitottabb volt, mint a „pravoszlávia, önkényuralom, népiség” triászán nyugvó hivatalos doktrína. A szlavofilek ugyan nem fogadták el a nyugati, alkotmányos rendszereket, de maguk is indokoltnak találták az egyeduralom korlátozását. Ennek eszközét nem az alkotmányban látták, hanem a szólásszabadságban és a társadalmi autonómiában. Az államhatalomtól távolságot tartó közösség alatt azonban nem a társadalom egészét értették, hanem annak csak azt a részét, amelyik kellőképpen mủvelt és nyugati mintára képzett volt. Ugyanakkor az ország jövőjét nem a nyugati individualizmus követésében, hanem az orosz emberek lelki közösségének (szobornoszty) megteremtésében látták. Szerintük ez az utóbbi a pravoszláv (ortodox) egyházban és a faluközösségekben (obscsina) már meg is valósult, vagyis épp ezekre a hagyományokra támaszkodva lehetne megteremteni az orosz alkatnak leginkább megfelelő politikai rendszert.

Ezzel az idealizált önképpel - amit Pjotr Csaadajev szellemesen „retrospektív utópiaként” írt le - sokan nem értettek egyet. Leginkább azok nem, akik az értelmiségi elit nyugatos irányzatának mérsékelt ágához tartoztak. Ök azt szerették volna, ha Oroszországban a felülröl kezdeményezett reformok fokozatosan felszámolták volna az egyeduralmat és felszabadították volna a jobbágyokat, majd az új alkotmányos rendszer elkezdte volna az országot mindinkább a Nyugathoz közelíteni. A mérsékelt nyugatosoktól idegen volt az orosz történelmi fejlödés idealizálása, ,az orosz nép gőgös apoteózisa” (CsaAdaJEV, P. 1989, p. 277.). ${ }^{12}$ Annak különösségében ugyanis nem láttak semmi irigylésre vagy követésre méltót. Szerintük az „orosz út” sajátszerüsége megkésettségében volt, ezért az új alkotmányos rendszertől épp annak ellenkezőjét várták, mint amit a szlavofilek hirdettek. Vagyis azt remélték, hogy az új rendszer Oroszországot elkezdi felzárkóztatni és a Nyugathoz egyre hasonlóbbá tenni. Lényegében ők - vagyis mindenekelőtt Borisz Csicserin és Konsztantyin Kavelin, továbbá a hajdani dekabrista, Nyikolaj Turgenyev - voltak azok, akik szabadelvü gondolkodókként az alkotmányos eszmék oroszországi meghonosításának első szószólóivá váltak. Ők abban bíztak, hogy Oroszországnak sikerül megrázkódtatások nélkül átalakulnia egyeduralomból alkotmányos rendszerré. Ezzel szemben a nyugatos tábor radikális ága nem

12 Csaadajev levele Friedrich Schellingnek (1842. május 20.). 
bízott a reformokban, helyette a forradalomban látta az egyedüli megoldást. A radikális szárny kezdetben maga is liberális volt, de a 19. század közepén elkezdett a forradalmi szocializmus irányában tájékozódni. A Nyugaton születő szocialista eszmék oroszországi alkalmazásával azonban akadt némi probléma. Ezeket ugyanis eredeti formájukban a megkésett fejlődésü Oroszországban nem lehetett alkalmazni, szükség volt az orosz viszonyokhoz történő adaptálásukra. Ezt a feladatot jórészt Alekszandr Herzen és Mihail Bakunyin végezte el. Ök - látva az 1848-as forradalmak kudarcát és csalódva a nyugat-európai politikai fejlödésben - már a század közepén arra a következtetésre jutottak, hogy a Nyugat általuk legprogresszívebbnek tartott eszméje, a szocializmus előbb valósítható meg Oroszországban, mint Nyugat- és Közép-Európában. Mindezt arra alapozták, hogy Oroszországban létezik egy olyan intézmény, mégpedig az obscsina, amely lényegét tekintve maga volt a „szocializmus”. A faluközösségekben ugyanis nem létezett magántulajdon és az obscsina tulajdonában lévő földek rendszeres újrafelosztása az ott élő parasztok változó szükségleteinek megfelelően történt.

Következésképpen - álláspontjuk szerint - a „szocializmus” kiteljesítéséhez nem lesz másra szükség, mint forradalommal megdönteni az egyeduralmat és kisajátítani a földbirtokosok tulajdonában lévő földeket. A vállalkozás sikere már csak azért is valószínünek tünt, mert a radikális tábor úgy látta, a cári hatalomnak se az elit, se a lenézett, méltóságától megfosztott „nép” körében nincs erős támogatottsága. És mert az orosz történelem tele volt véres parasztlázadásokkal, a tömegek mozgósítása se tünt megoldhatatlan feladatnak. Ebben a mozgósításban kulcsszerep várt az értelmiségre (intyelligencija). Arra a sajátos társadalmi csoportra, amely létét az ország I. Péter kezdeményezte európaizálásának köszönhette. Többségüket nemesek és vegyesrendủek (raznocsinci) alkották. Politikai nézeteik, ha egyáltalán voltak, nem feltétlenül voltak radikálisok; csupán azoké, akik, a felvilágosodás gyermekeiként nem tudták elfogadni koruk társadalmi egyenlőtlenségeit és a politikai folyamatokból való kirekesztettségüket. Oroszországban ugyanis II. Sándor reformjai előtt a rendi önigazgatás intézményein túl - nem müködött semmiféle képviseleti rendszerés a sajtó sem volt szabad. Ezért a közügyek irántérdeklődőértelmiségiek se a politikai döntéshozatalban, se a döntések előkészítésében nem vehettek részt. Ennek ellenére rendkívül népszerüek voltak: a társadalmi és politikai emancipációt meghirdető álláspontjukkal rövid idő alatt ideológiai hegemóniájuk alá tudták vonni az orosz társadalom és a kultúra jelentős részét. Politikával a liberális vagy radikális értelmiségieken kívül - a hivatalnoki elitet leszámítva - jószerivel senki más nem foglalkozott. Ez nem is változott meg mindaddig, amíg a politizálás ellenzéki formája illegális tevékenységnek számított. Ebben a tekintetben az első érdemi változásra csak 1864-ben, a zemsztvo-reformmal került sor. A korlátozott jogkörü önkormányzatok, a zemsztvok felállításával 
legalább helyi szinten megteremtődtek a legális politizálás feltételei. Ez azonban továbbra sem változtatott az országos politika jellegén és a politikai rendszer természetén. Az utóbbi változatlanul egyeduralom maradt, amelyben továbbra sem volt helye országos hatáskörü, a törvényalkotásban közremüködő képviseleti intézménynek.

A zemsztvo-reform egyike volt azoknak a nagyszabású reformoknak, amelyek a 19. század hatvanas és hetvenes éveitől alapjaiban alakította át Oroszországot. A reformfolyamat elindításában - a krími háború (1853-1856) kínos kudarcán túl - számos egyéb körülmény is közrejátszott. Közülük talán a legfontosabb annak felismerése volt, hogy Oroszország, amennyiben nem változtat politikáján, nem lesz képes - sem katonai erejével, sem gazdasági teljesítményével - felvenni a versenyt Európa meghatározó hatalmaival. A krími vereség egyértelművé tette, hogy a közel három évtizedig tartó, Európától elzárkózó miklósi politika folytathatatlan. Továbbá arra is rávilágított, hogy az Orosz Birodalomnak - amennyiben az európai hatalmi játszmák meghatározó szereplője akar maradni - gyors és átfogó változásokat kell végrehajtania. Mindenekelőtt rendeznie kell a jobbágyok helyzetét: e nélkül esélye sincs a felzárkózásra. De nemcsak a jobbágyfelszabadítás feladata állt előtte. Szinte nem volt olyan terület, ahol ne kellett volna jelentős átalakításokba kezdenie. A II. Sándor kezdeményezte reformok - a jobbágyfelszabadítástól a modern igazságszolgáltatás rendszerének kialakításán át a korlátozott önigazgatás és az általános hadkötelezettség bevezetéséig-a társadalom életének számos területére terjedtek ki, ugyanakkor a politikai rendszer alapjait érintetlenül hagyták. Ez többek között azzal járt, hogy - miután nem jött létre központi törvényhozó testület és hiányzott a törvényelfogadás menetét egységesen szabályozó norma - a törvényalkotás a nyilvánosság kizárásával, különböző érdekcsoportok politikai küzdelmének kiszolgáltatva, nehézkesen és lassan haladt. A politika, legalábbis annak legális formája, továbbra is a kevesek ügyének számított, még akkor is, ha épp a „nagy reformokkal” vette kezdetét a modern politikai nyilvánosság oroszországi megszületése és a politika kiemelkedése az udvari intrikák világából.

A nagyszabású és felettébb ambiciózus reformok - miközben számos területet érintettek - lényegében változatlanul hagyták a birodalom politikai rendszerét. Azt a rendszert, amely a 18. század elejétől számos vonatkozásban módosult ugyan, ám egyeduralmi természetét egészen a 20 . század elejéig megőrizte. Mindez annak ellenére történt így, hogy az abszolút hatalom korlátozására számos javaslat született. Nemcsak a hatalom ellenfelei, de hívei közül is többen kezdeményezték az egyeduralom (szamogyerzsavije) alkotmány általi korlátozását. Ez az elképzelés azonban - részben a cári hatalom nyugati monarchiáktól eltérő természete, részben különböző gyakorlati megfontolások miatt - nem találkozott egyetlen orosz uralkodó akaratával sem. És amikor a 
politikai rendszer átalakítására - a japánoktól elszenvedett vereség nyomán kibontakozó 1905-1907-es polgári forradalom hatására - mégiscsak sorkerült, az így létrejött duális rendszert (Borisz Mironov), avagy pszeudo-alkotmányos monarchiát (Max Weber) az utolsó orosz cár olyan kényszer hatására elfogadott döntés következményének tartotta, aminek visszavonásáról soha nem mondott le. II. Miklós 1905. október 17-én kiadott történelmi jelentőségü kiáltványában ígéretet tett a polgári jogok - a vallás-, a szólás-, az egyesülési és gyülekezési szabadság - megadására és tiszteletben tartására, továbbá arra, hogy ezentúl az Orosz Birodalomban is szabadon lehet pártokat alapítani és müködtetni, aminek eredményeképpen a következő év tavaszán meg is választották az első országos képviseleti szervet, a tanácskozási jogkörü Állami Dumát. Ez egyben azt is jelentette, hogy a birodalom alattvalói, még ha felettébb korlátozott formában is, de politikai jogokhoz jutottak

A 19. század második felének reformjai jelentős változásokat hoztak, ám többségük csak részben bizonyult sikeresnek, míg némelyik kifejezetten ellentmondásos eredménnyel járt. Ennek számos oka volt. Mindenekelőtt az, hogy a reformokat követő első évtizedekben a gazdaság nehezen alkalmazkodott az új körülményekhez, miközben annak fő területe továbbra is a mezőgazdaság maradt. A felszabadított parasztok ,ideiglenesen kötelezett” státusza, a nekik juttatott osztásföldek kis mérete, a súlyos adóterhek és a földmegváltás költségei miatt a földesúrtól való függés számos vonatkozásban tovább élt. Még azokban a falvakban is, ahol sikerült az osztásföldeket idő elött megváltani, a gazdasági egymásrautaltság fennmaradt, többek között különböző bérleti formákban. A parasztok földesuraiktól való függése leginkább azért maradhatott fenn, mert a bérleti díjak kiegyenlítése továbbra is többnyire munkával és nem pénzzel történt. Ezt a helyzetet a földbirtokosok gond nélkül elfogadták, már csak azért is, mert jórészt ehhez voltak szokva. Ám az olcsó munkaerő sokakat megtévesztett, merthogy csak keveseket késztetett arra, hogy keressék és alkalmazzák a gazdálkodás modernebb és hatékonyabb formáit. Az újításoktól való elzárkózás a földbirtokosok egyre nagyobb részét vitte csődbe, vagy kényszerítette arra, hogy eladja földjét. A kilencvenes évek elejére a nemesi földbirtokok csaknem fele volt már elzálogosítva. Párhuzamosan ezzel megkezdődött a parasztság egyre növekvő vagyoni rétegződése, annak ellenére is, hogy ezt a folyamatot, ahogy a beruházási kedvet is, jelentősen visszafogta a föld tulajdonlásának faluközösségi formája.

A reformok persze nemcsak ezért jártak ellentmondásos eredménnyel. Ebben éppúgy közrejátszott az alkotmányozás elmaradása, a népképviselet ügyének megoldatlansága, mint az a körülmény, hogy az orosz társadalom rendi szerkezete a „nagy reformok” dacára is felettébb ellenállónak bizonyult. Komoly tehertételt jelentett a paraszti közösség tájékozatlansága és az őket fogva tartó tradíciók ereje is. Ahhoz azonban, hogy ezen a helyzeten változtatni lehessen 
az állam nem rendelkezett olyan kiterjedt és felkészült igazgatási apparátussal, amelynek révén képes lett volna a járások és a falvak szintjén is eredményesen beavatkozni, politikai akaratát érvényre juttatni. Ezek a tényezők együttesen olyan jelentős ellenerőt képeztek, ami miatt a reformok csak korlátozott és ellentmondásos eredményre vezethettek. Ám még ebben a formájukban is képesek voltak néhány évtized alatt jelentősen átalakítani a hatalmas birodalmat.

E nagyszabású, immár a politikai rendszerre is kiterjedő átalakulás közepette érte Oroszországot az I. világháború. Az Orosz Birodalom azonban ahhoz túl szegény volt, hogy viselni tudja a hosszan elhúzódó háború terheit. Ennek jelei már korábban, a 19. század nagy konfliktusaiban is megmutatkoztak, de a cárizmus „szerencséjére” mind a napóleoni, mind a krími háborút sikerült még azt megelőzően lezárni - az előbbit győztesként, míg az utóbbit vesztesként -, hogy kiderült volna az ország gazdasági gyengesége. Az 19041905-ös, ugyancsak vesztes Japán elleni háborúból is sikerült még a teljes összeomlás elött kilépni, de már akkor nyilvánvalóvá vált, hogy gondok vannak a hadsereg sorállományát adó parasztok kitartásával és lojalitásával. Ráadásul a feleslegesen vívott háború súlyos társadalmi elégedetlenséget keltett és döntő szerepet játszott abban, hogy - Európa többi részéhez képest évtizedeket késve - Oroszországban is polgári forradalomra kerüljön sor, és megkezdődjék a birodalom politikai rendszerének átalakítása. A „nagy háborúból” azonban - ellentétben a korábbiakkal - Szentpétervár nem tudott időben kilépni. Az elhúzódó és egyre nagyobb terhekkel járó háború következtében előbb súlyos ellátási gondok, majd kormányzati, végül pedig általános politikai válság alakult ki. Mindennek betetőzéseként 1917 februárjában újabb forradalomra került sor, ami rövid időn belül elsöpörte a cárizmust. Nem sokkal azt követően, hogy lemondott II. Miklós, kikiáltották a köztársaságot, szabadon engedték a politikai foglyokat, eltörölték a halálbüntetést, felszámolták a cárizmus utolsó napjaiig fennálló etnikai és felekezeti alapú diszkriminációt és előkészítették az Alkotmányozó Gyülésbe történő általános, egyenlö, közvetlen és titkos választást. A hatalmat gyakorló Ideiglenes Kormány első lépései közt ismerte el a lengyel területek függetlenségét és állította helyre a birodalomhoz tartozó Finn Nagyhercegség autonómiáját. De mert folytatni akarta a háborút, és mert nem ismerte fel a földkérdés jelentőségét, politikai erejét drámai gyorsasággal veszítette el. Olyannyira, hogy október végén, alig félévvel azok után, hogy kezébe került a hatalom, már nem tudott a bolsevikoknak ellenállni

1917 öszétől új korszak vette kezdetét Oroszországban. A bolsevikok irányította hatalom azonban csak egy évekig elhúzódó és rendkívüli veszteségekkel járó polgárháború eredményeképpen tudta stabilizálni helyzetét. Az 1922 végén létrehozott Szovjetunió óriási erőfeszítések és súlyos áldozatok árán megpróbálta leküzdeni az ország gazdasági elmaradottságát és újra a nagyhatalmak közé emelkedni. Ez azonban csak részben sikerült. A Szovjetunió 
ugyan katonai nagyhatalommá vált, de gazdaságának teljesítménye még a fénykorában - múlt század hetvenes éveinek közepén - sem tudta megközelíteni az Egyesült Államokét. És miután eljutott a csúcsra a szovjet gazdasági növekedés dinamikája már mintegy másfél évtizeddel a Szovjetunió felbomlása elött megtört és lassuló pályára állt, megalapozva ezzel mind a szovjet típusú társadalmi rend, mind a szovjet államkeret 1991 végi összeomlását.

\subsubsection{Időrendi tábla}

\begin{tabular}{c|l} 
dátum & \multicolumn{1}{c}{ esemény } \\
\hline 859 & Velikij Novgorod megalapíása \\
\hline 882 & Kijev az első keleti szláv állam, a Kijevi Rusz fövárosává válik \\
\hline $988 / 989$ & A Kijevi Rusz hivatalosan is felveszi a kereszténységet \\
\hline 1054 & $\begin{array}{l}\text { A nagy egyházszakadás: különválik a keleti és a nyugati } \\
\text { kereszténység }\end{array}$ \\
\hline 1108 & Vlagyimir megalapítása \\
\hline 1147 & Moszkva megalapítása \\
\hline 1223 & Elöször jelennek meg a mongolok a kijevi állam határainál \\
\hline 1237 & $\begin{array}{l}\text { A mongol erők átkelnek a Volgán: megkezdődik a Kijevi Rusz egyes } \\
\text { területeinek megszállása és függö helyzetbe kényszerítése }\end{array}$ \\
\hline 1300 & A metropolita székhelyének áthelyezése Kijevböl Vlagyimirba \\
\hline 1321 & A metropolita székhelye Vlagyimirból Moszkvába kerül \\
\hline 1380 & Az orosz erők Kulikovonál legyőzik a mongol-tatár sereget \\
\hline 1392 & Moszkva fennhatósága alá vonja Nyizsnij Novgorodot és Szuzdalt \\
\hline 1448 & $\begin{array}{l}\text { Az orosz ortodox egyház elnyeri - a Konstantinápoly által még el } \\
\text { nem ismert - önállóságot }\end{array}$ \\
\hline 1478 & III. Iván lerohanja Velikij Novgorodot \\
\hline 1480 & III. Iván véget vet a tatár függésnek \\
\hline 1510 & III. Vaszilij elfoglalja Pszkovot \\
\hline 1547 & IV. Iván felveszi a cári címet \\
\hline 1552 & IV. Iván meghódítja a Kazanyi Kánságot \\
\hline 1556 & IV. Iván legyözi az Asztrahanyi Kánságot \\
\hline 1582 & Befejeződik Nyugat-Szibéria meghódítása \\
\hline 1589 & A moszkvai metropolita pátriárka rangra emelkedik \\
\hline 1598 & Meghal az utolsó Rjurik-házi uralkodó, I. Fjodor \\
\hline 1605 & A ,zavaros idöszak” kezdete \\
\hline 1613 & Trónra lép az első Romanov-házi uralkodó, Mihail Fjodorovics \\
\hline 1652 & Moszkvai pátriárkává választják Nyikont \\
\hline 1703 & I. Péter „,nagy követjárása” \\
\hline & I. Péter megalapítja Szentpétervárt \\
\hline &
\end{tabular}




\begin{tabular}{|c|c|}
\hline dátum & esemény \\
\hline 1709 & Poltavánál I. Péter legyőzi a svéd királyt, XII. Károlyt \\
\hline 1721 & $\begin{array}{l}\text { Aláírják a nystadi békét: ezzel lezárul az 1700-tól tartó „északi } \\
\text { háború” }\end{array}$ \\
\hline 1721 & A Szenátus imperátorrá nyilvánítja I. Pétert \\
\hline 1721 & I. Péter felszámolja a pátriárkatust \\
\hline 1722 & Megjelenik a Rangtábla-törvény \\
\hline 1762 & A nemesség mentesül a kötelező állami szolgálat alól \\
\hline 1772 & Lengyelország első felosztása \\
\hline 1783 & Oroszországhoz kerül a Krím-félsziget \\
\hline 1785 & II. Katalin kiadja nemesi adománylevelét \\
\hline 1793 & Lengyelország második felosztása \\
\hline 1795 & Lengyelország harmadik felosztása \\
\hline 1812 & Napóleon serege betör Oroszországba \\
\hline 1825 & A dekabristák felkelése \\
\hline 1830 & Lázadás a lengyel területeken \\
\hline $1853 / 1856$ & A krími háború \\
\hline 1860 & Vlagyivosztok megalapítása a Csendes-óceán partjánál \\
\hline 1861 & A jobbágyfelszabadítás bejelentése \\
\hline 1864 & A zemsztvo-reform és a bírósági reform elindítása \\
\hline 1867 & Oroszország eladja Alaszkát az Egyesült Államoknak \\
\hline 1874 & Az általános hadkötelezettség bevezetése \\
\hline 1891 & Megkezdődik a transzszibériai vasútvonal építése \\
\hline $1904 / 1905$ & Japán-orosz háború \\
\hline $1905 / 1907$ & Az első polgári forradalom Oroszországban \\
\hline 1905 & $\begin{array}{l}\text { II. Miklós kiadja októberi manifesztumát és abban ígéretet tesz a } \\
\text { polgári jogok tiszteletben tartására }\end{array}$ \\
\hline 1906 & $\begin{array}{l}\text { Megválasztják az Állami Dumát, az első - tanácskozási jogkörü - } \\
\text { országos képviseleti intézményt }\end{array}$ \\
\hline 1917 & $\begin{array}{l}\text { A februári forradalom megdönti a cárizmust, az októberi forradalom } \\
\text { pedig a helyére lépö Ideiglenes Kormányt. A hatalom a bolsevikok } \\
\text { kezébe kerül. }\end{array}$ \\
\hline $1918 / 1921$ & Véres polgárháború Oroszországban \\
\hline 1922 & Létrejön a Szovjetunió \\
\hline 1991 & $\begin{array}{l}\text { Felbomlik a Szovjetunió, helyén létrejön a Független Államok } \\
\text { Közössége }\end{array}$ \\
\hline
\end{tabular}




\subsubsection{Irodalomjegyzék}

Ajánlott irodalom

Anderson, Perry 1989.: Az abszolutista állam. Budapest: Gondolat Bodin, JeAn 1987: Az államról. Budapest: Gondolat

ETKIND, ALEXANDER 2011: Internal Colonization: Russia's Imperial Experience. Cambridge: Polity Press

KAPPELER, ANDREAS 1992: Russland als vielvoelkerreich. Entsehung. Geschichte. Zerfall. München: C. H. Beck

Krausz Tamás - SzváK GyUla - Béládi László (szerk.) 1983: Az orosz történelem egyetemessége és különössége. Budapest: ELTE ÁJK

Milner-Gulland, Robin - Dejevsky, Nikolai 2000: Az orosz világ atlasza. Budapest: Helikon

Sz. BíRó ZolTÁN (szerk.) 1995: „Az orosz fejlödés különlegessége”. Replika december, pp. 91-177.

SzŰCS JENŐ 1983: Vázlat Európa három történeti régiójáról. Budapest: Magvető

TALlár Ferenc 1984: Utópiák igézetében. „Sajátos orosz fejlődés” és az orosz regényforma a XIX. sz. elsö felében. Budapest: Magvető

\section{További irodalom}

Becker, Seymour 1985: Nobility and Privilege in Late Imperial Russia. DeKalb: Northern Illinois University Press

Blum, Jerome 1971: Lord and Peasant in Russia. From the Ninth to the Nineteenth Century. Princeton: Princeton University Press

Csaadajev, P. 1989: Sztatyi i piszma. Moszkva: Szovremennyik

FlorenszKiJ, PAVel 1916: Okolo Homjakova. Szergijev Paszad: Tyipografija Szvjato-Troickoj Szergijevoj lavri

Mironov, Borisz 2014: Rosszijszkaja imperija: ot tradicii k modernu, v 3-h tomah. Szankt-Peterburg: Dmitrij Bulanyin

RaefF, Marc 1990: Ponjaty dorevoljucionnuju Rossziju. Goszudarsztvo $i$ obscsesztvo $v$ Rosszijszkoj imperii. London: Overseas Publications Interchange

RomANOvics-SzlavatyinszKiJ, A. 1870: Dvorjanszivo $v$ Rosszii ot nacsala XVIII veka do otmeni kreposztnogo prava. Szankt-Peterburg: Tyipografija Minyisztyersztva vnutrennih gyel 



\title{
6.2. A nyugati keresztény Európa ${ }^{13}$
}

\author{
ZSINKA LÁSZLÓ
}

\subsubsection{Szemléleti alapvetés}

A civilizációk történetében Európa (vagy a Nyugat) különleges helyet foglalt el az elmúlt ötszáz évben. Az európaiak kezdték el „felfedezni” a világot, amelyre Kolumbusz és Vasco de Gama hajóútjai hívják fel a figyelmet. Az európai kontinens kivételes szerepet játszott a globális világ felé vezető úton. Elöször Európában zajlott le az ipari forradalom, ami lehetővé tette egy olyan civilizáció létrejöttét, ahol a népesség többsége már nem az agrárszektorban találta meg megélhetését. Az európai kontinensen született meg az állam és a társadalom viszonyát átformáló társadalmi szerződés, a liberalizmus és a demokrácia eszméje, amelyek a 19-20. században világszerte átalakították az államok és a nemzetek politikai berendezkedését. Európában jött létre a hagyományos közösségközpontú társadalmakhoz képest az individualizmus értékrendje, amely lehetővé tette a kulturális modernitás megszületését. Az európai kontinens a gazdaság, a politika és a kultúra területén egyaránt rendelkezett olyan ,innovációkkal”, amelyek nemcsak megkülönböztették a többi civilizációtól, hanem egyedülállóvá tették fejlődését. Az európai civilizációról nem beszélhetünk anélkül, hogy ne keresnénk választ arra a kérdésre, miért Európa vált a modern világ kiindulópontjává.

A „miért Európa" kérdéskörét az angolszász történet- és társadalomtudományok a ,the rise of the West” (,a Nyugat felemelkedése”) kifejezés alatt tárgyalták az elmúlt fél évszázadban. Eredményeik jelentős mértékben hozzájárultak Európa civilizációs karakterének jobb megértéséhez. A Nyugat/Európa kivételes történeti fejlödésének problémája megfelelő kérdésfeltevésnek bizonyult a nyugati hegemónia időszakában. Manapság az ázsiai térség felemelkedésével nyilvánvalóvá vált, hogy a nyugati fölény korszaka az emberi civilizáció történetének csak néhány évszázadát képviselte, és a különböző társadalmak eltérő utakon juthatnak el a modernitás világába. Mindez az unilineáris szemléletmóddal szemben a multilineáris elméleteknek kedvezett; s az Európát és Észak-Amerikát egybekapcsoló Atlantikum történelmi jelentősége helyett a nagy ázsiai civilizációkat magába foglaló eurázsiai térség világtörténelmi szerepére világított rá. Az elmúlt évtizedekben hatottak a posztmodern áramlatok is, amelyek a Nyugat kivételességének (excepcionalizmus) viszonylagossá tételét tüzték ki célul (relativizmus).

13 A jelen tanulmány egyes részletei Európa felemelkedése címü készülő könyvem rövidített változatát alkotják, különös tekintettel A nyugati keresztény Európa születése és Európa első „,nekilendülése” az érett középkorban címü fejezetekre. 
A 20. század második felében a társadalomtudományi gondolkodás a Nyugat felemelkedését vizsgálva elsősorban a modernitás dinamikájának jobb megértésére törekedett. Az Európa szót leginkább az európai integrációs folyamattal, illetve annak szellemi és kulturális háttérével összefüggésben használták. Holott „Európa” régebbi keletű kifejezés, mint a „Nyugat”. Európa a görög mitológiában jelent meg először, és azt a föníciai királylányt jelölte, akibe Zeusz beleszeretett, majd magával vitte Kréta szigetére. A mítosz szimbolikusan utalt az ókori keleti civilizációk és a megszülető európai kultúra közötti kapcsolatokra. Fogalomtörténeti szempontból az tủnik lényeges mozzanatnak, hogy az i. e. 8-6. század között a mitológiai nőalak jelentésmódosuláson ment keresztül. A homéroszi eposzok keletkezése idején (i. e. 8. század) még aligha rendelkezett földrajzi jelentéssel, míg Hérodotosz, ill. a görög-perzsa háborúk korában (i. e. 5. század) már nagyjából azt a területet értették alatta, amelyet napjainkban is a kontinens területével azonosít a földrajztudomány.

Európa antik földrajzi fogalma bizonyos mértékig eltér a modern geográfia meghatározásától. A klasszikus ókorban az európai kontinens a Tanaisz (ma: Don) folyónál végződött, míg a jelenleg érvényes definíció szerint keletebbre húzódik, és egészen a Volgáig tart. Az ókori görögök és rómaiak alig rendelkeztek ismeretekkel Skandináviáról és a kelet-európai síkság északi részéről. Európa modern földrajzi fogalmát csak a 19. században határozta meg Volger, német geográfus, aki az Urált, a Volgát és a Kaukázust tekintette a kontinens keleti határának.

Európát a görög-római antikvitás idején földrajzi kategóriaként használták. A kora középkor kezdetén az elnevezés alig fordult elő a történeti forrásokban, ami kifejezésre juttatja, hogy az ókor végével átalakulóban volt a civilizációs tartalom, ami alapján Európát földrajzi definíción túlmutató szociokulturális jegyekkel lehetett felruházni. A Karoling Európa létrejöttével ez a strukturális tartalom született meg a keresztény államszervezés eredményei révén, amit Nagy Károly császárrá koronázása tetőzött be (800). Nem meglepő, hogy a frank uralkodót a korabeli források „Európa világítótornyának” nevezték.

$\mathrm{Az}$ ezredforduló után a kontinens mindinkább azonosult a „kereszténységgel”. Az Európa szót a 11-13. században jószerével nem használták. Ehelyett a „keresztény nemzetközösség” kifejezés vált elterjedtté Respublica Christiana -, érzékeltetve az európai kontinens és a keresztény hit azonosságát. Európa a késő középkortól jött ismét használatba a szekularizáció tendenciájának kibontakozásával. A kultúra laicizálódása a 17-18. századra vezetett oda, hogy a „kereszténység” elnevezés lassan kikopott a szóhasználatból. Ettől fogva az értelmiségiek az Európa szót használták, amikor a kontinens jellegadó vonásainak a leírására törekedtek. Ez kifejezte azt a szándékot, hogy az európai civilizáció jellegzetességeit is meghatározzák, aminek a kereszténység 
fontos, de nem egyedüli elemét képezte. A francia felvilágosodás során Voltaire már számolt azzal a ténnyel, hogy Európában számos ország, nemzet található, amelyek különböznek egymástól. Másfelöl létezik egy „európai dimenzió”, amely a nemzeti entitások közös hátterét alkotja, de nem azonosítható kizárólag a keresztény hittel.

Az ókortól eltérően Európát a modern korban nemcsak földrajzi fogalomként definiálták, hanem társadalmi és kulturális tartalmat is értettek alatta. Ennek értelmiségi reflexiója fokozatosan elmélyült a 19-20. század során. A kora újkor politikai gondolkodói a keleti „despotizmushoz” képest Európát a „szabadsággal” azonosították. A „hosszú 19. században” az emberi történelem kivételes színtereként tartották számon, ahol az emberiség emancipációja kibontakozhat, ami egyben a világtörténelmi fejlődés irányát is kijelöli. A 20. század első felében a keresztény és a polgári humanista gondolkodók szemében Európa olyan metafora lett, ami a „szabadság” és a „kereszténység” értékeit testesítette meg, amelyek szembeállíthatók a jobbés baloldali totalitarizmusokkal. A hidegháború idején ez a szemléletmód öröklődött tovább, amikor az Amerikai Egyesült Államokkal kibővülő „,szabad világ" a kommunista országokkal állt szemben. Napjainkban az Európa szó az integrációs folyamat technokrata összefüggéseivel válik azonossá. Ez arra utal, hogy elhalványulóban van az a civilizációs tartalom, ami az európai kontinenst más kultúráktól megkülönbözteti. Ezt a jelenséget egyes értelmiségi csoportok „kulturális/civilizációs válságként” tartják számon.

A nagy múltú Európához képest a Nyugat újabb keletủ kategória, amit a társadalomtudományok a 19. század végétől a modern világ születésének színteréül szolgáló euro-amerikai térség leírására használtak. Európa nemcsak szemléletileg, de földrajzilag is megkülönböztethető a Nyugattól, mert ez utóbbi magában foglalja Észak-Amerikát is. Európa a humán tudományok (humanities) érdeklődésénekatárgyátképezőeszmékésértékek-,,szabadság”, ,kereszténység”, „ész”, „humanitás” - foglalata, míg a Nyugat a társadalomtudományok (social sciences) bevett fogalmai segítségével - „kapitalizmus”, „piac”, „magántulajdon”, „racionális állam” - jellemezhető. A nyugatias fejlődés jellegadó vonásainak értelmezésében nagy jelentőségre tett szert Max Weber német szociológus a 19-20. század fordulóján, aki meghatározó módon járult hozzá a modernséggel kapcsolatos alapvető kategóriáink kimunkálásához. Míg Európa civilizációs-kulturális tartalmat jelenít meg, a Nyugat egy gazdasági és társadalmi modell kialakulását és lényeges jegyeit kívánja körülírni. A Nyugat földrajzilag az európai kontinens dinamikus nyugati felét és Észak-Amerikát kapcsolja egybe, de az általa felkínált modell egyetemessé tágítható, ahogyan az be is következett a hidegháború lezárulása után azoknak a politikusoknak a megnyilatkozásaiban, akik a liberális demokrácia és a szabad piac univerzális igényét hirdették. 
Amikor a Nyugatról kívánunk beszélni, nem kerülhetjük meg a „modernség”, a „modernitás” és a „modernizáció” ideáltipikus fogalmainak tisztázását. Gazdasági szempontból a modernség alatt a rokonságelvü vagy redisztributív termelési és elosztási viszonyok helyett a piac és a kapitalizmus létrejöttét, a preindusztriális agrártársadalmak helyett az indusztriális társadalom és az ipari nagyszervezetek kialakulását értjük. Társadalmilag a modernség a hierarchikus és a rendi társadalmak helyett az osztálytársadalmak kialakulásával járt, amit a születési egyenlőség és az egyéni teljesítmény határoz meg. Politikai tekintetben a „kormányzottak” közössége a modernitásban nem meghatározottja a „kormányzóknak”, hanem az „állammal” szemben a „társadalom” tesz szert prioritásra, ami a társadalmi szerződés és a képviseleti demokrácia fogalmaiban éppúgy kifejeződik, mint azállampolgárok hatalommal szembeni szabadságában és garantált jogaiban. Kulturális szempontból a közösségközpontú és tradicionális társadalmakkal szemben megjelenik az egyénközpontú értékrend (individualizmus). A modernitás többrétegü jelentéssel bír, és a Nyugat története úgy értelmezhető, mint ezeknek a dimenzióknak a megvalósulása.

A Nyugat nemcsak egyetemes gazdasági és társadalmi modellként fogható fel, hanem hegemón civilizációvá is vált az elmúlt századokban. Ma ennek a korszaknak a lezárulásával szembesülünk. Ebből fakad, hogy a nemzetközi kapcsolatok diszciplínája sokat foglalkozik a nyugati hegemónia helyén létrejövő multipoláris nemzetközi rendszerrel. A hegemón Nyugat kialakulása, fennállása és hanyatlása nagyobb elméleti távlatba helyezve is számos tudományos elemzés tárgyát képezte az elmúlt évtizedekben. Ezek közül alapvető kérdésnek tünik a nyugati hegemónia gyökerei, a nyugat-európai fejlödési jellegzetességek, valamint a nyugati gazdasági és társadalmi dinamika problémája.

Európa nyugati fele az elmúlt másfél ezer évben sok tekintetben különbözött a kontinens keleti felétől. A legfontosabb különbséget a nyugati (latin) és a keleti (ortodox) kereszténység közötti eltérések jelentették, amire egyre újabb megkülönböztető vonások rakódtak rá az évszázadok során. Meghatározónak bizonyult, hogy Nyugat-Európa Közép- és Kelet-Európához képest nagyobb múlttal rendelkező kereszténységre tekinthet vissza. Továbbá a latin Nyugat részesült a protestantizmus lendületében, a nagy földrajzi felfedezésekkel kialakuló atlanti világgazdaság dinamizmusában, a 17. századi tudományos forradalomban és a felvilágosodásban. Nyugati irányba kitáguló fele, az Amerikai Egyesült Államok az elmúlt két században olyan gazdasági és politikai erőre tett szert, ami a nyugat-európai és az észak-amerikai civilizációk közötti erőviszonyokat is átalakította.

Bár az európai eszméket gyökereztette meg, az észak-amerikai világ különbözött az európai ideáloktól. Az európai civilizáció kétezer éves múltjával szemben éles kontrasztot képez az észak-amerikai telepes-társadalom háromszáz éves története. Azészak-amerikai civilizáció is elsajátította a keresztény alapokat, 
a képviseleti demokrácia, a hatalommegosztás, az állampolgári szabadság és a szabad piac eszméit. A nyugati keresztény Európa nagyobb mértékben támaszkodott a katolikus tradícióra, a szabadság és a szolidaritás egyensúlyára, az autonóm közösségekre, a korporatív társadalomszervezésre és az etatizmus hagyományára. Az észak-amerikai társadalmakat a protestantizmus, a laissez faire, a szabad piac, a minimal state eszméje, az individualizmus és az egyéni kezdeményezés uralkodó szerepe jellemezték. Ezek a tényezők jól érzékeltetik, milyen erővonalak mentén különböztethetők meg a nyugat-európai és az északamerikai civilizációk egymástól.

A Nyugatot az euro-amerikai világgal azonosíthatjuk, amelynek két alrendszere a nyugat-európai és az észak-amerikai civilizációk. Egyes értelmezések a kettő közötti különbségeket emelik ki, és autonóm jellegüket hangsúlyozzák, míg más megközelítések a hasonlóságokra hívják fel a figyelmet. A jelen értelmezés keretében a nyugat-európai keresztény civilizációt és az észak-amerikai civilizációt önálló jelenségekként kezeljük, (és különálló tanulmányok keretében foglalkozunk velük). Másfelől a nyugati keresztény Európát megkülönböztetjük az ortodox keresztény világtól is, ami az Európa nyugati és keleti fele közötti lényegi differenciák elismerését jelenti. A nyugati és a keleti kereszténység nemcsak dogmatikailag és liturgikusan tért el egymástól, hanem önálló sajátosságokkal rendelkező keresztény kultúrák létrejöttéhez járult hozzá. Ezek - további történelmi tényezőkkel összekapcsolódva - eltérő arculatú civilizációk megformálódását eredményezték Európa nyugati és keleti részén.

\subsubsection{Alapelemek és keretek}

A modern történettudomány a „nyugati keresztény Európa” vagy a „nyugati keresztény civilizáció” helyett számos esetben az „európai civilizáció” kifejezést használta. Az európai civilizáció időbeli kereteinek megvonásakor azzal a kérdéssel szembesülünk, hogy a görög-római antikvitás az európai civilizációs örökség szerves részét képezi-e. Amennyiben a klasszikus antikvitást az európai civilizáció részének tekintjük, Európa kezdetei az ókori görög történelem hajnaláig, azaz Homérosz koráig (i. e. 8. század) nyúlnak vissza. Ha viszont arra az álláspontra helyezkedünk, hogy Európa a kereszténységgel és a germánsággal kezdődött, az európai civilizáció kezdeteit az i. sz. 1. évezred második feléig vezethetjük vissza.

Az első álláspontot vallotta magáénak a 19. századi német újhumanizmus, a másodikat Oswald Spengler A Nyugat alkonya (1918-1922) címü munkájában. A két világháború közötti polgári és keresztény humanista gondolkodók és történetírók - Gonzague Reynold, Christopher Dawson, Herbert W. Rüssel - a kereszténység kiemelkedő jelentőségét hangsúlyozták Európa megszületésében. 
Ugyanakkor alapvető fontosságú jelenségként tekintettek a keresztény-antik szintézisre, ami a klasszikus ókori örökség befogadását és átformálását jelentette a keresztény kultúra keretei között. Nézőpontjuk szerint az európai civilizáció története ugyan a kereszténységgel kezdődött, de az antikvitást Spenglertől eltéröen nem tartották „külsődleges” jelenségnek.

A kortárs történettudományi irányzatok nem mutatnak kitüntetett érdeklődést „Európa”, mint civilizációs egység kezdeteinek meghatározása iránt. Annyi mégis elmondható, hogy az európai kultúrával foglalkozó történészek nagyobb része a keresztény vallást alapvető tényezőnek tartja. A klasszikus antikvitás szerepét illetően megoszlik a történészek véleménye, de a kereszténység szerepének elismerése vitán felül áll. Ezzel együtt a modern történet- és társadalomtudományok megosztottak abban a kérdésben, hogy a kereszténység mely aspektusára helyezik a hangsúlyt az európai történelemben. A keresztény hit történelemalakító hatásának elismerése teszi lehetővé, hogy az „európai civilizáció” szinonimájaként „nyugati/latin keresztény Európáról”, „nyugati keresztény civilizációról” vagy „nyugat-európai keresztény civilizációról" beszéljünk.

A nyugati kereszténység egyes vonásai révén pontosabban meghatározhatjuk, mit értünk a keresztény hit történelemformáló szerepén. Egyrészt a kereszténység nemcsak vallás, hanem olyan hit- és tanrendszer, amelynek társadalmi következményei is vannak. Ezért beszélhetünk a keresztény hit társadalmi dimenziójáról, ami befolyásolta a társadalmi struktúrák és a politikai intézmények fejlődését. A kereszténység azon attitüdjéből, hogy nem politikai mozgalom - Jézus Krisztus Mohamedtől és utódaitól eltérően nem hozott létre államot - levezethető a szent és a profán megkülönböztetése, ami hosszabb távon a vallás és a politika közötti különbségtételhez, illetve a szekularizációhoz és a laicizálódáshoz vezetett az európai történelemben. Ehhez képest más világvallások által formált civilizációk hatókörében a szakrális és a profán közötti különbség, mint probléma kevéssé értelmezhető. Másrészt a kereszténység rendelkezik ugyan „társadalmi dimenzióval”, de - a hinduizmustól eltérően - nem azonosult teljes mértékben egyetlen társadalmi rendszerrel sem, hanem egyetemes küldetést hirdetett, és elismerte a társadalmi szférák viszonylagos autonómiáját. A keresztények alkalmazták a római jogot, és az iszlámtól eltérő módon nem hoztak létre autonóm vallásjogot a társadalmi viszonyok szabályzására. Jól érzékelteti ezt a jelenséget az angol nyelvben a Christendom és a Christianity közötti különbség. Az előbbi a kereszténység alatt egyaránt ért vallási, társadalmi és politikai univerzumot, míg az utóbbi az egyén személyes hitére utal. E két fogalom párhuzamos létezése már önmagában is kifejezésre juttatja a kereszténységnek azt a vonását, hogy nem akart azonosulni egyetlen társadalmi-politikai vagy jogi-etikai rendszerrel sem, hanem az egyén hiteként (is) igyekezett meghatározni magát. Ebben a távlatban kell utalnunk 
arra is, hogy az európai történelemben soha nem beszélhetünk a „tökéletes” keresztény társadalomról, vagy annak megnyilvánulásaként az úgynevezett keresztény „nagy középkorról”. Bár a középkor dele (12-13. század) a Christendom nagy korszaka volt, de ez nem jár azzal, hogy az egyének hite (Christianity) több vagy jobb lett volna, mint a megelőző vagy a rákövetkező századokban. A keresztény Európa legragyogóbb korszakaiban sem találkozunk homogén és ellentmondásoktól mentes keresztény társadalommal, ami nem azt jelenti, hogy kétségbe akarnánk vonni a középkori keresztény civilizáció nagyszerü teljesítményeit.

Harmadrészt a keresztény hitet világosan meg kell különböztetnünk a keresztény kultúrától. Az elmúlt két évszázadban egyre kevésbé beszélhetünk „keresztény Európáról” akár a szó hitbeli értelmében, akár társadalmi vagy etikai normarendszerként, de a keresztény kultúra attitűdjei napjainkig befolyásolják az európai civilizáció alakulását. Manapság az európai népesség alig tíz százaléka vallásgyakorló keresztény. Mégis a keresztény civilizáció reflexei az elvilágiasodott társadalmakat is orientálják.

Végül arra a tényre is fel kell hívni a figyelmet, hogy a keresztény hit társadalmi dimenziója nem függetleníthető attól a civilizációtól, amelyben kifejti hatását. A kereszténység csak a latin Nyugaton vezetett a szakrális és a profán szféra mind határozottabb elválasztásához, míg az ortodox kereszténység területén fennmaradt a vallás és az állam szoros összefonódása. A bizánci civilizáció története során mindig megfigyelhető volt a cezaropapizmus, ami a politikai hatalom keresztény egyház fölötti autoritását jelentette. Ezzel a jelenséggel az ortodox Oroszország történetében is találkozunk. A latin Nyugaton a Nyugatrómai Birodalom bukása (476) után évszázadokig nem koronáztak császárt, ami a pápaság független státuszát eredményezte. A korai germán királyságok nem rendelkeztek elegendő tekintéllyel a pápai hatalom autonómiájának megkérdőjelezésére, míg Bizáncban a császárság ereje és kontinuitása felhasználható volt a konstantinápolyi pátriárka hatalmának korlátozására. Tehát a szakrális és a profán szféra növekvő mértékü elhatárolódása nemcsak a keresztény doktrínából fakadt, hanem eltérő történeti környezetben fejtette ki hatását. Nem véletlen, hogy a szent és a világi szféra megkülönböztetését előmozdító invesztitúraharcokra Nyugat-Európában és nem Bizáncban került sor a 11-12. században.

A nyugati keresztény civilizációt nem kizárólag a keresztény vallás formálta, hanem számolni kell más történeti tényezők hatásával is. Az i. sz. 1. évezred egyik legizgalmasabb jelensége a keresztény vallás, az antik kultúra és a barbár törzsi hagyományok mély egymásra hatása. Már említettük a keresztény humanista történészek - Dawson, Reynold - mértékadó álláspontját, amely szerint a görög-római antikvitás ugyan önálló kulturális entitásként határozható meg a nyugati keresztény civilizációhoz képest, de befogadása és átformálódása a 
kora középkortól egészen a német újhumanizmusig alakította az európai kultúrát. Ennek eredményeként a klasszikus antikvitás elvesztette „idegenségét”, és egyre inkább a nyugati keresztény Európa „sajátja” lett olyannyira, hogy egyes újkori humanisták - mint Humboldt - ezt tartották az európai civilizáció lényegének. Az antikvitás ,átszármaztatása”, „beoltása” a nyugati keresztény civilizációba arra hívja fel a figyelmet, hogy a görög-római ókor nemcsak külsődleges elözménye az európai kultúrának, hanem hosszú évszázadokon át elevenen ható tényezővé vált. Ennek ellenére a nyugati keresztény Európa jóval több lett, mint a klasszikus antikvitás egyszerü beteljesedése. Mindezen megfontolások alapján a nyugati keresztény civilizációt „,második generációs” civilizációként határozhatjuk meg, amelynek a történetét az antik örökség befolyásolta, de korántsem határozta meg minden tekintetben. Az ókori előzmények ellenére a keresztény Nyugat alapvetően újszerü civilizációnak tekinthető.

Hasonló jelenséget figyelhetünk meg a barbár törzsi kultúrákat illetően. Az i. sz. 1. évezred során a germán, majd a szláv népek egyre szorosabb kapcsolatba kerültek a kereszténységgel és az antikvitással. A kölcsönhatások kibontakozhattak a kultúra síkján, ami például az antik mủvelődés átvételét jelentette az egykori barbár területeken létrejövő keresztény iskola keretei között. Társadalmi struktúrák egybeolvadására is sor kerülhetett, amire jó példa a késő római nagybirtokok ,áthasonulása” középkori feudális uradalmakká, amelyeket később a keresztény társadalomszervezés foglalt tágabb állami keretbe. Kormányzati minták is válhattak modellértékủvé, amit jól érzékeltet az antik városi önkormányzat ideájának továbbélése a középkori olasz városköztársaságokban.

A történettudomány bevett toposza, hogy az európai civilizáció történetét három alapvető tényező, (1.) a zsidó és a keresztény vallás, (2.) a görög-római antikvitás, valamint (3.) a népi-törzsi (majd nemzeti) kultúrák együtteseként írhatjuk le. Eszerint az európai civilizáció lényege az a mélyreható kölcsönhatás, amely a három alapvető elem között kibontakozott. Ezek a civilizációs alapelemek arra is felhívják a figyelmet, hogy Európa nem „egynemü”, homogén civilizáció, hanem bonyolult szociokulturális folyamatok terméke, ahol a kölcsönhatások kivételes mélysége eredményezte az európai kultúra egyedülálló karakterét. Egyes vélemények szerint „Európa” azóta létezik, amióta számolhatunk a három alapvető elem közötti kölcsönhatásokkal. Mások arra utalnak, hogy kulcsfontosságúnak kell tekintenünk a középkori „olvasztótégelyt”, ahol az alapelemek annyira áthatották, hogy radikálisan átformálták egymást. Az ebből fakadó feszültségek dialektikája az európai történelmet alakító tényezővé vált, ami egészen a modern korig hatást gyakorolt.

Amennyiben elfogadjuk, hogy Európa „lényege” az említett civilizációs alapelemek jelenléte és organikus kölcsönhatása, az európai civilizáció kezdetének - az eddig mondottakkal összhangban - az i. sz. 1. évezred elsö felét 
kell tekintenünk, amikor a kölcsönviszonyok kibontakozása már érzékelhetővé vált a kései antikvitás világában. Ez a felfogás a nyugati keresztény civilizációt olyan „összetett civilizációként” (complex civilization) határozza meg, amit nem egyedül a kereszténység formált. A kereszténység mégis kivételes jelentőségre tett szert, hiszen ez volt az alapvető elem, ami a többit egybefogta. Az „ernyőszerü” keresztény kultúra befolyásolta és „szabályozta” az antik és a barbár örökség átvételét. Ebben az értelemben mondhatjuk, hogy az európai civilizáció „tartalmát” a keresztény, az antik és a népi/nemzeti komponensek, de „formáját” egyedül a kereszténység alakította. Erre utalt a svájci történész Gonzague de Reynold is, amikor a „keresztény tetö” alá hozott Európáról beszélt.

Az európai civilizáció történetét egészen a 18. század végéig leírhatjuk a három civilizációs alapelem egymásra hatásaként. Viszont az elmúlt két évszázadban a „modernség”/,modernitás” térhódítása átrajzolta a képet, hiszen a keresztény hit és a klasszikus kultúra fokozatos letünéséhez vezetett. Ennek fényében érthető, hogy a 20. századi kultúrkritika előszeretettel beszél Európa „végéről”. A kultúrpesszimisták álláspontjával szemben arra kell felhívni a figyelmet, hogy a keresztény hit visszaszorulása ellenére számos keresztény érték szekularizált formában továbbél a modern társadalom keretei között. Ilyen a humanizmus eszméje, ami az ember méltóságának feltétlen értékében testesül meg, vagy a szabadság és a szolidaritás kívánatos egyensúlya iránti erős társadalmi elvárás. Bár a klasszikus kultúra iránti érdeklődés is lehanyatlott, de megmaradt a szövegek értelmezésére vonatkozó racionális kritika és hermeneutikai kultúra. Ezek alapján ma még beszélhetünk a nyugati keresztény civilizációról vagy európai kultúráról, bár más értelemben, mint a modern kor elött.

Anyugati keresztény civilizáció „második generációs”és „komplex”-több összetevőre visszavezethető - kultúra, amelynek a kezdeteit a késő római világba tehetjük, ahol első ízben vált történelemformáló erővé a kereszténység, illetve az antik társadalmak érintkezésbe kerültek a barbár népekkel. A nyugati keresztény Európa „végét” illetően megoszlanak a vélemények. A „kultúrpesszimisták” a régi európai értékek elvesztését hangsúlyozzák, míg a „modernisták” arra helyezik a hangsúlyt, hogy a nyugati modernség egyetemes modelljének - piacgazdaság, kapitalizmus, liberalizmus, demokrácia, individualizmus - megvalósulása révén az európai civilizáció fejlődése a legjobb értelemben beteljesedett. Az elmúlt évszázad megítélése attól függ, hogyan értelmezzük a modernitást Európa történetében. A nyugati keresztény civilizációt beteljesítő jelenségként fogjuk fel, aminek előzményei már a középkortól kimutathatók, vagy az európai civilizációs értékek ,antitéziseként” tekintünk rá. Ez utóbbi esetben kérdéses, beszélhetünk-e még nyugati keresztény civilizációról a 21 . században. 


\subsubsection{A nyugati keresztény Európa születése (200-1000)}

A nyugati keresztény Európa kultúrföldrajzi keretei a kora középkorban (7-11. század) az Alpoktól északra szilárdultak meg. Ezt megelőzte az antik civilizáció felvirágzása, amelynek sajátos vonásai az i. e. 8. századtól alakultak ki a Földközi-tenger medencéjében. A klasszikus ókor tengerparti városi civilizáció volt, amelynek a gazdasági és kulturális egységét a Mediterráneum kedvező tengeri infrastruktúrája biztosította. Az ókori görög poliszok a nagy görög gyarmatosítás (i. e. 7-6. század) után nemcsak az Égeikumot hálózták be, hanem a Földközi-tenger nyugati medencéjét és a Fekete-tengert is. A görög poliszok általában a tengerpart fizikai közelségében helyezkedtek el. Az antik civilizáció a Római Birodalom kialakulása után is megőrizte maritim jellegét. Augustus korában Róma hódításai révén körbefogta a Földközi-tenger egészét, amit nem véletlenül neveztek mare nostrumnak („,mi tengerünknek”). A görögrómai ókor a mediterrán világgal vált azonossá, $\mathrm{s}$ ez alapvetően befolyásolta az antik civilizáció karakterét.

\section{Az antik örökség}

Az antik örökség több vonatkozásban is hatással volt a nyugati keresztény civilizációra. Az ókori görögök találmánya volt a polisz, amely a „felülröl építkező" (up-bottom) államokkal és birodalmakkal szemben első ízben képviselte az önmagát kormányzó autonóm közösség eszméjét az európai történelemben. Az antik szabadság-toposz az európai civilizáció egyik jellegadó örökségévé vált, amivel a premodern társadalmakban alig találkozhatunk. A görögök fogalmazták meg először az ázsiai despotikus államokkal szemben a polgári szabadság gondolatát. Bár ez eltért a „modernek” liberális szabadságától, minta erejével hatott a középkori és a reneszánsz városállamokban (klasszikus republikanizmus), valamint az egész európai politikai hagyományban. Továbbá morálisan elítélték a zsarnokságot, és érveket hoztak fel az ellene való törvényes fellépés érdekében. Így a hatalom számonkérhetőségének gondolata jelentős előzményekre vezethető vissza az európai történelemben.

A filozófia, a nevelés, az irodalom, a képzőművészetek és a szaktudományok területén játszott úttörő szerepük miatt a görög-római örökség egészen a modern korig megtermékenyítette a nyugati keresztény civilizációt. A klasszikus antikvitás esztétikai norma erejével bírt, amit az európai kultúrtörténeti korszakok során eltérő módon értelmeztek, de mindig hathatósan jelen volt. Csak a francia klasszicizmus keretében lezajló „régiek” és „modernek” vitája eredményezte annak elismerését a 17. században, hogy a modern kor alkotásai önértékkel bírnak, sőt még az is lehet, hogy jobbak, mint a görög-római antikvitás értékei. A régiek és modernek vitája megalapozta 
a modernitás haladáselvü szemléletmódját, de azt megelőzően az antikvitás mủalkotásai bizonyultak irányadónak.

A klasszikus antikvitás egyik nagy hatású öröksége a humanizmus megszületésében ragadható meg. A humanizmus, mint emberközpontúság felfogható az európai civilizáció alapvető értékeként, ami a modern korban is egyfajta közös nevezőt jelentett a keresztények és az ateisták között. De látni kell, hogy az ókorban az „emberközpontúság” megfogalmazódása hosszú folyamat eredménye volt, és nagyszerü eredményei ellenére is csak korlátozottan teljesedett ki. Magát a humanizmus szót sem használták - ez utóbbi kifejezés újkori eredetü, amit a német újhumanisták részéről először Niethammer alkalmazott a 19. század elején -, hanem humanitasról beszéltek.

Az ógörög kultúra klasszikus korszakában (i. e. 5-4. század) az irodalmi és filozófiai szövegek tanúsága szerint még nem alakult ki az embert tudatosan a kozmosz középpontjába helyező egységes emberkép, bár a görög irodalom árnyaltabban fejezte ki az emberi érzéseket és gondolatokat, mint az ókori közel-keleti irodalmak. A klasszikus korban a görögök humanizmusa leginkább képzőművészeti alkotásokban testesült meg, amikor a szép emberi testet harmonikus és valós arányaiban ábrázolták. A szobrok nem az emberi méltóság eszméjét közvetítették, hanem az istenek és az olimpiai győztesek szépségét igyekeztek kőbe vésni, miközben vallomást tettek az ember nagyságáról és szépségéről is. Az ember méltósága csak Nagy Sándor hódításai után a hellenisztikus korban - i. e. 3-1. század - vált témává, amikor megnövekedett az iskolai művelődés jelentősége. Ettől fogva a görögök abban hittek, hogy az emberi méltóság a müveltség - enkükliosz paideia - elsajátításán keresztül, azaz a tanulás révén érhetô el. A kultúra megismerése az érvényes nevelési eszmény (paideia) jegyében történt, ami a művelődés anyagát is orientálta. A görögök szerint az iskolai műveltség felemeli és tökéletesíti az embert, és előmozdítja, hogy méltósága kibontakozhasson.

A hellenisztikus kor iskolai humanizmusa kései jelenség, és ezt örökölték meg a rómaiak. Nem véletlen, hogy Cicero a görög paideia szót az i. e. 1. században a latin humanitas kifejezéssel fordította le, és az általa megtestesített nevelési humanizmus öröklődött a középkor századaiban egészen a reneszánszig. Eredményei ellenére az ókor humanizmusának megvoltak a korlátai, és kérdéses lett volna fennmaradása is, ha nem találkozik a kereszténységgel, amely saját humanista tendenciákkal - bibliai humanizmus, keresztény humanizmus rendelkezett. Ezáltal felkarolta és megerősítette az antik humanista tartalmakat. A polgári korban az antik műalkotások népszerüségét nem az ókori humanizmus eredeti jelentésének pontos megértése és átélése okozta, hanem az, hogy az újkori polgárság előszeretettel fedezte fel saját emberközpontú szemléletmódját az antik szobrokban és irodalmi művekben. A görög, a római és a reneszánsz müalkotások ezért tettek szert hatalmas népszerüségre a 18-19. században. 
A Mediterráneumban a Krisztus utáni első századokban - a korai császárkorban - kirajzolódott egy messze ható következményekkel járó kultúrföldrajzi választóvonal. Amikor Róma meghódította a Földközi-tenger keleti medencéjét, számos görög anyanyelvü város került fennhatósága alá. A Római Birodalom magába foglalta a keleti Mediterráneumot, ami korábban a hellenisztikus kultúra magterülete volt. A császárság keleti provinciái görög kultúrájú vidékek voltak, míg a nyugati provinciákban - Nyugat-Európában és Észak-Afrikában - a latin nyelv és kultúra terjedt el. A görög Kelet és a latin Nyugat közötti kulturális különbségeket a császárság első századaiban még elfedte az egész birodalom területén egységes kétnyelvü iskolai müvelődés (bilingvis kultúra), de később az eltérések jelentékenyebbé váltak. Amikor 395-ben a nyugati és a keleti császárság véglegesen kettévált, a politikai határvonal létrejötte egyben a latin és a görög kultúrájú birodalomfél szétválását jelentette. A kora középkorban a Bizánci Császárság görög identitása éppúgy megerősödött, mint a latin Nyugat önazonossága. A görög Kelet, illetve a latin Nyugat kulturálisan megalapozta a római katolikus és az ortodox egyházak között kialakuló különbségeket, ami az európai civilizáció egyik alapvető választóvonalává vált.

A Római Birodalom maritim jellege ellenére a nyugat-európai provinciák - Hispania, Gallia, Britannia - meghódításával nagy kiterjedésü szárazföldi területek kerültek uralma alá az i. e. 1. - i. sz. 1. században. A nyugat-európai térség romanizációja és latinizációja nagyrészt a kelta kultúrára rétegződött rá, ami az urbanizáció és az írásbeliség elterjedését vonta maga után. A romanizáció évszázadok távlatában bontakozott ki - Gallia mintegy négyszáz évig volt római uralom alatt -, de mélyrehatónak bizonyult, hiszen megalapozta az újlatin nyelvek kialakulását. A provinciák területén nemcsak a római civilizáció, hanem a kereszténység is gyorsan terjedt a császárság első századaiban. A Nyugat-Európán belüli kultúrföldrajzi határok kialakulása során meg kell különböztetni azokat a területeket, amelyek hosszabb ideig római uralom alatt álltak. A középkorban a mai Franciaország és Spanyolország eltérő civilizációs előfeltételekkel rendelkezett, mint a Rajnától keletre fekvő területek vagy Anglia, ahol az angolszász bevándorlás erősen felülírta a római jelenlétet. Nem véletlen, hogy a középkori hűbéri társadalom magterületévé a mai Franciaország vált, amely egyszerre rendelkezett mély romanizációs és evangelizációs alapokkal.

\section{A barbár germán örökség}

A nyugati keresztény Európa kialakulásában nagy szerepet játszott az antik és a barbár társadalmak találkozása. A rómaiak nyugat-európai hódításaik során a kelta világgal kerültek kapcsolatba, amikor Julius Caesar elfoglalta Galliát (i. e. 58-49). A korai császárkor alatt - 1-2. század - a rajnai határ 
védelmében megismerkedtek a germánokkal is. A kelták Európa nyugati felén - a mai Franciaország, Belgium, Brit-szigetek, Németország és Ausztria egyes részein - éltek. Ök voltak Nyugat-Európa első név szerint ismert vaskori népessége, amely élén fegyveres arisztokrácia állt. A római hódítás előestéjén településeik kezdetleges városias jelleggel rendelkeztek. A germánok és a kelták törzsi szervezetben éltek, bár ennek bomlása a rómaiakkal való találkozás idején már megkezdődött. Egyikük sem tekinthetö igazi nomád népnek, amelyek az eurázsiai sztyeppfolyosón és a Fekete-tengertől északra fekvő füves vidékeken éltek. A germán és a kelta népek esetében falusi keretek között élö, földet müvelö és állattenyésztő csoportokról van szó, amiből könnyü volt az átmenet a paraszti társadalmak irányába.

Nyugat-Európában - Kelet-Európától és Belső-Ázsiától eltérően - a nomadizmus soha nem tett szert jelentőségre, de kezdettől fogva alapvető szerepet játszott a paraszti életforma. A barbárok nem abban különböztek a letelepedett rómaiaktól, hogy állataik legeltetése miatt vándoroltak, hanem általában nem éltek városokban, illetve az írásbeliség és egyéb civilizációs vívmányok kevéssé jellemezték őket. A nyugat-római birodalmat megdöntő nagy népvándorlás nem azért következett be, mert a germánok új legelöket kerestek állataiknak, hanem általában véve a kedvezőbb éghajlatú és gazdagabb délre törekedtek, valamint más népcsoportok - leginkább a nomád hunok - nyomása alá kerültek.

Európában a „nagy népvándorlás” (3-6. század) idején jöttek létre azok a nyelvhatárok, amelyek a későbbiekben jelentősen befolyásolták a kontinens történetét. Az Itáliai-félszigeten a romanizáció már a korai hódítások után érvényesült, így a latin nyelv elterjedt a köztársaságkor végén. Az 1-4. században Gallia és Britannia területén is kibontakozott a romanizáció folyamata, de kelta nyelvi szigetek is fennmaradtak. A Rajna-vidék felöl érkező germán frankok a népvándorlás korában nagyobbrészt a mai Észak-Franciaország vidékein telepedtek le. A dél-francia területeken a romanizálódott népesség megőrizte nyelvét és kultúráját, míg az észak-francia övezetben erőteljesebben érvényesültek a germán hatások. Angliában a római légiók kivonulása után a romanizálódott kelta (brit) népesség végül alulmaradt a Skandinávia felöl támadó germán angolszászokkal szemben. Így az angolszász nyelvi és kulturális réteg vált uralkodóvá, és csak az Ír-szigeten maradt fenn a kelta kultúra.

A késő ókori népvándorlás lezárulása után a germán és az újlatin nyelvek osztoztak Európa nyugati felén. Itáliában, az Ibériai-félszigeten, DélFranciaországban - a későbbi Occitánia - az újlatin nyelvek domináltak, míg Németország és Anglia területén a germán nyelvi réteg vált uralkodóvá. A mai Franciaország északi részén a kora középkorban a germán és a latin elem kiegyensúlyozott arányát lehetett megfigyelni. A kelta népesség csak kisebb nyelvi szigetekben maradt fenn, föleg Bretagne-ben és Wales-ben. A kialakuló nyelvi térkép egyik legfőbb sajátosságának a germán Észak-Európa és az újlatin 
Dél-Európa dichotómiája tekinthető. Érthető, hogy Leopold Ranke a 19. század egyik legnagyobb német történésze az európai civilizáció jellegadó vonását a germán és a latin népek együttéléséből vezette le.

Európa nyugati felét a kelta, a germán és az újlatin népek és nyelvek együttélésével jellemezhetjük. Ha Kelet-Európát is bevonnánk vizsgálódásainkba, említést kellene tennünk a szláv nyelvekről és a Feketetengertől északra lévő sztyeppfolyosón feltünő török népcsoportokról (hunok, kunok), valamint a görög nyelvröl a Balkánon. Nyugati irányban a görög kulturális hatások elsősorban Dél-Itáliában mutatkoztak meg.

Európa népi és nyelvi összetevőiről szólva nem szabad megfeledkeznünk a zsidó népesség jelenlétéről sem, amely diaszpórákban élt a keresztény Európa területén. Legnagyobb kulturális hatást a földközi-tengeri szefárd zsidók fejtettek ki. Muszlim népcsoportok is kerültek Nyugat- és Dél-Európába, elsősorban a kora középkori hódítások eredményeként. Egy részük azután is ott maradt az Ibériai-félsziget, Dél-Itália és Szicília vidékén, hogy a keresztények visszafoglalták ezeket a területeket. A zsidó és a muszlim kisebbségek sohasem voltak számottevőek, de kulturális jelentőségük messze felülmúlta létszámukat.

A barbárok közül a germánok játszották a legnagyobb szerepet az európai kontinens szociokulturális viszonyainak alakításában. A germán mondakör továbbélt a középkori, majd a modern kultúrában (Wagner operák). A germán szabad harcos eszménye megnehezítette a személyes alávetés lehetőségét a kialakuló hűbéri társadalmakban, és fenntartotta a politikai részvétel iránti igényt. A középkori Angliában a helyi kormányzásban a társadalmi részvétel egyes intézményei a régi germán jogszokásokra vezethetők vissza. A 19. századi skandináv modernizáció sikere kapcsán meg szokás említeni, hogy ezekben a társadalmakban a „törzsi demokráciából” egyenes út vezetett a modern demokráciába. E konkrét társadalomtörténeti példákon túl egyes történetfilozófusok, mint Oswald Spengler a „germán szellem” európai civilizációra gyakorolt hatására hívták fel a figyelmet.

\section{A latin keresztény kultúrközösség születése}

A kora középkor (7-11. század) legfőbb változásának az antikvitást maga mögött hagyó mediterrán civilizáció súlypontjának északnyugatra tolódását tekinthetjük. A nyugati keresztény civilizáció kialakulása a Frank Birodalom területén ment végbe a Rajna és a Loire által közrefogott - mai észak-francia - területeken a 6-8. század között. A maritim és urbánus antik civilizációval szemben a keresztény Nyugat-Európa kontinentális agrárcivilizáció volt, amit a városi középosztályok helyett katonai földbirtokos elitek irányítottak. A térbeli súlyponteltolódással együtt a mediterrán antik civilizáció egységének a felbomlása is bekövetkezett. 
Az antik civilizáció egysége a Nyugatrómai Birodalom bukása (476) után egy ideig még fennmaradt. Bár a Mediterráneum politikai egysége megszünt, a tengeri útvonalak másfél évszázadon át biztosították a gazdasági és a kulturális vérkeringést. A földközi-tengeri egység akkor szünt meg, amikor a muszlim seregek a 7. században elfoglalták a Mediterráneum keleti és déli partvidékét. Ettől fogva két ellenséges - keresztény és muszlim - kultúra nézett farkasszemet egymással a Földközi-tengeren, és a keleti kereszténység - Szíria, Egyiptom - jelentős területei a muszlimok uralma alá kerültek. Mindez hozzájárult a kereszténységen belüli erőviszonyok átrendeződéséhez, ami a római és a bizánci egyházak jelentőségének növekedéséhez vezetett. Az iszlám északabbra térítette el a mediterrán kereszténység súlypontját, ami előmozdította a nyugati keresztény Európa megszületését.

Aziszlám fenyegetés a latin kereszténység identitásánakakörvonalazódását is katalizálta. Amikor 732-ben Martell Károly nehézlovassága Poitiers-nál megállította a közép-franciaországi Tours felé előrenyomuló muszlim sereget, a frank majordomus győzelme az Alpoktól északra fekvő keresztény Európa „születésnapja” lett. Noha a poitiers-i csata jelentőségét igen eltérően ítélték meg a történészek - egyes vélemények szerint a frank hadsereg megóvta az európai keresztény civilizációt, mások szerint az ütközet csak kisebb fontosságú csetepaté volt -, annyi bizonyos, hogy a győzelemmel a nyugati keresztény civilizáció hatalmi központja, a frank állam megakadályozta, hogy a muszlimok behatoljanak Nyugat-Európába.

A mediterrán kereszténység egységének felbomlását egyéb tényezők is siettették. Nagy szerepe volt a képromboló mozgalomnak Bizáncban (8-9. század), amely megrontotta a viszonyt a pápa és a bizánci uralkodó között. A Nyugatrómai Birodalom bukása óta nem koronáztak császárt nyugaton. A pápák elismerték a bizánci császárt az egész Római Birodalom fejeként. Elfogadták a nyugat-római területek, így Itália formális uraként is, bár joghatóságát a germán királyságok miatt nem tudta gyakorolni. Viszonzásul a császárok elismerték, hogy a pápa az egész egyetemes egyház feje, ami nem jelentette azt, hogy beavatkozott volna a keleti egyházak ügyeibe. A keresztény ókorban az öt pátriárka - a konstantinápolyi, az alexandriai (egyiptomi), az antiochiai (szíriai), a jeruzsálemi, valamint a római pápa a „Nyugat pátriárkájaként” közösen irányították a kereszténységet. Bár széles önállósággal rendelkeztek saját területük kormányzását illetően, az általuk képviselt pentarchia, valamint az egyetemes zsinatok megtestesítették a mediterrán kereszténység egységét.

A mediterrán kereszténységen belül már az 5. században mutatkoztak törésvonalak.Aszíriaiésazegyiptomikeresztényekmonofizitákésnesztoriánusok lévén a 451-es khalkédóni zsinat óta fenntartásaikat hangoztatták a Róma és Konstantinápoly által képviselt krisztológiai dogma ellen. Ez a tanítás hosszabb távon előmozdította a keresztény humanizmus tágan értelmezett lehetőségét, 
hiszen Krisztus istenségét éppúgy teljesnek tartotta, mint emberségét, és a kettő szoros egységben fonódott össze. A khalkédóni dogma kérdésében a római és a bizánci egyház egyelöre közös nevezöre került a keleti monofizitákkal és nesztoriánusokkal szemben.

Ehhez képest néhány évszázaddal később a képrombolás Róma és Bizánc között hozott létre törésvonalakat. A képvita a bizánci császárok álláspontját igyekezett az egyházra rákényszeríteni, amennyiben Krisztus, a szentek és a szakrális tárgyú képek ábrázolása a zsidó és a muszlim valláshoz hasonló módon bálványimádásnak minősül. A pápák és a latin Nyugat - a Nagy Szent Gergely pápa (590-604) által megfogalmazott felfogás alapján - a képábrázolás mellett foglaltak állást. A megromló viszony miatt a bizánci császárok nem fordítottak elég figyelmet arra, hogy a pápát megfelelő védelemben részesítsék az itáliai longobárd fejedelemségek támadásaival szemben. Egyebek mellett ez indokolta II. István pápa döntését, aki személyesen utazott az Alpoktól északra fekvő frank területekre a 8. század közepén, és Kis Pippin király támogatását kérte a longobárdok ellen.

A pápaság és a Frank Királyság közötti történelmi szövetség jelentősen átrajzolta a kereszténység belső erővonalait. Egyrészt kifejezésre juttatta a nyugat-európai térség növekvő súlyát, amit egyelöre a frank állam testesített meg. Másrészt a pápák figyelme evangelizációs, kulturális és politikai szempontból egyre inkább az Alpoktól északra fekvő Európa felé irányult. Amikor 800-ban III. Leó pápa Rómában császárrá koronázta Nagy Károlyt, a nyugati keresztény Európa megformálódása kiteljesedni látszott. Három évszázad után újra császár uralkodott nyugaton, ami legitimációs vitákhoz vezetett Bizánccal, amely magát a római örökség egyetlen képviselőjének tartotta. A pápa és a frank uralkodók erősödő magabiztossága nemcsak Martell Károly, Kis Pippin és Nagy Károly katonai győzelmein nyugodott, hanem a megelőző kétszáz év evangelizációs sikerein, amelyek lehetővé tették, hogy a Frank Császárság a kiszélesedő keresztény Nyugat-Európa hatalmi és szellemi központjává váljon.

A 800-as római császárkoronázás előtti két évszázadban nagy jelentőségű változások játszódtak le Nyugat-Európában. A történészek egy része joggal hívta ezt a korszakot „Európa születésének” (the making of Europe, the birth of Europe). E kifejezés alatt a latin keresztény Európa vallási és kulturális egységének megszületését értjük a 7-8. században. Ezek a változások a keresztény evangelizáció sikereihez köthetők. Mohamed fellépésekor (610 körül) a kereszténység súlypontja a Mediterráneumban volt, és az Alpoktól északra fekvő vidékek távoli perifériáknak tüntek. A római uralom idején a kereszténység elterjedt a mai Olaszország, Spanyolország és Franciaország területén, de az angol és a német területek még térítésre vártak. A Britszigeteken az ír kereszténység ugyan komoly sikereket ért el az 5. századtól, de Rómától elszigetelten, önálló szokások kialakulásával fejlődött. Angliában a 
római fennhatóság emlékeként a kelta britek számottevő része ápolta hitét, de az angolszász hódítással az evangelizáció megtorpanni látszott. Ez indokolta Nagy Szent Gergely pápa döntését, aki negyven szerzetest küldött Angol-szigetre. A térítés eredményei következtében az angolszász királyok fokozatosan keresztény hitre tértek a 7. században, és nagy jelentősége volt annak is, hogy a térítés a római egyházzal való együttmüködésben következett be. Az ír szerzetesek visszaszorulásával a Rómából érkező egyházi hagyományok, liturgikus szokások, iskolai művelődés végleg bekapcsolta a Brit-szigeteket a nyugati kereszténység áramába.

Hasonló tendenciák voltak megfigyelhetők Németország területein. A Rajna melletti Ausztráziától, a frank állam törzsterületétől keletre és délre élő germán törzsek még pogányok voltak az 5-6. században. Bár ezeken a területeken már jártak korai térítők, az evangelizáció igazi sikere csak Szent Bonifác tevékenységével a 8. században teljesedett ki. Az angliai származású Bonifác kiváló kapcsolatokat ápolt a pápákkal és a frank udvarral. Rómával együttműködve nemcsak az evangelizáció, hanem az egyházszervezet és az iskolai művelődés alapjait is lerakta a német területeken. Nem véletlenül érdemelte ki a katolikus egyházi hagyomány részéről a „Germánia apostola” jelzőt. Tevékenysége révén a mai Németország jelentős része is a latin keresztény kultúrközösség részévé vált. Az angol és a német területek evangelizációja kitágította az Alpoktól északra fekvő latin kereszténység dimenzióit. 600 körül még csak a mai olasz, spanyol és francia területeken számolhatunk a keresztény hit és kultúra jelenlétével, de 800 körül Angliában keresztény királyok uralkodtak, és német földön már csak a harcias szászok megtérítése jelentett problémát. François Guizot, a neves 19. századi francia politikus és történetíró írt (Nyugat-)Európa öt „nagy nemzetéről” az európai civilizáció történetét tárgyaló könyvében, megemlítve az angol, francia, spanyol, német és olasz nemzeteket. Guizot-ra utalva elmondhatjuk, hogy 600 körül az angol és a német vidékek sorsa még kétséges volt, de 800 körül az öt későbbi „,nagy nemzet” már kereszténnyé vált. Az evangelizáció sikere a római egyházzal együttmüködésben bontakozott ki, ami lehetővé tette a latin kereszténység kultúrájának egységesülését. Ezért beszélhetünk „latin keresztény kultúrközösségről” a 7-8. századtól. Ezek a változások a keresztény Nyugat térbeli kitágulásával mentek végbe. Az iszlám elől visszahúzódó kereszténység új területeket nyert, és súlypontja is átrendeződött. A Karoling Császárság létrejötte csak betetőzte ezt a tendenciát.

Ezzel a folyamattal együtt a Mediterráneum egységének a felbomlása is kiteljesedett. Amikor Justinianus császár (527-565) arra törekedett, hogy helyreállítsa a Római Birodalom egységét, elképzelése még a mediterrán civilizáció egységének eszméjén alapult. Már említettük, hogy az iszlám 7. századi terjeszkedésével ez a civilizációs egység megszünt. Ettől fogva a keresztények és a muszlimok közötti konfliktusok tengeri frontvonala a két 
vallás összecsapásának jelentős összetevőjét alkotta. Egy ideig még fennmaradt a római és a bizánci egyház együttmüködése, amit jól megtestesít, hogy a 8. század elején úgynevezett greko-szír pápák - görög és szír származású egyházfők - uralkodtak Rómában. Ezt törte meg a képrombolás, ami végül Bizáncban a római katolikus állásponthoz közelálló képtisztelők győzelmével végződött. A két egyház növekvő hitbeli és kulturális eltávolodását ennek ellenére sem lehetett visszafordítani, noha az 1054-es egyházszakadás előtt formálisan még többször helyreállt az egység. Az ezredforduló előestéjén már három civilizációval találkozunk a Mediterráneumban, a bizánci ortodox, a muszlim arab és a latin keresztény kultúrákkal.

A képtisztelők - Damaszkuszi Szent János által megfogalmazott álláspontjának győzelme ellenére Bizáncban a teológiai doktrínák a mủvészetet szoros béklyók közé szorították. A nyugati keresztény müvészet, ahogyan már Nagy Szent Gergely is megfogalmazta, szent történetek elbeszélésére szolgált, míg Bizáncban az isteni dicsőséget nyilvánította ki szigorúan kötött formák között. Tekintve, hogy a nyugati müvészet kezdettől fogva narratívák elbeszélésére törekedett, a művészi formanyelv lehetóségei jóval tágabbak voltak, ami lehetővé tette, hogy a nyugati keresztény civilizáció képzőmüvészeti ábrázolásmódja elinduljon a verizmus - a valóság egyre hüségesebb bemutatása útján. Ennek köszönhető, hogy a latin kereszténység más civilizációkhoz képest egyedülálló módon foglalta magába a korstílusok változásának és fejlődésének lehetőségét, és megnyitotta az utat az emberközpontú - humánus, humanista tartalmak kifejezése előtt. Ennek a mủvészi fejlődésnek a legtágabb keretét a kora középkori képvita következményei szolgáltatták.

\section{A Karoling Birodalom történelmi szerepe}

A Karoling Frank Császárság 800 után nemcsak betetőzte a latin keresztény kultúrközösség kialakulásából fakadó lehetőségeket, hanem maga is a keresztény államszervezés mintaértékü kísérletének tekinthető, ami társadalmi és kulturális tartalommal töltötte meg az általa megteremtett egységet. A pápasággal szövetségre lépő Frank Birodalom az egyházi liturgia, a szerzetesség, az iskolai művelődés, valamint a társadalmi és politikai struktúrák egységesítését hajtotta végre. Mindez a kora középkori királyeszmény keretében zajlott, ahol a szakrális és a politikai funkciók szorosan összekapcsolódtak, bár a két szférát mindig megkülönböztették egymástól. Ennek alapján tekintette a történészek egy része Nagy Károlyt (768-814) Európa „megalapítójának”, holott ez kétes értékü állítás, hiszen a frank állam nem volt azonos az egész latin kereszténységgel (31. térkép). Mégis a Frank Birodalom hatókörében kibontakozó társadalmi és kulturális átalakulások mintául szolgáltak az egész nyugat-európai térség, majd az ezredfordulón a közép- és észak-európai periféria számára. Az európai 
civilizáció történetében Nagy Károly vált a keresztény Nyugat egységét megtestesítő egyetlen uralkodóvá, aki egyszerre volt kiváló hadvezér, valamint a keresztény egyház és művelődés szervezését előmozdító államférfi.

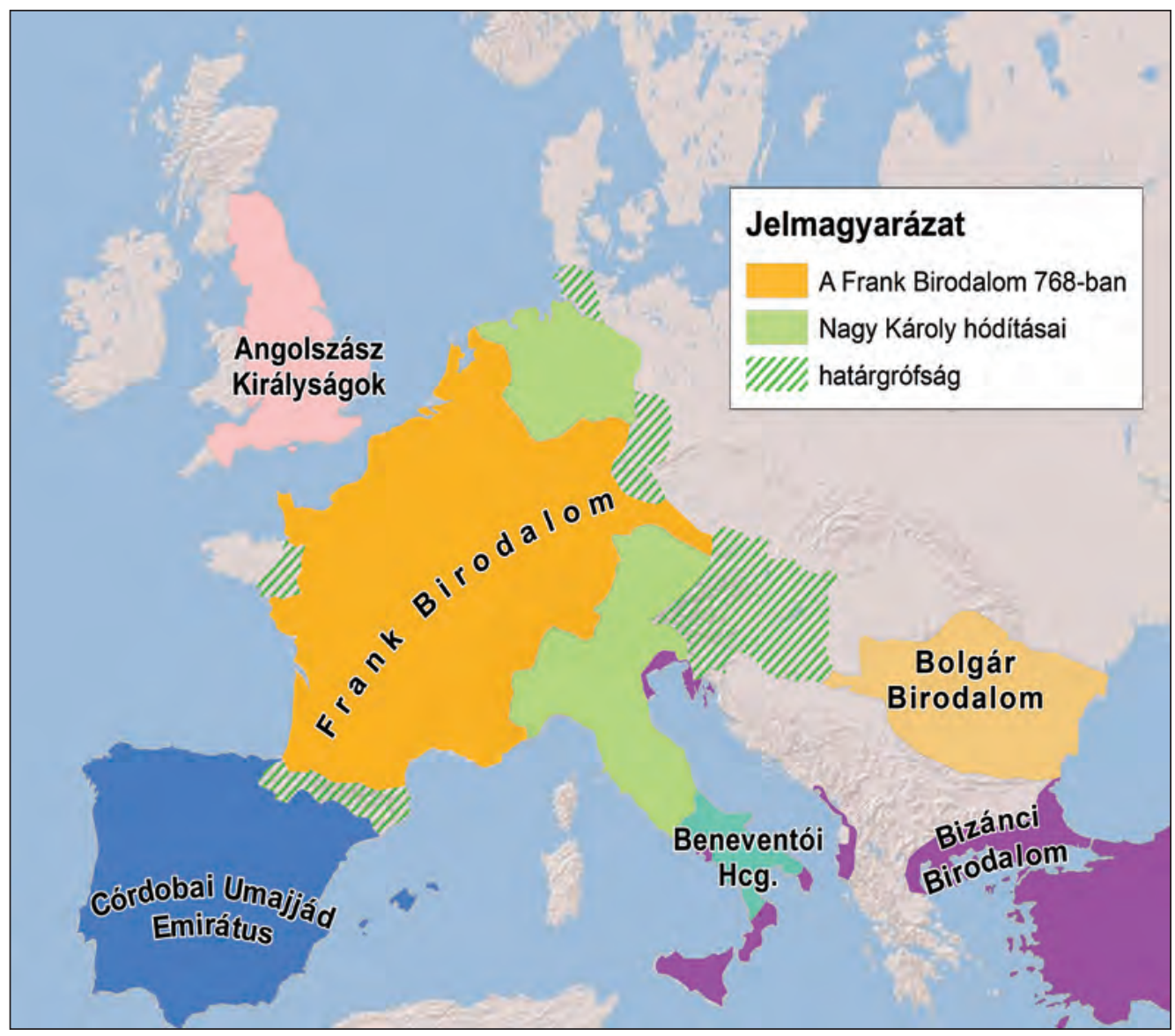

31. térkép: A Karoling Európa

Forrás: VARGA ÁGNES szerkesztése

A Karoling egyház- és mủvelődési reform következményei az európai kultúra egészére rányomták bélyegüket. Nagy Károly és tanácsadói a birodalom területén egységesíteni kívánták a Biblia és az egyházi liturgia szövegeit. A papság és a szerzetesek képzettségének hiányosságai miatt fennállt a veszélye annak, hogy a szent szövegek alapjául szolgáló klasszikus latinhoz képest az újlatin nyelvek terjedése szövegromlásokkal jár az egyházi hagyományban. A kereszténység a széleskörü írástudatlanság miatt azzal a kihívással szembesült, hogy szóbeliségen nyugvó kultúrává válik, ami megnehezítheti a szent szövegek pontos átörökítését. A Karoling-reformok erre kívántak választ adni az írásbeliség kultúrájának terjesztésével, illetve az egyházi és világi müvelődés 
alapjául szolgáló normaszövegek megteremtésével. Ennek legfőbb eszközéül a késő ókori latint használták, aminek messze ható következményei lettek a reformáció koráig.

Általában véve elmondható, hogy a kereszténység a „szent szöveg” vallása, és minden népnek olvasnia, értenie kell az evangéliumot. Nagyobb történeti távlatban a kereszténység terjedése a Biblia anyanyelvi fordításainak megszületését és a nemzeti irodalmak fellendülését eredményezte, ahogy arra a közel-keleti kereszténység is példákkal szolgál. Nyugat-Európa inkábbkivételnek tekinthető, ahol a latin nyelvre támaszkodó nemzetek feletti kultúra egészen a reformáció koráig érvényesült. Mindez a Karoling-reformoknak köszönhetö, amelyek jelentős következményekkel jártak, és évszázadokon át jellegzetes pályára állították az európai müvelődést. A Karoling-reformok lehetővé tették az egyházi hagyomány pontos megőrzését, de a helyi társadalmaktól elszakadó „univerzális” kultúrát hoztak létre, amely meghatározta az egész érett középkor egyetemi művelődését (12-13. század), sőt a reneszánsz humanizmusát (14-15. század) is. A középkornemzetek feletti latin kultúrája a nyugati keresztény Európa egységének egyik legfontosabb alkotóelemévé vált, aminek nincs megfelelő párhuzama az ortodox Kelet történetében. A nemzeti nyelvek ehhez a kezdeti állapothoz képest indultak viszonylag gyors kései fejlődésnek, és a reformáció katalizálta ezt a folyamatot a kora újkorban. A római egyház egyetemessége és a latin kulturális szerepe tette lehetővé, hogy a nyugat-európai civilizációt a nemzetek feletti és a nemzeti kultúrák dichotómiájában értelmezhessük.

A frank állam területe a mai Franciaország, Benelux államok, Olaszország, és Németország nagy részét foglalta magába. Nagy Károly elfoglalta a keleti német Szászföldet, a bajor és osztrák területeket, illetve a Dunántúlt és az Ibériaifélsziget északi részét. A császárkoronázás nemcsak azzal a következménnyel járt, hogy újra lett császár a latin Nyugaton, hanem kifejezésre juttatta azt az igényt is, hogy a latin kereszténység egyetlen birodalom keretében egyesüljön. Bár az angolszász királyságok mindig önállóak maradtak, Európa történetében Nagy Károly elöször hozott létre olyan keresztény birodalmat, amelynek súlypontja nem a Mediterráneumban, hanem Nyugat-Európában volt.

A Karoling Császárság Róma örökösének tartotta magát. A Róma-eszme a modern korig az európai politikai identitás fundamentumának tekinthető. Róma univerzális igényü birodalomként fogható fel, amely fénykorában az egész mediterrán antik civilizációt egyetlen politikai keretbe foglalta. Kettéválása, majd a Nyugatrómai Császárság bukása után a keleti Bizánc őrizte a „rómaiság” tudatát, amit jól kifejezett, hogy a latin maradt a közigazgatás és a hadsereg nyelve egészen a 6-7. századig. Amikor Nagy Károly és III. Leó pápa 800-ban nyugaton felújították a császárságot, a Róma-eszmére támaszkodtak, hasonlóan a szász Nagy Ottóhoz, aki 962-ben létrehozta a Német-római Császárságot. Az újkorban említhetjük Napóleont, akinek császárrá koronázása (1804) a Róma- 
eszme politikai hagyományát tükrözte, vagy Ferenc császárt, aki a Németrómai Császárság 1806-os megszünésével fontosnak tartotta, hogy megalapítsa az Osztrák Császárságot. Mivel a kései antikvitás alatt a császárság maga is kereszténnyé vált, a Róma-eszmében a politikai föhatalom igénye mutatkozott meg az európai keresztény civilizáció hatókörében.

Másfelől arra is érdemes felhívni a figyelmet, hogy a középkori császárság hatalmi realitás helyett idővel fikcióvá üresedett, és a „birodalmi modell" megvalósulása helyett politikai ideológiává vált. Bár a leghatalmasabb uralkodók a császári címre áhítoztak, a történészek inkább azt hangsúlyozzák, hogy a Nyugatrómai Császárság bukása után már nem jött létre igazi birodalom. Nagy Károly császársága átmeneti képződmény volt, ami csak rövid ideig állt fenn. A Frank Császárság felbomlása után a Német-római Császárság ahogy nevében is megmutatkozik - már inkább a német nemzethez, mint az egyetemesség eszméjéhez kötődött. Az ezredfordulót követően egymás után szerveződtek meg a keresztény monarchiák, amelyek közül ugyan a császárság volt a legtekintélyesebb, de az fel sem merült, hogy az egész nyugati keresztény civilizációt saját égisze alatt egyesítené. A 11-12. századtól inkább keresztény nemzetközösségről (Respublica Christiana) beszélhetünk, mint Római Birodalomról (Imperium Romanum). Az európai történelem iránya a római császáreszme befolyása ellenére a politikai partikularizmus megerősödése felé mutatott. Míg az Európán kívüli kultúrákban többször is felemelkedett egy civilizáció egészére kiterjedő birodalom, addig a latin keresztény Európában a növekvő erejű államok tettek szert nagyobb befolyásra. A birodalom hiányát az európai társadalomfejlődés jellegadó vonásaként szokás emlegetni. Nagyobb távlatban Nagy Károly birodalma is kérészéletủ átmeneti jelenségként értékelhető, bár a kortársak ezt bizonyára másként élték meg.

A történészek arra hívják fel a figyelmet, hogy a Karoling Európa határai meglepő azonosságot mutatnak a második világháború után létrejött Hatok Európájával (NSZK, Franciaország, Olaszország, Benelux államok). Az európai civilizáció történetében kétségtelenül körülírható egy „mag-Európa”, ahol az elmúlt ezer évben a gazdasági és a kulturális aktivitás összpontosult. Vitán felül áll, hogy ez a terület Nyugat-Európához tartozik, más szóval a „Nyugat” részét képezi, ahogyan azt a 20. században némi politikai felhangokkal állították. E térség nagyobbik fele részesült a romanizáció áldásaiban és a keresztény evangelizáció korai sikereiben. Innen, Észak-Franciaországból indult ki a 12-13. századi agrárforradalom, és a Rajna-vidék, Champagne és Burgundia vált Európa egyik legfőbb kereskedelmi ütőerévé a késő középkorban, amit magas várossűrüség jellemzett. A Karoling „kis-Európa” gazdasági magterületté válása megelőzte a nagy földrajzi felfedezésekből és az atlanti világgazdaság kibontakozásából fakadó lehetőségeket. Jó példát mutat arra is, hogy a történelemben milyen makacs szívóssággal képesek fennmaradni a nagy 
időtartamú tendenciák (longue durée). A második világháború után a nyugateurópai gazdasági növekedés erővonalai is a tágabb Rajna-vidékre, a Benelux államokra és Észak-Itáliára - a Karoling Császárság egykori középponti vidékeire - összpontosultak (az úgynevezett „Kék Banán” övezet).

\section{Európa ostrom alatt}

Nagy Károly halála után a Frank Birodalom bomlásnak indult. A Frank Császárság széthullásától az ezredfordulóig terjedő időszak a nyugat-európai történelem zavaros és nyomorúságos időszakát jelentette, amit jól kifejez, hogy Jean-Baptiste Duroselle francia történész az európai történelmet tárgyaló könyvében a 9-10. századot tárgyaló fejezetnek az „Európa ostrom alatt” címet adta. A latin kereszténység külső gyengesége összekapcsolódott a belső politikai megosztottságból fakadó nehézségekkel. A frank államot a hübériség kibontakozása dezintegrálta. Meggyengítette az uralkodói hatalmat, majd a hercegségeket és a grófságokat is. A feudális anarchia következtében az irányítás a fejedelmektől a politikai társadalom kezébe került. A hübéri kapcsolatok megszerveződése, a hübérurak és a hübéresek közötti kapcsolat alakulása az egész nyugati keresztény társadalomszerveződést alakító tényezővé vált.

A hübéri viszonyok terjedése mellett a másik nagy hatású esemény a Frank Birodalom felosztása volt, aminek legfőbb lépését a 843-as verduni megállapodás jelentette. A nyugati és a keleti frank állam a Francia Királyság és a Németrómai Császárság előzményét alkotta. A latin kereszténység magterülete ettől fogva nem egyesült egyetlen állam keretében, hanem a franciák és a németek osztoztak rajta. Az a tény, hogy Nyugat-Európa középpontja sem német, sem francia, hanem mindkettő, és egyik sem képes a másik fölé kerekedni, az elkövetkező évszázadok fontos tényezője lett, ami a modern nemzeti fejlődést is befolyásolta. Az európai történelemnek ez a vonása a Frank Birodalom felbomlása utáni két évszázadban kezdett kirajzolódni

Nyugat-Európa belső megosztottsága miatt nem tudott válaszolni a külső - viking, magyar, muszlim - támadásokra a 9-10. században. A vikingek bekalandozták az Északi- és a Balti-tenger világát. Elpusztították az ír szerzetesek számos kolostorát a Brit-szigeteken, és támadásokat intéztek a nyugati frank területek ellen. A kelet-európai folyókon délre haladva, valamint a Fekete-tengeren Bizánc ellen támadva megjelentek a Mediterráneumban. A magyar kalandozások kelet felöl jelentettek veszélyt. A magyar törzsek nemcsak a német területeket fosztogatták, hanem Itália és a Bizánci Birodalom számos vidékére is eljutottak. A latin keresztény Európa gyengesége a muszlimokkal vívott harcokban is megmutatkozott. Az iszlám a kezében tartotta Szardíniát és Szicíliát, és szaracén flották uralták a Földközi-tengert. A muszlim harcosok a provence-i hegyi településekről kiindulva fosztogatták a kereskedö karavánokat. 


\section{Az ezredforduló jelentősége}

A kora középkor szegényes agrárvilága alig biztosította az alacsony népsürüségű vidékek eltartását. Az ezredforduló felé haladva Nyugat-Európa kevés számú városias települése nem vehette fel a versenyt a bizánci vagy aziszlám civilizáció nagyvárosainak - Bizánc, Bagdad, Kairó, Córdoba - ragyogásával. Mindezt tekintetbe véve nehezen lehetett elképzelni, hogy a latin keresztény Európa hamarosan expanzív civilizációvá válik. Az első millenium körüli évtizedekben mégis meglepő gyorsasággal körvonalazódtak azok a változások, amelyek kitágították a nyugati kereszténység határait. Az ezredfordulón néhány generáció leforgása alatt Közép-Európa csatlakozott a latin kereszténységhez, ami a cseh, lengyel, magyar, horvát államalapítások kiteljesedését jelentette. A közép-európai térség keresztény államokká szerveződésével együtt Skandináviában is felgyorsult az evangelizáció és az államalapítás folyamata, ami Európa északi perifériájának a latin kereszténységhez kapcsolódását eredményezte.

Az ezredforduló eseményei révén a Karoling „kis-Európa” számottevő kitágulása következett be. A 9-10. századi Bizáncban, amely túlélte a 7-8. századi muszlim-arab hódításokat és a képvitát, átfogó politikai és kulturális megújulás bontakozott ki. A Bizánci Birodalom a Balkánon és Kelet-Európában sikeresen evangelizálta a szláv népeket. Az ezredfordulón az orosz államiság körvonalai is megszilárdultak. Mivel a római katolikus és az ortodox egyház eltávolodása ellenére még nem következett be az egyházszakadás (1054), Európa első milleniuma körül felsejlettek egy Nyugat-, Közép- és Kelet-Európára kiterjedő keresztény „,nagy-Európa” körvonalai. Nem meglepö, hogy az ismert lengyel történész, Oscar Halecki, akinek országa a nyugati és az ortodox Európa közötti szakadások szenvedő alanya volt, az ezredforduló „egységét” az európai történelem sarkalatos eseményeként tartotta számon, és pozitív felhangokkal értelmezte.

A latin keresztény Európa az ezredfordulótól magába foglalta a középeurópai és a skandináv államokat. Az észak- és a közép-európai országok nemcsak a római katolikus egyházhoz csatlakoztak, hanem azt a gazdaságitársadalmi modellt is adaptálták, ami Nyugat-Európában az érett középkorban kibontakozott. Ennek eredményeként Közép-Európában is megjelentek a városi autonómiák, a rendi parlamentek, a jogilag egységes jobbágyság, illetve az egyetemek, amelyek a „nyugatias társadalomfejlödés” lényegét alkották. Míg az orosz társadalmi fejlődés során sem rendi parlamenttel, sem nyugati városfejlődéssel nem találkozunk.

A latin keresztény civilizációhoz tartozás kultúrtörténeti szempontból is messze ható következményekkel járt. A római kereszténység országai nemcsak társadalomtörténetileg, hanem a müvészet története szempontjából is közös 
nevezöre hozhatók. Közép-Európában a román stílus után éppúgy a gótika, a reneszánsz, majd a barokk és a klasszicizmus következett, mint NyugatEurópában. Oroszországban vagy a Balkánon ugyanezek a korstílusok igen korlátozott keretek között érvényesültek.

\subsubsection{Európa első „nekilendülése” az érett középkorban (1000-1500)}

Walt Rostow, a második világháború utáni évtizedek neves gazdaságteoretikusa, az 1950-es évek végén dolgozta ki „szakaszelméletét”, amely azt sugallta, hogy előbb-utóbb minden társadalom eljuthat az ipari társadalomig, és élvezheti a fogyasztók számára megnyíló bőség áldásait. Rostow az iparosodás megindulását a stagnáló preindusztriális agrártársadalmak után a gazdasági növekedés tartóssá válásával azonosította, amit „nekilendülésnek”, azaz take off-nak nevezett. Azt az angol igét használta, amellyel a repülögép kifutópályáról történő felszállásának a pillanatát szokták jelölni. Az 1760-as években Nyugat-Európában kezdődő első ipari forradalmat tartotta a take off időszakának.

A gazdaságtörténészek az elmúlt fél évszázadban sokat foglalkoztak azzal a kérdéssel, hogyan bontakoztak ki a nekilendülés elöfeltételei a nagy földrajzi felfedezések és az ipari forradalom között a kora újkor századaiban (15001800). A take off előzményei között meg szokták említeni a protestáns etika hatását, a piac felemelkedését, az abszolutista állam szerepét és a gyarmatosítás következményeit. Azonban fel kell hívni a figyelmet egy jelentősebb tényre is, amelyet az 1930-as évektől kezdett feltárni a nyugat-európai történetírás. A modern európai fejlődés elképzelhetetlen lett volna a 12-13. századi nagy felhalmozási folyamat eredményei nélkül. Az érett középkorban (12-15. század) „forradalmak” sora játszódott le - agrár-, város-, népesedési, technikai, kereskedelmi forradalom -, amelyek alapjaiban rajzolták át a latin kereszténység arculatát.

A történettudomány a 19. században nagy jelentőséget tulajdonított az újkori polgárságnak és az ipari kapitalizmusnak, a nemzetállamok születésének, sőt - bizonyos értelemben joggal - ezeket tartotta Európa „lényegének”. Ehhez képest a 20. század derekától a történészek egyre inkább tudatosították azt a tényt, hogy Nyugat-Európa ugyan hatalmas teljesítményeket ért el Amerika felfedezése óta, de az európai civilizáció már a korábbi századokban is létezett. Európa nem képzelhető el az újkori civilizációs eredmények nélkül, de az európai történelem első nagy felhalmozási korszaka megelőzte a reneszánszt és a reformációt. Az érett középkort - Rostow szavaival - méltán nevezhetjük Európa első „nekilendülésének”, hiszen erőteljes dinamikát mutatott fel, ami maradandó hatást gyakorolt az elkövetkező évszázadokra. 


\section{A 11. századi fordulópont}

$\mathrm{Az}$ ezredforduló eseményei nemcsak a latin keresztény Európa térbeli kitágulását vonták maguk után, hanem a szellemi megújulás és az anyagi gyarapodás első lépései is kibontakozóban voltak. A 11. század a nekilendülés kezdetének fogható fel, ami aztán a 12-13. században teljesedett ki. Az ezredforduló után ritkultak, majd megszüntek a viking és a muszlim kalandozások. A nyugat-európai hübériség konszolidálódott, és egyes királyságokban mérséklődött a politikai anarchia (32. térkép). A német-római császárok kezdettől fogva az egyházreform élére álltak, és elősegítették a pápaság megújulását. Ehhez járult a cluny-i mozgalom, amely több száz kolostorban állította helyre a hitélet tisztaságát, és visszaszorította a világiak befolyását. A treuga Dei (Isten békéje) mozgalom pedig a lovagságot igyekezett rávenni a keresztény morál követésére. A hitélet megújulását a zarándoklatok Róma, Compostela - népszerűvé válása és Európa első szakrális monumentális nagyművészete, a román stílus születése jelezték. A fehér kőből épült hatalmas román templomok már a kortársak szemében is élesen elváltak környezetüktől, és a kisméretü preromán templomokhoz képest új kezdetet jelentettek az európai művészettörténetben. A növekvő művészeti teljesítmények anyagi hátterét az agrárszektor lassú nekilendülése biztosította. A keresztény Nyugat története során első ízben mutatott fel jelentékeny belső energiákat.

A népesség gyarapodása megteremtette Nyugat-Európa expanziójának demográfiai alapjait. A lovagság száma is növekedett, és szívesen kezdett katonai vállalkozásokba, valamint megerösödöben voltak a Földközi-tenger nyugati medencéjének olasz kereskedővárosai. Az ezredforduló előtt még a muszlimok uralták a tengert. A 11. század első felében azonban Velence éppúgy sikereket ért el a Mediterráneum keleti medencéjében, ahogyan Pisa is megsemmisítö vereséget mért a muszlim flottákra a Tirrén-tengeren. A keresztények szintén megtisztították Provence vidékét a muszlimoktól, visszafoglalták Korzikát, Szardíniát és Szicíliát, valamint ellenőrzésük alá vonták a Földközi-tenger nyugati medencéjét. A haditengerészeti győzelmeket az itáliai városok erősödő kereskedelmi aktivitása támasztotta alá. A 11-12. század fordulóján az olasz városok már logisztikai segítséget nyújtottak a meginduló keresztes hadjáratoknak. Amikor Orbán pápa 1096-ban a Szentföld elfoglalására szólította fel a lovagokat, küszöbön állt Nyugat-Európa első nagy népesedési és gazdasági fellendülése. A 12-13. századi demográfiai és agrárforradalom révén Európa „túlcsordult önmagán”. Ennek jeleként egymás után bocsátotta ki magából a keresztes seregeket.

A cluny-i mozgalom hatása Rómában is érezhető volt, és első ízben tette teológiailag magabiztossá a latin Nyugatot a kifinomult okoskodással élő ortodox görögökkel szemben. A latinok növekvő harciasságának és a konstantinápolyi pátriárka, Kerullariosz Mihály egyházpolitikai érdekeinek köszönhetően sor 
került az egyházszakadásra, ami betetőzte a római katolikus és a görögkeleti egyházak közötti eltávolodási folyamatot. A két egyház 1054-ben kölcsönösen kiátkozta egymást, ami a bizalmatlanság és ellenségeskedés forrása lett az elkövetkező századokban. Kevésbé ismert, hogy az egyházszakadás óta a latinok és a görögök számos kísérletet tettek az egység helyreállítására, mint a reneszánsz korában is, amikor a megerősödő Oszmán Birodalom elleni keresztény összefogást igyekeztek létrehozni.

Az egyházszakadás elmélyítette az Európa nyugati és keleti fele közötti civilizációs különbségeket. Hosszú távon hozzájárult egy Közép-Európától keletre fekvő vallási „vegyes övezet” kialakulásához, ami a mai Lengyelország keleti és Ukrajna nyugati részét foglalja magában. Ebben a zónában a római katolicizmus és a görögkeleti egyház egyaránt tevékenykedett, $\mathrm{s}$ bár gyengén - a cseh, lengyel, magyar Közép-Európánál kevésbé -, de jelen voltak a nyugatias hatások is. Ezen a területen került sor a kora újkorban a görög katolikus egyház létrejöttére, ami a lengyel katolikusok részéröl a helyi ortodox lakosság számára felkínált kompromisszumként is felfogható. Azok a görögkeletiek váltak görög katolikussá, akik elfogadták a pápát, de megtartották az ortodox liturgiát és hagyományokat.

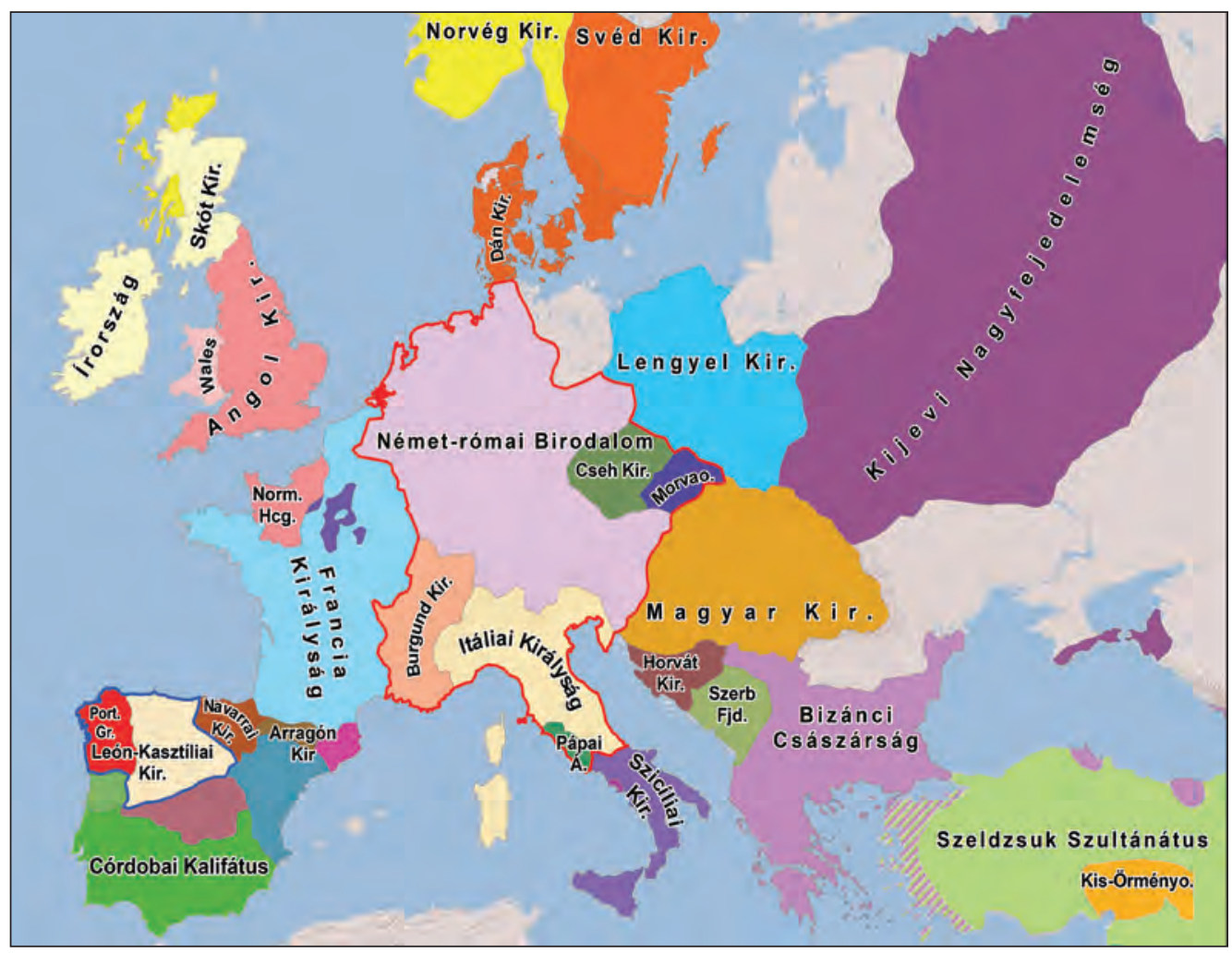

32. térkép: Európa a 11. század végén

Forrás: VARGA ÁGNes szerkesztése 
Az 1054-es egyházszakadást illetően meg kell említeni, hogy a 20. század második felében annak természete megváltozott, hiszen a katolikus egyház nagy reformzsinatán, a II. Vatikáni zsinaton (1962-1965) sor került VI. Pál pápa és Athénagorasz pátriárka személyes találkozójára, és kölcsönösen feloldották az egyházi átkot. Bár a két egyház közötti unió azóta sem jött létre, a katolikusok és az ortodoxok ökumenikus párbeszédet folytatnak egymással. E dialógus és egy új keresztény Európa-felfogás jegyében II. János Pál pápa a katolikus és az ortodox vallást a kontinens „két tüdejeként” határozta meg. Az ortodoxiának tett gesztusként Európa katolikus védőszentje, Szent Benedek mellett Cirillt és Metódot Európa „társvédőszentjeinek” nevezte 1980. december 31-én kelt apostoli levelében.

\section{Nyugat-Európa ,,forradalmai” az érett középkorban}

A 12-13. században erőteljes gazdasági és népesedési dinamika felívelésének lehetünk tanúi, aminek eredményeként az európai népesség száma legalább kétszeresére emelkedett. A változások az agrárszektorból indultak ki. A növekvő termésátlagok - egy elvetett mag két-három helyett négy-ötöt adott vissza -, az agrotechnikai újítások - a nehézeke, a fogatolás új módja és a háromnyomásos rendszer elterjedése - számottevő lehetőségeket nyitottak meg a termelés felső korlátait illetően. Ezzel Európa túljutott a nyomorúságos agrárviszonyok korszakán, ahol az éhezés állandó problémát jelentett. Az érett középkor „mezögazdasági forradalma” a Rajna és a Loire közötti észak-francia vidékeken bontakozott ki, és innen sugárzott szét Nyugatés Közép-Európába.

A 12-13. századi agrárforradalom a városok felvirágzásához vezetett (,,városforradalom”). A városok sohasem szüntek meg teljesen az antikvitás letünésével, de nagy részük lehanyatlott. Mostantól a gyarapodó agrárszektor biztosította, hogy a falu táplálja az újjászülető várost. A középkori városfejlődés az Európán kívüli civilizációkhoz képest kivételes várossürüséget, elmélyült város-falu munkamegosztást és egyre növekvő ipari aktivitást eredményezett. Az európai városok mérete általában kicsi volt, de intenzív jelenlétük mindenhol formálta a gazdasági viszonyokat. A legvárosiasabb övezetekben - ÉszakItália, Flandria - egy korai ipari civilizáció első jelei is megmutatkoztak. $\mathrm{Az}$ agrár- és városforradalom mellett technikai és kereskedelmi forradalom kibontakozásának is szemtanúi lehetünk. A korszak egyik legfontosabb találmányának a vízikerék tekinthető, amelyből a becslések szerint akár 200 ezer is lehetett, és mintegy tízmillió ember munkáját helyettesítette. A növekvő árucsere következtében kialakult az európai kereskedelmi hálózatok alaprétege. Az érett középkor eredményei megteremtették az újkori kapitalista fejlődés minimális előfeltételeit. 
Az érett középkor „forradalmai” révén alapvető jelentőségü gazdasági fejlődés ment végbe Nyugat-Európában. A föld megnövekedett eltartóképessége lehetővé tette a népesség gyarapodását. A növekvő agrártermelékenység mellett a népsürüség felső határa megközelítette a 30-40 fö $/ \mathrm{km}^{2}$-t, s emellett az agrárszektor táplálni tudott mintegy 10-15 százalék városi népességet. Ezeket az eredményeket csak az angliai mezőgazdasági innovációk következményei haladták meg a 18. században. Ezért mondhatjuk, hogy Európa gazdaságtörténete egészen az 1760-1780-as évekkel kezdődő „első ipari forradalomig” a 12-13. századi népesedési és agrárforradalom lehetőségeire támaszkodott. A városi lakosság számaránya Németalföld, Anglia, Észak-Franciaország és Itália egyes vidékein a 16-18. században túllépte a 15-20 százalékot, de egyedül az iparosodó Angliában került sor a városi népesség ,áttörésére” a 19. század első felében. Az ipari forradalom eredményeként 1850-ben az angol lakosság fele már városlakó volt.

Az agrár- és népesedési konjunktúra eredményei ellenére az érett középkor Európája nem rendelkezett a technikai és ipari fölény olyan mértékével, amely magyarázni tudná az újkori nyugati hegemóniát. Ezért vizsgálódásunkat ki kell terjesztenünk a vallási attitűdök, a társadalmi struktúrák és a politikai intézmények kérdésére, hiszen azok tették lehetővé egy olyan civilizáció kialakulását, amely a kora újkor századaitól egyre gyorsuló fejlődésre lett képes. Ebben a távlatban külön figyelmet kell fordítanunk a keresztény vallás társadalmi és kulturális következményeire.

\section{A keresztény hit alapvetö jellegzetességei}

A kereszténység nyugati társadalomfejlődésre gyakorolt hatásának bemutatása előtt magát a keresztény hitet is jellemeznünk kell. A kereszténység a zsidó egyistenhit ótestamentumi próféták által hirdetett radikális változatának örököse volt. A zsidók és a keresztények kezdettől fogva hittek abban, hogy Isten nemcsak a teremtésben, hanem a kinyilatkoztatásban és a történelemben is megnyilvánul, illetve párbeszédet folytat választott népével - előbb a zsidókkal, később az Egyházzal -, valamint a Megtestesülés és a Megváltás által lehetővé igyekszik tenni, hogy az ember természetfeletti létrend - az örök élet - felé haladó útja, amit az áteredő bün - az első emberpár bủne, amely az egész emberi nemre hatással van - elzárt, újra megnyílhasson. A kereszténység vallotta a zsidó monoteizmus teizmusát és perszonalizmusát, azaz a világtól külön álló személyes isten képzetét. Jézus Krisztus megtestesülése által a transzcendens Isten közeli és megismerhető lett az ember számára. A zsidó valláshoz és az iszlámhoz képest a keresztény vallás vonzerejét a transzcendenciának és az immanenciának az egyidejüsége adta. Az elö-ázsiai monoteizmusokban oly távoli istenkép személyessé és megtapasztalhatóvá vált. 
A keresztények kezdettől fogva természetfeletti távlatokban gondolkodtak végső boldogságukról. Evilági tetteiket a radikális szeretetparancs határozta meg. Már az első keresztény közösségek arra törekedtek, hogy hitüket cselekvéssel támasszák alá, és a világ számára felmutassák a krisztusi etika követelményeit. Az őskeresztény közösségek magukhoz vették Krisztus testét és vérét (eukharisztia), valamint felolvasták a Megváltó cselekedeteit hirdető szent szövegeket. A keresztények számára az áldozás és a jócselekedet praxisa mellett a hit intellektuális reflexiója másodlagosnak bizonyult, ami nem jelenti azt, hogy lebecsülték volna az értelem gyümölcseit.

A kereszténység a hellenisztikus misztériumvallásokhoz képest „nyitott hagyományt" hirdetett, és elutasította a szük vallási elit számára megismerhető ezoterikus tudás koncepcióját. A keresztények szerint nincs kétfajta tudás - az átlagos hívők és a beavatott kiválasztottak számára -, hanem Isten parancsai a Bibliából és a lelkiismeret szava révén mindenki számára megismerhetők. A keresztény tanítás egyik lényeges mozzanata a teremtés jóságába vetett hit, amit az áteredö bün sem írt felül. A teremtett világ szépsége a keresztények szerint Isten nagyságának bizonyítéka. A világ nem „földi siralomvölgy”, hanem Isten keze munkájának csodálatos eredménye. Lényeges tanítás szól a szabad akaratról (liberum arbitrium), amely szerint az ember rendelkezik a jó és a rossz közötti választás lehetőségével. A keresztények kezdettől fogva elutasították az erkölcsi relativizmus mindenféle formáját. A katolikusok a jó és a rossz megkülönböztetésének szükségességét hirdették, és úgy vélték, hogy a szabad akaratú ember a kegyelem révén még akkor is képes lehet erre, ha az áteredő bűn az emberi természet meggyengülését eredményezte.

$\mathrm{Az}$ alapvető tanítások azonossága ellenére a kereszténység a latin Nyugaton más irányba fejlödött, mint az ortodox Keleten. A kései antikvitás idején (4-6. század) a négy nyugati egyháztanító, Szent Ambrus, Szent Ágoston, Szent Jeromos és Nagy Szent Gergely nagyban hozzájárultak a latin kereszténység arculatának kialakításához. Szent Ágostonnak köszönhetően a nyugati teológiában az értelemhez és az érzelemhez képest fontos szerepet kapott az akarat. A teológiai gondolkodás fóárama a latin Nyugaton idővel elmozdult a racionális és az intellektuális gondolatformák irányába - skolasztika kialakulása -, bár azt is vallották, hogy a hitigazságok kizárólag az értelem útján nem foghatók fel. A keleti teológia Isten felfoghatatlanságát hangsúlyozta, ezért „negatív teológiát” hirdetett, míg a latinok hittek Isten korlátozott megismerhetőségében az ész által (,pozitív teológia”).

A nyugati kereszténységben a szerzetesség világ iránt nyitott változatai váltak uralkodóvá. A kiemelkedő jelentőségü bencés szerzetesség gyakorlatiasan szervezett közösségeket hozott létre, ahol az ima és a munka egyensúlyát akarták megteremteni. Keleten az elmélyült ima és a misztikus megtapasztalás elsődlegességét hangsúlyozták, és ez került a szerzetesi élet középpontjába. 
Nyugaton a szerzetesek felvállaltak oktatási szerepköröket. Már az 1. évezredben létrejöttek a „templom” és az „iskola” közötti szövetség alapjai, míg a keleti szerzetesség ezeket a feladatokat kevésbé vallotta magáénak. A latin kereszténységben a racionális gondolkodás és a világban való munkálkodás nagyobb szerepet kapott, ami nem jelenti azt, hogy a misztikus megtapasztalás és a világtól való elvonulás szükségességét a latin egyház ne vallotta volna. A nyugati kereszténység attitűdje bizonyos tekintetben elővételezte a modern világ megszületését.

A latin kereszténységet irányító pápák szerepe az európai civilizáció egyik jellegadó vonását alkotta. A katolikus tradíció mindig hangsúlyozta a római pápa, mint Szent Péter örököse kivételes helyzetét az egyetemes egyház vezetésében. A másik négy pátriárka által irányított egyházak - Alexandria, Antiochia, Jeruzsálem, Konstantinápoly - életébe a római pápák gyakorlatilag nem avatkoztak be az 1. évezred során. Kivételt képeztek az egész kereszténységet érintő hittani viták, ahol Péter utódjának tekintélye meghaladta a másik négy pátriárkáét. Viszont a latin Nyugaton - saját pátriárkátusuk területén - a pápák különleges befolyásra tettek szert. Ez abból fakadt, hogy évszázadokon át nem volt nyugaton császár, ezért a pápaság nélkülözte legfőbb hatalmi vetélytársát. A népvándorlás zavarai közepette a pápák gyakran közéleti szerepek felvállalására is kényszerültek, amit környezetük elvárt tőlük, hiszen biztosítaniuk kellett a rend és a béke minimumát. Ezért a kora középkori pápaság a latin Nyugaton olyan világi feladatokat is magára vállalt, amelyek hozzájárultak hatalma és tekintélye növekedéséhez.

A Karoling-reformok után kialakuló latin nyelvű egyházi kultúra letéteményeseként a pápa által irányított római katolikus egyház kifejezésre juttatta a nyugati kereszténység civilizációs egységét. Bár az egyházszakadás (1054) után a latin Nyugatra korlátozódott, maga az elnevezés - , katholikosz ”, azaz „egyetemes” - jól érzékelteti a pápaság univerzális önértelmezését és minden lényeges értéket magába foglaló küldetését. Az ezredforduló után a pápák erőteljes centralizáló intézkedéseket hoztak a római katolikus egyházban a 12-15. században. Ez a központosító tendencia a reformáció ellenhatásaként a 16. században, majd a liberális nemzetállamok korában is folytatódott. Így a katolikus egyház képes volt megőrizni autonómiáját a modern kor kihívásaival szemben, de a létrejött irányítási modell jelentősen eltért az egyház kormányzásának első ezer évében kialakult szokásaitól. A II. Vatkáni zsinat óta a római katolikus egyház a centralizáció mérséklésére törekszik, és decentralizált szervezeti megoldások létrehozását tekinti feladatának. 


\section{A keresztény hit társadalmi dimenziója}

A kereszténység nyugati társadalomfejlődésre gyakorolt hatása sokféle értelmezés tárgyát képezte a 19-20. században. A francia forradalom idején általánossá vált a megközelítés, amely a kereszténységet az ancien régime ideológiai bástyájaként tartotta számon. A 19. századi gondolkodók nagyobb része úgy vélte, hogy a kereszténység csakis a modernség ellentézise lehet. Ezt a leegyszerüsítő felfogást a vallásszociológia és a történettudomány a 20. század elején kezdte újragondolni. Ennek során számba vették a kereszténység azon sajátosságait, amelyek legtágabb értelemben a modern világ születésének alapjául szolgáltak. A kereszténység európai történelemben betöltött szerepét a megújuló történeti paradigma már nem a modernitás antitéziseként, hanem előzményeként fogta fel. A megváltozó elméleti keret az érett középkor szociokulturális jelenségeinek a jobb megértéséhez is hozzájárult.

Ebben a távlatban lényegesnek tünik, hogy a kereszténység megörökölte a zsidó monoteizmus radikalizmusát, ami a világtól különálló személyes transzcendens isten létét hirdette, ahol a „szent” kizárólag Istenben fejeződhet ki, ahogy arra a próféták határozottan felhívták a figyelmet. Emiatt mondhatta Max Weber, hogy a „mágiához” képest a kereszténység előmozdította a „világ varázslat alóli feloldását", és a deszakralizált világ megnyílt a racionális emberi tevékenység elött. Ezért állíthatjuk, hogy a modern tudomány és technika kialakulása bizonyos értelemben a kereszténységnek köszönhetö. A keresztény tanítás szerint Isten a világhoz képest egészen más. Ezzel szemben a „világ” immanens, és profán szféraként megkülönböztethető a „szenttől”. Ebböl vezethetö le a „szakrális” és a „profán” szférák elválasztása, aminek politikai konzekvenciái a szakrális és a világi hatalom szétválasztásához vezettek. Míg az iszlámban Mohamed és utódai, a kalifák a hívők vallási és politikai vezetői, addig Jézus - ahogy arra már utaltunk - nem alapított államot. A keresztény egyház mindig is megkülönböztette magát az államtól, még akkor is, ha Bizáncban a „cezaropapista modell” jóval kevesebb mozgásteret biztosított az egyháznak az állammal szemben, mint a középkori latin Nyugaton, ahol Gelasius pápa (492-496) - a két szféra közötti elválasztást és egyensúlyt érzékeltető „két kard” elmélete a politikai gondolkodás és gyakorlat szerves részévé vált. Az emberiség történetében általában „teokráciával” (= istenkirályság) vagy „cezaropapizmussal” - a szakrális és a profán szférák összefonódásával, hol az egyik, hol a másik szféra javára - találkozunk. Egyedül a latin Nyugaton valósult meg a szakrális és a profán területek elhatárolását, egyben egyensúlyát biztosító társadalmi modell. Ez a pápa és a császár hatalmi dualizmusában öltött testet, ami az érett középkor egyik politikai alapvonásává vált.

A transzcendens Isten és az immanens világ kettőssége a modern tudományok születése szempontjából is nélkülözhetetlen elöfeltételnek 
bizonyult. Az, hogy a „,földi dolgok” teremtményi mivoltukkal együtt bizonyos autonómiával rendelkeznek, és a teremtett világ saját törvényszerüségei szerint müködik, tág értelemben biztosította a kereteket az önállósuló humán és természettudományos gondolkodás számára. Aquinói Szent Tamás filozófiája a 13. században és a párizsi egyetem tanárai a 14-15. században nagyban hozzájárultak ahhoz, hogy a középkor végétôl a világ valamennyi történését nem az isteni akaratnak közvetlenül alávetett jelenségként, hanem autonóm törvényszerüségek következményeként kezdték értékelni. Mindez megteremtette a szekularizált filozófia és a szaktudományok kialakulásának a lehetőségét a kora újkori Európában. Végső soron ez vezetett az újkori tudományos forradalomhoz, ami megalapozta a nyugati világ technológiai fölényét az elmúlt három évszázadban.

A kereszténység hozzájárult az emberi személy méltóságának kiteljesedéséhez. Az európai humanizmusnak a görög-római forrásokon túl vallásos dimenziói is vannak. A keresztény tanítás szerint Isten saját képére és hasonlatosságára teremtette az embert, ahogy azt az Ószövetség első oldalain olvashatjuk. Mivel az ember istenképmás mivoltával kapcsolatos állítások a Szentírásban több helyen is megtalálhatók, az európai vallás- és kultúrtörténetben beszélhetünk a „bibliai humanizmus” vagy „keresztény humanizmus” jelenségéről. A szabad akaratú és az abszolútum iránt nyitott ember rendeltetése, hogy a Teremtő társaként beteljesítse a teremtés művében rejlö lehetőségeket. A keresztény humanizmus azt hangsúlyozza, hogy Isten nem korlátozza, hanem kiteljesíti a felé forduló embert. Az Isten hasonlatosságára teremtett ember a legfőbb záloga annak, hogy beszélhetünk az ember méltóságáról. Ennek jegyében a kereszténység magába fogadta és új jelentésekkel látta el az antik humanizmust. A klasszikus és a keresztény humanizmus együttes hatása az európai civilizációt az „emberközpontúság” kultúrájává avatta.

A kereszténység születése pillanatától az egyént szólította meg és egyetemes küldetést hirdetett. Jézus Krisztus minden ember számára elhozta az evangéliumot, és azt a feladatot adta apostolainak, hogy minden népnek hirdessék az „örömhírt”. Az egymáshoz képest exkluzív módon viszonyuló törzsi-nemzetségi csoportokhoz képest a kereszténység megteremtette az „individuális” és az „univerzális” fogalmait. A keresztény hittel leomlottak, de legalábbis másodlagossá váltak a törzsi-nemzetségi csoportok közötti válaszfalak, és megnövekedett az individuum szerepe. Ezt a mozzanatot Max Weber a nyugati fejlődés alapvető vonásaként tartotta számon. Az európai modernség individualizmusa és univerzális eszményei nem lettek volna lehetségesek a keresztény előzmények nélkül. A nemzetségi kötelékek meghaladása a modern társadalom kialakulásának is előfeltételét képezte, ahogy az más kultúrákkal való összevetésben világosan megmutatkozik. 
Nyugat-európai ,eredeti jellegzetességek”

A keresztény hit társadalmi dimenziója hozzájárult a nyugat-európai társadalomfejlődés sajátosságainak kialakulásához, de valamennyi „eredeti jellegzetesség" nem vezethető le kizárólag a kereszténység hatásából. A keresztény hit társadalmi vetületéből magyarázható mozzanatokon túl a középkori politikai fejlődés néhány egyéb alapvető adottsága - partikularizmus, decentralizáció - éppúgy jelentősnek bizonyult, mint a római jog szerepe vagy az antik önkormányzati szabadságok mintaértéke.

A „,birodalom” hiánya. Már utaltunk rá, hogy Nyugat-Európában a Római Birodalom bukása után nem jött létre a latin keresztény civilizáció egészére kiterjedő birodalom. A hübéri kapcsolatokon nyugvó középkori államkezdemények váltak a későbbi nemzetállamok alapjává (33. térkép). A legkülönfélébb territóriumok jöttek létre, amelyek egyáltalán nem, vagy csak névleg tartoztak szuverén fejedelmek és hübérurak fennhatósága alá. Ilyenek voltak az itáliai városállamok és a német városszövetségek. Az érett középkorban a latin keresztény Európa számos politikai és hatalmi központtal rendelkezett, amelyek állandóan vetélkedtek, de nem voltak képesek legyőzni egymást. Manapság a történettudomány úgy látja, hogy ez a policentrikus struktúra nagyban felelős azért a dinamikáért, amely a középkor második felétől egyre inkább érzékelhetővé vált. Ehhez képest az Európán kívüli civilizációkban gyakran újratermelödött a monolit ,birodalmi modell”.

Szakrális és profán szféra megkülönböztetése. Nagy jelentősége volt az invesztitúraharcok megindulásának a 11-12. század fordulóján, amelyek maguk után vonták a szakrális és a profán szférák közötti különbségek megvonását. A neves német társadalomtudós, Eugen Rosentock-Huessy az invesztitúraharcokat a Nyugat „első forradalmának” nevezte, amit mások is követtek, egészen a polgári forradalmakig. Az invesztitúra problémája attól vált különlegessé, hogy a vallás és a politika metszéspontján helyezkedett el. Hogy az egyházi tisztség beiktatásának a joga az egyházat illeti meg, vagy a világi uralkodót, kikényszerítette a szakrális és a világi hatalom természetéről való általánosabb reflexiót. Már utaltunk rá, hogy az invesztitúraharc során megfogalmazódó kompromisszum fontos tanulsága lett, hogy az európai történelemben sem a szakrális, sem a világi hatalom létezését nem lehetett kétségbe vonni. Az európai középkor egyik alapvető sajátossága abban állt, hogy egyik szféra sem volt képes a másikat végérvényesen maga alá rendelni, és a két terület közötti megkülönböztetés a kiegyensúlyozott erőviszonyok következtében állandósult, valamint doktrinális szempontból is elfogadhatóvá vált. A Nyugat-Európán kívüli civilizációkban maga az invesztitúra problémája sem lett volna értelmes kérdésfeltevés.

Szabadságintézmények és autonómiák. Az érett középkorban nemcsak gazdasági és demográfiai növekedés ment végbe, hanem számos új politikai 
intézmény létrejöttével is találkozunk. A felgyorsuló gazdasági és társadalmi mozgások a politikai gondolkodó Bibó István szavaival élve a ,szabadságok köreit” hívták életre, amelyek átalakították a társadalom szövetét. A VII. Gergely pápa által képviselt egyházreform a 11. század végén a katolikus egyház világi/profán társadalommal szembeni „szabadságát” védelmezte (libertas ecclesiae). A 1112. században a városok számbeli gyarapodása egyben a városi önkormányzatok kibontakozását eredményezte. Ezek az autonómiák a 13. századra az egész latin keresztény Európát átszőtték. Ugyanez történt a jobbágyi szabadságok kiterjedése kapcsán. A szabad költözködési jog a jobbágy elidegeníthetetlen jogává vált.

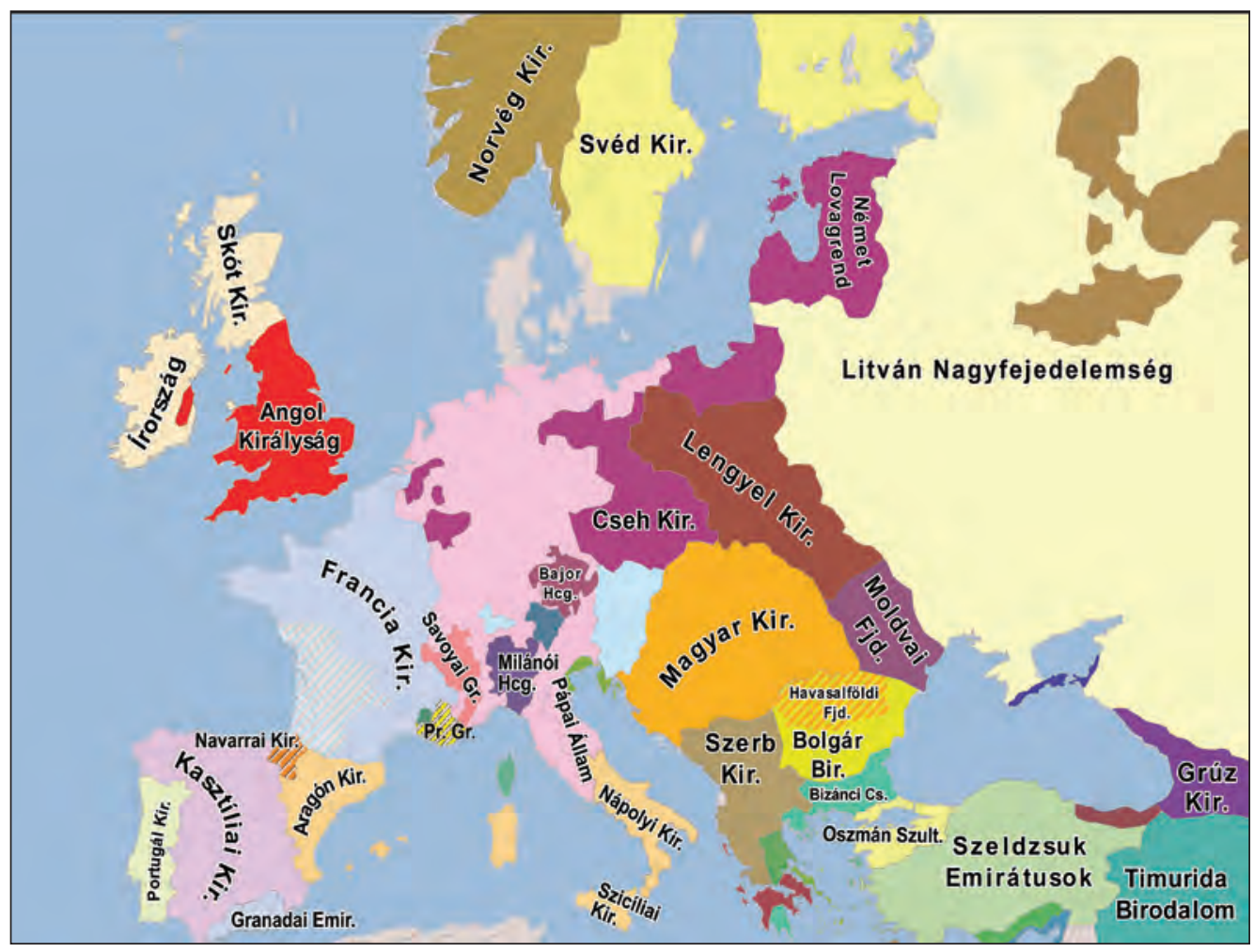

33. térkép: Európa a 14. században

Forrás: VARGA ÁGNES szerkesztése

Az érett középkor a politikai társadalom müködését illetően is nagy horderejü átalakulásokhoz vezetett. A hübéri viszonyokat szabályozó etikai normarendszer a hủbéres számára is garanciát jelentett az alávetés egyoldalú formáival szemben. A hübérür és a hübéres között létrejövő kapcsolat nem patriarchiális, hanem szerződésszerü viszony volt, ahol nemcsak a hübérúrnak voltak jogai, hanem mindkét fél vállalt kötelezettségeket. A 13. század során kialakultak a rendi parlamentek, amelyek az uralkodó és a nemesség közötti 
hatalommegosztás intézményesült formáiként müködtek. A 13-14. században fénykorukat élő egyetemek is jelentős ,szabadsággal” rendelkeztek. Ezek az intézmények horizontális szerveződésü testületek vagy lokális közösségek voltak. Ehhez képest az Európán kívüli társadalmakban nem találunk hasonló mértékben jogilag intézményesült autonómiákat. Meg kell jegyezni, hogy a „szabadság” nem modern individuális jogkövetelést jelentett, hanem egy-egy társadalmi csoportosulás - város, rend - kollektív jogaként jelent meg, ami illeszkedett a hierarchikus társadalomba. Mégis a középkori szabadságok kialakulása nélkül nem kerülhetett volna sor a modern szabadságeszme megjelenésére.

A nyugat-európai társadalomfejlődés „eredeti jellegzetességei” arra a szociokulturális jelenségcsoportra utalnak, amelyek a 11-14. században alakultak ki, és a nyugati keresztény civilizációt a modernitás sikeres előfeltételévé tették. A 12-13. századtól olyan társadalmi dinamika kezdeteinek vagyunk szemtanúi, amely az elkövetkező századokban egyre intenzívebb formában termelődött újra. Ez a felerősödő mozgás a reneszánsszal és a reformációval indult útjára, és a nagy földrajzi felfedezésekkel, a 17. századi tudományos forradalommal, a 18. századi felvilágosodással, a polgári és az ipari forradalmakkal, valamint a nemzetállamok születésével folytatódott, miközben Európa a világ urává emelkedett.

\subsubsection{A premodern és a modern határán (1500-1800)}

\section{A reneszánsz}

Az érett középkor gazdasági konjunktúrája a 13-14. század fordulóján véget ért. Az észak-francia gótikus katedrálisok építése jól kifejezte az 1100 és 1300 közötti felvirágzást. A több generáción át épülő hatalmas gótikus templomok világosan érzékeltették a rendelkezésre álló gazdasági energiákat. Ehhez képest az elkövetkező két évszázad a gazdasági, népesedési válságok és járványok kora volt. Az 1348-as nagy pestissel Európát története legnagyobb demográfiai katasztrófája érte, amelynek során a kontinens elvesztette népessége majdnem felét. Nem véletlen, hogy ebben az időszakban Európa térbeli expanziója is megtört. A Szentföld elveszett a keresztények számára, és a diadalmasan elörenyomuló Oszmán Birodalommal szemben a humanisták gyakori kifejezése lett a misera Europa (szerencsétlen/nyomorult Európa) toposza.

A gazdasági recesszió következményeit a történettudomány korábban borúlátóbban ítélte meg. Ma úgy látjuk, hogy a 15. század második felében már újra a konjunktúra jelei mutatkoztak. Az 1400-as évek végén meginduló nagy földrajzi felfedezések jól mutatják a nyugat-európai gazdaság magára találását. A történészek régebben azt feltételezték, hogy a földrajzi felfedezések nyomán kezdődő gyarmatosítás előmozdította a kora újkori Európa gazdasági 
növekedését. Ma a kolonizáció jelentőségét nem vitatva úgy vélik, hogy az európai kontinens újabb gazdasági nekilendülése már 1450 körül bekövetkezett. Így a gyarmatosítás a fellendülésnek nem annyira az oka, mint következménye volt. Az érett középkorban kialakuló szociokulturális struktúrák, amelyek a nyugat-európai társadalom nagyobb önmozgását tették lehetővé, a 14-15. századi válság idején kiállták a próbát. Európa kreatív választ adott a gazdasági recesszióra, ami az elkövetkező századokban gazdasági fellendüléshez vezetett.

A reneszánsz az európai kultúrtörténet egyik legjelentősebb korszakaként a 14-15. században bontakozott ki. A polgári kor kultúrtörténészei a 19. században kiemelkedő időszaknak tartották, mert az antik emberközpontúság újjászületését látták a reneszánsz müvészetben. Bár a történettudomány ma jóval árnyaltabban fogalmaz, és számos egyéb aspektusra is felhívja a figyelmet - a latin nyelvi norma megújulása, az ógörög és a héber tudás fejlődése, a muzeológia kezdetei az antik romok feltárásával, az olajfestés terjedése, a szerkesztett perspektíva megjelenése a festészetben és az iskolai művelődés programjának humanista megújulása -, a 14-15. században minden kétséget kizáróan folytatódott a kultúra individualizációja és szekularizálódása.

A 15-16. század fordulóján az európai történelem fordulópontjához ért. A reneszánsz müvészet verizmusa - Leonardo, Michelangelo és Raffaello alkotásaival - alig megismételhető tetőpontjára jutott, elkezdődtek az európai kontinens globális szerepét megalapozó földrajzi felfedezések, születőben voltak az első modern államok, és számolni kellett az európai államrendszer keretében formálódó hatalmi egyensúly kezdeteivel. Másfelől mindez a hagyományos agrártársadalmak és gondolkodási keretek között következett be. A kora újkorban - 1500 és 1800 között - a „premodern” és a „koraérett modern” jelenségek egyszerre voltak jelen az európai kultúrában.

\section{A reformáció}

A modern kor irányába mutató események szempontjából különös jelentősége lett a reformációnak, amely újszerü vallási és kulturális dinamikát hozott az európai történelembe. A középkori kereszténység egysége a római katolikus egyház hierarchikus szervezeti modelljében testesült meg. A Luther fellépésével kezdődő reformáció nemcsak az egységet szakította szét, hanem magátahierarchiát is megkérdőjelezte.Aprotestantizmus gyökereiről könyvtárnyi szakirodalom született, amely különféle aspektusokból vizsgálja a hitújítás okait a katolikus egyház morális visszásságaitól a hitélet formáinak késő középkori átalakulásáig. A reformátorok mindnyájan a hitélet radikális megújításának lehetőségét keresték. Az általuk hangoztatott jelszavak sola fides (csak a hit), sola scriptura (csak az írás), sola gratia (csak a kegyelem) jól érzékeltetik a reformáció alapvető irányultságát. A hitújítók a katolikusoktól eltérően azt 
vallották, hogy a jócselekedetekkel, aszkézissel vagy búcsúcédulákkal szemben egyedül a hit üdvözíthet. Az egyházi hagyományhoz képest csakis a Bibliát kell autentikus szövegként elfogadni. Az isteni kegyelem és az emberi szabadság viszonylatában felértékelték a kegyelem fontosságát a szabad akarat rovására, míg a katolikus tradíció a szabadság és a kegyelem együtthatását hangsúlyozta.

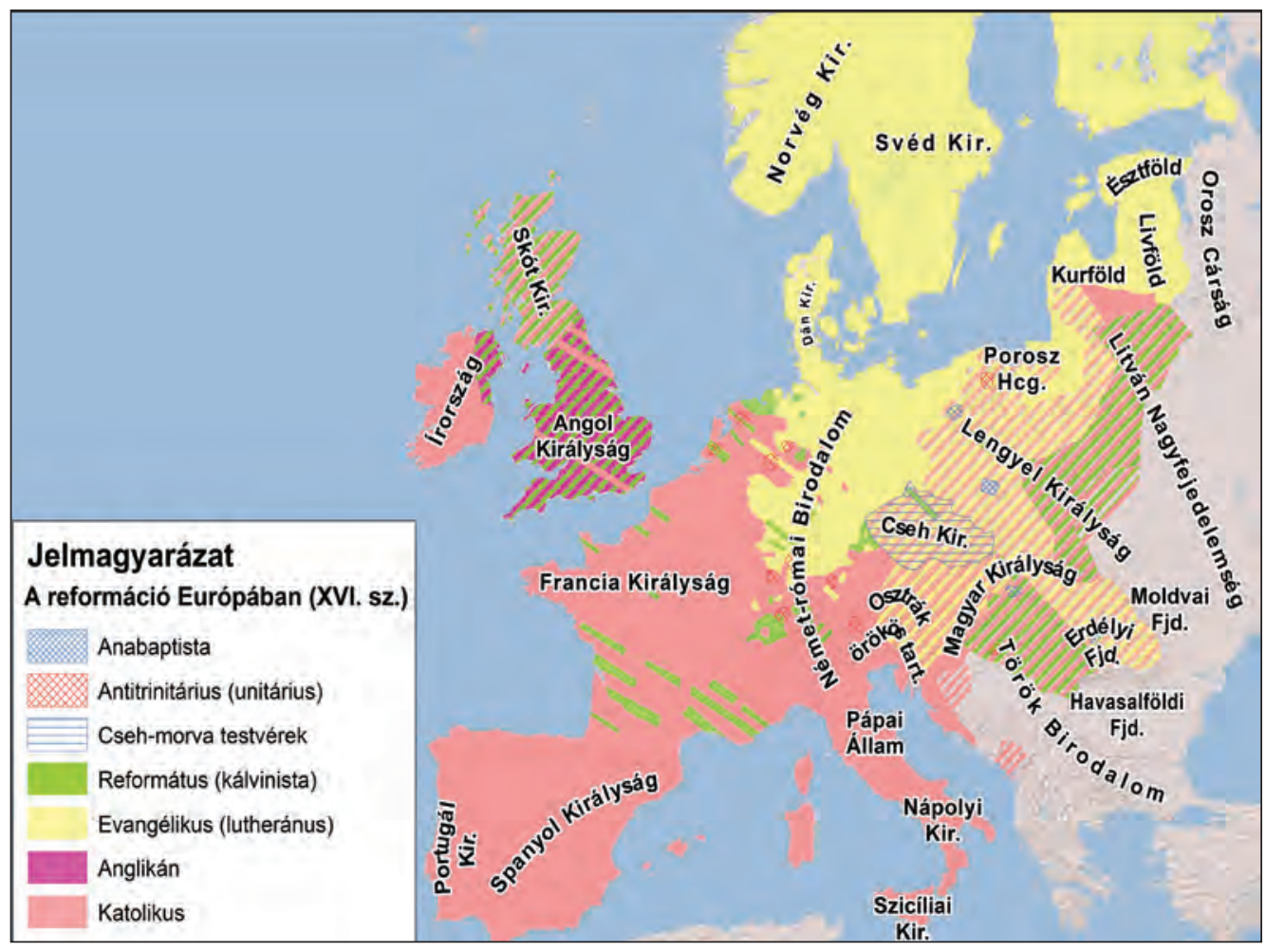

34. térkép: Vallási felekezetek a kora újkori Európában Forrás: VARGa ÁGNES szerkesztése

A protestantizmus történetében utalnunk kell a vallási irányzatok állandó differenciálódására, és az egyre radikálisabb csoportok megjelenésének tendenciájára. Ezekhez képest a lutheránus, a kálvinista és az anglikán egyházak hamar konszolidálódtak, de napjainkig születnek újabb neoprotestáns irányzatok főleg az Egyesült Államokban. Azokban az országokban, ahol a reformált vallások államegyházakká alakultak, az uralkodók lettek az egyházfők, mint Angliában, a skandináv országokban és a német fejedelemségekben (34. térkép). A pápa és a világi uralkodók „kettős hatalmával” szakítva a protestánsok elfogadták az államegyház koncepcióját, és kisajátították (szekularizálták) az egyházi birtokokat.

A katolikus univerzalizmustól megfosztva a reformált egyházak nagyobb mértékben gyökereztek a helyi sajátosságokban, és fokozatosan nemzeti 
egyházakká váltak. Ez a vonásuk az újkorban kialakuló nemzetállamok előzményeivé tette őket. Ebben az értelemben a protestantizmus felgyorsította a nemzetté válás folyamatát, ami a modern Európa egyik sarkalatos jelensége lett. A fejedelmi irányítást elfogadó lutheri egyházakhoz képest a radikálisabb kálvini egyház alulról szerveződő közösségekből állt. „Demokratikus” felépítése a kora újkori politikai fejlődésre is hatást gyakorolt, és előmozdította az abszolút monarchiák elleni polgári forradalmakat.

A reformációt a vallástörténészek tekintélyes része „modern” jelenségként tartotta számon az individuális hitformák előtérbe helyezése, a misztériumok kiküszöbölése, az egyéni bibliaolvasás és az írni, olvasni tudás fejlődése miatt. Másfelől arra is érdemes felhívni a figyelmet, hogy a protestánsok radikalizmusa számos esetben nem volt mentes az ellentmondásoktól. Az eleve elrendelés tana (predesztináció) oda vezetett, hogy Kálvin az emberi természetet sokkal sötétebben látta (antropológiai pesszimizmus), mint katolikus vitapartnerei. Az isteni kiválasztásnak ugyanis csak abban az esetben van jelentősége az üdvözülésben, ha az ember szabad akarata már egyáltalán nem játszik szerepet. Kálvin a predesztináció védelmében az áteredő bün emberre gyakorolt hatását jóval drámaibban ítélte meg, mint a katolikusok. Szerinte a természetében gyökeresen megromlott embert egyedül Isten és nem saját szabad döntései üdvözíthetik, ami nem éppen az individuum szabadságát középpontba állító azaz a „modernitás” felé ható - teológiai doktrína. Ezzel együtt Luther 1517-es fellépése óta a protestantizmus a hitegység megtörése révén olyan dialektikát vitt Európa történetébe, ami az újkori modernség irányába mutató történelmi folyamatok alapjául szolgált.

A reformáció szenvedélyes viták keretében terjedt szét a 16 . századi Európában. A 16-17. századi vallásháborúk következtében új vallásicivilizációs törésvonal volt kialakulóban, a protestáns Észak és a katolikus Dél dichotómiája. Max Weber nevezetes tézise nyomán a gazdaságtörténet rengeteget vitatkozott arról, hogy a protestantizmus valóban döntő szerepet játszott-e az újkori kapitalizmus kialakulásában. Az északi Európa gazdasági felívelése és a Mediterráneum lehanyatlása az angol, a holland és a német protestáns polgárságnak köszönhető-e, vagy egyszerüen az Amerika felfedezésével kialakuló atlanti világgazdaság jobb földrajzi helyzetbe hozta ÉszaknyugatEurópát?

A katolikusok és a protestánsok közötti különbségek még napjainkban is rányomják a bélyegüket a politikai viszonyokra, és hatást gyakorolnak az európai egységfolyamatra. Empirikus vizsgálatok támasztják alá, hogy az európai integrációt a második világháború utáni közvélemény „katolikus alkotásnak” tartotta. Brüsszel „etatizmusát”, „bürokratizmusát” a katolikus választópolgárok nagyobb mértékben elfogadták, mint az északi protestáns országok közvéleménye, amely a minimal state és a protestáns nemzeti 
kultúrák jegyében ösztönös ellenszenvet érzett az integráció hivatalnokaival és struktúráival szemben.

\section{A tudományos forradalom és a felvilágosodás}

A reformáció után az újkori modernség felé irányuló fejlődés következő lépésének a 17. századi tudományos forradalom tekinthető. Spinoza és Descartes utat nyitottak a ráció újszerü használatának. Viète, Descartes és Euler az algebra és a koordináta geometria alapelveinek megteremtésével lerakta egy egzakt tudományos nyelv alapjait, amely képes a matematika eszközeivel kifejezni a sík- és a térbeli geometriai alakzatokat. Ezzel az újkori fizika számára olyan apparátust szolgáltatott, amelynek a müszaki tudományok is haszonélvezői lettek. A késő reneszánsz tudományossággal megszülető heliocentrikus világkép, majd Galilei és Kepler gravitációra és a bolygók mozgására vonatkozó megfigyelései elővételezték a „végtelen” és a kozmosz újszerü fogalmának kialakulását. A tudományos világkép átalakulását Newton tetőzte be a mechanika - a fizikai mozgás - törvényszerúségeinek kidolgozásával és rendszerbe foglalásával. Newton fizikája a 18. századtól fokozatosan felváltotta az arisztotelészi fizikát, és egészen az einsteini relativitáselméletig uralkodó tudományos paradigma maradt.

„Miközben az algebrát és a geometriát közös nevezöre hozó analízis által kikovácsolódik a matematikai fegyver Viète-tel, Descartes-tal, Fermat-val, addig Galileitöl Descartes-ig szabatossá válik az az intuició is, hogy a természetet a matematika nyelvén lehet leirni. Föleg a Discours de la méthode (Értekezés a módszerről - a szerzö) (1637) remek kockavetése nyitja meg az utat a precedens nélküli intellektuális átalakulások folyamata elött, amely 1687-ben Newton Principia Philosophiaejában (A természetfilozófia matematikai alapelvei) teljesedik ki. A lángész kettös felvillanása; egyfelöl az anyag azonositása az euklidészi geometriából ismert kiterjedéssel, másrészt a középkori és az antik szillogizmus felváltása a matematikus intuitív indukciójával." (CHAUnU, P. 1971, pp. 13-14.)

A 17. századi tudományos forradalom nagy újítása nemcsak a természet törvényeit leíró egzakt matematikai nyelv megteremtésében ragadható meg, hanem meghonosodott a kísérleten nyugvó természettudományos módszer is. $\mathrm{Az}$ újkori fizika kísérleteken, mérésen és erre épülö modelleken, majd azok tesztelésén és korrekcióján nyugodott. Standardjai fokozatosan jöttek létre, és a tudományos metodológia nélkülözhetetlen részét képezték. Az ókori görögök természeti megfigyelései gyakran zseniális észrevételekhez vezettek, de sem az egzakttudományos nyelv, semakísérletimódszernemjellemezteőket.Aközépkor és a reneszánsz számos területen meghaladta az antik természettudományt, de igazi fordulópont csak a 17. századi tudományos forradalom során következett 
be. Ennek révén az európai civilizáció olyan tudományos apparátusra tett szert, amely lehetővé tette a világméretű ipari és technológiai fölény kialakulását a 19. században. Az iparosodás kezdetei a 18. századi Angliában a tudományos forradalom eredményei nélkül is bekövetkeztek volna, hiszen a kezdetleges gépek heurisztikus megfigyeléséken és a trial and error (próba szerencse) módszerén alapultak. De a 19. század utolsó harmadában kibontakozó „,második ipari forradalom", amelynek a húzóágazatait a vegyipar és az elektromosság alkotta, nem lett volna elképzelhető a modern természettudományok nélkül, amelyek fejlődését a kora újkori tudományos forradalom indította el.

A 17. századi tudományos forradalmat a történészek a 18 . századi felvilágosodással szoros egységben szokták tárgyalni. A történettudomány a két jelenséget együtt tekintette a modern Európához vezető út kulcsfontosságú szellemi előzményének. A tudományos forradalom tényleg összekapcsolódott a felvilágosodással, érdemes azonban felhívni a figyelmet arra, hogy az utóbbi főleg a társadalomról való gondolkodást újította meg, és a humán tudományok területén alkotott maradandót. A francia felvilágosodás Enciklopédiája egyrészt összegezte az átalakuló tudományos világkép és az alkalmazott tudományok - politikai gazdaságtan, agrártudományok, államtudományok - eredményeit, másrészt a társadalmi szerződés fogalmának kidolgozásával radikálisan újragondolta a politikai legitimáció problémáját. A felvilágosodás megalapozta a „kormányzók” ellenőrizhetőségének gondolatát, és megteremtette annak lehetőségét, hogy a modern politika fundamentumává a „kormányzottak” közössége váljon.

A felvilágosodás az első olyan eszmeáramlat volt az európai civilizáció történetében, amely nemcsak az egyház-, hanem a valláskritikát is müvelte. A reneszánsz humanistái több ízben kritikus észrevételeket tettek az egyház mint intézmény müködésével kapcsolatban, de fel sem merült, hogy megkérdőjeleznék a keresztény vallás alapvető tanításait. Ehhez képest a francia felvilágosodás során már számolni kellett az első deistákkal, materialistákkal, akik a természettudományos világképből újszerü filozófiai következtetéseket vontak le, és eljutottak a keresztény kinyilatkoztatás elutasításáig.

A felvilágosodás a keresztény antropológiát is újraértelmezte, amikor az embert végtelenül javítható és tökéletesíthetö lénynek gondolta el. Ez az antropológiai optimizmus vezethetett a fejlődéselvüséget középpontba állító „modernista” történetszemlélethez, amely az európai civilizáció lehetöségeit a végtelen haladás távlatában helyezte el. A felvilágosodással kialakuló modern eszmeáramlatok és a keresztény tanítás között növekvő távolság az újkori európai kultúra fontos vonásává vált. Ezzel együtt az európai polgárság nemcsak a felvilágosodás filozófiai programját teljesítette be, hanem a kereszténységből származó civilizációs alapértékek számos elemét is megőrizte. 


\subsubsection{Európa tündöklése és hanyatlása}

\section{A „hosszú 19. század” Európája}

Eric Hobsbawm előszeretettel használta a „kettős forradalom” kifejezést a 18-19. század fordulóján lejátszódó változások leírására. A neves angol történész úgy ítélte meg, hogy az 1760-as években kezdődő angliai ipari forradalom („első ipari forradalom”) a gazdaság, míg az 1789es francia forradalom a politika síkján vezetett alapvető átalakulásokhoz. Ezt megelőzően a kora újkor századai (1500-1800) az európai történelem hosszú átmeneti korszakát képviselték, ahol a premodern és a modern elemek egymás mellett éltek a politika, a társadalom és a kultúra területén. A reformáció, a tudományos forradalom és a felvilágosodás már ebben az időszakban is jól érzékeltette Európa növekvő dinamizmusát, amelyet a gazdasági és a politikai tendenciák - az atlanti világgazdaság kialakulása, a tőkefelhalmozás, a korai polgári forradalmak - erősítettek. A „kettős forradalommal” az emberi szellem eredményei a gyakorlatban is megvalósultak és „tömeges” jelenséggé váltak. Hobsbawmmal egyetértésben a „kettős forradalmat” a kora újkor és az újkor közötti korszakhatárnak tekinthetjük, ami megteremtette a polgári Európát, valamint kiteljesítette a modernitás ideáját és praxisát.

A francia forradalomtól (1789) az első világháborúig (1914) terjedő időszakot a történetírás „hosszú 19. századnak” nevezi. Az európai történelemnek ez a szakasza jól körülhatárolható karaktervonások mentén jellemezhető. Gazdaságilag a „hosszú 19. század” az iparosodás kibontakozásának a korszaka volt, amikor állandósult a növekedés, amit Walt Rostow a take off fogalmával írt le (ld fent). Az indusztrializációnak köszönhetően Európa hatalmas technikai fölényre tett szert a világ többi részével szemben, ami megalapozta a gyarmatosítás lehetőségét. Az európai nagyhatalmak gyarmattartóvá váltak, és a 19. század második felében a földgolyó tekintélyes részét ellenőrizték. Kivételes ipari kapacitásának köszönhetően az európai kontinens egyfajta „globális szerepre” tett szert, amit az európaiak a „fehér keresztény civilizáció” magasabb rendü voltával és univerzális missziójával támasztottak alá. Európa fölénye a „hosszú 19. század" gondolkodására is rányomta a bélyegét. A felvilágosodás szellemi örökségével és a gazdasági növekedéssel összhangban a történetfilozófusok - Herder, Condorcet, Hegel, Marx - az európai emberiség történetét egyetlen „nagy elbeszélés” keretében szemlélték. Az emberi emancipáció modelljeként írták le, ami a „történelem végén” eléri ideális megvalósulási formáját.

A „hosszú 19 században” a polgári Európa kiteljesedésének lehetünk szemtanúi, aminek vezető eszméi a liberalizmus, a demokrácia és a nacionalizmus voltak. Ezek az ideák a francia forradalommal születtek és a forradalmi eszmék elterjedésével váltak az európai kontinens uralkodó ideológiáivá. A liberalizmus 
és a demokrácia az egyéni és az állampolgári szabadságot állította a középpontba, ami a polgári liberális államok kialakulásával egyre több országban valósult meg. A nacionalizmus az európai történelem egyik meghatározó tényezőjével, az újkori nemzetállamok létrejöttével együtt bontakozott ki (35. térkép). A nemzeti eszme a „hosszú 19. század” leghatékonyabb mozgósító erejü víziójává vált, és valamennyi újkori politikai ideológia a polgári nemzetállam keretében teljesedett ki. A 19. század „uralkodó eszméi”, a liberalizmus, a demokrácia és a nacionalizmus szorosan kapcsolódtak egymáshoz. Közös vonásuk volt, hogy Európa és a világ történetét optimista módon és haladáselvü keretben szemlélték.

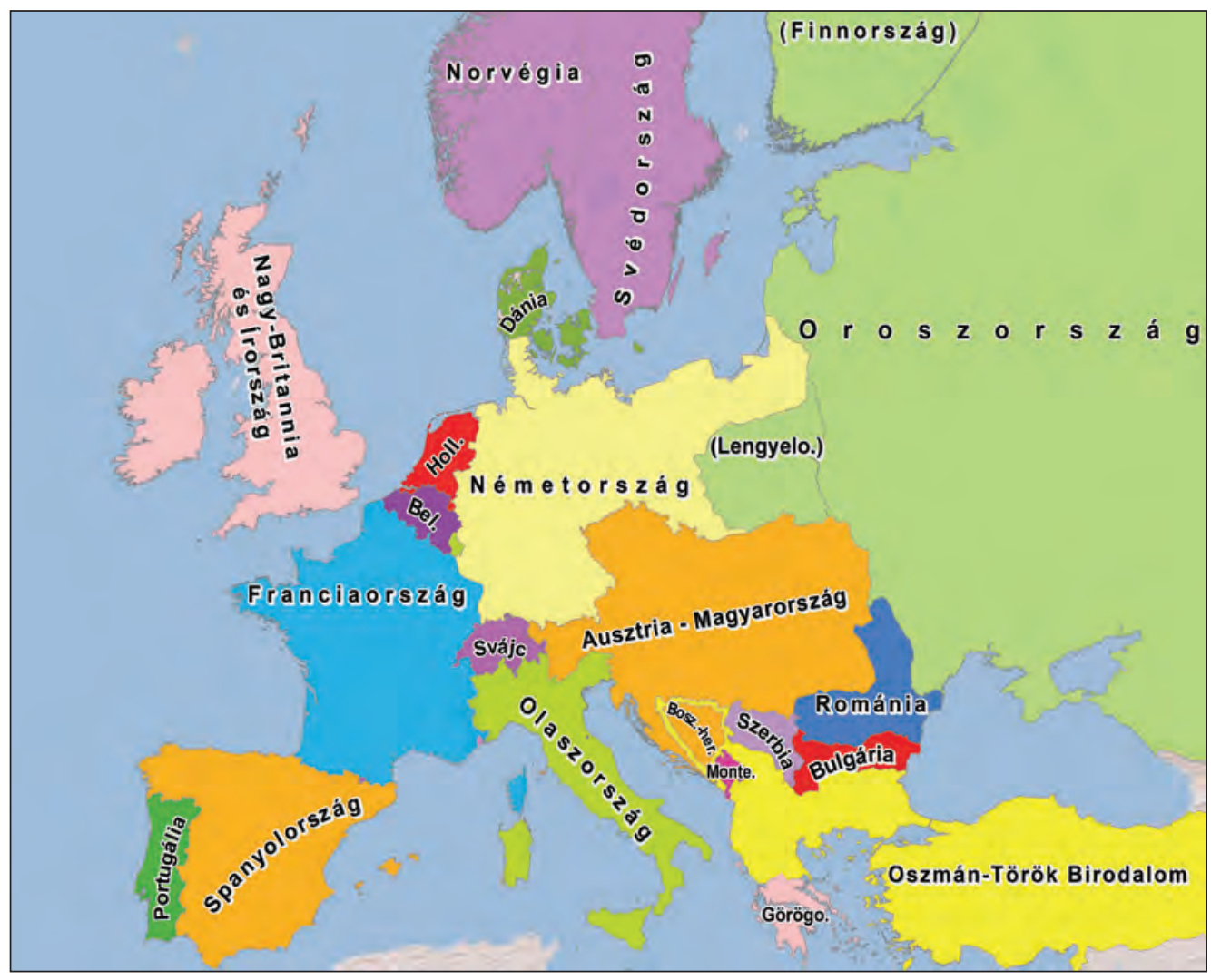

35. térkép: A nemzetállamok Európája a 19. század utolsó harmadában Forrás: VARGA ÁGNES szerkesztése

A „hosszú 19. század” progresszivizmusa az európai kontinens békéjén és prosperitásán nyugodott. Ebben az időszakban nemcsak a gazdasági fejlődés vált érzékelhetővé, hanem a napóleoni háborúkat lezáró bécsi kongresszus (1815) olyan államrendszert teremtett Európában, amely a hatalmi egyensúlyon és a nagyhatalmak közötti kooperáción alapult. Ezért a 19. század során viszonylag kevés katonai konfliktusra került sor. A háborúk általában rövid ideig tartottak, 
és nem terjedtek ki a civil lakosságra. A nézeteltéréseket sokszor nemzetközi konferenciák és kongresszusok keretében oldották meg. A polgári Európa a világtörténelem különleges színterének tünt, ahol nemcsak a gazdasági jólét és a prosperitás, valamint az államok közötti béke valósult meg, hanem arra is képesnek bizonyult, hogy értékeit a földgolyó egészén érvényesítse.

\section{Európa a „rövid 20. században”}

Az első világháború alapvető változásokhoz vezetett az európai civilizáció történetében. Nemcsak Európa gazdasági térvesztését gyorsította fel a felemelkedő Egyesült Államokkal szemben, hanem hatalmas emberi és anyagi veszteségeket okozott, ami megrendítette a haladásba vetett hitet. Az első világháború következtében jelent meg a „kultúrpesszimizmus” az európai értelmiségi körökben, ami a kontinens hanyatlásával számolt. A két világháború között megerősödő jobb- és baloldali szélsőségek a polgári liberalizmus leáldozását eredményezték, és autoriter rendszerek, diktatúrák kialakulásával jártak együtt. A „hosszú 19. századot” ezek alapján különböztetjük meg a „rövid 20. századtól". Az előbbi Európa világ feletti uralmával, a jövőbe vetett hittel, optimizmussal, a nemzeti liberalizmussal és az iparosodás eredményeivel, az utóbbi az európai kontinens térvesztésével, gazdasági, politikai válságokkal és agresszív tömegnacionalizmusokkal kapcsolódott össze.

A „,övid 20. század” jól érzékelteti, hogy az első világháború a világtörténelemben és az európai történelemben egyaránt fordulópontot jelentett. A „hosszú 19. század” eszméihez képest a két világháború között a politikai ideológia és praxis gyökeresen átalakult. A ,rövid 20. század” azonban az európai civilizáció történetének a leírására a második világháború utáni évtizedeketilletően már kevéssé bizonyul alkalmasnak. A hidegháború (1947-1989) évtizedeiben a gyarmati sorból felszabadult, nyugati világon kívüli országok számottevő részében autoriter rendszerek és diktatúrák jutottak uralomra, valamint törzsi, etnikai nacionalizmusok és véres konfliktusok kirobbanására került sor. Ehhez képest Nyugat-Európában a második világháború után konszolidálódtak a polgári demokráciák, továbbá 1945 és 1973 között rendkívüli gazdasági növekedés bontakozott ki. A „,rövid 20. század” fogalmát a történészek eredetileg a „hosszú 19. század” értékeinek és eszméinek a „visszavonásaként” értelmezték, de - a világ számos országával ellentétben - a nyugat-európai országokban 1945 után a liberális demokráciák megszilárdulása következett be.

A történészek szerint a „rövid 20. század” 1989-1990-ben ért véget, amikor megbuktak a kommunista diktatúrák és véget ért a hidegháború. Sokan úgy vélték, hogy a liberális demokráciák immár feltartóztathatatlanul terjednek el a világon. Eszerint a világtörténelem végre visszazökkenhet abba a kerékvágásba, ami a „hosszú 19. századot” jellemezte. Mások óvatosabbnak voltak, és arra 
hívták fel a figyelmet, hogy a hidegháború vége nem vezet feltétlenül a liberális demokráciák világméretű győzelméhez, hanem elképzelhető, hogy a 21. század a véres vallási és etnikai konfliktusok időszaka lesz. Akárhogyan fogjuk fel az elmúlt néhány évtized történéseit, az európai civilizáció kortárstörténeti értelmezését illetően fennmarad a kétértelmüség. Egyrészt kétségtelen, hogy Európa jelenleg a liberális demokráciák, a gazdasági és a politikai szabadság, az egyéni és az állampolgári jogok kialakulásának és megőrzésének a színtere, másrészt az 1973-as olajválság óta a nyugat-európai országok modellválsággal küszködnek, amit a civilizációs értékekbe vetett hit elbizonytalanodása jellemez.

A két világháború között a polgári és keresztény humanista gondolkodók egyszerre törekedtek Európa keresztény és liberális értékeinek megmentésére. A keresztény hagyományt éppúgy az európai örökség fontos részének tartották, mint az egyéni és az állampolgári szabadságot. Az irracionális gondolatformákkal szemben a racionalizmus hagyományát az európai kultúra fundamentumává avatták. A bal- és jobboldali szélsőségek a modern tömegtársadalom „barbarizálódásának” tünetei voltak számukra, amelyek a „régi” Európa végét jelentették. A nacionalizmusok szélsőséges formáival és a totalitárius ideológiákkal szemben úgy tekintettek Európára, mint a nemzetállami kizárólagosságot meghaladó - individuális és univerzális - értékek foglalatára. Erre támaszkodva a második világháború után a nyugat-európai polgári demokráciákat kimunkáló politikai elitek a keresztény és liberális értékeket akarták összhangba hozni az ipari társadalom és a piaci hatékonyság követelményeivel. Felfogásuk szerint a „kereszténység”, a „szabadság” és a „modernség” nem ambivalens fogalmak, hanem összekapcsolhatók egymással. Az 1945 utáni években a kereszténydemokrata politikusok ebből kiindulva törekedtek az európai integráció létrehozására, és arra, hogy a nyugat-európai demokráciákat az atlanti érték- és érdekközösségbe illesszék a kommunista fenyegetéssel szemben.

A második világháború utáni évtizedekben a nyugat-európai társadalmak sikeres modellnek bizonyultak, ami jelentős vonzerővel bírt a kelet-európai szocialista országok számára is. A kivételes gazdasági növekedés látványos szociális emancipációt tett lehetővé, ami hitelesítette a gazdasági eredményeket, és legitimálta a „szabályozott kapitalizmus” gazdasági és társadalmi modelljét. A polgári demokráciák sikere az egyéni szabadság és a társadalmi szolidaritás egyensúlyán nyugodott, ami akár az európai civilizációs értékek megvalósulásaként is felfogható a keresztény társadalmi tanítás szellemében.

A sikerek ellenére sem szabad megfeledkezni arról, hogy az 1945 és 1973 közötti időszak eredményeit kizárólag a gazdasági növekedés tette lehetővé, ami az amerikai üzemszervezési módszerek és a fogyasztói modell átvétele révén valósult meg. Ehhez járult az amerikai biztonsági védőernyő, a tőkeimport, valamint az USA gazdasági ereje által garantált nemzetközi pénzügyi rendszer. 
A két világháború közötti européer értelmiség még kritikusan viszonyult az Egyesült Államokhoz, mert az ipari tömegtársadalom negatív példáját látta benne. A második világháború után a nyugat-európai politikusok és értelmiségiek többsége már tisztelettel szemlélte az amerikai társadalom szilárd liberális politikai kultúráját. Ebben a fordulatban az is közrejátszott, hogy a második világháború alatt az Egyesült Államok beavatkozása döntőnek bizonyult a náci Németországgal szemben, valamint az, hogy a nyugat-európai polgári demokráciák a hidegháború idején biztos támaszra leltek az USA-ban. 1945 után az amerikai pénzügyi támogatás nélkülözhetetlennek látszott a gazdasági növekedés megindításához, ami az egyetlen hatékony eszköznek tünt a jólét növeléséhez, a középosztályok megerősödéséhez és a politikai szélsőségek visszaszorításához.

A második világháború után a nyugat-európai gazdaságpolitikák előmozdították a GDP növekedését és a társadalmi jólétet, de mindez egyre erőteljesebb „amerikanizálódással” kapcsolódott össze. Az életszínvonal emelkedett és a fogyasztói társadalom kiteljesedett, de Európa egyre inkább elvesztette kulturális identitását. Amíg a gazdasági növekedés töretlennek bizonyult, a politikusok és az értelmiségiek elfogadták a konjunktúra előnyeit. De az 1973-as olajválság után felerösödtek azok a kritikák, amelyek a nyugateurópai társadalom teljesítőképességével kapcsolatos kételyeket juttatták kifejezésre. Ettől fogva a társadalomtudományok joggal hangoztatják az európai gazdasági és társadalmi modell válságát.

Nyugat-Európa költséges szociálisellátórendszerekethozottlétre a második világháború utáni évtizedekben, amelyek a recesszió óta tehertétellé váltak, hiszen akadályozzák a gazdasági fejlődést. Leépítésük hatalmas ellenállásba ütközne, hiszen az általuk garantált jólét a társadalmi értékrend szerves részévé vált. A jóléti rendszerek fenntartása megnehezíti, hogy Európa megállja helyét a globális világgazdaságban, akár az amerikai laissez faire kapitalizmussal, akár a távol-keleti „fejlesztő állammal” szemben. A közelmúltban Nyugat-Európa alapvető dilemmájává vált, hogy adaptálja-e az 1980-as évektől felívelő északamerikai neoliberalizmus receptjeit, amivel kiteljesedne identitásvesztése. Avagy megőrizze jóléti vívmányait, amivel életben tart egy elkényelmesedő európai „reálszocializmust”? Az elmúlt évtizedekben az európai országok nehezen találtak sikeres válaszokat a globális újkapitalizmus kihívásaival szemben. Ehhez a modellválsághoz képest másodlagosnak tünnek az európai integráció intézményes továbbfejlődésével kapcsolatos aktuálpolitikai viták.

Ebben a perspektívában kell említést tennünk az európai egységfolyamatról. Európa egysége lényegében a felvilágosodás filozófiai örökségéből táplálkozó gondolat. A modernitás olyan „projektjéről” van szó, ami akár kozmopolita világállam létrehozásában is megtestesülhet. Az európai egység egy „nagy elbeszélés” végpontjaként fogható fel, ami azt feltételezi, 
hogy az „emberiség"/"Európa” története egy föderatív állam megteremtésével ideális nyugvópontra ér. Az ,alapító atyák” felfogásához képest az európai egység eszméje technokrata projektté nőtte ki magát a közelmúltban, ami alig talál kapcsolatot a közvéleménnyel. Azt sugallja, hogy az egységfolyamat beteljesülése Európa valamennyi gyengeségére választ adhat, holott éppen ez árulja el, hogy értelmiségi utópiáról van szó. Kérdéses, hogy az európai föderáció megvalósulása megoldhatja-e a gazdasági és a társadalmi modell dilemmáit. E problémák ellenére ahhoz sem fér kétség, hogy az integrációs folyamat az elmúlt hetven évben hasznos politikai megoldásokkal szolgált Európa népei számára.

Végül hadd térjünk ki a „civilizációs/kulturális válság” problémájára. Ez nem azonos a gazdasági-társadalmi modell válságával, noha a két problémakör között nyilván vannak átfedések. A „kultúrpesszimizmus” az első világháború vége óta foglalkoztatja az európai értelmiséget. Oswald Spengler A Nyugat alkonya (1918-1922) címü könyvének megjelenése óta hatalmas irodalmi termés született e tárgykörben. A modern társadalmak kialakulása a tradicionális értékek válságáhozvezetettazegésznyugati világban, aminekértelmezésérőlmegoszlanak a vélemények. Azt is vitatják, hogy egyáltalán beszélhetünk-e igazi krízisről. Amennyiben igen, milyen a természete, és melyek jellegzetes karaktervonásai? A válság a nyugat-európai keresztény civilizáció végleges letünéséhez vezet vagy megújulását segíti elő? Ebben a távlatban szokás említeni a társadalmi értékek növekvő hiányát, amelyek ellehetetlenítik a kollektív erőfeszítéseket, valamint a közösségek felbomlását, az atomizálódást és az anómiát. A család letủnése és a csökkenő gyerekszám az ,élettel" kapcsolatos alapvetó állásfoglalást illetően utal mély elbizonytalanodásra. Sokat vitatott kérdés az európai „nagy tradíciók” - kereszténység, antikvitás - elhalványulásának következménye.

Ebben az összefüggésben kell utalni arra, hogy az európai kontinens elvallástalanodásának tendenciája az egyik legnagyobb horderejü (vallás) szociológiai jelenségnek tủnik az elmúlt fél évszázadban. Míg az Egyesült Államokban a neoprotestáns egyházak keretében beszélhetünk „vallási reneszánszról" (religious revival), az európai kontinensen a történelmi egyházak nem értek el áttörést az evangelizáció terén. Az elmúlt évtizedekben a vallásgyakorlók számának további csökkenését tapasztaljuk. II. János Pál pápa (1978-2005) megfogalmazta Európa „újraevangelizálásának” programját, de a sikerek még váratnak magukra. Hasonló helyzet figyelhető meg a klasszikus örökséget illetően, hiszen az elmúlt fél évszázadban a latin nyelv és irodalom háttérbe szorulásának vagyunk szemtanúi. Felmerül a kérdés, hogy az „egyetemes” keresztény és klasszikus tartalmak nélkül a nemzeti kultúrák képesek-e ellenállni a bezárkózó nacionalizmusok kísértésének.

Manapság az európai civilizációt egyrészt a globális kapitalizmus versenye és a fogyasztói társadalom hatásai, másrészt a vallási, etnikai fundamentalizmusok és a „nemzeti bezárkózás” veszélye fenyegeti. A 
problémák megoldásához Európának választ kell adnia arra, hogyan újíthatja meg „nagy hagyományait” a plurális társadalom keretei között, és kettős harcot kell folytatnia a „fundamentalizmussal” és a „relativizmussal”. A vázolt dilemmák hordereje alapján nem meglepő, hogy a „kultúrpesszimisták” az európai értékek elvesztésétől tartanak és az európai civilizáció végét jósolják, ellenben a „modernisták” arra helyezik a hangsúlyt, hogy a Nyugat egyetemes modelljének - piacgazdaság, liberalizmus, demokrácia - megvalósulása révén az európai civilizáció fejlődése a legjobb értelemben beteljesedett. Bár véleményünk leginkább attól függ, milyen filozófiai előfeltételek mentén közelítünk a „civilizációs krízis” kérdéshez, világnézeti felfogásunk nem menthet fel a problémával való szembesüléstől.

\subsubsection{Időrendi tábla}

\begin{tabular}{c|l} 
dátum & \multicolumn{1}{c}{ esemény } \\
\hline i. e. 8. század & Homérosz eposzai \\
\hline $\begin{array}{c}\text { i. e. 5-4. század } \\
\text { i. sele } \\
\text { fázad első }\end{array}$ & Az ógörög civilizáció ,klasszikus” kora \\
\hline i. e. 5-1. század & A római köztársaság \\
\hline i. e. 3-1. század & A hellenisztikus kor \\
\hline i. e. 58-49 & Julius Caesar elfoglalja Galliát \\
\hline i .e. 27-i. sz. 14 & Augustus uralkodása. A Római Császárság kezdete \\
\hline 3-6. század & A nagy népvándorlás \\
\hline 4-6. század & A kései antikvitás \\
\hline 313 & A milánói ediktum a vallásszabadságról \\
\hline 354-430 & Szent Ágoston \\
\hline 395 & A Nyugat- és Keletrómai Birodalom kettéválása \\
\hline 451 & A khalkédóni zsinat \\
\hline 476 & A Nyugatrómai Birodalom bukása \\
\hline 590-604 & Nagy Szent Gergely pápa \\
\hline 7-11. század & A kora középkor \\
\hline 7-8. század & Az angolszász királyságok és Germánia evangelizációja \\
\hline 8-9. század & A képromboló vita Bizáncban \\
\hline 732 & A poitiers-i csata \\
\hline 1000 körül & Nagy Károly frank császárrá koronázása \\
\hline A lengyel és a magyar államalapítás. Velence és Pisa sikerei a \\
\hline Földközi-tengeren \\
\hline
\end{tabular}




\begin{tabular}{|c|c|}
\hline dátum & esemény \\
\hline 1054 & A nagy egyházszakadás \\
\hline 11-13. század & A román mủvészet kora \\
\hline 1075 & VII. Gergely: Dictatus Papae \\
\hline 1096 & A keresztes háborúk kezdete \\
\hline 12-15. század & Az érett középkor \\
\hline 12-13. század & Az invesztitúraharcok \\
\hline 12-15. század & A gótika kora \\
\hline $1225-1274$ & Aquinói Szent Tamás \\
\hline 14-16. század & A reneszánsz \\
\hline 1348 & A nagy pestis \\
\hline 1453 & Az oszmán-törökök elfoglalják Bizáncot \\
\hline 1492 & Amerika felfedezése \\
\hline $1500-1800$ & A kora újkor \\
\hline $\begin{array}{l}\text { 15-16. század } \\
\text { fordulója }\end{array}$ & Leonardo, Michelangelo, Raffaello müvészete \\
\hline 1517 & A reformáció kezdete \\
\hline 1637 & Descartes: Discours de la méthode \\
\hline 1687 & $\begin{array}{l}\text { Newton: Principia (= Philosophiae Naturalis Principia } \\
\text { Mathematica) }\end{array}$ \\
\hline $1760-1780$ & Az első ipari forradalom kezdetei \\
\hline 1789 & A francia forradalom \\
\hline 1789-1914 & A „hosszú 19. század” \\
\hline 1804 & Napóleon császárrá koronázása \\
\hline 1806 & A Német-római Császárság megszűnése \\
\hline 1815 & A bécsi kongresszus \\
\hline $\begin{array}{l}\text { 19. század utolsó } \\
\text { harmada }\end{array}$ & A második ipari forradalom \\
\hline 1914-1918 & Az első világháború \\
\hline $1914-1990$ & A „rövid 20. század” \\
\hline $1918-1922$ & Oswald Spengler: A Nyugat alkonya megjelenése \\
\hline 1939-1945 & A második világháború \\
\hline 1949 & A NATO létrejötte \\
\hline 1957 & A római szerződések. Az EGK létrejötte \\
\hline 1962-1965 & A II. Vatikáni zsinat \\
\hline 1973 & Az olajválság A gazdasági növekedés vége a fejlett ipari világban \\
\hline 1978-2005 & II. János Pál pápa \\
\hline 1989-1990 & $\begin{array}{l}\text { Annus mirabilis: A kelet-közép-európai kommunista diktatúrák } \\
\text { összeomlása }\end{array}$ \\
\hline
\end{tabular}




\subsubsection{Irodalomjegyzék}

Ajánlott irodalom

BRAGUe, RÉMI 1994: Európa, a római modell, Elsajátított önazonosság.

Piliscsaba: Pázmány Péter Katolikus Egyetem

Brown, Peter 1999: Az európai kereszténység kialakulása 200-1000. Budapest:

Atlantisz

Chaunu, Pierre 1971: A klasszikus Európa. Budapest: Gondolat

Chaunu, Pierre 1998: Felvilágosodás. Budapest: Osiris

Davies, Norman 2002: Európa története. Budapest: Osiris

DAwson, Christopher 1939: Európa születése. Budapest: Athenaeum

Duby, Georges 1984: A katedrálisok kora. Budapest: Gondolat

Garin, Eugenio 1988: Reneszánsz és müveltség. Budapest: Helikon

HALECKI, OsCar 1993: Európa millenniuma. Budapest: Századvég Kiadó, 2000

HoBSBAWM, ERIC 1988: A forradalmak kora (1789-1848). Budapest: Kossuth

HobSBAwM, ERIC 1998: A szélsőségek kora. Budapest: Pannonica

Lafont, Ghislain 1998: A katolikus egyház teológiatörténete. Budapest: Atlantisz

LE GoFF, JACQUES 2008: Európa születése a középkorban. Budapest: Atlantisz

SPENGler, Oswald 1994: A Nyugat alkonya I-II. A világtörténelem morfológiájának körvonalai. Budapest: Európa

SzŰCS JENŐ 1983: Vázlat Európa három történeti régiójáról. Budapest: Magvetö

További irodalom

Arendt, Hannah 1992: A totalitarizmus gyökerei. Budapest: Európa

Benda, Julien 1997: Az írástudók árulása. Budapest: Fekete Sas Kiadó

BleI, Karel 2002: Freedom of Religion and Belief: Europe's Story. Assen: Van Gorcum

Bloch, Marc 1970: La société féodale. Párizs: Michel

Braudel, Fernand 1985: Anyagi kultúra, gazdaság és kapitalizmus. 15-

18. század. A mindennapi élet struktúrái: a lehetséges és a lehetetlen.

Budapest: Gondolat

Cipolla, Carlo, M. 1989: Before the Industrial Revolution. London: Routledge Constant, Benjamin 1997: A régiek és a modernek szabadsága. Budapest: Atlantisz

Dawson, Christopher 1932: The Making of Europe: An Introduction to the History of European Unity. London: Sheed and Ward

Duby, Georges 1973: Guerriers et paysans. VIIe-XIIe siècles. Premier essor de 
l'économie européenne. Párizs: Gallimard

Duroselle, Jean-Baptiste 1965: L'idée d'Europe dans 1'histoire. Párizs: Denoël

Duroselle, Jean-Baptiste é. n.: Európa népeinek története. Budapest: Officina Nova

Eisenstadt, Shmuel 1969: The Political Systems of Empires. New York: Free Press

HaLECKI, OsCar 1950: The Limits and Divisions of European History. New York: Sheed and Ward

Hay, Denys 1957: Europe. The Emergence of an Idea. Edinburgh: Edinburgh University Press

Heater, Derek B. 1992: The Idea of European Unity. Leicester-London: Leicester University Press

Milward, Alan 1984: The Reconstruction of Western Europe. 1945-51. London: Methuen

Ortega y Gasset, José 1995: A tömegek lázadása. Budapest: Pont Könyvkereskedés

Pagden, Anthony (szerk.) 2002: The Idea of Europe. Cambridge University Press

Reynold, GonZague de 1941: Qu'est-ce que l'Europe? Fribourg: Éditions de la Librairie de l'Université

Reynold, Gonzague de 1944-1957: La Formation de l'Europe. I-VII. Fribourg-Párizs LUF-Plon

Rosenstock-Huessy, Eugen 1949: The Driving Power of Western Civilization: the Christian Revolution of the Middle Ages. Boston: Beacon Press

Rostow, Walt, W. 1960: The Stages of Economic Growth: A Non-Communist Manifesto. Cambridge: Cambridge University Press

Rüssel, Herbert W. 1997: Keresztény humanizmus. Budapest: EcclesiaKairosz

SAID, Edward 1978: Orientalism. London: Routledge and Kegan Paul

Schuman, Robert 1991: Európáért. Pécs: Pannónia Könyvek

Shestov, Lev 1967: Athènes et Jérusalem. Párizs: Flammarion

ToYnBeE, ARnOLD 1951-1955: A Study of History. London: Oxford University Press

Weber, Max 1982: A protestáns etika és a kapitalizmus szelleme. Budapest: Gondolat 
7. Amerika 



\subsection{Az észak-amerikai civilizáció}

\section{ZSINKA LÁSZLÓ}

Az észak-amerikai civilizáció fogalma föleg az Amerikai Egyesült Államokat jelenti - noha az angolszász telepes társadalmak, mint Kanada, Ausztrália, Új-Zéland felmutatnak hasonló vonásokat -, amely a második ipari forradalom óta a nyugati civilizáció meghatározó pólusává nőtte ki magát. Ebben a keretben nem foglalkozunk az európai emberek érkezése elötti indián társadalmakkal, amelyeket prekolumbiánus kultúráknak is szokás nevezni. A nyugati keresztény Európával foglakozó tanulmányunkban már utaltunk arra, hogy az európai civilizáció legalább kétezer éves történetéhez képest az északamerikai telepes társadalom 200-300 éves múltja legfeljebb egy, a Nyugat történetét tárgyaló könyv utolsó rövid fejezetének tünik. Kitértünk arra is, hogy az észak-amerikai civilizáció magáévá tette a keresztény alapokat, az egyéni szabadság és a piac eszméit. Az európai katolikus hagyományokkal szemben Észak-Amerikában nagyobb szerephez jutott a protestáns örökség, illetve a szabadság és a szolidaritás egyensúlyán nyugvó kontinentális politikai eszmékhez képest az angolszász tradíció keretében az individualizmusra és az egyéni kezdeményezőképességre került a hangsúly, valamint az etatizmus és a korporatív társadalomszervezés helyett nagyobb jelentőséget nyert a minimal state gondolata. Említhetjük még az amerikaiak optimizmusát, progresszivizmusát és pragmatizmusát, valamint számos egyéb „amerikai civilizációs értéket". Ebből kiindulva a jelen fejezet keretében a Nyugat / az euroamerikai világ másik ,alrendszerét”, az észak-amerikai civilizációt jellemezzük. Mivel ennek története lényegében az Egyesült Államok civilizációtörténetével azonos, az USA rövid kétszáz éves múltjából kiemeljük azokat az aspektusokat, amelyek napjainkban is ható civilizációs értékké és attitüddé váltak, valamint megvilágítjuk azt a történelmi környezetet, amelyben mindezek létrejöttek.

\subsubsection{Alapvető jellegzetességek}

Az első észak-amerikai gyarmatokat nagyobbrészt angliai puritánok alapították a 17. században, akik az anglikán államegyház és a királyi abszolutizmus zaklatásai miatt távoztak a szigetországból. A szorgalmas puritán közösségek gyorsan gyarapodtak az új hazában, és az angol gyarmati hatóságokkal való vitáik ellenére szabadságban éltek. A protestáns munkaetikának az amerikai kapitalizmus fejlödésére gyakorolt hatásáról könyvtárnyi szakirodalom született, akár a korai idöszakot illetően is. Ezek között szerepelt a puritán közösségek életmódjával kapcsolatos - a 19. századi 
történetírásban meghonosodott - elöítélek árnyalása, amely szerint az északamerikai protestánsokat ugyan jellemezte az önmegtagadás és az aszkézis bizonyos mértéke, de az evilági kultúrával szembeni fenntartásaik korántsem bizonyultak olyan erőteljesnek. A puritánok valóban elutasítottak egyes „világi hívságokat", de mindezt a józan és szorgos családi élet keretein belül tették, ami - egyéb körülményekkel társulva - lehetővé tette a tőkefelhalmozást. Ez utóbbi jelenségre utalt Max Weber nevezetes tanulmánya, A protestáns etika és a kapitalizmus szelleme (1905), amely eredetileg a nyugat-európai kapitalizmus sikere és a protestáns etika közötti összefüggést vizsgálta. A Weber-tézis európai gazdaságtörténetre kiható megállapításai mellett fel kell hívni a figyelmet az amerikai önértelmezés 18. század végén már kibontakozó alaprétegére, amelyet WASP-nak (White Anglo-Saxon Protestant) nevez a társadalomtudomány. Eszerint az Egyesült Államok protestáns kultúrájú országként született, amit sokáig az angolszász középosztály szokásai határoztak meg.

Mindez még ma is számos szokásban megtestesül, mint például a Hálaadás (Thanksgiving) ünnepében. A Mayflower fedélzetén 1620-ban Plymouth körül partra szálló, az Újvilágba érkező telepesek egy része az éhezés és a zord természeti körülmények áldozata lett. A telepeseket állítólag a wampanoag indián törzs segítette, hogy túljussanak a kezdeti nehézségeken, megtanítva nekik a kukoricatermesztést és a juharszirup előállítását. A bőséges őszi aratás után az életben maradottak ünnepséget rendeztek, megosztva a termést az indiánokkal.

Az egész országra kiterjedő módon először George Washington elnök (1789-1797) hívott fel a Hálaadás megünneplésére. Maga a hálaadás protestáns szokás volt, ami a zsoltárok szellemében többféle okból is kinyilvánítható Isten felé. Az Egyesült Államok létrejöttével a tagállamok feladata lett, hogy a Hálaadás napja(i)t meghatározzák. Abraham Lincoln elnök (1861-1865) 1863 októberében nyilvánította ki az egész nemzet számára a Hálaadás megünneplésének szükségességét. Eleinte november utolsó csütörtökjén, később november negyedik csütörtökjén ünnepelték. A Hálaadás ünnepének elterjedése összefügg a modern amerikai identitás megformálódásával. Szokásai a 19. század végén alakultak ki, amikor a polgárháború utáni megosztottság következményei és a bevándorlók nagy száma miatt növekvő igény mutatkozott az amerikai nemzeti azonosságtudatot kifejező ünnep iránt. A Hálaadás jól példázza az amerikai nemzeti identitás és a protestáns hagyományok közötti szoros kapcsolatot, amelynek élő hatása napjainkig tetten érhető.

Az angolszász protestáns örökség annak ellenére kivételes jelentőségü maradt, hogy a 19. század második felétől egyre nőtt a katolikus ír, olasz, latin-amerikai bevándorlók szerepe, és napjainkra az USA multikulturális társadalommá vált. A WASP-örökség szerepét jól érzékeltetik az amerikai politikai és kulturális elit sorait az elmúlt évtizedekben megosztó viták, 
amelyek általában az angolszász hagyományok és a multikulturalizmus hívei között zajlanak. A vita erejét az adja, hogy az amerikaiak a WASP-hagyomány történelmi szerepét manapság éppúgy nagyra értékelik, mint a nagymértékü bevándorláshoz kötődő olvasztótégely-kultúrát (melting pot). Manapság a konzervatívok (conservatives) éppúgy hivatkoznak a WASP fontosságára az „eredeti” amerikai értékek védelmében, ahogyan a liberálisok (liberals) az amerikai történelem alaprétegéhez tartozó jelenségként tartják számon a bevándorlásból eredő kulturális sokszínűséget.

Az Egyesült Államok magvát alkotó tizenhárom gyarmat területén a letelepedők száma gyorsan növekedett a szerény 17 . századi kezdetekhez képest. 1630 körül még csak néhány ezer telepes érkezett, de a 18. század elején a lakosság elérte a negyedmillió föt. Hetven évvel később a függetlenségi háború kirobbanásakor legalább kétmillió ember lakott az észak-amerikai angol gyarmatokon. Az 1790-es cenzus alapján az új köztársaság területén 3,9 millió volt a népesség. A tíz évvel később megtartott 1800 -as népszámlálás szerint az Egyesült Államoknak mintegy 5,3 millió lakosa volt, amikor a Brit-szigetek 15 millió, Franciaország 27 millió lakossal rendelkezett. A 18. század során Európa népessége a gazdasági konjunktúra és a kedvezőbbé vált éghajlati körülmények révén a becslések szerint másfél-kétszeresére, míg a jövendő USA lakossága hússzorosára emelkedett. Az európai és az észak-amerikai adatokat összevetve kivételes mértékủ gyarapodásnak vagyunk tanúi a születő Egyesült Államok területén, amely a világ népesedéstörténetében később is különlegesnek bizonyult. A jelentős növekedési ütem a 19. század során is mindvégig fennmaradt.

A gyors gyarapodás nemcsak az újabb bevándorlóknak volt köszönhető, hanem a gyermekek nagy számának is. A magas természetes szaporulat tényében kezdettől fogva szerepet játszott a protestáns családok Isten előtti elkötelezettsége, hogy „sokasodjanak” és „szaporodjanak”, valamint a földbőség, amely lehetővé tette, hogy a növekvő népesség újabb megmủvelhető területekhez jusson. A rendelkezésre álló föld, az új területek benépesítése, a nagyarányú bevándorlás és a magas természetes szaporulat később is az amerikai kultúra fontos összetevőit alkották.

Az amerikai telepesek nyugat felé hatolva mindig új földeket szerezhettek, ezért nem alakultak ki jelentékeny társadalmi különbségek. Az angol hatóságok kezdetben a középkori európai agrárgazdaságban megszokott személyes függőségen alapuló megoldások átültetésére törekedtek, ami a nagyobb földbirtokosok számára lehetővé tette volna az ingyen munkaerő biztosítását. A történetírás régebben a „feudalizmus” átültetésének kísérletéről beszélt, de manapság két okból sem szerencsés ezt a fogalmat használnunk. Egyrészt a nyugat-európai jelenséget illetően a történettudomány ma inkább a „hübéri társadalom" terminust használja, másrészt Alan Macfarlane nagy vitát kiváltó 
tanulmánya óta $-A z$ angol individualizmus eredete (1978) - az is kérdéses, hogy az amerikai telepesek számára mintaként szolgáló Angliában egyáltalán beszélhetünk-e „feudalizmusról”, illetve hagyományos értelemben vett „paraszti társadalomról”. Ehelyett inkább arra kell felhívni a figyelmet, hogy a történeti források kezdetben még utalnak olyan földmüvesekre, akik nem távozhatnak külön engedély nélkül uruk földjéröl, ráadásul a kötöttség néha örökletesnek tünik, mert ugyanez vonatkozik gyermekeikre is. Különösen azok kerültek nehezebb helyzetbe, akik eleve eladósodva érkeztek az anyaországból. $\mathrm{Az}$ is megfigyelhetö, hogy egyes esetekben kísérletek történtek valamiféle „feudális úriszék” müködtetésére, mert a bérlők ügyeiben a földbirtokos ítélkezett. Érzékelhető, hogy bizonyos területeken az angol korona egyfajta földbirtokos arisztokrácia megteremtésére tett kísérletet. Ezek a kezdemények azonban hamarosan háttérbe szorultak. A 18. században a legtöbb birtokos már szabad tulajdonos vagy szabad bérlő. Bár nem mindenki jutott saját földhöz, a letelepedők számára az egyre kommerciálisabb viszonyok között fejlődő 17. századi angliai agrárgazdaság jelentett viszonyítási alapot, ahol a földművelők többsége tulajdonos vagy bérlő volt. Végső soron a földbőség ellehetetlenítette a korona törekvéseit földbirtokos arisztokrácia vagy személyi függőségen alapuló rendszer megteremtésére.

Az európai agrárrendszer számos sajátossága a 12-13. századi agrárkonjunktúra és népességnövekedés kibontakozása óta szűkösen rendelkezésre álló föld tényéből fakadt. A földbirtokos elit és a földmüvelő közösségek a szükösség tényéből kiindulva szervezték meg vagy privilegizálták a földhasználatot. Európában a 12. századi agrárexpanzió kezdetén még bőségesen rendelkezésre álltak megmüvelésre váró földterületek - Fernand Braudel francia történész ezeket a földeket a „belső Amerikák” kifejezéssel illette -, amelyek az egyéni müvelés lehetőségeit erősítették (hospesek), de a népességnövekedés következtében a 13. századtól ezek a megoldások háttérbe szorultak, és általában a közösségi szabályozáson nyugvó művelésformák terjedtek el (open field). Az észak-amerikai gyarmatokon a földbőség végtelennek tünő távlatai miatt ez nem következett be, hanem az egyéni mủvelésformák szilárdultak meg. Az angol hatóságok ugyan kísérletet tettek arra, hogy az indián törzsek - a gyarmati háborúkban katonai szövetségeseik - területeit biztosítva elzárják az utat a telepesek nyugati irányú terjeszkedése elől a 18. században, ami véget vetett volna a földbőségnek, de törekvéseiket nem koronázta siker. Sőt ezekkel a tervekkel szembeni határozott ellenérzések - a gazdagabb és terjeszkedni akaró földbirtokosok és telepesek soraiban hozzájárultak a függetlenségi háború kirobbanásához, aminek győzelme végleg biztosította a nyugati irányú terjeszkedést. Az európai függőségi viszonyok arisztokrácia, hübériség, feudalizmus - hiánya az agrárgazdaságban kezdettől fogva elömozdította a kapitalista felhalmozást. Az amerikai társadalmat a 
függetlenségi harc előestéjén a szabad tulajdonosok széles rétege jellemezte, aminek később is nagy jelentősége volt a társadalmi és politikai jellegzetességek alakulásában.

$\mathrm{Az}$ „amerikai értékek” létrejöttében nemcsak a társadalmi struktúra sajátosságai, hanem a letelepedettek képviseleti jogai is nagy szerepet játszottak. A puritánok magukkal hozták az Óvilágból a kálvinizmus alulról építkező „,demokratikus” egyházszervezetét, másrészt az angol politikai életből a királyi hatalom és a parlament közötti viták alapján leszürhető tapasztalatokat. Ezek az angol polgári forradalom küzdelmeiben - részben a puritán hadsereg vitáiban - nyerték el formájukat. Az úgynevezett levellerek megfogalmazták a képviselettel egybekötött adózás elvét. Az 1688-as „dicsőséges forradalom” az alkotmányos királyság elveit illetően szolgált értékes tapasztalatokkal. Amikor a 18. századi telepesek Anglia felé tekintettek, a parlamentáris monarchia gyakorlatával találkoztak, ami tájékozódási pontként szolgált számukra.

Már az első telepes közösségek is megfogalmazták az igényüket arra vonatkozóan a 17. század során, hogy képviselettel rendelkezzenek. A király és kormányzói kezdetben ingadozó magatartást tanúsítottak, de végül elfogadták a gyarmatok igényét, hogy képviseleti testületeket hozzanak létre. Az egyes gyarmatokon eltérő megoldásokat alkalmaztak, de a képviselet intézménye fokozatosan megszilárdult. Volt, hogy a képviselők megválasztására a puritán egyházközségek tagjait hatalmazták fel, más esetben egyszerüen csak „szabad embereket”. A képviselő testületek kezdettől fogva fontosnak tartották, hogy az adók kérdésében is véleményt nyilváníthassanak. Bizonyos szempontból a függetlenségi harc közvetlen kiváltó oka felfogható úgy, mint a telepesek képviseleti és adózással kapcsolatos jogainak szúkítése elleni reakció. A 18. században a városok és a kisebb települések is kialakították helyi önkormányzataikat. Az amerikai társadalom „önkormányzati szelleme” - ahogyan Alexis de Tocqueville (1805-1859) is megfigyelte -, azaz a hivatali bürokrácia helyett létrejövő önigazgatás hagyományai legalább annyira a függetlenség előtti időszakra tehetők, mint a szabadság elnyerése utáni évtizedekre, amikor az önkormányzatok létrehozását az alkotmány is biztosította. A keleti partvidék formálódó elitje számára a 18. század során lehetőség nyílt az európai kultúrával és a felvilágosodás eszméivel való megismerkedésre. Amikor a hétéves háborúban (1756-1763) Franciaország elvesztette Kanadát, az utolsó kötelék - a francia királyi hadseregtől való félelem - veszett el, ami az amerikaiakat Angliához láncolta. A puritánok örökösei nem tartottak többé a katolikus franciáktól, és a koronával szemben felújították az angol polgári forradalom régi parlamenti - leveller - jelszavát, miszerint „képviselet nélkül nincs adózás". A kibontakozó függetlenségi háborúban (1775-1783) az amerikai telepesek nemcsak a küzdelmet nyerték meg, hanem közben az alkotmányos berendezkedést illetően is élénk vitákat folytattak. 
Az Egyesült Államok létrejötte és alkotmánya olyan tény, amely napjainkig hatóan rányomja bélyegét az angolszász politikai gondolkodásra és az amerikai önértelmezésre egyaránt. Az amerikai alkotmánnyal nemcsak egy jogi dokumentum született, hanem az európai felvilágosodás gondolkodása összegződött benne, és a szövegezés körüli elvi viták is tanulságosak voltak. Azon túl, hogy összefoglalták a kora újkori politikai filozófia mértékadó irányzatait - Montesquieu, Locke -, messze ható újításokat is alkalmaztak, amelyek az angolszász politikai eszmefejlődés fontos állomásává váltak. Az alkotmány és az amerikai patriotizmus közötti szoros kölcsönhatás éppúgy kivételessé teszi az Egyesült Államok történetét, ahogyan az is ritka, hogy egy politikai közösség alapító eszméi ilyen mértékben rányomják bélyegüket annak későbbi természetére, és a civilizációs fejlődést formáló tényezővé váljanak.

\subsubsection{A szabadság „megalapítása” az Egyesült Államokban}

1776. július 4-én Philadelphiában a II. Kontinentális Kongresszuson a tizenhárom gyarmat képviselői elfogadták a Függetlenségi Nyilatkozatot. A függetlenség deklarálása következtében meg kellett alkotni az egykori gyarmatok alkotmányos rendjét. Ehhez egy bizottságot hívtak életre, amely azt a feladatot kapta, hogy készítse elő a konföderáció tervezetét. Az elhúzódó viták következtében csak 1777 novemberében fogadták ela Konföderációs Cikkelyeket. Megalkotóit az szándék mozgatta, hogy a gyarmatokból lett államok minél nagyobb önállósággal rendelkezzenek a létrejövő konföderáció intézményeivel szemben. Az államok a konföderáció kezébe utalták a külpolitika és a hadsereg irányítását, a katonai vezetők kinevezését, az indiánokkal folytatott tárgyalásokat és a hitelfelvétel lehetöségét is. Valójában a konföderáció nem rendelkezett olyan erővel, hogy szükség esetén katonai vagy pénzügyi hozzájárulást kényszerítsen ki az államoktól. Ennek az alkotmányos szerkezetnek a gyengeségei már az 1780-as évek derekán megmutatkoztak, ami az állami és a szövetségi szint közötti hatáskörök újragondolásra késztette a függetlenségi háború vezetöit. Az új alkotmány tervezetét 1787-ben a pennsylvaniai Philadelphiában tartott konvenció vitatta meg, majd elfogadása után az államok is ratifikálták. Az újonnan létrejött föderáció jóval szélesebb hatásköröket biztosított a szövetségi törvényhozásnak és a végrehajtó hatalomnak, mint a Konföderációs Cikkelyek. Az alapítás körüli viták azt mutatják, hogy kezdetben nagyobb esélye volt egy konföderációnak, de az Egyesült Államok végül erős szövetségi központtal rendelkezö föderációvá vált.

$\mathrm{Az}$ amerikai alkotmány körüli jogi viták az egyes államoknak jelentékeny hatáskört biztosító konföderáció (államszövetség) és a szövetségi intézményeket széles jogosítványokkal felruházó föderáció (szövetségi állam) előnyeinek és hátrányainak mérlegelése során bontakoztak ki. A vitákban 
részvevő politikusok - Thomas Jefferson, James Madison, Alexander Hamilton - alkotmánnyal kapcsolatos álláspontjuk mellett általánosabb politikai filozófiai gondolatokat is kifejtettek. Leginkább a föderáció melletti érveket tárgyalta, de elvi dilemmáknak is teret adott a The Federalist Papers, amelynek szerzői között megtaláljuk Madisont és Hamiltont is. A föderáció és a konföderáció közötti választás több volt, mint egyszerü alkotmányos kérdés. Egyrészt hatalmi és államszervezési problémának tekinthető, mert egyedül az Egyesült Államok hatékony szövetségi szervei tehették lehetővé a gazdasági fejlődést és az ország védelmét. Másrészt a politikai közösség müködtetésének a kérdése volt, mert az állampolgárok részvételén nyugvó kormányzás első ízben jött létre egy nagy területü köztársaságban a történelem során.

Az alkotmányos vitákban Hamilton vált az erős szövetségi hatáskörök leghatározottabb képviselőjévé, amivel megelőzte korát, mert már az ipari forradalom hajnalán azt vallotta, hogy csakis az iparfejlesztés előmozdítása, a védővámok és egy központi bank létrehozása tehetik virágzó nemzetté országát. Úgy vélte, hogy az Egyesült Államok akkor lesz képes megvédeni érdekeit, ha erős szövetségi hatáskörök jönnek létre. Hamilton nem bízott a népben, ezért igyekezett minél inkább eltávolítani a kormányzást a demokrácia közvetlen formáitól. Képviseleti demokráciában gondolkodott, mert a személyes gazdasági érdekét előtérbe helyező amerikai átlagembert nem tartotta alkalmasnak arra, hogy állampolgári jogait közvetlen részvétel útján gyakorolja. Az emberek cselekedeteit szerinte az önszeretet mozgatja, ami a gazdasági haszon mellett a dicsőségvágyat is magába foglalja. Hamilton - a skót felvilágosodás képviselőitől eltérően - nem bízott abban, hogy a „kereskedő társadalmak” elterjedése hozzájárul a békés közállapotokhoz, mert a „becsület” és a „hatalom” helyett megjelenő újszerü „haszonelvüség” éppúgy teljes uralomra tör, ami az államközi kapcsolatokra is rányomja bélyegét. Ezért jutott arra a következtetésre, hogy az új köztársaságnak mihamarabb jelentős ipari termeléssel kell rendelkeznie. Hamilton gondolatai visszaköszönnek az amerikai polgárháború utáni republikánus szövetségi kormányok gyakorlatában, amelyek minden eszközzel az iparosodás elömozdítását tartották szem elött. Ennyiben nézetei megelőzték korukat, de hosszabb távon olyan politikai és gazdasági hagyomány kiindulópontjává váltak, amely a liberális szabadkereskedelmi gyakorlattal szemben a protekcionizmust, illetve a spontán iparfejlődéssel szemben a szövetségi kormány üzleti életet támogató tevékenységét előlegezte meg. Az elmúlt két évszázad története bőségesen szolgáltatott példákat erre a gyakorlatra.

Jefferson politikai világnézetét a Hamilton által kifejtett gondolatok ellentétének tarthatjuk. Jefferson hitt a közvetlen demokráciában, és minél szélesebb jogkörökkel akarta felruházni a helyi közösségeket. Úgy vélte, hogy az amerikai államokat - lakóhelye, Virginia esetében is ezt támogatta - az ókori 
görög városállamok méreteivel körülbelül azonos területekre kell felosztani, ahol a demokratikus részvétel a közösség kis létszáma miatt gyakorolható. Hamiltonnal ellentétben Jefferson optimista módon viszonyult az állampolgári erényekhez. Szerinte a „természetes demokrácia” keretei között kiválasztódnak a közélet iránt elkötelezett polgárok, akik alkalmasak társaik ügyeinek intézésére, és közülük kell megválasztani az ország vezetöit is. A szövetségi hatásköröknek Jefferson jóval szükebb hatáskört juttatott volna, mert a helyi közösségek önigazgató képességében bízva a lehető legtöbb jogkört helyi szintre kívánta delegálni. Hamilton szkeptikus utilitarizmusához képest Jefferson szemléletmódja Arisztotelész felfogását tükrözte, amely szerint az ember természeténél fogva társas lény (zoon politikón), ezért a politika és a közügyek alapvető hivatását jelentik. Hamilton ipart előtérbe helyező jövőképéhez képest a földbirtokos Jefferson olyan társadalomban gondolkodott, ahol az emberek többsége agrártevékenységet folytató farmer vagy városi kistulajdonos, boltos és kereskedő. A jeffersoni demokráciát a szabad tulajdonosok széles rétege alapozza meg. Ez egyfelöl összhangban állt a korabeli amerikai viszonyokkal, másrészt a hagyományos agrárvilág idillje az elkövetkező évtizedek iparosodása következtében egyre erőteljesebb nyomás alá került. Jefferson agrárius megfontolásai a későbbiekben az ipari kapitalizmussal, nagyszervezetekkel és a laissez faire gyakorlatával szemben gyanakvó vidéki kistulajdonosi csoportok populizmusát is az amerikai politikai tradíció részévé avatták. Az agrárius populisták a 19. század utolsó harmadában jelentős szerepre tettek szert az amerikai belpolitikában.

A jeffersoni demokratikus hagyomány tágabb értelemben is továbbélt az amerikai politikában. Maga Jefferson erőteljesen szimpatizált a francia forradalom plebejus eszméivel, míg föderalista vitapartnerei elitista módon gondolkodtak, és inkább a „dicsőséges forradalom” utáni Angliát tartották mintaképüknek. Távolságtartóan viszonyultak a népuralom eszméjéhez, és a függetlenségi háború lezárulása után külpolitikailag is Angliával szimpatizáltak. A jeffersoni hagyomány a mindenkori establishmenttel, a nagytőkés érdekcsoportokkal, avagy az állami szabályozással és korlátozásokkal szemben az egész nép minél teljesebb politikai és gazdasági részvételét, illetve annak igényét fejezte ki a közügyekben. A jeffersoni elvek akkor váltak hivatkozási alappá, amikor a szabad vállalkozást és a demokratikus részvételt szélesebb rétegek számára hozzáférhetővé kívánták tenni. Ennyiben a jacksoni liberalizmus éppúgy a jeffersoni hagyományra támaszkodott a 19. század első felében, mint a progresszivizmus a századfordulón vagy a roosevelti New Deal az 1930as években, bár ez utóbbi a régebbi amerikai ideálokhoz képest egyedülálló mértékben törekedett arra, hogy a szövetségi állami hatáskörök megnövelésével biztosítsa a minél teljesebb gazdasági-társadalmi emancipációt a nagy gazdasági válság után. 
Hamiltonhoz és Jeffersonhoz viszonyítva Madison politikai elképzelései összetettebbnek bizonyultak, és nehezebben helyezhetők el a helyi vagy szövetségi hatáskörök dichotómiájában, illetve egyfajta szintézis lehetőségét is hordozták. Elkötelezett republikánusként Madison behatóan tanulmányozta az ókori és a modern köztársaságokat. A legjobb kormányzat megvalósításával kapcsolatos általános természetű szkepszise nem tartotta vissza attól, hogy a The Federalist Papers egyik szerzőjeként kifejtse álláspontját. Madison teljes mértékben átérezte az Egyesült Államok létrejöttének kivételes újdonságát, amennyiben az ókori városállamokhoz képest nagy területü köztársaság született, amelynek kormányzása újszerủ feltételeket igényel. Számára az antik polisz a közvetlen népuralom olyan formáját jelentette, ahol vagy a többség ostobasága vagy zsarnoksága uralkodik. Madison szerint a nagyméretü köztársaság elkerülhetetlenné teszi a közvetlen részvételi demokráciától eltérő képviseleti rendszer alkalmazását. A nagy területü köztársaság esetében nagyobb esélye van annak, hogy arra hivatott képviselök kerülnek hivatalba, mert a nagyobb választási körzetekben több rátermett ember közül lehet választani. Másrészt a nagy köztársaságokban maguk az érdekek és érdekcsoportok is változatosabbak. Ez mérsékli annak lehetöségét, hogy egyetlen törekvés kerüljön hatalomra, ami megakadályozza a többség zsarnokságának uralomra jutását. Ezzel Madison gondolatmenete nemcsak az antik poliszokra emlékeztető közvetlen demokrácia rousseau-i és jeffersoni elvétől határolódott el, hanem a modern pluralizmuselméletek előfutárává is vált.

A képviseleti kormányzás és a szövetségi hatáskörök elönyeinek hangoztatása Madisont mégsem tette a központi hatalom olyan elkötelezett szószólójává, mint Hamiltont. Sőt kidolgozta a hatalom megosztásának elvét, amikor a három hatalmi ág (törvényhozás, végrehajtás, igazságszolgáltatás) szerepkörének, illetve a törvényhozás alsó és felső házának elkülönítésével, valamint az államok és a szövetségi jogkörök megkülönböztetésével az amerikai köztársaságot az egyén jogait védelmező alkotmányos berendezkedéssé akarta formálni. Madison a közvetett kormányzás érdekében lépett fel a helyi közösségeken alapuló közvetlen demokrácia modelljével szemben, másfelől attól is meg akarta óvni hazáját, hogy az állampolgároktól elidegenedő képviseleti kormányzás és a túlerejü végrehajtó hatalom a nép fölé kerekedhessen.

Az Egyesült Államok létrejöttét bemutató klasszikus tanulmányában Richard Hofstadter rávilágított az amerikai alkotmány keletkezésének körülményeire (HOFSTADTER, R. 1973). Szerinte az „alapító atyáktól” semmi nem állt távolabb, mint a forradalmi radikalizmus. Mindnyájan jómódú, művelt emberek és elkötelezett republikánusok voltak. A keleti partvidék tehetős földbirtokosaiként szoros kapcsolatban álltak az európai szellemi és intellektuális áramlatokkal. Az új alkotmány szövegezése során a nép hatalmát akarták garantálni, de korántsem úgy, hogy maga a nép vegye közvetlenül 
a kezébe a kormányzás felelősségét. Ezért valamennyien a képviseleti demokráciát tartották a legjobb megoldásnak. Még Jefferson is úgy tartotta helyesnek, ha a köztársaság képviselöinek és irányítóinak kiválasztása a helyi önigazgató közösségekben kibontakozó természetes szelekciós folyamat után, közvetett eljárással következik be. A képviseleti kormányzás biztosítja az irányíthatóságot, de a törvényhozó és a végrehajtó hatalom képviselöinek jogkörét a hatalommegosztás garanciái korlátozzák. Az Egyesült Államok ilyen kompromisszum jegyében született: a hatékony föderatív jogkörök érvényesítésével, de a hatalommegosztás ellensúlyával. Ezt a megoldást a vitatkozó felek végül valamennyien elfogadhatónak tartották. Bár eltérő hangsúlyokkal, mindnyájan föderációpártiak voltak, de tiszteletben tartották az egyén szabadságát és jogait. Ezért vállalhatta el Jefferson az első években nagyobb megalkuvás nélkül, hogy betöltse az új szövetségi köztársaság elnöki posztját, noha a föderatív hatásköröket illetően korábban minimalista felfogást képviselt.

Az alkotmányos tradíciónak ez a kettős öröksége napjainkig befolyásolja az amerikai állampolgári identitást, bár történelmi megvalósulási formái idővel módosultak. Az Egyesült Államok történetének első évtizedeiben a „föderációs” párt képviselte az erős szövetségi állam koncepcióját, és vele szemben szerveződtek meg Jefferson helyi autonómiához ragaszkodó „demokratái” (republikánus-demokraták). Később mindez megváltozott, mert az 1930-as évektől a szociális programokat és a jóléti államot felvállaló demokrata pártiak akartak nagyobb hatáskört juttatni a szövetségi törvényhozásnak és végrehajtó szerveknek, míg a republikánusok kifejezetten az államok jogait védelmezték. A szövetségi hatásköröket jelentősen kiterjesztő roosevelti New Deal és az 1960as években kibontakozó johnsoni Great Society politikájával szemben az 1980as évekig ellenzékbe szoruló republikánusok egyszerre törekedtek a gazdasági laissez faire biztosítására, alacsony adókra és a szövetségi kormány jogkörének korlátozására.

Hannah Arendt A forradalom (1963) címü nevezetes könyvében az Amerikai Egyesült Államok létrejöttét a ,szabadság megalapozásának” tartotta. Arendt megkülönböztette a „politikai forradalom” és a „társadalmi forradalom” fogalmát. Úgy vélte, a francia forradalom során a társadalomalakító elképzelések lettek végül elsődlegesek, míg az Egyesült Államok megalapításakor egyáltalán nem akarták a társadalmi viszonyokat megváltoztatni, hanem beérték új politikai intézmények létrehozásával. Ezért kerülte el az Egyesült Államok a forradalmi radikalizmust, és vált szilárd liberális demokráciává. Arendt fejtegetése is arra utal, hogy az amerikai képviseleti demokrácia eszméje hasonló irányba fejlődött, mint Jeremy Bentham vagy Benjamin Constant szabadsággal és demokráciával kapcsolatos gondolatai a 19. századi európai liberalizmus változataiban. Az antik polisz „egyszerü társadalmához” nem létezett visszaút, hanem „összetett 
társadalmak" és nagyobb területi államok keretei között kellett megteremteni a szabadság garanciáit. Ahogyan a politikai gazdaságtan területén Adam Smith az antik erényeszményt hagyta maga mögött $A$ nemzetek gazdagságában (1776), és megfogalmazta a piac múködési törvényeit az ,összetett társadalom” keretei között, úgy politikailag az amerikai alkotmány az ókori részvételi demokrácia helyett a modern képviselet polgári alapelvét valósította meg.

A neokonzervatív gondolkodók, mint például Irving Kristol a 20. század második felében az amerikai alkotmányos berendezkedés központi értékének - Hannah Arendt gondolatmenetéhez hasonlóan - a forradalmi radikalizmus elkerülését tartották, és megfogalmazták az amerikai „alkotmányos forradalom” konzervatív (avagy „óliberális”) olvasatát. Ebben a perspektívában az amerikai „forradalom” teljes mértékben különbözött a francia forradalomtól és más európai kontinentális forradalmaktól, mert nem fordult szembe a keresztény hagyományokkal, nem radikalizálódott, nem vezetett elitváltáshoz, és nem alakult ki forradalmi terror, hanem biztosította a szabadság intézményeit. A függetlenségi háború és az 1787-es alkotmány létrehozta az amerikai „démoszt”. $\mathrm{Az}$ amerikai nemzet nem valamiféle közös vérségi-népi leszármazás alapján született, hanem az alkotmányos jogokban, azaz a szabadságban való részesülés révén. Ennyiben az Egyesült Államok politikai identitása a szünoikiszmosz (egybe- vagy összetelepülés) révén létrejövő antik görög poliszokhoz vagy az ókori Rómához hasonlítható, ahol a város politikai-jogi struktúraként került megalapításra, míg római törzs vagy nép sohasem létezett. Ezt a tisztán politikai szerkezetet a jogokban való részesülés tartotta egybe, amit a római történelem folyamán több ízben kiterjesztettek. „Rómainak” lenni, nem törzsi-vérségi kötődést vagy kulturális csoportidentitást, hanem a római állammal szemben létrejött jogi természetű kapcsolatot jelentett. A populus Romanus, azaz a „római démosz" a közös jogokban való részesülés következtében jött létre. Ettől élesen eltér azoknak a politikai közösségeknek az identitása, ahol közös vérségi-törzsi származás alkotja a területi államhoz való tartozás alapját. Ilyennek tekinthető az újkori európai nemzetállamok többsége, amelyek a nemzeti azonosságtudat történetileg kialakult formáira épülnek. Ehhez képest az amerikai démosz nem támaszkodhatott közös népi eredetmítoszra, hanem a „szabadságban” - a polgári és politikai jogokban - való részesülést tekintette alapvető tájékozódási pontnak. Ennek köszönhetően az amerikai „nacionalizmus” egyfajta állampolgári patriotizmussá vált, ahol az alkotmányos jogokban való részesedés tartotta egybe az igen sokféle nyelvi-etnikai háttérrel rendelkező bevándorlókat.

Az amerikai alkotmány szövegezői az angol liberalizmus empirikustörténeti hagyományától eltérő módon John Locke (1632-1704) természetjogi felfogására támaszkodtak a „szabadság megalapozása” során. Amikor úgy tartották, hogy a Teremtő mindenkit egyenlő jogokkal ruházott fel nemcsak az idealizmus aspektusát, hanem egy univerzális eszmeiség távlati lehetőségét is 
belefoglalták az alkotmányba. Az angol konzervatív liberalizmussal szemben, amely a brit intézményeket egyedi történeti fejlödés kivételes eredményeként tartotta számon (excepcionalizmus), az amerikai gondolkodást mindig is megkísértette az egyetemes missziós tudat. Ezzel együtt az angol és az amerikai eszmefejlődés közös vonása lett, hogy mind az angol szabadságintézmények történeti kifejlődésével, mind az amerikai szabadság alkotmányos „megalapításával” maga a szabadság vált hagyománnyá. Ez a tény egyértelművé tette az olyan neokonzervatív/neoliberális gondolkodók szellemi pozícióját, mint Irving Kristol és Friedrich August von Hayek, akik joggal állíthatták a 20. század második felében, hogy a politikai hagyományok őrzése a régi „óliberális” elvek vállalását jelenti az angolszász világban. Az egyén politikai jogainak feltétlen tisztelete - következzen az angol habeas corpusból vagy az amerikai alkotmányból - konvergenciát hozott létre az angol és az amerikai liberális tradíció között, még akkor is, ha filozófiai antropológiai alapjai között jelentős különbségek - empirikus-történeti megalapozás az angoloknál, vagy racionálistermészetjogi háttér az amerikaiaknál - voltak érzékelhetők. Az angol társadalom hagyománytiszteletével szemben az amerikai gondolkodásmód mindig is hajlott egyfajta haladáselvű optimizmusra. Az amerikaiak progresszívizmusa és optimizmusa jelentős mértékben átszínezte az angolszász liberális tradíciót, majd annak internacionalista változatát a 20 . század során.

\subsubsection{Amerikai mítosz - amerikai értékek}

Az „alapító atyákat” a fent említett Hofstadter „konzervatív forradalmároknak" tartotta, de politikai örököseik jelentős újításokra voltak képesek. A függetlenség elnyerése utáni évtizedekben az amerikai demokrácia szellemisége több fontos intézkedésben is megmutatkozott. Az amerikai államokban elválasztották egymástól az államot és a vallást/egyházat. Virginia már 1786-ban biztosította a szabad vallásgyakorlatot, és megszüntette az anglikán egyház államegyházi jogosítványait, majd egyre több állam követte ezen az úton. Utolsóként 1833-ban Massachusetts hozott döntést erröl. A locke-i vallási tolerancia elvét az Egyesült Államokban komolyan vették, de mindez nem vezetett vallásellenes vagy közömbös légkörhöz. Tocqueville, a neves francia politikai gondolkodó arról számolt be a 19. század első felében, hogy az Egyesült Államokban a különféle egyházak és vallási csoportok nagy számával találkozhatunk, és élénk tevékenységük a civil társadalom fontos részét képezi. Az európai társadalmakban a vallás/egyház és az állam elválasztása hosszú és küzdelmes folyamat eredménye volt a 19. században, míg az amerikaiak szinte kezdettől fogva természetesnek tartották.

Tocqueville másik nevezetes megállapítása az amerikaiak vallásosságára vonatkozott. A francia politikai gondolkodó 1831-ben járt az Egyesült 
Államokban, és csodálkozva emlegette a keresztény Biblia erős befolyását a fiatal köztársaságban: „Amerikában a világ egyik legszabadabb és legfelvilágosultabb népe lelkes odaadással teljesíti minden vallási kötelezettségét." „Amerikában a valláson keresztül vezet az út a felvilágosodáshoz, az isteni törvények betartása juttatja el az embert a szabadsághoz." (ToCQueville, A. 1993, pp. 71-72.) Figyelemre méltó, hogy Tocqueville milyen határozottan érvelt amellett, hogy az Egyesült Államokban - a francia forradalom után kialakuló kontinentális politikai hagyománytól eltérően - a vallásosság és a felvilágosodás nem állnak szemben, hanem támogatják és kiegészítik egymást.

Az Egyesült Államok vallásossága és vallási sokszínüsége átívelt a 1920. századon, és az amerikai középosztályok fontos vonása maradt napjainkig. A Tocqueville korában érzékelhető vallási tolerancia egyaránt vonatkozott a protestáns kisegyházakra, majd a katolikusokra, és egyedül az ateista számított „morálisan gyanúsnak”. Az elmúlt évtizedekben Európához képest az USAban a szekularizáció tendenciája is kevésbé érvényesül, ami elsősorban a neoprotestáns csoportok evangelizációs sikereinek köszönhető („religious revival"), másfelől az amerikai vallásosság virulenciája kapcsolatba hozható jelentékeny történelmi előzményekkel is.

A vallás és az állam elválasztása mellett a másik korai politikai változás a választójog kiterjesztése volt a fiatal amerikai köztársaságban. Az európai polgári liberális társadalmakban cenzusos választójog volt érvényben a 19. században, és a választójogi reformok eredményeként csak fokozatosan csökkentették a szavazási jog vagyoni feltételeit. Ezért állította joggal Fareed Zakaria The Future of Freedom (2003) címü könyvében, hogy az újkori Európában kezdetben nem demokráciák, hanem liberalizáló autokráciák jöttek létre. Az általános választójog nem polgári liberális, hanem polgári demokratikus vívmány, amely a 19. század utolsó harmadától egyre több országban érvényesült. Ehhez képest az amerikai politikai gyakorlat joggal mondható „forradalminak”, hiszen már a 19. század első felében egyre több államban bevezették az általános (férfi) választójogot. Az Egyesült Államokban a polgári „szabadság” és a demokratikus „egyenlőség” - az előbbi hamiltoni és madisoni, míg az utóbbi jeffersoni hagyomány - kezdettől fogva szoros egységben bontakozott ki. A választójog kiterjesztésében az amerikai politikai rendszer „demokratizmusa” fejeződött ki, ami nemcsak a politikai berendezkedésben tükröződött, hanem az amerikai szellem egészére is rányomta a bélyegét. Az amerikai társadalom „demokratikus szelleme” élesen eltért a korabeli Angliától, amely - ahogyan Tocqueville is utalt rá - a „dicsőséges forradalom” után kialakult alkotmányos berendezkedés ellenére arisztokratikus társadalom maradt.

Az európai liberálisok cenzusos választójogban gondolkodtak, mert úgy ítélték meg, hogy az érdek fölé emelkedő tiszta ítélet a politikai vitákban akkor garantálható, ha a manipulálható szegények nem vehetnek részt a döntésekben. 
Általában véve a liberálisok arra törekedtek, hogy az antik demokráciák és a francia forradalom negatív tapasztalatait elkerülve megakadályozzák, hogy a vagyonosok szük rétege megvásárolja a nincstelenek szavazatait. Az Egyesült Államokban a választójog demokratikus kiterjesztését előmozdította, hogy a szabad tulajdonosok széles rétegein alapuló társadalom indokolatlanná tette ezeket a fenntartásokat.

„Az amerikai tapasztalat megkülönböztetöjegye-amelyet már Tocqueville is kiemel, de valójában eredete korábbra nyúlik vissza - az osztálynélküliség volt, a 'feltételek egyenlösége', ahogyan Tocqueville és mások akkoriban nevezték. Az emberi társadalomnak ez az új formája olyan mély benyomást tett Tocqueville-re, hogy mindjárt 'Az amerikai demokrácia' nyitómondatában a következöket irta. 'Az új jelenségek között, amelyek egyesült államokbeli tartózkodásom alatt figyelmemet felkeltették, a társadalmi rendek egyenlöségét találtam a legszembetünőbbnek.' Majd áttért annak a 'csodálatos hatásnak' a kifejtésére, amelyet egy ilyen egyenlöség gyakorol: '...véleményeket formál, érzelmeket kelt, szokásokat inspirál és azt is átalakitja, amit nem maga hoz létre. Ha a születésen alapuló formális megkülönböztetés hiánya egy odalátogatónak, aki a 19. század korai évtizedeiben fordult meg Amerikában, még mindig újdonságnak számított, akkor még inkább az volt egy századdal korábban, és nagymértékben befolyásolta az amerikai polgárok felfogását is. Amint egy angol utazó megjegyezte az 1760-as években: 'Mindenkinek van magántulajdona, és mindenki tudatában is van ennek.' Az osztálynélküliség ösztönzö ereje azzal, hogy utat nyitott a felemelkedés lehetöségének, megsokszorozódott, kíméletlen sarkantyúként müködött, keményen ösztökélve a gazdasági eröfeszitéseket... Az európaihoz hasonló arisztokratikus osztály-megkülönböztetések hiányában... az anyagi siker - a személyes gazdasági elöremenetel - vált a fó értékmérövé, amely egy amerikait honfitársai szemében megkülönböztetett. Mivel nem volt akadálya annak, hogy bárki... többet keressen, fogyasszon és halmozzon föl, mint szomszédja, ennek eredményeként, ahogyan Tocqueville jellemezte, 'valami tisztes materializmus' alakult ki. Ehhez David Landes szavaival 'az önbecsülés, az ambíció, a piaci versenyben való részvétel készsége, az individualizmus és annak szelleme társult."” (Friedman, B. M. 2010, pp. 132-134.)

A Tocqueville által említett „egyenlőség”, „demokratikus szellem”, „tisztes materializmus” és az amerikaiak munkaközpontú gondolkodásmódja összekapcsolódott a protestáns etikával. A kálvini tanítás szerint az eleve elrendelés felértékeli az isteni kiválasztás fontosságát, ezért a kálvinista hívő szünet nélkül keresi a túlvilági üdvözülés evilági jeleit. A szorgalmas puritán közösségek „Isten országának” ezen a földön való megteremtésével akarták kiválasztottságuk jeleit megtapasztalni, ami hatalmas cselekvési energiákat szabadított fel. Mindez ráadásul az „ígéret földjén” történt, azaz egy olyan országban, ahová a puritánok a jobb jövő érdekében vándoroltak be, és ahol 
a végtelen távlatok elővételezték „Isten országának” felépítését. Az amerikai területek benépesítésének lehetősége az „ígéret földjére” (azaz „Izraelbe”) való bevándorlás történelmi analógiáját jelentette a protestáns telepesek számára. Mindez csakis a jövőbe vetett bizalom révén vált elképzelhetővé. Az amerikaiak optimizmusa éppúgy levezethető a protestáns felfogásból, mint munkaközpontú „tisztes materializmusuk”. „Amerika” protestáns polgárai tevékenysége következtében nemcsak „van”, hanem leginkább „lesz” (de semmiképpen nem „volt”). Az amerikai optimizmus jövőbe vetett erős hittel kapcsolódott össze, és bízott abban, hogy a dolgokban a végtelen haladás távlata van. Ez a haladáselvü időfelfogás összhangban volt az európai felvilágosodás fejlődéselvü szemléletmódjával, de az Egyesült Államokban a hétköznapi életvilágokat is formáló érzés lett.

A 19. század során nyilvánvalóvá vált, hogy az Egyesült Államok a gyors társadalmi felemelkedés lehetőségét biztosítja a keményen dolgozó amerikaiak és a bevándorlók számára. Az American dream - James Truslow Adams kifejezése The Epic of America címü 1931-ben megjelent könyvében - azt az évszázados tapasztalatot is jelentette, hogy az Óvilágból érkező nincstelenek tisztesen végigdolgozott évtizedek után jó eséllyel középosztálybeli polgárként élvezhetik munkájuk gyümölcseit. Mindez azért vált lehetségessé, mert a munkaközpontú „amerikai értékek” kivételes gazdasági növekedéssel kapcsolódtak össze, amelynek a mértéke minden korábbi történelmi tapasztalatot felülmúlt. Az amerikaiak „progresszivizmusa” és „optimizmusa” abból is fakadt, hogy a gazdasági-társadalmi reálfolyamatok a 19. században alátámasztották a jövővel kapcsolatos pozitív várakozásokat.

$\mathrm{Az}$ amerikai társadalom „demokratizmusa” nem jelentett vagyoni egyenlőséget, legfeljebb a feltételek egyenlőségét. Mivel a legtöbb amerikai rendelkezett valamiféle magántulajdonnal - földbirtok, üzlet stb. -, az induló feltételek körülbelül egyenlők voltak. Erre támaszkodva a 19. század első felétől egy széles részvételen alapuló kapitalizmus sikeres kibontakozásának lehetünk tanúi, amit a „proletarizálódás” vagy „pauperizálódás” veszélye csak kevéssé kísértett meg. Ebben az összefüggésben kell szemlélnünk a jeffersoni demokratikus örökséget elmélyítő jacksoni liberalizmus fogalmát is. Andrew Jackson az Egyesült Államok elnökeként (1829-1837) már nem a keleti partvidék elitjéből származott, mint az „alapító atyák”, hanem az Appalachehegységtől nyugatra látta meg a napvilágot. Sikeres katonaként széles társadalmi elfogadottságra tett szert, és hatalmát az alapítók „elitizmusához” képest a „népuralom” kiterjesztésére akarta felhasználni. A régi establishment visszaszorítására irányuló törekvései akár plebejus színezetü törekvéseknek is tủnhetnek, de nem szabad megfeledkeznünk arról, hogy Jacksontól éppúgy távol állt a vagyoni egyenlősítésre törekvő kispolgár, mint a népboldogító társadalmi forradalmár szerepe. 
A jacksoni liberalizmus elsősorban arra törekedett, hogy megszüntesse a kormányzati monopóliumokat, és a szabad üzleti vállalkozást mindenki számára hozzáférhetővé tegye. A jacksoni liberalizmus elvei szerint a kormánynak egyik vállalkozót sem szabad előnyben részesíteni a másikhoz képest, és nem kínálhat fel olyan előnyt egyetlen üzletembernek sem, amelyet a többitől megtagad. A jacksoni liberalizmus nem a társadalmi különbségek csökkentését, hanem a széles részvételen nyugvó népi kapitalizmus sikerét kívánta elömozdítani. Ezzel az amerikai politikai hagyomány sokat hivatkozott összetevőjét alapozta meg, a szabad üzleti vállalkozás és a piaci szabadság egész nép számára gyümölcsöző következményeinek, illetve az üzleti életet aktívan támogató kormány áldásos tevékenységének gondolatát. A jacksoni liberalizmus jól érzékelteti, hogy az amerikai politikai kultúrában a demokrácia kiterjesztése nem a vagyoni egyenlősítést, hanem a lehetőségekben való egyenlő részesedést jelentette.

A ,progresszivizmus” és a „,demokratizmus” mellett meg kell említenünk az amerikai fejlődés egy további jellegzetességét, a „mozgó határ” állandó eltolódását nyugati irányba. Frederic Jackson Turner 1893-ban tette közzé nagyhatású tézisét a ,határvidék” (frontier) amerikai történelemben játszott szerepéröl. Turner szerint az amerikai nép a vadonnal való állandó küzdelemben született, ami a népjellem alakulását is jelentős mértékben befolyásolta. Bár az amerikai történész következtetéseinek egy része vitatható volt, kevés tézis eredményezett ilyen szerteágazó diskurzust az amerikai identitásról. Turner gondolatainak az amerikai historiográfiában betöltött szerepe jól érzékelteti, hogy maguk az amerikaiak is nagy jelentőséget tulajdonítottak a frontiernek, amely a végtelen lehetőségek szimbólumává vált számukra. Ebből ered, hogy a századfordulón, amikor a frontier a Csendes-óceánnál „lezárult”, válsághangulat ütötte fel a fejét, és sokan cikkeztek arról, hogy az Egyesült Államok kivételes fejlődése „végére ért” (36. térkép). A ,határvidék” fogalma jól rávilágít a 19. századi amerikai felemelkedés végtelen távlataival kapcsolatos pozitív értékítéletekre. A frontier konkrét lehetőséggé formálta a protestánsok ,ígéret földjére" vonatkozó várakozásait, és táplálta az amerikai optimizmust.

Turner frontierre vonatkozó tézise hozzájárult az amerikai identitással kapcsolatos nézetek árnyalásához. Megfogalmazása szerint a földrajzi környezet és a vele való küzdelem civilizációalkotó jelentősége messze felülmúlta az angolszász politikai intézmények, azaz az Angliából hozott vagy időközben kialakított intézményi örökség fontosságát. „'Az amerikai demokrácia nem teoretikusok álmodozásaiból született' - érvelt egyik tanulmányában Turner -, 'nem a Susan Constant fedélzetén jutott el Virginiába vagy a Mayflower-én Plymouthba. A demokrácia az amerikai erdők mélyéböl jött el, s mindig új eröre kapott, valahányszor a határvidék nyugatabbra vonult. Nem az alkotmány, hanem az eröteljes nép rendelkezésére álló szabad föld $s$ a természeti kincsek bösége alakította ki Amerikában a demokratikus társadalmat...' Más is kisugárzott az 
erdök sürüjéböl: 'A határvidék - állitotta Turner - serkenti az individualizmust' az amerikaiak jellemében." (idézi: DeGLER, C. N. 1993, p. 134.)

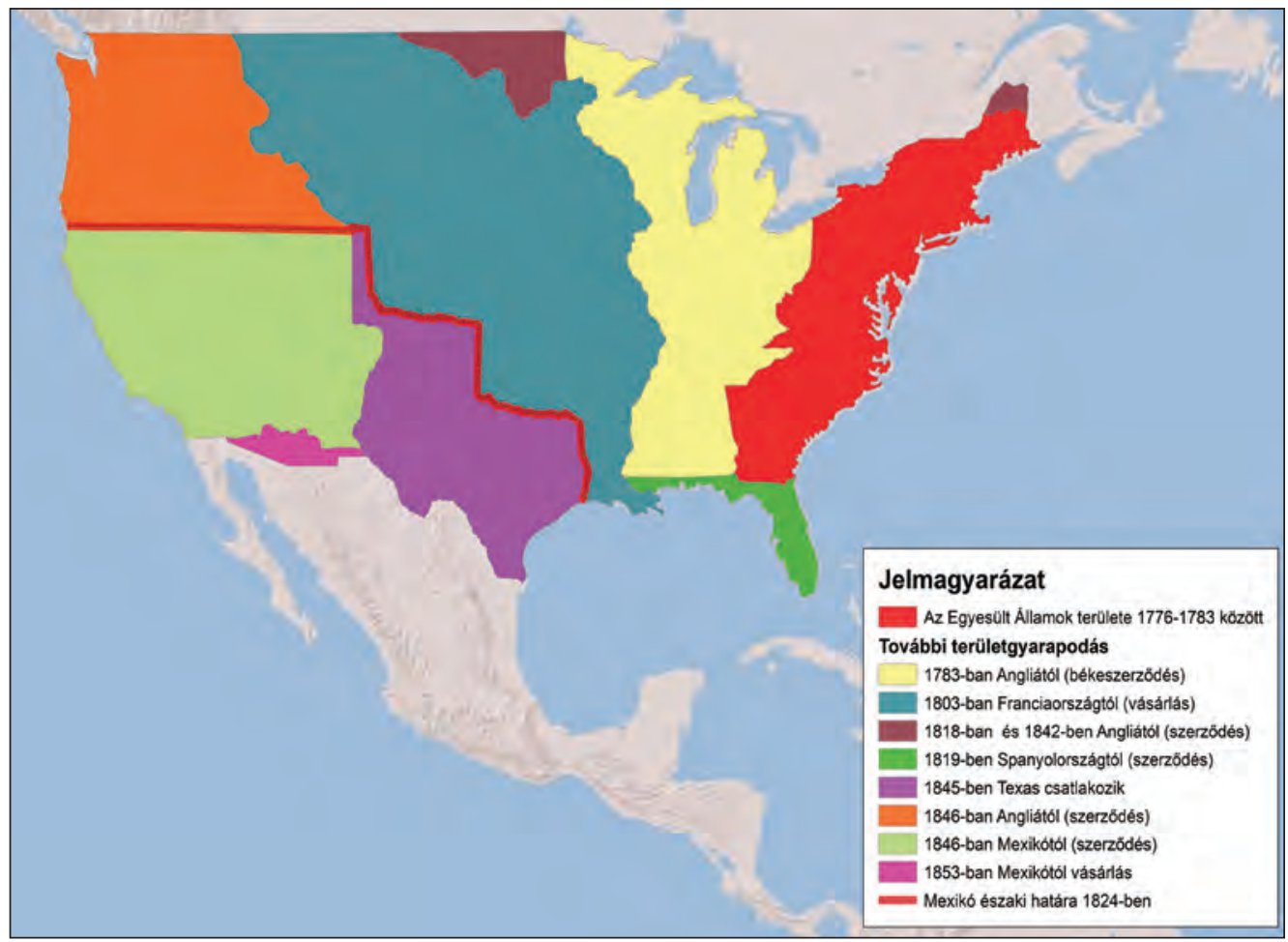

36. térkép: Az USA területi gyarapodása 1776-1853

Forrás: VARGA ÁGNES szerkesztése

Turner okfejtése a történelemformáló erők természetét illetően tünik tanulságosnak. A földrajz és az emberi társadalom kapcsolatát illetően a miliőelmélet (Montesquieu) és a földrajzi determinizmus (Ratzel) képviselői a természeti környezet társadalomalakító hatását emelték ki, míg a földrajzi posszibilizmus (Vidal de la Blanche) inkább a földrajzi faktorok lehetőségeket teremtő hatásáról értekezett, amit a társadalom vagy kihasznál vagy nem él vele. Az amerikai eszmények és a társadalom alakulása szempontjából a mainstream szemléletmód a földrajzi hatások helyett az angolszász intézmények jelentőségére helyezte a hangsúlyt. Ezek emberi erőfeszítések révén jöttek létre, és alkalmassá váltak a politikai értékek megalapozására, míg Turner sokat vitatott és némileg elnagyolt tézise a környezet elsődlegességére hivatkozott, amikor megkísérelte megmagyarázni az individualizmus és a demokrácia kialakulását. 


\subsubsection{Az Egyesült Államok felemelkedése}

Az Egyesült Államok a függetlenségi háború után a 19. század elején olyan gyár nélküli kapitalizmusnak, illetve szabad tulajdonosokból álló társadalomnak tekinthető, amely nemcsak Jefferson demokrácia-eszményére emlékeztetett, hanem Adam Smith „kereskedelmi társadalmára” is megfelelő példát szolgáltatott. Smith A nemzetek gazdagságában a piaci cserén alapuló tulajdonosi gazdaságot tartotta ideálisnak, ahol az állami beavatkozásokat a minimálisra csökkentik, így érvényesülhet a „láthatatlan kéz”, azaz a piaci önszabályozás ideája. A gyár előtti kapitalizmus világában a kommercializálódott agrárgazdaság, a társadalmi szerkezetet meghatározó széles tulajdonosi rétegek, valamint az etatizmus hiánya lehetővé tették, hogy Smith közgazdasági ideája az Egyesült Államokban közel kerüljön a megvalósuláshoz. Európában a királyi abszolutizmus hagyományaiból származó kiterjedt gazdasági szabályozást csak hosszú küzdelem keretében lehetett lebontani, míg az Egyesült Államok kezdettől fogva jó példát szolgáltatott a korlátozásoktól mentes piac és kapitalizmus érvényesülésére, ahol a tulajdon és a jövedelmek is kiegyensúlyozottan oszlottak meg a gazdasági szereplők között. A gyári kapitalizmus a későbbiekben átalakította az eredeti viszonyokat, de a vidék, a mezőgazdaság és a hozzá kapcsolódó kistulajdonosi rétegek jelentősége hosszú ideig érvényesült az Egyesült Államok történetében.

Az ipari fejlődés ellenére még a 19-20. század fordulóján is nagy szerepet játszott az agrárszektor, ami a mezőgazdasági export kivitelben betöltött szerepében is kifejeződött. A városi lakosság száma csak az első világháború után haladta meg a vidéki népességet, míg Angliában a lakosság körülbelül fele 1850-ben már városokban élt. Amikor az USA ipari hatalommá vált a 20. század elején, kivitelében a mezőgazdasági termékek más ipari országokhoz képest még igen nagy részarányt képviseltek. A „vidéki Amerika” fontossága a politikai kultúra sajátosságaiban is megmutatkozott. A keleti partvidék és a Nagy-tavak - majd a 20. század második felétől Kalifornia - hatalmas iparvidékeihez és nagytőkéseihez képest a nyugatabbra fekvő területek (Midwest) az agrárbirtokok és kisvárosok világát képviselték/képviselik, ahonnan a farmerek „populizmusa” éppúgy kiindulhatott, mint a városi középosztályok WASP-öntudata.

$\mathrm{Az}$ iparosodás ígéretes kezdetei ellenére a 19. század elején a tőkebefektetések számottevő része nem az ipari üzemek fejlesztését mozdította elö, hanem csatorna- majd vasútépítkezésekbe áramlott. Egy olyan hatalmas országban, mint az Egyesült Államok, a vasutat megelőző korszakban a csatornák tették lehetővé a nagy tömegű mezőgazdasági áruk szállítását, ami az árufelesleg többségét jelentette. A csatornák elősegítették a fuvardíjak radikális csökkenését - a szárazföldi közlekedéshez képest a vízi szállítás körülbelül egyötödébe került -, ami biztosította a mezőgazdaság kommerciális jellegét, 
illetve hosszabb távon kivételes erejü hatást gyakorolt a nemzetépítésre. Az Egyesült Államok, mint hatalmas területű köztársaság egyedülálló jelenségnek számított a 18. század végén, és sokak számára kétségesnek bizonyult, hogy egybetartható-e tartósan egy ilyen méretü ország. A 19. század első felében megépült csatornák, majd néhány évtizeddel később a vasutak nemcsak a mezőgazdasági, aztán az ipari termékek szállítását könnyítették meg, hanem az ország egységének is alapvető tényezőjévé váltak.

Az iparosodás kibontakozása révén a 19. század első felében megerősödött az a vélemény, hogy a vámok feladata nem elsősorban a költségvetési bevételek gyarapítása, hanem a fiatal amerikai ipar megvédése az erősebb konkurenciával szemben. A védővámok gondolatát nemcsak Hamilton támogatta, hanem gazdasági érdekcsoportok és publicisták is. A protekcionizmus az amerikai külgazdasági gyakorlat szerves részét képezte. Bár a függetlenség elnyerése után a nemzetek közötti szabad kereskedelem alapelve az Egyesült Államok külpolitikájának egyik fundamentuma lett, az ipar érdekei gyakran erősebbnek bizonyultak. Az USA mindvégig arra törekedett a 19. században, hogy ipari és mezőgazdasági termékeit vámvédelemben részesítse. Nem véletlen, hogy a német Friedrich List, akinek az európai közgazdasági elmélet a nevelővám és a védővámos elzárkózás gondolatát köszönheti, maga is hosszabban tartózkodott az Egyesült Államokban, és hatott rá az amerikai külgazdasági gyakorlat. A szabad kereskedelem irányába elmozduló angol kereskedelempolitikával szemben, amely saját mezőgazdasága számára is konkurenciát teremtett, az Egyesült Államok még a századfordulón is féltékenyen őrizte iparát és mezőgazdaságát. Bár a demokraták több ízben tettek kísérletet egy multilaterális szabadkereskedelmi rendszer megteremtésére a 20. században, a protekcionizmus iránti igények a republikánusokhoz vonzódó tulajdonosi középosztály köreiben mindvégig megmaradtak.

Az Egyesült Államok csak a polgárháború (1861-1865) utáni évtizedekben lett igazi ipari ország. Az 1880-as években már többen dolgoztak az iparban és a szolgáltatásokban, mint az agrárgazdaságban. Az USA a 19. század végére ipari nemzetté vált, ahol az ipari termelés meghaladta a mezőgazdaságban elóállított áruk értékét. 1890-ben az Egyesült Államok a világ legnagyobb ipari teljesítményével rendelkező hatalma lett. A gazdasági fejlődésnek a polgárháborútól az első világháborúig terjedő szakaszában a gyáripari termelés értéke tizenkétszeres, az ipari tőkebefektetéseké húszszoros növekedést mutatott. A gyáriparban dolgozó munkások száma legalább ötszörösére emelkedett. 1830ban az Amerikai Egyesült Államok a világ ipari termelésének 2,4, Anglia 9,5, Franciaország 5,2 százalékával rendelkezett. 1900-ban az USA 23,6, Anglia 18,5, Franciaország 6,8 százalékával. 1914-ben az amerikai nemzeti jövedelem már meghaladta a brit, a német, a francia és az orosz nemzeti jövedelem összegét. Az egy főre eső iparosodottság is jócskán megelőzte az európai kontinens átlagát. 
Ezek az eredmények a 19. század utolsó harmadában kibontakozó kivételes méretü ipari fejlődés következtében váltak lehetségessé. Figyelemre méltó, hogy az Egyesült Államok igen rövid idő - körülbelül négy évtized - leforgása alatt a világ első ipari hatalma lett. Felemelkedése nagyjából annyi időt vett igénybe, mint az 1973-as olajválságtól napjainkig tartó időszak. Ezekben az évtizedekben az életszínvonal is állandó növekedésen ment keresztül.

A szabad munkaerőmozgáson alapuló iparosodott Észak és a rabszolgatartó ültevényes Dél közötti polgárháború lezárulása utáni évtizedet helyreállítási időszaknak (reconstruction era), míg a századfordulóig tartó periódust ,aranyozott kornak” (gilded age) nevezi a történetírás. Az utóbbi elnevezés - Mark Twain ironikus szóhasználatára is utalva - jól érzékelteti a korszak ellentmondásosságát. Az amerikai gazdaság az ipari teljesítmény, a reálbérek és az életszínvonal gyors ütemü növekedését erőteljes konjunkturális ingadozások, spekulációs hullámok és nagy jövedelmi különbségek közepette valósította meg. Az amerikai kapitalizmusnak ez a természete napjainkig hatóan fennmaradt. Az Egyesült Államokban az üzleti élet, a tőkejavak és -mozgások, a pénzügyi szektor szabályozása az európai gyakorlathoz képest mindig komoly ellenállásba ütközött. Ettől csak a New Deal utáni évtizedekben tértek el érdemben, de az 1980-as években a dereguláció révén igyekeztek szabadabbá tenni a gazdasági mozgásokat. A 19. század közepétől a gazdasági fejlődés lendülete jól érzékelteti az amerikai kapitalizmus egyedülállóan dinamikus, egyben hektikus természetét.

Az amerikai gazdaság felíveléséhez nagyban hozzájárult a szövetségi kormányok polgárháború utáni gazdaságpolitikája. Az „északi örökséget” megtestesítő republikánus kormányzat a hamiltoni örökség jegyében arra törekedett, hogy az üzleti életet pártoló környezet megteremtésével és aktív intézkedésekkel - leginkább a vasúti építkezések elősegítése révén - kedvező hatást gyakoroljon a kapitalizmus fejlődésére. A businesst támogató álásfoglalás egyben azt is jelentette, hogy a sztrájkjogot a bíróságok a vállalkozás szabadságát korlátozó szervezkedésként tiltották, és egy ideig súlyos feszültségek alakultak ki a munka és a tőke között. A konfliktusok ellenére az Egyesült Államokban nem jöttek létre munkáspártok, hanem a bérharc elsősorban a szakszervezetek ügye maradt, akik pragmatikus módon a béremelések kikényszerítésére törekedtek, és nem fogalmaztak meg „osztályharcos” vagy politikai célokat. Az amerikai gyakorlat az indusztrializáció és az urbanizáció áldozatait és veszteseit sem annyira „etatista” költségvetési eszközökkel igyekezett támogatni, hanem a növekvő városok világában nagy szerepre tettek szert a protestáns egyházi és civil szervezetek, amelyek a szegényeken kívántak segíteni.

Az amerikai gazdasági növekedés egyik kulcstényezöje volt, hogy a 19. században az Óvilágból mintegy 60 millió ember indult el, hogy szerencsét próbáljon hazáján kívül. Ezek körülbelül kétharmada az Egyesült Államokban 
talált hazát magának. A népesség számbeli gyarapodása a munkaerőpiac állandó bővülését tette lehetővé. Az 1870-es évektől napjainkig az ország népessége alig 40 millióról körülbelül 300 millióra emelkedett. A kivételes gazdasági növekedés korszakában, 1896-ban az Egyesült Államok népessége elérte a 70 milliót, 1914-ben megközelítette a 100 milliót. A bevándorlás erőteljesnek bizonyult a századforduló éveiben, amikor a szakképzett és a szakképzetlen munkaerő egyaránt nagyban hozzájárult a konjunktúra dinamikájához.

A bevándorlási hullámok eredményeként a WASP-identitás fokozódó kihívások elé került. A 19. század közepén a németek és az írek, a 19-20. század fordulóján a mediterrán térségből - föleg olasz - és Kelet-Közép-Európából érkező bevándorlók mind színesebbé tették a hatalmas ország nyelvietnikai viszonyait. A századfordulós bevándorlással egyre nagyobb katolikus népességgel is számolni kellett az Egyesült Államokban. A 19. század során az asszimilációs tendenciák még erőteljesnek bizonyultak, amihez nagyban hozzájárult az a tény, hogy a bevándorlók többsége maga is amerikaivá akart válni. A szociológia és a történettudomány elsősorban ennek az időszaknak a tapasztalatait emelte ki, amikor megalkotta az „olvasztótégely” (melting pot) fogalmát, bár az elmúlt évtizedek kutatásai arra is felhívták a figyelmet, hogy az asszimiláció a bevándorlás „klasszikus” korszakában sem volt olyan mértékü, ahogyan azt korábban feltételezték. Mégis az angolszász protestáns középosztályok az erősödő kihívások ellenére egészen a 20 . század második feléig képesek voltak saját értékeik jegyében integrálni a bevándoroltakat. Ezek a tendenciák az 1960-as évek fekete polgárjogi mozgalmával és a nyugati partvidék államaiba történő ibero-amerikai bevándorlással törtek meg véglegesen, és máig feloldhatatlan problémát jelentenek.

A 19. századi gazdasági növekedést a vasútépítés rendkívüli méretei is előmozdították. A század második harmadában 50 ezer kilométer vasúti pályát építettek, ami az 1870-es évek elejére megkétszereződött. A századfordulón az Egyesült Államokban épült vasúti sínek hossza meghaladta a 300 ezer kilométert, amivel leelőzte az egész európai vasúthálózatot. 1914-ben ugyanez az adat már 400 ezer kilométer volt, amikor a hatalmas Oroszország összesen 75 ezer kilométer vasúttal rendelkezett. A közlekedési infrastruktúra kiépítése serkentette a GDP növekedését, és előmozdította a nyugati területek erőforrásainak bekapcsolását a gazdasági vérkeringésbe. A gyarapodó népesség, a bőségesen rendelkezésre álló nyersanyag és az egyre kiterjedtebb vasúthálózat a gazdasági fejlődés három alapvető pillérét alkották, amelyek között pozitív visszacsatolásokkal kell számolnunk. Az amerikai gazdaság olyan „táguló univerzumnak" bizonyult, ahol a szereplők tekintélyes része megtalálta számítását.

Az életszínvonal állandó gyarapodásának köszönhetően a századfordulón - Európát megelőzve - kialakulóban voltak a fogyasztói társadalom kezdeti 
körvonalai. Az amerikai munkás a magas bérezés miatt olyan fogyasztási szokásokat engedhetett meg magának, amire Európában csak három-négy évtizeddel később került sor. A magas munkabérek oka részint a határvidék (frontier) következményeiben keresendő. A kontinentális Európában az iparosodást előmozdította, hogy az elmaradott agrárgazdaságban nagy rejtett munkanélküliséggel kellett számolni. Ez a munkaerő a gyári kapitalizmus kialakulása után az ipari városokba áramlott, és hozzájárult a bérek leszorításához, amivel lehetővé tette a tőkés vállalkozó profitjának növelését. Ezért az európai országokban az ipari forradalom során nem beszélhetünk munkaerőhiányról. Ehhez képest az Egyesült Államokban a keleti partvidék ipari munkássága bármikor nyugatra vándorolhatott, ha a bérek nem bizonyultak számukra megfelelőnek. A határvidéken föld bőségesen állt rendelkezésre, míg munkaerő annál kevésbé. Ráadásul a piacra termelő farmgazdaságok racionális munkaszervezete nem ismerte a rejtett munkanélküliséget. Mindez vonzó bérekhez vezetett az agrárgazdaságban, ami közvetve magasan tartotta az ipari béreket is. Bár a történészek vitái során az is felmerült, hogy a nyugatra vándorlás inkább csak elvi lehetőség volt sokak számára, a „határvidék” önmagában is visszatartó erőnek bizonyult a bércsökkentő törekvésekkel szemben.

A magas munkabérek gépesítésre ösztönözték a vállalkozókat, mert ilyen módon próbálták meg kiváltani a drága munkaerőt. A gépesítés megnövelte a termelékenységet, számos esetben szakképzettséget igényelt, ami tovább emelte a munkaerő értékét, ez pedig ismét a munkaerőt kiváltó gépek alkalmazását mozdította elő. Az Egyesült Államokban a „második ipari forradalom” idején - a 19. század utolsó évtizedeiben - a gyáraknak nemcsak a mérete, hanem gépesítettsége is egyedülállónak bizonyult, ami hozzájárult az amerikai export egyre kiemelkedőbb versenyképességéhez az európai vetélytársakkal szemben.

A markáns gazdasági növekedés előmozdította az American dream beteljesülését. Az Egyesült Államok társadalma az „alapító atyák” korában széles tulajdonosi rétegekböl állt. A frontier lehetővé tette a tulajdonszerzést, és a szövetségi kormány támogatta, hogy a telepesek kedvező áron földhöz jussanak (Homestead Act). A tulajdon és a magas ipari munkabérek révén elkerülhetővé vált, hogy jelentékeny társadalmi csoportok deklasszálódjanak. Az Egyesült Államok a századfordulón nagy létszámú tulajdonosi középosztállyal, jól fizetett alkalmazotti és munkásrétegekkel rendelkezett. A gazdasági növekedés strukturális sajátosságai biztosították az „eredeti jellegzetességek” megőrzését, azaz a széles részvételen nyugvó kapitalizmus sikerét.

A századelőn „az élenjáró amerikai vállalatok, mint az International Harvester, a Singer, a DuPont, a Bell, a Colt és a Standard Oil technikailag legalább azonos, de gyakran magasabb szinten álltak, mint európai vetélytársaik, emellett sokkal nagyobb és gazdaságosabb belsö piacaik voltak, mint német, angol és svájci vetélytársaiknak... 'Mielött Andrew Carnegie 1901-ben eladta 
volna vállalatait a J. P. Morgan-féle United States Steel Corporationnak, már több acélt termelt, mint egész Anglia'... 1914-ben az Egyesült Államok 455 millió tonna szenet termelt, s ezzel jóval megelözte Nagy-Britannia 292 millió, valamint Németország 277 millió tonnáját. A világ legnagyobb olajtermelöje és vörösrézfogyasztója volt. Nyersvastermelése több volt, mint Németországé, Nagy-Britanniáé és Franciaországé együttvéve, acéltermelése majdnem egyenlö az elözö országok össztermelésével, még Oroszországot is hozzászámitva. Energiafogyasztása 1913-ban azonos volt Nagy-Britannia, Németország, Franciaország és Ausztia-Magyarország együttes szükségletével. Az USA több motoros jármüvet gyártott és használt, mint a világ többi része. Ez a gyorsan növekvö földrésznyi állam közel állt már ahhoz, hogy egész Európát maga mögé utasitsa." (KenNEDY, P. 1992, pp. 230-231.)

Azimponáló gazdasági növekedés kivételes strukturális adottságok mentén következett be. Az amerikai vállalat- és bankméretek messze meghaladták európai vetélytársaikat. A Morgan, a Carnegie és a Rockefeller családok ekkor váltak az amerikai bankszektor, acélipar és kőolajkitermelés kulcsfontosságú vállalkozóivá. A hatalmas vállalatméretek egyrészt hatékonyabb termelést tettek lehetővé, illetve a professzionális vállalatirányítás, management-technikák és mérnöki tevékenység szülőhelyévé lettek, másrészt, mint politikai befolyásolásra alkalmas monopóliumok erőteljes társadalmi vitákat gerjesztettek. Az Egyesült Államok úgy lépte át a 20. századot, hogy tapasztalatokat szerzett a nagytőke és a középosztályok közötti feszültségekből, amelyek azóta is formálják az amerikai politikai kultúrát.

A gazdaság hatalmas fejlődése a századfordulón már alig tette lehetővé, hogy az Egyesült Államok kimaradjon a világpolitikából. Az USA termékei nagy részét hatalmas belső piacán értékesítette, de bővülő késztermék exportja növekvő befolyást gyakorolt az európai nemzetgazdaságokra. Az amerikai külkereskedelmi aktívum Európával szemben már nemcsak az agrárexporton nyugodott. A Nagy-Britanniából származó tőkeimport többletforrások bevonását tette lehetővé, és meggyorsította a gazdasági növekedést. Az Egyesült Államok gazdasági vitalitását a 19-20. század fordulóján jól érzékelteti az exporttöbblet és a tőkeimport kombinációja. (Míg a közelmúlt külkereskedelmi deficitje már inkább az USA növekvő sebezhetőségére és versenyképességi problémáira utal.) Az amerikai gazdaság konjunkturális ingadozásai a századfordulótól hatottak az európai piacokra. Az amerikai spekulánsok képesek voltak megzavarni az európai fővárosok pénzpiacait. Közel volt az idő, hogy az Egyesült Államok rákényszerüljön arra, hogy világméretü külpolitikát folytasson, ha védelmezni akarta pénzügyi és exportérdekeit. Az európai nagyhatalmak és tőkecsoportok egyre jobban tartottak az USA gazdasági világhatalommá válásától.

Az amerikai felemelkedés legnagyobb következményekkel járó vállalkozása az amerikai liberális eszmeiség „nemzetközivé” tétele volt. Az 
első világháború idején a wilsoni elvek a liberális internacionalizmus egyfajta krédóját fogalmazták meg, és a nemzetközi élet alapelvévé kívánták emelni azokat. Az Egyesült Államok a 19. században nagyobbrészt izolacionista külpolitikát folytatott. Az amerikaiak nem akarták beleártani magukat a hatalmi egyensúlyon (balance of power) alapuló európai államrendszer ügyeibe. Véleményük szerint az „alapító atyák” által létrehozott Egyesült Államok erkölcsi értelemben is új kezdetté vált, mert az Óvilág machiavellista hatalmi politikájának meghaladására törekedett. Másfelöl az amerikaiak megengedhették maguknak az elzárkózást, hiszen egyetlen európai hatalom sem jelentett olyan mértékü fenyegetést, ami arra kényszerítette volna őket, hogy szövetséget keressenek egy másik európai állammal. Ráadásul a hatalmas amerikai belső piac egy ideig azzal a következménnyel járt, hogy az Egyesült Államok termékeinek csak jelentéktelen hányadát exportálta. Ez a tény még akkor is lehetővé tette a visszahúzódó külpolitika megőrzését, amikor a századforduló ipari fejlődése következtében az amerikai exportágazatok bővülésnek indultak. Úgy tünik, hogy az amerikai izolacionizmus nemcsak eszmei alapokon, hanem gazdasági tényezökön is nyugodott.

Az amerikai „elszigetelődés” nemcsak ellentéte az amerikai értékek világméretü terjesztésének, és az erre vonatkozó missziós tudatnak, hanem ugyanazon jelenség két oldaláról van szó. Az Egyesült Államok magasabb erkölcsisége tudatában határolódott el az érdekelvű „óvilági” politizálástól. De ugyanezen moralitás birtokában akár arra a következtetésre is juthatott, hogy politikai és etikai elveit meg kell, hogy ossza az egész világgal. Az amerikai mítosz a világméretủ misszió lehetőségét is magában foglalta, ahogyan a francia forradalmi nemzet is „fáklyává” vált Európa számára, legalábbis egyes 19. századi gondolkodók szerint. Az amerikaiak nemcsak optimista módon bíztak a haladás lehetőségében, hanem a frontier tapasztalata alapján azt is megtanulták, hogy az általuk képviselt életforma egyre nagyobb területekre terjedhet ki, ezért az sem meglepö, ha idővel „túlcsordul” Amerikán. Amíg az Egyesült Államoknak nem voltak jelentős érdekeltségei külföldön, és a frontier lehetővé tette a terjeszkedést az észak-amerikai kontinensen, az amerikai külpolitikai idealizmus az izolacionizmusban öltött testet. De a századfordulón egyrészt lezárult a frontier - a telepesek elérték a nyugati partvidéket -, másrészt az amerikai áruk ekkor jelentek meg nagyobb mennyiségben a világpiacon. Amikor az Egyesült Államok a Fülöp-szigetek kapcsán kimutatta csendes-óceáni érdekeltségét, valamint a „nyitott kapuk” elvének meghirdetésével kifejezésre juttatta, hogy nem közömbös számára az ázsiai kontinens, továbbá Theodore Roosevelt elnök (1901-1909) demonstratív módon világ körüli útra küldte az amerikai hadiflottát, a világ közvéleménye kezdte megérteni, hogy új korszak van születőben. 
Az első világháború előestéjén az amerikaiak jó úton voltak, hogy gazdaságilag lehagyják az európai kontinenst. Becslések szerint az 1920-as évek derekára ez mindenképp bekövetkezett volna, de az első világháború következményei felgyorsították a gazdasági erőviszonyok átrendeződését. Az Egyesült Államok az angolszász érdek- és értékközösség jegyében hatalmas hiteleket nyújtott Nagy-Britanniának az első világháború során. A hitelezők szempontjai is hozzájárultak ahhoz, hogy a Wilson-adminisztráció már nem volt olyan büszke az elveire, hogy ne vállalja a harcot, és szigorúan morális természetủ nemzetközi jogi érveléssel belépett a háborúba.

Woodrow Wilson elnök (1913-1921) 14 pontja, amelyet a szenátus és a képviselöház közös ülésén hirdetett meg 1918. január 8-án, az amerikai idealizmus jegyében elsỏ ízben tett kísérletet gyökeresen új alapokon álló liberális világrend kialakítására. A wilsoni elgondolások kantiánus szellemben születtek, amikor deklarálták a nemzetek szuverenitását és területi sérthetetlenségét. Követelték az annexió nélküli igazságos békét, a háború alatt megszállt területek kiürítését, a nemzeti önrendelkezést és a gyarmatokon élö lakosság érdekeinek figyelembe vételét. Kifejezésre juttatták a tengeri hajózás szabadságát és az akadályoktól mentes nemzetközi kereskedelem elvét. Javaslatot tettek egy nemzetek közösségét magába foglaló szervezet létrehozására, amely alkalmas a vitás kérdések békés rendezésére. A wilsoni törekvések újszerüsége nem abban állt, hogy az amerikaiak idealista módon álltak a nemzetközi viszonyokhoz, hanem inkább abban, hogy első ízben tettek kísérletet arra, hogy elképzeléseiket az egész világon érvényesítsék.

\subsubsection{A progresszivizmus és a New Deal}

A második ipari forradalom a 19. század utolsó harmadától az „indusztriális társadalom” kiépülését eredményezte, ami nagyban különbözött az első ipari forradalom kezdetleges gyári kapitalizmusától. A termelés megszervezése egyre nagyobb szerepet kapott a társadalmi viszonyok alakításában, sőt maguk a gyártási és termelési rendszerek is mind összetettebbé váltak. A megszülető városi-ipari tömegtársadalmak viszonyai egyre inkább befolyásolták a hétköznapi életvilágokat, és a terjeszkedő technikai civilizáció egyfajta „második természetként” mutatkozott meg. A nagyipari kapitalizmus emblematikus teoretikusának a német Max Webert (1864-1920) tekinthetjük, aki már nemcsak szabad vállalkozásról és laissez faire-ről beszélt, mint a klasszikus politikai gazdaságtan képviselői a 19. század első felében, hanem racionális gazdasági cselekvésről és bürokratikus államról. A modern kapitalista tömegtermelés kialakulását leíró többtényezős modellt vázolt fel, ahol a piac csak egyik tényezőként került szóba. Weber óta a (neo)klasszikus piacelméletek mellett számolnunk kell az ipari társadalom elméletekkel, amelyek a 
társadalomtudományos gondolkodás jelentős vonulatává nőtték ki magukat a 20. században. Jelzésértékü, hogy a második ipari forradalom következtében létrejött indusztriális társadalmak klasszikus esetének nem a nyugat-európai országok, hanem az Egyesült Államok tekinthető.

A második ipari forradalom következtében kialakuló városi tömegtársadalmak ellentmondásai újszerű társadalmi mozgalom kibontakozásához vezettek az USA-ban. A századfordulón a progresszív korszak sajátosan amerikai módon kívánt válaszolni a társadalmi és a politikai feszültségekre. Míg Európában az új demokratikus tömegpártok igyekeztek minél több képviselőt juttatni a parlamentbe, és a baloldal meghirdette a progresszív adózás és az államosítás programját, addig az Egyesült Államokban a progresszivizmus inkább civil mozgalomnak tekinthető, amely országos politikai szerepre is szert tett. Olyan nagy képességü elnökök azonosultak politikai célkitüzéseikkel, mint Theodore Roosevelt és Woodrow Wilson. A progresszívek helyi szinten az önkormányzatokban tapasztalható korrupcióval vették fel a harcot, és igyekeztek fellépni a monopóliumok, nagytőkés csoportok erősödő politikai befolyásával szemben. Támogatták a szövetségi szintü monopóliumellenes törvényhozást, a munkavállaló védelmét a munkaadóval szemben, a női választójogot és az oktatás kiterjesztését. A politikai részvétel kiszélesítésére irányuló elképzelései révén a progresszivizmus a jeffersoni örökség folytatásának tekinthető, de konkrét célkitüzéseire nagy hatást gyakorolt a 19. század utolsó évtizedeiben a frontier lezárulásából fakadó válsághangulat, valamint az a tény, hogy az Egyesült Államokban az iparvállalatok méretei és a tőkekoncentráció világviszonylatban is egyedülálló mérteket öltöttek. Sokan érezték úgy a századfordulón, hogy a „nemzet” nem jó irányba fejlődik, és a „lehetőségek hazájából” szük gazdasági érdekcsoportok országa lett, amelyek megvásárolják a politikai és a civil szférát.

A progresszivizmus arra törekedett, hogy visszaadja az amerikai alapértékekbe vetett hitet az indusztriális világ körülményei között, és helyreállítsa a széles részvételen alapuló kapitalizmus ethoszát, valamint kiterjessze az állampolgári és a szociális emancipáció esélyeit. A progresszívek meglehetősen tág alkalmi koalíciókat formáltak az országos és a helyi politikában egyaránt, megszerezve a városi középosztályok jelentős részének támogatását a korrupt gazdasági lobbikkal szemben. A „társadalmi evangélium” szellemében számos protestáns csoportosulás is felzárkózott mögéjük. A progresszivizmus egyik emblematikus alakjának John Dewey (1859-1952) tekinthető, akinek nevelésfilozófiája hozzájárult az iskolai oktatás reformjához. A pedagógiai pragmatizmus programjának meghirdetésével vissza kívánta szorítani a klasszikus nyelvek tanítását, és tanítványai kifejlesztették a gyakorlatias projekt-módszert. Pedagógiai nézetei révén Dewey az amerikai demokrácia modern apostola lett, aki haladáselvü gondolkodásmódjával erős 
hittel bízott a jobb jövőben. A progresszív korszak több területen megelőlegezte a New Deal intézkedéseit, de nem hirdette meg a jóléti állam programját, és csak laza kapcsolatban állt a századfordulós müvészeti modernséggel. Sajátosan „amerikai” jelenségnek tekinthetö, amikor az alkotmányos értékek tiszteletben tartásával a gazdasági és a szociális haladás mellett tört lándzsát, és ellentétben azokkal a populista farmer csoportokkal, akik agrárius nosztalgiával viszonyultak a „régi Amerikához” - vállalta a városi-ipari tömegtársadalmak problémáival való szembesülést.

Az 1920-as években a progresszív mozgalom vesztett lendületéből, másrészt célkitüzései részben megvalósultak. Az első világháború utáni évtized az amerikai történelem utolsó korszaka volt, amikor az Egyesült Államok polgárai még el tudták hinni, hogy a külvilág hatásait képesek országukon kívül tartani. Mindez nemcsak a wilsoni internacionalista elvek meghirdetése utáni izolacionista ellenhatásban fejeződött ki, hanem a bevándorlás korlátozásában és az idegenellenes nézetek felerősödésében. Pedig az 1920as évek markáns, bár hullámzó konjunktúra időszaka volt, ami lehetővé tette új munkaerő bevonását az iparba. A fordista-taylorista iparszervezési módszerekkel létrehozott rendkívüli méretü üzemek (economies of scale - méretgazdaságosság) ontották a tartós fogyasztási cikkeket - gépkocsi, háztartási eszközök -, és az átlagos amerikai család meg is tudta vásárolni azokat. A 1920-as években nemcsak az amerikai munkás reálbére ment keresztül komoly növekedésen, ami nagyobbrészt feloldotta a századfordulós társadalmi feszültségeket, hanem az Egyesült Államok ipari termelése elérte a világrészesedés mintegy 40 százalékát. Az 1920-as években bontakozott ki az egyre szélesebb fogyasztói középosztály, amely már a városi munkásság tekintélyes részét is magában foglalta. A kultúra fogyasztásának új szokásai alakultak ki, hiszen a háztartási gépek következtében a nők mindinkább meg tudták engedni maguknak az olvasást, mozilátogatást és a szórakozás egyéb formáit. Ebben a tekintetben az Egyesült Államok megelőzte Nyugat-Európát, ahol ugyanezek a fogyasztói szokások csak a második világháború után bontakoztak ki tömeges méretekben.

Az 1920-as évek egyfelől kiteljesítették az ipari-fogyasztói társadalom lehetőségeit, másfelől érvényben hagyták az régi (,,óliberális”) amerikai elveket a szabad vállalkozást illetően. Harding, Coolidge és Hoover republikánus elnökök egyaránt az állam korlátozott szerepét valló hagyományos felfogást képviselték. Jól érzékeltetik ezt a felfogást Calvin Coolidge elnök (19231929) nyilvános megszólalásai, aki a New Deal meghirdetése előtt néhány évvel összefoglalta a „régi” amerikai értékeket. Ezek a gondolatok az 1930-as évekbeli New Deal, majd az 1960-as évekbeli Great Society közötti időszakban idejét múltnak tüntek, és az 1980-as években Ronald Reagan elnöksége alatt tértek vissza eleven erővel a belpolitikába. 
„Egyetlen politikus sem képviselte olyan következetesen az amerikanizmus alapelveit, ... a kemény munkát, a mértékletességet, a lelkiismereti szabadságot, a kormányzati szabadságot... (mint Coolidge tette). 1925-ös újévi beszédének kulcsmondata volt: 'A gazdaságtan idealizmus a maga leggyakorlatibb formájában.' Ugyanebben az évben, november 19-én a New York-i kereskedelmi kamarához intézett üzenetében a laissez faire filozófia talán utolsó klasszikus állítását fogalmazta meg kristálytisztán és örökérvényüen. A kormányzatnak és az üzleti világnak mindig függetlennek kell maradnia, és szigorúan el kell különülnie egymástól. Nagyon fontos, hogy az egyiket Washingtonból, a másikat viszont New Yorkból irányitsák. Bölcs és körültekintö embereknek mindig fel kell lépniük a bitorlás ellen, amivel bármelyik oldal ostoba és mohó résztvevői megpróbálkozhatnak. Az üzlet a nyereség hajszolása, de morális küldetése is van: 'a társadalom kölcsönös, szervezett eröfeszitése annak érdekében, hogy elösegítse a civilizáció gazdasági feltételeinek létrehozását... Müködése szintisztán jogrendszeren nyugszik. A bizalom eléréséhez feltétlenül az egyenességnek, becsületességnek és jogszerüségnek kell jellemeznie. Tágabban értelmezve, a nemzet erkölcsi és szellemi tökéletesedésének egyik legnagyobb hatású húzóeleme’ Ez indokolja, hogy a kormány jogosult az üzleti világ sikereinek elömozditására azzal, hogy a biztonság keretein belül megteremti a piaci verseny feltételeit. Feladata, hogy gátat vessen a kiváltságok érvényesülésének, bárhol bukkannak is fel, és ne segítsen elö mindenféle rossz szándékú, jogszerü birtoklást azzal, hogy biztosítja számukra a jogorvoslatot. 'Bármilyen vagyon valódi értékének elsödleges eleme az a tudat, hogy annak felhötlen élvezete a közvélemény támogatását élvezi.' E nélkül a törvényes... védelem nélkül 'a hatalmas építmények darabokra hullanak, mint a régi Karthágó tengerparti birodalma...'Minél több üzleti vállalkozás szabályozza önmagát, annál kevésbé kell beavatkoznia a kormánynak a piaci verseny tisztessége érdekében. Annál inkább tud összpontositani a saját gazdasági feladataira, a nemzet szerkezetének formálására, amelyek keretein belül az üzleti világ növelheti a profitját és befektetéseit, béreket emelhet, és jobb minöségü termékeket és szolgáltatásokat nyújthat a lehetö legalacsonyabb árakon." (JoHnson, P. 2007, p. 247; 250)

Coolidge elveit olvasva megértjük, hogy elvbarátja és utóda az elnöki székben, Hoover miért vélte úgy a nagy gazdasági válság első éveiben, hogy az állami beavatkozás nem szükséges, hanem türelmesen meg kell várni a recesszió elmúlását. Sőt Hoover arról is meg volt győződve, ha a széles állami intervenció programját meghirdető Roosevelt és demokratái megnyerik az elnökválasztást, alapjaiban rombolják le az ,amerikanizmus” értékeit. Mégis, amikor az 1929-1933-as válság elmélyülésével Roosevelt elsöprő győzelmet aratott, és hozzákezdett elképzelései megvalósításához, egyetlen elnököt nem felejtett el olyan gyorsan az amerikai közvélemény, mint a nagy válság kezdetén tehetetlennek bizonyuló Hoovert. Az, ,amerikai értékek” doktriner érvényesítését felülírták a gazdasági válság anyagi és szociális szükségletei. 
Családja és müveltsége révén Franklin Delano Roosevelt elnök (19331945) akár az amerikai felső osztályok érdekeinek szószólójává is válhatott volna, mégis kivételes népszerüségü elnökként egy addig példa nélküli „forradalom” elindítója lett az Egyesült Államok történetében. Roosevelt inkább volt tettre kész és pragmatikus politikus és humanista, mint doktriner forradalmár, amikor arra törekedett, hogy az amerikai kisembert megmentse az éhségtől, az országot pedig kiragadja a kapitalizmus soha nem látott mélypontjából eredő összeomlástól. Saját értelmezése szerint Roosevelt Keyneshez hasonlóan - a szabadság és a „szabad társadalom” megmentésére és nem felszámolására törekedett, de ezt az érvelést politikai ellenfelei soha nem fogadták el. A radikális társadalompolitikai intézkedésekben a gazdasági laissez faire végét látták, ami - legalábbis kritikusai szerint - a polgári és a politikai szabadság szüküléséhez is vezethet. Rooseveltet a válság kivételes ereje tette a régi amerikai értékeket felülíró „,radikálissá”, bár saját felfogása szerint nem tett mást, mint széles részvételen nyugvó társadalommá akarta visszaváltoztatni az Egyesült Államokat, ahol az amerikai átlagember újra a lehetőségek hazájában érezheti magát. Ennyiben programja akár a jeffersoni örökség továbbviteleként is felfogható, bár az eredeti ideálokhoz képest jelentősen átalakult formában.

A Roosevelt-adminisztráció intervencionista intézkedései - az agrártámogatások, a társadalombiztosítás, a munkanélküli segélyek bevezetése, a bankok és a pénzügyi szektor szabályozása, munkaalkalmak teremtése stb. jól ismertek, és nincs szükség bemutatásukra. Vitatottabb téma az intézkedések hatékonysága és tudatossága. Kérdéses, hogy a válságból való kilábalás a New Deal következménye volt-e, avagy a piaci ciklus természetes mozgásáé, esetleg az 1940-es években felfutó hadikonjunktúráé. Az ortodox liberálisok túl radikálisnak, míg az újbaloldal (New Left) kevésnek tartotta a reformok társadalomalakító eredményeit. Ezeknél fontosabbnak bizonyult, hogy a New Deal a válság mélypontján nyújtott reményt és megélhetést, ami helyreállította a bizalmat az amerikai értékek és intézmények iránt. Az intézkedések az első években inkább gyakorlatias ötletek sorából álltak. Noha Keynes látogatást tett az amerikai vezetőknél, akik érdeklődéssel hallgatták nézeteit, csak az 1930-as évek utolsó harmadától beszélhetünk a tudatos keynesiánus gazdaságpolitikai gyakorlat kezdeteiröl.

Az 1940-es évek eleje fordulópontot hozott az amerikai makroökonómiai gondolkodás kialakulásában. Ekkortól beszélhetünk a nemzeti erőforrások felhasználását tervező, elemző csoportokés az országos statisztikák létrejöttéröl, amelyek nemcsak a második világháború alatti erőfeszítések optimalizálására törekedtek, hanem megteremtették azt a gazdaságpolitikai szemléletmódot és ökonometriai elemzési keretet, ami a keynesiánus közgazdászok egyeduralmához vezetett 1945 után a keleti partvidék egyetemein. Ennél is fontosabbnak bizonyult a New Deal közgondolkodásra gyakorolt hatása. Az 
amerikai állampolgár ettől fogva élete szerves részének tekintette az állam segítő jelenlétét szociális és jóléti ügyekben. E nézetek szívósságára utal, hogy a New Deal alapvető vívmányait a reagani gazdaságpolitika sem merte felszámolni az 1980-as években.

Roosevelt sikerei kiindulópontul szolgáltak az elkövetkező évtizedek „liberális progressziója” számára, ahol a szociális emancipáció szorosan összekapcsolódott az etatista megoldásokkal. A republikánus Coolidge konzervatívés, „óliberális” amerikanizmusával szemben Roosevelt gondolatainak újszerüsége világosan érzékelhető elnökjelöltként elmondott beszédében: „Minden embernek joga van az élethez..., s ez annyit jelent, hogy a kényelmes élethez is... Kormányzatunk, akár a hivatalos, akár a nem hivatalos, akár a gazdasági, akár a politikai... mindenkinek tartozik annyival, hogy lehetöséget adjon neki ahhoz, hogy a jólétböl, ipari társadalmunkból kanyaritson magának egy részt, amely kielégíti szükségleteit, méghozzá saját munkája révén." (Degler, C. N. 1993, p. 415.) Roosevelt elképzelése a jeffersoni demokrácia felfogásból táplálkozott, de túl is ment azon, mert nem pusztán a szélesebb politikai részvételt és az esélyek egyenlőségét, hanem a jólét elosztását helyezte gondolatmenete középpontjába.

\subsubsection{Amerikai civilizációs értékek a 20. század második felében}

A második világháború után Roosevelt utódja, Truman (1945-1953) a republikánusok megerősödő kongresszusi befolyása miatt a New Deal folytatásának nevezett Fair Dealt csak részben tudta keresztülvinni - a konzervatív kritika „lopakodó szocializmust” emlegetett -, de a demokraták hosszú évtizedekig megőrizték gazdaság- és társadalompolitikai kezdeményező szerepüket a közéletben. A második világháború után a demokrata kormányzás programja az Egyesült Államokban számos ponton hasonlóvá vált a nyugateurópai szociáldemokrata és szocialista pártok célkitüzéseihez, amennyiben a gazdasági laissez faire-rel szemben az erőteljesebb állami intervenció(keynesiánus etatizmus) elkerülhetetlenségéthirdette, másrésztazonosulta szociális-jólétiállam megteremtésének programjával, és később a „kulturális baloldal” értékrendjével. Azokat a politikusokat és szavazókat, akik a 20. században ezt a nézőpontot képviselték, liberálisoknak (liberals) hívják az Egyesült Államokban, míg velük szemben a korlátozott állam hívei a republikánusok közül kerültek ki, akiket konzervatívoknak (conservatives) nevez az amerikai szóhasználat. A „liberális” kifejezésnek a századforduló művészeti, majd 1968 kulturális modernsége adott új jelentést, míg a „konzervatív” szó arra utal, hogy a republikánus hagyományok magukba foglalják az alkotmány régi „óliberális” elveinek a védelmét, mint a szabad vállalkozás, a gazdasági laissez faire, a hatalommegosztás és a csekély hatáskörü szövetségi állam feltétlen tiszteletét. 
A „liberális” politikai közbeszéd nemcsak a jóléti programokat karolta fel, hanem a feketék emancipációs törekvéseit is, és támogatta, hogy a tőkés vállalkozók legyenek figyelemmel tevékenységük társadalmi költségeire. Ennyiben a demokraták a jeffersoni örökség továbbvivőinek is tekinthetők, mert a politikai és a szociális részvétel kiszélesítését akarták előmozdítani az amerikai kisember számára. További fontos szempont, amit a liberálisoknak és a konzervatívoknak egyaránt figyelembe kellett venniük, hogy az ipari társadalom kialakulása megváltoztatta a kapitalizmus eredeti természetét, ami a társadalomirányítás körülményeire is hatást gyakorolt. Nem véletlen, hogy a republikánusok által idealizált „kapitalista vállalkozó” hagyományos figurájához képest a demokraták nyitottabbak voltak a technokrata „társadalommérnök” (social engineering) tevékenysége iránt, sőt igényelték részvételüket a politikában.

Az 1945 utáni évtizedekben a demokraták kételyek nélkül elfogadták a New Deal örökségének folytatását. A republikánusok számára ugyanez csak bizonyos megszorításokkal volt lehetséges, de maguk is érzékelték, hogy a keynesiánus társadalommérnökség és a szociális juttatások programja olyan népszerüséggel bír, hogy a régi laissez faire elveit hirdetve nem lehetséges a választók bizalmát elnyerni. Ezért a republikánusok is alkalmazták a keynesi recepteket a gazdasági növekedés fenntartására, és nem nyúltak hozzá a jóléti állam alapvető vívmányaihoz, de - Eisenhower elnöksége (1953-1961) vagy a kongresszusi többség megszerzése esetén - igyekeztek megakadályozni a költségvetési újraelosztás mértékének növelését. Az Egyesült Államokban az „óliberális” hagyományok ereje miatt az állami szabályozás és a jóléti kiadások kiterjesztésének programja erősebb ellenállásba ütközött, mint a második világháború utáni Nyugat-Európában.

A demokraták szövetségi szabályozást, szociális államot és a hátrányos helyzetủ csoportok emancipációját hirdető programja a maga teljességében az 1960-as évek második felében bontakozott ki. Már Kennedy elnök (1961-1963) is hitet tett a Big Government mellett, amikor hangoztatta, hogy a kormányzati kompetenciák kiszélesítése nem feltétlenül jár negatív következményekkel, hanem a szövetségi kormány képes hatékonyan hozzájárulni az emberek problémáinak megoldásához. Utódja, Johnson (1963-1969) a Great Society programjának meghirdetésével ezen az úton haladt tovább, ami a nagyvállalatok tevékenységének szabályozását, a jóléti és az oktatási kiadások növelését, a szegénység elleni küzdelmet és a feketék polgárjogi mozgalmának a támogatását jelentette. Johnson arról híresült el, hogy ezeket a célokat a szövetségi hivatalok feladatainak és létszámának jelentős gyarapításával akarta elérni, és őszintén hitt abban, hogy a szövetségi bürokrácia intézkedései képesek célba érni a szociális kérdések területén. 
Johnson helyzetét megnehezítette, hogy elnöksége alatt az Egyesült Államok először szembesült gazdasági és hatalmi képességeinek korlátaival, valamint zavaros belpolitikai viszonyokkal, amelyeket az 1960-as évek második felének diákmozgalmai teremtettek. Két évtizeddel korábban, 1945ben az USA még a világ ipari termelésének felével és egyedülálló katonai képességekkel - az atombomba monopóliuma, kivételes méretű stratégiai légierö és hadiflotta - rendelkezett. Erre a gazdasági és hatalmi fölényre építve Roosevelt elnök kísérletet tett a második világháború utáni nemzetközi rend újjászervezésére. A roosevelti külpolitikai koncepció (Grand Design) a két világháború közötti izolacionizmus évtizedei után visszatérést hirdetett a wilsoni liberális idealizmushoz és a világméretü szerepvállalásához. Wilson elveit újragondolva Roosevelt és tanácsadói nemzetközi intézményi garanciákat akartak kialakítani a liberális világrend müködtetésére az ENSZ és szakosított szervei révén. Az 1945 utáni liberális internacionalizmus már több volt, mint elvek egyszerü foglalata, hiszen jól szervezett intézményi struktúrákkal rendelkezett.

Az Egyesült Államok a második világháború után nem tért vissza az izolacionizmushoz. Bár gazdasági és politikai érdekei - növekvő exportja, kiterjedt olajérdekeltségei - arra ösztönözték, hogy aktív külpolitikát folytasson, nemzetközi kötelezettségeit összhangba akarta hozni a liberális idealizmussal, azaz a „fáklya” szereppel. Világhatalmi szerepéből fakadóan olyan mennyiségü feladatot vállalt magára, hogy alig volt képes megfelelni azoknak az etikai elvárásoknak, amelyek az „amerikai küldetésből” fakadtak. A történészek nem véletlenül hangsúlyozzák, hogy az amerikai közvélemény szemében az USA 1945 utáni szerepvállalása miatt folyamatos volt a konfliktus a külpolitikai ideák és a nemzetközi hatalmi realitások között. Mivel az amerikai értékek a külpolitika területén „idealista” hozzáállást sugalltak, a közvélemény érzékenyen reagált, ha annak ellenkezőjével találkozott, ahogyan a vietnámi háború utóhatásaiban is megmutatkozott.

A második világháború utáni két évtizedben az Egyesült Államok még rendelkezett azokkal a gazdasági és katonai kapacitásokkal, amelyek lehetővé tették a szuperhatalmi szerep fenntartását. A koreai háború idején a szabad világ védelmében az USA határozott választ adott a kommunista blokk hatalmi törekvéseire. Amerika hatalma talán Eisenhower alatt volt a legnagyobb a bipoláris világban, amikor a „bekerítési félhold” megteremtése révén Japántól Törökországig szövetségesei sorával kötött megállapodásokat a Szovjetunió déli határain. Az 1950-es években több százezer katona állomásozott az USA-n kívül az amerikai érdekek védelmében.

Korlátlannak tűnő lehetőségei ellenére az Egyesült Államok feloldhatatlan ellentmondással szembesült a 20. század második felében, hiszen gazdasági erejének relatív csökkenése már a második világháború 
után megkezdődött. Bár ennek jelei csak az 1960-as évek derekától váltak láthatóvá, az USA mérsékeltebb gazdasági növekedést mutatott, mint NyugatEurópa, a szovjet blokk országai vagy Japán és a kelet-ázsiai országok. Az Egyesült Államok a 19-20. század fordulóján, az 1920-as évek végén és 1945-ben volt gazdasági teljesítőképessége csúcsán. A századelőn és a két világháború között izolacionista elveiből kifolyólag mégsem óhajtott jelentős nemzetközi kötelezettségeket vállalni. Ehhez képest gazdasági erejének mérséklődése a világméretü szerep, a Grand Design meghirdetésének a másnapján megfigyelhető volt.

Az 1960-as évek elején a Kennedy-adminisztráció jól érzékelte, hogy Nyugat-Európa újjáépülése és gyors gazdasági fejlődése következtében módosulóban vannak a nemzetközi gazdasági erőviszonyok. A világ közvéleményében az 1960-as évek derekától tudatosodott, hogy az amerikai gazdaság egyre komolyabb versenyképességi problémákkal küszködik. Mindez az amerikai GDP növekedési ütemének mérséklődésében és a külkereskedelmi mérleg hiányában is megmutatkozott. Johnson elnök épp akkor terhelte meg a Great Society kiadásaival a szövetségi költségvetést, amikor nagy szükség lett volna a vállalatokra nehezedő adóterhek csökkentésére. További problémákat hoztak felszínre a vietnámi háború 1960-as évek második felében tetőző hadikiadásai. A vietnámi háború nemcsak a hazai közvélemény számára vált vállalhatatlanná, hanem az USA népszerüsége világszerte is fogyatkozni kezdett. Az Egyesült Államok az 1970-es években az ENSZ-ben több ízben került a vádlottak padjára a fejlődő országok nyomására. Szokatlan helyzet volt ez egy olyan nagyhatalom számára, amely az ,amerikanizmus” értékei alapján meggyőződéssel állította, hogy nemzetközi ügyekben való részvétele csakis jót hozhat az egész világnak.

Az Egyesült Államok versenyképességi problémái éppúgy megnehezítették Johnson helyzetét, mint az 1960-as évek második felében kibontakozó egyetemi diákmozgalmak. A Great Society túlméretezettnek bizonyult a költségvetés számára, másfelől a New Left kevesellte a szegénység megszüntetésére tett erőfeszítéseket. A neomarxista és maoista hatások alatt álló diákszervezetek a vietnámi háborút határozott kritikával illették, ahol Johnson az USA „,arcát megőrizve” kísérelt meg kihátrálni a konfliktusból, ami legalábbis rövidtávon még nagyobb katonai eröfeszítéseket tett szükségessé. A liberálisok által felkarolt fekete polgárjogi mozgalom ezekben az években ért aktív szakaszába, és nem volt mentes a többségi társadalommal szembeni atrocitásoktól. A növekvő bel- és külpolitikai nehézségek vezettek oda, hogy Johnson a következö elnöki ciklusban már nem akarta jelöltetni magát. Visszavonulása ellenére a Great Society-vel kapcsolatos intézkedései kiváltották a republikánusok ellenszenvét. A konzervatívok mindenekelőtt 
Johnsont tették felelőssé az amerikai nagyhatalom hanyatlásáért. Egyrészt mert a hatalmas kormányzati kiadások révén gyengítette az amerikai gazdaság versenyképességét, ahelyett, hogy adócsökkentéssel előmozdította volna a vállalatok prosperitását, másrészt a vietnámi háborúban mutatott sikertelenség az USA nemzetközi megítélését is kikezdte, harmadrészt a demokraták által támogatott polgárjogi és szociális emancipáció kiengedte a társadalmi szelepeket. A szegények és a kisebbségi csoportok lázadása erőszakos formában a „fehér középosztály” (WASP) ellen irányult, ami a közrend felborulásával fenyegetett.

Az 1970-es években az Egyesült Államok újszerű nemzetközi problémákkal is szembesült. Az 1973-as olajválság nemcsak az amerikai gazdasági teljesítményre hatott kedvezőtlenül, hanem a külpolitika területén is megoldhatatlan helyzeteket eredményezett. Az USA-nak szembe kellett néznie azzal, hogy a kölcsönös függőségekkel (interdependencia) jellemezhető nemzetközi viszonyok világában már nem képes minden esetben hatékonyan befolyásolni az események alakulását. A Szovjetunióval szövetkezve a nemzetközi újbaloldal fenntartotta az Egyesült Államok „blokádját” a nemzetközi szervezetekben. Az Izraelt támogató amerikai külpolitika pedig az arab világban tette népszerütlenné. A gazdasági recesszió rossz hangulatú éveket hozott a belpolitikában. Nem meglepő, hogy a deklinizmus (= az USA hanyatlását hirdető szellemi irányzat) az 1970-es évek derekán már jelentős pozíciókkal rendelkezett az amerikai értelmiség soraiban, amikor az Egyesült Államok fennállásának kétszázadik évfordulóját ünnepelte.

A deklinisták tudatosították az amerikai nagyhatalom korlátait, és elemezték hanyatlásának okait, természetét. Mivel az 1973-as olajválság a gazdasági növekedés végét jelentette az egész világgazdaságban, ami jelentős aggodalmakat hozott felszínre, felfogásuk egyben világméretủ szellemi trendbe illeszkedett. Ebben az évtizedben Nyugat-Európában is számolni kellett az „europesszimizmus” megjelenésével, és a világgazdaság rendelkezésére álló természeti erőforrások korlátairól ekkor tette közzé első jelentéseit a Római Klub. A deklinizmus ennek a tágabb tendenciának az amerikai változatát jelentette, aminek fontos részét képezte a nagyhatalmi szerep válsága. Ebben a szellemi környezetben jelent meg a neokonzervatív kultúrkritika is, amely az amerikai értékek újrafogalmazására törekedett a konzervatív értékrend jegyében.

A New Deal megjelenésétől a demokraták erőterébe tartozó értelmiségiek és társadalommérnökök uralták az amerikai szellemi életet. Közös vonásuk volt, hogy hittek a társadalmi progresszió lehetőségében, a szociális emancipációt állami beavatkozás révén óhajtották elérni, és meg voltak győződve a Big Government előnyeiröl. Az amerikai politikai örökség 
jeffersoni ágára hivatkozva a népboldogítás sajátos változatát képviselték, amely alkalmazza az etatizmus eszköztárát. A konzervatívok egészen az 1960as évekig nem voltak képesek ütőképes szellemi fegyvertárat kialakítani velük szemben, hiszen a gazdasági növekedés lehetővé tette a szociális intézkedések kiterjesztését, ami rendkívül népszerü volt jelentős társadalmi rétegekben. A diákmozgalmak belpolitikai zavarai, az USA nagyhatalmi szerepének megbillenése és a nemzetközi versenyképességi problémák kellettek ahhoz, hogy a neokonzervatívok konzisztens nézeteket fogalmazzanak meg, amelyek helyeslésre találtak a republikánus politikai elit és a közvélemény széles köreiben.

A neokonzervatívok (Irving Kristol, Daniel Bell, stb.) az „eredeti” amerikai értékekhez való visszatérés szükségességét hirdették. Véleményük szerint az Egyesült Államok sikeres kapitalizmusa a WASP-osztályok vállalkozó szellemén nyugodott, amelynek a fiatal amerikai köztársaság politikai intézményei megfelelő keretet biztosítottak. A protestáns középosztályok a kapitalista felhalmozás elörevivői voltak, amit a szövetségi állam által garantált politikai szabadság tett lehetővé. A kialakuló kapitalizmus a vállalkozók érdemein nyugodott, hiszen az állam tartózkodott attól, hogy némelyeknek kedvezzen a gazdasági életben. A protestantizmus, mint vallási előfeltétel ennek hajtóerejévé vált, ami nemcsak a gazdasági fejlődést segítette elö, hanem meritokratikus kapitalizmust hozott létre. Ezért a sikeres vállalkozókat teljesítményük révén közmegbecsülés övezte. Ezek a vallási és szociokulturális tényezők az Egyesült Államokat a „lehetőségek hazájává” avatták.

A neokonzervatívok szerint az amerikai értékek „óliberális” vagy „konzervatív liberális” értelmezésével szemben a liberálisok az 1930as évektől egyre növelték az állami szerepvállalást, aminek romboló következményei lettek a társadalom egészére nézve. Egyrészt a jóléti kiadások csak emelkedő adókkal finanszírozhatók, amelyek elszívják az energiákat a sikeres amerikai kapitalizmus alapját képviselő vállalkozásoktól. Másrészt a növekvő redisztribúció károsan hatott a meritokratikus kapitalizmusra, mert anyagi javakhoz juttatta azokat is, akik nem mutattak fel egyéni teljesítményt. Harmadrészt az állami bürokrácia felduzzadása olyan szabályozási kultúra kialakulásához vezetett, ami hosszú távon a társadalmi pluralitás és a kulturális sokszínüség sérülését eredményezte.

A neokonzervatív kritika szerint az etatizmus elömozdította a homogenizációt, ami atomizációval járt és felbontotta a közösségi kötőerőket. Így legyengültek azok a kulturális természetü hajtóerők és motivációs mechanizmusok, amelyeken a hagyományos kapitalizmus sikere alapult. Jefferson és Jackson még széles részvételen alapuló kapitalizmusban hittek, amikor a népuralom kiterjesztésére törekedtek. Azonban a demokraták a 20. 
század második felében új értelmezést adtak a társadalmi progressziónak. Az esélyekben való egyenlő részesedés helyett az anyagi egyenlősítést állították a középpontba, szellemi értelemben pedig átvették az 1968-as kulturális baloldal álláspontját, ami értékrelativizmust hirdetett. A neokonzervatív kritika egyszerre vélte felismerni a gazdaság hanyatlásának okait, valamint kifogásolta a kulturális hajtóerők meggyengítését.

A neokonzervatív nézetek az 1980-as évek elejétől a republikánus érvrendszer mértékadó elemévé váltak, aminek kipróbálására Ronald Reagan elnök (1981-1989) hatalomra kerülésével került sor. Reagan egyszerre törekedett az amerikai nagyhatalmiság helyreállítására és az USA gazdasági teljesítményének növelésére. Ezt adócsökkentésen és dereguláción keresztül kívánta elérni. A Reagan-korszak külpolitikailag sikeresnek tekinthető, hiszen az Egyesült Államok végül megnyerte a hidegháborút, és világszerte megerősítette az amerikai tekintélyt. Gazdaság- és társadalompolitikai szempontból azonban vegyes következményekkel járt.

A Big Government visszaszorítása összhangban állt az „óliberális” elvekkel, a városi középosztályok és a farmerek igényeivel. Ennyiben az „eredeti” amerikai értékekhez való visszatérésnek tekinthető. Kezdettől fogva vitákat gerjesztett, hogy a biztosítási rendszer piaci irányú átalakítása sokak számára felidézte a színvonalas egészségügyi ellátásból való kiszorulás veszélyét. Reagan szerencséjére az 1980-as évek közepétől gazdasági fellendülés következett be, de annak hozadéka nem terült szét egyenletesen az egész társadalomban. A gazdagabb és a szegényebb rétegek közötti jövedelemkülönbségek nem csökkentek, sőt inkább növekedtek. A pénzügyi rendszer deregulációja következtében a megélénkülő tőzsdei aktivitás jelentős vagyonok felhalmozódásához járult hozzá valódi teljesítmények nélkül, ami a születő globális újkapitalizmus ellentmondásos természetére hívta fel a figyelmet.

Az 1980-as években az Egyesült Államok hatalmas elörelépést tett a versenyképes high tech ágazatok irányába, de nehéz eldönteni, hogy a szövetségi kormány adócsökkentő programja, vagy a „kis hidegháború” alatt megnövekedő katonai kiadások mozdították elő a struktúraváltást. A magánszektor nagy szövetségi megrendeléseket kapott a katonai fejlesztések terén, ami kedvezően hatott a müszaki fejlödésre. Az adócsökkentést és a nagyarányú fegyverkezést nem lehetett sikerrel folytatni egyidejüleg, ezért az Egyesült Államok a Reagankorszakban óriási adósságot halmozott fel. Az 1980-as évek mérlegét megvonva a külpolitikai teljesítmények nyilvánvalóak, de a gazdasági eredmények és társadalmi következményei ellentmondásosak. Kérdéses, hogy a Reagankormányzat gazdaságpolitikája valóban annyira forradalminak tekinthető-e, ahogyan azt a republikánusok hangsúlyozták, hiszen a költségvetési újraelosztás radikális visszaszorítására nem került sor. 
A Reagan-korszak napjainkig kijelöli az amerikai társadalomban zajló közéleti viták irányát. Nagyobb részük szorosan összefügg az amerikai civilizációs értékek értelmezésével. A hidegháború megnyerésével az Egyesült Államok, mint szuperhatalom egyedül maradt a nemzetközi porondon. Ezt a helyzetet a neves újságíró és politikai elemző Krauthammer „unipoláris pillanatnak” (unipolar moment) nevezte. Érvelését Fukuyama helyezte tágabb kontextusba A történelem vége és az utolsó ember (1992) címü nevezetes könyvében, amikor arra a következtetésre jutott, hogy a hidegháború végével a liberális demokráciáknak nincs alternatívája, és visszavonhatatlanul el fognak terjedni az egész világon. Mindkét gondolat jól érzékelteti az amerikai külpolitikai körök optimizmusát az USA lehetőségeivel és esetleges „fáklya” szerepével kapcsolatban az 1990-es évek elején. Az ezredfordulótól azonban egyre jobban érzékelhetővé váltak azok a nemzetközi változások, amelyek napjainkra egyértelművé tették, hogy az USA lassú térvesztése visszavonhatatlanul folytatódik, és multipoláris rendszer van kialakulóban.

A nemzetközi rendszer felemelkedő hatalmaival szemben legfeljebb az USA „relatív hanyatlásáról” beszélhetünk. Kétségtelen, hogy az amerikai gazdaság dinamizmusa ellenére ingadozó teljesítményt mutatott fel az elmúlt három évtizedben. A közelmúltban éppúgy érzékelhető a megújulóképesség érvényesülése, ahogyan strukturális gyengeségekkel is találkozunk. Az amerikai gazdaság kivételes innovációs potenciállal rendelkezik, de egyre jobban függ a külföldi erőforrásoktól. Az amerikai hanyatlás jövőbeli gyorsasága éppúgy nem jósolható meg pontosan, mint a vetélytársak felemelkedésének üteme. Az Egyesült Államoknak hozzá kell szoknia ahhoz, hogy egyre kevésbé alakítja környezetét, és nagyban függ a világban zajló folyamatoktól. Mivel 1945 óta a szuperhatalmi szerep és az „amerikai értékek” univerzalitásába vetett hit szorosan kapcsolódik egymáshoz, és az amerikai identitás szerves részévé vált, nem kizárt, hogy az USA nemzetközi térvesztése traumatizálhatja az amerikai nemzettudatot. A történelmi hagyományokra támaszkodva ez éppúgy vezethet izolacionista reakciókhoz, mint aránytévesztéshez a nagyhatalmi szerepvállalás erőltetésében.

Az „amerikai értékek” belpolitikailag is sokrétü nyomás alá kerültek. Egyrészt jól érzékelhető, hogy a Reagan-korszak „kaszinókapitalizmusa” rányomta a bélyegét az 1990-es évekre is, ahogy arra a neves közgazdász Stiglitz is felhívta a figyelmet tanulmányaiban. Az amerikai pénzügyi rendszer szabályozatlansága és hektikus müködése komoly kockázati tényező a társadalom egésze számára. Szintén problémát jelent a középosztályok lassú eróziója, a jövedelemkülönbségek növekedése, a közéleti procedúrák kiüresedése és a demokrácia „oligarchizálódása”. Ezek a tendenciák a 
széles részvételen alapuló kapitalizmus válságára hívják fel a figyelmet, ami az Egyesült Államok kétszáz éves története során az „amerikai értékek” (,,American dream”) alapját képezte.

Végül utalni kell arra is, hogy a konzervatívok és a liberálisok között elmélyülő konfliktus a Reagan-korszak óta feloldhatatlanak látszik. A republikánusok éppúgy az amerikai hagyomány sajátos értelmezését alakították ki, mint a demokraták. Ma azonban nemcsak arról van szó, hogy az előbbiek a The Federalist, az utóbbiak pedig a jeffersoni elvek alapján érvelnek. 1968 és a Great Society óta az etatizmus, a progresszivizmus és a kulturális baloldaliság szoros egységet képez, és minden területen szembenáll a neokonzervatívok és szövetségeseik által kialakított értékrenddel. Bár egy demokráciában természetes jelenség a vélemények pluralizmusa, manapság a nézetkülönbségek akkorák, hogy állóháborúvá alakítják az amerikai belpolitikát, és ellehetetlenítik azt a minimális konszenzust, ami az intézményrendszer müködőképességéhez szükséges.

Az amerikai függetlenség hajnalán Jefferson elvállalta az elnöki tisztet, noha elképzelései kevéssé érvényesültek a föderalista alkotmányban. Tehette, mert az alapvető kérdésekről, a népuralomról, a szabadságról és az állampolgári jogokról ugyanazt gondolta, mint politikai vitapartnerei. Az „alapító atyák” nézetkülönbségeik ellenére is hasonlóan vélekedtek a lényeges értékekröl, ami az amerikai demokrácia fundamentuma lett. Kérdéses, mi maradt mára ebből a konszenzusból, valamint a minimális egyetértés hiányában meddig működőképes az USA politikai berendezkedése. Az amerikai demokráciának nemcsak a gazdasági teljesítőképesség és a külpolitikai erő problémáira, hanem ezekre a kérdésekre is választ kell adnia, ha meg akarja őrizni vonzerejét a világ népei számára. Az Egyesült Államok története során több krízist élt át, amikor az amerikai értékek válsága fenyegetett, és képes volt jól reagálni a kihívásokra. Bízni lehet abban, hogy az amerikai társadalom megújulásra való képessége, ahogyan a múltban, most is átsegíti az országot a felmerülö nehézségeken. 


\subsubsection{Időrendi tábla}

\begin{tabular}{|c|c|}
\hline dátum & esemény \\
\hline 1492 & Kolumbusz felfedezi Amerikát \\
\hline 1763 & A franciák elvesztik a hétéves háborúban Kanadát \\
\hline 1773 & Bostoni teadélután \\
\hline 1776 & A Függetlenségi Nyilatkozat \\
\hline 1783 & A párizsi békével véget ér a függetlenségi háború \\
\hline $1789-1797$ & George Washington az USA első elnöke \\
\hline 1803 & Napóleon eladja Louisiana-t az USA-nak \\
\hline $1829-1837$ & Andrew Jackson elnöksége \\
\hline 1850 & Kalifornia az USA állama \\
\hline $1861-1865$ & Abraham Lincoln elnöksége \\
\hline 1861-1865 & Az amerikai polgárháború \\
\hline 1867 & Oroszország eladja Alaszkát az USA-nak \\
\hline 1869 & Elkészül az első transzkontinentális vasútvonal \\
\hline 1898 & A Spanyolország elleni háború kezdete \\
\hline 1901-1909 & Theodore Roosevelt elnöksége \\
\hline 1913-1921 & Woodrow Wilson elnöksége \\
\hline 1914 & Panama-csatorna megnyitása \\
\hline 1917 & Az USA belép az első világháborúba \\
\hline $1923-1929$ & Calvin Coolidge elnöksége \\
\hline 1929 & A tőzsde fekete péntekje, a gazdasági világválság kezdete \\
\hline $1933-1945$ & Franklin Delano Roosevelt elnöksége \\
\hline 1933 & A New Deal gazdasági program kezdete \\
\hline 1941 & Az USA belép a második világháborúba Pearl Harbour után \\
\hline 1945 & A második világháború vége, Hiroshima és Nagaszaki \\
\hline $1945-1953$ & Harry Truman elnöksége \\
\hline 1947 & A Nyugat-Európát megsegíteni hivatott Marshall-terv kezdete \\
\hline $1950-1953$ & A koreai háború \\
\hline 1953-1961 & Dwight Eisenhower elnöksége \\
\hline $1961-1963$ & John Kennedy elnöksége \\
\hline 1963-1969 & Lyndon Johnson elnöksége, a Great Society programja \\
\hline $1981-1989$ & Ronald Reagan elnöksége, az USA „megnyeri” a hidegháborút \\
\hline 1991 & Az első Öböl-háborúban USA legyőzi Irakot \\
\hline 2001 & Szeptember 11, a World Trade Center lerombolása \\
\hline $2009-2017$ & Obama az USA 44. elnöke, az első fekete elnök \\
\hline
\end{tabular}




\subsubsection{Irodalomjegyzék}

Ajánlott irodalom

Arendt, Hannah 1991: A forradalom. Budapest: Európa

Degler, Carl, N. 1993: Az élő múlt. Milyen erők formálták Amerika mai képét? Budapest: Európa

Friedman, Benjamin, M. 2010: Jólét és erkölcsösség. Budapest: Napvilág Jay, John - Hamilton, Alexander - Madison, James 1998: A föderalista. Budapest: Európa

Magyarics TAMÁs 2014: Az Egyesült Államok külpolitikájának története. Budapest: Antall József Tudásközpont

Stiglitz, JosePh, E. 2005: A viharos kilencvenes évek. Budapest: Napvilág TocQueville, Alexis 1993: Az amerikai demokrácia. Budapest: Európa

További irodalom

Adams, James, T. 2012: The Epic of America. New Brunswick, London: Transaction Publishers

Hofstadter, Richard 1955: The Age of Reform. New York: Alfred A. Knopf Hofstadter, Richard 1973: The American Political Tradition and the Man Who Made It. New York: Vintage Books

Johnson, Paul 2007: A modern kor. A huszadik század igazi arca. Budapest: XX. Század Intézet

Kennedy, Paul 1992: A nagyhatalmak tündöklése és bukása. Budapest: Akadémiai Kiadó

Kristol, Irving 1972: On the Democratic Idea in America. New York: Harper and Row

Lind Michael 1995: The Next American Nation. New York: Simon and Schuster

Lind, Michael 2012: Land of Promise, An Economic History of the United States. New York: Harper Collins

Macfarlane, Alan 1978: The Origins of English Individualism: The Family, Property and Social Transition. Oxford: Blackwell

SCHLEsinger Arthur M. 2003: The Coming of the New Deal: 1933-1935. New York: Houghton Mifflin Harcourt

Steinfels, Peter 2013: The Neoconservatives. New York: Simon and Schuster TuRner Fredrerick J. 1921: The Frontier in American History. New York: Henry Holt and Company

Zakaria, Fareed 2003: The Future of Freedom. New York: W. W. Norton and Company 


\title{
7.2. Latin-Amrika: civilizációk kölcsönhatásos rendszere
}

\author{
LEHOCZKI BERNADETT
}

\subsubsection{Bevezetés}

A latin-amerikai civilizációval kapcsolatos legfőbb dilemma abból ered, hogy amit ma Latin-Amerikának nevezünk (az amerikai kontinens újlatin nyelveket beszélő területei), az valójában nem más, mint három civilizáció találkozásának, összefonódásának, több évszázados kölcsönhatásának az eredménye. A Kolumbusz Kristóf (megh. 1506) vezette, ill. az ő nyomában a térségbe jött európai konkvisztádorok megérkezésekor, a bennszülöttekkel való találkozásuk „pillanatában” született meg Latin-Amerika, és terjedt ki (földrajzilag) a következő évszázadokban az európaiak benyomulásával a szubkontinensre. Meg kell ugyanakkor jegyezni, hogy Dél-Amerika geológiailag önálló kontinens, ellentétben pl. Indiával, amely vitathatatlanul Ázsia része.

Latin-Amerika határai máig változóban vannak, gondoljunk az Egyesült Államok déli területeinek államaira, amelyek az 1846-48 közötti mexikóiamerikai háború lezárultával kerültek az USA birtokába. Az így megszerzett területek lakossága már akkor is a spanyol nyelvet és/vagy az őshonos indián nyelveket használta. Akkortól beszélhetünk azonban a térségben az angol térnyeréséről, amely folyamat egyik eredménye a chicano (angol-spanyolnahuatl keverék) nyelv kialakulása, amelyet Spanlish-nek is neveznek, s amelynek önálló irodalma is van. A 20-21. században pedig beszélhetünk az USA további államainak hispanizációjáról. Az európai - spanyol és portugál hódítók érkezése előtt tehát nem létezett Latin-Amerika, a két világ találkozása hozta azt létre, majd az Afrikából behurcolt fekete rabszolgák milliói tovább színesítették Latin-Amerika jellegét, újabb dimenzióként léptek be az őslakosok és a fehérek alkotta együttélésbe.

A latin-amerikai civilizáció fontos sajátossága tehát, hogy nem tekinthető olyan „eredeti” civilizációnak, mint a nyugati, az iszlám vagy a kínai civilizáció, amelyek ugyan szintén fontos belső heterogenitást mutat(hat)nak, mégis közös gyökerekkel, vallással, értékrenddel rendelkeznek. A kérdés tehát az, létrejöhet-e „új” civilizáció korábban párhuzamosan, egymástól szeparáltan fejlődő civilizációk összetalálkozásából, immár több évszázados együttéléséből? És ha létrejöhet, megtörtént-e Latin-Amerikában? Valódi, ,,közös civilizációról” van szó, vagy pedig egyfajta speciális, hibrid rendszerröl, amelyben továbbra is minimális integrációban, inkább egymás mellett, nehezen oldódó társadalmi hierarchiában élnek az „eredeti” civilizációk tagjai? Tekinthető-e ugyanazon civilizáció tagjának 
a spanyol, olasz és német felmenőkkel rendelkező Buenos Aires-i bankár, a Sao Paolo környéki nyomorváros fekete cipőtisztítója és a Guatemala vidéki területein élő maja indián? Mi az, ami a latin-amerikaiságot adja, melyek a régió lakosságát egységbe rendező, összefüző kapcsok? Léteznek-e egyáltalán ilyenek, és ezek léte elégséges-e ahhoz, hogy latin-amerikai civilizációról beszéljünk?

Civilizációs szempontból fontos kérdés, hogy a történészek által LatinAmerikához sorolt 20 országot értjük az elnevezés alatt, vagy pedig ide soroljuk az Egyesült Államok határától Délre fekvő területek összességét; ily módon az angol és holland nyelvü közép-amerikai, illetve karibi területeket is ide tartozónak tekintve. A két értelmezés „különbségét adó területek” nem csak nyelvileg mutatnak eltérő vonásokat, ennél fontosabb különbség, hogy az említett angol és holland nyelvü területek csupán a 20. század második felében függetlenedtek, és a volt gyarmattartókhoz fúződő szorosabb politikai-gazdasági kötelékek más fejlődési pályára állították ezeket a területeket. Civilizációs szempontból érdekes kérdés az ő „hovatartozásuk”, de jelen fejezet fókuszán ez túlmutat, így alapvetően a történelmi értelemben vett Latin-Amerikával foglalkozom.

A térség neve, Latin-Amerika, egyértelmủen az európai gyarmati múltat idézi, nem veszi számba a bennszülött örökséget, illetve a fekete rabszolgák kultúrájának hatását, amelyek egyaránt fontos szerepet játszottak a mai LatinAmerika kialakításában, kulturális sajátosságainak összeérésében. Éltek ugyan alternatív - egyébként hasonlóan egyoldalú és pontatlan - elnevezések (IndoAmerika, Afro-Amerika, Ibero-Amerika, Ibero-Indo-Amerika), végül - francia(!) segédlettel - a Latin-Amerika kifejezés maradt fent és terjedt el a köztudatban.

ALatin-Amerika kifejezés egyoldalúsága, határozottEurópa-centrikusságajól mutatja a térség történelmi fejlődésének egyik legfőbb kihívását, a függetlenség óta rendszeresen visszatérő dilemmát: az európai, nyugati út követése a helyes, ez adja a felzárkózás garanciáját vagy valamifajta latin-amerikai modell „feltalálása” lenne célra vezető? A latin-amerikai politikai-gazdasági fejlődés visszatérő kerékkötője, hogy a kreol politikai-gazdasági elit tagjai a térséget nyugatinak, európainak vélik (erre utal egyébként a Latin-Amerika kifejezés is), nem veszik figyelembe a nemnyugati, ha úgy tetszik, premodern elemek, struktúrák továbbélését, és ehhez a feltevéshez igazítják a modernizációs stratégiákat is. Ebből persze az a kérdés is adódik, hogy értelmezhetö-e Latin-Amerika, az Egyesült Államokhoz hasonlóan, a nyugati civilizáció alrendszereként? Vagy ez csupán a kreol elitek vágyálma? Hogy a fentiekre választ találjak, vagy legalábbis felvázolhassam a latin-amerikai civilizáció legfőbb sajátosságait, és elhelyezzem a világ más civilizációi alkotta rendszerben, a következőkben a latin-amerikai térség nyelvi, etnikai, vallási jellegzetességeit veszem számba. Ezt követően a latin-amerikai civilizáció történetének legfőbb mérföldköveit ismertetem, az európaiak érkezésétől a 19. század végéig, végül azt igyekszem körüljárni, a 20. században Latin-Amerika civilizációs szempontból az egység, avagy a diverzitás irányába látszik elmozdulni? 


\subsubsection{A Kolumbusz előtti kultúrák}

$\mathrm{Az}$ amerikai kontinens benépesítését illetően a történelemtudomány sokáig nem alakított ki egységes álláspontot, de mára bebizonyosodott, hogy a kontinens benépesítésére nagyrészt a Wisconsin jégkorszak (i. e. 40000-7000) alatt került sor, amikor a Bering-szoros kb. 90 km-es száraz átjárót nyújtott Amerika és Ázsia között.

A Kolumbusz elötti Közép- és Dél-Amerika történelme négy nagy korszakra osztható: archaikus (i. e. 7000-2500), preklasszikus (i. e. 2500 -i. sz. 1), klasszikus (i. sz. 1-1000) és posztklasszikus (i. sz. 1000-1500) periódusra. $\mathrm{Az}$ archaikus kor végén jelentek meg az első falvak, amelyek a letelepedett életforma újdonságát hordozták, majd a preklasszikus korban a törzsi szerveződés és a mezőgazdaság alapú falusi életmód lett elterjedt Közép-Amerikában és az Andok térségében (37. térkép). A klasszikus korban ezen két pólus erősödésével már uralkodó által igazgatott entitásokat látunk, városok és kőből emelt szakrális központok épültek (81. kép). Mind gyakoribbá vált a háborúskodás, a katonák társadalmi státusza erősödött, megjelentek a birodalomépítés első csírái. A posztklasszikus korról tudunk a legtöbbet, mivel ezt a korszakot a spanyol hódítók érkezése zárja. E korszak legfőbb újítása a hatalom centralizálása, a megjelenő birodalmak háborúskodás útján történő területi növekedése és a korábbiakhoz képest erősebb társadalmi rétegződés volt.

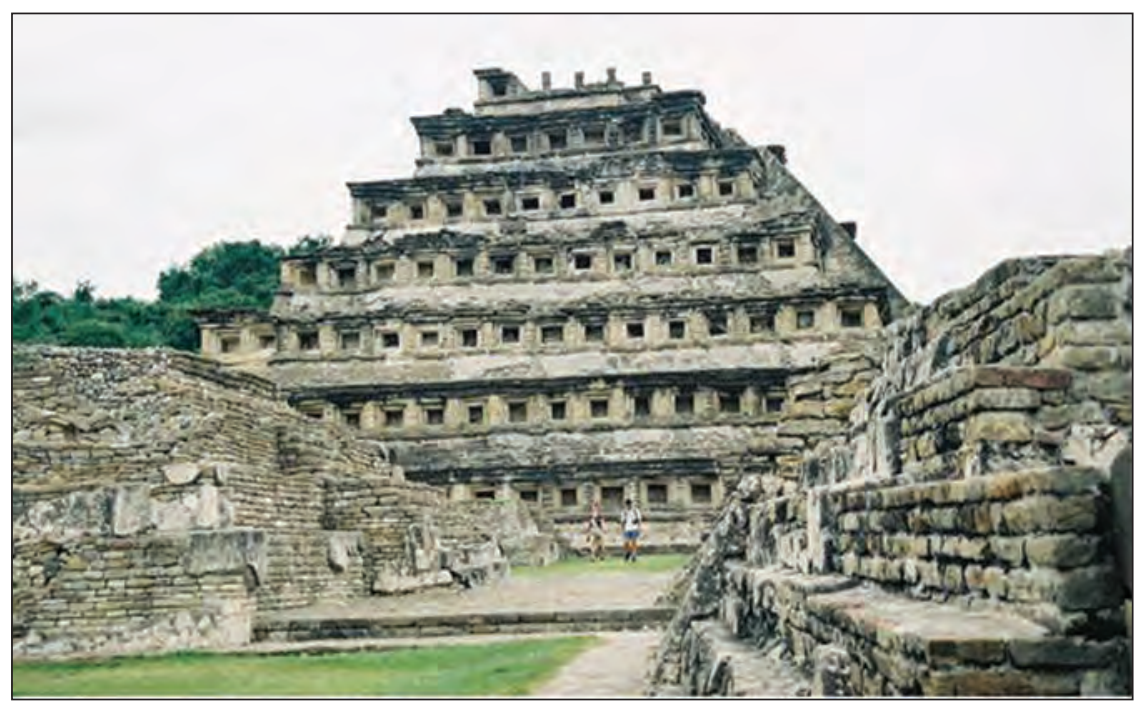

81. kép: A fülkék piramisa, El Tajín (Veracruz, Mexikó). Az eredetileg preklasszikus kori település 4. században épült, maja hatást tükröző piramisa

Forrás: Csicsmann LászLó felvétele 
Civilizációk Kelettôl Nyugatig

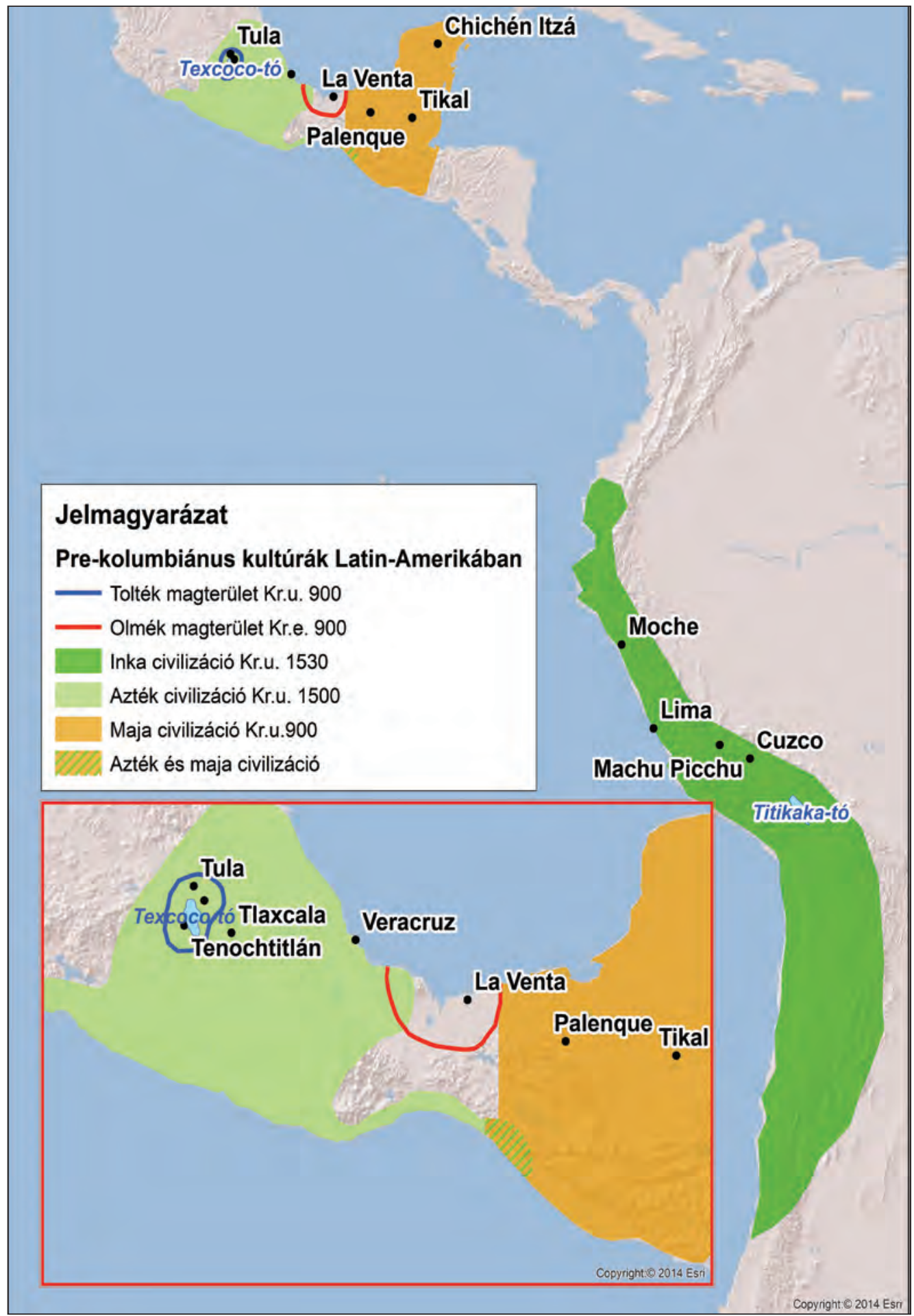

37. térkép: A Kolumbusz előtti főbb kultúrák elhelyezkedése Forrás: VARGa ÁGnes szerkesztése 


\section{Olmékok}

A preklasszikus korban (i. e. 1500-400 között) a Mexikói-öböl partján élt nép már kereskedni tudott az élelmiszerfelesleggel és az általuk készített tárgyakkal. Ezért kézmüiparuk tárgyai egész Közép-Amerika területén elterjedtek (82. kép). Köeszközöket használtak hatalmas épületek, közöttük piramisok emelésére. Uralkodóik képmását nagy méretű bazaltfejekben örökítették meg. Kultúrájuk hatott az őket követő maja kultúrára. Hanyatlásuk oka máig ismeretlen.

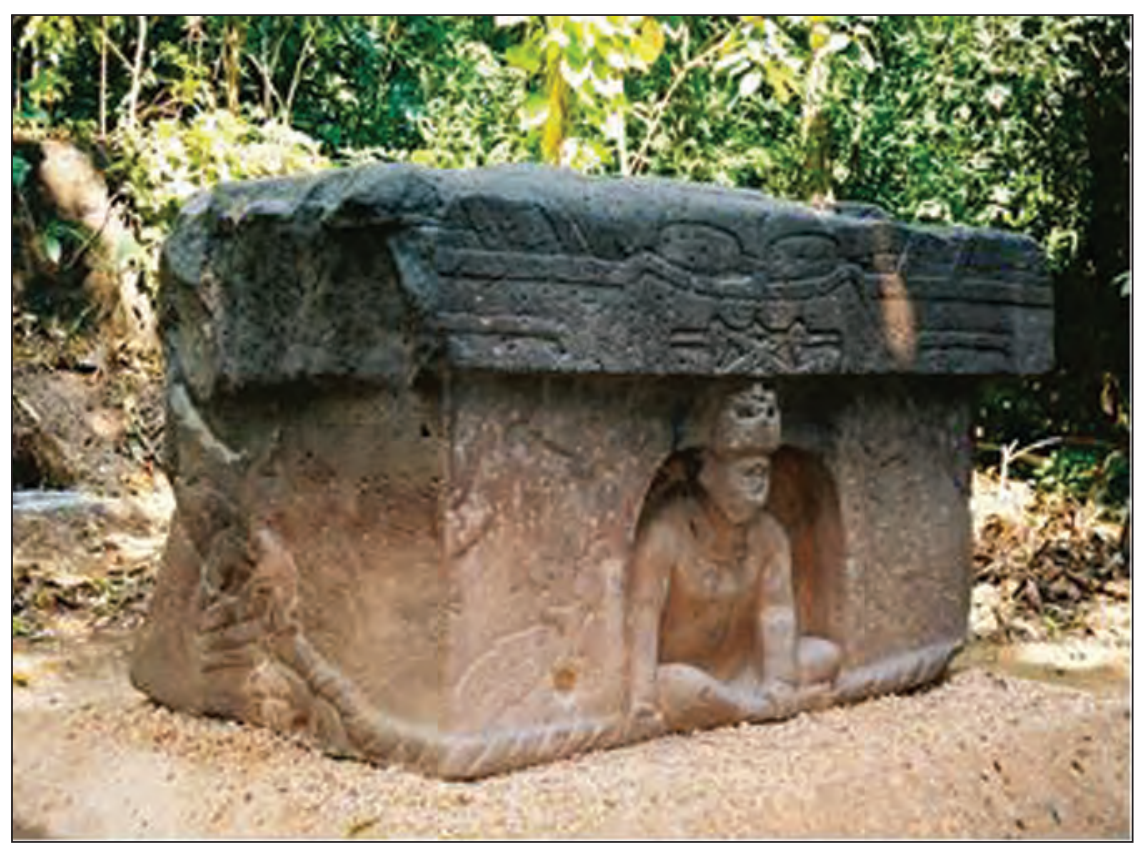

82. kép: Olmék oltár (La Venta, Tabasco, Mexikó)

Forrás: Csicsmann LászLó felvétele

\section{Maják}

A mai Mexikó déli területein, illetve Guatemala, Belize, Honduras és Salvador területén alakult ki a maja civilizáció, amelynek egyik jellegzetessége, hogy fennállása végig húzódott a klasszikus és posztklasszikus koron is. Szemben a többi posztklasszikus kultúrával a maják nem építettek központosított birodalmat, inkább intenzív kereskedelmi kapcsolatot ápoló városok összességéről van szó. A maják kiemelkedő matematikai és csillagászati ismereteikről, valamint monumentális építészetükről, piramisaikról híresek (83 -84. kép). Naptárrendszerüket és hieroglif írásukat több ún. mezo-amerikai kultúra is átvette. Arra ugyan nem jöttek rá, hogy a Föld kering a Nap körül, de 
ki tudták számolni a Hold és a Vénusz ciklusait, emellett a papok által készített táblázatok segítségével tudták, mikor lesz napfogyatkozás. Világképük ciklikus volt (52 éves periódusokban gondolkodtak), ezért is hittek a ciklus végén egy újabb ciklus kezdetében, illetve a világ végének eljövetelében.

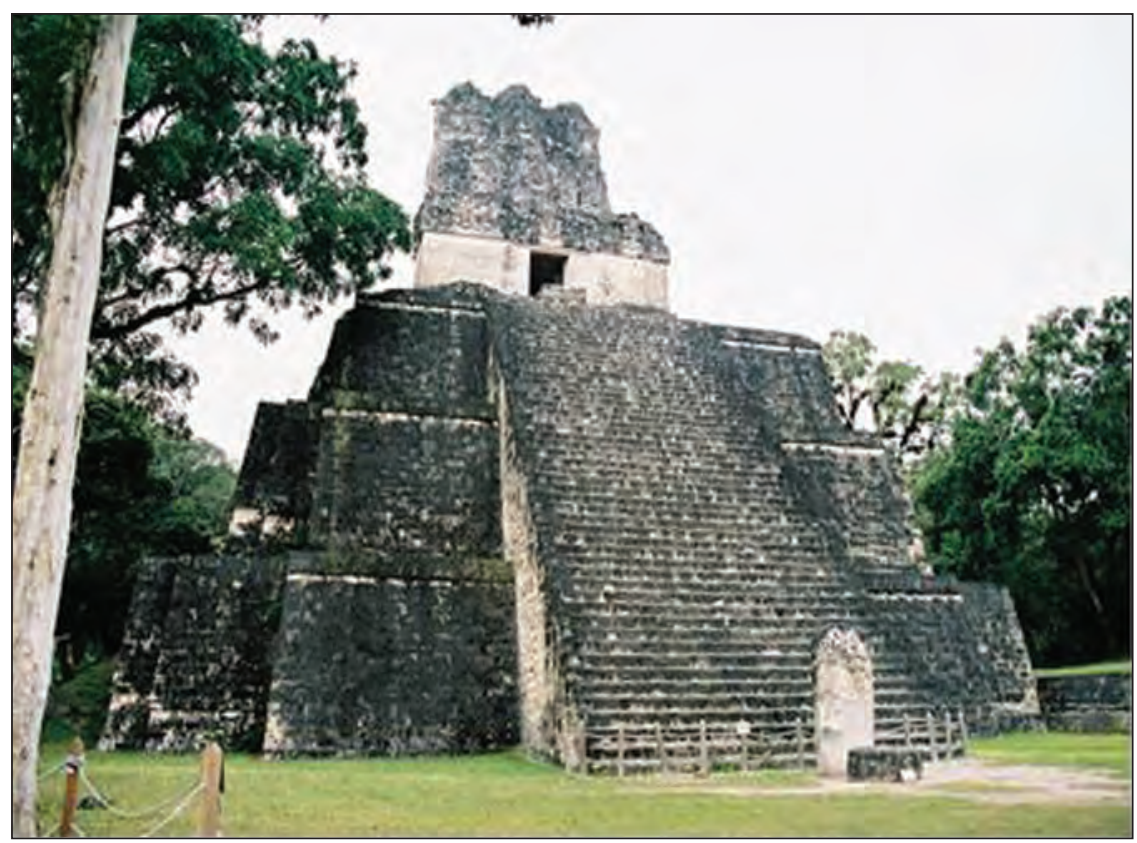

83. kép: Lépcsős piramis Tikalban (Guatemala), a maja civilizáció legnagyobb városában Forrás: Csicsmann LászLó felvétele

Aztékok

A maja területektől Északra, a mai Mexikó területén épült fel az Azték Birodalom, az 1428-ban Tenochtitlán (a mai Mexikóváros), Texcoco és Tlacopán városai között köttetett ún. Hármas szövetségböl. A meglehetősen gyors területi terjeszkedés adta a birodalom alapját a következő évtizedekben és az aztékok a térség rettegett uraivá váltak. Az azték uralom a leigázott népek adóztatására és munkára fogására épült, a meghódított területeket a központhoz lojális azték nemesek között osztották szét. Igen jól szervezett, strukturált társadalom volt az azték, a fennálló rendet társadalmi hierarchia és szigorú törvénykezés garantálta. Az elmúlt évszázadokban sok vitára adott okot és a spanyolokkal való találkozásra is kihatott, sőt közvetett módon a későbbi gyarmatosítás jellegét is befolyásolta az azték hitvilág. A térségben általános többistenhit volt itt is meghatározó, mára százhúsznál is több azték istenséget ismerünk, ám ezek attribútumai, a közöttük húzódó viszonyrendszer igen komplex, máig nem teljesen feltárt. A nagyszámú azték emberáldozatok vallási, kulturális, 
politikai és gazdasági hátterét évszázadokig komoly vita övezte és máig sincsen konszenzus ezek valódi motivációiról. Annyi azonban bizonyos, hogy az érkező spanyolok számára védhetetlen, barbár cselekedet volt az aztékok által rendszeresen gyakorolt ún. szíváldozat - amikor az áldozat fejét levágták, majd a szivét kivették és az isteneknek ajánlották. Amikor 1519-ben Hernán Cortés partra szállt a Mexikói-öbölben, az Azték Birodalom dicsőségének csúcsán állt, sőt még terjeszkedett is. Ennek ellenére 1521-re a birodalom összeomlott, Tenochtitlán romokban hevert.

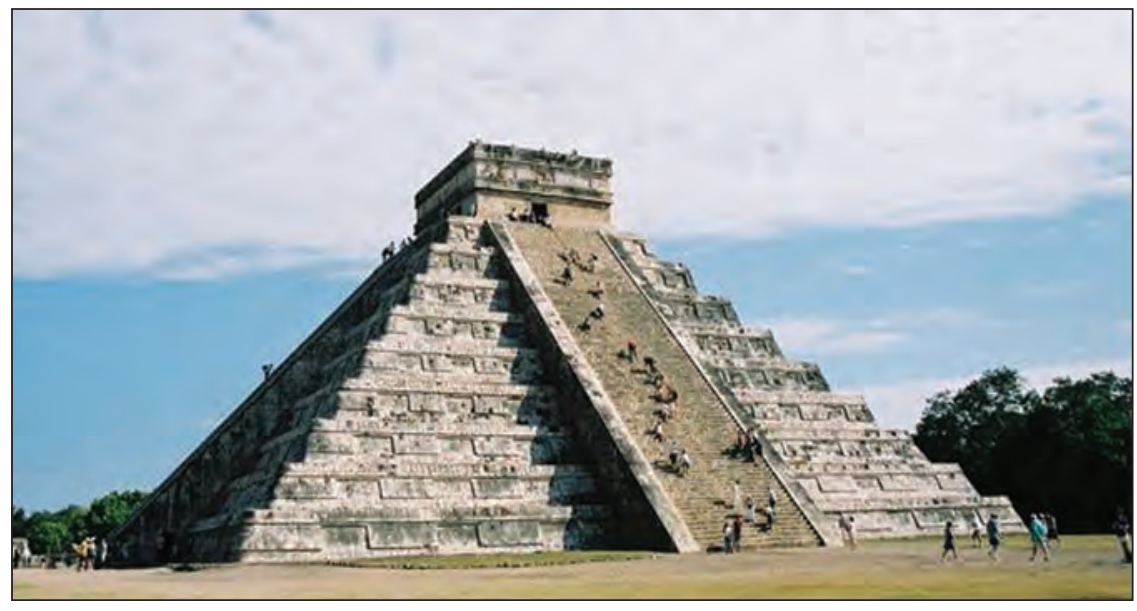

84. kép: Maja-tolték lépcsős piramis, Chichén Itzá (Yucatán-félsziget, Mexikó) Forrás: Csicsmann LászLó felvétele

\section{Inkák}

Az Inka Birodalom az Andok térségében helyezkedett el, rendkívül jól szervezett, erősen centralizált egység volt, Cuzco (mai Peru) központtal. Az inkák nem tudtak írni, kiemelkedőt alkottak viszont az útépítés, a kézmüvesség, a szövés és az orvoslás terén. A birodalom élén abszolút uralkodóként az inka állt, akit a Napisten leszármazottjaként isteni eredetủnek tartottak, de a hozzá rokoni szálakkal kötődő inka nemesség politikai legitimációját is isteni eredete adta. Az aztékokhoz hasonlóan az inkák is szük száz év alatt építettek komoly kiterjedésű birodalmat, a hódítások során pedig a leigázott törzsekre rendszeres adót vetettek ki. Az inka hitvilág és világnézet jól tükrözi az Andok térségének környezeti adottságait: a természethez füződő szoros viszony, a nap, a hegyek, folyók, erdők, stb. tisztelete mélyen beleivódott az andoki gondolatvilágba és máig hat az ott élőkre. Ugyanakkor az inkák komoly mérnöki tudománnyal rendelkeztek: hódításaik során mindig felmérték az új területeket, terveket készítettek a föld javítására, hogy növelhessék az adózás mértékét, illetve új 
öntözési rendszereket, folyók szabályozását, mocsarak lecsapolását, stb. célzó terveket dolgoztak ki. A mezo-amerikai kultúrákkal szemben az inkák világképe kronologikus volt - ebből a szempontból közelebb állt az érkező európaiakéhoz. A spanyolok érkezésekor az Inka Birodalom - az Aztékhoz hasonlóan - hatalma csúcsán állott, ennek ellenére az európaiak az 1580-as évekre véget vetettek az inkák uralmának.

Fontos hangsúlyozni, hogy a fent bemutatott, leginkább ismert prekolumbiánus birodalmak mellett számos bennszülött csoport élt a mai Latin-Amerika területén, csak kevéssé szervezett keretek között. Központi irányítás, adminisztráció, társadalmi struktúra, termelési módszerek terén a prekolumbiánus Latin-Amerika heterogenitását nem lehet eléggé hangsúlyozni. Ugyanakkor érdemes kiemelni, hogy az Európából érkező spanyolok elsősorban a szervezett birodalmakban élők területeit foglalták el - az első két alkirályság (Új-Spanyolország és Peru) az Azték és az Inka Birodalom romjain épült fel. A kevéssé fejlettnek tekintett, sokszor halászó-vadászó népek lakta területeket majd csak a 19-20. század folyamán „fedezik fel” és integrálják az európaiak által ismert Latin-Amerikába.

\subsubsection{A civilizáció összetevői}

Látszólag a latin-amerikai térség nyelvi és vallási szempontból egyaránt egységet mutat, de ahogyan látni fogjuk, ezen aspektusok mentén majdhogynem annyira színes képet találunk, mint az etnikai összetételt vizsgálva.

\section{Nyelvi sajátosságok}

Annak ellenére, hogy a Latin-Amerika kifejezés - az európai gyarmati múlton túl - a térségben használatos latin nyelvekre (spanyol, portugál és francia) is utal, a térség nyelvi szempontból ennél jóval színesebb képet mutat. Latin-Amerika 18 államában mintegy 400 millióan beszélnek spanyolul, a több mint 200 millió lakosú Brazíliában portugálul. A Karibi-térségben fekvő Haitin pedig francia a hivatalos nyelv. A gyarmatosítástól kezdve a Latin-Amerikában elterjedt európai nyelvek folyamatos kölcsönhatásban állnak az őshonos népek, illetve az Afrikából, Ázsiából és Európából érkező bevándorlók nyelveivel. Ennek a folyamatnak eredménye a Karib-térségben elterjedt ún. pidzsin (pidgin), illetve kreol nyelvek (angol, francia, holland és spanyol alapon), vagy az Argentínában honos spanyol-olasz keverék (cocoliche), illetve a Kolumbiához köthetö palenquero (amely afrikai nyelvek és a spanyol hibridje).

A latin-amerikai öshonos nyelvekkel kapcsolatban a kutatások összetett, ugyanakkor néhol egymásnak ellentmondó képet mutatnak. Latin-Amerikában ötszáz-hatszáz különböző őshonos nyelvet és még ennél is több dialektust 
tartanak számon. A térség több államában - például Peruban, Bolíviában - a spanyol mellett hivatalos valamely őshonos nyelv is, mint például a kecsua, a guarani vagy az ajmara.

\section{Etnikai összetétel}

Latin-Amerikában a három említett civilizáció találkozásának és aktív, több évszázados egymásra hatásának eredménye, hogy a térség lakossága a világ egyik legszínesebb/szélesebb bőrszínpalettáját mutatja. Az ázsiai, illetve arab bevándorlás tovább erősítette/színesítette ezt a folyamatot. Ez a rendkívüli etnikai diverzitás határozott latin-amerikai sajátosság. Erre utal José Vasconcélos mexikói író-filozófus - a mexikói forradalom (1910-1917) alatt és után oktatásügyi miniszter - 1925-ben megjelent Kozmikus faj (La raza cósmica) c. mủve, amely szerint a több száz éves keveredésből Latin-Amerikában új, ötödik faj született, a latin-amerikai.

A Latin-Amerikában élő etnikumok számbeli arányairól rendkívül változó, eltérö becslések jelentek meg a szakirodalomban. A források alapvetően a latinamerikai népszámlálásokon alapulnak, vagyis az egyes emberek önidentitását (vagy ha úgy tetszik, vágyott identitását) tükrözik. Pontos eredmény kimutatását nehezíti, hogy - tekintettel a több évszázados faji keveredésre - a latin-amerikai etnikai térkép nehezen leegyszerüsíthető a kérdőívekben leggyakrabban szereplö kategóriákra (fehér, mesztic, őslakos, fekete, mulatt); a kérdés összetettségére utal, hogy Brazíliában például több száz(!) kifejezést használnak a különböző bőrszínü csoportok leírására. Mindezt tovább bonyolítja, hogy szociológusok szerint egyes társadalmi terekben az egyének eltérö etnikai besorolásban látják, láttatják szívesen magukat. Az egyén lakóhelyétől, szociális beágyazottságától függ például, hogy tartva az őslakosokat, feketéket érő negatív társadalmi megítéléstől, diszkriminációtól, magukat „fehérebbnek” vallják, vagy pedig éppen az állam által pozitív diszkriminációban történő részesítés, esetlegesen az őslakosokkal való szimpatizálás vagy az őslakos/fekete identitás erősödése jegyében „színesebbnek” jelölik magukat. Az alábbiakban Latin-Amerika etnikai megosztottságát tekintve Anderle Ádám számadataira támaszkodom.

A latin-amerikai térség etnikai megoszlása mozaikszerü; az összlakossághoz képest mutatott arány szerint a szakirodalom megkülönböztet Mesztic-Amerikát (pl. Mexikó, Paraguay, Panama, Nicaragua), MulattAmerikát (pl. Brazília, Kuba, Haiti), Fehér-Amerikát (pl. Argentína, Chile, Costa Rica) és Indián-Amerikát (pl. Bolívia, Peru, Guatemala). A latin-amerikai összlakosság kb. 40 százalékát teszik ki a meszticek (230 millió), 35 százalékát a feketék és mulattok (190 millió), az őslakosok és a fehérek aránya hasonló (8-10 százalék), de a 7 milliós ázsiai népességet is meg kell említenünk a teljesség végett. 
Latin-Amerika őslakosainak földrajzi eloszlása változatos képet mutat; az öshonos lakosság túlnyomó többsége (90 százaléka) mindössze öt latinamerikai országban koncentrálódik: Bolívia, Ecuador, Guatemala, Mexikó és Peru. Latin-Amerika legjelentősebb indián népcsoportját az Andokban élő kecsuák teszik ki (10 millió fö), szintén több milliós tömböt alkotnak a mexikói és közép-amerikai maják, őket nagyságrendben az ajmara (Andok) és nahua (Mexikó) népek követik. Mindezeken túl Latin-Amerikában kb. 150 indián népet találunk. Társadalmilag az őshonos lakosságot két csoportra oszthatjuk: a nemzetgazdaságba integrálódott csoportokra (föként az Andokban, Mexikóban és Közép-Amerikában jellemző), illetve az elsősorban vadászatból, halászatból és gyüjtögetésből élő természeti népekre. Utóbbi csoport számaránya a 20. század folyamán erőteljesen csökkent, a felgyorsult globalizáció és urbanizáció eredményeként.

Latin-Amerikában földrajzilag az őslakosokhoz hasonlóan koncentrált az afrikai leszármazottak megoszlása: Brazíliában él a legnagyobb számú fekete és mulatt lakosság (egyes számítások szerint egyébként Nigéria után Brazíliában él a legtöbb fekete), emellett Ecuadorban és a Karib-térségben élnek jelentős arányban.

\section{Vallás: a legkatolikusabb kontinens?}

Latin-Amerika kapcsán sokaknak a „legkatolikusabb kontinens” kifejezés juthat eszébe. Abból a szempontból ez érvényes kategória Latin-Amerikára nézve, hogy az összlakosság arányában valóban a világ térségei közül a legtöbben vallják magukat katolikusnak; a latin-amerikai népesség mintegy 80 százaléka.

A vallási hovatartozással kapcsolatban azonban három fontos szempont árnyalja ezt a képet. Az első, hogy a latin-amerikai katolicizmus mennyiben felel meg az „európai értelemben vett” katolicizmusnak. Ez az aspektus abból a szempontból is kiemelkedő jelentőségü, hogy a latin-amerikai civilizáció értelmezhetö-e a Nyugat részeként. A gyarmatosítás korában az Európából „érkező” katolicizmus az Ibériai-félsziget babonákkal, hiedelmekkel átszőtt népi katolicizmusa volt. Az erőszakos eszközökkel történő katolicizáló folyamat széles körü vallási szinkretizmust szült a latin-amerikai térségben; ahogyan a latin-amerikai katolikus templomokban gyakori állatábrázolás is az őslakos kultúrák lenyomata, a latin-amerikaiak katolikus hite is sokszínű ősi bennszülött és afrikai hatásokat hordoz.

A következő fontos szempont, amely hosszabb távon alakíthatja a térség katolikus voltát; a protestáns egyházak elmúlt évtizedekben tapasztalható elöretörése. Számarányukat tekintve ugyan a katolikusok jelentős fölényben vannak, de szembetűnő egyfelől az arányok (relatíve) gyors változása, illetve a 
katolikus hívők passzivitása, szemben a protestánsok aktív egyházi részvételével. Mind e mögött a latin-amerikai katolikus egyház több száz éves erodálódási folyamatát kell látnunk.

Végül, a harmadik fontos szempont, hogy Latin-Amerikában sok esetben nem kizárólagos a katolikus hit gyakorlása, vagyis amellett, hogy az egyén katolikusnak vallja magát, előfordulhat, hogy esetenként részt vesz az őslakosok hitét vagy a feketék Afrikából hozott, legtöbbször katolicizmussal elegyített szokásait tükröző szertartásokon. Ezt a latin-amerikai gyakorlatot tükrözi a mondás, miszerint Haiti lakosságának 80 százaléka katolikus, 15 százaléka protestáns, és 100 százaléka vudu hívő.

\subsubsection{A latin-amerikai civilizáció története}

\section{Amerika felfedezése?}

Ahogyan a bevezetésben arról már volt szó, Latin-Amerika születése a spanyolok érkezéséhez köthető. Az Újvilág felfedezésének emléke, illetve annak interpretálása jól mutatja a latin-amerikai civilizáció belső kihívásait. Míg az európai konkvisztádorok, illetve az ő leszármazottaik számára Kolumbusz útja a dicsőséges múlt egy fontos eseménye, „történelmi ünnep”, a bennszülött lakosság számára alávetettségük kezdetének időpontja, kizsákmányolásuk origója. Az őslakosok számára tehát az amerikai kontinens „felfedezése” nemcsak, hogy nem pozitív töltetü, de még csak nem is felfedezés, hiszen az amerikai kontinenst az ő őseik fedezték fel. (Mindezen túl természetesen Európával a spanyolok ismertették meg az amerikai kontinenst.) A latinamerikai térség fekete lakossága számára hasonlóképpen negatív töltettel bír az amerikai kontinens felfedezése, hiszen alig néhány évvel később megkezdődött őseik rabszolgaként történő behajózása a kontinensre.

Történelmileg az Újvilág felfedezése a rekonkviszta folytatásaként értelmezhető. A rekonkviszta (visszahódítás) az Ibériai-félsziget araboktól történő visszafoglalásának több évszázados folyamatát jelöli, amelynek utolsó állomásaként 1492-ben a spanyolok - más európai csapatok segítségével - visszafoglalták Granadát. Az Ibériai-félsziget egészének visszaszerzését követően az ún. katolikus királyok (Kasztíliai Izabella és Aragóniai Ferdinánd) a katolikus egyház segítségével kívánták birodalmukat egységesíteni, hatékony központi kormányzást kidolgozva. Amerika felfedezése kiváló lehetőség volt a katolikus hit továbbterjesztésére, illetve a rekonkvisztát követően „elfoglaltság” nélkül maradt ún. hidalgo nemesség levezetésére.

Agyarmati Latin-Amerikaközel350éves történelmének fontos sajátossága, hogy az európaiakkal való „találkozás” leghamarabb (és „legsimábban”) a szervezett posztklasszikus birodalmakban (azték, maja, inka) történt meg, a 
vadászó-halászó életmódot folytató őslakosok csak később (17-18. század), vagy a gyarmati időszak alatt egyáltalán nem találkoztak a konkvisztádorokkal; vagyis Latin-Amerika csak a függetlenséget követően válik földrajzilag teljessé. A gyarmatosítás tehát nem volt „teljes”, alapvetően a szervezett birodalmakra terjedt ki; vagyis a prekolumbiánus kultúrák sokszínüsége földrajzilag eltérő intenzitású gyarmatosítást hozott. Mindezen túl fontos különbség mutatkozik a spanyol és portugál gyarmatosítási gyakorlat között: a spanyolok jóval aktívabb jelenléte centralizált gyarmati adminisztráció kiépítését tette lehetővé, a portugál gyarmatosítás inkább egyéni vállalkozások sorozata volt, amelynek eredményeként esetleges, decentralizált struktúrák jöhettek csak létre.

Demográfiai szempontból a gyarmati Latin-Amerika legnagyobb katasztrófája az őslakos népesség számának drasztikus csökkenése volt. Az ezzel kapcsolatos becslések rendkívül széles skálán mozognak, a források többsége 50-90 százalék közötti népességcsökkenést mutat. A mai Mexikó területén becslések szerint 11 millió indián élt a spanyolok érkezésekor, 1607-re közülük 2 millióan maradtak. Az Inka Birodalom 3,5 millióra becsült lakosságából pedig 1,5 millióan maradtak negyven évvel Francisco Pizarro érkezését követően.

Társadalmilag két látszólag ellentétes folyamattal jellemezhető a gyarmati időszak Latin-Amerikában. Egyfelöl a keveredés (mestizaje) volt a legfőbb demográfiai jellegzetesség. E tekintetben egyébként a latinamerikai területek eltérnek más európai gyarmatoktól, sehol máshol nem tapasztalható hasonló rendszerességủ és volumenủ keveredés az őslakosok, a behurcolt fekete rabszolgák és az európaiak között, amelynek eredménye a fentebb már tárgyalt etnikai sokszínüség. Ennek hátterében azt a tényt kell látnunk, hogy egyfelől a konkvisztádorok túlnyomórészt fiatal, egyedülálló férfiak voltak, másfelől az amerikai kontinens felfedezését követően még évtizedekig ritka jelenség volt európai nők érkezése a térségbe. Másfelől a spanyol irányítású alkirályságokba (38. térkép) szervezett gyarmati társadalmak börszín szerint, hierarchikusan tagoltak: a kreolok adták a legfelsőbb társadalmi réteget, alattuk a meszticek, majd az őslakosok, a mulattok és végül a feketék helyezhetőek el. A spanyol korona igyekezett ugyan bőrszín szerint jól elkülöníthető „kasztokba” zárni a gyarmati LatinAmerika népességét, a gyakorlatban azonban nem sikerült megakadályozni az őslakosokkal történő keveredést. Európából sokáig kizárólag fiatal férfiak érkeztek az Újvilágba, az első konkvisztádorok az Isten, arany, dicsőség hármas motivációjától fütve érkeztek a mai Latin-Amerikába. Nem családostul, a letelepedés szándékával jöttek tehát, sokkal inkább kalandvágytól indíttatva, a meggazdagodás reményében érkeztek. 


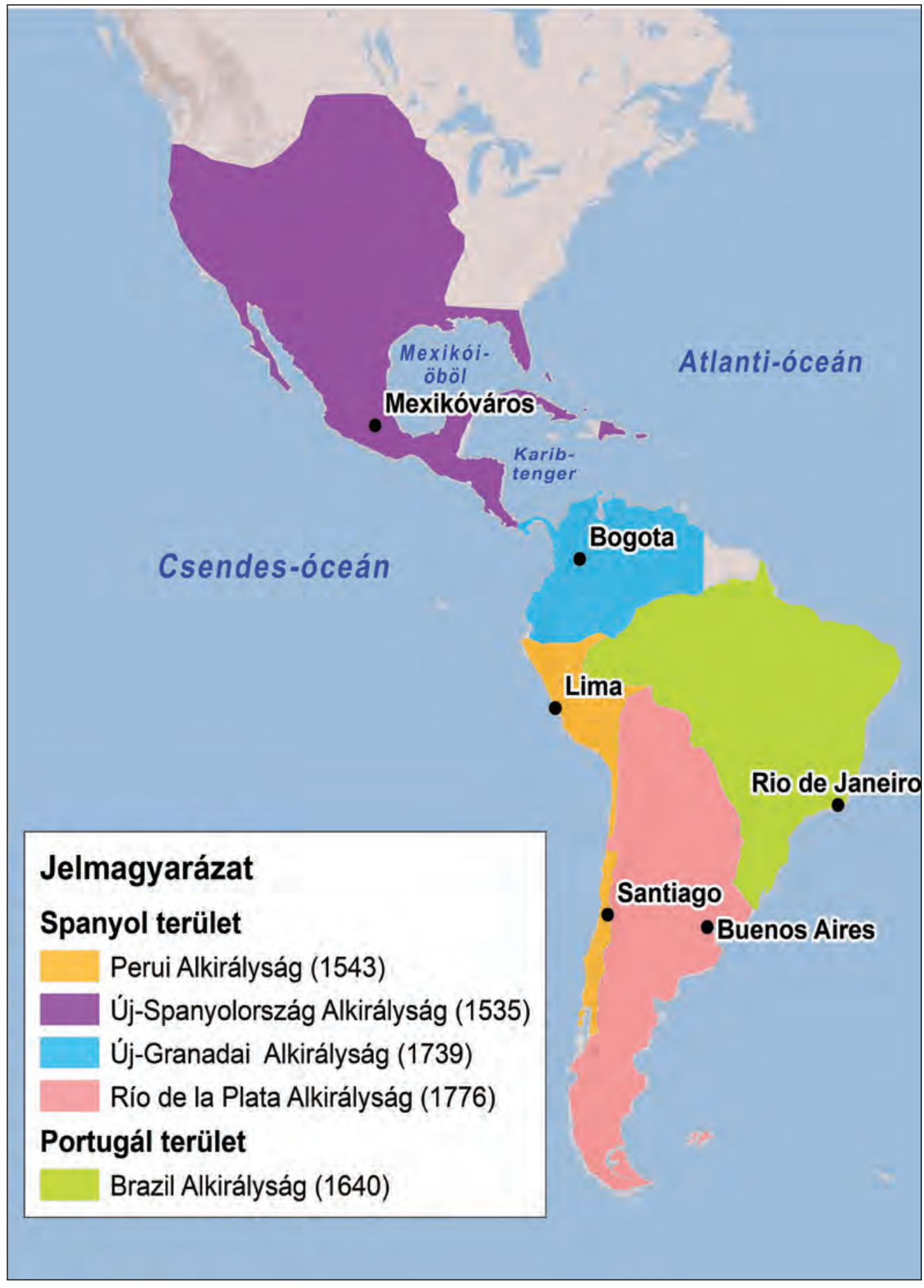

38. térkép: A gyarmati Latin-Amerika

Forrás: VARGA ÁGNES szerkesztése 
Civilizációs szempontból a gyarmati időszak legjelentősebb, legmeghatározóbb jelensége a két, helyesebben három világ találkozása az új kontinensen és az ezt kísérő „civilizációs sokk”, gyakorlatilag mindhárom fél részéről. A népi babonáktól átitatott, hitbuzgó katolicizmust exportáló konkvisztádorok megdöbbenve szembesültek az őslakosok olyan - számukra - barbár szokásaival, mint a véráldozat, az emberáldozat vagy az emberi hús fogyasztása (utóbbi kizárólag szakrális céllal történt). Az európaiak mélységesen lenézték és megvetették az őslakosok politeista hitvilágát, bálványimádatát. A gyarmati évszázadok alatt a fehérek mindvégig erkölcsi és civilizációs felsőbbrendüségük tudatában viseltettek az őslakosokkal és a feketékkel szemben. Pápai jóváhagyással és egyfajta (nem túl komoly) missziós tudattal vágtak bele az őslakosok ,civilizálásába”, valamint katolikus hitre térítésébe. Ezzel a tevékenységgel legitimálták hódításukat, és e mentén volt képes a katolikus egyház az anyaországihoz hasonló pozíciókat kiépíteni a spanyol gyarmatokon.

A civilizálás, illetve katolikus hitre térítés a gyarmatok egyes területein eltérő intenzitással, különböző aktorokkal és változó eszközökkel történt. A hódítók az első felfedezett területeken erőszakos eszközökkel kezdtek neki az őslakosok térítésének, ennek eredménye az őslakosok kultúráját őrző tárgyi és írásos emlékek jelentős részének elpusztulása. A civilizálás fontos eszköze volt az ún. encomienda-rendszer, amelynek keretében a konkvisztádorok a spanyol koronától egy darab föld mellé egy csoport őslakost is kaptak, akiket kényszermunkára és adózásra foghattak, cserébe civilizálniuk (értsd: európaivá nevelniük) kellett a munkaerőt. Tekintettel arra, hogy a konkvisztádorok a fentebb említett célkitüzésekkel érkeztek az Újvilágba, a térítés ezen formája nem igazán lehetett sikeres.

A katolikus egyház térítöi tevékenysége legtöbbször kevéssé volt hatékony: látványos miséket celebráltak, illetve tömeges kereszteléseket hajtottak végre, amelyek legtöbbször az öslakosok értetlenségét váltották ki. A spanyol inkvizíció gyarmatokra történő átültetése kevéssé hozta meg a várt eredményt.

A katolikus hitre térítés leghatékonyabb szereplőinek az Európából érkező szerzetesrendek bizonyultak. A ferences, domonkos és jezsuita rendi szerzetesek fáradságot nem kímélve igyekeztek átadni a katolikus tanokat a bennszülötteknek. Fontos aspektusnak bizonyult a nyelv kérdése: a szerzeteseknek fontos szerepük volt a nyelvi nehézségek áthidalásában, ők voltak azok, akik az őslakosok nyelvét elsajátítva igyekeztek kommunikálni a bennszülöttekkel. Az ő tevékenységük hamar rávilágított az olyan nyelven túlmutató, fogalmi kihívásokra, mint hogy például a bennszülöttek nyelvében (értsd: fogalomtárában) nem szerepeltek a katolikus hitgyakorlás egyes központi fogalmai, mint például a gyónás vagy a bün. Hasonló nehézségekbe ütközött az öslakos papok felszentelését célzó 
törekvés: az őslakosok számára érthetetlennek és felfoghatatlannak bizonyult a cölibátus gyakorlata. Hangsúlyozni kell a jezsuita szerzetesek jelentőségét a gyarmati Latin-Amerikában; e rend képviselői a térítői tevékenység mellett kiemelkedő szerepet játszottak a dél-amerikai szubkontinens földrajzi felfedezésében, elmerészkedtek ugyanis azon területekre is, ahol „vad” indiánok éltek, ami miatt a konkvisztádorok nem tekintették megtérülő befektetésnek ezen területek feltárását.

Domonkos rendi szerzetes volt Bartolomeo de Las Casas, a gyarmati Latin-Amerika legkiemelkedőbb indián védője is, aki már a 16. század közepén felemelte hangját az őslakosokat érintő brutális bánásmód, illetve született szolgaságuk tézise ellen. 1552-ben jelent meg Rövid beszámoló az Indiák elpusztításáról c. müve, amelyben az őslakosokat eszes, jóindulatú, hüséges népekként mutatja be, és igyekszik felhívni a spanyol korona figyelmét a gyarmatokon történő visszaélésekre. Las Casas vallási alapon, keresztény tanokból vezette le az őslakosok jogait, ezért is érdekes, miért nem említette egyáltalán a fekete rabszolgák helyzetét. Az indiánügy, a velük szembeni embertelen bánásmód egyébként az európai felvilágosodás egyik kiemelkedő jelentőségü témája volt.

Az európaiak térítöi tevékenysége az őslakosok körében egyébként is jóval kifinomultabbnak bizonyult, mint a feketék esetében. Az ültetvényes gazdálkodás keretei között ugyan - szemben az öslakosokkal - a feketék szinte kizárólagosan a kreolok fennhatósága alá tartoztak, katolikus hitre nevelésük mégis lassú lépésekkel haladt. Érdekes ugyanakkor, hogy a feketék hamarabb elsajátították uraik nyelvét, mivel tudatos spanyol, illetve portugál politika volt az egyes afrikai törzsek tagjainak „összekeverése” a gyarmatokon, hogy kevéssé tudjanak egymással kommunikálni és kulturális szokásaikat fenntartani - mindennek elsősorban gazdasági okai voltak, az ültetvényesek úgy tartották, így hatékonyabban dolgoznak majd a rabszolgák.

Az öslakosok és a feketék részéről is szinte a kezdetektől az ellenállás különbözö, igen változatos formái jelentek meg. Gyakori volt a szökés, az erőszakos felkelés, elterjedt a gyermek- és öngyilkosság gyakorlata, de szintén a gyarmati időszakhoz köthető az indán alkoholizmus problematikája. A civilizációs sokkot ugyanis súlyos pszichológiai nyomás kísérte a színesek életében: az öslakosokat - komoly emberáldozatokat követelő hódítás nyomán - megfosztották addigi életmódjuktól, földjeiktől, bálványaiktól és szokásaiktól, míg a fekete rabszolgáknak - szintén komoly emberáldozatokat követelö, embertelen „behajózást” követően egy új kontinensen, számukra idegen környezetben kellett, hogy a társadalom legalsó rétegébe tagozódjanak. Ezek a konfliktusok nehezítették a gyarmati Latin-Amerika társadalmainak életét, és szültek máig ható, súlyos sztereotípiákat, ellenérzéseket a térségben élő különböző etnikumok között. 
A gyarmati időszakot tehát Latin-Amerikában az európai konkvisztádorok fizikai fölénye kísérte végig, amely tükröződik a társadalmi berendezkedésen is; a három „találkozó” civilizáció tehát etnikailag ugyan keveredik, a kulturális életet alapvetően a fehérek azon törekvése dominálja, hogy civilizálják, illetve katolikus hitre térítsék az őslakosokat és a feketéket. Ez a törekvés csak részben teljesülhetett: egyfelől a missziós tevékenység módja, eszközrendszere, másfelől az érintett civilizációk alapvető különbségei, vallási és kulturális szakadékai miatt.

\section{A függetlenség kivívása: közös célok és törekvések?}

A latin-amerikai függetlenségi háborúk a 19. század első harmadában zajlottak. A függetlenségi mozgalmak megindulása belső és külső okokra vezethető vissza. Belső okként a mind határozottabb kontúrokat öltő kreol nacionalizmust kell megemlítenünk; a mind vagyonosabb, és mind gyakrabban Európába látogató, világlátott kreol elit réteg számára egyre terhesebbé vált a spanyol fennhatóság. Saját sorsuk felett kívántak rendelkezni, miután az újabb és újabb, az amerikai kontinensen született generációk mind kevéssé érezték magukat spanyol leszármazottnak, viszont egyre erősebben kötődtek az amerikai kontinenshez. Külső okként az európai felvilágosodást, és annak beszivárgását, az Egyesült Államok függetlenedését (1776) és a Spanyol Birodalom hanyatlását érdemes megemlítenünk. Miután Napóleon seregei elfoglalták az Ibériai-félszigetet, a latin-amerikai kreolok úgy látták - tartva egy erőszakosabb gyarmatosító fellépésétől -, hogy elérkezett az idő az önálló útra lépéshez, az Európában elfoglalt spanyolok nem lesznek képesek hathatós ellenállásra.

A függetlenségi harcok a kreolok irányításával, vezetésével folytak. Simón Bolívar (1783-1830), a latin-amerikai függetlenségi háborúk legfőbb hőse is Európában tanult kreol volt. Az ő személye központi jelentőségü a latinamerikai civilizáció szempontjából, mivel azt az egységet, ha úgy tetszik, „latinamerikaiságot" szimbolizálja, amely a latin-amerikai értelmiség és politikusi réteg gondolatvilágában ugyan a mai napig újra és újra visszatér, gyakorlati megvalósulása azonban késlekedni látszik. De nem egyedül ebben áll Bolívar és a bolivári eszme jelentősége: Latin-Amerika történelmének egyik legjelentősebb dokumentuma az 1815-ös jamaikai levél. Ebben Bolívar iránymutatást ad a térség jövőjére vonatkozóan: a függetlenség utáni Latin-Amerika alapjának a faji egyenlőségen nyugvó demokráciát tekinti, vagyis a latin-amerikai egység és összefogás mellett az egyes etnikumok közötti partnerséget, kiegyensúlyozott viszonyt is a továbblépés feltételének tekinti. Ez a politikai program a 19. századi Latin-Amerika számára olyan víziót fogalmazott meg, amely kívánatosnak tủnt, a realitások azonban nem engedték megvalósulását. 
A függetlenségi háborúk a kreol elitek hatalmát mentették át, a társadalmi struktúra/hierarchia nem sokat változott. Az anyaországtól való függetlenedés nem hozta el a rabszolgaság eltörlését, erre csak a 19. század második felében került sor; utoljára Brazíliában (1888), ahol a gazdaság erőteljesen függött a rabszolga-munkaerőtől. Az újonnan függetlenedő latin-amerikai államok alkotmányában ugyan - az Egyesült Államok, illetve Európa mintájára lefektették az alapvető emberi jogok védelmét, a színes rétegek továbbra sem élvezhettek teljes jogú állampolgárságot (ahogyan egyébként az Egyesült Államokban és Európában sem). A történészek ,konzervatív forradalmaknak” nevezik a latin-amerikai függetlenségi háborúkat, arra utalva, hogy az az egykori anyaországtól való függetlenségen túl nem hozott újat LatinAmerika társadalmi életében; tovább élt a gyarmati korból fennmaradt erősen hierarchizált, bőrszín szerinti tagozódás, mivel az uralkodó elitté váló kreolok nem kívántak forradalmi változásokat a társadalmi berendezkedést illetően. Számukra saját politikai, gazdasági és társadalmi pozíciójuk megőrzése, pontosabban megerösítése volt a legföbb célkitüzés, emellett nem is láttak mintát vagy modellt arra vonatkozóan, hogyan lenne lehetséges a társadalom nem fehér csoportjait bevonni a politikai és gazdasági hatalomba.

A függetlenséget követő évtizedek gyötrelmes időszak volt LatinAmerika számára; fegyveres harccal folytatódott a végső államhatárok kialakítása (39. térkép), az anyaország(ok) helyett új gazdasági partnereket kellett keresni, a politikai életben pedig intenzív vetélkedés folyt az új államok bel- és külpolitikai alapelveinek kialakításáért. A kreol elitréteg alapvetően liberálisokra és konzervatívokra oszlott, vagyis Európából importált eszmék mentén igyekeztek irányítani az újdonsült államok jövőjét, annak ellenére, hogy Latin-Amerikában nem zajlott le az ipari forradalom, nem létezett középosztály és nem alakultak ki az egységes - európai értelemben vett nemzetállam feltételei. Ahogyan tehát a gyarmati időszakban a spanyol hódítók az anyaországi mintákat kívánták ráerőltetni gyarmataikra, a függetlenséget követően a kreol elitréteg kívánta a nyugati eszméken és tapasztalatokon alapuló modernizálódást, felzárkózást.

A 19. század utolsó évtizedeiben az említett liberális-konzervatív párharc a liberálisok győzelmével zárult, amelynek eredménye a katolikus egyház pozícióinak visszaszorítása és általában a gyarmati múlttól való eltávolodás lett. Ebben a periódusban jelentkezett elöször Latin-Amerikában a „lemaradtunk” élmény, a felzárkózás reményét pedig a liberális kreolok a gyarmati múlttól való teljes elfordulásban és európaizálódásban látták. 
Civilizációk Kelettől Nyugatig

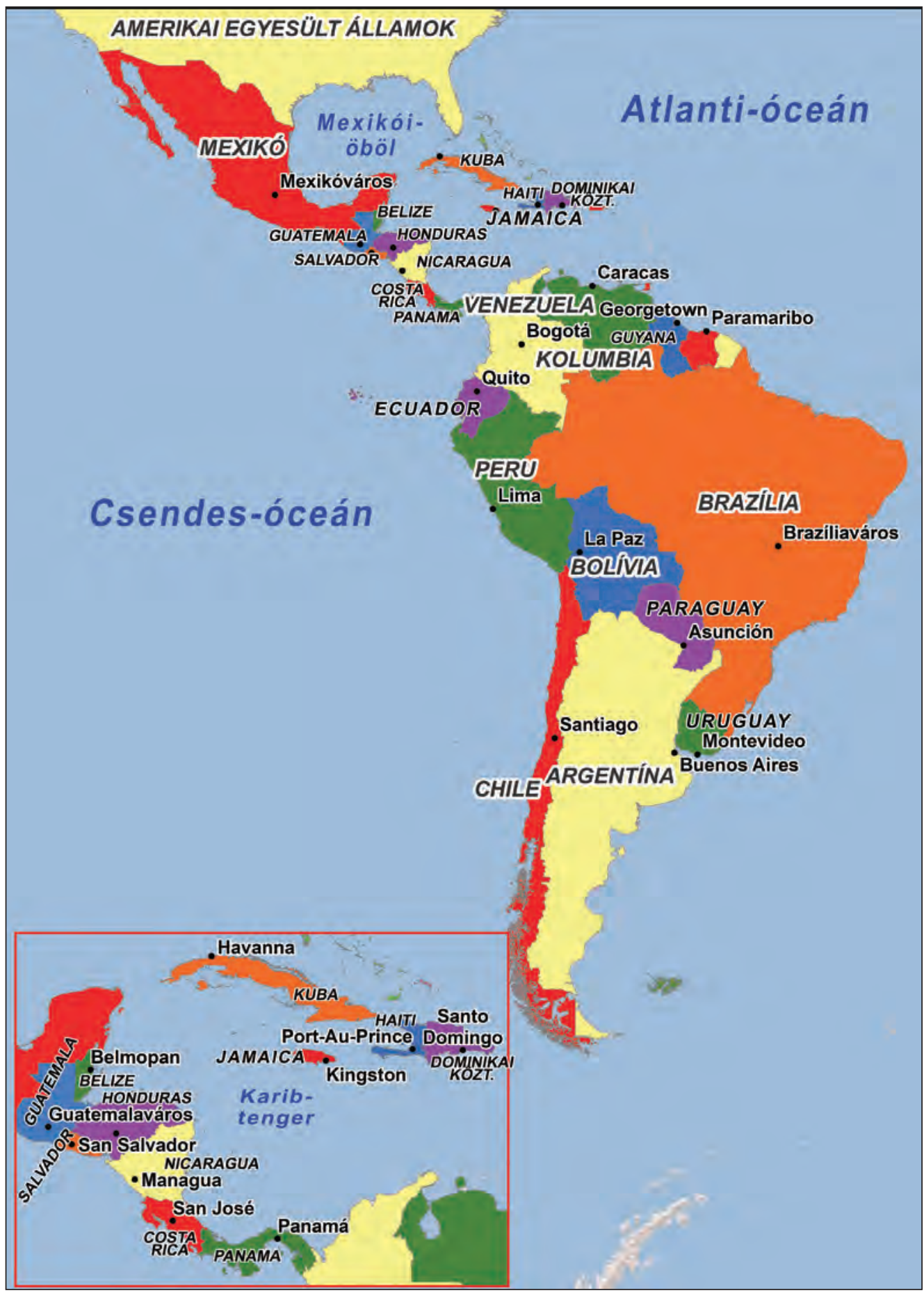

39. térkép: Latin-Amerika országai ma

Forrás: VARGA ÁGNES szerkesztése 
Ezt a törekvést, gondolatmenetet képviselték a kor ún. civilizálói, más néven a romantikus generáció, amelynek tagjai elsősorban argentin írók, költők, filozófusok voltak. Meglátásuk szerint a latin-amerikai elmaradottság oka és egyben a fejlődés legfőbb akadálya a színes rétegek jelenléte a társadalomban; ezek eltávolítása, egy európai vérfrissítés szükséges a Nyugathoz való felzárkózáshoz. A civilizálók erős politikai befolyását mutatja, hogy ezekben az évtizedekben több latin-amerikai országban is hivatalos kormányprogrammá lépett elő a „fehérítés” (blanquear), ami alapvetően az európai bevándorlás támogatásával kívánta a fejlődést megvalósítani. Ez a nyíltan rasszista elgondolás több szempontból is káros volt Latin-Amerika jövőjét illetően: egyfelől még mélyebb elöítéleteket hozott az öslakosokkal és a feketékkel szemben, másfelől nem volt hajlandó szembenézni a térség történelmi örökségével, a gyarmati múlttal, és azzal, hogy Latin-Amerika nem egyenlő a konkvisztádorok leszármazottjaival. A színesek „nyűgként”, „akadályként” történő percepciója erőteljes eltávolodást hozott a társadalom egyes csoportjai között, ami kizárta és a távoli jövőbe helyezte a közös, együttes fejlődés lehetőségét.

Az európai bevándorlás segítése, támogatása komoly migrációs hullámot indított el az 1870-es években, amely az 1930-as években csengett le, s amelynek eredményeként ezekben az évtizedekben több millió európai (fóként német, olasz, spanyol és közép-európai) érkezett Latin-Amerikába. A legföbb célpontok az Atlanti-óceán partvidékén fekvő országok (Argentína, Brazília és Uruguay) voltak, tehát ezen európai bevándorlás egyenetlenül érintette a térség államait.

A 19. század tehát több szempontból is fontos fordulópontot jelentett Latin-Amerika történelmében, hozadéka, öröksége azonban kettős: egyfelöl megnyílt az út az önálló, latin-amerikai fejlődés megteremtése előtt, másfelől viszont a függetlenedés módja és az azt követő évtizedek eseményei a latinamerikai egység, közös társadalmi célkitüzések ellenében hatottak, erösítették, mélyebbre vágták a belső társadalmi, etnikai törésvonalakat; megnehezítve Latin-Amerika 20. századi útját.

\subsubsection{0. századi dilemmák: nyugati vagy latin-amerikai út?}

A 19-20. század fordulójára több, Latin-Amerika jövőjét tekintve alapvető változás következett be. Kialakultak a végső államhatárok (Panama volt az utolsó függetlenedő állam 1903-ban), ami lehetőséget nyújtott a nemzetépítés folyamatának megindítására. A liberális politikai elit előtérbe kerülésével a századfordulóra megtörtént az egyház politikai életből való kiszorítása (állam és egyház különválása). A 19. század második felében meghatározó szereppel bíró európai hatalmak befolyását pedig fokozatosan, de biztosan átvette az Egyesült Államok. 
A nemzetépítés máig húzódó folyamat Latin-Amerikában, legmeghatározóbb és legszembetűnőbb sajátossága a kívülállók, a társadalom perifériáján élök, a marginalizáltak folyamatos harca a „bekerülésért”, társadalmi integrációért, egyenlő jogokért, társadalmi felemelkedésért, valódi állampolgárságért. Erröl szólt, vagy legalábbis ezt ismerte föl az 1930-as években megjelenő populizmus, ezt a célt szolgálta a forradalmi törekvések és gerillamozgalmak túlnyomó többsége - kevés sikerrel. A gyakori egybeesést mutató vagyoni és etnikai törésvonalak máig alapvető akadályai a latin-amerikai felemelkedésnek és az egységes latin-amerikai civilizáció fejlődésének.

A katolikus egyház háttérbe szorulása a 20. század elején magával vonta a katolikus hitgyakorlás gyengülését, amelynek a térségen később végigsöprő erőteljes urbanizáció csak újabb lökést adott. A század utolsó évtizedeiben jelentkező és máig tartó protestáns elöretörés mindemellett abban is gyökerezhet, hogy aktív részvételt biztosít híveinek, illetve számos társadalmi funkciót tölt be (oktatás, egészségügyi ellátás, alkoholisták, munkanélküliek segítése, stb.). A szegényeket felkaroló, számukra kiutat ígérő pünkösdi mozgalmak népszerüsége egyre szélesebb körünek látszik.

$\mathrm{Az}$ Egyesült Államok mind eröteljesebben kibontakozó, kezdetben elsősorban gazdasági, majd politikai-katonai befolyása, jelenléte a latinamerikai térségben komoly civilizációs hozadékkal bír. Az „Északi kolosszus” nagysága, gazdagsága súlyos ellentéteket szült az amerikai kontinensen. A 20. század folyamán a latin-amerikai öndefiníció, identitás alapvető elemévé vált az Egyesült Államokhoz füződő viszony, pontosabban az Egyesült Államoktól való elhatárolódás, a latin-amerikaiság szembeállítása a jenkik (latin-amerikai olvasatban szegényes) kultúrájával.

Ennek a gondolatnak egyik első képviselője volt az uruguayi José Enrique Rodó, akinek 1900-ban megjelent Ariel c. sokat idézett esszéje máig meghatározó mủ a latin-amerikaiságról való gondolkodásban, elmélkedésben. Rodó - a modernismo mozgalom jeles képviselöje - az ,amerikai ifjúságnak” címzett müvében Ariel szimbolizálja az érzelemgazdag, szenvedélyes Latin-Amerikát, míg Kalibán az önző, materialista, individualista Egyesült Államokat.

„Ariel maga az értelem és az emelkedett érzésvilág. Ariel az a tökéletesedésre sarkalló fenséges ösztön, amely felmagasztalja és a dolgok központjává teszi a sárból lett embert [...] eszményiséget és rendet jelent az életben, nemes sugalmazást a gondolkodásban, önzetlenséget az erkölcsben, jó ízlést a müvészetben, hősiességet a tettekben, finomságot a szokásokban. [...] Jóllehet ezerszer is legyőzte őt a megzabolázhatatlanul lázadó Kalibán, s számüzte a győzedelmes barbárság, s megfojtotta a csaták füstje [...] Ariel mindannyiszor legyőzhetetlenül feltámad, visszanyeri fiatalságát és szépségét." (Rodó, J. E. 1984) 
Rodó szerint a haszonlevüség erkölcsi alapelvén nyugvó Egyesült Államok Latin-Amerika legfőbb riválisa, az USA befolyásával szembeni ellenállás legfőbb szereplői a latin-amerikai fiatalság lesz, ezért ajánlja nekik Ariel c. művét, hiszen a spanyol-amerikai fiatalság felelősségének tekinti a regionális kulturális identitás megőrzését.

Az Egyesült Államok befolyásának visszaszorítása, a külső hatalmaktól való függetlenség a latin-amerikai írók, költők, filozófusok és gondolkodók gyakran visszatérő témája, ami a 20. század folyamán a latin-amerikaiság meghatározásának fontos referenciapontjává vált. Mindez persze nem jelenti azt, hogy az Amerika-közi kapcsolatoknak kizárólag konfliktusos jellege tér vissza minden gondolkodónál, de az Egyesült Államokhoz való viszonyulás, viszonyítás Latin-Amerika definiálása kapcsán alapvetőnek tünik. A 20. század első felében alkotó Alfonso Reyes mexikói író, filozófus, diplomata például sokkal inkább egységben gondolkodott Amerikáról:

„Az amerikai az egyetlen kultúra, amely elvben egykor majd túlláthat a nemzeti és etnikai akadályokon. Az amerikai dráma két főhősének - a latin világnak és az angolszász világnak - sajátos egyöntetüségét a demokratikus rokonszenv elve hozza egy szintre, s a homonoia felé tart. Az amerikai nemzetek nem érzik egymást oly idegennek, mint más földrészek népei. Három évszázadnyi előkészítés - a függetlenséggel és az új intézményekkel elindult -, százévnyi kísérletezgetés; továbbá ötven év összefogás és együttműködés. Így fest távlati képben Amerika útja." (Reyes, A. 1984)

A II. világháborút követően a dekolonizáció eredményeként a latinamerikai öndefiníció újabb elemmel bővült: a harmadik vagy fejlődő világ részeként határozhatta meg magát, közösséget vállalva az ekkor függetlenedő afrikai, ázsiai országokkal. Bár civilizációs/kulturális értelemben ezek a területek kevés rokonságot mutatnak Latin-Amerikával, a hasonló politikai-gazdasági kihívások, illetve az egyes karibi területek függetlenedése aktivizálták a térség kapcsolatait a fejlődő államok csoportjával.

A 20. század második felében a gyorsuló globalizáció a latin-amerikai térséget is elérte. Ennek hatása és eredménye - hasonlóan a világ más fejlődő régióihoz - egyfelől a technológiai újítások megjelenése és elterjedése, másfelől a jövedelmi egyenlötlenségek kiszélesedése a latin-amerikai társadalmakban. Latin-Amerika belső társadalmi és etnikai törésvonalait tovább erősíti a globalizáció nyomán érkező modernizáció, a nyugati termelési struktúrák, pénzügyi intézmények, politikai berendezkedés átvétele, ami azonban nem éri el a társadalmak egészét, annak pozitív hozadékát csupán a társadalom felső, túlnyomórészt fehér rétegei élvezhetik.

$\mathrm{Az}$ őslakosok és a feketék helyzete kettős tendenciát mutat: egyrészt a globalizációval összefonódó urbanizáció eredményeként az 1960-1970es évektől erősödik a színesek asszimilációja, mind távolabbra kerülnek az 
őslakos nyelvek és szokások, a városokban felnövő generációk elveszítik kapcsolatukat felmenöik kultúrájával. Ugyanakkor ezen tendenciákra adott természetes válasz az indiánmozgalmak mind szervezettebb fellépése, mind szélesebb körü követeléseik. Hasonló folyamatok játszódnak le a térség fekete lakosságának körében. Az elmúlt évtizedek fontos újdonsága, hogy megjelentek - és gyors fejlődést mutatnak - azok a törekvések, amelyek keretében Latin-Amerika történelmében elöször maguk az őslakosok, illetve a feketék állnak ki jogaik mellett, követelnek szélesebb elismerést, autonómiát, illetve kulturális jogaik tiszteletben tartását. Átformálódni látszik tehát az a több száz éves gyakorlat, miszerint a kreol elitek képviselői gondolkoznak és rendelkeznek a színesek hovatartozásáról, társadalomba illesztéséről, avagy kiiktatásáról. Az öslakos és fekete mozgalmak térnyerése mindenképpen pozitív folyamatként értékelhető e csoportok identitáskeresésében, társadalmi felemelkedésében. Ugyanakkor az eddigi tapasztalatok azt mutatják, hogy a mind artikuláltabb követelések a már korábban sem egységes latin-amerikai társadalmak további fragmentálódása irányába hatnak, olyan súlyos belső társadalmi konfliktusokat generálva, mint amit Bolíviában láthatunk az egyes etnikai csoportok között.

$\mathrm{Az}$ 1980-as években söpört végig a latin-amerikai térségen a demokratizálódás folyamata, ami a demokratikus intézmények kiépítése mellett a cenzúra megszünését, az emberi jogok előtérbe kerülését és a társadalmi mozgalmak, civil szervezetek elszaporodását és professzinalizálódását is hozta. A szélesebb politikai részvétel, az általános választójog bevezetése mindenképpen pozitív fejlemény a latin-amerikai társadalmak politikai aktivitását illetően. Ugyanakkor a demokratizálódás eredményeként kapnak mind komolyabb lehetőségeket, építenek erősebb hálózatot és fognak össze szervezettebb formában az olyan táradalmi csoportok, mint a bennszülöttek, a rabszolgák leszármazottai, a nők vagy a földnélküli mezőgazdasági munkások. Mindez érzékeny kérdéseket vet fel a latin-amerikai társadalmakon belül és sok esetben erősíti a belső konfliktusokat.

A 20. század tehát egyszerre hatott az egység, a latin-amerikaiság megtalálása, a latin-amerikai sajátosságok meghatározása, a társadalmi kohézió vágyának erősödése irányába és a fragmentáció, a széthúzás, a több évszázados belső kihívások felszínre törése irányába. Kérdés, hogy a következő évtizedekben a globalizáció és a technológiai fejlődés, illetve a demokratikus politikai berendezkedés, a civil szféra erősödése képes lesz-e a társadalmi harmonizáció irányába hatni, a következő generáció tagjai közelebb kerülnek-e egymáshoz ebben a koordinátarendszerben vagy pedig a globalizációra adott helyi válaszok, a gyökerekhez visszatérő identitáskeresés kerekedik felül, ami várhatóan a meglévő belső társadalmi konfliktusokat erősíti majd. 


\subsubsection{Konklúzió}

Ahogyan a fentebb leírtakból kitünik, a latin-amerikai civilizáció léte, és legfőképpen annak sajátosságai távolról sem egyértelmüek. Arra a kérdésre, létezik-e latin-amerikai civilizáció, a civilizáció fogalmának értelmezése függvényében tudunk választ adni. Amennyiben civilizáció alatt a „legszélesebb kulturális entitást", illetve közös történelmi, vallási, kulturális hátteret, gyökereket értünk, Latin-Amerika nehezen értelmezhetö önálló civilizációként. Ugyanakkor, a latin-amerikaiak „közös” több száz éves múltja, pontosabban együtt (egymás mellett?) élése mégis csak ad valamifajta együvé tartozást, közös identitást. A kérdés tehát az, elfogadható-e külön civilizációként három civilizáció egymásra hatása, ahogyan a címben is szerepel: kölcsönhatásos rendszere, egymás mellett élése? Elegendő-e a vágyakozás az egységre, az összetartozásra, a közös jövőre?

Az ibériai hódítók leszármazottainak jelenléte és meghatározó szerepük a térség államainak politikai, gazdasági berendezkedésében, útkeresésében, több száz évre visszanyúló irányító szerepük a felzárkózási stratégiák kigondolásában (átvételében) és gyakorlatba ültetésében tehetné Latin-Amerikát nyugativá, a nyugati civilizáció egy leágazásává. Ezzel a megközelítéssel mégis vitatkoznunk kell. Egyfelöl, mert a Latin-Amerikában élők többsége mesztic származású, az évszázadokat átkísérő keveredés, ha nem is hozott létre egy új, „,kozmikus fajt”, a „kevertek” (meszticek, mulattok, zámbók) egyértelmü túlsúlya elválasztja Latin-Amerikát a Nyugattól. Másfelől, mert a Nyugat nem tekinti részének LatinAmerikát, nem vállal vele közösséget (a rendszeresen megrendezésre kerülő ibéro-amerikai csúcstalálkozók inkább a spanyol külpolitikai eszközrendszer egy elemének tekinthetőek, semmint a civilizációs összetartozás kifejeződésének), és bár a latin-amerikaiak öndefiníciójában, identitáskeresésében a Nyugathoz való viszony, a Nyugat utolérése jelen van, de az öndefiníció azzal szemben, ahhoz képest fogalmazódik meg.

Latin-Amerika első pillantásra, kissé távolról nézve valóban nyugatinak (vagy ahhoz hasonlónak) tünhet, hiszen a térség lakosságának túlnyomó többsége magát katolikusnak vallja és az ide sorolt országok mindegyikében európai a hivatalos nyelv. Egy lépéssel közelebb azonban már inkább mozaikszerủ a kép: „vegytiszta” katolicizmus helyett inkább szinkretizmust látunk, míg az európai nyelvek mellett - ha nem is mindenhol - számos öslakos nyelvvel, illetve a feketék hozta nyelvi elemekkel találkozunk. A kép csak összetettebbé válik, ha számba vesszük az ezekre a törésvonalakra rakódó etnikai sokszínúséget.

A fenti gondolatok abból indulnak ki, hogy Latin-Amerikát mégis egyként kezeljük, de a latin-amerikai civilizáció vizsgálatánál egy másik nézőpont lehet a „latin-amerikai” kategóriától való eltekintés. Ebben az esetben az a kérdés: hol és milyen határvonalakat húzunk? A déli kúp (Cono Sur) államai, azaz Chile, 
Argentína és Uruguay, amelyek a „legfehérebb” és legkatolikusabb országok Latin-Amerikában, sorolhatóak-e a nyugati civilizációhoz? Még ha igen is a válasz, és ha ezeket az országokat (vagy a térségben élö katolikus fehéreket) kiemeljük (átemeljük a Nyugathoz), itt el is akadunk: mit kell tennünk a többi mesztic és mulatt többségü-latin-amerikai népességgel, hiszen nem sorolhatóak semelyik civilizációhoz?

Mindez pedig elvezet minket ahhoz a dilemmához, hogy csupán az a tény, miszerint a latin-amerikai államok nem sorolhatóak a Nyugathoz, más civilizációhoz pedig végképp nem, önálló civilizációvá teszi-e a Latin-Amerikát? Ha igen, akkor annak sajátosságait pontosan az a máshol nem tapasztalható hibriditás, változatosság és sokszínűség adja, amelynek összefogása, közös útja a térség elsődleges, egyik legfőbb kihívása.

\subsubsection{Időrendi tábla}

\begin{tabular}{c|l} 
dátum & \multicolumn{1}{c}{ esemény } \\
\hline i.e. 6000-3000 & $\begin{array}{l}\text { Mezögazdasági tevékenység megjelenése Mezo-Amerikában és az } \\
\text { Andok térségében }\end{array}$ \\
\hline i.sz. 150-900 & Maja klasszikus periódus \\
\hline $1300-1500$ & Az Azték és Inka Birodalom felemelkedése \\
\hline 1492 & $\begin{array}{l}\text { A spanyolok visszafoglalják az Ibériai-félszigetet (reconquista) és } \\
\text { Kolumbusz Kristóf felfedezi Amerikát }\end{array}$ \\
\hline 1494 & A tordesillasi szerzödés \\
\hline 1524 & Az Indiák Tanácsának megalapítása Spanyolországban \\
\hline 1535 & $\begin{array}{l}\text { Új-Spanyolország néven az első alkirályság létrehozása Spanyol- } \\
\text { Amerikában az Azték Birodalom romjain }\end{array}$ \\
\hline 1537 & $\begin{array}{l}\text { Sublimus Deus, III. Pál pápa kinyilvánítja, hogy az indiánok } \\
\text { emberek }\end{array}$ \\
\hline 1655 & Az angolok megszerzik Jamaicát \\
\hline 1767 & A jezsuiták kïuzése Spanyol-Amerikából \\
\hline 1804 & Haiti függetlensége \\
\hline $1810-1824$ & Függetlenségi háborúk Latin-Amerikában \\
\hline $1864-1870$ & $\begin{array}{l}\text { Hármas Szövetség (Brazília, Argentína és Uruguay) háborúja } \\
\text { Paraguay ellen }\end{array}$ \\
\hline 1888 & A rabszolgaság eltörlése Brazíliában \\
\hline 1898 & Spanyol-amerikai háború \\
\hline 1903 & Panama függetlensége \\
\hline 1910 & A mexikói forradalom kitörése és a Pán-Amerikai Unió létrejötte \\
\hline $1932-1935$ & Chaco háború Bolívia és Paraguay között \\
\hline 1948 & $\begin{array}{l}\text { Megalakul az Amerikai Államok Szervezete és Costa Ricában } \\
\text { eltörlik a hadsereg intézményét }\end{array}$ \\
\hline
\end{tabular}


7.2. Latin-Amerika: civilizációk kölcsönhatásos rendszere

\begin{tabular}{c|l} 
dátum & \multicolumn{1}{c}{ esemény } \\
\hline 1952 & A bolíviai forradalom kezdete \\
\hline 1959 & A kubai forradalom győzelme \\
\hline 1964 & A katonaság átveszi a hatalmat Brazíliában \\
\hline 1967 & $\begin{array}{l}\text { Miguel Ángel Asturiast irodalmi Nobel-díjjal tüntetik ki, Gabriel } \\
\text { García Márquez megjelenteti a Száz év magányt }\end{array}$ \\
\hline 1973 & $\begin{array}{l}\text { Katonai puccs vet véget Salvador Allende elnökségének Chilében, } \\
\text { az új elnök Augusto Pinochet }\end{array}$ \\
\hline 1979 & Sandinista hatalomátvétel Nicaraguában \\
\hline 1982 & $\begin{array}{l}\text { Az adósságválság kezdete Latin-Amerikában, Mexikó bejelenti } \\
\text { fizetésképtelenségét }\end{array}$ \\
\hline 1991 & Megalakul a Déli Közös Piac (MERCOSUR) \\
\hline 1992 & $\begin{array}{l}\text { Rigoberta Menchú guatemalai emberi jogi aktivista Nobel-békedíjat } \\
\text { kap }\end{array}$ \\
\hline $2001-2002$ & Politikai, gazdasági és szociális válság Argentínában \\
\hline 2003 & $\begin{array}{l}\text { Az Egyesült Államokban élö hispán lakosság száma meghaladja az } \\
\text { afro-amerikaiakét }\end{array}$ \\
\hline 2006 & $\begin{array}{l}\text { A demokratikus úton megválasztott Evo Morales ajmara származású } \\
\text { politikus elnöki beiktatása Bolíviában }\end{array}$ \\
\hline 2010 & Létrejön a Latin-Amerikai és Karibi Államok Közössége (CELAC) \\
\hline 2015 & $\begin{array}{l}\text { Történelmi jelentöségü találkozó Raúl Castro és Barack Obama } \\
\text { között a panama Összamerikai Csúcstalálkozón }\end{array}$ \\
\hline
\end{tabular}




\subsubsection{Irodalomjegyzék}

\section{Ajánlott irodalom}

ANDERLE ÁdÁm 1992: Latin-Amerika története. Budapest: Pannonica

ANDERLE ÁdÁm 2002: „Nemzet és identitás Latin-Amerikában”. - In: BALOGH

ANDrÁs (szerk.): Nemzet és nacionalizmus - Ázsia, Afrika, Latin-Amerika.

Budapest: Korona, pp. 407-544.

BENKÖ JudiT 1985: Népek, kultúrák találkozása a conquista utáni LatinAmerikában. Világtörténet (3): pp. 85-114.; továbbá: In: BoGLÁR, LAJos (szerk.): Kultúrák sorsa a fejlödö világban. Budapest: MTA Orientalisztikai Munkaközösség, pp. 102-124. - http://real-j.mtak. hu/2116/1/Vilagtortenet_1985.pdf-2017.01.10.

BERKICS ERIKA 2008: „A latin-amerikai nyelvi etnikai mozaik”. Külügyi Szemle (3): pp. 124-147. - http://kki.hu/assets/upload/Kulugyi_ Szemle_2008_03_A_latin-amerikai_nyelvi_e.pdf-2017.01.10.

Eakin, Marschall C. 2007: The History of Latin America: Collision of Cultures. New York: Palgrave Macmillan

Grigulevics, I. R. 1981: Kereszt és kard: A katolikus egyház SpanyolAmerikában a XVI-XVIII. században. Budapest: Kossuth

Reyes, Alfonso 1984: „Amerika küldetése”. - In: Scholz, László (szerk.): Ariel és Kalibán: A latin-amerikai esszé klasszikusai. Budapest: Európa, pp. 297-301.

Rodó, José EnRiQue 1984: „Ariel”. - In: Scholz, László (szerk.): Ariel és Kalibán. A latin-amerikai esszé klasszikusai. Budapest: Európa, pp. 81109.

Veresegyházi Béla 1992: Amerika felfedezése: kisenciklopédia 1492-1600. Budapest: Primo

Williamson, Edwin 1992: The Penguin History of Latin America. London: Penguin Books

Williamson, Robert C. 2006: Latin America: Cultures in Conflict. New York: Palgrave Macmillan 


\section{8. Ábrajegyzék}

\subsection{Térképek}

sorszám

cím

p.

1. Kína elhelyezkedése és természeti viszonyai

49

2. Az első, mitikus dinasztia feltételezett elhelyezkedése 62

3. Kínai területek i. e. 5. századtól i. e. 221-ig 66

4. Kína az i. e. 3. század végén 68

5. Kínai államok a 10. század első felében 71

6. Kína a 13-14. században 73

7. Kína területe az utolsó uralkodóház idején 77

8. Japán domborzata, föbb vulkánjai és nagyvárosai 92

9. Az indiai szubkontinens 137

10. A Maurja Birodalom i. e. 250 körül 146

11. A Gupta állam és szomszédai i. sz. 400 körül 147

12. A Mogul Birodalom legnagyobb kiterjedése (17. század vége, 18. század 148 eleje)

13. India a brit fennhatóság idején 1906-ban 149

14. Az ősatyák vándorlása a Biblia alapján 193

15. Törzsi tagolódás a Biblia alapján 195

16. Az Asszír Birodalom Izrael beolvasztása után 197

17. A világ muszlim népessége 2018-ban 226

18. Az iszlám világ föbb etnikai és kulturális csoportjai 2018-ban 227

19. Az iszlám világ földrajzi jellegzetességei 228

20. Az iszlám világ keletkezésének központi terülein fekvő arab államokat 230 fogja össze az 1945-ben Kairóban alapított Arab Liga, amelynek jelenleg 22 tagja van

21. Az iszlám térhódítása 238

22. A Mamlúk Szultánátus legnagyobb kiterjedése 250

23. Az ún. puskapor birodalmak 253

24. Az iszlám főbb irányzatai és jogi iskolái 262

25. Afrika nyelvcsaládjai 300

26. Afrika vallásai 313

27. A gyarmatosítás előtti főbb államok Afrikában 315

28. Ortodox egyházak Európában és a Közel-Keleten 328

29. Moszkva befolyási övezetének területi gyarapodása a 16. századig 332

30. Oroszország területi gyarapodása a 17. századtól az I. világháborúig 333

31. A Karoling Európa 375

32. Európa a 11. század végén 382 
Civilizációk Kelettől Nyugatig

sorszám

cím

p.

33. Európa a 14. században

390

34. Vallási felekezetek a kora újkori Európában

393

35. A nemzetállamok Európája a 19. század utolsó harmadában 398

36. Az USA területi gyarapodása 1776-1853 425

37. A Kolumbusz előtti főbb kultúrák elhelyezkedése 452

38. A gyarmati Latin-Amerika 461

39. Latin-Amerika országai ma 466 


\subsection{Képek}

sorszám

cím

p.

1. Az Inglehart-Welzel-féle kulturális térkép 31

2. A modernizáció és a nyugatosítás viszonya 34

3. Családi oltár, amelyen jól látható a politika és a vallások keveredése, $\quad 47$ Jünnan (Yunnan) tartomány

4. Paj (Bai) nemzetiségü buddhista női közösség az idősek ünnepén, Jünnan 52 (Yunnan) tartomány

5. Az írás szentsége. Szabadtéri kalligráfia Pekingben 53

6. Életkerék. Kőfaragás a buddhista, konfuciánus és taoista hitet is tükröző 55 Tacu (Dazu) barlangokból, Szecsuan (Sichuan) tartomány

7. Ösök temploma, Tengcsungban (Tengchong), Jünnan (Yunnan) tartomány 58

8. Az agyaghadsereg Hszian (Xi’an) város közelében 68

9. A kínai nagy fal építése a Han-dinasztia idején kezdődött 69

10. Feliratos kőtáblák a Jün-csü (Yunju) templomban, Peking közelében 70

11. Népi színjáték Kunmingban, Jünnan (Yunnan) tartomány 72

12. A vulkanikus Hakone-hegység ma is aktív kénes nyílásai 94

13. Az egyik legnagyobb sintó szentély, a Fusimi Inari-szentély kapusora 97

14. A japán Zen buddhizmus elvei alapján tervezett kert (Kómjóin, Kiotó) 98

15. Dzsómon-kori kerámia 102

16. A korabeli harcos viseletét jól tükröző terrakotta szobor (haniva) 104

17. Az eredetileg 586-ban alapított Haruna-szentély 105

18. Nara-kori női viselet 106

19. Heian-kori női viselet 107

20. A császárt, a császárnét és három udvarhölgyet ábrázoló babák Heian-kori 108 viseletben a Hina macuri (Babaünnep) alkalmából kiállítva

21. Szamuráj viselet 109

22. A kamakurai Nagy Buddha 110

23. Az eredetileg a 16. sz. végén épült oszakai várkastély és kertje 112

24. Az Edo-kor elején épült kastély Himedzsiben 113

25. Edo-kori házbelső 114

26. Felhőkarcolók Tokióban 124

27. Reklámok a Dótonbori negyedben (Oszaka) 126

28. Hagyományos, mégis modern japán tálalás 127

29. Reggeli rítus a Gangeszen Váránaszínál 140

30. Jógapózban ülő férfialak. Indus-völgyi pecsételő, Mohendzsó-dáró 152 (Pakisztán), i. e. 2600-1900

31. Meditáló Buddha. Dombormű a Nagy Sztúpa keleti oldalán. Száncsí (Madhja Pradés), Gupta korszak, 5. század közepe körül 
sorszám cím p.

32. A Nagy Sztúpa. Száncsí (Madhja Pradés), i. e. 3. század - i. sz. 1. század 165

33. Rádzsagriha uralkodója, Bimbiszára kíséretével elhagyja a palotát, hogy 166 meglátogassa a Buddhát. Dombormű a Nagy Sztúpa keleti kapuján. Száncsí (Madhja Pradés), i. sz. 1. század 2-3. évtizede

34. Faistennő a Nagy Sztúpa keleti kapuján. Száncsí (Madhja Pradés), i. sz. 1. 167 század 2-3. évtizede

35. Budhagupta uralkodása idejéből származó oszlop felső része a mitikus napmadár, Garuda ábrázolásával. Éran (Madhja Pradés), Gupta korszak, i. sz. 484.

36. A Végtelenség kígyóján fekvő Visnu (részlet). Dasávatára templom, Deogarh (Uttar Pradés), 6. század eleje

37. Lingam Siva arcának ábrázolásával. Udajagiri (Madhja Pradés), 4. sz. barlang. Gupta korszak, 5. század első negyede

38. Khadzsuráhó templomai. Csandélla-dinasztia, 11. század 178

39. Arunácsalésvara templom, Tiruvannámalai (Tamilnádu) 179

40. A gválijari (Gwalior) erőd, Madhja Pradés. Mai formájában a 15-16. 183 században épült ki

41. Tóratekercs a Munk-Munkácsi gyüjteményből, MILEV 202

42. Tóramutató, Marrakes, Zsidó Múzeum 203

43. A marrakesi Lazama zsinagóga 203

44. Babiloni Talmud. Prága: Landau, 1832.

45. Imasál (talit) ezüstveretekkel, MILEV 208

46. Szefárd mezuza Macedóniából 209

47. Kosszarvból készült kürtöt (sófár) fúvó férfi. Ünnepi imakönyv (mahzór), 213 Dél-Németország, 13. sz. vége

48. F. Kaskeline, Szukkot ünneplése a templomban, MILEV 215

49. Menóra ábrázolása Maimonidész, Misné Tóra című művének kéziratában, 216 Északkelet-Franciaország, 1296.

50. Pörgettyü, hanukai játék, MILEV 217

51. Széderre terített asztal 218

52. A kopár vidékeken a mai napig a datolyapálma oázis a megélhetés egyik 229 legfőbb forrása

53. Az eredetileg a 8. sz. végén az abbászida kormányzó által építtetett monasztiri erőd (Tunézia), amelyet a későbbi helyi dinasztiák idején is használtak és kibővítettek

54. Arany dínár arab felirattal, Mahdiai Múzeum (Tunézia)

55. A Fátimidák által a 11. században épített Báb al-futúh (Hódítások kapuja) 246 Kairóban. A háttérben a 6. fátimida kalifáról elnevezett Hákim mecset egyik minaretje

56. A bahri mamlúk an-Nászir Muhammad ibn Kaláún szultán által a 14. század elején a kairói citadella területén építtetett mecset 
57. A hitvallás arab szövegének kalligráfiája egy kairói mecset falán

58. Mihráb és minbar egy kairói mecsetben

59. Mekka és Medina egy 18. században másolt muszlim imakönyvben

60. Az 1356-ban épült kairói Szargatmis madrasza, amelyben mecset és mauzóleum is található

61. Ali bölcs mondása kalligrafikus elrendezésben: „Nincs magasabb tisztesség az iszlámnál". Kairó

62. Az Okba ibn Náfi által 670-ben alapított kajraváni nagymecset, amely végső formáját az Aglabida dinasztia uralma alatt, a 9. században nyerte el

63. A 879-ben épült kairói Ibn Túlún mecset és minaretje

64. Három 15-17. századi madrasza ívánjai Szamarkand egykori föterén (Régisztán, azaz „poros tér”)

65. Kúfi írásos Korán részletek $(1: 7 ; 12: 53)$ a 8 . századból, a fejezeteket elválasztó dísszel. Isztambul, Iszlám Müvészeti Múzem

66. Kúfi írásos felirattal díszített íván. Bahádur Dzsalangtús madraszája, Szamarkand, 17. század

67. Feliratokkal gazdagon díszített csempeburkolat. Buhara, Abdallah Hán madraszája, 16. sz.

68. Az arab kalligráfiát felhasználó modern kairói utcai művészet

69. Énekmondók (griot) Szambala király udvarából (Medina, Mali)

70. Egy 19. századi észak-ghánai családi krónika első lapja

71. A kameruni bamum nép írásával készült könyv, 1910 körül

72. Etióp kézirat evangélium kivonatokkal és imákkal ge’ez nyelven. A képen jobbra Mihály és Gábriel arkangyalok

73. A Tídzsánijja szúfi rend helyi vezetői Niger délnyugati részén, Kiota városkában

74. Holland ábrázolás Benin városáról (ma Nigériában), 1668.

75. Három benini harcost ábrázoló benini joruba bronzlap, 16-17. század

76. Joruba bronzportré Ife városából, ma a British Museumban

77. Arany mérésére szolgáló asanti rézszobrocskák Ghánából, az angliai Beaney House of Art and Knowledge (Canterbury) gyüjteményében

78. A lalibelai (Etiópia) Bete Gijorgisz (Szt. György-templom)

79. A Nagy-Zimbabwe épületegyüttesének részlete

80. A dzsennéi Nagymecset, a szudáni gótika egyik legkiemelkedőbb alkotása

81. A fülkék piramisa, El Tajín (Veracruz, Mexikó). Az eredetileg preklasszikus kori település 4. században épült, maja hatást tükröző piramisa

82. Olmék oltár (La Venta, Tabasco, Mexikó)

83. Lépcsős piramis Tikalban (Guatemala), a maja civilizáció legnagyobb városában

84. Maja-tolték lépcsős piramis, Chichén Itzá (Yucatán-félsziget, Mexikó) 



\section{Fogalmak}

$\quad$ fogalom
adzsami
afrocentrism
ágama (szanszkrit)
ahimszá (szkt.
,nem-ártás")
ahl al-bajt
aladura

jelentés

Az arab ábécé betükészletét különböző afrikai nyelvek lejegyzésére használó írás.

Az amerikai fekete értelmiség körében létrejött, az afrikai gyökerekhez való visszatérést pártoló szellemi irányzat.

Devocionális hindu iskolák vallási szövegei. Léteznek saiva, vaisnava és sákta ágamák, az utóbbiakat tantráknak is nevezik.

Az erőszakmentesség és mindenféle élet tiszteletének elve az indiai vallásokban.

A Próféta háza népe, vagyis a családja.

„Fohászkodó” szekták; a dél-nigériai kereszténység egyik sajátos típusa, amelyben az afrikai hagyományok erősen keverednek a keresztény tanokkal.

allodiális birtok Általánosságban a hűbéri szolgáltatástól mentes szabad birtok, ami Oroszországban az apáról fiúra szálló örökbirtoknak, a votcsinának felel meg.

anómia

Atársadalmiértékek és normák iránymutató szerepének meggyengülése, amely általában a modern társadalmakban, illetve nagyobb társadalmi változások hatására léphet fel.

áranjaka (szkt. A Védákhoz füzött kommentárirodalomból az áldozatok ,erdei könyv”) jelképrendszerét fejtegető misztikus szövegek.

aranyozott kor

Mark Twain kifejezése a 19. század utolsó harmadának amerikai társadalmáról, amit gyors gazdasági fellendülés, hatalmas méretü cégek és monopóliumok felemelkedése, valamint korrupció és a nagytulajdonosi csoportok politikára gyakorolt hatása jellemzett.

arhat (szkt.

„érdemes",

A buddhista hierarchiában a legmagasabb rang.

„, tiszteletre méltó”)

árja (szkt. „,nemes”) Az indoeurópai nyelvcsalád indoiráni ágát beszélő népcsoportok önmegnevezése.

artha (szkt.

„, haszon",

„vagyon")

askenázi

átman (szkt.)

audiencia

Pénz vagy megélhetés; az életcélok egyike a hinduizmusban.

Németország, ill. Észak-Franciaország területéről származó zsidók.

Egyéni lélek.

A spanyol-amerikai gyarmati periódus legfontosabb intézménye és kormányzati egysége, amely az igazságszolgáltatást, a közigazgatást és a pénzügyeket vonta maga alá, de ellenőrizte az egyházat is.

autarchikus fejlődés Olyan fejlődési modell, amely az önellátásra épül. Az ezen fejlődési utat követő államok, általában hátat fordítanak a világkereskedelemnek és alacsony külkereskedelmi forgalmat bonyolítanak le. 


\author{
fogalom \\ autokefál egyház \\ avatára (szkt. \\ „, alászállás”, \\ „,megtestesülés”) \\ axis mundi (latin \\ „világtengely") \\ bakufu \\ bantu
}

bar-micva

benefícium

bhakti (szkt.

„odaadás",

„,imádás”)

Bhárat Mátá (szkt.

India Anya)

bódhiszattva (szkt. „megvilágosodás lényegu"”)

brahman (szkt.)

bráhmana (szkt.)

bráhmí

busi

caudillo jelentés

A keleti, avagy ortodox kereszténység önálló egyházai.

Elsősorban Visnu földi megtestesüléseit értik alatta. Ezek a következők Matszja (Hal), Kúrma (Teknős), Varáha (Vadkan), Naraszinha (Emberoroszlán), Vámana (Törpe), Parasuráma (Csatabárdos Ráma), Ráma, Krisna, Buddha (vagy Balaráma), Kalki.

Egyes vallásokban a világ középpontja, ahol átjárás van az égi és a földi világ között. Kapcsolatban áll a világfa elképzelésével is.

$\mathrm{A} \rightarrow$ sógun kormányzata.

A niger-kongói nyelvcsalád, mintegy 250 nyelvből álló csoportja, amelyeket Afrika egész déli felében beszélik.

A tizenharmadik életévét betöltött fiú, akinek a zsidó vallás parancsolatait (micváit) be kell tartania. Ugyanígy nevezik azt az ünnepséget is, melyen a fiú elöször teljesít nyilvánosan olyan parancsolatot, amit korábban soha.

Általánosságban a hűbéri szolgáltatás fejében adott birtok vagy javadalom, ami Oroszországban az állam szolgálatáért kapott szolgálati birtoknak, a pomesztyének felel meg.

Áhítatos, feltétlen istenszeretet, a középkori hindu vallásosság jellemzője.

$\mathrm{Az}$ indiai függetlenségi mozgalom során kialakult nemzeti jelkép, India anyaistennőként való megszemélyesítése.

A $\rightarrow$ mahájána buddhizmus könyörületes, segítő lényei. A Buddha maga is bódhiszattva volt korábbi születéseiben, valamint utolsó születésében a megvilágosodásáig.

Az abszolút létező.

1. A legfelső társadalmi rend, a papi varna tagjai. Elsődleges feladatuk az áldozatbemutatás és a szent szövegek tanulmányozása, magyarázata és hagyományozása volt, később mindenfajta írástudást igénylő és értelmiségi foglalkozás fö letéteményeseivé váltak. 2. A $\rightarrow$ Védákhoz füzött kommentárok, amelyek az áldozati rítusok szabályait és magyarázatát tartalmazzák.

Az i. e. 3. századtól feliratokon ismert írás az ókori Indiában; a mai indiai írások ebből fejlődtek ki.

$\rightarrow$ szamuráj

Spanyol-Amerikában a függetlenségi háborúk idején megerösödött katonai vezető, aki kliensrendszerével és haderejével képes volt egy térség irányítására, sokszor az országos politikát is befolyásolva. A 20. században a kifejezés erőskezü politikai vezetőt jelöl Spanyolországban és Latin-Amerikában. 
fogalom jelentés

cezaropapizmus A keresztény egyház és az állam szoros összefonódása az állam vezető szerepével. Elsősorban a görögkeleti egyházak esetében Bizáncot és Oroszországot illetően szokás cezaropapizmusról beszélni a középkori és az újkori történelem során. A történészek véleménye megoszlik a cezaropapizmus fogalmának használhatóságát illetően.

cunami

Tengerrengés (tengerfenék földrengése) vagy tenger alatti vulkán kitörése következtében kialakuló szökőár (japán jelentése „kikötői hullám").

csakra (szkt.

Napszimbólum. A buddhizmusban a Tan jelképe, a hinduizmusban

„,kerék”,

„,diszkosz”)

Visnu fegyvere.

csakravartin (szkt.) Egyetemes uralkodó, császár.

daimjó

Tartományt birtokló $\rightarrow$ szamuráj nagyúr a 14-19. században.

darsana (szkt.)

Óind filozófiai irányzat, iskola, a hat ortodox rendszer $(\rightarrow$ szánkhja, $\rightarrow$ jóga, mímánszá, védánta, vaisésika, njája).

deszakralizáció/

Ezeket a szavakat rokon értelmű kifejezésként szokás használni, szekularizáció/

laicizálódás másfelöl saját jelentéssel is rendelkeznek. Számos jelentésréteget foglalnak magukba, elsősorban a társadalmi normák, értékek és intézmények szakrális (vallásos/,szent”) irányultságának, jellegének a megszünését értik alatta a modern korban.

deus otiosus

Olyan istenség, aki a világ megteremtésével befejezte feladatát, s a továbbiakban nem szól bele a teremtett világ müködésébe.

déva (szkt.)

Védikus istenek.

dévanágari (szkt. A szanszkrit, hindi, maráthi, stb. lejegyzésére szolgáló szótagírás, a „, isteni városi”) $\rightarrow$ bráhmíból fejlödött ki.

dévarádzsa (szkt. , istenkirály”)

Az istenként tisztelt uralkodó kultusza Délkelet-Ázsiában.

dhamma (páli)

A buddhista Tan.

dharma (szkt.)

A vallás, vallási kötelesség, viselkedési norma, törvény. Az életcélok egyike a hinduizmusban.

diarchikus rendszer Két hatáson, avagy erőn alapuló rendszer, mint amilyen az I. Péter előtti Oroszország volt, ahol a világi és egyházi hatalom közös, egymásnak alá nem vetett akarata érvényesült.

diaszpóra (a. $m$. Szülöföldjén kívül élö etnikum tagjai.

szórvány)

diffidatio

A hüségeskü felmondásának joga, a „hüség visszavonása”.

digambara (szkt. A dzsaina vallás szigorú aszkézist folytató szerzetesrendje.

„égruhájú”)

dravida (szkt.)

A hindu templomépítészet déli stílusa.

dzimmi (arab

„védelem alatt

A keresztények, zsidók és zoroasztriánusok jogi helyzetét jelölte az álló") 


\begin{tabular}{|c|c|}
\hline fogalom & jelentés \\
\hline dzsaina (szkt.) & $\begin{array}{l}\text { A dzsainizmus követöje. Indiában ma mintegy } 4,5 \text { millió dzsaina él, de } \\
\text { számuk a diaszpórával együtt meghaladja a } 7 \text { milliót. }\end{array}$ \\
\hline $\begin{array}{l}\text { dzsáti (szkt. } \\
\text { „születés”) }\end{array}$ & $\begin{array}{l}\text { Későbbi, portugál eredetű szóval } \rightarrow \text { kaszt. Az indiai társadalom } \\
\text { örökletes foglalkozási csoportjai, amelyeket endogámia és közös } \\
\text { rituális hagyomány jellemez. }\end{array}$ \\
\hline dzsátidharma (szkt.) & $\begin{array}{l}\text { Az egyén születési csoportjára }(\rightarrow d z s a ́ t i) \text { vonatkozó vallási } \\
\text { kötelezettségek és életmódra vonatkozó előírások az indiai } \\
\text { társadalomban. }\end{array}$ \\
\hline dzsihád (arab) & $\begin{array}{l}\text { „Eröfeszítés” Isten és az iszlám érdekében. A „nagy dzsihád” a hit } \\
\text { megerősítéséért folytatott harc, míg a „kis dzsihád” a külső ellenség } \\
\text { ellen folytatott harc. }\end{array}$ \\
\hline Dzsina (,,Gyöztes”) & $\begin{array}{l}\text { Vardhamána Mahávíra Kr. e. 599-527 vagy 540-468 között élt. } \\
\text { Magát nem tartotta vallásalapítónak, hanem huszonnegyediknek a } \\
\rightarrow \text { tírthankarák (szkt. „ösvénycsináló”, „gázlókészítö”) sorában. }\end{array}$ \\
\hline dzsiva (szkt.) & Lélek. \\
\hline egungun & $\begin{array}{l}\text { A dél-nigériai jorubák egyik legfontosabb szellemfigurája, az ősök } \\
\text { szelleme, amely maszkos szertartások során jelenik meg az utódok } \\
\text { előtt. }\end{array}$ \\
\hline $\begin{array}{l}\text { első kivándorlás (al- } \\
\text { hidzsra al-úlá) }\end{array}$ & $\begin{array}{l}\text { A korai iszlám történelem azon epizódja, amikor (még Mohamed } \\
\text { próféta életében) a kialakulóban levő mekkai muszlim közösség egy } \\
\text { csoportja kivándorolt Etiópiába. }\end{array}$ \\
\hline emir (arab) & $\begin{array}{l}\text { Katonai parancsnok, aki önállóan kormányoz egy területet, de elismeri } \\
\text { a kalifa fennhatóságát, elsősorban vallási kérdésekben. }\end{array}$ \\
\hline endogámia & Csoporton belüli házassági kötelezettség. \\
\hline etnikai vallás & $\begin{array}{l}\text { Egyetlen népcsoport által gyakorolt vallás, amely nem is törekszik } \\
\text { hittételeit más népcsoportok körében is elterjeszteni. }\end{array}$ \\
\hline fatva (arab) & $\begin{array}{l}\text { Jogi döntés az iszlámban, válasz egy feltett kérdésre, amely a büntető } \\
\text { jog, a vallási szertartások vagy a hétköznapi élet valamely területére } \\
\text { vonatkozik. }\end{array}$ \\
\hline felonia & Hitszegés, a hübéri eskü megsértése. \\
\hline $\begin{array}{l}\text { felszabadítás } \\
\text { teológiája }\end{array}$ & $\begin{array}{l}\text { Az 1960-as években Latin-Amerikában megerösödő mozgalom, } \\
\text { amely az evangéliumi szegénység fogalmát alapul véve a katolikus } \\
\text { egyház egyik legfőbb feladataként a szegények és elesettek védelmét } \\
\text { jelöli meg, a társadalmi igazságtalanságok felszámolását középpontba } \\
\text { helyezve a tanításról a gyakorlatra helyezte a hangsúlyt; legfőbb } \\
\text { képviselöje a perui Gustavo Gutiérrez filozófus-teológus. }\end{array}$ \\
\hline fikh (arab) & $\begin{array}{l}\text { Jogtudomány, amelyet az isteni törvény ( } \rightarrow \text { saría) forrásainak az } \\
\text { elmélyült tanulmányozása után, egyéni eröfeszítéssel a jogtudósok } \\
\text { (fakíh, tbsz. fukahá) dolgoznak ki, általános elvek, ill. részletkérdések } \\
\text { vonatkozásában. }\end{array}$ \\
\hline
\end{tabular}


fogalom

foquismo

frontier

garbhagriha (szkt. „,anyaméhház”)

gerontokrácia

Great Society

griot

gullah

hacienda

hadisz (arab)

halál (arab)

han

harám (arab) havélí jelentés

Ernesto Che Guevara elképzelései alapján formálisan Régis Debray francia filozófus által megfogalmazott elmélet, amely a kubai forradalom sikerétől vezérelve igyekszik általános receptet adni a fennálló rend elleni gerilla hadviselésről, miszerint kis központokból (foco) indulva kell a fegyveres harcot indítani, ami az általános elégedetlenség miatt szélesebb támogatást nyerve az egész társadalmat mozgósítja és a gerillák mellé állítja.

Az Egyesült Államok nyugati („mozgó”) határa, amely a telepesek terjeszkedése révén egyre nyugatabbra tolódott el a 19. században. A frontier klasszikus tézisét kimunkáló Turner szerint számottevő mértékben hozzájárult az amerikai civilizációs jellegzetességek kialakulásához.

A hindu templomok szentélye.

Az a társadalmi berendezkedés, amelyben az uralom a közösség legöregebb tagjainak kezében van.

A demokrata Johnson elnöksége alatt az 1960-as évek derekán kezdeményezett szociális és jóléti intézkedések együttese főleg a szegénység felszámolására és az egészségügyi ellátás kiterjesztésére az Egyesült Államokban. A Great Society a társadalmi emancipáció kiteljesítésére törekedett, és a második világháború utáni jóléti állam amerikai változatának megteremtésére tett kísérletként értékelhető.

Francia eredetű szó, azt a sok afrikai társadalomban létező $\rightarrow$ endogám kasztot jelenti, amelynek tagjai a hagyományok memorizálásával, továbbadásával és (gyakran zenekísérettel történő) előadásával foglalkoztak.

Dél-Karolina állam (USA) partvidékén kialakult, erős afrikai hatást tükröző nyelvjárás és kultúra.

Önellátó nagybirtok a spanyol és portugál gyarmatokon, rendszerint mezőgazdasági termelésből és állattenyésztésből tartja el magát, egyszerre ad otthont a tulajdonos családjának és a dolgozó személyzetnek.

Mohamed próféta hagyománya, szóbeli közlése, amelyet továbbadtak, akik hallották. Két része az isznád, azaz a hagyományozók láncolata és a matn, a tulajdonképpeni szöveg.

Az iszlám vallási előírásainak megfelelő, kötelezően követendő módon elvégzett cselekedet, pl. az állatok levágásának módja.

Kína legnagyobb, a lakosság 92 százalékát kitevő népcsoportja. Bár nyelvileg és szokásait tekintve több kisebb csoportra bontható, mégis ők alkotják a kínai nép és a kínai civilizáció alapját.

Tilos, bün az iszlámban, amelyet a bírónak (kádi) kell megítélnie.

Nagyméretü hagyományos városi lakóház Indiában, esetenként palota. Belső udvar köré épül. Legtöbb esetben építészeti és kulturális jelentőséggel bíró épülettípus. 


$\quad$ fogalom
helyreállítási
idöszak
heterodoxia
hidzsra (arab)
hínajána (szkt., ,kis
kocsi”, ,keskeny
ösvény”)
hsziungnu (xiongnu)

hudúd (arab)
hupa
idzsmá (arab
,közmegegyezés”)
idzstihád
(arab „egyéni
eröfeszités”)
ie

imám (arab)

inkvizíció

izolacionizmus

jóga (szkt.) jelentés

Az amerikai polgárháború (1861-1865) utáni bő évtized elnevezése az Egyesült Államok, de legföképpen a legyőzött déli államok történetében, amikor végbement a déli területek szövetségi állam kereteibe való beillesztése, különös tekintettel a felszabadított rabszolgák helyzetének rendezésére.

Más, avagy idegen hit.

Mohamed próféta kivándorlása Mekkából Medinába 622-ben, ami egyben a muszlim időszámítás, az 1. holdév, kezdetét is jelenti.

Azoknak a buddhista iskoláknak az összefoglaló neve, amelyeknek a tanítása szerint a megvilágosodás csak kivételes kevesek számára érhető el. A hínajána iskolák száma egykor elérte a tizennyolcat, de ezek közül mára csak a $\rightarrow$ théraváda iskola maradt fenn.

Egykor Kínától északra élő, ázsiai hunoknak is nevezett nomád törzsszövetség, amely hosszú ideig háborúban állt a kínai állammal is, így jelentősen hozzájárultak a nagy fal felépitéséhez. A kínaiak egy része szerint a magyarok ősei, így Magyarország kínai nevében Hsziungjali (Xiongyali) - is megjelenik a rájuk történö utalás.

„Határok”, amelyeket Isten jelölt ki, és amelyek átlépését jelentik a föbünök. Ezeknek a büntetését a Korán egyértelmúen leírja, pl. gyilkosság, lopás, házasságtörés, rágalmazás esetén.

Zsidó esküvői baldachin.

Egy jogi irányzat, iskola jogtudósainak a megegyezése egy bizonyos elóírás kérdésében, egy adott korban, ill. területen.

Amikor a muszlim vallástudósok isteni kegyelem révén elmélyülten tanulmányozzák az isteni kinyilatkoztatás különböző szövegeit $(\rightarrow$ Korán és $\rightarrow$ hadisz $)$ és próbálják megállapítani Isten szándékát.

A $\rightarrow$ busi családmodell. Japán patriarchális hierarchikus család, öröklődő családnévvel és vagyonnal, magán földbirtokkal.

A szunnita iszlámban imavezető, előimádkozó, a sítáknál Mohamed próféta családjának Ali fiaitól származó tagjai, akiket Isten kijelölt, hogy a közösséget vezessék.

Az eretnekség kiirtását célzó törvényszék, Spanyolországban 1478-ban kezdte meg müködését, Spanyol-Amerikában a 16. század második felében lépett fel, szorosan összefonódva az államapparátussal.

Az amerikai külpolitika egyik sajátos vonása, ami különféle történeti helyzetekben többször is érvényesült a 19-20. században. Aktív világpolitika helyett az USA nemzetközi kötelezettségekkel és a külvilággal szembeni tartózkodását fejezi ki és tartja kívánatosnak. Többféle változata és mértéke létezik, ám tiszta formában aligha érvényesült, és csak erős fenntartásokkal használható az amerikai külpolitika leírására.

Testgyakorlatok és meditációs technikák, amelyek célja a legfőbb világprincípiummal való egyesülés. 


fogalom
jom kippur (héber
„engesztelönap”)
juga (szkt.)

kakadoxia

kalifa (arab ,,utód”)

kalpa (szkt.)

káma (szkt. ,vágy”) kami

karkhána

karma (szkt. ,tett”)

karósthí

kaszt

Kaurava

kávja (szkt. „,költemény”)

kibla (arab)

kijász (arab „analógia”)

kofun

kongói bársony jelentés

Zsidó ünnep.

Világkorszak. Brahmá isten egy napja ( $\rightarrow$ kalpa) négy ilyen korszakból áll (szatja, tréta, dvápara és kálijuga), melyek egyre csökkenő időtartamúak, s bennük az erkölcsök fokozatos romlása figyelhető meg. E szemlélet szerint az emberiség jelenleg a 432 ezer év hosszú kálijugában él, melyből ötezer év telt el.

\section{Tévhit.}

Mohamed halála után a muszlim közösség vallási és világi vezetője, később Isten földi helytartójának nevezik.

Az indiai mitológiai hagyományban a világegyetem fennállásának egy ciklusa, amely Brahmá isten egy napjának felel meg. Időtartama 4,32 milliárd földi évvel egyenlő.

Szerelem, érzékiség; a hindu életcélok egyike.

A japán hiedelemvilág istenségei. Szinte megszámlálhatatlanul sokan vannak, a természeti jelenségekben lakoznak, de haláluk után emberekböl is válhatnak kamik. Az ember élete tölük függ, a kamik segíthetnek, megharagudhatnak, de kiengesztelhetők szertartásokkal, áldozatokkal, imákkal. Minden közösségnek, családnak saját védőistensége volt, gyakran egy dicső ős személyében.

Udvari kézmüves mühelyek, melyek a delhi szultánok és a Mogul udvar szükségleteinek kielégítésére állították elő termékeiket.

Az elöző élet cselekedetei által meghatározott sors.

Az ókori Gandhárában használt írás.

Portugál eredetű szó az indiai társadalom születési, foglalkozási egységeinek megjelölésére.

Kuru leszármazottai, a Pándavákkal szembenálló királyi család a Mahábháratában.

Egyetlen szerző által írott epikus költői alkotás az óind irodalomban.

Imairány, amelyet az imafülke (mihráb) jelöl, s amelynek mindig a mekkai Kába, „Isten Háza” felé kell néznie.

A muszlim jogtudósok módszere, amelynek segítségével kiterjesztik a vallási szövegek utasításait olyan dolgokra is, amelyeket azok nem tartalmaznak.

Halomsír (tumulus, japánul „régi sír”), hasonló a szinte egész ÉszakÁzsiában található kurgánhoz. Japánban a 3-6. században az előkelők sírjait, sírkamráit hatalmas földhányásokkal borították be, hasonlóan az akkori koreai királyságok szokásaihoz.

A rafiapálma rostjaiból készített, bársonyszerü, hímzett szövetanyag, amely a Kongó-medence müvészetének egyik sajátos válfaja. 
fogalom jelentés

Korán (arab

„,hirdetések”)

Az iszlám szent könyve, amely az iszlám tanítása szerint szó szerint Isten szava arab nyelven, amelyet Isten Mohamed prófétával küldött le a Földre, hogy megerösítse és véglegesítse a korábbi prófétákkal leküldött könyveit.

korcsoport (age set) Nagyjából hasonló korú személyek alkotta, pontosan meghatározott társadalmi szerepet játszó, intézményesült társadalmi kategória.

korlátozott

írásbeliség

Az írás használatának az a szintje, amikor az írásbeliség csak

(restricted literacy) specializált szakemberek sajátja és csak bizonyos speciális társadalmi

(rendi) korporáció és vallási célokra használatos.

Egy adott rend által alkotott közösség, illetve annak önigazgató testülete.

kóser

A zsidó vallás előírásainak megfelelő.

koutou

A kínai császár köszöntésére szolgáló ősi rítus, amely két térdre ereszkedéssel és a homlok kilencszer történő padlóhoz érintésével jár.

krisztológiai dogma Krisztus isteni és emberi természetének viszonyát értelmező egyházi tanítás.

ksatrija (szkt.) Az ind társadalomban a harcosok rendje. Hagyományosan közülük kerültek ki a királyok és ők alkották a katonai arisztokráciát.

kultúrpesszimizmus Egy kultúra/civilizáció jelenével és jövőjével kapcsolatos negatív ítéletek együttese. A kultúrkritika tágabb körébe tartozó jelenség, amely elsősorban a nyugati kultúrkörben jelent meg, és főleg az európai civilizációval kapcsolatos pesszimista értékítéleteket fogalmazott meg értelmiségi körökben a 20. század során. Ezek a kultúra hanyatlására és az organikus közösségek szétesésére stb. vonatkoztak.

kumbh mélá (szkt., Tömeges hindu zarándoklat a Gangeszhez, amelyre négyévente forgó hindi) rendszerben kerül sor Allahábádban (Prajág), Haridvárban, Nászikban és Uddzsainban. Mint a világ legnagyobb békés vallási összejövetele 2017-ben felkerült az UNESCO szellemi, kulturális örökség listájára.

kuraka

Indián előkelö, aki a spanyol-amerikai gyarmati rendszerbe épülve a privilégiumokért cserébe segítette a belső rendet és beszedte az indiánoktól az adót.

kusita

Az afroázsiai nyelvcsalád egyik csoportja, amely Afrika északkeleti térségében terjedt el.

laicizálódás

laissez faire

legizmus $\rightarrow$ deszakralizáció

Közgazdasági nézet és gazdaságpolitikai felfogás, amely szerint az a helyes, ha az állam minél kisebb mértékben avatkozik be a gazdaságba.

A kínai bölcseletek egyik fontos ága, amelynek elnevezéséből is adódóan központi szereplője a jog, azaz a szabályokon és törvényeken alapuló társadalmi rend. Egyik fontos tényezője a moralitás, azaz a társadalmi normákat a jogi normákkal egybeolvasztó szemlélet. A jog és az erkölcs nem volt elválasztható egymástól, miközben a bírói és az adminisztratív hatalom is egységet alkotott, így nem meglepö, hogy az autoriter szokásjog alapján egyén és állam viszonyában rendszerint az utóbbi javára dőltek el a vitás ügyek. 


\begin{abstract}
fogalom jelentés
levellerek

„Egyenlősítők”. Az angol polgári forradalom (1640-1649) egyik irányzata, amely tagadta a nemesség elsőbbségét, jogegyenlőséget és széles választójogot követelt.

lingam (szkt. ,jel”) Férfi nemi szerv, fallosz, termékenységi szimbólum; a hinduizmusban Sivával asszociálják.

machismo

A macho szó a portugál és spanyol nyelvben a közösség vagy a szélesebb társadalom által elvárt férfiszerepre vonatkozik, alapvetően az erő, a bátorság és a bölcsesség értékei mentén; az 1960-1970-es években latin-amerikai feministák kezdték el használni a machismo kifejezést, erősen kritizálva a latin-amerikai patriarchális társadalmak rendszerét.
\end{abstract}

madzhab (arab) Jogi és rituális irányzat, iskola a szunnita iszlámban, amely összefogja a jogtudósok egyéni tevékenységét, bár nem feltételezi egyértelmü elöírások követését, meghagyja a jogászok önálló gondolkodását. A négy elismert iskola, hanafi, máliki, sáfii és hanbali, a 10. századra alakult ki azzal a céllal, hogy biztosítsa a külső, elsősorban az állam beavatkozása ellen a jogtudomány önállóságát.

magas szintü Kínában a késő császárkorra a birodalomban kiegyensúlyozottá vált a egyensúly csapda kereslet és a kínálat a hatékony kereskedelmi és termelési rendszereknek köszönhetően, a helyi áruhiányokat ki lehetett egyenlíteni más területek többletével, és rendkívül olcsó volt a munkaerő. E tényezők együttes hatása azt eredményezte, hogy a technológiai fejlesztésekbe és ezáltal további hatékonyságnövelésbe való tőkebefektetés nem volt kifizetődő, így Kínában nem ment végbe az ipari és technológiai forradalom.

mágikus realizmus Múvészeti irányzat, amely a latin-amerikai irodalom 20. századi felvirágzásával vált szélesebb körben ismertté. Lényege, hogy az elbeszélésben legendákat, népi hiedelmeket, mítoszokat használ fel, a valóság csodás elemekkel, fantasztikummal kevert. A latin-amerikai irodalomban Gabriel García Márquez Száz év magány címü regénye tekinthető a mágikus realizmus alapművének.

Mahábhárata (szkt.

Óind eposz, amely a Bharata nemzetség két ága, a Pándavák és a „A Bharaták nagy háborúja") Kauravák Hasztinápura trónjáért folytatott küzdelmét beszéli el számtalan mellékszállal átszőve.

mahádzsanapada

(szkt. , nagy

ország”)

A buddhista források a Maurja kort megelőzően 16 jelentősebb államról számolnak be Észak-Indiában, melyek a Kr. e. 6-4. században álltak fenn.

mahájána (szkt. „,nagy kocsi”, „széles ösvény”)

A buddhizmus Indiától északra elterjedt ága. Fontos szerepet játszanak benne a $\rightarrow$ bódhiszattvák, akik segítőkként és a Tan védelmezőiként a mahájána buddhizmus eszményképét testesítik meg.

mahdi (arab)

Isten küldötte az iszlámban, akit Isten vezérel az igaz útra, az ítéletnap eljövetele előtt jön a Földre megváltóként. A síiták szerint az eltűnt 12. imám fog visszajönni, mint mahdi imám. A történelemben többen is állították magukról, hogy ők a mahdi, utoljára a 19. sz. végi szudáni felkelés vezére. 


\begin{tabular}{|c|c|}
\hline fogalom & jelentés \\
\hline $\begin{array}{l}\text { májá (szkt. } \\
\text { „illúzió”, ,mágia”) }\end{array}$ & $\begin{array}{l}\text { Természetfeletti hatalom, boszorkányság, mágia, Visnu kilenc } \\
\text { energiájának egyike; a jelenségek világának nem valós jellegére utaló } \\
\text { fogalom. }\end{array}$ \\
\hline majordomus & $\begin{array}{l}\text { Kora középkori tisztség a Frank Birodalomban. A majordomus a királyi } \\
\text { udvar első embere, a királyi birtokok felügyelöje és a hadsereg irányítása } \\
\text { is feladatai közé tartozott. A meggyengülő Meroving-királyok idején } \\
\text { fokozatosan átvette az állam irányítását a } 7-8 \text {. században. }\end{array}$ \\
\hline $\begin{array}{l}\text { mandala (szkt. } \\
\text { „kör”) }\end{array}$ & $\begin{array}{l}\text { Mágikus vagy szimbolikus jelentéssel bíró kör alakú diagram, az indiai } \\
\text { vallásokban a meditációnál használt vizualizációs segédeszköz. }\end{array}$ \\
\hline mantra (szkt.) & $\begin{array}{l}\text { Varázsige, ráolvasás; az istenség megidézésére alkalmas misztikus } \\
\text { szótag vagy szótagok sora. }\end{array}$ \\
\hline maritim jelleg & Tengerparti jelleg. \\
\hline maszk & $\begin{array}{l}\text { Afrikai felfogásban az arcot takaró fa- vagy fémtárgy és a hozzá } \\
\text { csatlakozó, egész testet elrejtő ruházat, amely mögött a hit szerint a } \\
\text { szertartások során egy szellem tartózkodik. }\end{array}$ \\
\hline $\begin{array}{l}\text { mátriká (szkt. } \\
\text { „anya”) }\end{array}$ & $\begin{array}{l}\text { Isteni anya, anyaistennő. Számuk különbözö lehet, de gyakran hét } \\
\text { (szaptamátriká, „Hét Anya”). }\end{array}$ \\
\hline $\begin{array}{l}\text { megszállottsági } \\
\text { kultuszok }\end{array}$ & $\begin{array}{l}\text { Az emberi testbe beköltöző szellemek kibékítését és békés eltávolítását } \\
\text { szolgáló vallási kultuszok (pl. zár az arab világban, vudu a karibi } \\
\text { térségben). }\end{array}$ \\
\hline mezuza & $\begin{array}{l}\text { A zsidó otthonok ajtófélfájára helyezett kis tok, benne } \\
\text { pergamentekercsekre írt tóraidézetekkel. }\end{array}$ \\
\hline micva & Zsidó vallási parancsolat. \\
\hline $\begin{array}{l}\text { minimal state, } \\
\text { éjjeliőr állam }\end{array}$ & $\begin{array}{l}\text { Elsősorban a liberális és a libertárius nézetekhez kötődő államfelfogás } \\
\text { a 19-20. századi nyugati politikai gondolkodásban, amely igyekszik } \\
\text { minél szükebbre vonni az állam szerepét, elsősorban gazdasági, de } \\
\text { politikai téren is. Ebben a felfogásban az állam nem elsősorban a } \\
\text { „közjó” letéteményese, hanem az egyéni szabadság garanciája. }\end{array}$ \\
\hline Misna & $\begin{array}{l}\text { A zsidó vallásjog egyik alapmủve, törvénygyüjtemény, amelyet az } \\
\text { i. sz. 2. századig szóban hagyományoztak, majd írásba foglaltak. }\end{array}$ \\
\hline $\begin{array}{l}\text { mita } \\
(,, \text { kényszermunka”) }\end{array}$ & $\begin{array}{l}\text { A felnőtt férfiak munkakötelezettségét jelölő kecsua eredetü fogalom, } \\
\text { gyakorlata a prekolumbiánus időkig nyúlik vissza. A gyarmati } \\
\text { időszakban elsősorban a bányákban végzett indián kényszermunkára } \\
\text { vonatkozik. }\end{array}$ \\
\hline $\begin{array}{l}\text { móksa (szkt. } \\
\text { „megszabadulás”) }\end{array}$ & $\begin{array}{l}\text { Megváltás a hinduizmusban, a lélek kilépése az újjászületések } \\
\text { láncolatából és egyesülése a transzcendens valósággal ( } \rightarrow \text { brahman). } \\
\text { A négy életcél egyike. }\end{array}$ \\
\hline monofiziták & $\begin{array}{l}\text { Krisztológiai tanítás az ókeresztény korban, amely az 5-6. században } \\
\text { élesztett jelentős vitákat, s az egyiptomi és a szíriai egyházakban } \\
\text { gyakorolt számottevő hatást. Eszerint Krisztusban egy természet } \\
\text { van, mert az isteni természet mintegy magába olvasztotta az emberi } \\
\text { természetet. A római és a konstantinápolyi egyház elvetette a monofizita } \\
\text { tanítást. }\end{array}$ \\
\hline
\end{tabular}


fogalom jelentés

mufti (arab)

multilineáris szemléletmód

muríd (arab „akaró”)

nágara (szkt.

„,városi”)

Natarádzsa (szkt. „,Tánckirály”)

négritude

nesztoriánusok

New Deal

nirvána (szkt.

„kialvás”, Páli

nibbána)

nitisásztra (szkt.)

óhitü szakadárok

ókimi

orisa
Jogi döntéshozó az iszlámban, olyan jogtudós, aki fel van készülve arra, hogy a neki feltett kérdésre egyéni erőfeszítése eredményeképpen vallásilag hiteles választ $(\rightarrow$ fatva) adjon.

$\rightarrow$ unilineáris vs. multilineáris szemléletmód

1. Az iszlámban a misztikus $(\rightarrow$ szúfi) mesterek tanítványainak az elnevezése, akik el akarnak érni Istenhez a misztikus úton. 2. Föleg Szenegálban, a volof népcsoport körében elterjedt iszlám misztikus (szúfi) rend.

Észak-indiai templomépítészeti stílus.

Siva egyik megjelenési formája, amely a világegyetemet elpusztító és újjáteremtő erők egyensúlyát szimbolizálja az istenség kozmikus tánca formájában.

A francia nyelvü fekete értelmiség körében divatos, a fekete népek szolidaritását és egységét hangsúlyozó szellemi irányzat.

Nesztoriosz krisztológiai tanítása az 5. században, amely Krisztus isteni és emberi természetének megkülönböztetése és elválasztása irányába ható felfogást fogalmazott meg. Bár tanítását az 5 . században az egyházi többség elítélte, ma a dogmatörténet inkább szerencsétlen megfogalmazásnak, mint tévtanításnak (eretnekségnek) tekinti álláspontját. A nesztoriánus keresztények missziója a 1. évezredben bontakozott ki az ázsiai kontinensen.

A nagy gazdasági világválság (1929-1933) hatására az Egyesült Államokban F. D. Roosevelt elnöksége alatt hozott intézkedések együttese, amelyek az állami beavatkozás kiterjesztésén keresztül megkísérelték a nehéz helyzetbe kerülő társadalmi csoportok megsegítését, jövedelemviszonyainak stabilizálását. A New Deal széles állami szerepvállalást hirdető gazdaság- és társadalompolitika volt, amely túlment a $\rightarrow$ laissez faire és a $\rightarrow$ minimal state gyakorlatán. Munkaalkalmak teremtésére, állami beruházásokra és szociális juttatásokon keresztül a keresleti oldal stabilizálására törekedett.

A megvilágosodás állapotának elérése a buddhizmusban, a $\rightarrow$ karma kialvása, a lét kötöttségeitől való megszabadulás.

Politikai etikát taglaló művek.

Azok az ortodox keresztények, akik nem fogadták el a Nyikon pátriárka által az 1650-es években kezdeményezett egyházi reformokat és ezért a hivatalos egyház keretein kívülre kerültek.

Az ókori Japánban az uralkodó megnevezése („nagykirály”) a (7. századi) kínai mintájú reformokig.

A nigériai jorubák és brazíliai leszármazottaik körében vallási tisztelet tárgyának tekintett istenségek (vagy szellemek) egyike. 


\begin{tabular}{|c|c|}
\hline fogalom & jelentés \\
\hline Pándava & $\begin{array}{l}\text { Pándu leszármazottai, a hatalomért vetélkedő királyi családok egyike a } \\
\rightarrow \text { Mahábháratában. A Pándava fivérek Judhisthira, Bhíma, Ardzsuna, } \\
\text { Nakula és Szahadéva, közös feleségük Draupadí. }\end{array}$ \\
\hline pátriárka & $\begin{array}{l}\text { 1. Ősatya, az Ószövetségben Ábrahám, Izsák és Jákob. 2. Keresztény } \\
\text { egyházfö. }\end{array}$ \\
\hline pauperizálódás & $\begin{array}{l}\text { Társadalmi jelenség, egyének, csoportok és társadalmi rétegek } \\
\text { elszegényedése. }\end{array}$ \\
\hline pentarchia & $\begin{array}{l}\text { Az ókeresztény korban és a kora középkorban kibontakozó felfogás, } \\
\text { amely az 1054-es egyházszakadás után bizonyos mértékig az ortodox } \\
\text { kereszténység gyakorlatában is továbbélt. Eszerint a keresztény } \\
\text { egyházat öt egyházfő (pátriárka) - Róma, Alexandria, Antiochia, } \\
\text { Jeruzsálem, Konstantinápoly - irányítja, akiknek különleges tekintélyét } \\
\text { ősi alapítású egyházuk biztosítja. }\end{array}$ \\
\hline peón & Spanyol-amerikai napszámos vagy képzetlen mezőgazdasági munkás. \\
\hline peszah & Zsidó húsvét. \\
\hline pin-jin & $\begin{array}{l}\text { A kínai írás 1950-es években kifejlesztett hivatalos, nemzetközileg } \\
\text { elfogadott átírása latin betúkre. }\end{array}$ \\
\hline pír & $\rightarrow$ sejk \\
\hline populus Romanus & $\begin{array}{l}\text { Római nép. A jogokkal rendelkező polgárok összessége az ókori } \\
\text { Rómában. }\end{array}$ \\
\hline $\begin{array}{l}\text { pradaksina (szkt. } \\
\text {,jobb felé”) }\end{array}$ & $\begin{array}{l}\text { Az óramutató járásával megegyező irányú mozgás vagy körüljárás. Az } \\
\text { indiai vallásokban a rituális körüljárás iránya. }\end{array}$ \\
\hline pravoszláv & $\begin{array}{l}\text { Az összetett görög szó az „ortodox” szláv fordítása, amelynek jelentése: } \\
\text { igazhitű. }\end{array}$ \\
\hline $\begin{array}{l}\text { preindusztriális } \\
\text { társadalom }\end{array}$ & $\begin{array}{l}\text { Az iparosodás (gyáripar, gyári kapitalizmus) előtti társadalom, ahol a } \\
\text { lakosság nagy része az agrárgazdaságban tevékenykedik, a demográfiai } \\
\text { viszonyokra általában az élve születések és a halálozások magas száma } \\
\text { jellemző, illetve nem találkozunk tartós gazdasági növekedéssel. }\end{array}$ \\
\hline progresszivizmus & $\begin{array}{l}\text { A 19-20. század fordulóján kialakuló társadalmi reformtörekvések } \\
\text { és azok elérésére törekvő mozgalmak összefoglaló elnevezése az } \\
\text { Egyesült Államokban. A progresszivizmus a régi amerikai ideálok } \\
\text { - széles részvételen alapuló kapitalizmus - jegyében vissza akarta } \\
\text { szorítani a nagytőke és a monopóliumok befolyását az országos } \\
\text { és a helyi politikában, a közélet tisztaságára, a monopóliumok } \\
\text { szabályozására, a női választójog megteremtésére, az oktatás } \\
\text { reformjára, hozzáférhetőségének kiszélesítésére, és általában véve } \\
\text { az ipari modernizáció negatív következményeinek a mérséklésére } \\
\text { törekedett. }\end{array}$ \\
\hline $\begin{array}{l}\text { púdzsá (szkt. } \\
\text { „tisztelet”) }\end{array}$ & $\begin{array}{l}\text { Az istenség tiszteletére elvégzett cselekmények, pl. virág, étel, víz } \\
\text { felajánlása. }\end{array}$ \\
\hline $\begin{array}{l}\text { puránák (szkt. „régi } \\
\text { történetek”) }\end{array}$ & $\begin{array}{l}\text { Enciklopédikus prózai mủvek, az indiai mitológiai és történeti } \\
\text { hagyomány gyüjteményei. }\end{array}$ \\
\hline pu-tung- & A hivatalos kínai államnyelv, amely a pekingi dialektuson alapul. \\
\hline
\end{tabular}




\author{
fogalom \\ rádzsadharma \\ (szkt.) \\ rádzsput \\ Rámájana (szkt.) \\ rasza (szkt. ,,iz”) \\ rasztafári \\ Requerimiento \\ (,,követelés”)
}

Ricurjó

romanizáció

ros ha-sana

saiva

Sákjamuni (szkt. „, Sákják bölcse”)

Sákjaszinha

(szkt. , ,Sákják

oroszlánja")

sakti (szkt.)

saría (arab ,út”)

sejk jelentés

A királyok kötelességei a hinduizmusban.

A szanszkrit rádzsaputra, „királyfi” szóból. Nyugat-indiai ksatrija nemzetségek, fontos szerepet játszottak a Mogulokkal szembeni ellenállásban.

Óind eposz, Ráma királyfi számüzetését, felesége, Szítá elrablását és visszaszerzését, végül hazatérésüket és Ráma Ajódhjá királyává koronázását beszéli el. Szerzőségét Válmíkinek tulajdonítják.

A müvek íze vagy karaktere, domináns érzelme. Számuk általában nyolc vagy tíz sringára (szerelem/szeretet), víra (hősiesség), bíbhatsza (undor), raudra (harag), hászja (öröm, komikum), bhajánaka (félelem), karuna (szánalom), adbhuta (csodálkozás), sánta (nyugalom), vátszalja (atyai szeretet); az utolsó kettő elmaradhat.

Jamaicából származó, az Afrikába való visszatérést propagáló sajátos vallási irányzat és közösség.

A Kasztíliai Tanács által 1513-ban írt dokumentum, amelyet a spanyol hódítók ultimátumként olvastak fel a meghódított indiánok előtt tolmács nélkül, követelve tőlük, hogy fogadják el a spanyol fennhatóságot. A dokumentum vallási és jogi alapokon igazolta a spanyol hódítást és hirdetett igazságos háborút az ellenszegülő bennszülöttekkel szemben.

701-ben kiadott törvénykönyv, amely a kínai mintájú jogrendszert és államrendszert vezette be Japánban.

A római civilizáció és a latin nyelv elemeinek elterjedése a meghódított tartományok (provinciák) területén. Elsősorban a római császárkorban bontakozott ki az 1-4. században. Hosszabb távon a latin nyelv és iskolarendszer meghonosodásával és a római urbanizációs vívmányok elterjedésével járt.

Zsidó újév.

Másképpen sivaita, azaz Siva követöje; a Sivát középpontba állító hindu vallási irányzatok gyüjtőneve.

A Buddha egyik neve. Arra utal, hogy a mai Nepál határvidékén élő sákja törzs tagjaként született.

A Buddha egyik neve.

Női teremtő energia; megszemélyesített formában az Istennővel (Déví) azonos.

Az iszlámban az isteni törvény, az az egyenes út, amelyet Isten kijelölt a muszlimok számára az élet minden területére vonatkozóan. $\mathrm{Az}$ isteni útmutatásokat és elöírásokat a szövegek, ( $\rightarrow$ Korán és $\rightarrow$ hadísz $)$ tartalmazzák, amelyeket a jogtudomány $(\rightarrow f i k h)$ fejt ki és értelmez.

Misztikus mester az iszlámban, aki már megvalósította célját, Istennel bizalmas viszonyba került és az a feladata, hogy onnan visszatérve irányítsa a tanítványokat, akarókat $(\rightarrow$ muríd). 


\begin{tabular}{ll}
\multicolumn{1}{l}{ fogalom } & jelentés \\
síta & Az iszlám egyik fő irányzata, amely Ali kalifa, a Próféta unokatestvére \\
& és veje pártjából, követőiböl alakult ki. Nem fogadják el a választott \\
& kalifákat, csak Ali leszármazottait, az $\rightarrow$ imámokat. Attól függöen, \\
& hogy hány imámot ismernek el, vannak 12 imámosok vagy imámiták, \\
& 7 imámosok vagy iszmáiliták és 5 imámosok, zajditák.
\end{tabular}

sintó (japán)

sógun

sramana (szkt.)

súdra (szkt.)

svétámbara (szkt.

"fehér ruhájú")

Száhel-övezet

szalaf (arab „kegyes ösök")

szamszára (szkt.)

szamuráj (busi)

szanátana dharma

(szkt. „örök vallás”)

szangam (szkt.)

szangha (szkt.)

szánkhja (szkt.)

szanszkára (szkt.)
$\mathrm{Az}$ „Istenek útja”, archaikus természetimádó hiedelemvilág; szertartások, varázslások, helyi kultuszok halmaza, eredetileg erkölcsi tanítások és metafizikai mondandó nélkül. Az ösök tisztelete, a természeti jelenségek imádata, a szellem halhatatlanságába vetett hit jellemezte, milliónyi $\rightarrow$ kamival.

A $\rightarrow$ szamurájok legföbb hübérura Japánban, a császártól nyert (katonailag kikényszerített) felhatalmazással 1192-től az egész országra kiterjedő végrehajtó és ellenőrző rendszert épített ki vazallusaival. Hatalmának alapja a földtulajdon volt, és az erre épülő feudális hierarchia, amelyben személyes függőség kötötte össze a hübérurat és a vazallust.

Vezeklő, vándoraszkéta, a heterodox tanítások követője a Kr. e. 1. évezredben.

Az óind társadalmi rendszer (varnarendszer) négy osztálya közül a legalsó. A rituális beavatásban nem részesülő, ún. egyszer született szolgarendűek tartoztak ide.

A dzsaina vallás egyik felekezete.

A Szaharától közvetlenül délre húzódó száraz szavannaövezet.

Az első három muszlim nemzedék tagjai, akiknek a szavai és cselekedetei a Próféta szokásait tükrözik és segítenek a muszlimoknak a vallásilag helyes utat követni.

Az újjászületések láncolata, lélekvándorlás.

Japán harcos réteg, a 9. századtól alakult ki föként vidéken a helyi elit fegyveresekböl. A harcos csapatok eredetileg családi alapon szerveződtek, tagjaikat erös függöségi rendszer kötötte össze. A harcosokat a szaburau (,szolgál valakit”) szóból képzett szaburai, szamurai kifejezéssel kezdték megjelölni, illetve a busi (,harcos lovag”) névvel. Társadalmuk a hűbéri függőségi rendszeren alapult.

A hindu vallásra használt kifejezés, amely annak a kasztok és a szekták vallásgyakorlatában meglévő különbségek feletti örökérvényü spirituális aspektusát hangsúlyozza.

Az ótamil irodalom neve.

A buddhista szerzetesek közössége.

A purusa (tudat) és a prakriti (anyag) kettősségén alapuló dualista filozófiai rendszer, a hat ortodox óind $\rightarrow$ darsana egyike.

Megszentelő szertartás, az élet fontos állomásait kísérő ún. átmeneti rítus. A kétszer születettek számára 12 (egyes források szerint 16 vagy 40) ilyen szertartás van elöírva. 


$\quad$ fogalom
szefárd
szekularizáció
szinkretizmus
szlavofilizmus
szóma (szkt.)
sztélé
sztrídharma (szkt.)
sztúpa (szkt.)

jelentés

Az Ibériai-félszigetről származó zsidók. $\rightarrow$ deszakralizáció

Az a vallási jelenség, amikor különböző eredetű vallási hagyományok összekeverednek és egységes egyveleget alkotnak; a népi vallásosság gyakori jellemzője. Kínában ez az eltérő nézetek összeegyeztetésére való törekvés. Egyik jellemző megjelenési formája, hogy a kínai (keleti) emberek lehetségesnek tartják egyszerre többféle igazság létezését is. Mindez befogadóvá teszi szellemi értelemben a keleti kultúrákat, amennyiben képesek más szellemi irányzatokat a saját képükre formálva adaptálni, nem ragaszkodnak kizárólag egyik vagy másik filozófiához, valláshoz, hanem pragmatikus módon mindegyikből alkalmazzák a számukra hasznos tanokat.

Az 1840-es években kialakuló orosz ideológiai irányzat, amely egyik változata volt az európai romantikus nacionalizmusnak. Az irányzat hívei kiálltak a nyugat-európaitól eltérő sajátos orosz fejlődés mellett.

A védikus áldozatoknál használt növényi eredetü, kábító hatású erjesztett ital.

Emlékmünek emelt nagyméretű kőtábla, kő- vagy faoszlop.

A nőkre vonatkozó vallási előírások a hinduizmusban.

Buddhista emlékmü, ereklyetartó. Az első sztúpákat a Buddha testi ereklyéinek elhelyezésére emelték, később szimbolikus jellege került előtérbe. Miniatür és fogadalmi változatai is léteznek.

szudáni gótika

A nyugat- és közép-afrikai agyagépítészet sajátos stílusa, amelynél a hatalmas, tornyos agyagépületekbe eleve beleépítik a faállványzatot, amelynek használatával évről évre újravakolható az épület.

szúfi (arab)

szunna (arab

Az iszlám misztikus irányzatának a követője.

Mohamed próféta cselekedeteinek és szavainak az összessége, amit Isten sugallt neki, és amelyet a muszlimoknak követniük kell az élet minden területén.

Szunnita

Mohamed próféta szokásainak követője, az ortodox, ún. közösségi iszlám irányzatának az elnevezése, jóllehet a síiták is azt mondják, hogy ők a Próféta $\rightarrow$ szunnáját, szokásait követik.

szútra (szkt.

„vezérfonal”)

szünoikiszmosz

Tömör formában megfogalmazott tankönyv vagy kézikönyv.

Az ókori Hellasz történetében falvak és kisebb települések „összetelepülése” egyetlen városállammá, amivel föleg a görög történelem első századaiban (i. e. 8-6. század) találkozunk. A szünoikiszmosz eredményeként a lakosok egyazon polisz polgáraivá váltak, ami az együttélés politikai szabályainak (,alkotmány”) a kidolgozásával is járhatott.

szvadharma (szkt.) ～Az egyén saját életfeladatai, vallási kötelességei. 


\author{
fogalom \\ szvasztika (szkt., a \\ $s u+$ aszti, ,jó-lét" \\ szóból)
}

talit

Talmud

tefillin

tennó

teokrácia

tetragrammaton

théraváda (páli

„, vének tanitása”)

tien-hszia (tianxia)

tírthankara (szkt. „ösvénycsináló”, „gázlókészitö")

Tóra

tributárius rendszer

trimúrti (szkt. „, hármas forma”) udzsi

umma (arab)

\section{jelentés}

Tört szárú kereszt, az indiai civilizációban ősi napjelkép, a hindu, buddhista és dzsaina vallásban a jólét és jószerencse szimbóluma.

A zsidó vallásban használt imalepel.

A zsidó vallásjog egyik alapműve, a $\rightarrow$ Misna magyarázata és kifejtése. A zsidó vallásban használt imaszíj.

A 7. századtól a japán uralkodó megnevezése kínai mintára (,az Ég uralkodója” vagy ,az Ég ura”).

Olyan politikai rendszer, amelyben a világi hatalom forrásának az adott kultúra istenét tekintik, az ilyen államot nevezik teokratikus államnak.

Isten négy betüből álló tulajdonneve, amelyet a zsidó hagyomány szerint tilos kiejteni.

A napjainkra fennmaradt egyetlen $\rightarrow$ hínajána buddhista iskola, Srí Lanka, Mianmar (Burma), Thaiföld, Laosz, Kambodzsa és Vietnam déli részének vallása.

Az „ég alatti” holisztikus világszemlélet, a konfucianizmus egyik fontos eleme, amely filozófiai alapot és magyarázatot ad a $\rightarrow$ tributárius rendszernek. A tradicionális kínai gondolkodásban az ég alatti nem csupán a fizikai világot jelenti, hanem valójában egy olyan kulturális fogalomról van szó, amelybe a moralitás és általában a világ müködése, rendje is beletartozik.

Adzsainizmus tanítói. A hagyomány szerint a dzsainizmus alapítójaként számon tartott Vardhamána Mahávíra a 24. tírthankara volt a sorban.

Törvény, tan. Mózes öt könyve a Bibliából.

A kínai tributárius rendszer lényege az egyenlőtlenség, amelyet ugyanakkor áthat a $\rightarrow$ tien-hszia és a „nagy harmóniára” - ta-tung (datong) - való törekvés szelleme. A rendszer lényege, hogy a világon létező dolgok (esetünkben: emberek, népek, országok) nem egyenlők, a középpontban Kína áll, amit koncentrikusan vesznek körbe az egyéb területek. Ugyanakkor minden az ég alatt egyetlen nagy, hierarchikus rendszer része, amelyben per definitionem nem léteznek ellentétek, minden ország a Kína által vezetett világhoz tartozik.

Hindu istenhármasság, melyben Brahmá a teremtő, Visnu a fenntartó, és Siva a pusztító istenség szerepét tölti be.

Nemzetség vagy törzs az ókori Japánban. Harcos arisztokráciaként saját területeket birtokoltak, amelyeket a dolgozó és adózó köznép müvelt. Vezetője a nemzetségfő volt, tagjai a családtagok. A kínai jogrendszer és államrendszer átvételével a 7. században elvileg megszüntették a nemzetségi rendszert, valójában tovább élt az ókor folyamán.

A muszlimok közössége, bárhol is éljenek. Eleinte egy fajta „Szupertörzs” volt. 
fogalom jelentés

unilineáris vs. multilineáris

szemléletmód

upanisadok (szkt.)

urdu (urdú, „tábor")

vadzsrajána (szkt. „gyémánt kocsi", „gyémánt ösvény") vaisja (szkt.)

vaisnava

varna (szkt. „szin”)

varnásramadharma (szkt.)

vásztusásztra (szkt.) Véda (szkt. „,tudás”)

verizmus

viaszvesztéses eljárás

WASP (White Anglo-Saxon Protestant)

zebu
Az unilineáris szemlélet a társadalomtudományokra jellemző fejlődéselméleti megközelítésmód a 20. század második felében, amely szerint a modernitás egyféle módon érhető el, és ennek példáját a nyugati modernizáció adja. Ehhez képest a multilineáris nézőpont inkább azt hangsúlyozza, hogy a modernitás többféle úton érhető el, amihez az egyes civilizációk eltérő alapokat teremtenek.

A $\rightarrow$ Védákhoz kapcsolódó ezoterikus szövegek, elméleti-filozófiai spekulációkat tartalmaznak.

A muszlim hódítókkal Indiába érkezett, arab elemeket tartalmazó perzsa nyelv és a helyi nyelv keveredéséből létrejött indiai nyelv. Gazdag költészete alakult ki.

$\mathrm{A} \rightarrow$ mahájána buddhizmus tantrikus változata. Ezoterikus rendszer, melyben a meditáció pszichés állapotait istenségek személyesítik meg.

Az ind társadalom harmadik rendje, melybe földmüvesek, kereskedők, kézmüvesek tartoztak.

Másképpen visnuita, azaz Visnu-hívő; a Visnut középpontba állító hindu vallási irányzatok gyüjtőneve.

Az ind társadalom hierarchikus alapegysége. Négy varna létezett, a $\rightarrow$ bráhmana, a $\rightarrow$ ksatriya, a $\rightarrow$ vaisja és a $\rightarrow$ súdra varna. Az első három varnába a rituális beavató szertartáson átesett ún. kétszer születettek tartoztak, míg a legalsó varna tagjainak feladata az első három varna szolgálata volt.

A társadalmi osztályokra $(\rightarrow$ varna) és életszakaszokra (ásrama) vonatkozó kötelességek, rituális elöírások.

Az építészet kézikönyvei az indiai irodalomban.

$\mathrm{Az}$ árják legrégibb és legszentebb vallási-irodalmi müvei. A négy Véda (Rigvéda, Jadzsurvéda, Számavéda, Atharvavéda) magját egyegy himnuszgyüjtemény alkotja.

A valószerűség hangsúlyozása a művészetek ábrázolásmódjában.

A fémöntésnek az a technikája, amikor a szobor elkészült viaszmodelljének helyét egy agyagformában fémmel töltik ki. Egyaránt megtalálható pl. az Indus-völgyi civilizációban és az afrikai (joruba) fémmüvességben.

Angolszász protestáns középosztály, amelynek karaktervonásai kiemelkedő szerepet játszottak az Egyesült Államok történelmi fejlődésében, és számottevő mértékben hozzájárultak az amerikai civilizációs értékek kialakulásához.

Dél-ázsiai eredetű szarvasmarhafajta, tudományos neve Bos taurus indicus. Feltehetőleg az Indus-völgyi civilizációban domesztikálták. Ismertetőjegye a vállpúp, amelyről púpos marhának is nevezik. 



\section{Civilizációk \\ Kelettől Nyugatig}

Jelen kötet a világ nagy civilizációit tárja az olvasó elé, bemutatva történeti korszakaikat kialakulásuktól a 20. század első feléig. A szerzők célja az volt, hogy az eseménytörténeten túlra tekintve, olyan kultúra és civilizáció történeti könyvet írjanak, amely napjaink eseményeiben is segíti az eligazodást, abból a megállapításból kiindulva, hogy a jelen a történelemben gyökerezik. A maga nemében egyedülálló vállalkozás először foglalja egyetlen kötetbe magyar nyelven a földgolyó összes jelentős, ma is fennálló civilizációját. Ugyanakkor a kötet térségeket kezel összefoglalóan, nem pedig modern országokat. Ez még akkor is igaz, ha egyrészt három civilizáció ma egy-egy ország területén található (Kína, Japán és India), másrészről, a három Közel-Keleten kialakult monoteista vallás (a judaizmus, a kereszténység és az iszlám) két térség (Közel-Kelet és Európa) civilizációját is alapvetően meghatározta. A gazdagon illusztrált kötet fejezetei végén található irodalomjegyzék további támpontokat ad az egyes civilizációk elmélyült tanulmányozásához. 